

\section{GIIT OF}

Dean Frank H. Frobert
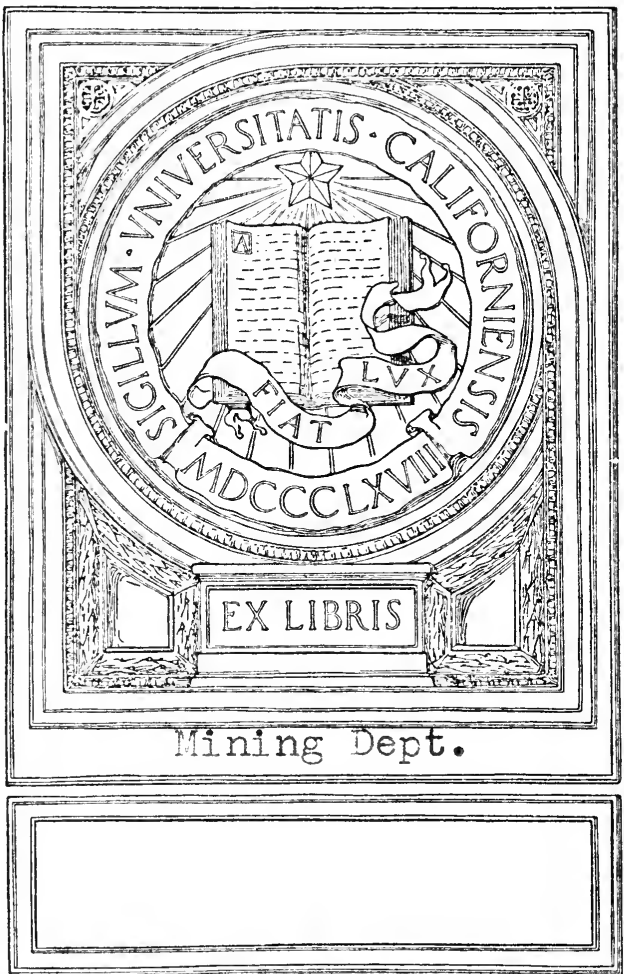
, 
A价代 
So our dever

Sin

tra

on atthanis - fo

Letamar

Arfoer

A TEXT-BOOK

oF

ORE AND STONE MINING. 


\section{NEW VOLUME OF GRIFFIN'S MINING SERIES.}

EitTed bY Prof. LE NEVE FOSTER, D.Sc., F.R.S.

MINE ACCOUNTS AND MINING BOOK-KEEPING. A Manual for the Use of Students, Managers of Metalliferou-Mines and Collieries, and others interested in Mining. Witil very numerons Examples taken from the Actual Practick of leadiny Mining Companies throughout the world. By JAMrs G. LA wN, Assoc. R.S.M., Professer of Mining at the South African School of Mines, Capetown, Kimberley, and Johannesburg. In large 8vo. 10s. $6 \mathrm{~d}$.

ELECTRIC SMELTING AND REFINING. A Practical Manual of the Extracion and Tre:tument of Metals by Electricil Methods. Being the "ELEKTROMETAlluRgie" of Dr. W. Borchers. Translated from the Second German Edition by Walter G. M'Millan, F.I.C., F.C.S., Lecturer in Metallurgy at Mason College, Birmingham. In large 8vo. With numerous Illustrations and Three Folding: Plates. 21s.

PRACTICAL GEOLOGY (AIDS IN). Bv G. A. J. Cole, F.G.S., Professor of Geology, Royal College of Science, Dublin. With numerous Illustrations. SECOND EDITION. 10s. 6d.

COAL MINING. By H. W. Hughes, F.G.S., Assoc. R.S.M. With 490 Illustrations. THIRD EDITION. 18s.

MINE SURVEYING. By B. H. BRough, F.G.S., formerly Instructor of Mine Surveying, Royal School of Mines. Sixth Edition, Illustrated. 7s. 6d.

TRAVERSE TABLES; computed to Four Places Decimals for every Munte of Angle up to 100 of vistance. By Richard Lloyd GURDEN, Authorised Sirveyor for the Governmeit of New South Wales and Victoria. Fourth Edition. 21s.

BLASTING AND THE USE OF EXPLOSIVES. By O. GuTTMANN, A.M.Inst. C.E. With Folding Plates and Illustrations. 10s. 6d.

ASSAYING. By J. J. Beringer, F.C.S., F.I.C., and C. Beringer, F.C.S. HOURTH EDITION. 10s. 6 d.

ELEMENTS 0\% METALLURGY : The Art of Extracting Metals from their Ores. By J. Arthli PhilLips, C.E., F.C.S., F.G.S., and H. Bauerman, F.G.S. With numerous Illuntrations. THIRD EDITION. 36s.

\section{NEW METALLURGICAL SERIES.}

EDITED BY

W. C. ROBERTS-AUSTEN, C.B., F.R.S., Chemist and Assayer of the Royal Mint; Prof. of Metallurgy, Royal College of Science.

1. INTRODUCTION TO THE STUDY OF METALLURGY. By the Editor. Fourth Edition.

2. GOLD. By T. K. Rose, Assoc. R.S.M., D.Sc., Assistant-Assayer of the Royal Mint. SkCond Edition, Revised and Enlarged. 21s.

3. COPPER. By Thos. Gibв, Assoc. R.S.M., F.I.C.

4. IRON. By Thos. Turner, Assoc. R.S.M., F.I.C. $16 \mathrm{~s}$.

5. STEEL. By F. W. Harbord, Assoc. R.S.M., F.I.C.

6. METALLURGICAL MACHINERY. By H. Jenkins, Wh.Sc., Assoc. R.S.M., Assoc. M.Inst C.E., of the Royal Mint.

7. ALLOYS. By the EDITor.

$$
\text { ** Other Volumes in Preparation. }
$$

London : CHARLES GRIFFiN \& CO., Ltd., Exeter Strekt, Strand. 

$\therefore \ldots$

$\therefore \because \therefore \therefore$

$\because \because$

$\therefore$

$\because \because \div$

$\therefore$ Dive

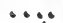

$\therefore \therefore$

$\cdots$
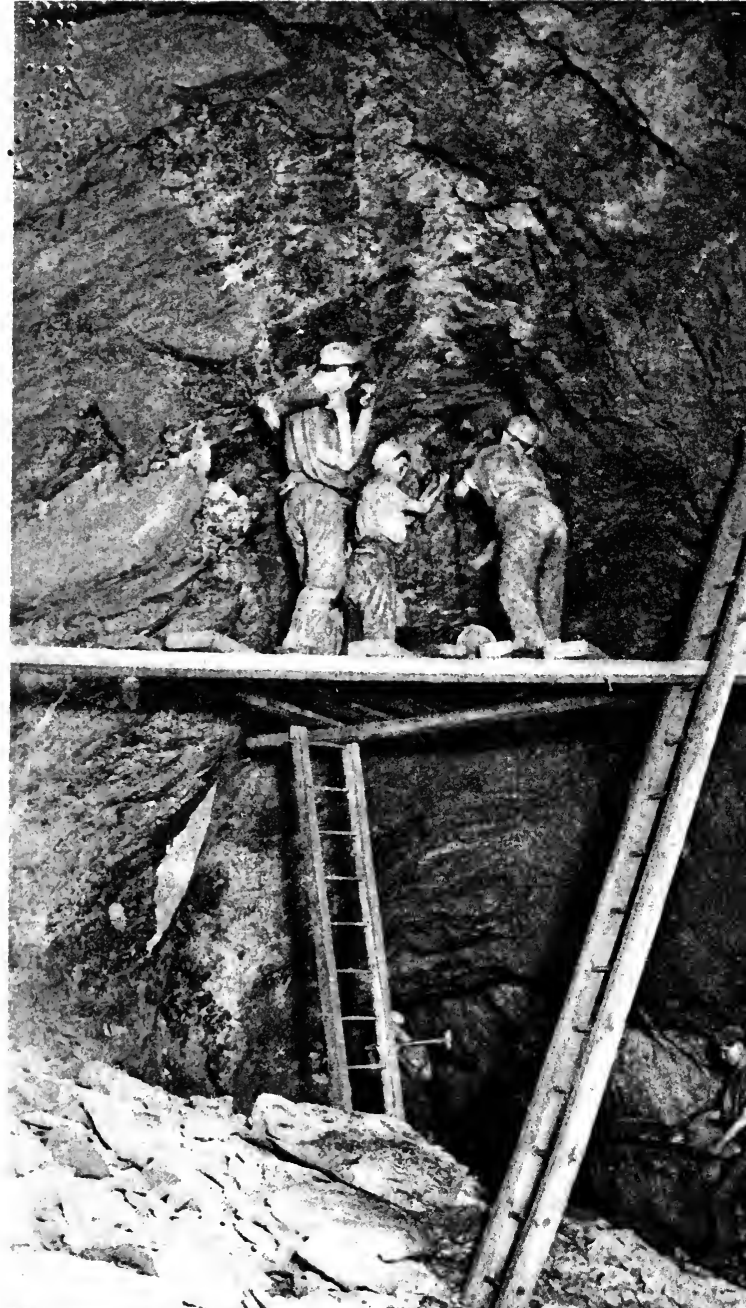

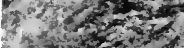

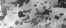
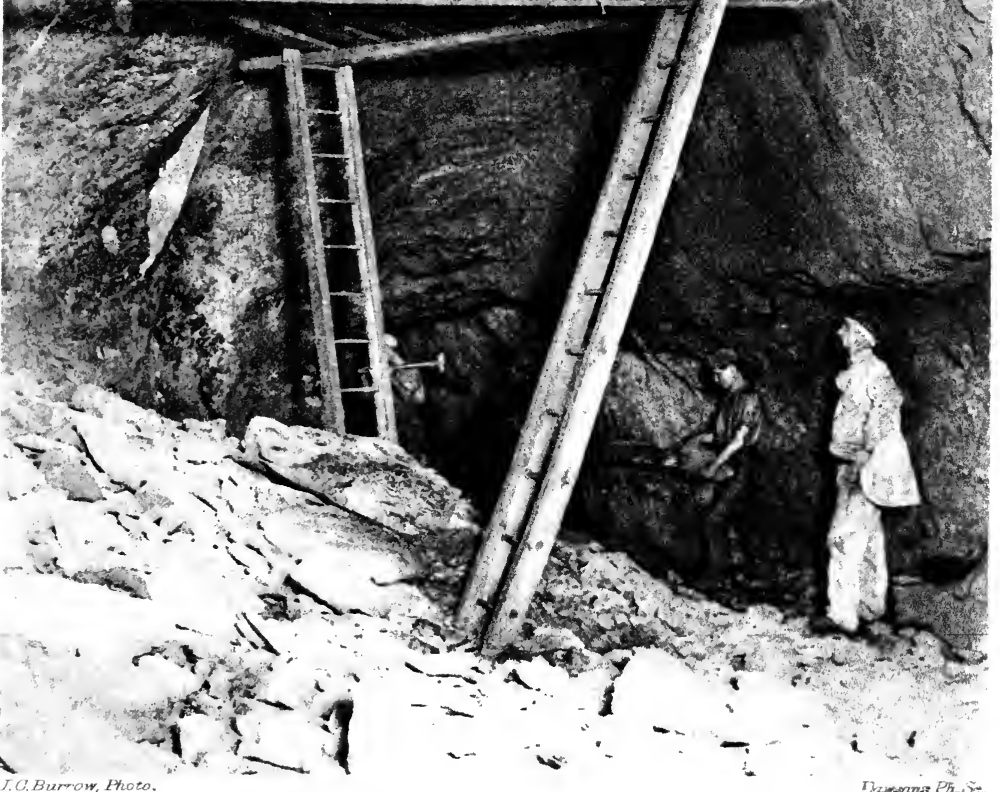

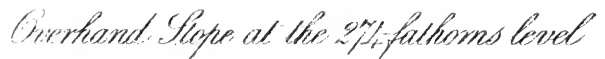

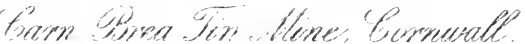




\section{$\Lambda$ TEXT-BOOK \\ O F \\ ORE \\ AND STONE MINING.}

EY

C. LE NEVE FOSTER, B.A., D.Sc., F.R.S.,

ASSOCIATE OF THE ROYAL SCHOOL OF MINES, ONE OF HER MAJESTY'S INSPECTORS OF MINES, AND PROFESSOR OF MINING AT THE ROYAL COLLEGE OF SCIE VCE, LONDON, WITH WHICH IS INCORPORATED THE ROYAL SCHOOL OF MINES.

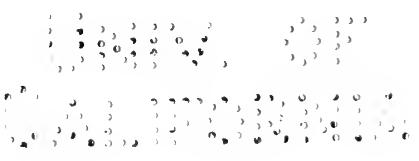

SECOND EDITION.

WITH FRONTISPIECE AND 716 ILLUSTRATIONS.

LONDON :

CHARLES GRIFFIN \& COMPANY, LIMITED, EXETER STREET, STRAND.

1897.

[All rights reserved.] 


\title{
GIET OF
}

\section{OEAN FRANK H PROBERD}

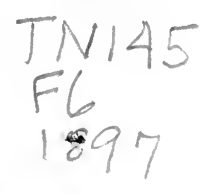

\author{
AINING DEPT.
}

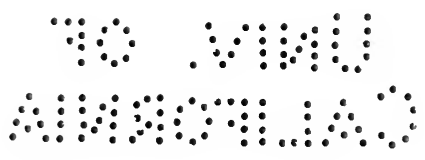

Printed by Baldantynk, Hanson os Ca. At the Ballantyne Press 


\section{PREFACE.}

THE object of my text-book is to assist students in acquiring a knowledge of the art of mining. Books and lectures are not intended to take the place of practical teaching at mines, but they render the training more thorough and complete in many ways: they serve to explain the principles of the art, to solve difficulties which perplex the beginner, to suggest matters which he should observe, to tell him of things beyond his ken, and to supply him with a system for arranging his ideas methodically.

It will be seen by my numerous references that $I$ have not hesitated to avail myself of very varied sources of information, and that I have taken care to avoid dwelling too much upon English examples.

As far as possible I have set my face against the indiscriminate use of the local slang of any particular district. Mining is quite difficult enough without introducing unnecessary technical terms, and if words which are generally understood by English-speaking nations will express our ideas clearly, it is far better to employ them than to fall back upon provincialisms which vary from one district to another; on the other hand, certain expressions may sometimes recommend themselves by reason of their pithiness, for adoption into our tongue.

Within the limits of this preface it is impossible to name 
all the persons to whom I am indebted for matter contained in this volume. Many useful facts have been picked up while visiting mines at home and abroad, and in the course of conversation with my colleagues. I therefore gladly record my obligations to mining men generally, whom I have invariably found ready to give me the benefit of their experience.

I have to thank the Council of the Institution of Civil Engineers, the Council of the Institution of Mechanical Engineers, the Editors of Engineering and of the Engineering and Mining Journal, M. Paulin Arrault, Mr. Augustus Bowie, Mr. William Galloway, Messrs. Letcher and Michell, and others, for permission to reproduce some of their figures. A few of the blocks have been borrowed from Mr. Hughes' "Text-book of Coal Mining."

Mr. J. G. Lawn and Mr. L. H. Cooke have given me valuable assistance in correcting proofs, and the former especially has saved me from some of the pitfalls which beset the path of an author who is passing a book through the press. The very full index prepared for me by Mr. S. W. Price will facilitate reference to my pages.

LlañdudNo, NoRti WALES,

May, 1894.

\section{ERRATUM.}

Page 675, owing to an error in the original, the scale is incorrect, an the readings should be multiplied by $1 \frac{1}{2}$. 


\title{
GENERAL CONTEN'TS.
}

\author{
INTRODUCTION
}

Chapter I.-Mode of Occurrence of Minerals.

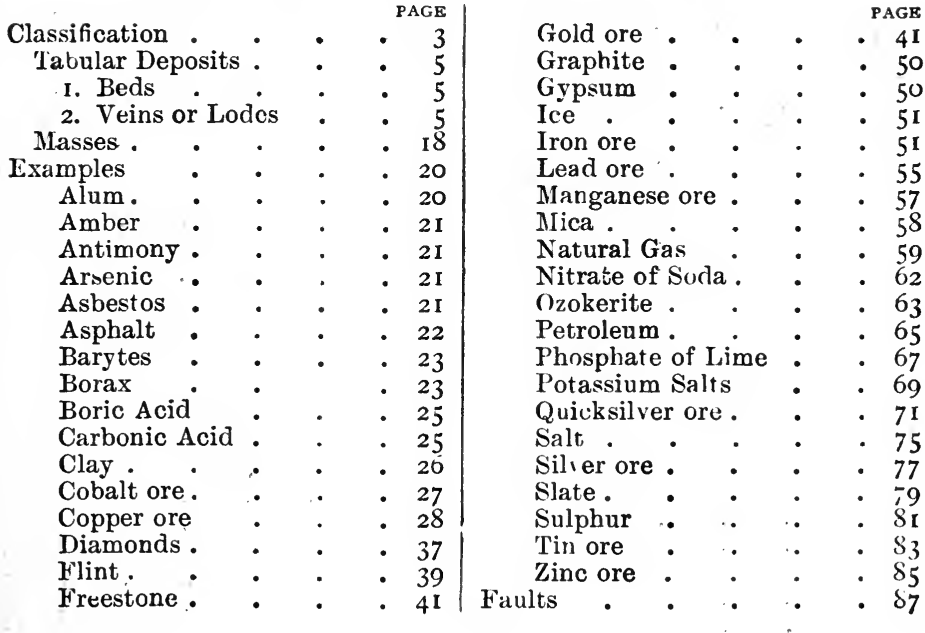

Cilapter II.-Prospecting.

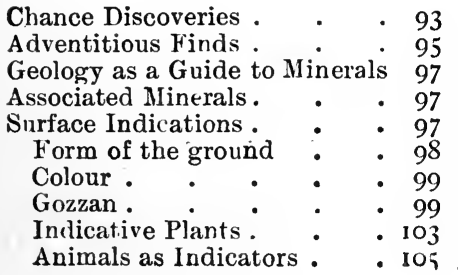

\begin{tabular}{|c|c|c|c|}
\hline Shoading & & & \\
\hline Hushing & - & & \\
\hline Piercing & & $\bullet$ & \\
\hline Lode Light & & $\dot{\theta}^{\prime}$ & \\
\hline Altered Veg & éatic & in & \\
\hline Old Workin & & $\cdot$ & \\
\hline Names of $P$ & laces & $\bullet$ & \\
\hline Divining $\mathbf{R o}$ & & - & \\
\hline Dipping Ne & edle & $\bullet$ & \\
\hline
\end{tabular}


Chapter XI.-Lighting.

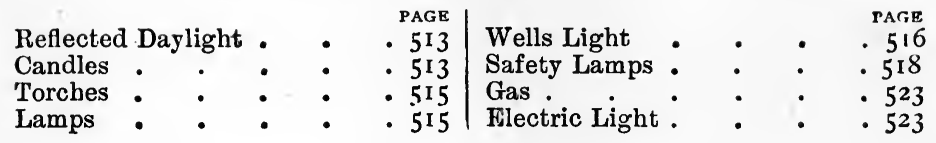

\section{Chapter XII -Descent and Ascent.}

Steps and Slides

Ladders \begin{tabular}{l|lll} 
- 526 & Buckets and Cages : & . & . 531 \\
.527 & Man Engine & . & . 534
\end{tabular}

\section{Chapter XIII.-Dressing.}

I. Mechanical Processes

Washing

Hand Picking . $\quad 541$

Breaking Up : . 542

Agglomeration or Consolidation

Screening : . . 566

II. Processes depending upon Physical Properties . 568

Motion in Water

568

Simple Fall in Water . 570

Upward Current Sepa-

Separation by Water

Flowing down

Planes . . 579

Plane Tables : 579

Percussion Tables 584

Travelling Belts . 585

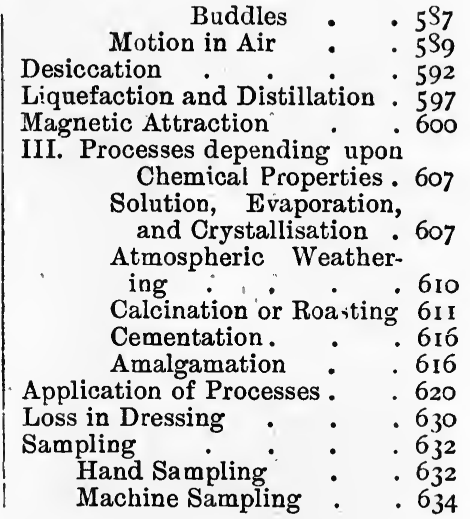

\section{Chapter XIV.-Principles of Employ ient of Mining} LABOUR.

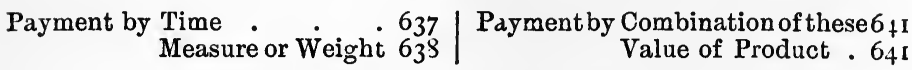

Chapter XV.-Legislation Affecting Mines and Quarries.

Ownership . . . . 653

Taxation . . . . 655

Working Regulations.$\quad .655$

Metalliferous Mines Regulation Acts . 656 Coal Mines Regulation Act . 662

O.her Statutes affecting Mines 662

Alkali Acts : : . . 665

Boiler Explosions Acts . . 666

Brinc Pumping Act . . 666
Elementary Ellucation Acts . 666

Enployers' Liability Act . 636

Explosives Act . . . 666

Factory and Workshop Acts 667

Quarry Fencing Act . . 667

Rivers Pollution Prevention

Act $\therefore . .067$

Stannaries Act . . . .668

Truck Acts . . . . 668 
Chapter XVI.-Condition of the Miner.

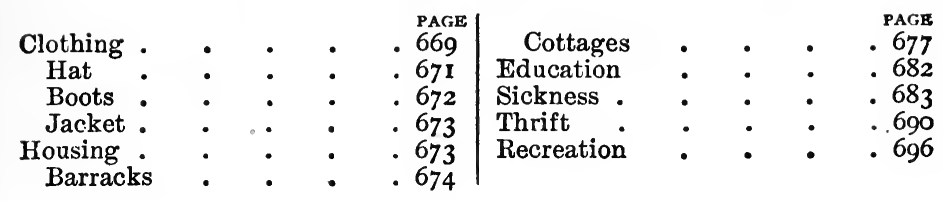

\section{Chapter XVII.-Accidents.}

Death Rate of Miners from Ac-

cidents
Relative Accident Mortality Underground and Aboveground 699

Classification of Accidents $\quad 702$

Underground Explosions of Fire Damp or Coal Dust.
. 704

- 704
Falls of Ground 704

Shaft Accidents $\quad$. 705

Miscellaneous . . . 706

On the Surface . . . 7II

By Machinery • . 7 II

Boiler Explosions . . 7 I I

Miscellaneous . . 7 I I

Ambulance Training $\quad: \quad .712$ 



\section{LIST OF ILLUSTRATIONS.}

Frontispiece: Overhand Stoping, Carn Brea Tin Mine, Cornwall.

\section{OCCURRENCE.}

FIG.

I. Stratified deposits, section .

2. Lead lode in slate, Wheal Mary Ann, Menheniot, Cornwall : 6

3. Tin lode in granite, West Wheal Basset, Cornwall . • - 7

4. Section of lode, Canton mine, Otago, New Zealand . . . 8

5. Diagram to show underlie . • . . . . . . 10

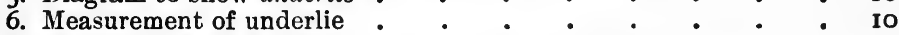

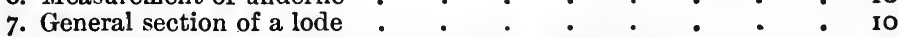

8. Longitudinal section of a lode showing ore-bodies : : $\quad$ II

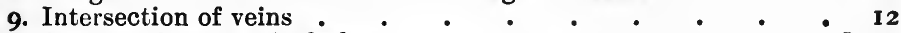

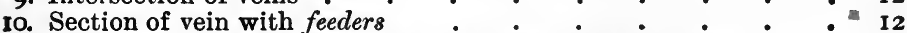

11. Plan showing fahlbands, Kongsberg silver mines, Norway : - 12

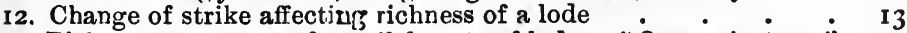

13. Richness or poverty of parallel parts of lodes : "Ore against ore" 17

14. Hæmatite deposit, Ulverston . . • . • • • 19

15. Calamine deposit, Altenberg, Moresnet $\quad . \quad$. $\quad$ • $\quad$. 19

16. Stockwork, Mulberry mine, near Bodmin, Cornwall . . $\quad 19$

17. Borax Lake, California, plan . . . . . . $\quad$. 24

18. Cobalt ore, Skutterud. Norway . . . . • • . 27

19. " " New Caledonia . • . . . . . . 28

20. Section across Mansfeld district . • • • • • . $\quad$ - 28

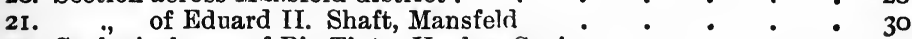

22. Geological map of Rio Tinto, Huelva, Spain $\quad \cdot \quad \cdot \quad \cdot \quad \cdot 3^{\circ}$

23)

24
25 Cross-sections of South Lode, Rio Tinto - . - . $\quad 32$

20)

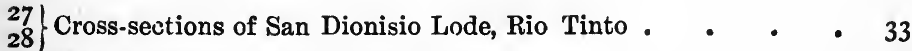

29. Map of Lake Superior copper district . • • • • • $\quad 35$

30. De Beers mine, Kimberley, vertical section . . . . : 38

31. Plan of diamond-bearing deposits, Kimberley . • . . $\quad 3^{8}$

32. Section of strata at the flint mines, Brandon, Suffolk . 40

33. " " Salisbury mine, Johannesburg • • - 42

34. " Sheba mine, Barberton . • • 33

35. " auriferous alluvium, Caratal District, Venezuela. : 44

36. " showing auriferous "raiuwash," Caratal . . . 45

37
38 Saddle-reefs, Bendigo • • • • • • • • 46, 47 
FIG.

39. Mount Morgan mine, Queensland, section to illustrate geyser PAGE

40. " " $"$ view of deposit . . . . . . . 49 theory

4I. " " sections based cn late developments . . . 50

42. Gypsum mine, Nottinghamshire .

43. Sections of ironstone bed, Cleveland

44. Chapin Iron mine, Lake Superior, section

45. Lead-bearing sandstone, Mechernich, general section

46. Evening Star mine, Leadville, Colorado, section .

47. Manganese ore bed, near Barmouth, North Wales

48. Natural gas ; section through Findlay, Ohio

49. Nickel deposit, New Caledonia

50

$5 \mathrm{I}$

52

53

" bearing veins, New Caledonia .

" deposit, Sudbury, Canada

54. Nitrate of soda, Chili .

55. Ozokerite at Boryslaw, Galicia, plan

56. " " filling fissures, Boryslaw .

58. Baku oil region, section

59. Spouting oil well, Bakú

60. Deposit of phosphate of lime, Beauval, France • • • $\quad 68$

61. Bed of phosphatic nodules, South Carolina. . . . . 68

62. Potassium salts and rock salt, Stassfurt . . . . . 70

63. Quicksilver-bearing sandstone, section, Ekaterinoslav, Southern Russia

64. Cross section of quicksilver deposit, Great Western mine, Californ 72

65. Longitudinal section

66. Cross section of Eureka mine, Nevada

$67 . \quad \cdot \quad \cdot \quad \cdot 77$

68. " " " the Oakeley Quarries, Festiniog. $\quad . \quad \cdot \quad \cdot 81$

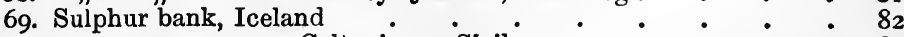

70. " seam, near Caltagirone, Sicily . . . . . 82

$\left.\begin{array}{l}71 \\ 72\end{array}\right\}$ Cross sections of tin veins, St. Agnes, Cornwall . . • . 84

73. Map of part of Vegetable Creek, New South Wales . • . 85

74. Cross section showing "deep-leads" of tin ore, Vegetable Creek 86

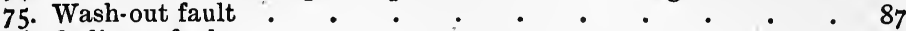

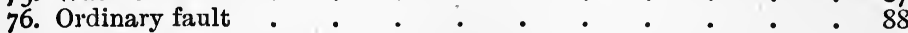

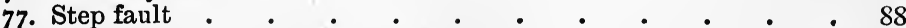

78. Fault with zone of broken rock . . . . . . . $\quad$. 88

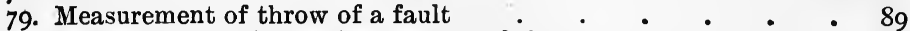

8o. Section of fault indicating amount of throw . . . . 89

$\left.\begin{array}{l}8 \mathrm{r} \\ 82\end{array}\right\}$ Variation of throw along the strike of a fault . . . . 90

83. Reversed fault showing bending of strata . . . . . 90

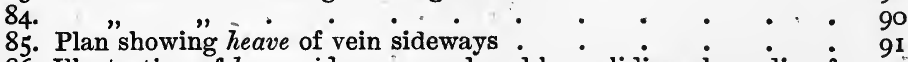

86. Illustration of heave sideways produced by a sliding along dip of fault

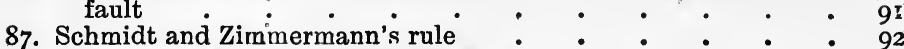

88. Succession of faults, Penhalls mine - • • • • . . 92

\section{PROSPECTING.}

89 Section of mineral vein showing projecting outcrop of a hard vein. 
FIG.

90. Cross-section of lode with gozzan

91. Longitudinal section showing relation of the gozzan to natural drainage level .

93. Dipping needle used in searching for iron ore

BORING.

94. Earth auger cr gouge • • • • • • • • • II4

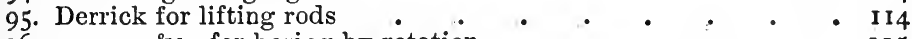

96. , \&c., for boring by rotation . . • • . - II5

97. Screwed coupling for hollow boring rods . • • • • I16

98. Rotating and guiding arrangements and loose connection . I II

99. Boring bit with two sets of cutters . . . . . . . II7

I00. Cutting out a core with diamond drill . . . . . . II8

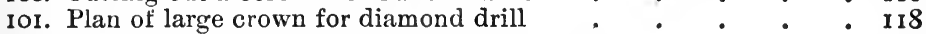

102. Arrangement of core tube and sediment tube . . . . . II9

103. Core-extractor . . • • . . . . . . . II9

104. Dauntless diamond drill . . . . . . . . . . . 120

105. Little Champion diamond drill : • • • • • • 123

106. Smali diamond drill for prospecting . . . . . . . . ' 123

107. Chisel bit . • . • . . . • • . . 125

108. Screw-juint for boiring-rods . • . . • • • 125

I09. " " " with connecting socket . . . 125

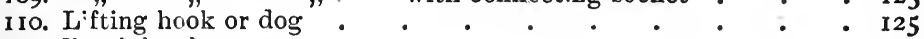

II Retaining key . • • • • • • • • •

112. Cap, or lifting ring and socket . . . . . . . $\quad$ 125

113. Portable plant for boring with rods . . . . . . 126

114. Set of tools for use with above . . . . . . . I27

115. Shell-pump or sludger . • . , . . . . . 128

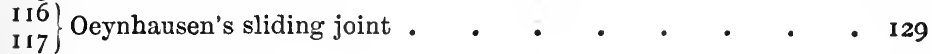

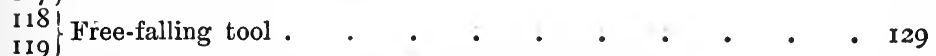

120. Arrault's free-falling tool used with bumping piece . . . 130

121. Enlarged view of catch for free-falling tool . . . : I30

122. Kind's free-falling tool . . . . . . . . . r30

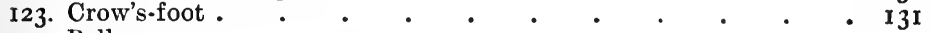

124. Bell-screw • • • • • • • • • • 13I

125. Riveted lining tube with screwed joints $\quad . \quad+\quad . \quad$. 13I

126. Lining tube with flush screwed joint . . . . . 13I

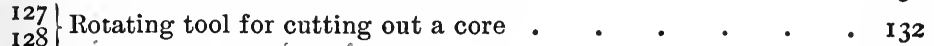

129. Core extractor . . . . . . . . . . 132

130 $130 \mathrm{~A}$ Compass-case for marking core $\quad . \quad$. . . . $\quad$ • 133

13I. Wooden boring rod used in Galicia . . . . . $\quad$ - 134

132. Rig for boring by the Canadian system . . . . . $\quad$ r 35

133. American rig for boring a well . . . . . . . 138

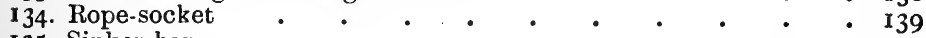

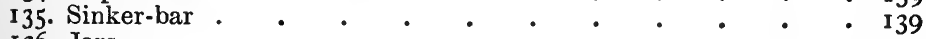

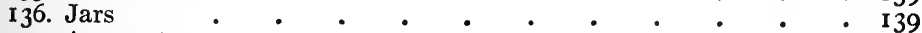

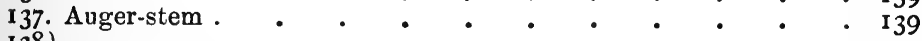

1 38
139 Bit

140. Temper screw

141. Sand-pump .

142. Method of working maul for drive-pipe $\cdot{ }^{\circ} \quad \cdot \quad \cdot \quad$ I40 
143. Boring plant, Mather and Platt's system • • • • • I43

144. Enlarged view of Mather and Platt's cylinder and pulley : $\quad$ I44

145. Mather and Platt, boring head and turning device . . . 146

146. Recording phial for Macgeorge's clinograph . . . . 147

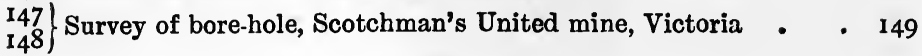

\section{BREAKING GROUND.}

149. Poll-pick

150. Double-pointed pick

I 5 I. Pick used for cutting $j a d$, Bath stone quarries

152. ", with movable blade, Mansfeld

153. Acme pick .

154. Universal pick

155. Cornish gad

156. Saw for cutting freestone

157. Elliott drill .

158. Ratchet drill

I59. Jumper used at $\dot{\text { Mechernich }} \dot{\circ}$

160. " " in Northamptonshire

161. " " in Festiniog slate mines

162. ", " in Cleveland iron mines.

163. Borer or drill

164
165 Cutting edge of drill, Minera, North Wales

166. Bore-hole with triangular section

169. Tamping bar

Needle, or pricker $\bullet \quad \cdot \quad \cdot \bullet^{-} \cdot \bullet^{-} \cdot 161$

17 I. Charging spoon and scraper - . . . . . . 161

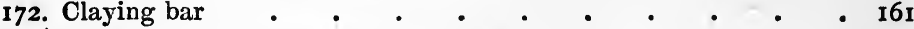

173 Knox system of boring rending holes . . . . . . 162

175. Reamer, or broach for enlarging holes by the Knox system . 162

176. Hanarte air-compressor . • • • • • • . 165

177. Dubois and François air compressor . • • . . . . 166

178. Ingersoll-Sergeant air-compressor . • • • • • 167

179. Valve of Ingersoll-Sergeant air-compressor _ . . . . 168

180. Arrangement of steam and air cylinders . . . . . $\quad$ - 68

181. Underground reservoir for compressed air, Mansfeld _ . 169

182. Joint for compressed air main, Blanzy . . . . . 170

$\left.\begin{array}{l}183 \\ 184\end{array}\right\}$ Mode of fixing air main in shaft . . . . . . 170

185. Eadie and Sons' joint for lap-welded pipe • • . . . . 170

186. Dunbar and Ruston's steam navvy . . . . . . 174

187. Kincaid and McQueen's bucket dredge . . . . . 176

188. Priestman's grab dredger . • • • • • . 177

189. Steavenson's twist drill on carriage, worked by electric motor . I79

190. " " " " petroleum engine ISo

191 )

192
193 Bits used with machine drills $\quad . \quad$. . . . $~ 18$ I

194. Shaped hars of steel for cross-bits . . . . . 182

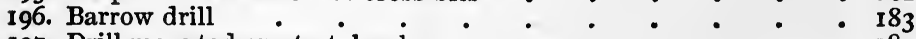

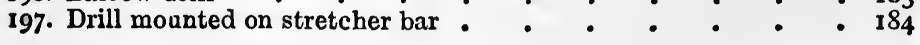


204. Franke drill . $. \quad . \quad . \quad . \quad . \quad . \quad . \quad$ I90

205. Use of Franke drill and undercutting chisel, Mansfeld copper mines

206. Hirnant drili $\bullet \cdot \bullet^{\circ} \cdot \bullet^{-} \cdot \bullet^{-} \cdot{ }^{\circ}$ I9I

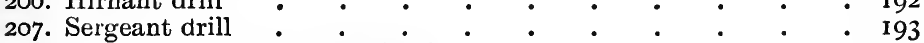

208.

209. Adelaide drill

turning mechanism $\quad . \quad$. $\quad . \quad . \quad$. 194

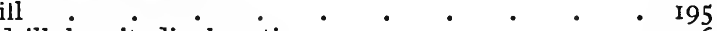

Io. Darlington drill, longitudinal section . • • • • • •

211. " " side elevation . . . . . . 196

212. " " mounted on stretcher-bar . . . . 197

213. Marvin electric drill, working parts . . . • . . 198

2I4. Franke's mec h`nical chisel . . . . . . . . 200

215. Gillott and Copley's undercutting machine. . . . . 203

216. Walker's circular saw . • • . . • . . . 204

217. Wire saw . . . . . . . . . . . 205

218. Stanley's tunneliing machine, side elevation . . . . . 207

219. Elliott multiple wedge, longitudinal and cross sections . . 248

220

221

222

Strength of explosives as shown by Trauzl's lead block test 216

224

225

226. Detonator, Nobel's, treble strength • • • • • - 218

227. " $"$ quintuple strength . . . . . 218

228. Firing a charged hole . • . . . . . . . 219

229. Rifting hole with air-spare above charge, Knox system . $\quad 219$

230. Simultaneous fuse of Bickford, Smith \& Co. . . . . 219

231. Brain's high-tension electric fuse . • • . . 220

232. Nobel's " " " " . • . • • 221

233. " low-tension " " $"$. . . . 22 I

234. Planning holes for driving a level by hand . • . . • $\quad 222$

235. Section of lode with gouge or selvage . $\quad . \quad+\quad . \quad+\quad .222$

236. Arrangement of holes fur driving a level with a machine drill

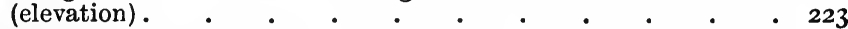

237. Arrangement of boles for driving a level with a machine drill

(longitudinal section) . • • • • • • $\quad$ • 223

238. Halkyn drainage tunnel, arrangement of holes for driving . 223

239. Driving level with Ferroux drill and bosseyeuse, Bex, Switzerland 224

240. Arrangement of holes for sinking a shaft, Foxdale, plan . $\quad 225$

24I. " " " " " section . 225

\section{SUPPORTING EXCAVATIONS.}

242. Level with cap or bar supporting roof . . . . $\quad 232$

243. " $"$, and leg . . . . . . . . 232

244
245 Joints between cap and leg . . . . . . . 232

246. Timber frame and lagging for level • • • . . $\quad 232$

247. Horned set for level in loose ground . $\quad . \quad+\quad . \quad+\quad . \quad 233$

248. Timber frame and lagging for heavy ground, Comstock lode . 233

249. Timbering for level, Rio Tinto mines $\cdot e^{-} \cdot{ }_{b}{ }^{\cdot} 233$ 
FIG.

250. Pigsty timbering for wide level, cross-section _ . . . $\quad$ - 234

25I. " " " " section along liue of strike - 235

252. Spilling in loose ground, longitudinal section . . . . $\quad 236$

253. " " " cross section . . . • . 236

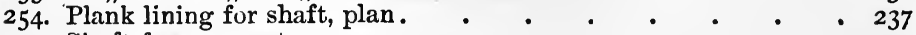

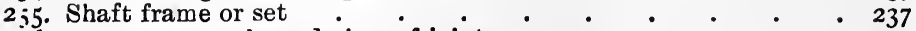

256. " " enlarged view of joint $\quad$ • • • • • • • $\quad$ • 237

257. Plan of timbering for shaft, Comstock lode . . . . . 238

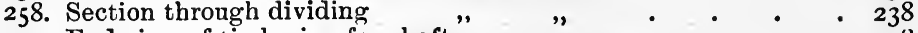

259. End view of timbering for shaft, , $\quad$, $\quad . \quad . \quad . \quad . \quad 238$

260. Plan of timbering for shaft, Calumet and" Hecla mine $\quad$ • $\quad 239$

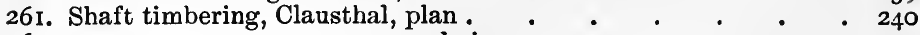

262. " " " . . . . . 24I

263. Timbering" chamber for water-wheel, Clausthal . . . . . $\quad$. 241

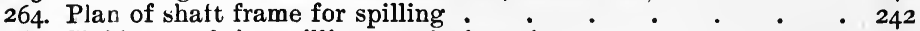

265. Sinking shaft by spilling, vertical sertion . . . . . $\quad 243$

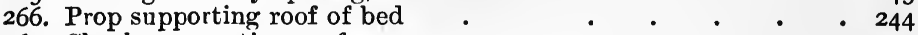

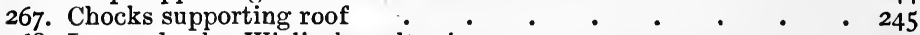

268. Large chocks, Wieliczka salt mines • • • • • • $\quad 245$

269. Pigsty timbering in stopes, Day Dawn mine, Queensland . $\quad$ - 245

270. Square set, Comstock lode, Nevada, elevation . . . . 246

27I. " " " , plan . . . . . 246

272. " " application in overhand stopes 246

273. " Richmond mine, Nevada . • • • • . 247

274. " timbering in overhand stopes, Broken Hill mines, sectional elevation. • • • • • . 248

275. "timbering in overhand stopes, Broken Hill mines, horizontal section . . . . . 248

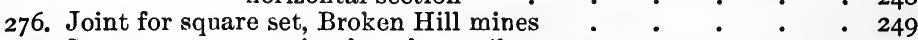

277. Square sets supporting hanging wall . $\quad$ • $\quad$ • $\quad$ • $\quad$ • 249

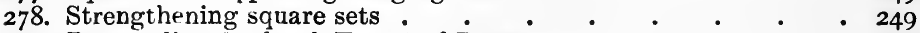

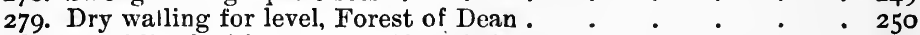

280. Lei el lined with masonry, Clausthal . . . . . . $\quad 250$

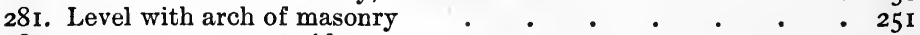

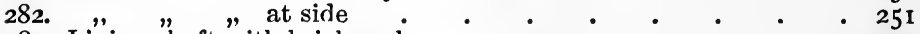

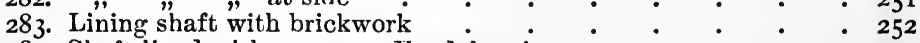

284. Shaft lined with concrete, Foxdale niine - . $\quad$ - $\quad$ - $\quad$ - 253

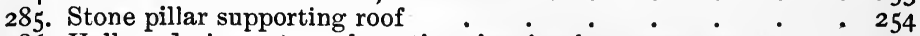

286. Halkyn drainage tunnel, section showing iron supports $\quad$. 255

287. " " " cast-iron prop and chair . . . 255

288. " " " " section of iron rail used . . . $\quad$ • 256

289. Section of steel beam, Nunnery Colliery, Sheffield . • • $\quad$ - 256

290. Steel beam on timber legs • • • • • • • • • $\quad$ • 257

291. Rolled steel caps and legs forming frame for level $\quad$ - $\quad$ - $\quad 258$

292 Section and plan of steel plate used . . . . . $\quad . \quad 25^{8}$

294. Level lined with curved iron rails, Hartz • • • • • 258

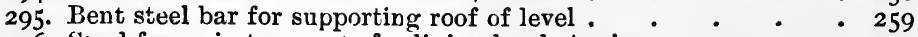

296. Steel frame in two parts for lining level, Anzin . . . . . $\quad$ - 259

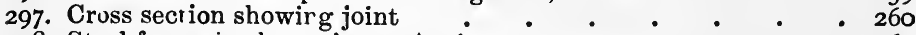

298. Steel frame in three pieces, Anzin $\quad . \quad+\quad . \quad+\quad . \quad+\quad . \quad 260$

299. Circular frame for level, channel steel $\quad . \quad$. $\quad . \quad$. $\quad$. 26 I

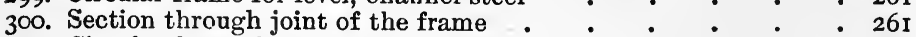

301. Circular frame for level, bulb-tee steel $\quad$ - . . - . $\quad$ - 262

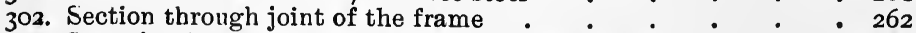

303. Iron ring in two parts for supporting shaft lining $\quad$. $\quad . \quad$ - $\quad 263$

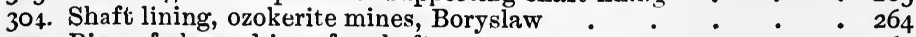

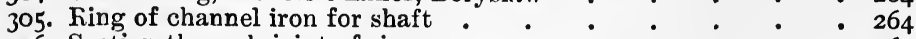

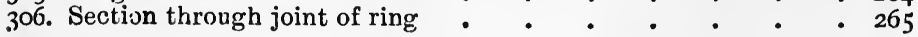


Prop of I-steel, and plan of end

308. Solid wooden tubbing for shaft, plan .

309. Sections of cast-iron wedging cribs . . . . . . $\quad$ - 267

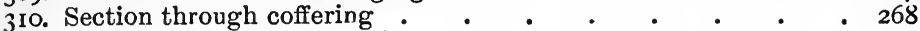

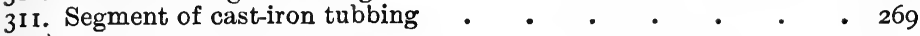

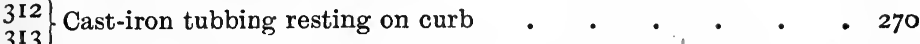

314. Small composite borer or trépan, Kind-Chaudron system . $\quad$ - 272

3I5. Large composite borer $\quad$ " $\quad$, $\quad$, $\quad$ • 273

316. Section of tubbing with moss-box " , ", 274

317. " ., , ", compressed, and false tubbing 274

3I. Enlarged section of the three wedging curbs $\quad . \quad$. $\quad . \quad$ • 274

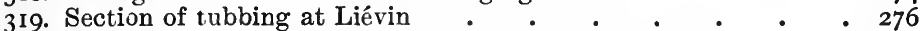

320. Sinking by freezing process in watery strata, Siberia. $\quad . \quad 279$

32r. " " " " " " • " . 280

322. Poetsch's freezing process, section of freezing tube . . . . 282

323. " " " vertical section of shaft . . . 282

\section{EXPLOITATION.}

324. Open workings for iron ore, Northamptonshire • • • • $\quad$ • 287

325. " " plan shou ing arrangement of workings . . 288

326. Section of terraces, Penrhyn slate quarry . . . . . . 288

327. View of opencast, Rio Tinto mines . • • • • • • 289

328. Section of Mulberry mine near Bodmin, Cornwall . . . $\quad$. 289

329. Section shuwing effect of a larye blas, Messina . . . 290

330 $\}$ Details of the tunnel for large blast , . . . . 29I

332. China clay workings, Hensbarrow, Cornwall • • . 292

333. End view of flume and trestle . . . . . . . . $\quad$ • 294

334. View of flume carried acrnss a valley . • . . . • • 294

335. " , " " by iron brackets on side of cañon . • 295

336. Riveted wrought-iron water pipe . . . . . . . 295

$338\}$ Pressure box or "bulkhead" . . . . . . . . . . 296

339. Monitor . • . 296

341. Hydraulic mining, attacking the gravel bank $\quad \bullet^{-} \quad \cdot \quad \cdot \quad \cdot \quad 297$

342

343 Sluice box

344 )

345

346

Hydraulic elevator . $\quad$ • . . . . . . 300

349. " " at the Blue Spur, Otago, New Zealand . 301

350. Working salt by bore-hole, Middlesbrough. • . • . 305

351. Plan of bore-holes, Middlesbrough $\quad . \quad$. . . . . 306

352. Section of underground gypsum quarries, Paris . . . . . 309

353. Plan " " " • • . 309

354. Underground workings for stone, near Bath, plan $\dot{*} \cdot \dot{*} 3$ I0

355. " " " " vertical section . 3IO

356. " ", " plan • . 310

357. Plan showing pillars, Marston Hall salt mine, Northwich • • 3II

358. Vertical section " " " . . 3II

359. Underground workings for slate, Festiniog, plan " . $\quad . \quad \cdot 313$

360. " " " " cross-section . . 313

36r. " $\quad " \quad, \quad$ French Ardennes, cross-section 313 
PAGE

362. Working ironstone, Cleveland, plan . . . . . . 316

363. Restronguet tin stream works, plan . . . . . . . 317

364. " " section • • • • • 317

365. Cross-section of the Red Point and Damm channels, California . 319

366. Plan of longwall workings, Mansfeld copper mine . • . 324

367. Transverse section of an ore mine, lode worked by vertical shaft 326

368. Longitudinal " " " • • • . • 326

$\left.\begin{array}{l}369 \\ 370\end{array}\right\}$ Underhand stoping, original method . . . . . . $\quad$. 327

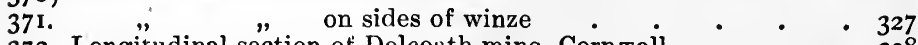

372. Longitudinal section of Dolcoath mine, Cornwall $\quad . \quad$. $\quad 3^{28}$

373. Transverse section " " . • • 329

374. Over hand stoping, with rubbish sto"wed on stulls $\quad . \quad+\quad \cdot 329$

375. " " cross-section . . . . . . 330

376. " " " excavation left open - . • • • • $\quad$ • 330

377. " on a narrow lode, cross-section . . . . 330

378. Working a wide lode with filling up, Van mine . . • • • 33r

379. Wide lode worked by cross-cutting, transverse section . . 334

380. " " • • • . 334

381. " $\quad$ worked in slices, parallel to the dip. $. \dot{ } . \dot{ } 335$

382. " worked in horizontal slices, with filling up, Foxdale Mine . . . . . . . . . 336

$\left.\begin{array}{l}383 \\ 384\end{array}\right\}$ Working a wide lode having a hard and a soft part . • • 337

385. Rio Tinto, pillar and chamber workings, vertical section . 339

386. " " " plan of preliminary

387. " " " " plan of completed

chambers $\quad$. 339

388. Working "churns," Forest of Dean • • • • • • • 340

389. Plan of De Beers Mine, new system of working $\cdot \quad \cdot \quad \cdot \quad \cdot 34 \mathrm{I}$

390. " of drivages and chambers . • • • • • • $\quad$ • 342

391. Vertical section of drivages and chambers . . . . $\quad . \quad$ - 342

392. Hæmatite deposit, North Lancashire, cross-section $\quad . \quad$. $_{342}$

393. " " plan of main levels and crosscuts . • . 343

394. " " plan of workings . • . . . . $\quad$ • 344

395. "̈.

396. Working zinc cre, Diepenlinchen mine . • . . . . 346

\section{HAULAGE.}

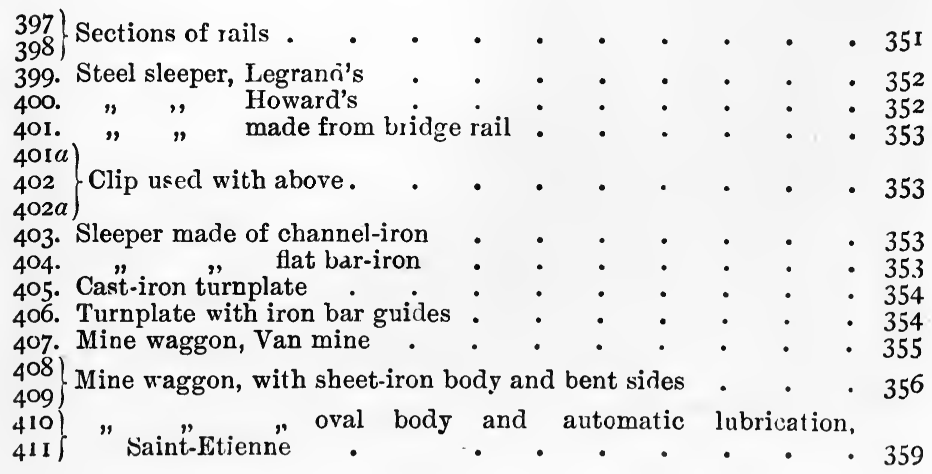


$\left.\begin{array}{l}412 \\ 413\end{array}\right\}$ Steel waggon, Llanbradach colliery . • . . . . . 359

4I4. Self-oiling pedestal . . . . . . . . • 36 I

4I5. Diagram, main and tail rope system : $\quad . \quad \cdot \quad . \quad . \quad . \quad 366$

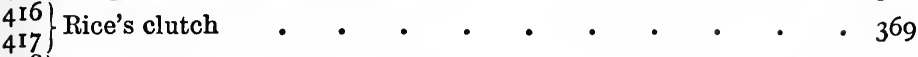

$418)$

419 Endless rope system, plans of sidings . . . . . . 370 420

421. " " • • • • 3 37 I

422. Drums and air-brake of self-acting incline, Bilbao $\quad . \quad .^{*} \quad .377$

423. Aërial ropeway, Otto's system, view of tub . . . . . $\quad$ - 382

$\left.\begin{array}{l}424 \\ 425\end{array}\right\} \quad " \quad$ " $\quad$ iron standard . . . . 383

$426 . \quad " \quad$ " $\quad$ " $\quad$ " clip, side view . . . . 384

427. " " " " " " cross-section of clip $\quad . \quad$. $\quad .384$

428. " " " " " plan of clip . . . . 384

429. " " " "

430. " " Gottessegen Colliery, Upper Silesia : • • $\quad$ • 385

\section{HOISTING.}

43r. Turbine and connections for wirding, Great West Van mine $\quad 390$

$\left.\begin{array}{l}432 \\ 433\end{array}\right\}$ Compound winding engine, Llanbradach Colliery . • • 39r

434. Drum with reserve length of rope $\quad . \quad$ • . . . 392

435. " " " " section . . . . . 392

436. Reel for flat rope, elevation " . $\quad \cdot \quad \cdot \quad \cdot \quad \cdot \quad \cdot \quad \cdot \quad \cdot 394$

437. " " • • • • • • • • 394

438. Wooden pulley-frame, side elevation . . . . . . . 395

439. " " . . . . . . . . 395

440. " plan " . . . 395

44I. Wrought-iron" head-gear, "Ruck Shaft," De Beers mine : . 396

442. " "Incline Shaft" " , . • 397

443. Winding pulley . . . . . . . . . . . . 398

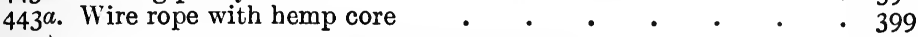

$\left.\begin{array}{l}444 \\ 445\end{array}\right\} \quad " \quad$ ordinary, new and when worn . . . . . 400

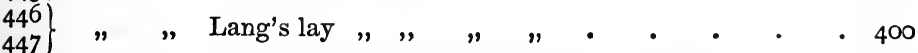

$\left.\begin{array}{l}448 \\ 449\end{array}\right\}$ " " Latch and Batchelor's "flattened strand" . . 400

450. " " " " . . 400

45I. " " Elliot's" locked coil" . . . . . . . 40 I

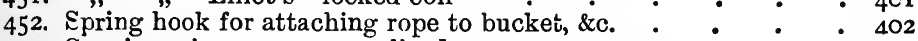

453. Capping wire ropes, eye spliced on . . . . . 4402

454. " " " eye made with screwed clamps . . . 402

455. " " " " " " " section . 402

456. " " " " socket" riveted on " . $"$ " . . . . 402

$\left.\begin{array}{l}457 \\ 458 \\ 459\end{array}\right\} \quad " \quad$ " $\quad$ for locked coil rope, outside view and sections 403

$460\}$ I " " " improved form of clamped capping . . 403

462. Wrought-iron kibble ", " " " . . 404

463. Aërial incline, "Blondin," used at granite" quarries, near Aberdeen 
PAGE

464. Galloway's improved wire rope guides for bucket . . . 408

465. " walling stage, elevation . . . . . . 409

466. " " " plan of lower floor . . . 4 4 49

467. Filling skip in" shaft . . . . . . . . . . . 4II

468. Self-discharging skip, De Beers mine, plan . . . . . 412

469. " " " " side elevation . . . 412

470. Improved" shoot with double doors, De Beers mine $\quad . \quad$. $^{\circ} 3$

47 I. Automatic dumping arrangement for inclines, side elevation . 4 413

472. " " " " " $\quad$ " perpendicular "Rock" shaft

473. De Beers mine, side eleva-

474. " " $" \quad$ tion $\quad \cdot \quad$ front eleva-

475. Ormerod's detaching link . tion" of a part $\cdot{ }^{\prime} \cdot 4^{15}$

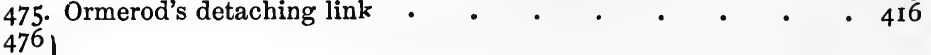

477

$\left.\begin{array}{l}478 \\ 479\end{array}\right\}$ Self-discharging skip, Frongoch mine . $\quad . \quad+\quad \cdot \quad \cdot 417$

481. Cage, Comstock lode, front elevation . . . . . . . 418

482. " " " side elevation : . . . . . 4 I 8

$\left.\begin{array}{l}483 \\ 485\end{array}\right\}$ Haniel \& Lueg's keps for cage . . . . . . . . 420

$\left.\begin{array}{l}486 \\ 487\end{array}\right\}$ Detaching hooks, King \& Humble's . . . . . . $44^{22}$

$\left.\begin{array}{l}488 \\ 489\end{array}\right\} \quad$ " Walker's . . . . . . . . 423

490. " " " open. . . . . . . 424

\section{DRAINAGE.}

491. Wooden dam in level, plan • • • . . . . . 430

$\left.\begin{array}{l}492 \\ 493\end{array}\right\}$ Spherical wooden dam. $. \quad . \quad . \quad . \quad . \quad . \quad . \quad .431$

494 .

495. Brick dam in shaft, vertical section

497
498 Galloway's pneumatic water tank, vertical section . . . 438

499. " $\quad$ automatic water tank, side view . . . . 439

500. " " " . . . . 4 4 40

$\left.\begin{array}{l}501 \\ 502\end{array}\right\}$ Bowden's automatic tanks for use on slopes . . . . $44 \mathrm{I}$

503. " " dumping at head of slope . . 44I

504. Compound double-acting pumping engine, Mansfeld . . . . 444

505. Strapping-plates for wooden pump rod . . . . . 445

506. V-bob, side elevation . . . . . . . . . . 446

507. " plan . . . . . . . . . . . . 446

508. Fend-off bob, side elevation . . . . . . . . . 446

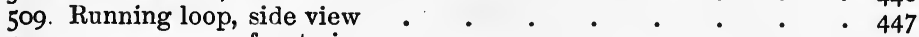

510. " " front view . . . . . • . 447

5II. West \& Darlington's hydraulic plungers for working inclined rods . . . . . . . . . . . . 447

512. Drawing lift in shaft, vertical section: $\quad \cdot \quad \cdot \quad \cdot \quad \cdot \quad \cdot \quad \cdot 447$

$5 \mathrm{I} 3$
$5 \mathrm{I} 4$ Pump bucket for single valve . . . . . . . 449 


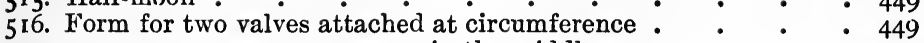

$517 . "$. $"$ in the middle . . . . 449

518. Shape of leather band for packing pump bucket $\quad . \quad$. $\quad .449$

519. Lifting pump used on the Comstock lode. . . . . . . 45I

520 Rising main, joint and mode of supporting column in shaft, Com-

$52 \mathrm{I}$ stock lode . . . • . • . . . . 45I

522. Plunger pump in shaft, vertical section : . . . . 451

$523\}$ Hake's mouth valve . . . . . . . • 453

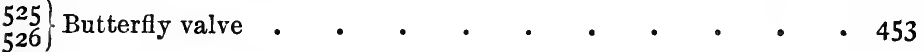

$527\}$ Trelease's valve • • • • • . • . • • 453

530 Teague's noiseless valve, vertical section, side view and plan $\quad .454$

532. Double-beat valve fixed in place, vertical section . • • 454

533. " " " open . . . . . . . . 4 454

534. " " " elevation of valve and lower seat . . . 454

535. Rittinger pump, elevation • • . • • • • • 456

536. " " . • • • • • • 456

537. Balance bob" .

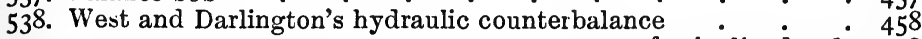

539. " " " " for inclined rods 458

540. Bochkoltz regenerator. ". . . . . . . . . 459

541. Rossigneux's system of counterbalancing . . . . . . 460

542. " " " . . . . 4lan . 460

543. Catches . . . . . . . • . . . 46r

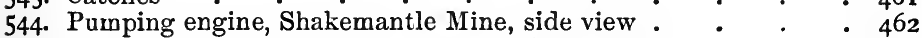

545. " " " " front view . . . 463

546. Pumps fixed̈ in shaft " $\quad "$ side view . $\quad . \quad . \quad$. 464

547. " " " " front view . . . 464

548. Pumps in shaft, bottom lift, Shakemantle Mine, side view $\quad .465$

549. Plan of shaft " " • • • • 465

550. Pumps in shaft, bottom lift " " front view . 465

551. Underground pumping engine, Mansfield . . . . . 468

552. " " plan . . . . 468

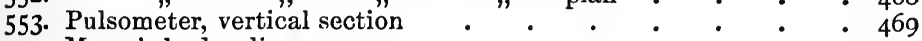

554. Moore's hydraulic pump . . . . . . . . . . 470

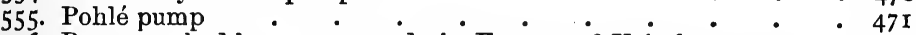

556. Pump wo ked by compressed air, Evans and Veitch $\dot{\bullet} \cdot \dot{*} \quad \cdot 471$

557. " " " " cylinders for working valves . 472

\section{VENTILATION.}

558. Natural ventilation by two shafts joined by a level . . . 483

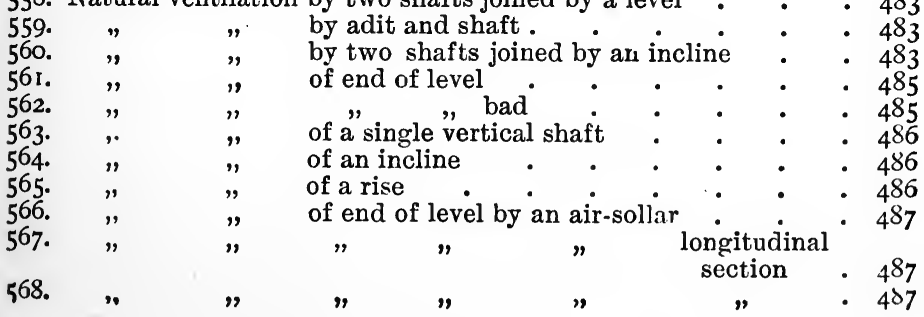


FIG.

569. Natural ventilation of shaft by an air pipe

570. Method of ventilating a rise • • • • • • • • 488

571. " " . . . . . . . . 4 489

572. " " . . . . . . 489

573. Ventilating furnace, vertical section . . . . . . . 49

574. " " plan . . . . . . . 491

575. " " front elevation . . . . . . 49I

576. Williams' water-jet apparatus . . . . . . . . 492

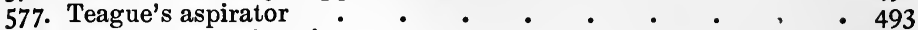

578. Hartz blower, elevation . . . . . . . . 494

579. " " section . . . . . . . . . . . 494

580. Roots' blower, cross section . . . . . . . . . 494

581. Capell fan, vertical section . . . . . • . . • 495

582.,$\quad$ cross section . . . . . . . . . 495

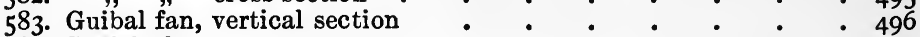

584. Schiele fan " " . . . . . . . . . 497

585. Waddle fan . . . . . . . . . . . . . 4497

586. Lunge's apparatus for testing the air of mines . . . . 504

587. " " valve-tube, vertical section . . . . 504

588. Water-gauge, model to illustrate action of . • . . 508

589. Murgue's graphic representation of the influence of the sides of airways upon the amount of friction . . . . . 5II

\section{LIGHTING.}

590. Candle holder, United States • • • • • • • 514

59r. " " ("Spider"), Australia . . . . . . 515

592. Lamp for burning oil, Scotland . • . . . . . 516

593. Wells light . • • • • • • • • • • • 517

594. Davy lamp • • • • • • • • • • • • 519

595. Clanny lamp . . . . . . . . . . 519

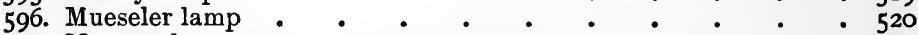

597. Marsaut lamp • • • • • • • • •

598. Ashworth's Hepplewhite-Gray lamp : . . . . . . . 522

599. Sussmann electric lamp . • • • • • • • • 523

\section{DESCENT AND ASCENT.}

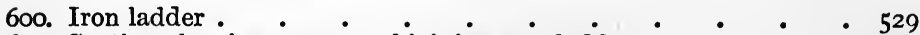

6or. Section showing manner of joining two ladders . $\quad$ • $\quad$ • $\quad$ • 529

602. Arrangement of ladders in shaft $. \quad . \quad . \quad . \quad . \quad$. 530

$\left.\begin{array}{l}603 \\ 604\end{array}\right\}$ Double-rod man-engine . . . . . . . . . 534

605. Single-rod man-engine $\quad$ • . . . . . . 534

\section{DRESSING.}

6o6. Rotary diamond washing machine
607 . Revolving drum for washing smalls before picking $: \quad . \quad$. 540

608. Scraper

609. Ragging

6ro. Spalling

6II. Cobbing

612. Bucking

6r3. Thin wedge for splitting slate, North Wales

6i4. Blake's rock-breaker, section 


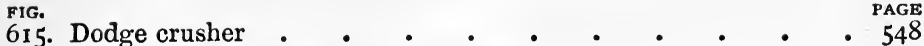

6I6. Io-stamp battery with wooden frame. . . . . . . 549

617. Single discharge mortar . . . . . . . . . 549

618. Tappet

619. Cam

620. Stamp head, shoe, and die .

621. Steel shoe and die before and after wear

622. Ball's steam-hammer stamp

623. Leavitt's differential steam-cylinder

624. Cornish crushing rolls

625. Rolls, cross section

626. Krom's roll, section

627. Krom's crushing rolls, side elevation

628. Edge-runner

629. Ball pulveriser, Krupp-Grusonwerk, cross-section

630. " " " longitudinal section

631. Carr's disintegrator", section

632. Gates crusher

633. Huntington mill, plan

634. " " sectional elevation.

635. Paxman's improved roller and yoke, section

636. " " " " plan.

637. Sawing machine for slate.

639. Greaves' circular slate-dressing machine

640. Perforated sheet-metal, with round holes, $1 \mathrm{~mm}$.

641. " " " " "

642. " " " " " "

642a. Trommel for making four classes $\quad \cdot \quad \cdot 567$

643. Experiment to show separation of minerals by free fall in water 569

644 Tossing and packing in keeve . . . • . . 57 I

646. Experimental jigging-sieve . • • • • • • • 57 ז

647. " jigger . • • • • • • • 572

648. Two-compartment jigger, front sectional elevation . • . 573

649. " " " c . . . . 573

650. Experimental jigger with fixed sieve . • • • • • • . 573

651. Jigger with piston moving horizontally, Frongoch mine, crosssection

652. Jigger with piston moving horizontally, longitudinal crosssection • • • • • • • • • • • 574

653. Pyramidal separator, Jacométy and Lenicque, sec:ion $\quad \cdot \quad$ • $\quad 574$

654. " " plan • • • 575

655. Upward current separator, Frongoch mine, section :.$\quad$. 576

$656 . \quad " \quad " \quad$ " . . 576

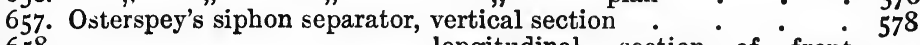

658. " " " longitudinal section of front

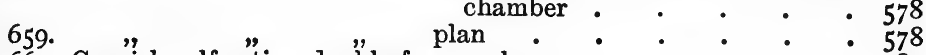

660. Cornish self-acting double frame, plan $\quad \cdot \quad \cdot \quad \cdot \quad \cdot \quad \cdot 578$

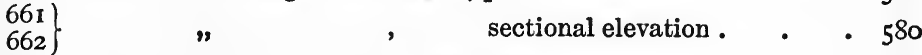

663. Linkenbach table, sectional elevation _ . . . . 588

664. " " plan . . . . . . . 582

665. Revolving round table, Jacométy and Lenicque . • . . $\quad$. 584

666. " " " " . 584

667. Rittinger's side-blow percussion table, plan $\quad . \quad \cdot \quad \cdot \quad \cdot 585$

668. Frue vanner, diagrammatic longitudinal section . . . 585

669. Stein's endless belt, side elevation . . . . . . 587 
FIG.

670. Stein's endless belt, plan • • • • • • • $\quad$ • $5^{87}$

67 I. " " " end elevation . . . . . . 587

672. Convex round buddle, sectional elevation . . . . . 588

673. " " " plan . . . . . 588

674. Experimental pneumatic jigger . . . . . . . . . 590

675. Clarkson-Stanfield concentrator . . . . . . . 59I

676. Tanks and drying floors for china clay, plan and a cross-section. 593

677. Kiln for drying fuller's earth, section . . . . . 595

678. Ruelle's revolving drier, longitudinal section _ . . . . 596

679. Large kiln, Sicilian sulphur mines, vertical section . • • 599

68. " " " " plan . . . . . 599

681. Chase" magnetic separator, longitudinal section (diagrammatic). 601

682. Conkling magnetic separator . . . . . . . . 601

683. Hoffmann magnetic separator . . . . . . . 602

684. Kessler magnetic separator . . . . . . . . . . 603

685. Lovett-Finney magnetic separator . . . . . . . 603

686. Ball-Norton magnetic separator . • . . . . . 603

687. Buchanan magnetic separator . . . . . . . 604

688. Friederichssegen magnetic separator, longitudinal section : : 605

689. ", ", plan . . . . . 605

690. Wenström magnetic "separator" . . . . . . . . 605

691. Edison's magnetic separator . . . . . . . . .

692. Brunton's calciner, sectional elevation . . . . . 614

693. Hockin's calciner, longitudinal section . . . . . 615

694. " " plan . . . . . . . . 615

695. Sampling-quartering . • • . . • . . . . 633

696. shovel . . . . . . . . . 633

697. Clarkson's rapid sampler . . . . . . . . . $\quad .635$

698. Bridgman's ore-sampler, first apportioner . . . . . . 635

699. " " . . . . . 635

\section{CONDITION OF WORKMEN.}

700. Barracks for workmen, Eisleben, front elevation • • . 675

701. " " . . . . 675

702. Cottage, Bolsover Collieries, front elevation : $\quad \cdot \quad \cdot \quad \cdot 678$

703. " " " . . . . . 678

704. " " " " first floor plan $\quad$. $\quad . \quad$. $\quad$. 678

705. " " " ground plan . • . . . 678

706. Dry or changing house, Levant Mine, Cornwall, side elevation . 680

707. " " " " plan . . 680

708. Shower-baths, Anzin Collieries, France " . . • • . . 68I

\section{ACCIDENTS.}

709. Lowmoor jacket and Furley pattern stretcher . • • $\quad 712$

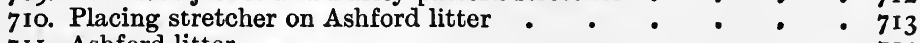

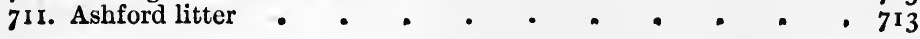




\section{LIST OF ABBREVIATIONS.}

Ann. Mines.-Annales des Mines.

Ann. Rep. R. Cornwall Pol. Soc.-Annual Report of the Royal Cornwall Polytechnic Society.

B. u. h. Z.-Eerg- und hüttenmännische Zeitung.

Bull. Soc. Ind. Min.-Bulletin de la Société de l'Industrie Minérale.

Coll. Guard.-The Colliery Guardian.

Comptes Rendus Mensuels, Soc. Ind. Min.-Comptes rendus mensuels de la Société de l'Industrie Minérale.

Eng. Min. Jour. or E. M. J.-The New York Engineering and Mining Journal.

Jahrb. f. d. Berg-und Hüttenwesen im K. Sachsen.-Jahrbuch für das Bergund Hüttenwesen im Königreiche Sachsen.

Jahrb. f. Geol. Min. Paläont.-Jahrbuch für Geologie, Mineralogie und Paläontologie.

Jour. Roy. Inst. Cornwall.-Journal of the Royal Institution of Cornwall.

Jour. Soc. Arts. - Journal of the Society of Arts.

Jour. Soc. Chem. Ind.-Journal of the Society of Chemical Industry.

Mem. Geol. Survey.-Memoirs of the Geological Survey of Great Britain.

Min. Jour.-Mining Journal.

Min. Stat.-Mineral Statistics of the United Kingdom.

Neues Jahrb. f. Miner. Geol. u. Paläontologie.-Neues Jahrbuch für Mineralogie, Geologie und Paläontologie.

Oest. Zeitschr. f. B.- u. H.- Wesen.-Oesterreichische Zeitschrift für Bergund Hüttenwesen.

Phil. Trans.-Philosophical Transactions.

Proc. Fed. Inst. M. E.-Proceedings of the Federated Institute of Mining Engineers.

Proc. Inst. Civil Eng. or Proc. Inst. C. E.-Proceedings of the Institution of Civil Engineers.

Proc. Inst. Mech. Eng. or Proc. Inst. M. E.-Proceedings of the Institution of Mechanical Engineers.

Proc. Min. Inst. Cornwall.-Proceedings of the Mining Institute of Cornwall.

Proc. South Wales Inst. Eng. - Proceedings of the South Wales Institute of Engineers.

Quart. Jour. Geol. Soc.-Quarterly Journal of the Geological Society. 
Rec. Geol. Survey, India.-Records of the Geological Survey of India.

Rep. Miners' Assoc. Cornwall.-Report of the Miners' Association of Cornwall and Devon.

Stat. Min. France.-Statistique de l'Industrie minérale en France.

Irans. Amer. Inst. M. E.-Transactions of the American Institute of Mining Engineers.

Trans. Inst. Eng. and Shipbuilders in Scotland.-Transactions of the Institute of Engineers and Shipbuilders in Scotland.

Trans. Inst. Marine Eng. - Transactions of the Institute of Marine En. gineers.

Irans. Manch. Geol. Soc.-Transactions of the Manchester Geological Society.

Trans. Min. Assoc. and Inst. Cornwall.-Transactions of the Miners' Association and Institute of Cornwall.

Trans. Min. Inst. Scotland.-Transactions of the Mining Institute of Scotlaud.

Trans. N. of Eng. Inst. Min. Eng.-Transactions of the North of England Institute of Mining and Mechanical Engineers.

Trans. R. Geol. Soc. Cornwall.-Transactions of the Royal Geological Society of Cornwall.

Irans. Technical Soc. Pac. Coast.-Transactions of the Technical Society of the Pacific Coast.

Zeitschr. d. d. geol. Gesellsch.-Zeitschrift der deutschen geologischen Gesellschaft.

Zeitschr. f. B.- H.- u. S.-Wesen.-Zeitschrift für das Berg- Hütten- und Salinenwesen im preussischen Staate. 


\section{A TEXT-BOOK}

OF

\section{ORE AND STONE-MINING.}

\section{INTRODUCTION.}

Tue art of mining, in the broadest sense of the word, consists of the processes by which the useful minerals are obtained from the earth's crust. This definition is wide, for it includes under the term "mine" both open and underground excavations; but it excludes subterranean workings which are simply used as passages, such as railway tunnels, sewers, and galleries for military purposes.

The word "mine" is derived from a low-Latin verb meaning to lead, and equivalent to "ducere;" we have the French word " mener," from the same source. No doubt originally the mineral deposit itself was called the "mine" or "lead," and this signification has not been entirely lost, for we still find the word "mine" used as a synonym for "seam" in the case of coal and ironstone.

I must remark that the word "mine," or its equivalent in other languages, varies in signification in different countries on account of legal enactments or decisions which define it. In the United Kingdom it is the nature of the excavation, and not the nature of the mineral, which decides whether the workings are a mine or not. For legislative purposes the term "mine" is restricted to workings which are carried on below ground by artificial light; but in common parlance this rule is not ob-erved, and the word used depends upon the mineral itself. Thus the underground workings for building stone near Bath, and for slate at Festiniog, are usually spoken of as quarries, but are treated legally as mines.

In Belgium, France, and Italy, on the other hand, the workings for mineral are classified according to the mineralogical nature of the substance wrought. The French law of 18 ro makes three classes of workings: mines, minières, and carrières. Deposits of gold, silver, lead, copper, sulphur, coal, and beds or veins of iron ore form mines. Under the head of minières, for which we have no equivalent word in English, are included bog iron ore, pyritous earths fit for working, sulphate of iron, aluminous earths and peat, whilst the carric̀res, or quarries, comprise workings for 
stone, clay, sand, etc., whether above or below ground. The statute or 1866 has assimilated the minières to the quarries, and the law now becomes very like that of Italy (1859), which distinguishes simply mines (miniere) and quarries (cave). Deposits containing metallic ores (excepting metal-bearing sand or earth), sulphur, bitumen, coal, or lignite are worked as "mines," whilst pits from which sand and gravel are obtained become legally "quarries." The consequence is that what is merely an underground stone quarry in France would be a mine in England; whilst open workings for iron ore, such as those of Northamptonshire, would be true mines under the French or Italian laws.

In a general text-book upon mining, it is therefore necessary to go beyond the British definition of a mine and to include the methods of working minerals in excavations open to the daylight, as well as in those which are purely subterranean.

The mining of coal is a subject of so much importance, especially in this country, that it requires a special treatise; this has been prepared by my friend, Mr. H. W. Hughes, ${ }^{*}$ and my task consists in describing the methods of winning and working all other useful minerals, whether solid, liquid, or gaseous. Furthermore, as it is customary for the miner to cleanse or prepare his ore or stone for sale, I shall explain the processes which are usually carried on at the mine, and can be fairly included under the convenient term "dressing." Finally, a few remarks will be made concerning legislation affecting mines in the United Kingdom, the condition of workmen, and the accidents to which they are exposed.

The subject has been divided into the following chapters:-

(I) Occurrence, or manner in which the useful minerals are found in the earth's crust.

(2) Prospecting, or search for minerals.

(3) Boring.

(4) Excavation.

(5) Supporting excavations.

(6) Exploitation, or working away of minerals.

(7) Haulage, or transport along roads.

(8) Winding, or hoisting in shafts.

(9) Drainage, or removal of water.

(Io) Ventilation.

(I I) Lighting.

(I 2) Descent and ascent.

(I3) Dressing.

(14) Principles of employment.

(I 5) Legislation.

(I6) Condition of workmen.

(I 7$)$ Accidents.

* A Text-Book of Coal Mining, London, ISg2. 


\section{CHAPTER I. \\ MODE OF OCCURRENCE OF MINERALS.}

Classification of mineral repositories.-Beds.-Veins.--Masses.-Causes affecting the productiveness of veins.-Theories concerning the formation of veins.--Examples of mineral deposits arranged alphabetically. - Fdults or aislocations.

CLASSIFICATION.-Various conditions may be taken as the bases of classification of the rocks which form the crust of the earth. One striking characteristic is the presence or absence of beds or layers. A rock made up of parallel beds, or layers, or strata, is said to be stratified; a rock in which no such structure exists is called unstratified. When we examine the stratified rocks closely, we find that, as a rule, they have been formad at the bottom of seas, lakes, or rivers by the gradual deposition of sediment, by precipitation from solutions, and by the growth or accumulation of animal or vegetable organisms. As instances may be cited beds of sandstone or clay, formed by particles of sand or mud settling down in water; beds of rock salt, resulting from the gradual drying-up of inland seas; beds of limestone, formed out of old coral reefs; beds of coal, due sometimes to plants growing upon the spot and sometimes to plants washed into likes or estuaries.

The unstratified rocks are frequently crystalline. In the case of recent volcanoes we see molten rocks issuing forth from the earth, spreading over it, and consolidating into a crystalline mass, and we may fairly assume that many of the crystalline rocks now met with at the surface were at one time in a soft fused condition. Internal evidence leads to the belief that the process of consolidation often took place at a very great depth, and on this account geologists have subdivided the crystalline unstratified rocks into volcanic, which hardened like recent lavas near the surface, and plutonic, which became solid under the heavy pressure of thick masses of superincumbent strata.

One class of crystalline rocks has given rise to much controversy, viz., the rocks in which the crystals of the constituent minerals are arranged in roughly parallel layers. The rock has a flaky structure, and is known as a crystalline rchist. Some crjstalline schists have all the appearance of being altered sedi- 
mentary strata; in others the foliated structure is considered to be the result of pressure upon pre-existing crystalline rocks.

We therefore may classify the principal rocks as follows :
I. Stratified.$\left\{\begin{array}{l}\text { Sedimentary origin. } \\ \text { Chemical origin. } \\ \text { Organic origin. }\end{array}\right.$
2. Unstratified . $\left\{\begin{array}{l}\text { Volcanic. } \\ \text { Plutonic. }\end{array}\right.$

The crystalline schists must be placed in one or other of these two great divisions, according as they are looked upon as an altered form of stratified or of unstratified rocks.

'This classification is not entirely satisfactory. For instance it separates two of the products of a volcano. Volcanic ash falling into the sea will settle down and form a stratified rock, whilst the lava issuing from the same vent is unstratified. Again it does not include sea-water, an important source of salt. However, for the purpose of the miner a simple classification is advisable, and it will be found sufficient for his purpose so long as it is recollected that occasional anomalies must be expected.

Any one of the five classes of rocks just mentioned may be extracted from the crust of the earth for commercial purposes.

Among the bedded or stratified rocks coal is the most important, but in addition we have beds which are commercially valuable on account of the metals they contain, such as copper, gold, iron, lead, manganese, silver, and tin, or pl ecious stones such as diamonds, garnets, rubies and sapphires; other valuable beds are native sulphur, rock-salt, and innumerable kinds of stone for building, decoration, paving and road-making, clays for making pottery and cement, oil-shale and alum-shale.

From the unstratified rocks we obtain supplies of stone for a great variety of purposes.

In addition to mineral deposits, which consist mainly of original constituent members of stratified or unstratified rocks, we have a third important class in which the repository of the valuable mineral has come ixto existence subsequently to the consolidation of the rocks which surround it. If the repository is, roughly speaking, tabular or shect-like, it is called a minercal vein or lode, and if in any other form it is a mass.

Hence the series of mineral repositories might be classed according to their origin as follows:

$$
\begin{aligned}
& \text { Primary origin } \cdot\left\{\begin{array}{l}
\text { Stratified. } \\
\text { Unstratified. }
\end{array}\right. \\
& \text { Secondary origin } \cdot\left\{\begin{array}{l}
\text { Veins. } \\
\text { Masses. }
\end{array}\right.
\end{aligned}
$$


But even here we encounter difficulties, for unstratified rocks sometimes occur in the form of veins; besides which primary origin is not a term which is strictly applicable to beds formed from sediment which consists of fragments of other rocks.

It is not unnatural, therefore, that outward form should have been chosen as a convenient basis of classification, and accordingly mineral repositories have been separated into:

$$
\begin{array}{ll}
\text { Tabular or sheet-like } & \cdot\left\{\begin{array}{l}
\text { I. Beds. } \\
\text { 2. Veins. }
\end{array}\right. \\
\text { Non-tabular } \quad \cdot \quad & \text { 3. Masses. }
\end{array}
$$

TABULAR DEPOSITS.-These are repositories which have a more or less flattened or sheet-like form. 'They may be divided according to their origin into (r) beds or strata; (2) mineral veins.

(x) Beds.-The characteristic feature of a bed or seam is that it is a member of a series of stratified rocks; the layer above it is called the roof, the one below it is the floor. Its thickness is the distance from the roof to the floor measured at right angles to the planes of stratification; its dip is the inclination downward measured from the horizontal; its strike is the direction of a horizontal line drawn in the plane of stratification.

The thickness of workable beds varies within very wide limits. The productive part of the copper-shale at Mansfeld is only 3 inches to 7 inches thick; and one of the beds of goldbearing conglomerate at Johannesburg is only 6 inches to 2 feet across; we find, on the other hand, the lead-bearing sandstone of Mechernich, in Rhenish Prussia, is 100 feet ( $3 \circ \mathrm{m}$.), and a bed of brown coal at Brühl in the same neighbourhood no less than $13 \mathrm{I}$ feet $(40 \mathrm{~m}$.) thick. The principal bed of slate at the Oakeley Quarry, Festiniog, is 120 feet thick $(36.5 \mathrm{~m}$.).

It must not be supposed that the thickness of a bed necessarily remains uniform. Occasionally this is the case over a very large area; but frequently the thickness varies, and the bed may dwindle away gradually, or increase in size, or become divided into two, owing to the intercalation of a parting of valueless rock; but, in spite of such variations, a bed is much more uniform in thickness and composition than a vein. Fig. I shows beds of shale, limestone, iron ore and sandstone, any one of which may be the object of a mining undertaking.

(2) Veins or Lodes.-Veins or lodes are more or less tabular or sheet-like mineral deposits, formed more or less entirely since the enclosing rocks (country), and either occupyir.g cavities formed 
originally by fissures, or consisting of rock altered in the vicinity of fissures. A simple and typical example of a vein is shown in Fig. 2, representing a lead lode in slate at Wheal Mary Ann in Cornwall.* It is evident that a fissure in the slate has been filled up by the successive deposition of bands of mineral on both sides. The unfilled cavities are called lochs (Wales and Isle of

FIG. 2.

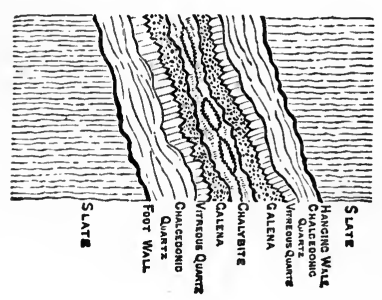
Man), or vugs $\uparrow$ (Cornwall). The definition given above differs somewhat from that of some standard authors, whose opinions I will quote.

Werner says : "Veins are special tabular mineral repositories which nearly always cut across the stratification of rocks and so far have a different lie to them, and are filled with a mineral mass differing more or less from the surrounding rocks ;" and further, $\S$ "Mineral veins may

be more exactly defined by saying that they are fissures in the rocks which have been subsequently filled up with various minerals differing more or less from the surrounding rock." Carne's definition is this: $\|$ "By a true vein, I understand the mineral contents of a vertical or inclined fissure, nearly straight, and of indefinite length and depth." Von Cotta's is shorter: " "Mineral veins are the contents of finsures," whilst Grimm says:** "Veins are fissures in rocks which have been wholly or partly filled with minerals." Von Groddeck's explanation runs thus :† " Veins are fissures which have been filled up."

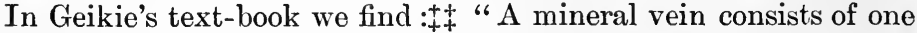
or more minerals deposited within a fissure of the earth's crust." Professor von Sandberger's idea of a vein is the same:§§ "True veins, that is to say, fissures filled with ores." In France \|\| and Italy $\|$ similar definitions prevail.

* C. Le Neve Foster, "Remarks on the Lode at Wheal Mary Ann, Menhenist," Trans. R. Geol. S'oc. Cormwall, vol. ix. p. 153.

t Probably taken fiom the Cornish word "fogou," a cave.

\$ A. G. Werntr, Neue Theurie von der Entstehung der Gänge. Freiberg, I791. p. 3 .

§ Ibid.

II J. Carne, "On the Relative Age of the Veins of Cornwall," Trans. $l$.

Geol. Soc. Cornuall. Penzance, 1822, vol. ii. p. 51 .

I Die Lehre von den Eralagerstätten. Freiberg, 1859, p. Iо2.

** Die Lagerstätten der nutzlaren Mineralien. Prague, 1869, p. 97.

t+ Die Lehre von den Lagerstätten der Erze. Leipsic, I879, p. 3 I.

\#+ Text Book of Geology. London, 1882, p. 591.

$\S \S$ Untersuchungen üler Erzgänge. Wiesbar en, I882, p. 4.

III Hat on de la Goupillière, C'ours d'Exploitation des Mlines. Paris, 1833, r 3.3 .

$99 \mathrm{~V}$ Zoppetti, Arte Mineraria. Milan, I882, p. 16. 
As long ago as the year 1864,* Mr. Richard Pearce brouglit forward the theory that miny of the tin lodes of Cornwall have been formed by the alteration of granite, and my own $\dagger$ investigations have convincerd me that he is right. The lodes appear to be bands of stanniferous rock formed by the alteration of granite in the vicinity of fissures. The tabular mass of tin-bearing rock ro or $I_{5}$ feet thick, called the lode, is traversed by sundry fissures and passes without any distinct walls or boundaries into non-stanniferous granite; sometimes the main fissure is a few inches wide filled with crystallised quartz and other minerals. This filled-up crack answers to the common definition of a vein, but the rest of the stanniferous mass does not. It has no definite bounding planes, it contains no fragments of the surrounding rocks, and presents no appearance of having been formed by the deposition of minerals upon the sides of an open rent (Fig. 3). As much of the stanniferous rock as will pay for working is known as the lode. I think the geologist must give way and suit his definition to

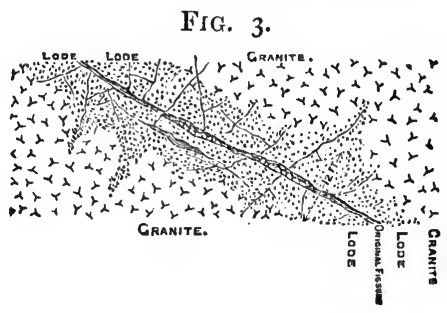
the wants of the miner. It is too much to expect the miner to give up a term consecrated by universal usage, simply because geologists have made the mistake of supposing that all lodes have been formed on the same plan.

If Cornwall furnished the only exceptions to the time-honoured definition of a mineral vein, one would perhaps hesitate in proposing any alteration; but when similar or somewhat similar cases are met with in other parts of the globe, the necessity for some change becomes apparent.

Mr. Kendall $\ddagger$ says that the hæmatite veins of the Lake District (England) are not filled fissures, but are substitutional deposits, the result of a gradual replacement of the original rock by other mineráls.

Mr. S. F. Emmons $§$ takes a similar view: "I consider it reasonably certain that a very large proportion of the so-called fissure-veins in the Rocky Mount:ain region, notably those in

* R. Pearce, "The Influence of Lodes on Rocks," Rep. Miners' Assoc. Cormwill. Truro, $186 \%$, p. I8.

+ C. Le Neve Foster, "On the Great Flıt Lode South of Redruth and Cimborne and on some other 'Tin-deposits formed by the alteration of Granite," Quart. Jour. Geol. Soc., Lond n, 1878, vul. xxxiv. pp. 640-653.

$\ddagger$ J. D. Kendall, "On the Mineral Veins of the Lake District," L'rans Manch. Geol. Soc. Manchester, 1894, vol. xviii. p. 292.

$\S$ R. C. Hills, "Ore Deposits of Summit District, Rio Grande County, Colorado." Condensed for the Enyineering and J/ining Journal, by S. F'. Emmons. Enj. Min. Juur. IS 3, vol. xxxv. p. 334 . 
Colorado and Montana, are simply the alteration, silicification, and mineralisation of the country rock along certain planes which for some reason or other offered exceptionally easy access to percolating mineral solutions, and are not the filling up of preexisting cavities in the rock, as is generally supposed to be the characteristic of a true fissure-vein."

Some of the lodes of Otago, New Zealand,* may be described as

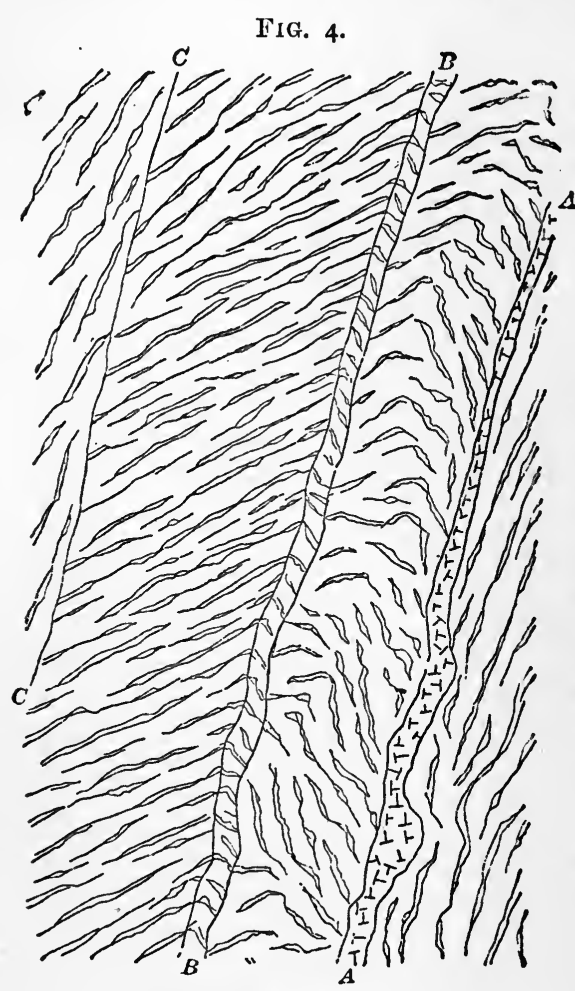

CANTON MINE belts or zones of auriferous mica-schist without any definite boundaries ; Fig. 4 shows one of them, which is worked at Canton mine. AA is $\triangle$ a vein of quartz, BB a channel or zone of disturbed and distorted schist, CC a false wall or plane, along which there has been a shifting of the strata. The vein $A A$, which has been formed along one of the lines of fracture and dislocation, is called the "indicator," as it acts the part of a guide to thi miner in his endeavours to follow the auriferous channel ; but the precious metal is not confined to the space between $\mathrm{A}$ and $\mathrm{C}$.

The question as to what constitutes a vein or lode has been more thoroughly threshed out in the United States than elsewhere, because in some parts of that country the miner's title to his property depends upon the definition of the word. The consequence is that the term "lode" has been defined by judicial decisions.

In the year I 877, Mr. Justice Field, in the celebrated Richmond v. Eureka case, gave the following interpretation $\uparrow$ " We are of

* Rickard, "The Gold-fields of Otago," Trans. Amer. Inst. M. E. Meting of June 1892 .

+ Transcript of Record. Supreme Court of the United States, Nos. 1038 
opinion, therefore, that the term lode, as used in the Acts of Congress, is applicable to any zone or belt of mineralized rock lying within boundaries clearly separating it from the neighbouring rock."

This definition, which has been framed for the practical working of an Act of Congress, is not a satisfactory one for the scientific miner, because it would include a bed or seam, whilst it would excluàe some of the Cornish tin lodes which have no distinct boundaries.

Some subsequent decisions cover more ground, for they ignore the question of shape. Judge Hallett* gave the following charge in the case of Hyman v. The Aspen Mining and Smelting Company : "It may be said that with ore in mass and in position in the body of a mountain, no other fact is required to prove the existence of a lode of the dimensions of the ore. As far as it prevails, the ore is a lode whatever its form or structure may be, and it is not at all necessary to decide any question of fissures, contacts, selvage, slickensides, or other marks of distinction, in order to establish its character. As was said in another case $\dagger$ in this court: 'A body of mineral or mineral-bearing rock in the general mass of the mountain, so far as it may continue unbroken and without interruption, may be regarded as a lode, whatever the boundaries may be. In the existence of such body, and to the extent of it, boundaries are implied."

While quoting these decisions on account of their importance to prospectors and to holders of mining property in the United States, I think it wise to adhere, for the purposes of the student, to the definition I have proposed, and to consider tabular shape and origin subsequent to that of the enclosing rocks as the chief characteristics of mineral veins or lodes. No doubt a very large number of mineral veins are simply the contents of fissures; others are bands of rock impregnated with ore adjacent to fissures; others, again, have been formed by the more or less complete replacement of the constituents of the original rock by new minerals.

Veins may occur in stratified or unstratified rocks, and in the former they usually cut across the planes of bedding.

Like a bed, a vein has its dip and strike; but as the dip of veins is generally great, it is often measured from the vertical, and is then spoken of as the underlie, underlay, or hade. Instead of being expressed in degrees, the underlie is sometimes measured by the amount a lode plunges under cover, or away from the vertical, in a distance of $\mathrm{I}$ fathom ( 6 feet) measured along the dip. Thus

and 1039. The Richmond Mining Company of Nevada v. The Eureka Consolidated Mining Company. Appeal from the Circuit Court of the United States for the distrist of Nevada, p. 604. Filed January 17, 1878.

* "The Aspen Case," Eng. Min. Jour. New York, vol. xliii. I887, p. 21.

+ "The Smuggler Case," op. cit. p. 20. 
if $\mathrm{AB}$ (Fig. 5) represents a lode, and $\mathrm{AC}=6$ feet, $\mathrm{AD}$ being vertieal, draw the line $\mathrm{CE}$ at right angles to $\mathrm{AD}$, the inclination is measured by the relation of $\mathrm{EC}$ to $\mathrm{AC}$.

If $\mathrm{EC}=2$ feet the underlie is said to be 2 feet in a fathom. This approaches very closely to a dip of $70^{\circ}$, or FIG. 5. underlie of $20^{\circ}$, whilst I foot in a fathom, for most

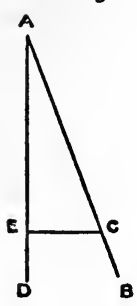
practical purposes, corresponds to a dip of $80^{\circ}$, or underlie of $10^{\circ}$. This method of expressing the dip enables it to be determined with a rule or tape. If $\mathrm{AB}$ (Fig. 6) is a lode at the end of a mining tunnel (level), the miner has simply to measure the distance $\mathrm{EC}=6$ feet, drop a stone from $\mathrm{C}$ and ascertain the distance from $\mathrm{D}$, where it falls, to E. However, there is the disadvantage that some miners take the standard fathom vertically and not along the dip; therefore, to avoid any chance of confusion it is wiser to express the inclination of veins in degrees, and not by "feet in a fathom."

The bounding planes of a vein, VV (Fig. 7), are called the walls or cheeks, and they are frequently smooth and striated, showing that one side must have slid against the other. These striated surfaces are called slickensides. At the Halkyn mine, Flintshire, the whole side of one of the levels, for a distance of ten yards, is a smooth flat polished surface, with small strix, precisely like the scratchings produced upon rocks by the action of glaciers. In this particular case the striations are horizontal ; more frequently they are inclined. The wall above a lode is called the hanjiny

Fia. 6.

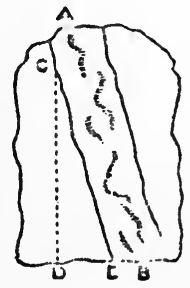

ГIส́. 7 .

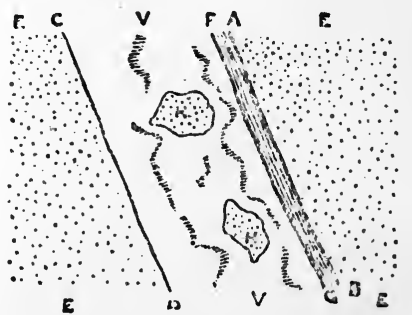

wall, $\mathrm{AB}$, the one underneath, the foot wall, $\mathrm{CD}$. The rock surrounding or enclosing the lode is called the country, EE. I give this term, not because I wish to perpetuate a mere Cornish provincialism, but because it has crept into use elsewhere. To use the words country rock, as is done very frequently, is to be guilty of tautology. I may here remark, once for all, that, as a general rule, it is best to avoid local technical terms, and as far as possible employ words which are understood by every one; but 
some expressions are so convenient on account of their brevity that they may fairly be adopted into our language. It is not uncommon to find a layer of clay, FG, between the lode and the enclosing rocks; such a layer is called a selvage, dig (Cornwall), gouge (U.S.), or alta (California). A large mass of the adjacent rock found enclosed in the lode is called a horse, $\mathrm{HH}$.

The valueless components of a lode which surround the ore are often spoken of as forming the gangue. I mention the word in order to enter a protest against its use, because, in its passage to us from the German through the French, it has lost part of its original meaning. We already have the words veinstone, lodestuff, and matrix, which are more strictly correct and more easily understood than gangue, which, by Englishmen, should be consigned to oblivion.

Veins often continue for a great distance alung their strike. The Van lode in Montgomeryshire is known for a length of nine miles, whilst the Great Quartz Vein in California has been traced for a distance of no less than eighty miles.

Veins are of less uniform productiveness than beds, and are rarely worth working throughout. Rich portions alternate with poor or worthless portions. The rich parts have received various names according to the forms they assume: Fig. 8 represents a longitudinal section along the strike of a lode, and the stippled parts are ore-bodies. $\mathrm{BBB}$ are bunches; $\mathrm{A}$ is a large

FIG. 8.

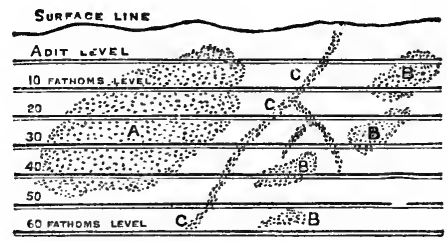

bunch or course of ore; when an ore-body forms a sort of continuous column we have a shoot (chute,U.S.). Ore-bodies which upon being excavated leave chimney-like openings are called pipes (C). In the United States the Spanish word bonanza, literally meaning "fair weather" or " prosperity," is frequently used for a rich body of ore. The inclination of a shoot in the direction of the strike is called its pitch and sometimes its dip, though it is better to restrict this word to the meaning it receives among geologists.

It is of the utmost importance to the miner to know where he may expect to find a rich ore-body in a mineral vein. Experience shows that many conditions affect its productiveness, * viz. :-

I. Intersections with other veins.

2. Nature of the adjacent rock.

3. Change of dip.

4. Change of strike.

* Sre alsn, L. Mrissentt, Cbservations on the Rich Parts of the Lo'es of Cornucll. Translated from the French by J. H. Collins. London and 'Truio, I 877 . 
(1) Intersections of veins.-AB (Fig. 9) is a vein intersecting another CD at an acute angle $\mathrm{AEC}$; it is frequently the case that there is an enrichment about the junction $\mathbf{E}$. If the lines $\mathbf{A}^{\prime} \mathbf{B}^{\prime}$, $\mathrm{C}^{\prime} \mathrm{D}^{\prime}$ represent the lodes at a lower FIG. 9. level, then $\mathbf{E E}^{\prime}$ indicates the line of intersection, which may be the axis of

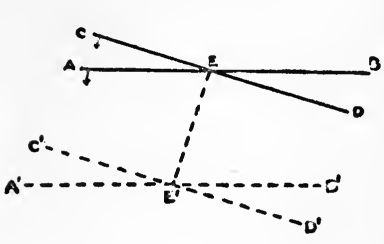
a shoot of ore upon one of them; but when the angle AEC approaches a right angle a favourable result is not expected.

If $\mathrm{AB}$ (Fig. IO) represents a section of a lode along the dip, and $\mathrm{CD}, \mathrm{EF}$, and $\mathrm{GH}$ are small veins (feeders, droppers) falling into it, an increase in the productiveness of the lode often occurs near the intersection.

(2) Nature of the adjacent rock.-Few facts are more generally recognised than the influence of the enclosing rock upon the productiveness of a lode. I will cite some well-known examples. In the Alston Moor district the veins cross alternating beds of limestone, sandstone, and shale; they are generally more productive in the limestone than in the sandstone or the shale.

At Kongsberg, in Norway, the silver veins are productive in the

Fig. IO.

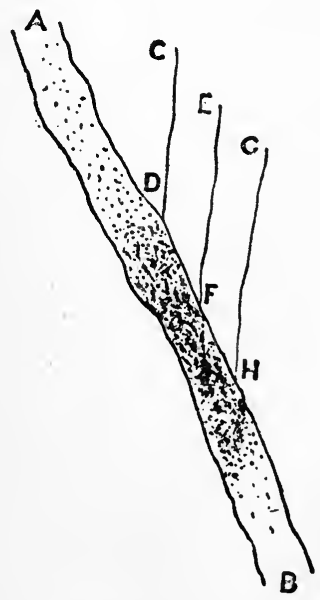

FIG. II.

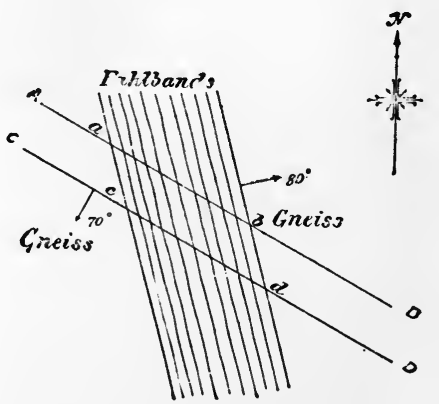

fahlbands, that is to say, quartz schist, mica schist, hornblende schist, and chlorite schist impregnated with iron pyrites and other metallic sulphides, but are poor where they cross the gneiss. The lines $\mathrm{AB}$ and CD in Fig. I I represent two such veins in plan; the portions $a b$ and $c d$ are worth working, but the other parts are not. 
In the Gympie* gold field, Queensland, the veins are richest in certain bands of black shale. Four principal belts of black shale have been recognised, and their influence is so thoroughly known that "the fact has determined the system of mining on the field."

Turning to another part of Australia, we may notice the "indicators" at Ballarat. $\dagger$ These are narrow beds, some only $\frac{1}{2}$ inch thick, parallel to the planes of stratification of the enclosing slate, and full of small cubical crystals of iron pyrites. Their dip is nearly vertical, and they can be traced for miles. When a quartz vein crosses an "indicator" there is usually rich gold along the line of intersection. Mr. Charles King says: "About ten of these ' indicators' are known within a width east and west of I, 400 feet, and in the case of six out of these, the quartz crossing them contains, at the line of intersection, exceedingly rich patches of gold, frequently in nuggets many ounces in weight." Why only six out of the ten indicators should have the enriching effect is not stated.

A third instance of the enriching effect of a pyritiferous rock is afforded in the Thamest gold-field of New Zealand, where, instead of a narrow "indicator," there is a marked belt of rock, 60 to 80 feet thick, in which the veins prove remunerative. This "congenial" bed is a felspathic sandstone containing pyrites, and is probably a volcanic ash. The veins are poor, or die out altogether on entering the harder diorite or underlying slate.

Even in the case of earthy minerals the same phenomenon occurs. At Wotherton mine, in Shropshire, the barytes vein is wide and worth working when the adjacent rock is volcanic ash, but narrow and valueless in shale.

Lead veins in Derbyshire, which are productive in limestone, rarely yield much ore in the toadstone, an interbedded lava.

(3) Change of dip.-In a given vein the parts approaching verticality are often noticed to be richer than those which are comparatively flat.

(4) Change of strike.-The veins of a mining district are commonly found to have the same prevailing strike. Thus the tin and copper lodes of the Camborne FIG. I2. and Redruth districts, Cornwall, $\S$ usually run from S.S.W. to N.N.E., and are spoken of

* R. L. Jack, Annual Report of the Department of Mines, Queensland, for the year i 885 . Brisbane, 1886 , p. 58 .

+ C. Le Neve Hoster, "Mining Industries," Reports on the Colonial Sections of the Exhibition. London, 1887, p. 18.

$\mp$ Op. cit. p. 35 .

$\$$ Henwood, "On the Metalliferous Deposits of Cornwall and Devon," Tians. R. Geol. Soc. Conn. Penzance, 1843 , vol. v. p. 250. 
as east and west lodes. Slight changes in the direction of the strike are sometimes followed by variations in the productiveness; in the case of a lode with an average strike represented by the dotted line $a b$, it may happen that the parallel parts $a b, c d, e f$, are poor, and the parallel parts $b c$ and $d e$ rich* (Fig. I2).

Too much stress must not be laid upon this question of strike, because there are so many exceptions to the rule that a certain strike is favourable. For instance, the two principal mines in the Isle of Man, Laxey and Foxdale, are wrought, one upon a north and south vein, the other upon an east and west vein, only a few miles apart; and at St. Just, in the extreme west of Cornwall, the mean direction of the lodes is $35^{\circ} \mathrm{N}$. of W., and therefore quite different from what it is in the chief metalliferous region; but with individual lodes changes of strike should not pass unnoticed.

Formation of Mineral Veins.-Though this book is intended to deal mainly with the working of mines, a few remarks concerning the origin of veins are necessary-first, because the posteriority of their formation is one of their chief characteristics; and, secondly, because a knowledge of the manner in which useful minerals came to be concentrated along certain lines may enable us some day to predict the precise spots where subterranean riches are accumulated.

The principal theories are;

I. Fracture and motion with mechanical filling.

2. Fracture and injection of molten matter.

3. Fracture and deposition from solutions

(a) from above.

(b) from below.

(c) from the sides.

4. Fracture and sublimation, or deposition from gases.

(I) Mechanical Filling.-If a rock is fractured, and one side of the crack slides against the other, a vein of crushed material is formed. If the rock is shale or slate, the rein is a band of clay more or less mixed with uncrushed fragments, and in Cornwall is known as a flookan.

(2) Injection.-Veins formed by the injection of a molten or plastic rock into fissures are usually known as dykes.

(3) Deposition from Solution.- The lode at Wheal Mary Ann, Cornwall (Fig. 2), is an instance of a vein formed apparently by deposition from solution. Many of the common constituents of mineral veins, such as silica, carbonate of calcium, sulphate of barium, are known to be slightly soluble in water, whilst the metallic sulphides can be formed by the reduction of a soluble sulphate, or by the reaction of a soluble sulphide or sulphuretted

* Charles Thomas, Remarlis on the Geology of Cornwall and Devon. R.druth, I859, p. 5 . 
hydrogen upon metallic compounds. Some metallic sulphides are soluble in alkaline solutions.

Much discussion has arisen concerning the place whence the mineral-bearing solutions came. The theory that they came from above finds few upholders nowadays, and the battle rages principally between the advocates of the ascensional theory, or supposition that the minerals came up in solution from very great depths, and the upholders of the lateral secretion theory, in which it is assumed that they were leached out of the adjacent rocks and re-deposited in the vein cavity. This latter theory has been powerfully espoused of late years by Professor Fridolin von Sandberger,* who has pursued his investigations with great ardour. He shows that small quantities of antimony, arsenic, bismuth, cobalt, copper, lead, silver, and tin are contained in silicates such as augite, hornblende, mica, and olivine, which are essential constituents of plutonic and volcanic rocks; and he concludes that these rocks are the sources from which the lodes have derived their riches.

Prof. von Sandberger's views have not been allowed to pass unchallenged, for Prof. Alfred Stelznert combats his methods of analysis.

It is naturally impossible to affirm with certainty that a given mineral, such as mica, contains lead for instance, so long as there is a possibility that particles of galena were mixed with it. 'The absolute freedom of the rocks submitted to analysis, from any mechanical admixture with pyrites or other sulphides is a necessary foundation-stone of von Sandberger's theory. It is against this point that Professor Stelzner directs his attack, and he shows, by the results of numerous carefully conducted experiments, that the metals found on analysis by Professor von Sandberger did not necessarily come from the silicates, but may have been derived from mechanically mixed sulphides which had resisted his attempts to remove them. Stelzner points out that the occurrence in the country of sulphides, similar to those existing in the lodes, may be explained quite as well by their having travelled from the fissure into the adjacent rock, as in the reverse direction.

With reference to the silver found in the rocks, Stelzner remarks that the mica of granite at S ilzbächle in the Black Forest, stated by von Sandberger and others to contain 0.001 to 0.006 per cent. of silver, was found to be absolutely free from any traces of the metal when assayed with special precautions at the Mining College of Freiberg.

Under these circumstances von Sandberger's theories must for the present be looked upon as not entirely proven, much as one

* Untersuchungen über Erzgänge. Wiesbaden, 1882 and 1885 .

$\dagger$ "Die Lateralsecrerions.'Theorie und ih e Bedeatung für das Pribramer Ganggebiet," Jahrbuch der li.k. Bergalademien zu Lenben und Pribram und der ligl. ung. Bergaliademie zu. S'chemnitz, vol. xxxvii. 
would like to be able to account in so direct a manner for the influence of the country upon the contents of the lodes.

The views of Mr. Becker,* with reference to the quicksilver mines of California and Nevada, deserve special mention, because the adherents of both parties will probably claim them as supporting their theories. To avoid any chance of mistake, I quote verbatim: "The evidence is overwhelmingly in favour of the supposition that the cinnabar, pyrites, and gold of the quicksilver mines of the Pacific slope reached their present positions in hot solutions of double sulphides, which were leached out from masses underlying the granite or from the granite itself." Mr. Becker supposes that the hot alkaline solutions were the products of volcanic agencies, and he decidedly leans to the view that they took up the heavy metals in their passage through the granite itself, and not from rocks underlying it.

Even if the ore was not leached out of the immediately adjacent rocks, these may have influenced its deposition either chemically or mechanically. It is possible that a certain bed may act as a reducing agent upon a solution which touches it, and so cause precipitation; this may be the reason why rich gold has been deposited where the pyritiferous "indicators" intersect the Ballarat lodes. The mechanical effect is also very simple. A fissure formed in a soft rock is likely to be filled up by pieces of the sides dropping in, especially if there is any sliding of the hanging wall upon the foot wall; on the other hand, if the rock is hard, the chasm will remain open and leave a space for the reception of ores. This fact gives a reason for the steep parts of lodes being sometimes richer than the flatter parts. If a wavy cut is made in a piece of card or paper to represent the fissure, and the " hanging wall" slid down a little, we have open spaces where the fissure is steep, whilst the "walls" touch where the fissure is flatter, leaving no room for any deposition of ore to take place. A wavy crack of this kind may be caused by variations of hardness and fissility, such as happen when shale is interbedded with limestone; here the crack will be propagated more readily along the planes of stratification of the shale than across them. After a slight shift of the "hanging wall" downwards, the cavities in the limestone become receptacles for mineral deposits, whilst the crack contains little but crushed rock in the shale.

In a like manner the variation in productiveness noticed upon a slight alteration of strike may be due to change in the nature of the "country," which not only caused a deviation from the general direction of the fissure, but also affected its ore-bearing qualities. Here, too, we find an explanation of the phenomenon called "ore against ore." In Fig. I 3 let ABCD, and EFGH

* "Geology of the Quicksilver Mines of the Pacific Slope," Monography of the U.S. Geol. S'urey, vol. xiii. p. 449. Washington, IsoS. 
represent a plan of two parallel lodes, $\mathrm{BC}$ and $\mathrm{FG}$ being rich parts; the miner notices that an improvement in the productiveness takes place in both lodes when the strike changes from $\mathbf{E}$. and W. to $\mathbf{E}$. $25^{\circ} \mathrm{N}$., and that the rich part, $\mathrm{BC}$, is opposite the rich part $\mathrm{FG}$. This is not surprising if the parts $B C$ and $F G$ are in a special be't or zone, included between the lines HK, LM, eapable of exerting either a mechanical effect upon the size of the vein-cavity by its hardness, or a chemical effect by its composition.

The adjacent rock may likewise have affected the lode by its porosity or by its impermeability, in the former case by

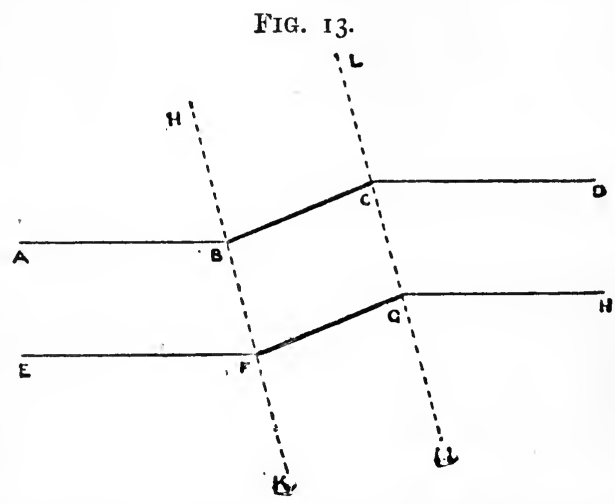
affording an easy channel for the solutions which brought in the minerals, and in the latter by interposing a dam which prevented or delayed their escape.

(4) Sublimation.-The sublimation theory meets with little favour nowadays, though certain minerals known as constituents of lodes are formed in furnaces, or can be produced artificially from gases. Neariy half a century ago, Daubrée * produced crystals of oxide of tin by passing a current of stannic chloride together with steam through a red-hot porcelain tube. One great objection to the universal acceptance of the sublimation theory is that many of the minerals found in lodes would be decomposed at high temperatures.

Formations.-The lodes in some districts are grouped into different classes according to their mineralogical characters, and careful observations have shown that those which are similar in mineral contents usually agree in strike and in age. Distinctions of this kind have been skilfully worked out at Freiberg + in Saxony, where six of these classes or "formations" are recognised. Anomalies.-It must be understood that we cannot expect Nature to make distinct lines of demarcation between the different kinds of mineral repositories. Though we may be able to see clearly that

* "Recherches sur la production artificielle de quelques espèces minérales cristallines, particulièrement de l'oxyde d'étain, de l'oxyde de titane et du qnartz. Observations sur l'origine des filons titanifères des Alpes." Ann. Mines, 49 série, vol. xvi, 1849, p. I29. Compt. Rend., vol. xxix. I849, p. 227 , and vol. $x \times x .1850$, p. 383 .

+ Freibergs Berg-und Hïttenwesen. Freiberg i. S., 1893, p. 32. 
a seam of coal is contemporaneous with the enclosing rocks, and that a vein, intersecting successively beds of limestone, shale, and sandstone, is evidently of later formation, cases frequently occur in which the origin of the mineral is uncertain.

For example we have the lead-bearing sandstone of Mechernich, the silver-bearing sandstone of Utah, the gold-bearing conglomerate of the Transvaal. The grains of sand and the pebbles of quartz are unquestionably of sedimentary origin; but opinions differ as to whether the lead, silver, and gold were deposited originally with the sand and gravel, or were introduced subsequently by metal-bearing solutions, which found a passage through the beds. It has been shown by Mr. Becker* that ample space exists in an ordinary sandstone for the deposition of ores. Supposing that all the grains were true spheres of the same size, and as closely packed together as possible, there would be 26 per cent. of interstitial space. If this space is even partly occupied by an ore, the percentage of metal may very easily be sufficient to render the stratum worth working. For example, a sandstone with a specific gravity of 2.25 requires only 3.7 per cent. of its interstitial space to be filled by cinnabar with a specific gravity of 8 , in order to furnish an ore with ro per cent. of mercury, about the average contents of the rock worked at Almaden. This $3^{\circ} 7$ per cent. is " less than half the interstitial space in some indurated sandstones employed for paving streets." In the case of sandstones worked for mercury, it seems to be quite certain that the cinnabar was brought in by aqueous solutions long after the deposition of the sediment-indeed, long after the solidification and upheaval of the rocks.

According to Dr. Sorby, the iron of the well-known Cleveland bed was "derived partly from mechanical deposition and partly from subsequent replacement of the originally deposited carbonate of lime." $\uparrow$

Other cases of more or less complete replacement may be cited. We find chalk changed into flint, limestone into chert; and if "subsequent origin" were the only characteristic distinguishing a vein from a bed, we should be landed in a dif' cu'ty. It will be found convenient to consider as seams any strautied deposits in which the impregnated, altered, or pseudomorphous mass occupies the position of an original bed, and to call the sheets veins when they cross the bedding-planes, or occupy a fissure, or have been formed by the alteration of a rock at the side of a fissure.

MASSES. - These are deposits of mineral, often irregular in shape, which cannot be distinctly recognised as beds or veins. Such, for instance, are certain of the red hæmatite deposits of

* "Geology of the QuicksilverDe posits of the Pacific Siope," Munograples of the U.S. Geol. Survey, vol. xiii. p. 399. Washington, 1888.

+ Quart. Tour. Geol. Soc., vol. xxxv., I879, p. 85. Anniversary Address of the President. 
the Ulverston district (Fig. I4),* which occupy irregular cavities in the Carboniferous Limestone. They may have been formed

FIG. 14.

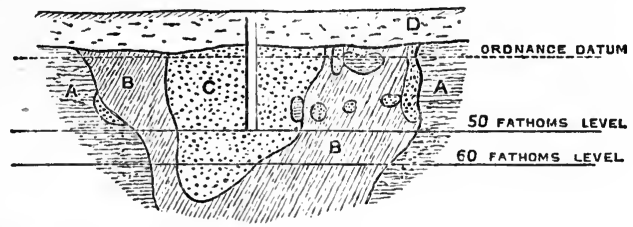

A, the enclosing limestone ; $B$, red hæmatite ; $C$, sand and clay; $\mathrm{D}$, a thick capping of glacial drift.

by the percolation of water bringing down iron in solution from overlying rocks, which by gradual replacement changed part of the limestone into a mass of hæmatite. Other examples of masses are the calamine deposits of Altenberg (Fig, I5), $\uparrow$ Sardinia, and

FIG. 15.

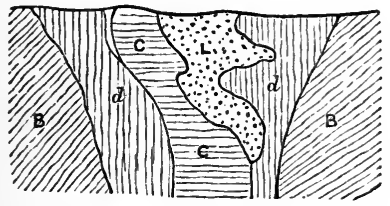

$\mathrm{B}$, the enclosing slate, $d$, dolomite, C, calamine, L, clay.
FIG. 16.

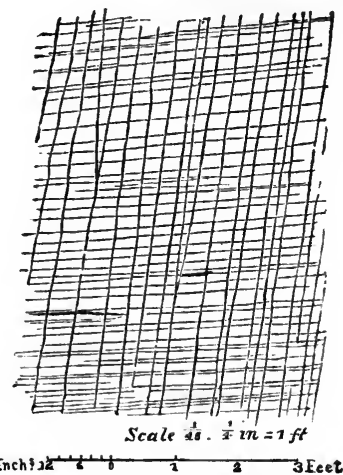

Mulberry Mine, near Bodmin.

Lombardy, the huge upright "necks" or "pipes" of diamondbearing rock in South Africa, and the granite decomposed in situ worked for china clay in Cornwall.

Under this head also are included by most authors the so-called " stockworks," " reticulated masses " or " network deposits," names applied to masses of rock intersected by so many little veins as to make the whole worth excavating.

Fig. I6 shows a number of steeply dipping strings of cassiterite, generally only two or three inches apart, intersecting beds

* "Beschreibung der Rotheisenerzlagerstätten von West Cumberland und North Lancashire," Stahl und Eisen, 2 Jahrgang, No. 12, Plate VI.

† M. Braun, Zeitschr. d. d. geol. Gesellsch., vol. ix. (1857); and A. von Groddeck, Die Lehre von den Lagerstätten der Erze. Leipsic, I879, p. 2.42. 
of slate. The mass of rock penetrated by this network of little tin veins is 300 yards long by more than 30 yards wide, and the whole of the stanniferous stone is quarried and stamped.*

EXAMPLES.-These abstract definitions are not sufficient; the student should see how they can be applied to particular cases ; and I now propose to give a series of examples of the modes of occurrence of the most important minerals. $\Lambda$ s the same mineral may be found in a bed, a vein, or a mass, it is simplest, for the purposes of the miner, to classify these examples alphabetically. I therefore arrange the information about tin, for instance, under one head, instead of separating the tin veins from the stockworks, and these from the alluvia. The minerals to which I propose to refer are:

Alum, amber, antimony ore, arsenic, asbestos, asphalt, barytes, borax, boric acid, carbonic acid, clay (including china clay, fire clay, fuller's earth, potter's clay), cobalt ore, copper ore, diamonds, flint, freestone, gold, graphite, gypsum, ice, iron ore, iron pyrites, lead ore, manganese ore, nitrate of soda, ochre, oil shale, ozokerite, petroleum, phosphate of lime, potassium salts, quicksilver ore, salt, silver ore, slate, stone, strontium sulphate, sulphur, tin ore, zinc ore.

Alum.-The alum-stone $\dagger$ obtained at Allumiere and Tolfa, near Civita Vecchia, occurs in very irregular veins, which are supposed to be due to the action of heated water and sulphurous gases upon the felspar contained in trachyte.

An important deposit of alunite has lately been discovered+ in New South Wales, at the Bullahdelah Mountain, which rises up from the bank of the Myall River, a tributary of Port Stephens. Marked cliffs, overlooking the river, consist of alunite in varying quality, ranging from pure alunite to a mineral in which there is as much as 40 per cent. of silica. The deposit is traced for over a mile in length and nearly three-quarters of a mile in breadth, the thickest band of stone being from 60 to 70 yards in width. The average composition of the rock now being worked is as follows :

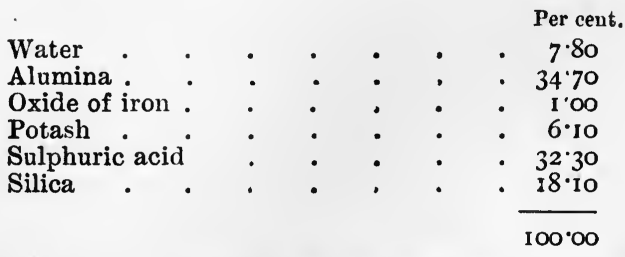

" C. Le Neve Foster, "On some Tin Stockworks in Cornwall," Quart. Jour. Geol. Soc., vol. xxxiv., I878, p. 655.

† A. K. de la Grange, Le Trachiti della Tolfa e le formazioni alluminifere. Rome, 1881.

$\ddagger$ MS. information from Mr. S. Herbert Cox, A.R.S.M., the discorerer of the alunite. 
The surrounding rocks belong to the Carboniferous system of New South Wales, and it is supposed that the alunite has been formed by solfataric action upon dykes of a felsitic rock.

Amber.-This fossil resin is found in a bed of Tertiary age, which extends along the shores of the Baltic from Western Russia to Denmark. The principal workings are about halfway between Memel and Dantzig, and the amber is obtained by diving and dredging in the sea and by ordinary mining inland. After a storm pieces are cast up on the shore. The stratum containing the amber is known from its colour as the "blue earth."

Antimony.-Antimony ore usually occurs in veins. In York County, New Brunswick,* the veins are from a few inches to 6 feet wide in Lower Silurian slate. The veinstone is white quartz, calcite, and iron pyrites in small crystals. The ore raised from the mine contains about ro per cent. of stibnite.

Arsenic.-The white arsenic of commerce is mainly obtained from mispickel, which is either mined by itself or more commonly in connection with the ores of copper, tin, or gold. It is therefore in most cases a by-product in the preparation of these ores for the market.

Asbestos.-The asbestos of commerce is in part chrysotile and in part the fibrous variety of hornblende. Italy and Canada are the chief sources of supply, and in both countries the mineral is found in veins in serpentine. The principal Italian mines are in the Susa and Aosta valleys and the Valtellina.t In one of the mines in a tributary of the latter valley the rock is "cut in every direction by thin seams of asbestos, which seem to start as from a centre and spread out in every direction, and these again are traversed by thin seams both horizontally and diagonally. Entering into the rock, these seams generally converge to a centre, where the various thin seams unite themselves, and here a pocket of a ton or a ton and a half of asbestos may be found, and then all appearance of its presence ceases. Continuing to work inwards, the seams generally re-appear and spread themselves out as before."

The most important of the Canadian quarries are situated in the townships of Thetford and Coleraine, in the province of Quebec. A belt of serpentine runs through the district, and it is intersected by innumerable small veins of chrysotile, varying in width from a mere knife-edge to about 6 inches at the most, the fibres of the mineral running almost at right angles to the walls. The common width of the veins is from I to 2 inches, and as they "cross and recross each other in every direction and at

* E. M. J., vol. xvi., 1873, p. 7 ; and $B . u . h . Z .1874$, p. 237.

† James Boyd, "Asbestos and its Applications," Jour. Soc. Arts, vol. xxxiv. (1886), p. 583. J. A. Fisher, "Mining, Manufacture and Uses of Asbestos," Trans. Inst. Marine Eng., vol. iv., I892. 
every angle," * the whole of the enclosing rock has to be quarried in order to get out the asbestos.

Asphalt.-The various modes of occurrence of asphalt or bitumen have been described by Malo ${ }^{\prime}$ and Greene, + and the following table is made up from their works :

State.

I, Nearly pure $\left\{\begin{array}{l}\text { viscous } \\ \text { solid }\end{array}\right.$

2. Mixed with earthy matter

3. Mixed with sand . (bituminous sandstone)

4. Impregnating limestone (bituminous limestone)
Localities.

- Pitch springs in Alabama, France, Venezuela.

Dead Sea, Cuba, Texas, Utah.

- Pitch Lake, Trinidad.

- California, France, Utah.

Colorado, Cuba, France, Mexico, Sicily, Spain, Switzerland.

The nearly pure asphalt does not occur in sufficiently large quantities to be worked on a commercial scale, and the Pitch Lake of Trinidad,§ long known as a natural wonder, has not been utilised to any great extent until of late years. The lake occupies an area of 99 acres, and is on an average from 20 to 30 feet deep. Its surface is not one continuous sheet, but is broken up by pools and channels of rain water; the asphalt is nearly everywhere solid enough to walk on. The crude asphalt has the following composition :\|

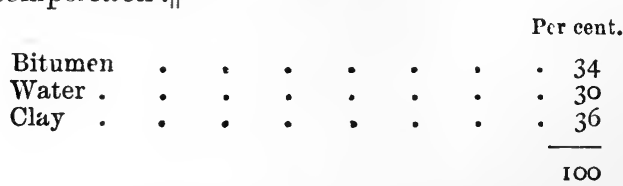

"The bituminous sandstone of California is found in large quantities at various points between San Francisco and Los Angeles. It contains about I 2 to 18 per cent. of bitumen, and the rest is quartz sand, in grains about one-tenth of an inch in size."'

We now come to the bituminous limestone. Val-de-Travers, in Switzerland, and Seyssel, in France, are the most important sources of this rock for paving purposes. At Seyssel there are no less than seven beds of bituminous limestone, varying from Io to 20 feet ( 3 to $6 \mathrm{~m}$.) in thickness. One analysis of the rock** was as follows :

* Boyd, op. cit. p. 586.

+ Léon Malo, L'Asphalte. Paris, 1888, p. 20.

¥ F. V. Greene, "Asphalt and its Uses," Trans. Am. Inst. M.E., vol. xvii. 1888, p. 355 .

§ Wall, Report on the Geology of Trinidad. London, 1860, pp. 94, I40.

II Malo, op. cit., p. 75.

** Notice sur la Société civile de bitume et d'asphalte du C'entre. Paris, 1889, p. 7 . 


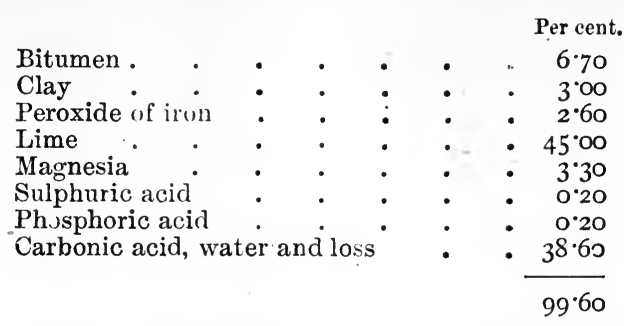

Barytes.-This mineral frequently accompanies lead ore, but veins are sometimes worked for it alone, as at Wotherton in Shropshire.

Borax.-The American borax deposits* now being worked are situated in a vast depression known as the Great Basin, which exists between the Sierra Nevada on the West and the Rocky Mountains on the East. Much of the region is a desert with rivers and lakes which have no visible communication with the ocean. The rivers lessen in volume gradually from absorption and evaporation, and end in lakes. During the rainy season soda is dissolved out of felspars contained in the lava which covers much of the country, and in the dry season the salts of soda crystallise out at the surface in the form of efflorescent crusts, I 2 to 18 inches in thickness. The rain dissolves this crust, which is carried away in solution into the rivers, and eventually into depressions which form saline lakes.

The two principal deposits, known as Borax Lake and Teel's Marsh, were discovered in 1873 ; the former lies in the Mojave desert in California, $45^{\circ}$ miles S.E. of San Francisco, and the latter is in Nevada. The Borax Lake is oval in shape, its greatest length and greatest breadth being 12 miles and 8 miles respectively (Fig. I 7). The greater part of the lake is covered with a hard crust from a few inches to several feet in thickness, consisting of various salts. On the top of this crust there is usually white efflorescent matter mixed with sand, whilst under it is black mud containing much iron sulphide, saline matter, and sulphuretted hydrogen.

The lake may be divided into three sections, containing respectively: (I) borax, (2) bicarbonate of soda, (3) common salt. Near the centre of the borax section, an area of about 300 acres is covered with water, I inch to I foot deep, and the mud underneath is full of large crystals consisting of carbonate of soda and common salt, with a large proportion of borax. The ground around this "crystal bed" is a dry hard crust containing carbonate and sulphate of soda and 1 per cent. of borax. Upon this hard crust there is efflorescent matter containing on an average :

* C. Napier Hake, "An Account of a Borax Like in California," Journ. Soc. Chem. Ind., vol. vii.. (1889), p. 854 . 


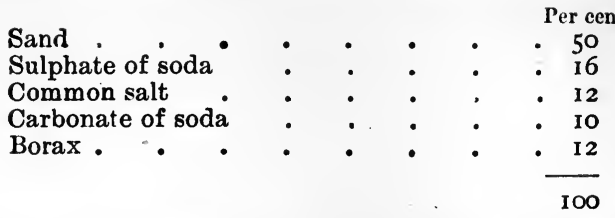

This surface efflorescence, which is about an inch thick, is scraped off with shovels and swept into windrows, leaving space

FIG. I7.

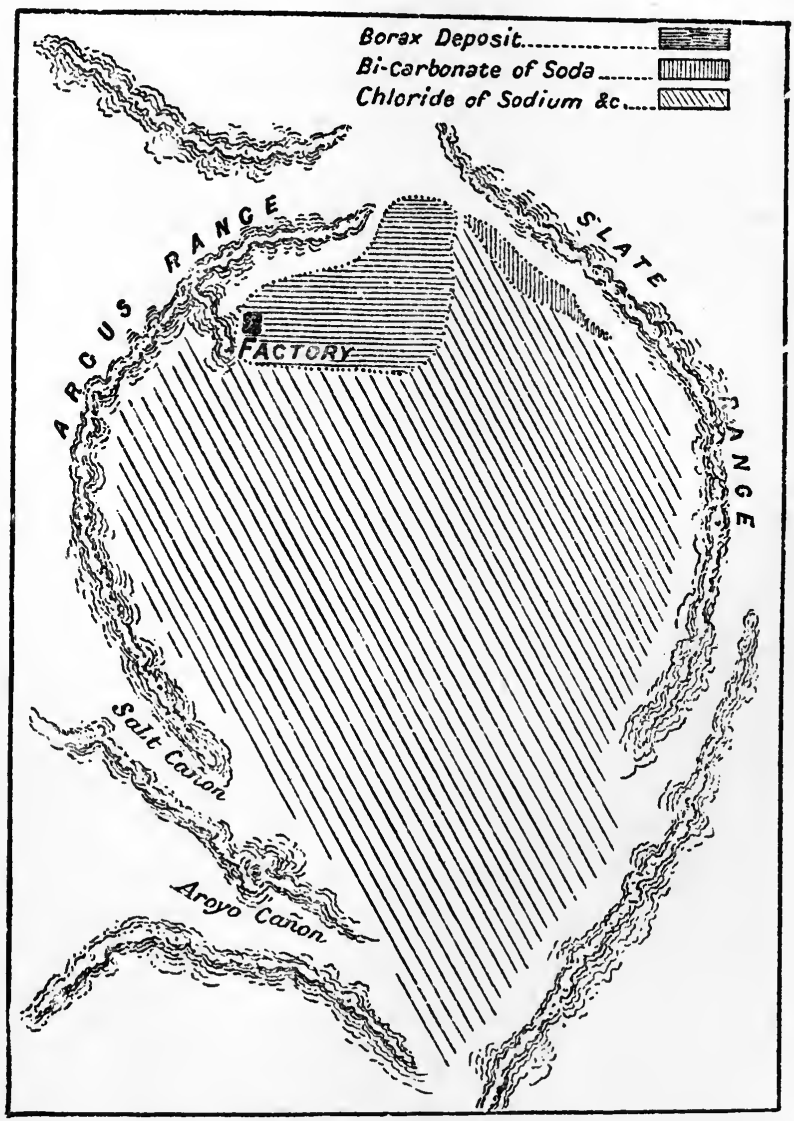

enough between them for a cart to pass. When the surface has been cleared, the moisture finds its way up again by capillary action and is evaporated by the sun. The formation of the 
efflorescence is allowed to go on for three or four years, and then the new crop is scraped off. The sand is blown on by high periodical westerly winds.

The question naturally arises: Why is the borax mainly confined to one part of the lake? It appears necessary in order to produce the efflorescence that the crust should touch the water, so as to get a supply of the saline matter. The borax section is the lowest part of the lake, and the hard crust dips into the water. When the level of the water is low during a very dry season, the formation of the efflorescence goes on slowly or ceases altogether. In addition to borax there are sundry deposits of borate of lime in the same region.

Boric Acid. - Boric acid is obtained in considerable quantities from gaseous emanations which come to the surface through innumerable fissures, probably dislocations, in the Eocene and Cretaceous rocks of Central Italy.* The best known localities are the four contiguous parishes of Pomarance, Castelnuovo di Val di Cecina, Massa Marittima, and Montieri, in the province of Pisa. A pit is dug around any natural "steam-puff," or "blower" (soffione), water is run in, and the steam and other gases, which boil up through it, leave a little boric acid in solution. The gases that escape are steam, a good deal of carbonic acid and nitrogen, some oxygen, and a little sulphuretted hydrogen. The very weak boracic solution is concentrated by heat derived from some of the steam-puffs. The total production of the provinces of Pisa and Grosseto in I89I was 1775 metric tons of boric acid, worth $£ 35,500$, and 2056 tons of borax worth $£ 53,456$.

Carbonic Acid.-Liquetied carbonic acid is now a regular article of commerce, and Germany has taken the lead in utilising the natural supplies of the gas. In r883 a bore-hole was put down for carbonic acid at Burgbrohl, $\uparrow$ near Andernach on the Rhine, and since then others have been made at Obermendig, Tönnistein, Hönningen, and Gerolstein. All have been successful ; they show that the subterranean supplies of carbonic acid are very plentiful, and that in places where the gas is already known to issue, nothing but a comparatively shallow hole is needed to increase the quantity very considerably.

At Hönningen, about five-eighths of a mile (I kilometre) from the Rhine, an emanation of carbonic acid gas had long been known, and was piped off to compression works before any boring had been made. The rocks in which the carbonic acid occurs at Hönningen consist of greywacke and clay-slate, with vein-like masses of quartz; they belong to the Lower Devonian or so-called

Jervis, Guida alle Acque Minerali d'Italia, Turin, I868, p. I2 I ; and 1 Tesori sotterranei dell' Italia, Turin, 1874 , p. 427.

† Heusler, Sitzungsberichte der niederrheinischen Gesellschaft für Natur- und Ileilliunde in Bonn. Meeting of July 9, I888. 
Coblentz beds, and the bore-holes at Burybrohl, Obermendig, and Tönnistein have been put down in strata of the same age.

The Hönningen hole was bored with a diameter of $\mathrm{I}_{3}$ inches $(33 \mathrm{~cm}$.) to a depth of 230 feet $(70 \mathrm{~m}$.) from the surface. The first water containing carbonic acid was met with at a depth of 92 feet $(28 \mathrm{~m}$.$) , and it still remains at this level. The quantity$ of gas is greater than was given off by the old emanation at the surface, and is reckoned to be 500 litres (nearly r 8 cubic feet) per minute, corresponding to 720 cubic metres $(25,428$ cubic feet; of gas, or I kilog. $(2 \cdot 2$ lbs.) of liquid carbonic acid in twenty-four hours.

The Hönningen spring differs from some others by the fact that at a depth of 230 feet $(70 \mathrm{~m}$.) the water is already at a temperature of $72^{\circ} \mathrm{F} .\left(22^{\circ} \mathrm{C}\right.$.), and probably a higher temperature would be reached if the hole were deepened. A second hole has been bored to a like depth by another company at a distance of 50 feet ( 5 m.) from the first, and a good supply of gas has been obtained.

At Gerolstein the bore-hole passed through alluvial gravel into solid dolomite, and was stopped at a depth of ${ }_{5} 6$ feet $\left(47 \frac{1}{2} \mathrm{~m}\right.$.). It seems probable that the hole has penetrated into a wide fissure filled with loose fragments of dolomite. The water which flows out contains such an excess of carbonic acid that it froths up at the surface. The quantity of water coming up is 8476 cubic feet (240 cb. m.) in twenty-four hours, with an estimated minimum of I 660 cubic feet (30 cb. m.) of carbonic acid gas per hour.

Though natural outflows of this gas are common, especially in volcanic regions, the number of places where they are utilised commercially is small. In addition to the German localities, I may mention two places in Italy.* There are springs of water impregnated with carbonic acid and emanations of the gas at Cinciano, in the Valle d'Elsa, province of Siena, which are used for making pure bicarbonates of potash and soda from the crude carbonates, and also for making white-lead from the acetate, the gas being perfectly free from any sulphuretted hydrogen. Similar blowers (soffioni) at Montione, near Arezzo, are employed for the latter purpose.

Clay (including common clays, china-clay, fire-clay, fuller's earth, pipe-clay, potter's clay).

As a rule, clay occurs in the form of stratified deposits, and this is the case with an important 13ritish clay, the fire-clay of the Coal Measures, which is found in beds sometimes several feet in thickness and usually under a seam of coal. The coal is often too thin to be worked and may be only $\mathrm{I}$ inch thick, but both coal and the underlying fire-clay may be worth working together. Various beds of clay of Secondary and Tertiary age are dug in England

"Jervis, Guida alle Acqu" Minerali d'Italia. Turin, 1868, pp. 54, 63. 
for making pottery, drain pipes, and Portland cement. The beds of fuller's earth near Bath are of Oolitic age, whilst those which are mined in Surrey belong to the Lower Greensand.

The china clay* of Cornwall and Devon exists in irregular deposits of a totally different nature; they consist of granite decomposed in situ, not by atmospheric agencies as is often stated, but far more probably by hydrofluoric acid brought up by deep-seated fissures. That the decomposition was due to the veins or fissures seems evident from the fact that the altered rock occurs in bands adjacent and parallel to them. Where the veins are numerous a very large mass of china clay may be found, extending for a width of a hundred or more yards, and a length of a quarter of a mile or half a mile along their strike; the depth. to which the alteration of the granite continues is quite unknown. The veins are often tin-bearing, and workings for tin have led to the discovery of china clay; indeed the two minerals may be worked together. The altered granite consists of quartz, white mica, sometimes a little gilbertite, and felspar which has been more or less completely converted into kaolin. This last mineral is easily separated when the soft rock is washed down by a current of water, for it is so finely divided that it is the last to settle when the milky stream is led into depositing pits.

Cobalt.-The cobalt ore worked at Skutterud in Norway is found in certain bands of quartz schist and mica schist which contain small particles of cobalt glance, skutterudite, cobaltiferous mispickel, ordinary mispickel, iron pyrites, and other metallic sulphides.

The accompanying figure (18) illustrates what I saw at Skutterud some years ago; $a, a, a$, are bands of mica schist with little or no cobalt ore; $b, b$, are bands of quartz schist containing the cobaltic minerals dissemi-

FIG. 18.

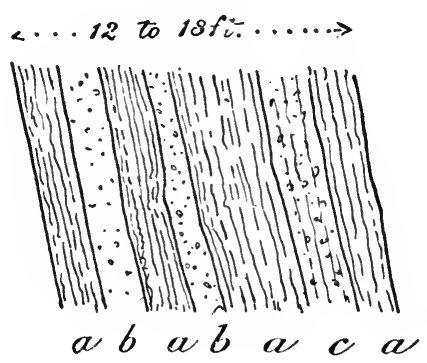
nated through them, and $c$, a cobaltiferous band of mixed quartz schist and mica schist.

The rocks appear to be altered sedimentary strata, and the deposits must be spoken of as bedis. The strike is N. and S., and the beds dip at a very high angle to the east. Quartz schist is the rock most likely to be cobaltiferous, the mica schist may be also worth working, but hornblende schist is poor. The cobaltic beds are commonly two or three fathoms wide, but a number of

* J. H. Collins, The Hensbarrow Granite District. Truro, 1878. And, "On the Narure and Origin of Clays: the Composi.ion of Kaoliuite," Min. Mag. Lunclun, vol. vii. (18 87 ), p. 205. 
adjacent beds may produce a much greater thickness of cobaltiferous rock.

In New Caledonia* the mode of occurrence is totally different.

Fig. 19.

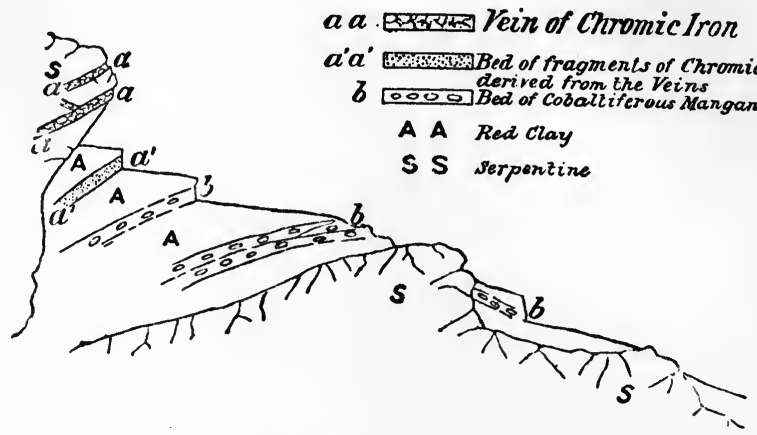

The cobalt is found as a hydrated oxide, without a trace of sulphur or arsenic, intimately associated with hydrated oxide of manganese, in irregular " pockets" of red clay in serpentine. In Fig. I9 $\mathrm{S}$ is the serpentine and $\mathrm{A}$ the red clay; $a$ a represent veins of chromic iron in the serpentine; $a^{\prime} a^{\prime}$ is a little stratum of fragments of chromic iron derived from these veins, whilst $b b$ are beds of cobaltiferous manganese ore in the clay. The ore lying about on the surface or obtained from these pockets has from $2 \frac{1}{2}$ to 3 per cent. of cobalt.

At Rhyl, in Flintshire, there is a curious irregular cavity in

FIG. 20.
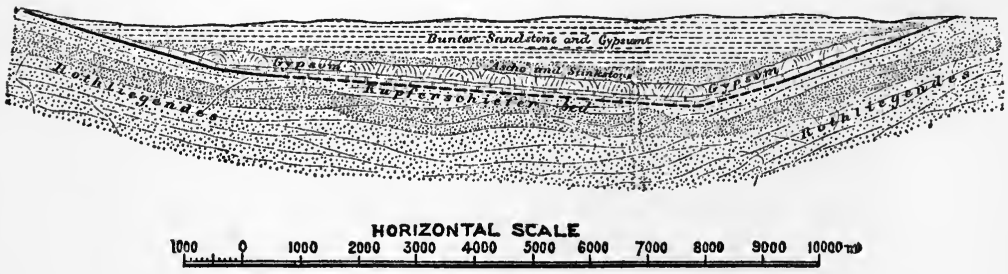

VERTICAL SCALE THREE TIMES THAT OF THE MORIZONTAL SCALE

the Mnuntain Limestone filled up with red clay which encloses small lumps of asbolane. This deposit was worked on a small scale for several years.

Copper.-The most important copper mines of the world

* Levat, "Mémoire sur les progrès de la métallurgie du nickel." Anr. Minex, 9e série, vol. i. p. 147.

+ Irans. Ii. Cornwall Gcol. Soc., vol. x. p. 107. 
nowadays are those of Mansfeld in Germany, Rio Tinto and Tharsis in Spain, San Domingos in Portugal, Lake Superior, Arizona and Montana in the United States.

Germany.-Copper mining has been carried on near Mansfeld, in the Prussian province of Saxony, since the commencement of the twelfth century, and the district is specially interesting from the fact that theore is found in a bed or seam, which can be worked with profit in spite of its thinness and comparative poverty in metal.

The Mansfeld district (Figs. 20 and $2 \mathrm{I}$ ) is mainly occupied by the rocks of the following formations :-

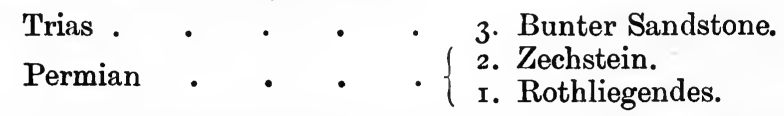

(I) "Das Rothliegende," or the red floor, is the old miners' name for the sandstone and breccias lying almost immediately below the bed of cupriferous shale. In contradistinction to the ore-bed, it is also called "das Todtliegende" (the dead floor). It can always be distinguished by its characteristic red colour. One of its most constant beds is the so-called "porphyry conglomerate," consisting of pebbles of milk-white quartz, hard siliceous slate, and grey and reddish porphyry,

(2) The Zechstein formation consists of three divisions. The lowest division comprises the "Weissliegendes," the bed of copper shale and the Zechstein. The middle division consists of the anhydrite or older gypsum, or of its equivalent the "Rauchwacke," "Asche," "Rauhstein" and Stinkstone; the upper division is made up of variegated clays with intercalations of gypsum, the residues left when some of it is dissolved away (Asche), and calcareous or dolomitic concretions.*

The "Weissliegendes" is petrographically like the "Rothliegendes" below it, and is looked upon by many as merely an uppermost bed deprived of colour. Above it with great regularity comes the ore bed, a blackish, bituminous, marly shale, about 15 to 18 inches thick.

The ore of the shale bed is usually disseminated through it in the form of fine particles (Speise), which impart a metallic glitter to the surface of cross-fractures. A golden yellow colour indicates chalcopyrite, a bluish and reddish variegated look, bornite, and a steel grey, seen more rarely, is due to copper glance; whilst a greyish yellow denotes a predominance of iron pyrites, and a leaden grey, galena. The following minerals also occur : cinnabar, blende, kupfernickel, speiskobalt, and compounds of manganese, molybdenum and selenium. Oxidised ores are found at the outcrop,

* The figures and some of the details concerning the Mansfeld mines are borrowed from a pamphlet entitled " Der Kupferschieferbergbau und der Hiittenbetrieb zur Verarbeitung der gewonnenen Minern in den beiden Mansfelder Kreisen der Preussischen Provinz Sachsen." Eisleben, I889. 
and are naturally of secondary origin. In addition to the finely disseminated grains, there are often small strings of bornite and copper glance, generally parallel to the bedding, and thin coatings of copper glance, bornite, chalcopyrite, and native silver along the

FIG. 2 I.

Section of Eduard II. Shaft.

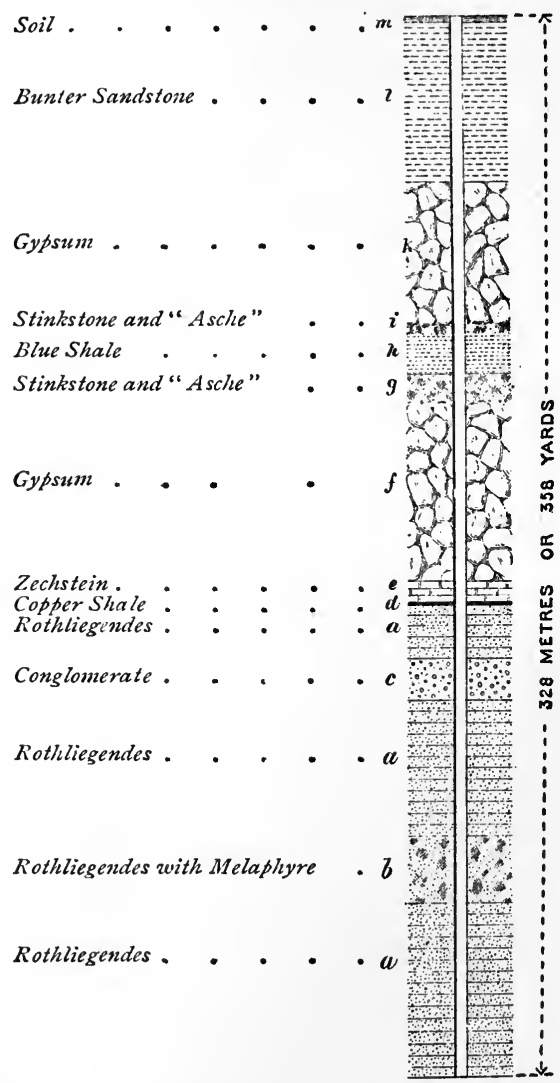

planes of bedding or in cross joints. Finally there may be small nodules of copper ore lying singly.

The whole of the bed of copper shale is ore-bearing; but, as a rule, only the bottom 3 or 4 inches are rich enough to be worked with profit. Occasionally 6 or 7 inches can be taken, and in exceptional cases the whole of the bed goes to the smelting works. Although there are minor variations, the shale is fairly regular. 
as regards ore-bearing when dealt with on a large scale. On an average, in the true Mansfeld district, between Gerbstedt and Eisleben, it contains 2 to 3 per cent. of copper and ${ }^{6} 6_{3} \mathrm{oz}$. of silver to the ton of copper ( 5 kil. per metric ton).

The importance of the copper shale will be appreciated from the fact that in the year I 888, I 4,178 persons were $\epsilon$ mployed at the mines, or more than all the miners of Cornwall and Devon. The output of ore was 469,7 16 metric tons, which produced 13,600 metric tons of refined copper, and 77,950 kilogrammes (208,845 Troy pounds) of silver.

Spain and Portugal.-The famous mines of Rio Tinto,*

FIG. 22.

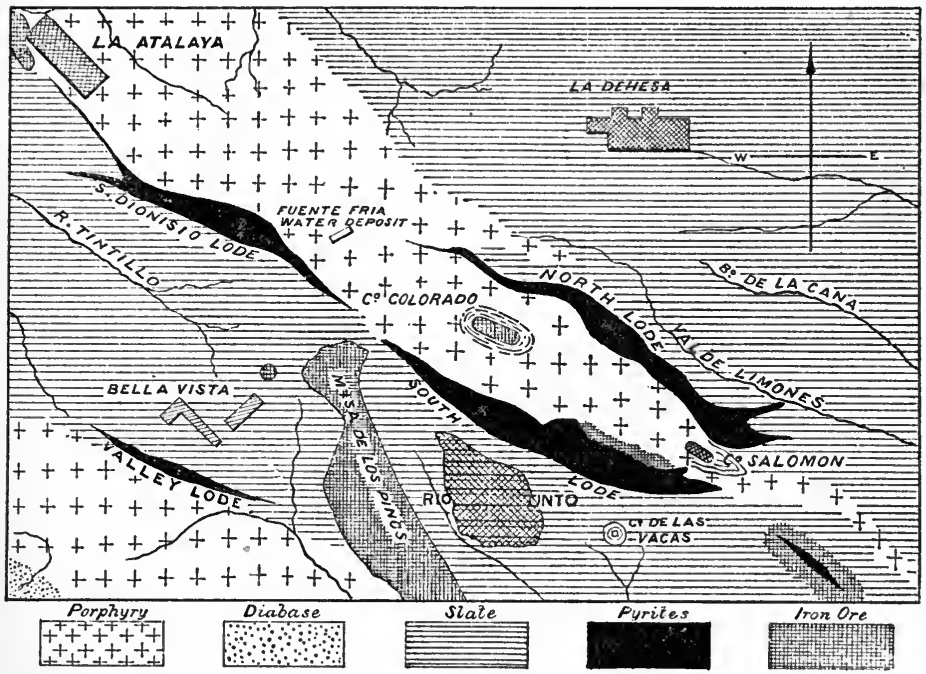

Tharsis, and San Domingos are contained in a great metalliferous belt of country, I40 miles long by 30 miles wide, stretching across the province of Huelva in Spain and into Portugal. The rocks consist of slate of Upper Devonian age, often altered locally into jasper, talc schist, chiastolite schist, etc., with great intrusions of quartz and felspar-porphyries, diabase, quartzsyenite, and granite. The geological horizon of the slate has been determined by finding Posidonomya Becheri, P. acuticosta, a goniatite allied to G. subsulcatus and other fossils. The strike of the slates is about $15^{\circ}$ to $25^{\circ}$ north of west, and the dip either

* Collins, "On the Geology of the Rio Tinto Mines, with some General Remarks on the Pyritic Rrgion of the Sierra Morena," Quart. Journ. Gecl. S'sc., vol. xli. (1 885 ), p. 245 . 
vertical or at a high angle to the north. Through having the same general strike as the slate, the masses of porphyry may appear to be interstratified, but a close examination of the junction proves them to be intrusive.

As shown by the map (Fig. 22), there are four principal deposits of pyrites at Rio

FIG. 23.

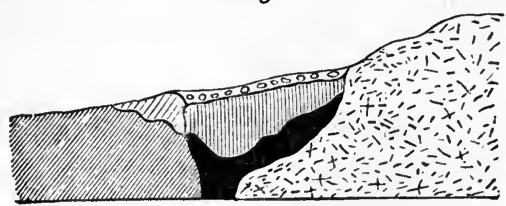

Fic. 24.

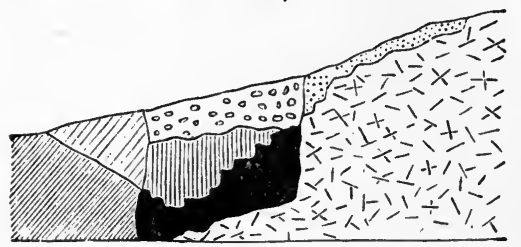

Hilk. 25 .

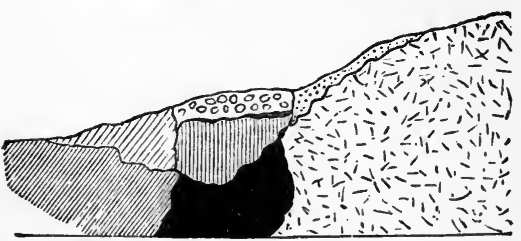

FIG. 26.

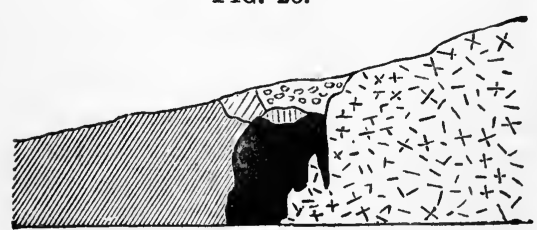
Tinto, viz., the North Lode, the South Lode, the San Dionisio Lode, and the Valley Lode. They all occur at or near the junction of the porphyry and the slate; and they are supposed by Mr. Collins to occupy cavities produced by fissures. On the other hand, the somewhat similar deposit of the Rammelsberg mine in the Hartz is now unanimously considered by geologists to be of sedimentary origin, and to be strictly conformable to the surrounding beds of slate.

The South Lode, the one most largely wrought hitherto, is sometimes as much as 450 feet ( $140 \mathrm{~m}$.) wide, and is known along the strike for a distance of about a mile, or, indeed, for two miles if the San Dionisio lode is considered to be an extension of it to the west. Fig. 23 is a cross-section of the South Lode at San

Inocente shaft, and Figs. 24, 25, and 26 are taken at points a little to the east.

INDEX FOR FIGS. 23 TO 25.
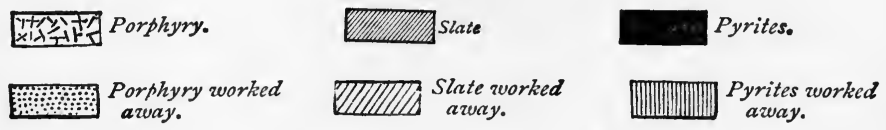

$\because 0000$ Ferruginous breccia and gozzan. 
Figures * 27 and 28 show the curicus manner in which the San Dionisio lode swells out suddenly at a depth of about $\mathrm{s} 50$ metres from the surface, and actually attains the enormous width of 200 metres. A, is slate; $\mathrm{B}$, porphyry ; C, cupreous pyrites ; D, iron ore, the "gozzan" or iron cap of the lode. The slate is dipping steeply towards the lode, as indicated by the lines denoting planes of bedding. The hatching of $\mathrm{C}$ itself does not represent any structure. It will be interesting geologically and important commercially to watch the further development of the workings upon this remarkable lode.

The character of the ore varies a good deal. Mr. Collins names fourteen different kinds. The principal are: (I) Ore treated for copper on the spot, and (2) that which is exported. The former consists of fine-grained and compact iron pyrites with I to $2 \frac{1}{2}$ per cent. of copper, existing as copper-pyrites minutely disseminated throughout the mass, and the latter only differs by being richer in copper, and containing up to $3 \frac{3}{4}$ per cent.

Little veins of copper-pyrites, erubescite, and occasionally copper-glance, more or less mixed with iron - pyrites, quartz, blende, and other minerals, traverse the mass, and there is sometimes a compact mixture of galena, blende, chalcopyrite, and iron-pyrites resembling the "bluestone" of Anglesey.

Few mines in the world are of more importance than Rio Tinto. The quantity of ore extracted in $1892 \dagger$ was I, 402,063 tons of 2 I cwt., of which 995, 15 I tons were for local treatFIG. 27.

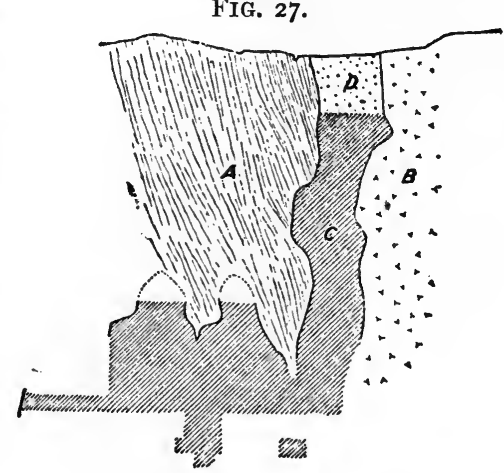
ment and 406,9 I 2 for shipment to Great Britain, Germany, and the United States. The average percentage of copper was $2 \cdot 8$ I 9 .

The deposits of iron ore marked on the map are horizontal beds, probably formed at the bottom of lakes in Miocene times. The ore is brown hæmatite, with varying proportions of silica. The sections show that the upper part of the pyrites has been converted into a gozzan; much of this is a good iron ore, and is being stocked for disposal at some future time.

* From drawings kindly supplied by Mr. James Osborne, the general manager of the Rio Tinto Mine-.

$\dagger$ Rio Tinto Co. Ltd., Twentieth Annual Report, April 1893. 
The Tharsis and San Domingos mines are likewise vast undertakings, and the total imports of cupreous iron-pyrites into this country alone from Spain and Portugal in I891 amounted to 608,000 tons, worth over one million sterling.*

FIG. 28.

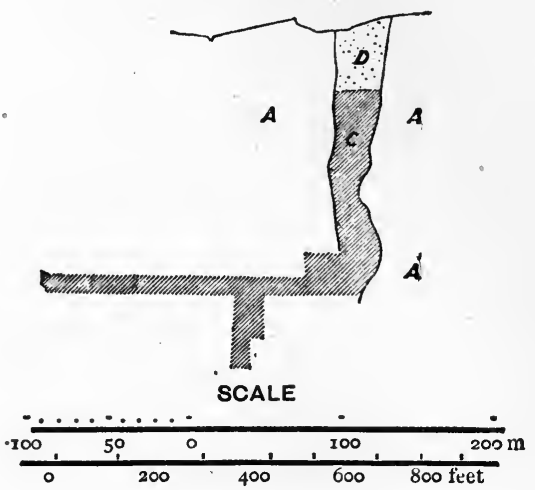

United States.-Crossing the Atlantic, we will now turn our attention to the mines on the southern shore of Lake Superior, which are remarkable for their productiveness, and which are equally attractive to the geologist and to the miner.

The copper-bearing district + lies on a long peninsula, ${ }_{5} 5$ to 20 miles wide, with a north-easterly trend, which projects into Lake Superior (Fig. 29 $\ddagger$ ) some 60 miles beyond the general run of its southern shore, and terminates in Keweenaw Point. The western half of the peninsula is formed by rocks belonging to the Keweenaw Series, considered by many to be younger than the Huronian and older than the Cambrian. They consist of sandstones and conglomerates, interstratified with flows of eruptive rocks of various kinds.

The beds dip to the north-west, at an angle of $22^{\circ}$ in the northern part of the mineral district, and in going south the dip increases to $56^{\circ}$. 'The outcrop of the actual copper-bearing part of the series occupies a belt of country from 4 to 5 miles wide.

* Min. Stat. for 1891. London, 1892, p. 59.

† R. D. Irving, "I'he Copper-bearing Rocks of Lake Superior," United States Geol.Survey. Washington, I883. Douglas, "The Col per R+sources" of the United States," Trans. Amer. Inst. M.E., 1ol. xix. I890, p. 679; and Jour. Soc. Arts, vol. xli. 1892, p. 39.

† Engineering, vol. 1. 1890, p. 553; and Guide-book prepared for the mumbers of the Iron and Steel Institute, I 890. 
The modes of occurrence of the copper may be classified as fullows :
A. BEDS $\left\{\begin{array}{l}\text { 1. Copper-bearing conglomerate and sandstone. } \\ \text { 2. Copper-beating amygdaloid. }\end{array}\right.$
B. Veins.

A. (I) The deposits of the first class are beds of conglomerate and sandstone impregnated with native copper. In most cases the cupriferous beds are interstratified with diabase flows; but

FIG. 29.

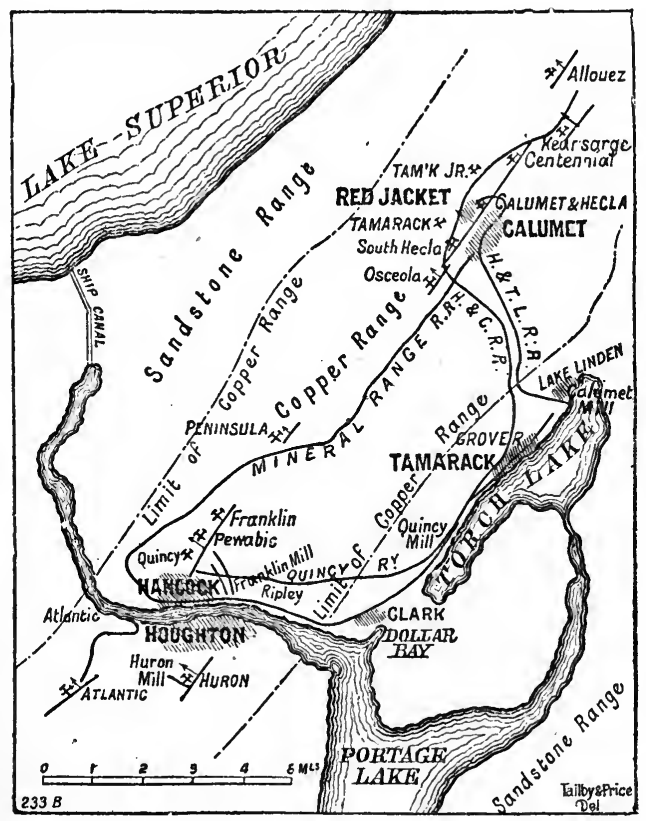

this connection between the proximity of diabase and the presence of copper is not universal. The copper occurs as the cementing material of the pebbles and grains of sand, and also replaces the pebbles themselves, large stones several inches or even a foot in diameter being converted into the native metal. The copper has evidently been deposited from aqueous solutions. By far the greatest proportion of the Lake Superior copper is obtained from these conglomerates.

A. (2) The cupriferous amygdaloids are portions of the old lava flows, and are not strictly speaking beds as defined, though it is convenient to call them by that name.

Often they are highly altered and have lost all sign of haring 
once been vesicular; the native copper which they contain must have found its way in long after their eruption.* It is usually very irregularly distributed, and the parts rich enough to be worked may he surrounded by much poor or barren rock. The presence of epidote and calcite is regarded as a good indication for the proximity of copper.

B. As the cupriferous lava beds and conglomerates are locally called "veins," it is necessary to say that the real veins run in a direction at right angles to the general trend of the beds, and are almost vertical. Their usual width is from one to three feet, but it may become as much as 10, 20, and even 30 feet. They are largest and richest when they have amygdaloid or loosetextured diabase for their walls, and they become pinched up and worthless in the compact greenstone or sandstone. To a great extent they consist of altered rock, and are an instance of lodes formed by replacement of the "country." According to Irving these veins were formed by copper-bearing solutions which found a path through zones of fissured rock, instead of following certain easily permeable beds. The copper is in the native state, and generally in masses of considerable size, the largest found weighing nearly 600 tons.

The following statistics relating to the Lake Superior mines are taken from a guide-book prepared for the members of the Iron and Steel Institute in 1890.

\begin{tabular}{|c|c|c|c|c|c|c|c|}
\hline Name of Mine. & $\begin{array}{l}\text { Nature of } \\
\text { deposit. }\end{array}$ & $\begin{array}{l}\text { Depth } \\
\text { in feet. }\end{array}$ & $\begin{array}{c}\text { Tons rock } \\
\text { hoisted } \\
\text { r88g. }\end{array}$ & $\begin{array}{c}\text { Tons } \\
\text { Refined } \\
\text { Copper } \\
1889 .\end{array}$ & $\begin{array}{l}\text { Tons } \\
\text { Copper } \\
\text { to date. }\end{array}$ & $\begin{array}{c}\text { Per cent } \\
\text { copper } \\
\text { in rock } \\
\text { stamped. }\end{array}$ & $\begin{array}{l}\text { Dividends } \\
\text { to date. } \\
\text { Dollars. }\end{array}$ \\
\hline Allouez • & $\begin{array}{l}\text { Conglo- } \\
\text { merate }\end{array}$ & $\mathbf{1 7 0 0}$ & 126,125 & $88 I$ & II, 427 & 0.76 & \\
\hline $\begin{array}{c}\text { Calumet and } \\
\text { Hecla . . }\end{array}$ & " & $375^{\circ}$ & 807,918 & 24,334 & $301,53^{8}$ & $3^{\circ}$ OI & $33,350,000$ \\
\hline Peninsula . & " & 600 & - & 368 & -1 & - & \\
\hline $\begin{array}{l}\text { Tamarack . } \\
\text { Atlantic. . }\end{array}$ & $\begin{array}{c}\text { Amygda- } \\
\text { loid }\end{array}$ & $\begin{array}{l}2818 \\
1660\end{array}$ & $\begin{array}{l}196,707 \\
288,040\end{array}$ & $\begin{array}{l}5,518 \\
1,849\end{array}$ & $\begin{array}{l}16,624 \\
23,786\end{array}$ & $\begin{array}{l}3.26 \\
0.66\end{array}$ & $\begin{array}{r}\text { I, } 200,000 \\
560,000\end{array}$ \\
\hline Copper Falls & $"$ & I 500 & - & 435 & Io, 789 & 0.70 & 100,000 \\
\hline Franklin & " & 2620 & 186,740 & 2,173 & $31,96 I$ & I 87 & 960,000 \\
\hline Huron & $"$ & 1800 & $\mathrm{I}_{59,333}$ & 1, rog & Io, 652 & 0.98 & \\
\hline Kearsarge . & " & 1000 & $76,54 \mathrm{I}$ & 960 & $I, 384$ & $I 7 I$ & 80,000 \\
\hline Osceola. & ", & 2162 & 208,299 & $2,6_{3} \mathrm{I}$ & 25,312 & $I \cdot 29$ & $I, 222,500$ \\
\hline Quincy & & 3070 & 123,998 & 3,203 & 53,250 & $27^{2}$ & $5,250,000$ \\
\hline Central & Véins & 2900 & $\begin{array}{l}\text { Mostly } \\
\text { mass. }\end{array}$ & 635 & 20,355 & & $\mathrm{I}, 930,000$ \\
\hline
\end{tabular}

As will be seen from these figures, the Calumet and Hecla mine is the most important on Lake Superior. The bed of copper-bearing conglomerate is from 8 to 25 feet thick, and

* Irving, Op. cit. p. 42 I. 
about 12 feet on an average. The dip is $37 \frac{1}{2}^{\circ}$ to the north-west. The depth of the mine which is given in the table is measured on the dip, and would be about 2,280 feet if measured vertically ; but these figures are now greatly exceeded, and shafts are being sunk which will enable the Calumet and Hecla and the Tamarack mines to be worked to the enormous depth of 5000 feet.

The very low percentage of copper in the Atlantic amygdaloid, which nevertheless is worked at a profit, is remarkable; but, unlike the amygdaloids generally, the Atlantic rcck is very regular in its yield. This makes up for its poverty.

Arizona* produces large quantities of oxidised ores of copper, especially the oxide and carbonates, wh:ch occur in or adjacent to the Carboniferous limestone. Sometimes there are irregular orebodies at the contact of the limestone with granite or with sandstone. Masses of sulphuretted ores which have escaped decay show whence the oxidised ores have been derived.

The Butte district, Montana, $\uparrow$ has surprised the world of late years by the enormous quantities of copper ore which it has sent into the market. The deposits are east and west lodes in granite, usually dipping steeply to the south. The main lode, which supports the celebrated Anaconda and Parrott mines, has proved productive for a distance of three miles along the strike. The principal ores are erubescite, copper glance, and chalcopyrite. Everywhere near the lodes the granite is soft and friable, and often contains ore-bodies. Though the granite has been greatly fissured, it seems likely that much of the ore does not fill up cracks, but has gradually taken the place of the rock by a process of substitution. The width of the lodes varies considerably; however, on an average it may be taken at ten feet. The copper ore is silver-bearing, the proportion varying from $\frac{1}{2} \mathrm{oz}$. per unit of copper to $2 \mathrm{oz}$. per unit.

The upper parts of the veins consisted of oxidised minerals, from which the copper had been leached out almost entirely, but in which the silver was retained and formed the original object of the mining. At the Anaconda mine there was no copper worth speaking of for the first 400 feet in depth; then came a rich zone of oxisulphides and erubescite, considered to contain some of the copper which had been dissolved out of the vein at a higher level, and after lasting for 200 feet it was succeeded by the unaltered sulphides.

Diamonds.-By far the most important diamond district in the world is Kimberley, in Cape Colony, 648 miles by rail from Cipe Town. Strange to say, most of the precious gems are

* Douglas, Op. cit.

† Douglas, Op. cit. Vore'sang, "Mittheilungen üher den Kupferbersbau in Nord-America," Zeitschr. B.- H.- u. S.-Wesen, vol. xxxix. I8nI, p. 23!. (i. vom Rath, "Ueber das Gangrevier von Butte, Montana," N. Julirl. f. Miner. Gi.sl. u. I'aï̈ont., vol. i. (1S8j) p. 158. 
obtained from four deposits situated in close proximity to each other; indeed, all four are included in a circle three miles in diameter. The masses of diamond-bearing rock may be described as huge vertical columns, of round, oval, or kidney-shaped section, as shown by Figs. 30 and 31.* The unweathered diamond-bearing

FIG. 30 .

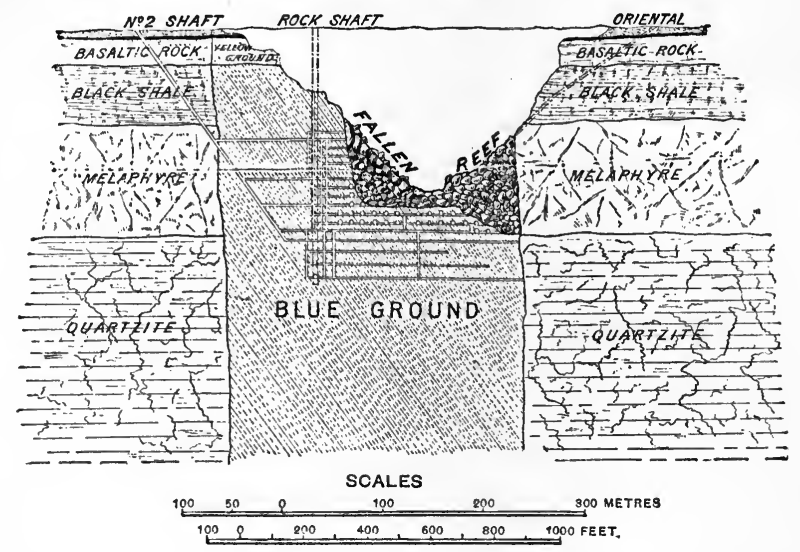

rock, locally known as "blue ground," or "blue," is a breccia, consisting of fragments of shale, basalt, diorite, and a little sandstone, cemented together by olivine rock containing diamonds and various other minerals, such as bronzite, biotite, talc,

FIG. 3I.

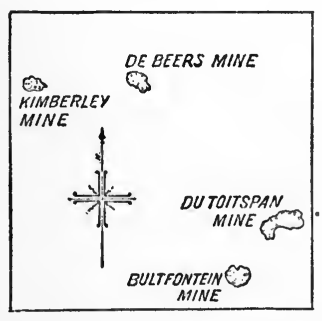
garnet, graphite, magnetite, and iron pyrites. The surrounding rocks, locally called " reef," are beds of carbonaceous and pyritiferuus shale lying horizontally, and sheets of basalt and melaphyre, under which comes quartzite. The melaphyre is a hard amygdaloidal rock, which has also been called olivine diabase. $\uparrow$ Large detached masses of the surrounding rocks are sometimes included in the "blue," and are then known as "floating reef." The upper parts of the deposits have been decomposed by atmospheric agencies, and changed into a soft friable earth to a depth varying from 45 to 60 feet, and the colour is yellow, instead of the slaty blue of the unweathered rock. The surrounding rocks have naturally shared in this weathering.

* De Beers Consolidated Mines, Limited, Second Annual Report, r89o, including a technical report with plates. + Ilid. p. I3. 
The diamond-bearing rock appears to be the filling-up of the necks or throats of old volcanoes by a mud from below. From ti.e frequent occurrence of broken diamonds it is fairly inferred that the gems were not formed in situ, but were carried up with the "blue."

Not only does the yield in diamonds vary in the different mines, but the diamonds themselves have their peculiar characteristics, which enable the expert to say at once from which mine a stone has been obtained. The average yield of the "blue ground" per load of 16 cubic feet $*$ is as follows :-

\begin{tabular}{|c|c|c|c|c|c|c|}
\hline \multicolumn{2}{|l|}{ Area. } & \multicolumn{2}{|c|}{ Carats per load. } & \multicolumn{3}{|c|}{$\begin{array}{l}\text { Value per carat } \\
\text { in } 1889 .\end{array}$} \\
\hline Bultfontein & $\bullet$ & - $\quad \frac{1}{5}$ to $\frac{1}{3}$ & & - $£_{I}$ & & \\
\hline De Beers . & & - $\quad\left[\frac{1}{5}\right.$ to $1 \frac{3}{3}$ & - & I & 7 & 6 \\
\hline Du Toit's Pan & . & - $\frac{1}{6}$ to $\frac{1}{3}$ & . & - $\quad \mathrm{I}$ & 19 & 101 \\
\hline Kımberley & . & - $\quad \mathrm{I} \frac{1}{4}$ to $\mathrm{I} \frac{1}{2}$ & & I & 7 & 9 \\
\hline
\end{tabular}

In addition to these four mines there are some other workings in the neighbourhood, such as Wesselton and St. Augustine; whilst at Jagersfontein, 80 miles to the south in the Orange Free State, there is a similar deposit, producing stones of the finest water.

The commercial importance of the diamond deposits cannot be overestimated, for the value of the diamonds produced annually at Kimberley is between three and four millions sterling, or more than the value of the gold produced by any one of the British colonies. $\uparrow$

Until lately, the largest diamond found weighed $428 \frac{1}{2}$ carats in the rough state, and $228 \frac{1}{2}$ carats after cutting; it came from De Beers mine. This large stone has been eclipsed by one of $969 \frac{1}{2}$ carats discovered at Jagersfontein in the month of June last.

In addition to diamonds found in a solid matrix, there are those from the river diggings. It was in the recent alluvium of the Vaal River that diamonds were first discovered in 1867 , and though thrown into the shade by the output of the mines, the gravel is still washed by parties of men scattered along the banks of the river for a distance of 70 miles.

Diamonds are found in alluvial gravel and in conglomerate in Brazil, India, and other localities.

Flint.-It may be thought strange by some that I give flint a

* Sixteen cubic feet of broken ground correspond to about 9 cubic feet of solid ground.

† Further information about the Kimberley diamond mines will be found in the following publications:-T. Reunert, "Diamond Mining at the Cape," History, Productions, and Resources of the Cape of Goor Hope. Cape Town, I886. C. Le Neve Foster, "Mining Industries," Reports on the Colonial and Indian Exhibition. London, I887. E. Boutan, "Sur l'état actuel des mines de diamants du Cap," Génie Civil. Paris, January 26, $10 \$ 9$. 
place among the important minerals which deserve special description. My reasons for mentioning it are twofold. First, the

FIG. 32 .

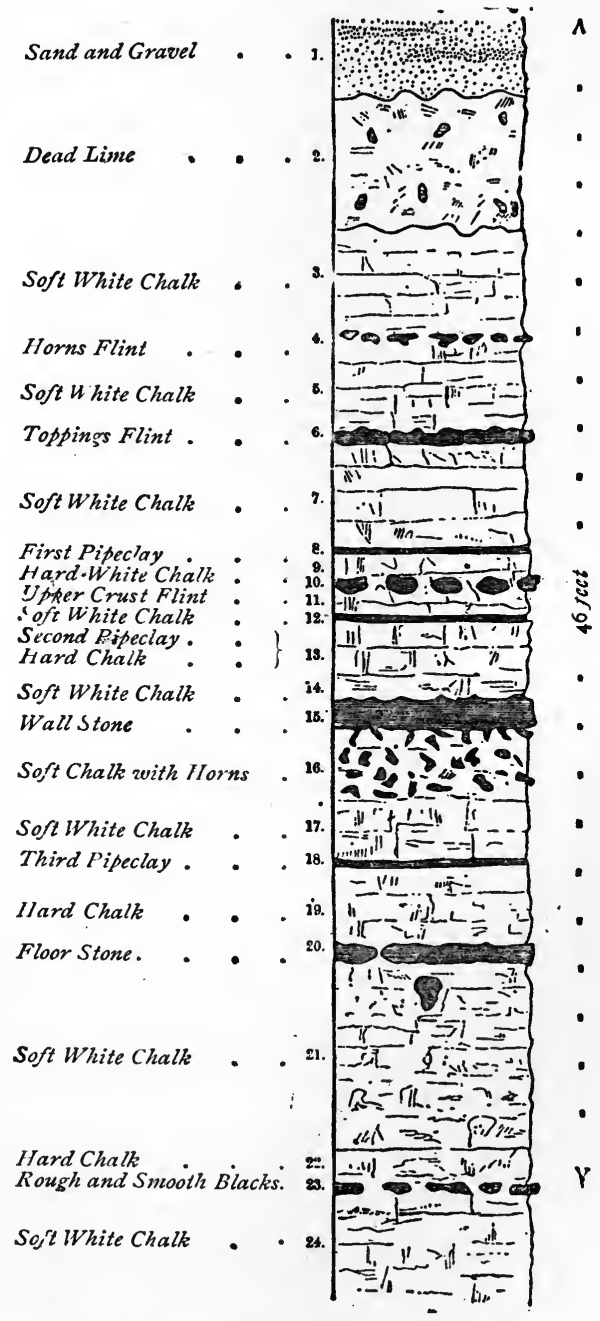

earliest underground workings in this country were probably for flint; and secondly, flint affords a good instance of the replacement of an original bed by another mineral. 
Pits in the chalk known as "Grime's graves,"* were at one time a puzzle to the antiquary, but it is now generally conceded that they are the mine shafts by which beds of flints were worked for the manufacture of stone implements in Neolithic times.

This old trade of flint mining still survives at Brandon in Suffolk, for though stone hatchets and arrow-heads are no longer wanted, there is still a market for gun-flints in parts of Africa. The mode of mining the stone, splitting off flakes and knapping them into gun-flints has been admirably described and illustrated by Mr. Skertchly in one of the "Memoirs of the Geological Survey of England and Wales." Fig. 32 represents a section of the beds in which the flint occurs. It shows that the layers of flint are sometimes continuous, and sometimes consist merely of a succession of nodules which do not touch each other. Some of the flint has knobs and even horn-like projections, the transformation from chalk into silica not being confined strictly to one particular layer of the original sea-bottom. The principal bed is the "floor-stone," No. 20, about 8 inches thick, but other layers are mined from time to time for building stone or gun-flints..

Freestone.-Freestone is largely quarried in England from beds of Jurassic age, and the so-called "Bath stone" is not only quarried but also mined at Corsham in Somersetshire, and at Weldon in Northamptonshire. The bed worked in the Corsham underground quarries varies from 8 to 24 feet in thickness, lying almost flat; it is a typical oolitic limestone which can be sawn freely in any direction. $\$$

Gold.-This metal is so widely distributed over the earth that it will be impossible to compress into the space at my disposal anything more than a very summary description of the principal modes of occurrence in beds, veins, and masses.

Beds.-During the last few years the attention of capitalists, miners, and geologists has been often directed to the marvellous resources of the Witwatersrand\| or simply "Rand" goldfield, in the Transvaal or South African Republic, and situated about 35 miles south of Pretoria, the capital. The gold is obtained entirely from beds of conglonerate or puddingstone called banket, which is the Dutch name for almond rock, the hardbake of the British schoolboy, because the pebbles look like

* The word "grave" no doubt corresp onds here to the German Graben, a ditch or trench, and has no reference to burial.

+ On the Manufacture of Gun-Flints, dec. London, 1879.

$\mp$ A more or less regular and continuous layer of flints is locally called a sase or sese, which recalls the French word "assise."

\$ C. Le Neve Foster, "Some Mining Notes in 1887," Trans. Min. Assoc. and Inst. Cornwall, vol. ii. p. 136. Camborne, 1888.

II A very complete summary of papers upon South African Geology is given by Mr. Gibson in his memoir, "The Geology of the Gold-bearing and Associated Rocks of the Southern T.ansvaal," Quart. Juur. Geul. Soc., vol. xlviii. (1892), p. 406. 


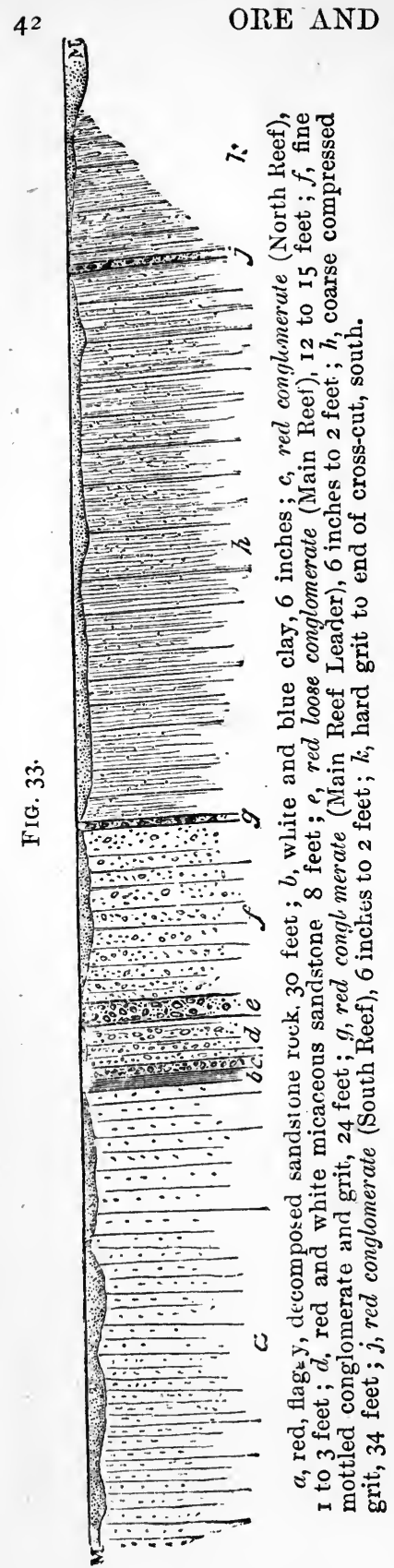

the almonds in the sugar. The layers of auriferous conglomerate lie conformably among beds of sandstone, shale, clay, and quartzite. At Johannesburg the beds strike east and west and dip to the south. The conglomerate consists mainly of pebbles of white quartz, and in the upper parts of the workings they are cemented together by oxide of iron, sand, and clay. Below the influence of atmospheric agencies, the cementing material is found to consist largely of silvery-grey micaceous matter with cubical crystals of iron pyrites, and the colour of the banket changes from red and brown to blue and bluish grey. It is quite evident from the examination of specimens that much of the ferruginous matter in the upper parts of the conglomerate is derived from the decomposition of iron pyrites, and visible gold is seen in the cavities formerly occupied by crystals of that mineral. The bulk of the gold is said to exist in the cement and not in the pebbles; but some assays made by the late Mr. Richard Smith show that this is not invariably the case.

Fig. 33 , a section across the Salisbury Mine at Johannesburg, shows four beds of auriferous conglomerate, known respectively as the North Reef, the Main Reef, the Main Reef Leader, and the South Reef.

As would naturally be expected in the case of beds which must have been deposited in shallow water, there are frequent variations of character and thickness in a short distance.

Whilst certain beds of conglomerate are auriferous, others are not,

* Gibson, Ibid. p. 411. 
or contain merely traces of gold. The sandstone, as a rule, is not auriferous, but layers within the banket may be worth working. The richest beds are the Main aud South Reef with some of the thin "leaders." The gold is not distributed uniformly through the bed of banket; but upon the whole there is far greater regularity of yield than can be expected in a vein, and as a rule the whole of the bed is worked away like a seam of coal, without poor portions being left. The fact of being able to form a rough approximate estimate of the probable yield of a given area of banket is of the utmost commercial importance.

The Rand output in 1892* was 1,2 10,865 ounces of bar gold; the average total yield of the conglomerate stamped was $12 \frac{1}{2} \mathrm{dwt}$. of gold per ton, of which about four-fifths were obtained at once by amalgamation at the mills, and one-fifth by subsequent treatment of the tailings and concentrates.

The gold-bearing strata are supposed to be of Devonian age.

Whether the gold was deposited at the same time as the pebbles of quartz, or whether it was brought by the sulusequent

FIG. 34.
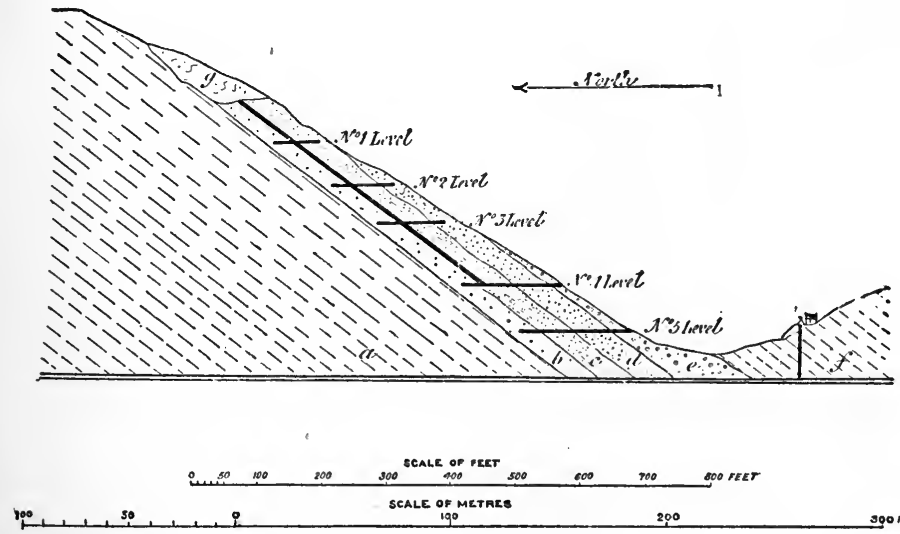

soomernet

$a$, hard grey siliceons shale; $b$, massive quartzite, becoming talcose and highly auriferous in zones; $c$, schistose quartzite, becoming argillaceous in places; $d$, impure sandstone quartzite, $e$, quartzose breccia with fragments of felsite and clay shale; $f$, hard grey siliceous shale; $g$, highly auriferous sandy matter resulting from the disintegration of the bed $b$.

infiltration of mineral solutions which found their easiest channels of escape through the most readily permeable beds, has nct been decided; but where the bulk of a deposit consists of IS93.

* Phillips, "Address to the Rand Chamber of Mines," January 2Gth 
materials of undoubted sedimentary origin, it is best for the miner to call it a "bed" or "seam," and leave the question of origin to be settled later on by the geologist.

Fig. 34 represents a section of the Sheba mine, Barberton,* where the gold is obtained from a bed of auriferous quartzite.

Fig. 35 is a section of an auriferous alluvium in the Caratal district of Venezuela. $\dagger$

FIG. 35 .

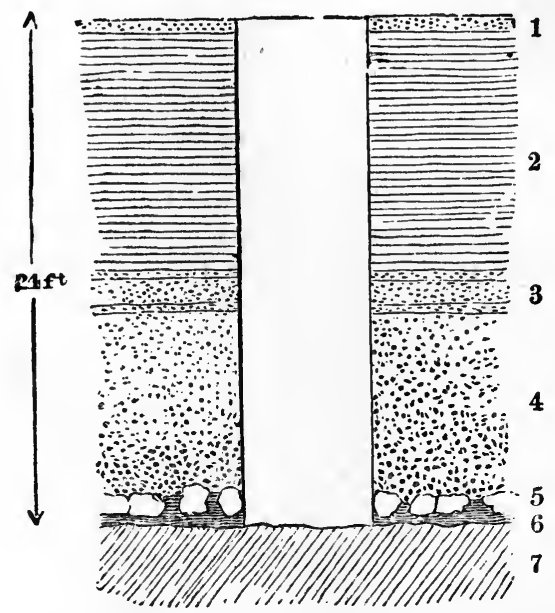

The following is the succession of the beds:-I. Soil. 2. Tird clay, showing no signs of stratification. 3. Soft clarey " moco de hierro." 4. Hard brown iron ore ("moco de hierro"), with pieces of quartz in it and a litile clay. 5. Blocks of vein-quartz, often auriferous. 6. "Greda," or pay-dirt, a yellow ferr "ginous clay containing nuggets and small grains of gold. 7. "Cas_ajo," decomposed schist, lorming the "bcd-ruck."

Fig. $3^{6}$ explains how a superficial gold-bearing "rainwash" may result from the denudation of a bed of auriferous gravel.

Some of the deposits of gold in Brazil occur under totally different conditions. The precious metal is found in beds of jucotinga, the local name for a friable mixture of micaceous iron earthy brown iron ore, oxide of manganese, lithomarge or talc, a little quartz, and small lumps and granules of gold. The beds of jacotinga occur as subordinate bands in the rock known as itabirite, composed mainly of micaceous iron, specular iron, mag-

* MS. of C. J. Alford, F.G.S.

+ C. Le Neve Fonter, "On the Caratal Gold-field," Quart. Jour. Geol. Suc., vol. xxv. I869, p. 340. 
netite, and granular quartz. Some of the beds of itabirite i.ro worked as iron ores.

Fig. 36.

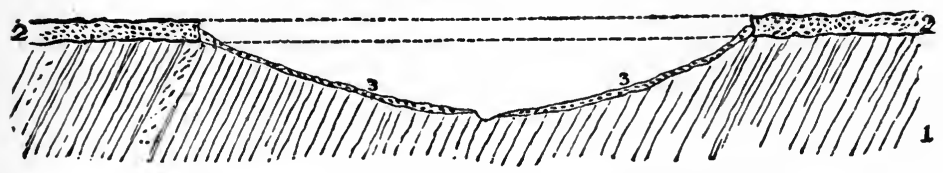

I. Schist ("Cascajo") or felstone forming the bed-rock of a ferruginous gold-bearing gravel ("moco de hierro") 2 ; 3 . Ked ferruginous earth ("Tierra de flor") containing nuggets of gold.

Though the jacotinga forms beds, the gold is not uniformly distributed through it, but is concentrated in productive shoots.

Veins.-The veins usually consist in great part of quartz, and contain in addition iron pyrites, or some other heavy metallic sulphides, such as galena, zinc blende, copper pyrites, magnetic pyrites, stibnite and mispickel. The gold is principally in the metallic state, even when enveloped in pyrites, which is so frequently the case; but it occurs also in combination with tellurium, and with bismuth.

The "Great Quartz Vein," or "Mother Lode," in the Sierra Nevada of California is the first deposit that must be noticed; for it is remarkable by its length, its width, the number of mines which are dependent upon it, and their annual yield of the precious metal. Some of the most important facts concerning it have been described by Whitney.* The axis of the Sierra Nevada is a mass of intrusive granite, which is flanked by metamorphic Triassic and Jurassic rocks ; the existence of fossils proves the gold-bearing strata to be of Secondary age. The rocks in which the principal gold veins of this region occur, are slates of various kinds, such as clay-slate, talcose slate and chloritic slate, which form a marked belt, sometimes 18 miles wide, running through the country for fully 150 miles. The slates are accompanied by a band of serpentine sometimes a mile wide. "Associated with the serpentine is the very remarkable mass of quartz known as the 'Great Quartz Vein,' which may be traced for a distance of 80 miles from Amador Connty to Mariposa County in a general S.E. by S. direction." $\dagger$ "This powerful lode is made up of irregularly parallel plates of white compact quartz and crystalline dolomite or magnesite, $\ddagger$ more or less mixed with

* The Auriferous Gravels of the Sierra Nevada of California. Cambridge, U.S., I880, p. 45 .

+ Op. cit. p. 46 .

\$ Whitney adds the note- " In the only specimen which has thus far been chemically examined, the supposed dolomivic portion proved to be an intimate mixture of quartz and magnesite." 
green talc; and these plates, which somewhat resemble the 'combs' of ordinary lodes, are either in contact or separated from each other by intercalated layers of talcose slate." "The quartz is the auriferous portion of the lode, although it is far from being uniformly impregnated with gold." "The talcose slate bands in the vein are often themselves more or less auriferous." In one place the vein is $26 \mathrm{I}$ feet wide measured horizontally across it, and it dips to the north east at an angle of $60^{\circ}$. Whitney says it is not proved to be a fissure vein, and he is more inclined to consider it as a metamorphosed belt of rock.

The map of the lode given by Collins,* shows seventy-seven mines which are now being worked, or which have been profitably worked in recent times, and we learn from him that the auriferous quartz contains small quantities of metallic sulphides, such as iron pyrites, mispickel, marcasite, chalcopyrite, and galena, The quantity of gold produced from the quartz treated varies from 3 dwts. to 15 or 20 dwts. per ton, and the "Great Quartz Vein". or "Mother Lode" is estimated to yield about two million dollars worth of gold annually.

The gold veins, or " reefs," in Victoria are found in the Upper and Lower Silurian rocks. The gold is especially associated with

Frg. 37 .

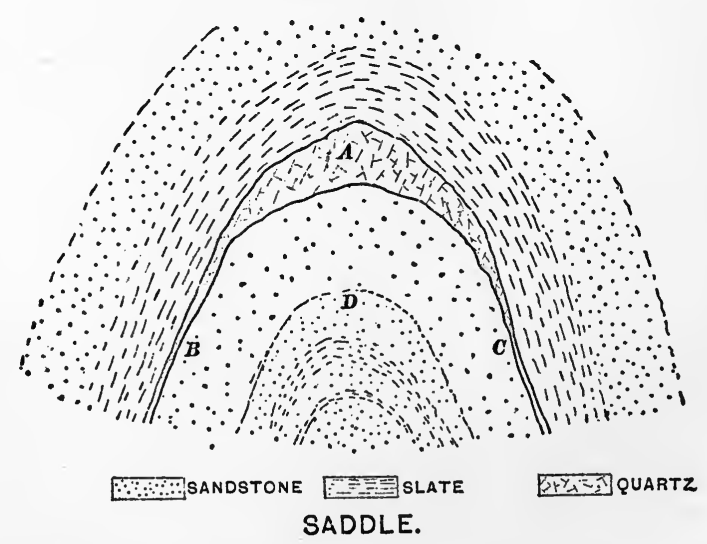

iron pyrites; when it decomposes a cellular honeycombed quartz is left behind, and the gold is unmasked and rendered visible in the little rusty cavities. Other heavy metallic sulphides are common here as elsewhere.

The peculiarities of the so-called "saddle-reefs" of the Sand-

* "Notes on the Grieat Mother Lode of California," Jour. Roy. Inst. Cornwall. Truro. Vol. ix. (1S56), p. 64 . 
hurst or Bendigo gold-field, Victoria, which differ considerably from typical veins, have been very clearly explained by $\mathbf{M r}$. T. A. Rickard,* from whose useful memoir the following account is borrowed. These reefs are arch-like masses of quartz conformable to the bedding of the surrounding Lower Silurian slate and sandstone, as shown by the letters B A C in Fig. 37. The part A is called the "cap" or "apex"; B is the "west leg" and C the "east leg," because the main anticlinal axes strike N.N.W. and S.S.E. The part D is known as the "centre country," the rocks to the east of $\mathrm{C}$ form the " east country," and those to the west of B the "west country." The inclination of the line of the ridge, northwards or southwards, is spoken of as the "pitch," in order to distinguish it from the dip of the strata. There may be more than one such saddle, or a long succession of them, one below the other (Fig. 38), but they are not all equally auriferous. Thus, out of five which have been discovered and explored at " 180 " mine, only three have proved to be worth working for gold.

Similar masses of auriferous quartz have been found at some of the synclines ("inverted saddles"), and worked to a slight extent. Very large dividends have been paid by many of the companies working the "saddle-reefs."

Masses.-Having given examples of auriferous beds and veins, I come to masses. Treadwell mine, $\uparrow$ situated on Douglas island, Alaska, owes its

FIG. 38.

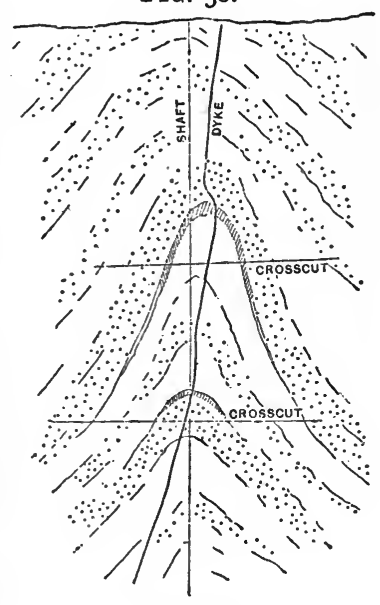

SADDLES existence to a mass of auriferous altered granite, 400 feet wide and of considerable length. The rock, which appears to have been a hornblende granite originally, now consists principally of quartz and felspar, with a little calcite and specks of iron pyrites, and it is traversed by strings of quartz, iron pyrites, and calcite. The original rock was probably crushed and fissured, and then brought under the action of solutions which penetrated into it in all directions, and so produced the alteration. The yield is considerably less than $\frac{1}{2}$ oz. per ton, but as the deposit can be

p. 463 .

* "The Bendigo Gold-Field," Trans. Amer. Inst. MI.E., vol. xx. (I8gI),

+ G. M. Dawson, "Notes on the Ore-deposit of the Treadwell Mine, Alaska," American Geologist, I889, p. 84 ; and Frank D. Adams, "On the Microscopical Character of the Ore of the Treadwell Mine, Alaska," Ilisl. p. 88 . 
worked opencast, the cost of getting is low. Much of the gold is free, and can be extracted by amalgamation in spite of its being enveloped by pyrites.

This mass may be called a stockwork or net-work deposit.

The productive Mount Morgan mine,* near Rockhampton, in Queensland, while astonishing the world by its richness, affords a puzzle to geologists which has not yet been satisfactorily solved.

The auriferous deposit, which is worked as an open quarry, is a mass of brown bæmatite, sometimes stalactitic and containing a little silica, which passes gradually into a ferruginous siliceous sinter. Some of it is spongy and frothy in appearance, and so full of cavities that it will float upon water like pumice. The precise nature of the gold-bearing mass is well illustrated by twenty views which accompany the "Third Report" of Mr. R. L. Jack, the Government geologist.

Both the sinter and the brown iron ore contain gold, and yield on assay several ounces to the ton. The auriferous stone

Fig. 39.

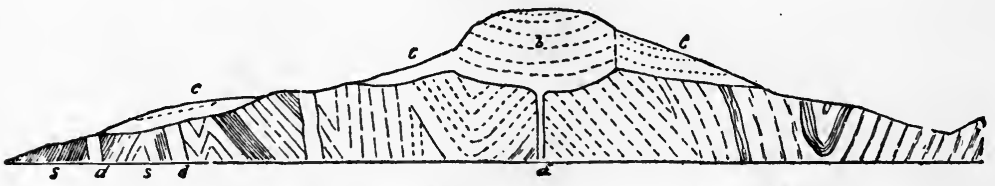

$a$, pipe of geyser (theoretical) ; $b$, cup-deposit of geyser; $c$, over-

flow deposit of geyser; $s$, metamorphic rocks; $d$, rhyolite dykes.

caps a hill rising about 500 feet above the neighbouring tableland, and the most important part of it is the actual top or crown, an oval mass 300 yards long by 170 yards wide.

Mr. Jack considers that the deposit is the product of a geyser, and he explains his views by the section (Fig. 39). This naturally represents the present condition of the hill, much of the original geyser deposit being supposed to have been removed by denudation.

The gold exists in a state of great fineness, and the metal extracted is of extreme purity, for it contains $99^{\circ} 7$ of gold, the rest being copper, a trace of iron, and a minute trace of silver. Dr. Leibius, of the Sydney Mint, speaks of it as the richest native gold hitherto found.

Without having examined the deposit upon the spot, one scarcely likes to criticise the conclusions of so able an observer as Mr. Jack; but looking at his section of the No. I tunnel, we find that the auriferous mass must repose upon highly pyritous rocks, such as quartzite full of fine pyrites, in which the latter constituent may sometimes predominate. The suspicion

* R. L. Jack, "Mount Morgan Gold Deposits." Brisbane, 1884. Second Report, 1889 ; and Third Report, 1892. 
naturally crosses one's mind that the gold-bearing cap may simply be due to the decomposition and weathering of the pyritiferous rock. Mr. Jack combats this theory, and says that it is disproved by three facts: Ist. A dyke of dolerite in the quartzite does not reach up into the overlying sinter. 2 nd. The pyritiferous quartzite is poor in gold. 3 rd. The silica of the sinter is hydrated. He therefore still maintains his original opinion that the sinter and ironstone were deposited by a thermal spring on the pyritous quartzite, and are not altered portions of it.*

Mr. Rickard, $\uparrow$ while disagreeing with the geyser theory, concurs in Mr. Jack's opinion that the deposit is not an alterfid portion of the pyritous quartzite, though he remarkis that the

Fig. 40.

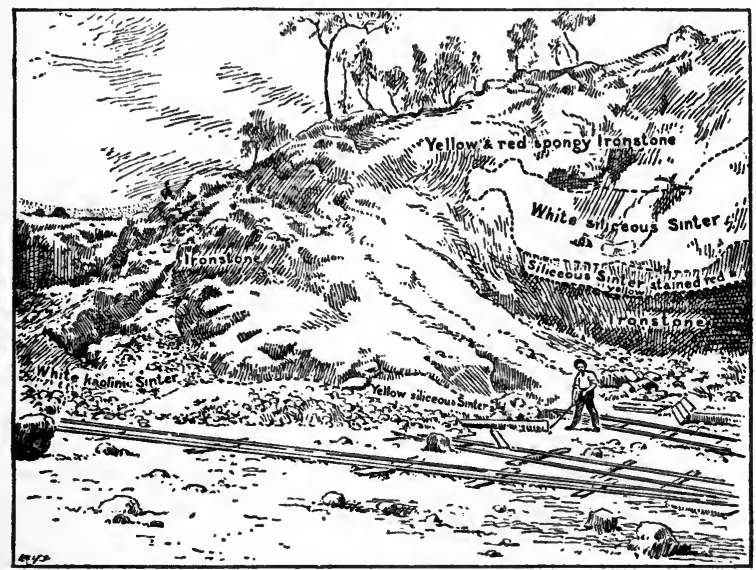

Mount Morgan rock bears a strong outward resemblance to the decomposed outcrop of the Broken Hill lode in New South Wales. This can be easily imagined from an inspection of the views given in Mr. Jack's third report, from which the outlines of Fig. 40 have been copied. The theory propounded by Mr. Rickard (Fig. 4I) is that the auriferous stone of Mount Morgan is rock shattered by the intrusion of dykes, and then altered by th" percolation of underground mineral solutions, which found an easy passage through the cracked and fissured mass. He points out that the gold may have been derived from the poor pyrites disseminated through the quartzite, or from the sandstone of the district, which has been shown to be auriferous.

The quantity of stone treated by chlorination at Mount Morgan

* Second Report, p. 4.

+ "Mount Morgan Mine, Queensland," Trans. Amer. Inst. M.E. vol. 3x. (1891), p. 133 . 
in the twelve months ended 3oth November, 1889, was 75.4 I 5 tons, from which $323,54^{2}$ oz. of gold were obtained, equal to

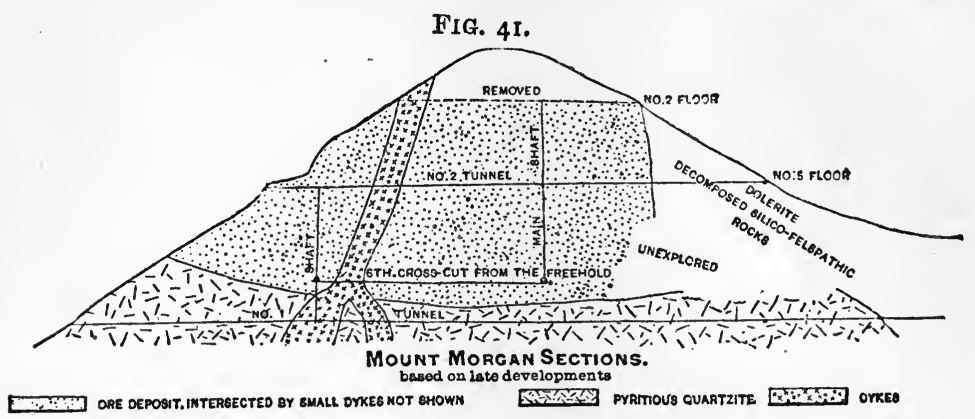

4 oz. 6 dwt. per ton. The gold was sold for $£ \mathrm{I}, 33 \mathrm{I}, 484$, and

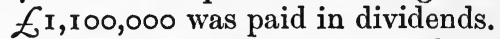

Graphite.-The great graphite mines of the world are those of Ceylon, where the mineral is found in layers from a few inches to several feet in width, in gneiss and mica schist. The graphite is associated with quartz and a little iron pyrites.

There are various graphite deposits in Austria and Bavaria.* At Kaiserberg, in Styria, the mineral is found in graphitic schist ; the beds vary in thickness very rapidly from a few inches to 20 feet.

In Lower Austria, Moravia, Bohemia, and Bavaria graphite occurs in gneiss usually accompanied by granular limestone. The Passau graphite is in the form of small black scales, and appears to take the place of some of the mica in a highly felspathic gneiss ; the thickness of the beds varies greatly, but may be as much as I6 feet $(5 \mathrm{~m})$.

The Bavarian mines produced $335^{2}$ tons of graphite in 1888 .

Gypsum.-As one of the principal uses of gypsum is for making plaster-of-paris, we naturally turn to the French metropolis for an example of the mode of occurrence of this mineral. The gypsum is found in beds from 50 to 60 feet thick, which are of Upper Eocene age (Fig. 352).

In England and elsewhere, the Triassic rocks have long been remarkable for containing valuable beds of gypsum, and they are largely worked in Derbyshire and Nottinghamshire. Fig. 42 represents the layers of nodules in a gypsum mine at Kingston-onSoar, Nottinghamshire. There are three beds a few feet apart in the New Red Marl. The bottom bed consists of large spheroidal masses, varying from 5 to 8 feet in thickness, and 5 to ro feet in diameter; above it are two layers of "balls" and nodules, more or less continuous. The highly gypsiferous marl, locally called

- Th. Andrée, "Der österreichische und bayerisch3 Graphitbergbau," B. u. h. Z. 1890, p. 269. 
"fault," B, between the big balls, A A, is left, so as to form pillars, which support the roof of the workings.

White translucent alabaster for statuary purposes is mined at Castellina Marittima, ${ }^{*}$ in the province of Pisa. Its mode of occurrence resembles that just described, for it is found in irregular spheroidal or kidney-shaped masses called "ovuli" by the workmen, from a few inches to several feet in diameter, and occasionally weighing more than a ton each. The grey marl surrounding the nodules is of Pliocene age. The alabaster is saccharoidal and very fine grained.

Ice.-Bysome persons this mineral maybe considered beneath notice, but the trade in ice is so large that it deserves at least a passing mention. The United States $\dagger$ are the largest producers of natural ice in the world,

FIG. 42.

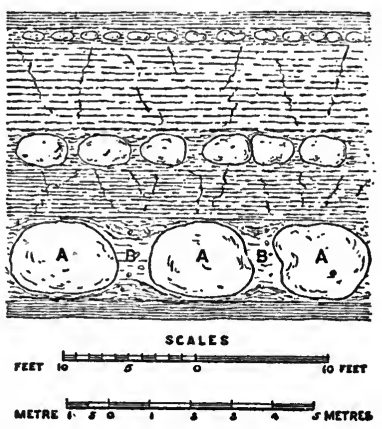
and in some years $12,000,000$ tons are gathered from the lakes and rivers, and especially from the Hudson. The gathering in of the ice crop affords employment to "I 2;000 men and boys, I,000 horses, and I00 steam engines." Much ice is exported from Boston, and Norway also is a country with a large ice trade.

Iron.-This metal is very widely distributed over the globe, and affords examples of many modes of occurrence, though veins of iron ore are quite driven into the background by the yield of beds, and especially those of the Jurassic age.

The most productive European deposits at the present time are : the bed of iron ore in the Cleveland district, the masses of red hæmatite in Cumberland and North Lancashire, the bed of brown hæmatite in German and French Lorraine, and Luxemburg, and the beds of red and brown hæmatite near Bilbao, in Northern Spain.

The bed of ironstone worked in the Cleveland district of North Yorkshire is found in the Middle Lias. Mr. Kendall $\ddagger$ gives the following general section of the rocks:-

* Jervis, I tesori sotterranei dell' Italia, vol. ii. p. 419, and vol. iv. p. 3 I 8. † "The Trade in Ice," Jour. Soc. Arts. London, 1890, vol. xxxviii. p. 765 .

\$ "The Iron Ores of the English Secondary Rocks," Trans. N. of Eng. Inst. Min. Eng., vol. xxxv. (1886), p. I I3. Barrow, "The Geology of North Cleveland," Mem. Geol. Survey 1888. 


\begin{tabular}{|c|c|c|c|}
\hline & Description. & $\begin{array}{l}\text { Thick- } \\
\text { ness. }\end{array}$ & Characteristic Ammonite. \\
\hline $\begin{array}{c}\text { Middle } \\
\text { Lias }\end{array}$ & 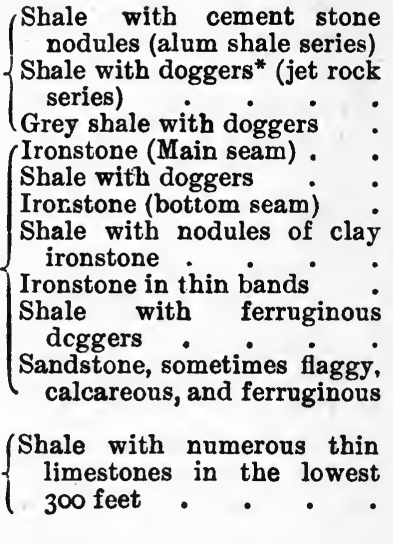 & $\begin{array}{rl}\text { ft. } & \text { in. } \\
\text { I } 5 & 0 \\
48 & 0 \\
30 & 0 \\
\text { I I } & 6 \\
10 & 6 \\
2 & 9 \\
20 & 0 \\
1 & 9 \\
30 & 0 \\
40 & 0\end{array}$ & $\begin{array}{l}\text { A. communis } \\
\text { A. serpentinus } \\
\text { A. annuiatus } \\
\text { A. spinatus } \\
\text { A. margaritatus } \\
\text { A. capricornus, Ja- } \\
\text { mesoni, armatus, } \\
\text { oxynotus, Buck- } \\
\text { landi, angulatus, } \\
\text { and planorbis }\end{array}$ \\
\hline
\end{tabular}

Fig. $43 \dagger$ illustrates sections of the bed at Eston and Upleatham.

FIG. 43 .

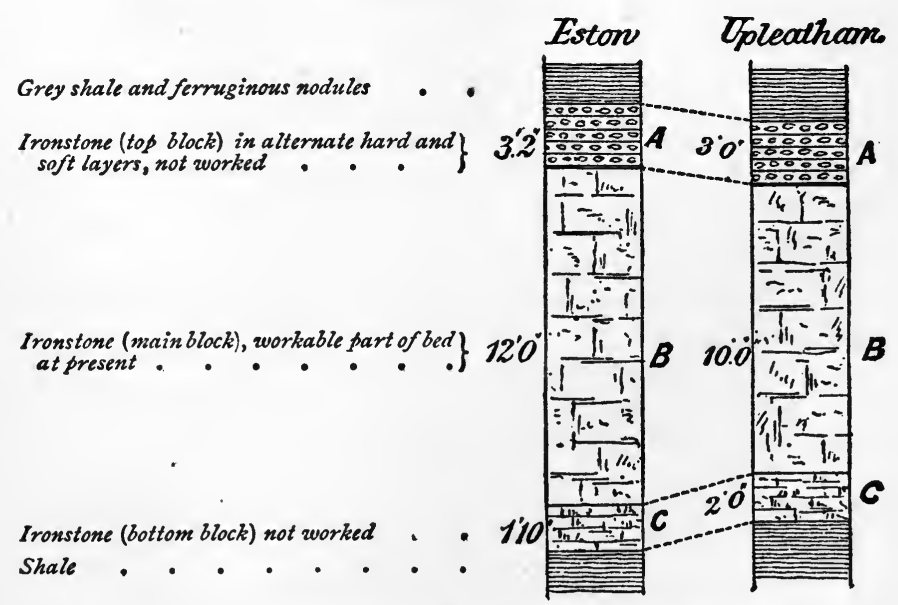

The Main Seam practically furnishes all the Cleveland ore. It probably extends over an area of $35^{\circ}$ square miles, though it

* Doggers are nodules of ironstone.

+ Kendall, Op. cit. Fig. 5, Plate XIII. 
cannot be profitably worked over anything like the whole of this district. The average thickness where worked is about ro feet. The beds dip very gently about $\mathrm{r}$ in $\mathrm{r}_{5}$, to the south-east. The seam is thickest and best at Normanby, Eston, and Upleatham; in proceeding to the south-east, partings of shale appear, and split up the main seam into numerous comparatively thin layers of ironstone, with a smaller percentage of metal. Some of the ironstone is oolitic and of a greenish grey colour, but much of it is not oolitic, and is bluish grey in colour, resembling a mudstone. 'The iron exists chiefly as carbonate, some of which, according to Dr. Sorby, was deposited mechanically, whilst the rest was formed chemically by replacement of carbonate of lime. As a general average, it may be said that the ore contains 30 per cent. of iron. The district produced $5,128,303$ tons of ore in 1891 .

The masses of red hæmatite worked in Cumberland and North Lancashire have already been noticed (Fig. I4).

The great iron-field of Lorraine,* much of which became the property of Germany in $187 \mathrm{r}$ after the Franc s-Prussian war, stretches out from Nancy past Metz and Diedenhofen into Luxemburg. It may be called 60 miles long by 10 to 12 miles wide ( $100 \mathrm{~km}$. by 15 to $20 \mathrm{~km}$.).

The iron-bearing strata belong to the Lower Dogger or Brown Jura (Inferior Oolite), and consist of marly sandstone, marl and sandy clay, interstratified with beds of limestone and iron ore.

In places there is no iron, and in others, especially in the south and on the eastern edge, the beds of ore are thin. On the other hand, at Esch, in Luxemburg, four beds of iron ore and their partings of limestone and sandstone make up a total thickness of 65 feet $(20 \mathrm{~m}$.), and at Deutsch-Och and Oettingen three beds and the partings are 32 feet ( $10 \mathrm{~m}$.) thick; then at Hayingen the total thickness sinks to 20 feet $(6 \mathrm{~m}$.), and at Ars there is only one bed 5 to 6 feet thick. The strata are slightly undulating, but the general dip is $r$ to $2 \frac{1}{2}$ in a hundred to the south-west. The iron exists in the state of hydrated oxide, probably for the most part as $2 \mathrm{Fe}_{2} \mathrm{O}_{3} 3 \mathrm{H}_{2} \mathrm{O}$, which constitutes the roe-like grains which are so characteristic of the ore.

The oolitic particles are enclosed in a calcareous matrix, which may contain quartz. The matrix is always more or less ferruginous, and sometimes consists of a greenish mineral, which is probably a silicate of iron. The ore has usually from $3^{2}$ to $3^{8}$ per cent. of iron and from $\frac{1}{2}$ to 2 per cent. of phosphorus; there is also a little sulphur, due to occasional small strings of iron pyrites. The name "minette," or " little, unimportant ore," was given many years ago to this bed in contradistinction to the

* Wandesleben, "Das Vorkommen der oolithischen Eisenerze (Minette) in Lothringen, Luxemburg und dem östlichen Frankreich." Der IV. Allgemeine Deutsclie Bergmannstag in Hulle (Saale). Festbericht und Verinandlungen. Halle, i890, p. 297. 
"mine" or " minerai de fer fort," a much richer ore found in the neighbourhood, which is now no longer worked.

Nearly a hundred blast furnaces are dependent upon the " minette" for their supplies of ore, and in 1888 they produced $2,500,000$ tons of pig iron, or 40 per cent. of the total production of Germany, Luxemburg, and France. More than four-fifths of all the iron ore raised in this last country is obtained from this bed. The amount of ore still available in German Lorraine is estimated at 2,100 million tons, or enough to maintain the present rate of production for $75^{\circ}$ years.

Sweden is justly famous for its great deposits of magnetite. These are generally lenticular masses, often similar in shape to the Rio Tinto copper veins, and enclosed by highly metamorphosed rocks, such as gneiss, mica schist, and the hard compact hällefinta of the Swedish geologists.

It would not be right to quit the subject of iron ore without mentioning at least one of the mines situated in the neighbourhood of Lake Superior, where the Menominee, Gogebic, Vermilion and Mesabi districts are producing large quantities of mineral.

At Chapin Mine* near the town of Iron Mountain (Mich.) there are huge lenticular masses of hæmatite, which lie parallel to the enclosing Huronian strata (Fig. 44). $\uparrow$ One large lens is

FIG. 44 .

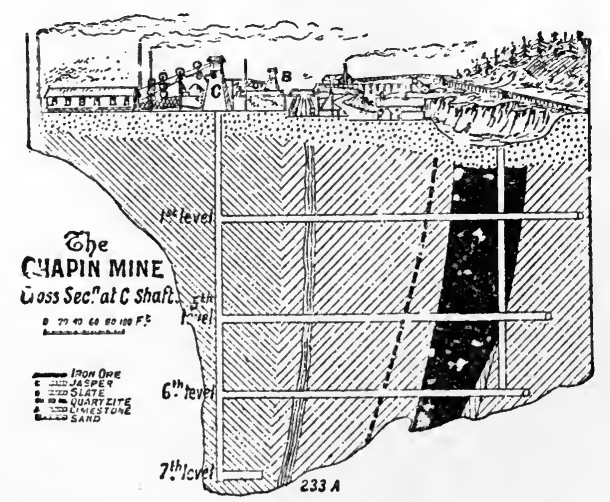

half a mile long, I 30 feet wide in the middle, and gradually tapering out to a point at each end ; it strikes $15^{\circ} \mathrm{N}$. of $\mathrm{W}$., and dips from $70^{\circ}$ to $80^{\circ} \mathrm{N}$., and the axis of the lens pitches $30^{\circ} \mathrm{W}$. The ore contains about 63 per cent. of metallic iron, and only 0.07 per cent. of phosphorus.

* Larsson, "The Chapin Iron-mint, Lake Superior," Trans. Amer. Inst. MI.E., vol. xvi. (1887), p. I19.

t Engineering, vol. I. (1890), p. 552. 
Lcad.-Though lead ore is largely wrought from veins, one of the great mines in the world obtains its supplies from a bed. The lead-bearing sandstone at Mechernich, in Khenish Prussia,* is of Triassic age (Bunter) and is on an average nearly roo feet thick. It rests upon and is covered by conglomerate, and is often split up into two or more beds by thick partings of conglomerate. The ore exists in the form of little concretions of galena and grains of quartz, but these are not uniformly distributed through the sandstone. The concretions are from $\frac{1}{25}$ inch $\left(1 \mathrm{~mm}\right.$.) to $\frac{1}{8}$ inch $(3 \mathrm{~mm}$.)

FIG. 45 .

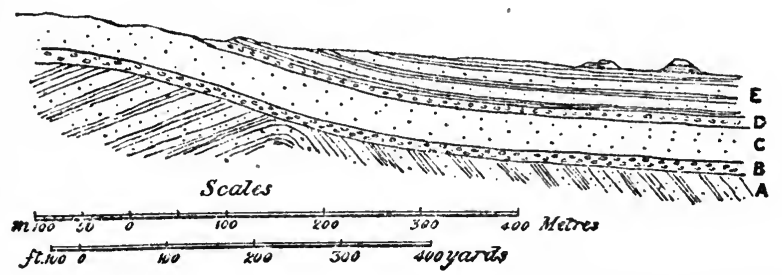

A, greywacke ; B, conglomerate ; C, lead-bearing sandstone ; $\mathrm{D}$, conglomerate ; E, so-called " red rocks," consisting of red, yellow, and white sandstone, with variegated shales and clay.

in diameter, and are harder than the surrounding sandstone, which is generally very friable. When the rock is pulverised the little shot-like masses remain, and are called "knots" (Knotten), whence the name "Knottensandstein" given to the bed. The amount of metallic lead in the sandstone is between 2 and 3 per cent.; but the concretions themselves contain from 20 to 24 per cent. According to the statement of accounts presented to the shareholders, $\uparrow$ the average percentage of lead contained in the whole of the sandstone treated in 1890 was $2 \cdot 318: 347,706$ cubic metres $(454,806$ cubic yards) of sandstone, were raised from the mine and open work, and yielded 36,245 tons of lead ore for smelting and 733 tons of potter's ore. This would be at the rate of I04 kil. of dressed ore per cubic metre, or $1 \frac{1}{2}$ cwt. per cubic yard, but it must not be forgotten that the bulk of the ore-i.e., that which goes to the furnaces-is not highly concentrated and contains only 54 per cent. of metal. The proportion of silver in it is $5 \frac{3}{4}$ ounces (I 80 grammes) per metric ton.

The history of Leadville, in Colorado, seems like a romance when we read of the rapid development of the mines, the creation of a large and important town, the erection of smelting works and the building of railways, under very adverse conditions, in

* Der Bergbau und Hüttenbetrieb des Mechernicher Berqwerks-ActienTereins. Cologne, 1886.

† Mining Journal, vol. lxi. (1891), p. 499. 


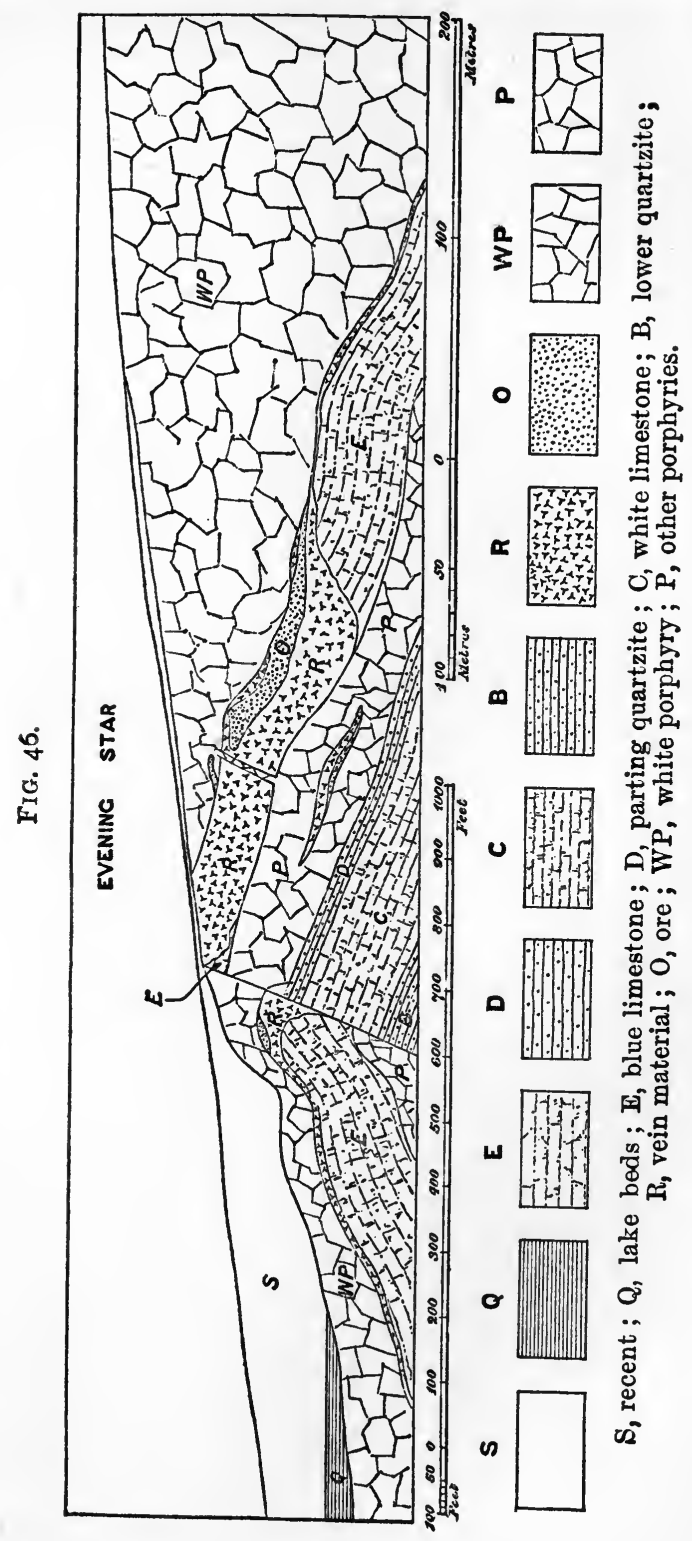


the heart of the Rocky Mountains, all within the space of four or five years. It affords additional proof that the miner is the true pioneer of civilisation. The Leadville deposits have been admirably described by Mr. S. F. Emmons,* from whose exhaustive report I borrow, not only the following facts, but also a section across one of the mines (Fig. 46).

The principal deposits of the region are found at or near the junction of white porphyry with the underlying Blue Limestone, which is the lowest member of the Carboniferous formation. This bed is about $15^{\circ}$ or 200 feet thick, and consists of dark-blue dolomitic limestone. At the top there are concretions of black chert. The porphyry occurs in intrusive sheets, which generally follow the bedding, and almost invariably a white porphyry is found overlying the Blue Limestone. This porphyry is of Secondary age. It is a white homogeneous-looking rock, composed of quartz and felspar of even granular texture, in which the porphyritic ingredients, which are accidental rather than essential, are small rectangular crystals of white felspar, occasional double pyramids of quartz, and hexagonal plates of biotite or black mica. Along the plane of contact with the porphyry the limestone has been transformed, by a process of gradual replacement, into a so-called "vein" consisting of argentiferous galena, cerussite, and kerargyrite, mixed with the hydrous oxides of iron and manganese, chert, granular cavernous quartz, clay, heavy spar, and "Chinese talc," a silicate and sulphate of alumina. The vein seems to have been formed by aqueous solutions, which took up their mineral contents from the neighbouring eruptive rocks, and brought about the alteration of the limestone as they percolated downwards through it. In Carbonate Hill a gradual passage may be observed from dolomite into earthy oxides of iron and manganese. The masses of workable ore are extremely irregular in shape, size, and distribution. They are often from 30 to 40 feet, thick vertically, and occasionally 80 feet, but only over a small area. The rich ore bodies are commonest in the upper part of the ore-bearing stratum. At Fryer Hill the Blue Limestone is almost entirely replaced by vein material. The metallic ores appear to have been deposited originally as sulphides; the oxidised or chloridised ores found near the surface are the products formed by the percolation of surface water like any ordinary gozzan.

Manganese.-The great manganese-producing countries of the present day are Russia $\uparrow$ and Chili, and in both the ore is derived from beds, and not from veins or masses. At Tschiatoura in the Caucasus, about thirty miles from Kwirilly station on the PotiTiflis Railway, there are beds of manganese ore of Miocene age. The beds worked are from 5 to 6 feet thick $\left({ }^{\circ} 5 \mathrm{~m}\right.$. to $2 \mathrm{~m}$.), and

\footnotetext{
*Geology and Mining Industry of Leadville, Colorado. Washington,
1886.
}

† B. u. h. Z. 1890, pp. 32, 215 . 
are made up of several small seams of clean manganese ore, separated by partings of soft sandstone and clay. The manganese exists principally in the form of $\mathrm{MnO}_{2}$, and the ore contains 50 to 55 per cent. of metal. The mines are at present heavily handicapped by the long and expensive carriage to $\mathrm{K}$ wirilly station, but this will be reduced when a railway is made.

Both in Wales and Belgium there are beds of manganese ore in the Cambrian rocks. The Welsh beds are about a foot thick (Fig.

FIG. 47 .

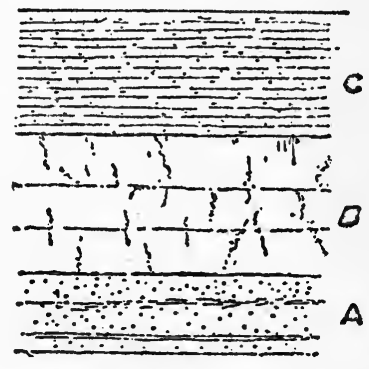

Zuches

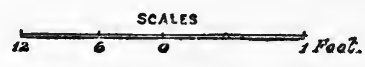

47), sometimes running up to I 8 inches or 2 feet. The manganese is principally in the form of carbonate, though there is a little silicate, and near the surface these have been converted into hydrous oxides. The ore is interbedded with fine-grained sandstone, hard mudstone, and shale, also manganiferous, and often containing chlorite, iron pyrites, and magnetite; the whole mangaviferous series is enclosed in the regular Cambrian grits and conglomerates. The ore

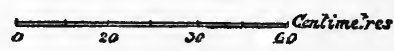

A, fine-grained sandstone with magnetite, ch'orite, and iron pyrites; $\vec{B}$, manganese ore; C, fine-grained shaly sandstone. contains from 20 to 32 per cent. manganese.

Marble. - The famous white statuary marble of Italy is found in the Apuan Alps from Carrara to Stazzema, on the S.W. slope of the mountains, and from Fivizzano to Vagli Sotto on the N.E. slope.* It occurs in very thick beds, with the stratification some ${ }^{\text {imes }}$ well defined, but generally completely obliterated, and it rests upon compact limestone, which in its turn lies upon pre-palieozoic mica-schist and talc-schist. The age of the marble beds has not been ascertained without doubt; some geologists say they are Triassic, whilst Jervis calls them pre-palaeozoic.

Mica.-This mineral is obtained in North Carolina at the present time, just as it was in the days of the prehistoric mound builders, from veins of giant granite, or granite in which the constituent minerals have crystallised on a huge scale. According to Phillips, $\uparrow$ a single block of mica has weighed nearly a ton, and

* Jervis, I Tesori solterranei dtll' Italia, vol. iv. p. 26r.

+ "Mica Mining in North Carolina," Eng. Min. Jour., vol. xlv. (1888), p. 286. 
pieces 6 feet long and 3 feet wide are sometimes met with; a single crystal of felspar weighing $800 \mathrm{lb}$. is preserved in the State Museum at Raleigh. The veins are from 30 to 40 feet wide, and are enclosed in mica schist, of which they follow the strike and . dip; but they occupy fissures which took place along planes of easy fracture, and being of subsequent origin to the surrounding rocks, are veins and not beds.

Natural Gas.*-Though the Chinese were before the Americans in their use of natural gas, it is to the United States that we must look for examples of gas springs, which have been so largely turned to account during the last ten years, more especially in Pennsylvania, but also in Ohio and New York.

According to the late Mr. Ashburner, $\uparrow$ the gas in these States comes from beds of Palæozoic sandstone and limestone. $\mathrm{He}$ considers, with many others, that both gas and petroleum have been formed by the decomposition of animal and vegetable remains in the rocks, and that in order to have a productive gas region, it is necessary that there should be a porous or cavernous rock to contain the gas, and an impermeable covering, such as shale, to prevent its escape, conditions resembling those required for artesian wells. A further condition is that the strata should be bent into a dome, anticlinal or arch, at the crown of which the gas will be found; but if the rocks have been much disturbed, contorted, and fissured, natural vents have been formed, through which the gas will have escaped. The rocks now containing the gas are often those in which it was generated.

There are several gas-producing beds of sandstone in Pennsylvania, in the Carboniferous rocks ; but the most important supplies are obtained from sands of the Venango-Butler oil-group, belonging to the Catskill Rucks of the Devonian period. There are other gas-sands in the Chemung and Portage rocks, also of the Devonian Period, but lower down. Some of them produce both gas and oil.

The most productive gas-bearing rocks in Ohio are the Berea grit in the Sub-carboniferous period, and the Trenton Limestone in the Lower Silurian period.

The section (Fig. 48), $\ddagger$ shows the Silurian and Devonian strata bent into an arch or dome at Findlay, Ohio, where gas and petroleum are obtained by boring into the 'Trenton Limestone, the reservoir in which they are confined by the Utica Shale.

The gas varies in composition, not only from well to well, but also from time to time in the same well. Some analyses given by Prof. Lesley show that the gas of a certain well contained upon

* Topley, "The Sources of Petroleum and Natural Gas," Jour. Soc. Arts, vol. $\operatorname{xxxix.~(1891),~p.~} 421$.

+ "The Geologic Distribution of Natural Gas in the United States," Trans. Amer. Inst. M.E., vol. xv. (1886-87), p. 505.

$\ddagger$ Topley, Op. cit. p. 4 I 3 . 
FIG. 48.

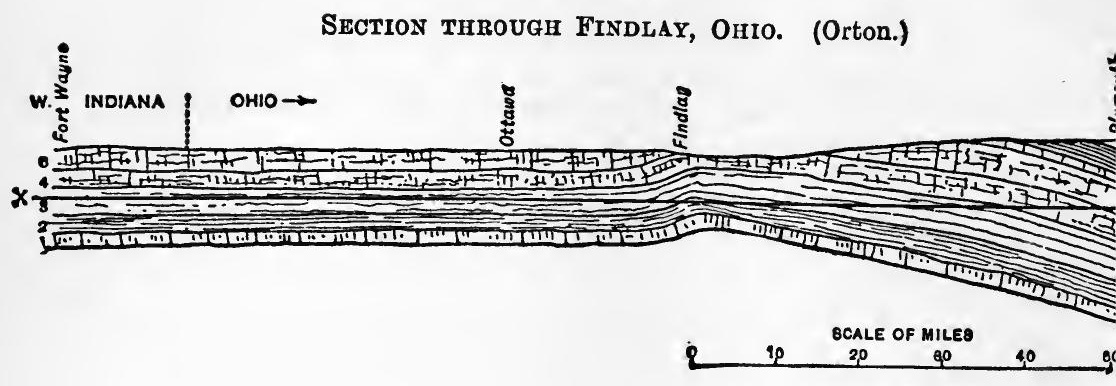

$x-x$ Sea Level

Devonian $\begin{cases}7 . & \text { Ohio shale. } \\ 6 . & \text { Upper Helderberg limestone. }\end{cases}$

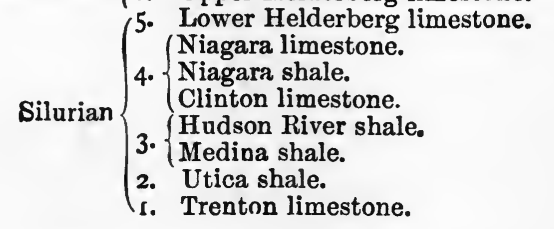

different occasions from 50 to 75 per cent. of marsh gas, 9 to 35 per cent. of hydrogen, 4 to 12 per cent. of ethylic hydride with small quantities of olefiant gas, oxygen, carbonic oxide and carbonic acid, and in one instance as much as 23 per cent. of nitrogen, though usually this gas was absent. The pressure of the escaping gas is often very

IIIG. 49.

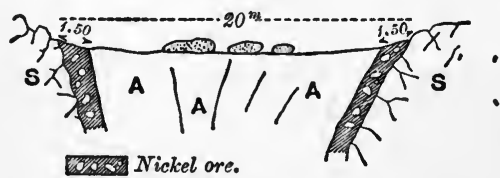

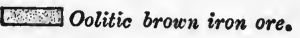

S Serpentine.

A Red Clay. great, and in one case reached $45^{\circ} \mathrm{lb}$. per square inch.

Nickel. - Until recently our supplies of this metal were obtained from sulphides or sulpharsenides, and especially from nickel-bearing pyrrhotine. The discovery by Garnier of hydrated silicate of nickel and magnesium in New Caledonia revealed the existence of an unsuspected source of wealth. The nickel is found in serpentine, ${ }^{*}$ either at the contact of this rock with "pockets" of red clay, or near such a contact, but never in the" clay itself.

"Levat, "Mémoire sur les progrès de la métallurgir du Nickel," A Mines, ge série, vol. i. (1892) p. 141 . 
Figs. 49,50 , and $5 \mathrm{I}$ are examples of various types of such deposits. In all three cases $A$ is the pocket of red clay, and $S$ is the serpentine. In Fig. 49 the nickel ore lies between the rock and the clay. In Fig. 5o there are a number of interlacing veins in the serpentine forming a network deposit which is quarried, whilst in the case represented by the Fig. $5 \mathrm{I}$, the original fissures were bigger, but less numerous, and are now filled up with nickel ores forming veins FIG. 50.

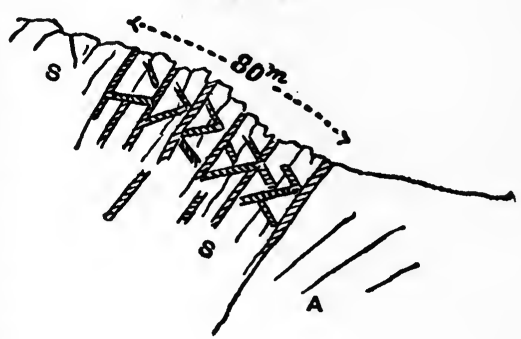
20 to 26 feet in width. The ferruginous red clay often contains the hydrated oxides of manganese and cobalt, besides chromic iron (Fig. I9). Largelumpsof limonite are frequently found lying upon the clay, Fig. 49. The ore which is exported has from 7 to 18 per cent. of nickel.

Of still later date are the discoveries of nickel ore at Sudbury* on the FIG. 5r.

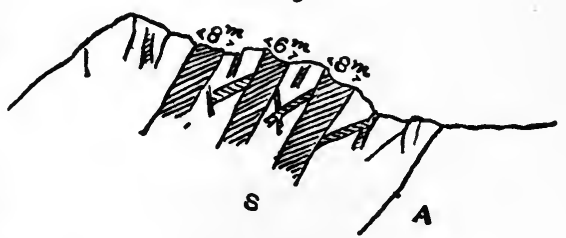
Canadian Pacific Railway, about 40 miles north of Georgian Bay. Here the ore is a nickel-bearing pyrrhotine associated with

F1G. 52.

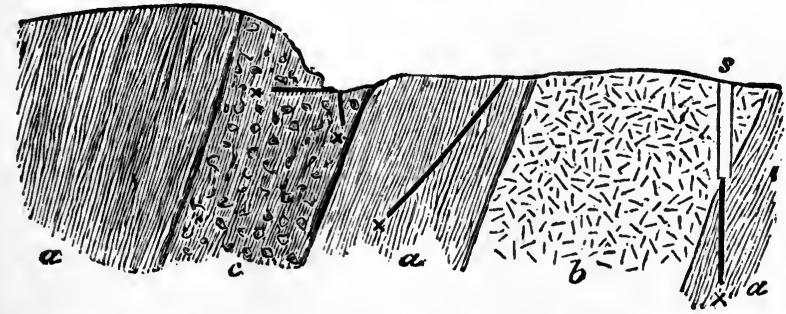

$a$, Huronian strata ; $b$, diorite ; $c$, ore-body ; $s$, shaft ; $x x$, boreholes.

chalcopyrite. These two minerals form large ore bodies (Figs. 52 and 53 ) in or near a belt of diorite in a district occupied

* Collins, "On the Sudbury Copper Deposits," Q. J. G. S., vol. xliv. (1888), p. 834, from which paper the two figures are borrowed. Snelus and Colquhoun in the special volume of Proceedings, The Iron and Steel Institute in America in $1890, \mathrm{pp} .213,359$. 
by rocks belonging to the Huronian and Laurentian systems. The shape of the ore bodies is very irregular, but their size is great; some are hundreds of feet long, by a hundred or more feet in breadth. The two minerals are worked and treated

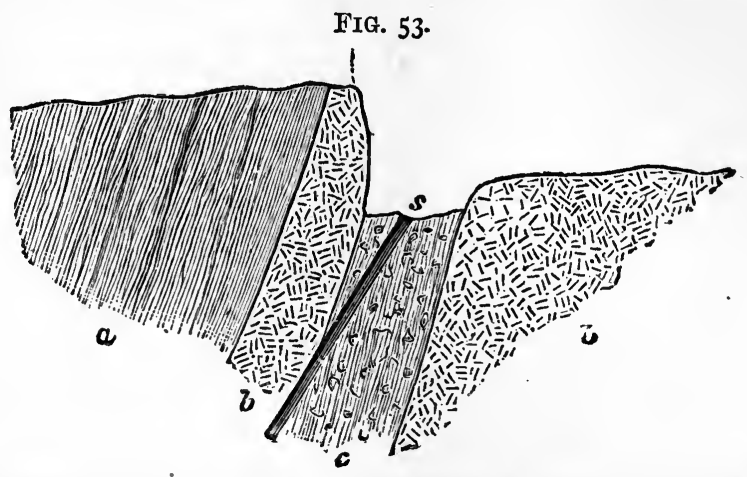

$a$, Huronian rocks ; $b$, diorite ; $c$, ore-mass ; $s$, shaft on diagonal vein.

together, for picking by hand has been found to be impracticable on a commercial scale, and separation by the ordinary washing process is impossible, owing to the small difference between their specific gravities.

Ore of good average quality contains 4 per cent. of nickel.

Nitrate of Soda.-The existence of beds of nitrate of soda, cubic nitre, in the rainless regions on the West Coast of South

FIG. 54.

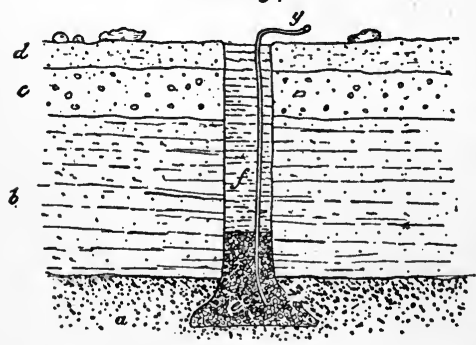

$a$, soft earth ; $b$, "caliche" ; $c$, conglomerate ; $d$, sand; $e$, charge of gunpowder; $f$, tamping; $g$, safety-fuse. America had been noticed in books on mineralogy for many years; but it was not till this mineral was found to be a valuable fertiliser that steps were taken to work it on a large scale.

The raw nitrate of soda (caliche) is found in beds from 6 inches to I 2 feet thick, beneath a covering of hard conglomerate (costra) from I to Io feet thick, as shown in Fig. $54 .^{*}$ It is supposed that it has been formed by the action of animal and vegetable matter upon salt left by the evaporation of sea-water, and this theory is supported by the fact that guano and the remains of

* Harvey, "Machinery for the Manufacture of Nitrate of Soda at the Ramirez Factory, Northern Chili," Proc. Inst. C.E., vol. lxxxii. (Session 1884-85), p. 337 . 
birds and fish are found close to the caliche, and also by the presence of iodine, an element pertaining to the sea, in the form of iodides and iodates.

Another theory, that of Dr. Carl Ochsenius,* is that salt lakes were formed by the elevation of a barrier which shut out the sea, that these gradually evaporated, that carbonic acid due to volcanic agencies converted some of the chloride of sodium into carbonate, and that finally guano dust, wafted by the prevailing breeze from guano islands near the coast, brought nitrogenous matter, which eventually became oxidised and converted the carbonate into nitrate.

An analysis of caliche given by Mr. Harvey is as follows :-

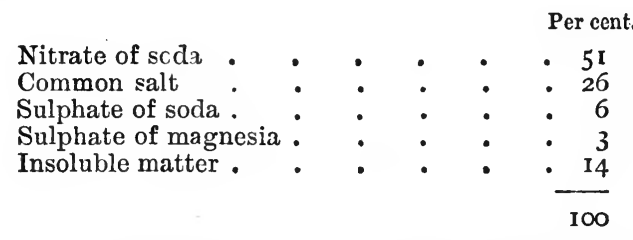

This sample was richer than the avernge; for the best caliche contains about 40 to $5 \circ$ per cent., middle $3 \circ$ to 40 , and poor caliche $\mathrm{I} 7$ to 30 per cent. of nitrate.

Ozokerite.-The most productive ozokerite mines are found at

FIG. 55.

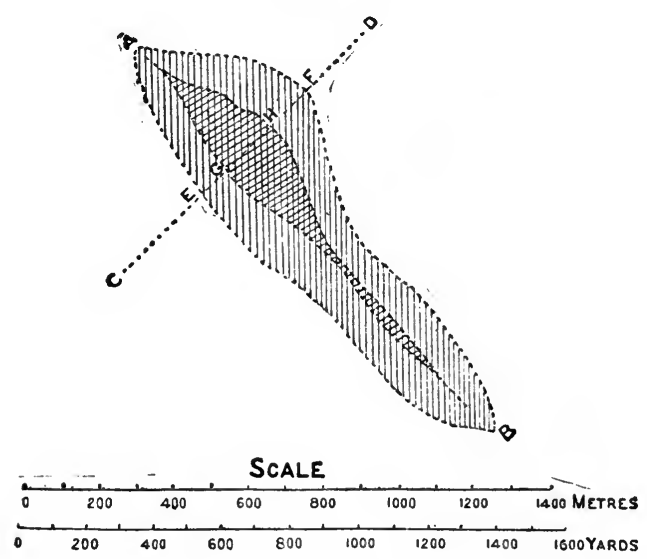

Boryslaw, near Drohobycz, in Galicia. The mineral oceurs in an oval area some $\mathrm{I}, 500$ yards long and a quarter of a mile wide at the broadest part, with the long axis, $A B$, running in a N.W. and

* Eng. Min. Juurn., vol. xlvi. (1888), p. 152. 
S.E. direction, or parallel to the trend of the Carpathians* (Fig. 55). The surrounding rocks are beds of sandstone and shale of Miocene age, bent into a dome like a dish-cover, whilst the productive area itself consists of the same strata traversed by a main set of

FIG. 56.

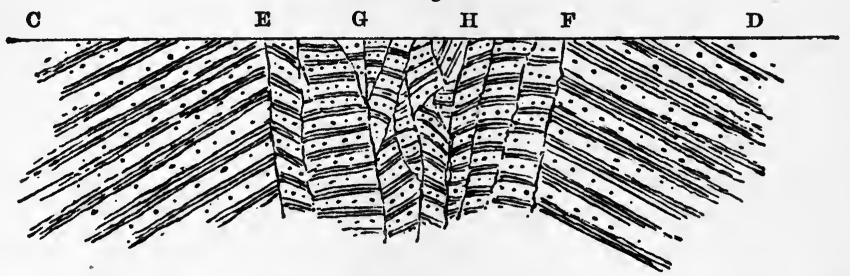

fractures in the direction $\mathrm{AB}$ (Fig. 55), and numerous crossfractures. In this mass of shattered, crushed, and faulted rock the ozokerite has been deposited; it fills every crack and crevice into which it could penetrate, sometimes crossing the stratification

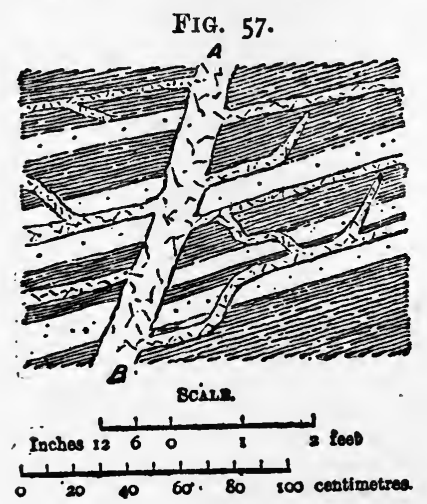

and sometimes following the planes of bedding for some distance, and then breaking across in an irregular manner (AB, Fig. 57). The veins vary in thickness from a mere knife-edge to several feet.

Fig. 56 is a diagrammatic section along the line CD (Fig 55), and is intended to convey some idea of the jumble of rocks between $\mathbf{E}$ and $\mathbf{F}$, the centre part from $\mathrm{G}$ to $\mathrm{H}$ being specially cracked, squeezed, and faulted. The richest mines are those sunk in the deeply-shaded part of the plan, corresponding to GH of the section. Petroleum is found in the rocks within the ozokerite area and also in those surrounding it for a certain distance, but there is less on the north side than on the south.

* For much of the information concerning Boryslaw, I am indebted to explanations given to me on the spot by Mr. A. Platz, manager of the largest mine. 
Petroleum.--The conditions under which rock-oil is found in the earth's crust are precisely the same as those described in speaking of natural gas, viz., a porous bed for storing the mineral, an impermeable bed for preventing its escape, and very often an anticlinal arrangement of the strata, though this is of less importance than in the case of gas.

The three great oil regions of the world at present are Baku, Burmah, and Pennsylvania. I put Baku first, because the existence of the eternal fires of the Apsheron Peninsula on the Caspian Sea has been known for about 2,500 years, and because some of its wells have surpassed in productiveness anything met with elsewhere. The principal wells are in the

FIG. 5 .

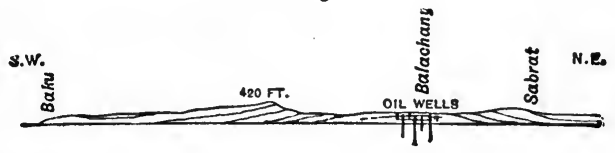

Ealakhani-Saboontshi district, some eight miles North of Baku, and at Bibi-Eibet, a little to the south. The rocks are of Lower Miocene age,* and consist of sand, calcareous clays, marls, and in places compact sandstone. The sectiont (Fig. 58, after Abich) shows the wells on the crown of a low anticlinal. The petroleum is found in three well-defined beds of sand; these sands are in a semi-fluid condition and contain salt water in addition to petroleum and carburetted hydrogen gas. Sometimes the pressure of the gas amounts to $300 \mathrm{lbs}$. per square inch.

At some of the wells it is necessary to pump up the petroleum, but at others it rises naturally and occasionally with great force and in immense quantities. In fact, Tagieff's spouter $\ddagger$ in 1886 actually threw up, on the eighth day after oil had been struck, the immense quantity of $1 \mathrm{I}, 000$ tons or $2 \frac{3}{4}$ millions of gallons in twenty-four hours. The flow then diminished and was got under control by the engineers, and reduced to a quarter of a million gallons a day. Fig. 59, copied from a photograph, $\S$ represents a spouting well at Baku.

The principal oil-fields of Burmah\| are situated near the villages of Twingoung and Beme, about a mile and a half east of Yenangyaung on the Irrawaddy, and 130 miles south of Mandalay. The rocks belong to the Tertiary period and are probably of Miocene age, the prevailing strata being clayey sands

* Vasilieff, "The Oil Wells of Baku," Proc. Inst. C.E., vol. Ixxxiii. (1885-6), p. 406 .

+ Topley, Op. cit., p. 429.

¥ Marvin, The Coming Deluge of Russian Petroleum. London, I886, p. 9.

$\S$ Lent to me by Mr. Boverton Redwood.

$\| \mathrm{F}$. Noetling, "Report on the Oil Fields of Twingoung and Beme, Burma," Records of Geol. Survey of India, vol. xxii. (1889), p. 75. 
and soft sandstone. The petroleum is found in beds of soft sandstone, which, together with partings of blue clay, have been proved to be 200 feet thick, and are probably very much more. The sandstone is soaked with petroleum, which oozes gradually into the wells, but certain layers are richer in petroleum than others. The lower strata of the formation are more productive than the upper ones. The oil-bearing rocks are overlain by thick beds of blue

FIG. 59.

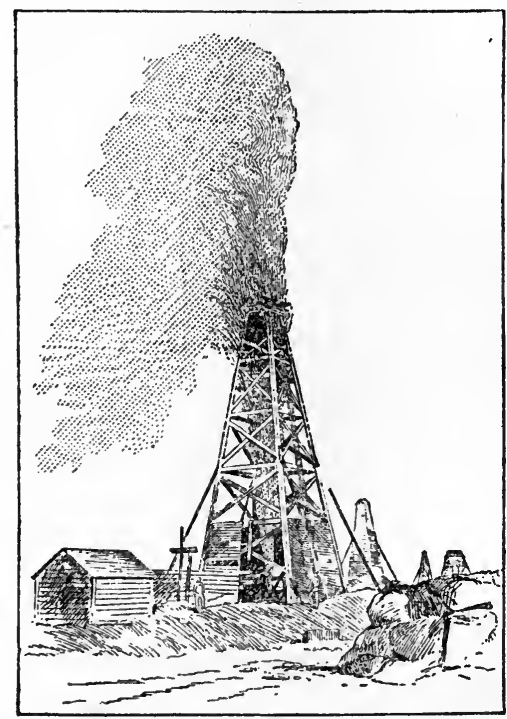

clay which prevent the petroleum from rising. The greatest depth reached by a Burmese well is 3 io feet. Noetling thinks that the oil was produced in the sandstone formation in which it is now found, though perhaps not in the uppermost beds.

At present there are no flowing wells, but these might be obtained if the oil-bearing strata were tapped at a greater depth, for then the gas which accompanies the petroleum would be under greater pressure. Where beds lie as shallow as they do at the existing workings, the gas has already drained off to a great extent through cracks in the strata. The highest daily yield of a single well was 500 viss, * but many of what can be called fairly rich wells produced upwards of 100 viss a day. The yield decreases rapidly during the first two years to the extent of at least 25 per cent., and after ten or fifteen years a well does not produce more than 5 per cent. of what it did at first. The total daily production of the two fields ranges from 15,000 to 20,000 viss per day.

$$
\text { * } 1 \text { viss }=3 \cdot 05_{57} \mathrm{lbs} \text {. }
$$


The year 1859 marks the first discovery of petroleum on a commercial scale in the United States, though the oil had been known as long ago as 1627 .

The strata which yield oil in Pennsylvania and New York belong to the Devonian and Carboniferous periods. They are beds of sand and sandstone, sometimes coarse-grained, and are the same as those producing gas; in fact a well may often produce hoth gas and petroleum, or first gas and then a little oil. In Obio the two chief sources of oil are the Trenton Limestone [Lower Silurian] and the Berea Grit near the base of the Carboniferous rocks.*

Phosphate of Lime.-The trade in this fertiliser is very large, and fortunately the sources of supply are numerous. Deposits of phosphate, of lime are found in rocks of all ages, from the Laurentian to the recent period. I may mention specially apatite from Canada, and various kinds of phosphate from the Cretaceous rocks in Europe, from South Carolina, Florida, and the West Indies.

The Laurentian rocks are the home of the apatite in Canada. The principal mines are in the county of Ottawa (Q.), and the mineral occurs mainly in pyroxenite, sometimes as a contemporaneous bed and sometimes as a vein of posterior origin.

The beds are from I foot to 3 or 4 feet thick, and the veins from a few inches to 8 or ro feet wide.

Though worked to some extent in Bedfordshire, Buckinghamshire, and Cambridgeshire, the Cretaceous rocks have of late years yielded far more abundant supplies of phosphate in France than in England. In the mining district of Arras $\nmid$ deposits of phosphate of lime are worked in three horizons: (I) At the base of the Gault, in the form of a bed of nodules, generally about 2 inches thick, and sometimes as much as 6 inches thick; (2) above the Gault, in the form of beds of nodules, 6 inches $(15 \mathrm{~cm}$.) to 3 feet 3 inches ( $1 \mathrm{~m}$.) thick; (3) in the state of sand, in more or less regular pockets, in the upper beds of the Chalk. This sandy phosphate is covered by a bed of clay with flints, above which comes brick-earth (Fig. 60). The sides of the pockets are formed by the chalk with Micraster cor-anquinum, or "Santonien"; whilst the fossils in the pockets belong to the base of the "Sénonien," or chalk with Belemnites quadratus. The pockets are generally contiguous to each other, but vary a good deal in depth up to 65 feet $(20 \mathrm{~m}$.). The phosphatic deposit is a

* Ashburner, Op. cit. Topley, Op. cit. Weeks, "Petroleum," Mineral Resources of the United States. Calendar Year 1886. Washington, 1887, p. $45^{8}$; and Calendar Years 1889 and 1890, p. 287.

† Statistique de l'Industrie Minérale et des appareils à vapeur en France et en Algérie pour l'année 1886. Paris, 1888, p. 243. Figure 60 is taken from my own notes, and differs slightly from the one given in the official volume. 
very fine yellowish and occasionally white sand, which under the microscope is found to consist of transparent concretionary grains,

FIG. 60.

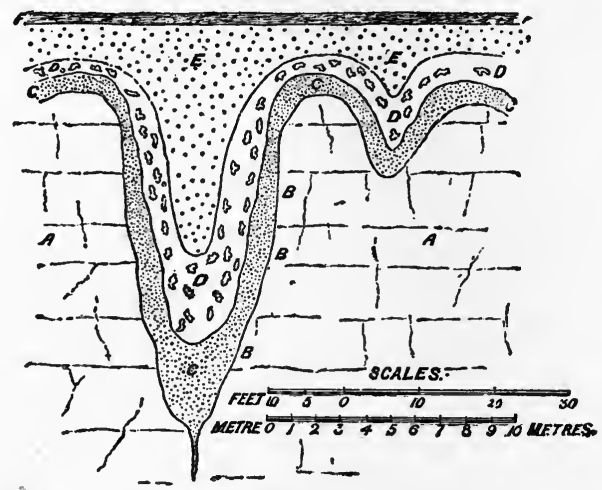

A, chalk ; B, phosphatic chalk ; C, sandy phosphate of lime; D, clay with flints ; E, brick-earth; F, soil.

made up of concentric layers; its average thickness may be taken at 3 feet 4 inches $(1 \mathrm{~m}$.) The chalk adjacent to the pockets is

Fig. 61.

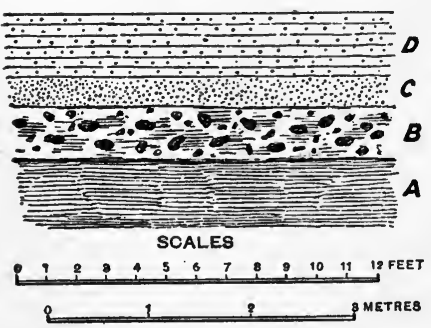

A, Ashley marl (Eocene) ; B, bed of phosphatic nodules; C, ferruginous sand; D, clayey sand.

to a seaport, the trade has increased very rapidly. The mineral occurs in the form of nodules, from the size of a pea to that of a man's head, in a bed from a few inches to $2 \frac{1}{2}$ feet thick, the average thickness being 7 to 9 inches (Fig. 6I). With the nodules are found bones of fish and especially teeth of great sharks, together with teeth of the

* R. A. F. Penrose, "Nature and Origin of Deposits of Phosphate of I.ime:" Bulletin of the "I.S. Geol. Survey, No. 46. Wa: hington, 1888, p. 6 . 
horse and other land animals. The deposit is considered to be of Post-Pliocene age.

The existence of valuable deposits of phosphate in Florida* was not known till - I887. There are four different kinds of the fertiliser-(I) "hard rock" phosphate, (2) "soft" phosphate, (3) "land "pebble" phosphate, (4) "river pebble" phosphate:

The "hard rock" is a hard, massive, light grey phosphate of lime, with cavities lined with secondary mammillary incrustations of the mineral. It has been produced by the alteration of Eocene and Miocene limestone, and yields about 36 or 37 per cent. of phosphoric anhydride $\left(\mathrm{P}_{2} \mathrm{O}_{5}\right)$.

The "soft" phosphate includes material resulting from the disintegration of the hard phosphate, and also highly phosphatic sands and clays, rarely averaging more than 22 per cent. of phosphoric anhydride.

The "land pebble" phosphate is made up of pebbles of various sizes, up to that of a walnut. They consist of an earthy material carrying pisolitic grains of phosphate of lime, or of a substance resembling the hard rock phosphate. The percentage of phosphoric anhydride is about $3^{2}$.

The "river pebble" phosphate is found in the beds of the present rivers, and also in their ancient channels. The pebbles are blue, black, and grey in colour, and contain the bones and teeth of various animals. They yield from 20 to 28 per cent. of phosphoric anhydride.

The phosphate of lime worked at Aruba and Sombrero, in the West Indies, was originally a coral limestone; its conversion into phosphate has been effected by the percolation of water containing phosphoric acid derived from the dung of sea-fowl. This interesting fact is made very plain by finding corals themselves changed into phosphate of lime. In the island of Redonda, owing to a difference in the rocks acted on by the drainage from the excrement, the mineral produced is phosphate of alumina.

Potassium Salts.-'The deposits of various potassium salts at Stassfurt belong to the Bunter Sandstone formation of the Magdeburg-Halberstadt basin, and workings have now shown that they attain a thickness of very nearly 3000 feet (900 metres).

The beds may be divided according to their chemical composition into four regions, $\uparrow$ which in descending order are :-

* Eldridge, "A Preliminary Sketch of the Phosphates of Florida," Trans. Amer. Inst. M.E., vol. xxi. (1892), p. I96. Wyatt, The Phosphates of America. New York, I89 I.

+ Führer zum vierten Dergmannstag, 1889. Halle a. d. Saale, 1889, p. xxxiv. 
APPROXimate Thickness. Fet. Metres.

4. Carnallite region.-Carnallite is the double chloride of potassium and magnesium

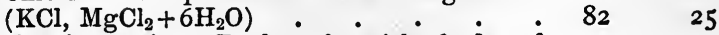

3. Kieserite region.-Rock salt with beds of

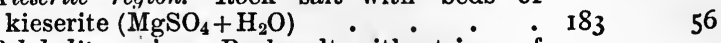

2. Polyhalite region. - Rock salt with strings of polyhalite $\left(\mathrm{K}_{2} \mathrm{SO}_{4}, \mathrm{MgSO}_{4}, 2 \mathrm{CaSO}_{4},+2 \mathrm{H}_{2} \mathrm{O}\right) \quad 197 \quad 60$

I. Rock-salt. - An exceedingly thick bed.

As is shown by the section (Fig 62), the edge of the carnallite region consists of kainite $\left(\mathrm{K}_{2} \mathrm{SO}_{4}, \mathrm{MgSO}_{4}, \mathrm{MgCl}_{2}+6 \mathrm{H}_{2} \mathrm{O}\right)$; this

\section{FIG. 62.}

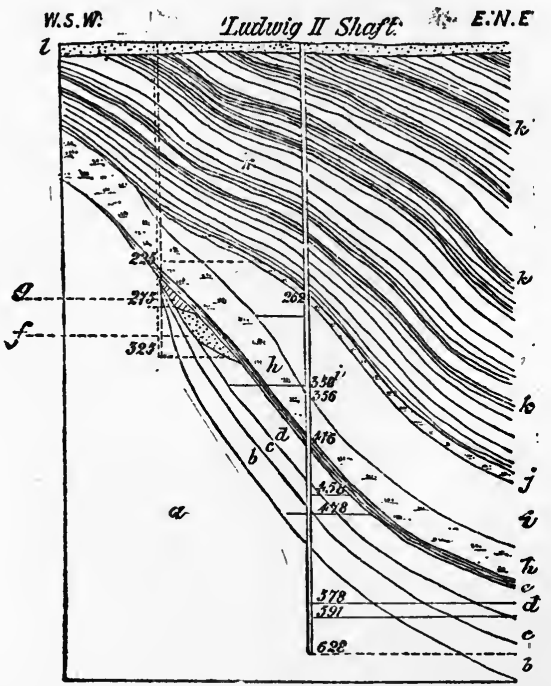

$a$, Older rock salt; $b$, polyhalite region; $c$, kieserite region; $d$, carnallite ; $e$, saliferous clay ; $f$, kainite ; $g$, sylvinite ; $h$, gypsum and anhydrite; $i$, younger rock salt ; $j$, gypsum; $k, k$, variegated marls with thin beds of limestone and of oolite; $l$, diluvium and alluvium. The depths marked are in metres.

is considered to be of secondary origin, and so also is regarded the sylvinite, a mixture of potassium and sodium chlorides with their sulphates, which occurs in workable quantities.

Above the potassium salts is a bed of saliferous clay 26 feet $(8 \mathrm{~m}$.) thick, and then 290 feet $(90 \mathrm{~m}$.) of anhydrite, which forms the floor of the Bunter beds. At several places there is a younger bed of rock-salt from I 30 to 400 feet $(40$ to $120 \mathrm{~m}$.) thick.

Rock-salt is worked to a small extent, but the potassium salts, 
especially carnallite and kainite, are the main objects of the mining.*

Quicksilver.-The principal quicksilver producing mines at the present time are Almaden, in Spain, Idria, in Carniola, and New Almaden, in California. There are also several other mines in California, and workings of some importance in Russia and Italy. Peru was at one time remarkable for its quicksilver deposits at Huancavelica, but these are no longer worked. China possesses some little-known mines in the province of $\mathrm{Kwei-Chau.}$

The relative importance to the world of the principal deposits is shown by the following table, taken from Mr. Becker's monoglitph. $†$

Product of the principal districts, in Spanish flasks of

75 SPANISH POUNDS, OR $34^{\circ} 507$ KILOGRAMMES.

\begin{tabular}{|c|c|c|c|c|c|c|}
\hline & 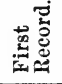 & $\begin{array}{l}\text { Up to } \\
\text { I700. }\end{array}$ & $\begin{array}{c}1700 \text { to } \\
1800 .\end{array}$ & $\begin{array}{l}1800 \text { to } \\
1850 .\end{array}$ & $\begin{array}{l}1850 \text { to } \\
1886 .\end{array}$ & $\begin{array}{c}\text { Total to } \\
\text { Jan. } 1886 .\end{array}$ \\
\hline $\begin{array}{l}\text { Almaden } \cdot \\
\text { Idria. } \\
\text { Huancavelica } \\
\text { California . }\end{array}$ & $\begin{array}{l}\text { Year } \\
\text { I564 } \\
\text { I525 } \\
\text { I57 I } \\
\text { I } 850\end{array}$ & $\begin{array}{c}517,684 \\
399,86 r \\
88 r, 867 \\
-\end{array}$ & $\begin{array}{r}1,221,477 \\
608,743 \\
543,642 \\
-\end{array}$ & $\begin{array}{r}\mathbf{I}, 091,075 \\
242,226 \\
75,604 \\
-\end{array}$ & $\begin{array}{r}1,135,576 \\
301,549 \\
- \\
1,429,346\end{array}$ & $\begin{array}{l}3,965,812 \\
1,55^{2}, 379 \\
1,501,113 \\
1,429,346\end{array}$ \\
\hline & & $\mathrm{I}, 799,4 \mathrm{I} 2$ & $2,373,862$ & $\mathbf{I}, 408,905$ & $2,866,47 \mathrm{I}$ & $8,448,65^{\circ}$ \\
\hline
\end{tabular}

Mr. Becker has brought together a vast array of useful facts concerning the occurrence of quicksilver in his valuable monograph, which may be very briefly summed up as follows:Cinnabar is found in rocks of all ages and of all descriptions, viz., conglomerate, sandstone, quartzite, limestone, shale, slate, serpentine, crystalline schist, and basic and acidic volcanic rocks, but it exhibits a preference for sandstone. The quicksilver deposits are found along lines of country marked by past or present volcanic disturbances. This fact is made very plain by a map of the world on which are indicated all important occurrences of the metal.\$

Some cinnabar has certainly been precipitated from hot solutions brought up by volcanic springs, and it seems likely that many of the quicksilver deposits have been formed in this manner.\|

'The cinnabar is often found filling up interstitial spaces of the rock, and if the rock is sedimentary it sometimes cuts across the planes of stratification, and sometimes runs parallel to them.

* Precht, Die Salz-Industrie von Stassfurt und Umgegend. 4th edition, Stassfurt, I889.

+ Becker, "Geology of the Quicksilver Deposits of the Pacific Slope," Mlonographs of U. S. Geol. Survey, vol. xiii. Washington, 1888, p. 7 .
$\ddagger$ 1bid. p. 50.
§ 1bid. p. I5.
$\|$ Ibid. p. 55 . 
Spain.-The famous and productive Almaden mine is situated on the northern slope of the Sierra Morena, where the rocks coming up to the surface are of Silurian and Devonian age. These rocks are beds of sandstone and quartzite interstratified with slate and a little limestone. The cinnabar occurs impregnating the sandstone; the slate is rarely, if ever, quicksilver-bearing. There are three principal deposits extending for a distance of 200 to 220 yards ( 180 to $200 \mathrm{~m}$.) along the strike, the dip is almost vertical. The total useful thickness of the three beds is reckoned to be 40 feet $(12 \mathrm{~m}$.), and the mercurial rock yields on an average ro per cent. of metal. It seems probable that these sandstone beds were impregnated by aqueous solutions which came up from below. They may be called veins or beds according to the definitions one chooses to adopt for a vein. No doubt the cinnabar is of subsequent origin to the main part of the stratum; but the same may be said for the copper in the conglomerate beds of Lake Superior, and possibly for the gold in the "banket" of South Africa. The quicksilver solutions deposited their metal in cavities existing between the particles composing the sandstone, and I think in a case of this kind, where more than 90 per cent. of the deposit is matter of detrital origin, it is most convenient to speak of the deposits as beds. However, in two of the mercurial strata there are little strings and seams, either parallel to the bedding or crossing the planes of stratification in all directions. Looked at on a small scale, these strings could be called veins, but when one has to deal with the workable stratum as a whole it may be called a bed.

Austria.-At Idria, in Carniola,* cinnabar occurs in the Triassic

Fig. 63.

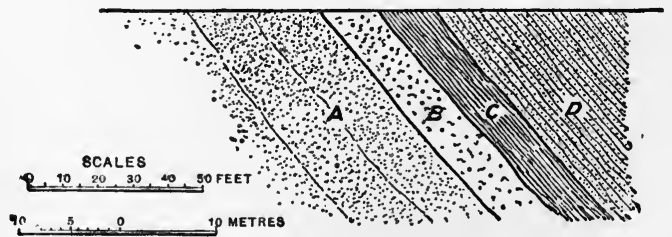

A, compact sandstone ; B, less compact sandstone impregnated wi h cinnabar 13 to 16 feet ( 4 to $5 \mathrm{~m}$.) thick; $\mathrm{C}$, shale ; D, thinlybedded sandstone.

rocks in three ways : (I) impregnating beds of shale, conglomerate and dolomitic breccia ; (2) filling up of cracks like ordinary fissure veins ; (3) in irregular veins across the mass, making a stockwork. Lipold supposes that it was introduced by watery solutions in late Tertiary times.

* Das k. k. Quccksillerverli za Idria in Krain. Vienna, ISS1. 
Russia.-An interesting and important deposit is being worked at Ekaterinoslav in Southern Russia, a section of which is given in Fig. 63. The cinnabar is disseminated through a sandstone, which lies between another bed of sandstone of a more compact nature and a bed of shale. Once more we have a case in which the mercurial solutions made their way upwards along the easiest channels they could find.

California.-The quicksilver deposits of California* are found in various parts of the State, from the extreme north to Los Angeles. The most important mine is New Almaden, situated about fifty miles to the S.E. of San Francisco.

In California, as in Austria, the deposits of cinnabar are of several types, even at one and the same mine. Thus, at New Almaden the commonest kind of ore-body is a network of veins and veinlets through the rock, in fact a stockwork. If the disturbance produced a clean fissure instead of a multitude of irregular cracks, then the single rent was filled up and produced what some would call a typical vein. Lastly, if the mercurial solutions traversed beds of sandstone, they deposited some of their contents in the interstitial spaces between the grains, and so formed an ore-bearing stratum. All three kinds of ore-bodies were formed by the same process of deposition, the difference, if I may use the simile, depending upon the lodgings that happened to be vacant, and not upon the lodger who came to take up his abode there, nor upon the vehicle that brought him to his new home.

The ore-bodies at New Almaden

FIG. 64.

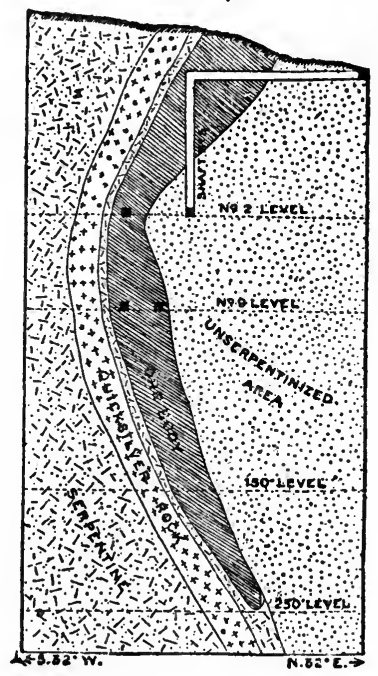
occur close to faults filled with clay and fragments of rock, more or less rounded by the attrition produced by movements of the "country." The name given to these faults by the miner is "altas," a Spanish term referring to their usual position on the hanging side of the deposit. It seems as if the impermeable clay had arrested and directed the course of the ore-bearing solution as it ascended; this is highly probable, and it is an explanation which has been offered in many cases when the ores of other metals have been found to " make up against a slide."

The surrounding rocks at New Almaden are metamorphosed

* Becker, op. cit. p. 317. 
sediments of Neocomian age, pseudodiorite, pseudodiabase, phthanites, sandstone, shale, and serpentine. The minerals accompanying the cinnabar are iron pyrites, marcasite, quartz, calcite, dolomite, magnesite, and rarely chalcopyrite.

The deposit worked at Great Western mine, 70 miles north of San Francisco, is a tabular reticulated mass of rock (Fig. 64),* impregnated with cinnabar and a little native quicksilver. It lies between serpentine and a very slightly altered Neocomian sandstone. The serpentine is accompanied by a belt of black opaline rock, called the "quicksilver rock" by the miners. The

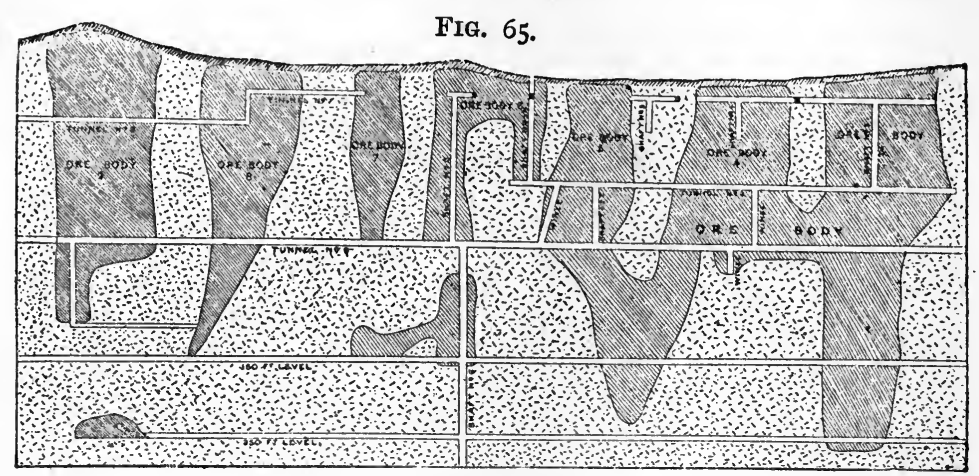

Scale of Feet.

longitudinal section (Fig. 65) explains that the ore-bodies are separated by spaces of barren ground, just as they are in an ordinary lode.

The Sulphur Bank mine is of interest because the solfataric action, which no doubt caused the deposition of the cinnabar, is still going on. At first the surface was worked for sulphur, which had been formed by deposition from sulphuretted hydrogen escaping through basalt, just as it does in so many places in the other volcanic areas. A few yards below the surface, the sulphur proved to be cinnabar-bearing, and lower down cinnabar was found in large quantities.

Cinnabar has since been worked from the strata underlying the basalt. There are beds of shale and sandstone of Neocomian age, in which the quicksilver ore is found as impregnations and irregular seams. The ore is accompanied by quartz, opal, iron pyrites, calcite, bitumen, and marcasite. This last mineral contains small quantities of gold and copper. Hot spings are common

* Becker, op. cit. p. 36 
in the mine, and many of them give off gases, viz., carbon dioxide, sulphuretted hydrogen, marsh gas, nitrogen and ammonia.

Nevada.-From a scientific point of view, one of the most interesting mineral deposits in the United States is that of Steamboat Springs in Nevada, only six miles from the Comstock lode. A number of hot springs exist along a series of fissures about a mile in length; siliceous sinter is being deposited by them, and there are also mounds of sinter formed by springs that are no longer flowing, or whose only sign of activity consists in emanations of steam, sulphuretted hydrogen, carbonic anhydride, and sulphurous anhydride. These solfataric gases also escape with the water at some of the living springs.

The sinter is found on analysis to contain many of the heavy metals, viz., antimony, arsenic, cobalt, copper, gold, iron, lead, manganese, mercury, silver, and zinc, some of them certainly existing in the form of sulphides.

A sample of the water taken from a spring with a temperature varying from 167 to $184^{\circ} \mathrm{Fahr}$. $\left(75\right.$ to $84.5^{\circ} \mathrm{C}$.) was analysed; it showed weighable quantities of arsenic and antimony, and a trace of mercury; as it cooled it could be seen to deposit the sulphides of antimony and arsenic together with silica.

In one part of the district, instead of sinter, a deposit like that at Sulphur Bank, consisting of sulphur and cinnabar, has been formed; and it has been worked for the commercial extraction of mercury.

Salt.-Sea water, salt lakes, brine springs and wells, saliferous marls and rock-salt are the sources of this very important mineral.

The extraction of salt from sea-water is carried on in Southern Europe and other countries, where the heat of the sun is sufficient to evaporate the water which has been led into shallow ponds; and the industry is fostered in many cases by the traffic in salt being a Government monopoly.

In South Africa and elsewhere salt is obtained from "pans" or shallow inland lakes, which become partially dried up in the hot season.

Natural springs yielding brine are not uncommon, and brine wells are dug or bored so as to reach a salt-bearing stratum.

At Northwich, ${ }^{*}$ in Cheshire, there are two main beds of rocksalt, each from 84 to 90 feet thick, separated by a bed of hard marl 30 to 33 feet thick. All these beds belong to the Keuper division of the Triassic rocks. The amount of rock-salt mined in England is small, only about one-tenth of that obtained from brine, which is pumped from flooded mines, and from wells or boreholes penetrating saliferous strata. * Dickinson, "Report on the Salt Districts," Reporis of the Inspectors of
Mines for the Year 1881, p. 55. 
Silver.-All galena carries some silver, and in very many cases there is enough to make the extraction profitable. Copper ores also are frequently argentiferous : the silver in the Mansfeld cupriferous shale has already been mentioned, and the ores of the Butte district, Montana, are often rich in the precious metal; it is needless, however, to dwell upon this and similar sources of silver, though they are of great commercial importance. Among well-known silver mines may be mentioned those of the great Comstock Lode in Nevada, the Eureka and Richmond mines in the same State, Huanchaca in Bolivia, and Broken Hill in New South Wales.

Comstock Lode.-This remarkable lode strikes about north and south and dips about $43^{\circ}$ to the east. The vein, which is usually from 20 to 60 feet thick and as much as several hundred feet thick in some places, consists in the main of crushed and decomposed portions of the " country" together with clay and quartz. The surrounding rocks are syenite and propylite, according to King,* or diorite and diabase, according to Becker. $\dagger$ The latter says that the so-called propylite is only a decomposed form of other rocks. The silver is found native and in the form of silver glance, polybasite, stephanite, and occasionally pyrargyrite; other minerals in the vein are quartz, iron pyrites, copper pyrites, besides oxides of iron and manganese, sulphates of calcium and magnesium and carbonates of magnesium, calcium, lead and copper. The ore-bodies are soft and irregular.

The heat of the Comstock lode is noteworthy. In the 2700 feet level of the Yellow Jacket mine, Mr. Becker found the temperature of the water to be $153^{\circ} \mathrm{Fahr}$. and that of the air $126^{\circ} \mathrm{Fahr}$., whilst the water of the Yellow Jacket shaft at a depth of 3065 feet had a temperature of $170^{\circ} \mathrm{Fahr}$.

Eureka-Richmond.-The nature of the curious lode worked at the Eureka-Richmond t+ mines will be best understood by reference to Fig. 66; much of it is a mass of crushed limestone of Cambrian age lying between two faults, a main one dipping N.E. at an angle of $70^{\circ}$, and a secondary one which is much flatter.

The main fault is a fissure filled with clay or with decomposed rhyolite and clay, varying from a few inches to 15 feet in width. It shifts the rocks many hundreds of feet, and at Eureka the throw exceeds 1400 feet. The valuable parts of the lode are orebodies of every possible shape and size, some measuring upwards of 100 feet in all directions. Above the water level, or horizon of decomposition by atmospheric agencies, the minerals constitut-

* King and Hague, "Mining Industry," U. S. Geol. Exploration of the Fortieth Parallel. Washington, I870.

+ "Geology of the Comstock Lode and Washoe District," Monograph 1II. of U. S. Geol. Survey. Washington, 1882.

$\ddagger$ Curtis, "The Silver-lead Deposits of Eureka, Nevada," Monog; VIII. of U. S. Geol. Survey. Washington, 1884 . 
ing the ore-bodies, are galena, cerussite, mimetite, wulfenite, with very little quartz and calcite, the remainder of the veinstuff being mainly hydrated oxide of iron carrying silver and gold, with some carbonate and silicate of zinc. Below the water level the minerals are pyrites, arsenical pyrites, galena, blende and a few other sulphides, besides silver and gold. One of the char-

FIG. 66.

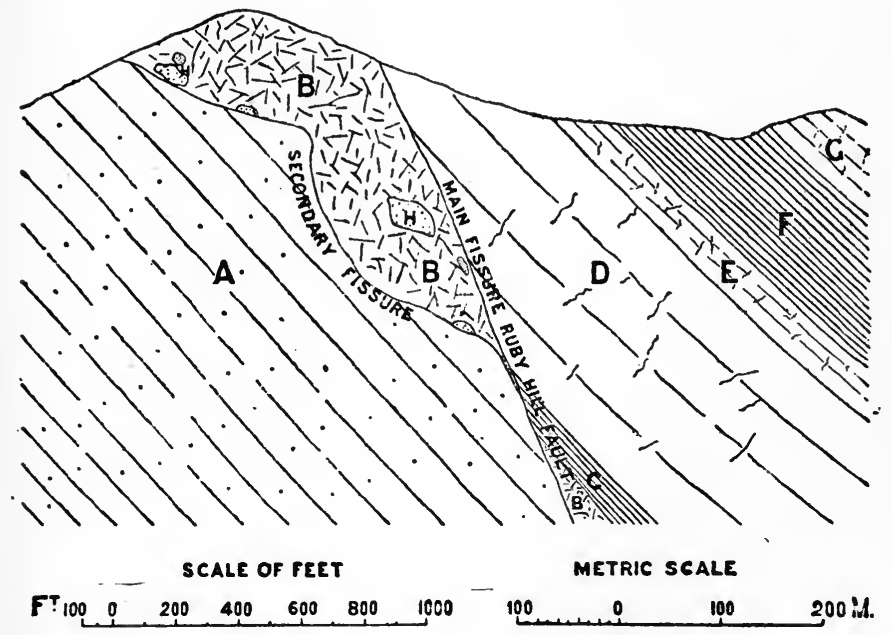

H. Ore.

G. Hamburg Limestone.

F. Secret Cañon Shale.

E. Stratified Limestone.

D. Limestone,

C. Shale.

Prospect Mountain Limestone.

B. Crushed Limestone.

A. Prospect Mountain Quartzite.

acteristics of the ore is the presence in it of gold in paying quantities. It is considered by Mr. Curtis that an eruption of rhyolite caused the upheaval which made the main fault in Ruby Hill; this eruption occurred in the Tertiary period. It is supposed that solfataric action decomposed some nassive rock and so formed metalliferous solutions, which ascended and, penetrating into the limestone, deposited the ore. Some of the ore is probably pseudomorphous after limestone. The average contents of all the Richmond ore worked in 1879 were :

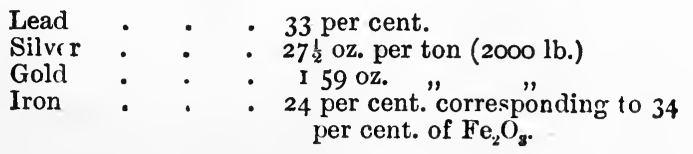


Huanchaca.-The mines of Huanchaca are situated near the town of that name in the department of Potosi in Bolivia, at a great altitude, for the entrance of the San Leon adit is I 3,500 feet above the level of the sea. The silver lodes occur in a soft decomposed trachyte; the actual silver-bearing mineral is fahlerz, containing about ro per cent. of the precious metal. Fortunately for the shareholders the percentage of silver increases with the depth of the mine. The accompanying minerals are galena, blende, iron pyrites, copper pyrites, with heavy spar and quartz, and rarely a little stibnite and pyrargyrite. The main lode runs about east and west, and is from 3 to ro feet in width ( 1 to 3 metres); it has three particularly rich shoots which incline from west to east. The total output of silver in 1887 was 4, 2 I 4,5 IO oz. ( 13 I, 086 kil.).

At the famous Potosi mines also, the silver occurs in a fahlerz.

Broken Hill.- The mines at Broken Hill are remarkable for their enormous output of silver and lead during the last few years. They are situated in the Silverton or Barrier Ranges district of New South Wales, near the western boundary of the colony. The deposit is generally spoken of as a vein or lode, but there seems some doubt whether this appellation is correct; further developments of the workings may prove that it is a bed. The vein, if it may be so called, runs, roughly speaking, N.E. and S.W.; the dip varies, being sometimes to the S.E. and sometimes to.N.W., and is always steep. At and near the surface, the vein * consisted of dark-brown hæmatite, of ten blackened by psilomelane, together with ferruginous carbonate of lead, kaolin, and the chloride, chlorobromide and iodide of silver; besides these there were pyromorphite, atacamite, cuprite, malachite, and chrysocolla, with quartz, quartzite, and garnet rock. Below this upper weathered zone, containing minerals usually met with in gozzans, come the sulphides, especially galena and zinc blende, together with pyrites, chalcopyrite, and mispickel. Some of the galena is so intimately mixed with the blende as to render its separation by any ordinary dressing process very difficult, if not commercially impossible. Ores of this class $\dagger$ contain 15 to 40 per cent. of lead, 15 to 30 per cent. of zinc, and 8 to 24 ounces of silver to the ton, and at present the owners of the mines have not settled what method of treatment will prove the most efficacious and economical. The width of the lode is from 15 to 316 feet. The enclosing rocks are gneiss and garnetiferous mica and talcose schists, and the vein lies

* John Provis, "Report on the Broken Hill Proprietary Co.'s Mines," contained in the Company's Reports and Stutements of Accounts for the Half Year ended Nov. 30th, 1886. Melbourne, Victoria. Jamieson and Howell, "Mining and Ore-treatment at Broken Hill, N.S.W.," Proc. Inst. C.E., vol. cxiv. (1892-93), Part IV.

+ Schnabel, "Vorschläge zur Verarbeitung australischer silberhaltiger Blende-Bleiglanzerze," B. u. h. Z., I882, p. 429. 
parallel to the planes of foliation. In the seven years ending 3 Ist May, 1892,* the principal mine, owned by the Broken Hill Proprietary Company, produced 984,349 tons of ore, which yielded $36,512,445$ ounces of silver and I 5 I,945 tons of lead, worth altogether $£^{8,252,138}$, of which $£_{3}, 896,000$ has been paid in dividends and bonus.

Silver-bearing Sandstone. - Silver is found in workable quantities in certain beds of sandstone, interstratified with shale, concidered to be of Triassic age, at Stormont in Southern Utah.† All the strata contain at least some traces of silver, but three or four special horizons were rich enough to be worked; even here the precious metal was distributed irregularly, and mining was confined to rich "shoots" or chimneys, which sometimes followed one particular stratum of the general ore-bearing bed, and sometimes cut across it. It is supposed that silverbearing solutions came up through the rock, and flowed along the portions which they found most porous. The precipitation of the silver was, perhaps, caused by the presence of organic matter. The metal exists in the form of sulphide and chloride, though there is a little native silver. These minerals are disseminated through the sandstone, and occur especially along the planes of bedding and of fracture. The ore-beds were mined for a thickness of six, eight, or even ten feet, though the whole of the rock was not always worth milling. Much of the ore milled about 1879 contained from 20 to $30 \mathrm{oz}$. of silver per ton, and yielded by amalgamation 15 to $24 \mathrm{oz} . \ddagger$

Garfield Mine, $\$$ near Calico, California, owes its existence to a network deposit or stockwork. The surrounding rock is liparite or rhyolite, which is traversed near by a number of irregular fissures. The cracks contain kerargyrite and embolite, with chrysocolla and heavy spar, and the stockwork may be described as a breccia of liparite cemented by the argentiferous and other minerals.

Slate.-Wales is so renowned for its slate that the example of a deposit of this mineral may fairly be taken from the Principality. About two-thirds of the Welsh slate are got from beds of Cambrian age in Carnarvonshire, and one-third from beds in the Lower Silurian (Ordovician) rocks in Merionethshire. The quarries in the former county are mostly open, whilst in the latter the local conditions have led to the adoption of true mining, especially at Festiniog, which can boast of the most extensive underground

* Company's Half-Yearly Report, dated July 27, i892, p. 86.

+ R. P. Rothwell, "Report on the Stormont Silver Mining Company's Property, Silver Reef." Utah, 1879.

¥ Jackson, "Silver in Sedimentary Rocks," Report of the Directors of the U.S. Mint. Washington, $188 \mathrm{r}$, p. $3 \dot{8} 4$.

$\S$ W. Lindgren, "The Silver Mines of Calico, California," Trans. Amer. Inst. M.E., vul. xv. (I\&S6-87) p. 725. 
workings for slate in the world. The northern part of the parish of Festiniog is occupied by the outcrop of a thick series of slaty rocks (K, Fig. $\left.67^{*}\right)$, resting upon coarse volcanic agglomerate, $\mathrm{H}$, and interstratified with thinner beds of volcanic ash, and intersected from time to time by intrusive dykes of diabase, locally called whinstone. The beds have a general northerly or northwesterly dip of $20^{\circ}$ to $35^{\circ}$, whilst the cleavage planes throughout the district dip at a greater angle than the bedding by about $15^{\circ}$, and very nearly in the same direction.

Owing to peculiarities of texture, due apparently to the fineness of the sediment deposited upon the old sea-bottom, certain beds or sets of beds furnish a slate which can be split into very smooth sheets, as thin as $\frac{1}{16}$ inch and even less. Any set of beds worked as a whole is known locally as a " vein," but it does not necessarily furnish saleable roofing material for its entire thickness. Some-

FIG. 67.

Dolwen. Foel.

Foel Rydd.

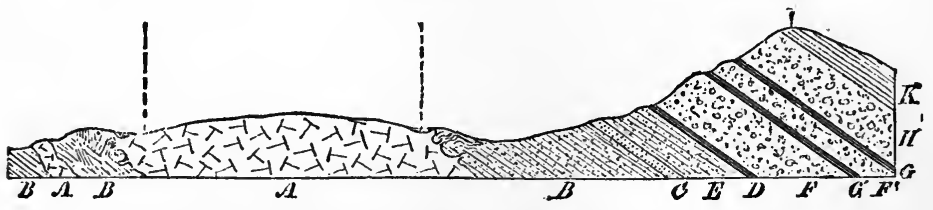

A, granite; B, Tremadoc rocks ; C, Garth Grit ; D, Lower Slate ; $\mathrm{E}$, Arenig rocks above the grit ; F, Lower Agglomerate; $\mathrm{F}^{\prime}$, Middle Agglomerate; G', Middle Slate; G, Upper Slate; H, Upper Agglomerate ; $K$, Llandeilo slates.

times unprofitable rock is taken away above the good slate in order to reach a firm layer, such as a bed of volcanic ash, or a "whinstone" dyke, which can be trusted to stand as the roof of the underground chambers, and at others the fine-grained slate has beds of coarser sediment interstratified with it, which cause irregularities in the planes of cleavage, and so give rise to inferior products.

The "Old Vein," famous for the quality of its slates, is 120 feet (36.5 m.) thick at the Oakeley quarries, where other "veins" of less importance are also being worked (Fig. 68). At some of the other quarries of the district, beds of slate in the underlying rocks of the Arenig series are found to be profitable, such as $G^{\prime}$ in Fig. 67, and $\mathrm{I}$ in Fig. 68.

The property possessed by the slate of rending along planes, cutting across both dip and cleavage, must not be forgotten, for upon it depend both the getting of the rock and the direction given to the supporting pillars. At the Oakeley quarries the "line

* Jennings and Williams, "Manod and the Mozlwyns," Q. J. Geol. Soc. vol. xlvii. (I891), p. 368 . 
of pillaring," that is to say, the direction along which the croserending or rifting takes place most readily, runs about $\mathrm{N} .7^{\circ} \mathrm{W}$., whereas the dip is N. $40^{\circ} \mathrm{W}$. The planes along which the slate rends or " pillars" best are at right angles to the cleavage planes, not quite vertical, but dipping at a high angle to the east; the consequence is that the eastern side of an underground chamber at these quarries overhangs slightly.

The value of a slate bed, or "vein," depends greatly upon the number and nature of the natural joints by which it is intersected. If they are very numerous, the workings will yield blocks too small for making the larger and higher priced sizes of slates; if they are rare, more expense will be incurred in severing the material from its bed. Disturbances of the strata resulting in

Fig. 68.

\section{Section of the OAKelex Quarries, Festiniog.*}

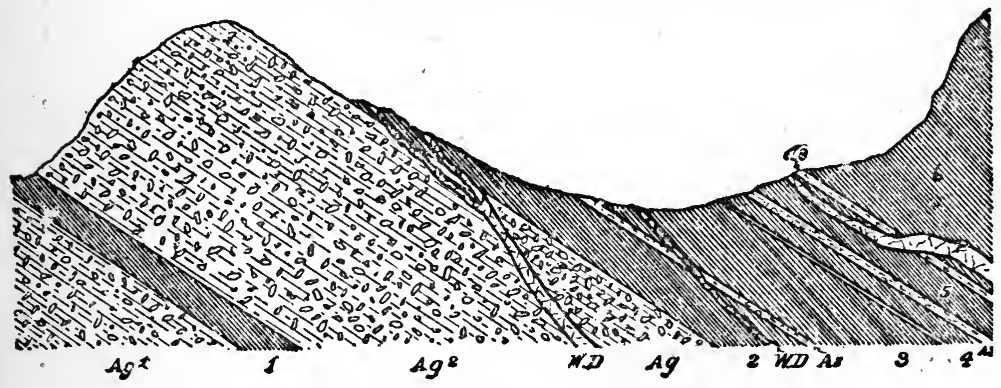

$\mathrm{Ag}^{1}, \mathrm{Ag}^{2}, \mathrm{Ag}$, volcanic agglomerates; I, slate vein worked at Wrysgan and New Quarry, Diphwys ; 2, new or south vein ; 3, old vein; 4, 2 A vein ; 5 , back vein; 6 , north vein ; WD, "whinstone" dykes (diabase); P, porphyrite ; As, volcanic ash.

fissures filled either mechanically with clay and broken slate, or chemically by the deposition of quartz, may render the "vein" utterly worthless in places; but, as in the case of other bedded deposits, changes in productiveness are far less frequent than with lodes.

Sulphur.-The industrial sources of sulphur are: (I) deposits of native sulphur, and (2) iron pyrites.

Native sulphur occurs as a product of volcanic emanations, and in sedimentary deposits.

The amount of sulphur obtained from deposits of volcanic origin is small; but this mode of occurrence is of geological interest, because we can observe the processes of accumulation in actual operation, whereas usually the secrets of Nature's laboratory are hidden from us.

* Made by Mr. G. J. Williams, F.G.S. 
Deposits of this kind are generally found at or near spent volcanic craters, the emanation of sulphurous gases being one of their last signs of activity. Sulphur has been worked on a small scale

Fic. 69.

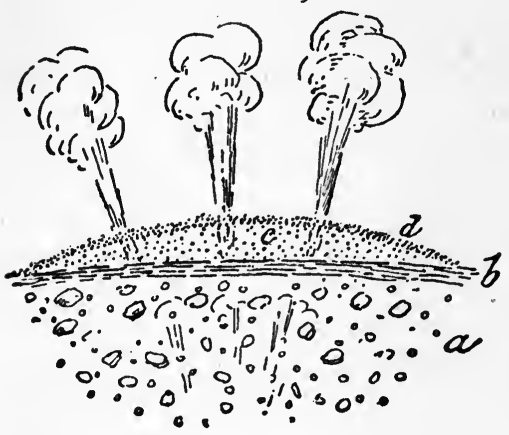
at the famous Solfatara of Pozzuoli, near Naples, at Vulcano, one of the Lipari Islands, and in volcanic regions in various parts of the world.

In Iceland a little column of vapour may be seen issuing from the ground, and the low mound around it consists of a crust of sulphur covered by a thin coating of blown sand. The gases coming out of the earth contain sulphuretted hydrogen in addition to steam, and

when they reach the surface some of the former is oxidised, and sulphur is deposited as shown in Fig. $69 ; a$ is the underlying rock, a decomposed lava, $b$ clay, $c$ the native sulphur, and $d$ sand blown over the little mound, and retained by the moisture due to condensation of the steam. I have already alluded to Sulphur Bank and Steamboat Springs, in speaking of quicksilver.

Seams or beds of sulphur occur in Sicily, Calabria, the Romagna, and other parts of Italy, and also in Croatia, Spain, and France. By far the most important beds are those of Sicily.

The accompanying section, borrowed from Baldacci * (Fig. 70), shows a section of the country near Caltagirone. The letter $a$

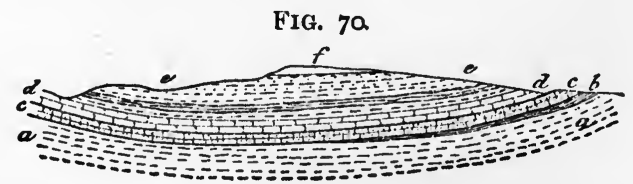

denotes beds of clay (Tortonian), $b$ is tripoli (Sarmatian), $c$ is the bed of sulphur-bearing limestone, $d$ white marl or marly limestone with foraminifera, called "trubi" in Sicily; $e$, blue clay; $f$, calcareous tufa. The beds $a, b, c$ are considered to belong to the Upper Miocene, whilst $d$ is placed in the Lower Pliocene, and $e$ and $f$ in the Upper Pliocene.

The beds of tripoli are made up chiefly of the siliceous remains of radiolaria, diatomaceæ, and sponges, together with marl.

- Descrizione geologica dell' Iscla di Sicilia. Rome, 1886, p. 296. 
The sulphur-bearing bed varies from a hard white limestone to a grey marly limestone, and from this to a marl ; the sulphur itself is always in the native state, forming little globules, laminæ, or irregnlar lenses, varying in thickness and extent. It is often crystallised, and associated with it are celestine, gypsum, calcite, and arragonite ; in the clayey beds there is also bitumen, which is objectionable, as it gives a dark colour to the product obtained by liquation.

The thickness of the sulphur seams varies within very wide limits. Beds $20^{\circ}$ feet thick are common, and at Lercara the stratum reaches the enormous thickness of 164 feet $(50 \mathrm{~m}$.). Frequently there are two or three beds; at the great Somatino mine, for instance, the deposit is 100 to I I 5 feet ( 30 to $35 \mathrm{~m}$.) thick, divided into six separate seams, from 6 to 25 feet ( 2 to $8 \mathrm{~m}$.) each, by partings of barren rock.

As a rule, a bed less than 5 feet $(1.50 \mathrm{~m}$.) in thickness is not worth working, unless it is exceptionally rich or conveniently situated for working.

The yield of the sulphur rock may be taken on an average at about 22 per cent., though occasional rich seams give as much as 45 per cent.

Parodi* subdivides the seams according to quality, thus :

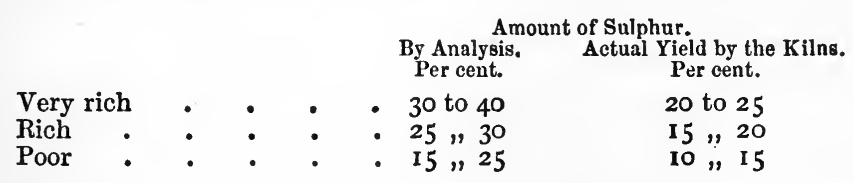

The Sicilian deposits are considered to have been formed by chemical precipitation from aqueous solutions in lakes. $\dagger$

The deposits on the Italian mainland also belong to the Miocene period, and the sulphur beds are known to extend for a long distance on the east of the Apennines. Often there is but one seam 6 to 10 feet $(2$ to $3 \mathrm{~m}$.) thick; the rock is poorer than in Sicily, for it contains only 18 to 20 per cent., and the yield by the kiln (calcarone) does not exceed $\mathrm{I} 2$ per cent. on an average.

After the description of the deposits of cupreous pyrites at Rio Tinto, it is quite unnecessary to say anything further about such sources of sulphur. Iron pyrites containing no copper is sometimes worked, and Cae Coch Mine, in Carnarvonshire, affords an example of a deposit of this kind.

Tin.-Tin ore is obtained from veins, beds, and a variety of irregular deposits.

It is natural for an Englishman to take his illustrations of

* Sull' estrazione dello Solfo in Sicilia. Florence, 1873, p. то.

+ "No'izie sulle condizioni dell' industria solfifera e di quelle ad essa affini," Rivista del servizio minerario nel 1899 . Florence, $1890, \mathrm{p}$. clxv. 
veins from Cornwall. Figs. $7 \mathbf{I}$ and 72 represent two veins in the parish of St. Agnes.*

FIG. 71 .

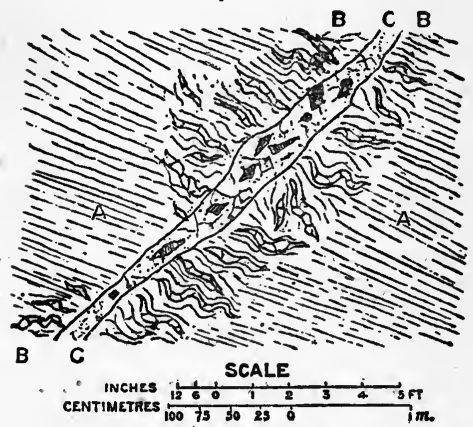

A, slate (killas) ; B, capel-that is to say, slate altered into a hard darkcoloured mass of quartz and schorl with short lenticular veins of quartz, and traversed by little strings of cassiterite and chlorite; $\mathrm{CC}$, the leader, consisting of quartz, cassiterite, chlorite, a little iron pyrites, and pieces of capel.
FIG. 72.
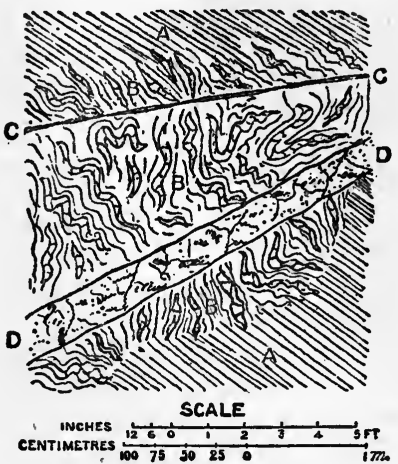

$\mathrm{AA}$, slate (killas); $\mathrm{BB}$, capel as above; $\mathrm{CC}$, small leader or vein of tinstone and quartz; DD, main leader, consisting of iron pyrites, cassiterite, and chlorite, containing about $2 \frac{1}{2}$ per cent. of tirstone.

Many of the veins in granite are due to the alteration of the rock in the neighbourhood of fissures, as has been already explained (Fig. 3). The so-called carbonas of the St. Ives district are essentially masses of stanniferous schorl rock, very irregular in shape and connected with a main lode by a cross joint or fissure. They seem to be altered granite.

Mulberry Mine, near Bodmin (Fig. I6), has already been cited as an instance of a network deposit or stockwork.

At Altenberg, in Saxony, there is a huge mass of tin-bearing rock, locally known as "Zwitter" or "Zwittergestein." Von Cotta $\dagger$ has shown by analyses that it is merely granite, which has lost about 3 per cent. of silica and 2 per cent. of potash, and has taken up about 4 per cent. of ferrous oxide and $\frac{1}{2}$ per cent. of oxide of tin. It has been worked for tin during a period of several centuries.

Beds containing tin ore in the form of rolled pebbles and sand occur with the alluvial deposits of existing valleys in many countries. The principal Cornish deposits have long

* C. Le Neve Foster, "Remarks upon some Tin Lodes in the St. Agnes District," Truns. R. Geol, Soc. Cornwall, vol. ix. p. 206.

+ B. von Cotta, "Die Steingruppe im Hofe der Bergakadernie," Festschrift zum hundertjährigen Jubiläum der Königl. Sächs. Bergakademie zu Freiberg. Dresden, I886, p. 157. 
been exhausted, though as lately as 1873 tin ore was raised from a bed under Restronguet Creek, a branch of Falmouth Harbour (Fig. 364). In the Malay Peninsula alluvial deposits or "stream works" are yielding large quantities of ore; and New South Wales is remarkable not only for its recent stanniferous alluvia, but also for much older deposits, which, like the ancient gold gravels, have been preserved under a covering of basalt. The accompanying map (Fig. 73) shows part of Vegetable Creek, New South Wales; the stippling by the side of the creek represents the tin-bearing alluvium, which has been worked by open pits. The rest of the courtry is granite, except the shaded part at $A B$

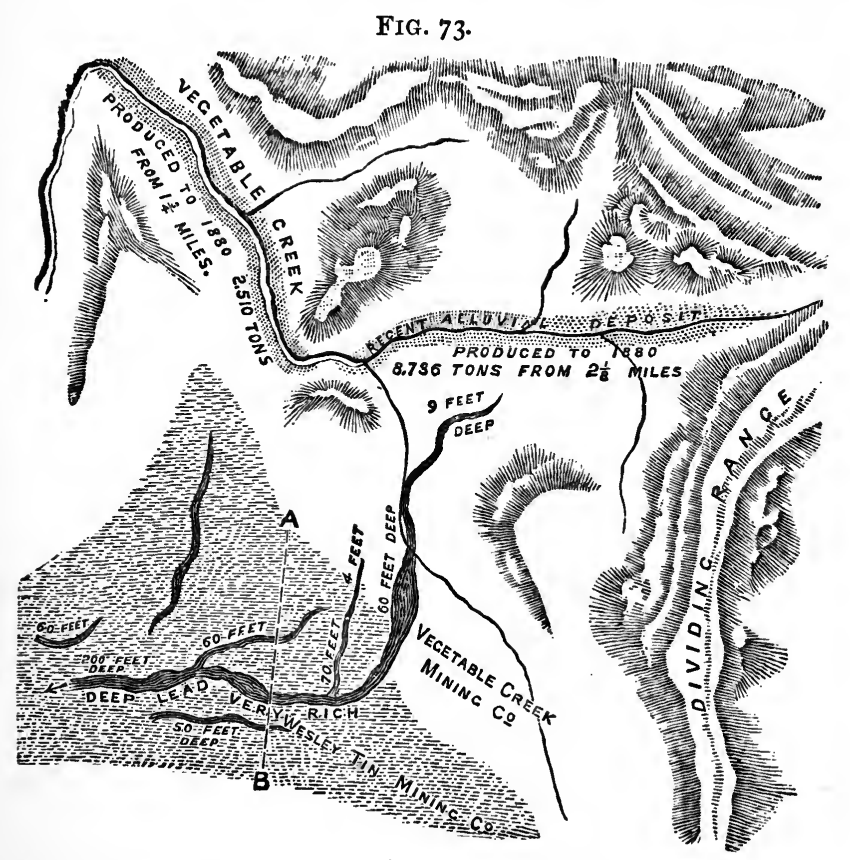

which denotes basalt; this flowed down an old valley and filled it up entirely, as shown by the section (Fig. 74). The hard cover of lava has preserved the stanniferous alluvium and the white clay from denudation. Old alluvia of this description are known as " deep leads."

Zinc.-Zinc ore is found in veins, beds, and irregular masses.

Liuderich mine, situated near Bensberg, on the right bank of the Rhine, not very far from Cologne, derives large quantities of blende from a huge vein in the Devonian rocks. The actual horizon is that of the "Lenneschiefer," which is classed as Middle 


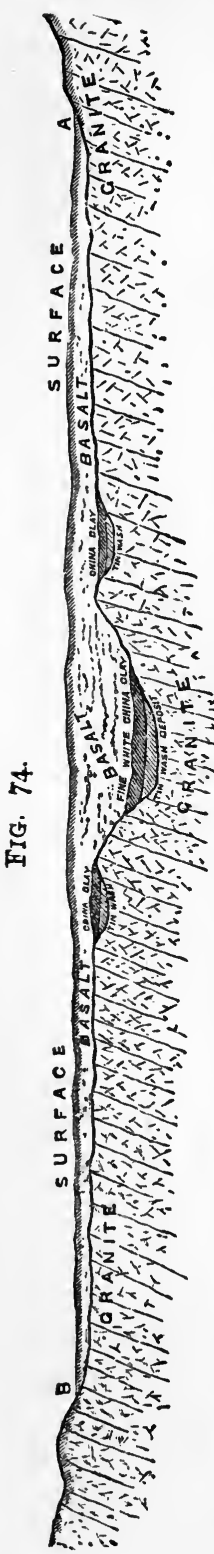

Devonian. The rocks are slate, interstratified with sandstone and slaty sandstone. The lodes of the district, as a rule, run E. and W., or a little north of west ; the Lüderich mine, however, is an exception, for the lode strikes, roughly speaking, north and south. It may be best described as a zone or belt of broken and disturbed rock, 40 to 50 metres wide, containing ore in irregular veins and masses. The ore-bodies are usually lenticular in shape, dying out gradually in every direction; they sometimes consist of solid blende for a width of several yards. The minerals found in the lode are: blende, galena, copper pyrites, iron pyrites, fahlerz, quartz and, rarely, chalybite. The fahlerz is silver-bearing, and the blende always contains cadmium, and occasionally gallium. The total production of the mine in 1890 was 8304 tons of blende ready for the smelter, and 423 tons of lead ore. It is therefore of more importance as a zinc mine than any in this country.

The largest zinc mine in the British Isles at the present time is Minera, near Wrexham. It may be safely inferred from its name that it was worked during the Roman occupation of the country; but the object of the mining in those days, and, indeed, until quite a recent date, was lead and not zinc ore.

The surrounding rocks are Carboniferous Limestone and Millstone grit, and as the lode is a well-marked fault, the Coal Measures are met with on the downthrow side. There are two principal veins running parallel to one another in a general N.W. and S.E. direction, and dipping steeply to the N.E. ; and where productive they are nearly perpendicular. They vary in size from a mere cleft in the rock to a width of 18 feet; a fair average size is 6 feet. Besides these two main veins there are numerous branches and ramifications. The valuable minerals are zinc blende and galena, and, as would be expected, the matrix consists mainly of calcspar. In the upper parts of the mine to a depth of 220 yards, galena was met with in large quantities, and the mine made considerable profits upon its sales of lead ore; but during the last twelve years blende has greatly predominated. At the present time it may be reckoned that the "stuff" 
brought up from the mine yields $7 \frac{1}{2}$ per cent. of blende and $1 \frac{1}{2}$ per cent. of galena. The total production of the mine in $189 \mathrm{r}$ was 5433 tons of zinc ore and 906 tons of lead ore ready for the market.

At *Ammeberg, near the northern extremity of the Wetter Lake, in Sweden, zinc blende occurs in beds. The surrounding rock is $a$ schist consisting of felspar and quartz, with a little mica, which may be regarded as a variety of gneiss. The blende is accompanied by iron pyrites, pyrrhotine, hornblende, chlorite, garnet, tourmaline and other minerals, and in places it may be plainly seen to replace the mica of the gneiss. The Ammeberg beds are worked on a large scale by the Vieille Montagne Company.

Diepenlinchen mine, near Stolberg, in Prussia, is interesting not only on account of being a large producer of zinc ore, but also because some of it is derived from a great stockwork, a form of deposit less common with zinc than tin. The stockwork consists of an oval mass of limestone, about I 20 metres long from east to west, and 50 metres across from north to south. In this region the limestone is full of cracks, which have been filled up with zinc blende, and this mineral is also seen lining small irregular cavities in the rock; judging by its structure it has been deposited layer after layer, and probably from an aqueous solution. The rock is so intermingled with blende that the whole of it has to be worked away, and the separation of the valuable constituent from the waste is effected by dressing.

Fig. 15 is a section across one of the irregular masses of calamine at Altenberg, in the neutral territory of Moresnet, between Belgium and Prussia.

FAULTS.-All kinds of deposits are subject not only to irregularities dependent upon their mode of formation, such as a gradual thinning out or thickening, but to others which have taken place subsequently. Sometimes a bed, such as $A B$, has had a portion denuded by a current during the general period of deposition. Such an occurrence is called a "wash out" fault, or " dumb fault" (Fig. 75).

In addition to irregularities of this kind, deposits suffer from the disturbances which have taken place in the rock masses which contain them. Slight undulations of the strata are cornmon, and when the disturbance has been greater, the beds are bent into arches and troughs, or anticlinals and synclivals. Further, a

* A. von Groddeck, Die Lehre von den Lagerstätten der Erze. Leipsic,
1879, p. II I. 
lateral pressure may have been sufficient to cause great crumplings and contortions, and in places to invert the order of succession, in other words to make the newer beds lie under, instead of above, the older ones. When beds are much bent there is often a thickening in the anticlinals and synclinals, and a corresponding thinning in the connecting limbs.

A bed may be so folded and crumpled as to lose its original

F1G. 76 .

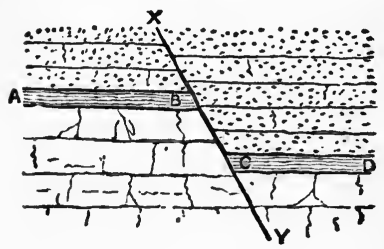
sheet-like form in places, and assume the shape of an irregular mass. This may happen even with a coal seam.*

The disturbances of the rocks may finally produce rents, accompanied by displacement, which are called faults, heaves, throws, or slides.

We will take the case of a bed (Fig. 76). AB is a seam which ends suddenly at $B$, whilst the continuation is found at a lower level, CD. The two parts of the bed must have originally been on the same horizon, but subsequently a fracture took place along the line $\mathrm{XY}$, followed by a movement of one side or both sides. As a rule the portion of rock on the upper or hanging wall side appears to have slid downwards, or the under portion to have been thrust upwards.

The rent may be clean, sharp, and narrow, with the shifted portions of rock touching each other; or there may be a suc-

Fig. 77 .

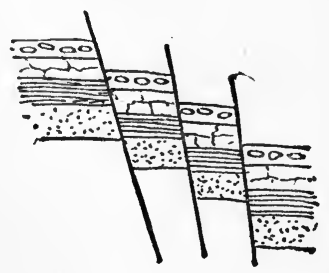

FIG. 78.

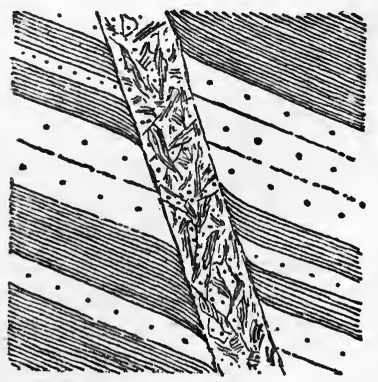

cession of fissures producing a step-like arrangement of the seam (Fig. 77) ; frequently the cracks are filled up with clay, or there is a zone several yards in width composed of broken fragments 'and clay, produced by the attrition of the sides of the two rock masses (Fig. 78). Signs of rubbing may be seen upon the walls

J. Callon, Lectures on Mining, vol. i. p. 63, and Atlas, Plate VIII., Fig. 44 . 
in the form of grooves and scratches, or polished surfaces known as "slickensides." A fault is of the same origin as a mineral vein ; the filling is due either to mechanical or chemical agencies, or to both combined, but does not happen to be worth working commercially. The prolongation of a valuable mineral vein may be unproductive on entering certain rocks, and will then be looked upon as a fault. Thus, some of the mineral veins of the Carboniferous Limestone in Flintshire appear to be continued as faults in the Coal Measures.

The throw of a fault is measured by the amount of vertical displacement. If $\mathrm{XY}$ is a fault shifting a bed $\mathrm{AB}$ (Fig. 79), draw $\mathrm{BE}$ vertical and $\mathrm{CF}$ at right angles to $\mathrm{BE}$. Then $\mathrm{BF}$ is the vertical downthrow, CF represents the horizontal displacement, and $\mathrm{BC}$ the shift along the line of dip.

The study of faults is important hecause the miner working the bed $\mathrm{AB}$ (Fig. 78), wants to know after reaching the fault $X Y$ where to find the continuation of the deposit. The rule is to follow the greater angle. The angle ABY is greater than the angle $\mathrm{ABX}$, and the missing part may be expected somewhere along the line BY. If the miner were working from $\mathrm{D}$ to $\mathrm{C}$, the same rule would apply, for the angle DCX is greater than DCY.

This rule gives the direction of the throw, but affords no indication as to its amount, which may vary considerably. If the beds are distinctly marked by lithological peculiarities or by fossils, the miner can obtain useful information by driving through the fault into the rocks upon the other side. Suppose, for instance, that a valuable bed of shale AB (Fig. 80) ended off suddenly against a fault $F G$. A continuation of the workings in the direction $\mathrm{AB}$ comes upon a bed of conglomerate, which the miner recognises as one

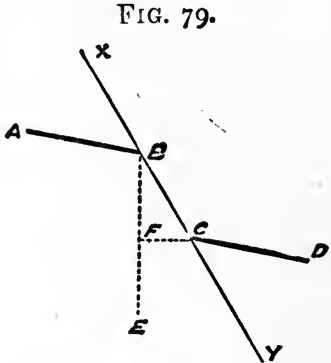
that is usually 40 feet above him. He can fairly conclude that the distance $\mathrm{BE}$ at right angles to the prolongation of $\mathrm{DC}$ will be 40 feet. As the respective dips of the bed and of the fault are known, the angle $\mathbf{E B C}$ can at once be ascertained and the distance $\mathrm{BC}$ calculated.

The throw of a fault is not always the same; it varies along the strike, and finally dies away altogether. This will be understood by making a slit with a penknife through a sheet of cardboard 
or india-rubber, and pressing down one side; the throw diminishes from a maximum at $\mathrm{C}$ to nothing at $\mathrm{A}$ and $\mathrm{B}$ (Fig. 8I). Change in the direction of throw may be due to the beds on

Fig. 8r.

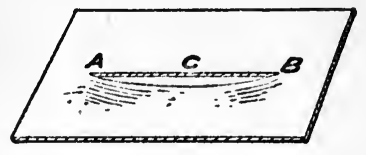

Fig. 82.

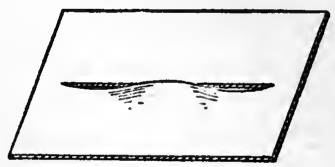

one side of a fault being puckered or bent, whilst they are flat or dip evenly on the other (Fig. 82).

The distance to which some faults may be traced is very great. The Gorze-Ars-Metz fault* extends from St. Julien in France, right across Lorraine to beyond the Saar, near Wacheren, a total distance of 53 miles ( 85 kilometres), and another fault in the same district is known for 28 miles (45 kilometres). The throw of a fault varies from a few inches to hundreds and even thousands of feet.

Near a fault a bed is often found to dip more steeply, as if it had been bent before it broke. 'This is the case with the great iron ore bed of Lorraine.t The usual dip is very slight, only I to $2 \frac{1}{2}$ in a hundred, but near faults it is decidedly more, and reaches 4 in a hundred.

The rule that the portion of the hanging wall side has shifted downwards along the dip of the fault is not without exceptions,

FIG. 83 .

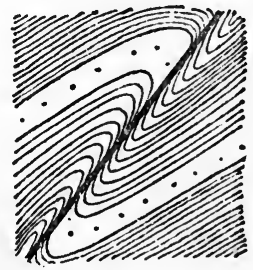

FIG. 84.

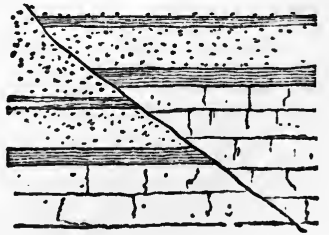

especially in localities where rocks are much bent and folded. Heim shows by a series of figures the various stages in the production of a displacement of this kind, which is known as a reversed or overlap fault (Fig. 83). Fig. 84 also shows a reversed fault.

As mineral veins have been formed in regions where rocks have been broken and dislocated, it is only natural to expect that

* Wandesleben, “ Das Vorkommen der oolitischen Eisenerze (Minette) in Lothringen, Luxemburg und dem östlichen Frankreiche." Festschrift und Verhandlungen Der $1 \mathrm{~V}$. Allgemeine Deutsche Bergmannstag in Hdile (Saale.) Halle, 1890, p. 301.

† Ibid. p. 301 . 
they also should be affected by movements and shiftings of the earth's crust. Owing to the fact that veins are usually highly inclined, and that there is often much difficulty in deciding how the dislocated rocks fitted together before they were shifted, the vein miner speaks of faults in different terms to the bed miner. Instead of talking of downthrows and upthrows, he looks at the shift produced sideways and calls it a heave. The miner driving a horizontal tunnel $\mathrm{AB}$ (Fig. 85) in a vein, comes into the fault $X Y$ at the point $B$, and finds that his vein ends off suddenly ; in order to regain it he is obliged to drive sideways in barren ground from $\mathrm{B}$ to $\mathrm{C}$, where he meets with the continuation along the line CD. The miner says that there has been a lefthand heave, because whether driving in the direction $\mathrm{A}$ to $\mathrm{B}$ or $\mathrm{D}$ to $\mathrm{C}$, he finds the faulted portion to the

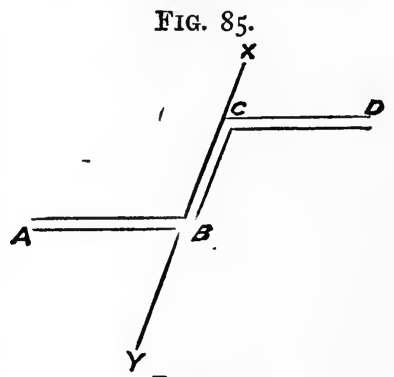

Plan. left hand. It is evident in many cases from the striations upon the walls of the faults, that the displacement of the two adjacent rock masses took place, not along the line of greatest dip, but in a diagonal direction, causing a shifting sideways as well as downwards. Nevertheless, where beds or veins are not horizontal, a mere shift along the line of dip is suffcient to cause a heave sideways. This will be understood from Fig. 86. Let AB and CD represent two portions of the lode dislocated by the fault EF. The point $\mathrm{B}^{\prime}$ corresponded originally with $\mathrm{B}$, and the dislocation was caused by the simple sliding of $\mathbf{B}^{\prime}$ along the line of dip of the fault. Here again the miner would speak of the heave as taking place to the left.

The subject of the heaves of lodes and beds has been elucidated by Schrnidt,* Zimmermann $t$ and others.

Zimmermann's rule for finding the lost part of a vein on the other side of a fault is as follows :

Lay down upon paper the line of strike of the lode and the line of strike of the fault (cross-course), and by construction ascertain the horizontal projection of the line of their intersection; from the point where the cross-course was struck by the lode, draw a line at right angles to the strike of the former and directed to its opposite wall. Notice on which sile of the line of

* Theorie der Verschiebung älterer Gänge. Frankfort, 1810.

+ Die Wiederausrichtung verworfener Gänge, Lager und Flotze. Darmstadt and Leipsic, 1828 . 
intersection this perpendicular falls, and, after cutting through the cross-course, seek the heaved part of the lode on that side.

Thus let AB (Fig. 87) represent, at some given depth, the line

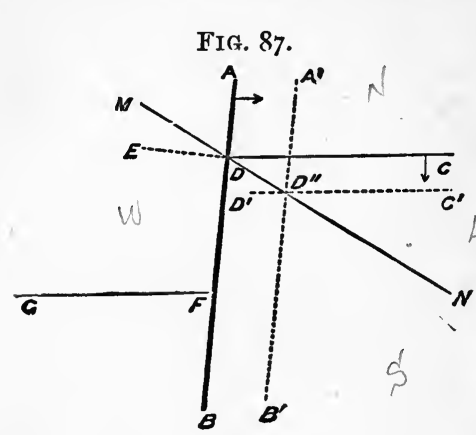
of strike of a fault or crosscourse dipping east, and CD the line of strike of a lode dipping south, and we will sup. pose that in driving from $\mathrm{C}$ to $\mathrm{D}$, in a westerly direction, the fault has been met with at $D$. Knowing the dip of the lode and that of the fault, it is easy to lay down, on any given scale, $\mathrm{A}^{\prime} \mathrm{B}^{\prime}$ and $\mathrm{C}^{\prime} \mathrm{D}^{\prime}$, the lines of strike of the fault and lode respectively at a certain depth, say ten fathoms, below AB.

The point $\mathrm{D}^{\prime \prime}$, where $\mathrm{A}^{\prime} \mathrm{B}^{\prime}$ and $\mathrm{C}^{\prime} \mathrm{D}^{\prime}$ meet, is one point of the line of intersection. Join $\mathrm{D}$ and $\mathrm{D}^{\prime \prime}$ and prolong on both sides. The line MN represents the horizontal projection of the line of intersection of the two planes. At $\mathrm{D}$ erect $\mathrm{DE}$ at right angles to $A B$, and directed towards the opposite wall of the fault. As

FIG. 88.

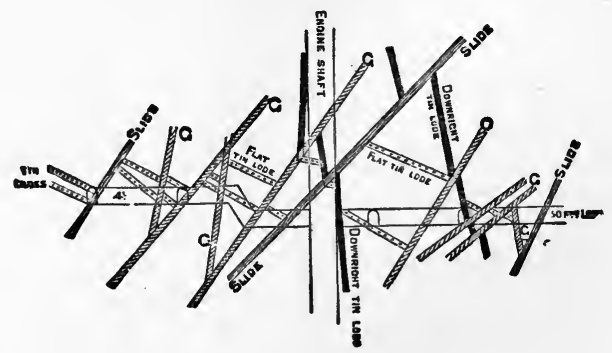

DE falls south of MN, the miner, after cutting through the fault would drive in a southerly direction, and eventually strike the lode again at $F$. It will be at once understood that if the miner were following the lode from $\mathrm{G}$ to $\mathrm{F}$, the perpendicular would lie to the north of the line of intersection, and following the rule he would drive in that direction, after cutting through the fault.

When several faults dislocate lodes one after the other very great complications may arise.

Fig. 88* is, fortunately for the miner, an unusual instance of a succession of faults.

* J. W. Pike, "On some remarkable Heaves or Throws in Penhalls Mine," Quart. Jour. Geol. Soc., vol. xxii." (1866), p. 537. 


\section{$(93)$}

\section{CHAPTER II.}

\section{PROSPECTING.}

Chance discoveries.-Adventitious finds.-Uses of geology.-Associated minerals.-Surface indications : form, colour, gozzans, springs, indicative plants, burrows of animals. - Shoading.-Hushing.-Piercing.Lode-lights.-Altered regetation and other indications.-Old workings, slag heaps, ruins. - Names of places.-Divining-rod.-Dipping needle. -Qualifications of the prospector.

Chance Discoveries.-The number of discoveries of valuable mineral deposits by pure chance is very great. I will mention a few cases, mostly recent, taking the minerals in alphabetical order.

Amber.-Pieces of amber cast up on the shores of the Baltic after storms, no doubt were the first sources of supply of the mineral, and eventually led to a search for the parent beds.

Cobalt.-The cobalt ore recently worked in Flintshire was discovered in 1870 , by Mr. Gage, who happened to test with the blowpipe some black matter which formed strings in the Carboniferous Limestone.

Copper.-The owner of a sheep run on Yorke's Peninsula, South Australia,* picked up some atacamite on the coast in 1859 , and became convinced that there were deposits of copper ore inland. In 1860 he came across the workings of a wombat which had thrown out a quantity of this green ore in making its burrow. Pits were put down, and the great Wallaroo lode was thus discovered. Other lodes in the district were afterwards hit upon in the same way, or from green ore thrown up by some burrowing insect.

Diamonds.-The fate of South Africa has been wholly changed by the finding of diamonds. Mr. O'Reilly, a trader, describes his discovery in these words :-

"In March I867, I was on my way to Colesberg, from the junction of the Vaal and Orange Rirers; I outspanned at Mr. Niekerk's farm, where I saw a beautiful lot of Orange River stones on his table, which I examined. I told Niekerk they were very pretty. He showed me another lot, out of which I at once picked the 'first diamond.' I asked him for it, and he told me I could have it, as it belonged to a Bushman boy of Daniel

* S. Higgs, "Some Remarks on the Mining District of Yorke's Perinsula, South Australia," Trans. R. Geol. Suc. Cornwall, vol. ix. p. 127. 
Jacobs." Mr. O'Reilly then sent the stone to Cape Town for examination, when it turned out to be a true diamond, worth $£ 500 . *$

The value of the diamonds produced annually far exceeds that of the gold of any one of our colonies.

Gold.-The story told of the finding of gold in California, in $184^{8}$, is that Marshall, who was superintending a sawmill, happened to see something glittering in the mill leat. It turned out to be gold. He found more nuggets, and soon the discovery was noised abroad.

In Australia the first discoveries of gold were by chance.

The attention of Dr. Plassard was directed to the existence of gold in Venezuela from seeing some specimens in the possession of a native.

Iron.-Traces of soft hæmatite, noticed among the roots of an overturned tree, led to the discovery, in $189 \mathrm{I}$, of the important Biwabikt iron mines of the Mesabi range, Minnesota.

Nickel.-The Sudbury nickel deposits were discovered in making a cutting for the Canadian and Pacific Railway, and even then it was the copper which first attracted notice.

Phosphate of Lime.-In May 1886, a geologist, M. Merle, took it into his head to analyse the sand of an apparently abandoned pit, which had been worked for centuries in order to give bricks a violet tint much esteemed in the neighbourhood. He found it contained 77.85 per cent. of phosphate of lime. This was the origin of the workings in the Upper Chalk at Beauval, in the department of the Somme.‡

The discovery of the phosphate beds of Florida§ was made in the autumn of 1889 by an orange-grower, who out of curiosity sent to a chemist a sample of the white subsoil of his grove; this turned out to contain 80 per cent. of phosphate.

Quicksilver.-The Redington Quicksilver Mine,\| in California, was discovered in making a cutting for a road.

Silver.-A man made a fire to cook his food and protect himself from the cold, near the site of Catorce, 9 in Mexico, and in the morning found silver shining in the ashes. This was in 1775 ,

* T. Reunert, "Diamond Mining at the Cape," Official Handbook to the Colonial Exhibition. History, Productions, and Resources of the Cape of Good Hope. Cape Town, I886, p. 178.

+ Winchell, Twentieth Annual Report of the Geol. and Nat. Hist. Survey of Minnesota, p. I57. Minneapolis, I893.

¥ Statisque de l'Industrie Minérale en France pour l'année I886. Paris, 1888, p. 252.

§ Ledoux, "The Phosphate Beds of Florida," Eng. Min. Jour., vol. xlix. (1890), p. 176.

|| Becker, "Geology of the Quicksilver Deposits of the Pacific Slope," Monographs of the U.S. Geol. Survey, vol. xiii. p. 10. Washington, I888.

T Chism, "The Catorce Mining District," Eng. Min. Jour., vol. xlviii. (1889), p. 340 . 
and three years later another man pulled up a bush to throw upon his fire, and found native silver in the roots. Mining soon began, and between 1779 and 1812 the district yielded ore worth from thirty to forty million pounds sterling. Tradition relates that the famous silver mines of Potosi, in Bolivia, were discovered in a similar manner in 1538 , by the accidental displacement of a bush which had small lumps of native silver among the roots.

The existence of silver in the Province of Famatina, in the Argentine Republic,* was made known by a pure accident. Leita and Echavarria were making a journey, in 1811 , across the Andes, and during a terrible storm, took refuge in a cave, and there passed the night. In the morning they found that the stones they had put round the fire at night were white, and on further examination silver was plainly to be seen in them.

Adventitious Finds. - Search for one mineral often leads to the discovery of another. The working of veins for tin ore has revealed the presence of the decomposed granite which furnishes china clay.

The finders of the Comstock + lode worked it at first for gold, being quite ignorant of the presence of rich silver ore.

In the winter of $1858-59$, some prospectors washed a panful of earth from a broad-topped mound which one of them had noticed previously. This gave gold to the value of fifteen cents, a high average return. They then noticed a gopher hole in the mound, and took up the earth which had been thrown up. This they washed, with satisfactory results, and at once staked out claims. Another part of the lode was discovered by some other prospectors, who had dug a hole in order to make a little reservoir. for water. They chanced to wash some of the earth, and to their surprise found it rich in gold. The upper part (back) of the lode was then worked for this metal. They threw away bits of a black rock which they found mixed with the earth and yellow sand, and when, at a depth of 3 or 4 feet, they came upon a vein of the black mineral, they had not the least idea that it was valuable. Pieces, however, were carried away by curious visitors, and one was given to Mr. Melville Attwood for assay. He discovered that it was worth $\$ 3,000$ per ton for silver and $\$ 876$ for gold. The black mineral was sulphide of silver, and the yellow sand proved to be the chloride. The working of the Comstock lode for silver dates from this discovery, which was in June 1859.

There are reasons for supposing that the original discoverers of the Comstock lode were two brothers na med Grosh who had found a rich vein of silver in 1856 . But one brother died from

* Hoskold, La République .Argentine, p. 19.

† Lord, "Comstock Mining and Miners," Monographs of the U.S. Geol. Survey, vol. iv. pp. 34-55.

$\ddagger$ Op. cit. pp. 27-31. 
the effects of a slight accident, and the other soon after succumbed under the hardships he had undergone in crossing the snows of the Sierras in December 1857 . The knowledge of this vein was then lost for a time.

In $1885^{*}$ some natives or Spaniards took to M. Bastide specimens of what they thought was calamine from the top of Djebel Toumai-Kebir, Department of Oran, Algeria. It turned out to be phosphate of lime.

When boring for rock salt in 1839 near Stassfurt, $\uparrow$ the Prussian Government found brine with chloride of magnesium and chloride of potassium. Later, in 1852 , they sank two shafts through the beds containing these minerals, without in any way recognising their value, in order to work the rock-salt underneath. However, it was not long before this mistake was corrected, and the potassium salts soon becarne the main object of the mining.

The sub-wealden bore-hole near Battle, which was put down for general information concerning the underlying strata, met unexpectedly with a bed of gypsum, which is now regularly mined.

The bed of salt in the Cleveland district was discovered in 1863 by a boring made for the purpose of getting water. The total area now proved is 20 square miles; and if the approximate average thickness of the bed is taken at only 90 feet, it may be estimated to contain II 5,200,000 tons of salt per square mile. $\$$

A bore-hole was put down in Louisiana near Lake Charles on the New Orleans-Tezas Railway in search of petroleum, $\S$ and a rich bed of sulphur-bearing rock, 100 feet $(30 \mathrm{~m}$.) thick, was pierced unexpectedly. Owing to the watery nature of some of the strata by which it is overlain, it has not yet been worked.

According to a statement issued by the Broken Hill Proprietary Company, Limited, $\|$ the original claims of this productive silver mine were pegged off under the impression that the outcrop was that of a tin lode.

The Sulphur Bank $\uparrow$ in California was originally worked for sulphur, and the fact of there being quicksilver was long unsuspected.

Instances of valuable minerals passing unrecognised are common.

It is related that the original proprietor of the site of Mount

* Statistique de l'Industrie minérale en France pour l'année I886. Paris, 1888 , p. 285 .

+ Führer zum vierten allgemeinen Deutschen Bergmannstag. 1889 . Halle a. d. Saale, 1889, p. xxxiii.

¥ Marley, "On the Cleveland and South Durham Salt Industry," Trans. Ferl. Inst. M.E., vol. i. (1889-90), p. 342.

$\S$ Rivista del Servizio Minerario, I 888 , p. clxxxiii.

II Report and Statement of Accounts for Half-year ending November 30 , 1S86. Melhourne, Victoria, I886, p. 57.

I Becker, op. cit. p. Io. 
Morgan gold* mine used to sell some of the auriferous stone, which resembles pumice, as hearthstone for cleaning doorsteps.

Geology as a Guide to Minerals.-A knowledge of geology will often serve to guide the miner. Coal has been discovered in the south-east of England by very careful reasoning, based upon the geological structure of South Wales and Somersetshire on the west and that of Northern France and Belgium on the east.

M. Meugy, $\dagger$ Inspector-General of Mines, hearing of the discovery of phosphate of lime in the Lower Greensand of England, concluded that similar deposits might occur in the Cretaceous rocks cf France. Search was made, and valuable deposits were found in $185^{2}$.

Geology also affords the miner aid by enabling him to identify certain horizons in stratified rocks by their fossils. The valuable bed itself may not always be fossiliferous, but definite horizons above or below it may be recognisable, and so guide the miner in his explorations.

Associated Minerals.-The existence of valuable minerals may be suspected from meeting with some of their common associates, and, even for the sake of its importance to the prospector, the subject of the paragenesis of minerals deserves careful study.

The facts are specially marked in the case of tin ore. Cassiterite is usually associated with minerals containing boron and fluorine, such as tourmaline, topaz, fluor-spar and lithia mica, and also with wolfram, chlorite, and arsenical pyrites; masses of magnetic iron ore are frequently accompanied by rocks containing garnets, hornblende, and epidote.

Zinc blende is a common hanger-on of galena, which likewise often has barytes in its train. Galena invariably contains silver, and frequently enough to enhance its value.

The associates of gold in quartz veins are various metallic sulphides, such as iron pyrites, magnetic pyrites, copper pyrites, mispickel, galena, zinc blende, stibnite, tetradymite, and bismuthine.

Salt is accompanied by gypsum and anhydrite, and frequently has its habitat in red rocks. Mottura explains this by pointing out that when sea water is evaporated, the first precipitate is oxide of iron, that gypsum crystallises out next, and later the sodic chloride.

SURFACE INDICATIONS.-The indications which guide the prospector are precisely those upon which the geological surveyor depends in making his maps, viz., form of the ground, colour, nature of the decomposed outcrop, ordinary springs, mineral springs, indicative plants, altered vegetation, burrows of animals, old workings, slag heaps, ruins, names of places and old records.

* W. H. Dick. A Mountain of Gold. Brisbane, I889, p. I1.

† Stat. Min. France, I886. Paris, I888, p. 280. 
Form of the Ground.-If the valuable mineral is harder or softer than the surrounding rocks, it will affect the manner in which the surface is sculptured by atmospheric agencies. Hard rocks will project in some way, soft ones will be cut into hollows, especially if they are impermeable. The uutcrop of a hard bed will be denoted by a steep face or escarpment, and unyielding mineral veins project above the surface in the form of huge crags (Fig. 89).

FIG. 89.

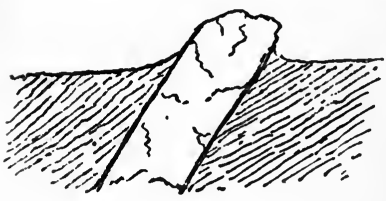

In parts of our country, these outcrops have been worked away and are no longer apparent; but lodequartz blanched by weathering may often be seen standing up several feet above the surface on the Welsh hills, and the run of some lodes can be traced for a long distance by a succession of such outcrops.

In the United States and in Australia this phenomenon is common.

At the Great Western Quicksilver Mine* in California, the outcrop of the vein appears as a dike over 100 feet wide, and having precipitous sides in places 75 feet high.

Some of the silver veins of Butte, Montana, crop out, according to vom Rath, $\dagger$ as great wall-like ridges of brown and black rock, which is quartz containing the oxides of iron and manganese; the Rainbow lode stood up 20 feet above the surface.

The Broken Hill lode at Silverton, New South Wales, was traceable for fourteen miles by the outcrop of huge black crags consisting of ferruginous quartz, brown ironstone, pyrolusite and other minerals, which in places rose to a height of 50 feet above the ground, and were ro to 120 feet wide.

Speaking of the outcrops of gold veins of the Hodgkinson goldfield of Queensland, Mr. R. L. Jack, $\ddagger$ the government geologist, says, "they can be followed from hill top to hill top, forming at times insurmountable walls a hundred feet high ; as, for example, in the peaks west of Mount Tenison Woods. In other places denudation has left their remains on hill sides or hill tops in the form of huge cubes of quartzite, from which the surrounding soft rocks have crumbled away. These cubes stand up weird and solitary, like the " perched blocks' of Alpine and Arctic lands."

The tin lodes of San Jacinto in California are found in a country destitute of all vegetation except grass, and their black outcrops are said to be unusually distinct.§

* Luther Wagoner, “The Genlogy of the Quicksilver Mines of California,” Eng. Min. Jour., vol. xxxiv. (1882), p. 334 .

† Neues Jahrb. f. Miner., Geo?., u. Paläontologie, 1885, p. I62.

+ Handbook of Queensland Geology. London, 1886, p. 27.

$\S$ Benedict, "The San JacintoTin Mines," Eng. Min. Jour., vol. 1. (ISgo), p. 452 . 
The Great Quartz Vein of California has "a very conspicuous outcrop, forming the crest of the hills, so that it can be readily seen from a distance of several miles."*

The "main reef" of auriferous conglomerate at Johannesburg, in the Transvaal, could be traced in places by the pebbles on the surface.

Soft minerals like clay offer less resistance to rain, flood, and frost, are more deeply cut into, and give rise to hollows. Thus the bed of clay known as the Gault, occupies a depression between the hard and pervious beds of the Chalk and the Lower Greensand.

The presence of the masses of decomposed granite which furnish china clay $\dagger$ is almost always indicated by a slight depression of the surface.

The ore bodies in the Sierra Mojada, Mexico, are softer than the enclosing rocks, which often stand out when the ore has been worn away by weathering.‡

Colour.-Colour is an important factor in the discovery of mineral deposits. Sometimes the ore itself has a distinct hue. When Garnier was exploring New Caledonia in 1863, he was struck by the special green colour of the rocks, and he found that it was due to coatings, veins, and lumps of a hydrous silicate of nickel and magnesium, which is now largely worked.

Copper minerals will produce green, blue, and red stains, which catch the attention very quickly. Iron gives a red or brown colour, manganese a black; lead may furnish a green, a yellow, or a white coating, cobalt a pink one, whilst cinnabar is the natural vermilion. Coloured minerals are often used as pigments by savages, and in this way may be brought to the knowledge of the explorer.

Gozzan.-A mineral deposit near the surface is frequently so altered by atmospheric agencies that it bears little resemblance to the undecomposed bed or vein which will eventually be met with at a greater depth. A bed of hard shale will crop out at the surface as a soft clay; but the most common cases of change are furnished by the conversion of sulphides into oxides or oxidised compounds, and the removal of some of the mineral in the form of a soluble sulphate. Thus iron pyrites, which is such a frequent constituent of mineral veins, is converted into hydrated oxide of iron, and a vein, originally consisting of iron pyrites and quartz, becomes a honeycombed brown and yellow rock, the removal of the iron pyrites in the form of a soluble sulphate leaving cavities which are only partly filled up by oxide. The ferruginous solutions which flow away stain and discolour the adjacent rock.

* Whitney, The Auriferous Gravels of the Sierra Nevada of California. Cambridge, U.S., I880, p. 46.

† J. H. Collins, "The Hensbarrow Granite District." Truro, 1878, p. 7.

¥ Chism, "Ore Deposits of Sierra Mojada," Irans. Am. Inst. M.E., vol. xv. $(1886-87)$, p. 549 . 
The ferruginous outcrop of mineral veins has been noticed in all mining countries. In Cornwall it is called gozzan, and this term has been carried by the ubiquitous Cornish miner to other English-speaking countries, though in Australia we hear of ironstone blows.

In Germany the iron hat gives the proverb-

Es ist kein Bergwerk nie so gut,

Es hat denn einen eisern Hut;

translated by the late Sir Warington Smyth as follows-

"A lode will ne'er cut rich and fat, Unless it have an "iron hat."

In France the chapeau en fer is the equivalent of the German expression, whilst the Italian miner, ascribing the cindery, burntup appearance to the action of fire, calls such outcrops bruccioni.* The Spanish term colorados has reference to the red tint due to iron oxides. In some parts of South America, such as the Argentine Republic and Bolivia, the word pacos is used for the oxidised ores.

The nature of a gozzan varies naturally very greatly, not only in different districts, but also in different parts of the same lode. If the vein originally consisted very largely of iron pyrites, the gozzan will be mainly ochre and brown iron ore, of ten in botryoidal and stalactitic forms. If quartz was present also, a cellular, cindery, cavernous, ferruginous rock is the result of the atmospheric weathering.

Other metallic minerals will leave their traces. Galena becomes changed into anglesite, cerussite, pyromorphite, and mimetite. The sulphides of copper yield native copfer, melaconite, cuprite, malachite, chessylite, together with phosphates, arseniates, and silicate of the metal, and sometimes the oxychloride or oxysulphide. Carbonate of manganese gives rise to black oxides, whilst argentiferous minerals furnish native silver, kerargyrite and embolite.

Gold is unlocked from enveloping sulphides, and specimens of quartz may be seen from nearly every gold-field in which cubical cavities, left by the removal of iron pyrites, are partly "lled up with ochre and delicate skeletons of the precious meta. Gold may exist in combination with other elements and be lil. ted by the weathering process.

The depth to which the oxidising and leaching action proceec. is often considerable. In the Comstock lode $\dagger$ " the quartz is reddened and the iron minerals more or less oxidised to a depth of 500 feet, but it is probable that the lower roo feet are chiefly

* Zoppetti, Arte Mineraria. Milan, I882, p. 85.

+ Hague, Mining Industry of the Fortieth Parallel. Washington, 1870, p. 75 . 
coloured by the percolation of the surface waters." Sometimes there is a sharp line of demarcation, sometimes a gradual passage, between the gozzan and the sulphides.

In the sections of a mineral vein, Figs. 90 and 9I, A, is the gozzan, showing itself occasionally by rough crags at the surface; $\mathrm{C}$, represents the undecomposed sulphides, and B is an intermediate zone where the process of alteration is incomplete. At Huanchaca silver mine, Bolivia, the oxidised ores near the surface are called pacos, the transition oxysulphides mulatos, whilst the unchanged sulphides are known as metales frios. In the longitudinal section, Fig. 91, the alteration is shown as ceasing

FIG. 90.

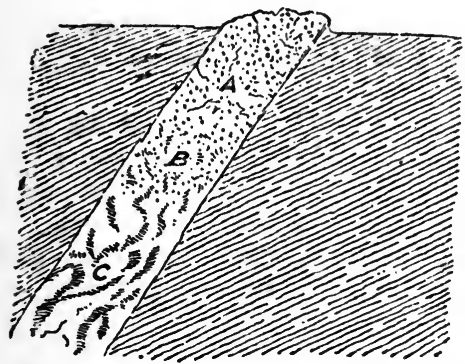

FIG. 9I.

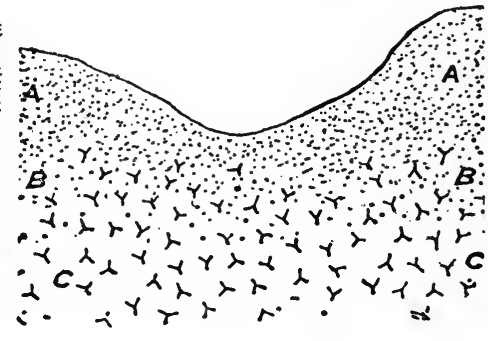

soon after the level of the bottom of the valley is reached, that is to say when the water no longer has an easy exit; but circumstances may bring about a system of circulation causing the rainwater to penetrate below this level, and then the gozzan will naturally extend to a greater depth.

Gozzan is important to the miner not only because it is an indication of a lode, but also because the ore is sometimes more valuable from the decomposition of the sulphides. This is specially the case with gold and silver. Gold, as already explained, is set free from a tight covering of pyrites, or possibly from a state of combination with some other element, and can now be easily caught by quicksilyer. The miner speaks of the ore as "freemilling" on this account. Silver, when brought into the native state, or converted into chloride, is likewise readily extracted by amalgamation.

In the case of argentiferous lead veins, chloride of silver mixed with carbonate of lead and oxide of iron is more acceptable to the smelter than a complex mass of metallic sulphides. The removal of zinc blende by atmospheric agencies, no doubt through its conversion into a soluble sulphate, is of much importance; for the ore is thus freed from an ingredient which gives trouble in the lead furnaces, and which cannot be satisfactorily separated mechanically when very intimately mixed with galena, iron pyrites and other sulphides. Furthermore the removal of some 
of the heavy worthless ingredients, whilst the silver remains fixed as insoluble chloride, raises the tenour of the ore in the precious metal. Lastly, the upper parts of the vein are more cheaply worked from their softness, and the small cost of pumping and winding. Under these circumstances the fact of a mine sometimes becoming less profitable, or wholly un profitable, when the zone of sulphides is reached will easily be understood.

These points must not fail to be considered by the miner; he must recollect that the zone of the oxidised ores will be succeeded by sulphides, more costly to work, and sometimes requiring totally different treatment.

Gozzans should be carefully assayed, especially for silver. Instances could be given of gozzans having been stamped and worked for gold, to the utter neglect of the silver which was by far the more valuable ingredient.

In Cornwall gozzans of copper lodes have been worked for tin ore, which was originally enclosed in or mixed with copper and iron pyrites. Owing to its insolubility it resisted the weathering which carried away the copper and some of the iron in solution.

The Anaconda mine* at Butte, Montana, now famous for its enormous output of copper, was originally bought as a silver mine. For a depth of 400 feet the ores contained no notable quantity of copper; this metal had been carried off in solution, whilst the silver, converted into an insoluble chloride, was rendered proof against any further action of rainwater.

Deposits of cupreous iron pyrites may have the copper and sulphur so completely removed that the remaining oxide of iron is worked as an ore of this metal. $\dagger$

The iron ores of Bilbao are the decomposed portions of deposits of the carbonate. The weathering has had two useful effects, it has raised the percentage of iron, and it has lowered the a mount of sulphur by decomposing the iron pyrites, which occurs in small quantities in the unaltered ore.

The seams containing native sulphur in Sicily often show no trace of that element at the surface, as the sulphur-bearing limestone weathers into a soft, white, grey, or yellowish white, granular or pulverulent variety of gypsum, called briscale by the miners, and considered by them to afford important indications concerning the bed itself. In this case the sulphur has gradually become oxidised and has combined with some of

* Douglas, "The Copper Resources of the United States," Trans. Amer. Inst. M.E., vol. xix. (1890-91), p. 679 .

† Moxham, "The 'Great Gossan Lead' of Virginia," Trans. Amer. Inst. Ji.E., vol. xxi. (1892), p. I34.

† Lorenzo Parodi, Sull' estrazione dello Solfo in Sicilia. Florence, 1873, pp. 7, 24; and I. Baldacci, Descrizione geologica dell' Isola di Sicilia. Rome. 1886 p. 106. 
the lime to form a sulphate; and it is only natural to suppose that the thicker and the richer the original bed was, the greater will be the amount of briscale produced, and the more apparent its signs on the surface.

Each mineral therefore has to be considered separately, and I may mention a few other special cases.

Veins of asbestos have been discovered by noticing a white powdery substance in cracks in the rocks, which led to fibrous asbestos when worked.

Steam-puffs are indications of the small superficial deposits of sulphur in volcanic districts; and here sight is aided by the sense of smell, for I recollect remarking the odour of sulphuretted hydrogen long before I rode up to some sulphur banks in Iceland. In Tuscany the natural steam-puffs which yield boracic acid are plainly visible, and bore-holes* are also put down to produce them artificially where the rocks are hot at the surface, and so give hopes of tapping vapour at a shallow depth.

Some of the successful bore-holes for carbonic acid gas in the Eifel, Germany, were planned on account of natural emanations of the gas in the immediate vicinity.

Attention has been directed to petroleum by a layer or an iridescent film of the oil upon pools of water, and the odour is sometimes perceptible for a long distance. Off Baku, on the Caspian, even the sea is sometimes covered with an oily film of petroleum.

Brine springs point to salt, chalybeate springs to iron, but not necessarily to deposits of any commercial value; the same may be said of water impregnated with sulphuretted hydrogen as an indication of native sulphur. Springs of ordinary water may be expected to appear where a pervious bed rests upon an impervious one, so that the outcrop of a bed of clay under sandstone is often denoted by a succession of springs, in addition to the change in the form of the ground.

Even when the valuable deposit presents no striking outcrop, it may be followed by observing some more marked attendant. Thus the "red bar" $\uparrow$ of the Johannesburg district, is a bed of dark red slate which is seen protruding above the surface, a little to the north of the gold-bearing conglomerate, for a distance of 20 miles along the strike.

In California $\ddagger$ a dark opaline or chalcedonic rock, known to the miners as "quicksilver rock," is associated with the deposits of cinnabar, and owing to its comparative hardness stands out sometimes as a projecting outcrop.

Indicative Plants.--As plants derive part of their nourich-

* Jervis, 1 tesori sotterranei dell' Italia, vol. ii. p. 428.

+ Quart. Jour. Geol. Soc., vol. xlvi. (I89o), Proceedings, p. 4.

\# Becker, "Geology of the Quicksilver Deposits of the Pacific Slope, Monographs of the U.S. Geol. Survey, vol. xiii. p. 360. Washington, I 838. 
ment from their roots, and as different plants require different foods, it is only natural to suppose that a change of soil causes a change in the vegetation.

Beds of porous limestone let the rain soak down at once, the soil is shallow, and the foothold for trees is not so good as in the case of clays. Thus the chalk hills are bare, and the Weald clay is the home of the oak from a mechanical reason, in addition to the chemical one of nourishment.

Clays will retain water and naturally be the habitat of rushes and other moisture-loving plants.

The effect of salt in the rocks is especially marked, and Gätzschmann* gives a long list of plants which either flourish best when getting salt, or cannot exist without it.

The flora of Monte Catini, $\uparrow$ in the province of Lucca, well known for its brine baths, resembles that of the coast, although 24 miles away from the sea, and separated from it by the Pisan Hills.

My friend, Mr. S. IIerbert Cox, tells me that the run of the deposit of alunite which he is working in New South Wales, is marked by a lighter green in the colour of the leaves of the eucalyptus trees which cover the district. He has also noticed in New Kealand that the Karacca trees growing upon limestone have darker leaves than those growing upon slate. A band of limestone can be traced in this way.

The subject of indicative plants is dealt with in an interesting paper by Raymond, $\ddagger$ who gives some additional details concerning the calainine pansy of Rhenish Prussia, mentioned by Gätzschmann. This pansy, called by botanists Viola calaminaria, is peculiar to the calamine-bearing hills near Aix-la-Chapelle, and in Westphalia. The blossoms are almost always yellow; but on the borders of the zinc regions some are light violet, or bluish, or mixed yellow and blue, and are supposed to be hybrids between $V$. calaminaria and the ordinary wild pansy, $V$. tricolor. Analysis has revealed the presence of zinc in the plant and in the sap. This plant is said to have been recognised at Horn Silver Mine in Utah, the ore of which contains zinc blende.

The lead plant, Amorpha canescens, Nutt., is a low shrub, I ft. to $3 \mathrm{ft}$. high, whitened with hoary down. The plant is most abundant in Michigan, Wisconsin, and Illinois, and miners believe that it flourishes best where lead ore exists in the soil.

Dr. F. Stapff found that prospectors for phosphorite, in Estremadura were guided by a creeping plant with bell-shaped flowers, Convolvulus althoooides; in Montana the Erigonum

* Die Aufsuchung und Untersuchung von Lagerstätten nutzbarer Mineralien. Leipsic, 1866, p. 32 r.

+ Jervis, Guidu alle acque minerali d'Italia. Turin, 1868, p. 12.

¥ Trans. Am. Inst. M.E., vol. xv. (1886-87), p. 647 . 
ovalifolium, Nutt., is looked upon as an indication of silver ore in the vicinity.

Animals as Indicators.--Animalis also may occasionally render services to the prospector. I have already mentioned the case of the wombat, by whose burrows copper was discovered in South Australia. Prospectors seeking for tin lodes in Victoria* have also been guided to success by the ore thrown out from decomposed dykes by this animal. Ledoux† says that a useful indication of phosphate of lime in Florida was furnished by anthills and gopher holes, which showed small whitish grains of the mineral in the earth.

Gätzschmann $\ddagger$ mentions cases of the discovery of valuable ores by the scratchings of the beaver, the bear, and the marmot, as well as by the wallowing of pigs; he also brings forward instances in which the first indications of mineral wealth were afforded by stones kicked up by a horse, or tossed out by a bull, or lying in the nest of a vulture, or found in the crop of a grouse.

At the Caratal diggings in Venezuela, a bird callerl the minero was thought to mark the site of gold-bearing gravel. I often heard its notes when passing pits where gold was being obtained, and it is possible that it preferred certain trees which grew upon the old alluvia. In fact, as so many animals obtain their food from special plants, it is evident that the fauna dependent upon the flora must be affected indirectly by the minerals of the soil. The special case of there being more genera and species of snails in a limestone country is a case in point. Lastly, the tracks of animals may lead to salt springs which they frequent.

Shoading.-The prospector seeks for natural sections of the rocks such as occur in cliffs, or in river valleys and their tributary gullies and gorges. He examines the materials constituting the river beds, especially when the water is low in the dry season, often digging up and washing portions in a pan or in a batea, in order to ascertain whether they contain traces of the heavy ores or metals.

If, while prospecting in a valley, he discovers stones that have the appearance of having once belonged to veins or other valuable deposits, he endeavours to trace them to their source, and is, perhaps, rewarded by finding similar fragments, but less waterworn, as he goes up the stream. Further on he may come upon large blocks of veinstuff lying about, and finally find the veins laid bare in a gorge, or at the bottom of a brook, or possibly projecting above the soil in the form of huge crags of quartz in the manner already described.

\footnotetext{
* Victoria, Reports and Statistics of the Mining Department for the Quarter ended March 3I, 1890, p. 15. Melbourne, I890.

† A. R. Ledoux, "The Phosphate Beds of Florida," Eng. Min. Jour., rul. xlix. leb. 1890, p. 176 . 
Loose pieces of veinstuff found lying about on the surface are known in Cornwall as shoad-stones; and shoading is the term given to the process of tracking them to the parent lode.

If the prospector has ascertained the existence of a lode by shoad-stones, and has some idea of the position of the outcrop which lies concealed under the soil, he proceeds to dig trenches across the presumed line of strike, until he hits upon the back of the lode. When the covering of soil is too deep for trenching, a little shaft is sunk, and a tunnel is driven out at right angles to the supposed course of the vein.

Loaming in Australia corresponds to shoading. The prospector washes earth from the base and slope of a hill till the specks of gold are pretty frequent, and then endeavours to trace the gold uphill to the reef that furnished it. When he can no longer get gold by washing he concludes he has gone past the outcrop of the reef, and he proceeds to search for it by trenching. Reefs have been discovered in this way which showed no surface indication whatever.*

Hushing. †-Hushing consists in causing a stresm of water to rush down a hillside, and cut a ditch through the soil, which will lay bare the outcrops of veins, if any exist. A reservoir is made at some suitable spot on the high ground, and a shallow gutter is dug down the slope along the line which it is proposed the stream should take. The water is allowed to run down gently at first, and then as a torrent, which scours out a trench to the solid rock. An examination of the trench and of the stones washed out of it may result in the discovery of a vein.

Piercing.-In some special cases when the mineral lies very near the surface, and is either harder or softer than the surrounding rock, the searcher makes use of a sharp pointed steel rod, which he thrusts into the ground. The well-known French $\downarrow$ burr-stones, lying in soft sand and clay at a depth of ro to 18 feet, are found in this way; whilst in the Isle of Man superficial pockets of umber in the Carboniferous Limestone are detected by the ease with which the rod runs down.

Kauri gum, a semi-fossil resin of New Zealand, which occurs in lumps of about the size of a hen's egg a few inches below the surface in the high ground, and a few feet in the swamps, is sought for by a similar tool.

Mr. Lawn informs me that in the Furness district a pointed iron rod is occasionally used in searching for shallow deposits of hæmatite, lying within 6 or 8 feet of the surface. The miner examines the point of the rod after thrusting it through the thin

* "The Gold-fields of Victoria," Reports of the Mining Registrars for the Quurter ended March 31. 1888. Melbourne, I888, p. 68.

+ Willinms, Natural History of the Mineral Kingdom. Edinburgh, 1789, vol. i. p. 370.

$\ddagger$ Callon, Lectures on Mining. London, ISSI, vol. ii. p. $4 \mathrm{I}$. 
covering of soil, and if he finds it to be red, he concludes that there is iron ore underneath. If the indications are sufficient, he sinks a little pit and begins to work the ore.

The valuable bed of phosphatic nodules in Suuth Carolina* is much harder than the overlying sand and clay; the prospector carrying a steel rod works it down, until he meets with the resisting stratum. He notes the depth, which is under I5 feet, as no phospbate is at present worked deeper than that, and after walking on Ioo feet further forces the rod down again. By thrusting down the rod at regular intervals in this way, and noting the results, he obtains a general idea of the lie of the phosphate bed, and proceeds to make a more minute examination by sinking exploratory pits, ro feet by 5 feet, at intervals of 500 feet. The phosphate rock laid bare is taken out, carefully sampled and analysed, and in this way a very fair estimate can be made of the yield of a given area.

The process of testing a bed of mineral by pits is sometimes carried out on a very extensive scale. According to Winchell $\$ 60,000$ have been spent in mere explorations at the Biwabik Iron Mine, $\uparrow$ in the Mesabi Range, Minnesota; but in this case the pits were practically small shafts, many of which exceeded I०० feet in depth.

Lode-lights.-Appearances of flame above mineral veins are said to have been seen, and at all events are sufficiently well established to have received a special name, "lode-lights," in Cornwall. It is possible that a will-of-the-wisp (phosphoretted hydrogen) may have been produced occasionally by the action of organic matter and water upon phosphates, which are so common in the upper parts of mineral veins.

Marsh-gas is known in the workings of some lead lodes, and may have occasionally issued in sufficient quantity to produce flame when ignited accidentally.

Altered Vegetation and other indications.-One hears of differences in the appearance of the vegetation along the line of mineral deposits, of places where the snow will not lie in the winter, and of vapours hanging over the ground. Though some writers refuse to put any value on these indications, they should not be entirely overlooked, because the outcrop of a lode, of different nature and texture to the surrounding rocks, may readily cause the phenomena just mentioned. One need only look at the rubbish-heaps of some mines, especially those yielding pyrites, which remain year after year bare and barren, to understand the blighting and withering action of the products of decomposition of some minerals upon vegetation. It is only natural to suppose that

* Wratt, The Phosplates of America. New York, 1891, p. 49.

+ "The Binabik Mine," Trans. Amer. Inst. M.E., vol. xxi., IS92-3, p. 95I ; and Geol. and Nat. Hist. Survey of Minnesota. Tiventicth Auu. liep. fur the year i891. Minneapolis, I893, p. 156. 
grass would grow less luxuriantly upon a wide pyritous vein than upon adjacent slate, and that a decided streak of altered colour and growth would be visible upon the turf.

A very simple experiment will convince the student more readily than the mere statement. Spread a thin layer of earth upon a tray, and imitate the outcrop of a lode by scraping away some of the earth and re-placing it by powdered iron pyrites or marcasite. Now scatter mustard seed over the surface, and water frequently. In the course of a few days there will be a crop of mustard on the earth, but the track of the pyrites will be marked by a bare streak on which the seeds have been killed by sulphate of iron formed by its decomposition.

The rapid disappearance of snow on the outcrop of a lode has been noticed at Ducktown Mine, Tennessee, ${ }^{*}$ among other places. The oxidation going on in a pyritous lode near the surface must produce a certain amount of heat, which would make the outcrop of a lode warmer than the adjacent rock; but one need not have recourse to this hypothesis in order to account for phenomena of this kind. Mineral veins are often channels along which underground waters circulate; this water may come near to the surface in places, or even issue forth as a spring, and the proximity of the comparatively warm water may keep the outcrop warm enough not to freeze. In a porous cavernous gozzan it is easy to imagine the existence of slow currents of the air which would have the same effect.

The fact of a vein often being a channel of water will also explain the rising of vapours from lodes under certain favourable conditions of the atmosphere.

Where the surface is cultivated and the natural springs are tapped by adit levels or other mine workings, these appearances cannot be looked for to any great extent; and it is not unlikely that the old miners, who have handed us down traditions con. cerning the signs of mineral veins, were keener observers of nature than some of their successors, just as the savage mav be guided by marks which do not catch the eye of the civilised traveller.

Old Workings, Slag Heaps, Ruins.-Signs of old workings, such as pits and rubbish-heaps, often tell useful tales. When workings were shallow, miners put down shafts in close proximity, and the line of a series of shafts and rubbish-heaps will give a fairly correct idea of the strike of a lode. The rubbish-heaps will show what was the ore worked, and with what it was associated.

It even happens that mining refuse, thrown away as worthless in the ditys when dressing appliances were crude and rough, will pay for being worked over again. On the other hand it is not safe

* Wendt, "The Pyrites Deposits of the Alleghanies," Eng. Min. Journ., vol. xli. (1886), p. 408. 
to conclude that, because it paid to work a mine some centuries ago, the same ore will yield a greater profit or even be worth working nowadays. The change in the value of the precious metals, and the change in the remuneration of the labourer, must be duly weighed before a decision can be arrived at.

It is important to ascertain why the old mines were abandoned. If no good reason, such as a sudden inrush of water, or the breaking out of a great war, for instance, can be assigned for the stoppage, it is usually safe to assume that no great riches have been left in sight; statements to the contrary must be very carefully sifted.

Minerals that were at one time worthless or even regarded as obnoxious, such as nickel and cobalt ores, or zinc blende, become valuable by the discovery of new or improved processes of manufacture or smelting. An instance of this kind has occurred quite lately. Some forty years ago the outcrops of beds of impure carbonate of manganese in North Wales were worked for the black oxides, the gozzans, in fact, which had been produced by the weathering of the deposit near the surface. The undecomposed carbonate was at that time of no value and was carefully separated by cobbing and rejected; and the workings had to be abandoned when the black oxide diminished in quantity at a shallow depth, and was replaced by unweathered ore. Owing to the use of ferromanganese in making steel, the carbonate can now be utilised, and the ore is regularly mined and sent to the blast furnaces to be smelted with iron ore.

On the other hand the discovery of a new process may be the means of cansing a mine to be unprofitable. The discovery by Weldon of a method of regenerating the oxide of manganese used in making bleaching powder, seriously affected manganese mining by lessening the demand for the ore.

Old mine plans, reports, and deeds should be consulted when available; and information should be sought from official geological surveys and mining records when they exist, as they do in this country. A prospector told me a few years ago that he missed securing some manganese properties in North Wales, from not being aware that a government geological map of the district had been published, showing some of the outcrops of the manganiferous bed.

Slag heaps afford indirect evidence of mining, and like old rubbish-heaps may occasionally be worth smelting. The most notable instance of late years has been the profitable treatment of such heaps at Laurium, in Greece.

Ruined cities, or other indications of a country having been more thickly populated, are sometimes adduced as proofs of its mineral wealth. Where it is possible to show, from remains found in the towns or encampments, that the inhabitants were engaged in mining or smelting operations, the prospector may fairly lay stress 
upon evidence of this kind. It has often been supposed that some of the old entrenchments in Cornwall were made for the protection of diggers or smelters of alluvial tin ore; and after the careful explorations of Mr. Theodore Bent at Zimbabwe, in Mashonaland, most persons will be disposed to agree with him that this old city and its fellows owed their existence to gold mining.

Names of Places. - Local names may sometimes supply information, either by denoting some natural feature connected with the deposit, or by recording in some way the existence of mine workings. They will be found in all languages, and I need only give a few instances. "Cae Coch," near Trefriw, in Carnarvonshire, means the "red field," from the chalybeate springs, which are due to the existence of a bed of iron pyrites now being worked. "Graig Goch" or " red rock," a name which is not uncommon for mines in Wales, denotes no doubt that the vein was discovered by a red ferruginous outcrop, and so does the name "Fron Goch " or " red breast." Red Mountain, near Birmingham, Alabama, owes its name to the outcrop of an important bed of iron ore. "Glasdir," meaning "blue ground," is the name of a copper mine in North Wales. I cannot help suspecting that the locality was so called in consequence of the blue colour given to rocks or stones by coppery minerals derived from chalcopyrite near the surface. "Balmynhir" or the "diggings at the long stone," denotes workings for tin in the neighbourhood of a "menhir" or erect stone in Cornwall. Sometimes the substance is named, as in the words Tincroft, Stahlberg (steel mountain), Porto Ferraio (iron port) in Elba, Gebel Zeit (oil mountain) on the shores of the Red Sea, Yenang-yaung (Creek of oil), the site of the petroleum wells in Burmah. The names Leadhills (Scotland), Bleiberg (Germany), and Gebel-el-Kohol (Tunis), all have the same signification, and have been given from the existence of workings for lead ore. "Al maden " means " the mine," and turning from Spain to our own country, we find "Minera," near Wrexham, with a similar signification given in this case by the Romans, instead of the Moors. The Smoky Mountains, ${ }^{*}$ in North Carolina, were called by the Indians "Unaka," from their word "Unakeh," meaning "white," because they obtained white kaolin from them.

Salt is indicated by the prefix "Sal," "Salz," or its equivalent "Hall," in numerous names of places.

The German word for miner, "Bergmann"-i.e., mountain man or highlander-reminds us that the old ore-seekers were hillmen, and found their treasures among the mountains, and we constantly find the word "Berg" (mountain), or its equivalent in other languages, forming part of the names of mines or mining towns. Schneeberg, Marienberg, Freiberg, in Saxony, are instances, and of recent date we have Mount Morgan in Queens-

* W. B. Phillips, "Mica Mining in North Carolina," Eng. Min. Journ., vol. xlv. (1888), p. 398. 
land, and Broken Hill in New South Wales. In the list of copper mines of South Australia* I find no less than twenty-six names of mines beginning with "Mount," in addition to others containing the word " hill" or "knob."

Other names refer to mining or smelting operations. The village of Pestarena, near Monte Rosa, was evidently so called from the crushing of gold ore in the days of the Romans. "Cinderford," in the Forest of Dean, points to old heaps of iron slag, and such a name as " hammer pond," in the Weald of Kent and Sussex, likewise tells us of iron working in days gone by. But no stress should be laid upon names; they afford at most an indication of the existence of a mineral, without any evidence of its value at the present day.

Divining Rod.-Belief in the divining rod, or dowsing rod, has not died out completely even in Cornwall, where one still

FIG. 92.

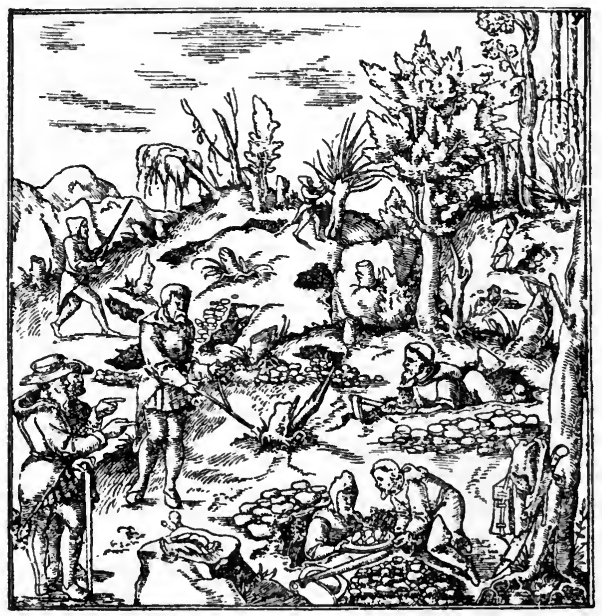

meets with educated persons who profess to be able to discover mineral veins by the dipping down of the forked twig when they walk across them.

Fig. 92, reduced from Agricola, $\dagger$ shows old German miners searching for veins with the rod.

Dipping Needle.- In the special case of magnetic iron we have a safer guide. In Sweden a magnet, suspended so that it can dip

* H. Y. L. Brown, "A Record of the Mines of South Australia." Adelaide, $189 \mathrm{c}$.

+ De re Metallicâ, Basle, I 556, p. 28 ; and Brough, "Cantor Lectures on Mine Surveying," Jour. Soc. Arts, vol. xl. (1892), p. 803 . 
in any direction, is regularly used for tracing masses of magnetic iron ore, even when concealed by some thickness of drift or some depth of water; when the lakes are

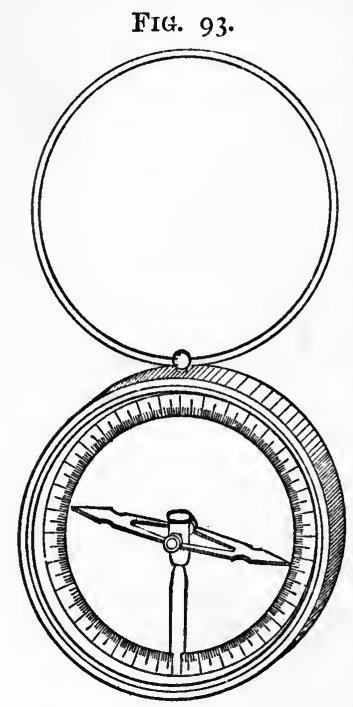
frozen over in winter, this kind of prospecting is easy.

The miner carries his compass carefully over the ground, and on approaching magnetic ore the needle dips towards it; the amount of dip increases, until at last, when standing directly over the deposit, the needle becomes vertical, and remains so as long as there is a strong mass of ore underneath it. The boundary of the deposit can thus be laid down on a map with some degree of accuracy.

The modification of theSwedish dipping needle shown in Fig. 93, borrowed from Brough,* has been adopted in the United States. Improved methods devised by Brooks, Thalén, and Tiberg are described by the same author.

Qualifications of the Prospector. - From the above observations it will be seen that the miner is greatly aided in his search by a variety of natural indications; but in a new and unsettled country the physical difficulties of travel are often so great, that strength of body and the capability of supporting fatigue and hardships become some of the most important qualifications of the prospector. He should have a general knowledge of geology, aud understand mineralogy sufficiently to recognise all the common and valuable minerals and their ordinary associates, and to confirm his opinion by simple tests. The pick, shovel, and pan should be handled with ease, as well as the rifle and the gun. Keen and good eyesight is a sine qua non; a myopic prospector would fail to recognise natural features, and a colour-blind person would not be struck by important differences of tint.

The mode of discovering minerals by boring is a subject of so much importance that it requires a separate chapter.

* A Treatise on Mine Surveying. London, 1891, p. 261. 


\section{CIIAPTER III.}

\section{BORING.}

Uscs of bore-holes.-Methods of boring holes:-I. Boring by rotation; Auger; Diamond drills.-II. Boring by percussion with rods; Iron rods, wooden rods; Driven wells.-III. Boring by percussion with rope; American system; Mather and Platt's system.-Surveying bore-holes.

\section{The uses of bore-holes are numerous :}

I. To reach a mineral deposit by a small hole and ascertain its nature, depth from the surface, thickness, dip, and strike, with the object of working it if possible.

2. To ascertain the nature of the subjacent rocks for engineering purposes, such as their suitability for railways, canals, locks, sewers, or foundations of bridges and buildings.

3. To obtain liquids, such as ordinary water, mineral water, brine or petroleum, which either rise to the surface, or have to be pumped up from a certain depth.

4. To make absorbent wells in dry and porous strata.

5. To obtain gases, such as natural inflammable gas, carbonic acid gas, or vapours containing boric acid.

6. 'To drain off gas from rocks, and water or gas from mine workings.

7. To make passages for conveying power into underground workings by steam, water, wire-ropes, or electricity.

8. To put signal wires or speaking tubes into underground workings.

9. To introduce cement into unsound foundations in order to strenthen them, and also into mine-workings in order to dam back water.

10. To sink holes for lightning conductors, house-lifts, or piles.

11. To sink mine shafts.

The methods of boring holes for these purposes are:

I. By rotation.

II. By percussion, with rods.

III. By percussion, with ropes.

I. BORING BY ROTATION.-Auger.-Soft rocks, such as clay, soft shale, sandy clay, and sand can be bored by an open auger (Fig. 94), like the well-known carpenter's tool.

The mode of working consists* in twisting the tool round by means of a cross-head or spanner, and lengthening it as the hole is deepened. The lengthening rods are made of wood or iron, the iron ones being $I \frac{1}{2}$ inch gas-pipe, with screwed pin

* Darley, "Artesian Wells," Engineering, vol. xxxix. (1885), p. 633. 
and box ends welded on. Even when iron rods are used, some made of pine, 4 inches by 4 inches, are added in order to take off part of the heavy weight by their buoyancy in water. For raising the rods an iron or wooden derrick is employed, such as is
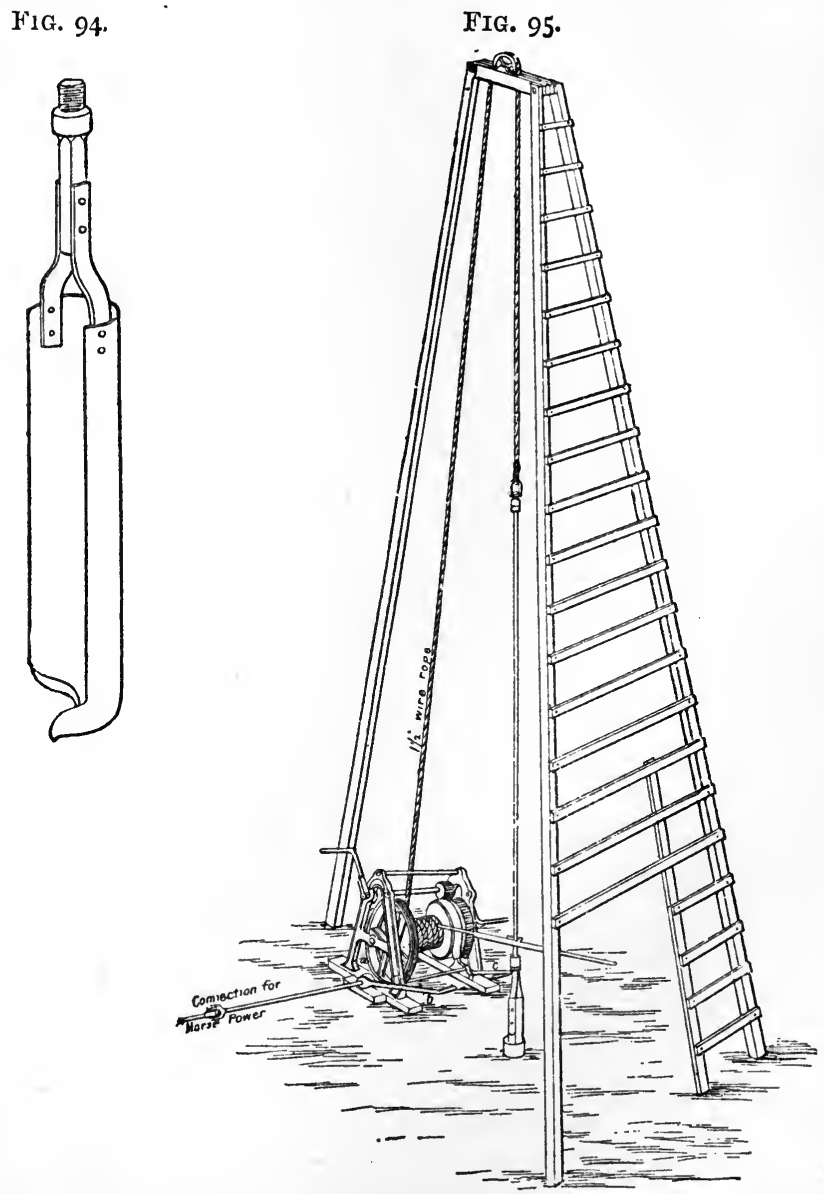

shown in the figure 95. It is 30 feet high, so as to give room for pulling up a rod of the usual length of 25 feet, which is drawn up by means of a crab-winch with a $1 \frac{1}{2}$ inch iron or steel wire rope. The winch is worked by hand or horse-power as required. The top rod is made of square iron, and the cross-head or capstan spanner can be fixed to it at the height most convenient for handling. 


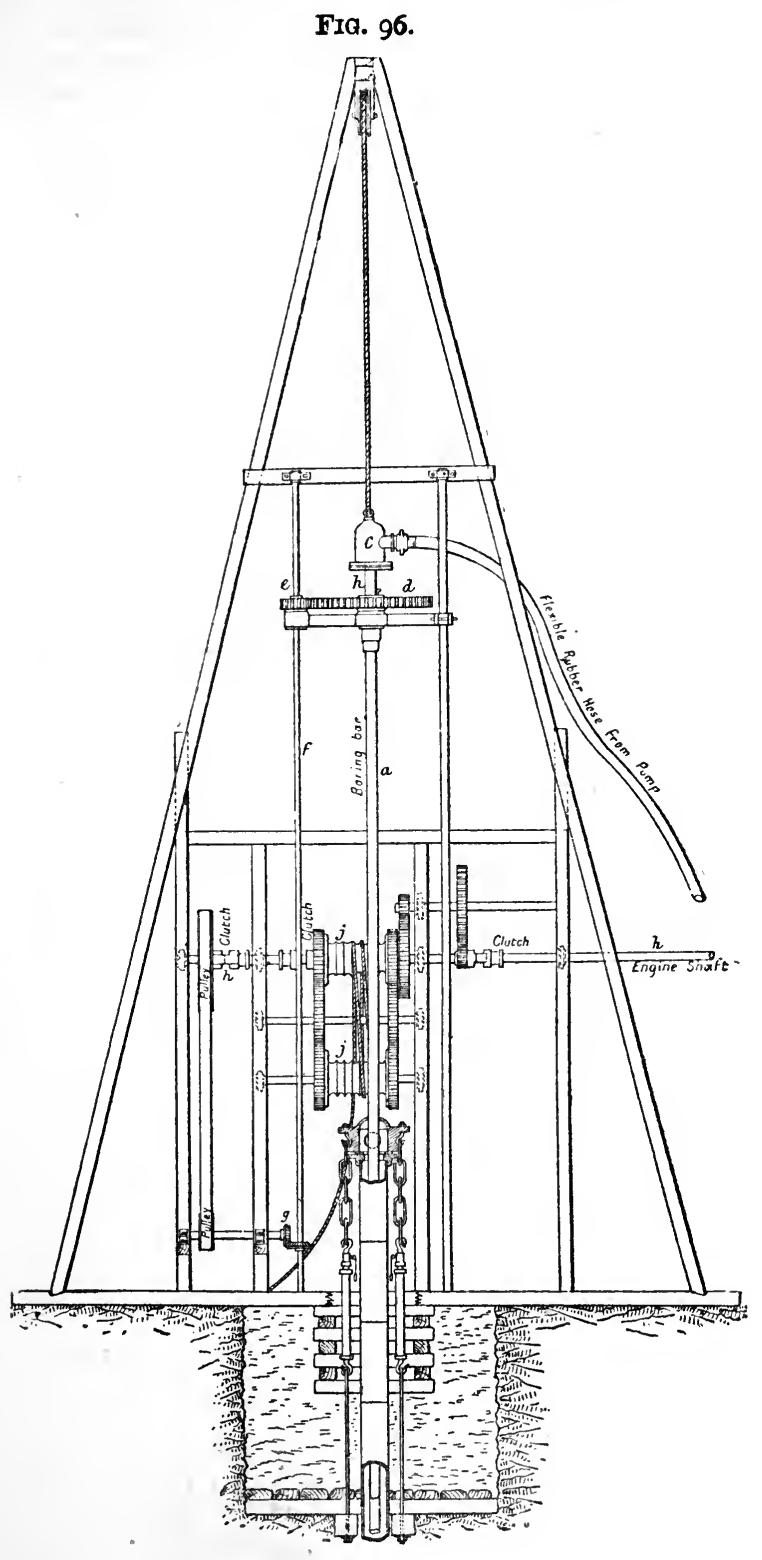


The process of boring consists in turning the rod by twc men at the capstan until the working tool has filled itself ; it has then to be drawn up and emptied. In drawing up, each rod has to be unscrewed and taken off, and the process is reversed when the tool, after having been cleaned out, is again lowered.

In favourable strata holes are bored 400 feet deep at the rate of 25 feet a day by this method; it is obvious that, owing to the time occupied in raising and lowering the rods, the first part of the boring is performed at a much greater speed than the last.

In order to obviate the loss of time which ensues in raising and lo vering the rod, for the purpose of extracting the contents of the auger, a current of water may be sent down through the hollow rod, and made to ascend in the annular space be-

FIG. 97. tween it and the side of the hole with sufficient

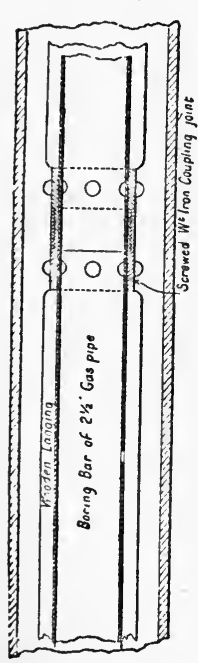
velocity to carry up the débris.

Fig. 96, again borrowed from Darley,* shows the derrick and general arrangement of the plant : $a$ is the boring rod made of $2 \frac{1}{2}$ inch (internal diameter) gas-pipe or lap-welded iron pipe, in lengths of 25 feet. The separate rods are joined, as shown in Fig. 97, by screwed spigot and socket connections which are riveted on.

The short topmost piece of rod $b$ (Fig. 98), carries the chamber $c$, at the base of which the head of $b$ can revolve freely. On the same rod $b$ is keyed the spur-wheel $d$. This is actuated by the pinion $e$ upon the vertical shaft $f$, which receives its motion from the horizontal shaft $h$ (Fig. 96), through a belt and the mitre wheels $g$.

The boring rod is driven at a speed of 80 to I 00 revolutions per minute. It is easy to understand from the figure how the rope $\operatorname{drums} j$ are worked from the same shaft $h$ at slow or high speed by using one or other of the two clutches upon this shaft. Water is pumped into $c$ by a hose, descends the rod, and passing through the bit ascends with the sludge and chips of rocks.

As the bit and rods descend, the carrier under the spur-wheel $d$ follows them, and also the pinion $e$, which is losse upon the square shaft $f$.

Fig. 99 represents a favourite form of cutting tool or boring bit, which begins by making a small hole and then speedily enlarges it to the full diameter.

As the lining tubes are usually 7 inches in diameter, the annular space botween the tube and the boring rod is large,

$$
\text { * Op. cit. p. 684. }
$$


and this is diminished by adding a lagging of wood (shown in Fig. 97) for the purpose of increasing the velocity of the upward current and so promoting the discharge of the débris.

The rapidity with which some holes are bored by this machinery is considerab!e. Mr. Darley mentions that a hole had been bored

FIG. 98 .

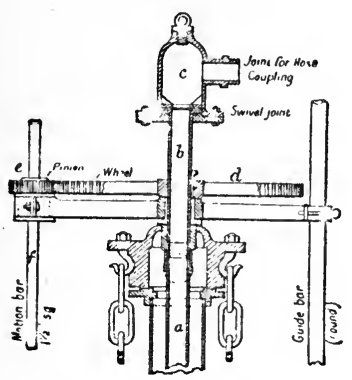

FIG. 99.

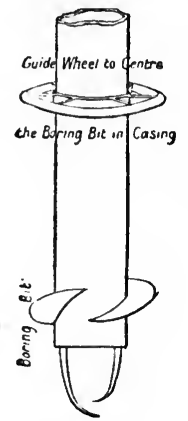

to the depth of 500 feet, and cased all the way in $11 \frac{3}{4}$ days, including the time occupied in putting up the derrick.

Another rotatory method for sinking wells or exploring in soft or moderately hard ground consists in revolving the casing or lining tube, which is shod with hard steel teeth,* whilst a stream of water is forced down through it; the water ascends in the narrow annular space between the tube and the sides of the hole. The core is gradually washed away by the descending current, and the inventors claim that any clay carried up by the water forms in time a protecting shell to the sides of the bore-hole, if composed of very loose strata. They even send down clay, chaff, bran, or cement by the tube for the express purpose of its making a resisting lining shell.

In the alluvium of the Mississippi at New Orleans a 7 -inch well was bored in this manner 500 feet deep in 48 hours.

For boring holes not exceeding 40 or 50 feet ( 12 to $15 \mathrm{~m}$.) in depth, which may be required for geological surveys or for investigating shallow-lying deposits, a convenient portable set of tools has been arranged by Messrs. Van den Broeck and Rutot. $\dagger$ It consists of the following parts : ( $\mathrm{I})$ a series of rods 4 feet $\mathrm{I}$ inch $(\mathrm{r} \cdot 25 \mathrm{~m}$.) long, which can be put together by screw joints; (2) either a chisel cutter or a twisted auger, for doing the actual boring; and (3) a handle which is attached to the topmost rod. As accessory

* Encyclopedia of Well-Sinking Appliances. The American Well Works, Aurora, Illinois, U.S.A., I886, p. 183 .

† "Un nouvel appareil, portatif de sondage pour reconnaissance rapide du terrain," Bulletin Soc. Belge de Géologie, tome ii. (Année I888), 29 Mai. 
parts, there are spanners for unscrewing the rods, a key for supporting the rods during this operation, and a second handle which can be fixed on any part of the line of rods if more force is required for the work. By a very ingenious clip, each joint can be so fixed that it cannot become unscrewed during the process of boring. The diameter of the large auger is $1 \frac{3}{4}$ inch (45 mm.) and the cutting part has two wings which are of service in penetrating the ground. The chisel is used for hard seams, such as ironstone, grit, and beds containing fossils or pebbles; like the auger, it is $1 \frac{3}{4}$ inch across. The apparatus is very portable, for no part is more than 4 feet $I$ inch long; each rod weighs 4.4 lbs. ( 2 kil.), and the total weight of all the plant required for making a boring 40 feet deep is only 64 lbs. (29 kil.).

Diamond Drills.-The most important kind of boring by rotation is done with the diamond drill. The working part of

Fra. ron.

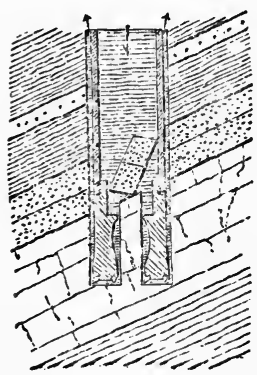
the drill consists of the so-called crown, which is a short piece of tube made of cast steel, at one end of which a number of black diamonds are fastened into small cavities. The crown is screwed on to wrought-iron pipes, w hich constitute the boring rod. This is made to rotate, and the result is that an annular groove is cut at the bottom of the hole, leaving a core which often breaks off of itself, is caught by a little shoulder, and brought out with the rod (Fig. 100).* In places where it is not necessary to make any verification of the rocks traversed, the crown may be arranged with diamonds in the centre also, so that the whole of the bottom of the hole is ground away. The débris in either case are washed away by a stream of water, which is forced down the tube and flows up the sides of the hole.

In order to prevent capital from being

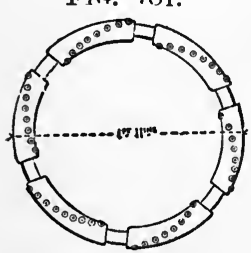
locked up in a stock of large crowns, Messrs. Docwra sometimes fix the diamonds in steel plugs, which will fit holes in any ring. The diamonds can then easily be taken out of one crown and placed in another without resetting.

The crown represented in Fig. ror was the largest employed at the deep boring at Northampton. It was screwed to a tube 30 feet long (Fig. IO2), which enabled cores of almost that length to be cut without withdrawing the tool. The object of the open sediment-tube above the core-tube was to catch

* Eun=on, "On a Deep Boring at Northampton," Min. Proc. Inst. C.E., vol. lxxiv. (1883), r. 270. 
any coarse particles too heavy to be carried up by the water, as well as any fragments falling from the sides of the hole.

Though pieces of the core often broke off of themselves and came up in the tube, it was necessary to use the extractor (Fig. 103) ; it consisted of a ring A, which was screwed by a few threads to the core-tube in the place of the crown. On reaching the bottom of the hole the screwing-up was continued, and the descent of the portion $\mathbf{C}$ gradually forced down six teeth, such as $B$, into the position shown by $\mathbf{B}^{\prime}$, gripping the core tightly. If not broken off completely by this action, it gave way when the tuhe was pulled, and came up inside it.

The "Dauntless" (Fig. I04) is one of the diamond drills made by the Bullock Manufacturing Company, of Chicago, for boring prospecting holes, and is capable of drilling a 2 -inch hole to a depth of more than 2000 feet, and furnishing cores of $1 \frac{7}{16}$ th inch in diameter. Cores showFIG. In3. ing visible gold have

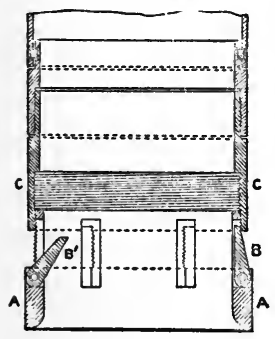
lately been brought up from a hole 2500 feet deep, bored by one of these drills near Johannesburg.

The machine is constivucted as follows: A is ore of a pair of cylinders, driven by steam cr compressed air, which work the bevel wheel

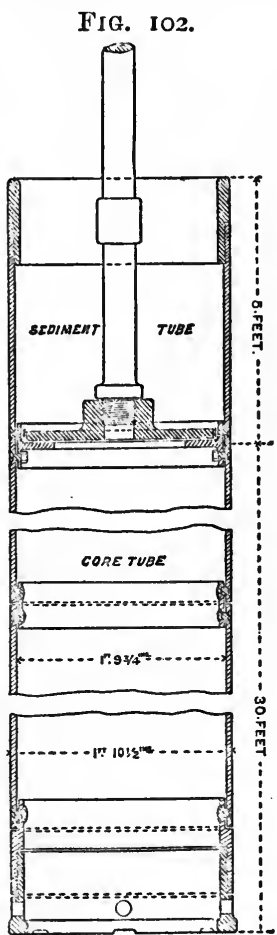

$\mathrm{B}$ by gearing. The feed-screw $\mathrm{CC}$ can slide readily up and down through B; but as $\mathrm{B}$ carries a feather lying in a slot in $\mathrm{C}$, the latter is driven round when the former rotates. $D$ is tho crown set with diamonds, screwed on to the first piece of boring tube $\mathbf{C}^{\prime \prime}$, attached to $\mathbf{C}$ by the chuck $\mathbf{C}^{\prime}$. The hose, $\mathbf{E}$, coming from a special pump, brings in a continuous supply of water which passes down $C^{\prime}$ and comes out through $D$. $\mathrm{F}^{\prime}, \mathrm{F}^{\prime \prime}, \mathrm{F}^{\prime \prime}$, and $\mathrm{G}^{\prime}, \mathrm{G}^{\prime \prime}, \mathrm{G}^{\prime \prime \prime}$, constitute the differential feed-gear for causing the feed-screw $\mathrm{C}$, and consequently the bit $\mathrm{D}$, to descend as tho hole is deepenerl.

$\mathrm{F}^{\prime}, \mathrm{F}^{\prime \prime}$, and $\mathrm{F}^{\prime \prime \prime}$ are connected with $\mathrm{B}$ so that they revolve when it does; 'G', G", and $G^{\prime \prime \prime}$ are loose upon the counter-shaft, but any one of them can be made fast to it by operating the clutch $H$. $\mathrm{K}$ is a toothed wheel attached solidly to the bottom of a feed-nut through which $\mathbf{C}$ passes; when $\mathbf{K}$ rotates it causes $\mathbf{C}$ to ascend or 
descend. $\mathrm{L}$ is a wheel equal in size to $\mathrm{K}$, which it drives when its shaft is rotated by $G^{\prime}, G^{\prime \prime}$, or $G^{\prime \prime \prime}$.

If $F^{\prime}$ and $G^{\prime}$ had the same number of teeth each, one revolution

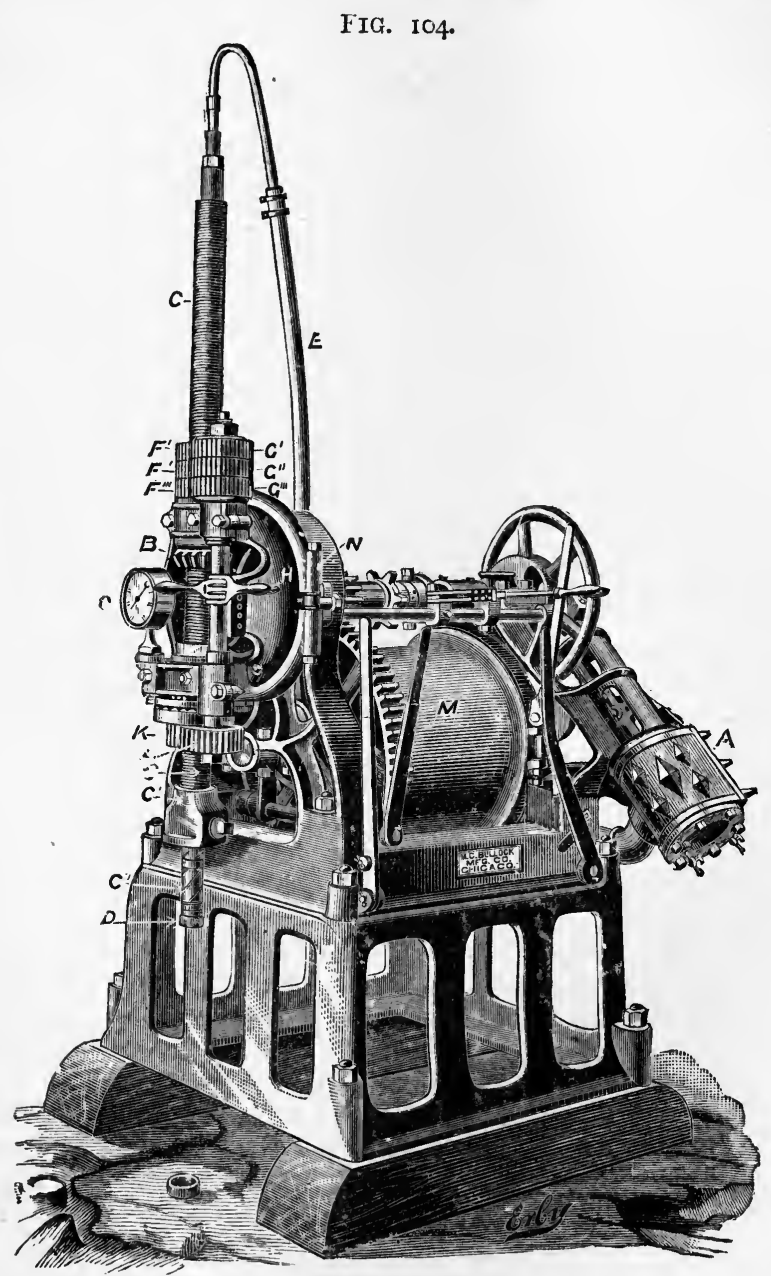

of $\mathrm{B}$ would make one revolution of $\mathrm{G}^{\prime}$, one revolution of $\mathrm{L}$, and one revolution of $\mathrm{K}$; consequently the feed-nut attached to $\mathrm{K}$ would be revolving at the same rate as $\mathrm{C}$, and $\mathrm{C}$ would not descend. In reality $G^{\prime}, G^{\prime \prime}$, and $G^{\prime \prime \prime}$ have a slightly smaller number of teeth than $F^{\prime}, F^{\prime \prime}$, and $F^{\prime \prime \prime}$; therefore one revolution of $F^{\prime}$ causes slightly 
more than one revolution of $\mathrm{G}^{\prime}, \mathrm{K}$ moves rather faster than $\mathrm{C}$, and $\mathrm{C}$ descends slowly. As arranged in this particular case, the gear $\mathrm{F}^{\prime} \mathrm{G}^{\prime}$ causes $\mathrm{C}$ to descend $\mathrm{I}$ inch for every 300 revolutions, the gear $F^{\prime \prime} G^{\prime \prime}$ gives a feed of $I$ inch for every $45^{\circ}$ revolutions, and $\mathrm{F}^{\prime \prime \prime} \mathrm{G}^{\prime \prime \prime}$ a similar feed for $75^{\circ}$ revolutions. The driller is thus enabled to regulate his feed to the hardness of the rock bored. In practice these three speeds of advance have been found sufficient.

M is a drum which is used for hoisting the rod out of the hole; $\mathrm{N}$ is the hinge upon which the whole of the boring head can be turned, so as to leave the mouth of the hole perfectly free while raising or lowering rods. $O$ is the thrust register, upon which is indicated by a dial the resistance exerted by the rock against the bit. This is an addition of great importance, for by watching the indicator the driller can detect changes in the hardness of the strata passed through, and can measure the exact thickness of the hard and soft beds before he has seen either the cuttings or the cores. The thrust register prevents the possibility of drilling through a bed of coal or other mineral without its being noticed, as has happened when the seam was so soft that it failed to furnish a core. The rod is lengthened as the drilling proceeds by screwing on piece after piece between $\mathrm{C}^{\prime}$ and the topmost rod projecting above the hole.

Mr. Bullock has recently brought out a contrivance by which the core can be drawn up through the hollow boring rods without removing them from the hole. The immense saving of time effected in this manner is of supreme importance when boring at great depths.

The large rock drill used by the American Diamond Rock Boring Company, * for putting down holes to a depth of 2000 feet, consists of a 20 horse-power boiler with two oscillating 6-inch cylinders and the necessary gearing for working the drill, all mounted on a carriage, so that the whole machine is readily moved from place to place. The feed is effected by gearing, or by hydraulic pressure, a $2 \frac{3}{4}$-inch crown is employed, leaving a 2-inch core. Each separate drill rod is 10 feet long. The total weight of the machine is about four tons.

The new $\dagger$ Victorian Giant Drill, said to be the largest and most powerful drill in Australia, contains some improvements suggested by experience. The cylinders are $7 \frac{1}{2}$ inches in diameter, and are made stationary, because the heavy vibrations of oscillating cylinders are imparted to the boring rods and diamond bit, and do harm to the machinery. The winding drum has a friction pulley and a brake, which enable the rods to be lowered without working the engine, and so prevent unnecessary wear and tear.

* Eng. Min. Jour., vol. xlviii. (1889), p. 569.

$\dagger$ Victoria, Annual Report of the Secretary for Mincs for the Year 1889 . Melbourne, 1890, p. 35 . 
Various parts are strengthened, and there is an arrangement for working the steam expansively.

This method of boring is expensive. During the year 1889 , the cost of prospecting for gold by diamond drills in Victoria* was Ios. $3 \frac{1}{2}$ d. per foot bored, exclusive of the wear and tear of diamonds, taking the average of a total 18,454 feet bored. The cost for the wear and tear of diamonds for 30,294 feet bored in search of coal and gold is put down at $£ 6000$, or nearly 4s. per foot. In the borings executed by the Government of New South Wales, $\uparrow$ the cost for diamonds is very much less, varying as a rule from Is. to $2 \mathrm{~s}$. per foot. This may probably be accounted for by the fact that most of the New South Wales bore-holes were made in the comparatively soft Carboniferous strata, whilst some of the bore-holes for deep leads in Victoria had to traverse hard basalt.

The cost at Broken Hill, where a boring 3 inches in diameter was carried from I 122 feet to a depth of 1880 feet in I889, was $\mathcal{E}_{\mathrm{I}}$ 9s. I० $\frac{7}{8} \mathrm{~d}$., or, roughly speaking, 3 os. per foot, exclusive of ottice salaries, store wages, rent, and the Superintendent of Drills' travelling expenses. The rocks traversed were gneiss, mica schist and quartzite, sometimes garnetiferous. The average rate of boring was only $5^{\circ} 7 \mathrm{I}$ inches per hour, whilst in the sandstone and shale of the Carboniferous strata there was a progress of 9 to $3^{\mathrm{I}}$ inches per hour, at a cost (exclusive of the items mentioned above) of $6 \mathrm{~s}$. $2 \mathrm{~d}$. to $18 \mathrm{~s}$. $4 \mathrm{~d}$. per foot. The average working cost of 7854 feet bored by the Department of Mines, New South Wales, in 1889 , including all expenses, was r $4 \mathrm{~s}$. $3 \frac{1}{4} \mathrm{~d}$. per foot. Of the total 7854 feet, no less than 7096 were in strata of Carboniferous age, and only 758 in metamorphic schists; the holes were from $2 \frac{1}{2}$ inches to 4 inches in diameter.

With reference to the rate of boring, it must be remembered that the figures given refer to the speed obtained while the machine was at work, but the average amount of deepening of the hole at Broken Hill during the year was little over 2 feet per day. Omitting Sundays, there were $3 \mathrm{I} 3$ working days. Only 199, or less than two-thirds, were employed in boring; of the remainder, 86 were occupied in repairing, $\mathrm{I} 5$ in reaming, 4 by delays, 9 by holidays; the working day was eight hours.

The amount of core obtained at Broken Hill compared with the total depth bored was as much as $97 \frac{1}{2}$ per cent., and the average for the total 7854 feet referred to above was 89.33 per cent., a very excellent result.

Small diamond drills, which will bore in any direction, and which are driven by hand, compressed air, or electricity, are largely used underground for prospecting. The hand drill of a

* Op. cit., p. 63.

t Annual Rerort for the Dipartment of Mines, New South Wales, for the Icar I889. Sylney, 1890, p. I39. 
Swedish boring company* gives cores $\frac{7}{8}$ inch in diameter. Exploration by these little machines is very decidedly cheaper than by driving or sinking by hand in hard rocks, and fully ten times as quick. On the other hand, the ground is not opened out as it would be by a shaft or drift, and the sample furnished is but small.

Several good veins have been discovered by the aid of the little hand-machine in Scandinavia-for instance, a copper lode 15 feet $(4.5 \mathrm{~m}$.) wide at Röraas, and iron lodes from 32 to 65 feet ( $10 \mathrm{~m}$. to $20 \mathrm{~m}$.) wide at Dcnnemora and Persberg.

The hand-power drill of the Bullock Manufacturing Company, Chicago, is a somewhat similar little machine, and it is said to be

FIG. 105.

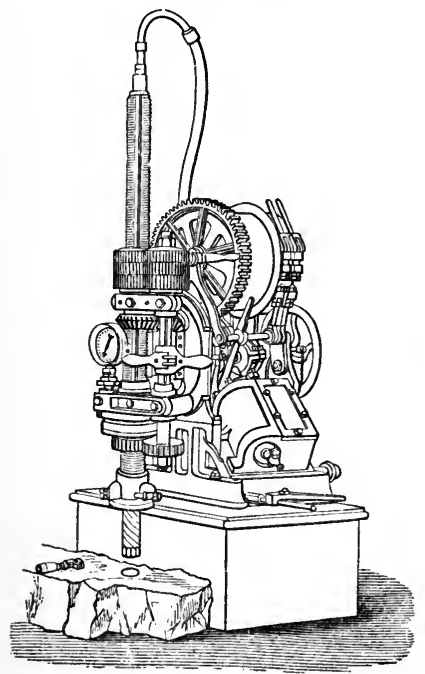

FIG. I06.

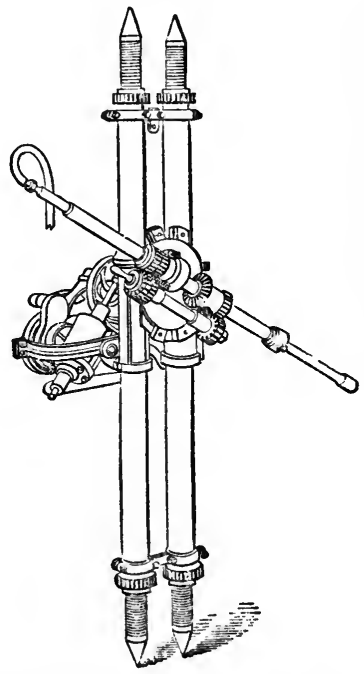

capable of boring a hole of $\mathrm{x} \frac{3}{4}$ inch diameter, with a $\mathrm{I}_{16} \frac{3}{16}$ inch core, to a depth of 400 feet.

Machines driven by compressed air are often employed at ore mines in the United States for exploratory purposes. Fig. I05 shows the Little Champion prospecting drill. Two inclined cylinders drive a horizontal crank-shaft, which works bevel gear, causing the drill to revolve. At the same time a counter-shaft is likewise set in motion, and this effects the advance of the drill by driving the feed screw, in the manner already explained in the description of the "Dauntless" machine

* Nordenström, "Die Diamantbohrmaschine mit Handhetrieb," $B . u . h$. Z. 1889, pp. 389 and 449 ; and Pétiton, Bul. Soc. Ind. Min., ३e Série, vol. iii. (1889), p. 1395 .

+ Eng. Mlin. Jour., vol. xxxiii. (I8\&2), p. I 19. 
(p. 1 20). The feed-screw and its connections are carried by a swivel-head, and this can be turned so as to drill holes at an angle. The drum shown above the cylinders is used for hoisting out the drill-rods by a rope. The rods are lap-welded iron tubes $I_{5}$ inch in diameter, fitted with a bayonet joint.

Another light portable prospecting drill for underground work is represented in Fig. 106.* It is intended for driiling holes $I_{4}^{1}$ inch in diameter to a depth of 150 feet. The cores which it yields are $\frac{7}{8}$ inch in diameter. It has double oscillating cylinders $3 \frac{1}{2}$ inches in diameter, with $3 \frac{1}{2}$ inches stroke, which are run up to is speed of 800 revolutions a minute. The drill can be set to bore in any direction by turning the swivel-head on which it is carried.

The Sullivan prospecting drill is a diamond borer driven by an electric motor on the same frame as the drill. The motor also works the force-puinp. The feed is not by toothed wheels as shown in the figures, but by friction gearing. It will bore at any angle to a depth of 300 feet.

Georgi's $\uparrow$ electric diamond drill, primarily intended for boring holes for blasting, can also be employed for prospecting underground.

Substitutes for Diamonds.-Olaf Terp $\downarrow$ uses emery instead of diamonds. In some cases he puts in the fragments of emery loose at the bottom of the hole and allows them to wedge themselves into grooves in the boring crown, which is made of soft metal. Another plan is to make the boring crown entirely of emery. The speed of rotation is three or four times as great as with diamonds, and holes can be bored from $\frac{3}{4}$ inch $(20 \mathrm{~mm}$.) to 3 feet 4 inches $(\mathrm{r} \mathrm{m}$.) in diameter. Beal bores with small chilled cast-iron shot, which are dropped into the hole while a wrought-iron tube is revolving in it. The débris are carried up by water, and the cores are extracted in the ordinary way.

\section{BORING BY PERCUSSION WITH RODS.}

Iron Rods.-The rods are either of iron or wood. In France preference is given to iron, and the following details relate to modes of construction now employed by M. Paulin Arrault, $\S$ the well-known boring engineer of Paris.

The actual boring apparatus consists of the cutting tool, the rods, and the driving machine; but in addition it is necessary to

* Eng. Min. Jour., vol. xxxiii. (1882), p. 273.

+ Juhrb. $f$. d. Berg- und Hüttenuesen im $K$. Sachsen, 1890 , p. 95.

¥ Olaf Terp's "Bohrmaschine mit Schmirgelbohrkrone," B. u. h. Z., I890, p. 415 .

$\S$ 'I'ne figures are copied by permission from M. Arrault's work, Outils et procédés de Sondage. Paris, 1890. 
have clearing tools, and appliances for remedying accidents, lining the bore-holes, and obtaining samples of the rocks traversed.

Cutting Tools.-The actual cutting tool is usually a chisel (Fig. r07) of some kind ; for soft rocks the edge is strajght; for hard rocks there are wings to guide the tool and keep the hole vertical, or even special guides above it. For diameters not exceeding 40 inches $(\mathrm{r} \mathrm{m}$.), there is usually only one chisel; but the actual cutting blade is sometimes made in a separate piece fastened by gibs and cotters to the tool carrier (Fig. I 8 ). In boring larger holes the chisel is made of two, three, or four separate blades.

Boring Rods.-The boring rods are made of iron of square section. The usual mode of connection is by a screw-joint such as is shown in Fig. 108, Fig. 107.

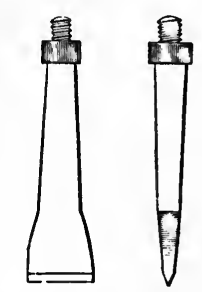
care being taken to have all the bars alike, so taht any two bars can be screwed together. M. Arrault prefers to have a connecting socket (Fjg. IO9). The ordinary rods have a thread at each end, to one of which is screwed a socket or sleeve which is fixed by a pin. This socket then receives the end of another rod, which is screwed up until both ends meet. When the thread of a socket becomes worn, it is taken off and put on to the other end of the rod; in a Figs. 108 \& 109. similar manner, if the thread of a rod is worn, the socket may be screwed on to it and the unworn end used in the process of jointing and unjointing. The rods are generally screwed up to the right and are turned in that direction; but in special cases it may be necessary to have the sockets fixed by two pins, or to have a special joint or a left-handed thread.

The height of the tower, derrick, or shears erected above the bore-hole should be some

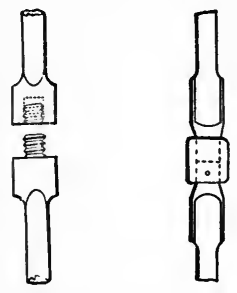
multiple of the length of the rods, so as to be able to detach or attach two or three lengths at a time, instead of having to make and unmake every joint.

FIG. IIO.

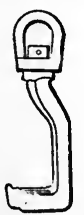

FIG. III.

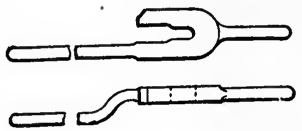

FIG. 112.

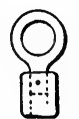

Arrault's rods vary in length from I foot 8 inches $(0.50 \mathrm{~m}$.) to 20 feet $(6 \mathrm{~m}$.), being usually an exact number of metres, and in size from $\frac{7}{8}$ inch $\left(22 \mathrm{~mm}\right.$.) to $3 \frac{1}{2}$ inches $(90 \mathrm{~mm}$.) on the side. 
They have two shoulders at each extremity, so that the upper one can be used with the lifting hook, Fig. I Io, when the lower is resting upon the key, Fig. I I I.

A cap such as Fig. I I 2, may be screwed on and used instead of the lifting hook for raising the rods by the rope.

Working the Rod.-The up-and-down movement of the rods may be obtained in various ways. For depths not exceeding 60 to 80

FIG. II 3 .

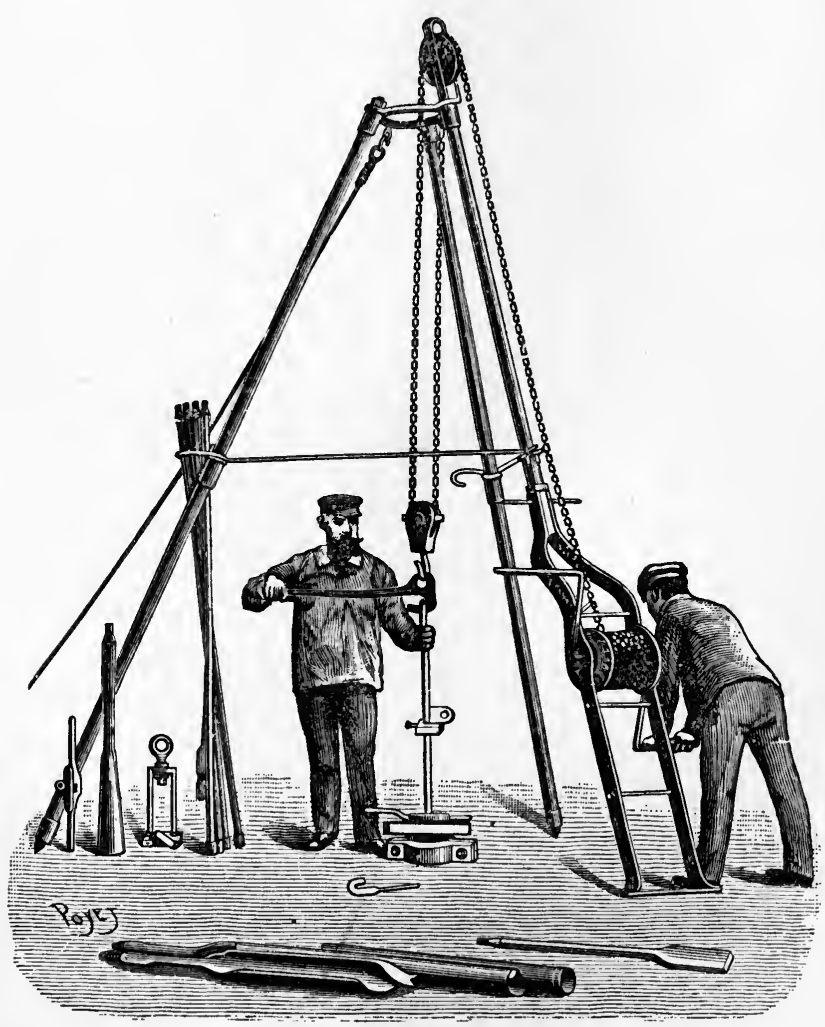

feet, nothing can be simpler than the device shown in Fig. I I 3 . The man at the windlass raises the rods by turning the handle, and the master borer detaches them and causes them to fall by simply pressing down the end of the hook, which he holds in his right hand. The chain is lowered, the hook put in, the rods are raised by the winch, and then again allowed to fall, the master borer taking care to turn them a little eash time. 
Fig. I 4 shows the principal tools supplied by Arrault for a small boring.

For greater depths a lever has to be employed, the rods being suspended at one end, while the other can be pressed down by men using their hands or fect. The spring pole is another arrangement; the pole is pulled down to make the stroke, and its elasticity lifts the rod again. The length of the stroke can be

FIG. II4.

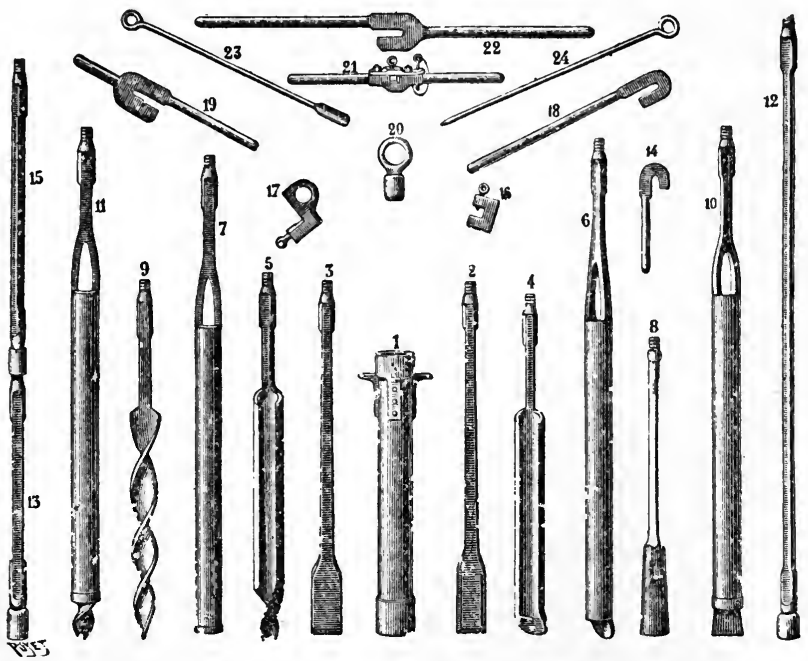

I, guide tube; 2 , bit or chisel with wings; 3 , straight bit or chisel : 4, ordinary open scoop or wimble; 5 , scoop or wimble with auger; 6 , closed scoop ; 7 , slunger with ball valve ; 8 , bellscrew or screw grab ; 9, auger ; 10, combination bit and sludger with ball valve; II, combination auger and sludger with ball valve; I2, boring rod; 13 , matching piece ; 14 , wrench for unscrewing rods ; 15 , matching or lengthening piece ; 16 , clamp; 17, clamp with eye ; 18, wrench ; 19, retaining or supporting key; 20, cap; 21, tiller; 22, double wrench; 23, scraper; 24, picker.

rendered uniform during the boring by means of a screw in a swivel-head at the top of the rod.

With deep holes, and especially those of large diameter, steam machinery has to be employed for working the rod. Arrault frequently uses a winch driven by steam. The chain to which the rods are attached passes over a pulley hung from a derrick and is coiled on a drum, which is loose upon the main axle of the winch; it can be thrown in and out of gear by a clutch moved by a lever. It is easy therefore to raise the rods by working the winch, and then let them drop by simply releasing the clutch. 
Occasionally a direct-acting engine is placed immediately above the bore-hole, but a commoner arrangement is to employ a single-acting cylinder with its piston acting at one end of a beam, while the rods are attached to the other end. A favourite plan also is to actuate the beam by a connecting rod worked by a crank.

Process of Boring.-The actual machinery has now been described, and the mere boring appears to be a very simple matter, consisting only in lifting the rod a little and allowing it to drop, after turning it slightly before each stroke. Nevertheless the process of putting down a bore-hole is far more complicated than it might seem, for there are numerous operations which take up much time. In the first place the débris must be removed by a clearing tool, and before this can be lowered the cutting tool must be taken off. The swivel-head is disconnected, and a cap screwed on; a length of rod is now drawn up by a hand or a steam windlass, the retaining key is put under a shoulder, and the joint unscrewed by another key. It is well to have as many caps as there are lengths to be drawn up, and then each length can be suspended in the boring house or derrick.

As son as the hole is free the clearing tool is lowered, either by the rods in precisely the same way as the boring chisel, or by means of a rope and windlass. The clearing tool FIG. II5. is usually a hollow cylinder with an ordinary clack or a ball valve (shell pump or sludger) (Fig. I I5). It is worked up and down a little till it is filled, and it is then drawn up to the surface and emptied. The operation is repeated if necessary, and the boring is resumed with the rod. Sometimes a cutting blade is added to the sludger so that it bores a little and picks up the débris at the same time. In certain rocks such as marls, it is convenient to have a shell-pump with a lip. It is fixed to the rods, and when it is turned a little as well as moved up and down, it soon fills itself.

Oeynhausen's Joint and free-falling tools. - When a hole of large diameter is being bored, the weight of the rods is so great that much vibration ensues when they are suddenly arrested by the chisel striking against the bottom. Various devices have been contrived for overcoming this difficulty, among which may be mentioned Oeynhausen's sliding joint and three methods of making the tool fall independently of the rod. Oeynhausen's contrivance (Figs. I I 6 and I 7 ) consists of an upper piece $a$ provided with a slot in which the lower piece $b$ can slide; $b$ is prevented from dropping out by a crosshead and carries the boring chisel, whilst $a$ is attached to the line of rods.

When a down-stroke is made and the chisel strikes the bottom, the piece $a$ slides over $b$ and is therefore but little affected by any jar produced by the blow of the tool. The lengtlı 
of the stroke is arranged so that the top of the slot will not descend far enough to touch the crosshead; $a$ is then raised once more and again catches the crosshead.

One of the simplest arrangements for making the tool fall independently is the sliding joint shown in Fig. 118 . Thepiece supporting the boring tool has two wings (Fig. I I9) which rest upon shoulders, at the top of a long slot in a cylinder attached to the lowest rod ; by giving the rods a sharp turn to the left, the wings lose their support and the tool drops.

The actual process of boring is carried on in the following manner :The line of rods suspended to a chain is raised by a steam winch.

Fig. I I9. Steam is then shut off, and

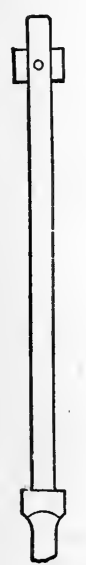
the master borer by a sudden twist of the tiller causes the bayonet joint to act; the tool drops and makes its cut. The rods are then lowered, and the slot comes down over the wings which are pressed by the inclined surfaces at the end on to the Frgs. II6, 117 \& Ir8. shoulders; the steam is turned on again, and the operations of winding up, stopping, twisting, letting the tool fall and lowering are repeated. The contrivance acts so easily that it is sometimes used even for comparatively shallow bore-holes.

The free fall is obtained by Arrault in a different manner when the boring is done by a beam (Fig. 120). The tool is suspended from the catch $h$ (Fig. 121). The part $a b$ has a pin $i$, which lies in an oval hole. While the rods are being lifted the beam strikes a bumpingpiece, and their upward movement is suddenly checked; inertia carries the catch $a b$ up a little, the end $a$ strikes an inclined surface and causes the end $b$ to move outwards and detach the tool. When the rods are lowered the part $h$ hooks itself on without difficulty, and the chisel is raised and dropped.

This tool requires the boring rod to be guided, for otherwise the hole might not be bored straight. 
Fig. 122 explains a well-known free-falling tool invented many years ago by Kind.* The head of the actual boring rod is held

FIG. I21.

Fig. 120.

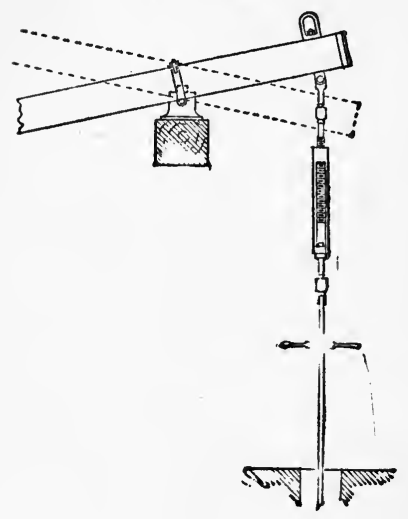

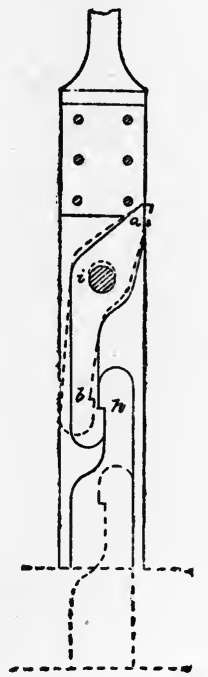

FIG. 122.

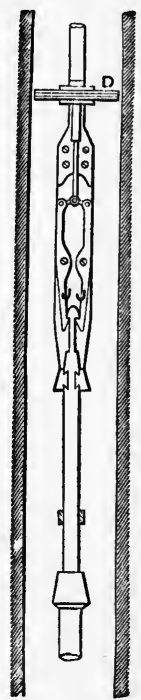

by a click or grapple. When the main rod descends, the resistance of the water in the hole checks the sliding disk D; the jaws $\mathrm{J} J$ are opened by the little rod which connects them to $\mathrm{D}$, and the boring part falls and strikes the bottom without any injurious vibrations being communicated to the main rod. When the disc descends further, the head is caught again by the click.

Accidents.-Tools for putting things right in case of accident are numerous, and many of the contrivances which have been invented by engineers are extremely ingenious.

Among the accidents is a breakage of the rod. If the rods are not caught in any way, a claw called the crow's-foot (Fig. 123) is lowered and turned round till it catches a rod below one of the shoulders; it is then drawn up. Sometimes it is found that a hole has suddenly deviated from the vertical, owing to a difference in hardness in the rock, which causes the chisel to work more easily on one side than the other. One method of remedying this evil is to fill the bad part with cement, and rebore it very carefully.

Broken ropes can be caught hold of by tools resembling a corkscrew. The tool shown in Fig. 124 serves to cut a thread upon the end of a broken rod. The position of the broken end is first

* J. Callon, Lectures on Mining, vol. i., Atlas, Plate IX., Fig. 52. 
ascertained by taking an impression upon tallow or wax, and the cone is then lowered on to it; by turning it round a thread is cut on the broken end, which can now be raised with the rods and tools attached to it.

If the cutting chisel is broken, some kind of grasping nippers must be used, and there are contrivances for making them act when they have reached the bottom of the hole.

Linings. - Where the strata are soft and would fall in, or where it is necessary to shut off the inflow of certain water-bearing beds in order to confine the well to one particular source of

FIGS. $123 \&$ I 24 .

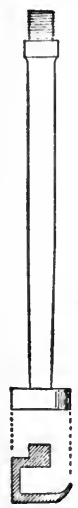

FIG. 125 .

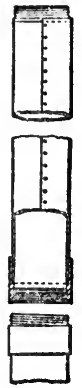

FIG. 126.

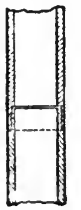

supply, the hole has to be lined with a tube. Tubes are made of iron, copper, or wood. This last material is seldom employed nowadays, because it occupies so much space, and because it is not easy to make good wooden tubes.

Fig. I 25 is a tube of riveted sheet iron with sockets fixed on, which enable the joints to be made by screwing. Fig. 126 is a tube with a screwed joint perfectly smooth outside and inside. Copper tubes are advisable when the water, such as that coming from pyritiferous beds, would attack iron and in tinse eat it away; but this difficulty is also overcome by putting earthenware pipes inside, and filling up the interspace with cement.

Cores.-Though the fragments brought up in the sand-pump will indicate the nature of the rocks which are being traversed, it is often desirable to obtain a core of the actual stratum itself, which will show the direction and amount of the dip of the rocks, and possibly contain fossils and so afford valuable knowledge concerning their precise age. A core is cut out either by rotation or percussion. In the former case the tool consists of a sheet-iron cylinder (Figs. 127 and 128) armed at the bottom with 
steel sawing teeth; in the latter the cylinder is surrounded by four cutting chisels, which chip out a ring and leave a solid cylinder standing.

The core now has to be detached, and for this purpose various contrivances may be adopted. One of Arrault's tools is shown in Fig. 1 29. It is a hollow cylinder $a$ attached to the fork $b c$, with a longitudinal slot containing a sliding bar $d$, armed with a toothed wedge $e$, which is prevented from dropping out by the shoulder $f$. The bar $d$ is further kept in position by the spring $g h$, fixed at

$$
\text { FIGE. } 127 \& 129 .
$$
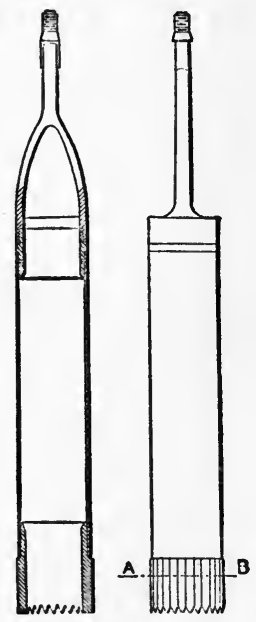

Section at A B.

\section{FIG. I29.}

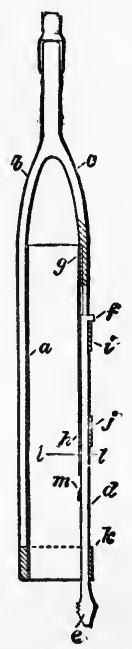

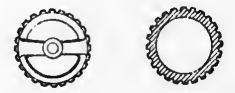

the top of the tube, which presses it against the two outer plates $i j$ and the ring $k ; l$ is a little slot in the spring, and $m$ a small stud upon the bar $d$. When this tool is lowered over the core and the wedge $e$ touches the bottom of the annular groove around it, the tube slides down and forces the wedge inwards; the weight of the rods causes sufficient pressure to drive the teeth of the wedge into the core and break it off. In the meantime the slot $l$ has passed over the stud $m$; the wedge is thus prevented from slipping down, and the core is held till it is drawn up to the surface.

In order that the direction of the dip may be ascertained from the core, it is necessary to know exactly how it stood when it was 
in situ. In Victoria* the rods and the core-breaker are put together at the surface, and all the joints are marked in a straight line with a chisel. The rods are then taken apart, and are carefully screwed together in precisely the same manner when they are lowered into the bore-hole. If the position of the marks at the surface is noted while the core is being detached, the direction of the dip can at once be determined. To prevent the possibility of error from a movement of the core after it has been detached, it is marked while at the bottom of the hole with a vertical scratch or groove. This is made by a sharp steel point on the gripper as it slides down over the core.

A method lately invented by Arrault consists in lowering a compass, enclosed in a case made of phosphor bronze, on to the

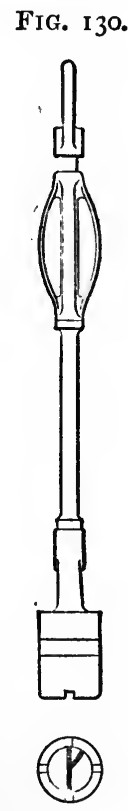

Frg. I3OA.

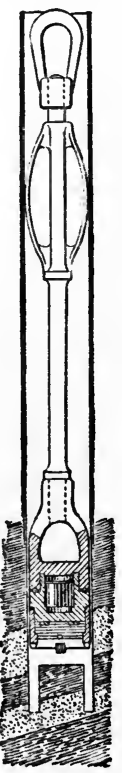

top of the core (Figs. I30 and $\mathrm{I} 30 \mathrm{~A}$ ). The case has an indiarubber base, with two grooves filled with felt impregnated with a thick ink. The compass case also contains clockwork, arranged like an alarum, which can be made to liberate a catch and so clamp the compass. The compass is lowered by a rope, and sufficient time is given to enable it to assume its proper position before

* Reports and Statistics of the Mining Department, Victoria, for the Quarter ended IIurch $3 I, I 89 I$, p. 28, with Plate. 
it is fixed by the clockwork. It is drawn up, the core is then extracted, and by means of the ink marks the compass can be put upon the core in precisely the same position as it originally occupied in the hole.

Instead of using ink marks, some plastic material* such as clay may be lowered on to the top of the core and allowed to remain long enough to take an impression. A clockwork arrangement in a watertight box above the plastic lump sets a magnet fast after the lapse of a given time as before, and when the core is brought up it is placed so as to fit the impressions, the orientation of which is known by the magnet. $\dagger$

Wooden Rods. - In some districts wooden rods are found more suitable than iron ones. They have been used in Canada, and they are preferred in Galicia. Fig. I3I represents the manner in which the rods are made for boring oil wells in that country. The rods employed in Galicia are of ash, 32 feet 10 inches ( $10 \mathrm{~m}$.) long, and 2 inches in diameter; at each end a forked iron coupling is riveted on, terminating by a conical male or female screw, and in the middle are two strapping plates of iron to give more strength and stiffness. To the end of the lowest rod is attached an Oeynhausen sliding joint which carries a sinker bar with the cutting chisel attached to it. The sinker bar is from 20 to 30 feet (6 to $9 \mathrm{~m}$.) long, and weighs from 12 to 15 cwt. ( 600 to 750 kil.).

The top of the line of rods is fastened to a chain (Fig. I 32); this makes three turns round one end of the boring beam, capped for this purpose by a casting with a spiral groove, and is then wound on to a little windlass placed on the beam. The beam receives its up-and-down movement from a connecting rod attached to a crank upon the axle of a wheel driven by a belt from a small steam-engine. $f$

After boring, the chain is unfastened, and the rods are drawn up by means of a hemp or manilla rope I $\frac{3}{4}$ inch $(45 \mathrm{~mm}$.) in diameter, which is also used for working the sand-pump. The master borer can perform all the necessary operations while sitting in front of the hole. By means of the rope $a$ he can work the windlass upon which the chain is coiled, and by pulling the lever $b$ he can throw in or out of gear the

* B. u. h. Z., 189o, p. 205.

$\dagger$ Reports and Statistics of the Mining Department, Victoria, Quarter ended March $3 I, I 89 I$, Dip contrivance, p. 28.

¥ Syroczynski, "Note sur le forage canadien," Bull. Soc. Ind. Min., tome iii., $3^{\mathrm{e}}$ Série. Saint-Litienne, 1889, p. 1417. 
pulley which drives the drum with the winding rope, and so raise or lower the rods or the sand-pump. The lever $c$ actuates a brake which enables him to stop the machinery, if necessary, and with his left foot he can press upon a pedal $e$, and so regulate the steam valve, and alter at pleasure the speed of the engine.

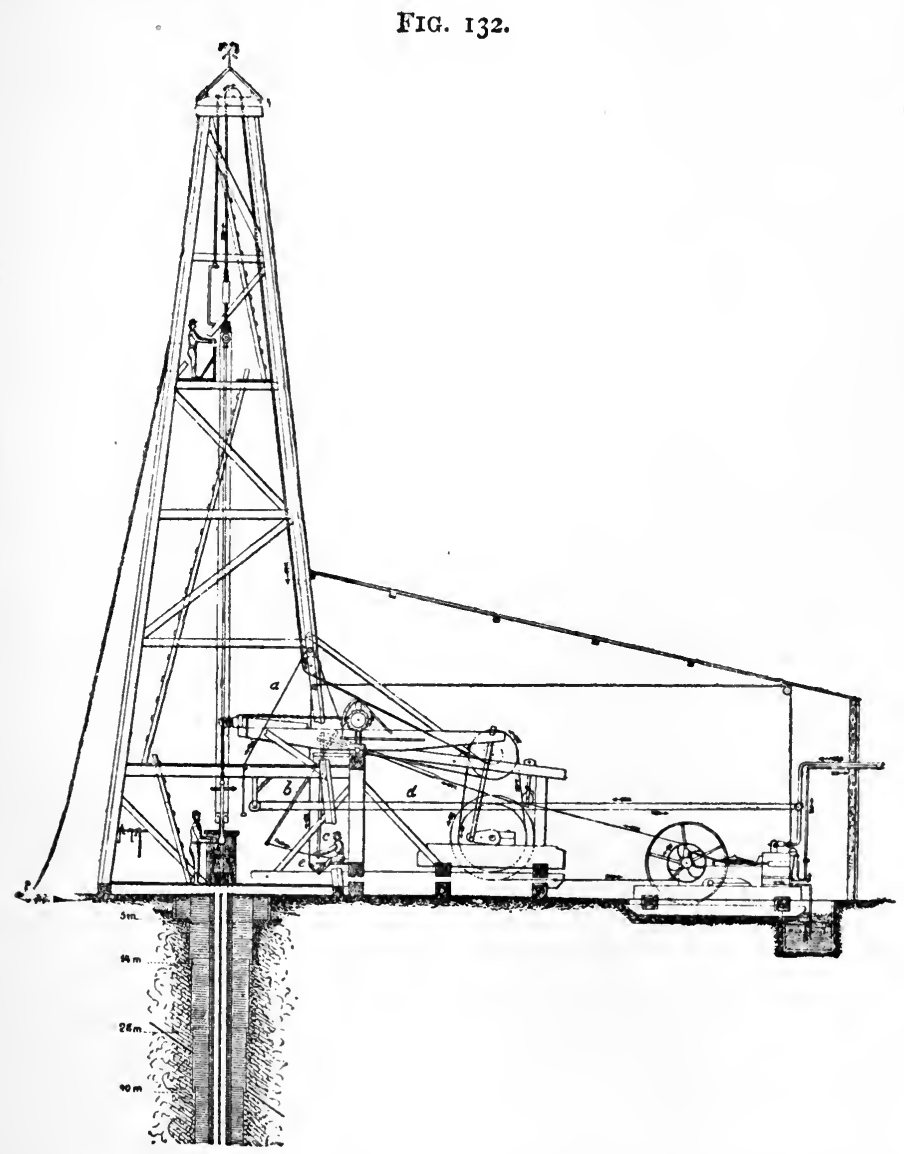

The cord $d$ works a second steam valve. Two other workmen, one at the bore-hole, and the other on a platform 33 feet ( $10 \mathrm{~m}$.) above him, are shown in the act of unscrewing and putting away the rods.

During the actual boring, the two assistants stand at the hole and turn the rods, whilst the mister borer remulates the blow by 
the cord $a$ which commands the windlass, and the cord $d$ which controls the admission of steam.

The tower or derrick is about 50 feet ( 15 to $16 \mathrm{~m}$.) high, and I 6 feet $(5 \mathrm{~m}$.) square at the base. It is closed in with planks. The adjacent space required for the steam-engine, belts, wheels, \&c., is 35 square yards ( 30 square $\mathrm{m}$.). The end of the beam travels about 20 inches $(50 \mathrm{~cm}$.); but owing to the interposition of the sliding joint the stroke of the chisel is somewhat less. There are about 50 to 60 blows a minute. After work has gone on for a time, and the débris begin to accumulate, the rods are withdrawn and the shell-pump is lowered by the rope. It is a cylinder 32 feet (ro $\mathrm{m}$.) long, with a valve in the bottom; it fills itself, it is drawn up, and the valve is opened to discharge the sludge. In consequence of the lightness of the rods, the conicity of the screw joints, and the skill of the workmen, the various boring operations are carried on with surprising rapidity. Scarcely half a minute is required for unscrewing a joint, and a set of rods 650 feet long $(200 \mathrm{~m}$.) is drawn up or lowered in 10 or 12 minutes.

For a hole 1000 feet $(300 \mathrm{~m}$.) deep, the four operations of raising the chisel, lowering and raising the shell-pump, and again lowering the rods and chisel, do not require more than an hour.

Three men are required, of whom one is the master borer and one the engineman. Their wages do not exceed ro florins a day, and if the wages of the smiths, who are constantly required, are added, the total cost of wages per day will be from 15 to 16 florins.

The initial diameter of the hole varies from $9 \frac{3}{4}$ inches $\left(0^{\circ} 25 \mathrm{~m}\right.$.) to $15 \frac{3}{4}$ inches $\left(0^{\circ} 40 \mathrm{~m}\right.$.) in loose ground, and the final diameter is 4 inches $(2.10 \mathrm{~m}$.). The hole is lined with tubes throughout, they are made of welded sheet-iron screwed together and perfectly watertight.

The successive columns of tubes of the lower part of the hole are placed one within the other. They are not withdrawn till the hole is completed. The cost of the plant varies from 8000 to ro,000 florins, including a 12 to 15 h.-p. steam-engine, which, with its boiler, comes to 3500 florins. To this must be added the cost of the tubing, which, according to the diameter, varies from 3 to Io or I I florins per metre.

The boring contractors ask from 15 to 25 florins per metre for a boring estimated to be 1000 feet deep (300 metres), plus 50 per cent. of the petroleum obtained in the first case, or 30 per cent. in the latter. They leave the tubes necessary for preserving the well, provided they are paid one-half of their value. Contracts are also made for sinking wells at 50 florins per metre, without any interest in the output.

As an example of the work, a well was bored 738 feet deep 
$(225 \mathrm{~m}$.) at Wietrzno, by M. Suszycki, beginning with a diameter of $15 \frac{3}{4}$ inches $\left(0.40 \mathrm{~m}\right.$.) and ending with $5 \frac{3}{4}$ inches ( $145 \mathrm{~m}$.) in 90 days, of which 70 were occupied in actual boring. The average progress was ro feet 6 inches per day $\left(3^{\circ} 20 \mathrm{~m}\right.$.), the maximum $3^{2}$ feet $(9.8 \mathrm{r} \mathrm{m}$.) per day. Several wells have been bored to a depth of 1500 feet (over 450 metres) at Stoboda Runzwoska. Under some exceptionally favourable circumstances a hole 475 feet ( $145 \mathrm{~m}$.) deep was bored in eight days with 140 hours of effective work.

This system, therefore, seems suited to the conditions prevailing in Galicia. The American method of boring with the rope, which answers in Pennsylvania, where the beds are nearly horizontal, did not succeed in Galicia, with the soft Tertiary rocks, which often dip considerably. As regards the material for the rods, wood is to be preferred to iron in Galicia. Wooden rods are lighter and more easily manipulated than iron rods, besides which they are more easily repaired, a matter of much importance in districts far from foundries and engineering shops.

Driven Wells.- Under the head of boring by percussion may be classed the process of making driven wells, or Abyssinian tubewells, as they are often called in this country. A tube shod with steel is rammed down by a heavy weight, raised by men with ropes passing over a pulley, and then allowed to fall and strike a stop clamped to the tube. The tube is perforated just above the shoe, and when a water-bearing stratum of sand or gravel is reached, water flows into it, and can be pumped up. This, however, is a special process, and can scarcely be considered as true mining.

\section{BORING BY PERCUSSION WITH ROPE.}

American System.-The use of the rope for boring is of very ancient date in China, and the process has been brought to great perfection in America for the purprse of obtaining petroleum and natural gas. Within the last few years the American system has been employed at Port Clarence, on the Tees, for obtaining brine.*

The first operation consists in erecting the drilling rig, consisting of the derrick, steam-engine, band-wheel, walking beam, bullwheel and sand-pump reel.

The derrick (Fig. 133) is a framework in the form of an acute truncated pyramid, 72 feet high, 20 feet by 20 feet at the base, and about 3 feet square at the top. It is ingeniously constructed of 2 -inch plank, without any large or heavy pieces of timber, and

* C. Le Neve Foster, "Some Mining Notes in 1887," Trans. Min. Assoc. and Inst., C'irnuall, vol. ii. Truro, 1888, p. I28. 
it serves to carry two pulleys. The reason of its height is to enable the driller to raise the whole string of boring tools from the hole without any disjointing.

The engine has a horizontal cylinder, 8 inches in diameter, with a I 2 -inch stroke, and is reckoned to be of $1_{5}$ horse-power.

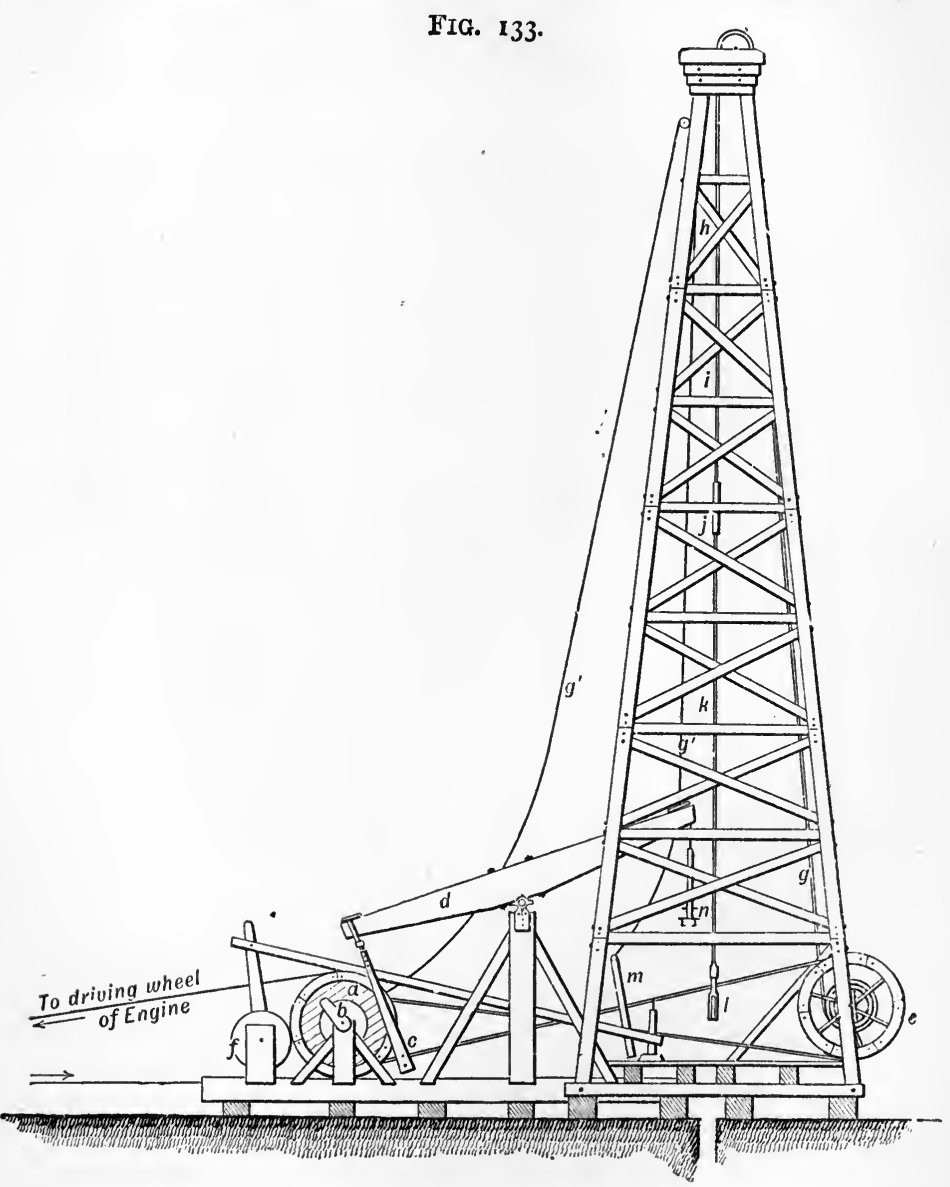

By means of a belt, power is transmicted to a wooden pulley (a) called the band-wheel; this is provided with a crank (b), and through a pitman (c) actuates one end of the walking beam $(d)$, 26 feet long.* A smaller pulley bolted to the band-wheel enables ihe bull-wheel $(e)$ to be driven by an endless rope, and, by means

* The figure shows the pitman taken off from the crank pin. 
of a lever, a friction pulley $(f)$ can be brought against the bandwheel so as to drive the sand reel.

These are the principal parts of the rig. In addition there are wanted :-

I. A set of drilling tools $(h, i, j, k, l)$.

2. A sand-pump $(m)$, or a bailer.

3. A rope $(g) \times \frac{7}{8}$ inch in diameter for lifting the tools.

4. A rope $\left(g^{\prime}\right) \frac{7}{8}$ inch in diameter for working the bailer or the sand-pump.

FIG. I34. FIG. 135. FIG. 136. FIG. 137. FIG. 138. FIG. 139.
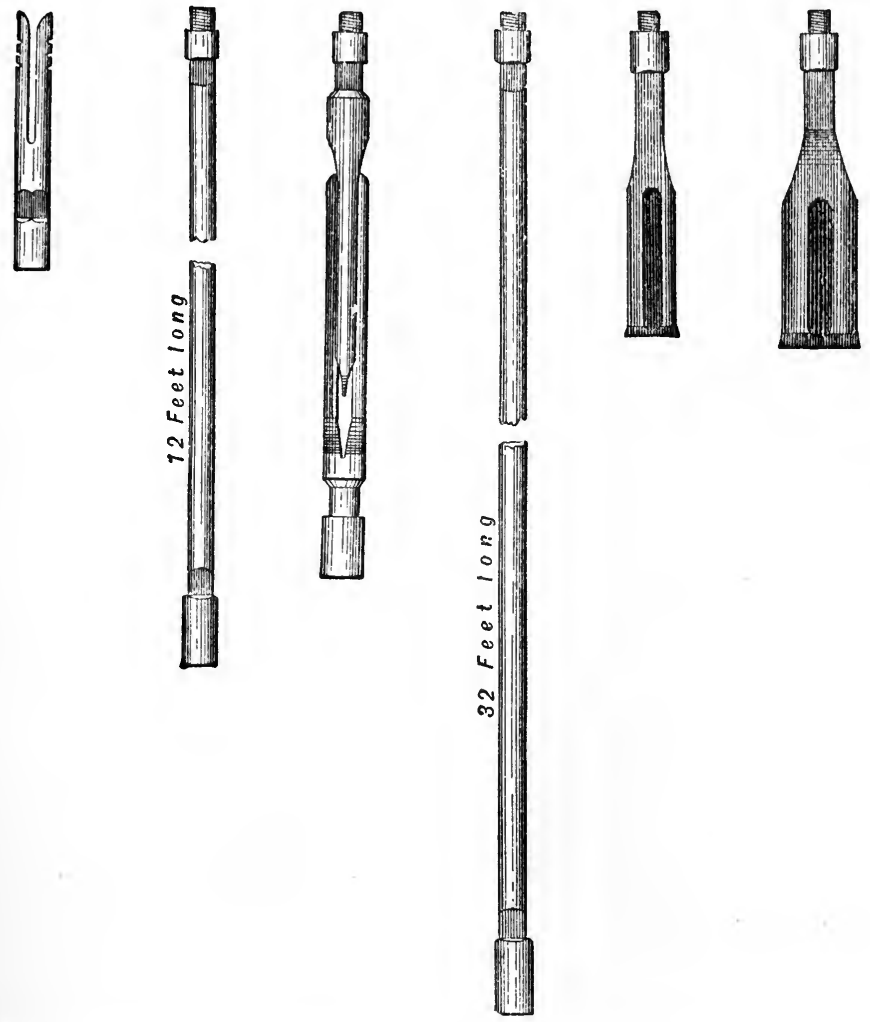

The set of drilling tools consist of the following parts :-

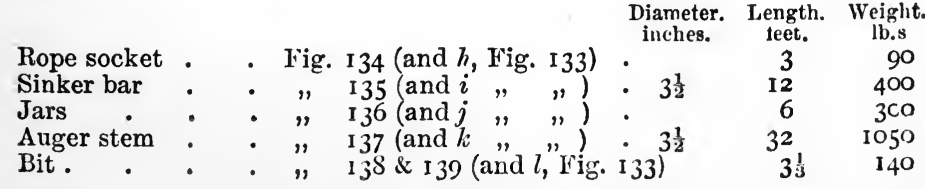


The jars are like two links of a chain, and their object is to enable an upward blow to be struck if the bit sticks; the force of this upward blow is increased by the momentum of the sinker bar.

The rope socket receives the end of the boring cable, any part of which can be connected to the walking beam by a clamp attachel to an adjustable link called the temper screw (Fig. 140).
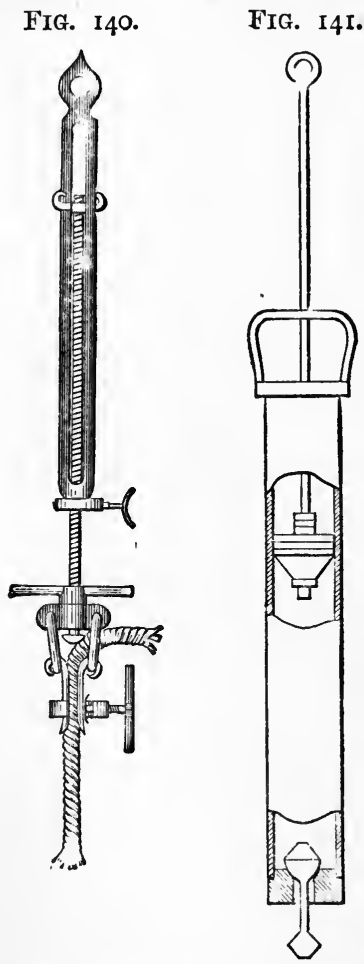

FIG. 142.

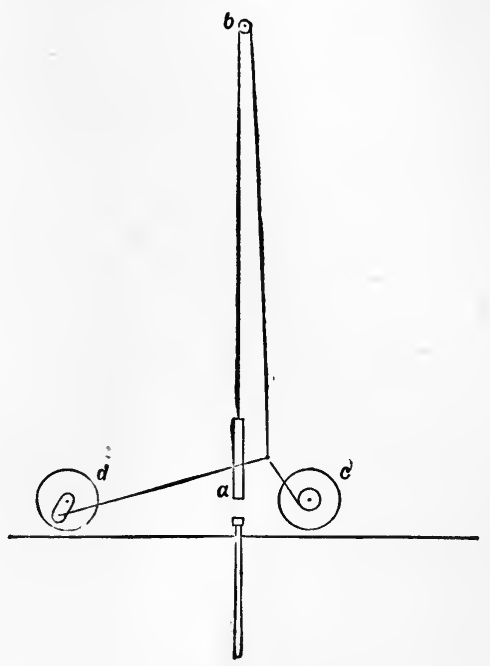

The bailer is a wrought-iron cylinder, 18 or 20 feet long, with a valve in the bottom, which opens as soon as its projecting stem touches the ground.

The sand-pump (Fig. I4I) is an iron cylinder, 5 feet or more long, with a valve in the bottom and a piston. When it is lowered to the bottom of the hole the piston descends, and when the piston is raised, it sucks the mud and débris into the cylinder, and they are retained by the valve.

When the hole has to pass through loose alluvial soil, a drivepipe (a a, Fig. $35^{\circ}$ ) is rammed down before any true boring begins. The drive-pipe is made of steel, $\frac{1}{4}$ inch thick, and is $8 \frac{1}{4}$ inches in 
diameter internally. It is supplied in ro-feet lengths, and these are connected, like gas-pipes, by screwed sleeve couplings, 14 inches long. The first pipe is shod with a sharp steel shoe.

The drive-pipe, protected at the top by an iron cap, is rammed down by a heavy wooden block (maul), like the ram or monkey of a pile-driver, working between two vertical guides, and length after length is added as it descends. The manner in which the blow is given will be plain from the accompanying diagram (Fig. 142), in which the guides are omitted. The maul $(a)$ hangs from a rope or cable which passes over the crown pulley $(b)$ at the top of the derrick and round the shaft of the bull-wheel $(c)$. Another rope is attached to the crank of the band-wheel $(d)$, and tied to the first rope. As the crank revolves it pulls the cable and raises the maul, and then letting the cable go back, causes the maul to drop.

When the pipe has been rammed down until the shoe is driven into hard ground, the earth inside has to be removed. A swivel-head is attached to the rope in place of the klock, and to it are screwed the sinker bar, or the auger-stem, and a bit. This is worked up and down like the maul, save that it is rotated; water is poured in, and soon the earth is knocked up into mud. The sand-pump is then lowered and the mud brought up. These operations are repeated, and when 60 feet have been cleared in this way the regular boring can be commenced.

The proper cable is placed upon the bull-wheel shaft, one end brought over the crown pulley and attached to the socket, and to this, in succession, the sinker bar, jars, auger-stem, and bit. I will now suppose the string of drilling tools to be hanging in the hole. The temper screw (Fig. I 40, and $n$ Fig. 133) is clamped to the cable, and its eye hung on to the hook at the end of the walking beam, the cable is now lowered, and the string of tools hangs from the walking beam. The engine is set in motion, and as the bandwheel revolves, the crank turns and causes the walking beam to move up and down, and the bit strikes a succession of blows at the bottom of the hole. The driller rotates the tool by turning the clamp round and round, this causes the slack of the cable to coil around the part below the temper screw. After a time he turns the other way, and the coils unwind; this process is repeated over and over again. As the hole deepens, the screw above the clamp is fed out, and when it can go no farther the clamp is loosened, and shifted higher up after the screw has been run back.

The gravel, sand, and mud made by the chipping motion of the bit, are removed by the sand-pump lowered and raised by the special rope on the sand-pump reel, driven by the friction pulley. An examination of the small fragments drawn up in the sandpump, tells the driller what rocks he is passing through. The two operations, drilling and clearing out, are repeated until the 
hole has reached the required depth. At Port Clarence the hole has to be lined with a steel tube (Fig. $35^{\circ}$, in which the size of the tubes is greatly exaggerated), $6 \frac{3}{4}$ inches in diameter internally; for the first 150 feet from the bottom the steel is half an inch thick, then five-sixteenths of an inch for 300 feet, and the remainder quarter-inch thick. With the sleeve couplings over them, they just pass down the drive-pipe. In the rock-salt and in the 600 feet of water-bearing sandstone, the lining pipe is perforated with holes one inch in diameter, and $\mathrm{r} 2$ inches apart vertically.*

By the American system the cost of a brine well at Port Clarence, 1000 feet deep, including the rig and a share of the boiler, is $\mathcal{E}_{\mathrm{r}} \mathrm{0}$, and it is drilled in three weeks.

Some wells bored by the diamond drill, on the other hand, cost $£ 3000$ each, and took three months to make.

The American system presents, therefore, very great advantages, especially in the case where holes have to be numerous, and where it is not certain how long a well will retain its productiveness. On the other hand, in making preliminary explorations of the rocks of a new district, the diamond drill may fairly claim the superiority, because it furnishes actual cores, showing the dip, which give a better idea of the strata than pounded fragments.

Though to English eyes the American "rig" appears rather rough, we cannot but admire its effectiveness, and also its suitability in the case of petroleum and brine wells. The "rig " erected for boring is utilised for pumping when the hole is completed, so that there is no unnecessary expense in the plant. The various parts of the "rig" are very simple in construction, and as timber is largely used in place of metal, repairs can be done by the master driller, without the aid of fitter or foundry. $\uparrow$

Mather and Platt's System.-Another method of boring with the rope is that which is employed by Messrs. Mather and Platt. I Its peculiarities are a flat rope, and a special contrivance for rotating the chisel.

Fig. I43 represents a side elevation of one of the boring machines.

A A, flat hempen rope $4 \frac{1}{2}$ inches broad, by $\frac{1}{2}$ inch thick; B B, boring head ; C, drum or reel for the rope, driven by the steamengine D ; E E, wooden or cast-iron frame; F, guide pulley ; G, flanged pulley carried in a fork on the top of the piston-rod of a vertical single-acting steam-engine shown by the dotted lines.

* For the process of obtaining the salt see Chapter VI.

+ Many of my figures and occasional explanations are borrowed from the useful Illustrated Catalogue of the Oil Well Supply Co., Limited, of Bradford and Oil City, Pennsylvania, who have furnished both the plant and the drillers for the wells bored on the American system at Port Clarence.

¥ W. Mather, "On Well-Boring and Pumping Machinery," Proc. Inst. Mlech. Eng., 1869, p. 278. 
BORING.

I 43

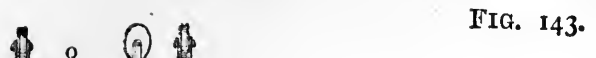


ORE AND STONE-MINING.

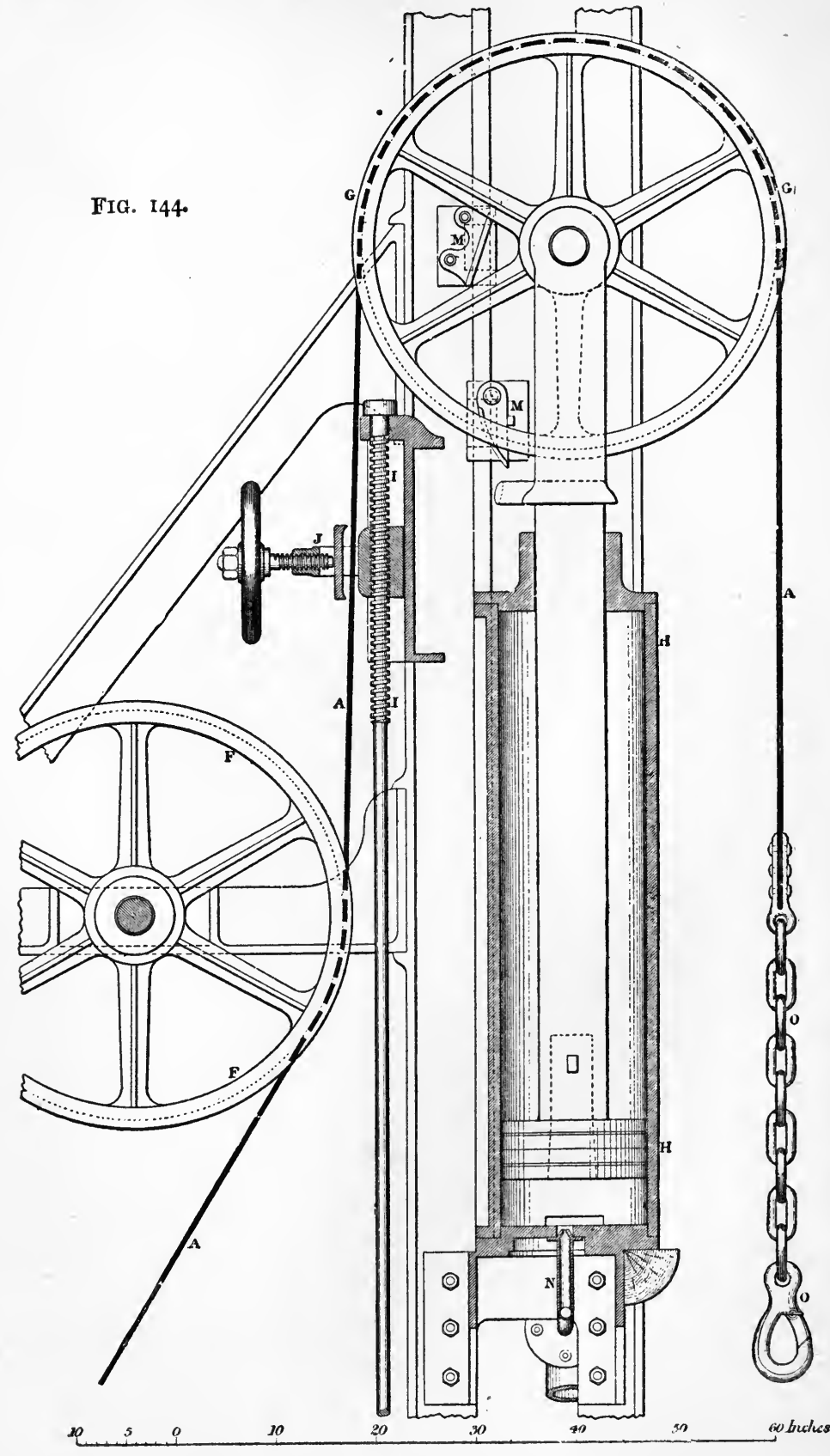


$\mathrm{J}$ is a clamp by which the rope $\mathrm{A}$ is fixed while boring is going on.

Steam is admitted below the piston (Fig. 144) raising the pulley $\mathrm{G}$; at the end of the stroke, the exhaust valve is opened, the steam escapes, and the piston, pulley, rope, and boring head all drop. The exhaust port is so arranged as to leave a cushion of steam which prevents the piston from striking the bottom of the cylinder. The steam and exhaust valves are worked automatically by tappets, M M, actuated by the piston-rod. The length of the stroke can be varied from I to 8 feet by shifting these tappets. The usual speed is 24 blows a minute.

The boring head (Fig. I45) forms a special feature of $\mathrm{Mr}$. Mather's invention. The chisels or cutters $\mathrm{D}$ are fixed by nuts in the cast-iron block $\mathrm{C} ; \mathrm{E}$ is a cylindrical block serving as a guide, aud $\mathbf{F}$ is a second or upper guide which assists in effecting the rotation. On its circumference there are ribs which catch in one direction; they are placed at an inclination, like segments of a screw thread of very long pitch. Each alternate plate has the projecting ribs inclined in the opposite direction, so that one-half of the bars turn the rod round in rising, and the other half turn it in the same direction during the descent; but they simply assist in producing the rotation which is mainly secured by the contrivance represented above $\mathbf{F}$. Two cast-iron collars, $G$ and $H$, are cottered to the top of the bar B, and their deep ratchet-teeth are set exactly in line with one another. $\mathbf{J}$ is a movable bush sliding upon the bar $\mathbf{B}$, and attached to the boring rope by the bow $\mathrm{K}$ and a short piece of chain.

The bush J. has ratchet-teeth on its upper and lower faces, but the upper teeth are set half a tooth in advance of the lower ones. During the ascent of the rope, the bush has the position shown in the figure; but when the tool strikes the blow, the bush descends, and the centre of the inclined surface of each lower tooth of $J$ strikes the point of a tooth of $G$, and then slides down on it, twisting $J$, and with it the flat rope, to the extent of half a tooth. At the commencement of the lift the bush $\mathbf{J}$ receives a further twist of half a tooth by coming against $H$. The flat rope is thus twisted altogether to the extent of one tooth, and in untwisting it turns the tool a like amount; automatic rotation of the cutters is thus secured.

$P$ (Fig. I43) is the shell-punp, or sludger, and $Q$ is an overhead suspension bar by means of which it is brought over the litt' $\theta$ table $\mathbf{R}$ in the tank $\mathrm{T}$. The screw $\mathrm{S}$ serves to raise the table $\mathbf{R}$ until the pump rests upon it, and on knocking out a cotter in the rod which supports the seating of the bottom valve, the sludge is speedily discharged.

One man can attend to all the operations of raising and lowering, changing the boring tool for the shell-pump or vice versd, 
ORE AND STONE-MINING.

FiG. 145.

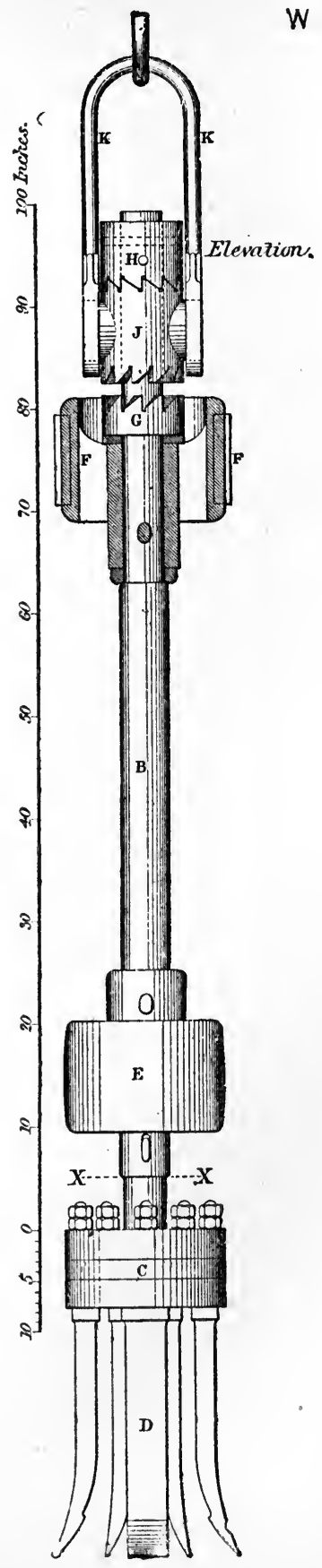


and regulating the boring. Two labourers are employed to change the cutters and clear out the shell-pump.

Cores may be cut out as in other systems of boring, and extracted, so as to show the nature and dip of the strata. As the rope is flat, cores can ho brought up without any twist.

The flat rope method is used by Messrs. Mather and Platt for holes from 20 inches to 45 inches in diameter. In the case of small holes from which no cores are required, they now adopt the American system on account of its expeditiousness.

From what has been said it is rery evident that a great diversity of practice exists in making bore-holes, and the miner may have some difficulty in making up his mind which system to adopt for any given purpose. In the case of large undertakings, he usually applies to some firm of engineers, who by long and constant experience in their art are able to guarantee success.

Surveying Bore-holes.-It is often assumed by boring engineers that the holes which they drill are perfectly vertical; but experience has shown that this is not always the case. It is, therefore, important to have some means of measuring the deviation of a bore-hole from the vertical, and surveying its exact course.

A useful instrument for this purpose is Macgeorge's clinograph.* It consists in the main of two glass bulbs, the upper one carrying a plummet, the lower one a magnetic needle; both bulbs are filled with gelatine. When hot the gelatine is liquid, and the plummet and the needle are free to move; when the gelatine is cold both are set fast. The gelatine simply serves as a clamp which will act of itself after a certain time.

'The exact construction is explained by Fig. 146. + The instrument consists of a cylinder terminating in a short neck and a bulb at the bottom. In this is a magnetic needle Fig. 146. attached to a hollow pear-shaped glass float, which will always stand upright upon its pivot and so enable the needle to swing round without touching the sides. A smaller glass cylinder, with a bulb at the top, is inserted through an air-tight cork and a brass capsule at the upper end of the large one. Its lower end passes into a cork, which prevents the escape of the float of the needle. The upper bulb contains a delicate plummet of glass, with diminutive hollow float at the top and a solid ball

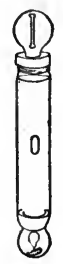
at the bottom, which is prevented from dropping out by a delicate grating. It is carefully adjusted to the specific gravity of the solidifying fluid which fills the cylinders and bulbs, and is so arranged that it will assume a vertical position whenever it is free to move.

* "The Clinograph," Engineering, vol. xxxix. (1885), p. 260 "The Diamond Drill Clinometer," Min. Jour., vol. liii. (1883), p. I509.

† Brough, Mine Surveying, p. 276. 
In order to make use of these dip-recorders, or clinostats, as Mr. Macgeorge calls them, six are placed in a bath of warm water, which is heated nearly to boiling. In the meantime a brass cylinder is also heated by filling it several times with boiling water, and when the clinostats have been inserted one after the other into it, it is lowered into the bore-hole and allowed to remain there for two or three hours. By this time the gelatine will have set; the brass case is drawn up and the clinostats are examined one by one in a special instrument designed by $\mathrm{Mr}$. Macgeorge. This has an arrangement for placing the clinostat in exactly the same position which it occupied in the bore-hole, and for enabling its angle of inclination and its magnetic bearing to be measured very accurately. The mean of the six sets of observations is then taken as representing the correct deviation.

If a bore-hole is approximately vertical, and the strata comparatively cool, the brass tube containing the clinostats may be lowered with a wire rope; but if the strata are hot or the borehole somewhat flat, $\frac{1}{2}$-inch iron pipe is employed for inserting the brass case. Care is taken to interpose a distance tube of brass between the case and the pipes, to prevent their action on the magnets. If the bore-hole is warm, cold water is forced down the pipe so as to flow outside the case with the clinostats, and congeal the gelatine.

If observations are made at regular intervals, say at every 100 feet, the path of the bore-hole can be traced with great accuracy. The apparatus may also be used over a core extractor when it is necessary to ascertain the direction and amount of the dip of the strata. Macgeorge employs a brass tube set excentrically, and provided with a bell-mouth below. This receives the end of the core, and the excentricity of the tube causes pressure on one side which makes the core break off. The core-extractor contains an inner tube, slotted from end to end, which expands as the core enters it and nips it tightly.

Mr. Macgeorge gives numerous instances of ascertained deflections of bore-holes. At Scotchman's United mine, Stawell, Victoria (Figs. 47 and I 48), a bore-hole 370 feet deep, put down with a diamond drill, was found to have a deviation of 37 feet 3 inches It is calculated that $\mathcal{E}^{2} 3$ II would have been saved if the path of the drill had been surveyed before the driving was commenced. At the Oriental Company's mine a bore-hole turned out to be 60 feet 9 inches out of its proper course in a depth of 425 feet. Similar cases of deflection have been noted in bore-holes made in Germany both by the diamond drill, and by the percussive method.

The deviation from the vertical may likewise be recorded by Nolten's* method, which depends upon the etching action of

* P. K., "The Deviation of Bore-holes," Colliery Guardian, vol. liii. (1887), p. 775 . 
FiGs. 147 \& 148.
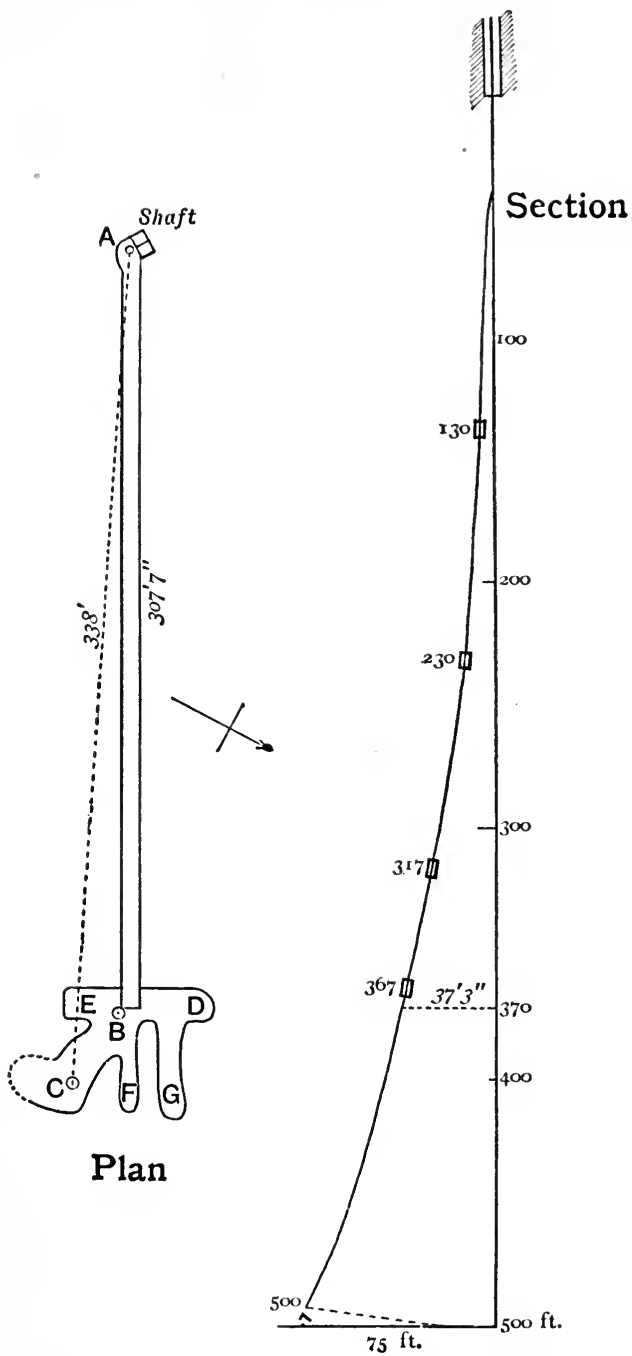

A, shaft; B, supposed position of the bore-hole; A B, level driven out from A to strike the bore-hole; $C$, actual position of the bore-holes; D, E, F, G, drivages made in search of the borehole. The section shows that if the bore-hole had been continued to a depth of 500 feet, the deviation wolild have amounted to 75 feet. 
hydrofiuoric acid upon glass. A glass cylinder with a truly flat bottom, and the sides at right angles to the base, is partly filled with dilute hydrofluoric acid, put into a case, carefully lowered into the hole, and allowed to remain there for half an hour. The acid eats into the glass, which is then drawn up. The line of etching records what was the horizontal plane when the cylinder was in the bore-hole, and the angle between it and the flat bottom measures the deviation from the vertical.

Trouvé* has designed an electric lamp with a mirror set at an angle of $45^{\circ}$, which is lowered into the bore-hole and gives an image of the strata. The observer at the surface examines this image by mears of a telescope.

* Eng. Min. Jour., vol. 1. (1890), p. $4^{83}$. 


\section{( 15 I )}

\section{CHAPTER IV.}

\section{BREAKING GROUND}

Hand tools : Shovel, crow-bar, pick, wedge, saw ; tools for boring holes.Excavating machinery.- Transmission of power-by air, water, and electricity.-Diggers, dredges, rock-drills, groove-cutters, tunnellers. -Explosives and blasting.-Driving and sinking.-Fire-setting. Excavating by water.

HAND TOOLS.-The kinds of ground in which mining operations have to be carried on vary within the widest limits, from loose quicksands to rocks which are so hard that the best steel tools will scarcely touch them.

Shovel.-Loose ground can be removed with the shovel. Probably some of the first digging tools were merely pointed sticks; indeed, the Burmese workman of to day uses an iron-shod stake for sinking oil-wells. Shovels vary a good deal in 'shape' and make, according to the special purposes for which they are employed, and also according to the fancies of the users. The plate or blade is usually made of steel, and it is pointed in front, so as to penetrate easily into the earth or stone that has to be moved. A wooden handle is attached to it by a socket or two long straps. The handle is often made of ash, and is usually short, but in Cornwall and Devon a long one is preferred.

In dealing with clay and sticky earth it is advisable to have the plate as smooth as possible; the shovel with a hollow underneath at the junction with the socket is objectionable for material of this kind, because the cavity becomes choked, and the tool is then less easily wielded. Even the projecting rivets sometimes used to ' attach the socket to the plate cause a slight hindrance, which means unnecessary waste of power. Shovels, like all other hand tools, should be made as light as possible, consistent with strength, in order to relieve the workmen from the unprofitable labour of moving useless dead weight.

In the special case of peat, sharp spades are employed, which cut through the woody fibres, and furnish lumps or sods of convenient form for drying and for subsequent use as fuel.

When it is desired to separate the larger stones from all finer material, a fork with several prongs is a convenient tool.

Crowbar.-This tool is an iron lever; it is used for prising off blocks of stone, and for shifting them after they have been detached. 
Pick.-What is called fair, soft, or easy ground, such as clay, shale, decomposed clay-slate, and chalk, requires the use of the pick and the shovel ; the pick breaks up the ground, and the shovel serves to shift it. The pick is a tool of variable form, according

FIG. 149.

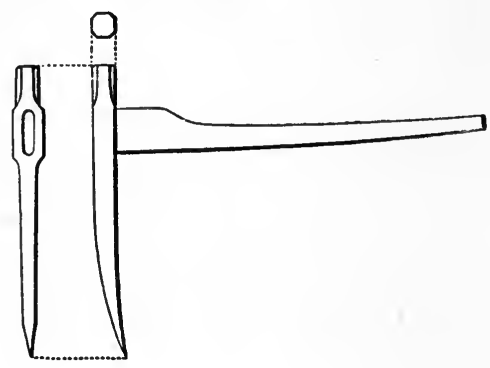

FIG. 150.

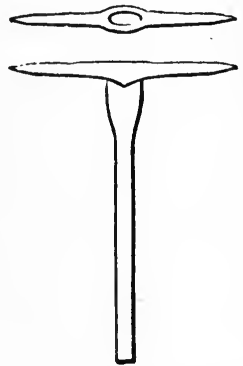

to the material operated on. Thus there are the navvy's pick, the poll-pick, with a point and a striking end (Fig. 149), and numerous varieties of the double-pcinted pick (Fig. I $5 \circ$ ), the special tool of the collier, but also largely used in ore and stone mining. The

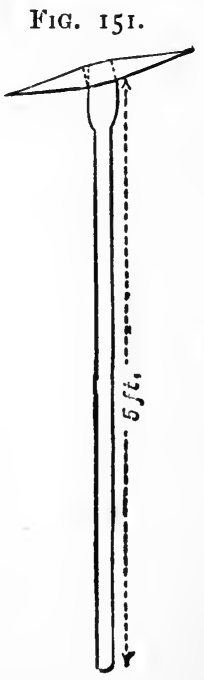

FIG. 152.

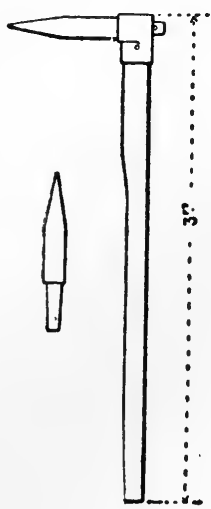

blades of picks are made either of iron with steel tips, or else entirely of steel. The latter is preferable, as it lasts so much longer. The tip may be a point or a chisel edge. The blade is usually set at right angles to the hilt or handle; but at the under- 
ground stone quarries at Bath and Weldon it is oblique, as shown in Fig. $15 \mathrm{I}$. The object of this form is to enable the miner to cut well into the corners of the deep horizontal groove required for excavating the stone. This pick weighs 5 lbs.

Blunted picks are sharpened by having the points heated in the blacksmith's fire, hammered to the proper shape and tempered. In order to save the trouble of carrying a large supply of tools, the blade may be made separable from the hilt, and the miner takes the blades only to the smithy when they are worn. Fig. ${ }_{52}$ shows a pick of this description used at Mansfeld.

Two well-known forms of pick with separate blades are the "Acme" and the "Universal" of the Hardy Patent Pick Company.

The Acme (Fig. 1 53) is a pick used for "holing," or cutting a groove in a soft rock, in which case it is advisable to have the tool

FIG. 153.

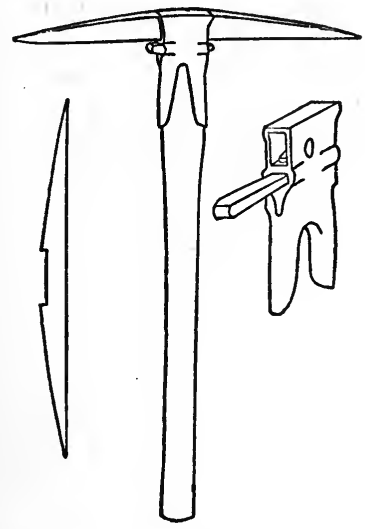

FIG. 154.

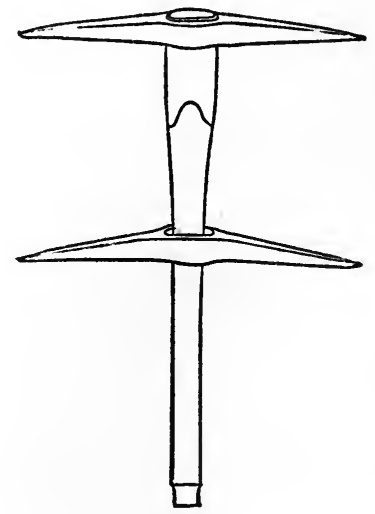

as narrow as possible, in order to avoid the unnecessary work which a broad eye would occasion. The blade is made with a notch at the top, and a wedge makes it fast to the head; blades vary from $\mathrm{I} \frac{1}{2}$ to $3 \mathrm{lbs}$. in weight.

The Universal (Fig. 154) has the large end of the shaft or handle fitted with a cast steel or malleable iron socket; the small end is put through the eye of the blade, which becomes firmly fixed, because the socket and eye are carefully made to gauge. By striking the small end of the handle on the ground the blade is loosened and removed. Blades of various shapes may be fixed upon the same handle, which is sometimes an advantage in remote districts.

The handles (" hilts" or "shafts") are commonly made of ash or hickory. In Australia and New Zealand the wattle furnishes a light, tough, elastic, and durable wood for the handles of picks 
and other tools. One of the best descriptions is the Golden Green Wattle (Acacia decurrens, var. mollis).

Wedge.-When the ground, though harder, is nevertheless " jointy," or traversed by many natural fissures, the wedge comes into play. The Cornish tool known as a gad is a pointed wedge (Fig. I 55). The so-called "pick and gad" work con-

FIG. 155. sists in breaking away the easy ground with the point of the pick, wedging off pieces with the gad, driven in by a sledge or the poll of the pick, or prising them off with the pick after they have been loosened by the gad. The Saxon gad is held on a little handle, and is struck with a hammer. It is used like the Cornish gad for wedging off pieces of jointy ground, and in former days even hard rocks were excavated by its aid. The process consisted in chipping out a series of parallel grooves, and then chipping away the ridges left between them. As a method of driving levels or sinking shafts, this process is naturally obsolete; but it is useful on a small scale for cutting recesses (hitches) for fixing timber, for dressing the sides of levels or shafts before putting in dams, and for doing work in places where blasting might injure pumps or other machinery.

Saws.-Freestone is sometimes excavated by sawing. The saws are 6 or 8 feet long, and I foot wide. The wooden handle

FIG. 156.

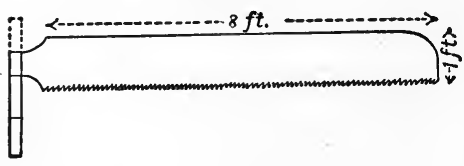
tion of the rocks met with by the miner, such as slate of various kinds, hard grit and sandstone, limestore, the metamorphic schists, granite, and the contents of many mineral veins.

Rocks of this kind are attacked by boring and blasting. The tools employed are the auger, jumper, or borer (drill), hammer or sledge (mallet, Cornwall), scraper and charger, tamping bar or stemmer, pricker or needle, claying bar and crowbar.

Augers. - At English gypsum mines a tool resembling the carpenter's shell-auger is regularly used for boring holes for blasting. It is worked by a cross handle, and makes a hole $1 \frac{1}{4}$ inch in diameter. Boring is done in the bituminous limestone of Seyssel by screw-augers in a similar manner.

Elliott Drill.-Screw-augers mounted upon stands are common. Fig. 57 represents the Eiliott drill, which consists of an auger inserted into a socket upon a feed-screw $c$, which works upon a worm-wheel $a$, held fast in a ring, when the screw clamp $b$ is tightened. On moving a ratchet brace backwards and forwards, 
$c$ is turned round, carrying the auger with it, and when the wormwheel is tight, it advances slowly at the same time. If a very hard piece of rock prevents the penetration of the auger, the worm-wheel slips in the ring, and, by suitably arranging the tightness of the clamp $b$, the machine can be made to accommodate its advance to the nature of the rock.

The drill itself is made of a bar of twisted steel, which clears itself of the débris to a certain extent; when it has penetrated as far as it will go, the clamp is loosened, enabling the feedscrew to be drawn back rapidly without rotating at all. A longer drill is put in, and work continued.

The light frame or standard is made in two halves, and by shifting a pin its length can be altered to suit the height of the

FIG. 157.

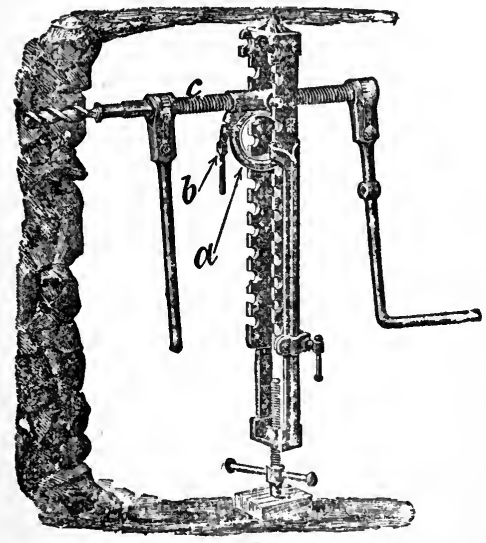

FiG. 158.

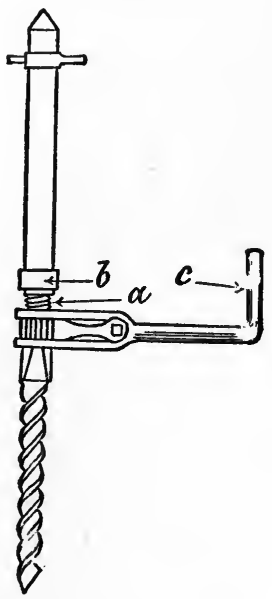

working place, whilst the final tightening is done by a screw at the bottom.

Ratchet Drill.-Where even more simplicity is required, a selffeeding ratchet drill can be employed, with a piece of timber set up in the working place as an abutment. An auger is inserted into a socket upon a feed-screw $a$ (Fig. $15^{8}$ ), working in the nut $b$, attached to a long sheath. When the ratchet handle $c$ is worked, $a$ revolves and at the same time advances from the feed-nut, carrying the auger with it. The sheath is prevented from turning by putting the eye of a pin over one of the projecting pegs at the rear end, and allowing the pin to be brought up by the first twists against the piece of timber. For enabling the feed-screw, after it has advanced to its full length, to be quickly returned into the sheath, the Hardy Patent Pick Company sometimes use Stayner's Patent 


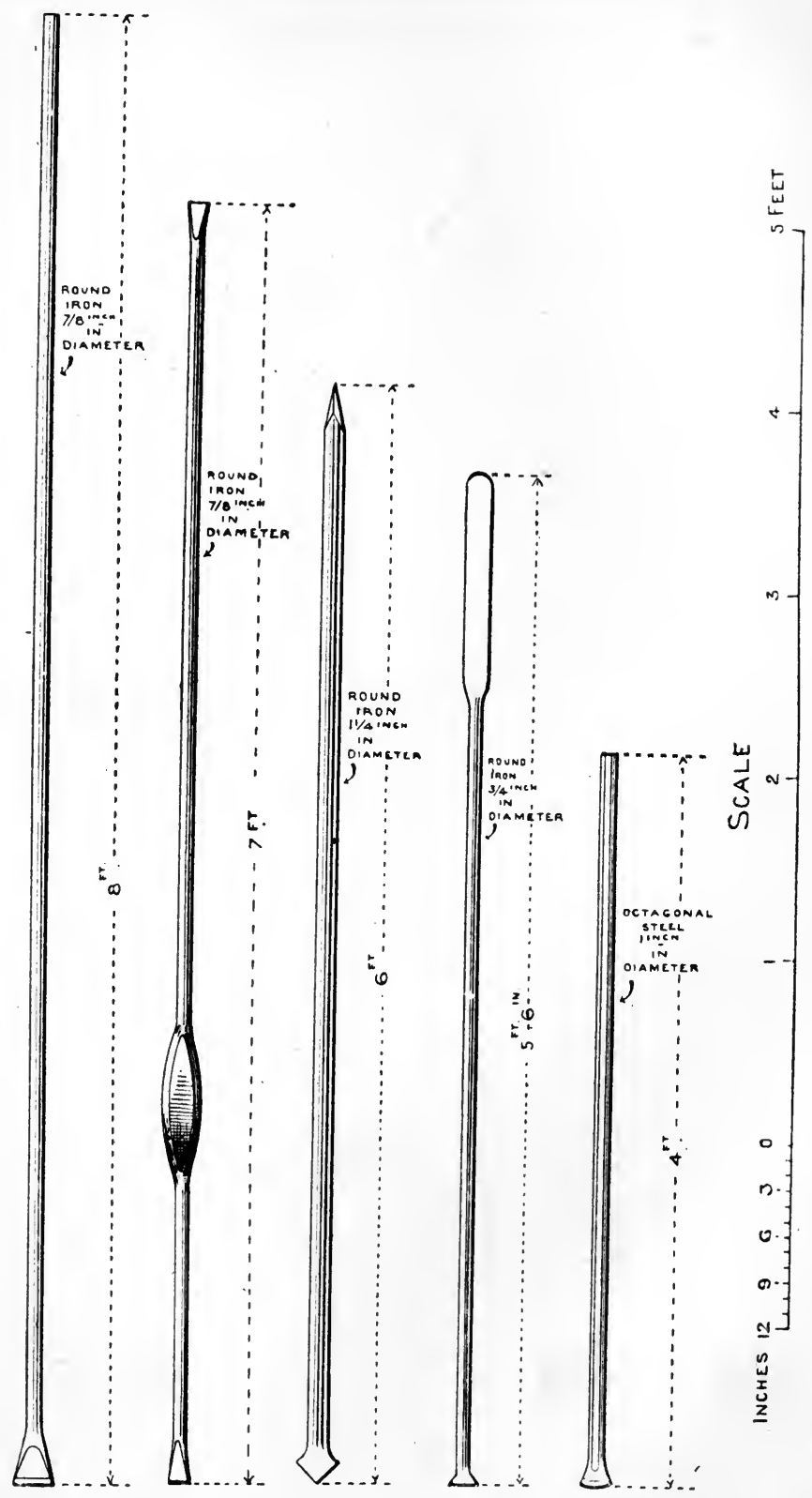

FIG. 159. FIG. I6I. FIG. 160. FIG. 162. Fig. I63. 
Split Nut, instead of an ordinary nut; when the split nut is loosened, the feed-screw can be moved back without loss of time in turning.

These augers worked by hand will do good work in moderately hard ground, such as tough shale, slate, and even sandstone.

Jumper.-The simplest tool for boring holes by percussive action is the jumper, a bar of iron tipped with steel, forged into a chisel-shaped edge. It is struck against the rock, and turned a little at each blow, and in this way chips out a cylindrical hole.

Fig. I 59 represents the jumper used in the lead bearing sandstone at Mechernich, made of a bar of iron $\frac{7}{8}$ inch in diameter, and 7 to 10 feet in length. As the rock is soft, the cutting edge can be made wide and sharp. The exact angle of the actual cutting edge of a jumper which I measured was $42^{\circ}$; the final sharpening is done with a file. At the open workings for ironstone in Northamptonshire, the edge comes to a point in the middle (Fig. I60).

The jumper used in the Festiniog slate mines (Fig. I6I) has a swelling in the middle, and both ends are sharpened; the short end serves for beginning a hole, the large one for completing it. The ordinary sharpening is done by heating the end red-hot, and filing it to the desired form while the jumper is held in a vice. It is allowed to cool gradually, and then is heated again in the forge, hardened in water and tempered.

The jumper for boring holes at any angle in the rock-salt of Cheshire has a swelling in the middle, and tapers gradually to each end.

The jumper of the Cleveland ironstone miner (Fig. 162) has the swelling at one end, and will bore holes at any angle. Like the Festiniog tool, it is sharpened by being hammered into shape, and finally filed when hot.

Borers.-When the rocks are harder, and also in situations where a jumper cannot be wielded, the miner must have recourse to the borer or drill, which is simply a steel chisel (Fig. 163).

The steel is brought to the mine in the form of round or octagonal bars, and is cut up by the mine-smith into pieces of the required length; one end is forged into a chisel-shaped edge, the exact shape and degree of sharpness varying according to the hardness of the rock. For hand-drilling the steel is usually $\frac{7}{8}$ inch to 1 inch in diameter, but $\frac{3}{4}$ inch or even $\frac{1}{2}$ inch steel is sometimes used. The old plan of making the drill of iron, and welding on a piece of steel for the cutting edge (bit), is almost extinct in this country.

The shape of the bit of the hand drills used at Minera mine, North Wales, is shown in Figs. 164 and 165 , the angle of the edge being $84^{\circ}$ The drills used with the compressed air machines at Minera are rather blunter than a right angle. At a limestone 
quarry, near the mine, the drills have two cutting edges arranged in step-fashion.

Drills for hard rocks are sharpened entirely at the forge; the cutting edge is hammered into the desired shape on the anvil

FIGS. $164 \& 165$.

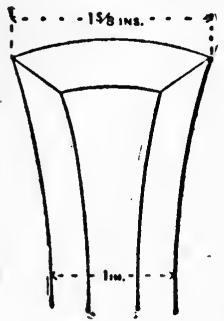
while red-hot, and then hardened to suit the particular requirements of the user. In many cases the desired temper is obtained by plunging the tool when at a blood-colour into cold water, and allowing it to remain there; but for soft rock the tool will work efficiently after the hardness has been reduced by annealing. In the case of slate the smith heats the end of the jumper to blood-colour, and just dips the edge into water for a few seconds. He now watches its colour as it cools down, and stops the annealing or tempering action by plunging the tool into cold water when a certain shade of blue has been reached. Some smiths rub the edge of the tool upon a piece of board with a little sand, in order to be able to follow the changes of hue with precision.

Before the introduction of machines, as many as fifty drills were sometimes blunted in boring a hole 2 feet deep by hand at an iron pyrites mine in Carnarvonshire. This is an exceptional case, but nevertheless the importance of having a good smith at a mine where much sharpening has to be done cannot be overestimated.

A tool called a "bull" is employed in boring holes in tough hæmatite and tough clay in some districts. It is a bar pointed at one end and provided with an eye at the other. It is driven into the ore with a sledge, and by putting another bar through the eye it can be withdrawn without difficulty. There is practically no difference between it and the claying bar (Fig. I 72 ).

Hammers.-The hole is bored by striking the drill with a hammer or sledge, and turning it after each blow. Boring is said to be single-handed if the miner holds the drill in one hand and wields the hammer with the other ; whilst it is called doublehanded when one man strikes and another turns. Sometimes there are two men to strike, one after the other, whilst a third man turns the drill.

In starting a hole a short drill is chosen, and longer ones are taken as the hole is deepened; the smith is careful to make the cutting edges (bits) diminish slightly in width as the borers increase in length, because the hole gradually decreases in diameter as the tool wears. The bore-hole is therefore not a true 
cylinder, but a frustum of a very elongated cone. It may even happen that, owing to the manner in which the miner has turned his borer, the section of the hole forms a triangle and not a circle. The deep holes bored for quarrying granite invariably bccome triangular after a small depth has been reached; but the sides are straighter and the corners less sharp than shown in Fig. 166, which represents a shape sometimes seen in slate.

Boring hammers and sledges are almost universally made of steel; but until comparatively lately iron

FIG. 166.

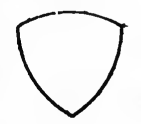
hammers with a steel face or pane were common, and even in some districts the head of the hammer was made entirely of iron, which was worn into a deep hole by the end of the hard steel drill.

The hammers for single-handed boring vary in weight from 2 to 6 or 7 lbs. The hammers used by the Festiniog miners and quarrymen weigh from $5 \frac{1}{2}$ to $7 \mathrm{lbs}$ (Fig. I67). The handle is ro to I 2 inches long. In some districts the head is curved slightly, se

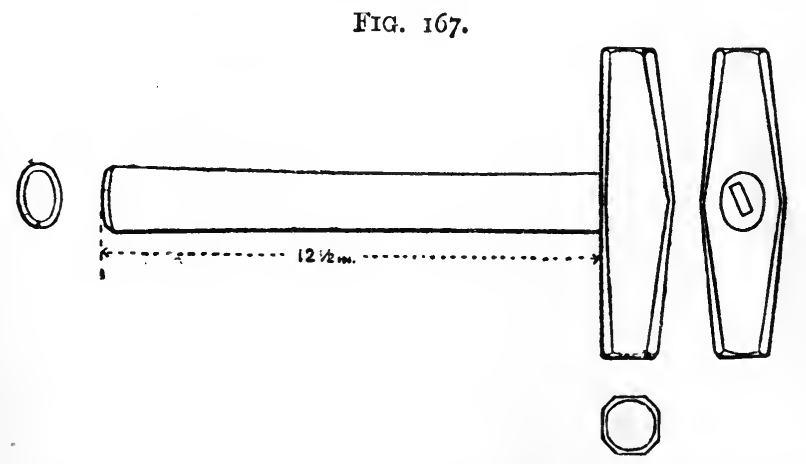

as to follow the circle in which it is swung. A good miner should be able to wield the hammer with either hand, because he may have to put in a hole close to either side of a level or stope; he should also be able to strike upwards, because occasions arise where a hole bored in this manner will be far more advantageous for removing rock than one bored downwards.

The double-handed bcring hammer or sledge (mallet, Cornwall) weighs from 6 to Io lbs. or more, and the handle is 2 feet or more long (Fig. I (68). If swung round by good hands, it strikes a very powerful blow.

In a rock-boring competition in Cornwall* a few years ago, thrue men from Tincroft mine, two striking and one turning, bored a hole I $_{3}$ inches deep in hard granite in 6 minutes 43 seconds,

* The West Briton, Aug. 9, 1888. 
making $9 \mathrm{I}$ blows per minute; three men from Dolcoath bored I $2 \frac{1}{8}$ inches in 7 . minutes 18 seconds, making 130 blows per minute, whilst a like number from Carn Brea bored $12 \frac{3}{8}$ inches in 8 minutes with II 7 blows per minute. The Tincroft men

FIG. 168. slung the sledge round, the others did not. The

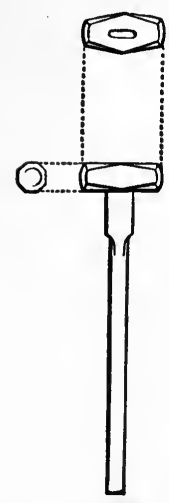
drills used were made of steel, $\mathrm{I}$ inch in diameter; but there was no restriction as to the size or shape of the bit. Of course these results are simply useful as showing what can be done under very favourable circumstances, and for a very short time.

If the hole is directed downwards, the miner throws in a little water and bores the rock wet. A ring of rope or leather put round the drill prevents the water from splashing him. The water serves three purposes: it renders the boring easier by holding the fine particles in suspension instead of their lying at the bottom of the hole; it keeps the tool cool, which makes it last longer, and it prevents dust, which would otherwise be breathed by the miner and tend to cause lung disease. In places where miners are paid by the depth bored, a higher price per inch is sometimes given for holes bored dry than for those bored wet. The depth bored varies with the rock, and the nature of the excavation; but in driving levels in the ordinary way by hand, the depth is commonly from 18 inches to 3 feet.

Scraper.-From time to time the miner draws out the sludge with a "swab-stick," or the dust with a scraper. The former is a wooden stick with the fibres at one end frayed into a sort cf mop ; the latter is a little disc at the end of a metal rod. For removing small bits of stone a rude syringe, called a "gun," is occasionally employed; it is a piece of gas-pipe, or an old gunbarrel, fitted with an iron piston made tight by hemp. It also serves for flushing out "uppers."

The accessory tools required subsequently for charging the hole, are the tamping-bar or stemmer, pricker or needle, charging-spoon, cartridge stick, and claying-bar.

Tamping-bar.- The tamping-bar or stemmer is a rod of wood, iron, cupper or bronze, or iron shod with copper, and it is used

FIG. 169.

\section{O}

for ramming in clay, pounded slate, sand, or the dust from the bore-hole or other suitable material upon the explosive, and so causing a resistance sufficient to make the gases generated by the blast rend the rock in the manner required.

The tamping-bar (Fig. I69) is sometimes a plain metal rod, with a little swelling at the striking end, but often a groove is left to 
lessen the chance of injuring the fuse; the use of this groove is more apparent when the pricker is employed.

Pricker.-The pricker or needle (Fig. 1 70) is a slender tapering rod of copper or bronze with a ring at the large end. It is used

FIG. I70.

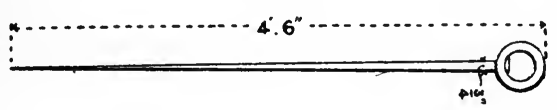

for maintaining a hole in the tamping through which the charge can be fired by a squib, rush or straw.

Charging-spoon. - The charging-spoon is a hollow halfcylinder of copper or zinc, at the end of a copper or wooden rod, which is used for introducing loose gunpowder into holes which

FIG. I7I.

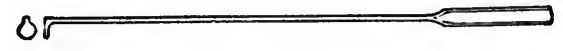

are more or less horizontal. The scraper and spoon are often combined (Fig. 17 I). In the Festiniog slate mines, a copper tube 5 feet long, with an expanded mouth, is sometimes used for putting a second charge of gunpowder to the bottom of a hole which has simply produced a rent, without severing the block of slate from the working face.

Under the Coal Mines Regulation Act of 1887 , prickers, scrapers, chargers and stemmers must not be made of iron or steel ; the Metalliferous Mines Act, 1872, likewise prohibits iron or steel prickers, but allows iron stemmers, provided they are not used in the early part of the operation of tamping.

Cartridge Stick.-The cartridge stick is a smooth cylinder of wood, around which paper is bent in order to make cases for holding gunpowder or the tamping material, when these have to be inserted into holes which have a very decided upward inclination. The paper is fastened by a little pitch softened in the miner's candle. One advantage of cartridges for all holes is the absence of danger from grains sticking to the sides; when powder is put in loose, a premature explosion may happen from such grains being ignited during the process of tamping and conveying fire to the charge.

FIG. I72.

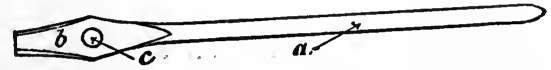

Claying-bar.-The claying-bar (Fig. I 72) is a smooth rod of steel $a$, expanded at. one end into an eye $c$. It was used formerly for lining wet holes with clay, and so rendering them temporarily 
watertight, and fit for holding a charge of gunpowder. Lumps of clay were put into the wet hole, and the claying iron was diven in by blows on the head $b$, forcing the clay into every fissure. By putting an iron bar through the eye, it could easily be twisted and withdrawn. Nowadays wet holes are almost invariably charged with some nitro-glycerine explosive, and the claying-bar is rarely required.

Rending Holes. - Where a stone can be made to rend along certain lines, cost may be saved by shaping the holes so as to start
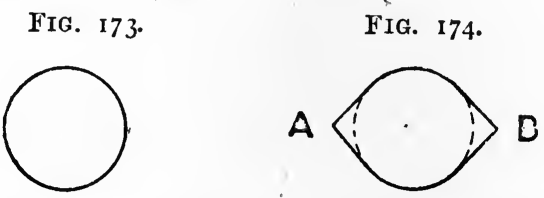

the rifts in the desired directions. This is the principle of the Knox* system of blasting employed at the sandstone quarries of Portland, Conn., and elsewhere in the United States. A round hole (Fig. 173) is drilled by hand or by machine, and then two V-shaped grooves (Fig. 174) are cut down with a reamer (Fig. r75) in the line of the proposed rift. The tool I FIG. 175. found in use at Berva, Ohio, is slightly different

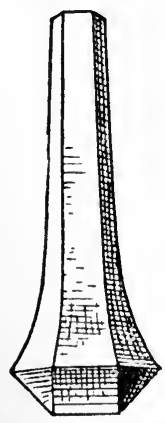
in shape, but acts in the same way. The hole, when fired, produces a crack or rift in the direction AB. Several holes may be bored in a line if necessary, and fired simultaneously by electricity. The Githen system, lately adopted by the Ingersoll-Sergeant Rock Drill Company, goes a step further; for machine drills are now being made which will bore holes with an elongated section in one operation.

USE OF MACHINERY FOR BREAKING GROUND.-One of the greatest improvements in the art of mining during the last quarter of a century has been the introduction of machines instead of human power, for performing some of the most laborious work in mining; the mine-owner is able to have work done more quickly and more cheaply, and the working miner is relieved from severe toil under unfavourable conditions.

The power may be generated on the spot, or can be transmitted underground from prime movers on the surface.

As means of generating power on the spot we may turn to steam, water, or petroleum.

* Saunders, "Dimension Stone Quarrying.-The Blasting Process." Trans. Amer. Soc. C.E., vol. xxv. (Nov. I89i), p. 504. 
Though boring machines in open quarries are often worked by steam supplied from small boilers which can be moved about on trucks, appliances of this kind are out of the question in most underground workings, on account of the nature and small size of the excavations, the inconvenience and danger caused by the fire and heat, and the trouble of getting rid of the products of combustion and of the exhaust.

Power can be obtained by bringing down water in pipes from the surface, or from overlying strita in which it is dammed back by a watertight lining (tubbing). This method has the advantage of requiring no plant except the pipes, but there is the disadvantage that the water must be pumped up again, unless the workings are drained by an adit level. However, it may be cheaper and easier to work the ordinary pumps a little faster than to erect, special air-compressing machines. Hydraulic power has the disadvantage, compared with pneumatic power, of not ventilating the workings; and in certain cases, when the floor is soft and clayey, or composed of rock-salt or saliferous marls, the flow of water would be objectionable.

The petroleum engine, an invention of modern times, is already in use in mines, not only for breaking ground, but also for pumping and hauling. It resembles a gas engine, save that the explosive mixture is produced by heating a spray of petroleum and air. It is found that the consumption of ordinary mineral oil is decidedly less than I pint per brake horse-power per hour ; reckoning the oil at $5 \frac{1}{4} \mathrm{~d}$. per gallon, the cost of a brake horse-power per hour is less than $\frac{1}{2} \mathrm{~d}$. The danger which these machines would introduce into some mines is self-evident, and they are not fitted for use in breaking ground unless the workings are of a nature to allow them to be moved about on rails. In the particular case of the thick bed of Cleveland ironstone, they are employed with advantage.

TRANSMISSION OF POWER.-The generation power in the working place itself is exceptional, and the problem usually to be solved is how best to transmit the power of steam or hydraulic engines at the surface to the machines employed underground.

Power is transmitted in mines in six different ways :
(I) By rods.
(2) By ropes.
(3) By steam.
(4) By air.
(5) By water.
(6) By electricity.

Rods of wood or iron are chiefly employed in the case of pumping machinery, and ropes in the case of hauling machinery, both of which will be referred to in later chapters.

Steam generated by boilers above ground, and conveyed by pipes under ground, does not commend itself for driving machincs at the working faces in mines. The drawbacks to its employment are the loss of pressure through condensation in the pipes, the 
inconvenience and danger of leaks, the discomfort of the hent, and the trouble of the exhaust steam. The first defect may be considerably lessened by carefully jacketing the pipes.

There remain, then : air, water, and electricity, all of which are in actual practical use at the present time.

Air.-'The transmission of power by compressed air has the immense advantage that the exhaust escaping from the machines benefits the ventilation of the mine; there is, on the other hand, the drawback of considerable loss of power.

Mr. Sturgeon* estimates that where the air is used without re-heating and without expansion, the engine worked by the air will develop only $3 \mathrm{I}^{\circ} 9$ per cent. of the power of the engine used in compressing it. In some actual cases where the efficiency has been tested practically, the loss of power has been far greater than even the 68. I per cent. calculated by Mr. Sturgeon. Professor Kennedy $\dagger$ found by experiments upon the transmission of power by compressed air in Paris (Popp's system), that the efficiency with cold air was 39 per cent.; in other words, it required 2.6 indicated horse-power at the central station to produce I indicated horse-power at the motor.

Air compressors are simply force-pumps, but the ingenuity of inventors has been largely exercised in order to overcome the shortcomings of the pneumatic mode of transmitting power. Attempts have been made especially to combat the loss of efficiency caused by the clearance spaces and by the heating of air when compressed. The effects of these two drawbacks are readily understood. Suppose the piston of an air-compressing cylinder to have reached one end of its course, the air in the clearance space on the compressing side is at the pressure produced by the machine; when the piston reverses its stroke, this air expands, and the admission valves will not open until its pressure has been reduced to a point just below that of the atmosphere. The first part of the stroke is therefore ineffective, and the greater the clearance, the greater is the difference between the theoretical volume of air, calculated from the diameter and stroke of the piston, and that actually delivered into the reservoir. However, from a mechanical point of view, the power required to compress the air in the clearance space is nearly all returned by its expansion when the piston changes its direction.

The loss of efficiency due to heating is felt in two ways: the power expended in producing heat is wasted, and the hotter the air the smaller is the actual quantity delivered by each stroke of the compressor. This latter evil may be lessened by various methods of cooling, and we are thus led to the following classitication of air-compressors :

* "The Birmingham Compressed-air Power Scheme." Paper read before the British Association. Birmingham, 1886, p. 15.

+ Rep. Brit. Assoc., 1889, p. 456. 
I. Water-column compressors.

II. Injection compressors.

III. Dry compressors.

I. Water-column Compressors.-The machines of this class have the advantage of using a cold surface for compressing, which absorbs the heat of the air with which it is in contact. 'They also get rid of the drawback of clearance or dead spaces, for the water can be made to expel all the air at each stroke, and, lastly, there can be no escape of air past the piston. An early form was that of Sommeiller,* and Ang-tröm's † compressor, used with success in Sweden in the infancy of rock-drills, was one of the same type. It consisted of two vertical barrels, connected at the bottom, and each provided at the top with an inlet and an outlet valve. The barrels were filled with water in such a manner that the up and down motion of the piston forced the air out or drew it in, according as the column was being made to rise or sink. The piston made only four strokes a minute.

Hanarte's compressor (Fig. I 76), now employed in France and Belgium, has a piston B travelling horizontally like that of Som-

FIG. $1 ; 6$.

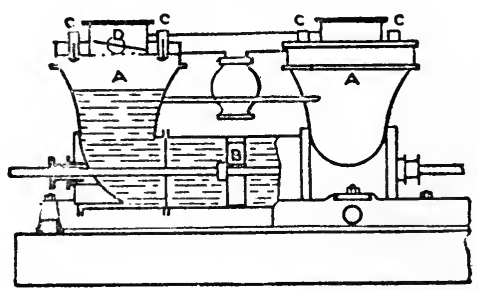

meiller, but the upright portions A A, instead of being cylinders, are paraboloids; $\mathrm{C} \mathrm{C}$ are the inlet valves, and D is one of the outlet valves. This arrangement allows a greater number of strokes per minute, because the speed of the water diminishes as it rises, although the speed of the piston may be uniform, and also because the area of the cooling surface increases in proportion to the amount of heating generated by compression. A Hanarte compressor erected at Blanzy $\ddagger$ in 1887 could not be driven at more than 24 strokes a minute, and gave some trouble from frequent repairs of the valves. Like other machines of this class, it also had the defect of dashing a little water through the valves, but on the whole it worked satisfactorily.

* Figured in Hughes' Text-Book of Coal, Mining, p. 49.

+ C. Le Neve Foster, "An Account of Bergström's Boring Machine, now in use at the Persberg Mines, Sweden," Trans. Min. Assoc. Cornwall and Devon, 1867, p. 7.

¥ Mathet, $\dot{L}$ 'air comprimé aux mincs de Blanzy. Saint Etienne, ı889, pp. 15,24 . 
II. Injeclion Compressors.-In the injection compressors, water is being constantly introduced in order to absorb heat from the air, and at the same time it has the effect of partly or completely filling up the clearance spaces, and of so still further contributing to the effective working of the machine. It is either drawn in through the admission valves, or, better, it is forced in as a spray. In a tinely divided state it will naturally act more efficaciously in a short time, which is of the utmost importance with a quickworking compressor.

Figure 177 represents one form of a Dubois and François injection compressor. $\mathrm{A}$ is the piston, $\mathrm{B} \mathrm{B}$ are the two inlet

FIG. 177 .

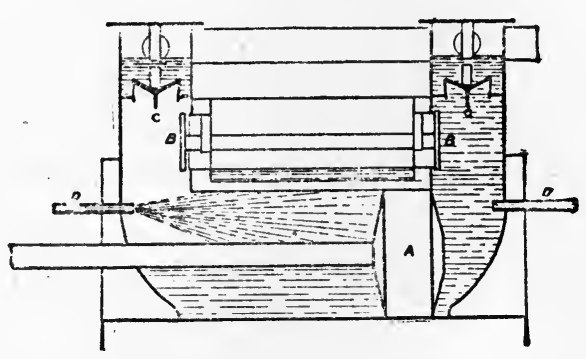

ralves, and $\mathrm{C} \mathrm{C}$ the two outlet valves. $\mathrm{D} D$ are pipes bringing in water, which is injected as a spray into the cylinder.

It has been found in many cases that, though the spray undoubtedly has a cooling effect, its use is coupled with the disadvantage that the piston and cylinder wear rapidly; therefore many engineers are of the opinion that it is better to put up with a slight imperfection in the cooling, than to have a loss of efficiency through a badly fitting piston.

III. Dry Compressiors. - Very many compressors are worked dry, and the air is cooled by its contact with the surface of the sides or ends of the cylinder, which are prevented from getting hot by the circulation of cold water outside them.

Among the dry compressors may be mentioned that of Burckhardt and Weiss, of Bâle, which was in favour at Blanzy* in 1889, on account of certain advantages which it possesses over other forms of machines, especially the great speed at which it can be worked, the delivery of a dry air, and the suppression of the evil caused by clearance. The benefit of a rapid stroke is that a small machine, costing less money, occupying less space, more easily

* Mathet, op. cit. p. 24. Further details concerning this compressor will be found in a pamphlet issued by the firm for the Paris Exhibition, 1889, and in the Revue Universelle des Mines et de la Mlétallurgie, 1889, p. 279 ; 1890, p. 202. 
transported, and more cheaply erected, does as much work as a large machine driven slowly. Great speed of working is rendered possible by effecting the distribution of the air by a slide-valve worked mechanically, instead of having valves which open and shut automatically, owing to the difference of pressure on their faces; and the injurious effect of clearance is greatly reduced by having a small passage in the slide-valve, which puts both sides of the piston into communication with each other at the end of every stroke. Consequently, when the direction of the piston is reversed, it at once begins to draw in air, instead of having the first part of its course ineffective, as is the case with many compressors. It must be pointed out, however, that the increase in the volumetric delivery of air effected in this manner is carried out at the expense of a certain amount of power. As already explained, the power required for compressing the air in the clearance space is not entirely thrown away in the ordinary machines; a part, at all events, is stored up for a moment, and helps the piston in its course as soon as the stroke is reversed. In the Burckhardt and Weiss compressor this power is wasted. The ccoling arrangements of this machine have been very carefully studied. A current of cold water is made to circulate not only around the cylinder as usual, but also at both ends, a matter of importance, because it is precisely at the ends that the heating is greatest, and that there is the greatest need of refrigeration. The piston and the slidevalve are kept greased with oil delivered drop by drop from one of Weiss's sight-feed lubricators.

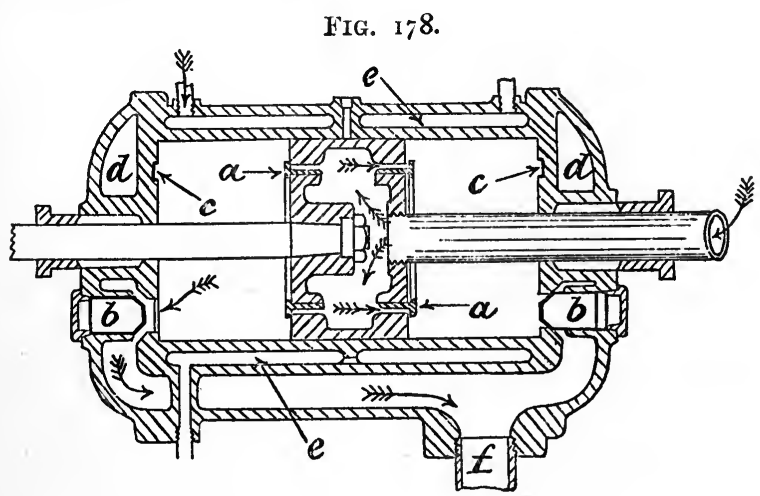

The long experience of the Ingersoll-Sergeant Rock Drill Company* has led them to adopt the compressor shown in Fig. 178. It has a double-acting air cylinder, with an inlet valve $a$ on each face of the piston. Fig. I 79 is a perspective view of one of

* Naunders, Compressed Air Production. New York, 1891, p. 22. 
these ring-shaped valves. The compressed air leaves the cylinder by the valves $b b$ (Fig. 178 ); $c c$ are grooves turned in the ends of the cylinder which receive the projecting parts of the valves on the piston, and so enable the clearance to be reduced to a minimum. The cylinder is kept cool by the circulation

FIG. 179.

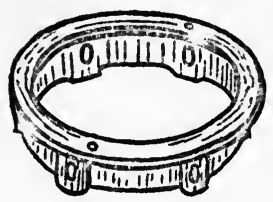
of water through the spaces $d$ and $e$, and, save where there is the outlet valve, the whole of each end participates in the refrigeration by means of the water-jackets, $d d$. The action of the compressor is simple. The air enters the piston by the tail pipe which is attached to it, and, according to the direction of the stroke, opens one or other of the ring-valves leading into the cylinder. When the direction of the stroke is reversed, this air is compressed, opens one of the valves, $b$, and passes out at $f$.

For very high pressures it may be advisable to use compound machines; that is to say, machines in which the compression is effected in two cylinders instead of one. The air is first partly compressed in a large cylinder, and, passing into a smaller one, is brought to the required high pressure. For the pressures ordinarily used in mining, say 50 to 70 lbs. per square inch, compound compressors are not, as a rule, thought necessary.

The usual type of air compressor used at mines is illustrated by the diagram, Fig. I80. A A are the two steam cylinders, $\mathbf{B}$ the fly-wheel, and $\mathrm{CC}$ the two air cylinders. It is sometimes thought

FIG. 180.

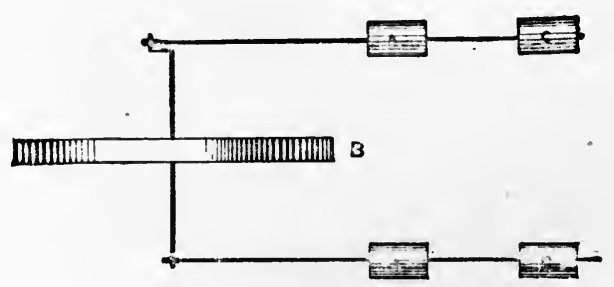

more economical to make the engine compound, and in that case one of the two cylinders takes the steam at high pressure and the other at low pressure, after it has somewhat expanded.

A point often neglected is the state of the air supplied to the compressor. The Ingersoll-Sergeant Company are quite right in insisting that the air should be taken where it is as dry, cold, and free from dust as possible.

In order to secure uniformity of pressure and get rid of water and impurities, the air is led from the compressor into a reservoir, often an egg-ended boiler; it should be provided with a safetyvalve, a pressure gauge, and also with a cock for letting off the 
water which collects gradually, especially in the case of wet compressors. Sometimes a gauge is added in order to indicate the height to which the water rises.

Several underground reservoirs have been constructed at Mansfeld.* One is a chamber $10 \mathrm{~m}$. long, $\mathrm{I}_{5}{ }_{5} \mathrm{~m}$. wide, and ${ }^{1} 5 \mathrm{~m}$. high at the mouth, and then enlarged to $3 \mathrm{~m}$. wide by $2.2 \mathrm{~m}$. high. All loose stone was carefully removed, and the walls were plastered over, first with cement, and then with a mortar made of equal parts of cement and sand. A brick dam was erected in the contracted mouth of the bottle-like chamber, and in order to make it thoroughly air-tight, a space 2 inches wide was left in the middle, and filled up with cement.

The dam is provided with a drain-pipe, $a$ (Fig. 18I), just above the floor, and a manhole pipe, $b, 20$ inches $(0.5 \mathrm{~m}$.) in diameter clear; $d$ and $e$ are two of the four pipes taking the compressed

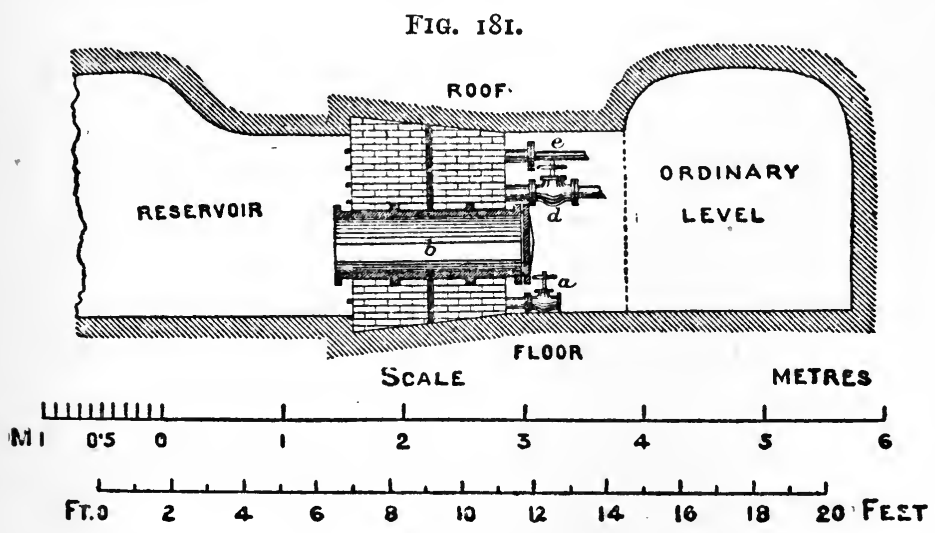

air into the workings. Each pipe has a strong cock, and the manhole cover carries a pressure-gauge. The drain-pipe $a$ is opened at least once a day, to blow off the cir'y water which accumulates.

The underground reservoirs have several advantages. In the first place they cost only one-third of what they would have done if constructed of sheet-iron; secondly, they serve as accumulators, and by storing up power make the machines far more independent of the compressors. Even if the compressor stops for a time, the underground machinery can go on working; besides, when the reservoir is at the surface, the machines nearest to it get a better

* Schrader, "Die neueren Fortschritte bei der Anwendung von Gesteins. Bohrmaschinen und die Versuche mit kleinen Schrämmaschinen beim Mansfelder Kupferschi_ferbergbau," Zeitschr.f. B.- H. -u. S.- Wesen, vol. xli., 1893 , p. II9. 
supply than those at a distance. A third advantage is the purification of the air, which deposits moisture, particles of dust, and lubricants. Lastly, an underground reservoir cannot explode.

The compressed air of a surface reservoir is conveyed into the mine by mains. They are often made of cast-iron with flange

FIG. IS2.
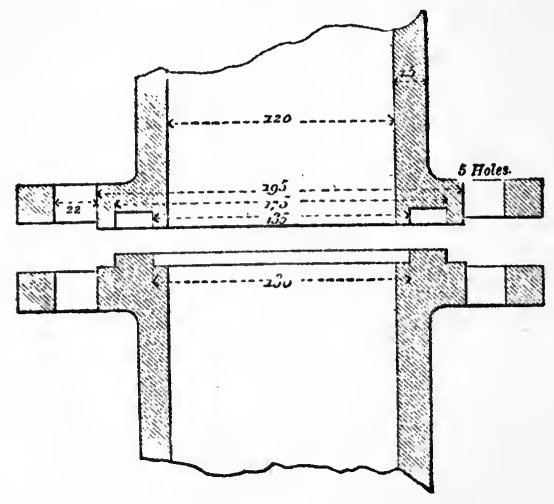

Fig. IS5.

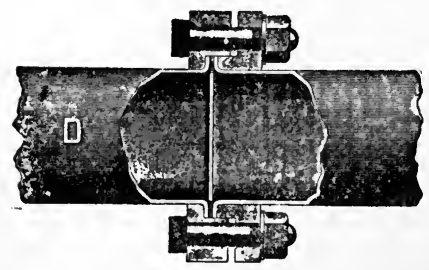

Figs. 183 \& 184 .

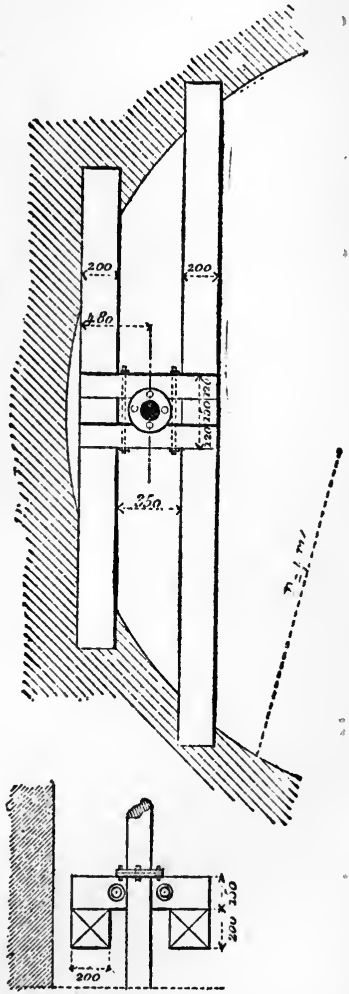

joints of some kind. Fig. 182 gives the joint used by Mathet at Blanzy for the pipes going down the shaft, which are $4 \frac{3}{4}$ inches ( $120 \mathrm{~mm}$.) in diameter inside. The joint is made air-tight by an india-rubber washer, placed in the groove shown in the upper flange, which is squeezed tight when the two flanges are drawn together by five bolts. The manner in which the pipe is supported in the shaft is rendered plain by Figs. 183 and 184 (the dimensions are in millimetres). Cross-beams are put in at intervals of about 100 yards, and the pipe is further kept in place by iron clamps driven into the brick lining of the pit every 20 yards. 
Messrs. Eadie \& Sons have several joints for lap-welded wroughtiron and steel pipes used in conveying air, steam and water, among which may be specially mentioned the one represented in Fig. 185 . In this case each end of the tube is turned up so as to form a small flange, after a loose ring has been slipped on. The loose rings are made with spigot and faucet, which can be drawn together by four bolts, and thus made to squeeze an india-rubber washer placed between the two pipes. Joints of this description are very easily and quickly made, and are found to remain staunch; they, therefore, commend themselves to the miner. The lap-welded wrought-iron and steel tubes have the advantage of lightness and cheapness, and as they are tested to at least 700 lbs. per square inch they are fully strong enough to stand far greater pressures than are met with in the air-mains of mines. In America the line of welding is sometimes spiral instead of longitudinal; and in this country Rylands' glass-lined iron pipe, 3 inches in diameter internally, has been chosen in one case for the sake of lessening the friction.

The air-compressors furnishing supplies to the Chapin Mine, Michigan, are situated at a distance of three miles from the workings, in order to take advantage of the Quinnesec Falls as a source of power. The main leading from the compressors is a riveted pipe made of $\frac{1}{4}$-inch wrought-iron, 24 inches in diameter, in lengths of 48 feet, and having expansion joints every ten lengths.

For branches conveying air from the mains to the actual working places, gas-pipe with screwed sockets is largely employed. Finally, when the machine has to be shifted continually, there is a piece of india-rubber hose, which should be covered in some way, so as to prevent its being unnecessarily worn when being dragged about over rough surfaces. Wire wound round the hose adds greatly to its durability. Flexible metallic tubing has been used with success in the place of india-rubber hose.

Water.-Force-pumps at the surface are made to drive water through pipes to places underground where hydraulic engines are worked by its pressure. They may be aided by an accumulator; that is to say, a cylinder into which the water is forced so as to lift a plunger supporting a heavy weight. The accumulator serves to regulate the load upon the engine working the forcepump, and to store up power while the mining machinery happens to be idle. It acts, in fact, like the reservoir used with an aircompressor. A second method of utilising power at the surface consists in drawing off water in pipes from the rising main of the pumps. In both these cases any natural fall of the water adds its effect to that produced by the engine above ground.

Hydraulic power has the great convenience, therefore, that it is sometimes obtainable without any extra plant being required. The water, after having done its work, runs out naturally if the workings are above an adit, but has to be pumped up if they are 
below it. However, it may be cheaper and easier to work the pump a little faster than to erect special air-compressing plant: Hydraulic power has the disadvantage, compared with pneumatic power, of not ventilating the workings, and, as already pointed out, of being objectionable with certain rocks.

Electricity.- This method consists in driving a dynamo by any available power at the surface, and then conducting the current by wires to an electric motor underground. The possibility of conveying power by wires is an immense convenience to the miner. 'Lhe advantages, compared with transmission by air or water, are that it is much easier to fix wires than pipes; wires occupy much less room, and do not suffer like pipes from movements of the rocks due to the workings. Like water, but unlike compressed air, electricity does not assist in ventilating the working place, and in fiery mines there may be danger from sparks.

Messrs. L. \& C. Atkinson, in speaking of electric transmission, in a very useful paper,* lately read before the Institute of Civil Engineers, say : "It will be seen that an efficiency of 67 per cent. can readily be obtained even when transmitting nearly roo h.-p. to a distance of more than two miles, and without any attempt being made to get specially good results, the whole plant being such as can be worked by unskilled men."

The following table has been prepared by Messrs. Atkinson to show the relative cost of transmitting power by compressed air and by electricity :

\begin{tabular}{|c|c|c|c|c|c|c|c|c|c|}
\hline System. & 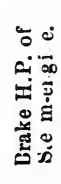 & 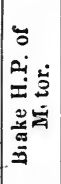 & 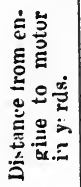 & 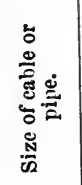 & 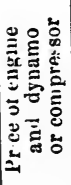 & 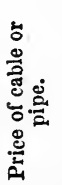 & 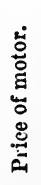 & 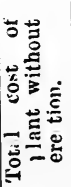 & 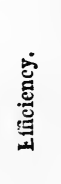 \\
\hline Electric - & 154 & I0 & $20 c 0$ & $\frac{7}{16}$ in. & $\underset{210}{£}$ & $\underset{192}{£}$ & $\underset{6}{6}$ & $\underset{1}{£}$ & $65 \%$ \\
\hline Compressed air & $33 * 3$ & 10 & 2000 & 4 ins. & 130 & 700 & 63 & 893 & $30 \%$ \\
\hline
\end{tabular}

Compared with compressed air, the plant is less expensive, and there is the immense advantage of a smaller loss of power in transmission.t According to experiments made with the electric p'ant at St. John's Colliery, Normanton, and Llanerch Colliery, Monmouthshire, the efficiency of the plant-i.e., the ratio between

* Proc. Inst. Civ. Eng., vol. civ. Session I890-9I, p. 89.

+ Snell, "Electrical Transmission of Power in Mining Operations." Paper read before the Lancashire Branch of the National Association of Culliery Managers, Wigan, September 28, 1889. 
the work done in pumping and hauling by the electric motor, and the work given out by the steam engine at the surface-is as much as from 43 to $48 \%$.

Making every allowance for the fact that these figures are given by avowed advocates of electricity, it undoubtedly seems that compressed air is at a disadvantage as regards cost and efficiency when compared with its youngest rival.

A combination of electricity and compressed air has been found advisable in some cases. The power is transmitted underground by electricity to motors which drive small air-compressors placed in the vicinity of the working places where percussive drills are required.

Hitherto the principal applications of electrical transmitting plant have been for pumping, winding, and hauling, and little has been done in the way of machines for breaking ground; but rotary and percussive drills driven by electricity are already beginning to be employed.

EXCAVATING MACHINERY.-The machines used for excavating may be classified as follows :

(I) Diggers.

(2) Dredges.

(3) Drills for boring holes for blasting or wedging.

(4) Machines for cutting grooves.

(5) Machines for excavating complete tunnels.

I. Steam Digger.-The steam navvy, though specially the machine of the railway or canal engineer, must not be forgotten by the miner, who has to excavate large quantities of comparatively soft deposits near the surface, or to remove overburden such as sand, gravel, stiff clay, or chalk. After a preliminary shattering by blasting, even hard rock may be shovelled up by these machines.

Amorig them we may mention Dunbar \& Ruston's Steam Navvy* (Fig. 186), largely used in making the Manchester Ship Canal. It is a steam crane which brings a bucket, armed with teeth and a sharp edge, against the side of the excavation, draws it up and drops its contents into a railway waggon. The figure needs but little explanation. A is the vertical boiler giving steam to two cylinders, one of which is shown at B. These are made to work drums for raising and lowering the bucket $\mathrm{C}$, by the chain $\mathrm{D}$, or for turning the jib G.

In order to work the navvy the bucket is lowered till the handle $\mathrm{E}$ is vertical; it is then brought against the bottom of the working face, and drawn up by the chain $\mathrm{D}$; the teeth enter the earth and open the way for the cutting edge. The bucket fills itself, is swung over the waggon by the jib, and 
emptied by pulling the cord $\mathrm{H}$. It closes automatically when lowered.

The depth of the cut depends upon the length of the radius given to the circular are described by the cutting tool. The radius, and therefore the cut, can be altered by a man, standing at the foot of the jib-post, who works the chain $\mathrm{F}$; this actuates a pinion gearing into a rack upon the bucket handle $\mathrm{E}$.

The navvy requires three men, one attending to the raising and lowering of the bucket and swinging of the jib; a second regulating the depth of the cut and the discharge, and lastly a

FIG. 186.

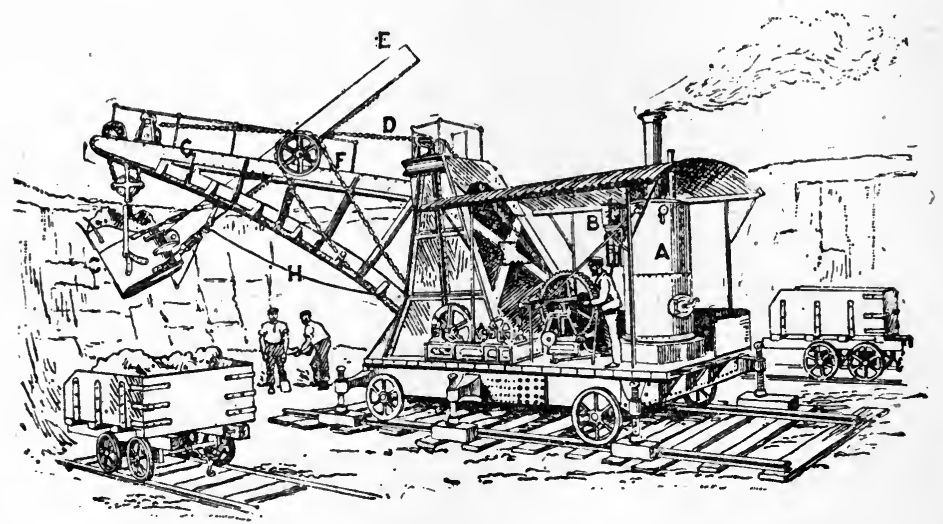

fireman. Each bucket contains I to $I_{\frac{1}{2}}$ cubic yards, and three buckets will fill a contractor's waggon. In ten hours this machine will excavate and load from 700 to 1000 cubic yards of earth.

When all the earth within reach has been excavated, the jack screws are loosened and the machine made to propel itself forward on the rails a few feet.

A somewhat similar machine is Wilson's Steam Crane Excavator. It is a ro ton steam crane to which a digging bucket can speedily be attached. The machine can therefore be used as a crane or as a digger, as occasion requires.

This is also possible with the Whittaker Excavator, which, like the two previous steam navvies, has been used for making the Manchester Ship Canal.

Steam diggers are much used by miners and quarriers in the United States, and especially the machines made by the Marion and the Bucyrus Steam Shovel Companies, which in principle resemble the Dunbar and Ruston Navvy. The Barnhardt Steam Shovel of the former company is employed in the Mesabi Range, 
Minn., and in other places, for stripping off overburden and for excavating iron ore, and the Bucyrus Company applies its digger with success to auriferous gravel, instead of washing it down by the hydraulic process.

Besides serving as true excavating machines, these steam shovels are found economical for loading ore from stock piles into railway waggons.

Another kind of digger may be spoken of as a dry dredge; a machine of this class, made by a Lübeck Company,* is in use, among other places, at a large openwork where brown coal is being worked near Brühl, between Bonn and Cologne. The excavating part of this steam digger consists of a long arm with a chain of buckets, like those of a dredge, which are brought successively against the face of the overburden and then carry the gravel into a hopper; side-tipping waggons are run under this hopper and quickly filled by opening a door.

The pulley which makes the endless belt of buckets revolve is set in motion by friction gear, so that there is no fear of a breakage, even when a bucket comes against some very hard place in the overburden which it cannot penetrate. The arm carrying the buckets can be raised and lowered as required.

Theoretically this machine will excavate rooo cubic metres ( 1300 cubic yards) in ten hours; the actual work is stated to be about 700 cubic metres (9I 5 cubic yards) in that time.

The Bucyrus Steam Shovel Company likewise makes a machine of this type.

II. Dredges.-The beds of rivers and lagoons, and even sea beaches and bottoms, sometimes contain minerals which can be excavated by dredges like those used for improving harbours. There are three types :-

(I) Bucket dredges.

(2) Grab dredges.

(3) Suction dredges.

I. Bucket Dredges.-Kincaid \& McQueen's machine (Fig. 187), used with success upon the Molyneux river, $\uparrow$ New Zealand, is in big barge, 66 feet long, with an endless chain of buckets and a pontoon on each side. The total width of the barge and two pontoons is 26 feet.

The buckets are worked by a steam-engine upon the barge, which also drives a cylindrical screen for separating any large stones. The engine is a vertical inverted compound steam-engine, with cylinders of 12 inches and 22 inches diameter respectively, and 18 inches stroke, working at a pressure of 60 lbs. per square inch.

* Lübecker Maschinenban Gesellschaft."

† Mines S'latement. By the Minister of Mines, the Hon. IV. J. II. Larnach, C.M.G. Delivered July 6, 1886, p. I7. 
The buckets can be made to raise as much as I 50 tons of stuff per hour, and to excavate to a depth of 25 feet below the level of the water. A steam winch serves for raising and lowering each

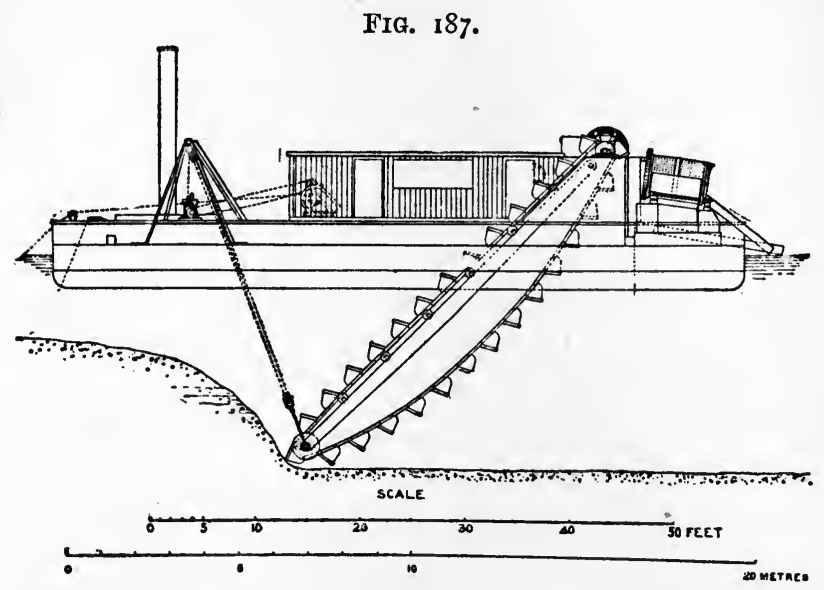

of the dredging ladders, or frames, carrying the endless chains of buckets, and also for working the mooring chains.

A dredge of a similar kind has been used on the river Orco, in Piedmont, * for the purpose of excavating an auriferous alluvium in order to extract gold from it, and with the further object of preventing floods by straightening the course of the river and embanking it.

The dredge has an engine of 50 h.-p., and is said to be capable of raising 3200 cubic yards of alluvium (2500 cubic metres) in 22 hours. It can excavate to a depth of 26 feet $(8 \mathrm{~m}$.).

2. A grab dredge consists of a single hemispherical or semicylindrical vessel, which is made so that it opens when lowered, fills itself on touching the earth and closes as soon as it is raised. The raising and lowering are done by a crane. The semi-cylindrical bucket may be armed with teeth; it descends with the teeth open and is drawn up with them closed.

Bruce \& Batho make some of their grabs with three or four sharp blades, like very pointed spades, which close upon being lifted, and form a hernispherical bucket. A somewhat similar grab dredge has been employed for stripping off the overburden from a bed of auriferous gravel in California. $\dagger$

The Priestman Grab dredger has been used for excavating the

* Gazzetta di Torin . May 11, 1886.

+ Eighth Annual Report of the State MIneralog.8t, for the year $18 S S_{.}$ Sacrameuto, I8S8, p. IoO. 
auriferous gravel of the river Nechi and its tributaries in the United States of Colombia (Fig. I88), and it likewise serves as a digging machine on land, and even for sinking shafts.

Fig. IS8.

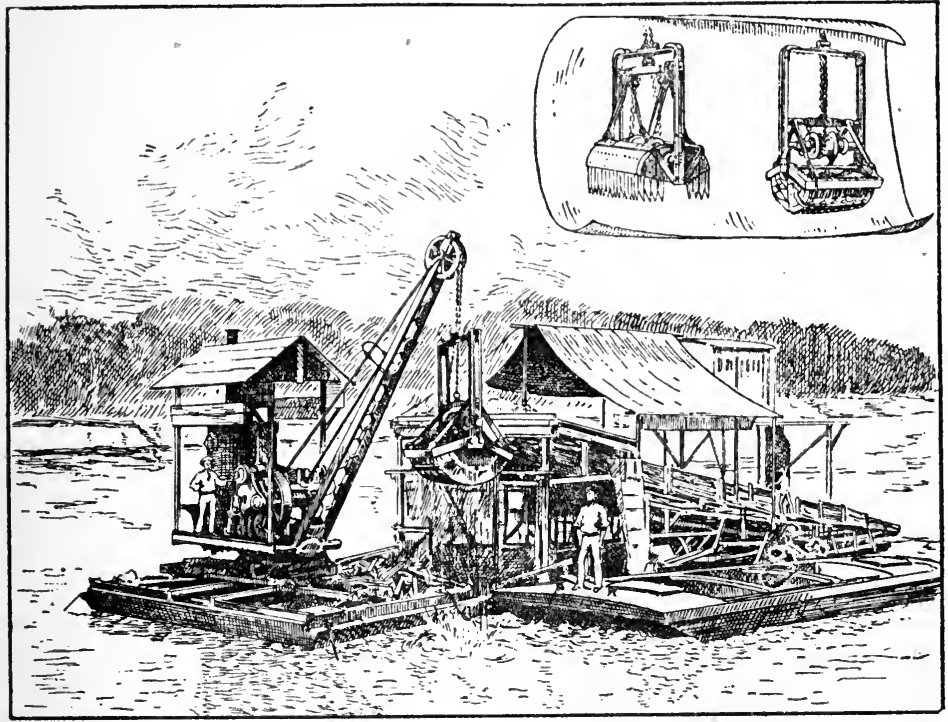

3. The Suction dredge may be described very shortly as a centrifugal pump arranged to draw up sand and gravel with the water. It is placed upon a barge, and the suction pipe can be lowered, raised, or moved from one side to the other, so as to attack any part of the sea or river-bottom. A Welman dredge of this type,* used for excavating the ocean beach at the mouth of the Waipapa Creek, has suction and delivery pipes I 2 inches in diameter. It appears to be doing excellent work where the bulk of the material to be treated consists of sand and fine shingle. The beach is reckoned to yield about 3 grains of gold per ton, whilst the working expenses are only 2 grains per ton.

III. Rock Drills.-Most of the machine drills have a percussive action, but a few are rotary ; for Stapff pointed out some years ago that if a rock may be chipped off by power communicated by a blow, it may also be chipped off by a similar amount of power communicated by pressure.

I. Rotary Drills.-Following the order I have adopted in

* Parliamentary Reports on the Mining Industry of Nevo Zealand. Wellington, 1890, p. 87 ; and I891, p. 75. 
the case of the hand tools, I will first speak of the rotary machines.

Brandt's rotary drill consists of a hollow borer which has a steel crown, with cutting edges, screwed on. The tool is kept tight against the rock by the pressure of a column of water, and is at the same time made to rotate by two little water-pressure engines, whilst a stream of water passing down through the borer washes away the chips and sand, and keeps the cutting edges cool. In principle, therefore, this drill resembles the original diamond boring machine of De la Roche Tolay and Perret, save that the crown is made of steel and not of diamonds. It has been used with success in railway tunnels and mines.

Brandt's machine was worked at one of the mines at Freiberg* in Saxony, with water at a pressure of 83.5 atmospheres, of which $5^{6} 6$ atmospheres were obtained by pressure pumps provided with an accumulator, and 26.9 atmospheres by natural fall, owing to the level in which the machine was used being 277 metres below the pump. The water was conveyed to the pump in iron pipes $1 \frac{1}{2}$ inches in diameter inside. The diameter of the holes was $2 \frac{2}{3}$ inches, and they could be bored in gneiss at the rate of $\mathrm{I}_{2} \frac{1}{2}$ inches per minute. The stretcher bar on which the machine is carried is hollow, and has a piston which can be forced out by hydraulic pressure so as to fix it firmly. A similar bar is sometimes used with percussive drills. $\dagger$

Comparative experiments were made at Freiberg between this drill, hand-labour, and a percussion drill, and the results given below are of much interest and importance. In the case of the two machine drills, the cost includes interest on and depreciation of plant, repairs, and the estimated expense of providing steam power, which would have been necessary if water power had not been available :-

\begin{tabular}{|c|c|c|c|}
\hline & Hand boring. & $\begin{array}{c}\text { Schram's } \\
\text { dr.ll. }\end{array}$ & $\begin{array}{c}\text { Brandt's } \\
\text { drill. }\end{array}$ \\
\hline $\begin{array}{l}\text { Distance driven per week in } \\
\text { metres } \\
\text { Cost in marks per metre driven } \\
\text { Wages realised by the miners in } \\
\text { marks, per eight-hours shift }\end{array}$ & $\begin{array}{c}0.95 \\
120-134 \\
1.85-2.05\end{array}$ & $\begin{array}{c}4 \cdot 5 \\
77 \cdot 4-85 \cdot 25 \\
3 \cdot 48-3 \cdot 66\end{array}$ & $\begin{array}{c}5 \\
5 \cdot 0 \\
74 \cdot 34 \\
3 \cdot 76\end{array}$ \\
\hline
\end{tabular}

The benefits of machine work are very marked iniced, both as regards rate and cost of driving, and wages earned by the men.

Brandt's rotary drill did its work cheaper and faster than Schram's machine; but nothing is said in the original notice of

* Jahrbuch für das Berg- und Hüttenwesen im Königreiche Sachsen auf das Jahr 1882, p. 18.

† Ann. Mines. Sér. 8, vol. ii. I882, Pl. I., Fig. 6. 
the advantage of a machine driven by compressed air for ventilating workings, such as advanced headings in which these drills are employed.

In Jarolimek's* drill the borer is likewise a rotating tube armed with steel teeth, but it is fed towards and pressed against the rock by a differential screw arrangement. Water passing through the hollow borer keeps the teeth cool and carries away the débris. The machine can be worked by hand, but a little water-pressure or compressed-air engine, or an electric motor will be preferable.

Experiments have been made lately at Zauckerode, $\uparrow$ in Sarony, with a diamond drill for boring holes for blasting.

The machine is a steel tube with a steel crown screwed on, containing four black diamonds; it is driven by a small electric motor upon a carriage on wheels in the level, by means of a shaft with two universal joints. This arrangement allows holes to be bored in any direction required for driving the tunnel. The holes are from $\mathrm{I} \cdot \mathrm{I}$ inch to $\mathrm{I} \cdot 3$ inches ( 28 to $34 \mathrm{~mm}$.) in diameter.

The result of the experiments is that in hard clay-slate with numerous veins of quartz, or in gneiss, granite, or rocks of similar

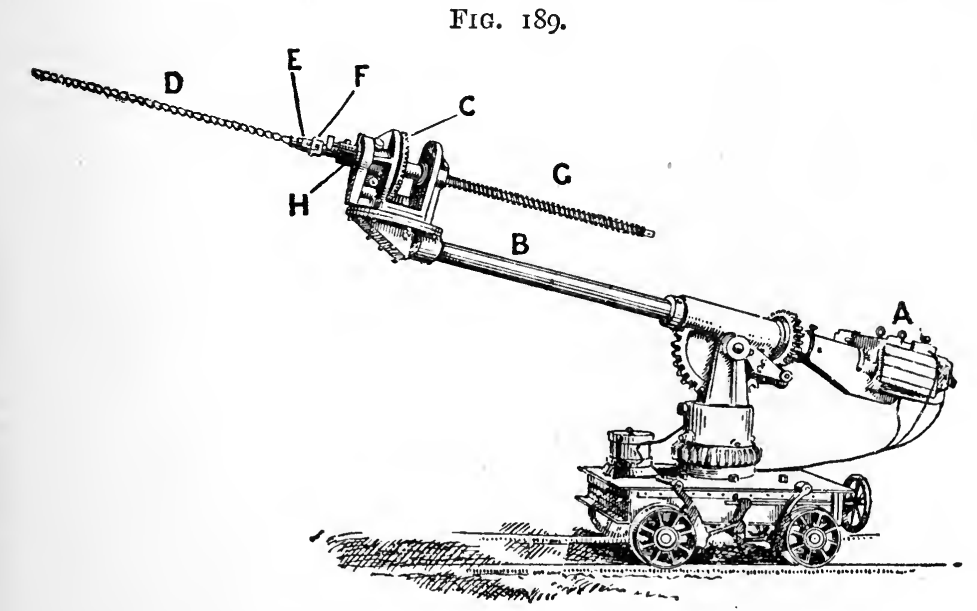

hardness, a level can be driven nearly twice as fast as by hand, and at about the same cost.

It is also possible to attach a motor of some kind.to a twist

* Oest. Zeitschr. f. B.- u. H.-Wesen, vol. xxix. (I88I), p. I84; and vol. xxx. (I882), p. IO3.

† Georgi, "Die Diamant-Bohrmaschine mit elektrischem Antriebe am königlichen Steinkohlenwerke zu Zauckerode," Jahrb. $f$. d. Berg- und Hüttenwesen im Königreiche Sachsen auf das.Jahr I890, p. 95. 
drill similar to Elliott's hand tool already described. The Jeffrey Manufacturing Company, Columbus, O., have well.designed drills of this class driven by air or electricity.

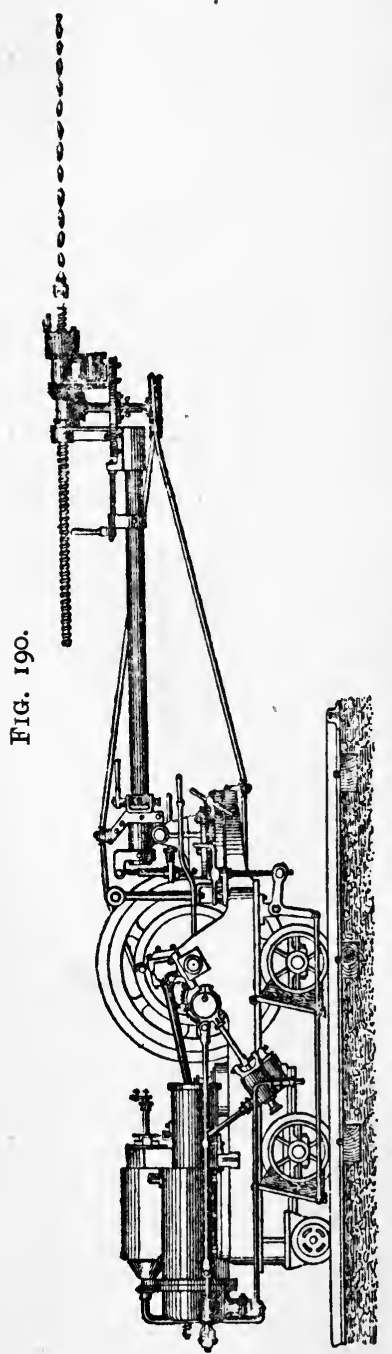

For working the Cleveland ironstone, Mr. Steavenson* is employing twist drills driven by water-power, petroleum engines or electricity. His latest drill is shown by Fig. I89: A, electric motor; B, hollow arm with a shaft inside driven by $A$, and working the bevel wheel $\mathrm{C}$ by suitable gearing; $\mathrm{D}$, twist drill ; $\mathbf{E}$, socket for drill; F, universal joint connecting the feed-screw G, to the drill-socket; $\mathrm{H}$, feed-nut. Fig. $\mathrm{r} 90$ is a similar drill worked by a Priestman petroleum engine. $\dagger$

The cost per ton of getting the Cleveland ironstone has been greatly reduced by the adoption of these machines in the place of hand-labour ; but, as is usually the case, the cost of explosives per ton of stone broken has increased, because holes are bored so easily and quickly that less care is taken in planning them. The extra cost of powder is more than repaid by the saving in labour.

The Sprague Electric Railway and Motor Company of New York $\ddagger$ have a small electric rotary diamond drill for boring holes for blasting. The motor is light and carefully cased in to preserve it from dust and dirt; it is mounted upon an adjustable stretcher bar, and it drives the drill direct.

2. Percussive Drills. - Machine drills are usually designed with a view of carrying out the three operations of hand-work-viz., the blow,

* Steavenson, "On the System of Working Ironstone at Lumpsey Mines by $\mathrm{Hv}$ draulic Drills," Proc. N.E. Inst. M. and $\mathrm{i}$. Eng.. vol. xxxvi. (1886-87), p. 67.

+ Unwin, "Petroleum Engines," Proc. Inst. C.E., vol. cix. (1891-92), part iii.

$\ddagger$ Eng. Min. Jour., vol. xlix. (1890), p. II I. 
the rotation, and the advance. As a rule a percussive drill consists of a cylinder with a piston, which is moved backwards and forwards by compressed air; the cutting tool or chisel is firmly attached to the piston rod, made specially strong to stand the great amount of shock to which it is subjected. 'The rotation is almost always effected by a twisted or rifled bar and a ratchet wheel; and, in order to keep the machine constantly in the proper position for work, it is fed forwards upon a cradle by the workman behind, who has merely to turn a handle, and so cause a screw to revolve inside a big nut attached to the machine. Drills which will advance automatically have been invented and used in some cases, but as a rule nowadays the automatic feed has been given up; indeed, it seems quite unnecessary to increase the number of the working parts and make the machine more complicated, simply to save the attendant the trouble of turning a handle.

Though the plain chisel-shaped edge is the commonest form given to the bits used with machine drills, it is by no means universal; other forms shown in the figures are the cross-bit, the

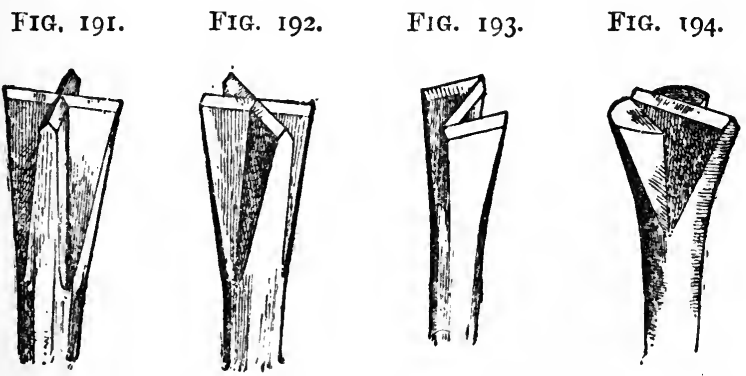

X-bit, the Z-bit, and the horse-shoe bit (Figs. 191, 192, 193, and 194). The object in all cases is to secure a perfectly round hole and so prevent jamming. If a band of hard rock crosses a hole in a slanting direction, the single-edged bit is apt to be diverted by it slightly, and become fast. At the outset also, when the drill is striking an uneven surface, it is not always easy to bore the hole properly; for this reason the first drill is sometimes made with the cross-bit, whilst the remainder of the hole is bored with the single chisel-edge, which will work properly when the hole is deep enough to act in some way as a guide for the tool.

Bits with two or three edges are not so easily sharpened as those which have but one; however, the work of the smith may be lightened by using a swage (dolly, U.S.A.), which is, practically, a steel mould, into which one end of the steel bar is placed when soft, whilst blows are struck upon the other end. This gives the proper shape, and the smith can finish up the bit upon the anvil. 
The adoption of the ingenious-shaped bars of the Crescent Steel Company of Chicago (Fig. 195) will likewise relieve the smith, but

FIG. 195. the saving of labour at the forge is not the only advantage claimed for

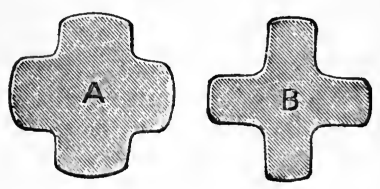
the invention. The shaped steel will discharge the débris more freely than round steel, a matter of no slight importance, for the cleaner the hole the more effective the blow ; the little chips should be got rid of as soon as possible, and any means of facilitating the discharge should be welcomed. A represents the pattern made originally for the iron mines of Lake Superior, and B the section preferred in the Rocky Mountains.

Less sharpening is required when boring by a machine than when boring the same depth by hand, and for two reasons: first, the bit suffers less, because the blow given by the machine is straighter and fairer; and secondly, owing to the greater force of the blow work can be done by the tools when they have become very much blunter than those which would be put aside in handdrilling. For machine-drilling in soft sandstone in Ohio, the borer is made with a narrow but perfectly flat bit, instead of being chisel-shaped. A flat-ended borer is likewise used by the Ingersoll-Sergeant Rock Drill Company for boring elongated holes by the Githens system. The tool does not rotate, and acts by pounding the bottom of the hole to dust. The object of the elongated hole is to make the rock rend along a pre-arranged line, a matt:r of importance in quarrying certain kinds of stone.

Percussive drills may be classified according to the power used for driving them, and those worked by air may be further subdivided according to the kind of valve employed for reversing the direction of the stroke.

The following table contains a list of several well-known drills, arranged according to their mode of action and alphabetically :- 
BREAKING GROUND.

Percussive Drills.

\begin{tabular}{|c|c|c|}
\hline Power. & Kind of distributing valve. & $\begin{array}{l}\text { Name of the } \\
\text { drill. }\end{array}$ \\
\hline Compressed air & $\begin{array}{l}\text { (1) Valve worked by mechanical } \\
\text { connections } \\
\text { (2) Air-driven valve } \cdot \\
\text { (3) Valve worked by mechanical } \\
\text { connections and air pressure - } \\
\text { (4) Two valves, a main one air- } \\
\text { driven, and an auxiliary one } \\
\text { worked by mechanical conncc- } \\
\text { tions } \cdot \\
\text { (5) No valve } \bullet \\
\text { (5) }\end{array}$ & $\begin{array}{l}\text { Barrow } \\
\text { Climax } \\
\text { Dubois and } \\
\text { François } \\
\text { Holman } \\
\text { Rand } \\
\text { Rio Tinto } \\
\text { Bickle } \\
\text { Coles } \\
\text { Eclipse } \\
\text { Optimus } \\
\text { Franke } \\
\text { Hirnant } \\
\\
\text { Sergeant } \\
\\
\text { Adelaide } \\
\text { Darlington } \\
\text { Minera } \\
\text { Marvin }\end{array}$ \\
\hline
\end{tabular}

For the purposes of this work it will be quite sufficient to describe only a few of these machines, especially as in many instances there is a great similarity between them.

(I) The Barrow drill* (Fig. 196) consists essentially of a gun-

FiG. 196.

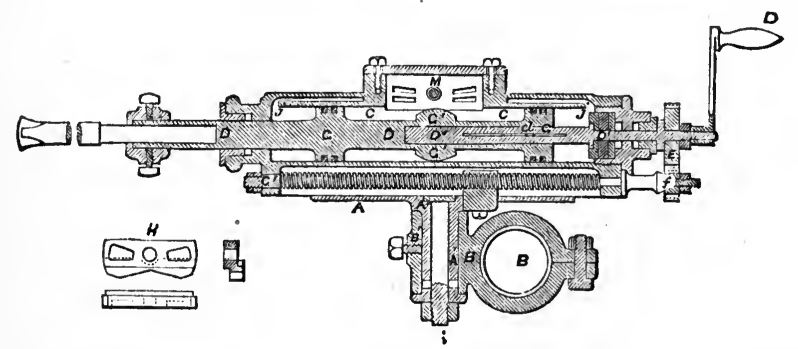

metal cylinder $\mathrm{C}$, about 2 feet in length and 4 inches in diameter, in which works a cast-steel piston-rod $\mathrm{D}$, fitted with two pistons $G$, about $\mathrm{I} 2$ inches apart, midway between which is the

* George Seymour, "On the Barrow Rock Drill," Proc. Min. Inst. Corn. wall, vol. i. (1876-83), p. 12. 
tappet or boss $G^{\prime}$. In a valve-box at the top of the cylinder is placed the oscillating slide-valve $H$ (shown separately), pivoted at $\mathrm{M}$; it is worked by the reciprocation of the tappet $\mathrm{G}^{\prime}$ coming in contact with its lower edges, which, for this purpose, are sloped at each end, as shown.

There are ports, corresponding with openings in the slide-valve face, for admitting the fresh steam or compressed air from the inlet pipe I (Fig. 197) to the ports $j$ (Fig. 196) at each end of the cylinder, and for letting the spent or exhaust air or steam escape by the exhaust pipe J (Fig. 197). This simple arrangement constitutes the whole valve gear of the machine.

"The borer is inserted into a hole formed in the fore-end of the piston-rod, and is fixed therein by means of a screw. Its rotation is effected by hand by means of the handle $\mathrm{D}^{\prime \prime}$ turning a spindle $\mathrm{D}^{\prime}$,

FIx. 197.

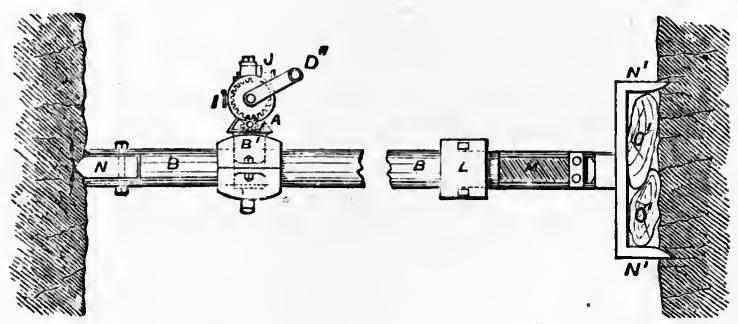

which is so fitted by means of the cotter $d$, made fast in the piston $\mathrm{DG}$, and fitting in a slot in the spindle $\mathrm{D}^{\prime}$, that the latter can slide in the piston DG, but when turned by the handle causes the piston to turn with it. The spindle $\mathrm{D}^{\prime}$ has a pinion $\mathrm{E}$, gearing into a pinion on the adjusting and feeding screw $\mathrm{C}^{\prime}$, so that when the piston $\mathrm{D}$ is turned by means of the handle $\mathrm{D}^{\prime \prime}$, the cylinder $\mathrm{C}$ is simultaneously pushed along the bed-plate $\mathrm{A}$. These pinions can be easily disconnected by loosening the nut $f$, and thus the piston and the adjusting screw can be turned independently of one another when required.

"The borers used are respectively $\mathrm{I} \frac{1}{4}, \mathrm{I} \frac{1}{8}$, and $\mathrm{I}$ inch in diameter, the length of the stroke 4 inches, and the maximum number of blows about 300 per minute.

"The gross weight of the machine, including the bed-plate and gudgeon, is about i 5 lbs.

"The bed-plate, A, of the machine is formed with a gudgeon $A^{\prime}$, which fits into and can be adjusted to any position in a socket formed in or on a clamp $\mathrm{B}^{\prime}$, which can be fixed on any part of the wrought-iron box or column $\mathrm{B}$, thus forming a universal joint. This bar or column can be placed in position either horizontally or vertically, as may be most convenient, but is 
generally placed across the level, against the sides of which it is spcured by means of the clamp $\mathrm{L}$, adjusting screw $\mathrm{M}$, and claws $\mathrm{N}$ and $\mathrm{N}^{\prime}$." Pieces of wood $\mathrm{O} \mathrm{O}^{\prime}$, are placed against the wall, and the claw is jammed against them by screwing out the bar.

The Climax Drill* (Fig. 198) recalls the Barrow; $\mathrm{A}$ is the cylinder, B B are the two pistons, and $\mathrm{C}$ the boss or swelling which strikes the valve $\mathrm{D}$ and rocks it up and down on the centre pin $\mathrm{E}$. The valve has two admission ports, $\mathrm{F}$ and $\mathrm{F}^{\prime}$, which, when passing corresponding ports in the valve-chest face, allow the compressed air to pass into $G$ or $G^{\prime}$. On the inner face of the valve, above $F$ and $\mathrm{F}^{\prime}$, there are two recesses, precisely similar to $\mathrm{H}$ and $\mathrm{H}^{\prime}$, which control the two ports on each side of the valve-chest face. In the position shown in the figure, the compressed air could pass from the valve-chest through $F^{\prime}$ into $G^{\prime}$ and drive the piston

FIG. 198.

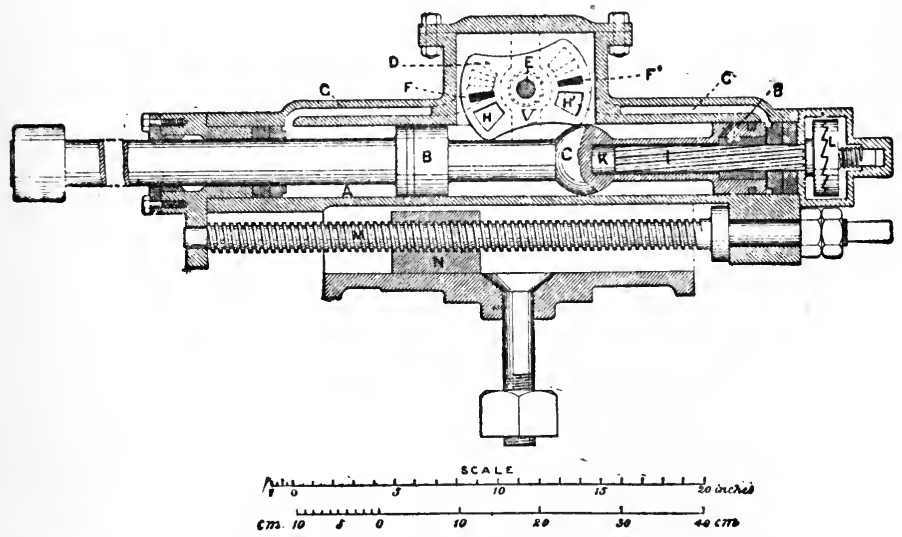

forward, whilst the air in the front part of the cylinder would escape by $G$, which is now put into communication with the exhaust port by the recess above $\mathrm{F}$. The object of the two recesses, $\mathrm{H}$ and $\mathrm{H}^{\prime}$, is to enable the valve to be reversed when one face is worn. The rotation is effected by a rifled bar I at the back end of the cylinder, which projects into a long cavity $\mathrm{K}$ in the rear piston and piston rod. It can be turned easily in one direction, but is prevented from moving in the opposite direction by the teeth of a crown ratchet clutch $\mathrm{L}$, a device which is thought by the maker to offer a better guarantee against injury than the ratchet wheel with one or two pawls common in most other drills. When the

* Figures and descriptions of the Bickle, Climax, Coles, Daw, Eclipse, Ingersoll, and Rio Tinto drills will be found in a paper by Carbutt and Davey, "On Recent Trials of Rock Drills," Min. Proc. Inst. Mlech. Eng., London, March 1891 . 
piston moves forward, the nut in the rear piston passes over the rifled bar, and causes it to turn round, but when the motion of the piston is reversed the rifled bar is prevented from turning by the ratchet clutch, the piston is forced to rotate, and with it the borer. $M$ is the feed-screw worked by a handle not shown in the figure, and $\mathrm{N}$ the feed-nut.

The Dubois and François Boring Ram (Bosseyeuse)* is a machine of a totally different type (Figs. 199 and 200); it bores large holes for the insertion of a wedge, and it is fitted with a ram for driving in the wedge, and so breaking the rock.

The machine has been specially designed for driving levels in mines where there is so much fire-damp as to render blasting

FIGS. 199 \& 200.

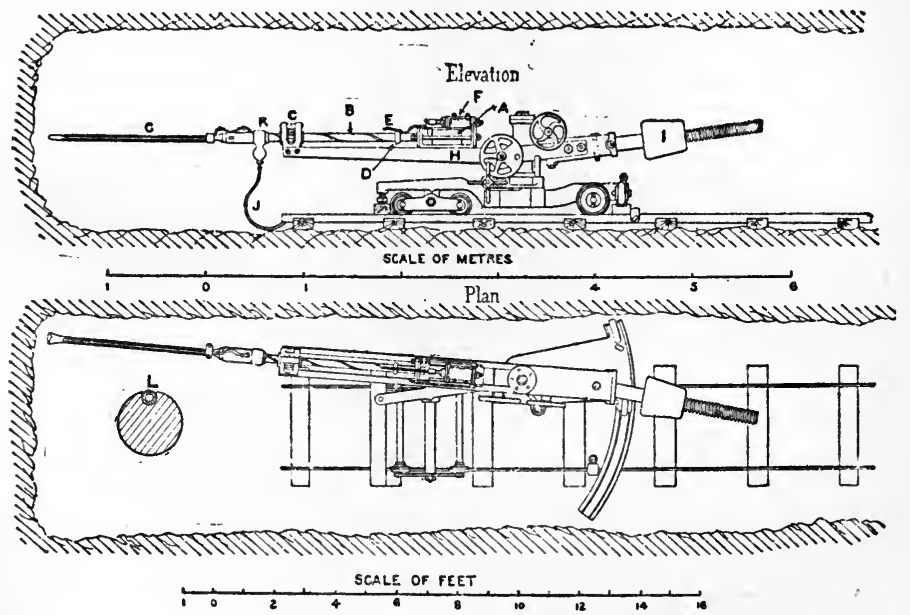

dangerous, and it therefore more esperially ecnerns collieries than ore and stone mines; but it should be mentioned in connection with the latter, because it will also bore holes for blasting, and because it is sometimes used for cutting a series of holes, and so creating a first opening, which enables blasting to be conducted with greater advantage (Fig. 239).

The boring cylinder, A, has a long piston $\mathrm{B}$, with spiral grooves which produce the rotation by means of a ratchet wheel $\mathrm{C}$, whilst the slide-valve, which effects the distribution, lies in the valvechest $\mathrm{F}$, and is brought into action when a swelling, $\mathrm{D}$, on the piston-rod touches a bent lever $\mathbf{E}$.

The borer, G, is fixed in the end of the piston-rod, and makes a hole 3 or 4 inches in diameter. As the hole is deepened, the

* IIathet, L'air comprimé aux mines de Blukzy, Saint-Etienne, 1889, p. 66. 
cylinder is made to travel alcng the frame, $\mathrm{H}$, by means of a screw, and at the same time the counterpoise, I, is also moved by a screw so as to balance it. The machine can be made to turn round the central column, and can also be moved in a vertical plane, so that holes may be bored in any direction; and the special carriage in use at the Blanzy mines permits the machine to be moved laterally, and take a position near the side of the tunnel.

The whole machine is very heavy, weighing no less than 2 tons I 3 cwt. (2700 kil.); but it is found that the greater power and stability so obtained fully compensate for any inconvenience caused by its weight.

At Blanzy one boring ram has taken the place of four small drills mounted upon one stand; and this diminution in the number of machines requiring attention is no inconsiderable advantage.

An ingenious contrivance used with the Blanzy boring ram must on no account be passed over-viz., the special pipe for conveying water to the bottom of the bore-hole. A small copper tube ( $\mathrm{L}$, enlarged cross-section, Fig. 200) lies in a groove in the borer, and carries in a jet of water which keeps the bit or boring edge quite cool, and washes out all the chippings as soon as they are produced. The tool is thus enabled to work fairly and freely the whole time, and the result at Blanzy has been a great increase both in the speed of boring and in the duration of the bits.

The water is supplied to the drill by the india-rubber pipe $J$, which leads to the hollow collar K. The collar is fixed with a water-tight joint upon the drill socket, so that the latter can revolve freely. The water finds its way through a hole in the drill-socket to the outside, when a short piece of india-rubber tube takes it to the copper pipe. The collar is kept in one position either by a weight hanging down from it, or by a rod which moves forwards with the machine. Care is taken to pass the supply of injection water through wire gauze, to remove any matter which might choke the small copper tube.

When the necessary holes have been bored, the drill is taken off and replaced by a strong ram or hammer-head, which is made to strike powerful blows upon a wedge ketween two feathers fitting into the hole. Large masses of rock are broken off in this way, and the level is driven with any required dimensions.

(2) The American Ingersoll Sergeant Eclipse Drill (Fig. 201) may be taken as an example of the machines having the valve worked by differences of air-pressure, which are caused by the opening and closing of certain passages by the piston in its course. It consists of the following main parts : the cylinder $A$, the piston $M$, the piston-rod $\mathrm{B}$, and the valve chest $\mathrm{C}$. The valve is like a $\mathrm{D}$-slidevalve, but its face is turned so as to fit the cylindrical interior of the valve-chest, and it is provided at each end with a piston. It 
therefore has the form of a spool or reel enclosing a D-slide-valve, and it moves backwards and forwards on a guide-pin. The air enters the valve-chest at $O$, and, when the piston has reached the position shown in the figure, it finds its way round the valve to $\mathrm{N}^{\prime}$, enters the port $\mathrm{P}^{\prime}$, and finally reaches the rear end of the cylinder; when the valve is reversed, it goes past $\mathrm{N}$ into $\mathrm{P}$, and to the front end of the cylinder. The port $\mathrm{P}$ is shown in the figure communicating by the slide-valve with the exhaust $\mathbf{E}$. The letters $\mathbf{S} \mathbf{S}^{\prime}$ represent a shallow recess cut round the piston, in reality making one piston into two $\mathbf{F ~}^{\prime}$ are two ports leading to the exhaust, and lastly $\mathrm{D} \mathrm{D}^{\prime}$ are two small ports which

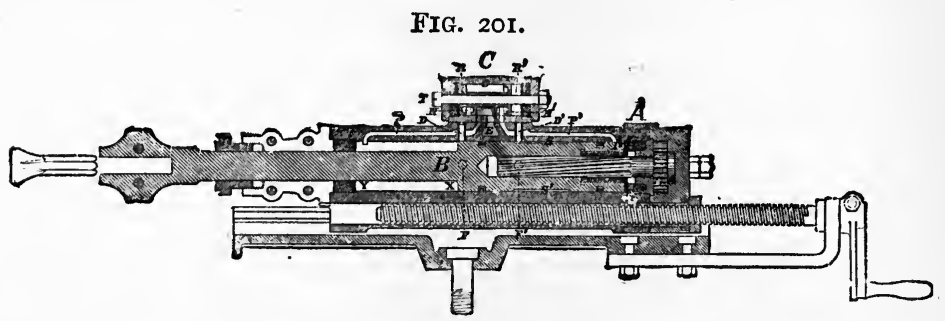

communicate crosswise with the ends of the valve-chest; that is to say, $\mathrm{D}$ is connected with the end $\mathrm{R}^{\prime}$, and $\mathrm{D}^{\prime}$ with the end $R$.

Bearing these details of construction in mind, the action of the drill can be followed. The drawing shows the machine ready to begin its forward stroke. The rear end of the valve-chest is connected with $D$, which is closed by the piston, whilst the front $R$ is open through $\mathrm{D}^{\prime}$ and the annular recess $\mathrm{S}$ to the port $\mathrm{F}^{\prime}$ and the atmosphere. The compressed air from $O$ leaking past the rear valve-piston presses upon it and keeps it in the position shown, for any air leaking past the other valve piston at the end $\mathrm{R}$ can escape via $\mathrm{D}^{\prime}, \mathrm{S}, \mathrm{F}^{\prime}$ and $\mathrm{E}$ into the atmosphere.

We will now suppose that the main piston $\mathbf{M}$ is being driven forward by the pressure behind it; the annular space $\mathrm{S}$ gradually approaches the port $\mathrm{D}$, but the length of the groove is so arranged that $\mathrm{D}^{\prime}$ becomes closed just before $\mathrm{D}$ is opened to the exhaust. When the new state of things has arisen-that is to say, when D is open to the exhaust and $D^{\prime}$ closed-the pressure in the space $R^{\prime}$ at once drops to that of the atmosphere, and the valve is driven across by the pressure upon the piston at the end $R$.

At both ends of the cylinder there is a strong india-rubber washer, protected by a steel washer, which is represented by a black line. If the miner fails to feed his machine forward properly, the elasticity of the washer prevents the end of the cylinder from being broken. The rotation is performed by the usual ritled bar and ratchet wheel, and the machine is advanced by 
turning the handle and so causing the carrying nut to move along the feed screw.

The Optimus drill, invented by Ogle, has two pistons, a large one in front and a small one behind. The compressed air, after acting at the rear end and making the tool strike its blow, is led to the front end of the cylinder, and pressing upin the large piston drives it back. The invertor claims considerable economy for his drill, because the backward stroke is made with air which usually goes direct to the exhaust.

Figs. 202 and 203 show one method of attaching the drills to the piston-rod. A is the pistonrod with an enlarged head, $\mathrm{H}$; $\mathrm{S}$ is FIGS. 202 \& 203.

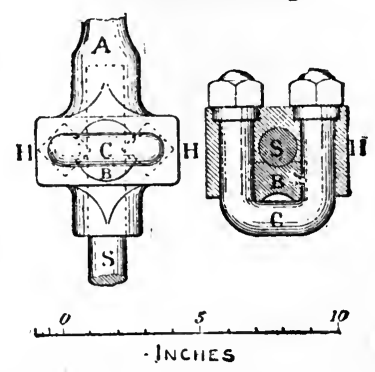
the shank of the tool which is gripped in the socket by a chucking block $\mathrm{B}$, tightened by a U-shaped clamping-bolt C.

(3) Franke drill.* This drill (Fig. 204) is especially interesting from being the smallest and lightest boring machine in actual use. Including the borer, it weighs only 16 lbs. ( $\left.7 \frac{1}{4} \mathrm{kil}.\right)$, and it may, therefore, be placed at one end of the scale whilst the ponderous "bosseyeuse" of Dubois and François occupies the other. Both in his drill and in his mechanical chisel, Franke adopts the principle of doing the work by a light blow repeated very rapidly indeed, instead of a heavy blow at less frequent intervals.

The principal parts of the machine are :-A, outer case or shell ; $A^{\prime}$, cylinder proper; $B$, piston; $C$, ring-shaped slide-valve, which can slide backwards and forwards in a short recess in the piston; $D$, tool-holder; $E$, pipe bringing air ; $F$, rear end of cylinder proper with admission ports; $G$, spiral spring; $H$, exhaust port; $I$, piston-rod ; $J$, striking head of piston-rod ; $P$, pin passing through the piston-rod; $a$, passage bringing air from $F ; b$, port admitting air to slide-valve; $c$, one of three longitudinal passages connecting the front end of the piston with the annular recess in which the slide-valve works; $e$, one of three similar passages connecting the same recess with the rear end of the piston; $f$, hollow centre of piston and piston-rod communicating by $g$ with the exhaust port $H ; h h$, two of the three radial passages which put the slide-valve $C$ into connection with $f ; i$, part of tool-holder; $j$, collar preventing the tool-holder from being driven back too far; $l l_{1}$, straight slots in the shell $A ; O o_{1}$, oblique slots in the

* Schrader "Die neueren Fortschritte bei der Anwendung von GesteinsBohrmaschinen und die Versuche mit kleinen Schrämmaschinen beim Mansfelder Kupferschieferbergbau," Zeitschr. f. B.- H.- u. 'S.-Wesen, vol. xli., I893, p. I 10. 
hollow cylinder $q ; q_{1}$, end of the cylinder $q ; r r_{1}$, ends of the pin $P$; $t$, pawls attached to $q_{1} ; u$, hexagonal end of the tool-
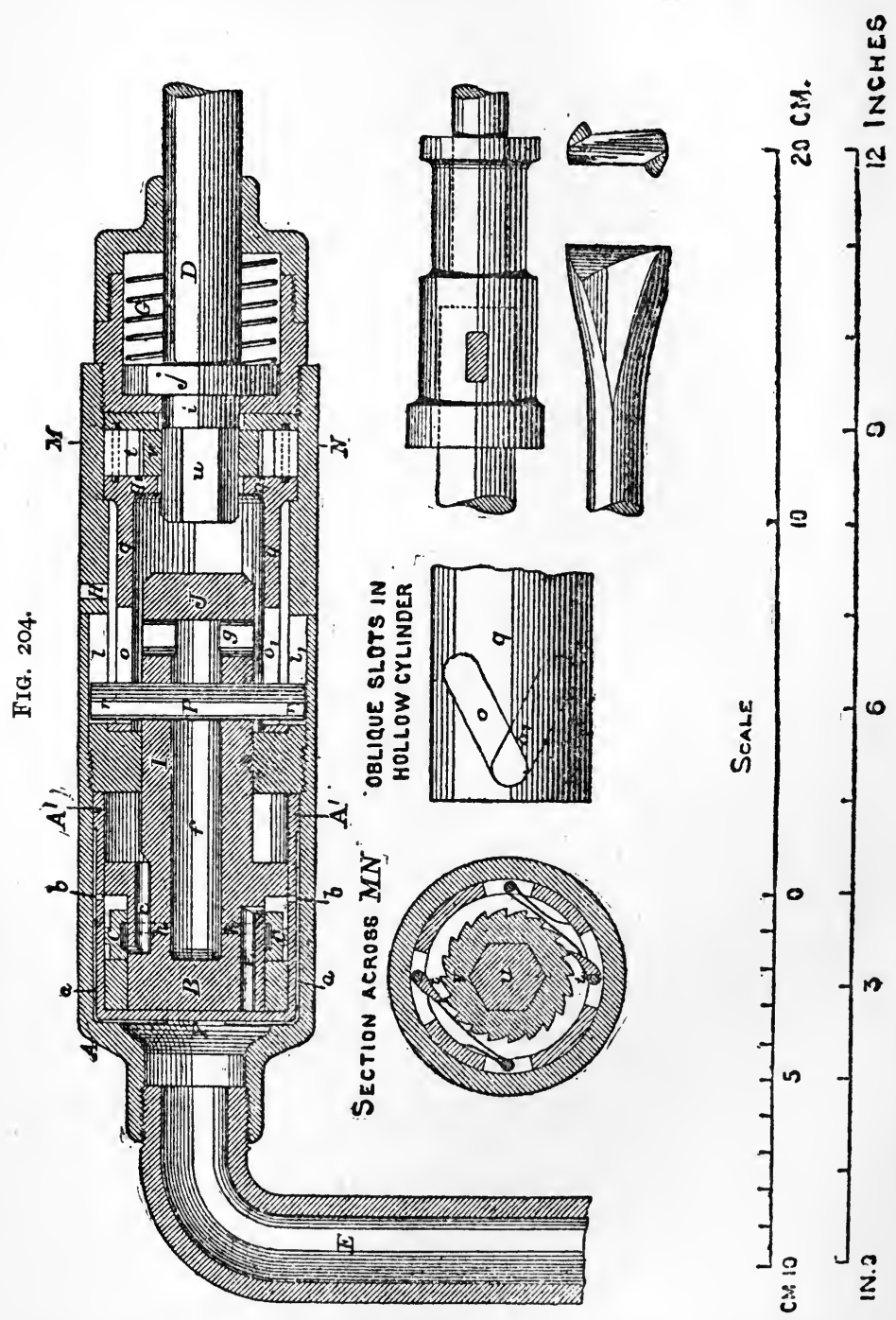

holder $D ; v$, ratchet wheel, which can slide upon $u$ but cannot rotate without it.

After this description of the parts, the mode of action of the 
machine can be easily understood. The air is brought by a flexible hose attached to $E$, and passing along the small passages $a$ outside the cylinder proper, enters it at $b$. In the position shown in the figure the lower $b$ allows the air to pass into $e$, press upon the rear end of the piston, and drive it forwards. During this time the air in front of the piston has an escape provided by the passages $c, h, f$, and $g$ to the exhaust port $H$. The complete stroke is $20 \mathrm{~mm}$. ( $\frac{4}{5}$ inch), and when the piston has travelled $17 \mathrm{~mm}$., the end of the piston rod $J$ strikes the head $u$, and the tool does its work at the bottom of the hole, provided of course that the machine is properly held. As the piston goes forwards it draws the slide-valve $C$ with it; as soon as $C$ has passed the port $b$, it is driven across the recess and the direction of the air is reversed. The front end of the cylinder is now in communication with the compressed air, whilst the space at the rear end discharges its contents via $e, C, h, f$, and $g$ into $H$. The slide-valve $C$ is then again shot across, and air is admitted to the rear end of the piston. The end of the piston-rod, $J$, is therefore constantly hammering upon $u$, and after each blow the spring $G$ brings the tool-holder back to its original position. The rotation of the tool is effected in a simple manner. The ends $r r_{1}$ of the pin $P$ are forced to travel in a direct line by the slots $l l_{1}$; but the slots $o o_{1}$

FIG. 205.

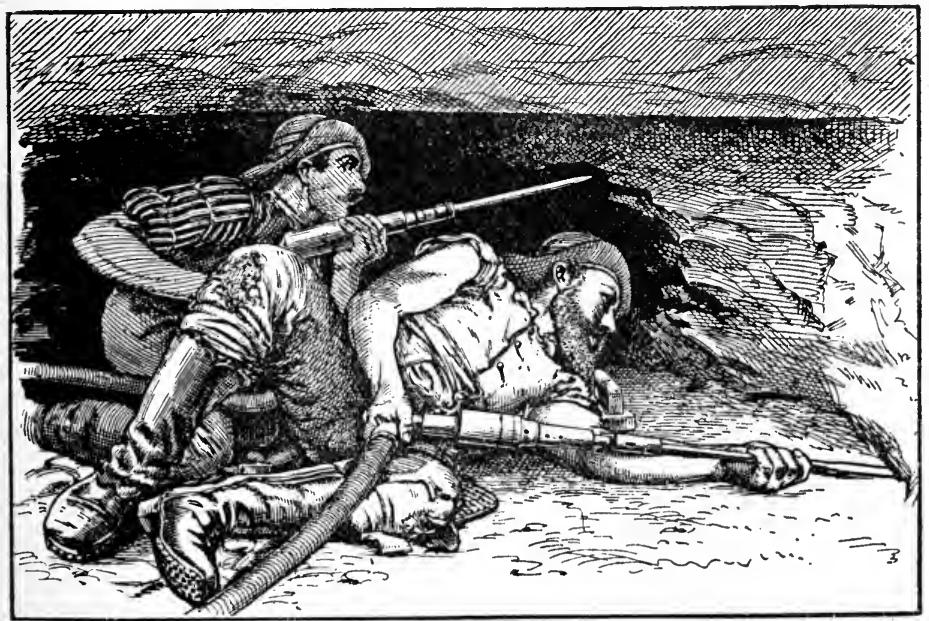

are oblique, and the pin $P$, therefore, causes the hollow cylinder $q$ to oscillate. During the forward stroke each pawl, $t$, is drawn over a tooth of the ratchet wheel $v$; during the back stroke it turns $v$ slightly, and with it the tool-holder. 
The borer is made of round steel $\frac{3}{5}$ inch ( $15 \mathrm{~mm}$.) in diameter, with a $\mathrm{Z}$-shaped bit I inch $(25 \mathrm{~mm}$.) wide. The number of blows

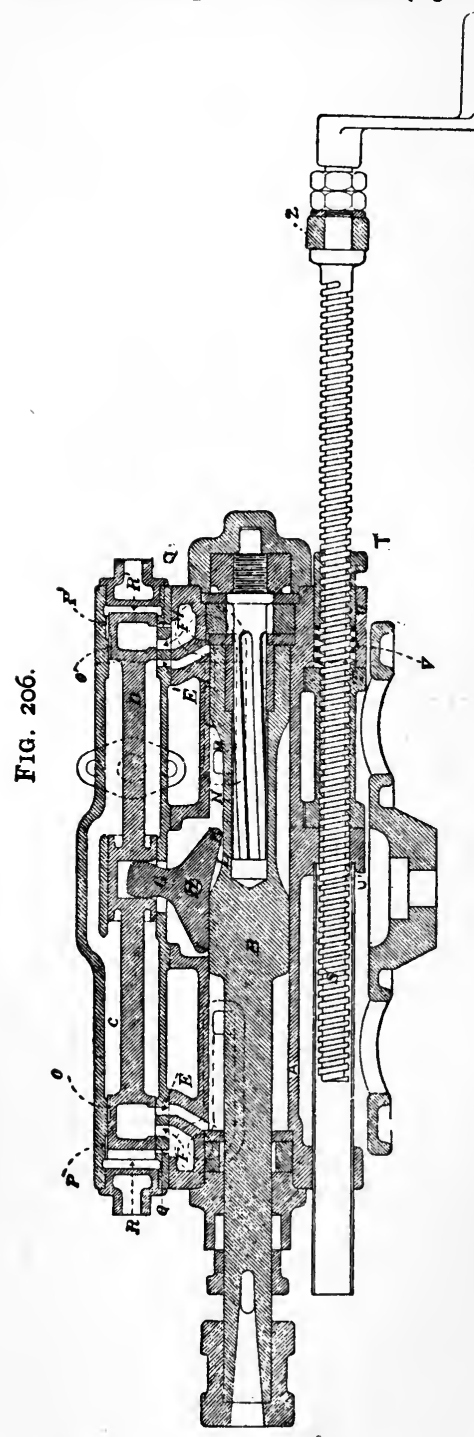
has not yet been determined exactly; but it probably reaches 8000 to 10,000 per minute. The moving parts of the machine are constructed of soft tough steel, except the slide-valve, for which good wrought iron appears at present to be the most suitable material.

The machine is used without any stand, and is simply held in the hands (Fig. 205, man in a kneeling posture).*

The Hirnant drill + of Messrs. Larmuth \& Co. is a machine with a tappet valve assisted by airpressure. In Fig. 206, $A$ is the cylinder, $B$ the piston, and $C$ the valve-chamber containing a piston-valve $D$, which works over the admission ports $E$ and $E^{\prime}$, and the exhaust ports $F$ and $F^{\prime}$. $G$ is a tappet, oscillating upon the pin $H$, when the noses $I$ and $K$ are struck by the curved shoulders $L$ and $M$ of an annular recess $N$ around the piston $B$.

In the position of the parts as figured, the compressed air brought into the valve-chamber is passing through $E^{\prime \prime}$ to the rear end of the cylinder, whilst the air in front is in communication by $E$ and $F$ with the exhaust. At the same time the air is also pressing upon the rear end of the piston-valve, for it escapes along the passage $O^{\prime} P^{\prime}$ made by planing flat surfaces upon the valve and the inside of the end of the chamber. The other end of the valve

* From a photograph supplied by the makers, Messrs. Friemann and Wolf, Zwickau.

+ Patent Office Specification No. 10,0jo, A.D. 1891. 
chest is put into communication with the exhaust by the small port $Q$, and as the flat surfaces $P$ and $O$ are not overlapping, there is no passage of compressed air. The pressure upon the rear end of the valve $D$ therefore tends to move it forwards, and assists in moving it forwards, the moment that the nose $I$ can drop down owing to the recess $N$ passing under it. The shoulders $L$ and $M$ would of themselves move the tappet, but the auxiliary air pressure has the advantage of reversing the valve without the shocks which are so destructive to the tappets of many drills. The cushion of air in the space $R^{\prime}$ prevents the nose $K$ of the tappet $G$ from striking the recessed part $N$ of the piston.

The long valve-chest has the advantage of shortening the inlet ports, and so making a saving in the consumption of compressed air:

This drill is further provided with a device for taking up any slackness of the feed-screw and feed-nut due to wear. $S$ is the feed-screw and $T$ the main feed-nut, placed between the two lugs $U$ and $U^{\prime}$, forming part of the same casting as the cylinder. $\mathrm{T}^{\prime}$ is a second nut, and between ' $\mathrm{T}^{\prime}$ and $T$ there is a space $V$ in which is fitted a spiral spring. ' $\mathrm{T}$ ' is prevented from turning by having a flat face resting against the cylinder cover. When the feed-screw and the nuts wear, $\mathbf{T}^{\prime}$ is forced away from $T^{\prime}$ by the spring and the slackness is remedied.

$Z$ is a collar upon a stirrup attached to the cradle, and furnishes a point d'appui for the advance of the machine when the screw $S$ is turned by the handle.

(4) The Sergeant drill has the

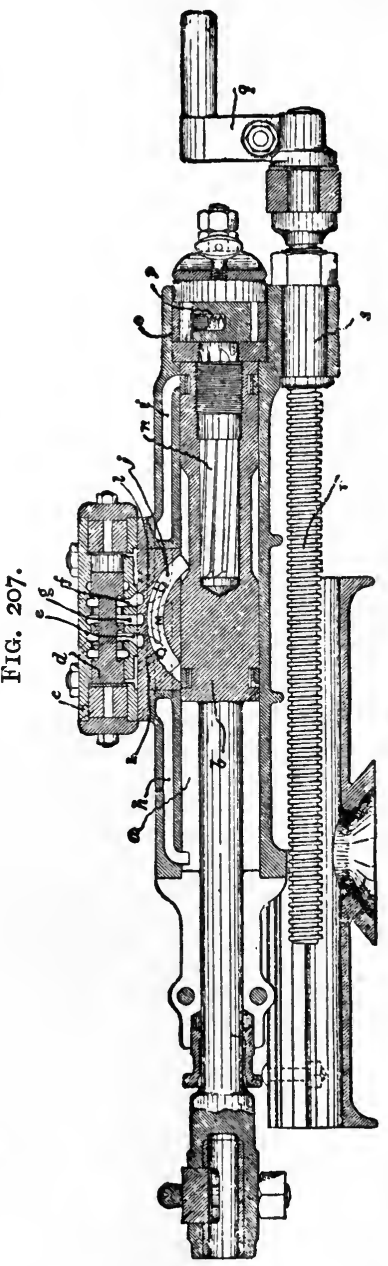
peculiarity of having two valves, a main valve and an auxiliary valve; the latter is moved backwards and forwards by inclines or shoulders upon the piston, and, by controlling certain air-passages, it causes differences of pressure which drive the former.

In Fig. $207 a$ is the cylinder, $b$ the piston with an annular recess 
turned in it presenting two inclined shoulders; $c$ is the valre-chest into which the compressed air enters from one of the sides; $d$ is the main valve, and as it moves to and fro it alternately places the port $e$ or $f$ in communication with the exhaust $g$; $e$ leads to the port $h$ and to the front end, and $f$ to the port $i$ and to the rear end of the cylinder; $j$, the auxiliary valve, is a slide-valve made in the form of a segment of a circle, and having a recess in one of its flat faces. It is slightly longer than its arc-shaped seat, so that one end of it always projects into the cylinder. The projecting end of the valve is caught by the corresponding shoulder of the piston as it passes, and it is thus being constantly knocked backwards and forwards. By means of its recess this segmental slide-valve puts the ports $k$ and $l$ alternately into communication with the port $M$, which opens into the exhaust. The port $k$ leads to the front end of the valve-chest, the port $l$ to the rear end; consequently the two ends are being alternately placed in communication with the exhaust. The compressed air leaking past the piston-like ends of the main valve escapes into the exhaust at one end of the valve-chest, but exerts a pressure at the other end where it is confined, and so throws the main valve over, changing the direction in which the air is being admitted into the cylinder. The piston makes its stroke, knocks over the auxiliary valve, which in its turn releases the pressure at one end of the main valve and causes it to move across once more.

The rotation is effected by a rifled bar, $n$, as usual ; but instead of there being a ratchet-wheel fixed to this bar with pawls attached to the cylinder, the rifled bar carries the pawls which work inside

F1G. 208.

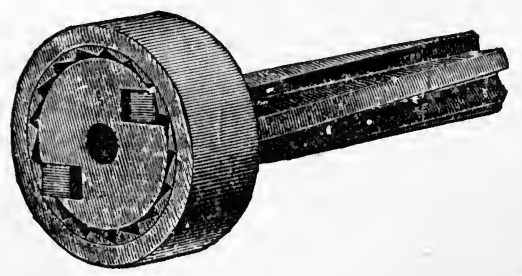
a ratchet-wheel, $o$, with internal teeth and a smooth exterior (Fig. 208). The pawls are pressed out by springs, $p$ (Fig. 207). So far the action is very like that of other drills, save that the pawls move round inside the wheel, instead of the wheel moving round under the pawls. The special peculiarity of the Sergeant rotating device is the mobility of the wheel if the drill jams in a hole. The ratchet-wheel $o$ lies loose in a recess behind the cylinder, and in ordinary working is pressed sufficiently firmly against the end of the cylinder by steel cushion springs to make the piston rotate without turning itself ; but if for some reason the borer jams in the hole and causes a strain upon the rifled bar, the wheel is capable of turning and so preventing a breakage.

The feed as usual is by hand; $q$ is the handle working the feedscrew $r$ in the feed-nut $s$. 
(5) In the drills of this class the piston performs a double function; it not only acts as a medium for receiving the pressure of the air, but it also itself uncovers or closes the passages by which the air enters or escapes, and so causes a reversal of the stroke without the intervention of any separate valve.

'The Adelaide drill (Fig. 209) comes first alphabetically, although

FIG. 209.

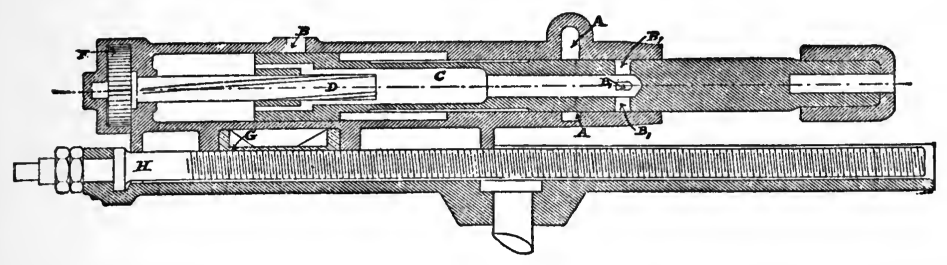

it was preceded in time by the Darlington drill, of which it may be regarded as a modification. $A A$ represent the annular port, admitting the air all round the piston, and $B, B$, are ports in the piston-rod. When the latter are opposite $A^{\prime} A$, air passes down through the space $C$ in the piston-rod to the rear end of the piston, and drives it forward till it uncovers the port $B$, which puts this part of the cylinder into communication with the atmosphere. At the same time $B, B$, have passed beyond the stuffing-box and part of the exhaust escapes in that direction; while this is happening the long shallow annular recess cut in the piston-rod is brought to $A$, the air presses on the small annular space at the front end of the piston and drives it back. It will be noticed that this drill uses the air expansively, for when once $B$, has gone past $A$ no further supply of power is taken in. $D$ is the rifled bar, $E$ the ratchet wheel, $H$ the feed-screw, and $G$ the feed-nut, similar to the corresponding parts of many other machines.

The construction of the Darlington drill will be understood by referring to Figs. 210, 2II, and 212; $a$ is the cylinder; $b$ the piston-rod; $c$ the borer; $d d$ are two openings for bringing in compressed air, either of which may be used according to the position of the drill ; $e$ is the inlet hose with a stop-cock; $f$, drillholder $; g$, stretcher-bar ; $h$, piston ; $j$, rifled bar for turning piston and drill; $k$, ratchet wheel attached to rifled bar; $l$, rifled nut fixed in the piston head; $m$, wood for lessening weight of piston rod and blocking space; $n$, portway for allowing the compressed air to pass to the rear of the piston and give the blow ; $o$, exhaust portway. The action of the drill is as follows:-The compressed air is always acting on the front end of the piston, and when the rear end communicates with the outer atmosphere, the piston moves rapidly backwards and uncovers the portway $n$. The compressed air rushes through and presses against the rear 
196 ORE AND STONE-MINING.

FIG. 2 Io.

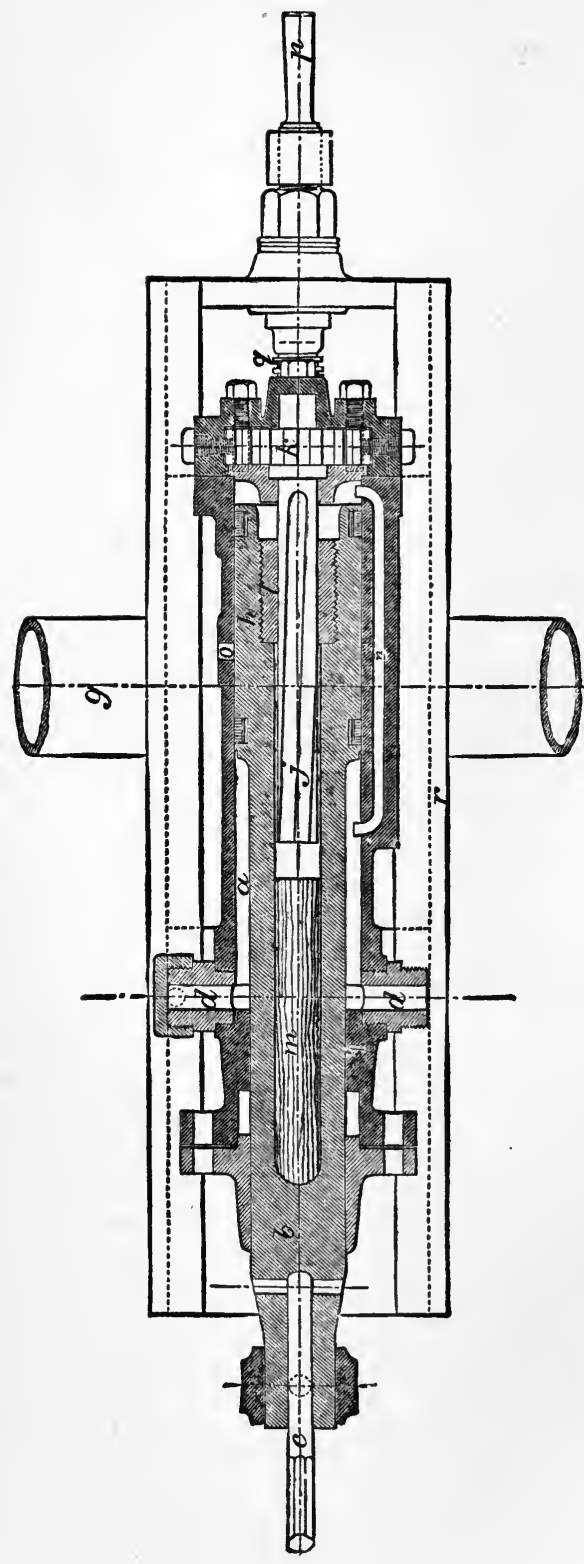

FiG. 211.

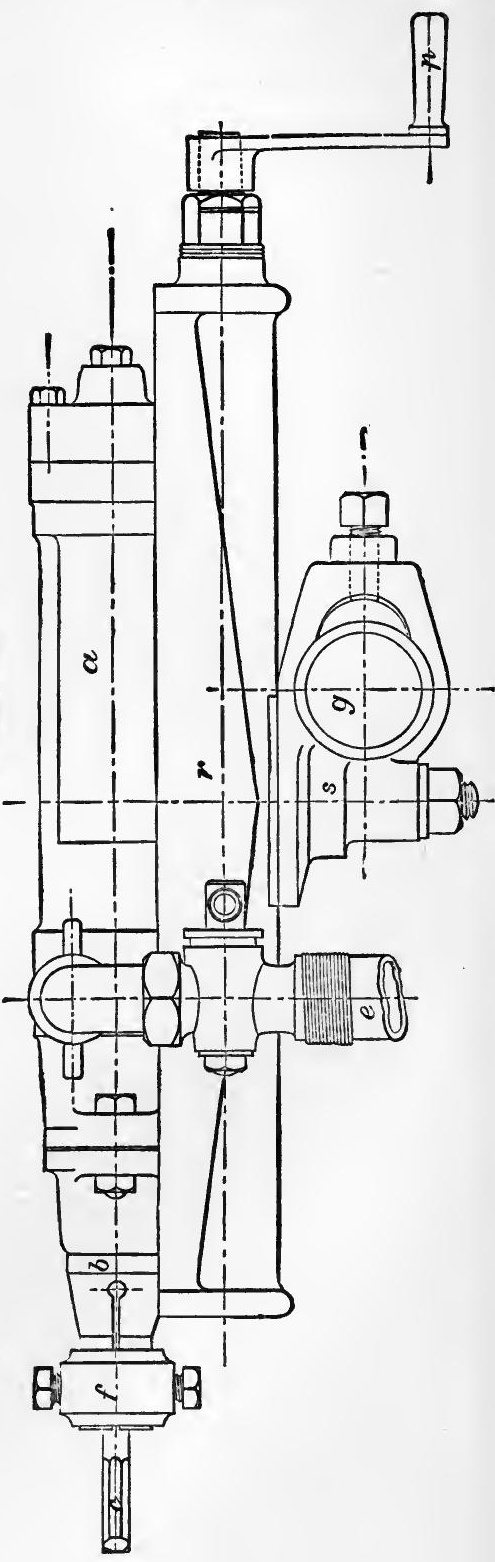


end of the piston, which has a greater area than the front end, the difference being equal to the section of the piston-rod. 'i'he piston is driven rapidly forwards, and the drill strikes its blow. At the same time it uncovers the exhaust port $o$, and then the constant pressure on the annular area on the front end of the piston produces the return stroke. The number of blows per minute is from 600 to 800 . The rotation of the drill is effected by the rifled bar. On the forward stroke of the piston, the bar with its ratchet-wheel is free to turn under a couple of pawls, and consequently the piston moves straight whilst the bar and ratchet-wheel turn. When the back stroke is being made,

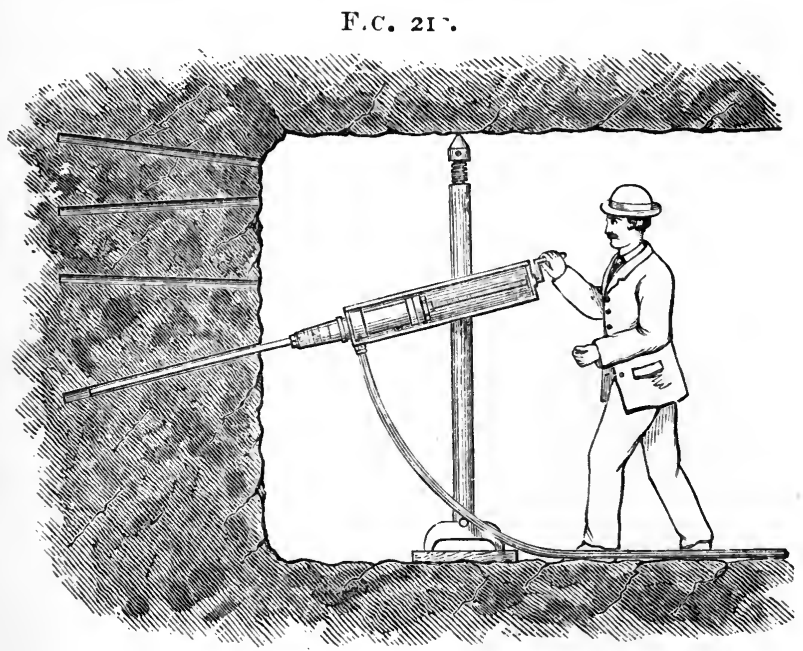

the ratchet-wheel is held by the pawls and the piston is forced to make part of a revolution. As the hole is deepened the cylinder is advanced forwards by turning the handle $p$; this works an endless screw, $q$, passing through a nut attached to the cylinder ; $\boldsymbol{r}$ is the cradle carrying the feed-screw and supporting the cylinder. It is centered on the clamp $s$. As this clamp can be fixed in any position on the bar, and as the cradle can be turned on the clamp, it is evident that holes can be bored in any direction.

In driving a level with a Darlington drill, it is usual to fix the stretcher-bar horizontally so as to command the upper part of the face; holes can then be bored with the cradle above the bar or below it. The bar is then shifted low enough to bore the bottom holes. It is found that all the necessary holes can be bored from these two positions of the bar.

The bar, therefore, has to be fixed only twice; the shifting of the machine for boring holes in various directions is managed 
by sliding or turning the clamp on the bar and by moving the cradle on the clamp.

Fig. 212 shows the stretcher-bar fixed in a vertical position, which is sometimes convenient.

In order to keep the holes clear, a jet of water, supplied from a hose attached to a $\frac{1}{2}$-inch gas-pipe leading from a cistern at a higher level, is made to play into them during the process of boring.

For sinking shafts, Mr. Darlington has the drill fixed in a cylindrical case with a large external thread, which works in a nut on the clamp. The drill is fed forwards by turning a handwheel attached to the case.

The Marvin Drill* of the Edison General Electric Company is based upon the principle that a spiral coil of wire assumes magnetic properties when a current is passed through it, and becomes capable of exerting a very strong attraction upon a bar of iron placed in a suitable position. The actual working parts of the drill are shown in Fig. 2 I3.

Fig. 213.

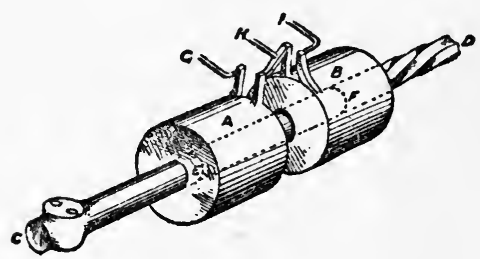
$A$ and $B$ are tivn hollow coils of copper wire (solenoids), through which passes the rod C D. The two ends are made of bronze, but the central portion, $\mathbf{E ~ F}$, is of iron. At the end $\mathrm{C}$ there is a socket for receiving the tool, whilst the end $\mathrm{D}$ is rifled and works in a ratchet-wheel, and so effects the rotation in the usual way. A current is led to the drill by a cable with three wires, shown separately by G, H, and I, and by means of a very simple revolving armature on the dynamo it can be made to pass, first through one solenoid, and then through the other, in each case returning by the wire $\mathrm{H}$. For instance, we may suppose that the current is passing through the front solenoid; this becomes magnetic and draws the iron core forwards, and so causes the tool to strike a blow. The current is then reversed by the revolution of the armature, and flows into the solenoid $\mathrm{B}$, which in its turn becomes magnetic and draws the iron back, for A has lost its magnetic power. The rear end of the rod C D is made to compress a spring, and so store up force which is utilised in increasing the strength of the forward blow.

The drill makes 600 strokes a minute, and is said to be capable of boring in granite at the rate of 2 inches a minute.

At the present time there are few, if any, electric percussive drills in regular use in mines, one objection to them being their

* "Electric Percussion Drills," Eng. Min. Jour., vol. li. (1891), p. 609. 
great weight compared with air drills of equal strength; but it is stated that they are loing good work at some open limestone quarries at Svracuse, ${ }^{*}$ N.Y.

IV. Machines for Cutting Grooves.-In working a seam the task of the miner frequently consists in cutting a deep groove parallel to the bedding with a pick, and so laying it bare above, below, or in the middle. Wedging or blasting will then break it away.

The first machines for cutting grooves very naturally imitated the miners' tuols, and were simply mechanical picks, but since then many other groove cutter's hive been applicd which are based upon different principles.

'They may be classitied as follows :-

1. Mechanical picks, chisels, and gouges.

2. 'Travelling jumpers and rock-drills.

3. Circular saws.

4. Endless chains with cutters attached.

5. Wire saw.

6. Revolving toothed bar.

(I) Mechanical Picks, \&c.-Some, like Firth's machine, swing a pick like a miner. The Sergeant machine is a strong rock drill with a chisel bit, which chips out a groove as a carpenter might cut out a mortice. It is mounted on two wheels and can be handled with ease. Carrett and Marshall's machine is a powerful gouge, worked by hydraulic pressure, which cuts out a groove in coal or soft rocks. 'These have all been designed more especially for the collier; but in Franke's mechanical chisel (Fig. 214) we have a tool which is being successfully employed in ore-mining. It is based upon the principle of striking a very large number of short and light blows instead of a comparatively small number of long and heavy ones. It resembles in some respects Crossley's mechanical caulking tool and McCoy's chisel.

The following description is derived from accounts given by Pilar and Schrader, $\dagger$ and from personal observations at Mansfeld; $a$ is the outer shell of the machine, $b$ the inner or real cylinder, $c$ the piston with the annular slide-valve $r, d$ the tool-holder carrying the chisel in a deep socket; the air is brought in to $a$ by the pipe $t$, and finds its way into $b$ through four broad, low passages, $m m$, and sizteen small ports, similar to $n n, \frac{1}{10}$ inch in diameter. The front part of the outer shell, $a^{\prime}$, serves as cylinder cover and as guide for the piston rod, and lastly to contain the tool-holder $d$, surrounded by two spiral springs in the space between the shoulder $p$, and the cover $s$. The opening, o, allows the air to escape in front of the piston-rod, and so makes the stroke easier; $l$ is the exhaust port, and $q$ a hole for lubricating; $\boldsymbol{r}$ is the ring valve,

* Eng. Min. Jour., vol. 1v. (1893), p. 491.

+ Johann Pilař, "Schıammeissel, System Franke, im Mansfeldischen," Oest. Zeitschr. B.- u. H.- W., vol. xl. (i892), p. 78. Schracler, op. cit. p. 17 I. 


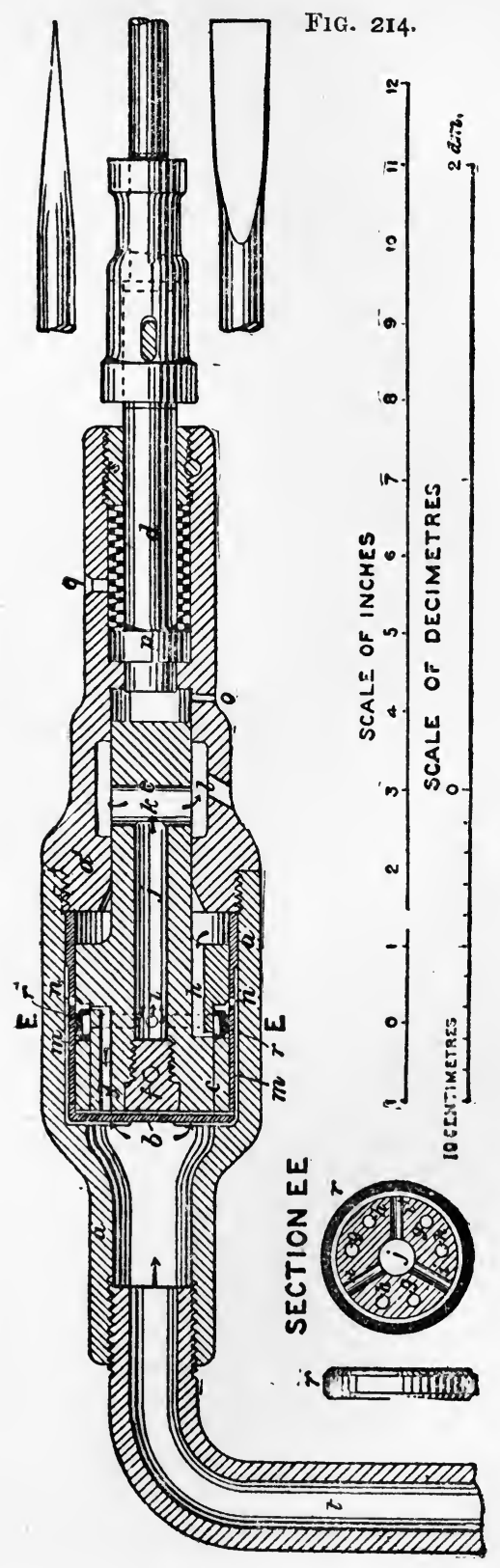


sliding upon the piston, and as soon as it is drawn past the port $n$, it is driven either forwards or backwards by the air pressure. In the position shown in the figure, representing the end of the return stroke, the valve $r$ has been driven back, and the air is enabled to pass from $m$ into $g$, and so to the back of the piston. The air in the space in front of the piston finds an exit along the three passages $h$, of which only one can be shown in the section, and entering the annular slide-valve, is brought by one of the three radial passages, $i$, into the hollow central part $j k$ of the piston and piston-rod, and eventually to the exhaust $l$. As soon as the piston, in its forward stroke, draws the valve $r$ past the port $n$, it is thrown over by the air pressure; $g$, through $r$, now communicates with $i$, and the air passes from the rear end of the piston to the exhaust; at the same time the three passages $h$ are connected with the admission inlets of compressed air, and the piston makes its return stroke. The piston is thus driven backwards and forwards, striking a rapid succession of blows, estimated at several thousand per minute, upon the back end of the tool-holder $d$, and as fast as the latter is knocked forwards it is drawn back by the action of the springs. The tool-holder is in no way connected with the piston, and is quite free to turn round.

The length of the stroke of the chisel is only 0.06 to $0.08 \mathrm{inch}$ (r.5 to $2 \mathrm{~mm}$.) As the annular slide-valve closes the ports $n n$ in passing, the air acts by expansion during the latter part of the stroke. The air-pressure employed at Mansfeld is $60 \mathrm{lbs}$. per square inch ( 4 atm.)

'The chisel is made of $\frac{1}{2}$-inch round steel with an edge $\frac{4}{5}$ inch wide; it is inserted in the strong socket of the tool-holder, and the miner simply holds the cylinder so that the chisel presses against the shale which he wishes to cut away (Fig. 205). It is said that a man can undercut or "hole" an area of 5 square feet ( 0.5 sq. m.) per hour. Each hewer has to make a "holing" about 10 feet $(3 \mathrm{~m}$.) long, and he carries it in to a depth of 20 inches to 2 feet from the face. The groove or "holing" is about $5 \frac{1}{2}$ inches ( $14 \mathrm{~cm}$.) high at the face, and becomes lower and lower as it goes in.

The men do not appear to suffer in any way from the vibrations of the machine, which weighs only ro lbs. (4.5 kil.) including the chisel.

(2) Travelling Rock Drills and Jumpers.-A groove may be made by boring a succession of holes immediately touching each other, or separated by small partitions which are broken down afterwards by a flat bit (broach). Most of the rock drill companies supply special quarry-bars or frames, upon which an ordinary boring machine can be mounted and made to travel, and thus cut a groove along any required line.

With the Ingersoll bar-channeller* a cutter is sometimes uscu

* Eny. Min. Juur., vol. xlix. (1890), p. 62. 
made of three chisels placed side by side, with their edges arranged like the three strokes of the letter $\mathrm{N}$, in the place of an ordinary borer. As the carrying frame can be inclined, the groove can be cut at an angle.

The Wardwell* stone channelling and quarrying machine may be regarded as a mechanical jumper, cutting a vertical groove. It is a portable 6 h.-p. engine with boiler, moving upon rails, which is made to lift a set of boring chisels or cutters consisting of five bars of square steel, clamped together in a line. The edges of the centre and outside chisels are transverse, whilst the other two are diagonal, and they are arranged in step fashion. Three cutters only act at a time, viz. the centre cutter, and either the two in front or behind it, according as the machine is being moved forwards or backwards. "The machine consumes $400 \mathrm{lb}$. of coal a day, and requires the services of three men. It will cut from 75 to 150 square feet of channel in marble, and 150 to 400 square feet of limestone and sandstone in a day, which is equivalent to the work of 50 men."

The Cleveland Stone Company, Ohio, employs no less than thirty-nine of these machines in quarrying sandstone, with the modification of having only three cutters instead of five.

'The channelling machines of the Ingersoll and Sullivan Companies running upon rails, either with or without a boiler, will cut vertical or inclined grooves.

(3) Circular Saws. - In alphabetical order the following may be named: Crump and Brereton, Gillott and Copley, Walker, Winstanley.

Crump and Brereton's $\dagger$ machine is used for quarrying stone in the United States. It will cut long vertical grooves 30 inches deep and about $\frac{5}{8}$ inch wide.

It consists of a frame on wheels, moving upon rails, which carries a small vertical boiler, steam-engine, circular saw about 5 feet in diameter, and the gearing necessary for driving it and causing the whole carriage to advance as the cut is made. The saw is a thin circular steel blade, about $\frac{3}{8}$ inch thick with slots all round the edge into which the teeth are inserted. They are arranged so that they divide the narrow cut of $\frac{5}{8}$ inch into 3 parts, each tooth taking $\frac{1}{4}$ inch. The teeth are sharpened by grinding. The saw is driven from the perinhery by a toothed wheel on each side, the teeth of which gear into two circular sets of holes cut near the circumference of the saw. It is said that while making a cut 30 inches deep in slate, it will progress at the rate of 4 inches a minute.

The Gillott and Copley $\ddagger$ machine (Fig. 215) has been specially

* Eng. Min. Jour., vol. xlvii. (1889), p. 500.

† Engineering, vol. xli. (I886), pp. ${ }^{154}, 272$.

¥ G. B. Walker, "Coal-getting by Machinery," Proc. Fed. Inst. Min. Eng., vol. i. $(1890)$, p. $12 \mathrm{~S}$. 
designed for cutting a more or less horizontal groove, under or in a seam of coal, but it can also be applied to seams of other comparatively soft minerals. It is a cast-steel or malleable iron wheel 4 feet in diameter, armed with removable teeth, which are alternately double and single. The groove which is cut is rather more than 3 inches wide, and is big enough to allow the bracket supporting the saw to enter it. Consequently, a cut can be made nearly as deep as the diameter of the saw.

Just inside the circumference there is a circular rack into which gears a bevel pinion driven by two compressed air engines with cylinders 9 inches in diameter and having a 9-inch stroke. The saw makes about 30 revolutions a minute. The two engines are upon the carriage which supports the saw. 'I'he carriage runs upon rails set at a gauge of I foot $7 \frac{1}{2}$ inches, and it draws itself

FIG. 215.

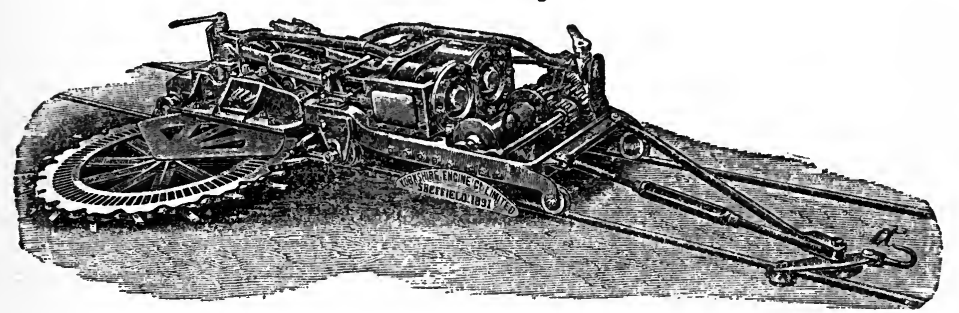

along by a wire rope, which has one end fixed at some convenient point of the working face, and the other coiled upon a drum attached to the carriage. The drum is made to revolve by a pawl and ratchet-wheel worked by the engines, and there are means of regulating the number of teeth taken by the pawl, and in this way the advance of the machine.

Two men are required for working the machine; the man in front lays down the rails and sleepers, which are taken up and passed to him by the man in the rear as soon as the machine has gone over them. The whole machine is only I foot 9 inches above the rails; its width, exclusive of the saw, is 3 feet 3 inches, and total length 9 feet; it weighs altogether 24 cwt. The makers state that it will undercut to a depth of 39 inches in hard coal or shale at the average rate of 12 yards per hour, with an air pressure of about 30 lbs. per square inch. 'The saw cuts from back to front, and therefore clears out the chippings that it makes.

The Rigg and Meiklejohn machine, which is in operation in Scotland, is a circular saw of somewhat similar construction.

The cutting of a preliminary groove in some of the Cheshire salt mines has long been done by Walker's circular saw (Fig. 2i6).

An improved form of the Winstanley saw is doing good work at 
the Blanzy collieries. It is a circular saw 5 feet $(\mathrm{r} .50 \mathrm{~m}$.) in diameter, with 28 removable cutters, all of one shape, upon its circumference. The cutters are arranged in fours, so that four of

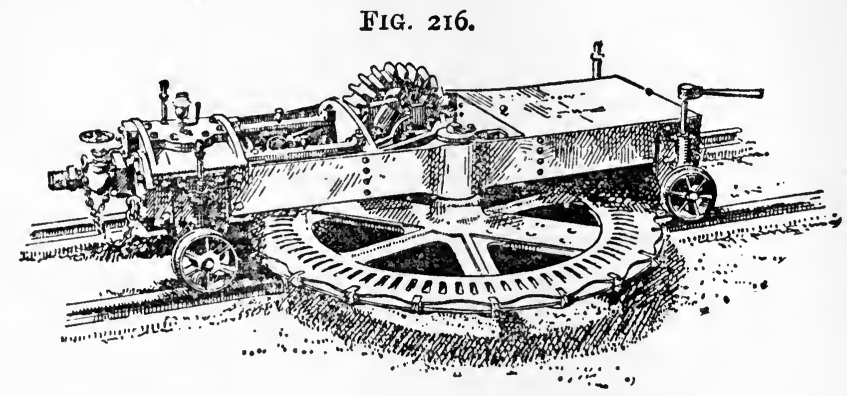

them cover the whole width of the holing, which is 3 inches $(7.6 \mathrm{~cm}$.) high. Two small compressed air engines, inside the waggon which carries the saw, drive a horizontal pinion, which gears into the spaces between the cutters; in fact, the saw is a cog wheel with a cutter inserted into each tooth. The depth of the holing is 4 feet. The total weight of the machine is $35 \mathrm{cwt}$. (I80o kil.)

(4) Endless chain with cutters attached.-Baird's machine,* which is used both for coal and ironstone, is of this type. A carriage moving on rails supports two cylinders worked by compressed air, and these set in motion an endless chain with cutters, which revolves round two pulleys, one at each end of a jib or arm. The jib can be made to extend under the seam for a distance varying from 2 feet 9 inches to 5 feet, and the groove which is cut is only $2 \frac{1}{2}$ inches high.

It is stated that a machine will make an undercut 2 feet 9 inches deep by roo yards long in 8 or ro hours.

(5) Wire Saw.-The most novel method of cutting stone is one which has been used at marble quarries in Belgium and elsewhere, and is called by the inventor the Helicoidal Saw System.

It consists in sawing grooves by an endless cord, composed of three steel wires twisted together, which travels on the rock, and is supplied with sand and water. The sand is drawn along by the spaces between the wires, and will cut even very hard stone. At present only vertical grooves have been cut; the first process consists in sinking two pits for receiving the pulleys which guide the cord in making its cut, and which have to be lowered as the cut is deepened. 'The pits are bored 2 feet 4 inches $(700 \mathrm{~mm}$.) in diameter by cylinders of sheet-iron, with the lower and cutting edge made of sheet-steel. The cylinder is made to rotate at the

* Walker, ilid. 
rate of 100 to 180 revolutions a minute by a vertical axis set in motion by a horizontal pulley at the top, driven by a wire rope, whilst sand and water are fed in to the cutting edge. As the annular groove is cut deeper and deeper, the cylinder is gradually lowered by a little winch and two wire ropes. The cylinders now in use are constructed so as to cut to a depth of ro feet 9 inches $(3.30 \mathrm{~m}$.). When this cut has been made, a core remains, which can easily be broken off at the bottom and lifted out. In the case of marble the core can be utilised and sold as a column. If there is a demand for smaller columns, boring cylinders of less diameter are used, and two or four holes are bored side by side. After the removal of the columns the thin intervening partitions of rock are broken down, and space enough is afforded for the introduction of a pulley and a frame.

Two of these pulley-pits are prepared at the two extremities of the line along which it is desired to make a saw-cut, which may be 50 feet or more in length, if required, and the carriers are then inserted. The carrier, made of channel iron, supports two pulleys, each 2 feet in diameter; one is fixed at the top, whilst the second is so arranged that it can be lowered by a large screw.

The cord for sawing in the quarry is about $\frac{1}{4}$ inch $(6 \mathrm{~mm}$.) in diameter, made up of three wires of mild steel, twisted together so

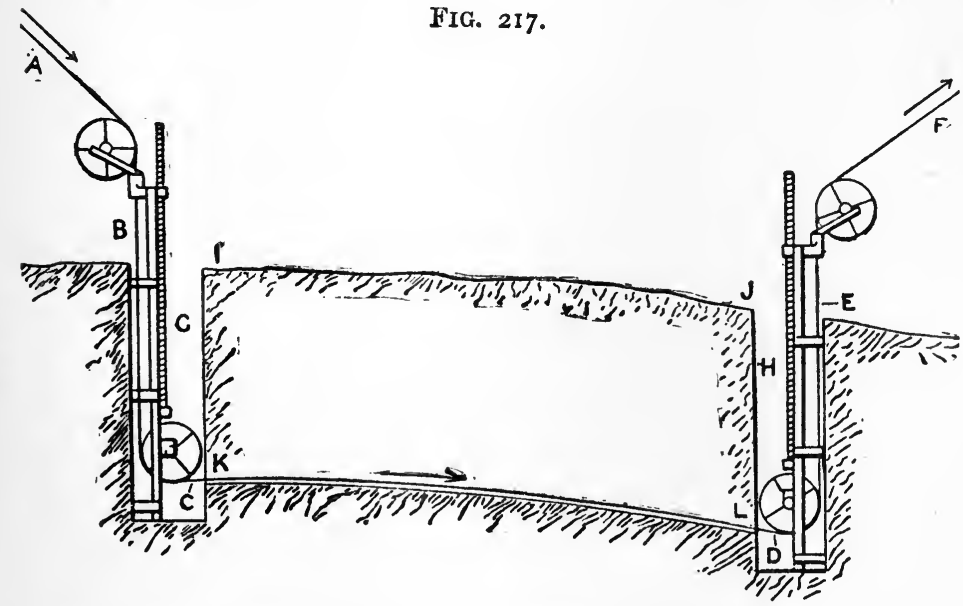

as to form a strand. It is driven at the rate of $\mathrm{I}_{3}$ feet $(4 \mathrm{~m}$.) per minute, and will deepen the cut in marble at the rate of 3 to 4 inches or more per hour. The friction of the spiral wires on the pulleys and rock causes the cord to revolve a little as it is carried forwards, and all parts of it are thus equally worn. When it is so much worn that it no longer presents spiral spaces which will 
hold sand, it has to be changed. If it breaks while in use, it can very easily be spliced.

Fig. 2 I 7 represents the arrangement adopted at the Traigneaux* Quarry, near Philippeville, Belgium. A B C D E F is the wire cord travelling in the direction shown by the arrows; $H$ and $G$ are the two pits which have been bored to hold the pulley-frames. When the cutting process began, the wire cord would have been running along the line $\mathbf{I} \mathbf{J}$; the groove is gradually deepened until at last it reaches the line $\mathrm{K} \mathrm{L}$.

When suitable vertical cuts have been made, the block is severed horizontally by means of wedges.

(6) Revolving Bar with Cutters.-Under this head may be classed the Bower, Lechner, and Legg machines, all of which have been designed for holing coal.

Bower's machine consists of a bar $3 \frac{1}{2}$ feet long, armed with steel teeth, which is made to revolve at the rate of 600 to 800 revolutions a minute by an electric motor. The bar rapidly cuts away a groove as the motor is made to travel along the rails; the groove is 5 inches high in front, and 3 at the back. $\dagger$

In the Lechner and Legg $\ddagger$ machines the cutting bar lies parallel to the line of the face, and not at right angles to it, as in Bower's coal-cutter.

V. Machines for Excavating Complete Tunnels - Hitherto machines of this kind have been little used. Three may be mentioned-viz., the Beaumont, Brunton, and Stanley tunnellers.

The Beaumont machine has received a good deal of notice, owing to its having been employed in the Channel Tunnel. It consists of a very heavy horizontal iron shaft, which is made to revolve by compressed air engines. The shaft carries a cross-head armed with teeth, which cut away the whole face by a series of concentric grooves. The chips are made to fall on to an endless chain with buckets, and are thus conveyed to a waggon behind the machine, so that no interruption of the work takes place for loading. The machine travels forward in a cradle which fits the bottom of the circular tunnel, and when the limit of advance is reached, the machine is lifted up by screw-jacks, and the cradle is once more brought under it, so that a new cut can be begun.

Like the Beaumont machine, Brunton's tunneller $\$$ excavates a circular drift by chipping away the whole face, but in this case the work is done by steel-cutting discs about ro to 20 inches in diameter, and from $\frac{1}{2}$ inch to I inch thick. As yet it has been little used.

* Copied from a pamphlet published by the Société anonyme internationale du fil helicoidal. Brussels, 1888.

† G. B. Walker, "Coal-getting by Machinery," Proc. Fed. Inst. Min. Eng., vol. i. p. 129 .

¥ Eing. Min. Jour., vol. xlvi. (J ane 1888), p. 399.

$\S$ Jour. Soc. Art.s, vol. xxii. (I873-74), p. 404 . 
Stanley's tunneller (Fig. $2 \times 8$ ), on the other hand, is a comparatively new machine already doing good work in driving headings in coal. It consists in the main of a strong central shaft, which carries a cross-head with two projecting arms. At the end of each arm are three steel teeth or cr:tters. The central shaft is made to revolve by a pair of small vertical compressed air-engines, and the teeth cut away an annular groove 3 to $4 \frac{1}{2}$ inches wide. The chijs

FIG. 218.

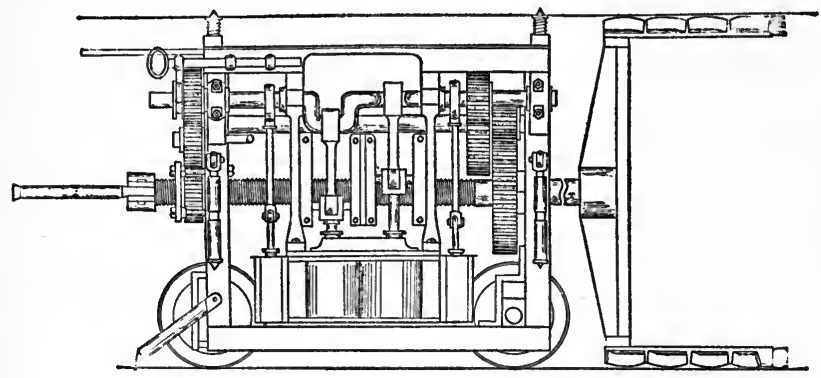

are brought out by scrapers attached to the arms which carry the teeth. The advance of the cutters is caused by the forward movement of the main central shaft ; this is screwed outside, and works in a nut attached to the frame. The rate of advance is therefore determined by the pitch of this screw and the speed with which it is made to turn round.

After boring the annular groove to the depth of a font or so, large lumps of the central core break off, and the machine is stopped to get them out. Work is then resumed till the arms have penetrated to their full length. The machine is stopped, the remaining part of the core is wedged out and cleared away, and now the frame is run forward and fixed for another cut. The rate of progress when working in coal is about I yard per hour, and during a trial of 24 hours the machine cut a tunnel 64 feet 6 inches in length. The diameter of the headings or tunnels is 5 feet. A machine for working in harder rock with a slower cut is being tried.

Stanley has also made a modification of his tunneller in which the whole of the face is cut into little pieces; the chips are carried off by an Archimedean screw and delivered into a waggon at the back.

MODES OF USING HOLES FOR BREAKING GROUND.-After holes have been bored, either by hand or by machinery, a force of some kind has to be applied inside them in order to produce a rending action. The commonest method is to employ an explosive, but the treatment of the subject would not 
be complete without a brief mention of some other processes. Holes inay receive:--
I. Wedges.
2. Water.
3. Wooden plugs.
4. Compressed air cartridges.
5. Hydraulic cartridges.
6. Lime cartridges.
7. Explosives.

I. Wedges.-When a hole has been bored, a compound wedge can be inserted which can do the work of splitting with far greater ease than a single wedge driven into a mere crack in the rock. The combination of three wedges is known as the plug and feathers, a flat wedge, the plug, being inserted between the feathers, which have the outer face curved. The feathers are placed in the hole and the plug is driven down between them with a hammer or sledge.

Varieties of this simple apparatus, in which the wedge or the feathers are moved by hydraulic pressure or by a screw worked

FIG. 219.

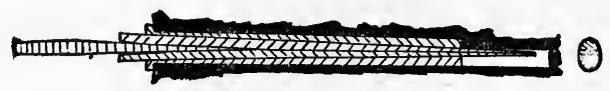

by hand, have been used for getting down coal. Fig. 2 I9 is the Elliott multiple wedge of the Hardy Patent Pick Company.

2. Water.-In cold climates the expansion of water in freezing can be utilised for rending rocks in open quarries. A row of holes is bored in the line along which it is wished to split off a block of stone, the holes are filled with water and well stopped with wooden plugs; when the water is converted into ice, the block splits off.

3. Wooden Plugs.-Dry oaken plugs are driven into holes and then watered. The wood expands and causes a fracture.

4. Compressed Air.-Air compressed to about $400 \mathrm{lb}$. per square inch has been employed experimentally in the place of gunpowder for breaking down coal.

5. Hydraulic Cartridges.-Levet proposes to use a flat metallic tube placed in a borehole, which is rammed up tightly. The flat metallic cartridge is then connected with an hydraulic press, and as soon as this is worked the cartridge expands, and the coal is broken off.

6. Lime Cartridges.-This plan is mentioned with the two last, not because it is employed in mines at the present time, but simply to complete the series of methods of applying a rending force in boreholes.

A small iron pipe is first placed in the borehole, which is $2 \frac{3}{4}$ inches in diameter, and then a cartridge of compressed lime 
with a groove to fit the pipe is inserted. The hole is now tamped up, and water pumped into the pipe, saturating the charge. Great heat is evolved, some of the water is converted into steam, the lime expands, and large blocks of coal are broken off:

7. Explosives.-Thirty years ago gunpowder was practically the only substance used for blasting at mines; but nowadays the number of explosives is great, and an exact classification is necessary before they can be conveniently studied.

With the permission of Colonel Cundill, R.A., I borrow the classification, as well as certain details, from his Dictionary of Explosives.*

I. Gunpowder ordinarily so-called.

2. Nitrate mixtures other than gunpowder.

3. Chlorate mixtures.

4. Nitro-compounds containing nitro-glycerine; this includes the grcat dynamite class.

5. Nitro-compounds, not containing nitro-glycerine (gun-cotton, \&c.)

6. Explosives in which picric acid, or a picrate, is a main constituent.

7. Explosives of the Sprengel type.

8. Miscellaneous explosives.

(I) Gunpowder.-Though gunpowder has lost much of its former importance, owing to the greater strength of many of its younger rivals, it is still largely employed for several reasons, viz., its relative cheapness; its slower action, which renders it more suitable for blasting in certain soft rocks and for producing rents without any violent smashing; and lastly, its freedom from certain dangers which cling to some of the nitro-compounds.

The formula commonly given for gunpowder is : 75 parts of saltpetre, 15 of carbon, and Io of sulphur; but the powder used for blasting in mines usually contains less saltpetre than that which is employed for sporting or military purposes.

The following is an analysis of mining powder by Captain Noble and Sir F. Abel :-

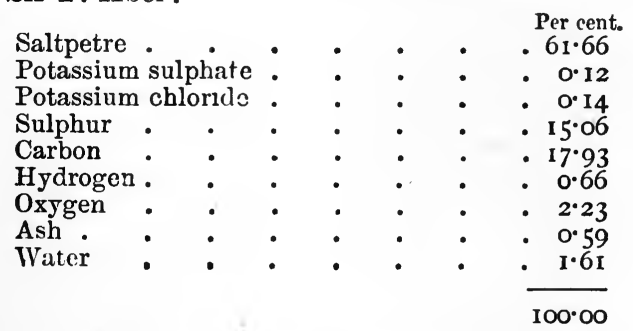

The products of the explosion of gunpowder, according to the same authors, $\uparrow$ are by weight :

* Dictionary of Explosives, London, 1889, p. vii.

+ "On Fired Gunpowder," Phil. Trans. I880, pp. 225, 27 S. 


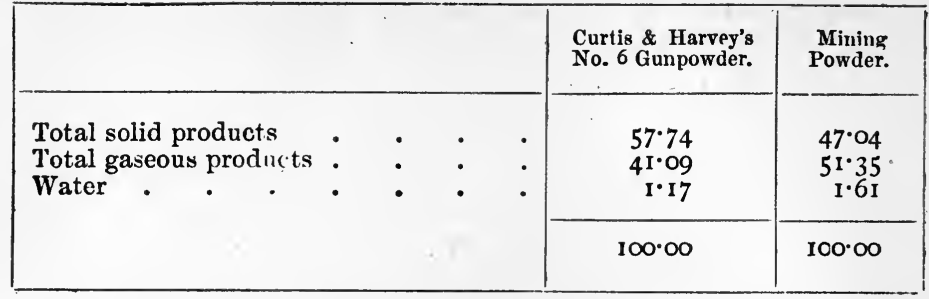

The solid residue of the mining powder consisted mainly of potassium carbouate, potassium monosulphide, and sulphur.

The percentage composition, by volume, of the gas produced was :

\begin{tabular}{|c|c|c|c|}
\hline & & $\begin{array}{l}\text { Curtis \& Harvey's } \\
\text { No. } 6 \text { Gunpowuer. }\end{array}$ & $\begin{array}{l}\text { Mining } \\
\text { Powder. }\end{array}$ \\
\hline $\begin{array}{l}\text { Carbonic anhydride } \\
\text { Carbonic oxide } \\
\text { Nitrogen } \\
\text { Sulphuretted hydrogen } \\
\text { Marsh gas } \\
\text { Hydrogen }\end{array}$ & 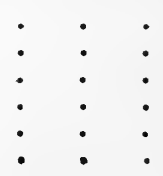 & $\begin{array}{r}50 \cdot 22 \\
7 \cdot 52 \\
34 \cdot 46 \\
2 \cdot 08 \\
2 \cdot 46 \\
3 \cdot 26\end{array}$ & $\begin{array}{r}32 \cdot 15 \\
33 \cdot 75 \\
19 \cdot 03 \\
7 \cdot 10 \\
2 \cdot 73 \\
5 \cdot 24\end{array}$ \\
\hline & & $100 \cdot 00$ & $100 \cdot 00$ \\
\hline
\end{tabular}

The volume (calculated for a temperature of $0^{\circ} \mathrm{C}$. and barometer $760 \mathrm{~mm}$. of mercury) of permanent gases generated by the explosion of I gramme of dry powder is :

Curtis \& Harvey's No. 6 . . . . $241^{\circ} 0$ cubic centimetres.

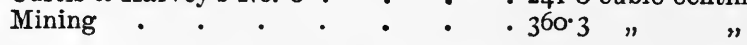

Mining powder is usually coarse-grained and highly-glazed, but the workmen who adhere to the old plan of firing with straws require a little fine-grained powder for filling them. In quarrying and mining slate, a fine-grained gunpowder of very good quality has been found by experience to answer best for rending the rock evenly without smashing it.

Gunpowder is used either loose, or in cartridges made by the men on the spot, or in cartridges supplied to them. Gunpowder compressed into cylinders of diameters suitable for bore-holes, and provided with a central hole for the insertiom of the fuse, has lately been brought forward with some success; but it has the great disadvantage, shared with all hard cartridges, of not fitting the bore-hole so closely as a pulverulent or plastic explosive.

(2) Nitrate Mixtures other than Gunpowder.-As nitrate of soda is very much cheaper than nitrate of potash, inventors have 
naturally tried it as a substitute for the most expensive ingredient of gunpowder. The drawback of such explosives is that they get damp, owing to the deliquescence of the nitrate of soda ; and some of the so-called waterproof cases have been insufficient in the humid climate of Great Britain to keep out the moisture sufficiently.

(3) Chlorate Mixtures.-Chlorate of potash is an unstable salt, very sensitive to friction and percussion, and the explosives made from it are so dangerous that only one, asphaline, has been licensed in Great Britain. It was so light and bulky that it never came into practical use.

Rack-a-rock is chlorate of potash soaked with " dead oil," a dark heavy oil consisting chiefly of hydro-carbons, and derived from coal tar, or with a mixture of equal volumes of dead-oil and bisulphide of carbon, or with dinitro-benzole. The cartridges of compressed chlorate of potash are dipped in the liquid when required for use; the two ingredients, when separate, are not explosive.

More than roo tons of this explosive were used in the great blast for removing the Hell Gate rocks in New York Harbour, besides which large quantities had been consumed in making the underground galleries. The variety employed at Hell Gate consisted of 79 parts of finely-ground chlorate of potash, and 2 I parts of dinitro-benzole.

(4) Nitro-compounds containing Nitro-glycerine.-Miners are deriving immense benefits from explosives of this class which includes dynamite and its congeners.

Nitro-glycerine or glyceryl nitrate is a light yellow oily liquid with a specific gravity of $1 \cdot 6$, which freezes at about $40^{\circ} \mathrm{F}$. $\left(4^{\circ} \mathrm{C}\right.$.), and explodes when heated to $360^{\circ} \mathrm{F}$. ( $180^{\circ} \mathrm{C}$.), or subjected to a shock.

Its chemical composition is expressed by the formula $\mathrm{C}_{3} \mathrm{H}_{5}\left(\mathrm{NO}_{3}\right)_{3}$, and it is prepared by the action of nitric acid upon glycerine. It is extremely sensitive to shocks, and under the action of a fulminating cap it explodes with great violence. It is less sensitive to blows and detonation when frozen than in the liquid state.

The results of its decomposition when perfectly exploded may be represented by the following equation :-

$$
{ }_{2} \mathrm{C}_{3} \mathrm{H}_{5}\left(\mathrm{NO}_{3}\right)_{3}=6 \mathrm{CO}_{2}+{ }_{5} \mathrm{H}_{2} \mathrm{O}+\mathrm{N}_{6}+\mathrm{O} \text {. }
$$

MM. Sarrau \& Vieille* have communicated to the Academy of Sciences the results of their researches concerning the decomposition of certain explosives, among which is nitro-glycerine. The

\footnotetext{
* "Recherches expérimentales sur la décomposition de quelques explosifs en vas clos; composition des gaz formés: "Cumptes Rendus, I830, pp. 10ز3 and III 12 .
} 
following table shows, in litres, the volume (at $0^{\circ} \mathrm{C}$. and $760 \mathrm{~mm}$. of mercury) of each of the gases per kilogramme of the substance exploded in a closed vessel.

\begin{tabular}{|c|c|c|c|c|c|c|c|c|}
\hline Kind of Explosive. & co & $\mathrm{CO}_{2}$ & II & $\mathbf{N}$ & 0 & $\mathrm{C}_{2} \mathrm{II}_{4}$ & $\mathrm{H}_{2} \mathrm{~S}$ & Total \\
\hline $\begin{array}{l}\text { Pure gun-cotton } \\
\text { Gun-cotton and nitrate } \\
\text { of potash (50 per cent. } \\
\text { each). } \\
\text { Gun-cotton (40 per cent.) } \\
\text { and nitrate of am- } \\
\text { monia (6o per cent.). } \\
\text { Nitro-glycerine } \\
\text { Ordinary blasting pow- } \\
\text { der. }\end{array}$ & $\frac{-}{64}$ & $\begin{array}{l}234 \\
171 \\
184 \\
295 \\
150\end{array}$ & $\begin{array}{r}166 \\
-\end{array}$ & $\begin{array}{r}109 \\
211 \\
147 \\
65\end{array}$ & $\begin{array}{r}6 \\
25 \\
-\end{array}$ & - & $\overline{-}$ & $\begin{array}{l}741 \\
325 \\
401 \\
467 \\
304\end{array}$ \\
\hline
\end{tabular}

If, however, the explosive is decomposed, at a pressure approaching that of the atmosphere, by burning or imperfect detonation, the volumes (again at $0^{\circ} \mathrm{C}$. and $760 \mathrm{~mm}$. of mercury) are very different, as shown below:-

\begin{tabular}{|c|c|c|c|c|c|c|c|}
\hline Kind of Explosive. & $\mathrm{NO}_{2}$ & co & $\mathrm{CO}_{2}$ & $\mathbf{H}$ & $\mathrm{N}$ & $\mathrm{C}_{2} \mathrm{H}_{4}$ & Total \\
\hline Pure gun-cotton & 139 & 237 & 104 & 45 & 33 & 7 & 565 \\
\hline $\begin{array}{r}\text { Gun-cotton and nitrate of } \\
\text { potash (5o per cent. of each) } \\
\text { Gun-cotton (40 per cent.) and } \\
\text { nitrate of ammonia ( } 60 \text { per }\end{array}$ & 71 & 58 & 57 & 3 & 7 & - & 196 \\
\hline cent ). & 122 & 65 & 103 & 12 & 112 & - & 414 \\
\hline Nitro-glycerine & 218 & 162 & $5^{8}$ & 7 & 6 & $\mathbf{I}$ & 452 \\
\hline
\end{tabular}

When these explosives are decomposed in this way, they liberate nitric oxide and carbonic oxide, and the analyses of MM. Sarrau \& Vieille confirm the practical experience of miners, who complain greatly of noxious fumes, when, owing perhaps to a bad detonator, a charge of dynamite or tonite fails to explode properly.

Nitro-glycerine was at first used alone, and was fired by a small cartridge of gunpowder inserted into a strong paper case containing the liquid ; this method soon gave way to the fulminating cap. Numerous accidents happened from the extreme sensitiveness of the blasting oil to percussion, and these led to its being given up in most countries. Nobel, who had introduced nitroglycerine, then invented a method of using the explosive with comparative safety, by causing it to be absorbed by some porous inexplosive substance. This was the original dynamite, but now 
various mixtures of nitro-glycerine and other substances are made, and we may place them all in the great dynamite class.

The dynamites may conveniently be arranged in two groups :

1. Dynamites with an inert base acting merely as an absorbent for the liquid nitro-glycerine. Example: Ordinary dynamite.

2. Dynamites with an active, that is to say, an explosive or combustible base. 'This explosive or combustible base may be charcoal, gunpowder or other nitrate or chlorate mixtures, gun-cotton or other active componnds. Examples :-Blasting gelatine, Gelatine dynamite, Gelignite, Hercules powder, Lithofracteur.

Dynamite was made originally by mixing 75 parts by weight of thoroughly purified nitro-glycerine with 25 parts by weight of infusorial earth, known as Kieselguhr, sufticiently absorbent in quality when mixed in the above proportions to prevent exudation of the blasting oil.

The British license for making dynamite now allows the addition of a little carbonate of amnonium and the substitution of carbonate of sodium, sulphate of barium, mica, talc, nitre, for a portion of the Kieselguhr.

At ordinary temperatures dynamite is a plastic mass, generally somewhat reddish in colour, owing to a little ferruginous matter in the infusorial earth. It freezes at about $40^{\circ} \mathrm{F} .\left(4^{\circ} \mathrm{C}\right)$, and when once frozen remains hard at higher temperatures than $40^{\circ} \mathrm{F}$.

In the frozen state it is less sensitive to blows and detonation than when plastic, but it is more susceptible to explosion when set on fire. At some seasons in certain climates it has to be thawed before being used. The natural warmth of some mines is sufficient to soften it in the short interval between the time it is taken below ground and the time it is required for use; but it is often necessary to resort to artificial thawing. A special pan is supplied by the makers for this purpose. It consists of an outer can filled with hot water, which encloses a receptacle for the explosive. The outer can is surrounded by a bag of painted canvas filled with a bad conductor of heat, so that the water retains its warmth for a long time. The warming-pan cannot be put on to a fire without the outer covering being burnt; if proper cans are supplied, the men are less likely to try the dangerous experiments of warming dynamite in an old meat-tin over a candle, or upon a shovel at the smith's forge, methods of thawing that are not unknown.

The trouble of thawing, and the possibility of the operation being performed in a dangerous manner by the miners, are decided disadvantages to dynamite; and these are not the only ones. Its behaviour with water is a source of danger. If left in contact with water, as happens sometimes when a hole misses fire, it disintegrates; the heavy oily nitro-glycerine separates, and finding its way into cracks is liable to explode with violence from the mere 
concussion, when the rock is struck with the pick, borer, or sledge. A fourth drawback lies in the fact that the whole of the charge does not always go off ; portions may remain intact and then explode unexpectedly from a blow, when work is resumed after blasting. On the other hand, the plasticity of dynamite and some other nitro-glycerine explosives is a decided benefit, because the charge can be pressed down so as to fit a hole which is not perfectly cylindrical, or a cartridge can be squeezed flat and inserted into a crack without boring any hole at all. Of course, the main advantage of dynamite and its congeners over gunpowder is their enor mous strength.

Atlas Powder.-This is a lignine dynamite, consisting of woorpulp or sawdust, nitrate of sodium and nitro-glycerine. It is manufactured in the United States.

Blasting Gelatine.-This powerful and favourite explosive is made by mixing nitro-cotton (nitro-cellulose carefully washed and purified) with nitro-glycerine heated to about $100^{\circ} \mathrm{F}\left(38^{\circ} \mathrm{C}.\right)$ until enough nitro-cotton has been disselved to convert the nitroglycerine into a jelly-like mass. The blasting gelatine in ordinary use contains 93 to 95 per cent. of nitro-glycerine, the remainder being nitro-cotton. In the plastic state it is less sensitive to a shock or blow than dynamite, but when frozen the reverse is the case. One great advantage which it possesses over ordinary dynamite is that it is practically unaffected by water. That it must be stronger than ordinary dynamite is evident at first sight, because an active explosive is substituted for a wholly inert substance. 'But there is the additional reason that the two explosives mutually assist each other. The explosion of nitro-glycerine, as we have seen, liberates free oxygen; that of nitro-cotton liberates carbonic oxide. In other words, the former explosive has more oxygen than is necessary for complete combustion, the latter less. The excess of oxygen of the nitro-glycerine makes up for the want of it in the nitro-cotton.

Gelatine dynamite is a mixture of 80 per cent. of blasting gelatine with nitrate of potassium and wood meal.

Gelignite is a similar mixture containing only 60 per cent. of blasting gelatine.

Giant pouder is a term used in America for dynamite. The Giant powder used in California consists of nitro-glycerine, nitrate of sodium and wood-pulp or sawdust. Like Atlas powder it is therefore a lignine dynamite. Several varieties are made containing from 20 to 80 per cent. of nitro-glycerine.

In Hercules powder, also an American explosive, the nitro glycerine is mixed with wood-pulp, carbonate of magnesium, and nitrate of sodium, or with carbonate of magnesium, chlorate of potassium, nitrate of potassium and white sugar.

Lithofracteur is no longer seen in England, though regularly used in the Australian Colonies. 
It may be looked upon as ordinary dynamite mixed with a crude sort of gunpowder.

One analysis gave-

\begin{tabular}{|c|c|c|}
\hline Vitro-glycerine & & \\
\hline Kieselguhr & & \\
\hline Powdered coal . & & \\
\hline itrate of soda & & \\
\hline Sulphur • & . & . \\
\hline
\end{tabular}

Other varieties of the explosive contain such ingredients as charcoal, bran, sawdust, nitrate of barium, bicarbonate of sodium.

(5) Nitro-compounds not containing Nitro-glycerine.The explosives of this class now in practical use are made from the nitro-compounds:-Nitro-cellulose, Nitro-benzole, or Nitronaphthalene.

Nitro-cellulose or gun-cotton is prepared by the action of a mixture of nitric and sulphuric acids upon cotton. A mixture of certain definite proportions and strength is used in order to secure the special product required as a blasting agent. It lacks the plasticity of dynamite and blasting gelatine, but it can claim the advantage of never requiring to be thawed. It is made up into cylindrical cartridges to suit bore-holes of various diameters, with a central hole for the insertion of the fulminating cap or detonator. Per se, gun-cotton is not largely used in mining. When gun-cotton explodes properly its decomposition may be represented by the following equation :-

$$
2\left(\mathrm{C}_{6} \mathrm{H}_{7} \mathrm{O}_{2}, 3 \mathrm{NO}_{3}\right)=9 \mathrm{CO}+3 \mathrm{CO}_{3}+7 \mathrm{H}_{2} \mathrm{O}+\mathrm{N}_{6} \text {. }
$$

One of the products of the explosion is the poisonous carbonic oxide. This disadvantage can be counteracted by the addition of a nitrate, and tonite is an explosive produced in this manner. It is a mixture of gun-cotton and nitrate of barium, sold in cylindrical cartridges coated with paraffin to keep out the moisture. By some miners it is preferred to dynamite for reasons of safety. It does not freeze, and there is no danger of exudation of an explosive oil, when a charge which has missed fire has to be left in a wet hole.

Ammonite is a mixture of nitrate of ammonium with mononitro-naphthalene. Bellite is a mixture of nitrate of ammonium with di- or tri-nitro-benzole. Roburite is essentially a mixture of nitrate of ammonium with chlorinated di-nitro-benzole. It is a yellowish-brown powder, and is sold in cartridges. Sometimes there is also some chloro-nitro-naphthalene as an ingredient. It is largely used in coal mining. Securite is an explosive of similar composition.

(6) Picric Acid and Picrates.-No explosives of this class are in use in mines or quarries.

(7) Explosives of the Sprengel Type.-Dr. Sprengel pre- 
pares explosives on the spot immediately before use, from substances which by themselves are not explosive. He mixes a combustible body with a highly oxidised body in such proportions that the supply of oxygen shall produce complete combustion, and he fires the mixture with a detonating cap.

Thus, for instance, nitro-benzole compounds are mixed with nitrates of ammonium, potassium, or sodium. These could be placed in Class 5. Rack-a-rock, mentioned in Class 3, is an explosive of the Sprengel type.

Dr. Sprengel's method cannot be employed in this country, because it is not legal to manufacture explosives, even by mere admixture of the ingredients, except in duly licensed factories.

(8) Miscellaneous Explosives.-Fulminate of mercury, used in making detonators, is the only explosive of this class which requires any mention. Detonators are small copper cylinders, closed at one end, containing a small quantity of fulminate of mercury. They are made of various sizes to suit different explosives.

Strength.-The strength of explosives may be compared by firing them in holes bored in leaden cylinders, and then

FIG. 220.

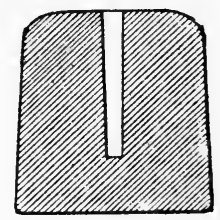

FIG. 223.

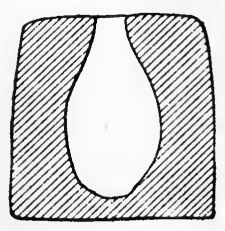

FIG. 221.

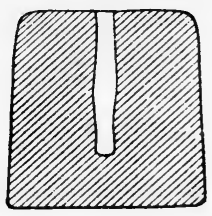

FIG. 224.

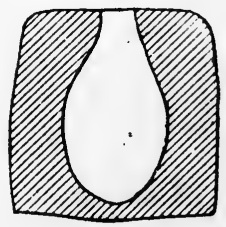

FIG. 222.

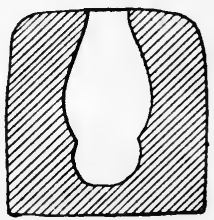

FIG. 225.
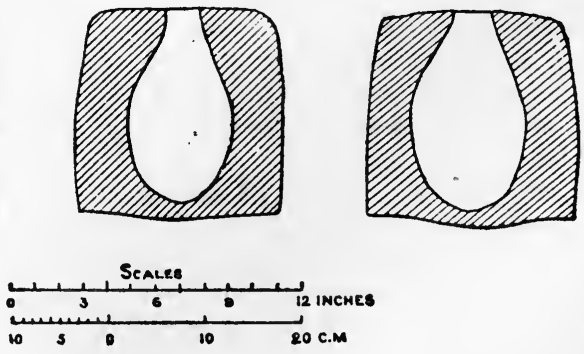

measuring the size of the cavity produced in each case. Fig. 220 shows a hole 6 inches deep bored in a strong block of lead. The firing of 20 grammes ( $11 \frac{1}{4}$ drachms) of gunpowder in such a hole enlarged it but slightly (Fig. 22 I), whilst the dilatation caused in similar holes by firing like charges of dynamite 
(Fix. 222), gelignite (Fig. 223), gelatine dynamite (Fig. 224), and blasting gelatine (Fig. 225) illustrates the enormously greater power of these nitro-glycerine explosives.

Charging and Firing.-The commonest method of firing a charge is by means of the safety fuse, a cord $\frac{3}{16}$ to $\frac{1}{4}$ inch in diameter, containing a core of gunpowder introduced during the process of manufacture. Upwards of forty or fifty varieties are made to suit the requirements of the miver and the quarryman. The cord is somewhat guarded against damp by tar, and, if more protection is needed, the covering is increased in thickness, and a layer of varnish is interposed. For wet ground the outer part of the fuse is formed by one or two spiral coils of tape or by gutta-percha. For blasting under water, the coat of guttapercha is often strengthened against injury by tape, or is doubled or trebled. If still more care is necessary in order to secure an absolutely impervious envelope, the fuse is made of lead tube, either bare or protected in various ways. Special fuses are supplied for export to warm countries. Fuse is usually sold in coils 24 feet in length, but it can be obtained in longer coils for special purposes. One or several white or coloured threads run down the centre of the core of powder, and serve as trade-marks by which the goods of different manufacturers can be recognised. They are sometimes impregnated with nitrate of potassium, with the view of carrying the fire along in case there should accidentally be a slight interruption in the continuity of the core. Safety-fuse burns at the rate of about two or three feet per minute, so it is easy for the miner to secure ample time for retreat by taking a sufficient length. Sometimes a fuse hangs fire, and many are the accidents that have been caused by returning too speedily to a hole on the supposition that the fuse had failed altogether. "Hang-fires" may be due to damp, imperfection in manufacture, or injuries before or after the fuse was put in the hole. Colonel Majendie has shown that oil exercises a very retarding effect upon the rate of burning of safety-fuse.

In blasting with gunpowder in the ordinary way, the charge is put in either loose or enclosed in a paper bag, and it is pressed down to the bottom of the hole with a wooden stick, whilst a piece of fuse also is inserted, extending from the charge well beyond the hole. If the powder is loose, the miner carefully wipes down the sides of the hole with a wet swab-stick, or with a wisp of hay twisted round the scraper, in order to remove any loose grains adhering to the fuse or the sides of the hole, and then presses in a wad of dry hay, moss, or paper. A little fine tamping, often the dust from boring a dry hole, is now thrown in and rammed down with the wooden charging-stick, and the same process is repeated until an inch or two of tamping has been introduced. The metal tamping-bar is now brought into operation, and the hole completely tilled. If the hole is pointing 
upwards, the stuff for tamping has to be done up in little paper cartridges, which are pushed up and then tightly rammed.

The hole is now ready for firing. As a rule the safety-fuse is not ignited directly. In open quarries a piece of touch-paper is attached to the end of the fuse, so that in burning it will eventually light the gunpowder. In mines a candle-end (snuff) is fixed under the fuse by a piece of clay; it is lighted to see that everything is all right and that it will burn properly, and then blown out. The miner puts his tools out of the way of danger, and after shouting "Fire" several times, sets light to the candle and beats a retreat to some place where there is no fear of being struck by the blast, and whence he can warn persons who might otherwise walk into danger unawares. The candle burns through the covering of the fuse, the fire reaches the core, and is soon conveyed to the charge, which explodes and does the necessary work.

The old plan of firing, which is still in use in many places, consists in inserting the needle into the charge and then tamping up the hole. Care is taken to draw out the needle a little as the tamping proceeds, so as to prevent too much force being required for its final withdrawal. The small hole left in this way serves for the insertion of a straw, rush, or series of small quills filled

F1G. 226.

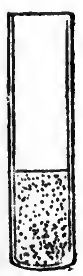

FIG. 227.

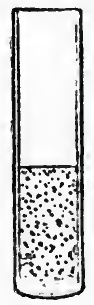

FIG. 228.

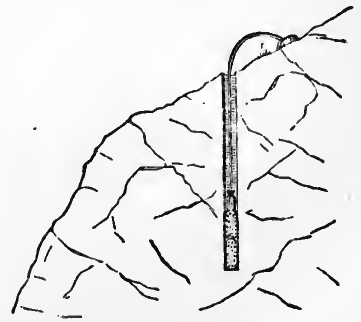

with fine powder, which, like the fuse, reaches from the outside to the charge. A short squib, which shoots a stream of sparks down the needle-hole, is also used occasionally. The straw or squib is lighted by some kind of slow match, made either by dipping a cotton strand in melted sulphur, or soaking a piece of paper or a wooden lucifer in the tallow of a candle; touch-paper is also used for the purpose.

Nitro-glycerine and nitro-cotton explosives are fired by the detonation of a strong cap, which is a small copper cylinder closed at one end, partly filled with a mixture of fulminate of mercury and chlorate of potassium. The amount of the fulminate required depends upon the explosive, and the makers supply detonators of different degrees of strength. 
The treble-strength detonators of the Nobel Company, supplied for firing dynamite (Fig. 226), contain 0.54 gramme of the mixture; whilst the quintuple detonators, for blasting gelatine (Fig. 227), have 0.8 gramme, and the sextuple detonators I gramme.

As full instructions for use are issued with every packet of the nitro-glycerine explosives, it is not necessary to repeat them here.

Fig. 28 shows a hole charged with two cartridges of blasting gelatine, a primer (i.e., a small cartridge) and cap, and afterwards filled up with water as tamping. The fuse is turned back and fixed by a lump of clay, and the little candle-end is placed in position for lighting.

Pfeiffer and Wiehenkel* propose to make blasting with high explosives safer and more efficient by interposing a column of water between the charge and the primer. The concussion produced by firing a primer at the mouth of the hole is communicated by the water to the charge, and is said to be sufficient to cause it to explode. Of course the explosive used should be one not liable to set free nitro-glycerine when in contact with water, as happens with dynamite.

In a few mines where the straw still lingers in place of the fuse, the detonator is squeezed on, and then gently inserted into the hole left by the withdrawal of the needle.

The workman employed in getting slate frequently desires to produce a rent without smashing the rock. He fills the hole,
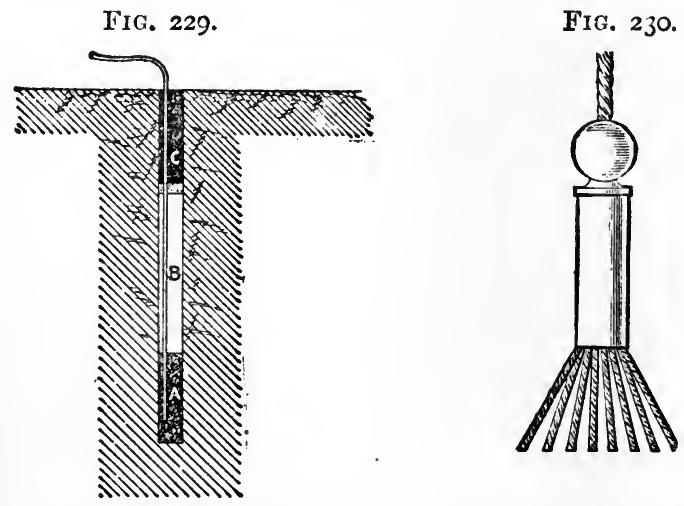

possibly 10 or 12 feet deep, almost up to the top, with a smallgrained gunpowder, and after ramming in a wad of dry moss and an inch of tamping, sets light to the fuse in the usual way. Provided his calculations are correct, the block is severed off cleanly, and not broken up.

\footnotetext{
* German Patent Specification, No. 67,793, 1893.
} 
In quarrying sandstone, Knox* has found it advantageous to leave an air-chamber above the charge of gunpowder in the rifting holes (Fig. 229). A is the powder, $B$ the air-space, and $\mathbf{C}$ the tamping resting upon a wad of hay, grass, oakum, or paper.

For the purpose of firing several holes simultaneously, Messrs. Bickford, Smith \& Co., the original inventors of the safety-fuse, have brought out a special arrangement, the action of which is rendered plain by the Fig. 230. An ordinary fuse is fixed into a metal case called the igniter, from which a number of instantaneous fuses convey fire to as many separate holes. It is found in practice that this fuse answers very well.

In mines where the atmosphere may be inflammable from the presence of fire-damp, the burning fuse may become a source of danger, and a special igniter has been devised by Messrs. Bickford, Smith \& Co., to prevent accidents arising from this cause. With the same object in view, frictional exploders have been introduced, which ignite the charge when a string is pulled; but these belong more especially to the domain of coal-mining.

Charges may be readily fired singly or simultaneously with the aid of electricity, either of high or low tension. Low-tension fuses have the advantage that they can be tested with a weak current and a galvanometer before use. If the galvanometer is not deflected, it is evident that the fuse is defective.

Fig. 23I shows a section of one of Brain's high-tension fuses. A is a cylindrical woodt $\mathbf{n}$ case containing a paper cartridge, $\mathrm{B}$, with

FIG. 23I.

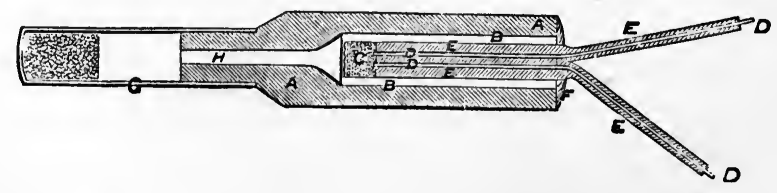

an electric igniting composition, $\mathrm{C}$, at the bottom. Two copper wires, D D, enclosed in gutta-percha, $\mathbf{E} \mathbf{E}$, reach down to the composition, where they are about $\frac{1}{50}$ inch apart. A copper cap or detonator, G, is fixed on the small end of the wooden case. The insulated wires, D D, are long enough to reach beyond the bore-hole. The ends of the wires are scraped bare, and one wire of the first hole is twisted together with one wire of the next hole, and so on, and finally the two odd wires of the first and last hole are connected to the two wires of a single cable, or to two separate cables extending to some place of safety to which the men can retreat. Here the two cable ends are connected by binding screws to a frictional electrical machine or a dynamo exploder.

The electricity passes through the wires, making a spark at

* See p. 162. 
each break, and so firing the electr ic igniting composition. The flame flashes through the hole, $\mathbf{H}$, and ignites the fulminating mercury, the detonation of which causes the explosion of the dynamite, blasting gelatine, or tonite surrounding the cap.

The fuses supplied by Nobel's Explosives Company are somewhat different. Their high-tension fuse (Fig 232) consists of a copper cap, A, into which has been pressed a mixture of fulminate of mercury and chlorate of potash, $B$; D D are two insulated wires, the terminals of which are embedded in Abel's flashing composition, $\mathrm{F} ; \mathrm{C}$ is waterproof cement, which serves to hold the wires in position and to close the detonator. The detonator and a few inches of the wire are dipped in shellac varnish, so as to make certain that no water can penetrate during use. The current of electricity produces a spark between the terminals, ignites the flashing composition, and fires the fulminate.

The low-tension fuse (Fig 233) differs in having a thin bridge of platinum wire, E, soldered across the terminals. This bridge is embedded in a composition, $\mathrm{F}$, consisting of gunpowder and gun-cotton.

FIGS. 232 \& 233.
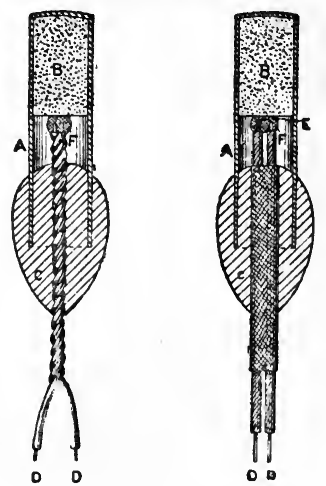

When the current of electricity passes through the bridge, it heats the wires to redness, igniting the composition and firing the fulminate as before.

Electric firing has the great advantage of enabling the miner to retire to a perfectly safe place before attempting to explode the charge. This is important in sinking shafts, where the means of escape are less easy than in levels. A second advantage is the absence of danger from a "hang-fire," an occasional source of accident with the ordinary safety-fuse. On the other hand, in the case of simultaneous blasting, it is impossible to be sure whether all the holes have gone off properly, and electrical firing was given up in driving a level in Saxony,* because unexploded dynamite cartridges were so frequently found among the rubbish after blasting.

DRIVING AND SINKING.-We now come to the application of the hand and machine tools in driving levels and sinking shafts.

A level or drift is a more or less horizontal passage or tunnel, whilst a shaft is a vertical or inclined pit.

In driving a level by hand labour in hard ground, the first

* Dannenberg, Jahrb. $f$. d. Berg- unt Hüttenwesen im K. Sachsen auf das Jahr 1890 , p. 37. 
thing the miner has to do is to " take out a cut," i.e., blast out a preliminary opening in the "end" or "forebreast." The position of this first hole is determined by the joints, or natural planes of division, which the miner studies carefully so as to obtain the greatest advantage from them.

Thus Fig 234 shows a case in which, owing to joints, it was advisable to begin with hole No. I, and then bore and blast 2, 3, and 4, one after the other. The miner, as a rule, does not plan the position of any hole until the previous one has done its work; in fact, he regulates the position and depth of each hole according to the particular circumstances of the case.

In many of the drivages at the Festiniog slate mines there is a well-marked inclined plane of separation, known as the "clay slant," along which the level is carried. The first holes are directed towards this "slant," and most of them are bored upwards; in this manner. wedge-shaped pieces of slate are easily blasted out, and subsequent holes are bored so as to increase the

FIG. 234.

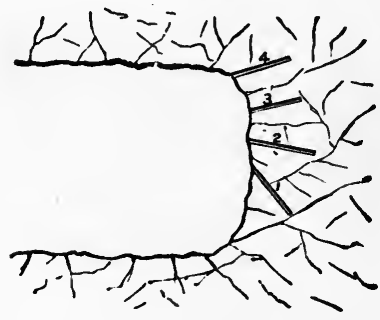

FIG. 235 .

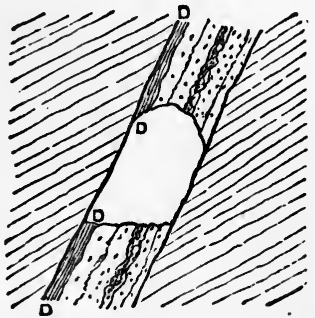

size of this opening until the whole face of the "end" has been taken away.

Though a vein and its walls may be hard, there is occasionally a soft layer of clay (D D, D D, Fig. 235) along one wall (dig, Cornwall; gouge, U.S.). The miner works this away with the pick, and, after having excavated the groove as deep as possible, blasts down the lode by side-holes, and so pushes the level forward.

At St. Just, in Cornwall, a narrow groove is worked out by a flat chisel called a peeker.

In sinking a shaft a similar method of proceeding is adopted. A little pit (sink) is blasted out in the most convenient part, and the excavation is widened to the full size by a succession of blasts, each hole being planned according to circumstances This series of operations is repeated, and the shaft is gradually deepened.

Where boring machinery is employed, less attention and sometimes no attention is paid to natural joints, because, when once 
the drill is in its place, it is very little trouble to bore a few more holes, and the work can be carried on according to a system which is certain of effecting the desired result.

A common mode of driving in hard ground is shown in Figs. 236 and 237. Four centre holes are bored about a foot

FIG. 236.

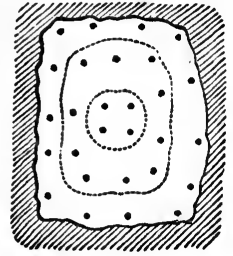

FIG. 237.

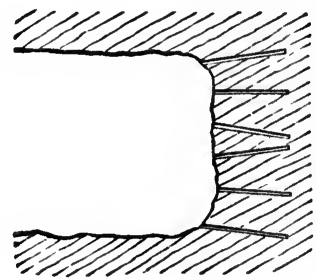

apart at first, but converging till at a depth of 3 feet they are within 6 inches or less of each other.

Other holes are then bored around them until the end is pierced by twenty or thirty holes in all. The four centre holes are charged and fired simultaneously, either by electricity or by Bickford's instantaneous fuse, and the result is the removal of a large core of rock. The holes round this preliminary opening are then charged and fired, generally in volleys of several holes at a time, and the level is thus carried forward a distance of 3 feet. If large holes are bored, and if the ground is more favourable, fewer will be required.

The Halkyn Drainage Tunnel (Flintshire) is being driven ( 7 feet high by 7 feet wide) in limestone by fourteen holes for each advance; they are started with a $3 \frac{1}{4}$-inch bit, and finished with a $2 \frac{1}{4}$-inch bit. The holes are placed as shown (Fig. 238), and are bored to a depth of about 3 feet 9 inches each. They are charged with dynamite, 25 lbs. being

FIG. 238.

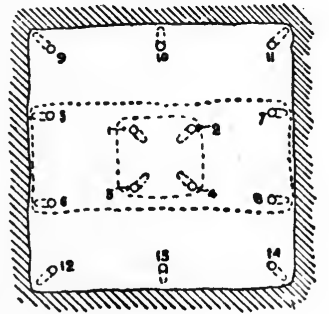
used for the fourteen holes, and then blasted in four volleys :-

Ist volley:-Nos. I, 2, 3, and 4 together, which take out the central core.

2nd volley:-The side holes, 5, 6, 7, 8, are fired.

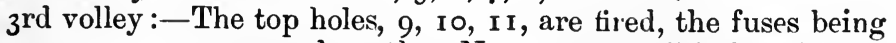
arranged so that No. Io goes off before Nos. 9 and I I.

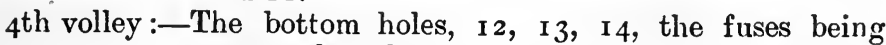
arranged so that No. 13 goes off before Nos. I 2 and 14 . 
Roughly speaking, it takes five hours to bore the fourteen holes, and five hours more to charge and blast them, and clear away the rubbish.

Some engineers direct the four centre holes so that they meet at the apex of an acute pyramid, and, after all have been charged with dynamite, only one receives a primer and cap, because the shock of the explosion of this charge is sufficient to fire the other three adjacent charges simultaneously.

The preliminary opening is not necessarily made in the centre of a level. Sometimes it is blasted out in the bottom or on one side where there are natural joints to favour one of these methods; but when the rock is uniform it is best made in the centre, for there the blasts can have the freest play.

At Bex, in Switzerland, where water power is abundant, a considerable saving in cost has been effected by cutting a preliminary groove in the centre line of the level by a bosseyeuse.

Seven holes, each $3 \frac{1}{2}$ inches $(8 \mathrm{~cm}$.) in diameter, are bored 2 inches ( $5 \mathrm{~cm}$.) apart in a straight line,

FIG. 239.

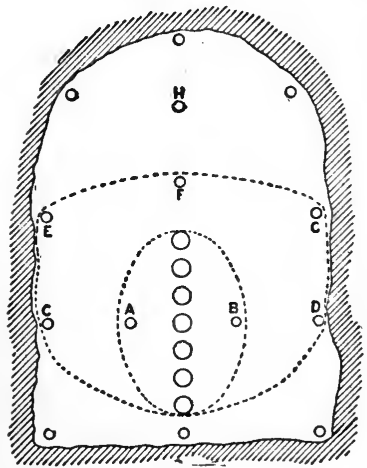
and the borer is then replaced by a tool which breaks down the partitions. A groove 2 feet ro inches $(86 \mathrm{~cm}$.) long and $3 \frac{1}{6}$ inch $(8 \mathrm{~cm}$.) wide is thus formed, and after the bosseyeuse has been removed, holes $1 \cdot 2$ inches $(3 \mathrm{~cm}$.) in diameter are bored around by a Ferroux drill as shown in the diagram, Fig. 239.

The holes A, B, C, D, E, F, G, are blasted at one time, but the fuses of $\mathbf{A}$ and $\mathbf{B}$ are cut shorter than the others, so that they go off first. The result of this volley is the production of a large opening, and then the firing of hole $\mathrm{H}$, and subsequently of the outside holes, completes the level for a length of 4 feet $(1 \cdot 20 \mathrm{~m}) .$.

In driving with the Ferroux drill in the ordinary way, blasting out a central core, with dynamite, the cost per metre of level driven was . . Fr. 7340

By using the bosseyeuse to make a central groove, and then the Ferroux drill for the remaining holes, the cost per metre was only . . . Fr. 3940

Saving effected by the use of the bosseyeuse . Fr. $34 \quad 00$

The saving therefore is as much as 46 per cent. ; but in this caso the extra water power required is costing nothing.

* Rosset. Notice sur les salines de Bex, Bex, r888, p. 2 1. 
In sinking shafts by boring machines, operations are conducted much in the same way as in levels, save of course that the holes are directed downwards.

Figs. 240 and $24 \mathrm{I}$ are a plan and a section of a shaft which was sunk at the Foxdale mines in the Isle of Man. About forty-five holes were bored in the bottom of the shaft, before the drills were removed. Two of the holes (A and B), and occasionally four, were

FIG. 240 .

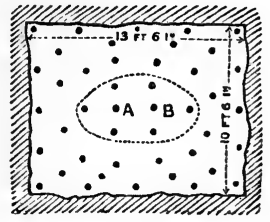

FIG. 241.

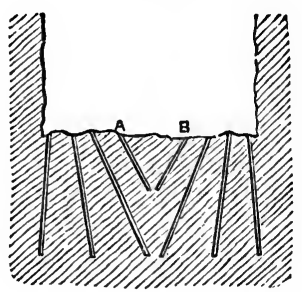

bored only 4 feet deep, and were blasted with ordinary fuse. They served simply to smash up and weaken the core; then the six holes nearest the centre, which were 8 feet deep, were blasted all together with Bickford's instantaneous fuse, and the result was the removal of a large core, leaving a deep sink. The remaining holes were fired in volleys of four at a time in the ordinary way. In this manner the shaft, which was in hard granite, was deepened at the rate of $3 \frac{1}{2}$ or 4 fathoms a month. Tonite was the explosive used.

FIRE-SETTIN G. - Though hard ground is almost invariably nowadays attacked by boring and blasting, the very ancient process of fire-setting is not quite obsolete. The effect of a fire is to make a rock split and crack, and render it easily removable by the pick or by wedges.

In $1876 \mathrm{I}$ saw a level in course of being driven in the Kongsberg silver mine, Norway, through crystalline schists, by this method. A fire of logs of fir was made in the end, and the smoke was conducted away to one of the shafts by an oval sheet-iron pipe, 2 feet by 1 foot.

It took eight cords of wood to drive I fathom of level, and the rate of advance was 9 fathoms in 7 months. The fire was usually made up twice in every 24 hours. In another part of the mine an adit level was being driven at the rate of 2 fathoms a month, with a consumption of 15 to 18 cords of wood. In this case an arch was built in the roof of the level to form a passage for the smoke, and the iron pipe was used near the end.

In driving in hard rock in the gold mines of Korea,* a pile of

*W. J. Pierce, "Gold Mining and Milling in Korea," Trans. A'n. Ins". M. E., vol. xviii., 1890, p. 363 . 
wood is set on fire near the face of the tunnel, and allowed to burn for 24 hours. The place is then allowed to cool for three or four days, when the miners return and break down the loosened rock with hammer and gad. Fire-setting is also employed in mining jade in Burmah,* and in quarrying stone in India. $\dagger$ Lastly, the Siberian prospector avails himself of the softening action of fire for sinking small trial shafts through ice and frozen ground in search of auriferous gravel.

EXCAVATING BY WATER.-We turn naturally from fire, one of the four elements of the ancients, to another, water, as a means of breaking ground.

Water can be applied either for dissolving the rock or mineral, or for loosening it and then carrying it away.

There are two (ases in which water may act as a solvent-viz., common salt and copper. It is used, as we shall see in speaking of the methods of working, to dissolve out salt from saliferous rocks, and it can also be employed for excavating upwards or downwards in rock-salt. For excavating upwards ("putting up a rise"), a jet of water is made to play upon the roof of a level, and means are taken to carry off the brine in troughs (launders) without dissolving away the floor. For sinking from one level to another, a bore-hole is first put down, and this is gradually widened by the solvent action of water.

When old workings containing the sulphides of copper are left exposed to the action of air and the percolation of rain water, part of the copper becomes converted into a soluble sulphate, and water pumped up from the mine may become a profitable source of the metal. This is the case at Parys mine in Anglesey.

There are also two cases in which water is made to act as a loosener and conveyer-viz., for working clay and gold.

A stream of water is turned on to the deposits of china clay, and, aided by work with a pick, it carries everything to settling pits. The most important application of water is the process of washing away thick beds of auriferous gravel, known as hydraulic mining. A huge jet of water under pressure is made to play against the bank of gravel, undermine it, cause it to fall, and so thoroughly disintegrate it that everything save the largest boulders is carried away in the stream. Full details of these processes will be given in Chapter VI. (Exploitation).

* Eng. Min. Journ., vol. xlviii., 1889, p. 359.

† Ibid., p. 547 . 


\section{CHAPTER V.}

\section{SUPPORTING EXCAVATIONS.}

Various kinds of timber used for supports.-Preservation of timber from dry rot.-Tools.-Timbering levels, shafts, and working places.Masonry, brickwork and concrete for levels and shafts.-Iron and steel supports for levels, shafts, and working places.-Special processes for sinking through watery strata : boring, compressed air and freezing methods.

Excavations made in hard ground will frequently stand without any props whatever for an unlimited time, but the miner has generally to deal with rocks which sooner or later give way unless supported. Consequently it becomes necessary to adopt means of securing the underground passages and working places, either during the process of excavation, or at all events very soon afterwards.

The methods of securing mining excavations may be classified according to the materials used for the protective lining, viz., timber, masonry, iron, or steel.

TIMBER.-In Europe, varieties of the following kinds of trees are those most frequently employed underground: Oak, larch, pine, fir', and acacia.

The oak is especially adapted for mining purposes on account of its strength and its durability. It will resist alternate exposure to wet and dryness, and under water it is almost imperishable. In England we have two principal varieties, Quercus robur pedunculata and Quercus robur sessiliflora.

The conifers, larch, pine, and fir, have the advantage of furnishing straight timber, of even grain, comparatively light, easily worked, having few branches, and less expensive than oak.

The larch (Abies larix or Larix Europaca, D. C.) is an excellent mining timber. The large amount of resin it contains seems to act as a preventive against decay. It is tough and strong, and lasts a long time, even when alternately wet and dry.

The American pitch pine (Pinus rigida) is a timber largely imported into this country for mining purposes, and it is used not only for securing shafts and levels, but also for pump-rods, bridges, sides of ladders, \&c. It is remarkable for its perfeetly straight growth; it is hard, highly resinous, and very durable. 
The Scotch fir (Pinus sylvestris) is a tree that furnishes a great deal of mining timber. The British-grown timber is largely used for props, whilst balks imported from Norway and Sweden serve for heavy work in many mining districts.

The spruce fir (Abies excelsa) is not a timber to be recommended for mine supports where durability is required.

The acacia has the property of resisting the effects of bad air and high temperatures very much better even than oak.

Mr. Fernow* gives the following list of the various kinds of mining timber which are available in the United States, each series being arranged in order of durability, beginning with the trees most adapted to resist decay.

\section{Eastern Range.}

Conifers.-Red cedar (Juniperus Virginiana, L.) ; White cedar (Chamcecyparis sphceroidea, Spach.); Arbor vitæ (Thuya occidentalis, L.); Bald cypress ('Taxodium distichum, Rich); Long-leaved pine (Pinus palustris, Miller); Red pine (Pinus resinosa, Ait.); Cuban pine (Pinus Cubensis, Griseb.) ; Short-leaved pine (Pinus mitis, Michx.).

Broad-leaved trees.-White oak (Quercus alba, L.); Post oak (Quercus $o^{7}$ itusiloba, Michx.) ; Chestnut oak (Quercus prinus, L); Live oak (Quercus virens, Ait.); Basket oak (Quercus Michauxii, Nutt.); Burr oak (Quercus macrocarpa, Michx.) ; Osage orange (Maclura aurantica, Nutt.); Hardy catalpa (Catalpa speciosa, Warder); Black locust (Robinia pseudacacia, I.) ; Honey locust (Gleditschia triacanthos, L.); Red mulberry (Morus rubra, L.); Chestnut (Castanea vulgaris, var. Americuna, A.D.C.)

\section{Rocky Mountain Region.}

Red cedar (Juriperus Virginiana, L.); Pinyon pine (Pinus edulis, Fngelm.) : Foxtail pine (Pinus Balfouriana, Murray); Douglas spruce (Pseudotsuga Douglasii, Carr.); Western larch (Larix occidentulis, Nult.); Durr oak (Quercus macrocarpa, Michx.)

\section{Pacific Slope.}

Yew (Taxus brevifolia, Nutt.); Red wood (Sequoia sempervirens, Endlicher); Lawson's cypress (Chamrecyparis Lawsoniana, Parl.); Canoe cedar (Thuya gigantea, Nutt.) ; Donglas spruce (Pseudotsuga Douglasii, Carr.); Western larch (Larix occidentalis, Nutt.); Live oak (Quercus chryso'epis, Liebm.); Post oak (Quercus Garryana, Dougl.).

The Douglas spruce, or Oregon fir or pine, is not only used in America, but also exported to Australia. It is a very straight wood, of even grain; it has the disadvantage of easily taking fire.

In Australia, the native woods are commonly used for mining purposes, and among them different species of Eucalyptus are sperially prominent.

The Jarrah (Eucalyptus marginata) is a native of Western

* "The Mining Industry in its Relations to Forestry," Trans. Am. Inst. M1.E., vol. xvii., I888, p. 264 . 
Australia. It gives a red, heavy, intensely hard wood, which is difficult to work with ordinary tools. It resists decay in a remarkable manner, in fact it is practically indestructible; the white ant and the "teredo navalis" will not attack it. Up to the present time there has been little need of mining timber in the colony of which it is a native; but it is exported to South Australia and New South Wales, and used for shaft-frames and other special purposes.

The grey or white iron-bark (Eucalyptus crelra, F. v. M.), and the red or black iron-bark (Eucalyptus leucoxylon, F. v. M.), both give hard, heavy, strong, and durable timber, and are among the most useful of the forest trees in Australia.

Grey box (Eucalyptus largiflorens) is a hard, tough, durable wood which lasts well underground. The young trees supply much prop timber in certain localities.

Stringy bark (Eucalyptus obliqua), possesses similar good qualities; and it is imported into Australia from Tasmania if the supply of the native-grown timber is insufficient or less easily obtainable. It is employed as sawn timber, or split, and the small trees make excellent props.

Among other species of Eucalyptus may be mentioned the slaty gum (E. bicolor, A. Cunn.), and bloodwood, (E. corymbosa, Sm.), both strong and durable and used for railway sleepers.

The prickly leaved tea-tree (Melaleuca armillaris) gives a hard, strong, heavy timber, lasting well underground.

New Zealand can boast of the magnificent Kauri pine (Dammara Australis), a slow-growing tree, some living examples being estimated to be 2000 years old.* It contains a fluid resin which oozes out from every part, and hardens into large masses of opaque gum. It is light, elastic, even-grained and strong. Besides being used for timbering mines in New Zealand, it is exported to Australia for the same purpose.

Matai (Podocarpus ferruginea), a reddish-brown, moderately hard wood, Miro (Podocarpus spicata), and Rewarewa (Knightia excelsa) may also Le mentioned among the New Zealand mining timbers.

In Japan the levels are sometimes timbered with bamboo.

Preservation of Timber.-Most authorities consider that the best time for felling timber is winter, when the wood has the least amount of sap in it, because fermentation of the sap is one great cause of decay. For this reason also, timber should be seasoned before it is used; that is to say, it should be allowed to dry gradually and so lose the sap by evapuration. Fernow $\dagger$ says that proper seasoning is more important than the time of felling. As regards

* Laslett, Timber and Timber Trees, London, 1875, p. 296.

+ Op. cit. and "Relation of Railroads to Forest Supplies and Forestry." Bulletin No. I, Forestry Division, Depa:tment of Agriculture, U.S.A. Washington, 1887 , pp. 37 and 67. 
the removal of the bark or not, there is a difference of opinion, but it certainly facilitates the seasoning; and in the case of oak the bark may be taken off for sale by the owner of the plantations, before he disposes of the timber to the miner. On the whole it seems advisable to remove the bark, and for two reasons-(I) less liability to rot, and (2) earlier indications of incipient crushing.

When stored at the mine, timber is best preserved under cover, protected from wind and weather, but with ample access of air; and it is important to remove all decaying wood, whether logs, chips, or sawdust, and destroy it by fire, so as to prevent the spread of the contagion. The timber should lie upon supports and not directly on the ground, and the pieces should not be placed too close together.

According to Laslett,* "the approximate time required for seasoning timber under cover, and protected from wind and weather, is as follows :-

Pieces 16 to 12 inches square
12 to 8 I 4 months.

Timber is of ten found to decay very rapidly in some mines, or in certain parts of a mine, owing to the spread of what is called dry rot. This is a white fungus which grows over the timber, and causes the woody fibre to decompose and become so soft and rotten that a knife or pick can be run in with the greatest ease.

Various methods of preventing dry rot have been tried with more or less success. Good ventilation is all-important, for timber is found to become affected most rapidly in places where the air is foul or stagnant. Water has a decided preservative effect, so much so that arrangements are sometimes made for causing it to trickle down continuously over the timber in a shaft, or to form a spray in timbered levels. Probably the water acts by washing off the spores of the fungus as fast as they are deposited upon the timber, and also by cleansing the atmosphere and keeping it cool.

Mine timber is also occasionally treated with antiseptics, such as brine (with or without chloride of magnesium), borax, creosote, carbolineum, coal-tar, corrosive sublimate, chloride of zinc, sulphate of zinc, sulphate of copper and sulphate of iron; but far less attention has been given to this subject by mining than by civil engineers, to whom the duration of railway sleepers (ties, U.S.A.) is a matter of much importance.

Treatment with a metallic salt is preferred to creoscting, if the timber is at all exposed to the risk of catching tire.

$$
\text { * Op cit. p. } 3^{16 .}
$$


The timber is treated in one of the following ways:-

(I) Steeping.-The timber is simply placed in the preservation solution, and allowed tu absorb what it can.

(2) Hydrostatic Process. - The preservative solution is forced in by hydrostatic pressure.

(3) Vacuum Process. - The timber is placed in boilers, and steam is admitted; the air and vapours are then exhausted, and a preservative turned in under pressure.

(4) Painting, i.e., application with a brush.

It was found by experiments carried on at Commentry during a long series of years, that one of the best methods was soaking the timber for twenty-four hours in a strong solution of sulphate of iron (green vitriol). The total cost was only $\frac{1}{2} \mathrm{~d}$. per yard of prop, whilst the timber lasted eleven times as long as when this simple treatment was omitted. "Carbolineum" is a patent preparation laid on with a brush like paint, which is well spoken of by the mining officials at Saarbrücken.* The cost of two coats of the preservative material on a prop 8 feet long by ro inches in diameter $\left(2.5 \mathrm{~m}\right.$. by $25 \mathrm{~cm}$.) is about $7 \frac{1}{2} \mathrm{~d}$.

The duration of a prop, or other piece of timber, is not the only point to be considered in deciding whether it is worth while paying the cost of some preservative treatment. The expense of the labour in the renewal of unsound timber, such as the cutting of fresh hitches, must not be overlooked.

Tools.-Timber is used in various forms-either whole and merely sawn into lengths, or hewn or sawn into square balks, or sawn in half, or sawn or split into planks of different thicknesses.

The tools used by the miner for shaping the timber are the saw and axe; in addition he requires a measuring staff, a sledge or a wooden mallet for driving the timber into its place, a hammer and "moil" for chipping out recesses or niches (hitches), plumb line and level.

The saws vary in different countries. In Great Britain the timberman's saw is the ordinary hand-saw of the carpenter, though a cross-cut saw worked by two men is used for cutting large props or balks. In the Hartz the timberman uses a saw somewhat resembling our cross-cut saw in shape, but smaller in size, and having the toothed edge curved, whilst in Saxony a frame saw is preferred. All large mines have a circular saw, and some are provided with special machines for cutting the joints of supporting frames.

'I'he axe varies in shape more according to the fancy of the user than any special difference in the purpose for which it is used.

The moil is merely a pointed steel bar. In order to ascertain the length required for a piece of timber to fit a given place, the timberman uses a measuring staff, consisting of two bars of wood

* Zeitscirr.f. B.- H. u. S.-Wesen, vol. xxxviii., 1890, p. 265. 
which are made to slide upon each other, and then fixed in any position by a thumb-screw. One end is often rounded so that it may reach to the bottom of the niche (hitch) which has been cut in the rock. The plumb line and level need no description.

The principal kinds of excavations in mines are levels, shafts, and ordinary working places. These will be taken in order, and the methods of securing them dealt with briefly.

Levels.-Though a level is an excavation of a very simple nature, the methods of timbering it vary considerably, because the parts requiring support may either be the roof alone, or the roof and one or two sides, or the roof, sides, and bottom.

If the roof only is weak, as is the case with a soft lode between two hard walls, a cap with a few boards resting on it (Fig. 242)

FiG. 242.

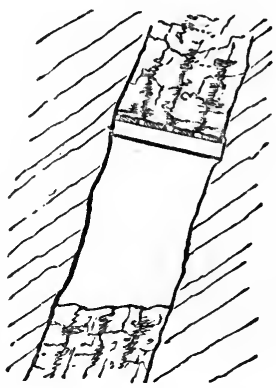

FIG. 243.

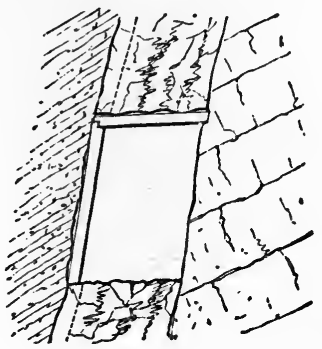

is sufficient to prevent falls. If one side is weak the cap must be supported by a side prop or leg (Fig. 243), and very often by two legs. The form of joint between cap and leg are numerous (Fig. 244), depending to a great extent on the nature of the

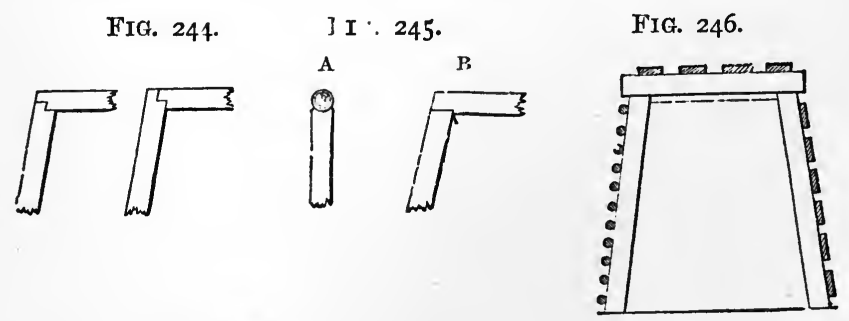

pressure, whether coming upon the top or sides, and also on the shape of the timber, whether round or square. With round timber the top of the leg may be hollowed out as shown in Fig. $245 \mathrm{~A}$; but occasionally the joint is flat, and a thick nail or nog is put (Fig. 245 B) to prevent the effects of side pressure, 
or, better, a piece of thick plank is nailed under the cap (Fig. 246).

Where the floor of a level is soft and weak, a sole-piece or sill becomes necessary, and if the sides or roof are likely to fall in, a

FIG. 247.
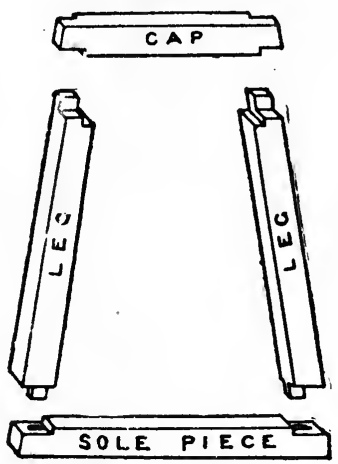

FIG. 248.

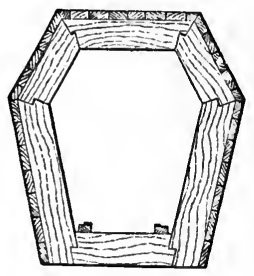

lining of planks or poles is used (Fig. 246). "IIorned sets" (Fig. 247)* are useful in loose ground.

Fig. 248 shows the special system adopted on the Comstock lode $†$ for some very heavy ground. The outer planks (lagging) are put close together, and the method of jointing has been carefully designed so as to prevent any yielding under the enormous pressure to which it is subjected. These levels are 6 feet high inside the timber.

As an instance of timbering on a much larger scale, $I$ give a representation of the supports at Rio Tinto, Spain (Fig. 249); the height of the level from the groundsill $(a)$ to the cap $(c)$ is $\mathrm{I} 2$ feet 7 inches $(3.85 \mathrm{~m}$.), so as to allow the passage of locomotives.

In driving levels for the deep FIG. 249.

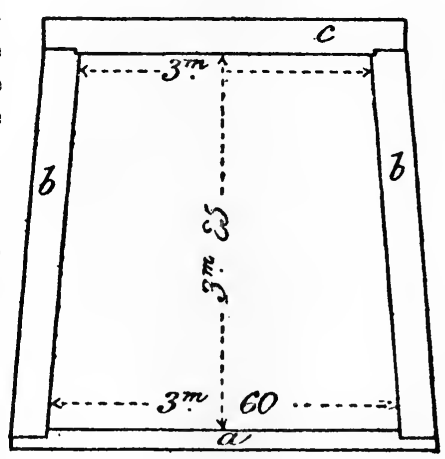
gold-bearing gravels in the Cariboo district, B.C., \$ spruce fir I to 2 feet in diameter, simply barked, is used for making the scts. The lagging is in pieces

* Rep. Insp. Mines, Victoria, for 1875, p. 7. Melbonrne, 1876.

† Hague, "Mining Industry," United States Geological Exploration of the Fortieth Parallel, vol. iii., plate iv., p. 113. Washington, 1870 .

$\ddagger$ Dawson, "General Note on the Mines and Minerals of Economic Value 
4 feet long, 5 inches wide, and 2 inches thick, and is split out of logs. The ground is so heavy that the frames (sets) are only a few inches apart in some places. Where the ground is very wet, spruce brushwood is placed behind the lagging.

In the Day Dawn mines in Queensland, * the gold vein sometimes attains a width of 60 feet; the hanging wall is not strong, and large portions of the lode itself are apt to slip away.

FiG. 250.

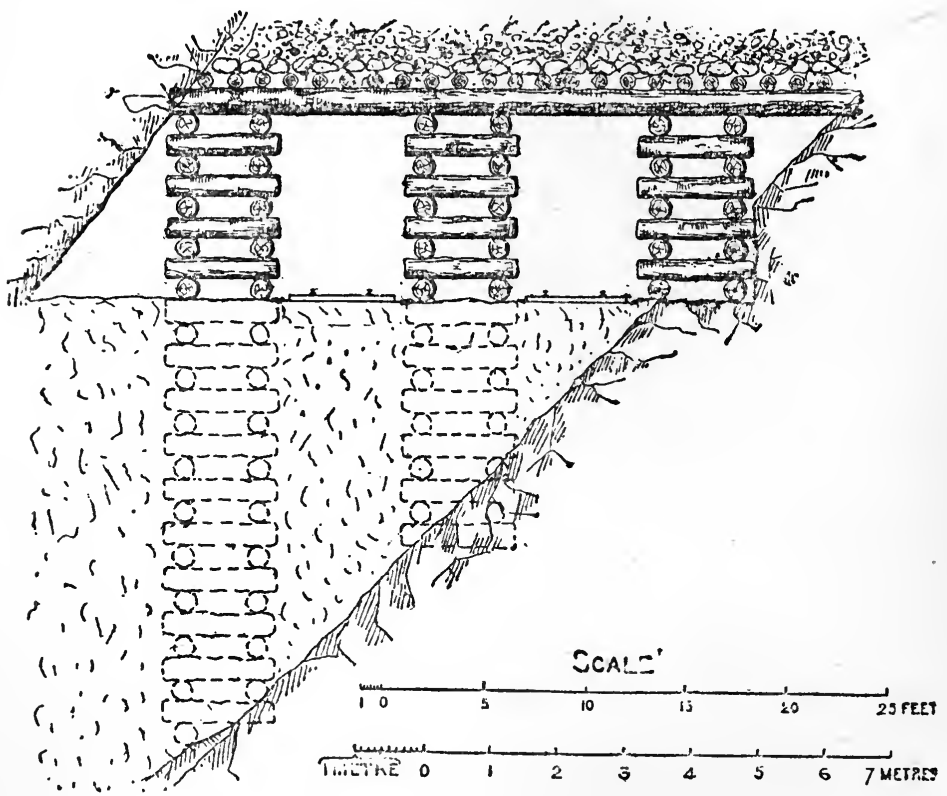

Though the levels could be driven without dificulty, it was found impossible, with the ordinary methods of timbering, to keep them open permanently after the vein had been worked away, and the whole pressure of the heavy ground on the hanging wall had to be supported. At last the so-called "pigsty" method was tried, and it has been found very successful. It consists in piling up $\operatorname{logs} 4$ to 8 feet long, two by two, crosswise, and so building a support which covers a comparatively large area.

Figs. 250 and $25 \mathrm{I}$ represent the pigsty timbering; the former is

of Briti-h Columbia," Geol. Survey, Canada. Reprinted from Canadian Pacific Railiray Report, is 77, p. 8.

* This description and the figures have been kinally supplied by $\mathrm{Mr}$. Joseph Shaliespear, one of the Government Inspectors of Mines in Queens. land. 
a section along the line of dip, the latter along the line of strike. As the drivage progresses, strong sills, Io to 12 inches in diameter, are laid along the floor of the level. These sills may be as much as 25 feet in length, and two of them are laid under each row of sties, which are placed about 6 or $8 \mathrm{ft}$. apart in the direction of the level. The number across the level depends upon the width of the lode, and the spaces between the rows of pigsties form the roads for the waggons. The cap-pieces are made of

FIG. 25 I.

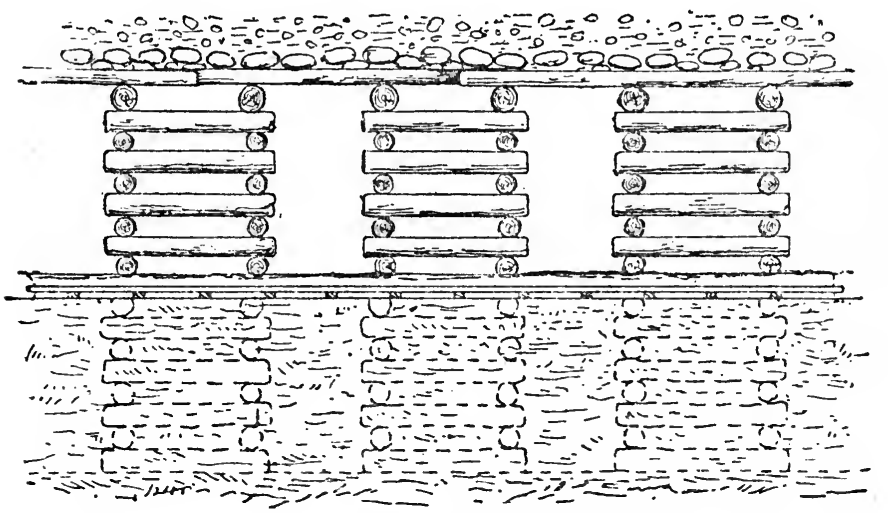

\section{SCALE}

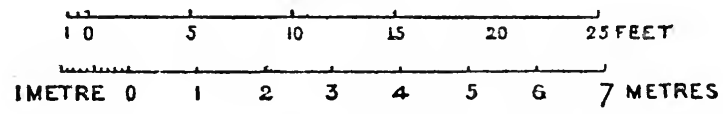

timber ${ }_{15}$ inches in diameter, and they rest upon the pigsties. Upon the cap-pieces comes a row of poles, which support the deads when the lode is worked away above.

Where the width of the lode is not too great, the sills are dis pensed with; the ground at the bottom of the level behind the end is excavated, and the pigsties are built up from the footwall. Consequently, when the lode is removed by the workings below, the level is not affected because the timbering is supported from the undisturbed footwall.

When sills are used in a very wide lode, pigsties resting upon the footwall are built up whilst the ore is being excavated, and they are arranged so as to come exactly under the sills and carry their weight.

This method of support requires a great deal of timber, but it has the advantage that the small logs used for the pigsties are inexpensive and easily handled, compared with huge balks required with the other systems. 
If the ground is loose so that the roof or sides, or both, will run in unless supported, the method of working called spilling, spiling, or poling is pursued. It consists in snpporting the weak parts by boards or poles in advance of the last frame set up. The process may be described as pushing out a protecting shield in very narrow sections, one at a time. The poles or boards (laths) are driven forward by blows from a sledge, and the ground is then worked away with the pick; this removal of ground enables the laths to be driven in further; the pick is now once more called into requisition, and by successive small advances the shield of poles or boards is extended a distance of 3 or 4 feet. Fig. 252 shows one of the advance poles partly driven, with the front end

FIG. 252.

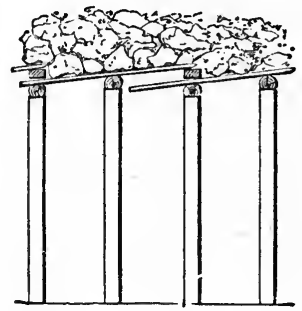

FrG. 253.

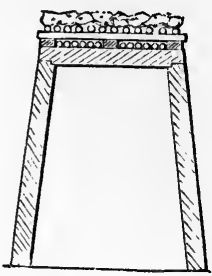

resting upon a set of timber; the pole behind it is in its final position. The section, Fig. 253, explains that the lower set of poles, those which are in the course of being driven, have room enough to slide on tc $\rho$ of the cap, owing to the blocks placed upon it being slightly thicker than their diameter.

In running ground it is necessary to have the laths fitting closely together, and the working face must also be supported by breast-boards, kept in place by little struts resting against the nearest frame. These are removed and advanced one by one, alter the laths in the roof, sides and bottom have been driven beyond them.

In a few instances the end of a level in running ground has been kept up by covering the entire working face with wooden wedges; an advance was gradually effected by driving them in with a heavy sledge. The sides and top of the level were protected by laths in the ordinary way.

Shafts.-The timbering required for shafts varies according to. the nature of the ground and the size of the excavation. A mere lining of planks set on their edges (Fig. 254) suffices for small shafts, correr-pieces being nailed on so as to keep the successive frames together.

The usual method of securing shafts is by sets or frames. Each set consists of four pieces - two lunger ones called wall plates, and 
two shorter ones called end pieces. They are joined by simply halving the timber at each end, as shown in Fig. 255, the wallplate being made to rest upon the end-piece, though this arrangement is sometimes reversed. A more complicated joint (Fig. $2{ }_{5}^{6}$ ) is often preferred. The separate frames are kept apart by distance

FIG. 254.

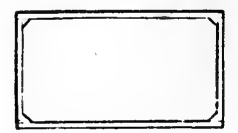

FIG. 255.

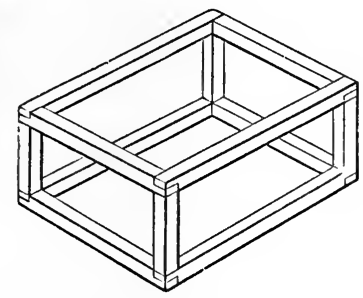

FIG. 256.

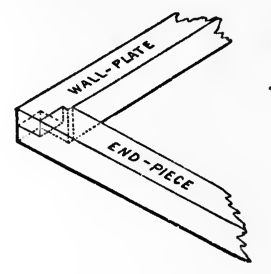

pieces (studdles, Cornwall ; jogs, Flintshire; posts, U.S.), and loose ground is prevented from falling in by boards or poles outside. The length of the distance pieces must depend upon the solidity of the ground. If the ground is very weak they are not used at all, and the successive frames are put in touching each other; in loose ground near the surface the distance between the frames may be 18 inches, for instance, and then increased gradually to 4 or 5 feet when the shaft has penetrated into harder strata.

The end-pieces are sometimes made long enough to project a foot or eighteen inches teyond the wall-plates, and rest in niches in the rock. Another plan is to insert bearers at regular intervalssay every 30 feet-under the end-pieces. The bearers are generally of oak, and in a shaft of medium size pieces 12 inches by 12 inches are taken, and cut four or five feet longer than the endpieces. They therefore project 2 to 2 feet 6 inches at each end into solid ground, and decidedly add to the security of the timber lining.

The sides of the shaft are further prevented from falling in by planks which rest against the wall-plates and the end-pieces. During the process of sinking, the last frames are kept in position by strong iron clamps, and when a length of 10 or I 2 feet has been completed, planks (lashings or listings) are nailed on inside, stretching over several frames and so binding them all together.

This lining of a shaft may be regarded as a very long box, with strengthening ribs at short intervals. As shafts are frequently used for the several purposes of pumping, hoisting, and affording means of ingress and egress by ladders, it becomes necessary to divide them into compartments. Pieces of timber parallel to the end-pieces (buntons or dividings) are fixed across the shaft, and serve to stay the wall-plates, to hold the guides or 
conductors, to support planks (casing boards), which are nailed to them so as to form a continuous partition or brattice, and to assist in carrying the ladder platforms.

The magnificent timbering of some of the shafts on the Comstock lode is described by Mr. James D. Hague* as follows :-

"The timbering consists of framed sets or cribs of square timber, placed horizontally 4 feet apart, and sefarated by uprights or posts introduced between them. Cross-timbers for the partitions between the compartments form a part of every set. The whole is covered on the outside by a lagging of 3-inch plank placed vertically."

Figs. 257, 258, and 259, copied from Mr. Hague's plates, illustrate this method of timbering. Fig. 257 is a plan of the shaft. " $S S$

FIG. 257.

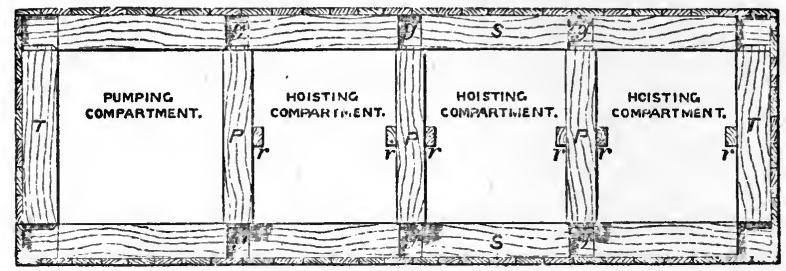

are the longitudinal or sill-timbers; $T T$, the transverse end timbers; $r$, guide-rods between which the cage moves; $g$, gains cut in the sill-timbers to receive the ends of the posts. The sheathing or lagging is seen enclosing the whole frame."

Fio. 258 is a transverse section through the partition-timber (dividing) $P$, of Fig. 257, " between the pumping compartment

FIG. 258.

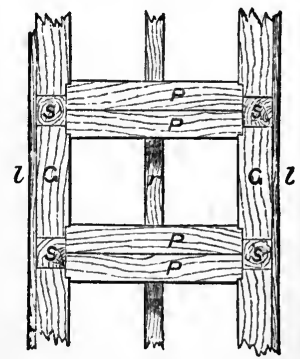

FIG 259.

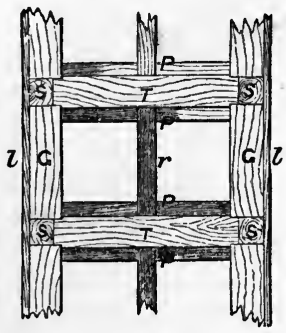

and the adjoining hoisting compartment, looking towards the latter. In this figure, $G G$ are the posts; $S$, the sill-timbers; $P$, the partition-timbers, the ends of which are framed with short

* "Mining Industry," Un ted States Geo'ogical Exploration of the Fortieth Iarallel, vol. iii. p. I03. 
tenons that are received in gains cut in the sill-timbers and the ends of the posts; $r$, guide rod; $l$, lagging or sheathing." Fig. 259 is an end view of the frame shown in Fig. 257.

"The single piece $T$ forms the end, while the double pieces $P$, forming the partitions, are seen beyond. The outer timbers of each set-that is, the two sides and ends of the main frame-are I 4 inches square, the posts, ten in number, four at the corners and two at each end of the partitions, are of the same size. The dividing-timbers forming the partitions are 12 inches square."

The pigsty system of supporting ground has been applied to an inclined shaft at Day Dawn* Mine in Queensland, in which the ordinary system of frames was proving inadequate. In this case the shaft had been sunk on the inclined lode; the ore had been removed on each side and replaced by "deads," and the sides and roof were supported by ordinary frames and laths. The manager took out a strip of deads on each side of the shaft, and as soon as sufficient room had been made, he built up a couple of pigsties, and then another two, and so on. The space between them served as a passage (winze) for winding-up the deads as the work progressed downwards. The ends of the long horizontal balks of iron-bark timber (caps) stretching across the shaft were made to rest upon the pigsties, and upon them were placed poles which supported the roof (hanging-wall). Since this method has been adopted there has been no trouble with the shaft. The subsidence of the hanging-wall has been going on, but the pigsties

FIG. 260.

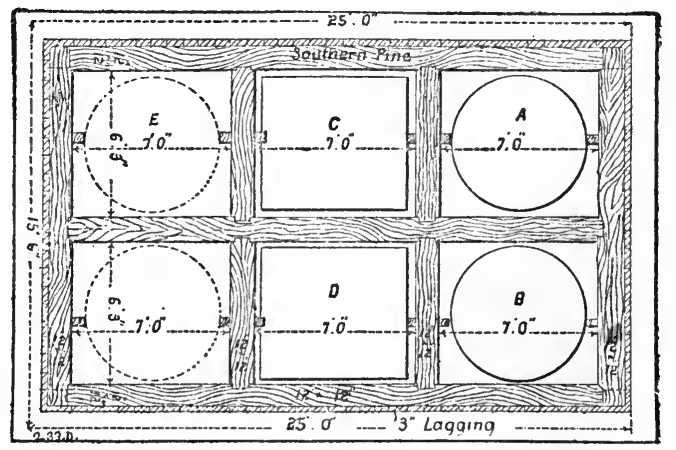

yield to the movement without becoming crippled or useless. Occasionally a cap piece breaks in the middle, in spite of its great size, but it can easily be renewed.

As an example of another large shaft may be mentioned the new

* MS. information kindly supplied by Mr. Joseph Shakespear, Government Inspector of Mines, Queensland. 
sinking at the Calumet and Hecla mines* (Fig. 260), which is expected to strike the copper bed at a depth of 3325 feet from the surface. The shaft is rectangular, 23 feet by 13 feet 6 inches within the timber, and divided into six equal compartments, 7 feet by 6 feet 3 inches within the timber. $A$ and $B$ (Fig. 260) are for receptacles for winding rock, $C$ and $D$ for cages for raising and lowering men, timber, \&c.; $E$ forms the upcast air-way, and $F$ is for air-pipes, \&c. The frames and the dividing-pieces are made of southern pine, 12 inches by 12 inches, and the whole is surrounded by a close lagging of 3 -inch plank.

At Clausthal in the Hartz, round timber is generally used, and special means are adopted for resisting the heavy pressure of the ground upon the wall-plates.

In Fig. 26I $a a$ are the wall-plates, made of timber $\mathbf{I}$ foot in

FIG. 261.

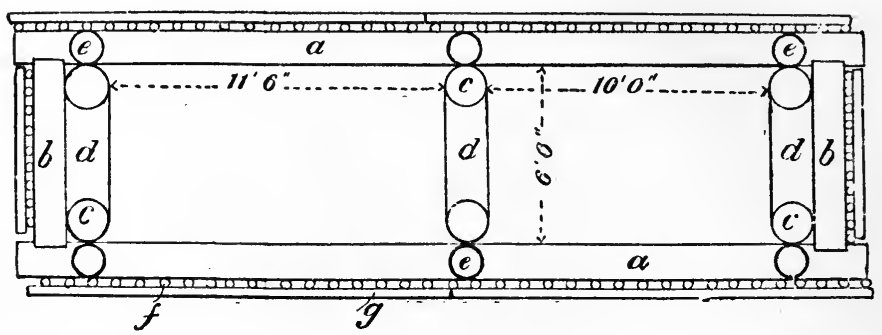

diameter; $b b$, the end-pieces; $e e$, the studdles, which are 18 inches long.

The end-pieces are not halved as in Fig. 255, but are slightly wedge-shaped, so as to preserve their whole strength for preventing the wall-plates from being squeezed together. However, reliance is mainly placed upon frameworks of round timber, 15 inches in diameter, placed at the ends and near the middle of the shaft, and shown in elevation in Fig. 262. Each framework consists of two pieces, 18 to 20 feet long (wall-posts, $c c$ ), kept apart by diagonal struts (stempels or spur-timbers, $d, d^{\prime}, d^{\prime \prime}$ ). The foot of the lowest stempel fits into a hitch cut in the long wall-post, whilst the head is merely hollowed out to suit the curvature of the opposite wall-post. All the other stempels are cut out in this way at both ends, and when the bottom stempel has been put in, the others are very speedily fixed one above the other. If necessary, a strong bearer, $h$, is put in from time to time under the wall-posts, and projects a foot or 18 inches into the ground on each side of the shaft ; thin poles placed vertically and horizontally, $f$ and $g$, prevent loose stones from falling in. 
Special excavations have to be timbered according to circumstances; thus a chamber for a water-wheel at Clausthal in the

FIG. 262.

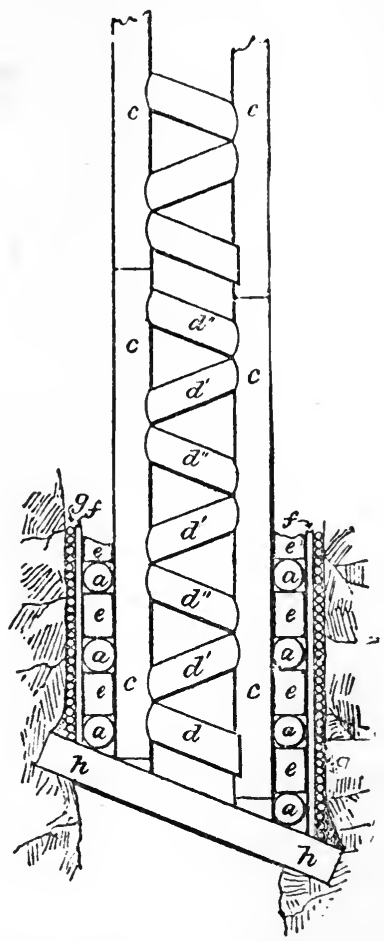

Fig. 263.

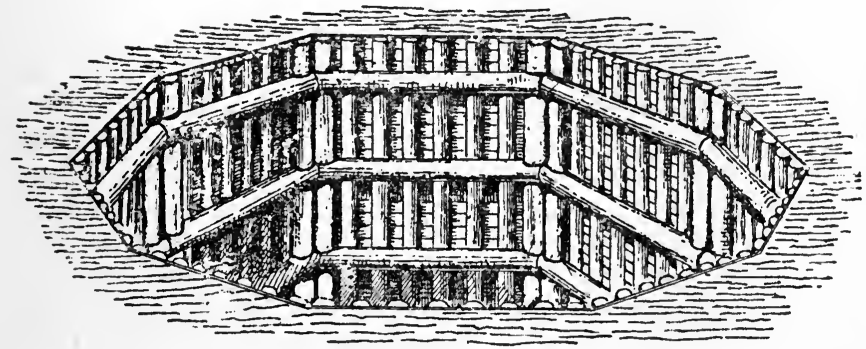

Hartz was made decagonal (Fig. 263). The main horizontal pieces at the side were of ro-inch round timber cut at the ends to the 
proper angle; behind them came half-round timber, trees 12 or 14 inches in diameter sawn in half, arranged vertically, and finally a backing of common planks; the successive horizontal frames were kept apart by studdles, one at each end of each side of the polygon.

Spilling.-When ground is loose, recourse is had to a spilling process like that described for levels. Strong balks of timber are

FIG. 264 .
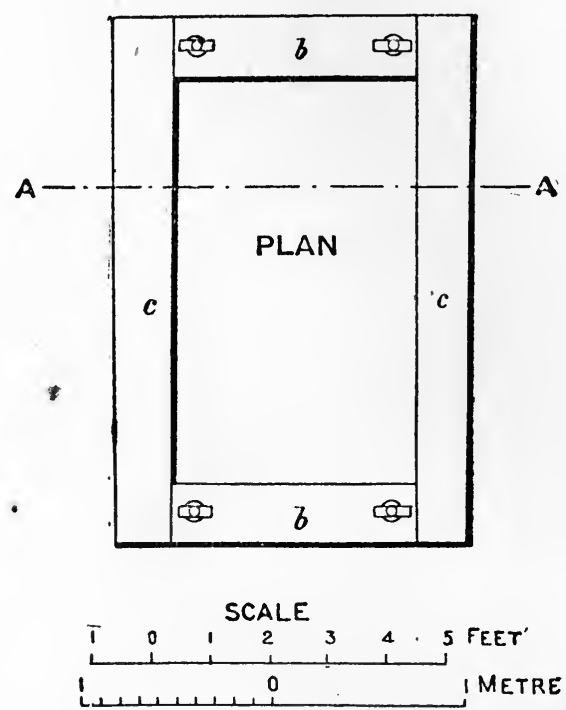

fixed at the surface or in solid ground in the shaft, and the first frame is supported upon these bearers; the next frame is hung from the first, the third from the second, and so on until the loose ground is passed.

In Fig. 265 a $a$ are the "bearers," which are made to project a couple of feet into solid ground; upon them rest the end-pieces $b b$ (Figs. 264 and 265), halved at the ends so as to support the two wall-plates $c c ; e e$ are two rods of 2 -inch round iron, which hold up the end-piece $d$ of the second frame or "set of timber." They are fixed tightly by means of cotters. The wall-plates $f f$ of the second frame rest upon the end-pieces in the usual way, and when it becomes necessary to put in a third set or frame, the endpieces $g$ are hung by cottered bolts from the frame above, $d ; h h$ are the wall-plates. The fourth frame with its end-piece $i$ and wall-plates $j$ follows in the same manner; therefore, until the pressure of the ground comes into play, the bearers $a$ a are carrying the whole weight of the timber. The pieces $k k$, known as 
"laths," are made of 2 -inch plank, 9 or ro inches wide, sharpened at the ends; they serve to keep the loose ground from falling into the shaft; $l l$ are the so-called "tailings" which keep the laths in position. The lath $k^{\prime}$ is one which is being put in; it has to be struck with a heavy sledge until it makes its way into

FIG. 265. Sectional elevation along line A A of Fig. 264.

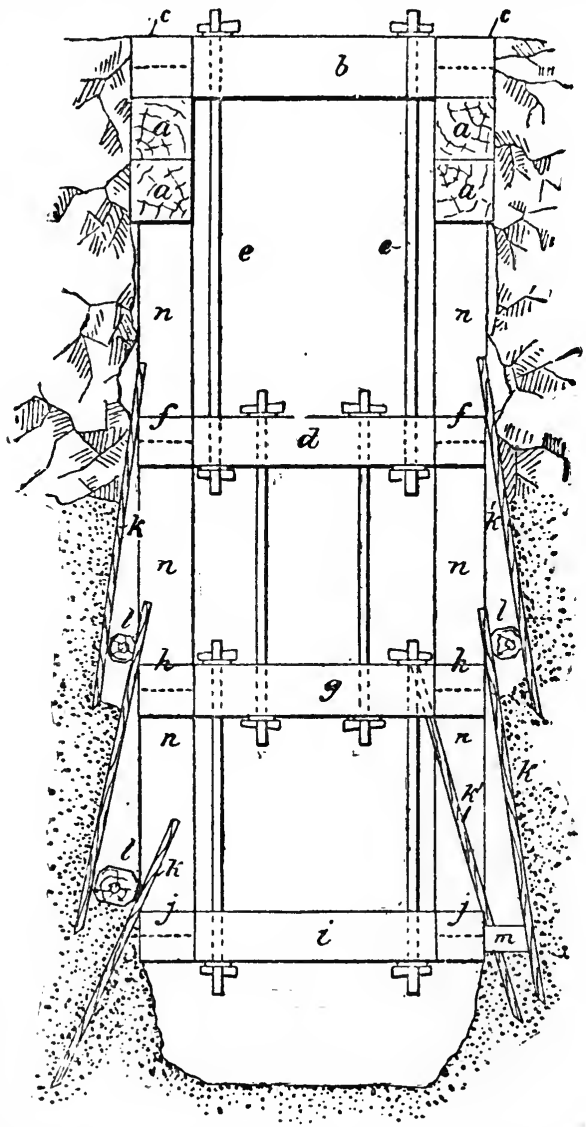

the loose ground. If very heavy blows are required, the head of the lath is protected by an iron shoe.

The piece $m$ is a stay put in for the purpose of keeping the set or frame in its place until the laths have been driven. The frames are kept at the proper distance apart, and the timber structure is stiffened by the usual corner posts $n n$ (studdles). 
The loose ground is excavated gradually, while each protecting sheath of planks is in process of being driven down, and in due

FIG. 266.

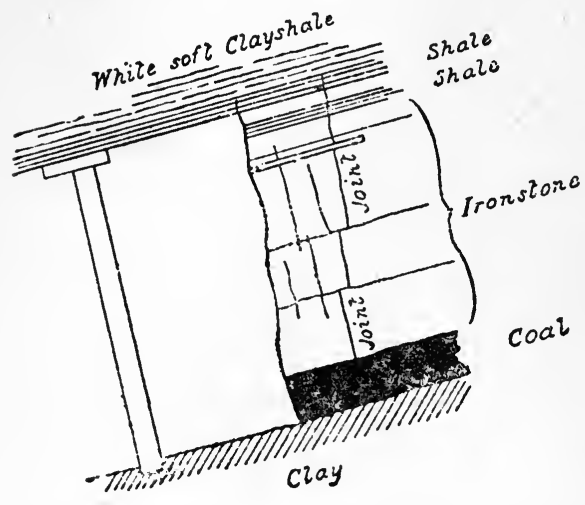
course another frame is hung on, and the operations of driving laths and excavating are repeated.

At mines on the Comstock lode, the bolts for keeping the frames together are made in two parts, with a tightening screw in the middle; great firmness is secured in this manner.

Working Places. The timbering of working places varies very greatly. The simplest case is that of a horizontal bed. Here, propsput in vertically often suffice to support the weight of the roof. The addition of a lid, a flat or slightly wedge-shaped piece of board at the top, extends the bearing surface, and, by presenting a smooth face to the top of the prop, enables this to be forced in more firmly into position than it could be against a rough roof. It also yields a little to the pressure of the roof, and lengthens the life of the prop in this way.

When the bed is inclined, the props are not set quite at right angles to the plane of bedding; one reason for this is that if so set they might be easily knocked out by an accidental blow from a falling stone.

Mr. Sawyer* has made out a table showing the deviation from the normal which should be given :

\begin{tabular}{|c|c|c|}
\hline \multirow{2}{*}{ Dip of Seam. } & \multicolumn{2}{|c|}{ Set or Underset of Posts. } \\
\hline & Minimum. & Maximum. \\
\hline $\begin{array}{c}6^{\circ} \\
12^{\circ} \\
18^{\circ} \\
24^{\circ} \\
30^{\circ} \\
36^{\circ} \\
42^{\circ} \\
49^{\circ} \\
54^{\circ} \\
\text { and upwards }\end{array}$ & $\begin{array}{l}0^{\circ} \\
0^{\circ} \\
1^{\circ} \\
1^{\circ} \\
2^{\circ} \\
2^{\circ} \\
2^{\circ} \\
3^{\circ} \\
3^{\circ}\end{array}$ & $\begin{array}{l}1^{\circ} \\
2^{\circ} \\
3^{\circ} \\
4^{\circ} \\
5^{\circ} \\
6^{\circ} \\
7^{\circ} \\
8^{\circ} \\
9^{\circ}\end{array}$ \\
\hline
\end{tabular}

*Accidents in Mines from Falls jo Lioof and Sides, London, ISS6, p. 50. 
Fig. 266, copic $d$ by permission from Mr. Sawyer, is an instance of a prop and lid $f o r$ working in a bed of clay ironstone.

Logs laid two by two crosswise (chocks or cribs), the pigsties of the Australian miner, form efficient supports. Fig. 267 represents the manner of using them in a bed of potter's clay; Fig. 268,

FIG. 268.

FIG. 267.
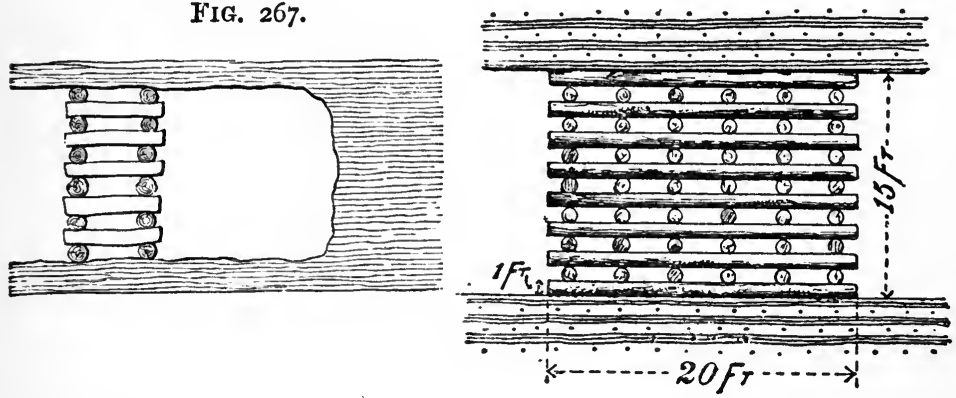

one of the huge structures which may be seen in the Wieliczka salt mines; and lastly, Fig. 269, ${ }^{*}$ the method adopted at Day Dawn

IIx. 269.

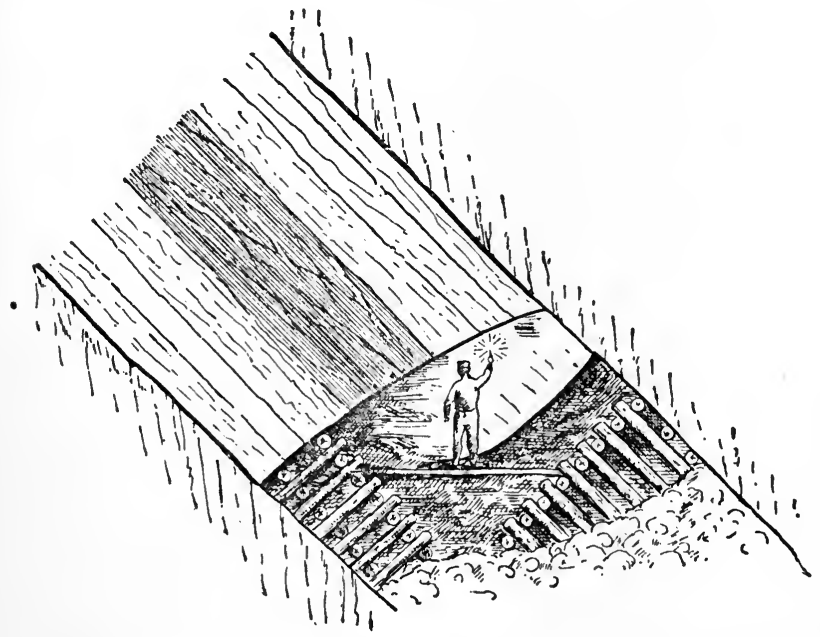

gold mine, Queensland, in the case of a vein. The pigsties for supporting the hanging wall are built up at intervals in the work-

* Kindly furnished by Mr. Joseph Shakespear, Government Inspector of Mines, Queensland. 
ing places (stopes), and then filled up with rubbish (deads, mullock). The pigsties on the foot-wall serve to keep up a portion of the vein until it is time to break it down. Square timber is used for chocks as well as round.*

According to Heathcote, the "square set" system of timbering, so largely used in the United States, is not an invention of Amcrican origin, as is usually supposed. It appears to have been

FIG. 270.

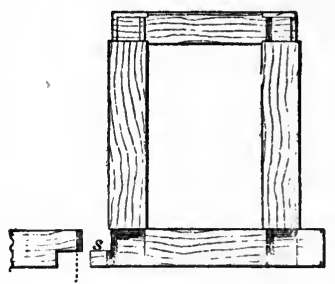

FIG. 27 .

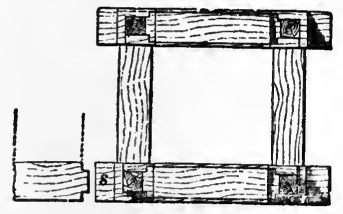

known in Australia as lcno ago as $\mathbf{1} 854$. The manner in which it is employed in Nevada for working away the soft "bonanzas," or ore-bodies of the great Comstock lode (Figs. 270, 271, and 272) is well described by Hague. $\dagger$ It consists in framing timber's together in rectangular sets, each set being composed of a square

FITY. 272.

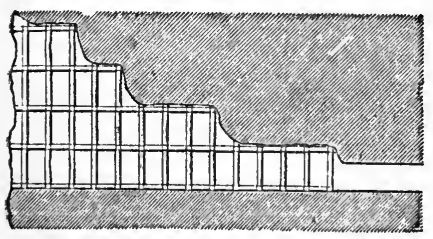
base placed horizontally, formed of four timbers, sills, and crosspieces, 4 to 6 feet long, framed together, surmounted by four posts 6 to 7 feet high, at each corner, and capped by a framework similar to that of the base. These cap-pieces, forming the top of any set, are at the same time the sills, or base, of the next set above, the posts, as the sets rise one above the other in the stope, being generally placed in position directly over those below.

"The timbers are usually of 12-inch stuff, square hewn or sawn." Each post has a tenon 9 inches long at the upper end, and a tenon of 2 inches at the other end, which fit into mortices in the cap and sill respectively; and "the sills and caps have short tenons on each end, and shoulders cut to receive the ends of the post and the horizontal cross-pieces." The walls of the excavation are sustained by a lagging of 3 -inch or 4 -inch plank.

* Discussion upon Messrs. Jamieson and Howell's paper, "Mining and Ore-treatment at Broken Hill, N.S.IV." Jlin. Proc. Inst. C.E., vol. cxiv., Session 1892-93. Part IV.

+ Op. cit., p. 112 . 
The whole width of the ore-body is stoped away at once, and its place supplied by timbering, and finally the vacant space is filled with waste rock derived frum dead work in the mine or from special excavations-underground quarries in fact-in barren ground. The stoping is carried on overhand, starting from an intermediate shaft or winze, and Fig. 272 will explain how the different frames are built up one above the other.

In the "Eureka district, Nevada," the system employed for securing the chambers left by the excavations of the ore-bodies is

FIG. 273 .

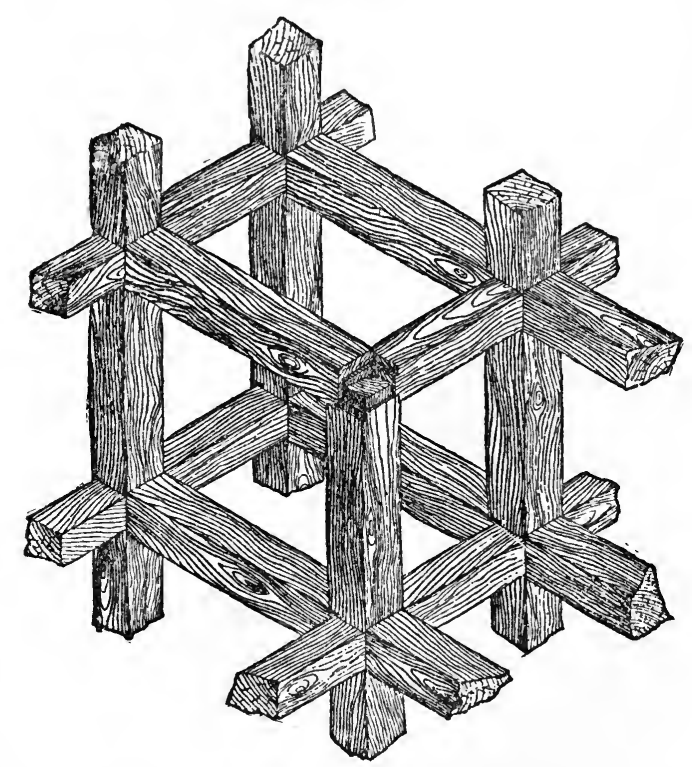

by similar square sets, but the mode of joining the pieces of timber presents some peculiarities.

Fig. 273 is a general view of a square set employed at the Richmond mine, which explains the manner in which the tenons and shoulders are cut. This complicated method of framing is admitted to be expensive, but its adherents claim that it possesses great strength. At Eureka mine the joint is simpler. The Eureka timbering is designed for resisting pressure in all directions, the Richmond method for offering the greatest resistance in the direction of the caps, the ties being placed parallel to the walls.

* Curtis, "Silver-lead Deposits of Eureka, Nevada," Mon. U.S. Geol. Survey. vol. vii, p. I 4. Washington. 1884. 
The dimensions of the pieces between the shoulders are : posts 6 feet, caps 5 feet, ties 4 feet, and the timber employed is pine
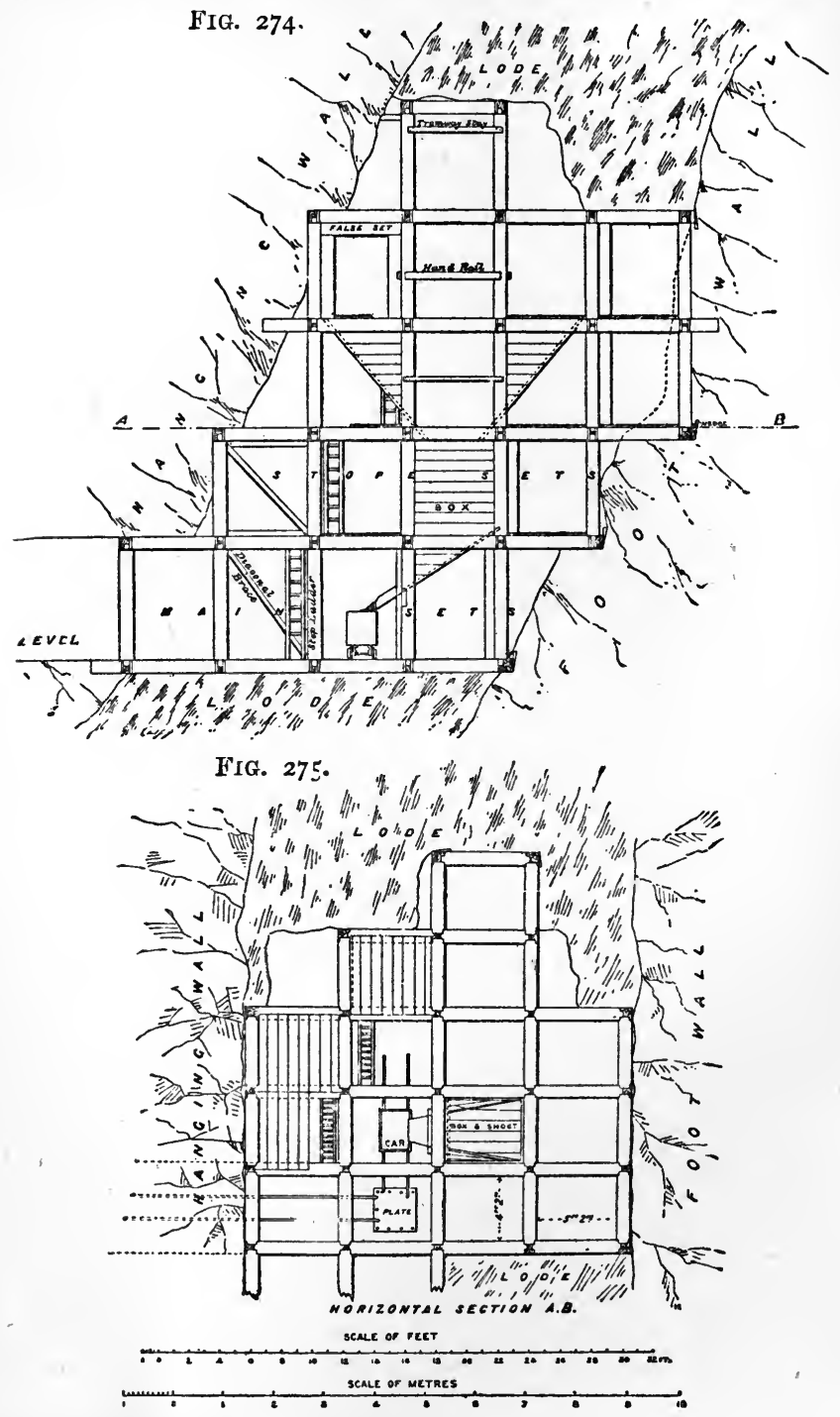

from the Sierra Nerada, hewn into balks I 2 by I 2 , IO by I 2 , or Io by 10 inches. 
Square sets are likewise adopted at the Broken Hill mines* where a wide and soft lode has to be stoped away (Figs. 274 and 275), and they are being tried in Hodbarrow mine in Cumberland. The joint used at Broken Hill $\uparrow$ is represented in plan by Fig. 276, in which A A are the caps, B B the struts, and $\mathrm{C}$ the tenon 4 inches

FIG. 276.

FIG. 277 .
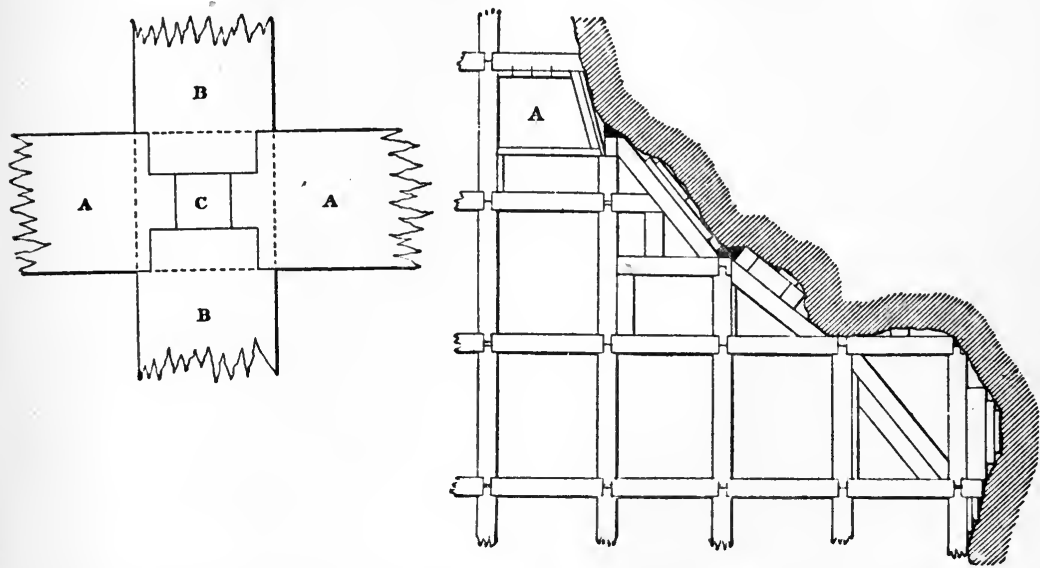

square on the end of the upright post or leg. Fig. 277 explains the manner of packing the hanging wall with timber, so that the load may be distributed evenly upon the supporting framework. It also shows how a weak spot at $A$ is further secured by horizontal stays.

When additional strength is required, a lining $\mathrm{A}$ (Fig. 278 ), or an angle-stay, $\mathrm{B}$, is put in ; and should these precautions appear insufficient to prevent a movement of the ground, the framework may be reinforcer in various ways, as illustratel by C, D, E and F (Fig. 278); $F$ is a solid ro-inch wall of timber.

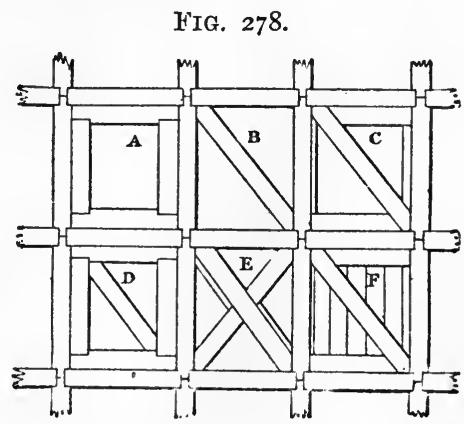

MASONRY.-Masonry has long been used for supforting the roof and sides of mining excavations. The materials necessary are stone, ordinary bricks or slag-bricks, and they may be built p. ${ }_{+}^{36 .}$ ileathcote, op . cit.

* Victoria, Annual Report of the Secretary of Mines for the Year 18S9, 
up alone (dry walling), or with the aid of mortar or hydraulic cement. Concrete, a mixture of hydraulic cement and small

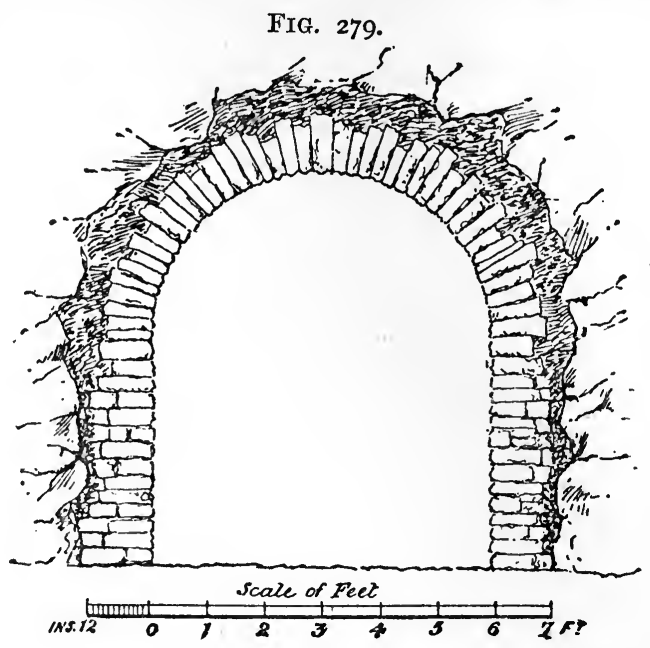

stones, is occasionally employed, and probably could be more so with advantage.

Once more I will take the three cases of a level, a shaft, and a working place.

Levels.-In levels dry walling and timber are sometimes FIG. 280.

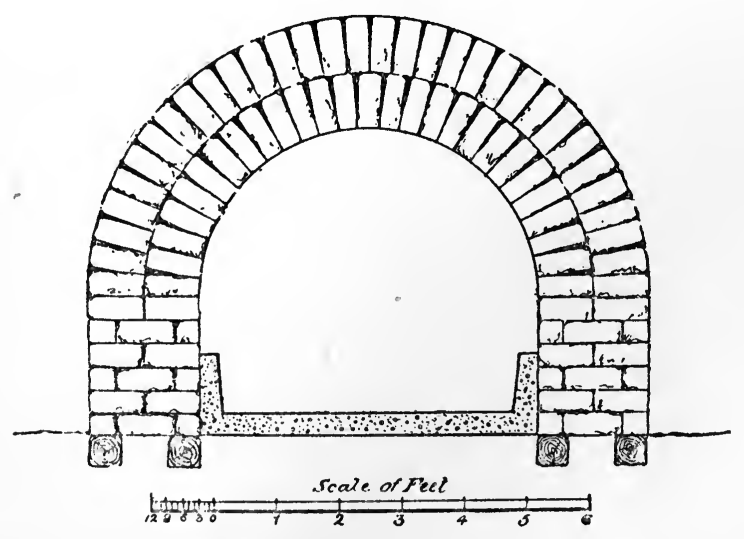

combined. Thus, after the excavation of a wide lode, the rubbish is piled up on the sides, walls are built up of the large 
stones, and caps of timber are laid across, which support the "deads" when the higher portions of the lode are taken away.

Fig. 279 represents a level in an iron mine in the Forest of Dean, where sandstone is available. The pieces are hewn and trimmed roughly, and a semi-circular arch is made to rest upon walls at each side.

Fig. $28 \mathrm{O}$ is a level in one of the mines at Clausthal in the Hartz; the sides are constructed of slag-bricks, and at the bottom of the tunnel there is a channel, made of concrete, for carrying water and preventing its percolation into lower workings, which would otherwise necessitate unprofitable pumping.

If both sides (walls) of a vein (Fig. 28I) are firm, an arch affords ample protection when the ore has been removed, and provides a resting place for the rubbish (deads, attle Corn.)

A vein is very often a fault, and soft beds may be found

FIG. 28I.

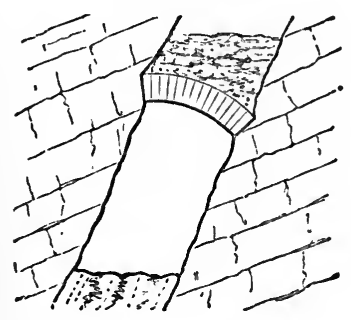

FIG. 282.

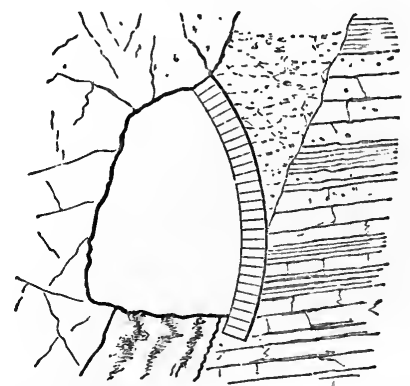

opposite a hard wall of solid rock. In this case the arch is made to reach from the roof to the floor (Fig. 282).

One of the main crosscuts at Mansfeld* was lined with concrete for a length of $1000 \mathrm{~m} .\left(\frac{5}{8}\right.$ mile); 12 metres ( 40 feet) a day were put in, and for this purpose 50 metres ( 164 feet) of centering were required. The laths were covered with thin sheet-iron, so as to prevent the concrete from sticking. The concrete was made of Portland cement, broken stone, and gravel, in the proportion of I to 7 , viz., I part of cement, $2 \frac{1}{2}$ of broken stone, and $4 \frac{1}{2}$ of gravel. $\mathrm{Up}$ to a height of 16 inches $(40 \mathrm{~cm}$.) from the ground, the layer of concrete was made thick enough to join on to the sides of the level, in order to assure a firm foundation. Above that height it was made only 6 inches thick, the sides of the level having been previously built up with dry walling.

The centering could be removed at the end of three days, but it was usually kept in four or five. It was found that five men could

* Pamphlet describing the exhibits of the Mansfeld Company at the Berlin Exhibition for the Prevention of Accidents, 1889, p. 20. 
put in $6 \mathrm{~m}$. (20 feet) of concrete lining in a shift of twelve hours. The cost per running metre was $3 \mathrm{I}$ marks $70 \mathrm{pf}$. ( $£$ I $8 s .4 d$. per yard).

Shafts.-Like levels, shafts are lined with masonry, brickwork, or concrete, and these have the advantage of being far more permanent than timber, and of requiring fewer repairs.

When due weight is given to the fact that the shafts are usually the main thoroughfares of a mine, the necessity of having a lasting lining becomes very evident.

This kind of shaft-lining is especially desirable in loose ground near the surface, because if the working is discontinued temporarily, the shaft still remains secure and available for use at any future time; whereas if timber is put in, it soon decays, the top of the shaft collapses, and much expense is incurred in the process of reopening it.

Another immense advantage of a shaft without timber is its immunity from fire.

The section of walled shafts is generally circular, as affording the best resistance to pressure. Elliptical walling is also met with,

FIG. 283 .
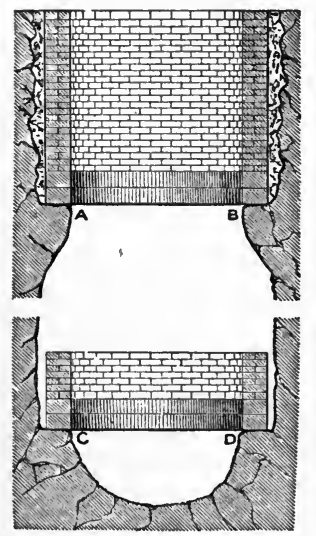
and sometimes the two long sides are made with a flat curve, and the two ends with a curve of much shorter radius. The walling may be dry or with mortar, according to circumstances. The masonry lining is put in either in one length, or in successive rings or sections in descending order, and this is the usual plan.

The shaft is sunk to a certain depth with a temporary lining of timber, and when firm ground has been reached, a bed is cut out on which is placed a crib or curb, A B, Fig. 283, * consisting of segments of timber forming a ring. This serves as a foundation for the brickwork, which is built up to the surface; the temporary timbering is sometimes left in and sometimes removed as the work progresses, and any vacant space is filled up with earth or concrete. Sinking is then resumed, and of a smaller diameter for a certain distance, so as to leave a bracket or ledge to support the curb. On arriving, after a certain depth of sinking, at another firm bed, a second curb, C D, is put in, and a second ring of brickwork built up. When the intervening ledge of rock is reached, it is carefully removed in small sections, and the brickwork brought up to the first curb. This process is repeated until the shaft is completed, or reaches rock in which no masonry is requisite. If,

* J. Callon, Lectures on MIining, vol. i. atlas, plate xxviii. 
owing to the nature of the ground, it is impossible at first to find firm seats for the curbs, it becomes necessary to hang them by iron bolts from a strong bearing frame at the surface, or to support them on iron bars fixed in the sides.

Fig. 284 shows a concrete lining put in at the top of the main shaft at Foxdale mine, in the Isle of Man. The shaft is rectangular, I 3 feet 6 inches by io feet 6 inches. The concrete serves not only to support the sides in the lcose, weak ground near the

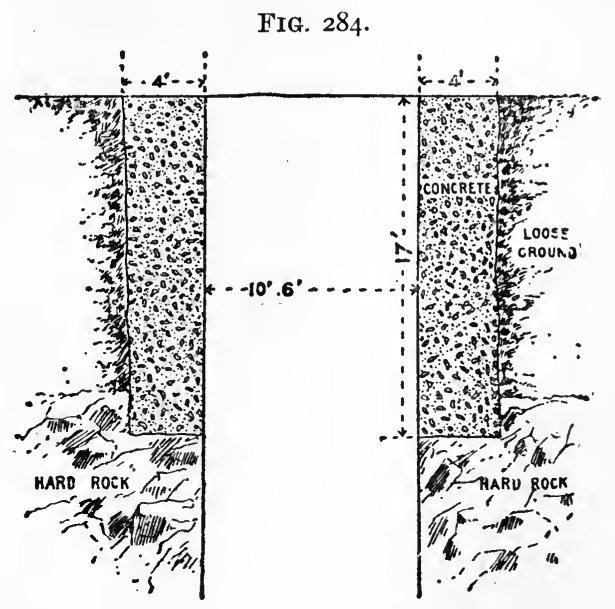

top, but also to keep out much of the surface water. The concrete was made of 4 parts by volume of stones $2 \frac{1}{2}$ inches to 3 inches across, 2 parts of sharp sand and I of Portland cement, and the total cost for materials and labour was I $3 s$. $6 d$. per cubic yard.

Some shafts in Germany have lately been lined with concrete blocks shaped so as to fit the curvature of the sides.* Each block is fluted at the top and at the ends, whilst the bottom has a beading, which lies in the channel of the block below it. As the blocks may weigh as much as one-third of a ton each, it is convenient to have some easy means of handling them. A vertical hole is therefore left in each block which receives a ring bolt, fixed by a cotter inserted through a horizontal hole. The block can then be easily slung to a rope and lowered into position, and on knocking out the cotter the bolt can be withdrawn. The spaces between the blocks, and also the bolt-holes, are filled with cement; the shaft thus receives what is practically a solid lining of concrete, which, besides supporting the ground, keeps back water and acts the part of tubbing. As pointed out by $\mathbf{M r}$.

* Zeitschr.f. B.- II.- u. S.-Wesen, vol. xxxix. 189r, p. 98. 
Brough,* a lining of this kind has the advantage over cast-iron and timber of not corroding or decaying, besides which its strength increases with age, and any expansion or contraction from changes of temperature are inappreciable. Finally, it is far cheaper than a lining of brickwork or iron.

The Monier system consists in strengthening the concrete by a coarse net-work or skeleton of iron wire embedded in it. Reinforced in this way, the fabric has greater tensile strength.

Working Places.-In temporary excavations, like working places, rough pillars, built up of lumps of waste stone or of the

FIG. 285 .

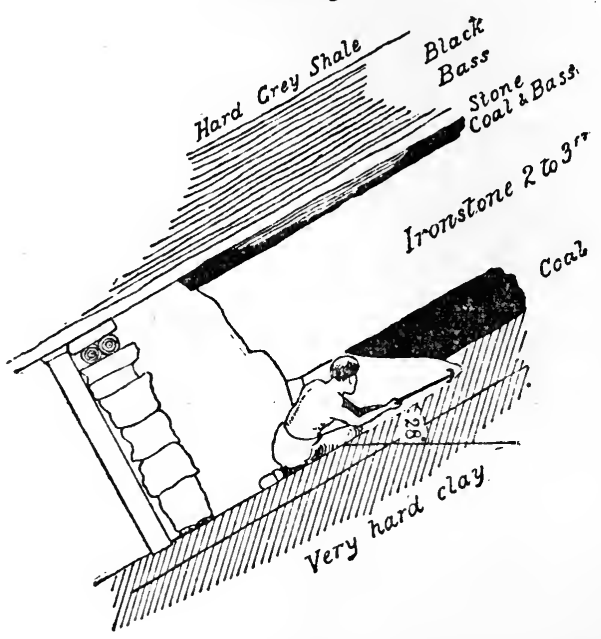

useful mineral itself, will take the place of timber in supporting the roof, or may be used as an adjunct to it, as is the case in Fig. 285, borrowed from Mr. Sawyer. $\dagger$

The timber at the top serves to make the pressure come gradually upon the stone. The post is eventually drawn out and the stone recovered.

Walls are also built up with waste stone enclosing spaces which are filled up with any available rubbish; and in some instances excavations are entirely packed with rubbish after the removal of the useful mineral.

It is only in exceptional cases that it is possible to incur the expense of building pillars with cement or mortar to support the roof and sides of working places; but masonry or concrete

* "Notes on the Use of Cement in Shaft-Sinking," Proc. N. E. Inst. II. E., 1893 .

† Op. cit., Fig. 4. 
arches may be constructed for carrying the rubbish used for filling the vacant places left by workings upon mineral veins.

METALLIC SUPPORTS. - There are various ways of using iron and steel as supports for levels, shafts and working places.

Levels.-In one part of the Halkyn Drainage tunnel, Flintshire, a combination of cast-iron and wrought-iron has been employed. Much of the level is in hard, solid limestone, and requires no lining of any kind; but where small beds of shale were intermixed with the harder rock, timber supports were put in. As the timber originally used was showing signs of decay, it was decided in 1887 to replace it by a more lasting material-iron.

The nature of the Halkyn supports will be easily understood by Fig. 286. There are two vertical props or legs, which are hollow cylinders of cast-iron, 6 feet 6 inches long, 5 inches in diameter

FiG. 285.

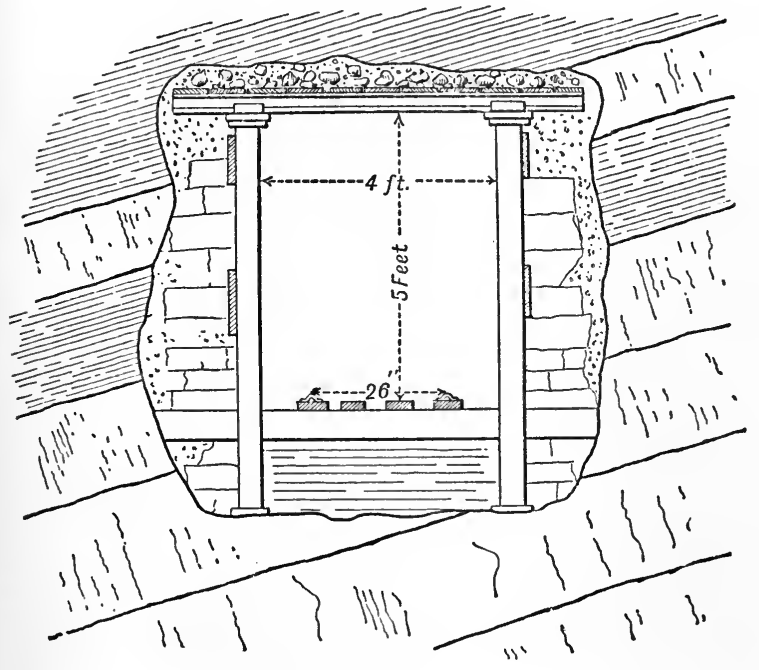

FiG. 287.

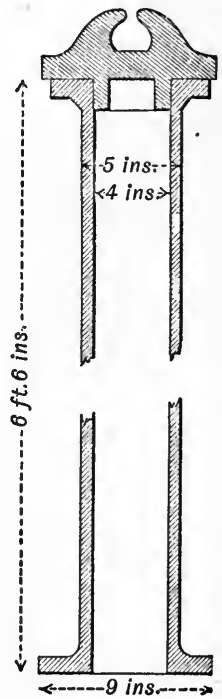

externally, and 4 inches internally, with a flange 8 inches in diameter at the top, and 9 inches in diameter at the bottom.

A chair, shown in section by Fig. 287, drops into the top of the iron column, and receives a reversed iron rail, 7 feet long, weighing II $_{7} \mathrm{lb}$. (50 lb. to the yard), the precise shape of which is shown on a larger scale by Fig. 288. The iron frames are placed about 3 feet apart, planks or rails are laid from one to the other, and the space between them and the roof tightly packed with stones. A dry stone wall is built up on each side, with an occasional plank or rail to make it firmer. Fig. 286 also shows a timber 
"spreader" above the water level, carrying longitudinal sleepers with bridge rails forming a waggon-way with a 26-inch gauge.

This method of support is designed for a case where the roof is weak, and where no great pressure is expected from the sides. It

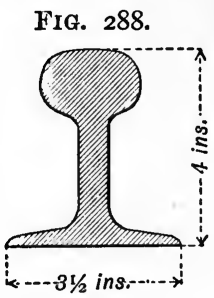

FIG. 289.

would evidently be unsuitable for the Cornish County adit in Gwennap, because the water would speedily eat away the iron. In the Halkyn adit, however, no corrosion need be feared; for iron rails which were laid near the mouth of the tunnel very many years ago have not been injured by the water. Its cheapness, as compared with the cost of the walling, was the reason why iron was adopted in Flintshire. It was estimated that to secure this part of the adit with the best Buckley brick and hydraulic lime, would cost over $f 4$ per yard, whereas the present method has cost only $£_{2} 4 s$. per lineal yard of tunnel. It cannot be denied that a brick lining would be more permanent, as the planks in the roof of the level will have to be replaced from time to time; but the cost of repairs is likely to be slight. In more recent work iron rails and old fire-bars are used instead of wooden lagging.

Steel beams have been used with success for some years at the Nunnery Colliery, Sheffield, in the place of timber. They are of I-section, 4 inches wide, 5 inches deep, with the web $\frac{3}{8}$ inch thick (Fig. 289), and they are considered by Mr. Bainbridge, the managing director of the colliery, to be of the same strength as I 2 -inch Norway balk. The beams are supplied in lengths of $6,7,8,9$, and ro feet, so as to suit drivages of various widths. There are two ways of using them-(I) as "bars," or caps, resting upon the timber legs; (2) as legs and caps.

Fig. 290 shows the former method-a horizontal cap, io feet long, rests upon two legs of round Norway timber, $8 \mathrm{to}$ ro inches in diameter, and a lug or band of wrought iron, $1 \frac{3}{8}$ inch by $\frac{3}{4}$ inch, shrunk on, prevents the leg from coming in sideways. The frames or sets are generally placed 3 feet apart, and old timber laid across from cap to cap forms the so-called lofting supporting the roof.

The steel beams are tarred over with unboiled gas tar, and some have been in use several years without showing any signs of deterioration, whereas the average life of English larch or Norway timber, at this colliery, is only two years. 
The beams cost about $£_{5}$ ros. per ton, delivered at the colliery; in other words, a ro-foot beam costs $8 s$. A beam of Norway timber ro feet by 12 inches by 12 inches would contain ro cubic feet, and at $8 \frac{1}{2} d$. per cubic foot, would cost $7 s$. I $d$. The difference in original cost is therefore not very great.

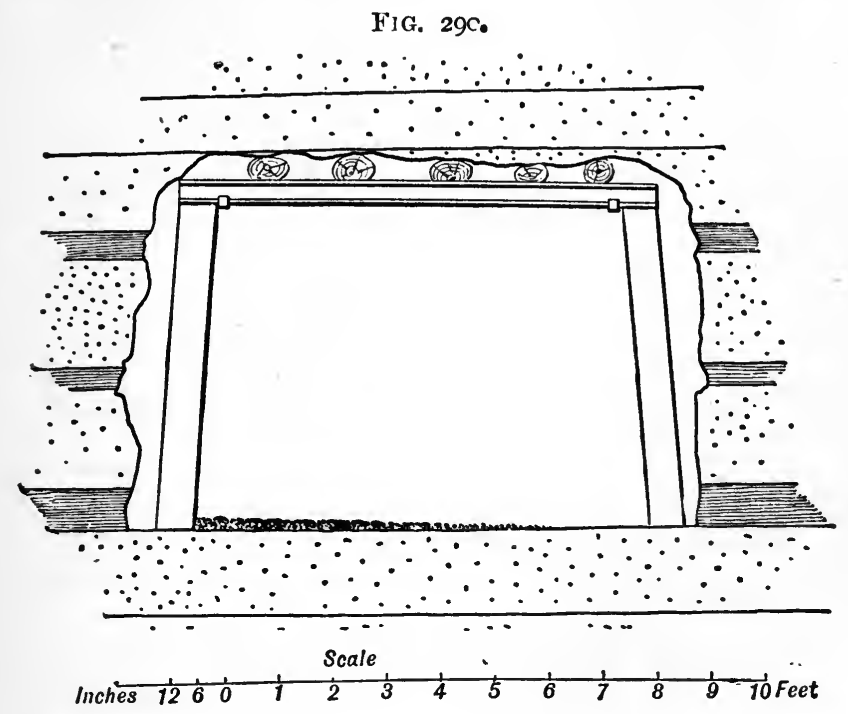

The advantages of the steel over timber beams are numerous :

I. Greater durability, which means a great reduction in the cost of repairs.

2. Possibility of using the beams elsewhere when taken out. If bent slightly, they can be reversed; if badly knocked about, they can be sent to the steel works and worked up again. In any case, they are of some value.

3. Lightness and handiness. A ro-feet steel beam weighs $\mathrm{x} 66$ lbs.; a Io-feet beam, 12 inches square, of Norway timber, weighs 3 cwt. The steel beams are not only lighter, but also less bulky, and consequently more easily handled. Therefore men can do more work in a given time.

4. Increased space for ventilation. The free space in a level will be from 5 to 7 inches higher with steel than with timber in lining an excavation of a given size. Six inches added to a height of 6 feet means an increase of $1-12$ th, or $8 \frac{1}{2}$ per cent., in the area of the airway.

5. Less deterioration of the air of the mine by decaying timber.

6. No danger from fire.

When girders are used as legs as well as caps (Fig. 291), a plate 
of rolled steel, of the shape shown in Figs. 292 and 293, is placed at each extremity of the leg. The plate is $\frac{1}{4}$ inch thick, $6 \frac{5}{8}$ inches

FIG. 29r.

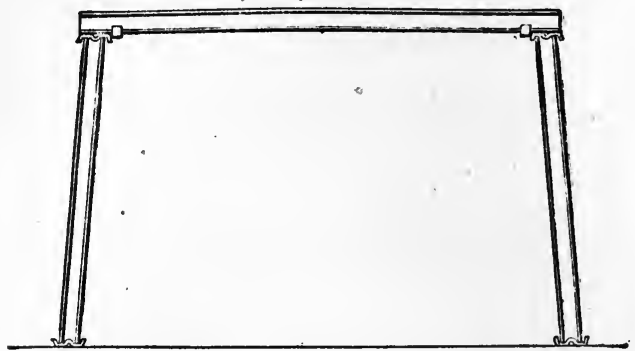

Fig. 292.

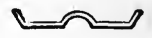

Fig. 293.

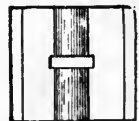

long, by 6 inches wide, with a slot $\frac{1}{2}$ inch wide and $2 \frac{1}{8}$ inches long. The web of the leg passes into this slot and is thus prevented from slipping sideways, while the turned-up rim prevents slipping outwards or inwards.

Lugs of wrought iron aro shrunk on to the cap as in the previous case.

In making the comparison of cost, it is necessary to recollect that I have chosen a case extremely favourable to steel, because the beams are made at Sheffield, and any waste material can be

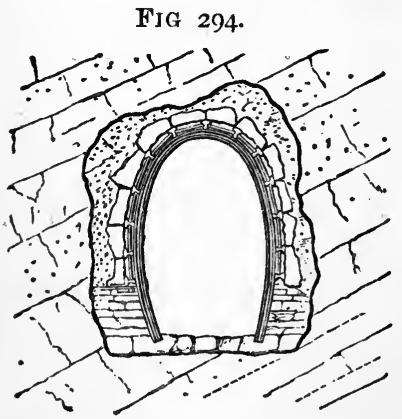
worked up again on the spot without having to pay a heavy cost of carriage back to the steelworks.

One kind of joint used in Belgium* for $\mathbf{I}$-iron is a flanged bonnet of cast-iron, which receives the top of the leg and one end of the cap. A wooden wedge is placed in the bonnet under the cap, so as to give a certain amount of elasticity to the frame.

In doing work with a new material, a servile imitation of the old forms is often remarked. "The fact of timber being most readily obtainable in straight pieces naturally led to the adoption of rectangular, trapezoidal or polygonal forms for supporting linings; but there is no necessity with iron or steel for copying the shapes which are most suitable with wood. This n as recognised by the Germans in the early days of iron supports. A method in use in the Hartz in 1872 consisted in bending an iron

* Habets, "Le matériel et les procédés de l'Exploitation des Mines," Extraits des Rapports du Jury International des Récompenses de l'Exposition Universelle d'Anvers, i885. Paris and Liége, I887, p. 6г. 
rail as shown by Fig. 294, and making it support other rails laid longitudinally, against which flattish stones were placed; the vacant place between these and the rock was filled with rubbish. The ends of the rails were footed in holes cut in large stones.

FIG. 295 .

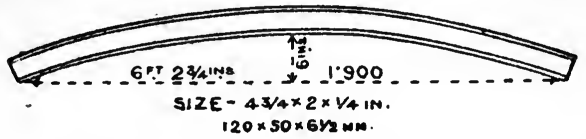

Some neat and effective forms of steel supports are made in France, where more attention has been paid to the subject than in this country.

Three kinds made of I-steel by the "Société anonyme des FIG. 296.

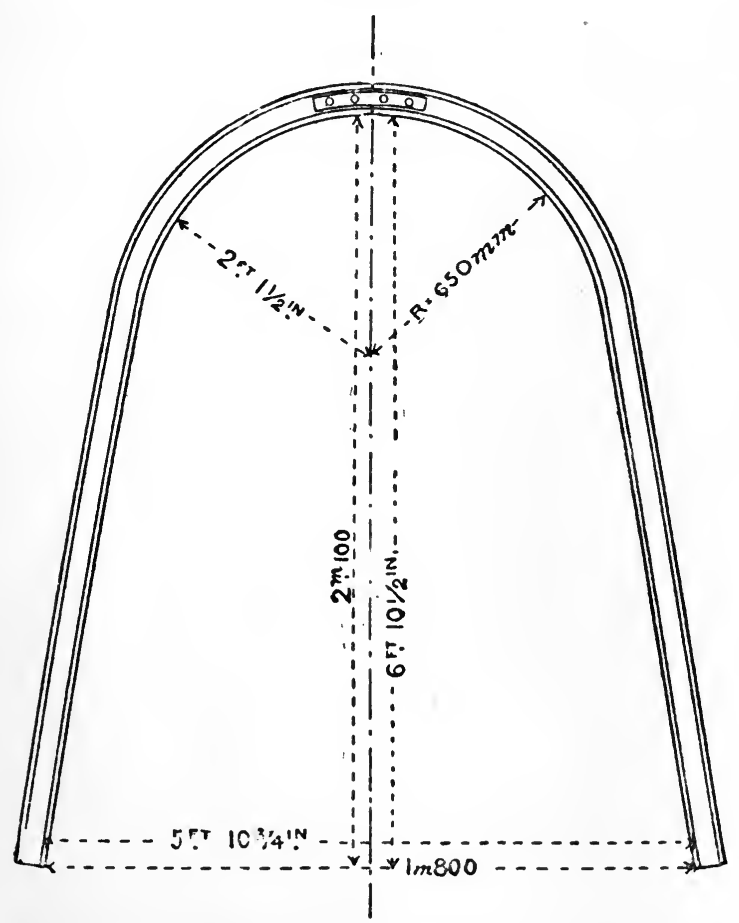

Hauts-Fourneaux, Forges et Aciéries de Denain et d'Anzin," will serve as good examples of steel supports for levels.

Fig. 295 is a slightly bent bar, the ends' of which are made to 
rest upon dry walls at the sides of a level. It, therefore, takes the place of an arch. Fig. 296 represents a favourite form of

FIG. 297.

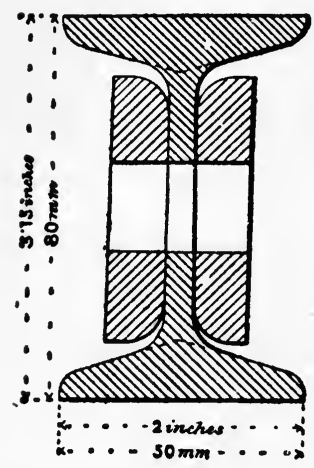
lining for levels ; it is composed of two side-pieces suitably bent at the top, and united by a couple of fish-plates (Fig. 297) and four bolts; in some cases a cast-iron sleeve is used instead of the fish-plates. When the floor is soft and liable to "creep," the frame may be made of three pieces (Fig. 298).

Some mines utilise old rails, weighing 36 to 40 lbs. per yard ( 18 to 20 kil. per metre) for frames. The rails are bent into semicircles, and two of these are united by sleeves of riveted sheetiron, in which they are kept tight by wooden wedges. Elliptical frames are used in the Freiberg district, made of two pieces of rail held together by a couple of fish-plates at the top and bottom.
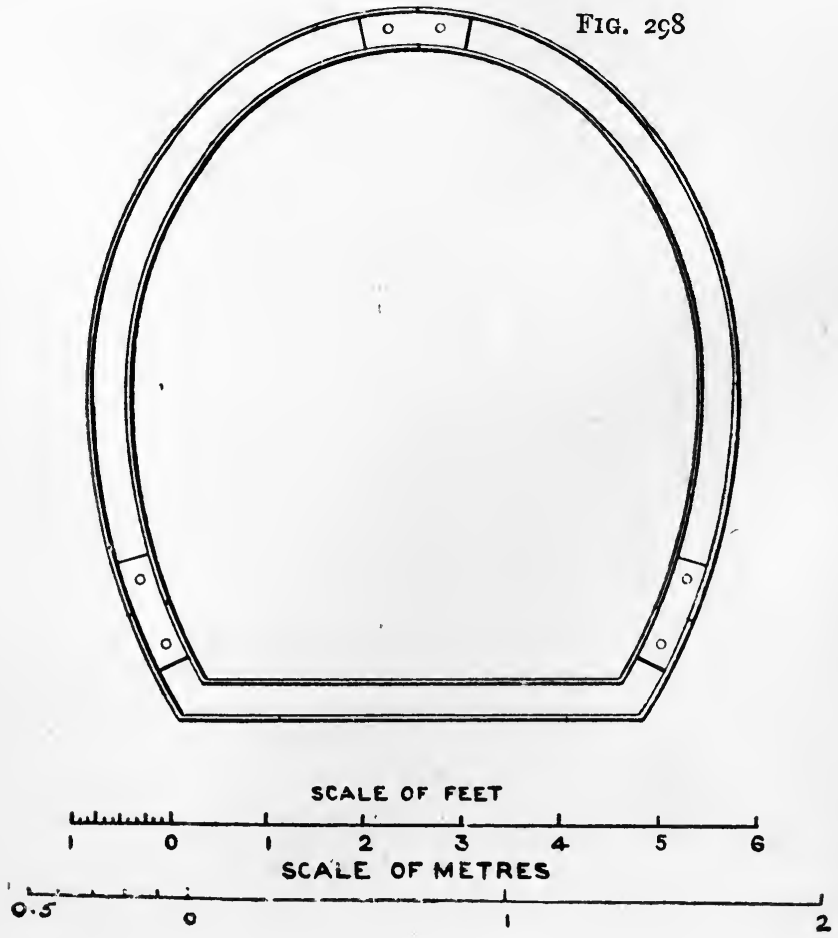
The frames made by the "Compagnie des Fonderies et Forges de l'Horme" (Loire) are almost invariably composed of two semicircles of mild steel. Two kinds of sections are employed-

FIG. 299.

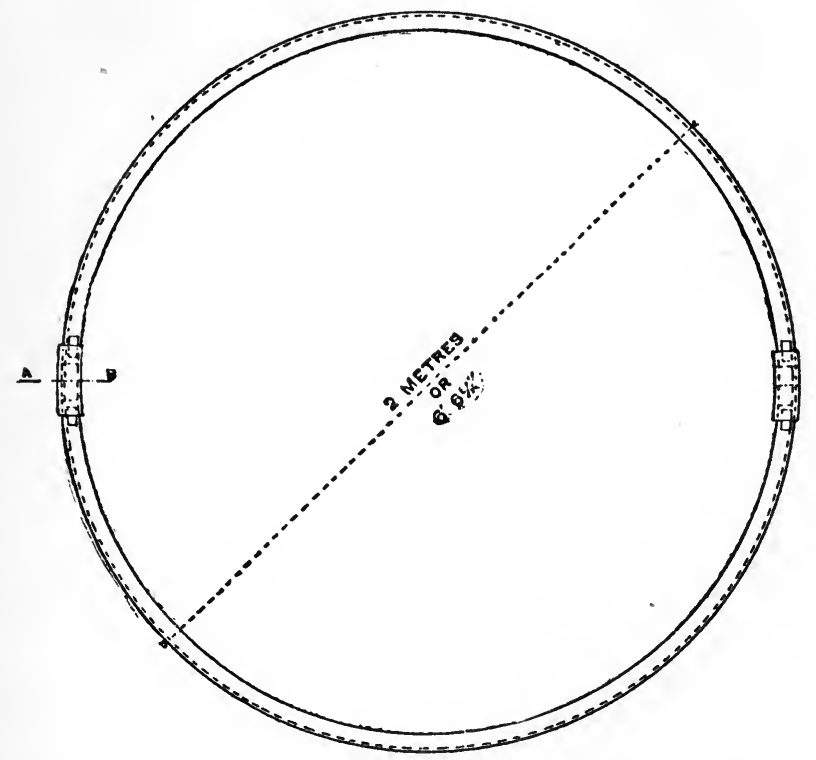

namely, channel steel and bulb tee steel. Bars of channel steel, 70 $\mathrm{mm} . \times 40 \mathrm{~mm}$., weighing I $6 \mathrm{lbs}$. to the yard, are sawn into proper lengths on leaving the rolls, and while still hot are bent into semicircles. The ends are carefully planed square, so that the top semicircle may rest accurately upon the lower one (Fig. 299). They are joined by sleeves made of sheet-steel, fixed by a couple of small iron wedges (Fig. 300). It is claimed by the Horme Company that these FIG. 300.

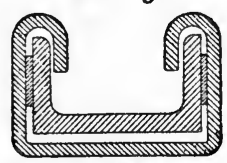

ection a frames never give at the joint.

Steel of bulb tee section, weighing 26 lbs. per yard, is employed for heavier ground (Fig. 30I). The sleeves are made of riveted sheet-steel, and are fixed by two wooden wedges, one on each side of the web (Fig. 302). Bars of $U$-steel of a hollow semicircular section are used as the lagging; the steel is $\frac{1}{8}$ inch thick and about $\mathrm{I}_{4}^{\frac{1}{4}}$ inch in diameter, weighing scarcely $2 \mathrm{lbs}$. per yard (I kilo. per metre), and it is usually cut in lengths just sufficient to go from one frame to the next. Small bars of steel of square section are employed for the same purpose. 
Iron and steel may be used with advantage instead of timber for the construction of supporting platforms (stulls) in veinmining. At Freiberg* full-sized rails are employed as crossbeams (stull-pieces); they are covered with small mine rails,

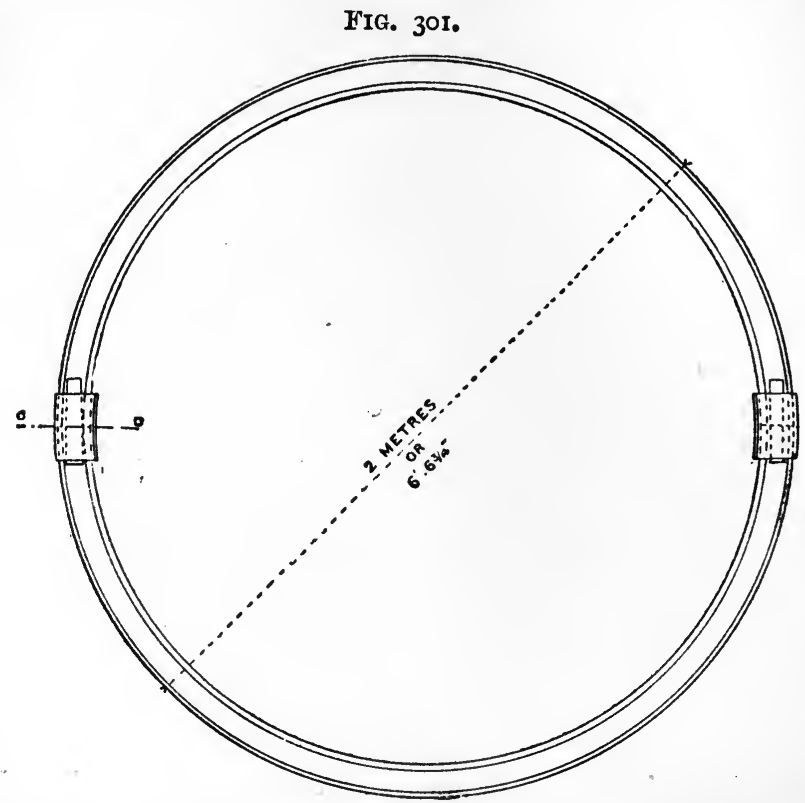

and these with flat stones. Where the pressure is not very great, wire rope is used for the covering. The rope is cut into pieces about 2 metres long, and the ends are

FiG. 302.

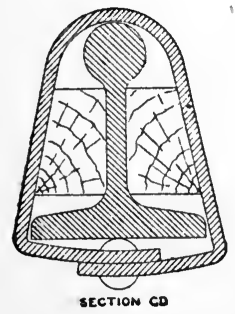
welded up and bent into hooks. These pieces are laid across the iron stull-pieces and covered with stones and rubbish.

In places where the two walls of a lode are likely to come together a little after a time, the stull-pieces are cut about I or $\mathrm{I} \frac{1}{4}$ inch shorter than required, and a wooden wedge is put in at each end. The pressure of the ground squeezes up the wedges gradually, and finally the rock comes against the iron. The rails used as stullpieces are often slightly arched so as better to support the weight of the rubbish, and the flange of the rail is placed underneath, as its long straight edge gives a better hold in the rock than its head. The rails are not cut across at right angles to their length, but are made somewhat longer above than below,

* Freilergs Berg- und IIittenwesen, Freiberg i. S., 1893, p. 176. 
in order that they may not drop through if small pieces of rock break off under them. In addition to all sorts of small rails, old fire-bars and old boiler-plates are occasionally utilised for "lagging."

A new departure in driving tunnels in soft ground is furnished by the Greathead* shield, by the aid of which two long parallel tunnels have been driven through clay and gravel, in London, for passenger traffic by an electric railway. As cases may arise in mines where this method would be available, it is desirable to explain briefly the mode of working adopted, and to indicate the sources where full details will be found. The tunnels of the City and South London Railway may most easily be described as long tubes of cast iron, built up ring after ring as the excavation progressed. The rings are $I$ foot 7 inches long, made in seven segments bolted together by $\frac{3}{4}$-inch bolts passing through the internal flanges. They therefore closely resemble the watertight lining of shafts known as " tubbing," to which reference will be made later.

The ground in the centre part of the end of the tunnel was dug out, and a cylindrical shield was forced forward by hydraulic jacks. The shield had a cutting edge and penetrated into the clay under the pressure. The clay was removed as the shield went forward, and at last, when the advance amounted to 20 inches, a new ring was formed by bolting together the segments, which then exactly fitted the inside of the shield. The progress of the shield left an annular empty space $1 \frac{1}{2}$ inches deep between the last ring and the surrounding clay, equal to the thickness of the shield. T'his was filled by injecting Lias lime grout through a hole in each segment, and so encasing the tunnel in concrete. The average progress per day was 13 feet 6 inches.

When the tunnel came to waterbearing gravel and sand, it was necessary to have an air-lock and keep the water back by compressed air. In order to prevent the escape of air into the porous gravel, the

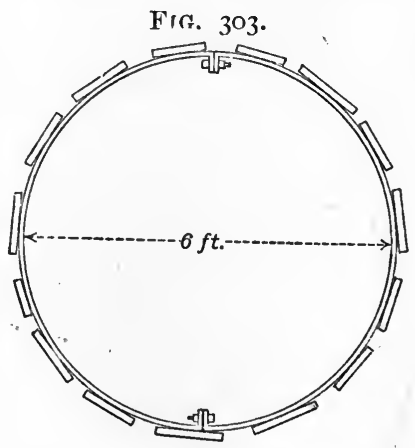
face was cut away in sections, and as each portion was exposed, a jet of grout was played upon it to close the interstices.

Shaft Linings of Iron.-Fig. $3 \circ 3$ shows a method of temporary support for sinking little shafts $3 \circ$ or 40 feet deep. Iron rings, 4 feet 6 inches to 8 feet in diameter are employed to keep lining planks in position. The rings are made in two or three segments, bolted together inside. The iron used is from $1 \frac{1}{2}$ to $2 \frac{1}{2}$ inches wide by $\frac{1}{2}$ inch thick. 
FIG. 304 .

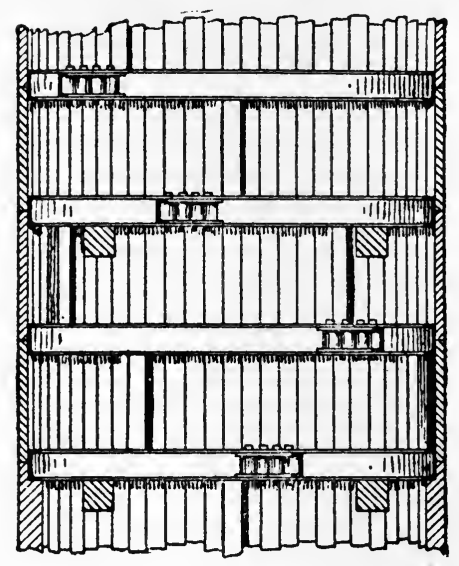

FIG. 355 .

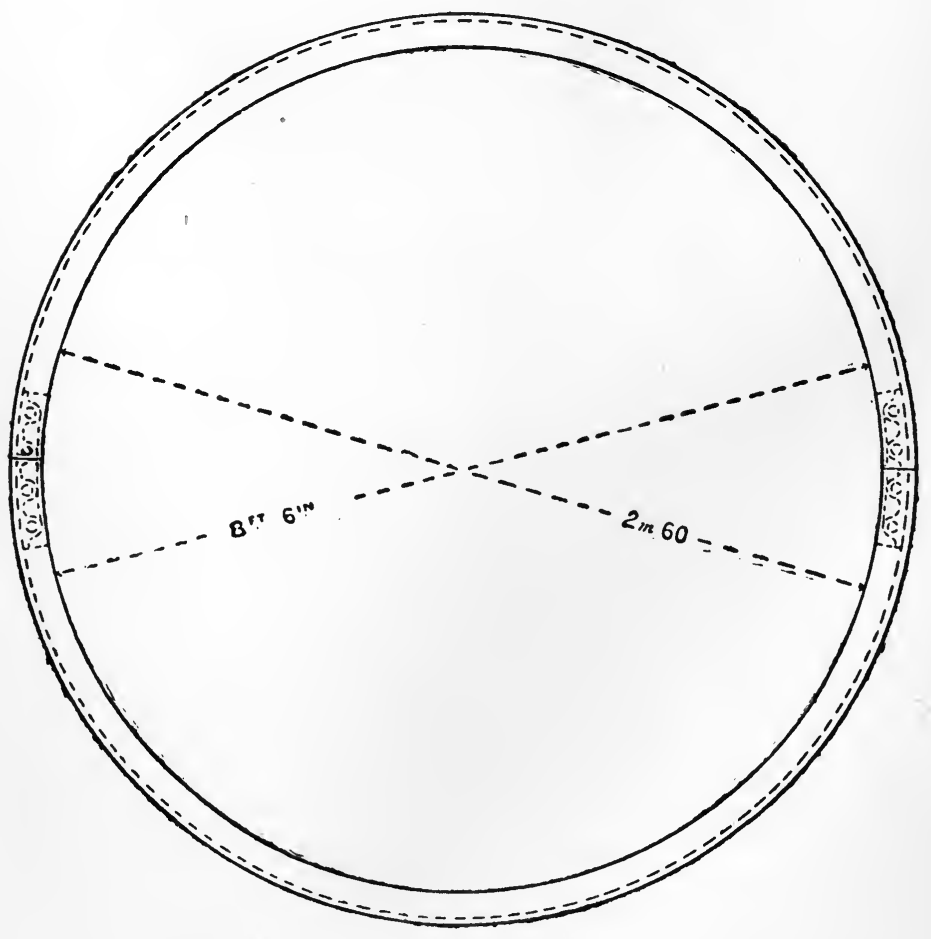


The rings may be hung one from the other by iron hooks, and channel iron may take the place of the flat iron in the circles around the shaft.

Steel and iron rings are also used in the case of permanent supports for shafts. The accompanying figure (304) shows the lining of a shaft at Boryslaw, adopted by Herr Platz, the director of the ozokerite mines belonging to the "Compagnie Commerciale Française." The shaft is kept open in very heavy ground by rings of channel iron placed I metre apart from centre to centre. Each ring is made in two halves and these are connected by two special castings, with holes for bolts ; they act the part of fishplates, two bolts being on one side of the joint, and two on the other. Around the rings come oak planks, 2 inches thick, and there are four distance pieces (studdles or posts) between every two rings. At intervals of 2 or 3 metres, two oak bearers are placed across the shaft, which serve to take up the weight of the rings if necessary, though, as a rule, the pressure of the ground holds the rings very firmly. The bearers are also utilised for carrying the guides or conductors for the cage.

Fig. 305 represents a ring simi-
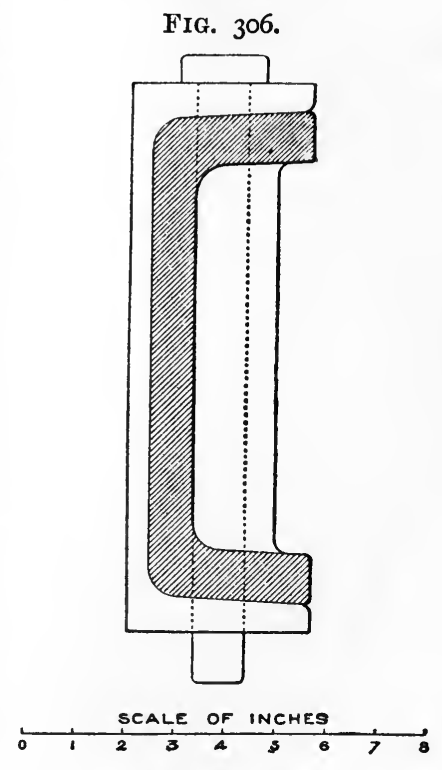
lar to those used at Boryslaw, made by the Witkowitz Ironworks for a shaft 8 feet 6 inches in diameter, and Fig. 306 gives the details of the connecting piece and bolts.

Working Places.-We may start with simple cast-iron props used instead of timber in places where they can be withdrawn. They are rather heavy, but they will serve over and over again. At some collieries a large number of these props, from 3 feet 6 inches to 5 feet 6 inches long, are employed, and they appear to give satisfaction. Naturally they have to be made of the same height as the particular seam which is worked, but any minor irregularities in the roof are suited by the thickness of the lid, or by making the lid of two pieces of board. They are set with the small end downwards. Cast-iron props are not suited for resisting cross pressures, and they are liable to break occasionally when they happen to fall. 
Howell's prop is a hollow lap-welded steel tube or pipe, 4 inches in diameter outside, with the ends expanded till they are slightly conical, in order that the top may receive a wooden plug which projects about $\frac{3}{4}$ inch above the steel. These props are used alone in working places, or in conjunction with bars of I-steel, to support the roadways. The foot of the prop in this case is set out about 6 inches in the bottom so as to prevent it from coming in sideways. The object of the plug is to obtain a certain amount of elasticity.

A third kind of prop is made of I-iron or steel, either cut off square or with the web cut out for a few inches, and the two flanges turned over so as to make ends with a larger bearing

FIG. 307.

FIG. 308.
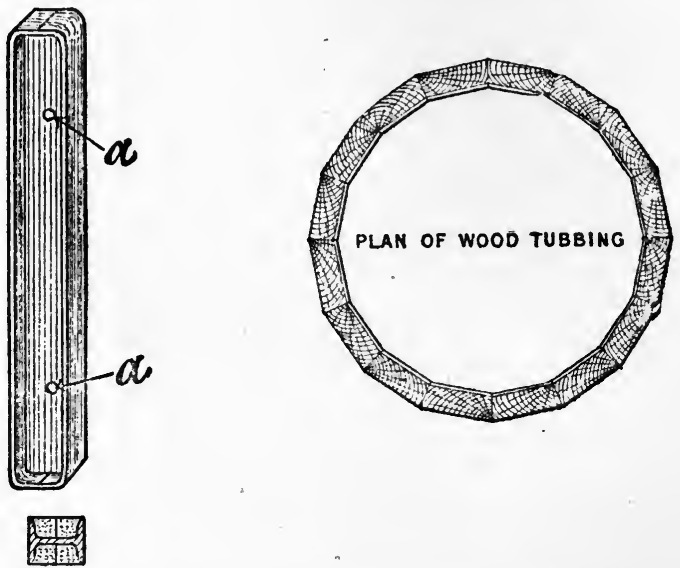

surface (Fig. 307). The holes $a a$ enable the props to be withdrawn by a hook.

WATERTIGHT LININGS FOR SHAFTS.-We must now turn to the spesial case of shafts which have to pass through watery strata. Here it is often advisable to put in a watertight lining, in oxder to prevent the inflow of water, and so save the expense of pumping it out day after day, and year after year.

The lining may be made of wood, brick, and hydraulic lime or cement, or, lastly, iron.

There are two kinds of wooden tubbing: (I) Plank tubbing, whence this kind of lining originally received its name; and (2) solid timber tubbing. Plank tubbing is made of boards from 2 to 3 inches thick, arranged vertically round the shaft and cut with a bevel like the staves of a cylindrical barrel. The planks are nailed on to rings of wood placed at suitable intervals. 
Solid wooden tubbing (Fig. 308) consists of carefully shaped blocks of oak or elm, with thin sheets of deal placed between the joints. The joints are wedged up as tightly as possible, and a lining of this kind can be made so as to resist a very considerable pressure of water, even 200 to $300 \mathrm{lbs}$. per square inch.*

The method known as "coffering" consists in lining the shaft with a wall made of brick and cement, or brick and hydraulic lime, and backing this up with puddled clay. It is specially used for keeping back the surface-water.

Full details concerning this method will be found in the paper $\dagger$ quoted below, and my description may be very brief. In one particular instance the shaft received first of all a temporary lining of 9-inch brickwork put in dry during the course of sinking, the successive sections being held up by wooden cribs or curbsthat is to say, rings of oak placed 4 to 5 feet apart. Each ring was hung from the one above it by vertical pieces of $I_{2} \frac{1}{2}$ inch plank

FiG. 309.
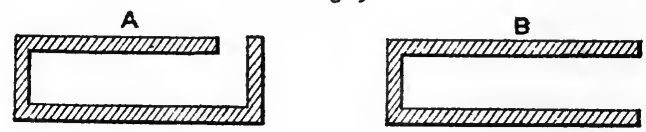

spiked on to both rings. When firm ground below the watery strata had been reached, a level bed was cut for putting in the wedging-crib-a ring made of segments of cast-iron, either like A or B in section (Fig. 309). By means of wedges driven in behind, it was made perfectly tight and stanch. Three courses of brickwork made with Roman cement were built up on the crib and the wedges behind it; they formed the foundation for the "coffering " proper, which consisted of three rings of brickwork in hydraulic mortar E E (Fig. 310), separated by the two rings of hydraulic mortar F F, and the puddled clay $D$. B represents the original lining of nine inches of dry brickwork put in against the watery strata. As water running down the sides of the shaft would render it impossible to carry out this kind of work satisfactorily, means had to be adopted for getting rid of it. A garland or circular launder was fixed around the shaft so as to intercept it before it could interfere with the work of coffering, whilst water coming in behind the coffering was drawn off during the progress of the work by placing a vertical launder against the preliminary lining of bricks. This launder was pierced with holes every three inches, and communicated at the bottom

* E. Bainbridge, "On the Kind-Chaudron System of Sinking Shafts through Water-bearing Strata," Proc. Inst. C.E., vol. xxxiv., 1871-1872, Plate 12.

+ N. R. Griffith, "On the Coffering of Shafts to keep back Water," Trans. N. Eng. Inst. Min. Mech. Eng., vol. xxvi., 1876-77, p. 3. 
with a block of wood which had a 3 -inch hole bored through it, opening into the shaft just above the wedging-crib. As it became

FIG. 3 I0.

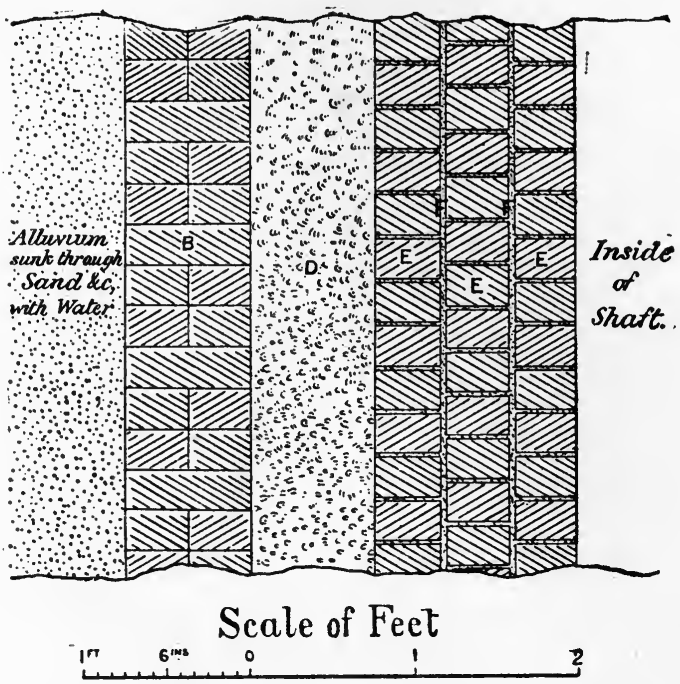

gradually buried by putting in the clay $\mathbf{D}$, the holes were plugged up, and finally the launder was filled with pieces of stone, and cement was run in.

The walling was done with hydraulic mortar, made of one of blue lias lime to two of sand, and the middle course was grouted in, either with a similar mixture or with pure Roman cement.

The advantage of coffering over the ordinary metallic lining known as tubbing is its cheapness. Mr. Griffith puts the cost of coffering a shaft he sank at $£$ Io $5^{s}$. per yard, and he estimates that a suitable cast-iron tubbing would have cost $f_{2} 3$ per yard. The pit was 20 feet in diameter clear within the original lining of dry bricks, and as the coffering was 2 feet thick, the final diameter of the pit was reduced to 16 feet.

Where the ground is soft, a cast-iron lining may be made to sink down by its own weight and by pressure applied to it. This process was adopted at Restronguet Creek, * a branch of Falmouth Harbour, in order to work a bed of stream-tin. The creek had Io or I 2 feet of water at high tide, and was nothing but a mudbank at low tide. A staging was constructed upon piles in the creek, in order to have room for working, and a first cylinder, with

* Taylor, "Description of the Tin Stream Works in Restronguet Creek, near Truro," Proc. Inst. M.E., 1873, p. I55. 
a cutting edge, was placed upon the mud, two more cylinders were then bolted on, and their weight caused the whole to sink down. The cylinders, made of cast-iron, were 6 feet high by 6 feet in diameter and $\mathrm{x} \frac{1}{4}$ inch thick, and they were joined by internal flanges faced in the lathe. Each ring weighed about $2 \frac{1}{2}$ tons, and was lowered by a crane through an opening in the stage, between guides in order to keep it vertical. When the first three rings had ceased to sink, the mud inside was cleared out, and further cylinders were added and forced down by pressure from the chain of a crab-winch. Afterwards an ingenious method of taking advantage of the rise and fall of the tide was resorted to. A huge girder was laid across the top ring, and a barge laden with stone was attached to each end. The fastening was made complete at high water, and when the tide fell the full weight of the barges came npon the girder, and so upon the shaft. The cylinder was thus sunk to the full depth without difficulty. During the sinking the core was always cleared out a little below the bottom of the cylinder before the barges were attached, and, if left for a day, the mud was found to swell up 3 or 4 feet into it. A total weight of about 250 tons was required to sink the cylinder

FIG. 311 .

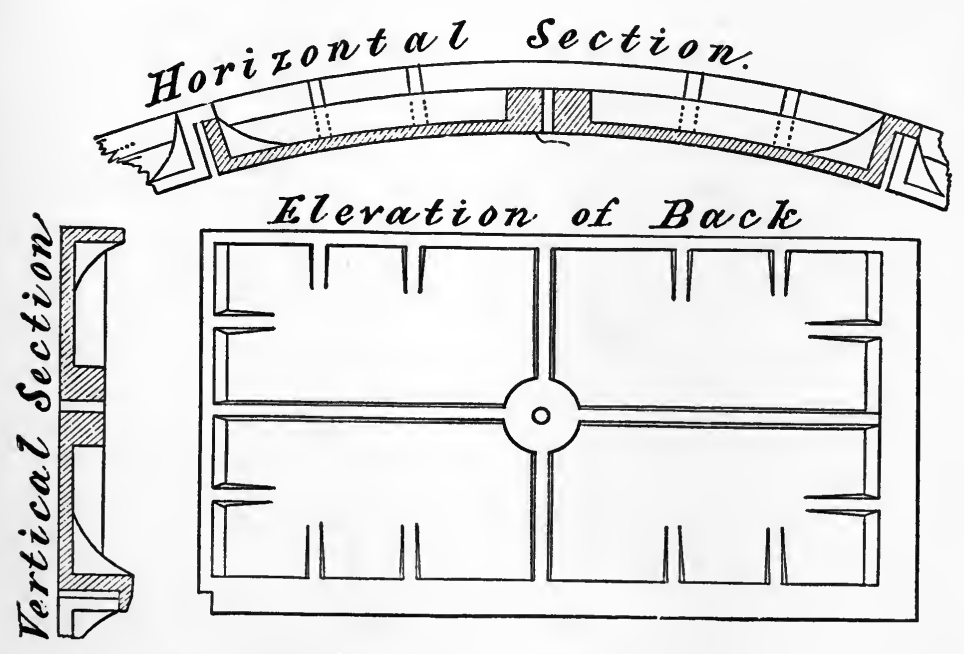

as it neared the bed of tin ore. Altogether, thirteen of the 6-fect rings were sunk, making a total depth of 78 feet.

The ordinary method of tubbing is that in which the rings are made up of segments, and as a rule the cylinder of cast-iron plates is built up within some temporary lining; this is carried down until it reaches some solid and impervious stratum below the 
water-bearing measures, fit to serve as a foundation. When such a stratum has been found, the sinking is continued for a few feet, and a bed is cut out very carefully, and trimmed perfectly even and horizontal, so as to receive the first crib or curb similar to those just described in the case of coffering. The curb is a hollow ring of cast-iron made in segments about 4 feet long. Strips of deal about $\frac{1}{2}$-inch thick are placed between every joint, and the segments are brought tightly together by wedging up the space between the outside of the curb and the rock. The joints are finally rendered perfectly stanch by driving in wedges into the deal strips. A second curb is laid upon the first, with intervening strips of deal, and the wedging process repeated; sometimes a third curb comes upon the second. The top curb is the foundation for the tubbing proper, which is built up segment after segment. The segments are usually $\mathrm{I}$ to 3 feet high and 4 feet long (Fig. 3 I I) ; their thickness depends upon the pressure of water they have to withstand and varies between $\frac{1}{2}$ inch and $3 \frac{1}{2}$ inches. They are smooth inside, but are strengthened with flanges and ribs on the side turned towards the ground.

The segments are kept in place by wedging them against the sides of the pit, and filling up the interspace with earth or concrete; thorough stanchness is secured by interposing a half-inch strip of deal or pitch pine at

FIGS. $312 \& 3$ I 3.
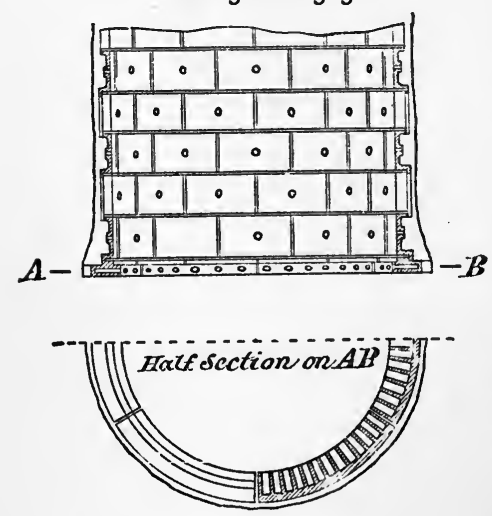
every joint, and finally driving in wedges when all the tubbing is fixed. Water coming in from the surrounding strata is allowed to escape through the central hole of each segment. A cast-iron lining cylinder (Figs. $3^{12}$ and 313 ) is thus built up inside the shaft until an impervious stratum above the water-bearing ground is reached; another wedging curb then completes the tubbing.' The joints are wedged up as tightly as possible, and finally. plugs are driven into the central holes of the segments. If the work has been properly performed, the lining will be watertight. The tubbing is sometimes put in by a succession of comparatively short sections, each resting upon its own wedging curb, and shutting off a portion of the water-bearing beds. If this method is pursued, each separate section is continued upwards to the next wedging curb above, resting upon a bracket of rock; this is cut away very carefully in small sections, and the last ring of segments made to join it exictly. When the amount of 
water is not excessive, it is usual to sink through the whole of these strata before setting a wedging curb and fixing the segments.*

In a few cases no temporary lining is used, and the segments are at once inserted in descending order, each ring hanging from the one above it. After several rings have been so fixed, a bearing-ring is put in and the wedging of the joints proceeded with. This process is repeated until strata are reached which require no such lining.

SPECIAL PROCESSES. - The amount of water met with has been sometimes so great as to render sinking by the ordinary methods quite impossible, on account of there rot being room enough in the shafts for fixing pumps sufficiently large to cope with the enormous feeders of water, and even where pumping is possible the expense may render it out of the question. A few figures quoted by Mr. Bainbridge $\dagger$ will give some idea of the enormous cost due to water-bearing beds. In Germany the sink-

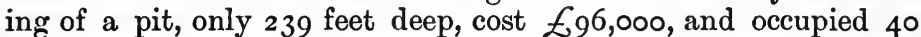
months, although the quantity of water pumped was only 606 gallons per minute. For another pit the corresponding figures were 570 feet, $£ 140,000$, 91 months, 2200 gallons. Taking eleven cases, it appears that the cost varied between $£_{36} 6$ and £245 per foot of sinking, and that the average rate at which the sinking progressed varied from $3 \cdot 9$ to $I 7 \cdot 2$ feet per month.

For dealing with cases of this kind, there are three principal methods of sinking which deserve special mention: (I) KindChaudron or boring method; (2) Triger or compressed air method; (3) Poetsch or freezing method.

Boring Method.-Kind's process as improved by Chaudron consists briefly in boring out the shaft by means similar to those employed for searching for mineral, and then lowering into the pit so formed a watertight lining of cast-iron, which can be made stanch at the bottom even under water. The great advantage of this process is that there is no pumping at all until the operations of sinking and lining are complete; and then, indeed, it is only the contents of the shaft itself that have to be drawn up.

The various stages of the process are as follows :-

(I) Alternately boring a small pit in advance, and enlarging it by a bigger tool to the full size of the shaft.

(2) Preparing a seat for the moss-box.

(3) Lowering the water-tight lining (tubbing) with its moss-box at the bottom.

(4) Putting in the outside lining of concrete.

(5) Pumping out.

This process has been frequently described at great length, and persons who require more details than can be given in a general

* Fainbrir'g, ibidem.

+ Ibidem. 
text-book will do well to consult the original papers mentioned below.*

The preliminary pit is bored 4 or 5 feet in diameter, and is always kept well in advance of the full-sized shaft, generally from 30 to 100 feet.

The tool used is a composite borer with fourteen cutting chisels $a$ fixed in round sockets (Fig. 3I4). Above the chisels there is

FIG. 3 I4. the cross-piece $b$, with two cutters, which serve
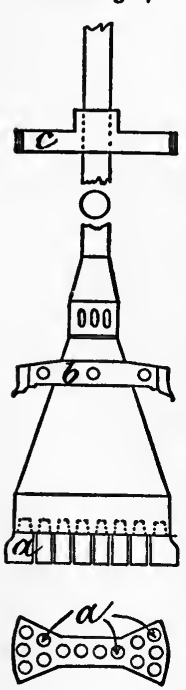
to trim off any slight irregularities; at the same time it acts as a guide, and so tends to ensure the verticality of the hole. There is also a second guide $c$ above it, without teeth. The total weight of this tool is from 7 to 8 tons. It is suspended from a series of pitch-pine rods, each 58 to 59 feet in length. Some used in Belgium were $7 \frac{3}{4}$ inches square. Those used at Marsden were only 5 inches square. At each end of the rod an iron fork is clamped and bolted on, terminating in a taper male or female screw. The top rod is connected to a strong chain hanging from one end of a huge horizontal wooden beam. The other end of the beam is attached by a chain to the piston of a vertical steam cylinder. When steam is admitted on the top of the piston, the rods and tool are raised, but as soon as the engine-man opens the valve which lets the steam escape, the rods and tool fall by their own weight, and the rock is chipped at the bottom of the hole. Two methods have been employed for avoiding the injurious vibrations of the rods which would occur if there were a rigid connection between them and the tool. One is a sliding joint similar in principle to that of Oeynhausen; the other is some free-falling arrangement, such as the catch actuated by a disc, which has already been described (Fig. 1 22).

The rods are turned in the usual way by a tiller, and they can be lowered, as the hole is deepened, by a screw similar to that used in small borings.

The mud and fragments produced in boring are cleared out by a sludger; that is to say, a hollow sheet-iron cylinder provided with semicircular flap-valves at the bottom. The sludger is sometimes worked by the rods and sometimes by a rope, which

* Chaudron, “Procédé Kind. Travaux exécutés en Belgique," Annales des Mlines, $5^{\circ}$ Série, tome xviii. pp. 435 et $s e q$. ; Smyth, "On the Sinking of Pit Shafts by Boring under Water, as practised by Messrs. Kind \& Chaudron," Trans. N. E. Inst. M. Eng., vol. xx., 1871, p. 187 ; Bainbridge, "On the Kind-Chaudron System of Sinking Shafts through Water-bearing Strata, without the Aid of Pumping Machinery," Proc. Inst. C.E., vol. xxxiv., I871-72, p. 43; Daglish, "On the Sinking of Two Shafts for the Whitburn Coal Company," Proc. Inst. C E., vol. lxxi., I832-83, p. 178. 
passes over a pulley at the top of the boring tower, and is coiled on a drum set in motion by a special steam-engine.

When a small shaft has been cut out in this way, either for part or the whole of its depth, the work of enlarging may commence. The enlarging tool is a huge composite borer (Fig. 3 I 5), with twenty-eight cutting chisels, weighing $16 \frac{1}{2}$ tons; in the centre it has a projecting loop of iron $a$, which fits loosely into the small shaft, and serves as a guide. The cbisels are arranged so as to make a sloping cut, in order that the sludge and chips may pass down easily into the inner pit.

In some cases the ordinary sludger is employed for clearing out this hole, but arrangements may be made for catching the débris in a special bucket, which is either placed at the bottom of the hole, or is hung from a little ledge cut for the purpose. When it is supposed that it is full, the boring rods are lowered and the bottom one screwed on to it. This operation might appear somewhat difficult, but by providing the female screw at the end of the bottom rod with a funnelshaped bonnet, it is guided into its proper course over the male screw on the sludger bucket, and the necessary connection is éasily made.

The shaft is thus sunk to the required depth, which must previously have been ascertained by a small borehole. When therefore it is known that a bed suitable

FIG. 315 .

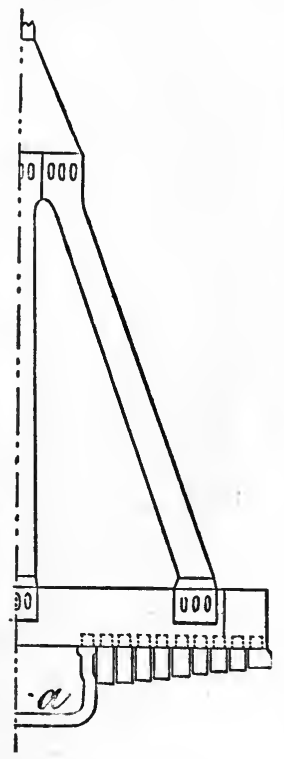
for a foundation below the water-logged strata has been reached, a seat is prepared by boring very carefully with the chisels arranged horizontally. The seat is scraped with a special tool, so as to clear off any stones, and the tubbing can now be lowered. The scraping claws can also be used just before the tubbing touches the bottom, as they will pass through the central equilibrium pipe which will be described immediately. The tubbing is made of rings of cast-iron joined by bolts through their internal flanges. A thin strip of sheet lead is put in the joint so as to make it stanch. The flanges are all faced in a lathe in order to secure not only a watertight joint, but also the perfect verticality of the whole column. At the very bottom there are two rings with flanges turned outwards, and the upper is capable of sliding down over the lower. The space between the two outer flanges is filled with moss, which is further kept in place by a net. Lastly, just above this moss-box, as it is called, a dish-like bottom is bolted on, carrying a central 
pipe which can be lengthened as the tubbing descends. The pipe is called the equilibrium tube.

The whole arrangement is best understood from Fig. $316 .^{*} \quad B$ is the bottom ring carrying the moss outside it; $A$ is the ring which can slide down over it telescopically; $G$ is the close bottom of the column of tubbing, $\mathrm{H}$ the equilibrium tube, $\mathrm{I}$ the space between

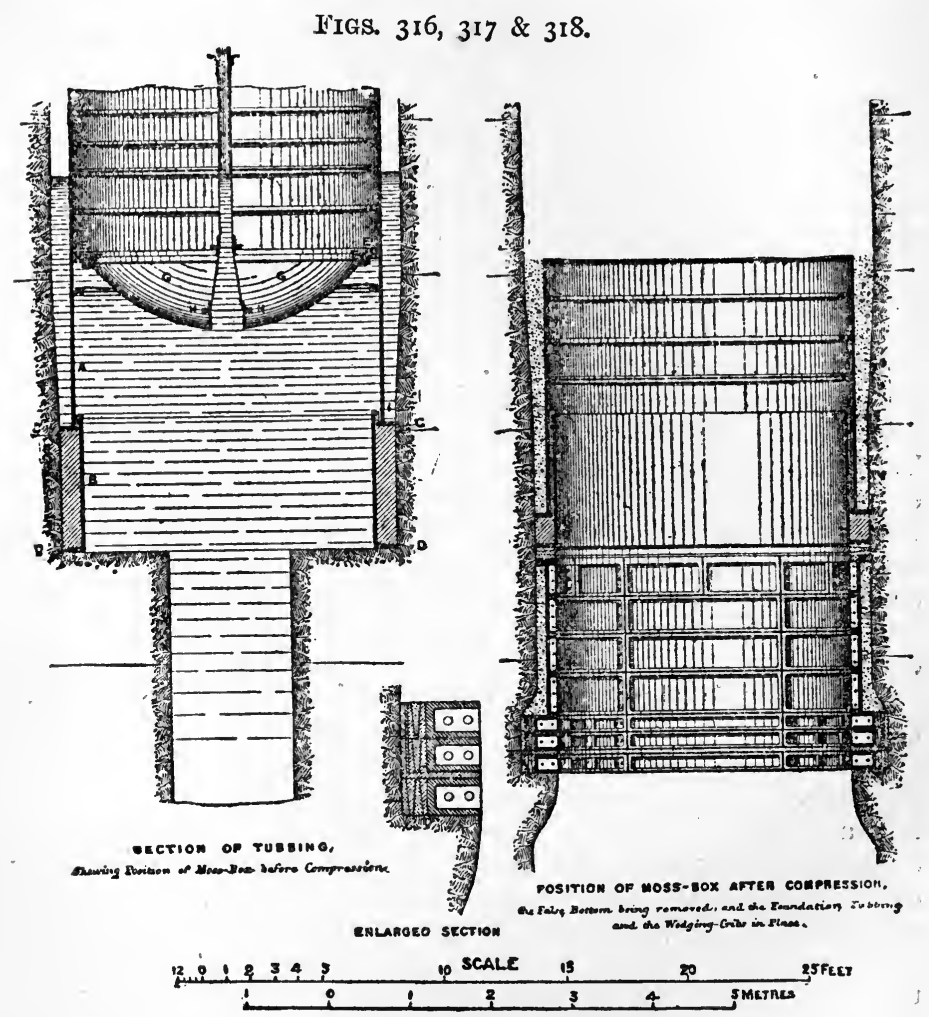

the tubbing and the sides of the shaft. The column is lowered into the shaft by means of six iron rods, to which lengthening pieces are added as required. The top part of each suspending rod is a strong screw, 13 feet long, working in a big nut on a frame above the shaft. The screwed rod, attached by a swivel to the rod below, can be turned round by a little winch. After a new ring has been put on, men at these six little winches lower the column slowly; but the whole weight of the column

* Daglish, op. exit. 
does not come upon the screws. The watertight bottom $\mathrm{G}$ causes the tubbing to displace so much water in the shaft, that the whole column could be made to float if necessary. Such buoyancy would be inconvenient; and it is desirable that the column should be made heavy enough to sink down of itself when the screws are worked. The necessary excess of weight is obtained by tapping the equilibrium pipe, and allowing a certain amount of water to flow into the annular space around it. The column weighted in this way finally arrives at the bottom of the pit, and the broad flange of the ring $\mathrm{B}$ rests on $\mathrm{D}$ as shown. When the lowering is continued, the ring $\mathbf{A}$ slides down over $\mathrm{B}$, which is stationary, and the flange $\mathrm{C}$ compresses the moss lying in the moss-box, squeezes it outwards against the sides of the shaft and makes a watertight joint (Fig. 3 I 7).

The next operation is filling up the annular space outside the tubbing with cement or concrete. The cement used in certain cases was a mixture of hydraulic lime with sand and trass. It is lowered in special boxes so constructed that their contents can be discharged when they have reached any required position. After ample time for hardening has been given, the water is drawn out of the shaft by a bucket; the dish-like bottom is now taken off, and the joint made by the moss-box can be examined. Even when this joint seems perfectly good, it is thought desirable by some to take the additional precaution of putting in a wedging curb in the ordinary way a little below the moss-box (Figs. 3 I 7 and 318$)$; a few rings of ordinary segmental tubbing are then built up in the interval. A careful joint is made, and the shaft is looked upon as permanently secure.

The advantages of the Kind-Chaudron process, which are enumerated at length in Sir Warington Smyth's paper, may be briefly summed up as follows: safety, economy and speed.

During the last few years several modifications of the original Kind-Chaudron process have been introduced with success, At Gneisenau near Dortmund all tubbing above the level of the water-bearing measures was discarded. A column of tubbing, closed at the top as well as at the bottom, and somewhat longer than the height of the watery strata, was lowered into the shaft; and in order to overcome its buoyancy a sufficient amount of water was let into it by a valve, worked by a rod reaching to the surface. When the moss-box had been compressed by the descent of the column, cement was lowered into the annular space, along special guide-ropes extending from the bottom ring but one of the tubbing to the top of the pit. This plan enabled the boxes to be sent down and drawn up more speedily than would have been the case if they had been loose. After allowing sufficient time for the complete hardening of the cement, the water was drawn out of the pit, and a regular wedging curb was put in above the column of tubbing and its protecting jacket of cement. 
This method of doing the work saved 190 yards ( $174 \mathrm{~m}$.) of tubbing at the top of the pit, and the gain in money was estimated at $£ 7500$.

At the present time the moss-box seems to be losing much of the prestige which it formerly possessed, and French engineers are content to rely solely upon careful cementing for a water-tight joint at the bottom of the tubbing. A shaft was successfully sunk a few years ago by the "Compagnie de l'Escarpelle" in the North of France without using either moss-box, equilibrium
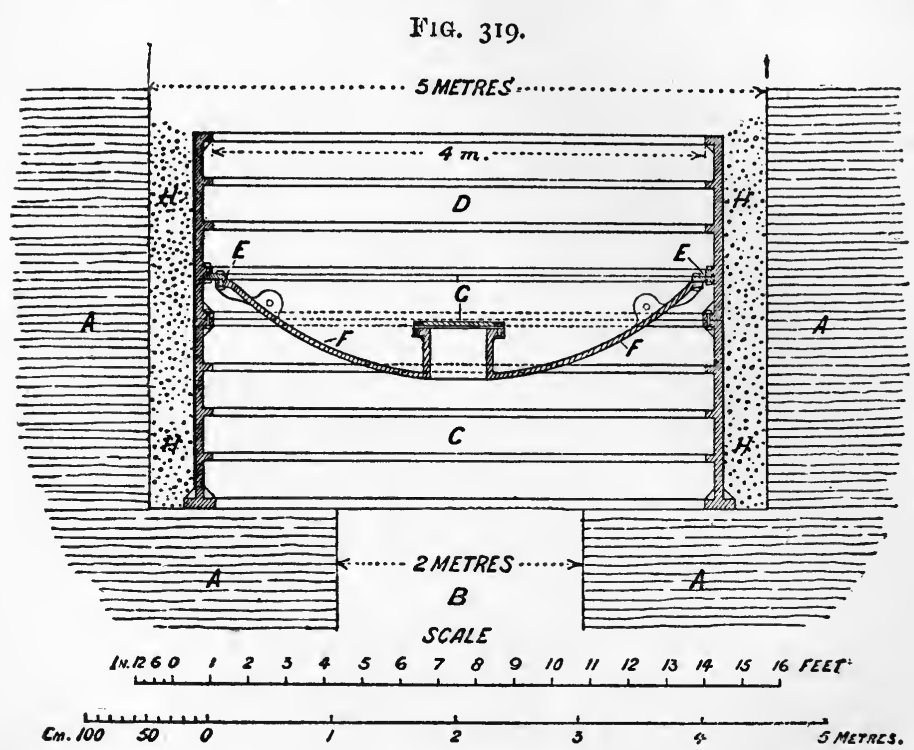

A, Green clayey marl, very plastic and impermeable (Dièves vertes). B, Small boring. C, First ring of tubbing, with strong shoe, weighing 12 tons. D, Second ring of tubbing. E, Ring bolted to a flange of D. F, False bottom bolted to E. G, Manhole cover. H, Concrete. The rings of tubbing are joined to each other by sixty bolts, and the upper and lower flanges are strengthened by brackets midway between the holes. These brackets have been omitted in the figure for the sake of clearness.

tube, or the subsequent wedging curb and false tubbing; and the Liévin Company in the same colliery district, when sinking two shafts in 1891-92, likewise decided to dispense with all the contrivances peculiar to the Kind-Chaudron method. The process of sinking was very much simplified. They bored the shaft in two operations : a first pit 2 metres (6ft. 6in.) in diameter was carried down some ten or twelve metres beyond the actual depth required, and it was then enlarged by a second tool, $4^{\circ} 90 \mathrm{~m}$. wide, to the full 
diameter of about $5 \mathrm{~m}$. (r $6 \mathrm{ft}$. 5 in.). This plan obviated all difficulty. due to a tooth dropping from the large borer; it had simply to be scraped into the small shaft and was left at the bottom until the completion of the tubbing. In the Kind-Chaudron process of boring the small and the large shaft alternately, it would have been necessary to fish up the tool before the smaller shaft could have been sunk any farther. On reaching the required depth the teeth of the large borer were fixed so as to cut a horizontal seat, which was then scraped clean with an Slike tool for the reception of the tubbing. The bottom ring was made with a shoe (Fig. 319), and was calculated to leave an annular space 14 inches $(35 \mathrm{~cm}$.) wide for cement, and the huge column with its watertight base was built up and lowered without any equilibrium tube. It floated like an enormous boat and was weighted with water so as to sink as required. After it had been very carefully brought into the centre of the pit, the concrete was lowered in specially contrived boxes which deposited it automatically on reaching the bottom. The successful result of these sinkings has justified the procedure of the Liévin engineers ; they are of opinion that, in any future sinking, time might be saved by doing the boring in three operations instead of two.

The following facts* relating to one of the pits lately sunk by the Liévin Company (No. 4 bis) show the rapidity with which the work can be carried out. Boring with the small tool began on the Ist of November 189i, and was stopped on the r4th of January 1892 , when a depth of 1 I I ${ }^{\circ} 7 \mathrm{I}$ m. ( 122 yards) had been reached. The large tool was set to work on the I6th of January, and by the 7 th of June following the pit had been bored to the depth of 100 metres (109 yards). A week was then occupied in cleaning the bed, taking down the boring plant, and making preparations for putting in the tubbing. Beginning on the I 4 th of June, the lowering of the tubbing was finished on the 29 th; it took three days to get the column into position and make it rest properly upon its seat, and three weeks to put in the concrete. After spending ten days in taking down the boring shed and plant, the engineers were able to begin drawing out the water on the 2nd of August, and they finished on the 7 th. The false bottom was brought up on the 8th of August, and preparations were at once made for continuing the sinking in the ordinary way. The sinking was recommenced on the 3 oth of August.

Compressed Air Method.--Sinking by the aid of compressed air came into notice after a successful application of this method by M. Trigèr in France about half a century ago. In this method a cylinder of cast-iron, made up by adding ring after ring at the surface, like a column of Chaudron's tubbing, is caused to sink gradually by the earth in the bottom being worked away;

" Kindly furnished by M. Desailly, the engineer in charge. 
and in order to prevent the water in the surrounding beds from coming in, air under pressure is led into a chamber at the bottom of the cylinder, which is shut off by a horizontal partition or diaphragm. Above this working chamber there is an "air lock," that is to say a closed space in the cylinder, with trap doors above and below. The two doors are never open at the same time. A man going down to his work passes into the middle chamber by the trap door, which is then closed; the lower trap door is now opened, and the man can descend into the working chamber. When he goes up, or when the bucket has to be drawn out, there is always this break of the journey, in order to prevent the working chamber from communicating directly with the atmosphere. Sinkings by this process have been made since Triger's time in various places, among others at Bettisfield colliery in North Wales,* though in this case the arrangements were not exactly the same as those originally employed in France.

There are two great disadvantages coupled with this method:

(I) The impossibility of going to a depth much exceeding 100 feet, because, speaking generally, a pressure of $45 \mathrm{lbs}$. per square inch; or three atmospheres above the normal pressure of the atmosphere is about as much as men can stand.

(2) The fact that the health of the men has been found to suffer from such an atmosphere. In all cases it appears advisable to avoid the sudden changes of pressure, and therefore invariably to make a little stay in the air-lock before going up or down.

Freezing Method.-The solidification of watery strata by cold may be effected naturally or artificially. In Siberia, $\uparrow$ when sinking shallow exploratory pits through watery strata in search of auriferous alluvia, advantage is taken by prospecting parties of the severe cold to let Nature form protecting walls of frozen ground.

In Western Siberia the process is as follows: Towards the end of the summer, square pits about 6 or 7 feet on the side are sunk as deep as possible without penetrating into the watery beds. The men then prepare log-huts, as dwellings for the winter, and lay in good stocks of firewood. After the first frost the snow is cleared out of the pits, and also from off the ground for a space several yards in diameter round the tops, in order to let the cold penetrate more freely. As soon as the ground is thoroughly frozen, the sinking is begun by a kind of fire-setting. Billets of wood are laid crosswise on the bottom of the ground and lighted. The fire thaws the ground for a short distance, and the workmen have to be careful that the heat does not penetrate too far, and so let in the water from the unfrozen strata a short distance be.

* Lupton, discussion on Mr. Daglish's paper, "On the Sinking of Two Shafts at Marsden," Proc. Inst. C.E., vol. Ixxi. I892-93, p. 197, with figure.

+ Helmhacker, "Ueber das in Sibirien iibliche Abteufen von Schurfschïchten im schwimmenden Gebirge," $B . u . h . Z$., 1891, p. 88. 
low line I, I, representing the junction of the frozen with the unfrozen ground (Fig. 320).

The workmen with pick and shovel remove the softened portion (a), and so deepen the shaft by some 4 to 6 inches. It is then left: for two or three days to freeze again, when the junction between frozen and unfrozen ground is carried to 2,2 ; a second fire softens the part $(b)$ which is rernoved, and then another exposure to the frost for two or three days makes the ground solid to 3,3 , when the part $(c)$ can be softened and taken out.

FIG. 320.

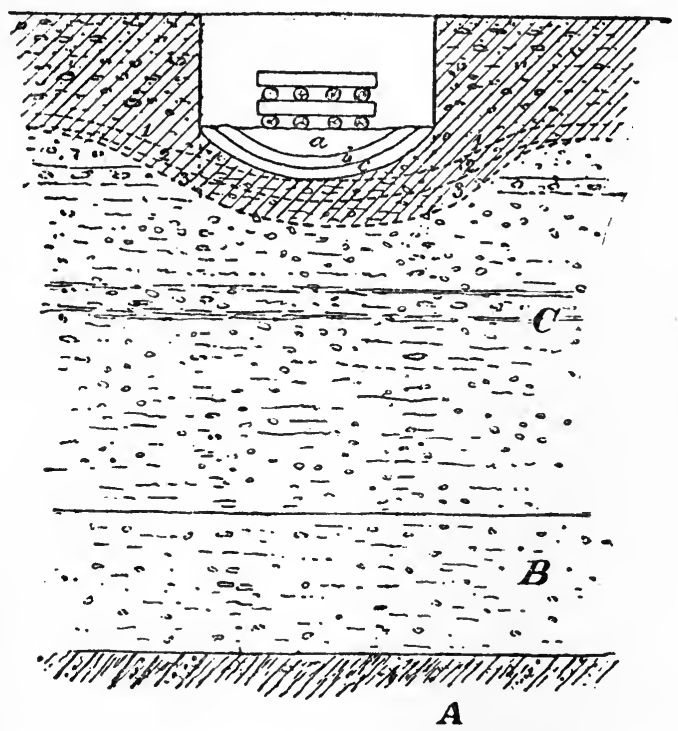

The alternate processes of freezing and thawing are repeated every three or four days, and each time the shaft is deepened from 4 to 8 inches. As the auriferous bed is approached, samples are washed from time to time to see whether there is any gold, and when the stratum containing the precious metal is reached (Fig. 321), all the earth is carefully washed and the amount of gold noted. Judging by results of similar undertakings in the district, it is possible to say whether or not it will pay to work the alluvium. In both figures, A represents the bed rock, B the stratum of gold-bearing gravel, $\mathrm{C}$ overlying gravel containing little or no gold, D timbering at the top. The hatching denotes ground that is frozen. The shafts are sunk to a depth of 16 to 26 feet.

In Eastern Siberia the conditions are more favourable for this kind of work, as the winter is longer, and therefore the shafts 
can be sunk deeper. But the principal advantage lies in the fact that much of the ground is eternally frozen; here the thawing can be carried on without any stoppages, and less care is necessary, save when the underlying unfrozen strata are reached. These have to be treated by alternate freezing and thawing as in Western Siberia. As a rule, however, the ground is eternally frozen for the whole thickness of the alluvium down to the bed

Fic. 321 .

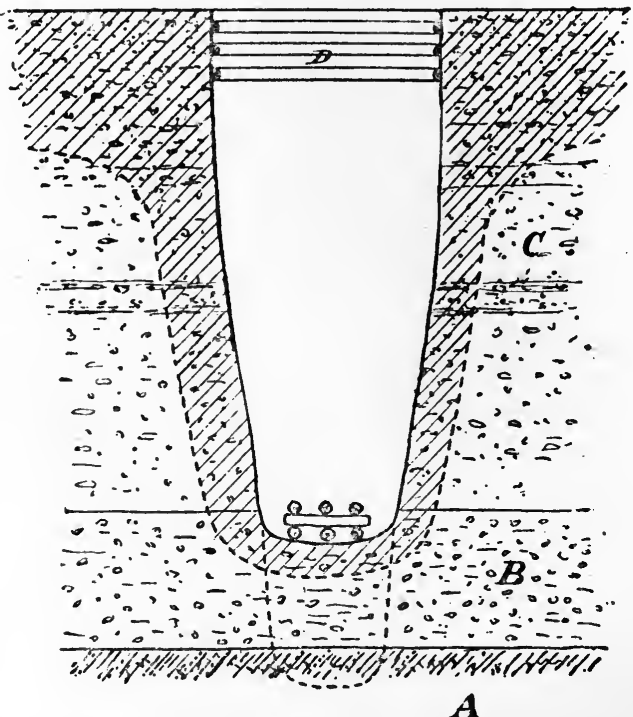

rock. Exploratory pits are sunk in Eastern Siberia to a depth of 85 feet $(26 \mathrm{~m}$.) by this method.

Shafts are even put down in shallow rivers to see whether their beds are gold-bearing. In autumn, when the water is shallow, a set of frames, like shaft frames, 6 or 7 feet square, is lowered till it touches the bottom, whilst the top is above the level of the stream. It is filled up with stones, and loose stones are placed around it. When winter sets in, the river freezes, and the contents of the box gradually become hard. A first layer of stcnes is then worked out with the pick, and the frost allowed to penetrate downwards. Another layer of stones is taken out, and again there is an interval for freezing. By repeating this process the contents of the box are removed little by little, and at last the river bed is reached and allowed to become hard and solid from the cold, whilst at the same time the water in the interstices between the outer stones has been congealed, and has 
formed strong protecting walls of icy conglomerate. Further sinking is now carried on as in Western Siberia.

In some cases the wooden box is dispensed with, and when the river is covered with a thick coat of ice, the prospector cuts out a space a few inches deep of the size of the shaft. The removal of a part of the ice at the top allows the cold to be felt further down, and the ice becomes thicker underneath. Another slice is taken off the top and again the cold penetrates further, and in proportion as the top is removed the bottom receives coat after coat of new ice. By successive thickenings the ice finally reaches the river bed, and the prospector can then proceed by the West Siberian method.

Poetsch's artificial freezing process consists in causing a very cold liquid to circulate in pipes through the ground, and so convert it into a solid mass, in which an excavation can be made without timber or other supports. While the ground is kept frozen some form of watertight lining is put in, sufficiently stanch to keep out the water when the cold-producing appliances are removed.

Poetsch employs a Carré machine for generating cold. Anhydrous ammonia gas is liquetied by compression in suitable pumps, and the liquid which leaves at a temperature of $102^{\circ} \mathrm{F} .\left(38^{\circ} \mathrm{C} .\right)^{\circ}$ is cooled by passing it throngh pipes surrounded by cold water. The cold liquid ammonia is then made to flow into a long series of pipes, placed in a large wooden tank containing a solution of chloride of calcium. The liquid ammonia expands into gas in these pipes, and extracts heat from the solution surrounding them to such an extent that the temperature of the contents of the tank is brought down to $8^{\circ}$ or $9^{\circ} \mathrm{F}$. $\left(-13^{\circ} \mathrm{C}\right.$.) The ammonia gas is returned to the compressor to be again liquefied and utilised for the production of cold.

The refrigerating solution of chloride of calcium is pumped from the tanks into a main, which leads it to a series of pipes, placed in boreholes arranged in a circle around the top of the proposed shaft. The pipes are double, that is to say, there is an inner small pipe $1 \frac{1}{2}$ or 2 inches in diameter for the downward journey of the cold solution, and an outer one $4 \frac{1}{2}$ to 7 inches in diameter, carefully closed at the bottom, by which the solution ascends and does its cooling work on the way. When it reaches the surface it returns to the ccoling tank, and is again refrigerated. The process is, therefore, cintinuous, the ammonia and the chloride being used over and over again. The nature of the freezing-tube will be evident from Fig. $322 * ; a$ is the large outer pipe connected to another, $m$, by the piece, $f ; n$ is a small

* Poetsch, "Ueber die verbesserte Ausführung des Gefrierverfahrens beim Schachtabteufen und Streckenbetrieb," Der iv. allgemeine Bergmannstag in Halle [S'sale]. Festbericht und Verhandlungen. Halle, 1890, p. 119, and Plate $x$. 
inner pipe, and the arrows show the course of the solution: Tlie supply of chloride is taken from a circular pipe at the top, fed

FIG. 322.

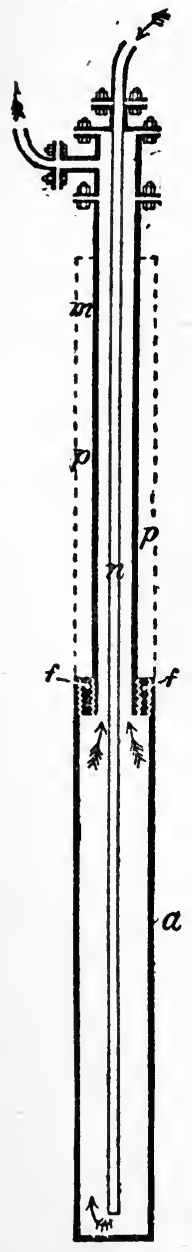

FiG. 323 .

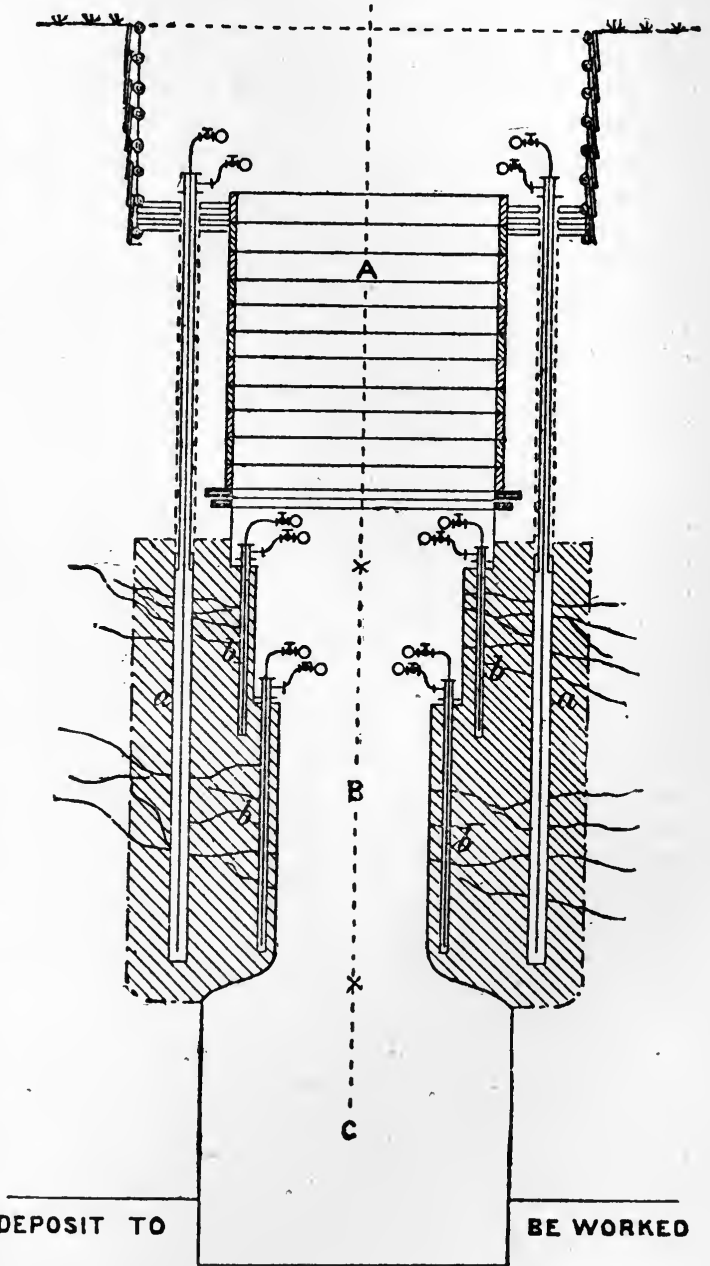

from the main, and in like manner the solution ascending the various pipes is collected by another ring and led back to the cooler. The particular pipe shown in the figure is destined for the case of a sinking, in which the upper part, $m$, is in strata that 
do not need to be frozen. The letter $p$ represents a jacket made of some bad conductor, to prevent the solution from becoming warmed unnecessarily in its ascent.

In sinking through ground consisting of watery strata alternating with dry measures, Poetsch advises the following method of procedure. A (Fig. 323) represents dry ground through which the shaft has been sunk and timbered in the ordinary way; B indicates watery beds where tubbing is necessary. Poetsch puts in first of all a circle of holes, $a$ a, round the outside of the shaft, and a smaller circle $b b$, around the inside. When these latter have frozen the ground adjacent to them, the still smaller circle of holes $b b$, are bored and fitted with refrigerating tubes; as soon as the ground about them has become converted into a solid protecting wall, the shaft is sunk with a reduced diameter, until the dry strata, C, are pierced. On reaching ground suitable for the wedging curb, the tubbing is built up in the ordinary way; the parts $b b$ are cut away, and by this time the freezing has become so complete at $a$ that there is no danger of the walls falling in.

In this process there is a risk of failure, or at all events of trouble, if there is any escape of the freezing solution from the pipes, because the ground impregnated with it would be uncongealable. Gobert proposes to overcome this difficulty, and at the same time to make the method more economical, by sending down anhydrous, or all but anhydrous, ammonia, and allowing it to vaporise in the tubes, instead of circulating a refrigerating solution. Intense cold is thus produced at the very point where it is required, and the ground is frozen. The ammonia gas is drawn out by a pump, and after having been reliquefied by pressure is used over again. Gobert claims for this process that both the original outlay for plant, and the subsequent running expenses, are considerably reduced. He has also been led by his experience to introduce improvements in the joints of the freezing pipes, with the object of ensuring absolute freedom from leakage, and of making the line of pipes quite flush outside, so as to facilitate their withdrawal at the end of the sinking.

It has been proposed* to inject powdered cement, by means of compressed air or steam, into watery strata, and so consolidate them sufficiently to render the sinking of a shaft a matter of no great difficulty.

The Haase Process, $\uparrow$ for sinking through quicksands, consists in forcing down a set of wrought-iron tubes around a circular or rectangular area destined for the shaft. The narrow interspaces between the tubes are closed by angle-iron and T-iron riveted on longitudinally, which form a joint permitting vertical motion and stanch enough for the work in question. Water forced

* Colliery Guardian, vol. 1xi. I89r, p. 1089.

† Zeitschr. f. B.- H.- u, S.-Wesen, vol. xxxvii. I889, p. 204. 
down a hollow boring rod in the middle of each tube loosens the sand and carries it up to the surface. The tube can then be driven down by a screw-jack or an hydraulic press. The tubes are carefully guided in order to ensure a strictly vertical path; and as soon as they have been forced down into hard or comparatively hard rock, the quicksand can be excavated, for the iron lining prevents any influx from the outside.

Instead of iron tubes, Haeuser* employs sheets of corrugated iron, with tongues riveted on so that the bottcm of each sheet is held by the top of the one below. Like the Haase tubes, the sheets are forced down with a strong screw-jack. Another plan adopted by Haeuser consists in making the protecting shield of pieces of flat iron 6 inches wide; each "lath," if it may be so called, is connected to its neighbour by a longitudinal groove formed by riveting on two strips of iron.

* Herold, "Das Schacht-Abteufen im schwimmenden Gebirge mit Haase' schem und Haeuser' schem Verfahren beim Braunkohlenwerk 'Zwenkau' in ¿wenkau," Jahrb. f. d. B.- und H.- Wesen i. K. Sachsen, I891, p. 27. 


\section{CHAPTER VI.}

\section{EXPLOITATION.}

Classification of methods of working-(I) Open works of all kinds, including hydraulic mining. (2) Excavation of minerals under water. (3) Extraction of minerals by wells or bore-holes. (4) Underground workings.

THE methods of working mineral deposits may be naturally arranged into two great classes-viz., open works, in which the excavation is open to the sky; and underground works, in which the miners perform their labonr in chambers or passages under a cover of rock or earth, and in which they usually need artificial light. But there are in addition two other classes of workings, used in combaratively exceptional cases, which require a place in any complete classification. Gold-bearing gravel and phosphates are occasionally dredged up from river-bottoms; and liquid, gaseous, or soluble minerals ean be got by wells or bore-holes. Consequently it is necessary to subdivide the subject into four heads :

r. Open works of all kinds, including hydraulic mining.

2. Excavation of minerals under water.

3. Extraction of minerals by wells or boreholes.

4. Underground workings.

OPEN WORKS.--Some minerals are always obtained in this way ; others are worked open before regular underground mining begins; and, thirdly, it often happens that underground and surface workings are both being carried on simultaneously in adjacent parts of the same mine. Among the minerals worked opencast are the ores of copper, gold, iron, lead and tin, to say nothing of all sorts of stone.

The advantages of open works may be summed up as follows:

(a) Complete removal of the mineral without any loss in the form of pillars.

(b) No expense or trouble as regards ventilation, men always working in good air ; no danger of explosions.

(c) No expense for lighting, unless work is carried on at night.

(d) No expense for timbering.

(e) Possibility of laying out the work in larger steps or stopes than can usually be done in underground working places.

$(f)$ Easier supervision. 
On the other hand, there is usually the immense disadvantage of it being necessary to remove a great deal of waste rock covering the deposit, technically known as overburden. Work too may be stopped by bad weather, such as heavy rain or snow; open quarrying may spoil land or interfere with roads or canals, so that the benetits do not all lie with the open works. The cryolite of Greenland* is worked opencast from April to December, and during the rest of the year the miners are employed below-ground.

One of the simplest cases of working away a mineral is that of borax in California. The efflorescence has merely to be swept into wind-rows and carted away to the refining works.

The beds of nitrate of soda in Chili are worked by large blasts as shown in Fig. 54. $\dagger$ A small shaft is sunk a little below the bottom of the "caliche" and enlarged in order to receive a charge of slow burning powder made on the works. The explosion loosens and breaks up the ground over an area about twenty yàrds in diameter. The hard overlying stratum of "costra" is then easily removed, and the "caliche" is broken up' into lumps, which are taken to the lixiviating and crystallising works.

Generally the first process in an open working is the removal of the overburden, and the manner in which this is done depends upon the nature of the ground.

A first example may be taken from Northamptonshire, where very large quantities of iron ore are obtained from beds of Jurassic age. Similar beds are also worked in the counties of Lincoln and Oxford.

The actual bed of ore at Cranford in Northamptonshire is from 8 to 12 feet thick, and the amount of overburden taken off is sometimes as much as 20 feet; when this thickness is exceeded the ore can no longer be worked with profit.

The soil or "meat earth," which is from 8 inches to 2 feet deep, is put aside carefully, for it has to be restored to make the surface good and available for tillage. The remainder of the overburden is cut away in one or more steps or "stopes," for the convenience and safety of the workmen, the base of any step being usually about equal to its height. The accompanying figure (324) represents a pit at Kettering in Northamptonshire, in 1889 , where 15 feet of overburden were being removed from a 12 -feet bed of ironstone. The soil having been cleared off with the shovel, the men undercut the first stratum with a double-pointed pick at $a$ and then drive down a crowbar at $b$ and another at a little distance from it. By working the bars backwards and forwards they cause a big block to break off along the dotted line. This crumbles in its fall, is shovelled into barrows, wheeled across the planks, and tipped on to

* "Die Kryolitverarbeitung in der Eresundschen Fabrik in Kopenhagen," B. u. h. Z., 1893, p. 69 .

† Robert Harvey, "Machinery for the Manufacture of Nitrate of Soda at the 'Ramirez' factory, Northern Chili," Proc. Inst. Cin. Eng., vol. lxxxii, I $884-85$, p. 34 I. 
the bank. After the top has been cleared away for a few feet, the next bed is treated in the same way, and then the third, until the

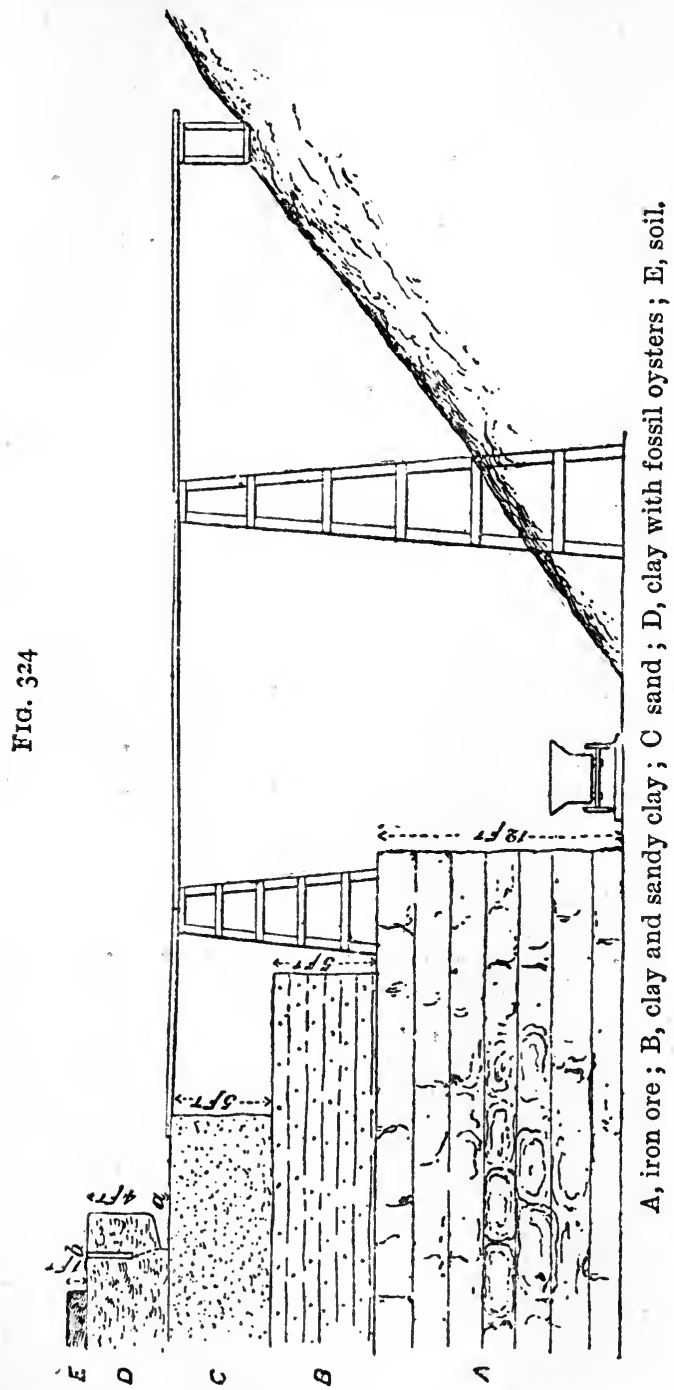

ironstone is reached, and laid quite bare. The ore can usually be easily broken with the pick and at once loaded into small waggons, holding about a ton each. Occasionally a shot is fired, in order 
to loosen parts that are hard. The loading is done with an eightpronged fork, so as to separate the fine ore which the smelters refuse to take. If there is much fine, the ore is sifted; one man stands over a wheel-barrow holding a round sieve, with a halfinch mesh, and another shovels the ore to him. The fine drops into the barrow and can be wheeled away, while the coarse is thrown into the waggon. The men working on the overburden are paid per cubic yard, and those excavating ore are paid per ton of ore placed in the trucks.

The working faces are long, in order that a large number of men may be employed at one time. As surface rent must be paid whilst the ground is useless, the soil is put back with the least possible delay, and tillage then goes on once more upon fields which have been lowered several feet. In the figure a small waggon is

FIG. 325.

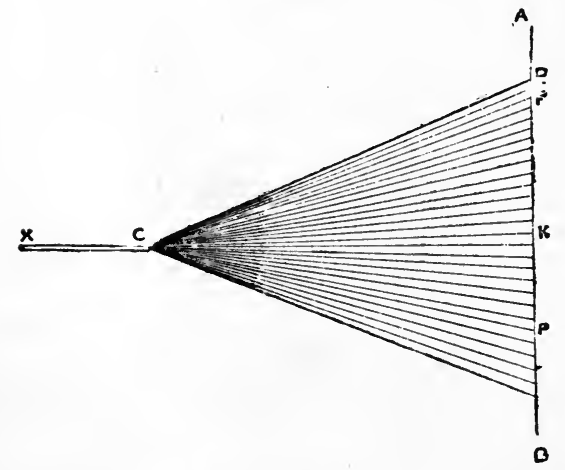

FIG. 326 .

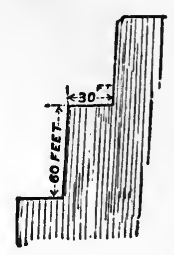

shown, but in some of the pits a full-sized railway waggon is brought into the cutting and loaded directly with 8 or 1o tons of ironstone. When a slice ro or 12 feet wide has been removed all along the face, the rails are shifted and a fresh cut taken.

The workings start, for instance, from some convenient point, $C$ (Fig. 325), connected to a main railway or wharf at $X$, and the tirst line of workings is supposed to be shown by $C D$, reaching to the boundary of the property $\mathrm{AB}$. The successive positions of the working faces take such lines as $\mathrm{CE}, \mathrm{CF}$, \&c., radiating out from $\mathrm{C}$ as a centre, and all the ground CDK may have been given back to the farmer, before the working face has assumed the position CP.

In hard rocks the steps may be made very much higher. Thus, at the great Penrhyn slate quarry, near Bangor, in North Wales, the valuable slate and the valueless overburden are both taken away by a series of terraces on an average 60 feet high by 30 feet wide, as shown in Fig. 326.

The great opencast at Rio Tinto (Fig. 327) is a huge open pit 
from which the ore is got by a succession of stopes, benches or terraces, 33 feet to 50 feet high. The pit is oval in shape, and 650 yards $(600 \mathrm{~m}$.) in length on the top of the ore.

FIG. 327.

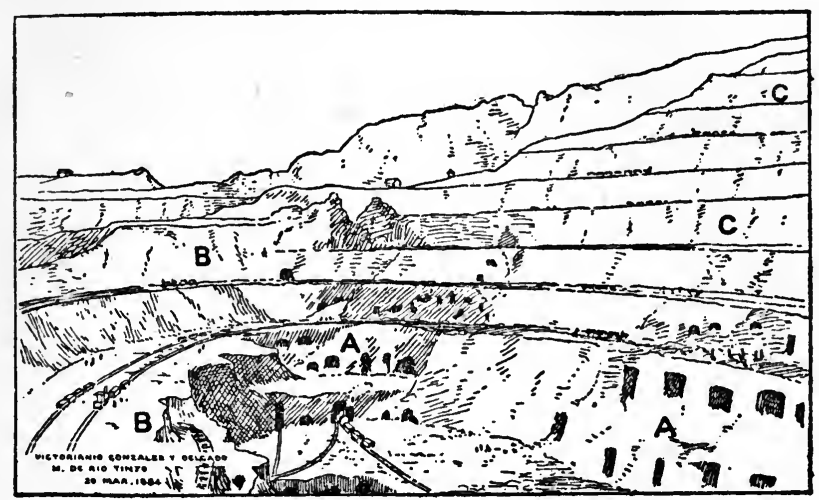

A, cupreous pyrites ; B, slate ; C, porphyry.

The opencast at the Mechernich lead mine is also worked in a similar manner. The Government regulations make it necessary that the base of each step shall be at least ro feet wide, so that

Fig. 328.

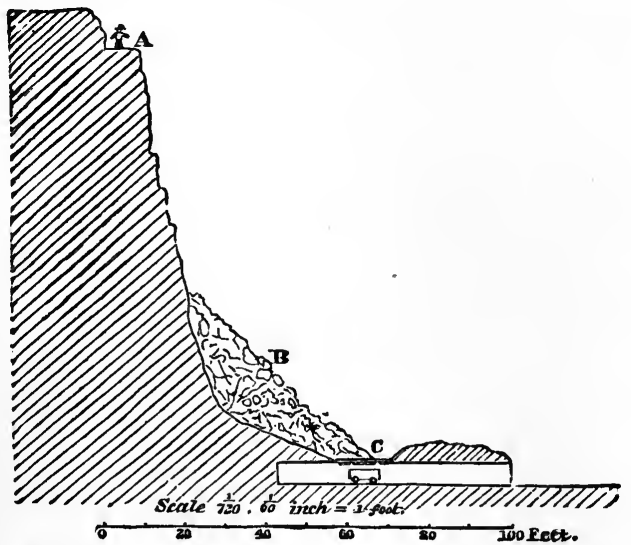

stuff may not roll down from one floor on to the men working below. The actual width is very much more, being usually 26 feet $(8 \mathrm{~m}$.), whilst the height is 33 feet ( $10 \mathrm{~m}$.)

When the rock is firm enough to stand for a great height, it is sometimes found convenient to take it down in one vertical slice 
without making a series of steps. The general appearance of Mulberry mine, * near Bodmin in Cornwall, which is worked in this manner, will be understood by a reference to Fig. 328. Men standing at $\mathrm{A}$ bore and blast holes, which throw the rock to $\mathrm{B}$, under which a level has been driven with an opening $\mathrm{C}$, usually closed by a covering of timber. A waggon is run in under this opening and is easily filled.

Another method is that of firing a very large blast, which brings down thousands of tons of rock at a time. It is prepared by

Fig. 329.

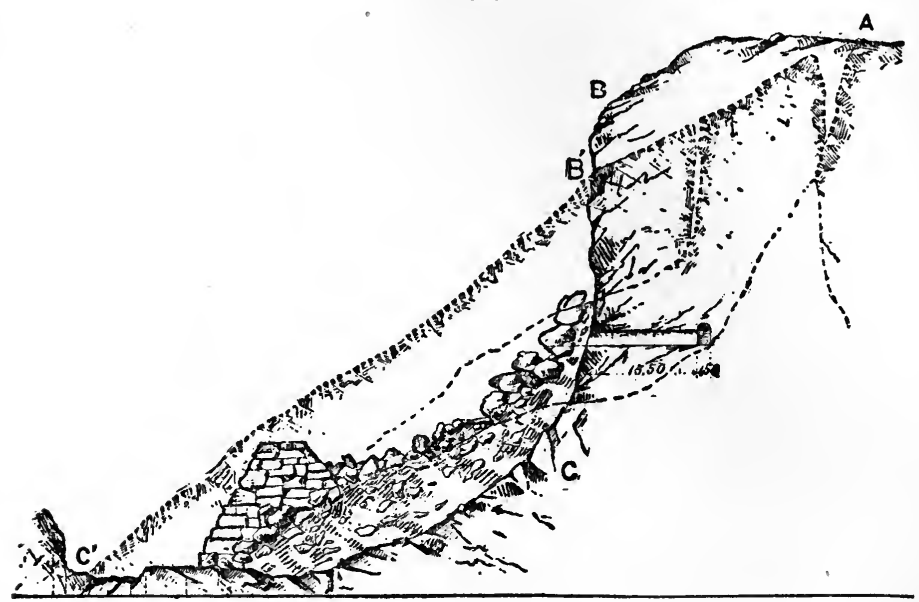

SCALEY

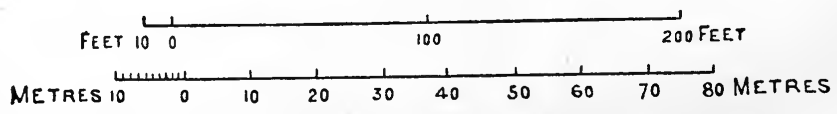

$A B C$, Outline of the face of the quarry before the blast;

$\mathrm{AB}^{\prime} \mathrm{C}^{\prime}$, Outline after the blast.

driving in a tunnel at right angles to the face of the quarry and making one or more chambers, which are charged with gunpowder or some other explosive; the tunnel is tamped up like a gigantic shothole, and the charge is fired by a fuse or by electricity.

As an example of a blast of this kind, I take some workings for building stone near Messina (Fig. 329). $\dagger$ A tunnel was driven into the face of the limestone quarry for a distance of 56 feet ( $7 \mathrm{~m}$.), and then turned off at a right angle. The chamber

* C. Le Neve Foster, "On Some Tin Stockworks in Cornwall," Quart. Jour. Geol. Soc., vol. xxxiv. 1878, p. 655 .

+ Falangola, "Sulle grandi mine nella roccia calcarea della cater? Peloritana (Sicilia) e nella roccia granitica di Baveno (Lago Maggiore)," Rivista di Artiglieria e Genio, vol. iv. 1887, p. 343. 
so formed was lined with a quick-setting cement in order to keep out any moisture, and a cubical wooden box was built up inside and charged with 64 bags of gunpowder, or in all $31 \mathrm{cwt}$. ( $600 \mathrm{kil}$.)

Four ordinary fuses, placed in a long box with sawdust, furnished the means of firing the charge. The tunnel was then filled up in the manner shown in Figs. 330 and 33r. The object of the slightly sinuous form of the tunnel was to increase the resistance of the tamping.

The effect of the large blast was to break up and move more than $\mathrm{x} c 0,000$ cubic yards $(80,000 \mathrm{c} \mathrm{m}$.) of rock, with the advantage

FIGS. 330 \& 331.

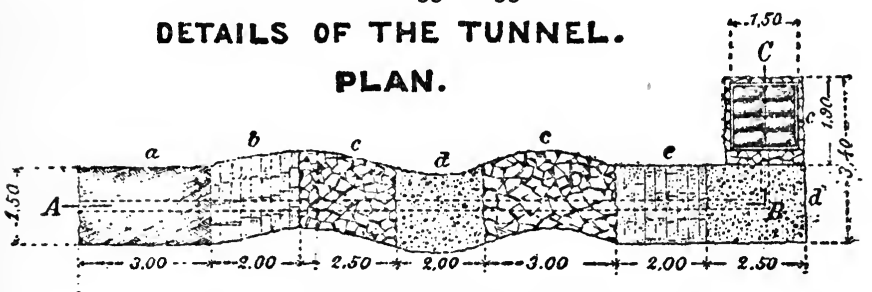

SECTION ALONC THE LINES AB.BC.

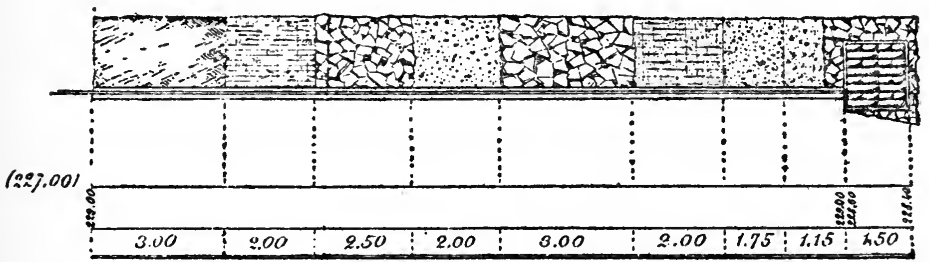

$\boldsymbol{a}$, damp earth beaten in ; $b$, brick wall built with common mortar ; $c$, dry stone wall; $d$, wall built with a quick-setting cement; $e$, wall built with hydraulic lime; dimensions in metres.

of producing less small stone than would have been the case if the ordinary method of quarrying had been employed. The dotted line $\mathrm{A} \mathrm{B}^{\prime} \mathrm{C}^{\prime}$ shows the outline of the face after the explosion.

We now come to an important class of workings, namely, recent alluvial beds, such as river gravel containing diamonds, gold or tin ore. The banks may be left high and dry when the river is low, or the stream may be diverted and any pools drained by some simple pump. The whole process of working often consists merely in digging up the earth with pick and shovel, and washing it on the spot with a pan or batea. If there is not enough fall for discharging the refuse, in places where the operations are on a large scale, it becomes necessary to raise the earth by some appliance, such as the hydraulic elevator (Fig. 345).*

* Rickard, "Alluvial Mining in Otago," Trans. Amer. Inst. M1. E., vol. xxi. 1892, p. 445 . 
Dams for diverting rivers are sometimes of considerable size. For instance, on the Feather river, in California, there is a dam 80 feet wide and 50 feet high. The water is carried off in a "flume" or launder, 50 feet wide and 6 feet high.

The sand of beaches is occasionally scraped up at low tide and washed for gold or tin ore.

Hydraulic Mining.-Under this head it is convenient to include all methods of working in which water is used for breaking away the ground, and not to restrict the term, as is most commonly done, to the process of working auriferous gravel by a jet of water under considerable pressure.

I will take some examples:

I. China Clay Workings in Cornwall.*-The first operation is the removal of the overburden, and a small shaft is then sunk in

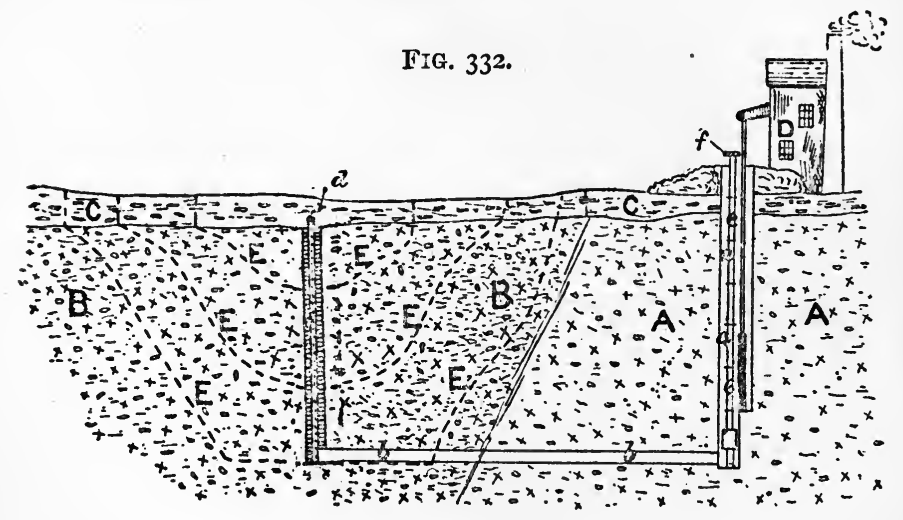

A, undecomposed granite; B, decomposed granite ; C, overburden ; $D$, engine-house; EE, EE. successive outlines of the open pit; $a a$, shaft; $b b$, level ; $d$, top of upright launder placed in the small shaft sunk in the middle of the decomposed granite; $e e$, column of pumps through which the milky stream of china clay and mica is lifted to the launder, $f$.

the middle of the area to be worked ; the bottom is put into communication with the surface either by an adit level, if the contour of the ground is favourable, or by a tunnel and shaft (Fig. 332 ), if the contour of the surface does not permit the driving of an adit save at a prohibitory cost, or if it is more convenient to have the settling pits close by. The shaft has to be fitted with pumps. A stream of water is led on to the decomposed granite, which the workman loosens with a heavy pick; the disintegrated particles are carried away in suspension to a fir $t$ settling pit, where the coarse grains of quartz are deposited, and

* Collins, The Hensbarrow Granite District, Truro, 1878, p. I7. 
the milky stream then falls down the launder $d$, into the level and either runs out naturally or is pumped up to the surface. It passes on to other settling pits, and deposits first the mica and then the very finely divided kaolin.

2. Auriferous Gravel-The process known as "booming," * practised in California, Colorado, Idaho and Montana, consists in discharging the contents of a reservoir all at once on to beds of auriferous gravel. The powerful stream carries away the stones and dirt into wooden troughs or launders, called "sluices," and leaves behind the gold on the bed-rock, or in the upper part of the run of sluices. In Peru $\dagger$ a similar process is adopted.

By a natural transition from "booming," we come to "hydraulicking," $\ddagger$ a process in which a jet of water under pressure is made to play against a bank of auriferous gravel, break it down, disintegrate it, and wash it into wooden troughs, arranged so as to catch the gold by means of mercury on special floors, and at the same time to discharge the stones, sand and mud.

For the purpose of storing a proper supply of water, large reservoirs have to be constructed, sufficiently high above the gravel bank to secure the necessary amount of pressure. They are formed by erecting dams across the valleys, and they are made either of earth, cribs of timber, or dry rubble masonry. One of the largest in California is the Bowman reservoir, with a high water area of 500 acres and a dam roo feet high, which cost $\$ 151,521$, or speaking roughly $£ 30,000$.

The water is taken to the place where it is required by $(\mathrm{r})$ ditches ("leats," Eng.); (2) flumes; or (3) pipes. (I) The ditches are cut out on the sides of the hills, and the earth thrown out serves to strengthen the lower bank. The shape most commonly adopted for the ditches is a half-hexagon, or the upbank may be made with an angle of $60^{\circ}$ and the lower with $65^{\circ}$. The gradient or " grade " varies according to circumstances from 7 to 20 feet per mile.

(2) Fiumes are merely wooden troughs, or "launders," as we should call them in England. Figs. $333 \ddagger$ and $334 \S$ show the manner in which they are usually made and supported. In valleys or cañons with very precipitous sides, the flume is sometimes carried by iron brackets let into holes bored in the rock and hung by

* Culifornia State Mining Bureau, Ninth Annual Report of the State Mineralogist for the year ending December 1,1889 , p. 122, Sacrawento I890. Bowie, A Practical 'Treatise on Hydraulic Mining in California, New York, I 885 , p. 8 I.

† Kohlmorgen, "Die Goldgruben von Carabaya in Peru," $\boldsymbol{B} . \boldsymbol{u} . \boldsymbol{h}$. Zeitung, 1890, p. 303 .

\# This account of " hydraulicking" is in the main based, by permission, on Bowie's Practical Treatise on Hydraulic Mining in California, New York, 1885 .

$\S$ Taliesin Evans, "Hydraulic Mining in California," The Century Magazine, vol. $\mathrm{xxv} . \mathrm{I} 883, \mathrm{p} .332$. 
FIG. 333.

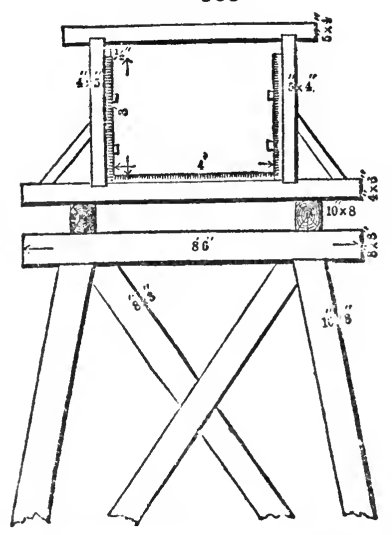

iron rods (Fig. 335).* Where it is possible, ditches should be put in instead of flumes, because the latter cost more for maintenance. They also suffer more from wind, snow and storms, and lastly they are liable to destruction from fire. On the other hand, it may be impossible in some cases to put in ditches, or the ground may be too hard and too porous to make a ditch advisable. When water is scarce, the loss by soakage and evaporation is a matter of importance.

(3) The third method of conveying water is by iron or steel pipes. They are useful in crossing a deep valley, for they save the expense of conFig. 334.

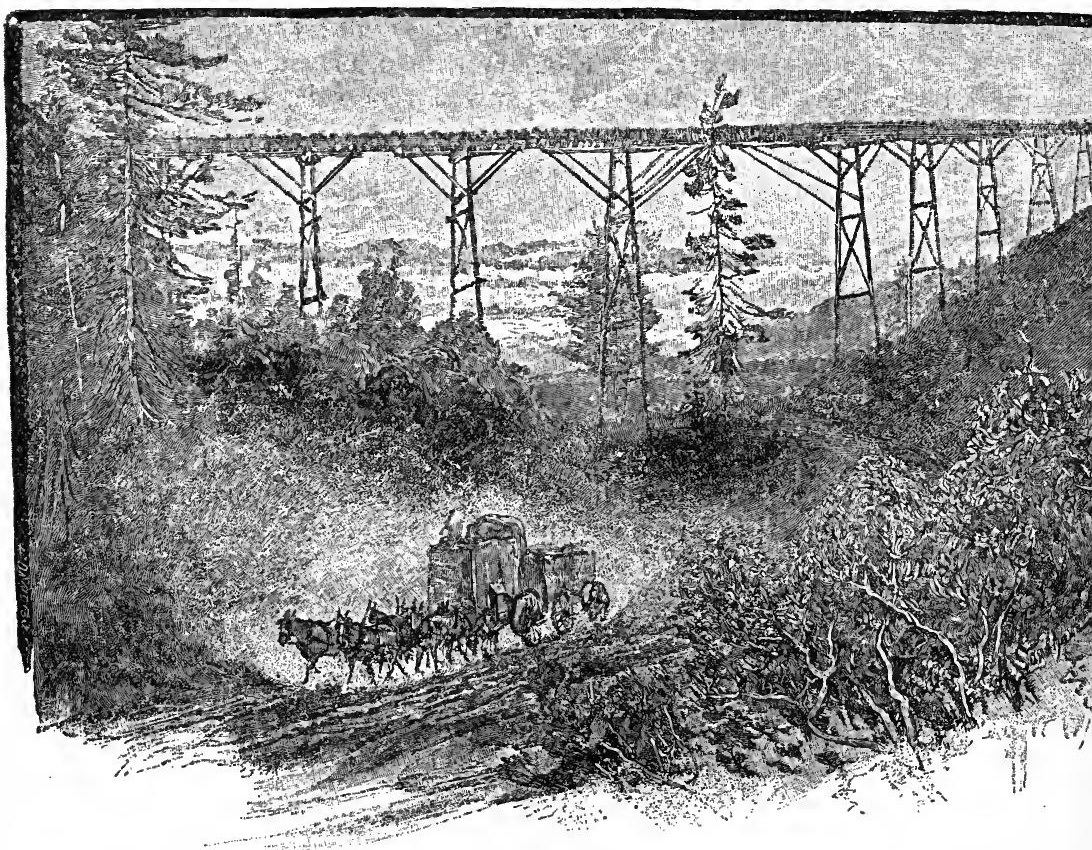

structing a very long ditch round its head, or a very high trestle bridge across it. Pipes crossing deep valleys are called "inverted

* Bowie, op. cit. 
siphons," although the principle of the siphon in no way comes into play.

'l'he pipes are made of riveted iron or steel, and one form of

Fig. 335 .

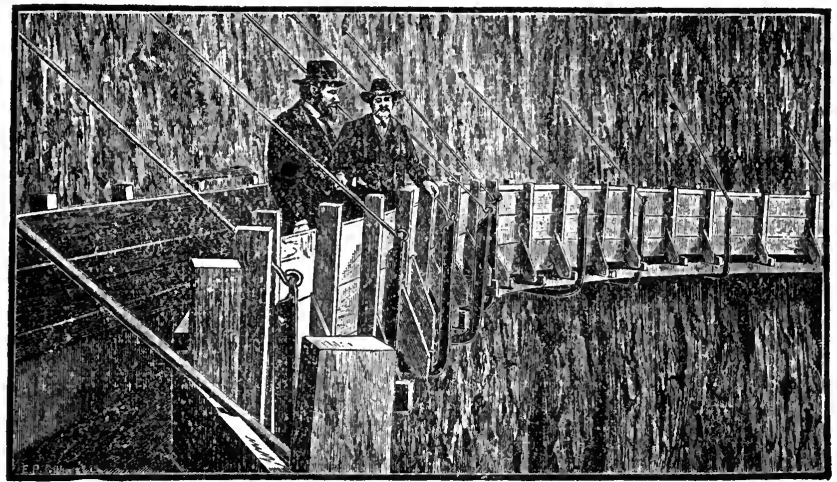

joint is shown in Fig. 336, made tight by running in lead and caulking it. The riveting may be straight or spiral. To prevent rusting, the pipes are coated externally and internally with a mixture of coal.tar and bitumen. Some of the pipes used for conveying water in this way are 20 or even 30 inches in diameter, and in such cases the thickness of the iron is from No. I 6 to No. I4 B.W.G.

Whether brought by ditch, flume or pipe, the water is led to the so-called "pressure-box" or "bulkhead" (Figs. 337, 338, and $\left.339^{\dagger}\right)$, a cistern situated at a sufficient elevation to give the jet the force it requires. The cistern is strongly made, and has a grating $\mathrm{A}$ to catch floating sticks which

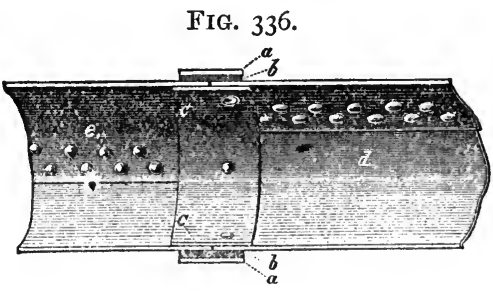

$a$ is a wrought-iron collar; $b$, the lead; $c$, a nipple of sheet-iron riveted to one end of the pipe $d$, each length having a similar nipple.

might otherwise choke the pipe. At the bottom there is a receptacle $\mathrm{B}$ to receive gravel and sand, which are discharged from time to time by opening a hatch at $\mathrm{C}$.

The pipe leading away from the pressure-box is similar to that used for crossing valleys, and it is brought down into the workings; if it is advisable to attack the bank in two places at once, the pipe is forked, each branch having its valve. The pipe terminates in a nozzle from 5 to 9 inches in diameter known as a

$$
\text { * Bowie, op. cit. + Bowie, op. cit. }
$$


"monitor." The monitor shown in Fig. $340^{*}$ is provided with an arrangement by means of which one man can deflect it with great ease. If the nozzle $\mathbf{B}$ is in a straight line with $\mathbf{A}$, the stream passes through it unimpeded; when it becomes necessary

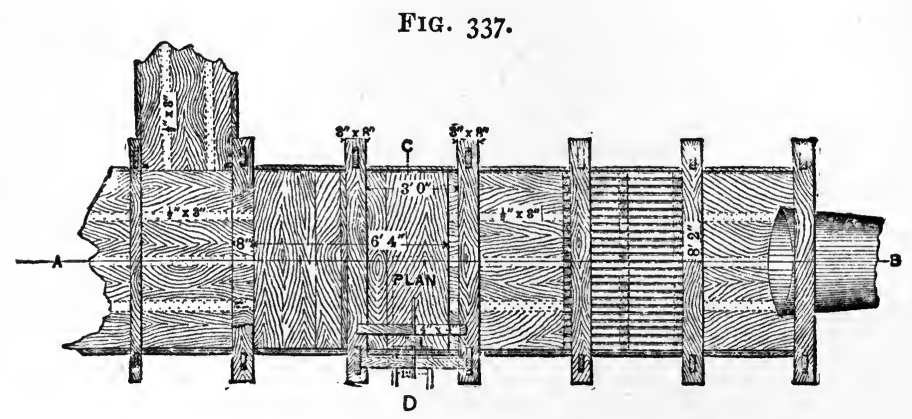

Fig. $33^{8}$.

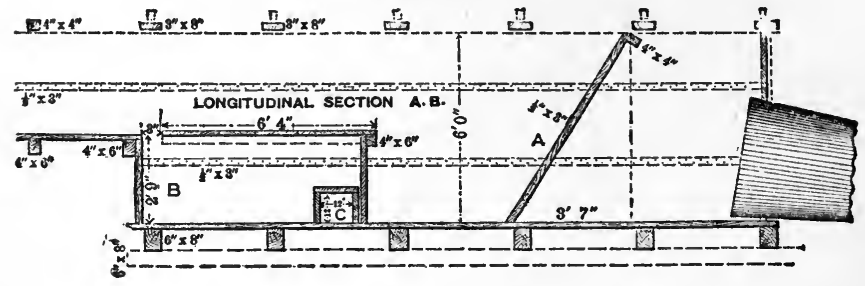

Fig. 339.

FIG. 340.
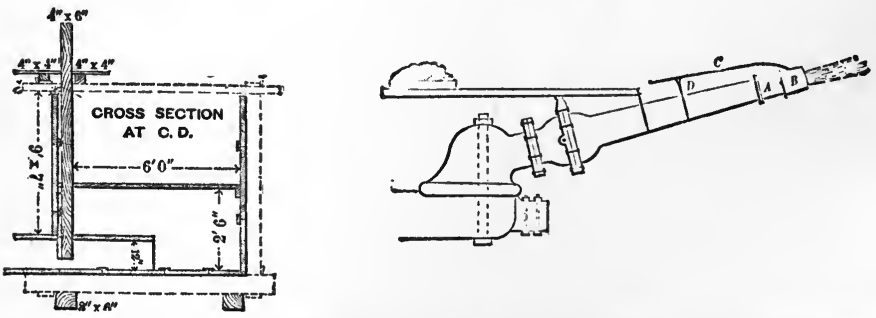

to turn the water on to another part of the gravel bank, the lever $\mathrm{C}$ is held to the side to which the jet has to be deflected. The pressure of the water in B then moves the monitor as desired.

The manner of using the powerful jet of water to wash down banks of gravel is well depicted in Fig. 34r, borrowed from Mr. Evans' interesting article.

If the gravel is cemented into a hard conglomerate, drifts

- Bowie, op. cit. 
are run into the bank; they are charged with a number of $25 \mathrm{ll}$. kegs of powder, tamped up, and fired by electricity. The jets of water will then do the rest.

The gravel washed down by the jets of water is led first into ditches cut in the "bed-rock," and then into "sluices." Sluices are large troughs or launders lying upon the ground, and paved with loose blocks of wood or with stones, in order to form a

FIG. 31 I.

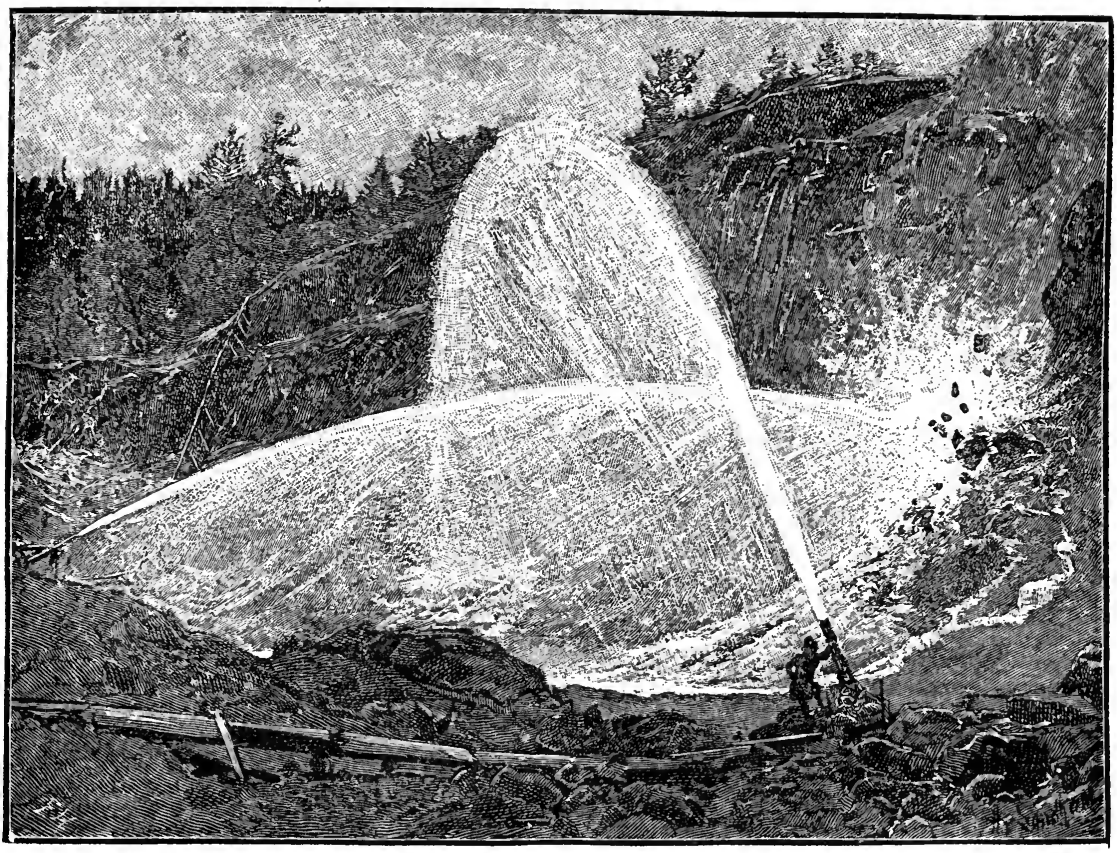

surface fit for catching the gold and the amalgam. Figs. $342,34,3$, and 344 . $^{*}$ show a section, elevation and plan of a sluice-box with two kinds of lining ordinarily adopted. It will be seen that the sluice in this case is a trough 5 feet 3 inches wide, made of $1 \frac{1}{2}$ inch plank at the sides and 2 -inch plank at the bottom, upon which are placed blocks of wood $20 \frac{1}{2}$ inches square, and $\mathrm{I}_{3}$ inches deep, set with the grain on end. They are separated at the bottom by cross strips of wood $I_{4}^{1}$ inches thick, and the sides are protected by blocks 3 inches thick. At one end the paving is of large stones.

The sluice is generally made in twelve-foot lengths, and the inclination is commonly defined by the fall given to such a length.

* Bowie, op. cit., p. 222. 
FIG. 342

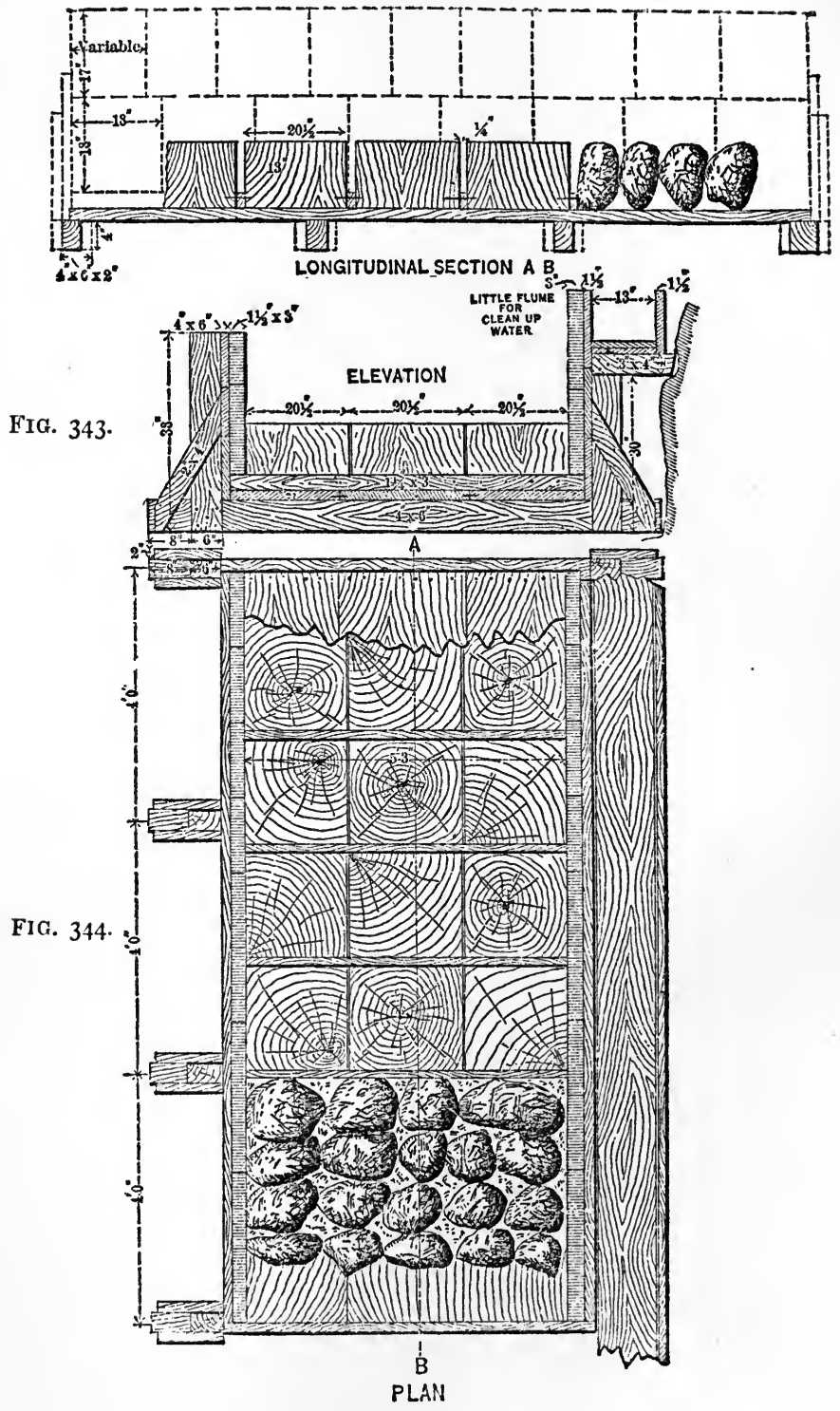


Thus it is said that the grade is 6 inches, meaning 6 inches to 12 feet or $\frac{1}{2}$ inch to the foot. The run of sluices may be several hundred or several thousand feet long.

The false-bottoms for sluices are called "riffles." The wood preferred for the block-riflles is that of the "digger" pine (Pinus sabiniana). Longitudinal riffles are made of poles, wooden rails covered with strips of iron, or iron rails, In New Zealand* the riffles are sometimes made of transverse bars of angle-iron, riveted to angle-iron or placed in a wooden frame, which enables them to be reversed when worn. The sluice-boxes are lined with thin sheet iron, and sacking or cocoa-nut matting is placed under the riffles to assist in retaining the gold.

In order to catch its gold more effectually, the finer material is taken out and treated separately in broad sluices called " undercurrents," at the side of the main one. A grating of bars of iron, I inch apart, called a "grizzly," is fixed across the main sluice, and the fine gravel and sand which drop through are led to a broad, shallow, sloping box, eight or ten times as wide as the sluice itself, and paved like it with stones, wooden blocks, or longitudinal riffles. The finer portions of the gravel, after passing over the "undercurrent" and depositing much of their gold, are once more turned into the main sluice lower down.

The big boulders rushing down the sluice are of service at first by breaking up gravel which is much cemented together, but at the same time they naturally wear out the sides and the pavement. It is therefore advisable to get rid of them, as soon as they have done all the useful work they are capable of performing. This is effected by arranging a "grizzly" or grating which will deliver the boulders into a ravine or gully, and so dispose of them without any further cost.

Mercury is added several times a day at the head of the sluice; and the upper part, say, the first rooo feet, is cleaned up every two or three weeks. At the time of the clean-up the washing down of the gravel bank is stopped, or the current is diverted into a parallel line of sluices. A small quantity of water is turned into the sluice which is to be cleaned up, the blocks are then taken out, washed, and put on one side. All the amalgam is picked up with iron scoops, washed, and squeezed through canvas or leather, and the amalgam is retorted. The spongy gold remaining behind in the retorts is then finally melted into bars. The mercury recuvered by condensation is used over again.

When the bed-rock is below the drainage level, the hydraulic elevator* may be employed. A jet of water under heavy pressure

* Rickard, "The Gold-fields of Otago and Alluvial Mining in Otago," Trans. Amer. Inst. M. E., vol. xxi. I892, p. 443 and 455 ; Parliamentary Reports on the Mining Industry of New Zeulund, Wellington, 1891, p. 67, witt: plates. 
is brought by a pipe A (Figs. 345 to 348 ) to the nozzle B, and rushes up the pipe $D$, producing a powerful suction in the "hopper" C. The water and gravel are carried up against the cast-iron striking plate $S$, and then run down the sluice-boxes.

\section{FIG. 345 .}

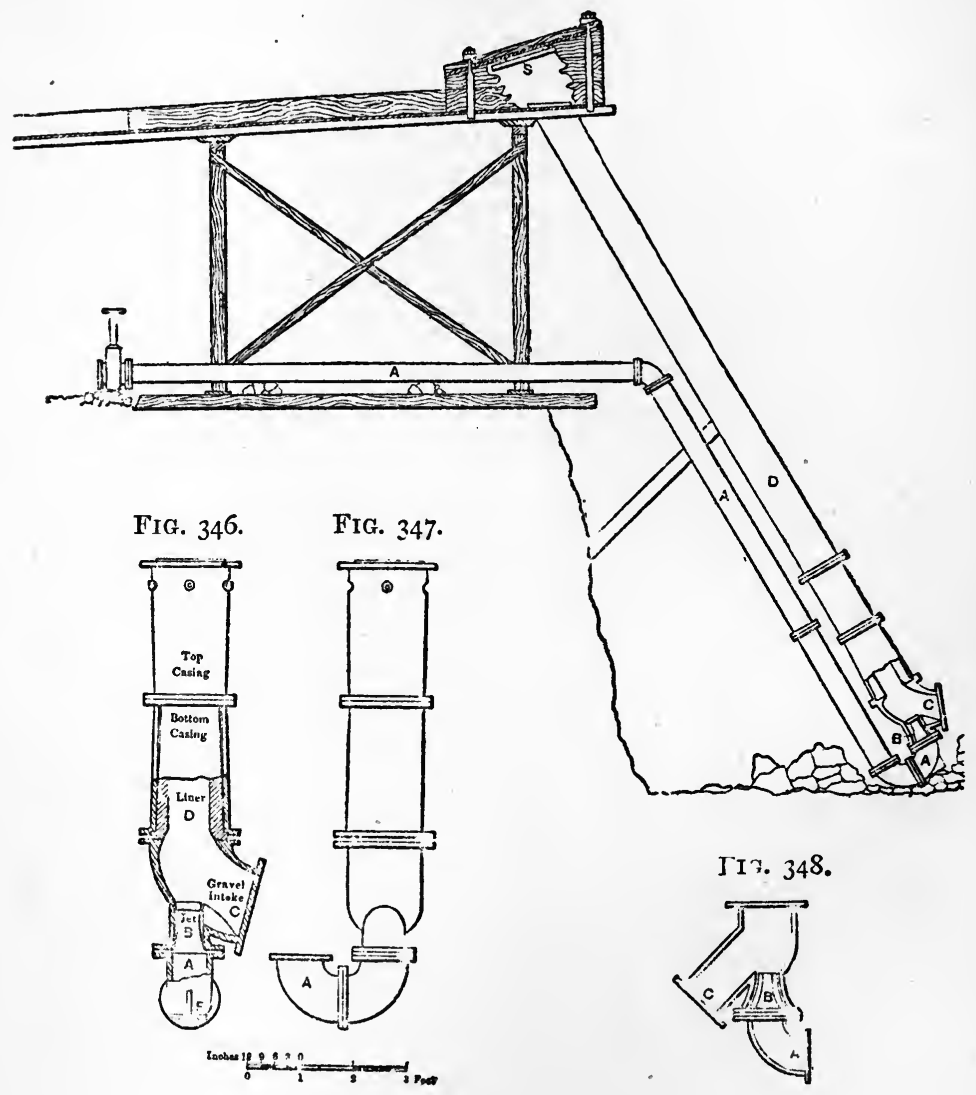

Fig. 349 explains the method of using the elevator for treating an immense accumulation of tailings at the Blue Spur, Otago, N.Z. On the left hand side is a huge nozzle playing upon the face of the tailings, 59 feet high, and washing down the gravel and sand of which they are composed. To the right is the first elevator, which raises the stuff $15 \frac{1}{2}$ feet into a set of sluice-boxes, and further to the right is a second elevator lifting it 56 feet vertically into another run of sluice-boxes. 
The quantity of water used is measured by a unit called the " niner's inch," * which unfortunately is not invariably the same. The term means the quantity of water discharged per square inch of sectional area of an orifice cut through a vertical board, forming one side of a box. The discharge will necessarily vary with the height of the surface of the water above the orifice, the thickness of the board, and the shape and nature of the orifice; as these factors of the problem are not the same in all localities, it is impossible to give one definite value for the miner's inch of water. The orifice is usually rectangular, but it may differ in height and width. However, the quantity represented by the miner's inch may be taken as varying from 2000 to 2600 cubic feet per

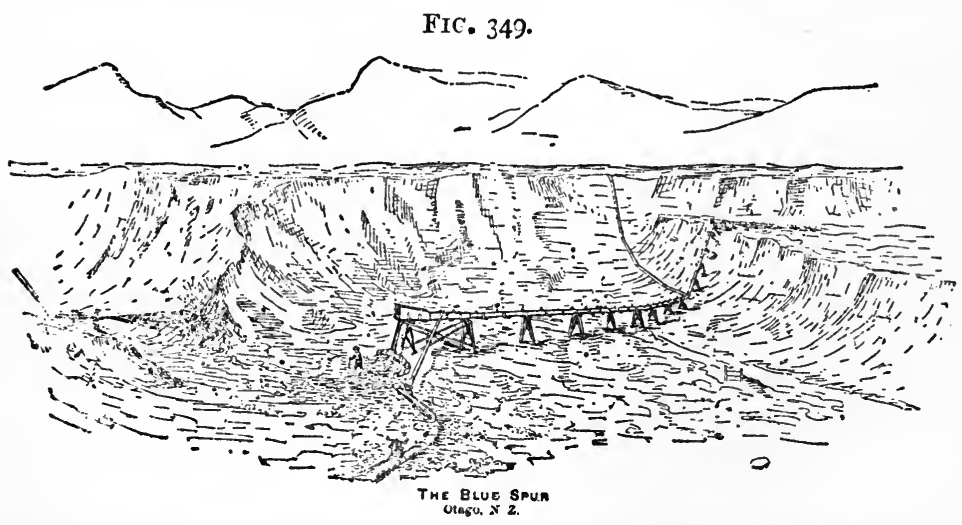

24 hours; in some cases the outflow is reckoned for 1o hours only, and is spoken of as the "ten hours miner's inch."

Under these circumstances it is evident that great care must be taken to ascertain precisely what inch is meant, before making any estimates based upon this uncertain unit, the miner's inch.

The "duty" of the miner's inch is "the quantity of material washed by an inch of water in 24 hours." As might be expected, the duty varies very considerably, indeed from I to $4 \frac{1}{2}$ cubic yards. The duty necessarily depends upon the pressure of the jet of water, and upon other causes, such as "character of the material washed, height of banks, use of explosives, size and grade of sluices, and class of riffles. The sluice affects the duty of the inch in so far as its capacity regulates the quantity washed." †

Under favourable conditions at Cherokee Flat, $\ddagger-v i z .$, fine

" "The Auriferous Gravels of California," Ninth Annual Report of the State Mineralogist for the year ending December 1, 1889; Sacramento, 1890, p. 122 ; and Bowie, op. cit. p. 124.

+ Bowie, op. cit. p. 268 . p. 124. $\quad$ + Bowie, op. cit. pp. 268, 269. 
material, high banks, head of 300 to 350 feet, and grade $\frac{1}{32}$, $5 \cdot 5$ cubic yards are said to be the duty of the miner's inch.

At Osceola,* in Nevada, the average washing in 1890 was $1 \cdot 62$ cubic yards to the inch of water and it was expected that the duty would be raised eventually to 2 cubic yards.

It is hardly necessary to say that the yield of the gravel varies between very wide limits, and it is consequently impossible to lay down any average for the hydraulic mines of California or any other country. But the accompanying table gives the results of actual work, and will at all events show that poor gravel, containing gold worth only Io or I 5 cents, say, $5 d$. to $7 \frac{1}{2} d$. per cubic yard, can sometimes be made to pay good profits.

With the exception of Osceola, the works were all in California; the figures are borrowed from Mr. Bowie, and many other examples of the yield of auriferous gravel will be found in his work and in Mr. Hammond's report.

A cubic yard of gravel is estimated by $\mathrm{Mr}$. Hammond to weigh from $I \frac{1}{2}$ to $I \frac{3}{4}$ tons.

One of the great difficulties with which the hydraulic miner has to contend is getting rid of the enormous quantities of refuse produced by his washings. Some idea of these quantities will be gathered from the statement that one working alone, the Gold Run Ditch and Mining Company, was for a period of eight years discharging 4000 to 5000 cubic yards of sand, gravel and boulders daily into a tributary of the Sacramento. As a natural consequence banks were formed in the river, obstructing the navigable channels, rendering overflows more frequent and destructive, and causing valuable land to be destroyed by deposits of sand. Litigation ensued, and some years ago the Superior Court of Sacramento decided that the hydraulic mining companies must build dams to impound the coarse and heavy débris, or take other means to prevent their being washed down the rivers.

The consequence of this decision was a great diminution of the amount of hydraulic mining carried on in the State; but quite lately an Act of Congress has been passed which will allow work to be resumed at many of the mines.

(2) EXCAVATION OF MINERALS UNDER WATER. - In Chapter IV. mention was made of dredges of various types, which are employed for the purpose of extracting gold-bearing sand and gravel from the beds of rivers. Gold is not the only mineral worked in this fashion; in South Carolina phosphate of lime is dredged up from river-bottoms, and in Prince Edward Island a shell-marl obtained in a similar manner is sold as a fertiliser. Lastly, on the coast of Germany, between Dantzig and Memel, two forms of subaqueous work are applied to the getting

* Eng. Min. Jour., vol li., r891, p. 630. 


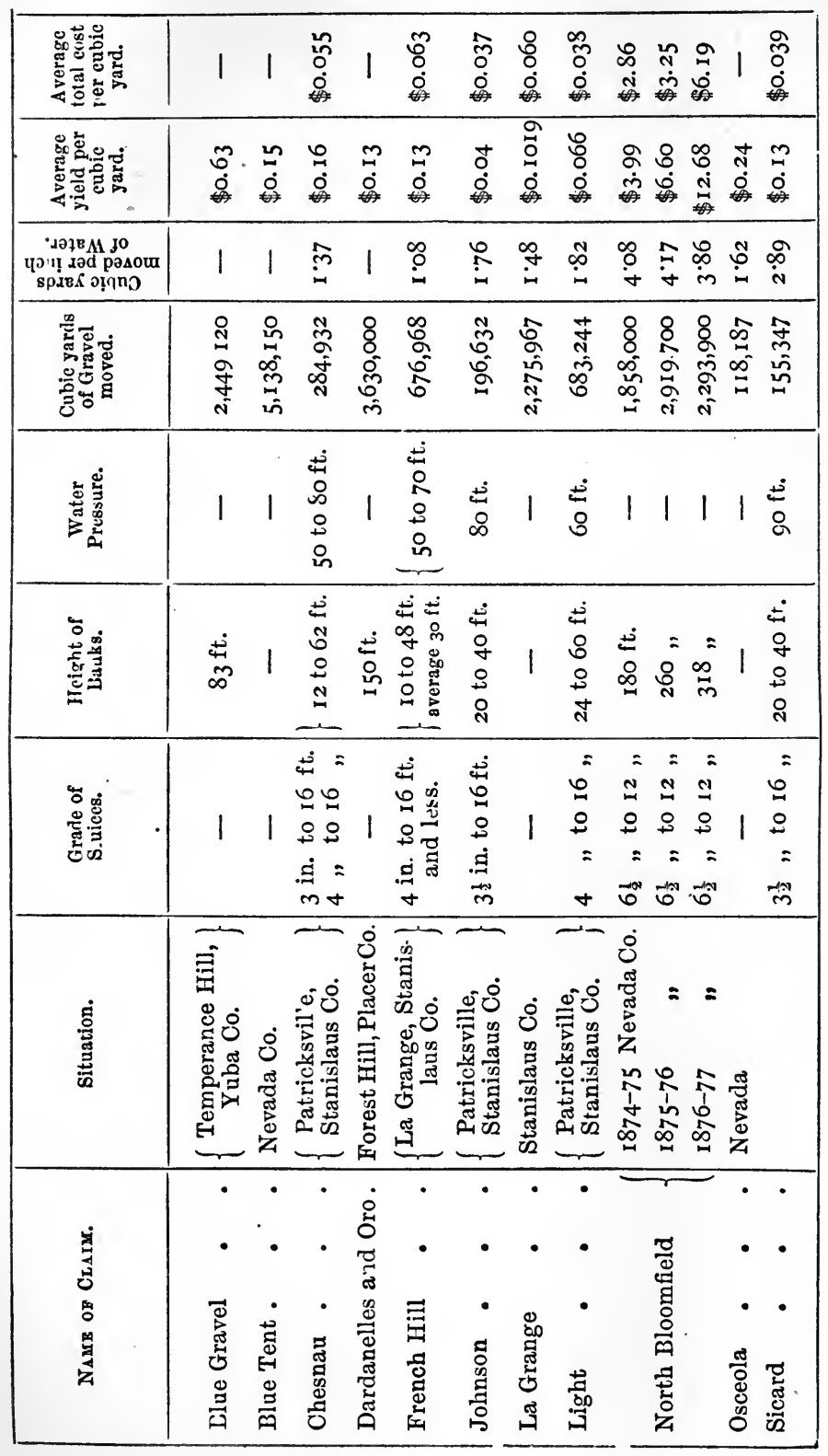


of amber.* Some is dredged up by bucket-dredges, and some is obtained by divers. The divers go out in boats about threequarters of a mile off the Brüster Ort lighthouse, and after anchoring they descend to work the amber bed, being equipped with regular diving dresses, and supplied with air by pumps worked by their comrades. Carrying a crowbar and a pronged iron, the diver searches for masses or lumps of amber and detaches them from the parent bed, or finds them already loosened and dislodged by storms.

(3) EXTRACTION OF MINERALS BY WELLS AND BOREHOLES.-Liquid, gaseous and soluble minerals are sometimes obtained by one of these two methods. The principal are : carbonic acid, natural inflammable gas, petroleum, and salt.

Carbonic Acid.-Underground supplies are tapped by boreholes, and the getting consists simply in piping off the gas from the top.

Natural Gas.-Precisely the same remark applies in the case of the natural gas used for fuel in Pennsylvania, the occurrence of which has already been described.

Petroleum.-This mineral may be got either by wells or boreholes. In the United States, in Galicia, and in the great oildistrict on the Caspian Sea, boreholes are sunk by one of the processes described in Chapter III., and it is found that the oil will either rise to the surface or part way to the surface. In this latter case it has to be drawn up by pumps. In order to increase the flow of oil from the surrounding rocks into the bore-hole, it is usual to break up and crack the oil-bearing stratum by a torpedo. This is a powerful charge of some explosive contained in a tin cylinder, which is lowered into the hole to the required depth and then exploded. Nitroglycerine, dynamite or gunpowder are employed, but of course the last is only used when its more powerful rivals cannot be obtained. As much as a hundred quarts of nitroglycerine may be used for one blast, in which case the explosive is let down in separate cylinders, each containing twenty quarts. The explosion of the top cylinder fires the charges in the others.

In Burmah the petroleum is got by wells, and this was the manner by which the great Russian deposits were worked until comparatively lately. The oil gradually oozes out of the surrounding strata and accumulates in the bottom of the well, whence it is drawn up by earthenware pots.

Salt.-The great bed of salt at and near Middlesbrough is worked by making a borehole and putting in two tubes and a pump, so arranged that water from a superincumbent bed of sandstone travels down, dissolves the salt, and is then drawn up. The process pursued will be apparent from an inspection of the

* "The Amber Fisheries of the Baltic," Evening Standard, Sept 12, 1888. 
figure. A drive-pipe an (Fig. 350) is first rammed down through the alluvial soil, in the manner described by Fig. 142, and a borehole, 8 inches in diameter, is put down through the sandstone, gypseous marl, and the whole thickness of the rock-salt, until it has reached

FIG. 350 .

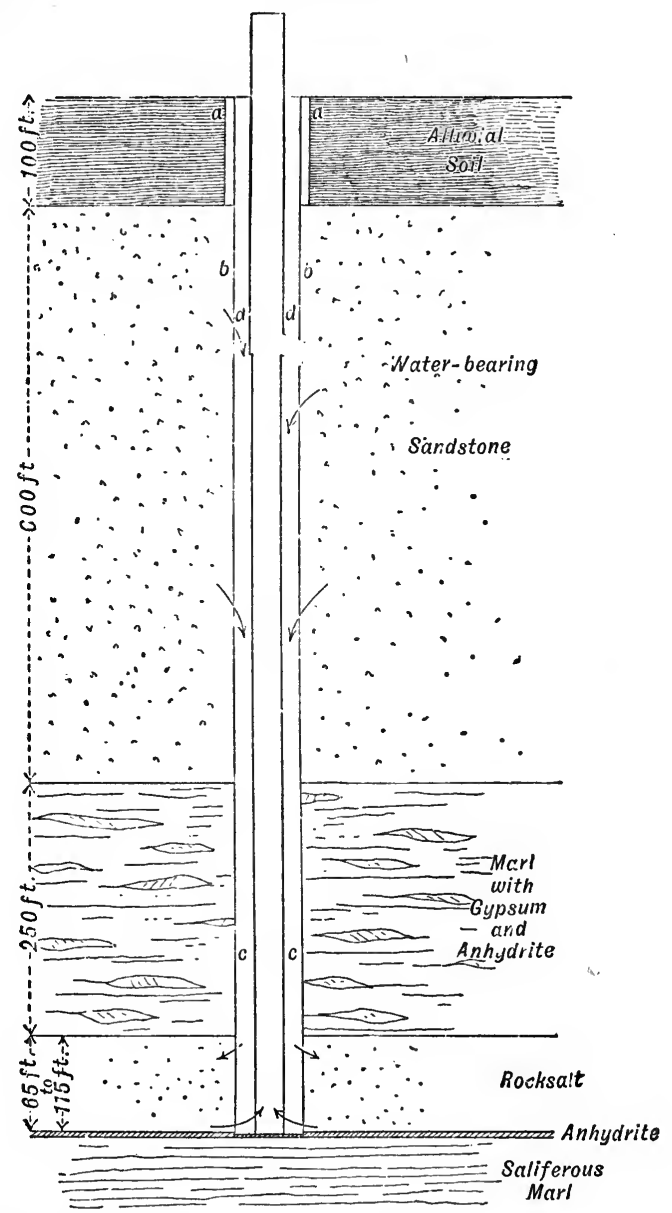

the underlying anhydrite. It now has to be lined with a steel tube $b b$ (Fig. 350, in which the size of the tubes is greatly exaggerated), $6 \frac{3}{4}$ inches in diameter internally; for the first $15^{\circ}$ feet from the bottom the steel is $\frac{1}{2}$ inch thick, then $\frac{5}{16}$ inch for 300 feet, and the remainder is $\frac{1}{4}$ inch thick. With the sleeve 
couplings over them, the tubes just pass down the drive-pipe. In the rock-salt and in the 600 feet of water-bearing sandstone, the lining pipe is perforated with holes $\mathrm{I}$ inch in diameter, and 12 inches apart vertically.

Lastly, a steel suction pipe (Fig $35^{\circ}, c$ ), 3 inches in diameter internally, and $\frac{1}{4}$ inch thick, made in 20 -feet lengths, united by sleeve couplings, is lowered into the borehole; about 240 feet from the surface is fixed a brass working barrel (Fig. 350, $d$ ), 6 feet long, $4 \frac{3}{4}$ inches in diameter and $\frac{1}{2}$ inch thick, and above it steel tubes, 43 inches in diameter, which reach to the surface. The working barrel has a ball valve at the bottom. When the pump bucket, also fitted with a ball valve, has been let down by a series of rods, and the last one has been connected to the end of the walking beam, the extraction of brine can commence. It is evident from the figure that when a pump is set in motion at $d$, water will ascend the suction pipe, and its place will be taken by water from the sandstone. This descends the outer tube to the rock-salt, brings it into solution, and is pumped up as brine. As the pumping proceeds, the rock-salt is gradually eaten away all round the borehole; in time the marl roof must fall in, and eventually the pipes will get more or less choked, and the brine will be too weak to be worth pumping.

The rate of pumping is regulated so that the brine is delivered

FIG. 35 I.

-

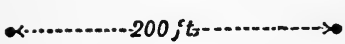

with 25 per cent. of salt. As it comes up it is full of gas, which is mainly nitrogen with a small proportion of hydrocarbons.

The boreholes are arranged in fours at the corners of a square, with a diagonal of 200 feet (Fig. 35I).

The brine is delivered into a large storage and settling-pond, whence it flows into sheet-iron evaporating pans.

If there is no natural supply available, as is the case in the Middlesbrough district, fresh water from the surface is run down the outer pipe, and the dissolving proceeds as before.

Natural sheets of saline water or brine can be tapped by wells or boreholes in some districts; indeed salt was worked in this way in Cheshire long before the discovery of the rock-salt. Some of the Cheshire salt is derived from brine pumped up from inundated mines worked originally for rock-salt, which are now full of water and cannot be entered.

This therefore is practically a combination of underground work with extraction by solution, and the process which in these cases has been finally adopted, through force of circumstances ${ }_{1}$ is sometimes found advisable from the commencement. 
Callon* describes and figures the method of working the salt marls of the Salzkammergut by huge elliptical chambers. A network of drivages is first of all made at the floor of the proposed chamber, and then fresh water is brought in, until it fills the excavations and gradually eats away the pillars and roof. The brine is pumped up and the clayey matter falls on the floor of the chamber and is left there.

At Bex in Switzerland the process is similar, only it has to be adapted to the nature of the deposit worked. The salt occurs in the form of large lenticular masses of saliferous anhydrite surrounded by anhydrite free from salt. The lenses are from ro to 50 metres wide, and are known to extend to a depth of 300 or 400 metres, dipping almost vertically.

A main shaft is sunk and the saliferous rock is reached by crosscuts and dissolved away in slices roo metres thick at a time.

An intermediate shaft, or winze, is sunk from the crosscut, and when it has reached a depth of roo metres a second crosscut is put out, from which two long drivages, 2 metres high and $1.50 \mathrm{~m}$. wide, are made in the direction of the major axis of the deposit. By a series of drivages at right angles to each other, the lowest part of the slice is cut up into a set of square pillars about 5 or 6 metres on the side. Water is let into the winze, and is allowed to rise to the level of the upper crosscut. It dissolves the salt from the rock, is pumped up, piped out to the surface through a long adit, and evaporated. As the strongest brine sinks to the bottom, the pumps are made to take their supply from the lowest part of the workings. The saliferous anhydrite contains from 25 to 30 per cent. of salt, and when this has been dissolved out, the rock does not fall to pieces as might have been expected. Gypsum is soluble in water containing so to I4 per cent. of salt, $\tilde{\text { so }}$ the first action of the water is to dissolve some of the anhydrite; but when the brine becomes more concentrated, gypsum is deposited in the form of small crystals, which bind the anhydrite into a firm mass. Consequently the leached rock stands perfectly well by itself, and there is no fear of the sides falling in.

One of these large workings, when once properly laid out, will go on furnishing brine for thirty or forty years. The rate of pumping is regulated so as to supply brine with 25 to 26 per cent. of salt.

A last instance of a combination of underground workings and extraction by watery solution may be taken from Parys Mountain in the island of Anglesey. During the active working of the Parys mine many years ago, poor copper ore which had been broken, but which would not pay for the expense of winding and dressing, was left underground. Under the action of air and

* Lectures on Mining, vol. ii. p. 23 ; Atlas, plate xliji. Figs. 25 I, 252. 
moisture, the chalcopyrite in the refuse and in the pillars is gradually decomposed, producing a certain quantity of soluble sulphate of copper. Rain finding its way down the mine dissolves the sulphate, and the pumps draw up a strongly coloured water, which in contact with scrap iron yields merchantable copper precipitate. The mine is now worked solely in this way.

In a like manner a little copper has been got from the water flowing out of the County adit in Cornwall.

(4) UNDERGROUND WORKINGS.--The methods employed for excavating minerals underground are almost as various as the different forms in which the minerals themselves occur.

The deposit must first be reached by a shaft, or, where the contour of the country permits it, by an adit. The choice between these two methods of attack must be entirely governed by the circumstances of the case. In a comparatively level country, it would be impossible to bring in an adit capable of rendering any real service without going to a distance which would make the cost of driving prohibitory; but among the mountains an adit may be the quickest and cheapest means of entering productive ground. It has the advantage of enabling all pumping to be dispensed with for a time, of reducing subsequent water-charges, of affording an opportunity of easily utilising water supplies in the neighbourhood, and often of bringing out the mineral to a more suitable locality for treatment than could be obtained by raising it perpendicularly to the surface. Instances often occur in which the adit can be driven along the course of the deposit itself, and so furnish valuable data concerning it. A shaft 'sunk upon the dip of a deposit has this same advantage; but here it is necessary to remark that the term "shaft" does not always convey the same meaning. The ore-miner uses the word to denote not only a vertical pit, but also one sunk upon a vein, even if the inclination is but slight. There are portions of shafts in Cornwall which do not dip more than ${ }_{5}$ degrees from the horizontal. Shafts with an inclination of $60^{\circ}$ or $70^{\circ}$ from the horizontal are common in vein-mining, and no ore-miner would think of calling them by any other name. On the other hand, the coal-miner seems to confine the word shaft to vertical pits. If a pit is sunk vertically till it meets a seam of coal, and is then continued along the dip of the bed, the latter sloping part of the excavation, even if it has a dip of $50^{\circ}$ or $60^{\circ}$, is called an "in; cline," and not a shaft. The term "slope" is used in places to denote an inclined pit along the dip of the strata.

We will suppose that the deposit has been struck by a shaft, incline, or level. The problem is how to remove it to the best advantage. As the conditions are so various, it is advisable to classify the methods according to the nature of the deposit, and treat separately the modes of working-(I) beds ; (2) veins; and (3) masses. 
BEDS. - Two great divisions stand out prominently: (A) Methods in which the bed is cut out into pillars; and (B) methods in which the bed is removed at once without this preliminary treatment. In the former the pillars may either be left as permanent supports, or they may be removed in a second stage of the process of exploitation. We have thus three principal processes of working to consider ${ }_{7}$ as shown in the following table :

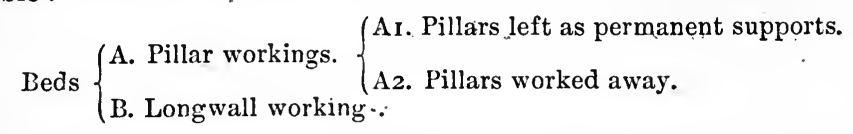

A I. Pillars Left as Permanent Supports.-This system is adopted with minerals of no great intrinsic value, as it is often better to lose much of the mineral in the form of pillars, than to go to the expense of putting in artificial supports during the period of exploitation.

The method can be best understood by giving a few characteristic examples taken from minerals of various kinds-viz., gypsum, iron pyrites, limestone, salt, and slate.

Gypsum.-Figs. $35^{2}$ and 353 represent in section and in plan the chambers and pillars of the underground gypsum quarries at Paris, which supply the stone from which the well-known plaster is made.* The principal bed is from 50 to 60 feet in thickness. Pillars are left ro feet square at the base, and the stalls between them are I 6 feet wide. The workings are slightly arched, and are not carried up to the true roof, for the purpose of better maintaining the security of the chambers, because heavy damages would have to be paid if they "caved in" and rendered the surface useless. A similar layer of gypsum left for the floor prevents "creep"- that is to say, a rising of the floor owing to the thrust of the pillars, and enables the underground roads to be kept in order with little expense.

In Nottinghamshire the poor parts of the bed of gypsum are left as pillars, and they are sufficiently frequent to prevent any waste of good rock for supports.

Iron Pyrites.-At Cae Coch Mine, near Llanrwst in North Wales, there is a bed of iron pyrites, about 8 feet thick, which is worked by leaving pillars from 2 to 3 yards in diameter, at intervals of 8 or 10 yards. The pillars are somewhat irregular, because where the roof is firm and strong more space can be

* Callon, Lectures on Jining, vol. ii. plate xli. 
left without support. If the roof appears at all weak, the pillars are made closer together. The excavations are slightly arched at the top, so as to obtain a little more strength.

Limestone. - A considerable quantity of limestone is wrought in this country by underground mining, especially in Wiltshire, Worcestershire, South Staffordshire, and Scotland.

The beds of freestone which are worked near Bath occur in the Great Oolite, and vary from 8 or 9 to 18 or 24 feet in thickness; the dip is slight, being only $I$ in 33 .

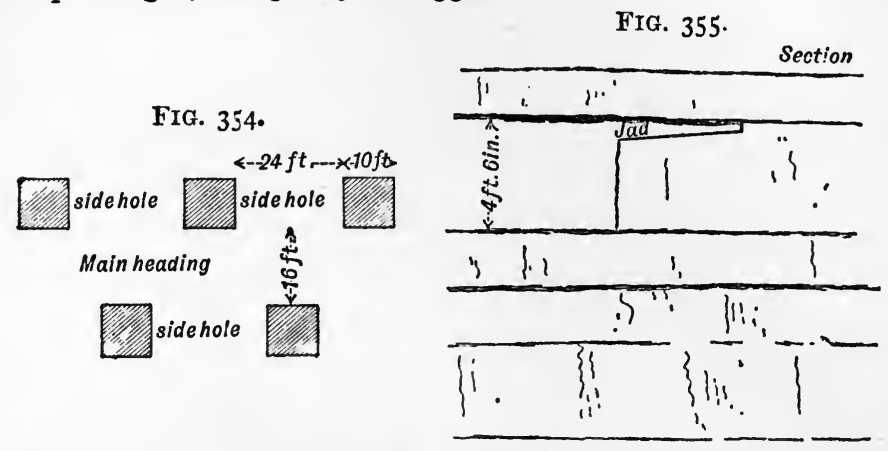

The bed of stone, which it is proposed to work, is reached by an inclined plane, and a main heading is driven out 15 to 16 feet wide, with "side holes" at right angles, as wide as the roof or ceiling will admit with safety, say 20 feet to 24 feet, leaving pillars io feet square and upwards (Fig. 354). If any rock is unsound, it is left as a pillar, and this may cause some irregularity in the plan of the mine.

The first process in removing the stone consists in excavating the "jad," a horizontal groove at the top of the bed, which is

FJG. 356 .

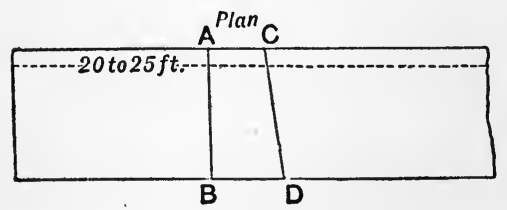
cut in for a depth of 5 feet and a width of 20 to 25 feet (Figs. 355 and 356 ).

After the jad has been excavated with the pick (Fig. 355), a vertical cut is made with a saw along the line BA (Fig. 356), and another along the line DC, and a piece $A B D C$, called the "wrist," is wedged up from the bottom or off from the side; it breaks along the line AC. When the "wrist" has been removed, the blocks are simply cut out with saws. These saws are 6 or 8 feet long by ro inches to 12 inches wide. The first saw used in the jad has to be narrower, and is called the "razor saw."

The heaviest saw weighs $56 \mathrm{lbs}$, and the handle can be fixed 
as shown by the dotted lines (Fig. 156), or entirely below the eye for working inmediately below the roof.

When set free by sawing on all four sides, the block is easily detached by wedges driven in along a plane of bedding. The blocks are lifted off by cranes, and either loaded at once on to trucks or stacked inside the quarry, after having been roughly dressed with an axe or with a saw.

A workman can saw I 5 square feet of the softest beds in an hour.

In the neighbourhood of Dudley there are two beds of Upper Silurian limestone worked by true mining. The top bed is from I 6 to 18 feet thick, and it is got by a system of pillars and chambers. The pillars are 8 yards square, and the stalls between them 13 to 17 yards. Near the outcrop both the pillars and the stalls are rather smaller than this. The top 2 feet of stone are left to support the roof.

Salt.-The salt mines of Cheshire* are an excellent example of pillar and chamber workings. The bed is 84 feet thick, but only

FIG. 357.

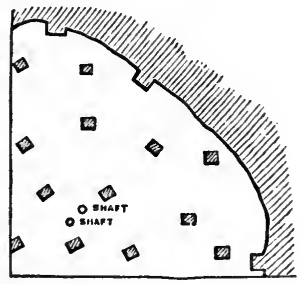

FIG. 358 .

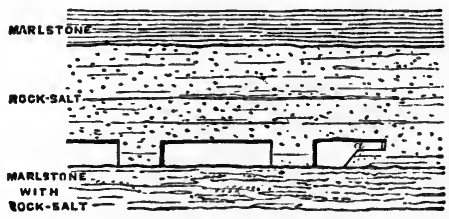

the bottom part, 15 to 18 feet thick, is mined. Pillars ro yards square are left promiscuously, about 25 yards apart, or closer if thought desirable in any special places. Fig. 357 represents part of Marston Hall Mine near Northwich. The bed is almost horizontal, and is reached by two perpendicular shafts ; wide stalls are then driven out on all sides. The workings are advanced by making an excavation in the upper part called the "roofing" ( $a$, Fig. $\left.35^{8}\right)$; and the lower two-thirds of the thickness worked are got by blasting slanting holes. This part is called the " benching." The roofing is made by holing or under-cutting by hand, or better by a Walker circular saw driven by compressed air (Fig. 216), and bringing away the salt by horizontal holes bored with a jumper and charged with gunpowder.

The old method of working s.lt in Roumania $\uparrow$ was by bellshaped pits, which were widened out gradually till their diameter

* Dickinson, "Reports on the Salt Districts," Reports of the Inspectors of Mines for the Year 1881 , p. 66.

+ Notice sur la Roumanie. Exposition Universalle de Paris en 1889 , pp. 116 to 119. 
reached 160 to 200 feet ( 50 to $60 \mathrm{~m}$.), after which the sides were carried down vertically.

Nowadays long chambers are excavated with intervening pillars. A chamber is begun by driving a level ro to 50 feet wide ( 3 to $16 \mathrm{~m}$.), and this is deepened and widened at the same time, so that the sides make an angle of $30^{\circ}$ to $45^{\circ}$, until the full width of 164 feet $(50 \mathrm{~m}$.), is attained; the excavation is then continued with vertical sides. The section therefore resembles that of an ordinary house. A gangway is carried round the roof for the purpose of inspecting it regularly.

At Turgu Ocna Mine there are four of these chambers which will eventually vary from roo to I6o feet in width ( 30 to $49 \mathrm{~m}$.) and 450 to 560 feet ( 138 to $170 \mathrm{~m}$.) in length, and afford a total working area of 22,000 square yards (1 8,550 square metres).

As regular blocks of almost. uniform weight are preferred for exportation, great pains are taken to get out the rock-salt in the form which meets with the readiest sale, and to reduce the quantity of "smalls" to a minimum. The blocks are cut by hand or by machine. Three cutting machines are used: one makes horizontal cuts in the direction of the long axis of the chamber, the second vertical cuts, and the third transverse cuts, so as to divide the rock-salt into regular cubes, about one foot on the side, weighing $\mathrm{r} 32 \mathrm{lbs}$. each (6o kil.).

Slate.-In the Festiniog district in North Wales the principal bed is 120 feet ( $36 \frac{1}{2}$ metres) thick in places, and there are others from 30 to 70 feet thick; these beds are spoken of as "veins," though they are true sedimentary deposits. The dip of the beds is from $20^{\circ}$ to $30^{\circ}$ or $35^{\circ}$, whilst the dip of the planes of cleavage is about $45^{\circ}$; the strike of the planes of cleavage is very nearly the same as the strike of the planes of bedding.

The method of working consists in making a series of parallel chambers (openings) separated by pillars (walls). 'These do not follow the dip, but run somewhat askew, because it is found that the slate rends well at right angles to the cleavage planes in a direction which does not coincide with the dip exactly. The width of the chambers along the line of strike varies according to the firmness of the bed selected as roof of the chamber, and is commonly from 35 to 50 feet. The width of the intervening pillars is usually somewhat less.

The workings are divided into a succession of floors about 50 feet one below the other vertically. The first operation consists in reaching the bed by means of an adit or an incline sunk along the dip of the bed and then levels are driven out along the strike, A BCD (Fig. 359, plan ; Fig. 360, cross section), under some bed which offers the necessary guarantee of solidity, very often an altered volcanic ash. When a new level, such as D (Fig. 360), has been driven a certain distance it is connected with the level above by an inclined drift called a "roof." The "roof," or "rise" as it would be called by 
an ore-miner, is a passage about 4 feet high, and 4 feet wide, generally excavated from below upwards, on account of its being more economical to let the broken rock fall into the level underneath than to draw it up by hand, which becomes necessary if the pass?ge is made by "sinking"-i.e., excavating from above downwards. The "roof" is usually carried up on one side of the proposed new chamber. The third step in the process is the "widening," or excavation of the rock on one side of the "ronf," until the slate is uncovered for a width of 40 or 50 feet. The result of this work is the formation of an inclined open space 40 feet long, for instance, along the strike, and stretching up from one level to the next one $5^{\circ}$ feet above it vertically. While this work is going on, the level is being prolonged; a distance of 30,40 or 50 feet is left for the pillar, and eventually a new "roof" is put up for a second chamber.

In most cases the excavation of the "roof" and the process

FIG. 359.

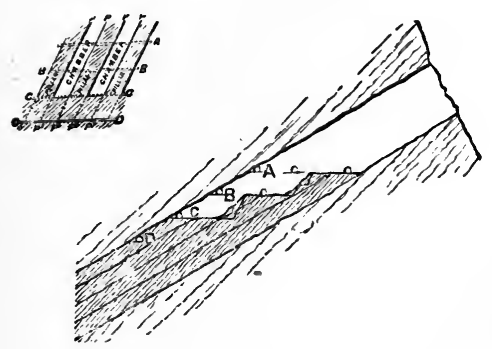

FIG. 36I.

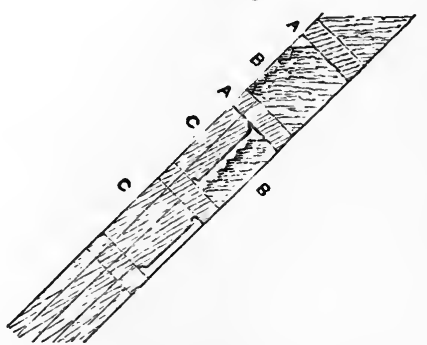

of widening go on at the same time, because it is found that the atmosphere of a small passage like a "roof" naturally becomes bad during work, unless it is provided with some special ventil itilig appliance, whereas if the amount of space is increased, the impurities introduced into the atmosphere are spread over a greater volume of air, and the evil is lessened.

This preliminary work of driving levels, "roofing up," and "widening," is all done by a special set of men, known as "miners," to distinguish them from the slate-getters, who are called "rockmen," for slate is par excellence "the rock" in the district.

The productive period of the life of a chamber now begins. The first duty of the rockmen is to examine very carefully the roof of the chamber, which ought to have been left perfectly secure by the miners; but as the rockmen have to work under it possibly for ten years or more, they naturally are anxious to feel that every chance of a fall has been prevented as far as possible. In the early part of the working of a chamber, when the roof is within reach, the examination can be made with ease; 
later on when the slate has been excavated, or partly excavated, long ladders are required, and the task becomes much more difficult.

Having satisfied themselves and the agents that all is safe, the rockmen proceed to remove, bit by bit, the huge mass of slate lying between their floor and the one above it. Such a mass will sometimes be sufficient to produce merchantable slate worth $£_{10,000}$ or even $£^{1} 5,000$, and to give work to a small gang of men for fifteen years.

In the plan (Fig. 359), the lines PP' are the sides of the chambers and also indicate the direction of the "pillaring." When the slate is taken away a large chamber is left, and the series of chambers one above the other forms a huge continuous inclined opening stretching down from the surface, it may be, for a distance of several hundred yards. Between each two of such openings, there is the supporting pillar, nearly if not quite equal in size to that of the excavation. The consequence is that very nearly onehalf of the available slate is lost in the form of pillars; much again is entirely wasted in making the preliminary drivage, the "roof," the "widening," and the "free side." There is a further loss in getting the blocks and, as we shall see later on, in making the e into marketable roofing slates or slabs. Indeed it is reckoned that even a good "vein" will yield only about 40 per cent. in the form of blocks, and that two-thirds of this are wasted in the subsequent dressing. Therefore, the slate miner does not sell more than one-tenth to one-sixth of the slate rock which he lays bare in a chamber, to say nothing whatever of the loss in the form of pillars, which have to be left in the mine as permanent supports.

There are varieties of this method of working. For instance, at Aberllefenny in Merionethshire, ${ }^{*}$ a bed 60 feet thick, dipping at an angle of $70^{\circ}$, is worked by alternate pillars and chambers with a much smaller loss in supporting rock. The pillars are from 24 to $3 \circ$ feet long, ard the chambers 100 to 187 feet along the line of strike. Indeed even at Festiniog, there are chambers at Wrysgan Mine, where the roof is very strong, more than 130 feet in length, whilst the pillars are only 50 feet.

At Angers, in France, the beds dip at a high angle, and the underground workings are carried on like an open quarry under a strong roof of slate; the floor is being continually worked away in steps, and an immense open chamber is left with perpendicular sides.

In the French Ardennes the beds of slate are inclined at lower angles, and in this respect more resemble those at Festiniog; but the pillars run indefinitely along the strike, instead of approaching the line of dip. The cross-section (Fig. $3^{6} \mathrm{r}$ ) shows

* C. Le Neve Foster, "Notes on Aberllefenny Slate Mine," Trans. $R$. Geo.. Suc. Curnuci'l, vol. x. p. 169. 
these pillars AA, and the chambers between them. The attack of the bed is made from below, and not from above as in Wales, and the slate is removed slice after slice parallel to the bedding. The men stand upon the rubbish, which finally fills up the chambers completely. In the figure the upper chamber is exhausted, the next one is half worked out, and in the lowest only one slice has been taken off.

This method of mining is favoured by the presence of natural joints, which can be utilised for forming the roofs of the chambers without any cutting.

In this case the walls of the excavation are supported eventually, not only by the pillars, but also by the rubbish, and other instances may be found where a filling up with waste rock constitutes a feature of the method of working. For instance, the thick seam of carnallite or kainite at Stassfurt is worked by huge chambers, between which pillars are left. The Prussian Government, fearing that, in spite of wide pillars, a "caving-in" may possibly occur, has ordered all the excavations to be filled up. The cheapest method of doing this is by working out chambers in the bed of rock-salt, lying geologically below the potash salts, and using the salt as stowing. The chambers in the rock-salt stand well without fear of the roof giving way.

At the Wieliczka salt mines it has been found that the natural pillars, originally supposed to afford ample support, are not always capable of preventing the roof from falling, and in some places they are supplemented by huge timber frames (Fig. 268), which are nothing more than "cogs" or "pigsties," on a gigantic scale.

A 2. Pillar Workings with Temporary Pillars. - It is naturally far more satisfactory from an economic point of view to leave as little of a deposit as possible : a larger output can be got from a given working area if everything is removed, and it seems a pity after a bed of mineral has been discovered, and after all the dead work of sinking shafts and driving levels. has been accomplished, to allow any of the valuable material, the very object of the mining, to be left behind. We therefore now come to the cases in which driving galleries and cutting up the bed into pillars form only a first stage in the actual exploitation.

The most important example in this country, after coal, is the mining of ironstone in the Cleveland district. The bed has an arerage thickness of about 12 feet (Fig. 43) where worked. If the contour of the country is not suitable for bringing in adit levels, two vertical shafts are sunk, one of which is shown in Fig. 362. An almost level road, the mainway, is driven out with a width of 5 yards; drivages are put out, at right angles to it, at intervals of 20 yards, called bords, also 5 yards wide. and at distances of 30 yards apart cross-drivages are made, called walls. These are only 4 yards wide. By this system of galleries, 
the bed is cut up into a series of pillars, 30 yards long by 20 yards wide, and owing to the size of the tunnels the quantity of ore got out in this preliminary stage is by no means small. When the bed has been divided up in this way, the work of removing the pillars begins. As a rule, the attack begins on pillars situated near the boundary, so that whilst the first carving out proceeded towards the boundary, the removal goes on in the opposite direction -viz., towards the shaft. A place or $\operatorname{drift} a b$ is worked across the

Fig. 362.

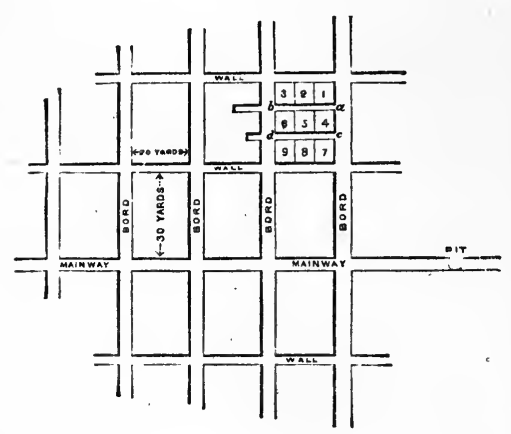
pillar for a width of 2 to 4 yards, and then, starting from the drift $a b$, the rectangle beyond it is removed by drivages, called lifts, sometimes two in number, sometimes three, as shown in the figure and marked I, 2 and 3. It may be necessary in some cases to leave a little of the pillar, in order to keep out the fallen ru'sbish beyond and to prevent a too sudden fall of roof. According to circuinstances, it may be a corner of the pillar that is left, or a narrow strip on one side. The working place is timbered during the removal of the ironstone, and when all has been taken out the timber is withdrawn and the roof allowed to fall. While the lifts $\mathrm{r}, 2,3$, are being workerl away, another place $c d$ is being diven across the pillar, which is a preparation for anotl er set of lifts 4, 5, 6; lastly, lifts 7 , 8, 9 are worked away, and with the exception of occasional small colners or strips, the removal of the pillar is complete, and its place is taken by fallen rubbish. The ironstone is got by boring and blasting; the holes are bored by hand or by machine, and gunpowder is the explosive mostly used. The jumper employed and the three forms of mechanical augers have already been described.

Varieties of this method of pillar working naturally occur, but they all come back to this main principle, when the bed is of a thickness which enabies it to be dealt with in one operation.

As another example I will take a bed of alluvial tin ore, to which I have already alluded in speaking of the sinking of a shaft through mud near Falmouth (p. 268).

The bed of stanniferous gravel varied in thickness from 3 inches to 7 feet, but as a rule it was not thick enough for men to stand upright when at work; the marimum width was roo yards. It was reached by a shaft $D$ sunk through the mud of the tidal creek, and also by a shaft $\mathrm{C}$ and level $\mathrm{AA}$ in the hard slate (Fig: $3^{6} 3$ and $3^{6}+$ ). Main levels EE were driven in the gravel 


\section{EXPLOITATION}

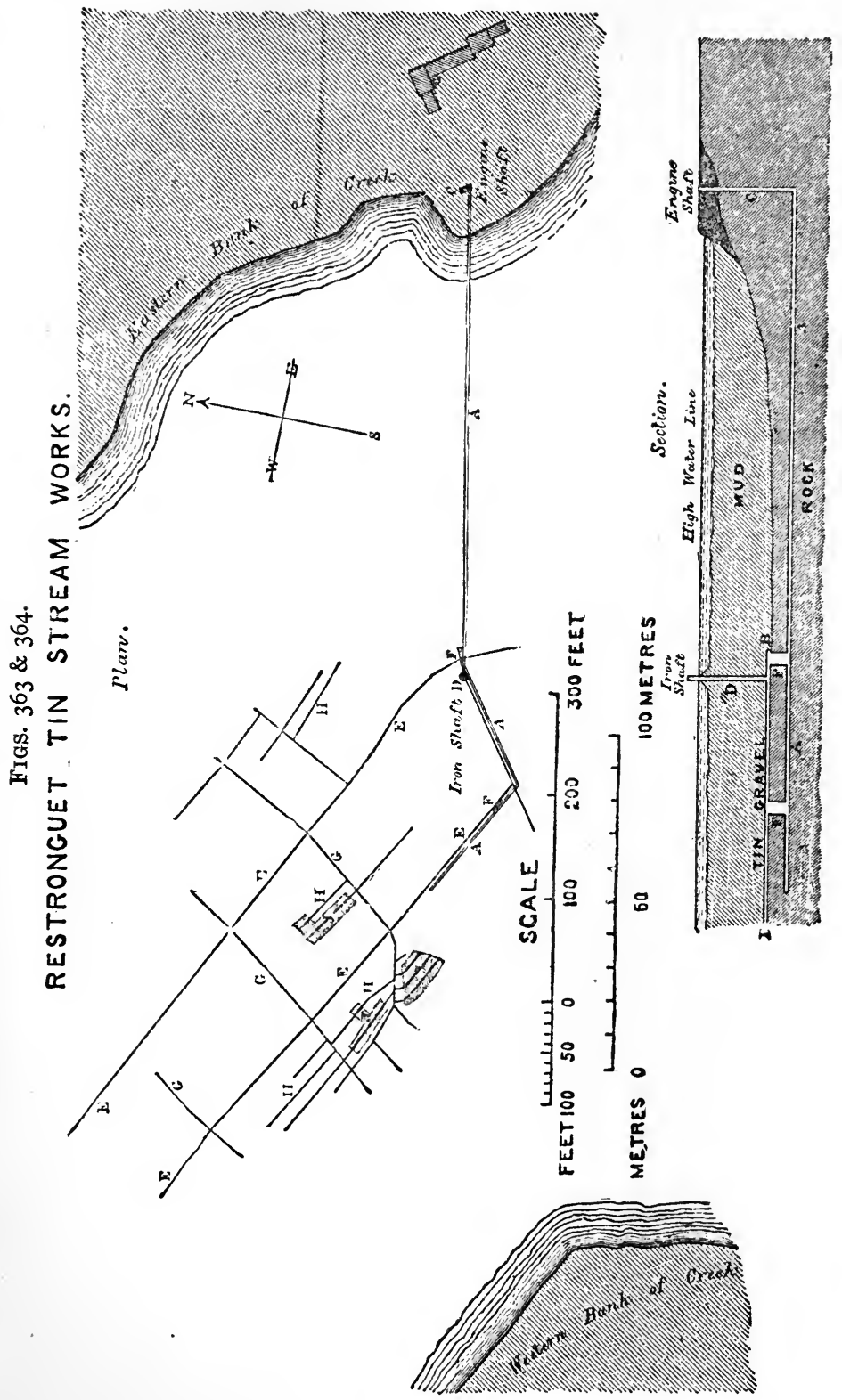


bed 20 fathoms apart, and air levels GG, all strongly timhered. Cross or stripping levels $\mathrm{HH}$, 4 feet apart, were pushed out from one air level to the other, and the gravel was removed for a distance of 7 feet on each side, as shown by the shading $J$. The mud forming the roof was allowed to fall, and fill up the empty spaces. The gravel was wheeled in barrows to the main levels EE, and conveyed by a railway to one of the passes FF, which led to large bins, whence it could be drawn off into waggons in the main rock-level $\mathrm{AA}$, and sent to the shaft.

Drift mining, or the working of auriferous alluvial gravel, is carried on in a similar manner. Old river beds which carry gold are common in California, and especially in Sierra and Placer Counties. These beds once occupied the lowest ground of the district, and became covered over by true lava flows, volcanic ash and mud, sometimes also by the deposition of pipeclay and infusorial earth. The streams were diverted and cut themselves new channels, which in process of time were so much deepened as to lie many hundred feet below the level of the old buried auriferous beds. The width and thickness of the old gold-bearing alluvia vary greatly, as might be expected from observing the bed of a river at the present day, and the gold is not uniformly distributed in the gravel. The total thickness of the goldbearing gravel may amount to as much as 600 feet. In driftmining the workings are confined to the "pay-lead," usually the very bottom of the channel, varying from 100 to 150 feet in width on an average.* Where there is a rich gravel with $\$ 5$ to $\$ 8$ per cubic yard, the leads may be only 50 to 75 feet wide; where gravel with $\$_{2}$ to $\$_{4}$ is being mined, they are often 300 feet to 400 feet wide.

By tracing the junction of the underlying slate and the volcanic capping (Fig. ${ }^{6}{ }^{6} \dagger$ ), an idea is obtained of the run of the ancient valley, and arrangements are made for reaching the old river-bed, either by an adit driven into the hillside, or by a shaft sunk from the top. Working by shafts entails the expense of winding and pumping, and adits are therefore preferred. In fixing a position for the adit, care is taken to start it so that it will come in a little below the level of the gold-bearing gravel, and so that it will afford sufficient tip-room for the waste material. The adit of the Forest Hill Divide Company, Placer County, is 600 yards long, some others are nearly a mile in length before getting underneath the old channel. When the goal has thus been attained, a level is driven in the general direction of the "lead," or, roughly speaking, at right angles to the first part of the adit; the whole of this work is carried on in the slate or "bed-rock," in order

* Hammond, "The Auriferous Gravels of California," California State Mining Bureuu, Ninth Annual Report of the State Mineraloyist, Sacramento, I 890 , p. III.

† libid., plate ú. 
to save the cost of timbering and repairs, which would be considerable in the gravel itself. Rises (upraises, U.S.A.) are put up into the gravel bed, and, after a preliminary division into

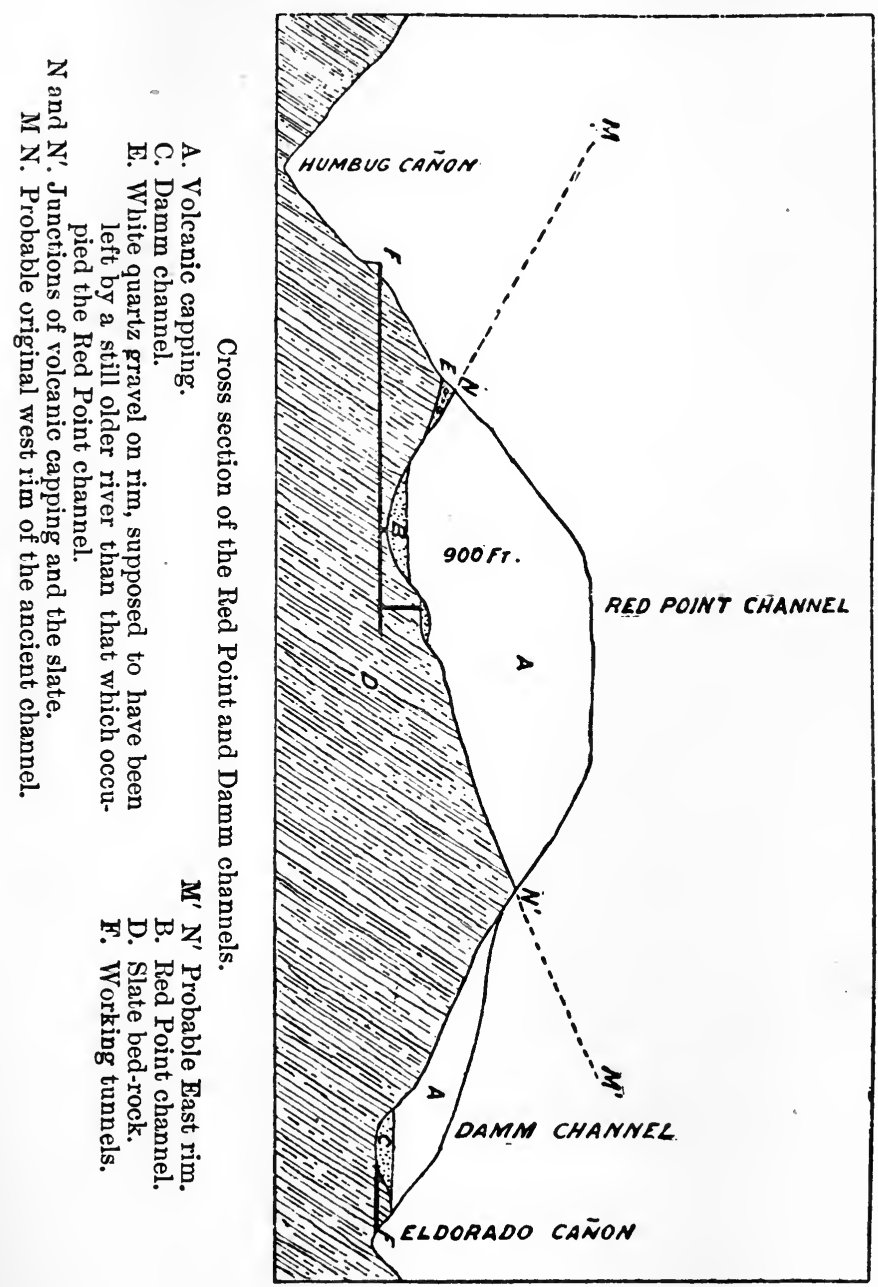

blocks by a series of cross drivages, the bed is worked away. The gravel is wheeled to the rises (passes, chutes, U.S.A.) leading to the main tunnel, and thence drops into waggons which are drawn out by horses to the surface. 
It is reckoned in Placer County, California,* that, in the case of a mine producing 250 tons (or carloads) of gravel a day, the total cost of getting, tramming, washing and agency is about $\$ 1.10$, or 4 s. $6 d$., perton. The yield in this region varies from $\$$ I to $\$$ IO per ton (carload,) and may be taken at $\$ 2.50$ or Ios. per ton on an average.

The method of working by temporary pillars is not confined to beds of small or medium thickness.

The lead-bearing sandstone at Mechernich furnishes a good example of what can be done in a rock which, though far from being hard, will nevertheless allow large excavations to be made without any timber. As has been already mentioned, the bed of sandstone is sometimes as much as Ioo feet thick. Drivages are made in the bottorn part of the bed, about $2 \mathrm{~m}$. high by $2 \mathrm{~m}$. wide, and these are followed by a series of cross drivages, dividing the bed up into a number of square pillars, $6 \mathrm{~m}$. by $6 \mathrm{~m}$, , or $8 \mathrm{~m}$. by $8 \mathrm{~m}$., resembling the squares of a chess-board. Then, beginning at the outer part of the boundary of the sett, the miners proceed to remove the whole of the sandstone from the floor to the roof, and at last let the roof of conglomerate fall in. As a rule they convert the space covered by four adjacent pillars into one chamber. This is done by cutting round each of the four pillars and gradually reducing it in size, until at last there is an open space where the four pillars stood, say a square 22 to 24 yards ( 20 to $22 \mathrm{~m}$.) on the side, the height still being the same as that of the original drivages-i.e., 2 metres. Standing upon the broken rock, the men now attack the roof, which they can often get away in layers of about 5 feet in thickness, by cutting a big groove round the periphery of the chamber and often putting in a suitable blast. The central part will then fall in one mass breaking up as it strikes the ground. A second layer is taken off and the chamber again heightened 5 feet. While this work is going on the roof is sounded by being struck with a long pole. The miners learn by the sound given out whether the rock is firm or not, and regulate their work accordingly. They work upwards till they reach the conglomerate, and having cleared out all the ore allow the roof to fall in. It is important that the roof should fall in, because, as long as it remains, it throws its weight upon the other adjacent pillars ; but when it has come down, the pillars have only to support the weight of the strata immediately above them. In the direction of the dip, the chambers are sometimes made larger, and six pillars are taken instead of four. With a very strong roof the chambers may even cover an area of 109 yards by 43 yards ( $100 \mathrm{~m}$. by $40 \mathrm{~m}$.).

At Mechernich the workings are arranged so that the chamber remains open until the last moment, the roof not falling in till

* "Bergmännische Mittheilungen von der Pariser Weltaustellung," I889, B. u. h. Zeitung, I89o, p. 314 . 
the completion of the process of excavation. The sulphur seams of Sicily are wrought differently.* The thick beds are pierced by networks of tunnels superposed one above the other, and the workings are allowed to fall in. After a time, when the collapse is complete, the miners make drivages in the mass of crushed and broken pillars, and so reap a second harvest.

The details of the mode of procedure are as follows: When the dip of the beds is less than $30^{\circ}$, one set of tunnels is driven along the strike and another set along the line of dip. The tunnels are made 8 to $\mathrm{I}_{3}$ feet $(2.5$ to $4 \mathrm{~m}$.) wide. Those along the strike are 8 to 13 feet apart, and those along the dip 10 to 16 feet apart, leaving rectangular pillars between them. If the dip exceeds $45^{\circ}$, tunnels as before are driven along the strike, and these are intersected by horizontal cross tunnels running from the roof to the floor of the deposit. The height and width of these tunnels do not as a rule exceed ro feet $(3 \mathrm{~m}$.). If the bed is thick the tunnels are traced out in superposed planes, leaving a solid slice of ground 8 to io feet $(2.5$ to $3 \mathrm{~m}$.) thick between any two successive networks of drivages.

The first part of the process is now complete, and it is followed by the thinning of the pillars. Beginning near the boundary of the mine, a tunnel is driven through a pillar, or two tunnels are driven if it is a big one. The sides of the tunnels are cut away gradually, until at last the weight of the superincumbent rock breaks down what remains of the pillar; sometimes shots are put in to effect or hasten the fall. As much sulphur rock as possible is taken out, and the next pillar is treated in the same way, and so on, always proceeding from the boundary towards the shaft.

This method of working has been the cause of the worst accidents and of the majority of the fires, especially when the stratum is thick, and several sets of tunnels have been driven one above the other. In some parts of the Colle Croce mines, Lercara, there have been as many as ten working horizons one above the other, each horizon, or slice, being 16 feet $(5 \mathrm{~m}$.) thick, and the bed itself 164 feet $(5 \circ \mathrm{m}$.). Sometimes mines of this kind have "caved in" of themselves; in other cases the general breaking up and crushing together has been produced intentionally by bringing down some of the lowest pillars by a few shots. During this crush the heat produced by the friction of great masses of rock falling against one another is sufficient to make the sulphur take fire. The mine is then closed, and the fire eventually dies out for want of oxygen, though there are instances of fires going on burning for more than sixty years. When the fire is supposed to be completely

* "Sui sistemi di lavorazione impiegati nelle solfare del gruppo di Colle Croce in Lercara, e sui provvedimenti da adottarsi per migliorarne le condizioni di sicurezza," Rivista del servizio minerario nel $19 S 9$, Florence, I890, pp. 67 to 99 . 
extinguished, work is begun in the broken mass, by driving a series of tunnels, along much the same lines as those made originally in the virgin bed. The tunnels are supported by walling and timber. A similar network is then made at a level 18 feet $(5.50 \mathrm{~m}$.) above, and in some instances there are three such sets of levels in "the broken" one above the other. The tunnels of the lowest horizon are widened out, and by means of suitable shots the whole mass of broken rock is made to fall again, and of course the tunnels disappear. This process of making a network of levels at two or three horizons is repeated, and the "caving-in" is brought about again until the sulphur-bearing rock is exhausted, or so much barren stuff from the roof is mixed with it as to make the work unprofitable.

The crushes themselves have not generally been accompanied by accidents, but work in the broken ground has been very fatal.

For working these deposits, and especially the thick ones, a filling-up method is preferable, and the "ginesi," or residues from the treatment of the sulphur-rock in kilns, are ready at hand as the most convenient material for the purpose.

The filling-up method enables the sulphur bed to be worked away completely, whereas with the method of networks of drivages followed by falls, fully one-fifth or even one-fourth of the mineral is lost. Besides, there are fires and subsidences of the ground causing fissures which let water in, and therefore producing more danger to the men and also to the adjoining mines.

The Italian Inspectors of Mines are of opinion that poor beds, which could not be wrought profitably by the filling-up process, may in certain exceptional cases be worked by the old method, because the firmness of the rock increases as the percentage of sulphur diminishes. However, they limit the number of superposed working floors to three, and stipulate that an upper floor shall be entirely worked out before a lower one is taken away.

It is estimated that in the year $1889^{*}$ only 43 per cent. of the sulphur produced in Sicily came from virgin ground, and that all the rest was obtained from drivings among broken pillars and workings that had "caved in."

B. Longwall.-Having discussed the various ways of working a bed by permanent or temporary pillars, we now come to the so-called longwall method. In this case there is ro preliminary carving out into pillars, but the mineral is worked away in long faces, whence the name applied to the system.

A typical case is found in the workings for copper shale in the Mansfeld district, Germany. $\dagger$

- Rivista del servizio minerario nel 1889, p. 76.

+ This account of the workings of the copper shale is based upon the description in the pamphlet, "Der Kupferschieferbergbau und der Hüttenbetrieb zur Verarbeitung der gewonnenen Minern in den beiden Mansfelder lireisen der Preuss. Provinz Sachsen, 1889," and upon personal observations. 
The bed, as already mentioned, is usually from 3 to 5 inches thick, but it makes up for its thinness and poverty by its uniformity of yield, at all events compared with a mineral vein.

It is worked for a distance of I I miles (I 8 kil.) along the strike, and the present plan of operations consists in having a set of shafts for every $2 \frac{1}{2}$ miles (4 kil.), that is to say a set of shafts serves for the workings $I_{4}^{\frac{1}{4}}$ mile ( 2 kil.) on each side of it. The great difficulties encountered in sinking shafts through the watery measures above the copper shale have led to the adoption of the system of driving out long crosscuts to intersect the bed on the floor side. These crosscuts can be driven with speed by machine-drills, and various mechanical means are available for haulage. On the other hand, in spite of the considerable improvements which have been introduced into shaft sinking by the Kind-Chaudron process, much time is required and a very heavy expenditure of capital. There is also the consideration that if the shafts were on the roof side, crosscuts would have to be driven at the level of the adit in order to get rid of the water. These crosscuts would sometimes traverse the troublesome gypseous measures, full of unknown pools, and they would be above the worked-out bed of copper shale and therefore be subject to slight sinkings of the ground. Crosscuts in the measures below the copper shale do not present these difficulties. Of course it would be possible to lift the water to the surface and not discharge it into the adit. 'This would entail extra expense for pumping, and in this particular instance there is the further objection that the water is so salt that it cannot be discharged without damage into any small brook. It therefore becomes necessary to conduct it into a river like the Saale, too big to be seriously affected by the briny stream from the mines.

The workings are arranged in a succession of floors taken exactly $62.7 \mathrm{~m}$. apart. This distance is the equivalent of 30 German fithoms, and is $68 \frac{1}{2}$ yards. To save expense, crosscuts are put out from the shaft at every second floor, that is to say, they are vertically I 25.4 metres one below the other. Drivages along the strike are pushed out on each side of the crosscut, and by putting up "rises" each level is brought into communication with the one above. Intermediate tunnels are then driven along the shale from a point midway between the two crosscuts, and the bed is now traversed by levels along the strike, at intervals of 62.7 metres vertically, which constitute the main working roadways. As the dip is about $5^{\circ}$ or $6^{\circ}$, the distance from one main roadway to the next is as much as 600 to 800 yards, and constitutes a long working face or "longwall." In Fig. 366, A B represents a main level, and CD the next one below it. E F is the working face, which is cut away gradually till it becomes $\mathrm{E}^{\prime} \mathrm{F}^{\prime}$, and then $\mathrm{E}^{\prime \prime} \mathrm{F}^{\prime \prime}$, and so on.

This working face is occupied by a string of miners, in fact as 
many are employed as the space will accommodate. The workman lies upon his left side, reposing upon a shoulder-board and a legboard. The latter is strapped to the thigh, but the former is free, and is shifted as required. The work comprises the following successive operations-(1) Holing with the pick; (2) wedging down the copper shale; (3) blasting down the roof ; (4) stowing the deads. The holing is done in the lowest part of the bed of copper ore, along the hard and smooth floor. Enough of the roof is taken down to give the miner just room enough to do his work. It is best to have as much as 23 inches $(58 \mathrm{~cm}$.), but if there is a convenient smooth plane of bedding for forming the roof at a height of $18 \frac{1}{2}$ inches $(47 \mathrm{~cm}$.) no more is taken down; indeed, in some exceptional cases the height is only $15 \frac{3}{4}$ inches $(40 \mathrm{~cm}$.).

FIG. 366 .

PLAN

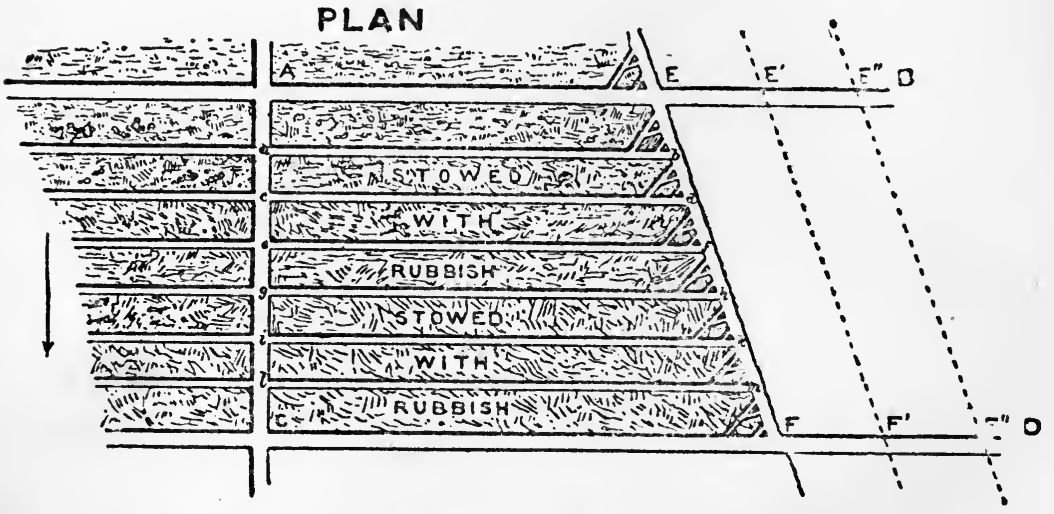

The barren rock serves as material for stowing or filling up, and as the quantity is more than sufficient for this purpose, some of it has to be drawn up to the surface.

It is necessary to have roads for taking away the ore from the face, and they are formed by reserving passages in the stowing and by blasting down the roof, so as to give sufficient height. These divisional roads are shown by the letters $a b, c d, e f, \& c$. The interval between them varies from 50 to 120 yards; and in all cases there are diagonal branch roads leading from the railroad towards the face, which is finally reached by the so-called "Fahrten." They are low passages in the stowing, along which the ore is dragged by boys in little carts. The diagonal roads, however, are made 5 feet high by blasting down the roof. Owing to the small scale of the diagram it is impossible to show all the branch roads connecting the working face with the levels running along the strike. The direction given to the working face is a matter of importance, for it 
enables the amount of pressure coming upon the rock to be varied. The pressure is felt most when the face is parallel to the strike and the working carried up to the rise ; it is felt least when the face is parallel to the strike and the work is proceeding downwards. If the face runs in a direction parallel to the line of dip, the pressure is intermediate in amount. Therefore by regulating the line of the face, the mining autborities have it in their power to cause what amount of pressure they think most desirable for the work. As a rule the line chosen for the working face lies snmewhere between the line of strike and the line of greatest dip.

in new ground in the deeper workings, holing with the pick is a very laborious operation, and has on that account been given up ; in such places the shale is got by blasting. After the lapse of three-quarters of a year or a year and a half, when a large area has been worked awily and the roof begins to subside upon the stowing, pressure is felt on the working face and the holing becomes much easier. In order to bring about this state of affairs as soon as possible, Jäger drills worked by compressed air have been employed in getting the ore.

The Mansfeld longwall has the peculiarity that more deads are produced than can be stowed away in the excavations; these are therefore packed very full and the amount of subsidence is not great.

In some other varieties of the longwall method there is no stowing at all and the roof is allowed to fall in, or the amount of rubbish produced by the seam is insufficient to fill up the empty spaces. There is also a diversity of practice with regard to the direction in which the longwall face is carried, sometimes the seam is worked by longwall outwards-that is to say, the face is carried from the neighbourhood of the shaft towards the boundary of the property, in others it is carried " honewards" from the boundary towards the shaft.

2. VEINS. - In the case of a vein, an exploretory pit is often sunk upon it for 20 or 30 fathoms, and, if the indications found in driving out levels warrant further prosecution of the mine, a first working shaft is put down to intersect the lode at a depth of 100 fathoms or more from the surface. Crosscuts are then driven out at intervals of $10, x_{5}$, or 20 fathoms to reach the lode as shown in Fig. 367 , which represents a section at right angles to the line of strike. Sometimes the main shafts are carried down all the way along the dip of the vein, though perpendicular shafts have the advantage of being better suited for quick winding and cheap pumping, to say nothing of the rapid ascent and descent of the miners in cages. If an inclined shaft appears to be advisable, great care should be taken to sink it in a straight line. The worst shafts are the crooked ones so common in 
Cornwall, vertical perhaps for the first hundred fathoms until the lode is struck, and then carried downwards along its varying dip.

Whatever kind of shaft is adopted, levels are driven out along the strike of the lode, as shown in the longitudinal section (Fig. 368), in the hope of meeting with valuable ore-bodies such as are represented by the stippled portions of the figure. For the purpose of affording ventilation, and still further exploring the ground and working it, intermediate shafts, called winzes (Cornwall), or sumps (North Wales), are sunk in the lode from one level to the other. In some cases the communicating passage is excavated upwards, or, in other words, the miner "puts up a

Firs. 357 .

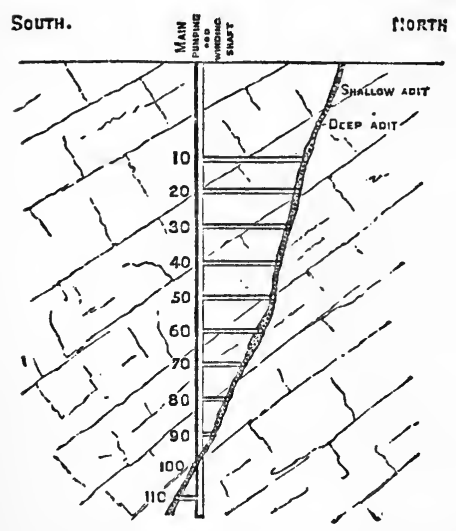

FIG. 368.

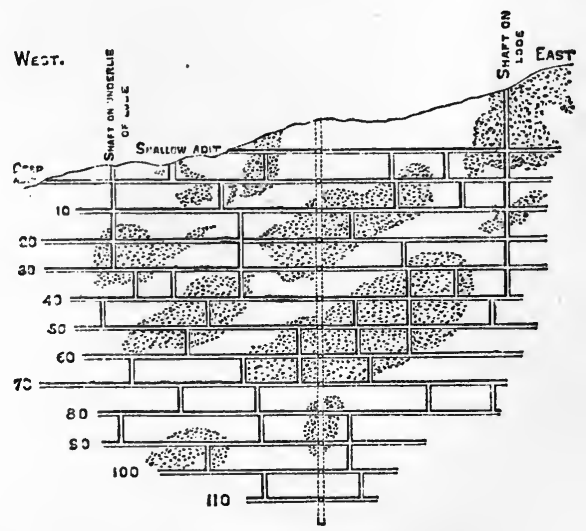

rise." When the communication is complete, there is no difference whatever between a rise and a winze.

On looking at the longitudinal section (Fig. 368), which may be regarded as representing a common state of things, it will at once be remarked that only certain parts of the vein are valuable. When dealing with a bed or seam, we constantly find that the whole area covered by it can be worked away profitably. With a lode this is the exception, and therefore the problem of exploitation is not the same in the two cases. The vein-miner has to remove portions of a sheet-like deposit usually dipping at a high angle, and the bed-miner to excavate the whole of a sheet-like deposit lying frequently nearly horizontal. The unworked portions of the lode serve to support the hanging wall, and form in this way the equivalent of irregular pillars.

The actual mode of removing the valuable part of the lode itself depends a great deal upon circumstances-viz., its width, the nature of its contents, and that of the walls or enclosing rock; but the methods of working may generally be brought 
under one of two heads-viz., underhand stoping or overhand stoping. The word "stope" is equivalent to step, and the term "stoping" means working away any deposit in a series of steps. Underhand or bottom stopes are workings arranged like the steps of a staircase seen from above, whilst overhand or back stopes are like similar steps seen from underneath. Both methods have their advantages and disadvantages, and both are largely used.

We will first take undelband stoping, as this is the older

FiG. 369 .

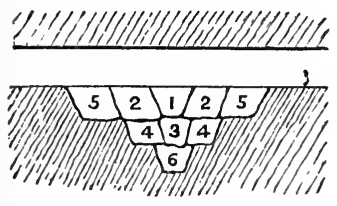
Fig. 370.

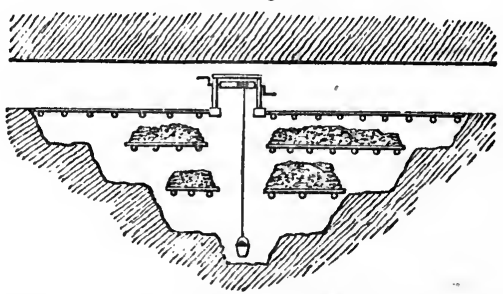

method. In the old days the miner began in the floor of the level (Fig. 369), and sank down a few feet, removing the part $\mathrm{I}$; he followed with $2,3,4$, \&c., until the excavation finally presented the appearance shown in Fig. 370 . Any valueless rock or inineral was deposited upon platforms of timber (stulls), and the ore was drawn up into the level by a windlass. One great disadvantage of this method was the cost of winding up the ore and water by hand labour. At the present day the disadvantage would not be so great, because power is so easily conveyed to underground winches by compressed air or electricity. There always remains, however, the necessity of providing much timber for the stulls, if there is a large quantity of worthless stuff in the vein, or if the sides are weak. The advantages are that ore can be worked away as soon as a level is driven, FIG. 37 I.

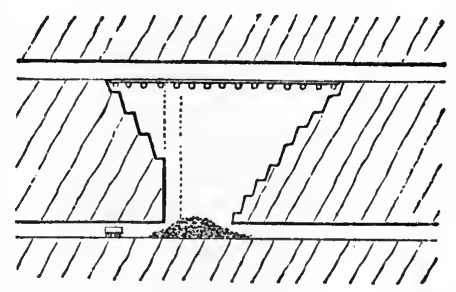
that the men are always boring downwards, and, lastly, that the ore can be carefully picked after it is broken, without fear of any valuable particles being lost.

A more economical method of working by underhand stopes, and one largely employed in Cornwall at the present day, consists in reserving any attack upon the ore-ground until a lower level has been driven. A connection is then made between the two levels by sinking a winze from the upper one, or by putting up a rise from the lower one.

The work of stoping is commenced from the two upper ends of 


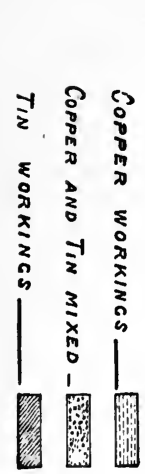

FIG. 372.
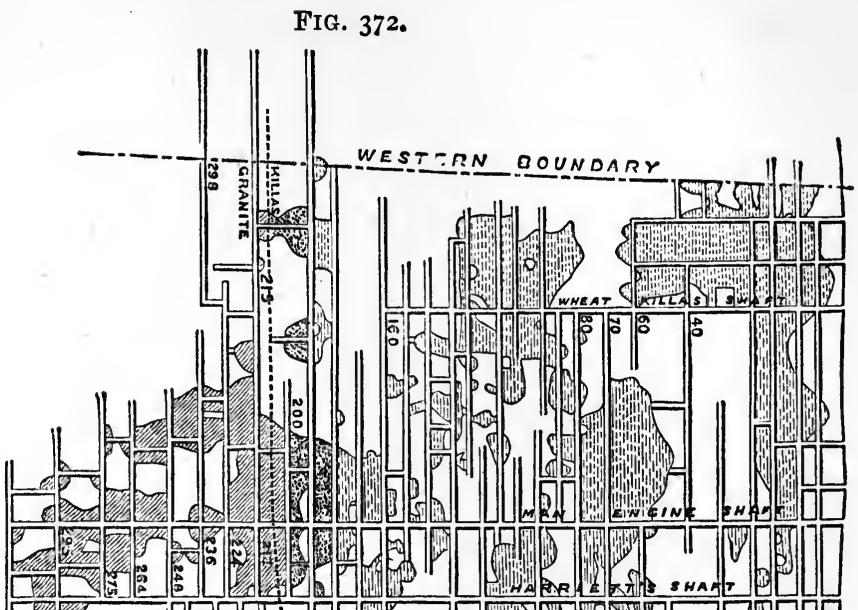

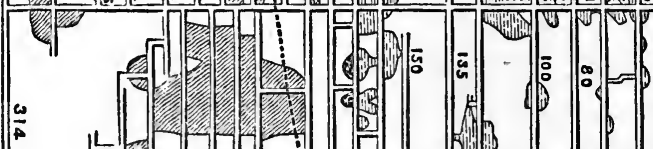

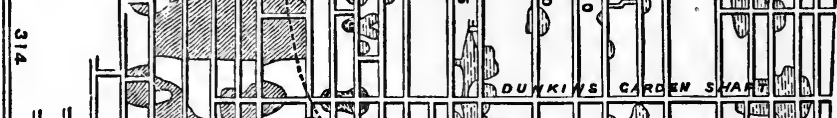
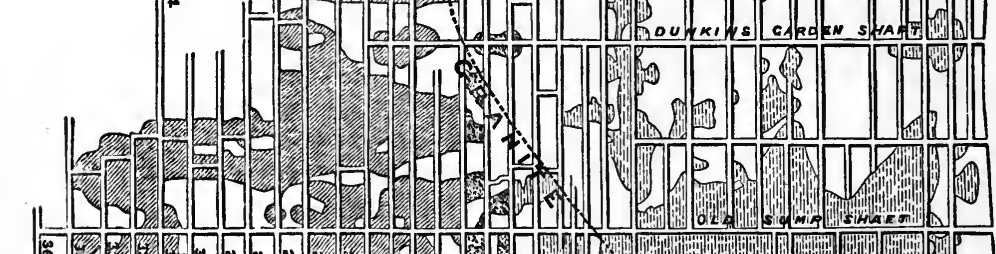

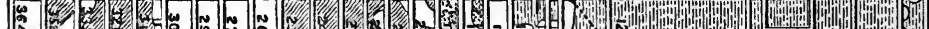
1.

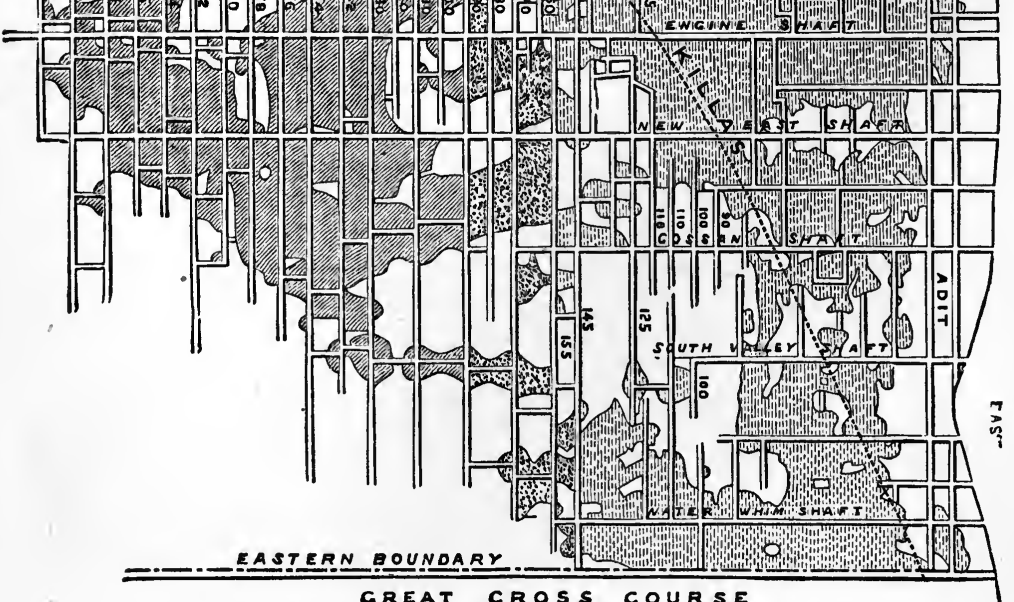


this intermediate shaft, and the lode is removed in a succession of steps, the workings assuming the appearance exhibited in Fig. 37 I. The steps are generally made steep, so that the ore may readily roll down into the winze, and so that the boreholes may do better execution; but these steep stopes are dangerous if a man happens to slip and fall. The huge open chasms left by the removal of a wide lode in this way are also a source of danger, for there is always a risk of falls of rock, and from places which cannot easily be examined.

Figs. 372 and 373 explain the general arrangements for working Dolcoath, the largest tin mine in Cornwall. "The lode, after producing copper ores for a considerabie depth, changed its character and became rich in tin. The workings for tin are confined almost entirely to the granite. The section (Fig. 373) shows that the main shaft of the mine is at first vertical and then carried down on the dip of the FIG. 374.
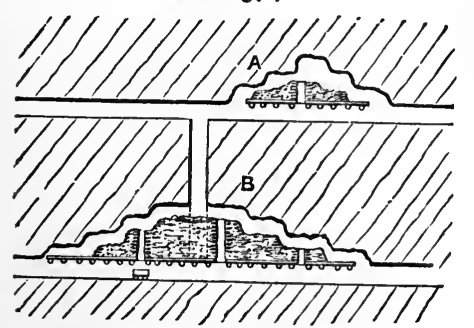

lode. The mine is now considerably deeper than indicated in the figures, but the method of working remains the same.

The process of overhand stoping is precisely the reverse of that which has been described: the work is commenced from a rise (Fig. 374, A), or better, from the two ends of a winze (Fig. 374, B). As sonn as the men have excavated a sufficient height of the level, they put in strong pieces of timber from wall to wall (stempels, stull-pieces), and cover these cross. 
pieces with boards or poles, and throw down the rubbish upon the platform (stull, bunning) thus formed. In the midst of the rubbish, chimney-like openings (mills, passes) are reserved, lined with boards or dry walling, and closed at the bottom with shoots provided with doors. The ore is thrown into these passes, which

FIG. 375.

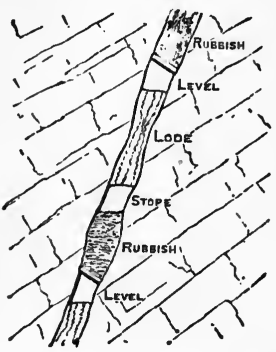

FrG. 376.

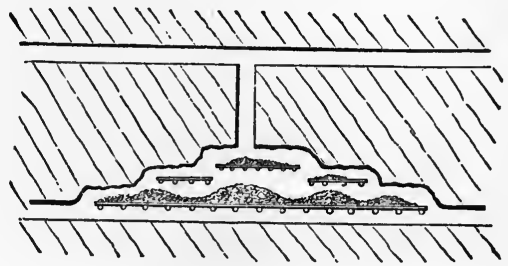

are tapped when necessary. The ore falls into the tram-waggon placed ready to receive it.

Fig. 375 is a transverse section, showing the rubbish resting on the stulls. This may be called the typical mode of stoping, when the lode affords enough rubbish for the men to stand on, and to keep them close to the rock they are attacking. Very often such is not the case, and the whole of the lode has to be sent

Fig. 377 .

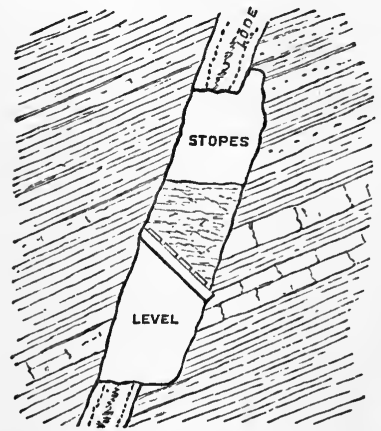
up to the surface for treatment. If the walls are firm, a stull is put in, and a sufficient heap of broken ore is left upon it to give the men good standing ground; the excess is thrown over the ends of the stull, or the great heap is tapped by cutting a hole in the supporting platform and letting a quantity of ore run down into the level.

Another method consists in putting in temporary stages or platforms upon which the men stand to do their work, whilst the excavation is left as an open space (Fig. 376). This mode of working is incompatible with weak walls. If a lode does not afford rubbish enough for completely filling up the excavated space, or if it is too narrow for the men to do their work comfortably, one of the walls may be cut into and blasted down (Fig. 377), in order to give the men a firm bed of rubbish to stand on while at work, and to prevent any chance of a collapse of the mine. In certain special cases rubbish is sent down from the surface to fill up the excavations. 
The advantages of overhand stoping are-that the miner is assisted by gravity in his work, that no ore or rock has to be drawn up by hand labour, and that less timber is required. On the other hand, the miner is always menaced by falls of the roof of his working place; but as he is close by, he can constantly test the solidity of the roof and sides by sounding them with his sledge. If the rock rings clearly he feels safe, but if it emits a dull hollow sound he knows that it must be taken down at once, or be supported in some way. A last disadvantage of overhand compared with underhand stopes, is the chance of valuable particles of ore being lost in the rubbish; but this loss can be prevented by laying down planks or sheets of iron while the lode is being broken down.

When very wide lodes have to bo worked, recourse is often had to a filling-up method, and, indeed, such a method becomes imperative if the sides are weak. The great lode at the famous Van Mine, in Montgomeryshire, once the premier lead mine of the United Kingdom, had to be worked in this fashion, and as the work was carried out very carefully and systematically, no better example of the method can be chosen.

The lode is evidently a fissure vein as it cuts across the planes of bedding and of cleavage of the adjacent slate rock. It is composed of three parts: the flucan or soft lode B (Fig. 378), the bastard lode $\mathrm{C}$, and the regular lode $\mathrm{E}$. The flucan consists of clay and soft broken slate. The

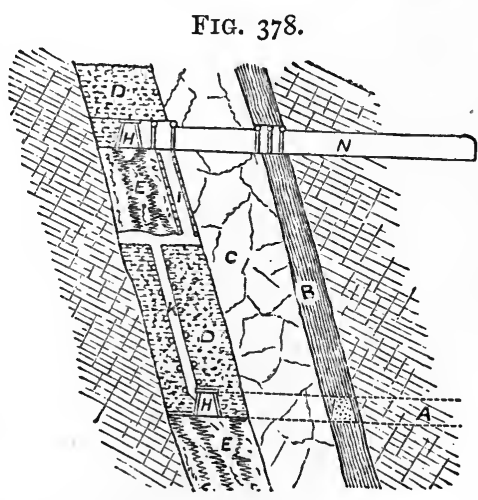
bastard lode is a mass of slate rock, 4 or 5 fathoms wide, between the flucan and the regular lode; it is much softer than the true country, and, though intersected by numerous small strings of galena, is rarely rich enough to be worked. The regular lode consists of masses of slate traversed by veins of galena, or it is a breccia of fragments of slate cemented together by quartz, galena and blende. The regular lode was at times as much as 48 feet ( $14.60 \mathrm{~m}$.) wide, and if the excavation formed by the removal of such a quantity of rock had been left open, the hanging wall would speedily have fallen in, and indeed even during the progress of the work the men would have been exposed to very great danger. A filling-up method was therefore adopted, and as soon as the ore had been removed the open spaces were packed with rubbish.

Crosscuts were driven out at vertical intervals of about $\mathrm{I} 5$ fathoms to reach the fucan $\mathrm{B}$, which was chosen for driving a preliminary 
east and west level on account of its softness. This preliminary level enabled the regular lode to be reached very quickly in several places by short crosscuts, from which the first level in the lode was pushed out east and west.

The next process consisted in stripping away. both sides of the level, as far as the footwall on the north and the bastard lode on the south, unless the latter happened to be productive, in which case it likewise was excavated. This left a space about 7 feet high, which was at once filled with deads, save a working level reserved in the middle, which was properly secured with timber. Endeavours were always made to keep this level as straight as possible, so as to facilitate the tramming. The letter $\mathrm{H}$ in Fig. 378 represents this working level. Upon its completion the preliminary level became superfluous; the timber was drawn out and allowed to crush together, as shown in the lower part of the figure.

In the meantime, starting from the level above, winzes were sunk, 20 or 30 fathoms apart, in the flucan or in the lode itself, if the flucan happened to be too far away from the productive part. The winzes served not only for ventilation, but also as shoots for the rubbish used in filling up; they were called passes, I (Fig. 378). They were carefully timbered and divided into two compartments: one was used as a passage for the rubbish, the other was provided with ladders, and formed a footway, besides affording access to the other compartment, in case it became choked with the waste rock shot down it.

As soon as arrangements for supplying the deads were complete, stoping was begun. The height taken off in each stope varied, according to the firmness of the lode, from 2 to 6 feet, and when the ore was removed the excavation was packed with rubbish (D) drawn down from the nearest pass, such as I (Fig. 378), and wheeled in a barrow to the place where it was wanted. As the passes were made at close intervals, the amount of wheeling was very little. The broken ore was thrown down into a pass or mill, $\mathbf{K}$, whence it could be drawn off at pleasure into a waggon. The ore-passes were of the same size as the winzes sunk for letting down the rubbish, and were timbered and divided into two compartments in the same way.

The lode itself furnished enough rubbish to fill up about onethird of the excavation; waste rock was likewise obtainable from workings in dead ground, such as crosscuts, and the preliminary or permanent levels; and finally slate was quarried at the surface, shot down special shafts, and trammed through a level such as $\mathrm{P}$, and a crosscut $N$ and level $H$, to any special pass where it was required. 'To prevent any loss of ore among the loose stones used for filling up (stowing), it was usual to spread over the top of the rubbish a layer of soft flucan for a depth of a few inches, and when the lode had been stoped away to the required hejght, this floor 
was shovelled into the ore-passes and went to the dressing floor with the rest of the stuff. It was found cheaper and better to dress a few extra tons of stuff than to pay for laying down boards or sheets of iron to catch the fine ore.

Slice after slice was taken off in this way, and the long working face formed by the roof of the stopes corresponded in some measure to a longwall face in bed mining. On arriving within 12 feet of the old workings above, packed with rubbish, it was unadvisable to make openings of the full width of the lode, and the ore was got by crosscuts. A level was driven along the strike in the middle of the lode, or on one side if more convenient; crosscuts, from 5 to 8 feet wide, were started from each side of it, and driven north and south to the footwall and hanging wall respectively, the ground being supported by strong props of timber. The lode standing on the sides of the crosscut was then removed by a series of cross drivages similar to the original crosscut, only, as one side was free, the work was much less expensive, costing abont $£ 4$ per fathom instead of $\mathcal{E}$ io. The empty spaces were packed with waste to the top, and as much of the timber was drawn away as could be removed with safety.

When the lower half of the $\mathbf{r} 2$-feet slice had been taken away in this fashion by a series of short contiguous cross drivages, another level was driven along the strike above the old one which had been filled with rubbish. Crosscuts similar to the ones below were driven, save that spilling had to be resorted to, as the roof was formed of the deads of the earlier workings. Whilst this work was going on, the miners could recover any pieces of timber which had been left in the midst of the rubbish used for stowing the lower half of the slice. The legs or forks were always put in with the large end uppermost, and could be drawn up by putting a chain round the top and applying a lever. As soon as the upper half of the I 2 -feet slice had been taken off by these cross drivages, the working level $\mathrm{H}$ above it was filled up and abandoned.

The block of lode ${ }_{5} 5$ fathoms high was thus removed entirely, and its place filled by rubbish ; consequently there was no danger of the walls falling in and of the mine collapsing. No high openings were made during the progress of the work, so the roof and sides could be sounded and examined without scaffolding; any loose pieces could be taken down at once, and there was little fear of their falling unawares upon the miners.

Before a block was completely stoped away, the so-called permanent level at the bottom had to be prepared, in order to furnish a road for conveying deads to the block beneath. Crosscuts, $\mathrm{N}$, were pushed out from the level $\mathrm{H}$, at intervals of 20 or 30 fathoms, to a distance of ro fathoms beyond the flucan, and "ends" were driven east and west till they met and formed a continuous gallery, P. Riails were laid and the road was reary for use.

Several men were kept constantly employed at a quarry 
adjoining the mine for obtaining slate, which was trammed to and shot down one of the two special rubbish shafts. These could be tapped at the adit, and the supplies were conveyed by tramroads and other special shafts, used as shoots, to the places where they were required. Excepting the first two rubbish shafts from the surface, no shoots were made more than ${ }_{5} 5$ fathoms deep, because it was found by experience that the timber was broken up very quickly by the fall of the stuff when they were deeper. The bottom of one shoot was always near the mouth of the next, so that the rubbish never had to be trammed far; and in some instances the shoots were so near that, by fixing a few planks in a sloping direction, the waste rock ran directly from one to the other.

I have entered somewhat into detail in this case, because wide lodes with weak walls have often given much trouble, when the attempt has been made to work them with the use of timber

F1G. 379.

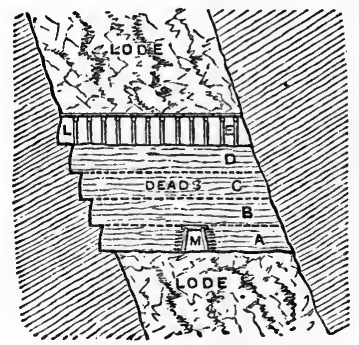

FIG. 3 Eo.

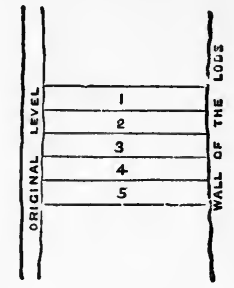

supports. The amount of timber required at the Van Mine was small, and many of the pieces were used over and over again. Another advantage in this particular case was the certainty that no ore was lost or left behind; for although money was sometimes spent in breaking down poor parts of the lode to make sure of not missing any lead ore, the barren rock could be utilised for filling, instead of drawing supplies from quarries at the surface.

At the Van Mine the lode was firm enough to allow the whole width to stand without supports during the time a stope was carried along, except in the case of the two last slices at the top of a block. These, as we have seen, were taken off by a succession of contiguous crosscuts. When a lode is wide and too weak to stand open with safety for its whole width, the crosscut method may be applied from the beginning, instead of confining it to the last slices.

The method is illustrated by Figs. 379 and 380 . 'The lode is removed in successive horizontal slices, A B C D E, beginning at the bottom, and for each slice a level, $\mathrm{L}$, is driven, either wholly in the lode, or partly or entirely in the country; from this level, 
crosscuts are put out 6 or 8 feet wide, as shown in the plan (Fig. 380). These are regularly timbered, according to the necessities of the case, and when No. $\mathrm{J}$ is completed, No. 2 is begun, and the rubbish from No. 2 thrown in to the empty space of No. I crosscut. If the quantity is insufficient, deads are brought in from the surface or from exploratory workings in worthless rock in the neighbourhoud. Sometimes the crosscuts are not driven side by side, but $\mathrm{I}$ and 5 may be driven first, leaving 2,3 , and 4 as a solid pillar; then 3 is worked away, and finally 2 and 4 between the timber and rubbish on each side. The greater part of the timber can be recovered when the next slice above is taken off, as the props are put in with their small ends downwards, and can be drawn up with a lever. M (Fig. 379) is a level reserved in the deads fur traffic and ventilation. This method of working is applicable not only to lodes, but also to irregular masses.

The mode of working the soft ore-bodies such as are met with in the Comstock lode, in the Eureka-Richmond mines, Nevada, and at Broken Hill in New South Wales, has been already described in the chapter upon timbering. The excavations are supported by huge frames of timber, made by adding one "square set" to another as required, and are finally filled up entirely with rubbish.

Another method of working a wide lode is to attack it in slices parallel to the dip, removing each slice separately, as if it were a lode of ordinary dimensions, and filling up with rubbish (Fig. 381).

We have here been supposing that the whole of the lode is taken away from wall to wall. Other cases may arise. Thus at Foxdale mine, in the Isle of Man, we have to deal with a vein of lead-bearing rock which is not ore-bearing for its entire width. The vein runs east and west, and in places is I 40 feet wide. Levels are driven along the northern and southern boundaries, and show whether or no there is any payable ground on these walls; crosscuts put through from time to time further prove the lode, and sometimes there may be three parallel workable portions with barren rock between them. Each of these portions, which will rarely exceed $\mathbf{I} 2$ feet in width, is then treated as a separate lode.

The rule at Foxdale (Fig. 382 ) is to drive the levels 15 fathoms apart, and to effect a communication between two adjacent levels at intervals of 30 fathoms, either by a rise or a winze. The lode thus becomes cut up into blocks I 5 fathoms deep by 30 fathoms long, in the direction of the strike. These blocks are worked away from below upwards in separate "pitches," each 10 fathoms long, arranged like three steps. The block therefore affords 
three pitches, or subordinate blocks. Thus if $A B D C$ represents a block contained between an upper level $\mathrm{AB}$ and a level CD, I 5 fathoms below it, and bounded on the two ends by the winzes $\mathrm{AC}$ and $\mathrm{BD}$, we must first divide it in imagination into the three parts AEGC, EFHG, and FBDH. The removal of each pitch, or third of a block, is confided to a separate set of men. The first set begin at the bottom of AEGC, and take off a slice 6 feet thick, filling up the vacant space with rubbish; then they begin a second slice, and go on taking off slice after slice until they reach the level above.

Work upon the second division-viz., EFGH, is not begun until the first slice of the adjacent "pitch" has been filled up,

FIG. 382.

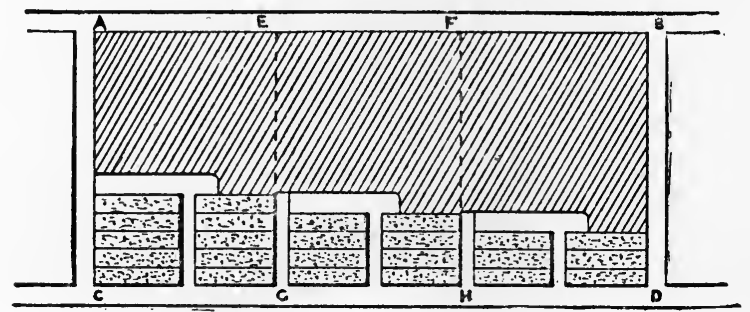

SCALE

024668910121416182022 TATHOMS

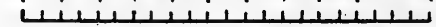

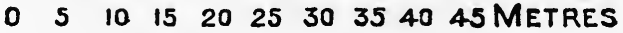

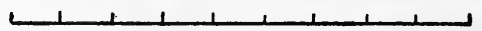

and in the same way blocis EBDH is not attacked until at least one slice of EFHG has been worked away. At some given time the workings will have assumed the form shown in the figure.

If, as is often the case, there is a hard and a soft part in the lode, the work in the overhand stopes goes on as follows: Starting from a winze, the miners push on a drivage in the soft part, and timber it up with a cap resting upon the hard side and upon one leg (Fig. 383). This renders the working of the hard part very much less expensive, for it can be got by shots which take full effect in such large openings. Before blasting out the side, the caps are supported by a longiludinal carrier resting upon a few upright props in the manner shown in figure 384 .

All the rock is picked in the mine, and any waste is used for filling up. At last the whole excavation that has been made is packed, with the exception of a passage, 18 inches high, below the caps, along which the men can creep if necessary. A floor of planks is laid down, and serves to make a bed to prevent the 
FIG. 383 .
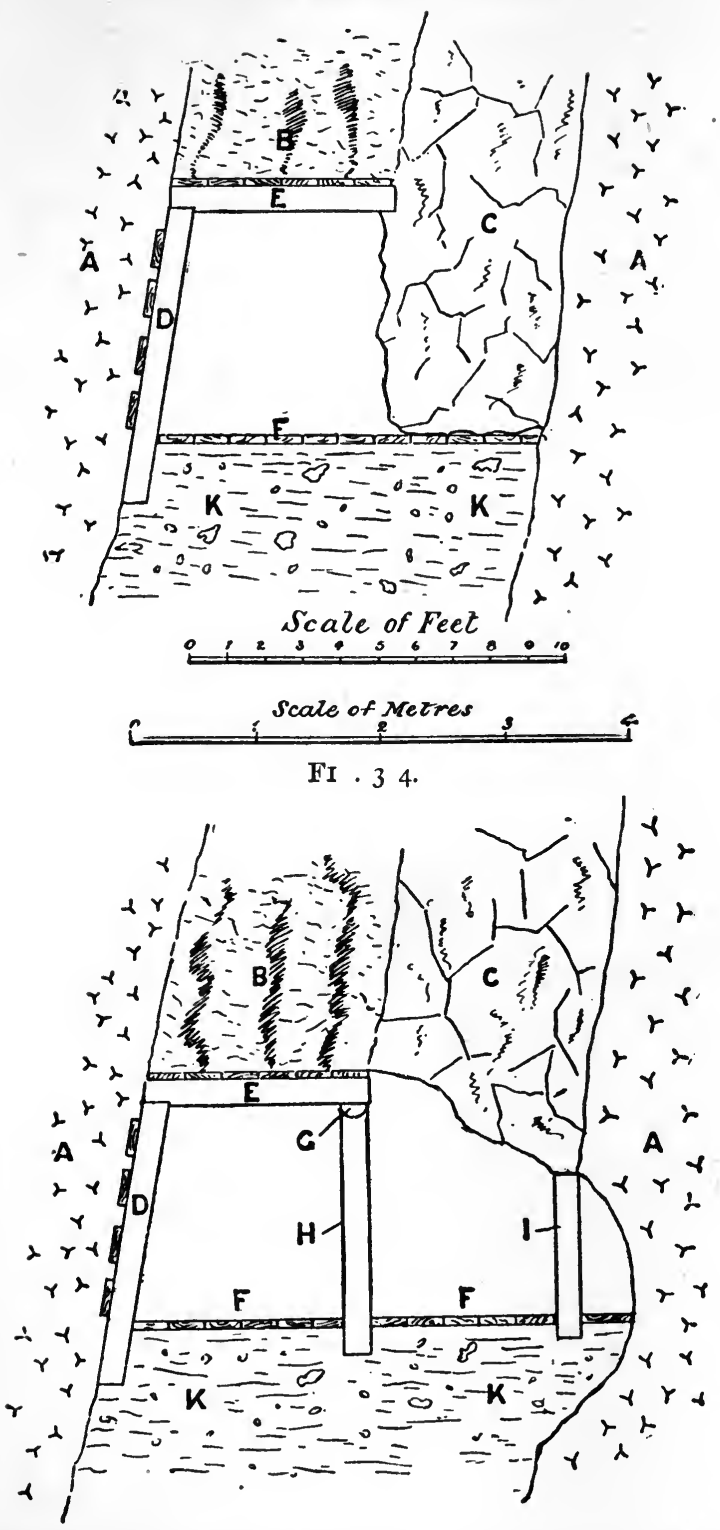

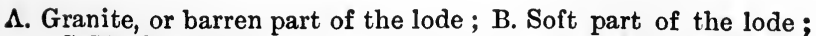
C. Hard part of the lode ; D. Leg ; E. Cap ; F. Floor of planks ; G. Longitudinal cap or carrier; H. Prop ; I. Prop ; K. Filling of waste rock. 
loss of small ore when the next stope or slice is taken off. Shoots or "passes" lined with timber are reserved in the rubbish; there is generally one at the end of each pitch and one in the middle. In this way the miner always has one close at hand, and never need wheel the ore very far. The shoots are furnished with doors at the bottom, and the ore is drawn off directly into waggons underneath without any shovelling.

Care is taken to drive a crosscut from time to time, to prevent any chance of possible bunches of ore in the sides being missed. Waste rock obtained in this way is always useful for filling up. The Foxdale lode furnishes about enough barren rock to fill up the excavation, without its being necessary to draw supplies from the surface.

The timber buried in the rubbish is not lost, for it can be withdrawn when the next slice is taken off. A piece of $\frac{1}{2}$-inch iron chain is made fast round the top of the leg, which always has the small end at the bottom, and the hook of a special lever is put into a suitable link. The fulcrum of the lever is carried by an upright bar attached to a square base, and by applying pressure to the lever the leg is gradually pulled up.

Wide Lodes worked with Pillars and Chambers.-The present method of working the wide veins at the Rio Tinto mines may be briefly described as pillar and chamberwork, with a solid roof and floor between the working horizons. For the present the pillars must be looked upon as permanent.

The details of the system are as follows: A vertical shaft is sunk in the adjacent rock, and crosscuts are driven out to the lode at intervals of 25 metres ( 82 feet); these form the main working floors or horizons. A main level is carried along the strike of the lode at each horizon, and, by sinking from one level and rising from the one below, a vertical intermediate shaft is formed, effecting a communication between them. All this preliminary work is done by the aid of rock drills. An intermediate level is next pushed out along the strike by hand labour midway between the two main levels; the vein may then be regarded in imagination as divided into a series of horizontal slices, each I $2 \frac{1}{2}$ metres in thickness, as shown by the dotted lines, $\mathrm{AB}, \mathrm{CD}, \mathrm{EF}$, \&c. in the section (Fig. 385 ). The formation of pillars now begins: the lower part of each slice is cut up by a network of drivages 3 to $3 \frac{1}{2}$ metres wide, and 3 to $3 \frac{1}{2}$ metres high, at right angles to one another, leaving pillars $6 \frac{1}{2}$ to 7 metres square (Fig. 386). A very large amount of ore is produced in this way. The next stage in the process of mining is heightening and widening the chambers; in ordinary hard pyrites the pillars can be thinned down until they measure only 3 metres by 3 metres, and the chambers can be carried to a height of 9 to so metres. Where the ground is weak more has to be left for support. The two plans (Figs. $3^{86}$ and 387 ) show the 
initial size and the final size of the pillars, whilst the section (Fig. 385) further explains the progress of the work. At the 225metres horizon there are preliminary levels 3 metres wide and pillars of 7 metres; at the $212 \frac{1}{2}$-metres horizon the enlargement of the chambers has begun; at the 200-metres level the process has been carried further, and at the two upper horizons it has been completed, the pillars being reduced to 3 metres. The solid slice of ore, $2 \frac{1}{2}$ to $3 \frac{1}{2}$ metres thick between two storeys, remains for the present untouched, and forms with the small pillars a reserve stock which can be removed at some future time. Great care is taken to arrange the pillars vertically one under the other with
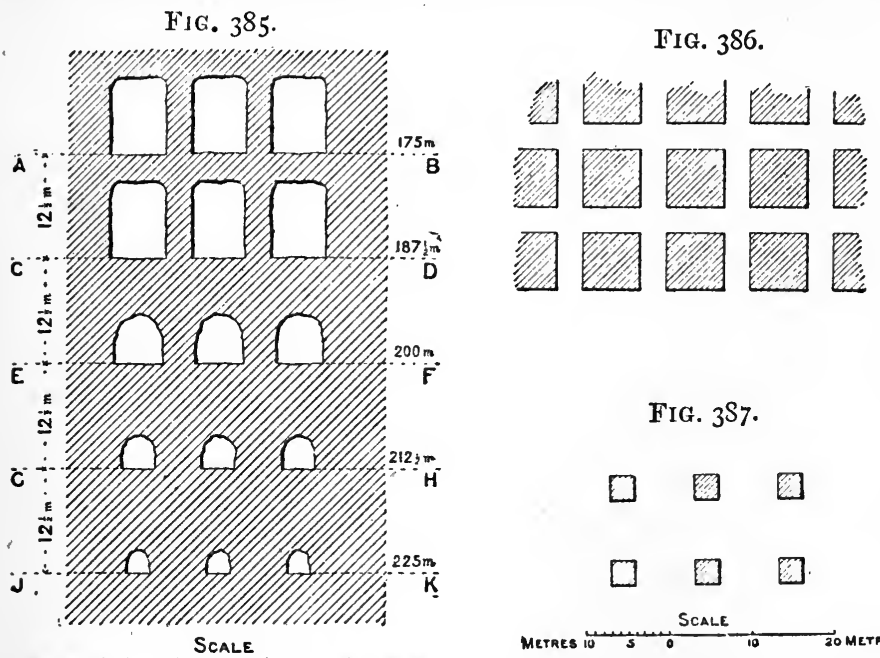

Metaesio's 0 io 20 Metres

FIG. 397 .

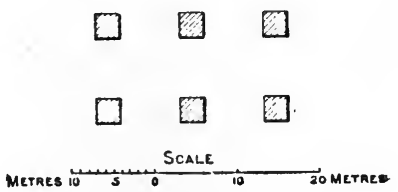

their centre lines coinciding exactly. When operations have been finished, the workings have the appearance of very high columns supporting huge arches. It must not be supposed that the honeycombed part of the vein formed by the deserted chambers is entirely unproductive; a very large surface of ore is left exposed to the action of air and moisture, oxidation goes on, copper and iron sulphates are produced, and during the rainy season water trickling down the sides of the caverns carries them in solution to the bottom of the mine. The coppery water pumped up from underground is led into precipitation pits, similar to those employed for treating the cupreous solutions obtained more rapidly from the ore burnt at the surface.

At the present time the quantity of ore in sight is so great that it is not necessary to devise schemes for removing the reserves; but the work might be accomplished by a filling-up process, beginning at the bottom. The pillars and the intervening 
solid floors of ore could be removed as horizontal slices, followed by a filling up with rubbish let down from the surface. In this manrer the workmen would always be standing on firm ground within casy reach of the ore.

3. MASSES. - The methods of working masses may be classified thus:

(a) Method by chambers without filling up.

(l) Method by horizontal slices, taken in descending order, allowing the surface to sink down.

(c) Method by horizontal slices, taken in ascending order, with complete filling up.

(a) The first of the three methods is applicable when the enclosing rock is strong enough to allow chambers to be worked out without

Fig. $3 \& 8$.

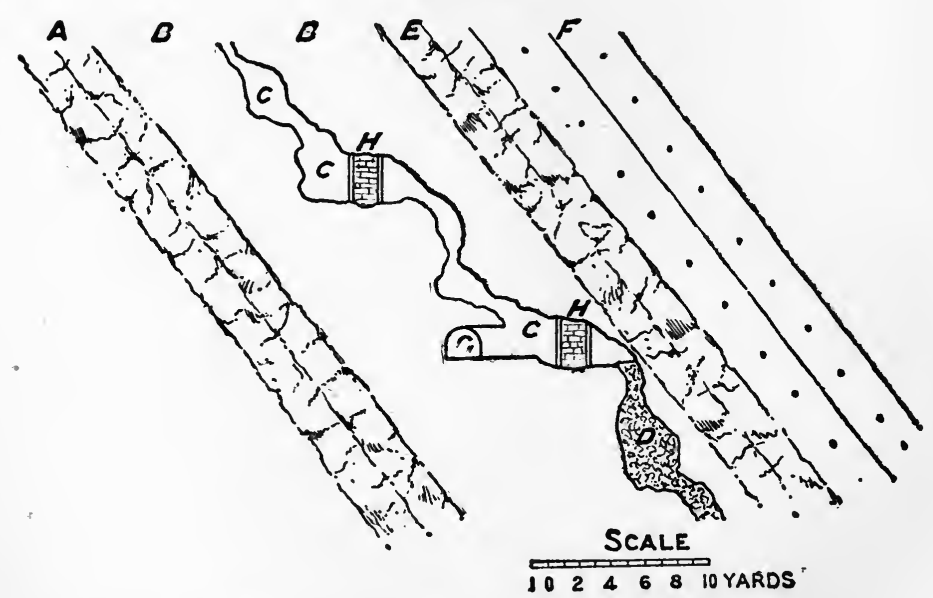

A. "Grey limestone"; B. Limest one, the so-called "Crease measures"; C. Chambers or caverns left by the excavation of the ore; D. Brown hæmatite; E. Top or Whitehead limestone; F. Sandstone (Millstone Grit); G Main level; H. Supporting pillar built up of stones and timber.

danger from the roof and sides falling in. As an instance I may take the so-called "churns" of the Forest of Dean, which are worked for iron ore. Brown hæmatite occurs in irregular pockets in a certain bed of the Mountain Limestone(Fig. 388), which is from I 4 to 16 yards thick, and usually dips at a considerable angle. At the particular mine chosen as an example the dip is $52^{\circ}$. Perpendicular shafts are sunk, and the ore-bearing limestone is reached by crosscuts at vertical intervals of 100 to 150 feet. A good main level is driven along the strike of this bed, and small crosscuts are put out in order to search for the churns, which have often been 
followed down from the surface to a depth of 200 yards. The exploitation consists in removing the soft ore with the pick, and supporting the roof with occasional props or rough walls built with pieces of barren rock; timber and stone may be used together, as shown in the figure. If the pocket is very steep it is worked like a mineral vein; the men stope the ore away overhand, standing upon platforms of timber erected across the chasm left by workings below.

(b) An excellent example of the second method of working is furnished by De Beers diamond mine, where a mass of diamond-

FIG. 389.

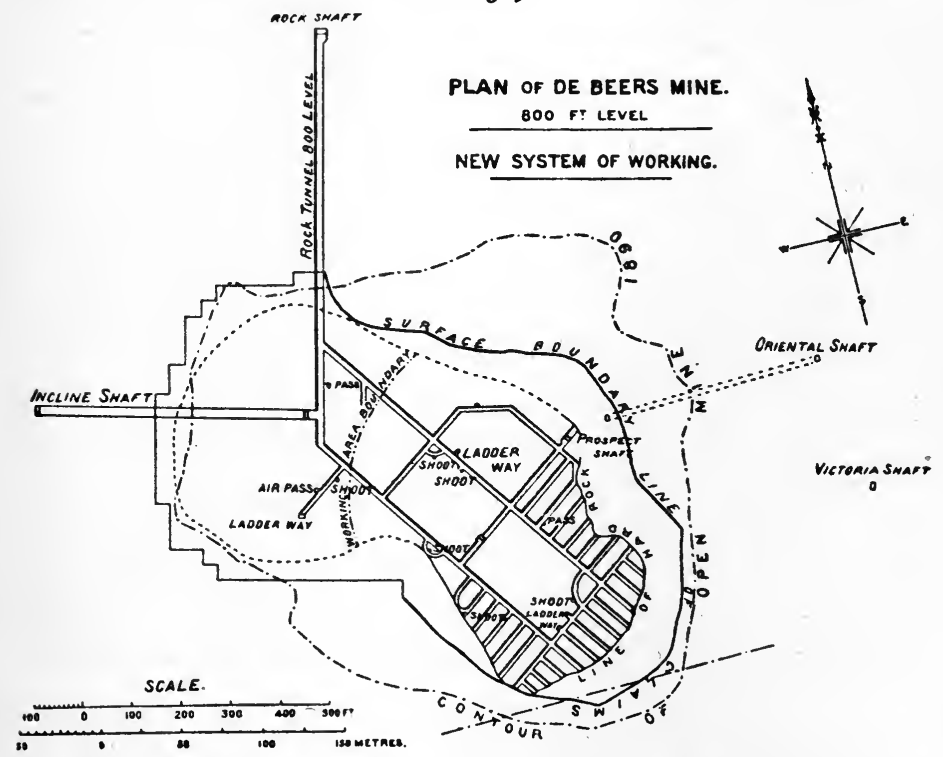

bearing rock occurs as a huge vertical column, with an irregular oval section (Figs. 30 and 3I). It was worked for many years as an open quarry, but falls of the surrounding rocks (reef) caused so much trouble, as the huge pit increased in depth, that underground mining had to be adopted.

The system consists in excavating chambers, and then letting rubbish from the open pit above run in and fill them up. The details of the method will be plain from consulting Figs. 389, 390, and 39I, which are copied from the second and third annual reports of the De Beers Company. The deposit is reached by an inclined shaft sunk in the surrounding rocks, and main levels are driven at successive horizons which are from 90 to 120 feet apart vertically. Fig 389 shows these main drivages at the $800-$ 
FIG. 390.

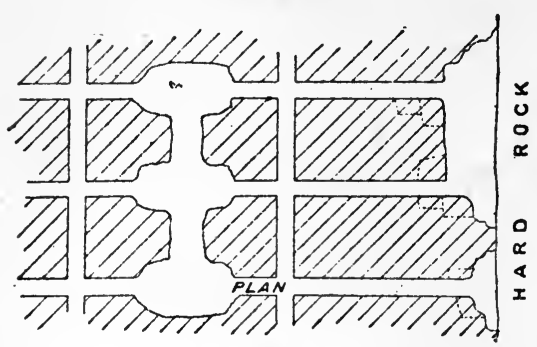

Scales

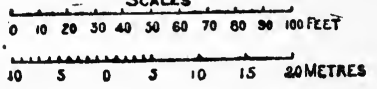

FIG. 391.

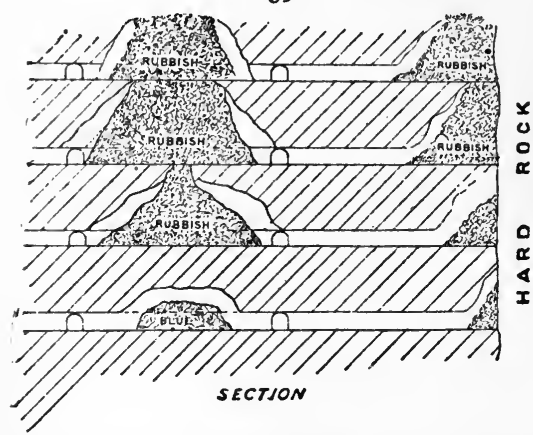

feet level; there are two principal drivages parallel. to each other and following the direction of the axis of the rough oval, and from them cross tunnels are put out at intervals of 36 feet, and extended to the limits of the "blue," or, when directed towards each other, till they meet. Another set of levels is driven at a depth of 30 feet below the main tunnels, and a third set at a further depth of 30 feet. The block of ground between two main horizons thus becomes divided up into a series of horizontal slices, 30 feet thick, each of which is cut up by a network of tunnels 36 feet apart extending to the surrounding rock.

When this rock is reached, the tunnels are widened out till two adjacent working-places meet as shown in the plan (Fig. 390). The next process is to rise, or work upwards, until the "blue" is traversed and the waste fallen rock FIG. 392.

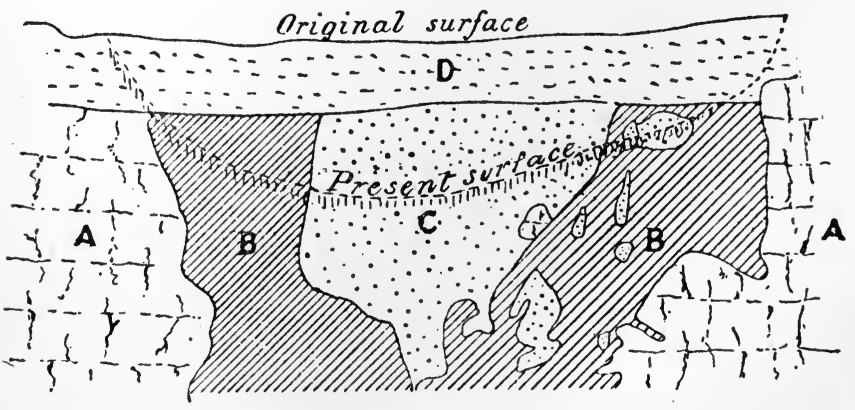

A. Enclosing limestone ; B. Red hæmatite; C. Sand and clay ; D. Glacial drift. 
above it is met with. This is allowed to run in and form a heap upon which the workmen stand, in order to blast down the remaining part of the slice of "blue." As this is taken away the waste rock (reef) follows. Fig. 39r also shows that the workings in an upper slice are always further advanced than those in a lower one. Only the main levels are provided with regular tramways: The blue got in the intermediate levels is thrown
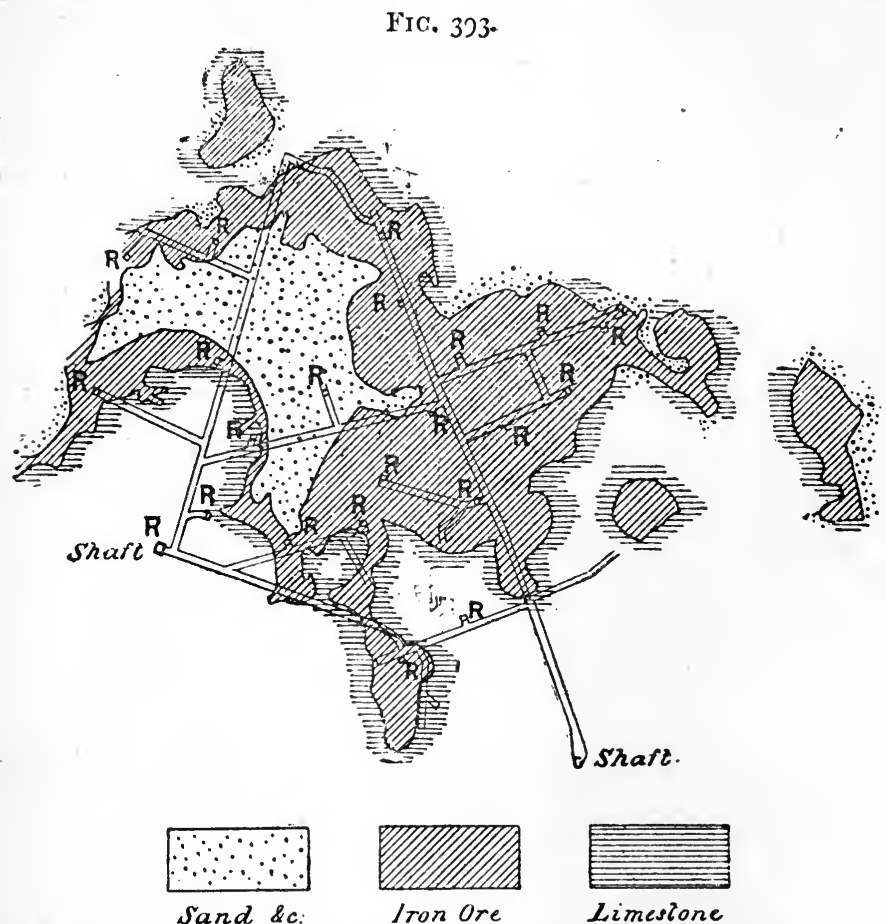

down shoots, and so finds its way to the main level, whence it can be hoisted to the surface.

A somewhat similar mode of working is customary in the iron mines of North Lancashire, which have to deal with irregular masses of hæmatite in the Mountain Limestone (Fig. 392).*

Shafts are sunk at a distance from the deposit, which is reached by crosscuts at intervals of ro fathoms vertically. Levels and cross levels are then driven which bring all parts within easy reach (Fig. 393). Rises, R, R, are put up from the main floor

* I am indebted to Mr. J. G. Lawn, A.R.S.M. and De la Beche Medallist, for his notes on the method of working; from these, and from my own recollections, this description has been written. 
or horizon to the next one above, and the deposit is now taken away in slices or "heights," 9 or Io feet thick. $A$ and $B$ of Fig. 394 represent two adjacent rises. The men starting from $A$, push out the drift $I$, and those from $B$ the drift $I$, until they meet, for the sake of ventilation. This air-road $I I$ has to be kept open while work is proceeding in the slice or height in this district. Branch drifts, 2 and $I I$, are carried forward to the boundary of the deposit or of the area the men have to work, and lastly comes the robbing of the ore by a series of drifts, such as $3,4,5,6$, or $I I I, I V, V$, in the order of the numbers. The work is thus carried on towards a rise and not from it. After the ore is robbed, the roof crushes in, smashing the timber. and forming a safe ceiling for the workings in the

FIG. 394 .

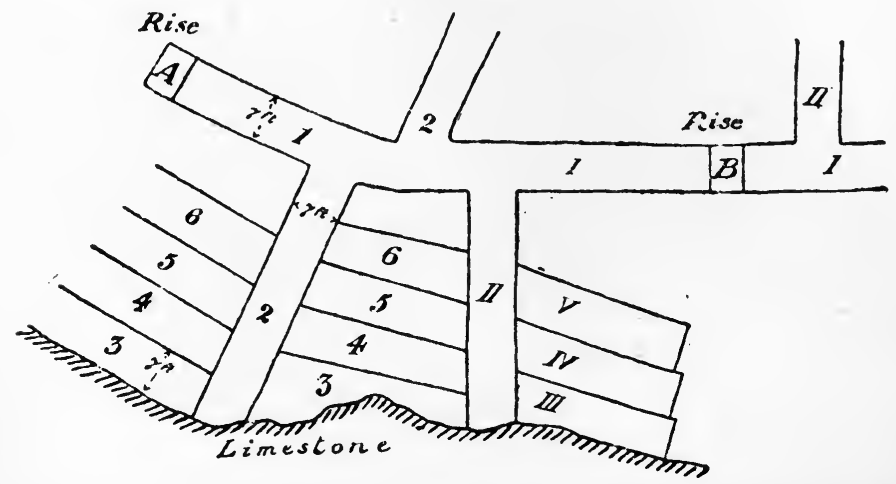

next slice underneath. The surface sinks down in proportion as the ore is removed, so that in some parts of the district immense holes exist, giving evidence of the working out of vast bodies of hæmatite underneath (Fig. 392). As the overlying drift often contains clay, rain water collects in these holes, and it has to be pumped out lest it should break through and drown the miners.

The rises are usually made 6 feet by 4 feet 6 inches within the timbering, which consists of sets of Norway or Swedish timber 6 or 7 inches square, simply halved at the joints and placed directly one above the other. Most of the rises are divided into two compartments by pieces of 3 -inch plank cut to the right length and wedged in; these are made firm by nailing on to the rise-timber "listing pieces," strips of wood 3 inches by $\frac{3}{4}$ inch, on each side. One of the compartments serves for a ladderway, for pulling up timber and for an airway; the other as a receptacle for the ore. The latter is called a "hurry," and is provided at the bottom with an inclined shoot through which the ore can be let into waggons or "bogies" at pleasure. Somretimes 
the rise is made 9 feet by 4 feet 6 inches, and divided into three compartments-viz., two hurries, and a ladderway between them. One hurry then serves for ore, and the other for rubbish.

When the men have all but removed one slice or "height," they take out the timber of the rise on one side, in order to start a new drift; it is about 7 feet wide, and is supported by frames, each made of a cap or head-tree resting upon two legs or "forks." To protect the men while working in the forebreast, small planks (spiles) are driven under one head-tree and over the next, and, if necessary, along the sides behind the props. The men are not allowed to advance more than 4 feet beyond their timber. As soon as the slice above is quite exhausted, they open out at the other side of their rise, and after putting in a strong covering of

FIG. 395 .

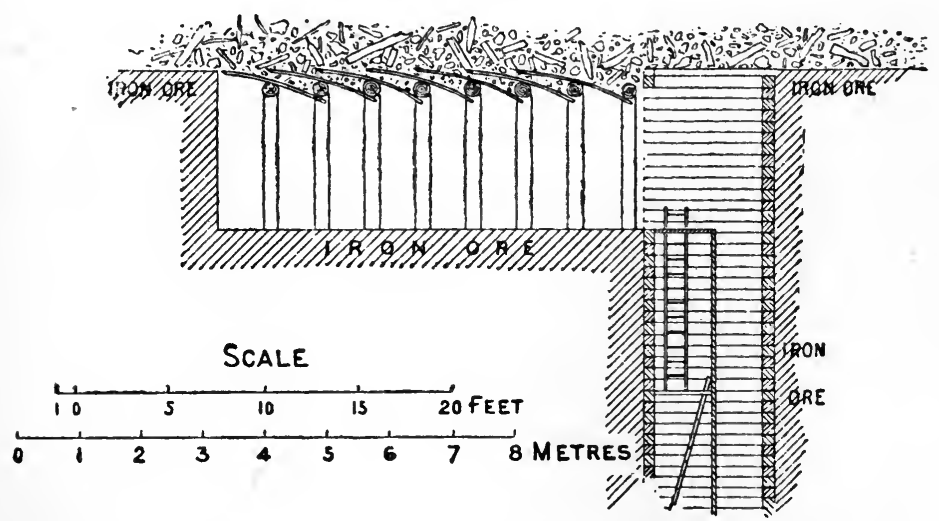

timber, they clear all the rise of its lining down to the level at which they are working. In driving below the old timber and rubbish, it is necessary to be careful that the supporting frames are properly put in and kept well forward; they are often held in place by nailing spiles to them, but this is only necessary before they get the weight from above. It is possible in many cases to save much of the timber used in lining the drifts which are made for robbing the ore, but in all cases the roof comes down very quickly, whether the timber is left in or not.

(c) The last method-namely, working away the mass by horizontal slices, in ascending order, with complete filling upexactly resembles that which is adopted for certain wide veins, such as the lode at the Van mine, Montgomeryshire. However, it may be well to mention, as an example, the great zinc ore stockwork at Diepenlinchen, near Stolberg. The Mountain Limestone is full of cracks and cavities containing blende, which cannot be worked to advantage without breaking down the whole 
of the rock. The limestone is ore-bearing over an oval area, I 20 metres long from east to west and 50 from north to south ( 30 yards by 54 yards).

This great mass of zinc-bearing rock is subdivided for the purpose of working into a series of storeys or floors, each 16 metres ( $52 \frac{1}{2}$ feet) thick vertically, and a main level is driven along the major axis of the oval at the bottom of each storey, as shown in Fig. 396. Cross-cuts, I 4 metres apart, are driven out north and south from each main level, and are connected with similar crosscuts below by winzes. The block of ground between two main levels is then taken away in slices, 2 metres thick, in ascending order. However, with the view of saving the expense of putting

FIG. 396.

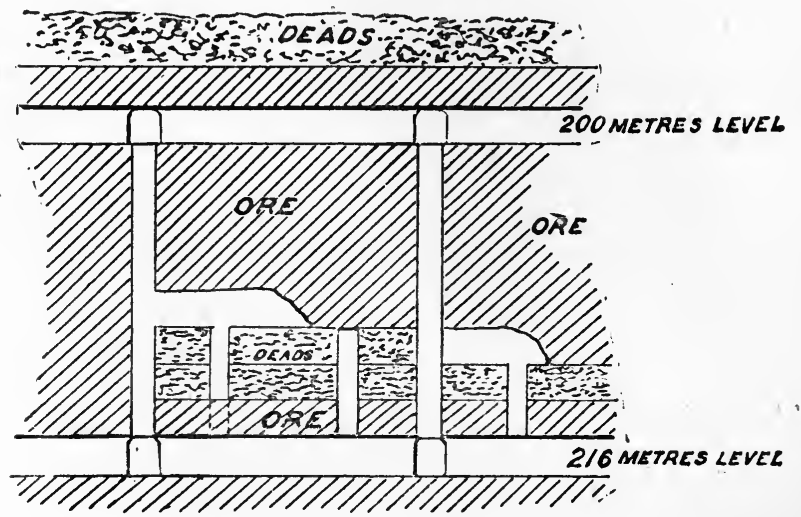

in timber to support the deads, which would be necessary if the main roads had to be kept up in a part of the mine. stowed with rubbish, the first two slices-that is to say, the one in which the levels are driven and the one immediately above it-are left intact at the outset. Work is started from a winze at a point 2 metres above the top of the level, and the whole area of the deposit cleared out for a height of 2 metres; the excavation is then filled up with deads. The deads are obtained by picking the rock broken down in the stopes, or from any drivings or sinkings in barren ground, and also by sending down supplies from the surface. Shoots are reserved in the stowing for throwing down the ore, which is drawn off at the bottom when required.

Fig. 396 shows the stoping going on between the 200 and the 216-metres levels. When the stopes come, up to the sole of the 200-metres level, the ore surrounding the network of levels and that of the overlying slice can be attacked. By this time this double slice, 4 metres thick, is somewhat crushed and broken. 
It would be dangerous to have the wide working-places, which can be excavated without fear in virgin ground; therefore, just as happened in the Van Mine, the two last slices are got by a series of small drivings, in which the miners resort to a process of spilling. By applying this process the remainder of the ore is obtained in safety, and the final result is that the great mass of zinc-bearing rock is replaced by barren material with the expenditure of very little money for timber. 


\section{CIIAPTER VII.}

\section{IIAULAGE OR TRANSPORT.}

Underground transport-Shoots-Pipes-Carriage by persons-SledgesWheeled vehicles-Mechanical haulage-Boats-Transport above ground by similar means and by aërial ropeways.

Afrer having been excavated, the mineral must be conveyed to the surface. In very many cases the journey is performed in two stages-first, along a more or less horizontal road to the shaftbottom; and thence by a vertical or inclined road which leads up to the daylight. The first process is often spoken of as haulage and the second as winding; but there is no distinct line of demarcation between the two, for certain sloping passages, called shafts by the ore-miner, would be denied that name by the collier. It will be convenient to say a few words here about transport above ground, although, strictly speaking, this subject should not be dealt with until after the chapter on winding.

The transit of the mineral from the working-place to the shaft may be carried on in part or wholly by one of the following processes :

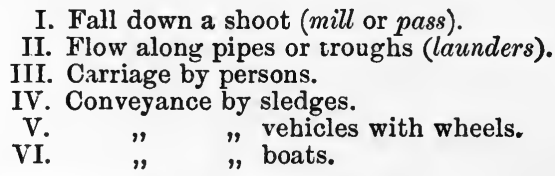

I. FALL DOWN A SHOOT.-This first method is one to which reference has already been made more than once in describing the modes of working. When a deposit is inclined at a steep angle, or when a mass has to be dealt with, the mineral will readily drop from the working-place to the level below. The passages provided for this purpose are called "shoots," "passes," or " mills."

If the excavation is filled up with rubbish, a space like a small shaft is reserved in the stowing by building a wall with some of the large stones. This kind of "pass" may be described as a large chimney, about 3 feet in diameter, lined with coarse rubble masonry. To prevent choking, it is advisable to make the pass slightly conical, the large end at the bottom. It may 
be constructed in the middle of the rubbish, or if there is a convenient smooth face on the footwall of a lode, a semicircular wall built against it encloses a space very suitable for the purpose required. The pass may serve also as a climbing way for the men, especially if it is provided with a chain; but it should be used in this manner only for short distances. It is far better to keep the ore-pass distinct from the climbing way, in case any stones should lodge on the sides and fall during the ascent or descent of the men.

A pass is often lined with timber instead of stone, and sometimes it is merely an intermediate shaft or winze set apart as a shoot. At the Van Mine the passes, whether they are small shafts sunk on purpose, or passages reserved in the rubbish used as filling, are 6 feet by 3 feet, within the timber; each pass is divided into two unequal compartments by a partition made of $\mathrm{x} \frac{1}{2}$-inch plank nailed to cross-timbers called dividings, and the larger one is closely lined with similar planks. This forms the "shoot" proper. The small compartment is provided with ladders and serves as a climbing way, and is also useful in case the larger one should become choked; a board can be taken out from the side at any time, and large stones obstructing the passage can be dislodged with safety. Vertical passes lined with timber sometimes have pieces of steel rail put across at intervals, to break the fall of the "stuff."

The pass is provided at the bottom with a mouth closed by a door of some kind, and when this is opened, the mineral falls out into the waggon which has been brought underneath.

II. FLOW ALONG PIPES. - This method of transport becomes available when one has to deal with liquid or gaseous minerals, or with solutions, but these cases occur more frequently above than below ground. However, brine is led along wooden launders and pipes in some salt mines. Natural inflammable gas in a few exceptional cases is piped off from a blower and buint for illuminating purposes; this is done at a salt mine at Bex in Switzerland.

III. CARRIAGE BY PERSONS.-The simplest and no doubt the oldest method of transport along underground roads is carriage by persons. It still survives in some places for short distances.

In the Forest of Dean, boys carry iron ore on the back in oval trays, called "billies," from the actual working-place to the nearest barrow-road or waggon-road. The tray is made of wood, with a rim of sheet iron, and is about 6 inches deep, 22 inches in length in the direction of the long axis, and 12 to 15 in the direction of the short one. The load carried in a "billy" varies, according to the nature of the ore and the strength of the lad, from 90 to II2 lbs. or even more. The lad goes on all-fours, using his hands to support himself as he makes his way through 
low and tortuous passages. This metiod of transport is rendered necessary by the nature of the excavations, which are very irregular; but the distances along which the ore is carried are small, generally from 30 or 40 to 50 yards, and rarely as much as Ioo yards.

The German miner commonly makes use of a tray into which he scrapes his mineral or rubbish with a tool like a hoe, and he then carries his load to the nearest "pass" or to a waggon-road in the immediate neighbourhood.

In the little slate mines near Cochem on the Moselle, men and lads carry up the blocks of slate upon their backs, walking upon steps cut in the rock. They come up with their hands upon the ground, bent almost double under the weight of the block, which rests upon a thick pad. Again, blocks of slate are still carried on the back from the working-place to the waggon-roads in the slate mines of the Ardennes. In the Sicilian sulphur mines the same method is common, and it is also found in some parts of Spain and China, where baskets are used, whilst bags are employed in Mexico and Japan. Indeed, in these cases, as at Cochem, the mineral is not only carried along comparatively level roads but is also brought to the surface.

IV. CONVEYANCE BY SLEDGES.-Sledges, or sleds, enable greater loads to be transported ; but they are not available unless the conveyance takes place along roads sloping downwards. They are little employed underground.

V: CONVEYANCE BY VEHICLES WITH WHEELS.We now come to the methods by which minerals and rubbish are usually transported both above and below ground-viz,, by some kind of wheeled vehicle. Here we may at once make two classes. A. Vehicles running upon the ground or on boards ; B. vehicles running upon rails.

A. Vehicles Running on the Ground or on Boards.Wheelbarrow: The simplest wheeled carriage is the barrow: It consists of a body with two handles and one wheel. The barrow used in Cornwall at the present day is not unlike that figured more than three centuries ago by Agricola. It has no legs, but in many ore-mines a barrow with legs is employed, somewhat resembling a navvy's barrow. Mine-barrows are usually made of wood, and have either a wooden or a steel wheel. The Cornish barrow is tipped sideways, whilst the barrow with legs is tipped either sideways or over the end. This latter form of barrow requires a higher and better level; it is a more advantageous appliance, as it throws a greater part of the load on to the wheel and relieves the miner's arms to a certain extent. The barrow often runs along the natural floor of the workingplace or level, but less labour is required if it is provided with a road made of planks or strips of iron.

Carts and Waggons - In the low passages, only 18 inches to 
20 inches high (Fahrten), leading from the working face of the copper-shale mines at Mansfeld to the main roads, tiny waggons on four wheels are employed.

Carts drawn by horses are used in some large underground quarries.

A mine waggon largely employed in Germany at one time, ani still seen occasionally, is the so-called Hungarian "Hund." It has a rectangular body resting upon four wheels, two small in front and two large near the middle; the workman presses down a little handle at the back to make the load rest upon the two big wheels only, and pushes the waggon along a board at the bottom of the level. The Germans have also used four-wheeled waggons running upon two boards; and they were sometimes provided with a projecting pin underneath which kept them upon the track.

B. Vehicles Running upon Rails.-The points to be considerd are $(a)$ the road; $(b)$ the waggons ; $(c)$ the power employed for traction.

(a) Railways. - Cast-iron tram-plates were introduced in the last century, and were succeeded by wrought-iron rails ; these in their turn are being superseded by rails made of steel. Various forms of rails are in use. The simplest is a bar of iron set on its edge, or a strip of flat iron nailed to longitudinal sleepers. Rails of the former kind are made, for instance, of bars $\frac{7}{3}$ by $2 \frac{1}{2}$ inches, or $\frac{3}{4}$ by $2 \frac{3}{4}$ inches, fixed by wooden wedges in slits cut in the sleepers. This rail has the disadvantage of wearing a groove in the flange of the wheel, but it is easily and quickly laid and readily bent into curves. Rails made of bars of round iron are used in some Welsh slate quarries.

The bridge-rail was in great favour at one time, either laid upon longitudinal or cross sleepers; but nowadays flanged T-headed rails made of steel are preferred. Care should be taken to have strong and well-laid lines, especially where there is likely to be much traffic. In this, as in many other departments of mining, it is very bad economy to cut down the original expenses too much. What is saved on the first cost will be spent over and over again in repairs, to say nothing of the loss of time and money caused by delays in the traffic.

The gauge varies from I4 inches to 3 feet or more; 20 inches to 22 inches is a common gauge in vein mining. The

FIG. 397 . F'IG. 398.

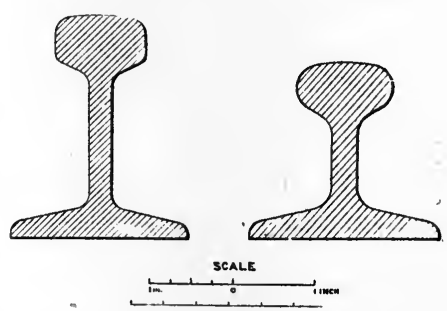
weight of the rails for such roads is from ro to $30 \mathrm{lbs}$. per yarl. Figs. 397 and 398 show the sections adopted respectively by Legrand of Mons and Howard of Bedford, for rails weighing 
r 8 lbs. per yard. The rails may be simply spiked to wooden sleepers, or they may be laid in chairs. In important roads fishplates should be used.

There is a tendency at the present day to adopt steel sleepers, which are supplied by the makers to suit roads of various gauges. They have proved to be very convenient and efficient, and in this country they are cheaper in the end than wood. Among their advantages are exact uniformity of gauge, easy and rapid

FIG. 399.

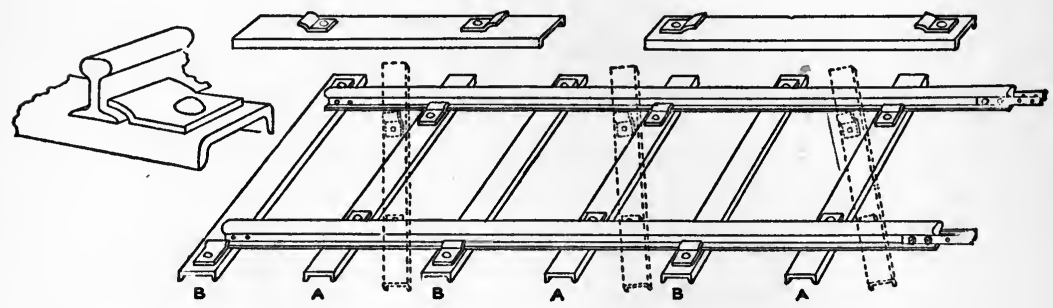

laying, fewer repairs. They are usually made of rolled steel, and the rails are fixed either by clips, or by clips and keys.

One form of road supplied by Legrand of Mons (Fig. 399), has the clips of one sleeper on the outside of the rail and those of the next on the inside of the rail. The clips are firmly riveted to the sleepers. In constructing the road, the sleepers B are laid at suitable distances apart, exactly parallel to one another; the alternate sleepers $\mathrm{A}$ are then put in obliquely, as shown by the dotted lines, and knocked into position with a hammer; the rails are joined by fish-plates.

Howard's sleeper (Fig. 400) is made from a plate of steel rolled with a corrugation; the lips which constitute the chairs for the

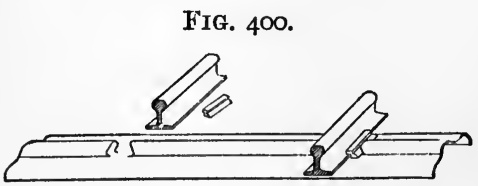
rails are formed by pressing down this corrugation without cutting away any of the metal. The jointing sleepers have a double corrugation, and the rails are fastened with a simple key which is serrated on one side. Some of Howard's sleepers for underground work can be used without any keys.

Bagnall's sleeper is also distinguished by longitudinal corrugations which stiffen it and prevent its buckling. The Widnes Chair and Sleeper Company prefer a section like that of a V-shaped trough; they claim that the penetration of this sleeper into the ground ensures great stability.

Where a mine has a stock of old rails or old iron, it is often more economical to convert it into sleepers than to sell it as scrap. 
There are several methods in use. White* of Widnes utilises old bridge rails (Figs. $40 \mathrm{I}$ and $40 \mathrm{I} a$ ) by inserting two clips (Figs. 402 and $402 a$ ) into a piece of rail cut to the required length; the clip is held in place by a pin which passes into a hole punched

Frg. 40 I.

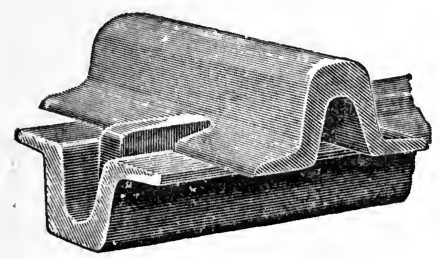

Fig. 402.

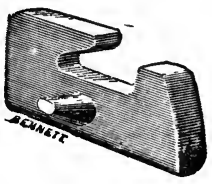

FIG. $40 \mathrm{r} \pi$.

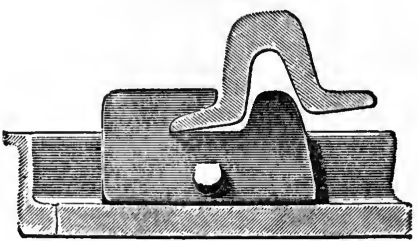

FIG. $402 x$.

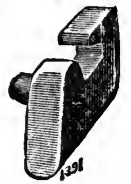

in the sleeper. At the Llechwedd slate mine in North Wales, two other methods have been devised by Mr. C. Warren Roberts (Figs. 403 and 404) for utilising old channel iron and flat iron. Stamped iron clips are riveted on so as to take the outer side of

FIG. 403 .

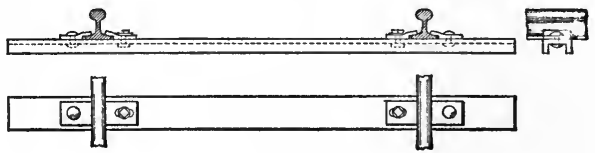

FIG. 404.
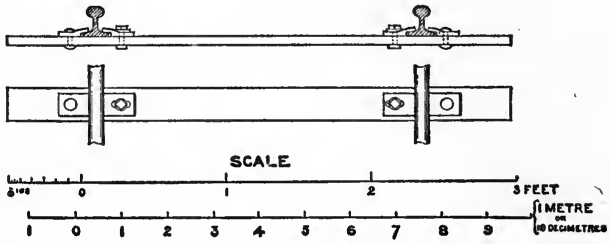

the flange of the rail, and similar clips are bolted on against the inner flange. In order to allow for any small irregularity in the width of the flange, the hole for the bolt is made oval, and this enables the clip to be adjusted to the flange exactly.

\footnotetext{
* Engineering, vol. 1v., I893, p. I46.
} 
Points and crossings must be provided. The points may be like those of an ordinary railway, with tongues moved by levers. Another plan is to leave gaps between the rails where the lines diverge or cross, and interpose plates of cast-iron upon which the flanges of the wheels run without any difficulty. This arrangement is suitable for cases where a man is pushing the waggon, for he can turn it on to whichever road he chooses, but it will not answer in the case of haulage by engine power. Each plate has a rim or edge on the outer side, which prevents the wheels from running off.

Flat plates are commonly used where there is a very sharp bend in the road, such as when a cross-cut joins a level almost, if not quite, at right angles. The plate is made of cast-iron with ridges forming prolongations of the rails as shown in Fig. 405 .

FIG. 405.

Fig. 406.
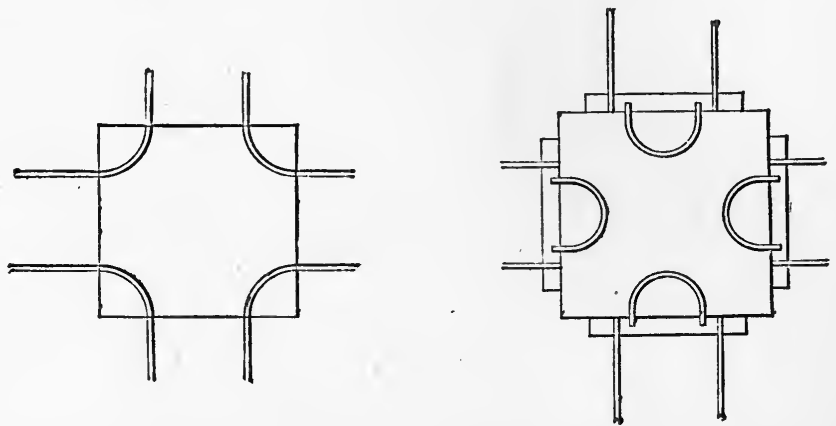

The waggon leaves the metals and the flanges of the wheels run upon the plate; as its surface is perfectly smooth, the waggon is easily turned into the required direction, and the curved ridges guide the wheels into the track which they hare to follow.

In places where there is a difficulty in procuring a casting, the plate may be made of sheet iron, and the necessary guiding ridges are formed by the overlapping ends of the rails. The flange of the rail is cut away for a length of 8 or 9 inches and also part of the web; the projecting piece of the head is then hammered out so that the top of the rail slopes down sufficiently to touch the plate.

Another device for guiding a waggon from a plate on to a line of rails is a curved piece of round iron, $I$ inch in diameter (Fig. 406). The two ends are bent at right angles and sharpened so that they can be driven into a sleeper at the edge of the flat plate. The ridge formed by this piece of iron, guides the inner side of the flinge of the wheel. 
The inclination of the road is not without importance, because there are usually waggons travelling in both directions, full ones going towards the shaft or other outlet from the mine, and empty ones returning to the working-places. The inclination downwards towards the shaft assists the work, but if it is too great the return journey causes a useless expenditure of labour.

The rule in many ore-mines is to drive the levels as flat as possible, with only just slope enough to make the water flow away; the tendency of the workmen is always to rise too mucb, aud one sometimes meets with old levels where, through carelessness or inattention of the agent, the loss of level is very considerable. An inclination of $\frac{1}{6}$ to $\frac{1}{8}$ inch per yard, or $\mathrm{I}$ in 216 to $\mathrm{I}$ in 288 is common.

The condition of the road between the metals deserves more at tention than is usually bestorved upon it. There is unnecessary labour on the part of the man or the horse employed in traction, if the road upon which he walks presents obstacles through great unevenness. I have seen roads which were simply a succession of deep puddles between the sleepers, a striking contrast to the well-kept main levels at the Mansfeld copper mines. These levels are carefully paved with artificial stones, made from slag at the Company's smelting works. The paving-stones are about 5 inches square at the top and 6 inches deep; they are also sold to the public, at prices varying from $\frac{3}{4} d$. to $\mathrm{r} d$. each.

(b) Waggons.-Mine-waggons are made of wood, iron or steel. They consist of a body or box resting on a frame carried by four wheels. They vary greatly in shape and size accurding to the nature of the excavation and the kind of material transported.

Figure 407 represents the plain but strong waggon of the Van Mine, Montgomeryshire, with a rectangular body of sheet iron, an oak frame and cast steel wheels. The top is strengthened by a band of flat iron. The wheels are $\mathrm{I} I \frac{1}{2}$ inches in diameter and FiG. 407. are just low enough to go under the body; they are therefore protected from blows, to which they would otherwise be liable from stones dropping during the process of filling. The waggon is emptied by being run in to a "tippler," that is to say, a cage turning on pivots, which enables it to be completely overturned.

At the Mansfeld copper mines the general shape is similar. Formerly waggons of various shapes and sizes were in use, but now one uniform model has been adopted. The body is made of sheet-iron $\frac{1}{8}$ inch thick, and the upper edge is strengthened by an iron band $\frac{11}{3}$ inch thick and $2 \frac{1}{2}$ inches wide, whilst the corners are stiffened with angle iron. The body is 3 feet $5^{\frac{1}{2}}$ inches long, 2 feet 2 inches broad, and 1 foot $\mathrm{ro}_{4}^{3}$ inches deep inside. The 
capacity of the waggon is $\mathrm{I} 3 \frac{1}{4}$ cubic feet, and it carries io cwt. The body rests upon two pieces of iron placed lengthwise, across which are fixed the two axles. The wheels are of chilled cast-iron with special grease-boxes. The gauge of the road is $19 \frac{1}{2}$ inches, and the wheels are $11 \frac{1}{2}$ inches in diameter, so that they can be placed under the waggon. The total height of the waggon is 3 feet 1 inch, and it weighs $716 \mathrm{lbs}$.

When made of sheet-iron or steel the sides can be bent, as shown in Figs. 408 and 409, and larger wheels can be employed without unduly raising the body.

In order to suit the small levels of some vein mines, the waggons are made long and narrow. In the Isle of Man, one meets with waggons 6 feet long and only 19 to 21 inches wide at the top; the depth being 2 feet. The sides slope inwards so that the bottom is only 13 inches wide by 4 feet 9 inches, or 5 feet long. The waggons are made of sheet steel about $\frac{3}{16}$ inch thick, or of $I_{1}^{\frac{1}{2}}$ inch

Fis. 408.

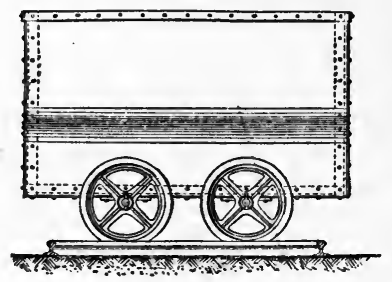

Fig. 409.

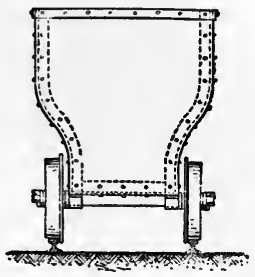

plank. The discharge is by a door at one end, kept in its place by a bolt. When the waggon has to be emptied, the miner knocks up this bolt and lifts the waggon up behind till it slopes enough for the "stuff" to run out. The top of the steel waggons is stiffened by a band of $\frac{1}{2}$-inch iron 2 inches wide firmly riveted on, and pieces of angle-iron, where the plates come together, give a further amount of strength. Wooden waggons have the bottom lined with sheet-iron $\frac{1}{8}$ inch thick.

The diameter and nature of the wheels vary. At one mine in the Isle of Man the wheels are $10 \frac{1}{2}$ inches in diameter, and run loose upon the axles, which are bolted to the frame under the body; they are 15 inches apart, from centre to centre. The wheels are brought close together with a view of making the waggons pass round curves without trouble. In order to render the tipping easy, the centre of the front axle is placed 6 inches in front of the middle of the waggon; the miner, therefore, has the greater part of his load balanced when he pivots his waggon on the axle of the. front wheels in the act of discharging it.

At a neighbouring mine under very similar conditions castiron brackets are bolted under the body to receive the two axles to which the wheels are firmly keyed, but the hinder axle is not 
in any way attached to the bracket; when it is desired to empty the waggon, the hind end is lifted up and both sets of wheels remain on the ground. The hind axle is made fast to the front one by a couple of straps, for otherwise the hind wheels might run away when the waggon was emptied. A disadvantage of this kind of waggon is that it may require two men to replace it on the road if it comes off; one may be wanted to see that the wheels will drop properly on to the rails, while the other is managing the body.

In both these waggons the wheels project outside the body, instead of being underneath it out of harm's way, but they are protected to a certain extent by the overhanging sides, and they can be further screened by riveting on little shields of sheet-iron. The lateral position of the wheels reduces the height of the waggon required for any given capacity, a decided advantage when it has to be filled with the shovel ; but in ordinary vein mining the ore ought to be drawn down from shoots, and therefore the kenetit of easier shovelling comes into play only when loading rubbish or ore in such places as the "ends."

In some mines the mineral is loaded in the level into an iron bucket (kibble) standing upon a trolley, which is merely a small platform upon four wheels. This trolley is pushed (trammed) to the shaft; the full kibble is hooked on to the winding rope and drawn up, whilst an empty kibble is placed upon the trolley and trammed along the level to the spot where it is again loaded from a shoot or by the shovel.

Wheels for mine-waggons generally have a single flange, and are made of ordinary cast-iron, chilled cast-iron, cast-steel, or forged steel. Steel and chilled cast.iron are the materials most. in favour; both have advantages. The wheels made of chilled cast-iron are rather heavier than those of steel, and are brittle; the flange, for instance, will break under a blow which will not damage a steel wheel; but a pair of chilled wheels will often outwear several pairs of steel wheels if they happen to escape the hard raps to which mine-waggons are liable.

Under Eyre's patent, wheels are made by forging a steel bloom under a steam-hammer into dies; they are reported to give great satisfaction and to be capable of standing much knocking about.

Wheels with two flanges are used in the Festiniog slate mines, and are considered best fitted for the work on account of the sharp turns in the roads.

Much difference of opinion and practice exists concerning the attachment of the wheels. Four systems are in vogue: uxles fixed and wheels running loose on them; wheels fixed to the axles, which run loose in pedestals attached to the frame or to the body of the waggon; thirdly, a rombination of these two systems-viz., wheels running loose on the axles and axles run- 
ning loose in the pedestals ; fourthly, one wheel fast on the axle, and the other loose.

At a first glance it might be thought that it would undoubtedly be best to follow the lead of the great railways, and have the wheels fixed to the axles, because experience has shown that this system answers so well above ground. Nevertheless, it must be remembered that the conditions of underground roads are often very different, the curves are frequently of very small radius, and there is usually more difficulty in keeping the roads in perfect order. By allowing the wheels and axles both to be loose, the Festiniog miner, for instance, who may be tramming out a block of slate i8 feet long, can slew his load on the truck and so pass round sharp curves which would oppose an insurmountable obstacle if the wheels or axles were fixed. Loose wheels with loose axles look clumsy and unnatural, aüd in spite of all that may be said in their defence, it is probable that it would in many cases pay the mine owner to improve the condition of his roads and so render a more stable form of waggon available.

Lubrication of the bearing parts is too often performed in a perfunctory and wasteful manner, especially in mines where the waggon never comes to the surface except for repairs. A little grease or oil applied at the beginning and in the middle of the shift is all that is considered necessary. Such a procedure must be defective; either there is too much of the lubricant at first, or there is too little after the waggon has been in use for a time.

An automatic lubricating apparatus is sometimes fixed in the road and every waggon is greased in going over it. The apparatus consists of a wheel placed in a trough containing the grease, and as each axle touches this wheel it receives a little lubricant. A defect of these lubricators is that when a waggon is going at great speed, as is the case with some systems of underground haulage, the grease is flung about and wasted; besides, where a bearing can be greased in this manner it is necessarily exposed to the dust or mud of the mine, which must cause wear and friction. It is better to provide constant lubrication and to protect the bearing parts as much as possible from dirt.

One method by which this object is attained is shown in Figs. 4 Io and $4 \mathrm{I}$ I, which represent a waggon used at some collieries at Saint Etienne, in France, and embodying the results of long experience. 'The whecl, which is made of steel, is placed under the waggon, and the journal is encased in a chamber kept full of oil. The chamber has two holes which serve for passing in the linch-pin and putting in the oil. They are afterwards closed with plugs. Other points which may be noticed about this waggon are its shape and mode of construction. The body is oval and made up of wooden staves like a barrel. 
As an example of a waggon constructed entirely of steel, I take a "tram" designed for the Llanbradach colliery by Mr. Galloway (Figs. 412 and 413). The body has the form FIG. 4 IO.

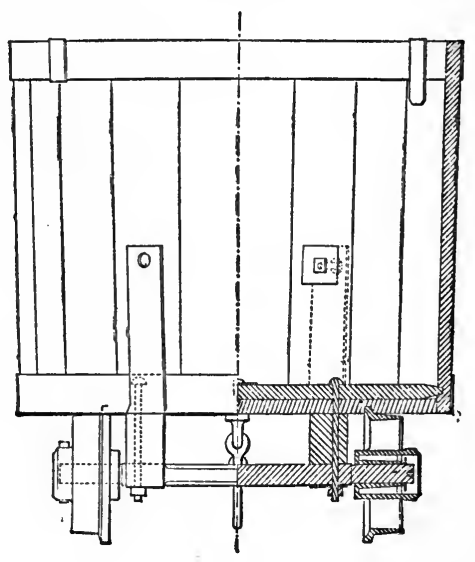

FIG. 4II.
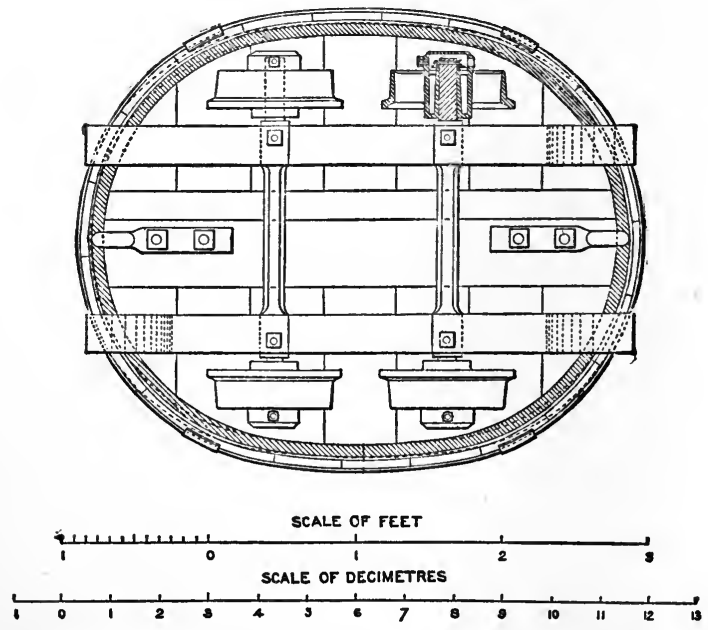

of a very blunt oval; it is made of sheet steel $\frac{5}{32}$ inch thick, stiffened round the top by channel steel. The wheels are fixed to the axles, which are kept constantly lubricated by Stauffer's lubricators placed immediately above them in the hollow axle- 
boxes The empty waggon weighs i $2 \mathrm{cwt}$. and will carry 2 tons of coal, when the load is built up higher than the sides.

When dealing with a tender mineral like coal, which decreases in value if knocked about, it is important to reduce the effects of bumping to a minimum; and with this object in view the waggon
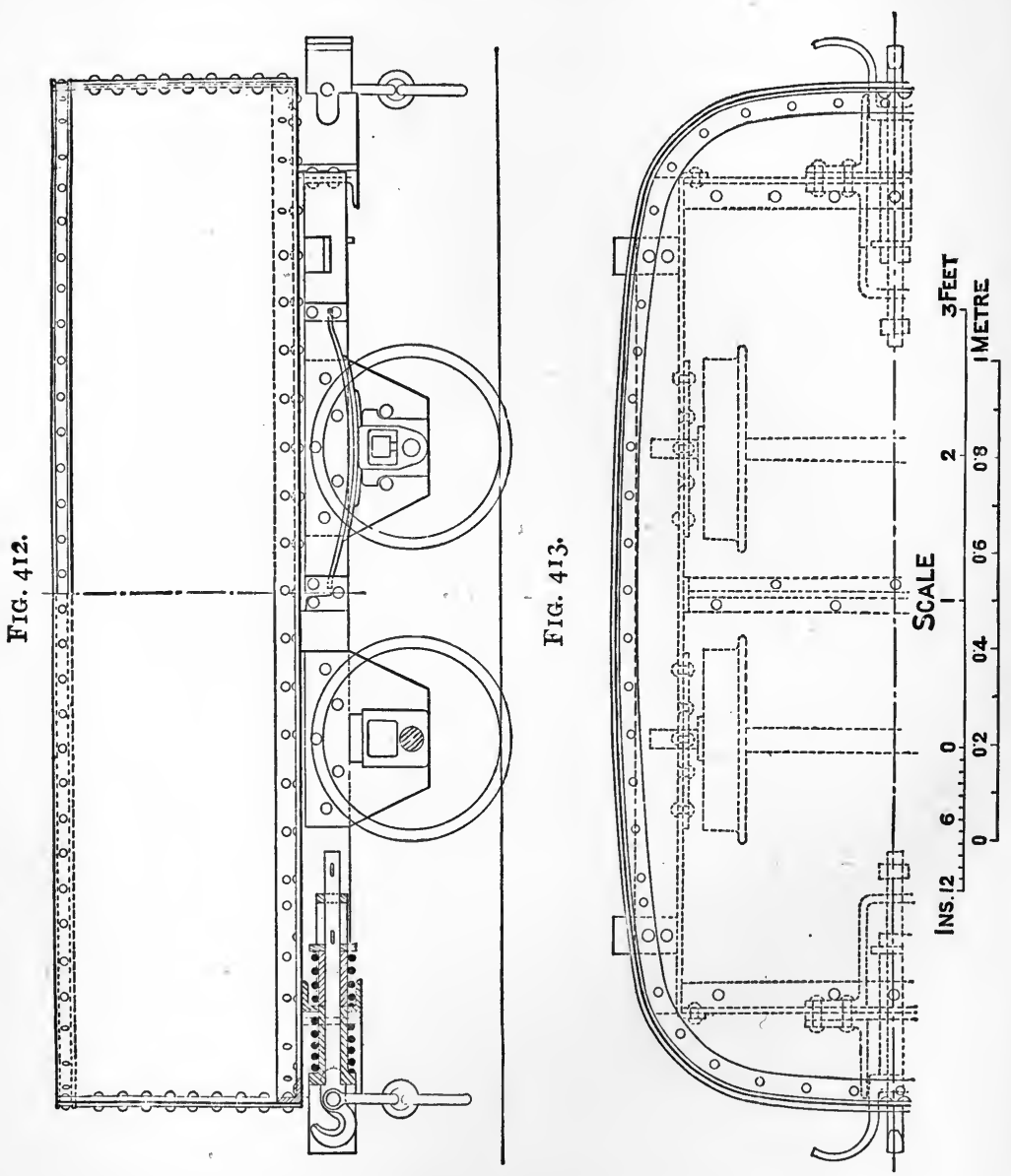

rests uron springs and the luffers are elastic. The consequence is that the waggon runs very smoothly, and is likely to require less expenditure for repairs than one constructed in the ordinary fashion without these appliances. There will likewise be a diminution in the quantity of dust dropped on the road, a matter of moment in collieries. 
The Hardy Patent Fick Company makes self-oiling pedestals for waggons with the wheels fast upon the axles (Fig. 4I4); $a$ is the upper part of the pedestal, and $b$ the lower part, containing felt or wool saturated with oil. This presses lightly against the axle and keeps it oiled for several weeks, without requiring any attention.

It will be seen from these remarks that a number of points have to be considered in designing a mine-waggon. They may be summed up as follows:

Smallest weight compatible with strength.

FIG. 4I4.

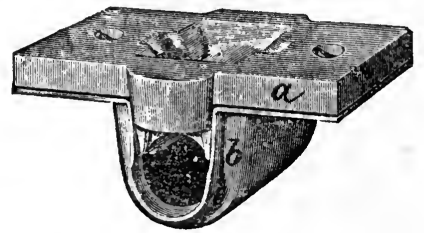

Small height, if the waggon is to be filled with the shovel.

Protection of the wheels from injury.

Constant lubrication.

Adoption of a uniform type of waggon for the mine.

Material which causes the least expenditure for repairs.

Easy handling and easy replacement upon the rails:

In a few exceptional cases the mineral raised in the mine does not require a box or chest. This happens with slate, for the blocks are brought up on trucks to which they are made fast by chains.

\section{(c) Power used for Underground Transport.}

The sources of power are as follows :

I. Men, boys, women, and girls.

2. Horses, ponies, donkeys, and mules.

3. Gravity acting upon the material moved.

4. Machines driven by steam, water, compressed air, and electricity.

r. Human Labour.-Female labour underground is prohibited by law in the United Kingdom, and no doubt it is destined to disappear in other countries. We need only deal with men and boys. Where the passages are high enough to take waggons standing 3 feet above the ground, men are usually employed for drawing or pushing them. It is convenient to have waggons small enough to be handled by one man, and also to be put back on to the road by one man, if by chance they leave the rails.

The large waggons and loads at Festiniog require two men, for the load of rubbish commonly amounts to $1 \frac{3}{4}$ or 2 tons. The waggon and load together may weigh as much as $2 \frac{1}{2}$ tons. The men who push out these waggons usually do the loading also, shovelling in the small pieces and lifting on the large ones.

2. Animal Labour.-Traction by horses or ponies is cheaper than using human power, but it is not always practicable to 
employ it. There are many ore mines in which it would be impossible to lower a horse down the shaft; and even where the descent could take place, there would often be the further drawback, that as the work proceeds with comparative slowness, owing to the hardness of the rock, there would not be "stuff" enough broken in a given time to keep a horse constantly emp.oyed at any particular level, whilst shifting it from one level to another would entail much difficulty.

The load drawn by a horse at the Festiniog slate mines is as much as eight waggons, a gross weight of 20 tons, or net weight of I 6 tons, along a road with an inclination of $\frac{1}{8}$ inch per yard.

Where a mine is entered by a shaft, the horses are stabled below ground, and much care is taken in many instances to provide proper accommodation for them. The stables are paved with bricks or concrete, sloping towards a gutter; each horse has its stall, or a loose board is hung between every horse and its neighbour. Clean water is at hand for drinking. At a French colliery I found the daily allowance of food to be as follows:

$$
\begin{aligned}
& \text { Oats . . . . . . . . } 10 \mathrm{kil.} \mathrm{(22} \mathrm{lbs.)} \\
& \text { Chopped hay from lentil and rye grass } \quad 5 \text { kil. (I I lbs.) } \\
& \text { Bran. . . . . } 2 \text { kil. (4.4 lbs.) }
\end{aligned}
$$

In addition each horse had 5 kil. (I I lbs.) of straw per day as litter.

The horses do not always belong to the mining company; at Festiniog, where the workings can be entered by adits, horses are hired from persons in the district, who supply a horse and man for eight shillings per day, and pay all the cost of food and stabling.

3. Gravity.-In working stratified deposits, it is often necessary or convenient to lower a waggon down an inclined plane made along the dip. At Mansfeld, for instance, instead of maintaining a number of levels at short intervals apart, it is more economical to reserve only a few for traffic, and abandon certain portions, as already pointed out in Chapler VI. The waggons then have to be lowered from the working level to one which is kept up as a main roadway. Inclines for this purpose have two lines of rails, one for the descending and the other for the ascending waggon. A wire rope or a chain passes round a pulley or drum at the top, the axis of which may be horizontal or at right angles to the plane of the deposit. Each end of the rope can be hooked on to a waggon, and the weight of the full waggon going down suffices to raise the empty one. The speed is regulated by a brake on the pulley or drum.

Another method of working inclines is to make the full waggon draw up a weight, running on a special line of rails, which is heavy enough to bring up the empty when it de- 
scends. In order to economise space, the line of rails for the weight may be made narrower than the one used for the waggon, and may be laid between the two main rails.

If the incline is steep, a carriage with a horizontal platform is provided. The mine-waggon is pushed on to this travelling platform and ascends or descends in its ordinary position.

4. Machinery.-Underground haulage may be carried on either by travelling engines or stationary engines.

Locomotives fired with coal have the great disadvantage of polluting the air by the products of combustion, consequently they are not available unless the ventilation is very good, nor unless there is absence of inflammable gases and freedom from the risk of setting fire to the timbering or to the mineral itself. A small locomotive of two horse-power nominal is used on an I $8 \frac{1}{2}$ inch track in the long adit of the Great Laxey lead and zinc mine in the Isle of Man; and at Rio Tinto in Spain a much larger engine plies in the adit on a line with a gauge of 3 feet 6 inches.

Locomotives driven by compressed air, carried in a reservoir upon a tender, improve the ventilation instead of injuring it, and are not a possible source of danger from fire; but, except in special cases, they cannot be worked so cheaply as engines fired with coal. However, the advantages they afford have led to their adoption in some mines; Lishman and Young's air locomotive is employed in several collieries in the North of England.

To overcome the inconveniences and dangers of engines of the ordinary type, fireless locomotives have been proposed and constructed. That of Lamm and Franck has a cylindrical reservoir, instead of the boiler, filled three-quarters full of water. The reservoir is heated by steam from the surface, until it is capable of giving off vapour with a pressure of 235 to $294 \mathrm{lbs}$. per square inch (I6 to 20 atmospheres). As the temperature and consequently the pressure of the steam supplied by the reservoir are constantly falling, a regulator is interposed between the reservoir and the steam cylinder, which enables both the pressure of the steam and the amount of expansion to be changed at will. This arrangement renders extra power available if a steep gradient has to be mounted.

Rolland's fireless locomotive is similar.* His reservoir has a capacity of $19 \frac{1}{2}$ cubic feet $\left(0.55^{\circ} \mathrm{cb} . \mathrm{m}.\right)$, and contains water at a temperature of $205^{\circ} \mathrm{C}$., or with a pressure of $235 \mathrm{lbs}$. per square inch ( 6 atmospheres). M. Rolland states that his locomotive, charged in this fashion, will run for 2 to $2 \frac{1}{2}$ miles ( 3 to $4 \mathrm{kms}$.). When going at a speed of $2 \mathrm{~m}$. ( 6 feet $6 \frac{3}{4}$ inches) per second, the locomotive exerts 6 h.p.; the speed of a horse may be taken as 0.9 to $1 \mathrm{~m}$. (3 to $3 \frac{1}{4}$ feet). The locomotive ready for work weighs three tons.

* B. und h. Zeitung, I890, p. 375. 
As pointed out by Rolland, the fireless locomotives have the following advantages in addition to being more economical :

No danger of fire and no inconvenience from smoke.

Improvement in the atmosphere of the mine, owing to absence of the horses and their droppings.

The Honigmann* locomotive depends upon the fact that a solution of caustic soda, of a certain strength, will absorb steam and give out heat. This heat is utilised to convert hot water into steam, which works an engine and then passes into the soda solution, causing a further development of heat. The process of steam-making goes on thus of itself, until the soda solution reaches a certain stage of dilution. The locomotive is restored to a state of activity by bringing back the solution to the proper degree of saturation. This is done by passing steam from a stationary boiler through coils of tubes in the reservoir containing the soda, a process occupying little time.

Experiments have been made, and will be continued, with the Honigmann soda locomotive, and also with Krauss' tunnel locomotive, at the Mansfeld copper mines.

Stationary Engines.-An enormous amount of underground traffic is carried on by some system in which the power for haulage is derived from an engine placed above or below ground; but the practice is far more developed in collieries than in vein mines, where the quantities of mineral to be handled are as a rule very much smaller.

With reference to the application of the power itself, the various systems of underground haulage might be classified thus:

Steam or water power at the surface, I. Ropes.

transmitted to machinery under- 2. Compressed air. ground by . . . . . 3. Electricity.

Water power below ground driving the machinery.

Steam power below ground driving the I. Boilers above ground, steam machinery . . .

Petroleum engine below ground driving the machinery.

2. Boilers below ground.

The subject of the transmission of power has already been sufficiently discussed in Chapter IV., and need not be dealt with here, save that it is necessary to point out that the conditions of the problem are not the same when power has tc be applied to haulage, as when it is required in a constantly changing working face. As the mineral has to be brought to the shaft, the engine and its boiler, if necessary, can be placed in the immediate vicinity of the pit-bottom and the exhaust steam can be got rid of without interfering with the comfort of the men or injuring the condition of the workings. Proper rooms can be made for the

* Official Catalogire of Royal Mining, Engineering, and Industrial Exhi. bition, Nercastle-on-Tyne, ז887, p. xxxvi. 
engine and the boiler, coal can be brought down and the ashes removed without difficulty. Everything can be arranged in a permanent and substantial fashion, so that steam power may be generated for haulage purposes below ground when it would not be practicable to employ it for breaking down the mineral. Again, when power has merely to be transmitted down a vertical shaft in order to work a drum near the bottom, endless ropes may be used, although they would be quite out of place if they had to be carried along narrow, low, and crooked levels. For subsidiary haulage purposes-that is to say, for bringing trams from the immediate vicinity of the workings to a main line-Galloway employs a small engine with two drums placed upon a waggon, which is small enough to go into the cage and which will run upon its own wheels along the underground railways. It can therefore be moved about as required, and when coupled up to the compressed air main can be set to work immediately to haul out trams, instead of employing horses for this work.

We will suppose that the question of the most suitable driving machinery has been settled according to the circumstances of the case, and that the miner has to consider how he will apply it to the transport of mineral.

Five systems are in use:

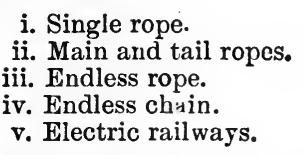

i. Single Rope.-This system is available with a road sufficiently inclined for the empty waggon to run down of itself, after the load has been brought up, and draw back the rope with it. One road will suffice, and the machinery required will be some kind of drum, around which the rope is coiled, and an engine for driving it.

The drum is usually placed horizontally; it is provided with a brake, and there is a disengaging clutch by which it can be thrown in or out of gear with the engine. A pair of horizontal engines, which have their cranks upon the drum-shaft, or which drive it by means of a pinion and spur wheel, form the common method of applying the power.

The wire rope has one end fixed to the drum and the other is provided with a hook of some kind; this is attached to a link of the coupling chain of the truck and the load is drawn up. On reaching the top of the incline or engine-plane, the waggon is unhooked, and either pushed or allowed to travel of itself, under the action of gravity, to the pit-bottom, where the onsetter runs it on to the cage in which it is raised to the surface.

An empty waggon is then hooked on and run on to the incline, and the engine-man, with his brake under proper control, dis- 
engages the drum by means of the clutch and lowers the load without using any steam. When worked in this way, the incline requires only one line of rails. A series of rollers have to be put in for the purpose of keeping the rope from trailing on the ground and of thus preventing much unnecessary wear and friction. These rollers are small wooden, east-iron, or steel cylinders, often with a low flange at each end to keep the rope in its place; they are laid horizontally and are capable of revolving around a horizontal spindle. Care is, or ought to be, taken to see that they are very correctly set and that they are well lubricated, so that they may revolve freely when the rope is drawn over them; otherwise the strands are sure to be worn down rapidly from rubbing against them.

The incline may also be worked with two lines of rails, after the fashion of the self-acting inclines; and this system has the advantage of being more economical, for the deadweight of the loaded waggon coming up is balanced by the weight of the empty one going down. It is not even necessary to have two lines all the way; provided there is a sufficient length of double line where

F1G. 4I5.

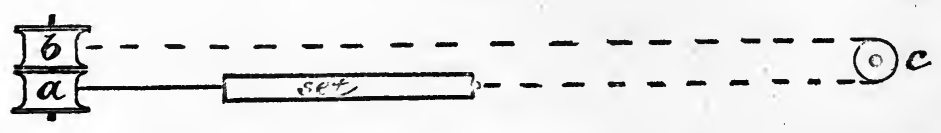

the waggons meet, the incline can be vorked with a length of single line at the top and a similar length of single line at the bottom. To prevent a waggon from running down in case a coupling link or the rope should break, a safety appliance, called a backstay, may be attached to it. It is a sort of fork which hangs behind the waggon, and just touches the ground; if the rope breaks, it digs itself into the road and prevents the waggon from going down. Of course it can only be used while the waggons are being raised, but it is during the journey of the loaded waggon that the rope is most likely to break.

ii. Main and Tail Ropes.-On the engine planes just described, the empty waggon goes back under the action of gravity; but with very slightly inclined, flat, or undulating roads this is impossible. One method of getting over this difficulty is to add a rope, called the "tail rope," which will draw the empties back; the rope which draws the full waggons is known as the "main rope."

The system is perhaps best explained by a diagram (Fig. 4I 5): $a$ is a drum upon which is coiled the strong main rope; $b$ is another drum upon which is coiled the tail rope, passing round the pulley $c$. The waggons are coupled together and form the train or "set," which may in reality consist of as many as too waggons. Suitable clutches enable either drum to be worked at pleasure by the 
engine, while the other is allowed to run loose upon the shaft. Each drum has a brake, by means of which the rope can be prevented from becoming too slack while uncoiling itself. When the drum $a$ is made to revolve by the engine, the main rope is wound up, the drum $b$ running loose, and the train or "set" is drawn from $c$ to $a$. Here the waggons are uncoupled and pushed to the shaft, or, better, the station at $a$ is arranged so that it is sufficiently high for the waggons to run down of themselves under the action of gravity. A new train of empties is then made up, the tail and main ropes are attached to it and the drum $b$ is set in motion so as to wind up the tail rope and draw the waggons into the terminus at $c$. It will be evident from a glance at the figure that the tail rope must be twice as long as the main rope. As the tail rope has simply a train of empties to haul out, it may be made smaller than the main rope, except in cases where the road has a downward inclination towards the shaft sufficient to cause the loaded train to run down of itself and draw the tail rope after it.

A single line suffices for this system of haulage; the main rope lies in the middle of the road, resting upon a series of horizontal rollers similar to those used upon ordinary inclined planes. Where there are curves, however, the rope must be guided by small vertical rollers. The tail rope is brought along the side of the road, or if more convenient, along a separate road, also resting upon rollers or pulleys and suitably guided at the curves. The system is applicable to roads of varying gradients, and arrangements can easily be made for working branches, by having a special piece of tail rope in each branch going round a pulley at the end of it. When mineral has to be drawn away from the branch, the piece of tail rope on the main road beyond the junction is disconnected, and the piece belonging to the branch is attached. Traffic then goes on as before, save that the train is made up in the branch. Another plan is to disconnect the tail rope at the end of the train, and couple one end of the branch rope to the train and the other to the free end of the ordinary tail rope. During the running of a train the tail sope then goes round the pulley at the end of the main road, passes round another at the junction of the two roads, proceeds along the branch round its terminal pulley, and back to a pulley which again puts it into the direction of the main road.

The trains are in a large number of cases made to run at a great speed, even as much as 10 or 15 miles or more an hour, and if by some mischance an accident does happen from one of the waggons getting off the road, a good deal of damage may be done to the train and roadway.

iii. Endless Rope.-A favourite method of underground haulage is by an endless rope passing round a pulley at each terminus, and generally travelling continuously in the same 
direction. The rope is kept in a state of tension by passing it round a tightening sheave, which in some instances is one of the terminal pulleys. The tightening sheave or pulley is carried by a frame running upon wheels, and is constantly drawn back by a heavy weight. The necessary grip of the rope is obtained by coiling it several times round the driving drum, or around a driving pulley with grooves and a second grooved pulley close by ; the rope wraps itself, for instance, upon three half circumferences of one pulley and two of the other. The speed of an endless rope is usually from two to three miles an hour, though instances might be cited of as low a speed as one mile an hour. The endless rope system admits of so many modifications that it is necessary at once to classify them before entering into any details. We may begin by making two broad divisions: *

Waggons attached singly at intervals along the rope.

Waggons attached in groups or trains (sets).

Waggons Attached Singly.-Two distinct lines of rails are required, because there is a constant stream of full waggons coming out to the shaft and a constant stream of empties going into the workings.

This class has two subdivisions:

Rope above the waggons.

Rope below the waggons.

When the rope is above the waggons, no rollers are necessary except at the curves. Several modes of attaching the waggon to the rope are in use.

If the gradient is all up hill a very simple clip is sufficient. The rope is made to rest in a fork on the waggon, and as it is bent slightly out of the line of pull when in motion, it is held tightly enough by friction to draw along the load. If the gradient varies, a fork is put on each end of the waggon, or a screw clip is employed; this resembles a pair of tongs, the jaws of which are brought tightly together by a screw worked by a handle, and hold the rope with a firm grip.

Another common attachment is by a piece of chain 6 or 8 feet long with a hook at each end. A boy puts one hook into an eye on the drawbar of the waggon, and giving the other end of the chain four turns round the rope makes it fast in the hook. To detach a waggon the boy presses down the chain near the waggon, takes out the hook from the drawbar, and then unwinds the other end from the rope. After a little practice the boys become very dexterous in this hooking on and off, and perform

* The classification and some of the information is taken from the Catalogue of the Royal Mining, Engineering, and Industrial Exhibition, Newcastle-on-Tyne, 1887, p. xxxiv. 
these operations with great rapidity. If there is a downward gradient the waggon would outrun the rope, and it is necessary to put a chain at the rear end as well as in front.

When the rope is below the waggons, rollers are required on the road, similar to those already described for engine-planes and main and tail ropes. The attachment to the rope is made by some form of clip. At the Hodbarrow iron mine in Cumberland, Rice's clutch (Figs. 4I6 and 4I 7) has been used for many years with good results. The rope can be put in or taken out sideways after raising the sliding piece A as far as the projecting pin. The clip is hung by its hook on to the waggon and the rope is lifted in; the motion of the rope draws the clip a little away from the vertical, and this slight deviation of the groove from the line of pull gives sufficient grip for haulage.

The number of clips or clutches is very great, and it would be useless to attempt to describe them all within the limits of this work.

An advantage of this system is the smooth and regular manner in which it works. The waggons are attached at intervals of about 20 yards or even less, and they arrive without the bustle of FIG. $416 . \quad$ FIG. 417. a long train. The men and boys are

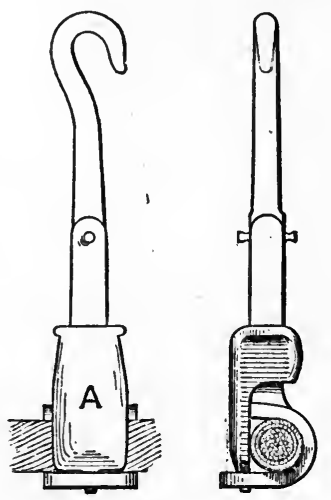
kept constantly employed, but have ample time for doing all that is required of them. If a waggon goes off the line, it is true that a large number of the succeeding ones may be thrown off too, before the damage becomes known; but the absence of a high speed tends to render the consequences less perilous than with the fast-running trains of the main and tail rope system.

Waggons Attached in Groups or Trains (Sets).-As in the previous case there are two subdivisions:

Rope above the waggons.

Rope below the waggons.

The former of these two methods is very easily understood. For instance, several waggons may be coupled together and the train thus formed is connected to the moving rope by a short piece of chain with two hooks, in the manner described for a single waggon. Other attachments are of course available.

The second subdivision admits of a great many varieties:

(a) Single road, with a siding or sidings for the full train to pass the empty one.-(aI) Single central siding.-The rope is arranged in the form of a double loop, represented diagrammatically by the dotted line (Fig. 4I8); S denotes the shaft end of the 
haulage srstem, $\mathrm{W}$ the end near the workings, and $\mathrm{C}$ the central siding. The full lines indicate the railroads. When moving in the manner shown by the arrows, the rope brings out a train of full waggons from the workings, and takes in a train of empties from the shaft. On arriving at the central siding the rope is stopped, the empties are shunted on to the siding, and the

FIG. 4I8.

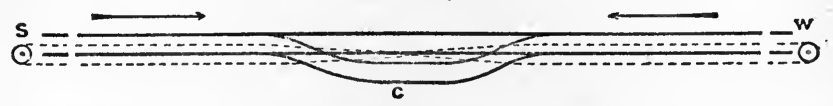

train of full waggons is attached to the part of the rope which has just brought in these empties. The empties are shunted back on to the main line and attached to the part of the rope just used for bringing out the full waggons. On reversing the motion of the engine, the empties proceed to the workings and the full train travels to the shaft.

(a2) One or more sidings.-The two ropes (Fig. 4r9) lie within the road, except at the sidings, each of which has one of them. There are points at the ends of the sidings, for diverting the trains on to the proper roads. Each train has a special truck, or

Fig. 4I9.
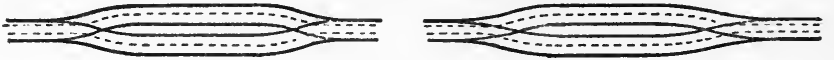

bogie, in front, upon which rides a conductor. It is his business to pick up with a hook the rope he requires, and grip it with his slutch; his train then moves along on to the main line till he comes to a pass-by. A boy attending to the points makes the train take the proper line, and if one train arrives a little too early for the passing, the conductor loosens his clutch and brings his train to a standstill until the other train has gone by. He can then proceed along the main road till it becomes necessary to cross a second train.

$(\beta)$ Two roads formed by three rails with one or more sidings for the passing of trains.-One-half of the endless rope (Fig. 420)

FIG. 420.

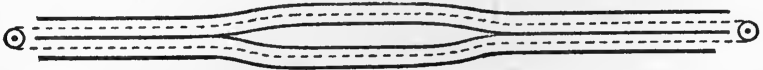

lies in the middle of one track, and the other in the middle of the other track. The trains pass as they did in the previous system; but there is the advantage that no points are required.

( $\gamma$ ) Two entirely separate lines of rails.-In this case (Fig. 42 I) no intermediate sidings or points are necessary, for each train has its own line, and the services of the conductor can be dispensed with. 
In making a choice between these various methods, much depends on the nature of the roads. At some mines it may be difficult to keep a road open of the width necessary for two separate lines of rails, or indeed for one; so that a system which can be worked by a single line with occasional sidings will be preferred. Besides, it may be necessary to introduce mechanical haulage into a mine laid out originally for horse traffic, and the expense of making a second road might be fatal to a double-line system, in spite of its manifest advantages.

FIG. 421 .

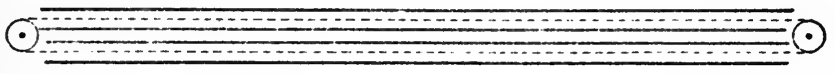

iv. Endless Chain.-This may be looked upon as a variety of the previous system, a chain being substituted for the rope. The chain is usually made to ride upon the waggons, and as each link lies in a plane at right angles to that of its neighbour, it is easy to devise a simple catch or clip. A common one is a bar with a fork at the top, which is attached to one end of the waggon. The waggon is pushed under the chain, which is sagging down a little, so that a link lying vertically drops into the fork; the next link will catch against the clip and set the waggon in motion. On arriving at the terminus the chain is raised by a pulley, and so lifted out of the fork. The waggons: are attached singly.

v. Electric Railways.-In the previous four cases we have been dealing with the transmission of power by is moving rope or chain, we now come to a totally different solution of the problem-viz., the transmission of power by a wire or wires to a motor which runs on a track and draws a train of cars after it.

As an example* of an electric railway, I may take one which has been running for some years at the Neu-Stassfurt mine, where potassium salts and rock salt are the object of the workings. The underground railway runs for a distance of nearly rooo yards (900 m.), along the strike of the deposit; a cable is brought down the shaft, and there are two insulated conductors hung from the roof of the level; one conveys the current to the electric locomotive by means of a slide, dragged along by a small rope, and the other has a similar slide for the return. The road in this case is perfectly horizontal, and the locomotive draws a train made up of 20 waggons. An empty waggon weighs 400 kil., and takes a load of $75^{\circ}$ kil.; 20 full waggons make up therefore a total weight of 23 tons. The locomotive weighs $2 \cdot 1$ tons, consequently the total weight of the train is about 25 tons. The steam engine for driving the dynamo at the surface is of about 20

* MS. notes and B. und h. Zeitung, 1888, p. 3 co. 
horse-power. The locomotive is 3 feet $\frac{1}{2}$ inch wide by 4 feet 11 inches high, and 8 feet 9 inches long between the buffers $(930 \mathrm{~mm}$. by $1500 \mathrm{~mm}$. by $2670 \mathrm{~mm}$.) and the centres of the axles are $18 \frac{3}{4}$ inches $\left(480 \mathrm{~mm}\right.$.) apart. The gauge of the road is $24 \frac{3}{4}$ inches $\left(628 \mathrm{~mm}\right.$.), and the diameter of the driving wheels $13 \frac{3}{4}$ inches $\left(35^{\circ} \mathrm{mm}\right.$.). The locomotive is made alike at both ends, with a seat for the driver, so that he can travel in either direction, without having to turn it round. It takes a train five minutes to run the 900 metres.

The cost compares favourably with that required for tramming by men or horses, and in 1888 the figures given were as follows :

\begin{tabular}{|c|c|c|c|}
\hline & Electric Ralway. & IIorses. & Men. \\
\hline Pfennige. & Pfennige. & Pfennige. \\
Cost of haulage per ton ? & $12 \cdot 9$ & $: 6.00$ & 34.20 \\
\hline per kilometre & .5 & & \\
\hline
\end{tabular}

Speaking roughly these figures are $1 \frac{1}{2} d$. per ton per kilometre for the electric railway, $1 \frac{3}{4} d$. for horses, and $4 d$. for men.

Comparing the electric railway with horse traffic, there are other advantages besides that of cost. The mine is kept much sweeter and cleaner, from the absence of the droppings of the horses, and in this particular case, the animals would suffer in their hoofs, from constantly walking in the damp salt.

The Neu-Stassfurt line is not working under the most favourable conditions for economy, because it cannot be kept fully employed; and considering the rapid strides which have been made during the last few years in electric transmission, it is certain that a line put up nowadays would furnish more favourable results. The line shown by Messrs. Siemens and Halske, at the late Frankfort Exhibition, had a single wire hung from the roof of the level, and the current was brought down to the motor on the locomotive by a running pulley held by a balanced arm, which ensured contact, although the distance between the wire and the locomotive was not always exactly the same. The return current travelled along the rails.

At Greenside mine in Westmoreland, there are two wires along the roof of the level, one for bringing the current to the electric locomotive and the other for the return.

VI. CONVEYANCE BY BOATS.-This is a very exceptional method of conveying mineral underground at mines; but it needs mention to make the subject complete.

In this country there is an adit level at the Tankerville and Bog mines in Shropshire, known as the "Boat level," because the ore was carried in boats to its mouth, a distance in some places of $1 \frac{3}{4}$ miles. As the adit had been driven with too great a fall originally, it was necessary to have small locks under- 
ground, and so subdivide the whole length into several parts, one slightly above the other. This level now serves simply as a drainage tunnel.

At the Dorothea Mine, near Clausthal in the Hartz, there is a level more than 400 yards below the surface, along which there was at one time a large amount of traffic by boats. The level is Io feet high, by 7 feet wide, with 5 feet of water in the bottom. The boats used on this underground canal were about $3 \mathbf{I}$ feet long, $4 \frac{1}{2}$ feet wide outside, and 3 feet deep. The part used for holding the ore had a capacity of about 220 cubic feet; the load was 5 or 6 tons of ore, and a full load would bring the edge of the boat within 6 inches of the water. The boat was propelled by the men, who pushed with their feet against the roof of the level.

\section{Transport above Ground.}

In commencing this chapter I said that it would be convenient in this place to take the subject of conveyance of mineral above ground, though, strictly speaking, it would not come until after the consideration of methods of raising ore and rubbish to the surface. This part of the subject must be treated in a somewhat summary manner for want of space, and also for the reason that much that has been said about underground traffic will apply in the case of conveyance above ground, indeed the same heads may be taken, with the addition of a seventh-transport by aërial ropeways.

I. Shoots made of timber, with the wearing parts protected by iron, can be applied in places where there is a sufficient amount of fall. In a hilly country it may sometimes be worth while sinking a shaft solely for the purpose of using it as a means of dropping ore to a lower level.

2. Flow along Pipes is made use of on a very extensive scale for the transport of natural gas, petroleum and brine.

The Annual Report of the Philadelphia Company, one of the six companies supplying Pittsburg, shows that in the year 1885 it had $33^{1}$ miles of mains and distributing pipes, which brought in the natural gas from distances of 22 to 24 miles; at that time it was estimated that there were at least 500 miles of pipes coming into the city. The mains vary in diameter from 3 inches to 30 inches, the largest sizes being made of cast-iron and the others of wrought-iron. There are more pipes of 8 inches in diameter than of any other size, and the mains are made to increase in diameter as they approach the city, in order to reduce the pressure of the gas. Many of the wells when shut would have a pressure of $500^{*}$ lbs. per square inch, and even when the pressure is far lower than this, it is necessary to reduce it in order to prevent leakage, which means not only diminished profits to the

* C. A. Ashburner, "The Geologic Distribution of Natural Gas in the United States."-Trans. Amer. Inst. DI.E., vol. xiv. 1886, p. 428. 
company, but also danger to the consumer. In the town the pressure nowhere exceeds I 3 lbs., and in many of the mains it is not more than 6 or $8 \mathrm{lbs}$., whilst in the low pressure mains it is only 4 or 5 ozs. per square inch.

Another case of conveyance of gas hy pipes is seen at the boreholes furnishing carbonic acid gas in Germany ; under its natural pressure the gas flows through wrought-iron pipes, either to the works where it is compressed into the liquid state, or to those where it is utilised for the manufacture of white lead.

Crude petroleum, which either rises naturally to the surface or is pumped up, has to be refined before it can be utilised commercially, and it has been found convenient in many districts to send the oil to the refineries by pipe-lines.* Pumps are employed for forcing the oil through the long lines of pipes, as there is no natural pressure in this case. The United Pipe-lines Company in America had, in 1886, "over 4000 miles of piping and 500 reservoirs, each holding from 20,000 to 30,000 barrels," $\dagger$ and probably now there are more than 5000 miles of pipe-lines in the United States.

The pipe-line from the Lima $\ddagger$ oil district of Ohio to Chicago is 210 miles long; the pipes are 8 inches in diameter, and each piece 22 feet long. The cost of the pipes alone was estimated to be $\$ 7000$ per mile, and the total cost of the undertaking, including the pumps and reservoirs, $\$ 2,250,000$.

Another of the great American pipe lines $\S$ connects Olean in the Bradford oil-field with New York City. It consists of two lines of 6-inch pipes, more than 300 miles in length, and it is divided into I I separate sections. At each station there are two tanks and a pump; when one tank is receiving oil, the other is supplying it to the pump for transmission to the next station further east, a week being required to complete the journey. As the lines of pipes follow the irregularities of the surface, ample pumping power has to be provided. One of the Worthington pumps $\|$ on this line exerts a pressure of $900 \mathrm{lbs}$. per square inch, and is capable of delivering $1,500,000$ gallons in 24 hours.

Mr. Marvin also mentions a pipe-line at the Burmese oil-fields made of lacquered bambous, for taking the oil from the wells to the river. Modest as this line appears compared with the great undertakings just described, it is nevertheless an advance upon the old plan of putting the petroleum into earthen jars, and carting it.

In this country, brine is sent by pipe-lines from the wells

* Redwood, "Petroleum and its Products."-Journ. Soc. Arts, xxxiv. 3886, p. 832; and "Cantor Lectures," published separately, p. 30.

† The Times, 29th September, 1886.

I Engineering, vol. xlv. I888, p. 439.

§ C. Marvin, "England as a Petroleum Power," London, 1857, p. 19.

|| Eng. Jin. Jour., vol. li. I89I, p. 745. 
to convenient places for evaporation or to alkali works, where it is used in making carbonate of soda by the Solvay process. Lastly, it has been suggested that the solution of the "caliche," or raw nitrate of soda, should be sent down in pipes to the coast for evaporation, instead of performing this process in the arid desert in the neighbourhood of the diggings.

The flow of mineral in suspension in water along troughs (launders), or channels made in the ground, or pipes, is a process which may be seen on the dressing-floors at metalliferous and other mines, as well as at china clay works. At the Mechernich lead mines the waste from the preliminary dressing-floors is forced by plunger-pumps through a large pipe to pyramidal boxes, in which the water is separated from the sand, so that it may be used over again.

Though not a true flow, I may here mention the conveyance of a mineral for short distances by revolving screws in troughs (" screw conveyors"), which serve to transport a mineral from one part of a factory or dressing-floors to another.

3. Human Labour.-In mountainous districts where the inhabitants are accustomed to carry their provisions, their hay or other agricultural produce upon their backs, it is not unnatural to find ore transported in the same way from the mine to the dressing-works. Not many years ago, gold ore was regularly carried to the little amalgamating mills in the Italian Alps on women's backs. The ordinary load for a woman down hill was roo lbs. (45 kil.). If the woman took tools or materials up hill, the load was naturally less, and amounted to about 75 lbs. (34 kil.). 'The ore was carried in a basket or creel (scivera), an appliance to which every peasant-girl had been accustomed from early youth.

Ore may be moved from one part of the dressing-floors to another by hand-barrows. These are merely rectangular trays or boxes, with a pair of handles in front and a pair behind. The handbarrow requires two persons to carry it (Fig. 6II).

Carriage on the head is met with in some countries.

4. Conveyance by Sledges.-Sledges drawn by men or horses still survive in some hilly districts. Even in Wales at the present day, manganese ore is sometimes brought down from the mine to the nearest cart-road in this primitive fashion. But it is a toilsome and unsatisfactory method of transport, and justifiable only in the case of trials, which have not yet proved a sufficient amount of ore to warrant the construction of a tramway or a ropeway.

5. It is by wheeled conveyances that minerals are most commonly transferred from one part of a mine to another, or from the mine to a railway or port of shipment. Wheelbarrows are applicable for distances measured by yards, such as one may have on dressing-floors, and carts are sometimes the only available means of transport for one or two hundred miles; but the traffic 
should be conducted in some cheaper fashion, by railways for instance, as soon as possible.

It is not necessary to go over all the old ground with regard to rails, sleepers, points and crossings; suffice it to say that though the surface railway resembles the underground one, it is generally better kept; first, because its defects are more palpable to every one by daylight than when seen by the glimmer of a candle, and secondly, because there are fewer difficulties in laying it properly and keeping it in order.

At the surface as well as underground we have self-acting inclines, and traction by locomotives and ropes.

Self-acting inclines stand the miner in good stead in hilly countries. There are either two entirely separate roads, one for the full waggon going down and the other for the empty which is being brought up, or there are three rails with a pass-by in the middle, or even a single road, except at the pass-by. The incline is worked by a drum at the top, placed most commonly on a horizontal axis, and of course provided with a brake.

As examples of large inclines, I may refer to those erected by the "Société Franco-belge des Mines de Somorrostro," * for bringing down iron ore to their railway, which then conveys it to the port of Bilbao. The lower of the two planes is 737 yards $\left(674 \mathrm{~m}\right.$.) long, with an average inclination of $30^{\circ}$, the maximum inclination being $36^{\circ}$ near the top. It is worked by steel wire ropes $1 \frac{1}{2}$ inch $(38 \mathrm{~mm}$.) in diameter, which are coiled around two conical drums, united by their bases and having a mean diameter of $16 \frac{1}{3}$ feet $(5 \mathrm{~m}$.). In order to regulate the descent of the trains, the drums are connected by gearing with an air-brake, identical in principle with the fly of a clock (Fig. 422). It is composed of four straight vanes made of wood and iron, about $6 \frac{1}{2}$ feet $(2 \mathrm{~m}$.) wide, and $16 \frac{1}{3}$ feet $(5 \mathrm{~m}$.) in diameter outside. Twelve waggons coming from the mine are coupled together so as to form a train, and when it starts down the incline, the air-brake begins to revolve and soon develops a considerable amount of resistance as the speed increases; the consequence is that the train descends with an almost uniform velocity. The strap-brake on the drum simply serves to moderate the speed if necessary and to stop the train; but in no case is much power required to work it. The train makes a journey in three minutes, and it takes three minutes to make up and couple on a train; therefore there is one train every six minutes, and as each waggon contains two tons, the quantity delivered by each train is 24 tons, or with ten trains an hour the quantity per day of ten hours will be 2400 tons. By increasing the number of waggons in each train, the day's work

* Exposition Universelle de 1889. Note sur l'Exposition de la Societé Franco-belge des Mines de Somorrostro en 1889 . Paris, 1889, p. I1. Les Grandes usines de Turgan. August, 1889, p. 50. Forges et Ateliers de Construction de Mme. Vve. Taza-Villain. 
IIAULAGE OR TRANSPORT.

FIG. 422.

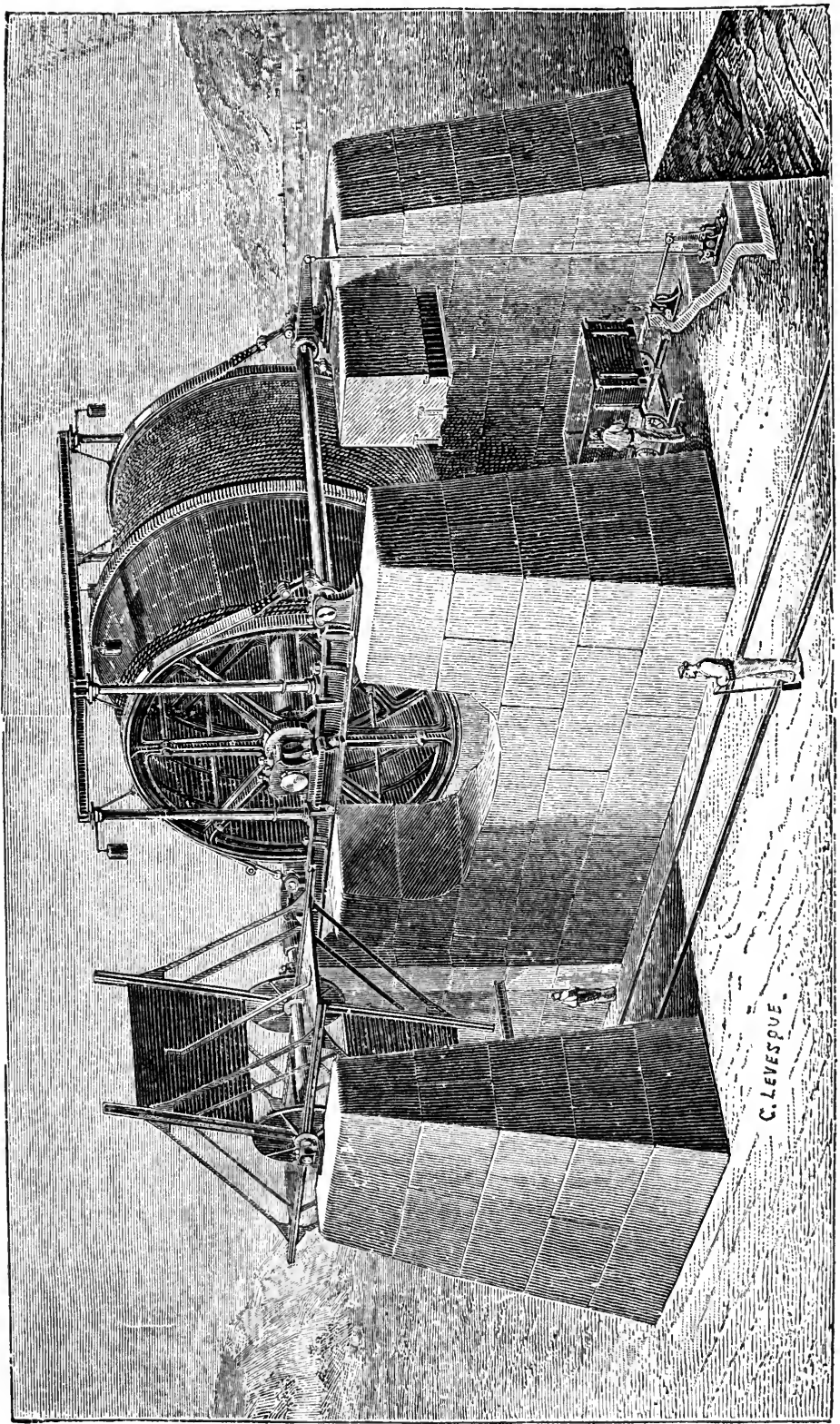


may be run up to 2600 tons. The fan-regulator has the advan. tage of saving the wear of the ordinary strap-brakes and of rendering the speed uniform. If nothing but a strap-brake was used, there would be a very great amount of friction, which might cause the wooden shoes to take fire; in any case it would throw a great strain upon the machinery, and involve the risk of a serious accident if it happened to break. The fanregulators avoid all these difficulties; but they must be made very strong, as they have to counteract a considerable amount of vis viva - at the particular incline mentioned no less than 428 horse-power. I have dwelt somewhat upon this fan-regulator, as it has been found extremely serviceable at Somorrostro, though little known elsewhere.

Locomotives burning coal can be used without inconvenience, and effect a great saving in most places, when compared with horse traffic. At the Festiniog slate mines, small locomotives running on a track with a $23 \frac{1}{2}$-inch gauge are employed for drawing trains of rubbish to the tips; the total weight of a train may be as much as 80 tons. As the men who are removing rubbish from the underground or surface workings are paid by the ton, the loads have to be weighed. When the trains are drawn by a horse, it is necessary to stop each time a waggon is brought on to the weigh-bridge; but when the locomotive is used, the train runs so smoothly that the waggons can be weighed during their passage, without any halts being made. This is a small advantage it is true, but it saves time and consequently money, and should therefore be noticed.

The endless rope and the endless chain conveying single waggons at stated intervals are both in favour, either for transporting the valuable mineral to any required spot, or for taking the waste to the tip or "dump."

An example of the former system may be seen at the De Beers* diamond mine, South Africa, where the gem-bearing rock lias to be exposed to the action of the atmosphere for some months in order to make it crumble away and become ready for the process of washing. Large areas have to be covered with the "blue," and cheap haulage is a matter of importance. The depositing floors commence at a point a mile from the mine and extend for three miles to the east and one mile to the west. The main line is three miles in length and it has two branches, one a mile long, and the other three-quarters of a mile long. The rope is driven by a horizontal engine, with two cylinders, each 14 inches in diameter, and having a stroke of 3 feet. It is $\frac{7}{8}$ inch in diameter and, as is very commonly the case elsewhere, it has an iron instead of a hempen core, in order to prevent a reduction of

* De Beers Consolidated Mines, Limited. Second Annual Report fur the Ycar ending 3 Ist March, I890, p. I7. 
section when it is subjected to continued tension. It is carried on the steel trucks, which can be tipped on either side, as the body is supported on two trunnions (H, Fig. 442). The device for attaching the rope to the waggon is very simple; the rope lies in a fork or "jockey," which is slightly out of the direct line of traction. The jockey is free to turn in a socket on the truck, and the slight bend given to the rope is sufficient to afford the necessary grip, even in going up an incline of $I$ in 20 . If the "blue" has to be deposited at a point nearer the mine than the terminus, the part of the rope beyond the place where the waggons are taken off is supported by pulleys.

Horses are employed to draw the trucks from the main rope haulage lines to the places on the floors where they have to be tipped.

The endless chain has been chosen for bringing down the ore from some of the mines of the Somorrostro Company,* in a part where self-acting inclines cannot be used because there is not a descent all the way. A second reason for adopting this system was the fact that it admits of considerable changes in the amount of traffic, by altering the speed of the chain and the distance between two successive trucks. It further allows branch lines to be taken off from the main one. At Somorrostro there are in all very nearly two miles $(3000 \mathrm{~m}$.) of endless chain haulage.

The greatest difference of level between the highest point at the Sol mine and the terminus at the station of Cadégal is 802 feet $\left(244^{\circ} 60 \mathrm{~m}.\right)$, and on one part of the line the gradient is as high as $29^{\circ} 5$ per 100 or $\mathrm{I}$ in 3.4 . The fall is so great that the chain requires no power but gravity to work it; in fact, it is necessary to use brakes to oppose the vis viva. Strap-brakes are employed in the same manner as they are on the inclines just described, solely for the purpose of stopping the chain. The danger of depending entirely upon such brakes for working inclines has already been pointed out, and a uniform speed is maintained by affixing fan-regulators working in water. They are chosen in this case in preference to the fans working in air, because the latter must revolve at a great velocity in order to be efficient, and therefore could not be applied to the slow chain haulage without gearing, which would introduce complications. These hydraulic governors are like the air-regulators in principle, except that the blades are immersed in water; the speed of the chain can be adjusted with the greatest nicety by altering the quantity of water in the tank in which the blades work, and so introducing the amount of resistance required.

The usual speed at which the chain is run is 5 feet $\left(\mathrm{I}^{\cdot} 5 \mathrm{~m}\right.$.) per second, but it can be raised to 6 feet 6 inches. The chain is made of $\frac{7}{8}$.inch $\left(22 \mathrm{~mm}\right.$.) iron, which corresponds to about $19 \frac{1}{2} \mathrm{lbs}$. per 
yard ( 9.826 kil. per metre). The last section, however, has harder work, and the chain is of $\mathrm{I}$-inch iron $(26 \mathrm{~mm}$.) and weighs 28 lbs. per yard (1 4 kil. per metre). Each waggon holds $17 \frac{3}{4} \mathrm{cwt}$. (900 kil.) of ore, and when the waggons are arranged 27 yards $\left(25^{\circ} 2 \mathrm{~m}\right.$.) apart, the chain haulage is capable of transporting $25^{\circ}$ to 2600 tons of ore a day, in addition to a certain amount of rubbish which is tipped before arriving at the port.

6. Conveyance of Mineral by Boats from one part of a mine to another is exceptional; but transport by canal or sea to the consumer is common, and is chosen whenever available on account of its comparative cheapness. It is of the utmost importance when dealing with large quantities of mineral to have cheap and rapid methods of shipping it. At Huelva, the shipping port of the Rio Tinto mines, the trains of ore are drawn on to a part of the pier which has just enough inclination to make a truck run down of itself. A workman then uncouples a truck and allows it to run opposite a shoot, which leads to the hold of the vessel lying alongside the pier. The truck is emptied by opening the bottom and letting the contents drop into the mouth of the shoot. The bottom is then closed and the truck is allowed to run on a little further, when it is shunted back on to a side line, and made to join the train of empties ready to be drawn back to the mine. After the locomotive has once hauled a train on to the proper part of the pier, the discharge of its contents into the ship proceeds very rapidly and requires the attendance of only one man.

The arrangements are so perfect that 500 tons can easily be loaded in an hour, but naturally a good deal of time is lost in shifting the steamers and berthing them. The greatest amount of work in loading at Huelva pier has been a little over 3000 tons in a single day. A steamer has been known to come into Huelva harbour by one tide, and leave by the next with a cargo of 1500 tons of ore.

The Somorrostro Company loads its iron ore at Bilbao in a similar manner. The Company has three wharves, at each of which 2000 tons can be shipped in a day; indeed a ship of 1490 tons has been loaded in six hours.

7. Aërial Ropeways.-These ropeways may be divided into five classes :
a. Single supporting rope, with or without a hauling rope.
b. Endless rope, which is the supporting rope and hauling rope at the same time.
$c$. Two supporting ropes and an endless rope for hauling the load.
$d$. Double endless travelling rope or cnain.
e. 'T'elpherage line.

a. Lines erected on the first of these principles may be seen in hilly countries. An iron or steel wire rope is stretched across a valley, and forms the rail supporting the load, which is put into 
a sack and hung on by a grooved pulley. If the heights of the departure and receiving stations are properly arranged, the load on going down the slope acquires enough momentum to bring it up to the station on the other side, without rushing in too violently. The objection to this system is that the sacks and the pulleys have to be carried back by men or women, but it has the merit of simplicity and cheapness. By the addition of a small hauling rope on a drum, the method is available for steep mountain sides; the load is lowered with use of the brake, and the drum is worked to draw up the empties along the supporting rope.

b. In this system there is an endless rope, supported by pulleys on strong wooden or iron posts placed at suitable intervals, which is set in motion by any available source of power. Suspended from the rope are the buckets or other vessels in which the mineral is carried. The buckets may be detachable at pleasure or they may be fixed. The former plan is the one brought out by Hodgson in 1869 . The bucket or other receptacle is suspended by an iron hanger from a grooved block of wood which rests upon the rope. The carrying block has a spindle with a small grooved pulley, which can be made to run upon a rail at each terminus and so let the rope move on without the load. The bucket is filled from a shoot or hopper while hanging on the rail at the loading terminus. A workman then pushes it along the rail until the carrying block is taken up by the rope, which is always in motion; the load now travels along suspended from the rope, the carriers being constructed so as to pass over the pulleys. On reaching the unloading terminus, the carrying block is again shunted on to a rail, and the bucket is tipped by lifting up the catch which had kept it from turning about pivots; after having been put into position, it is brought round to the point where the rope, after passing round a terminal pulley, is about to begin its journey back to the loading station. Here it is shunted on to the rope and travels along with it.

One great disadvantage of this system, in the case of steep inclines, is that the carriers may slip upon the rope, and that the loads either fall off or do damage in some other way. To overcome this difficulty, some of the constructors of aërial ropeways attach the loads to a clip which is tightly fixed to the rope. The clip must be of such a nature that it will pass the supporting sheaves or pulleys. When the inclination is sufficient, an aërial line of this description will work automatically, the weight of the full loads being enough to draw up the empties.

c. The third system has two fixed ropes, which serve as aërial rails and act solely as supports, and an endless travelling rope, to which the loads are made fast at pleasure. It resembles, therefore, the endless rope haulage, of which mention has been made for underground work, save that the rails are above the load instead of being below it. 
Ropeways working upon this plan have been perfected of late: years by Otto and by Bleichert in Germany, where they are commoner than in this country. They are constructed for distances of from 2 to 8 or even ro miles, with a carrying capacity of 600 to 800 tons per day of io hours. The separate loads may vary from $\frac{1}{2}$ cwt. to I ton each.

The points to be considered are :

Carrying rope and vessel.

Posts or standards.

Hauling rope and attachments.

Terminals and their shunting arrangements.

The kind of cable used on the most recent lines erected on the Otto system * is that known as "locked coil wire rope," the construction of which is explained in the next chapter (Fig. 45 I). It has the advantage of presenting a perfectly smooth surface, admirably adapted for the running of the grooved pulleys by which the load is suspended. The vessel in which the mineral is conveyed

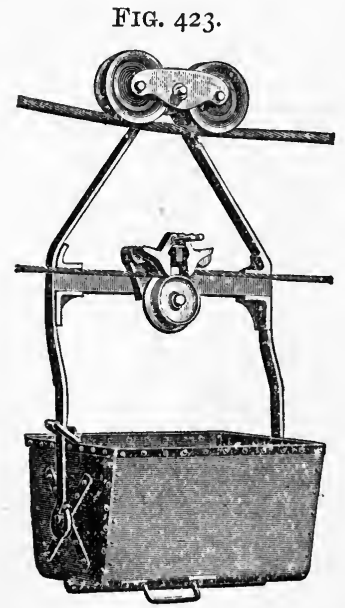
may be any convenient form of bucket or box, supported by pivots around which it can be easily tipped, or the actual mine-waggons may be slung up and the ore carried in them:

Each box, bucket, or waggon, is attached to a hanger suspended from a spindle placed midway between two grooved pulleys or wheels, which rest on the rope (Fig. 423).

The posts or standards are constructed of wood or iron, sometimes with two, and sometimes with four legs, suitably stiffened by braces and held in position by guy ropes or rods (Figs. 424 and 425 ). The four-legged standards are used for heavy loads or long spans. The distance between the standards varies according to the nature of the country, and is often about 30 to 60 yards; but where the country is much broken by ravines, these short spans are unattainable without standards of an impracticable height, and the cable is then made to stretch across very long intervals without intermediate supports. Spans of $55^{\circ}$ yards $(500 \mathrm{~m}$.) are not unknown.

The hauling rope must be very flexible, and is made of fine steel wire with a hempen core. The mode of attachment of the load varies with the gradient of the line. If the gradient is less than

* J. Pohlig, "Aërial Ropeways, Otto System."-Trans. Amer. Inst. M.E., vol. xix. I891, p. 760 . 
I in 6 , the amount of friction necessary for gripping the rope tightly can be obtained by bringing it between two flat iron discs and clamping them together with a screw. One of these discs is rigidly attached to the hanger, and the tightening screw of the other can be loosened automatically by providing it with a projecting lever, which comes in contact with a stop at the terminus.

If the gradient is between $I$ in 6 and $I$ in 3 , the discs are made

FIG. 424.

FIG. 425 .
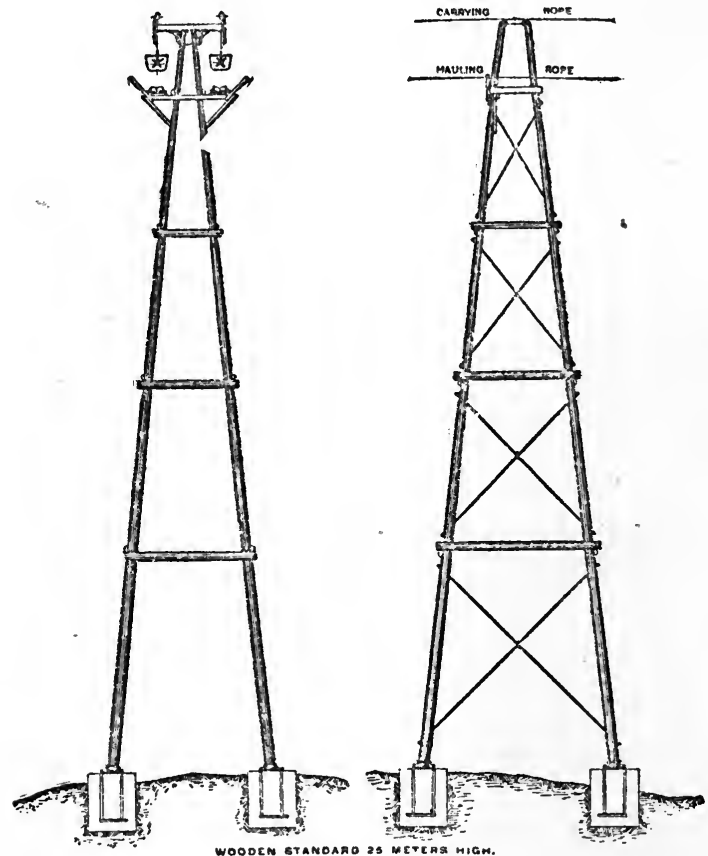

with corrugated instead of smooth surfaces. When the gradient exceeds $\mathrm{I}$ in 3 , another device has to be employed; projecting knobs are inserted into the rope at regular intervals, and on meeting with properly arranged stops upon the loads they cause them to travel along. Figs. 426,427 and 428 show the details of the arrangement.

Each terminus is provided with an iron rail which is fixed so as to meet the rope where the buckets have to be loaded or unloaded; by suitably arranging the end of the rail, the load passes quite smoothly from it to the rope and vice versa. 
An example of one of the Otto ropeways is given in Fig. 429, which is a section of the line put up for the Sheba Gold Mining FIG. 426.

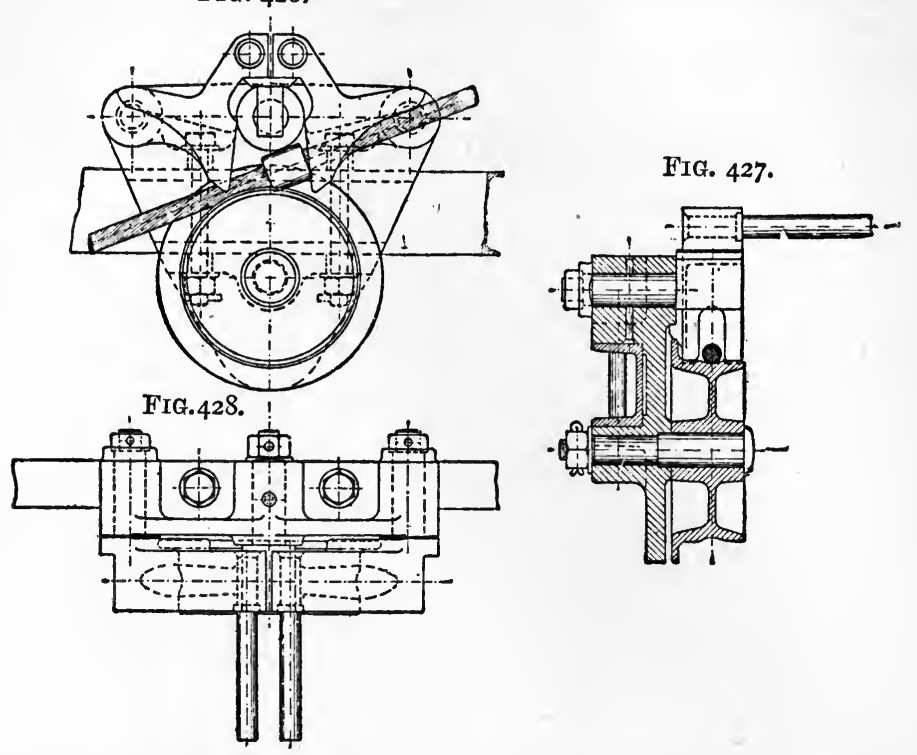

Company, Limited, Barberton ; it is $2 \frac{3}{4}\left(4^{\circ} 4\right.$ kil.) miles long, and will carry 150 tons per day of 10 hours. The maximum incline is $I$ in $1 \cdot 6$, and the greatest span 1480 feet $(45 \mathrm{Im}$.).

FIG. 429.
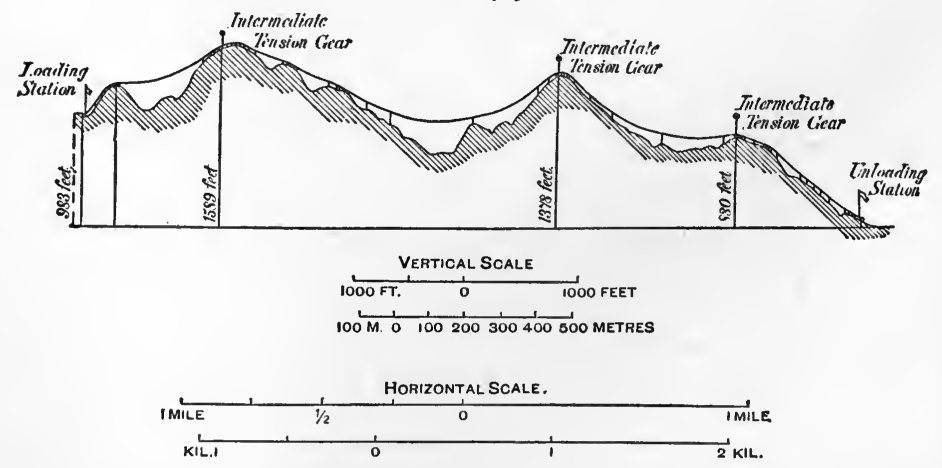

A line erected in Southern Spain for carrying iron ore is 9.69 miles ( $15^{\circ} 6 \mathrm{kil}$.), long, divided into four independent sections. The greatest span is 918 feet $(280 \mathrm{~m}$.), but on an average the sup- 
porting posts are only 44 yards $(40 \mathrm{~m}$.) apart. The hauling rope is made to travel at the rate of 100 yards $(90 \mathrm{~m}$.) a minute, and deliver two buckets, each containing $7 \mathrm{cwt}$. (350 kil.) in that time. This means a carrying capacity of I 200 buckets or 420 tons per day of to hours. The line has also been worked with

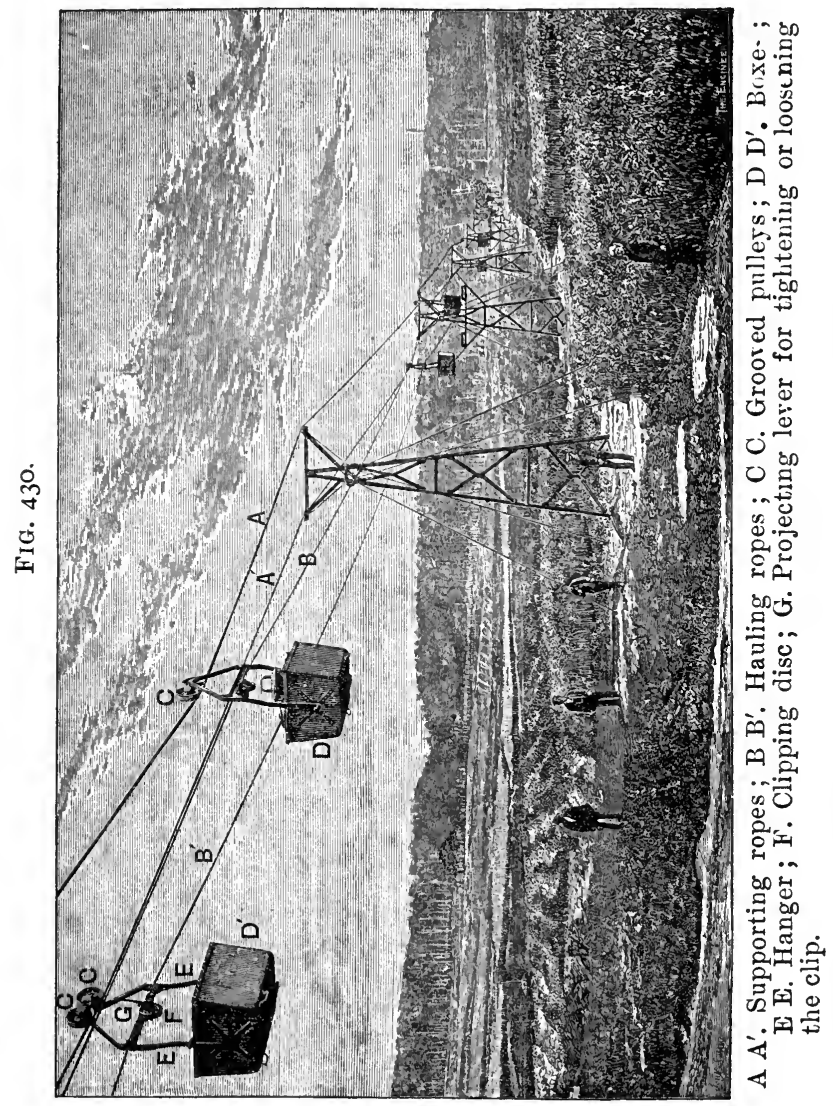

two shifts of 8 hours each, and has transported 900 tons in that time. The total cost of this line, which was surveyed, erected in a very difficult country, and ready to start in ten months,

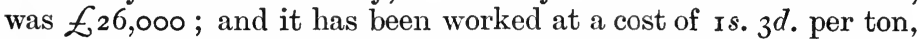
which includes all that is spent for labour, maintenance and repairs.

At the Menzel colliery in Upper Silesia, 500 to 700 tons of coal are carried in ten hours a distance of $\mathrm{x} \cdot 6$ miles, for $\mathrm{I} \frac{1}{4} d$. per 
ton per mile, including wages, repairs, interest on capital and depreciation of plant. Fig. 430 shows part of the line at Gottessegen colliery, Upper Silesia.*

A line carrying iron ore in Luxembourg is 3 miles long, and transports 300 tons of iron ore in to hours at a cost, again including all expenses - viz., wages, repairs, interest on capital, and depreciation of plant, of $4 \frac{1}{2} d$. per ton, or $x_{2} \frac{d}{2}$. per ton per mile. $d$ and $e$. Ropeways worked by these systems are rare.

* "Otto Patent Ropeway." -The Engineer, vol. lxvii. 1889, p. II5. 


\section{$(387)$}

\section{CHAPTER VIII.}

\section{HOISTING OR WINDING.}

Motors, drums, and pulley-frames.-Ropes, chains, and attachments.Kibbles, skips, and cages.-Keps, guides, signals.--Safety appliances, detaching-hooks, safety-catches, automatic stopping gear-Pneumatic hoisting.

By hoisting is meant raising the minerals from the underground workings to the surface. In speaking of the subject generally, it is more correct to say hoisting than winding, because this latter term implies the use of the rope, which is not quite universal. As already explained in the last chapter, there is no clear line of demarcation between haulage and winding. In the typical case of a vertical shaft and a nearly horizontal level, it is easy to make the distinction; but when the mineral is drawn up through inclines, the name given to the process depends upon local custom. Thus, part of the shaft at a Cornish tin mine is inclined at an angle of only $15 \frac{1}{2}^{\circ}$ from the horizontal, and nevertheless the work of drawing up the ore is always called winding.

In a few districts carriage on the back still survives; in Sicily, for instance, much of the sulphur rock is brought to the surface by boys on their backs up rough paths, or steps cut in the ground. As lately as ten years ago, I found slate being brought up on the back in the Moselle district. In Mexico and in China, too, the same method is pursued in some silver and other mines. However, this barbarous mode of raising mineral is simply mentioned for the purpose of condemning it.

The regular method of bringing a mineral to the surface is to draw it up a shaft or an incline by means of a rope. The subject is such a wide one that it must be treated under different headings as follows: (I) Motors, drums and pulley-frames; (2) Rope, or chain; attachments of the rope; (3) Receptacle for the mineral or waste rock ; (4) Other indispensable appliances, guides, signals, keps ; (5) Safety appliances.

I. MOTORS, DRUMS, AND PULLEY-FRAMES.Motors-As in other departments of mining, the motor employed may be worked by animal power, or by an engine driven by water, steam, compressed air, petroleum or electricity. 
(a) Animal Power.-The simplest contrivance for winding is a pulley supported by some suitable frame above the shaft; a bucket is attached to the end of a rope hanging down the shaft, whilst the other end, passing over the pulley, is drawn by men or women: they simply walk away from the shaft and haul up the bucket. Oil wells are sunk in Burmah by this primitive method of hoisting.

The usual method of applying human power is by a windlass. This well-known appliance consists of a wooden cylinder, about eight inches in diameter, provided with two iron handles and supported by two upright posts which are suitably stayed. A sliding bar, which can be drawn out either above or below the cylinder, serves to hold one of the handles, when required.

In this country, the ordinary windlass is used for shallow sinkings of twenty, thirty, or forty yards in depth, such as are made in commencing work at a mine, or in effecting a communication between two levels; but in countries where mining is less advanced, and where labour is cheaper, the windlass may form the sole means for hoisting from depths of a hundred and even two hundred yards. Thus, for instance, at Boryslaw, in Galicia, it is reckoned that six or seven thousand shafts have been sunk during the last thirty years, for the purpose of working ozokerite, to an average depth of one hundred yards, by human labour ; four, five, and even six men and women may be seen working the Boryslaw windlass. In the neighbouring country of Roumania, oil wells are sunk in like manner. The windlass is used either with one or two buckets; in the latter case the labour is lightened, for the weight of the empty bucket going down balances the dead weight of the bucket coming up with a load of rock.

As a rule too little attention is paid to the state of the axles and bearings. Windlasses, like other machines, cannot be worked with economy unless means are taken to prevent unnecessary friction, which is sure to arise unless the axles and bearings are kept perfectly true; this fact should be specially borne in mind when the mine-owner is employing expensive human power.

The capstan is an unusual form of winding machine at mines; it differs from the windlass by having its cylinder vertical. As an instance of its use, I may mention the little underground quarries at Swanage in Dorsetshire, where blocks of stone are drawn up inclines by means of capstans turned with bars, after the manner of those used on board ship.

When a horse is employed in the place of men, the bucket, attached to a rope passing over a pulley, is sometimes drawn up by making the animal walk away from the shaft. The framework and pulley constitute what is called a whipsiderry.

Animal power is usually applied by means of a machine called 
a horse-whim. It may be looked upon as a gigantic capstan, worked by horses, mules, or donkeys. It consists of an upright axle, usually of timber, supported at the bottom by an iron pin or pivot, which works in a hole in a large stone, forming a primitive foot-block. A horizontal beam, known as the driving beam, is attached to the axle, and above it comes a hollow wooden cylinder or drum, around which the rope is coiled, proper projecting horns or flanges being provided to prevent it from slipping off.

The other end of the axle works in an iron socket, carried by a great horizontal beam, known as the span-beam, which is supported by two legs. In this country the horse-whim is not roofed over, and it forms a prominent feature in many mining districts; where the weather is more severe, a house becomes necessary. The winding rope is coiled several times around the drum, and both ends, after passing over pulleys, hang down the shaft; when the horse walks round, one bucket is raised and the other lowered.

Before the introduction of steam, the horse-whim was a very important means of winding; and in countries where waterpower is lacking, coal dear, and fodder cheap, it still performs very useful services. As many as six to eight horses may be harnessed to a horse-whim for the purpose of working it.

(b) Water.-I will now pass on to the engines worked by water, steam, compressed air, petroleum, or electricity.

When the water-wheel is used for hoisting, it is necessary to have means of reversing the motion, in order to raise or lower the rope at pleasure. Two methuds may be employed: A double wheel with the buckets fixed in opposite directions; a single wheel provided with suitable gearing or belts. The double wheel is frequently seen underground in Germany; it has sluices (hatches) which will turn the water on to either side, and there is a brake for controlling the motion. The winding-drum is placed on the shaft of the water-wheel, and according as the water is turned on to the right-hand or to the left-hand side, the wheel revolves one way or the other.

When gearing is employed, a bevel-wheel upon the shaft of the water-wheel drives a pair of bevel-wheels, facing each other, which run loose upon the shaft of the drum. By means of a suitable clutch either of them can be brought into firm connection with the drum-shaft, and so made to drive it in the required direction.

Fig. 43I shows the method adopted at Great West Van Mine in Cardiganshire by Messrs. Urquhardt and Small. A, Girard turbine; B, belt driving the shaft of two pulleys C D ; E and F, pulleys loose upon the shaft; $\mathrm{G}$, clutch; $\mathrm{H}$, handle working clutch; $\mathrm{I}$, pinion driving spur-wheel on drum $J \mathrm{~J} ; \mathrm{K}$, brake strap; $\mathrm{L}$, pin connected, when required, to "bob" of pumps. The belt from $\mathrm{C}$ 
to $\mathrm{E}$ is straight, and that from $\mathrm{D}$ to $\mathrm{F}$ is crossed ; therefore the two pulleys $\mathrm{E}$ and $\mathrm{F}$ are always revolving in opposite directions. According as $\mathbf{E}$ or $\mathbf{F}$ is made fast to the shaft by the clutch $\mathbf{G}$, the pinion I turns the drum one way or the other.

(c) Steam.-Steam-engines em-

FIG. 431 .
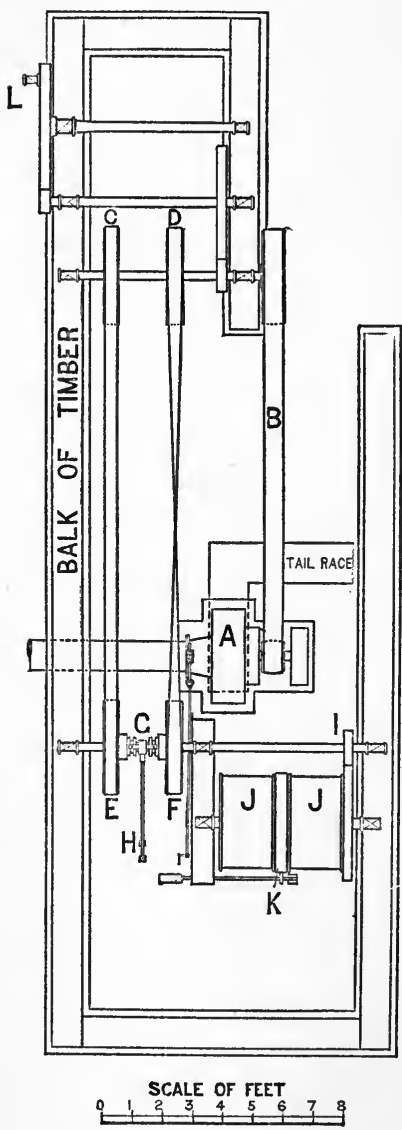
ployed for winding have usually two cylinders, either vertical or horizontal ; the latter are preferred. In some mining districts, notably in Cornwall, one finds a single vertical cylinder working a beam hy which motion is communicated to a fly-wheel; but for rapid work it is necessary to have more command of the engine than can be furnished by a machine of this kind.

It was the fashion at one time to put a pinion upon the crankshaft and a spur-wheel upon the drum shaft; nowadays for quick winding the drum is placed upon the same shaft as the cranks. This is called working on the first motion, whereas if gearing is used the method is said to be on the second motion. In any case the engine must be provided with an adequate brake, and where the drum is worked by gearing, it is necessary to have a brake upon the drum shaft, because otherwise there would be no means of arresting the descent of the load in case of fracture of some of the cogs. Although many winding engines work without expansion, automatic expansion gear is common, and some of the engines are arranged so that the commencement and end of the run shall be worked with the full power of the steam, and the middle of the run expansively. Compound engines, and indeed triple expansion engines, have been erected for winding purposes, though the advisability of employing them is questioned by some mining engineers; while fully admitting the value of this principle in the case of engines which are working constantly, such as those used for pumping, they contend that it is not advisable to complicate 
machinery which is performing very irregular work, and is being continually stopped and started.

Compound engines have, however, beon adopted recently for winding at Llanbradach Colliery, near Cardiff, by Mr. Galloway. The tivo cylinders on each side are arranged tandem fashion (Figs. $43^{2}$ and 433). A, high pressure cylinder; B, low pressure cylinder; $\mathrm{C}$, drum.

(d) Compressed Air.-Compressed air is largely employed when the hoisting engine has to be placed underground, and it is especially suitable for sinking intermediate shafts (winzes). Compact and handy forms of engines are supplied by various makers; many of them are similar to the steam winches used on board ship, and consist of two cylinders driving a pinion which works a spur - wheel placed upon the same shaft as the drum.

Occasionally, as for instance at the Long Tunnel, Walhalla, in Victoria, all the hoisting of a mine is done by a compressed air FIG. 432.

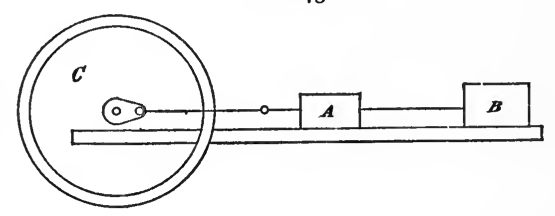

FIG. 433 .

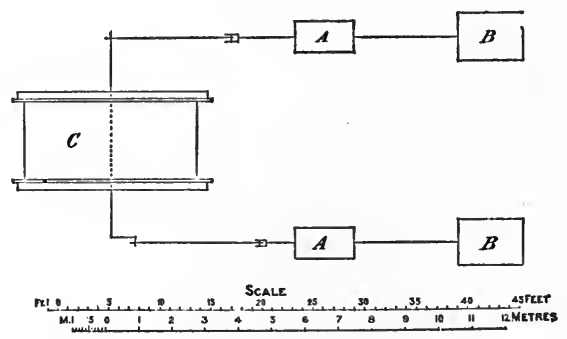

engine. The reason for this choice at the Long Tunnel was the fact that lode was reached by a long adit, in which compressed air appeared to be the most convenient method of transmitting power from a motor at the surface.

(e) Electricity.-Winding by electricity is as yet in its infancy; but, no doubt, in the course of a few years, we shall hear more of this convenient method of conveying power to the place where it is to be used. It is easy to understand that an electrical motor can be applied to the drum used for winding, its rapid motion being reduced to a suitable speed by means of gearing.

Drums. - A winding drum is usually a mere revolving cylinder, around which the rope coils itself. It is formed of two centrepieces keyed to the shaft, each carrying arms, to which are attached rings. Supported by these rings are pieces of plank or plates of iron or steel, which build up a hollow cylinder, the length and diameter of which depend upon the importance of the plant. In large mines one may see drums 20 and even 30 feet in 
diameter; with a drum of 20 feet, 10 revolutions mean coiling or uncoiling 209 yards of rope.

A drum constructed for Llanbradach Colliery is a hollow cylinder I 7 feet in diameter, and 8 feet wide. In Figs. 434 and 435, $\mathrm{A}$ is a cast-iron centre-piece ; B B are arms made of $\mathbf{H}$-steel, to which are riveted the crossbars of channel-iron $\mathrm{C}$. The skeleton formed in this way is covered with plates of steel $\mathrm{D}, \frac{3}{4}$ inch thick, which are fixed with countersunk rivets to $\mathbf{T}$-iron $\mathbf{E}$, where they meet. $F$ is the flange to prevent the rope from slipping off the drum, and $G$ the wrought-iron ring upon which the brake acts. A novelty introduced by $\mathrm{Mr}$. Galloway is the arrangement for keeping a reserve length of rope to supply the loss

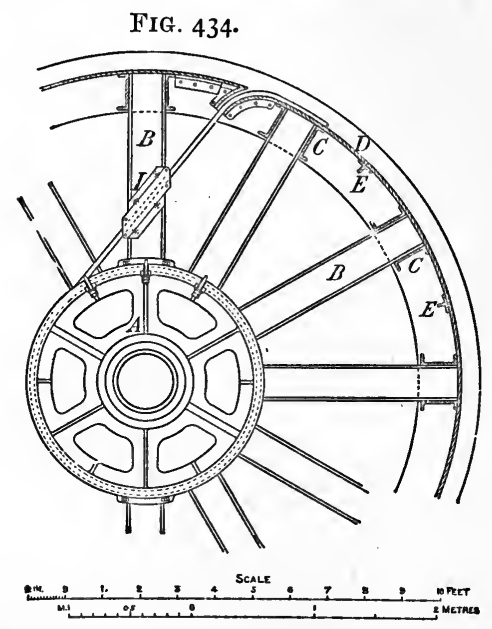

FIG. 435.

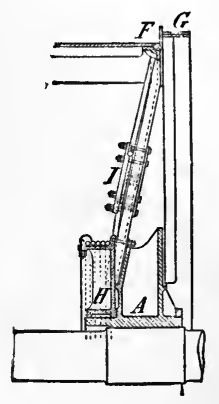

caused by successive re-cappings. Inside the main drum is the hollow cast-iron cylinder $\mathbf{H}$, capable of turning independently. When a new rope is put on, 50 yards of it are coiled upon $\mathrm{H}$, the bolts of the clip $\mathrm{I}$ are fastened, and the remainder is wound round the main drum. After re-capping the rope at the end of two months, it is easy to unloose the clip and draw out what is required. The drum is constructed as light as possible, in order to prevent power from being wasted in starting and stopping an unnecessarily heavy mass. The shaft is 20 feet in diameter and 550 yards deep to the first seam of coal intended to be worked; but it will be probably made 600 to 630 yards deep in time. The engine (Fig. 432) is expected to raise 200 tons of coal per hour with two mine waggons in each cage, each waggon carrying 2 tons.

An objection urged against the plain cylindrical drum is that it in no way compensates for the change of work required of the 
engine during the different phases of the act of winding. To make this plain, suppose one end of the rope to be at the bottom of the shaft with the full load attached to it, whilst the other end is at the top with nothing but an empty cage. On starting, the engine has to raise not only the weight of the load of mineral, but also the entire weight of the rope hanging down the shaft, and in deep mines with large cages, this weight is by no means inconsiderable. In proportion as the full cage is raised, the amount of dead weight of rope to be lifted becomes less and less. Eventually the full and empty cages meet; the two portions of the rope then balance each other, and the engine has simply to overcome the action of gravity upon the mineral; later on the rope of the empty cage is longer than that of the full one, and assists the engine in doing its work. At last when the load is nearing the top, the drum is feeling the full weight of the rope of the empty cage.

Constancy of load is easily obtainable with the cylindrical drum by the simple expedient of adding a balance rope-that is to say, a rope hanging down the shaft with one end attached to the bottom of each cage. Provided that this rope agrees in weight with the winding rope, the counterpoising is perfect, for on each side, in every phase of the ascent or descent, there is always the same dead weight acting upon the drum. This method is adopted at Llanbradach and also at De Beers Mine. The balance rope often, but not invariably, passes round a pulley at the bottom of the shaft.

With the same object in view the drum is made spiral or conical, or rather of a combination of two such drums united by their larger bases. The rope is so arranged that the diameter of the coil increases as the act of winding up proceeds. The load at the bottom of the pit acts upon the drum shaft with a small amount of leverage, and its leverage increases as the weight due to the rope diminishes. The reverse condition of affairs exists with the descending load: it has a large leverage while there is only a short length of rope hanging down the shaft, but as the weight thrown upon the drum increases, so the leverage diminishes.

Intermediate between the conical and the cylindrical drum is one which combines the two systems; the conical end is used for starting the load from the bottom and the main part of the operation is performed with the cylindrical surface.

When a flat rope is used instead of a round one, it is convenient, for the sake of distinction, to speak of the winding cylinder as a reel or bobbin (Figs. $43^{6}$ and 437).* It is provided on both sides with long radial arms, which serve the same purpose as the horns or flanges in the case of the drum; that is to say, they prevent the rope from slipping off sideways.

* Callon, Lectures on Mining, vol. ii. plate lxi. 
The flat rope coils upon itself, and as the winding proceeds the diameter of the coil increases, if the cage is being raised, or decreases if the cage is being let down. In this way there is a certain compensating action similar to that which is obtained with a spiral drum -in other words, at the moment of starting, when the load is at the bottom, the smallest amount of leverage is exerted upon the driving shaft of the reel; whereas at the end of the wind, when the load is least, it is exerting the greatest leverage.

FIG. 436.

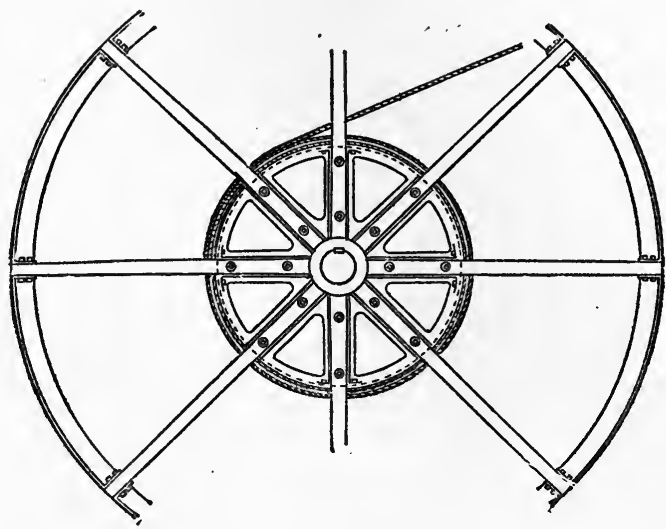

FIG. 437 .
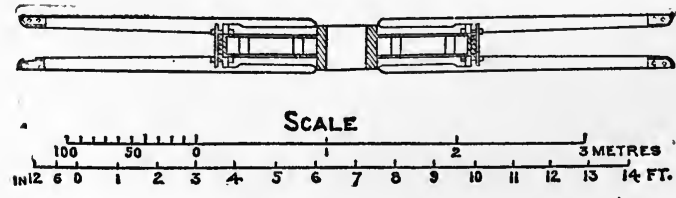

Pulley-Frames.-The framework at the top of the shaft for supporting the pulley or pulleys is known by different names. It is sometimes called the head-gear, the pit-head frame, or poppet heads (Cornwall). It may be constructed of timber, iron or steel, and metal pulley-frames are usually seen nowadays at large mines, where winding is conducted upon an extensive scale; at small mines and also during sinking operations a timber head-gear is common.

A kind of frame often used is shown by Figs. 438, 439, 440, from which it will be seen that four large upright posts support cross-beams A, B, C, D, upon which the pulleys rest. The frame is suitably stiffened by struts. Its principal duty is to resist two forces, 
one exerted by the load and rope hanging down the shaft, and the other by the rope which is being hauled in by the drum. At a

FIG. 439 .

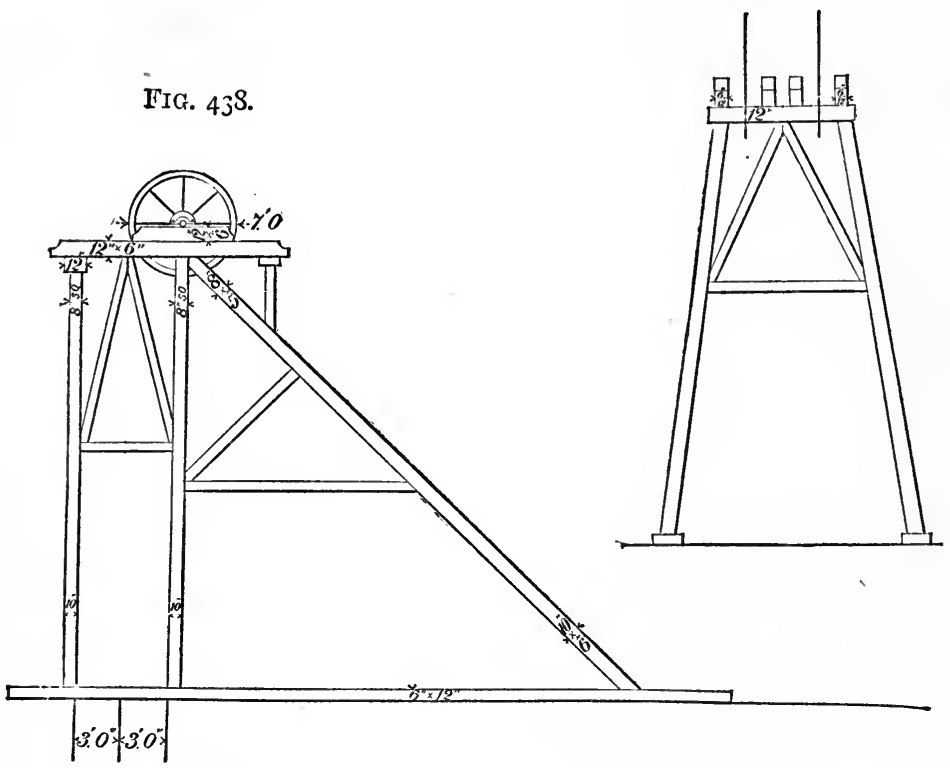

moment just before the load begins to move the two forces will be equal, and the direction of their resultant will be a line bisecting the angle between the two parts of the rope, and passing through

FIG. 440.
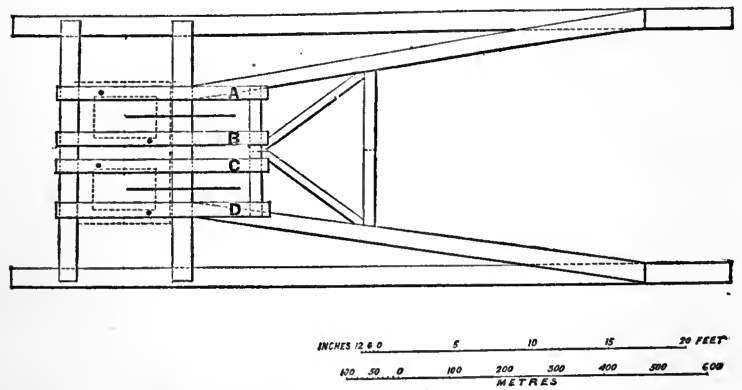

the centre of the pulley. Provision therefore should be made for resisting this pull, and this is effected by stays, such as are shown in Figs. 438 and 440, which represent a pulley-frame used for 
sinking a shaft some 200 yards deep at Halkyn Mine in Flintshire. The backstay may be placed in any position between FIG. 44I.

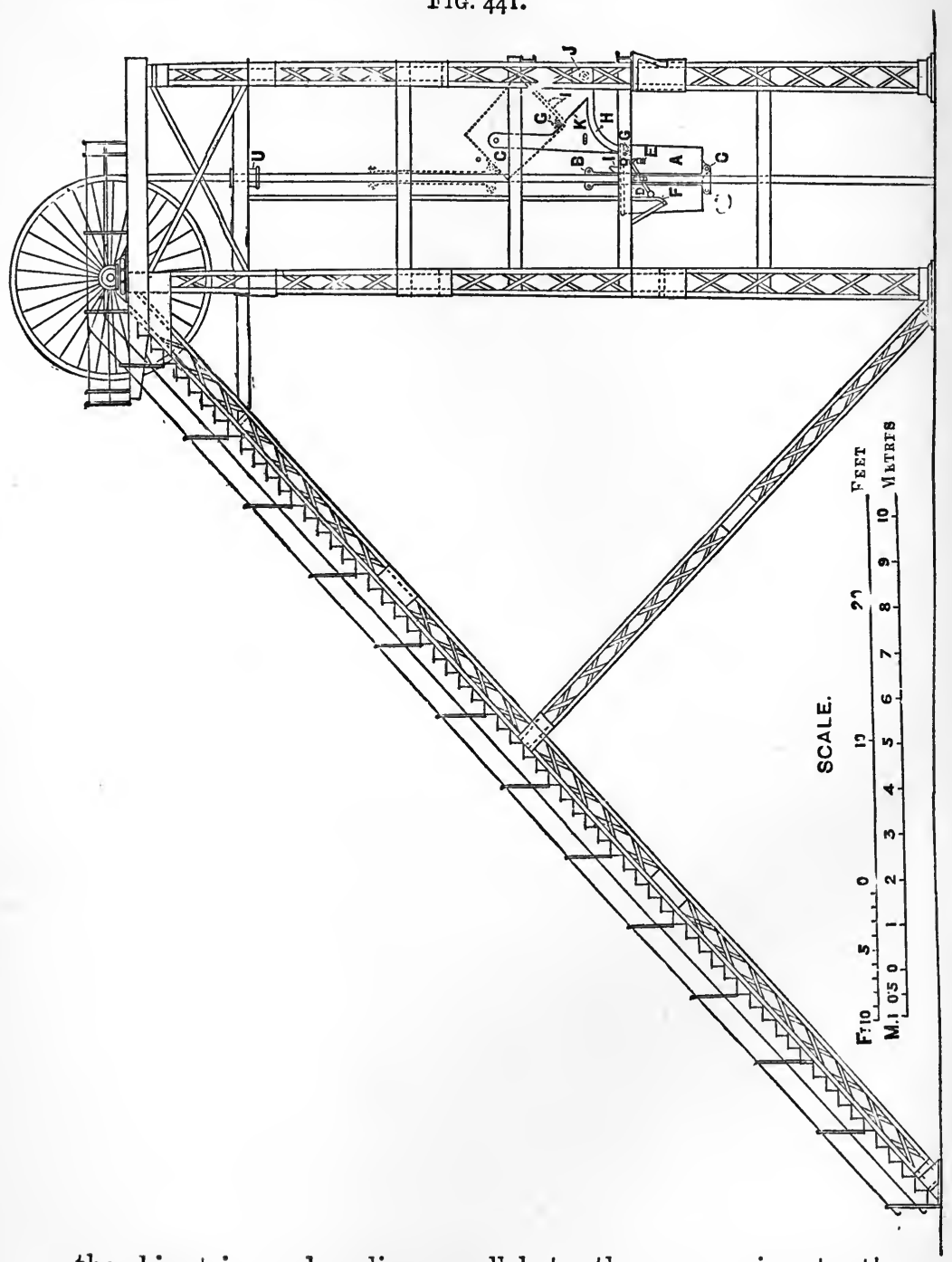

the bisectrix and a line parallel to the rope going to the drum.

During the sinking at Halkyn only one bucket was used, and 
as this had to hang in the middle of the shaft the pulley was placed between the two beams B and C. Now, the shaft is used for winding with two small cages and there are two pulleys, one between $\mathrm{A}$ and $\mathrm{B}$, the other between $\mathrm{C}$ and $\mathrm{D}$.

Fig. 44I shows the head-gear erected at the perpendicular " Rock shaft" of De Beers Mine, * whilst Fig. 442 represents the arrangements at the Incline shaft of the same mine.

The head-gear at both shafts is made of wrought-iron trellis work. At the Rock shaft the legs and stays are of $3 \frac{1}{2}$-inch angleiron, $\frac{5}{8}$ inch thick. The lattice bars are $3 \frac{1}{2}$ by $\frac{5}{8}$ inch; the total height from the ground to the centre of the pulleys is 6I feet.

FIG. 442.

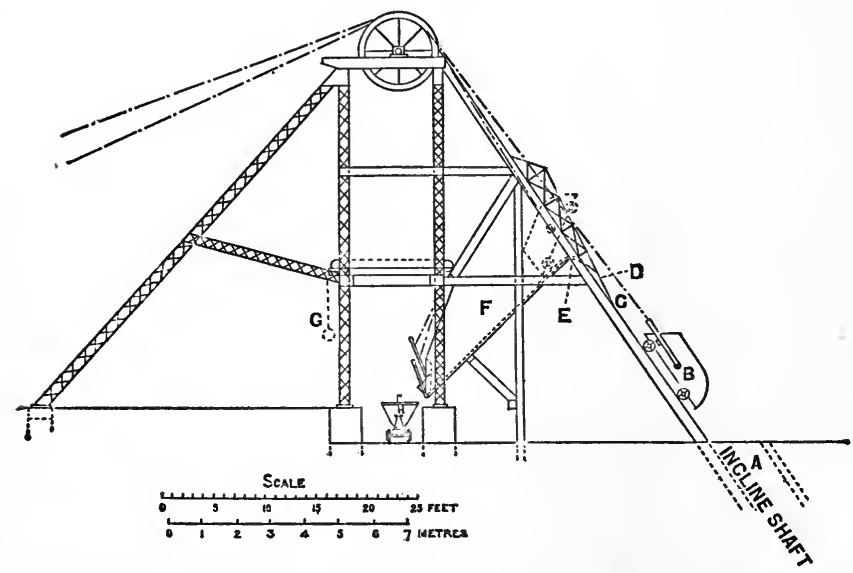

Pulleys.-Winding pulleys have to be placed on the pit-head frame in order to change the direction of the rope.

Nowadays, in all important windings, the pulleys are made from Io to 15 , and even 20 feet in diameter, in order to subject the rope as little as possible to sharp bendings, which would reduce its life.

The cast-iron boss, or centre, is joined by wrought-iron arms to a grooved rim also made of cast iron (Fig. 443). In course of time steel ropes wear away the rim, and to lessen this source of trouble, the part in which the rope lies may be chilled. The groove should fit the rope; for if it is too wide, the rope will rest upon a small part of its circumference and be liable to be squeezed.

At some mines pulleys are made with a light rim, which will not last for more than a year. The object in view is the prevention of wear from rubbing. When the speed of the engine is

* Second Annual Report of De Beers Consolidated Mincs, Limited, for the Year ending MIarch $3 T, 1890$, p. 16 and plates 10 and 7 . 
slackening, the pulley, in virtue of its momentum, tends to travel faster than the rope, and thereby to grind its surface. A diminution in the weight of the rim lessens the momentum, and therefore reduces the rubbing action. The advantage gained in this way, is considered sufficient to compensate for the more frequent changing of the pulleys.

2. ROPES, CHAINS, AND ATTACHMENTS.-Ropes. - Ropes are made of vegetable fibre of some kind, or of iron or

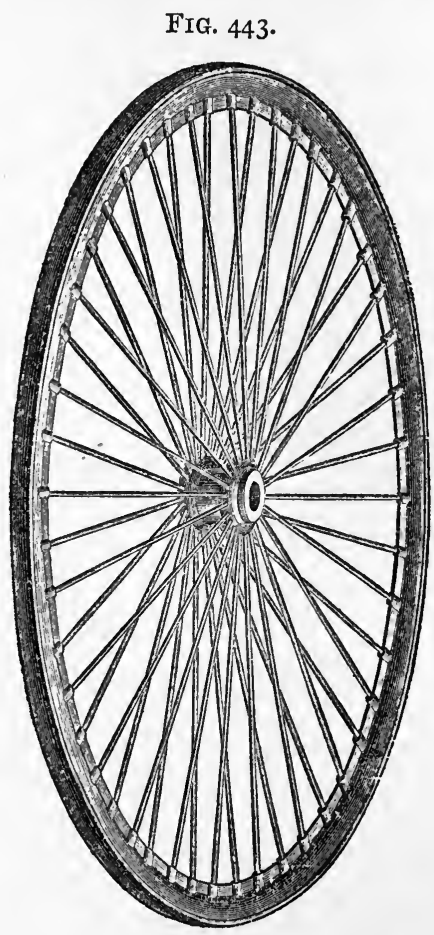

steel wire. The vegetable fibres used are hemp and manilla, which are twisted into yarn; the yarns are laid together so as to form strands, and finally the strands are laid together to form the rope.

For winding by hand, in sinking small intermediate shafts (winzes), a hemp-rope, about $\frac{7}{8}$ inch in diameter and made up of three strands, is commonly employed. For heavier work, either a round rope of larger section is necessary, or a flat rope formed by sewing together several round ropes.

Iron is very little employed nowadays for making wire ropes, its place has been taken by steel. 
The advantage of using steel as compared with iron, is evident from the following figures: *

\begin{tabular}{|c|c|c|c|c|c|c|}
\hline Kind of Wire. & 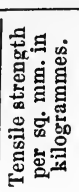 & $\begin{array}{l}\text { Kind of } \\
\text { Rupe. }\end{array}$ & $\begin{array}{l}\text { Total useful effect } \\
\text { in kilogrammetres. }\end{array}$ & 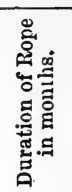 & 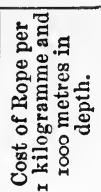 & Remarks. \\
\hline $\begin{array}{c}\text { Iron } \\
\text { Crucible } \\
\text { Cast Steel } \\
\quad, \\
\quad,\end{array}$ & $\begin{array}{r}60 \\
120 \\
120 \\
180\end{array}$ & $\mid \begin{array}{c}\text { Cylindrical } \\
, \\
\text { Tapering } \\
,,\end{array}$ & $\begin{array}{r}5,387,124,051 \\
26,519,326,190 \\
56,797,296,369 \\
69,898,974,017\end{array}$ & $\begin{array}{r}5 \cdot 5 \\
22 \cdot 3 \\
26 \cdot 1 \\
20 \cdot 8\end{array}$ & $\begin{array}{c}\text { Kreuzer. } \\
0.8 \mathrm{I} 7 \\
0.354 \\
0.198 \\
0.238\end{array}$ & $\begin{array}{c}\text { Ropestill } \\
\text { in use. }\end{array}$ \\
\hline
\end{tabular}

It must be remarked that the data concerning the last rope are incomplete, as it was still in use when the paper was written.

At Pribram, $\uparrow$ where winding is carried on in perpendicular shafts, one of which has attained the enormous depth of 3642 feet, the 'ordinary crucible cast-steel, with a tensile strength of I 20 kilos per sq. mm., was used up to the year I 885 ; since then they have employed wire of "patent crucible cast steel" or "extra" or "special crucible cast steel," with a tensile strength of $\mathrm{I} 80$ to 190 kilos per sq. $\mathrm{mm}$.; the results are most satisfactory, and the ropes, after having been in use for two and a half years, showed very little sign of wear, and not a single broken wire. The former ropes, made of ordinary cast steel, lasted on an average only 26 months.

Winding-ropes are usually made with six strands and a central core of hemp, each strand being made up of seven wires (Fig. 443a). The core is sometimes made of wire; for instance, if the rope has to work in a very hot shaft, or if it is used for haulage purposes with clips which require that the diameter should remain constant. In ordinary ropes the "lay" of the strand is like that of hemp ropes; that is to say, the reverse FIG. $443 a$. of the lay of the rope (Figs. 444 and 445).

Lang has improved the method of manufacture by making the lay of the strand the same as the lay of the rope; the wires are less sharply bent, and present a longer wearing surface.

* Habermann, " Ueber die Drahtseilfabrikation in Přibram mit besonderer Rücksicht auf die Drahtseile für die Verticalförderung." Beilage z. OestZeitschr.f. B.- u. H.- Wesen, I89 I, p. 8.

† Habermann "Anwendung verjüngter Förderseile aus gewöhnlichem und aus Patent- oder Extra-Tiegelgussstahldraht bei den grossen Schachttiefen des Pribramer Bergbaues." Oest. Zeitschr. f. B.・ u. H.- Wesen, vol. xxxviii. 1890, pp. 403, 415, 432. 
The result is, that whilst the wires of an ordinary rope wear quickly on the crown of the bend and break (Fig. 445), Lang's rope, with its greater wearing surface, has a much longer life. Figs. 446 and 447 are taken from actual examples of Lang's rope before and after use.

Haggie's patent Protector rope has a special covering destined

Figs. 444 and 445.
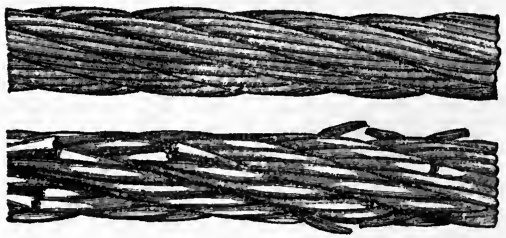

Figs. 446 and 447.
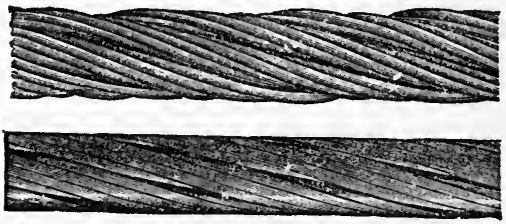

FrG. 448.

F'IG. 449.
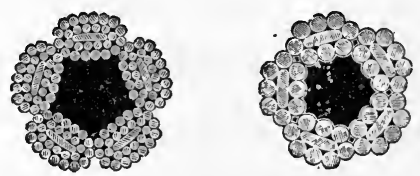

FiG. 450.

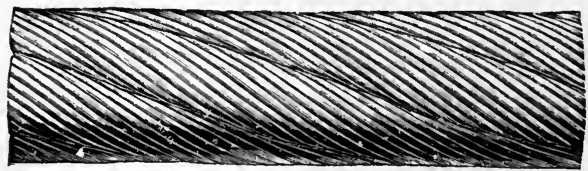

to take the wear. Each strand has a wire wound round it spirally, which protects it from rubbing, and therefore a more flexible wire can be used than would be advisable with an unprotected rope. Whilst an ordinary rope is weakened by the wear of its wires, the strength of the protected rope does not suffer from the gradual thinning of the covering.

Messrs. Latch and Batchelor have lately introduced a "flattened strand "rope (Figs. 448, 449, and 450) The object of the new method of construction is to obtain an outer surface more nearly cylindrical than that of the ordinary rope (Fig. 443a). The strands are oval in section, and this form is produced by "laying" ordinary wires round a flat wire or a

combination of wires. It is evident from the figures that the bearing surface of the rope is thus increased, or, in other words, that the liability of any individual wire to wear is lessened. It is asserted by the inventors that their rope has $5^{\circ}$ per cent. greater wearing surface than Lang's or ordinary ropes.

In designing the "locked coil wire rope," now made by Messrs. George Elliot \& Co., the inventor's departed entirely from the old traditions of manufacture. They considered, and very properly, 
that when one is dealing with a material like steel-wire, which can be obtained of very great length, it is quite unnecessary to copy the methods suitable for the short fibres of hemp.

These ropes are made of wires of different sections; some of the wires are V-shaped, others more like the letter $\mathbf{S}$, and the adjacent wires fit into one another like a set of spoons, the concave part of one wire receiving the convex part of the next. The rope is not composed of a series of strands, but of a series of concentric rings of shaped wires, and the separate wires form long spirals.

By consulting Fig. 45I, which represents one variety, it is evident that nearly the whole of the section of the rope is made up of useful material. There are scarcely any spaces such as exist between the wires and the strands of an ordinary rope, and consequently for any given section the locked coil variety of rope is stronger than a strand rope.

It is very flexible and has a smooth uniform surface, which makes it

Fis. 45 r.

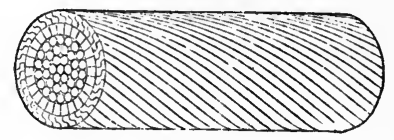
look at a little distance like a solid bar of iron. No one wire of the outer ring is more exposed to wear than the other; consequently there is not the danger of having broken wires, arising from the top of the crown being rubbed off by continued use (Fig. 445). Another advantage is the absence of any tendency to turn, whereas the ordinary rope with the spiral strands twists somewhat when passing over a pulley. In sinking a shaft with such a rope, the kibble spins round during its descent and ascent, involving a risk of accident, which is best avoided. However, strand ropes that will not twist are supplied by some makers.

The disadvantage of the locked coil rope is that it cannot be spliced, but sockets can be used for connecting one length to another.

Intermediate in character between the ordinary rope and the locked coil rope is the variety known as Laidler's patent "Sector wire ropэ." Each strand is cylindrical, and is composed of several wires in the form of sectors of a circle, and the strands are laid together to make the rope. Fathom for fathom, it is a little heavier than Lang's rope, but it is said to give a great deal of wear.

Chains.-Chains were largely used in ore-mining at one time. They have the advantage that they will coil round a small drum, and the further advantage that they will stand much rough usage, such as fell to their lot formerly in some of the crooked shafts in Cornwall. But there is the overwhelming disadvantage that a chain is no stronger than its weakest link; and now that wire ropes have come into use in mines, winding with the chain is practically a thing of the past. 
Attachments.-It is important to study the modes of connccting the rope to the receptacle by which the mineral is drawn up. In sinking by hand in Cornwall, the hemp rope is attached to the buckct by a knot known as the "gooseneck," which is said never to slip, and which is easily and quickly made; but where the bucket is emptied without being detached, this latter point is of little importance. In Wales and the Isle of Man a spring hook (clevis) is preferred, such as shown in Fig. 45.2, the rope being put through an eye and made secure by a large knot. This method is convenient when it is necessary to detach the bucket, and move it Fig. 452. away from the shaft before it is emptied. A third

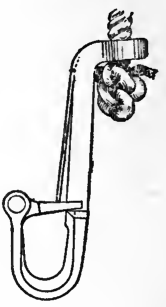
device is a spiral hook which will not allow the bucket to fall

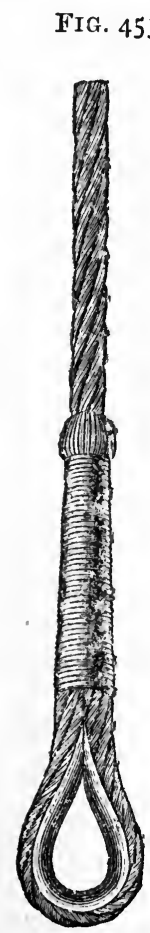

FiG. 454 . Fig. 456. off in the operations of raising and lowering, whereas it can be readily taken off by the workman.

With a wire rope it is necessary to form a loop of some kind, which can be attached to the load by a Dshaped link with a screw pin. There are several means of effecting this purpose. The ropes sent from the makers are often supplied with an eyo spliced in (Fig. 453*), that is to say, the end of the rope is turned round an eye and then spliced back so as to hold it firm. As there is not always a competent splicer at mines, methods of attachment have to be employed which are within the capacity of an ordinary smith. Thus the end of the rope may be bent back over an eye 
and held in position by three clamps (Figs. 454 and 455 ), ${ }^{*}$ or a socket may be riveted on (Fig. 456).*

Figs. $457,45^{8}$ and 459 represent a socket made by Messrs. George Elliot \& Co. for the locked coil rope and for ordinary round wire ropes. A, locked coil wire rope; B, socket; C, hollow conical plug; D, wire bound or "served" round the rope; $\mathbf{E}$, ends of the wires of the rope turned back over the cone; F, wire bound round them. After the end of the rope has been prepared in

FIG. 460 . FIG. $46 \mathrm{I}$.

FIG. 457. FIG. 45 S. FIG. 450 .
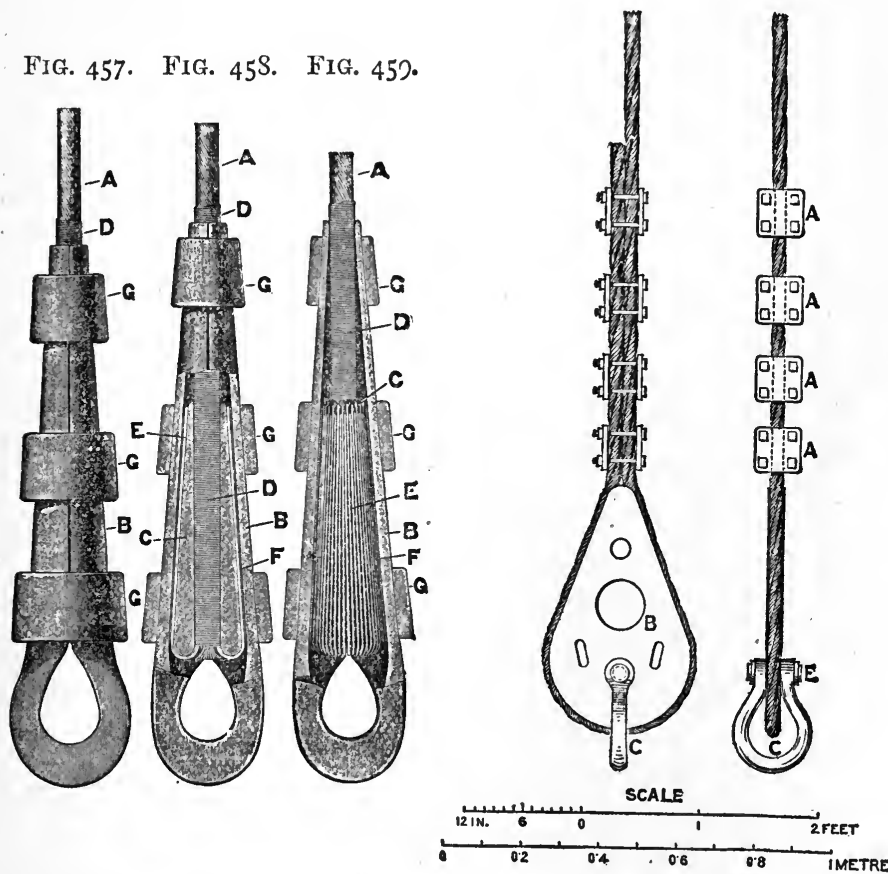

this way and drawn into the socket, the rings $\mathbf{G} G \mathbf{G}$ are driven down, and the fastening is complete.

Figs. 460 and 461 explain the "capping," which has been adopted at some collieries near Bristol, since the failure of a riveted socket. $\mathbf{A} \mathbf{A}$, clamps for holding the rope, each with four bolts; B, cast-iron plate with a groove all round it in which the rope lies; C, a large shackle attached to the iron plate by a pin $\mathrm{E}$.

A description of the method of splicing ropes will be found

* Copied, by permission, from Messrs. George Craddock \& Co.'s figures. 
in the catalogues of some of the well-known rope-makers, and need not be repeated here.

Splicing is not always adopted for joining two parts of a wire rope; sometimes a socket is attached to each end, and the two sockets are then connected by a D-link with a screw pin. It should be remarked that it is often at or near the socket that the rope wears, and consequently it is advisable to remove the sockets at regular intervals, cut off a piece of the rope, and replace the socket where the rope is good and sound.

I have hitherto been speaking of winding ropes of uniform section, but tapering ropes have advantages. Let us take the case of a wire rope which is hanging down a deep pit. The part of the rope at the bottom of the shaft has simply to support the cage or bucket and the load contained therein, whilst the part at the top must be strong enough to support not only the weight of the receptacle and its load, but also the weight of the rope below it. In other words, greater strength is required at one end of the rope than at the other, and on this account tapering ropes are sometimes employed.

The advantage of employing such ropes is especially felt in the case of very deep shafts, such as those of the famous lead and silver mines of Pribram already alluded to. Three of the principal shafts have the following depths:

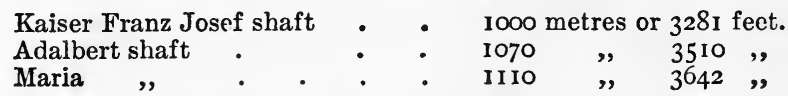

The taper is produced by using successively wires of smaller section, and not by reducing their number.

3. RECEPTACLES.- There are three kinds of receptacles in which the load is raised in the shaft: (a) Buckets (kibbles), baskets or bags which are swinging loose in the

FIG. 462. shaft; (b) buckets or boxes (skips, Cornwall)

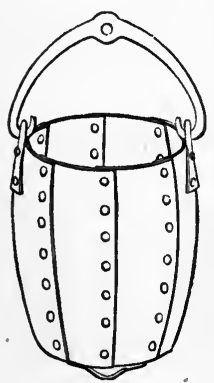
working between guides; (c) cages carrying one or more waggons.

(a) The buckets are made of wood, sheet iron, or sheet steel.

Wooden kibbles are made of staves in the same way as a barrel, and are suitably strengthened with bands of iron in order to resist the wear. A petroleum barrel cut down at one end may be easily converted into a kibble.

Various forms are seen - viz., round, elliptical, or square, and the sides are straight, or bulging in the middle. Fig. 462 represents a common form of sheet-iron kibble, made of hammered plates riveted together and closed at the bottom by a circular plate provided with a ring. At the top is the so-called bow, 
either a bar of round iron with a hook at each end and bent so as to form a loop in the middle, or else made thicker and provided with a hole, to which the rope or chain is attacked.

In perpendicular shafts, a lining of planks is often put in around the winding compartment, so that the kibble may glide up and down smoothly, without risk of catching against the sides.

In inclined shafts the "footwall" side is lined with boards (bed-planks) resting upon cross sleepers. Hard wood, such as oak or beech, will naturally last longer, and require fewer repairs than deal. In the Hartz, poles fixed lengthwise take the place of boards, which are customary in this country.

Other receptacles used in winding are baskets, whence comes the name corf (Korb, German), bags made of hides used in Mexico, small wooden platforms suspended by chains from the four corners, and, lastly, nets, which are employed in Roumania.

A word must be said about the actual loading and emptying of the kibble; sometimes, as already mentioned, the kibble is filled at the working-place or from a shoot (pass, Cornwall), and is then conveyed on a trolley to the shaft, where it is hooked on to the rope and drawn up. More frequently the filler, standing in an enlarged part of the level (plat) where it joins the shaft, loads the kibble with a shovel; in order to save time, two kibbles are often provided, one being filled while the other is making the journey to and from the surface. In this case it is necessary to have some kind of clevis, which will enable the kibble to be readily detached from the winding rope and quickly and securely fastened on again.

On the arrival of the kibble at the surface, the lander seizes an eye or ring at the bottom (Fig 462) by a pair of tongs suspended to a chain, and then gives the signal for the rope to be lowered slightly. The kibble turns over because it is suspended from the bottom, and its contents are shot out into a tram-waggon placed ready to receive them. During the operation of discharging the kibble, the mouth of the shaft should be covered by a hinged door, so as to prevent stones from falling down and injuring the filler in the plat.

The inconveniences of this method of winding are considerable, especially in inclined and crooked shafts. Rapid hoisting is out of the question. Power is wasted in overcoming friction, and there is great wear and tear of the bed-planks and casing boards ; and, unless constant attention is paid to repairs, holes are worn in which the kibble catches, causing the rope to break. 'The fall of a kibble and its contents not only does much damage to the shaft, but is also a source of danger to the men. In some old shafts the friction must have been enormous, for deep grooves have been worn in hard rock by the constant rubbing of the chain.

The aërial incline, known in Scotland as the "Blondin," is a 
convenient method of raising stone from open quarries, when it is necessary from time to time to alter the point at which loading takes place.

A B (Fig. $463^{*}$ ) is a strong upright post, held firmly in position by guy ropes, of which only one, $\mathrm{C} \mathrm{A}$, is shown. A D is a stout wire rope, fixed to the top of the post, and anchored at D on the opposite side of the quarry. It constitutes an aërial rail for two grooved pulleys contained in the travelling cradle $\mathbf{E}$. The rope $F$, attached to the cradle, passes over the large pulley $G$, and thence to a horizontal winding-drum, not shown in the figure. The engine-house is at the very edge of the quarry, and is so placed that the engine-man can look down to the bottom. The cradle $\mathrm{E}$ will run down from $\mathrm{A}$ to $\mathrm{D}$ by its own weight, and can be drawn up by winding the rope $\mathrm{F}$ upon its drum. A loop attached to $\mathrm{E}$ supports the large pulley $\mathrm{H}$, and the hoisting rope I. This rope passes under the pulley $\mathrm{K}$, over the pulley $\mathrm{H}$, over a pulley immediately by the side of $G$, and thence to a drum precisely like that of $\mathrm{F}$, and running upon the same shaft. $\mathrm{L}$ is a rectangular box, like the body of a waggon, which is loaded with stone at the bottom of the quarry, and hooked on to the four chains hanging from $K$; it is then drawn up and landed on to the truck M. I will suppose that the load has been hooked at the point $\mathrm{N}$ in the bottom of the quarry, vertically below $\mathrm{L}$ in its present position. The drum of $\mathrm{I}$ is thrown into gear by a clutch and the rope wound up. $K$ is gradually raised, and when it approaches $\mathrm{H}$, the drum belonging to $\mathrm{F}$ is thrown into gear; the ropes $\mathrm{F}$ and $\mathrm{I}$ are now wound up at the same speed, until $\mathbf{E}$ is drawn close up to A, with its load hanging directly over M. Winding is stopped, brakes are put on, and the drum of $I$ is disengaged by its clutch. By slackening the brake of $\mathrm{I}$, while that of $\mathrm{F}$ is kept tight, the load can be lowered on to M, which is trammed away as required. An empty box is hooked on, $K$ is wourd up a little, till it approaches $H$, and then, throwing the drum of $I$ out of gear, the engine-man lets both ropes run out under the control of their brakes. When $\mathbf{E}$ has reached its proper position, it is stopped by tightening the brake of the $\mathrm{F}$ drum; $\mathrm{K}$ then descends vertically till $L$ has reached the bottom of the quarry.

It is evident that by properly arresting the descent of $\mathrm{E}$, the box can be lowered so as to pick up a load at any point along the line $\mathrm{O} P$, which is vertically below A D. If after a time it becomes more convenient to load elsewhere, the anchorage at $\mathrm{D}$ is shifted accordingly.

At slate quarries in North Wales and Cornwall, the rope $\mathrm{F}$ is not used, and $\mathbf{E}$ is stopped by a clamp fastened at any desired point of the rope A D. The arrangement shown in Fig. 463 introduced many years ago by Mr. Fyfe at granite quarries near

* For the sake of making a clear diagram on a small page, Fig. 463 is not drawn to scale. 
HOISTING OR WINDING.

407

Fig. 463 .

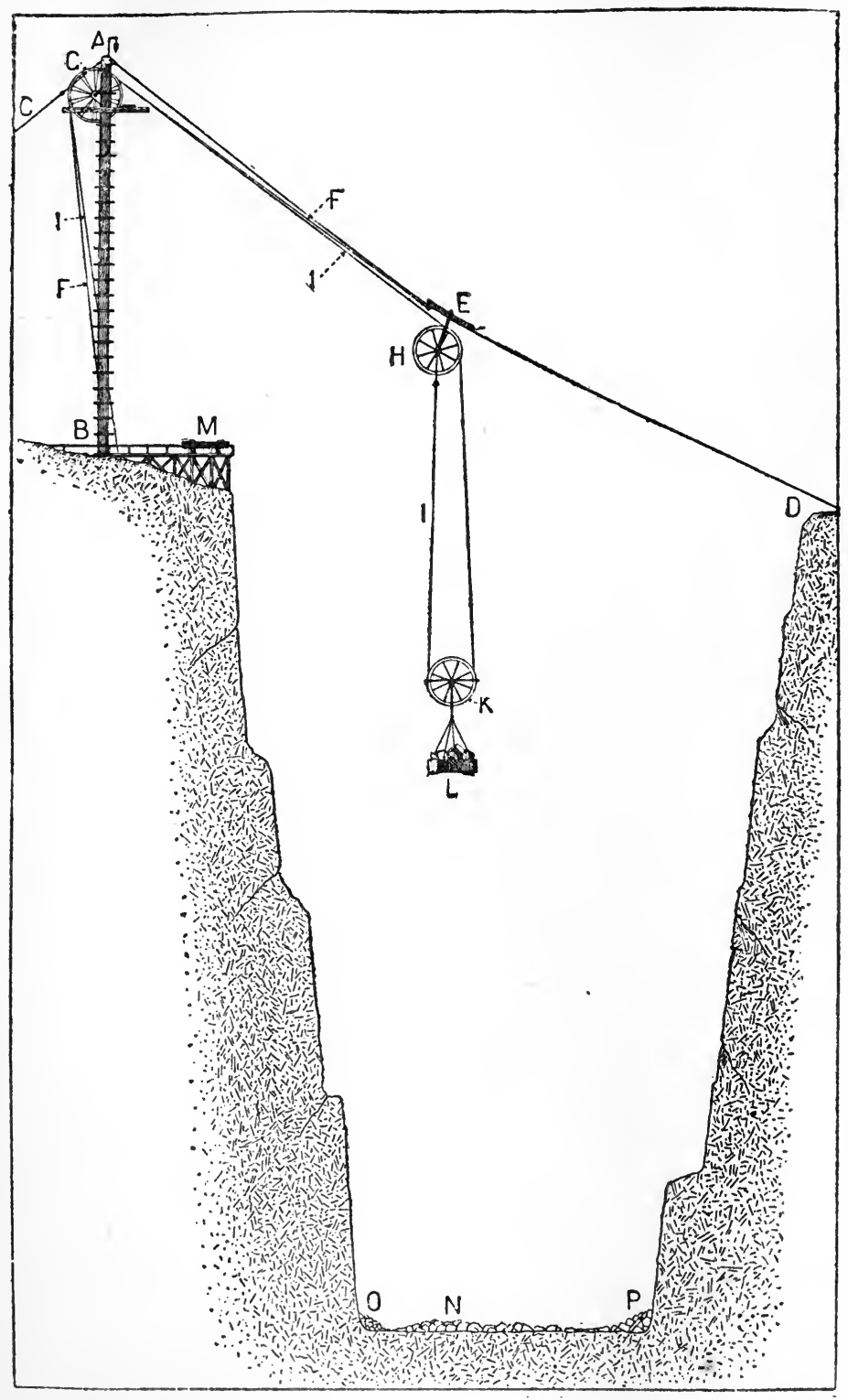


Aberbeen, is better, for it does away with the necessity of sending a man down the rope to adjust the clamp. A slightly different plan is in use at Easdale slate quarry in Argyllshire. The travelling cradle carries the usual hauling rope I, but in place of $\mathbf{F}$ there is attached to it an endless rope, which stretches across the quarry, and passes over suitable pulleys. So long as the endless rope is free to move, the cradle will run from $\mathrm{A}$ to $D$, but when the banksinan stops its travel by a screw clamp, the load ascends or descends vertically. If the slope of the carrying rope fixed across the quarry is too small to allow the cradle $\mathbf{E}$ to run of itself, an endless rope, worked by a drum, is used for hauling it backwards or forwards as required.

(b) Guided Buckets or Boxes.-When winding in shafts it is best to employ guides, in order to keep the receptacle in one proper c')urse, and prevent it from touching the sides. The guides may be chains, wire ropes, bars of wood or round iron, or, lastly, iron or steel rails.

Chains are rarely met with; the commonest method of guiding in perpendicular shafts is to hang two stout wire ropes from the top to the bottom of the pit, and to provide the winding receptacle with eyes which pass over them. They are kept taut by weights or screws.

Wire-rope guides may be used even in the case of a kibble; a cross-bar with two eyes is attached near the end of the winding lope ; though the kibble remains loose, it is so close to the crosshar that it can swing but little. By fitting wire-rope guides of this lind to perpendicular shafts originally worked with the ordinary

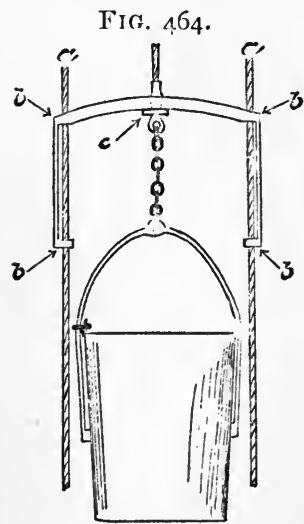
loose kibble, winding can be carried on with greater speed and safety, whilst the cost of making the alteration is comparatively small. There is the further advantage that the shaft when provided with guides becomes available for raising and lowering the men.

Some years ago Mr. William Galloway* introduced an ingenious method of applying these wire-rope guides to a shaft in the course of sinking. He provides two wire-rope guides coiled upon two drums which are worked by a steam crane, either separately or together. The guide ropes (a a, Fig. 464) pass over two pulleys at the top of the shaft, parallel to the winding pulley, and are attached to a platform, which serves as a walling stage, and is raised and lowered as required. A hole in the middle affords a passage for the bucket (kibble, bowk, hoppet).

* "Sinking Appliances at Llanbradach," Trans. South Wales Inst. of Eng., vol. xvi., 1888, p. 113 . 
As the shaft is deepened, the guide ropes are paid out from time to time, and in this manner it is only at the very bottom that the bucket is swinging loose. The guiding apparatus consists of a cross-bar having a round hole in the centre $c$, through which the winding rope passes. It has two legs with holes, $b \vec{b}$, at top and bottom which receive the guides. This rider descends as the bucket is lowered, but when the legs meet with the walling stage their motion is arrested; the kibble, however, can proceed further because the winding rope passes down through the central hole $c$.

After passing below the stage the kibble is unguided, but the distance it has to travel is rarely more than 15 or 20 yards. Before starting on its upward journey, the kibble is brought properly into line with the rope and steadied, and on arriving at the stage, an india-rubber buffer, carried by an iron plate at the bottom of the rope, lifts up the rider; the remainder of the ascent is performed without fear of the kibble swinging or catching.

Mr. Galloway's latest walling stage has two floors, ro feet 6 inches apart; the lower one is a circular platform of timber fixed to a frame of angle-iron $d^{1} d^{2}$ (Figs. $46_{5}$ and 466), and made to fit the inside of the shaft as closely as possible.

The part $h$ is hinged, and can be raised by means of the chain, when passing the crossbeams (buntons) which support a ventilating pipe. The upper floor of the stage is similar to the lower one, except that it is somewhat smaller in diameter, and is not made to cover the hinged segment below. The two floors are held apart by four corner pieces

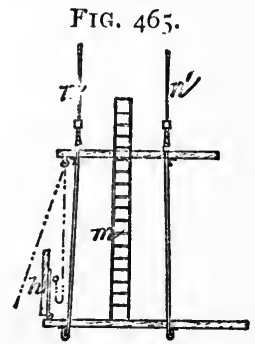
of angle-iron, to which are attached four plates of sheet iron, forming together a frustrum of a pyramid, 5 feet 6 inches square at the top, and 6 feet 6 inches square at the bottom. The object of these plates is to prevent men who are standing upon the lower stage from falling into the central opening, and at the same time the upper floor constitutes a protecting roof over their hears.

Men can climb from the lower to the upper platform by means of the ladder $m$ which passes through a small man-hole in the iron covering plates.

The two guide ropes which carry the stage are shown by letters $n n^{\prime}$.

This double stage is decidedly safer than the single platform originally employed by Mr. Galloway. 
Although primarily designed for sinking coal-pits, and most frequently applied for this purpose, this method of guiding was used with marked success in sinking a shaft at New Minera lead and zinc mine near Wrexham; it was found that the great advantage of being able to wind with safety at a higher speed, fully repaid the expense of putting in the guides.

In the Northwich mines, rock-salt is brought up in wooden buckets guided much in the same way, except that round iron bars are employed instead of ropes. Each length of rod has a socket at one end and a projecting pin at the other; the pin of one rod fits into the socket of the next and is fastened by a key driven through a slot. These guides are chosen in the special case of salt because they suffer less from rusting than those made of wire ropes, owing to the absence of interstices in which saline water would collect and corrode the iron.

We next come to the box of rectangular or circular section (skip), made of sheet iron or sheet steel. It usually has a sloping bottom, and is provided with a hinged door for discharging its contents; in some instances it is emptied by being turned over automatically on reaching the top of the shaft. The skip may be used in perpendicular, inclined, or crooked shafts. The guides or conductors are most commonly rectangular bars of wood, bolted to the end-pieces of the shaft and to the "dividings" in the manner shown by Fig. 257 .

If the shaft is perpendicular the skip may be guided by two $U$-shaped shoes of iron, which clasp the three sides of the conductor. If it is inclined the skip runs upon four wheels, as shown by Fig. 467 . In an inclined shaft the conductors sometimes have rails, upon which the wheels of the skip run, in others the timber is not protected in any way. Some of the skips in Cornwall are made to hold as much as a ton and a half of tin-bearing rock.

When winding is going on from any particular level, a stop, such as a strong bar of iron, is put across the shaft to arrest the skip; the miner, standing in the plat, shovels the mineral into it, and gives the signal to have it drawn up as soon as it is filled.

A better plan is to adopt the arrangement explained in Fig. 467 , which will easily be understood. $B$ is a strong plate working on a pivot which is put down to stop the skip; $\mathrm{C}$ is a pivoted hood turned over the mouth of the skip so as to prevent stones from falling into the shaft, and when this is in its place the workman raises the door of a large bin or hopper, and allows part of its contents to run out. The hopper has been filled by tipping waggons from the line of rails in the level above.

On reaching the surface a hinged sloping door is turned over the shaft, and the skip is lowered a little until it rests upon it; the workman (lander) then knocks up the bolt retaining the door of the skip, and the contents fall out into the tram-waggon placed to receive them. The lander replaces the bolt, the skip is raised 
slightly, the door pulled back, and the skip lowered once more into the shaft.

The skip is sometimes tilted completely over instead of being emptied through a hinged door; this arrangement is in use in some German mines, where the skip is made of wood and is guided on each side by two pins or rollers running between two con-

FIG. 467.

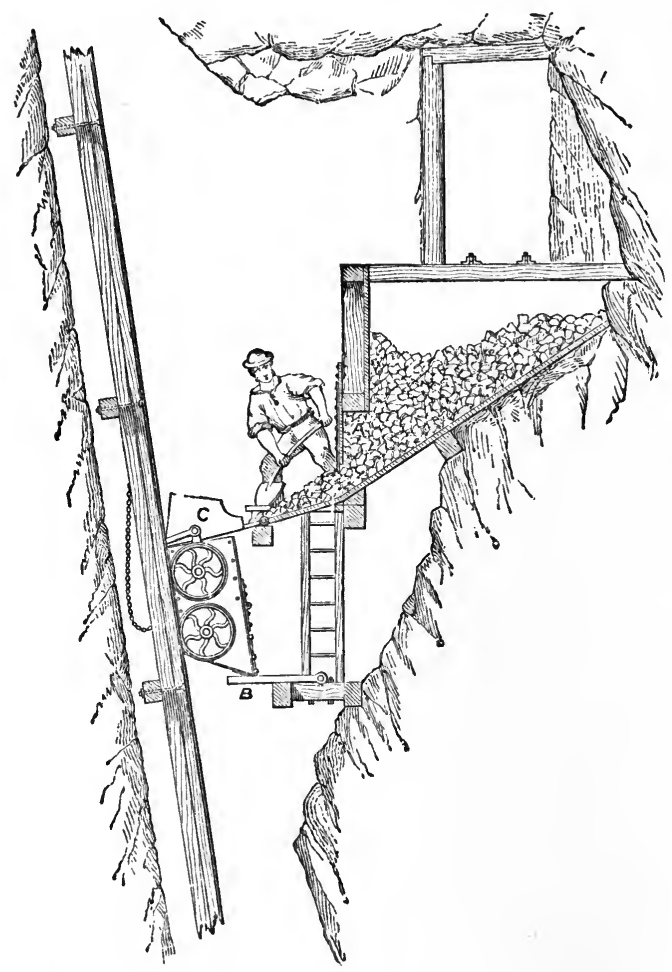

ductors. On reaching the surface, the two lower pins are supported and act as pivots, while the upper ones pass through openings in the front guides; the skip turns upon the lower pins, is tipped over, and so emptied.

Some very rapid work is done at De Beers mine* with a selfdischarging skip, which shows that this method of hoisting must not be despised, even by those who are accustomed to the winding of large quantities of coal from well equipped pits.

* Second Annual Report of De Beers Consolidated Mines, Limited, for the year ended 31st March 1890, p. 14, plate 8. 
The skip (Figs. 468 and 469) runs upon four flanged wheels, and the two upper or front wheels are half the width or tread of the two back or lower ones. The winding rope is attached to two chains, which are fixed to the cross-bar of a loop or stirrup which can turn upon pins fixed to the sides. The skip runs upon steel

FIG. 468.
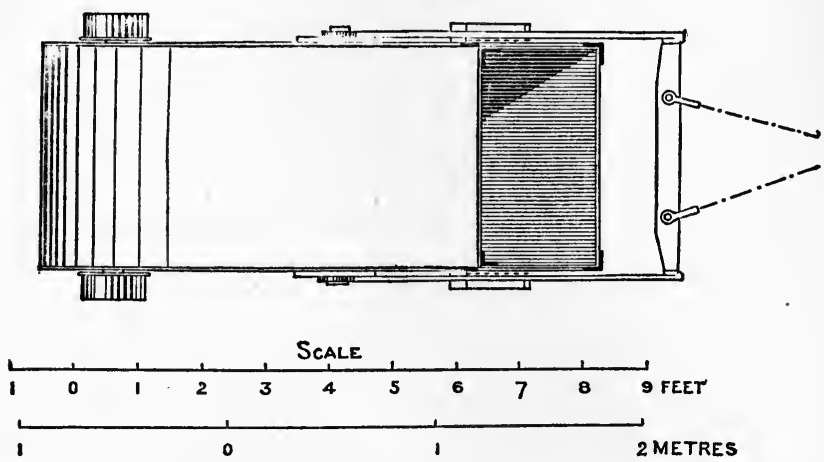

rails ( $46 \frac{1}{2} \mathrm{lbs}$. to the yard) laid upon what may be called conductors or longitudinal sleepers. At the bottom of the shaft there is an iron shoot, without any door, leading to the skip. During the descent of the skip, four end-tipping waggons are brought into position round the shoot, the catches of the flap-doors are loosened, and the doors held closed by two labourers. As soon as it is seen to pass, the trucks are tipped, and the signal is given

Fig. 469 .

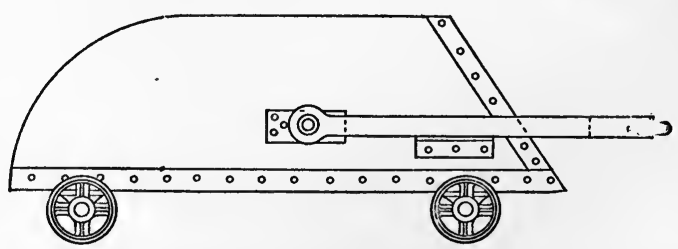

to wind up. The skips are filled so quickly at the bottom, that the man at the top sometimes receives this signal before he has. completely stopped his engine.

When the skip B (Fig. 442), ascending the incline shaft A, reaches the point $\mathrm{C}$, its rear, wheels are caught up by a special broad road $\mathrm{D}$, the gauge of which is wide enough to let the front wheels pass through. Whilst the front wheels are travelling on the rails $\mathbf{E}$, the rear wheels continue to mount, and consequently the skip turns over and discharges its contents into the bin F. 
$\mathrm{H}$ is a waggon waiting to be filled, and $\mathrm{G}$ a counterpoise to the discharge door.

On lowering the rope, the skip falls back into its original position and descends the shaft. The inclination of the shaft is $56^{\circ} 20^{\prime}$ from the horizontal. The skip-ways are 5 feet wide and $4 \frac{1}{2}$ feet high, and the gauge of the railway is 3 feet I I inches. There ars two tracks, which converge at the bottom into one, so that both skips can be filled from the same shoot. A skip holds 64 cubic feet, or 4 loads, weighing in all 2 tons 17 cwt., or 2903 kilos.

The best single day's work, in two shifts of ro to $1 \circ \frac{1}{2}$ hours each, was 6222 loads, or 4444 statute tons. The depth of the

FIG. 470.

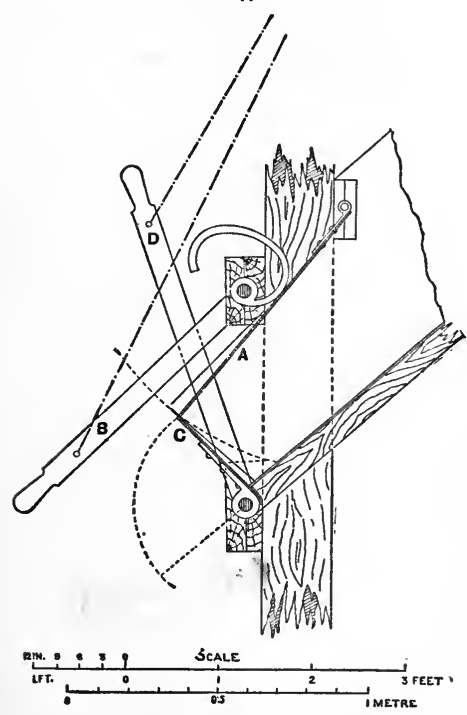

FIG. 47 I.

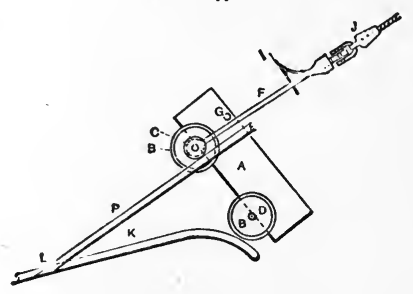

FIG. 472.

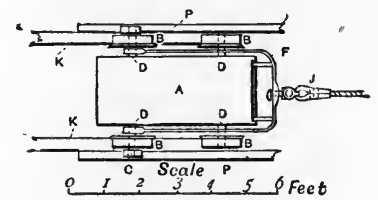

shaft is 840 feet along the incline, or 700 vertical; the speed in the shaft is 840 feet in 30 seconds, and the time occupied in tipping and reversing about 6 seconds. This rate of working has been carried on for an hour at a time, 5 skips being discharged every three minutes-that is to say, 285 statute tons per hour.

Fig. 470 shows the details of double-lipped mouth of the shoot at the bottom of the great bin (F, Fig. 442), which receives the blue ground brought up from underground. The door $\mathrm{A}$ is controlled by the cam worked by the lever $B$, and the door $C$ is upon the same axis as the lever $\mathrm{D}$. The discharge is thus easily regulated, and waggons can be filled with great rapidity.

The arrangement for inclines shown in Figs. $47 \mathrm{I}$ and 472 differs slightly from that adopted at De Beers. A waggon $\Lambda$, 
running upon four wheels $B$, is drawn up by the bow $F$, and the rope J. The bow is attached to the axles of the hind wheels,

FIG. 473 .

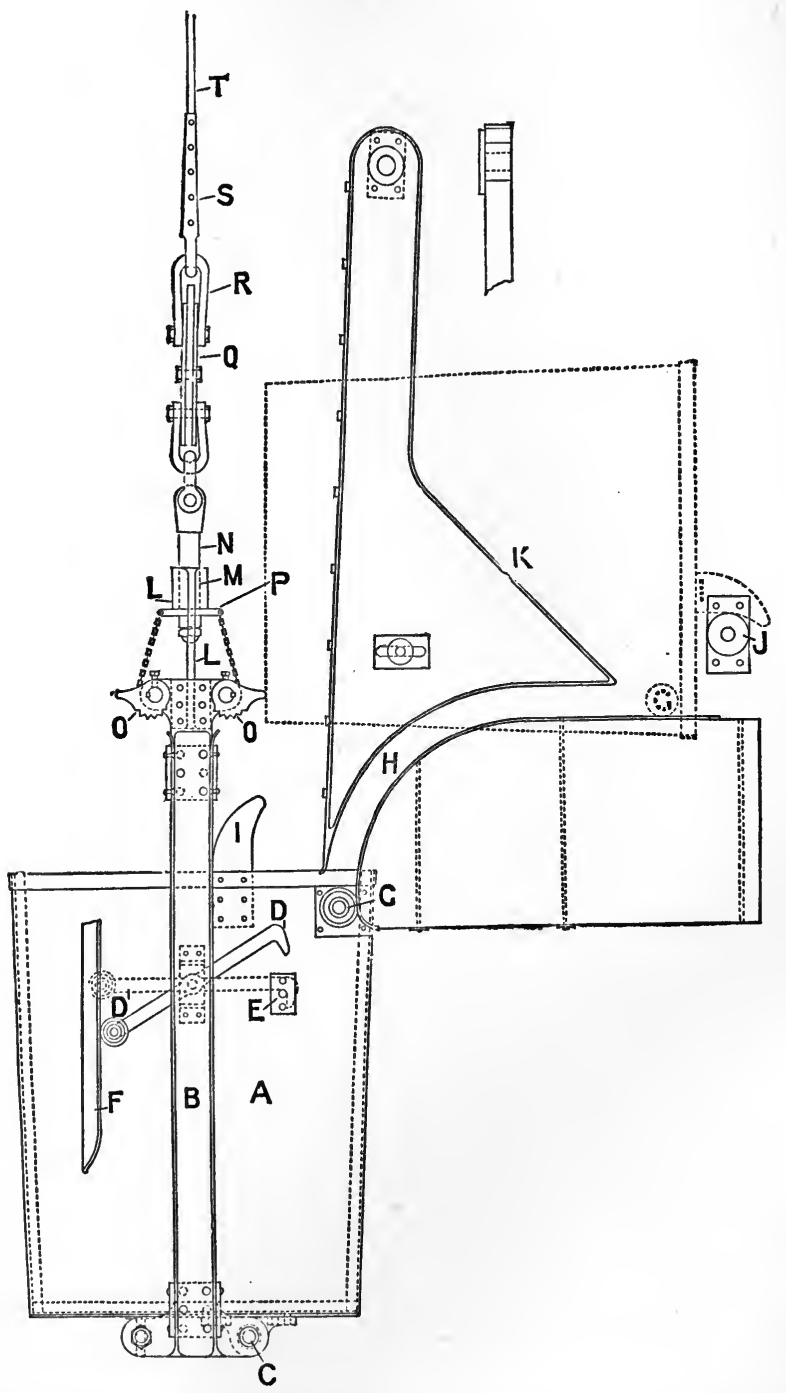

and in front it carries the door I of the waggon. $K$ represents the railway at the top of the incline, and $\mathbf{P}$ an additional 
outer line of rails at a steeper angle. When the waggon in its upward course reaches the point $L$, the rails $P$ pick up the small outer wheels $\mathbf{C}$ on the rear axle. These travel up at the steeper angle whilst the front wheels follow the rails $K$. Consequently, the waggon is tilted, and, as the front end or door is attached to the bow, the contents are shot out. The stud G keeps the waggon in position if it is drawn up too far. On lowering the rope, the waggon rights itself and descends properly.

Automatic tipping, or dumping, is also possible in perpendicular shafts. The "Rock" shaft at De Beers is 20 feet by 6 feet, divided into four compartments which are each 4 feet 4 inches by 6 feet within the timber: one for the pumps and ladder-way, another for a cage, and two for the skips.

Figs. 44 I, 473 and 474 * represent the arrangements adopted. $A$ is the skip, a box of rectangular section, 5 feet by 3 feet at the top and 6 feet deep; B, frame which clasps the wooden guide on three sides; $\mathrm{C}$, hinge by which the skip is.attached to the frame; $\mathrm{D}$, hooked bar which catches upon the pin $\mathrm{E} ; \mathrm{F}$, guide which presses the little roller $\mathrm{D}^{1}$ and so unhooks the catch; $G$, roller which travels along the guiderails $\mathrm{H}$ for causing the tipping ; I, nose upon the skip, which is temporarily caught upon the roller $\mathbf{J}$ during the tipping; $\mathbf{K}$,

FIG. 474 .

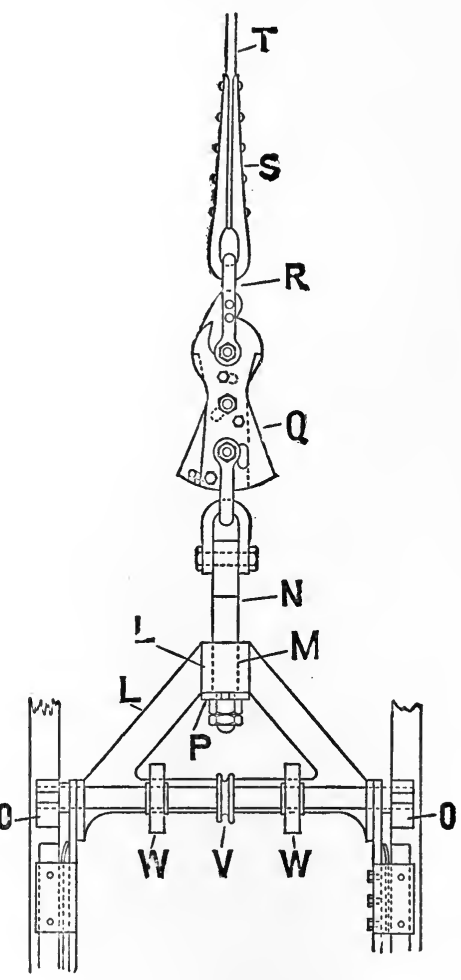
inclined guide for the roller G; I, crosspiece attached firmly to the side-frames $B$, with a hole $\mathrm{M}$, through which slides the strong square bar $\mathrm{N}$; O, toothed segments forming the safety catches; $\mathrm{P}$, plate attached by chains to the axles of the catches; Q, Ormerod's detaching link ; $\mathrm{R}$, shackle which is released; $\mathrm{S}$, rope-socket; T, wire-rope ; $\mathrm{U}$ (Figs. 44I and 475), bell-mouthed cylinder for causing the

* From drawings kindly supplied by the makers, The Grange Iron Co., Limited, of Durham. 
detaching link to come into action; $\mathrm{V}$, chain-pulley of safety catch ; W, strong spring, like a huge watch-spring.

After this explanation of the parts, the manner in which the tipping or dumping is performed will be easily understood. As long as the hook $D$ is horizontal, the skip is prevented from falling forwards, but on arriving at the top of the shaft, its roller $\mathrm{D}^{1}$ is drawn up against the guide $\mathrm{F}$ and the catch is released. By this time the roller $G$ has reached the guide-rails $H$, and whilst the frame $B$ follows a vertical path upwards, the box itself, held back by $\mathrm{G}$, turns upon the hinge $\mathrm{C}$ until it assumes the position shown by the dotted lines, with the nose I resting upon the roller J. As the frame ascends still further, the roller $G$ is drawn up along the inclined guide $K$, the bottom of the box is tilted up, and its contents are discharged into the bin or hopper. On lowering the rope the frame descends, the skip drops back into its original normal position and is clamped automatically by the bar $\mathrm{D}$.

Whilst the plate $P$ is held up against the cross-bar $L$, the chains of the safety catches $\mathrm{O}$ are drawn tight, and the teeth are held clear of the wooden guides in the position shown. The moment the rope breaks, the chains become slack, the springs are then free to uncoil slightly and they force the teeth into the wooden guides.

FIG. 475 .

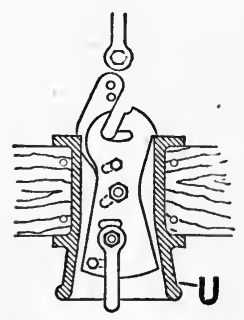

If, instead of a breakage of the rope, there is an overwind, the detaching link $Q$ is drawn into the bell-mouthed cylinder U (Fig. 475), the lower part of the link is squeezed, as it is too wide to pass through, and is thereby caused to throw out projecting shoulders which rest upon the top of $U$ and hold up the skip. By the same action the shackle $R$ is set free and goes with the rope over the pulley.

A self-discharging skip, suitable for vertical, inclined, or crooked shafts, is that of Messrs Kitto, Paul and Nancarrow, used at Frongoch mine in Cardiganshire.* (Figs. 476 to 480 ).

The skip is the usual box A, made of sheet iron or sheet steel, with four wheels B B, running on the vertical wooden conductors, $\mathrm{H} \mathrm{H}$, and prevented from leaving them by the back guide $\mathbf{D}$ (Figs. 477 and 479) at or near the bottom.

The bow or loop E, instead of being attached to the top of the skip, reaches down, and takes hold of the axles of the bottom wheels ; in its usual position (Fig. 478) it rests against the axles of the upper wheels, and holds the skip upright.

* C. Le Neve Foster, "Some Mining Notes in I887," Trans. Min. Asanc. and Inst. of Cornwall, vol. ii. p. I40. 
At the surface, each of the two ordinary conductors bends round and terminates in a horizontal piece, as shown in Fig. 480, whilst a front guide $\mathrm{H}^{\prime}$ is added on each side.

When the skip comes up, these front guides press upon the top wheels, and turn them on to the flat ends of the ordinary conductors. Deep grooves cut in the conductors at I enable the back guide $\mathbf{D}$ to pass through, and as the rope continues to be drawn up the bottom end of the skip is raised and its contents are tipped or "dumped" into a large bin or pass, from which the ore can be drawn away at pleasure. If the engine-man does not stop quite soon enough, the skip is simply drawn up a little way, resting upon the front guide, and the stop or stud $\mathrm{F}$ prevents it from assuming a wrong position.

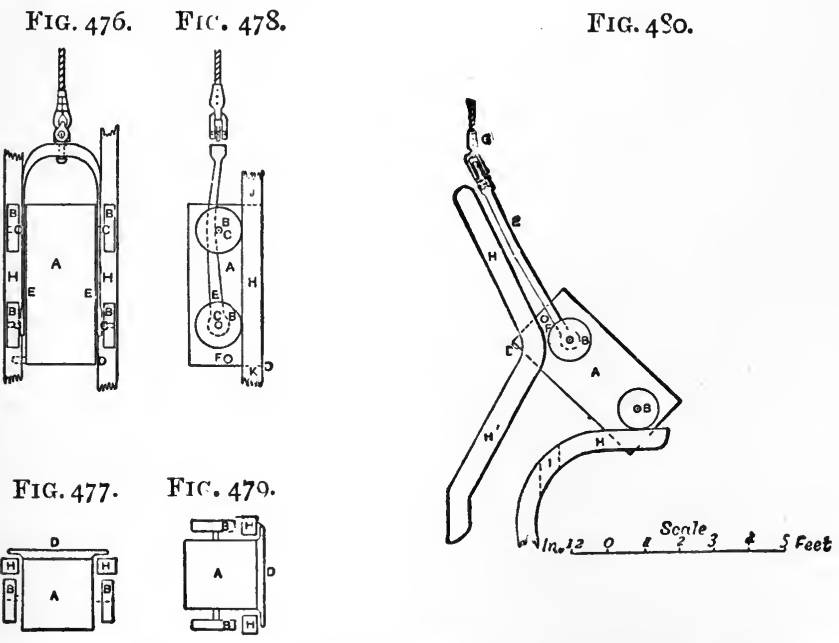

As soon as the engine-man begins to lower, the top wheels fall upon the flat ends of the conductors, and, turning upon them, the tail end of the skip drops, the back guide passes through the slot I, and the skip, resuming its upright position, descends the shaft.

The great advantage of this and other self-tipping arrangements is the saving of time and labour. The time occupied in lowering an ordinary skip on to the shaft-door, in knocking up a bolt so as to discharge its contents, in closing it again, and in raising the skip so that the shaft-door may be thrown back, is all saved, and the services of the lander are dispensed with.

(c) Cage.-The system of winding adopted almost universally at collieries is that of using cages; this method is likewise very general in mining seams of ore, and is not uncommon in the case of veins and masses. 
The cage, as its name implies, is a more or less open receptacle, which receives the waggon used for underground transport, and conveys it to the surface.

Figs. $48 \mathrm{I}$ and 482 represent the light and simple cage used in the mines on the Comstock lode: * it is a mere timber platform 5 feet by 4 feet, resting on iron bars $p$ and supported by iron rods on each side. It is provided with a sheet-iron bonnet to protect the men inside from anything falling down the shaft, and also with safety catches, which come into play if the rope breaks.

FIG. 48 I.

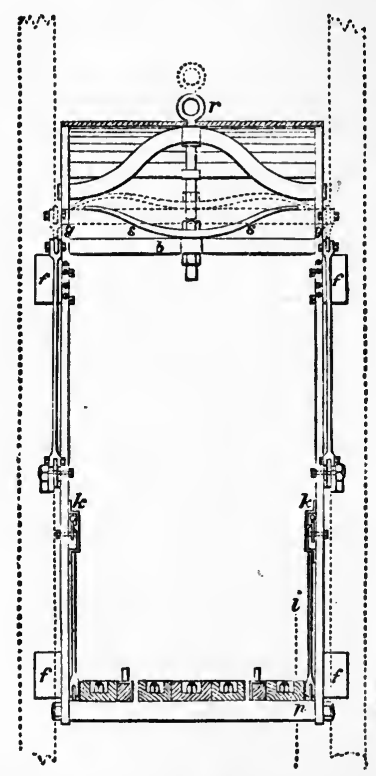

Fic. 482 .

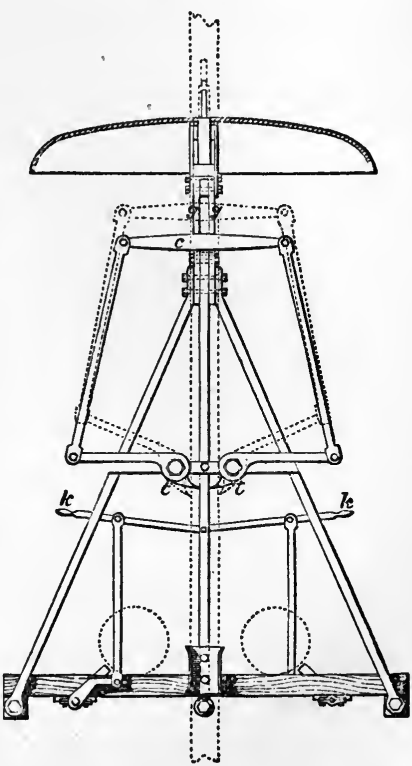

The hand levers $k k$ at the ends of the cage, raise up blocks which keep the tram-waggon in its place during the ascent or descent; $g g$ are the guides for the ends of the cross-bar $b$; $c$, the bar working the teeth $t t$ by levers; $f$ shoe or ear embracing the guiderod, or conductor, in the shaft; $r$, the lifting bar; $s$, a strong spring which comes into operation if the rope breaks.

This kind of cage looks somewhat bare to European eyes, and it is usual, on this side of the Atlantic, to make the sides less open than shown in Fig. 482.

The dimensions of the cage are limited by the size of the shaft; but where it is desired to raise a larger quantity of mineral than

* J. H. Hagure, “Mining Inōnstry," Rep. U. S. Geol. Expl. of qoth I'urullel, vol. iii., plate vii, p. 119. 
can be contained in one waggon, or in two placed side by side, the carrying capacity may be increased by constructing the cage with two or more platforms, technically called decks.

As a rule, the full waggon is drawn out of the cage at the top of the shaft, and is trammed to some convenient place wh re it is tipped ; of late years the ingenuity of American inventors has led them to introduce methods of tipping the waggon automatically on reaching the surface, without its leaving the cage, in order to save time in winding. Russell and Parson's automatic dumping cage, said to be doing good work in the United States, has its platform movable upon an axle underneath, which allows it to be tilted on one side or the other. The cage has the usual shoes at the top and bottom, which cover $5 \frac{1}{2}$ inches of the wooden guides or conductors; the tilting platform has its own two separate shoes, which clasp only $2 \frac{1}{2}$ inches of the guides. Whilst the cage is in the shaft, the platform is held in a horizontal position by its shoes running upon the guides. At the surface the wooden conductors are cut away for a depth of $2 \frac{3}{4}$ inches, so that, although the cage itself is guided, the small shoes are free to move sideways and permit the tilting, when the platform touches a properly arranged stop. The flap-door of the waggon is released automatically at the same time, and the mineral is shot out into a large bin at the pit-top.

4. OTHER APPLIANCES-Keps.-On arriving at the surface the cage is usually lifted a little higher than the landing platform, and supports of some kind (keps) are brought underneath it, so as to hold it up while the full waggon is drawn off and an empty waggon pushed on. The cage is then slightly raised, the supports (keps) are drawn back by a lever, and the descent begins.

Several methods of simplifying the work have been devised, and among them is that of Messrs. Haniel and Lueg,* which has been found to act satisfactorily at the well-known Mansfeld copper mines.

The kep $a$, which is made of steel (Figs. 483 to 485 ), has an inclined face $b$, and is provided with two slots, one horizontal and the other $d$ inclined. The former acts as a guide to the block $e$, which is loose upon the axle $f ; f$ is supported by the bearing $g$. The pin $i$, surrounded by a steel roller $h$, can slide in the slut $d$; it connects the two levers $k$, one on each side of the kep $a$, which are keyed to the axle $f$. These are kept in a horizontal position by a lever $m$ provided with a spring catch. The steel shoes $l l$, attached to the bottom of the frame of the cage, will, if desired, rest upon the inclined faces $b b$ of the keps. As long as the lever $m$ is held in the position shown in Fig. 483 , the keps cannot open under the pressure of the load, because the pin $i$ prevents any notion in a horizontal direction.

* The explanation and figures are borrowed from their description. 
When the lever $m$ is being drawn back, as shown by Fig. 484, the pin $i$ with its roller $h$ is forced up the slot and the keps slide back on the bed-plate of the bearing $g$, until the cage has room enough to pass; when it has gone down, the keps are returned to

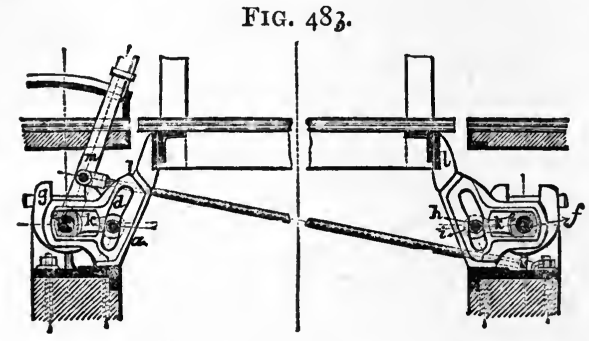

FIG. 484 .

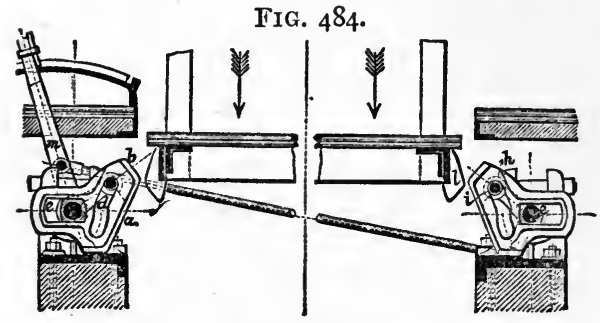

FIG. 485 .

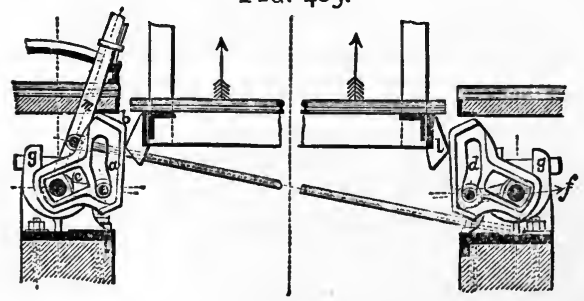
their original position (Fig. 483 ) by moving the lever $m$ forwards.

The ascending cage opens the keps by itself, for the shoes $l l$ turn them upwards (Fig. 485), the lower part of the slot $d$ being concentric to the spindle $f$. As soon as the cage has passed, they fall back into their normal position (Fig. 483), and the cage is lowered so as to rest upon them.

The advantage claimed for keps of this kind are: Economy of steam and saving of time, besides the increased duration of the rope, which no longer has to undergo the strain of starting the cage upwards before it begins its downward journey.

Signals.-It is necesjary to have some means of communication between the various on-setting places and the top of the shaft, so that the man at the bottom (on-setter, hooker-on) may be able to inform the man at the top (banksman, lander, or engine-man), when he is ready for the cage, skip, or kibble to be drawn up.

In shallow workings shouting is sufficient; when the pit becomes deeper a speaking-tube is sometimes put in, but the commonest method of signalling is by a cord made of seven galvanised wires, and varying in diameter from $\frac{1}{4}$ to $\frac{3}{8}$ inch. The object of the zinc coating on the wire is of course to prevent or delay rusting, which would otherwise go on rapidly in the damp atmosphere of many shafts. 
The cord is carried round curves and corners by means of cranks similar to those used for house-bells, only larger and stronger, and when it is pulled by a lever at the bottom, it moves a hammer which strikes a bell at the surface. Instead of a bell, a loose plate of iron is sometimes used, which makes a very audible signal; the number of strokes indicates what is required. The usual code is as follows :

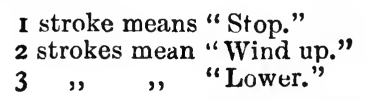

Various signals can be arranged to indicate when men are to be drawn up in place of the ordinary load of mineral; and sometimes a visible signal is combined with an audible one, a hand upon a dial recording the number of times the bell has been sounded. When persons are raised and lowered, there must also be means of signalling from the surface to the on-setting places; the object is to assure the men at the bottom that their signal has been correctly received and understood.

Electricity can also be called to the aid of the miner, and electric bells are common. Telephones * of various descriptions are sometimes used, but for the ordinary purposes of winding, the simple signal given by a bell is quite sufficient.

In addition to the signal for starting and stopping, there is an indicator which shows the engine-man the exact position of the load in the shaft.

The indicator may be a dial with a hand, worked by gearing connected with the crank-shaft of the winding-engine; the various stopping places are denoted in the same way as the hours on the face of a clock, the gearing being arranged so that the hand does not travel more than the entire circumference during the longest journey of the load.

Another form of indicator is an upright standard, 6 or 8 feet in height, with a slot, in which a pointer moves up and down. It is worked by a cord, or a steel band connected to the crank-shaft. The standard has horizontal lines, numbered according to the depths of the different stopping-places ; the gearing is contrived so that when the finger points to one of these lines, the cage is at the corresponding stopping-place.

The arrival of the load near the surface may be brought to the engine-man's notice in several ways: by a mark on the rope, by the pointer on the indicator, and by some audible signal, worked automatically by the winding-engine. A travelling hammer may be carried along by a screw, connected by gearing

* The first time the telephone was used for transmitting speech from underground workings of a mine was in September I877, when Mr. Arthur Le Neve Foster made some experiments at West Wheal Eliza, in Cornwall. 
with the crank-shaft, and eventually brought up against a bell ; it works in the same manner as the device upon typewriter's which warns the operator that he is coming to the end of a line. Instead of striking a bell, the traveller may open a cock and start a steam whistle.

5. SAFETY APPLIANCES - Overwinding - In rapid winding with large drums, a slight inadvertence on the part of the engine-man may cause the load to be drawn up against the pulley, and this is what is commonly known as over-winding. In the case of a drum 18 feet in diameter, a single revolution raises the rope $56 \frac{1}{2}$ feet; therefore, if even half a revolution is allowed beyond the proper number, an accident will ensue, unless the pulley frame gives a margin of nearly 30 feet.

There are various contrivances for preventing disasters of this

Fig. 485.

IIG. 487 .
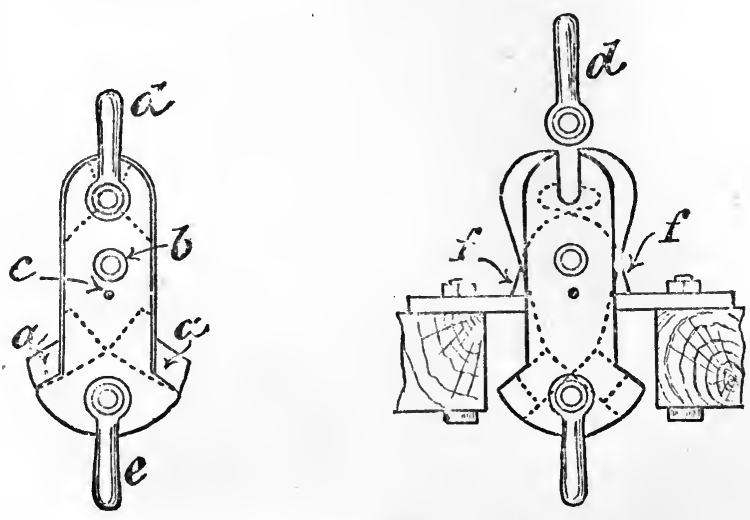

kind; one method consists in interposing between the rope and the cage a special appliance, called a detaching hook, which will sever the connection between them, allow the former to be wound up, and at the same time hold up the latter safely without damage to the load or persons inside.

Some well-known detaching hooks are those of King and Humble, Walker, and Ormerod (Fig. 475).

King and Humble's consists of an outer framework of two cheeks or sides, containing two inner plates which can move about a central bolt $b$ (Fig. 486). Each plate has a wing $a$, projecting beyond the framework. When in use the two plates are prevented from coming apart by a small pin or rivet, $c$.

If the cage attached to $e$ is wound beyond a certain height, the detaching hook is drawn into a round hole in a strong iron plate (Fig. . 487), and when the projecting wings, $a$, strike against this plate, they are forced to move inwards, the 
rivet is cut, the shackle $d$ at the end of the rope is set free, and two catches $f f$ are thrown out; these drop upon the plate and hold the cage firmly suspended.

Walker's detaching and suspending hook is like a pair of tongs, which hold the shackle at the end of the rope; the legs of the tongs are bent out, and if they are brought together the tongs open.

\section{FIG. 488 .}

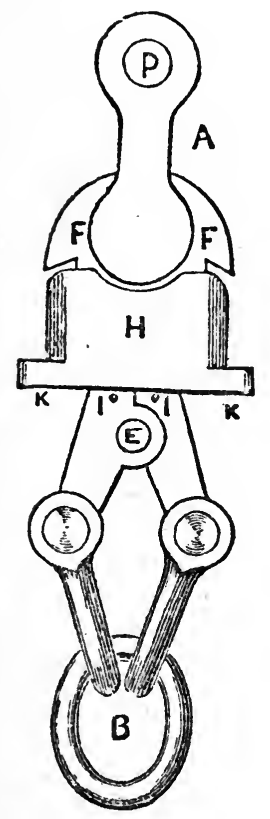

FIG. 489 .

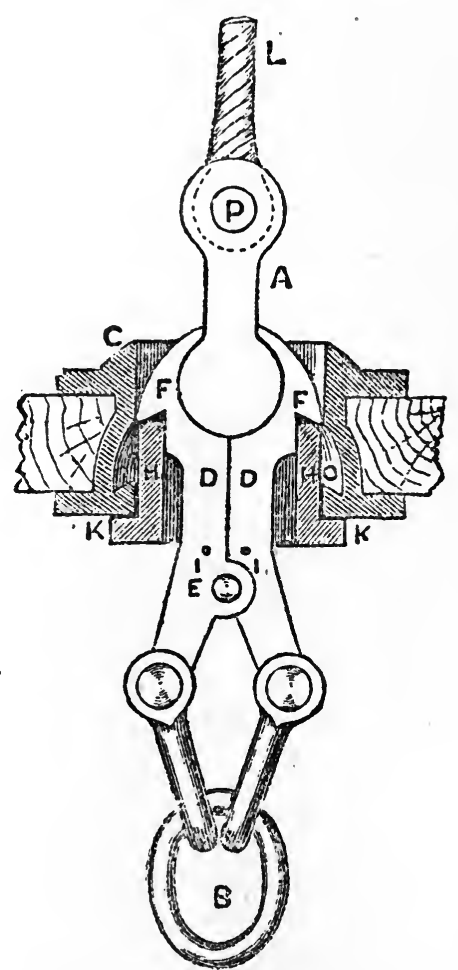

In Figs. 488,489 and $490, \mathrm{~L}$ is the end of the winding rope, and $A$ the shackle attached to it by the pin P. D D are the two jaws of the tongs, and F F are projecting hooks. $\mathrm{E}$ is the centre pin about which the jaws can move, and $\mathrm{H}$ an annular clamp which prevents the jaws from opening, as long as it is kept up by the two supporting pins I I. The cage or skip is hung on to the link B, and the weight of the load acting upon the two legs of the tongs tends to bring them together and open the jaws D D.

When winding is going on properly, the jaws are kept together 
by the clamp, and the load remains firmly attached to the rope; but if it is raised too high the detaching hook enters the strong ring $\mathrm{C}$, through which it can pass freely until the flanges $\mathrm{K} K$ of the clamp $\mathrm{H}$ strike against it. The pins I I are sheared off and

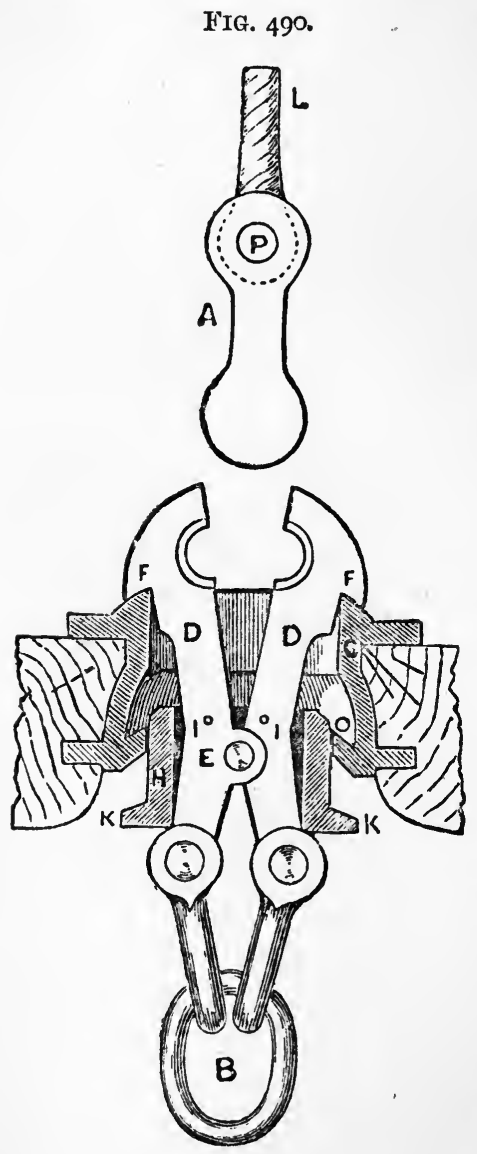
the clamp drops; but as soon as the hooks F F have passed through the ring, the jaws D D are drawn open by the weight of the load, the shackle is thus released and the hooks catch on the top of the ring C. As an additional precaution there is a projecting rim at $\mathrm{O}$, to catch the hooks if by some chance they should fail to act at the top.

Stopping Gear.-The disengaging appliances just described are designed with a view of correcting the effects of an overwind, by preventing the ascending cage from being dashed against the pulley, and then possibly falling down the shaft. But they in no way protect the descending cage from bumping on the bottom; even if they did, the old motto still holds good that "prevention is better than cure," especially as detaching hooks have been known to fail.

Engineers have therefore been anxious to obtain some means of automatically stopping the cage before it is raised too far, and many appliances for this purpose have been invented.

Three which were exhibited at the Paris Exhibition of 1889 deserve special mention, as they are in regular use at large and important mines-viz, the automatic speed-checkers and stoppinggears of Reumaux, Villiers, and Wéry.* M. Reumaux lays down

* Pamphlets issued by the Mining Companies at the Exhibition, and

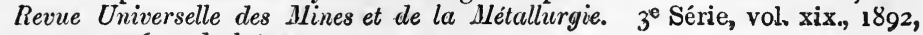
pp. 949-956, and plates. 
the principle that too much confidence must not be placed in an appliance which is only occasionally called into action ; and his selfacting speed-checker comes into play at every wind. When the cage in its ascent passes a point $30 \mathrm{~m}$. below the surface, a tappet upon the revolving indicator lifts a valve, and so puts one end of a piston valve into communication with the atmosphere; as steam or compressed air is pressing upon the other end, the valve moves and shuts off steam from the engine almost completely. The same release of pressure causes another valve to rise and let steam into the cylinder working the brake. If the engine-man, after turning on steam again, is again inattentive and allows the cage to be drawn up 2 feet above the landing, a second tappet upon the indicator once more causes the steam to be shut off; and a third tappet, by opening an exhaust passage, makes another valve drop and turn steam on to the cylinder controlling the brake. M. Reumaux's appliance is attached to all the winding machines used at the extensive Lens collieries, whether they are worked by steam or compressed air.

Villiers' apparatus is somewhat complicated, and cannot be properly understood without a figure. Suffice it to say that a nut travelling upon a screw sets gearing in motion and so actuates a friction clutch; this brings into play a regulator which opens a valve and lets out the compressed air from under a piston holding up a weight. The weight in dropping shuts off steam and puts on the brake. A second part of the apparatus, working in a different manner, produces like effects ; and, lastly, if the cage is wound up a certain distance above the landing, it strikes a catch which releases another counterpoise, the descent of which also causes the brake to act.

With Wéry's contrivance the connection between the winding drum and the checking apparatus is again effected by gearing and levers instead of fluid pressure. When the cage has reached a certain point near the surface, a nut travelling upon a screw lifts a rod carrying a pawl, which rests upon the teeth of a wheel turning round by clockwork. If the pawl rises more quickly than the wheel revolves, it lifts it, and by means of levers brings the steam-brake into action; the speed of winding is thus diminished. The clockwork is so regulated that the brake is not made to act unless the speed is excessive. To prevent danger from a slow overwind, a second rod acts in any case and turns steam on to the brake cylinder if the cage is drawn up too high.

Bertram* and Cobbold $\dagger$ have invented automatic stopping appliances which depend upon the action of a ball governor,

* "On Overwinding and its Prevention," Trans. Fed. Inst.M.E., vol. i., 1890, p. 55 .

+ "A Patent Apparatus, Indicator and Valves for the Prevention of Overwinding at Mines."-1bid., p. 6r. 
connected by gearing with the main driving shaft of the winding drum.

Paschke and Kästner's apparatus, used at many mines in tho Freiberg district, is spoken of favourably. It automatically shuts off steam and puts on the brake, not only when the cage is being drawn up too high, but also when the speed is excessive.

Safety Catches.-Much ingenuity has been displayed by various inventors during the last fifty years, with the object of providing some form of catch which will come into play if the rope breaks, grip the guides or conductors, and prevent the cage or skip from falling down the shaft.

Many of them are actuated by a spring, and one form has already been figured in describing the cage used on the Comstock lode (Figs. 48I and 482).

While the load is hanging from the rope, the spring $s s$ is drawn into the position shown by the dotted lines by the lifting bar $r$, the eye of which is figured in its two positions. The bar $c$ is drawn up at the same time, and the teeth $t t$ are held apart and kept clear of the guide. If the rope breaks, the spring forces down the bar $b$ and with it $c$; the teeth jam into the wooden conductor, and the cage is arrested and held firmly.

The safety catch used for the De Beers skip (Fig. 473) likewise depends upon the action of springs.

An objection often urged against safety catches is that they occasionally come into play when not wanted, and that owing to rust and disuse they get out of order, and sometimes fail to act at the proper moment; for these reasons they are less popular on this side of the Channel than on the Continent. Many engineers, rather than trust to contrivances which may possibly fail under the conditions met with in mines, are more inclined to put their faith in the following precautions:

I. Insuring an excellent quality of rope, by going to a maker of good repute and paying a fair price.

2. Frequent minute examination of the rope.

3. 'Testing pieces of the rope at regular intervals.

4. Protection of the rope from the action of the atmosphere or acidulous water in the mine by a suitable grease.

5. Cutting off the end of the rope where it is attached to the cage and re-making the attachment at regular intervals.

6. Discarding the rope after it has been in use a certain fixed time, even if it is apparently sound as far as outward examination can show.

Thie same feeling seems to have existed among the members of the Royal Commission upon Accidents in Mines, " for they say, "We have, however, examined several varieties of the safety cages in

* Final Report of Her Majesty's Commissioners appointed to inquire into Accidents in Mines, p. I09. London, 1886. 
use, as well as those exhibited at successive International Exhibitions, and we have considered a large number recently described and figured in an elaborate paper by Herr Selbach,* and we are unable to come to the conclusion that any one of them is a trustworthy safeguard against accidents." This opinion does not settle the question; for, on the other hand, I may refer to the conclusions which Menzel $\uparrow$ draws from the study of carefully prepared official statistics. Though far from asserting that existing safety catches are perfect, he shows that on the whole they did useful work during the seven years I 884-189o in the coal and ore mines of Saxony, and he considers that they should be applied to all cages used for winding men.

Springs.-The rope suffers the greatest strain at the commencement of the ascent of the cage. There is always a little slack rope, which is taken up as the winding begins, and this leads to the danger of a sudden strain being put upon the rope every time that it begins to lift the cage, especially in cases where winding is being carried on rapidly. In order to spare the rope from a shock of this kind and cause it to take the weight gradually, a steel or india-rubber spring may be interposed between the cage and the rope, arranged in such a fashion that the first action of the pull is merely to compress it; finally, when the compression has reached a certain stage the cage will be lifted. The bearings of winding pulleys are sometimes supported by springs with a similar object in view.

Testing Ropes.-The Commentry Fourchambault Mining Company keep a useful record of the state of their winding ropes by testing them at regular intervals. Once in every six months a piece of rope about 9 feet long is cut off and sent to a powerful testing machine, called the antheximeter, capable of breaking a new wire rope more than 2 inches in diameter. The machine registers upon paper not only the force required to break the rope, but also its elongation previous to rupture. By comparing the results obtained in this way, the gradual deterioration of the rope from wear can be followed with great precision. $\ddagger$

In the mines of the Dortmund district, no winding-rope can be used for raising and lowering men until it has been carefully tested in a manner prescribed by the Government authorities. A piece of the rope one metre in length is cut off, and the tensile strength and the flexibiiity of each wire are determined, with the exception of wires forming cores.

Pnoumatic Hoisting.-The most novel hoisting apparatus

* Zeitschr. fur das B.- H. - und S. - Wesen, vol. xxviii. I880. B. Abhandlungen, $\mathrm{p}$. $\mathrm{I}$.

† "Die in den Jahren 1884-1890, beim sächsischen Bergbau vorgekommenen Brïche von Förderseilen, Schurzketten und dergleichen." Jahrb. f. d. B.- u. H. Wesen i. K. Sachsen, 1891, p. 39.

¥ Comptes Rendus Mensuels, Soc. Ind. DIin. I89I, p. 257. 
is that of M. Blanchet, which was regularly at work in the Hottinguer shaft at Épinac in France for some years. M. Blanchet fixed in the shaft a large pipe with a piston, from which was suspended a cage carrying waggons. By exhausting the air above the piston the load was gradually forced up by the atmospheric pressure below it. The Hottinguer shaft is 660 yards deep, and the pipe was 5 feet 3 inches in diameter, made up of a succession of cylinders of sheet-iron about $\frac{5}{16}$ inch thick and 4 feet 4 inches high, joined by flanges and bolts. The 485 rings composing the long pipe weighed altogether $4 \mathrm{I} 8$ statue tons. The cage had nine decks, and arrangements were made for unloading three at a time; each waggon held half a ton, so that the total useful load was $4 \frac{1}{2}$ tons. The speed of hoisting was 20 feet per second. If two hoisting pipes are connected, the dead weights may be made to balance each other, and the power required is simply that which is necessary to overcome the weight of the useful load. All the men preferred the pneumatic hoist to the ordinary cage for descending and ascending the mine, and were regularly lowered and raised by it. The advantages claimed by M. Blanchet for this system are-(I) the possibility of hoisting from depths at which rope-winding would no longer be practicable; (2) getting rid of the costly ropes and dangers connected with rope-winding; (3) better utilisation of the engine power; (4) improvement of the ventilation and diminution of the amount of fire-damp. At the present time Blanchet's apparatus is no longer employed, but the disuse of the pneumatic method is in no way due to any difficulty in making it work satisfactorily.*

* Nougarède, "Etude historique sur le puits Hottinguer des Mines d'Epinac," Bull. Soc. Ind. Min. $3^{\mathrm{e}}$ Série, vol. vii., 1893, p. 563 . 


\title{
CHAPTER IX.
}

\author{
DRAINAGE.
}

Surface drainage-Dams-Drainage tunnels-Siphons-Raising water by winding machinery-Pumps worked by engines at the surfaceRittinger pump-Counterbalances-Bochkoltz's regenerator-Rossigneux's contrivance-Catches-Pumps worked by engines placed below ground-" Duty"- "Slip" - Co-operative pumping.

THE mineral having been raised to the surface, the task of the miner might appear to be at an end; but this is not the case, for it is further necessary that he should keep his mine free from water and foul air. These two indispensable operations of draining and ventilating require special appliances, which often add considerably to the general cost of mining.

Surface Water.-As far as possible the miner should endeavour to prevent the entry of water both at the surface and underground, and so escape the unnecessary expense of pumping it up. In some instances a good deal can be done in this direction; for it has been abundantly proved, in many cases, that the bulk of the water with which the miner is burdened is merely the result of the percolation of the rain falling in the district. The effect even of a prolonged rainfall is not usually felt at once, for it takes time for the water to find its way through minute cracks and crevices in the ground and reach the workings. In limestone districts, however, the rain may find large channels eaten out by atmospheric agencies, and affect mines at a depth of a couple of hundred yards within twenty-four hours after it has fallen.

It often happens that the mineral was quarried near the surface before underground mining was resorted to, and in that case there is always the danger of the old open pits forming a sink, so to say, which will collect water from the neighbourhood and let a considerable quantity percolate into the workings. To avoid such an objectionable state of things, the surface must be drained; special care is imperative where the ground is cracked by subsidences, and the neighbouring streams should be examined and the water carried along in launders or other safer channels, if their beds cannot be made stanch by filling the fissures with concrete. 
When working under the sea or a river, a rich lode must not tempt the miner to carry on his work too far. At Wheal Cock, near St. Just in Cornwall, the miners working in some overhand stopes actually bored more than one hole through to the seabottom. They were well aware of the proximity of the ocean, for they could hear the boulders crashing against each other in stormy weather, and they had wooden plugs ready, which they drove into the holes when they actually tapped sea water. But it was a dangerous experiment, and though in this case the rocks are so hard and compact that the amount of percolation is small, a narrow wall only four feet thick between the sea and the workings cannot be left without fear of trouble and danger from water above.

Dams.-In addition to preventing the access of water from the surface, it is advisable to cut off underground inflows as far as practicable. In the chapter upon supporting ground, impermeable linings of shafts and levels have been described, and where water can be shut out by tubbing or by coffering, the mine-owner is saved the constant expense of pumping; indeed, he is sometimes thus enabled to work deposits which he would not be able to reach if he had to fight against the enormous streams issuing from certain strata. Water from adjacent abandoned workings is shut out by dams-that is to say, artificial stoppings-placed in levels or shafts. They may be made of timber, brickwork, masonry or concrete, and, when intended for temporary purposes, of iron.

In erecting a dam the first consideration is the choice of a suitable place, for it is useless to take the trouble to put in a stanch stopping unless the ground is firm enough to support it,

FIG. 49I.

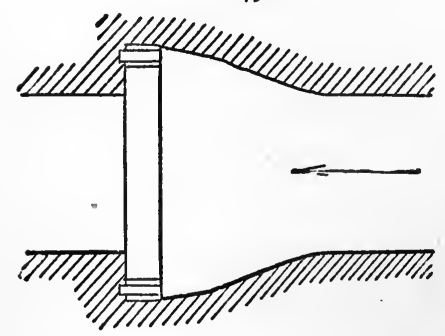
and free enough from cracks to prevent the water behind it from finding its way round to the front.

If the ground is thoroughly strong, a dam may be put in by cutting a recess in the sides of the level, as represented by Fig. 49I,* and stopping the water back by a wall made of horizontal balks of timber. Oak is usually chosen for the purpose. Before the timber is put in, the rock is very carefully dressed until the surface is perfectly smooth, and ready to receive a similar surface of wood. Each balk is wedged up against the side just in the same way as a wedging curb, and the joints between the separate balks are caulked.

* Callon, Lectures on Mining, vol. ii., rlate lxxri. 
For heavier pressures the spherical dam is available; it is constructed of wooden logs placed longitudinally and wedged up very tightly. A wooden dam of this kind has the advantage that it will yield a little if there are movements of the ground, whereas a dam constructed of bricks might become cracked and leak so badly as to be almost useless; the wooden dam is also more easily repaired. Oak, pine, and fir are all employed for making dams; the two latter are sometimes preferred to the former, because they are more easily wedged. The following account of a spherical dam is based upon a description written by Gätzschmann* (Figs. 492 to 495).

FIG. 492 .

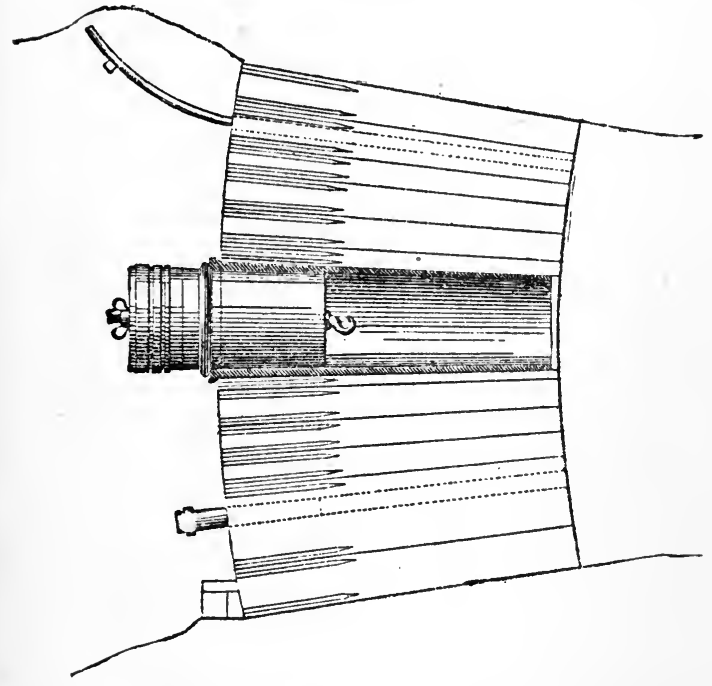

FIG. 493 .

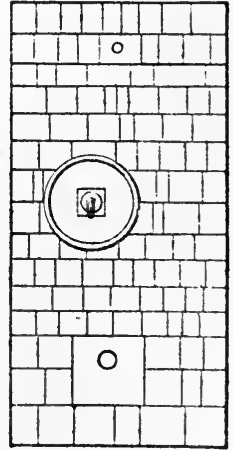

A nail is fixed upon a cross-piece in the middle of the level, about 23 feet $(7 \mathrm{~m}$.) from the proposed outer face of the dam, and the sides of the level are trimmed smooth with the greatest care along planes which would intersect in this point as a centre. Pieces of timber are cut in the form of truncated pyramids, the four faces of which converge to a centre agreeing with that chosen underground; they are fitted together at the surface, with the horizontal joints arranged along the lines of the same great circles of the sphere and the vertical joints alternating. When the logs have been duly fitted, the work of putting them in is begun. Tarred canvas is placed upon the floor of the level and the first row of

* Jahrbuch für den Berg- und Hütten-Mann auf das Jahr I84I, Freiberg. Combes, Traité de l'Exploitation des Mines. Paris, 1884, vol. ii., page :2 I, and plates. 
pieces laid down; the last piece acts as a keystone and is driven in with a sledge. One of the pieces of the second layer has a hole bored through it so as to let off any water during the progress of the work. When the middle of the dam is reached, a flanged castiron pipe is put in as a man-hole, and the other rows are built up to the roof, which has been covered with tarred canvas; a hole is bored through one of the pieces of the uppermost row but one and furnished with a bent pipe, which serves to carry off the air at the top when the dam is finally closed. The joints between the logs are made watertight by driving in wedges around them obliquely; the first wedges are of pine, the next are of hard wood, and the final set are of iron. A coating of cement, made of cart-grease, tar

FIG. 494 .

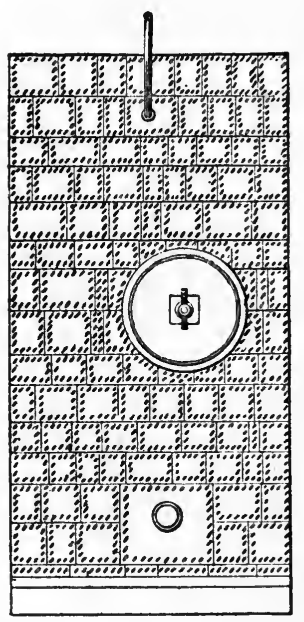

495. Fia.

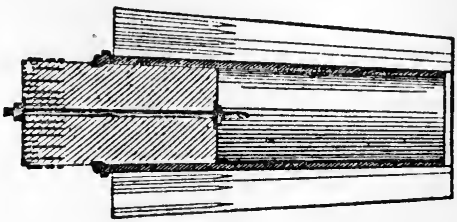

and slacked lime, completes the outer face of the dam. The miners then close the water-hole with a plug made of beech, and after retiring through the man-hole, draw into it a huge wooden stopper. The water is allowed to rise, and in due course some passes out by the air pipe ; the air-hole is then plugged, and the inside face of the dam is wedged up in the same manner as the outside. When exposed to considerable pressure a spherical dam of this kind is found to slide inwards a little. One which was put in at Churprinz Mine, Freiberg, shifted $19 \frac{1}{2}$ inches $(0.5 \circ \mathrm{m}$.) in the first fourteen hours after it had been closed, and $23^{\frac{3}{4}}$ inches altogether in the first ten days; after that the motion was exceedingly slow, in fact, almost imperceptible; but it did not absolutely cease for several years.

Fig. $49^{*}$ is a dam in an abandoned shaft, intended to shut

* Callon, Lectures on Mining, vol. ii., plate lxxvi., fig. 409. 
off any possible influx of water into the adjacent workings in case the tubbing should fail. It consists of a strong arch of masonry, covered by a thick layer of clay and a pavement of stones. The clay will keep the dam stanch even if the masonry becomes slightly cracked from movements of the ground, and the object of the stone pavement is to prevent the clay from being washed away suddenly in the event of a large crack being formed. The vertical pipe serves to carry down the water during the erection of the dam.

A temporary dam is sometimes required close to a shaft, in order to keep back the water of the mine, and prevent it from drowning the pumps while they are being repaired. A strong and tightly-fitting hinged door may suffice for the purpose; in the Furness district the door-frame is set in a very massive structure of concrete, brickwork and steel rails. A large pipe is put in at the bottom and fitted with a good valve, which enables the water to be let out gradually when the pumps are once more ready for work.

FIG. 436.

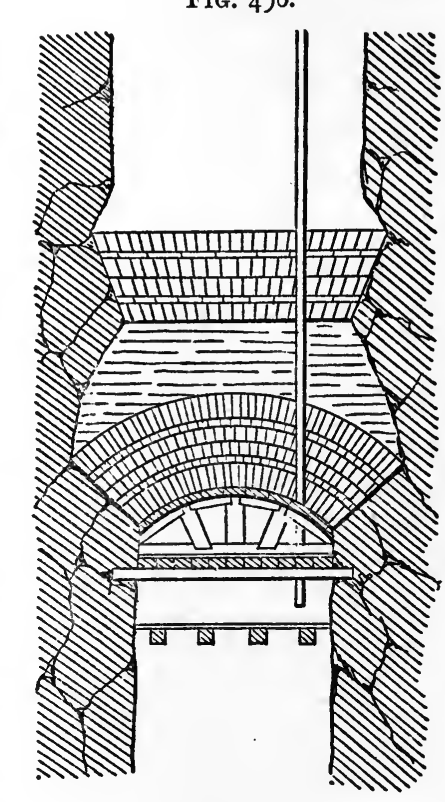

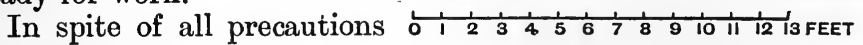
the miner generally has to contend with water which percolates into the workings. Four methods of getting rid of it are available-viz., drainage tunnels, siphons, winding machinery and pumps.

DRAINAGE TUNNELS.-An adit, day-level, or sough, is a nearly horizontal tunnel with one end opening at the surface, allowing the water to drain away naturally. In hilly countries mines are often worked entirely by adits, and even for the deeper workings the adit presents several advantages: it lessens the quantity of water percolating into them ; it diminishes the height to which the water has to be pumped; if the contour of the surface permits it, its outflow may be utilised for producing water power; and lastly, it affords a natural discharge for water used in driving hydraulic engines underground. On account of these 
very important advantages; some long and costly adits have been driven in certain metalliferous districts.

Thus in the Hartz, the Ernest Augustus adit or drainage tunnel, ("Ernst August Stolln") has been driven a distance of nearly $6 \frac{1}{2}$ miles into the Clausthal district. The total length of the adit, including its branches, is no less than 14 miles. It intersects many of the lodes at a depth of 400 yards from the surface. The total cost of this adit is estimated at $£ 85,500$.*

Another long adit is the celebrated "Rothschonberger Stolln," which unwaters some of the most important mines at Freiberg in Saxony. The length of the main or trunk adit is more than $8 \frac{1}{2}$ miles; the gradient of the greater part of it is only $I \cdot I 8$ inch in Ioo yards. Branches of this adit among the mines are more than 16 miles in length, so that the total length of the main tunnel with its ramifications amounts to about 25 miles. Most of the mines are now drained by it to a depth of 250 to 300 yards. The cost of the main tunnel was $£_{359,334}$, or nearly $\mathcal{E}_{24}$ per yard, but this includes the cost of eight shafts, heavy expenses for pumping from these shafts, the walling of the adit for $\frac{3}{4}$ mile, and all general exper ses. The length of time occupied in driving this adit was thirty-three years.

The "Kaiser Josef Erbstolln," in Hungary, is another remarkable mining tunnel, which was commenced in 1782 and completed in 1878 , at a total cost of $4,599,000$ florins. It is $10 \frac{1}{4}$ miles in length, extending from the river Gran to the town of Schemnitz, where it intersects the lodes at depths varying from 300 to 600 yards according to the contour of the surface.

In Bohemia I may mention the "Kaiser Josef II." adit which drains the Pribram mines. The length from the mouth to the Stefan shaft is $4 \frac{7}{8}$ miles, and the side branches bring up the total length to $13 \frac{5}{8}$ miles.

The great adit of the Mansfeld copper mines was begun in 1809 , and was seventy years in course of construction. It reaches from Friedeburg on the Saale to Eisleben. The first part was driven across the measures, and is, in fact, a crosscut, and it was then continued along the strike of the cupriferous seam. The total length is now $2 \mathrm{I}$ miles $(33,900 \mathrm{~m}$.). All the workings below its level, extending for a distance of more than I I miles ( $18 \mathrm{~km}$.), have their water pumped into it. The adit was driven with a rise of $I$ in 7200 ( $\frac{1}{2}$ inch in 100 yards). It is 9 feet 10 inches high $(3 \mathrm{~m}$.$) , and 6$ feet across $(1.85 \mathrm{~m}$.), in the middle where it is widest. The bottom part, 5 feet 8 inches in height, was carefully kept in the Rothliegendes so as to prevent percolation into the workings. Cross-timbers (spreaders) were put in about 5 feet above the

* Bauerman, "Note on the new deep adit in the Upper Hartz Mines," Trans. Min. Arsoc. Cornuall and Devon, I868, p. II. 
floor and serve to support a single line of rails and a gangway of planks.*

The adit at Monteponi, $\uparrow$ in Sardinia, recently finished, is $3 \frac{3}{4}$ miles (6 kil.) in length, and relieves the mine of its water for an additional depth of about 160 feet $(5 \circ \mathrm{m}$.).

The great County adit in Cornwall was driven for the purpose of draining the Gwennap copper mines, and it was pushed on to Redruth. 'This adit differs from those just mentioned by the fact that it commences in the mining district itself, and though the length of all the drivages amounts to more than 30 miles, the water from the most distant mine does not run more than 6 miles before reaching daylight. The average depth is only 70 or 80 yards from the surface. In fact this great adit, though a work of great utility when the Gwennap district was in a flourishing condition, is merely a network of shallow tunnels, often driven along the lodes themselves, and therefore for boldness of execution cannot for one moment be compared to the great adits in Germany and Hungary.

The Blackett level in Northumberland is an adit which has been driven a distance of about $4 \frac{3}{4}$ miles, and which will have to be extended about 2 miles further before arriving at Allenheads. Its depth from the surface at that place will be about 200 yards.

The main part of the Halkyn tunnel in Flintshire has now rcached a total length of 4 miles. The branch which goes out to Rhosesmor Mine is nearly half a mile long and a second branch has been commenced. The greatest depth from the surface is $23^{\circ}$ yards, and the average depth under Halkyn Mountain about 2 I 5 yards. The length and depth of the adit are not remarkable; but the quantity of water discharged is a matter of interest and importance. It is estimated that this adit is now discharging 15 million gallons or 66,000 tons of water in 24 hours, although the outflow is purely natural, for no mines are pumping water into it, It is easy to understand that the Rhosesmor Mine, though provided with powerful pumping machinery, was unable to cope with the springs it encountered.

In the United Kingdom, where the land and the minerals are parcelled out among various owners, an undertaking of this kind requires a special Act of Parliament, for otherwise one obstinate proprietor might bar the way altogether, or mines drained by the adit might refuse to pay for the advantages they received. Before the Halkyn tunnel was driven, the area which appeared likely to be benefited was duly determined, and the

* Der Kupferschieferbergbau und der Hüitenbetrieb zur Verarbeitung der gewonnenen Minern in den beiden Kreisen der Preuss. Prov. Sachsen. Hallo an der Saale, I 889 , page 48.

† Pellati, "I Progressi nelle Industrie Minerarie e Mineralurgiche Italiane," Industria, vol. v., 1891, p. 637. 
mines now worked within it have to pay a royalty to the tunnel company for every ton of ore they raise.

Fired by the success of the Halkyn adit, which has proved a lucky investment for the shareholders, a company has lately commenced driving a similar tunnel in the Llanarmon district.

The United States may fairly boast of the Sutro Tunnel, which enters the workings on the Comstock lode at a depth of 1700 feet from the surface. Work was begun on a small scale in October 1869 , and the tunnel was "holed" into the workings of the Savage Mine in July 1878 . The length of the main tunnel is $3 \frac{7}{8}$ miles, and the cost of excavating it and timbering it up to the date of its completion, September I, 1878 , was $\$ 1,367,577$. To this must be added $\$ 296,724$ for enlarging the heading, $\$ 384,824$ for cutting a drainage channel at the bottom of the tunnel and lining it with wooden launders or drain boxes, and the cost of repairs $\$ 43,44 \mathrm{I}$, making the total cost of the main tunnel up to October I88I, \$2,096,566. This sum does not include the expenses of management of the company.*

The size of the adit at first was ro feet high clear and ${ }_{5} \frac{1}{2}$ feet wide; but after 366 yards had been driven the dimensions were reduced to 6 feet high clear by 5 feet wide.

In the original scheme it was proposed to sink four shafts and expedite the work by having nine points of attack; however, this plan could not be carried out. The first two shafts were sunk down to the level of the tunnel, but the quantity of water met with proved such an obstacle that the tunnel was practically driven entirely from one end.

Work with machine drills was begun in April 1874, and the height of the heading was raised to $9 \frac{1}{2}$ feet, and the width to 13 feet, both outside the timber. In 1875 and 1876 the monthly progress was on an average $308 \frac{1}{4}$ feet. Much of the tunnel, indeed $45^{\circ} 5$ per cent. of the total length, had to be timbered.

In addition to the main tunnel there are branches along the course of the lode. In October I880, the length of the north branch was 4403 feet, and that of the south branch 4II4 feet. Both branches are 8 feet in width by 7 in height clear.

The quantity of water running out daily in 1879 was 12,000 tons, at a temperature of $123^{\circ} \mathrm{F}$. $\left(50^{\circ} 5 \mathrm{C}\right.$.) when leaving the mouth of the tunnel. All this water would otherwise have been pumped to the surface, at a cost estimated at $\$ 3000$ a-day.

The obstacles to the progress of the work were very great; not only was the heat extreme, but swelling ground was encountered which snapped the strongest timber. Thanks, however, to the untiring energy of Mr. Adolph Sutro, the difficulties were at

* Eliot Lord, "Comstock Mining and Miners." Monographs of the U. S. Geol. Survey, vol. iv., p. 342. Washington, 1883. There is an error of $\$ 4000$ either in one of the items or in the total; but I give the figures as they stand in the Report.-C. I. N. F. 
last successfully overcome, and this great work will long remain as a monument to his foresight, skill, and patient pertinacity.

The Atlantic-Pacific tunnel, which was commenced in I880 and then stopped for a time, is intended to pierce the heart of the Rocky Mountains, under Grey's Peak, Colorado. It will be driven from both sides of the watershed, and will have a total length of $4 \frac{3}{4}$ miles from end to end.

SIPHONS.-Siphons are used for draining mines in a few special cases in which the barrier over which the water has to be raised is very decidedly less than 33 feet.

The workings of a shallow mine in North Wales are kept clear of water by a siphon made of $1 \frac{1}{2}$-inch gas-pipe. At the crown there is an iron tank full of water, the contents of which can be run into the siphon by a 3 -inch pipe in order to start it.

At Mountfield gypsum mine, in Sussex, the water is brought to the shaft from the neighbourhood of the working-face, a distance of 300 yards, by a siphon also made of $1 \frac{1}{2}$-inch gas-pipe. It has two branches, but only one is working at a time. The water is lifted a height of 22 feet. When the water in the workings sinks, so that there is a danger of the siphon running dry, the foreman moves a lever which brings a pad of india-rubber against the outlet of the pipe, and so keeps it full and ready to act the next time it is wanted. A force pump is set up at the far end of the workings for filling the siphon if by any chance the water has run out.

WINDING MACHINERY.-When a mine cannot be drained by tunnels or siphons, it is necessary to raise the water mechanically, either to the surface, or at all events to an adit through which it can flow out naturally. If the quantity is not excessive, it is often convenient to use the winding machinery, and draw up the water in special buckets (water-barrels) or tanks. The bucket may be tilted over on reaching the surface, or it may be emptied by opening a valve at the bottom.

This means of raising water is commonly adopted in sinking shafts, when it may be desirable to wait till the whole or a portion of the pit is completed, before putting in the final pumping machinery. The water is usually lifted by hand into the bucket or tank, an operation involving a good deal of labour. Some of the baling may be avoided by collecting as much as possible of the inflow in a cistern above the bottom, and drawing off its contents by a hose into the bucket. This device is of no use for the water actually at the bottom, but baling may be dispensed with even in this case by the adoption of an ingenious arrangement invented by Mr. Galloway, and applied very successfully by him in sinking a shaft near Cardiff* (Figs. 497 and 498).

* "Sinking Appliances at Llanbradach," Trans. South Wales Inst. Eng. vol. xvi., 1888, p. 117 . 
By means of a pump at the surface, the air is constantly being exhausted from a pipe, which descends the shaft and terminates in a long piece of flexible hose provided with a stopcock. When the cylindrical water-barrel has been lowered to the bottom of the
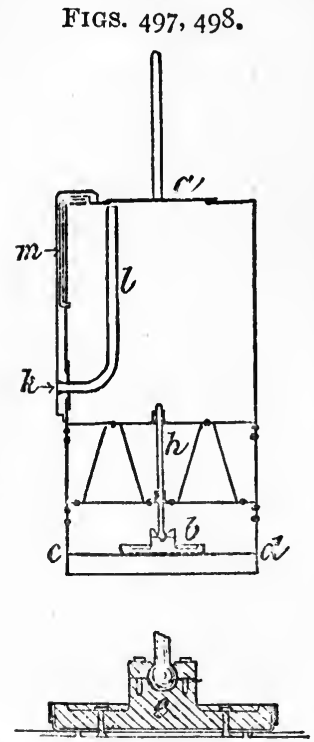

$a$, door for entering barrel if required; $b$, flat castiron valve attached to the spindle $h ; c d$, bottom plate of the barrel ; $e$, section of the valve showing universal joint attachment ; $l$, water-pipe, provided at the end $k$ with a coupling to which the suction hose is attached; $m$, water-gauge. shaft and is standing with its base in water, the flexible hose is quickly attached to it at the point $k$ by an instantaneous coupling, and the cock is turned. Water is at once sucked up through the valve $b$, and as soon as the gauge-glass $m$ shows that it has reached the desired height, the stopcock is closed and the hose uncoupled. On arriving at the top of the pit, the waterbarrel is lowered on to a trolley carrying a projecting conical block of wood, which knocks up the valve and allows the contents to run out.

It was possible with the aid of this contrivance, while sinking a shaft in hard sandstone at the rate of 5 to $5 \frac{1}{2}$ yards per week, to cope with an influx of 5000 gallons $(22.7$ cubic metres) of water per hour at the bottom.

A water-barrel can be filled automatically, when it can be made to plunge into a deep cistern or collecting pit (sump). Mr. Galloway's arrangement is shown by Figs. 499 and 500. The former represents his automatic water-tank with one side partly removed : $a$ is the winding-rope, $b$ the tank, which is guided in its descent and ascent by the studs $c$ (Fig. 500) running upon the guide ropes $e$. At the surface the tank is further steadied by side grooves, made of angle-iron $d$, which clasp the studs. When the tank is lowered into the cistern, the valve $k$ opens of itself and lets the water rush in. It is then wound up to the top, where the short lever at $o$ comes in contact with the piece of timber $p$; the rod attached to the valve is lifted, and the water rushes out by the sloping mouth $f$ into the wooden trough or launder $m$. The bar $p$ is movable about the point $q$, but it is kept down by the weight $u$ attached to the chain $s ; t$ is one of the pieces of timber to which the fixed guides are fastened, and lastly, $w$ is the suspending bow which passes quite round the tavk and forms a projecting loop at the bottom. This bow protects the bottom of the tank while it 
is standing in the cistern. The tank holds $2 \times 2$ gallons $(963$ litres), and can be drawn up 24 times an hour from a depth of

FIG. 499.

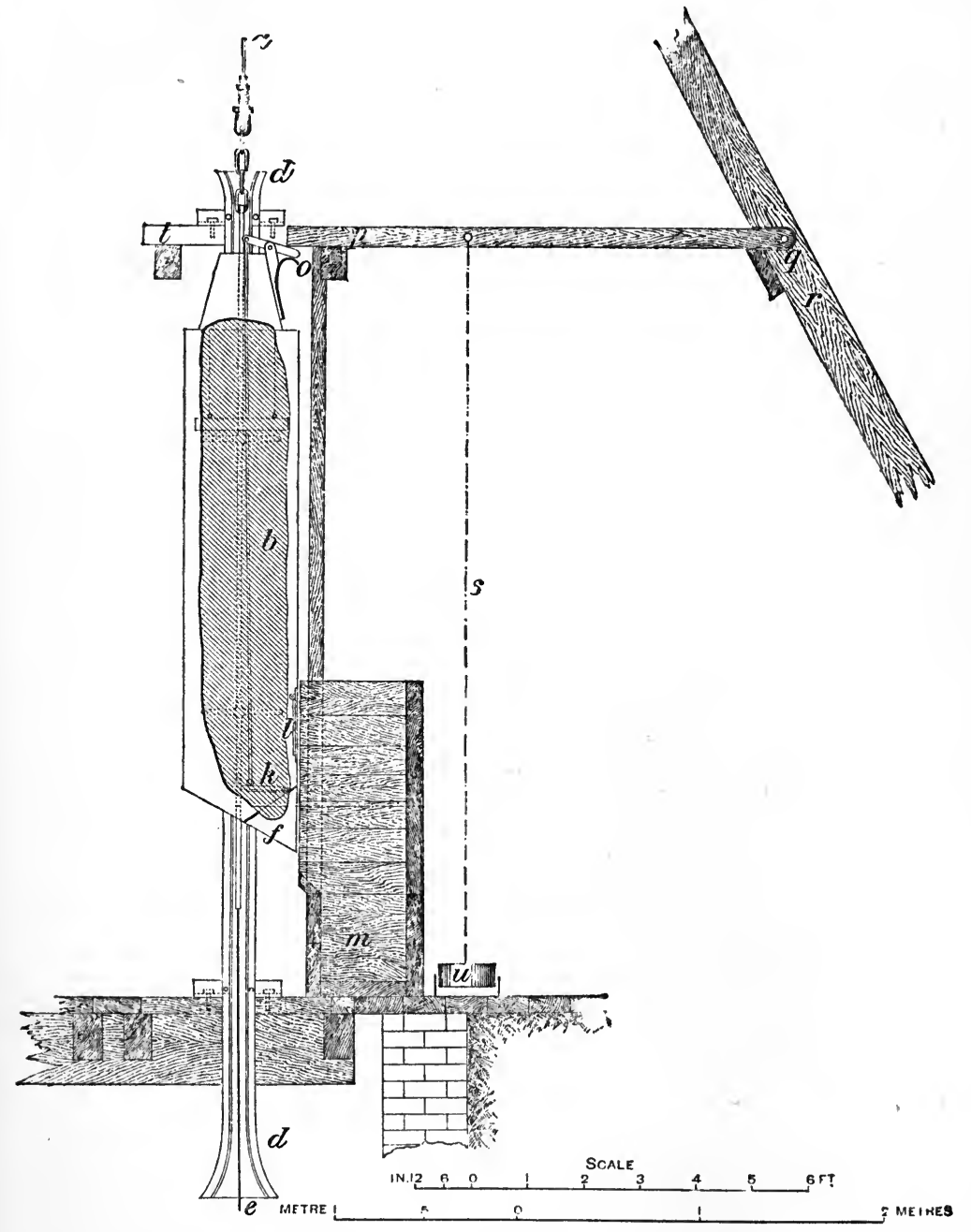

190 yards; it is therefore capable of raising 5000 gallons $(22.7$ cubic metres) in that time.

The arrangement just described was employed by Mr. Galloway when sinking, but it is equally available as a permanent method 
of drainage when the quantity of water is not considerable. The water is allowed to accumulate in a sump at the bottom of the shaft during the day-time, for instance, and at night, when no mineral is being wound, the ordinary cage is taken off and the water-barrel substituted for it.

FiG. 500.

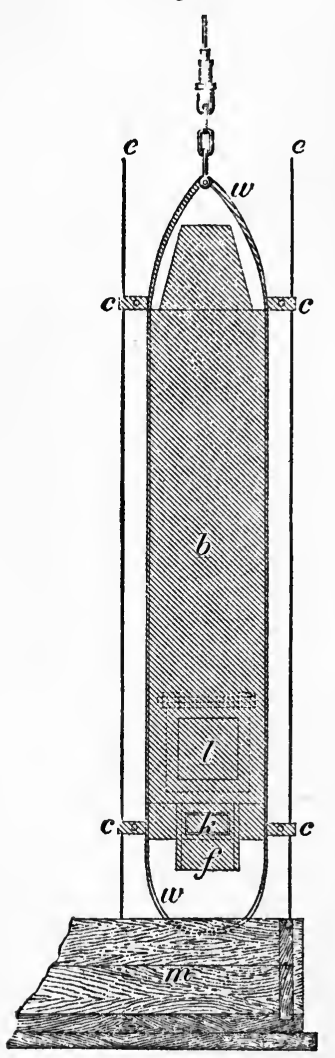

The water-barrel is also useful as an auxiliary, when the ordinary pumping machinery of a mine is unable to cope with some unusual influx of water, or has to be stopped for repairs. It is not necessary to adopt the construction shown in the figure, though that is a particularly advantageous one. The vessel for receiving the water and bringing it up is sometimes made like a large mine waggon; it is drawn up in the cage, like a "tub" of mineral, and is discharged at some point in close proximity to the pit-top. At the Van mine a tub of this kind holds about 220 gallons (I cubic metre). As a makeshift, an ordinary mine-skip may be turned into a water-barrel by fixing a wooden box inside it with a valve in the bottom.

Automatic emptying and filling is also obtainable where the mine is worked by inclines or "slopes," and the arrangement used by Mr. Bowden* (Figs. 501 to $5 \circ 3$ ) has the merit of allowing several tanks to be used in the place of a single large one, which might be too unwieldy for the mine. Each tank has an iron door at the rear end opening inwards, and a wooden door at the front end opening outwards. The front door is attached to the back door by an iron rod, so that it is held down as long as the back door is shut; however, the back door can open independently of the front door, because the rod has a sliding link at the rear end. The tipping or dumping is effected by the small wheels above the rear axles. They have a wider gauge than the regular wheels, and as each tank comes up to the surface, they are taken by an upper set of rails and tilt up the rear end. If the track upon which they travel has sufficient gradient towards the "slope," the

* Bowden, "Tandem Tanks for Hoisting Water from Flooded Slopes" Trans. Amer. Inst. DI. E., vol. xx., 1891, p. 343 . 
tanks will run down of themselves, after they have emptied their contents into the trough at the top.

PUMPS.-We now come to the main division of the subject of drainage, for the standard method of extracting water from underground workings is by some form of pump.

The varieties of pumps used in mines are numerous. In small sinkings, hand-pumps, either direct-acting or rotary, may be applied; steam-jet pumps, on the principle of the Giffard injector, and pulsometers are also used, but when we examine the

FIGs. 50i, 502.

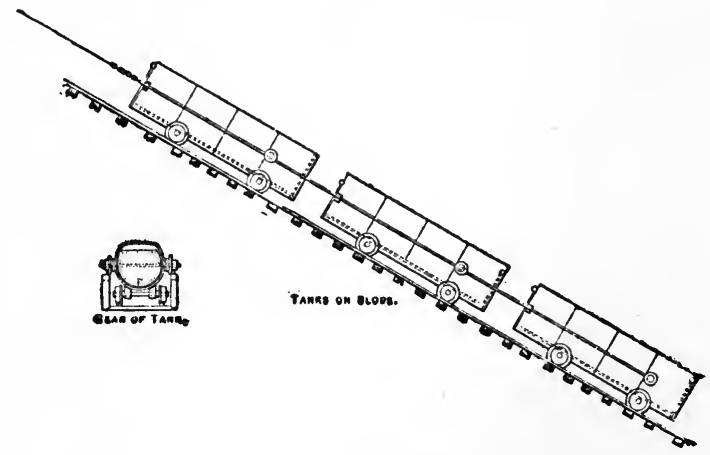

FIG. 503.

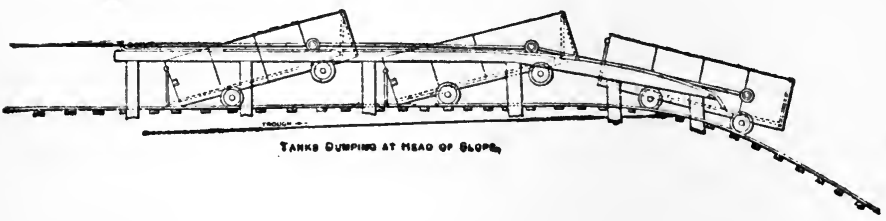

permanent machinery erected at large mines of considerable depth, we find that the prevailing types of pumps are few.

They may be classified, according to the situation of the engine working the pumps, into:

I. Lifting pumps and force pumps worked by power transmitted by rods from an engine at the surface or in the upper workings.

II. Force pumps worked direct from an engine immediately attached to them at or near the bottom of the workings.

Class I.-Engine at or near the Surface, Power Transmitted by Rods.

We may consider the subject under the following four heads :

(a) Motors.

(b) Rods.

(c) Pumps.

(d) Accessory arrangements : counterbalances, regenerators, catches. 
(a) Motors.-The engine may be driven by wind, compressed air, water, electricity, steam, or petroleum. (I) A ir.-Windmills have the disadvantage, which is often fatal, that the power is not constant; the same may be said of water power derived from brooks and rivers, which sometimes dry up; but the two cases are different. Streams dry up slowly and gradually, whilst air currents spring up or die away suddenly. By erecting an auxiliary steam engine, which can be set to work if the wind fails, the evil is overcome; and this remedy is adopted at the Mona mines in Anglesey, where a windmill has been in use for many years for working pumps. It raises water from a depth of 80 fathoms at the rate of about 90 gallons a minute. As the site of the mine on Parys Mountain is breezy, there is wind enough to work the mill for about one-half of the time pumping is required. A very large saving has thus been effected in the coal bills.

(2) Water.-Water power was for a long period the principal agent employed in draining mines, and it is still of the greatest use in many districts, reservoirs being constructed to collect and store the rainfall. Some idea of the scale upon which works of this kind are conducted will be gathered from the following figures relating to the Hartz mines.* In 1868 there were "sixty-seven reservoirs, covering an area of 604 acres, and having a total storage capacity of 336 millions of cubic feet."

The total length of the various leats, races, and other watercourses, including the six principal adits, is about $\mathrm{I} 70$ stature miles. The net power extracted is reckoned at 1870 horse-power, but less than one-fourth of this is used for pumping.

Water power is applied to pumping machinery by waterwheels, turbines, and rotary or non-rotary water-pressure engines. Excepting in the case of the latter, the rotary motion has to be converted into a reciprocating motion by a crank; and furthermore with turbines, the speed must be reduced very considerably by intermediate gearing.

Overshot wheels are the cornmonest forms of prime movers for working pumps by water-power; they are frequently from 40 to $5 \circ$ feet in diameter, and at Great Laxey Mine, in the Isle of Man, one of the wheels is no less than 72 feet 6 inches in diameter, and 6 feet in the breast. The power is conveyed from the water-wheel by a connecting rod to a quadrant or "bob," like a bell-crank, placed above the shaft, and when, owing to the contour of the ground, the wheel has to be erected at a distance, it is often connected to the bob by the so-called "flat rods," which are beams of wood, bars of iron, or pieces of wire rope. They are supported by pulleys or upright oscillating

* Bauerman, "Notes on the New Deep Adit in the Upper Hartz Mines," Rep. Miners' Assoc. Cornuall and Devon, 1868, p. $2 \mathrm{I}$. 
beams, and travel backwards or forwards with the motion of the crank.

Water-pressure engines share with turbines the advantage of being able to utilise any amount of fall, and the direct-acting water-pressure engine can be applied immediately to the main rod of the pumps.

(3) Stecm is, however, the power used par excellence for working pumping machinery, and the great inventions of Newcomen and Watt owed their birth to the necessities of mines, which could no 'longer be drained by the water power available on the spot.

The principal type of engine is that known as the Cornish engine; it is a single-acting condensing beam engine, working expansively, having the number of strokes regulated by an arrangement called a cataract. The cylinder of the Cornish engine is sometimes inverted and stands over the shaft, the main rod of the pumps being attached directly to the piston-rod. This type of engine, known as the Bull engine in Cornwall, dispenses with the heavy beam, but it has the great disadvantage of obstructing the mouth of the shaft. This objection is quite enough to forbid its use under ordinary circumstances. On the other hand, the mere reversal of the cylinder or cylinders, while retaining the beam, is often resorted to on account of the advantage it gives in greater stability and diminished cost of the engine-house.

A disadvantage of the Cornish engine is the fact that when it works with a high rate of expansion, there are great shocks and jars to all the parts of the rnachinery. The heavy mass of rods and its connections is started with a jerk, and naturally all the joints must suffer.

The compound engine, invented by Woolf and tried many years ago in Cornwall, starts more gradually and causes less strain upon the pump-rods and machinery generally. The cylinders may be placed one above the other, or side by side. At Ernst IV. shaft, Mansfeld, there are three cylinders placed side by side across the line of the beam, the high-pressure cylinder in the middle between the two low-pressure cylinders. The three piston-rods are attached to a crosshead which is connected to the beam. The cylinders are inverted.

Kley, of Bonn, has constructed compound engines with steam acting on both sides of the pistons. He makes the excess of the weight of the rod over that of the counterbalances sufficient to raise only half the weight of the water and to overcome the friction; and then in the descending stroke of the rod the steam again acts upon the pistons and so makes up for the insufficiency in weight. As the steam acts upon both sides of the piston, the same amount is consumed, it is true; but a smaller cylinder will do the work, and the original cost of the engine is lessened.

Fly-wheels have the advantage of setting the pumps and main 
rod in motion without the. injurious jerk which is inseparable from the Cornish engine worked at a high rate of expansion, besides reducing the risks of damage if a piston-rod breaks.

Kley has put up several pumping engines in Belgium, France, and Germany, of 30 to 560 horse-power, with a fly-wheel which serves solely to regulate the stroke of the piston, so that the crank always stops before or after the dead point till the cataract starts another stroke. The machines are double-acting compound beam engines.

M. Guinotte, the well-known Belgian engineer, also adopts the fly-wheel, and the machines he has erected at Mariemont and elsewhere are single-acting rotary engines with one cylinder. The peculiarity of his fly-wheel is that he can weight it in any way he pleases; and he so overcomes the difficulty which occurs in other rotary machines of its being impossible to work them below a certain speed. His object is to make the speed slow at the beginning and

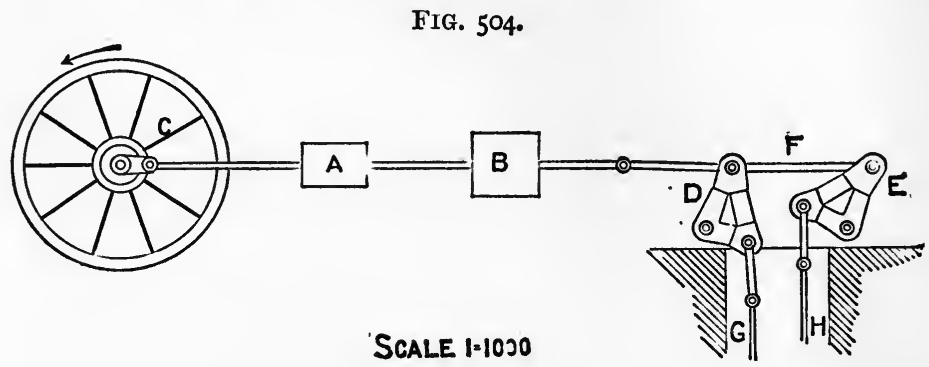

end of the stroke, so as to avoid the injurious shocks to the valves and machinery generally from sudden starts and stoppages.

The cylinders of a pumping engine may be placed horizontally, an arrangement which effects a decided saving in the cost of foundations and in that of the engine-house. The engine lately erected at the Otto IV. shaft at Mansfeld (Fig. 504) is a horizontal double-acting compound engine with a fly-wheel, working two pump-rods by means of quadrants. A is the highpressure cylinder, B the low-pressure cylinder, $\mathrm{C}$ the fly-wheel, $\mathbf{D}$ and $\mathbf{E}$ are quadrants, connected by $\mathbf{F}$, which raise and lower the two rods $G$ and $H$. The cylinder $A$ is 5 feet $2 \frac{1}{2}$ inches $\left(r^{\circ} 590\right.$ $\mathrm{m}$.) in diameter, and B 8 feet $\mathrm{I} \frac{1}{2}$ inches $(2.480 \mathrm{~m}$.). The stroke of the engine is 8 feet $8 \frac{3}{4}$ inches $(2.660 \mathrm{~m}$.), and the fly-wheel makes 1 I $\frac{1}{4}$ revolutions per minute. When working at this speed it is reckoned that it raises $35^{21}$ gallons ( 16 cubic metres) of water per minute, a total height of 906 feet $(276.35 \mathrm{~m}$.). The water is salt, and has a specific gravity of $I^{\circ} \mathrm{I}$. Each rod works a pump at the bottom, with a fixed hollow plunger $27 \frac{3}{4}$ inches $(705$ $\mathrm{mm}$.) in diameter and a moving "pole case," which lifts the water to a height of $46_{3}$ feet $\left(14 I^{\prime} I \mathrm{~m}\right.$.). Here the work is taken up by a 
Rittinger pump with plungers of $27 \frac{1}{2}$ inches $\left(700 \mathrm{~mm}\right.$.) and $21 \frac{1}{4}$ inches $(540 \mathrm{~mm}$.), and the water is raised by it to the adit level, an additional height of 443 feet $\left(135^{\circ} 25 \mathrm{~m}\right.$.). The stroke of the rods is 2 metres. When the full power of the engine is not required, one rod can be disconnected and the other is balanced by an accumulator.

At Diepenlinchen, near Stolberg, an engine of similar construction has been put up within the last few years, the dimensions of the two cylinders being almost the same as those adopted at Mansfeld. The problem at Diepenlinchen is to raise 2640 gallons ( 2 cubic metres) of water per minute from a depth of 328 yards (300 m.).

The compound engine, with its two cylinders placed tandem fashion horizontally, is largely used by Davey, whose principal improvement consists in his patent differential valve gear, which combines the action of a cataract with that of a slide valve.

(4) Petroleum.-Where coal is very expensive owing to the cost of carriage, a petroleum engine may be a convenient source of power for pumping on a small scale.

(b) Rods.-Having discussed the principal forms of engines used for pumping at mines, it now remains to consider how their power is applied to the pumps themselves.

The usual mode of transmission is by rods made of wood, wrought iron, or steel.

Wooden rods are commonly constructed in this country of pitch-pine beams of square section, united by plates of iron or mild steel (strapping plates, $a, b, c$, Fig. 5०5), which are held together by bolts, the butt end of one beam being brought against the butt end of the next. Other forms of joints, such as the scarf joint, are met with.

The iron and steel rods are either solid bars of round iron or steel, or beams built up from angle-iron or angle-steel, so as to obtain the desired stiffness without undue weight. It is proposed to use Mannesmann seamless steel tubes, which can be rolled in lengths of 70 feet, as rods for pumps.

The long beam, made up of a succession of pieces, constitutes what is called the main rod or spear-rod. It hangs down the shaft, either from the end of the beam of the engine, or from a quadrant such as is FIG. 505 .

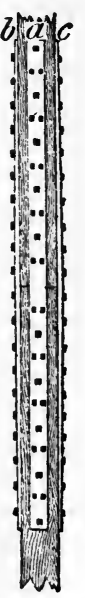
shown in Fig. 504, when the cylinder of the pumping engine is horizontal. In order to prevent it from vibrating sideways, it has to be guided; wooden rods are guided by cross bars of timber placed in the shaft, and they are protected from wear by pieces of plank (lining boards), which are renewed from time to time. The round iron or steel rods are kept in position by suitable collars fixed upon timber or metal supports. 
If the shaft is inclined, as so often happens in vein-mining, the main rod has to be supported at suitable intervals by cylinders of cast iron or steel, known as "shaft rolls." The roller turns upon a spindle as the main rod moves up and down (Fig. 539).

The bane of some mining districts, such as Cornwall, is the varying inclination of many of the pumping shafts, which have

FIG. 506.

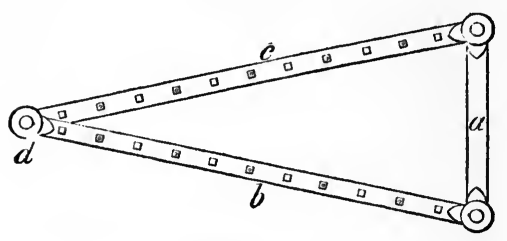

FIG. 507.

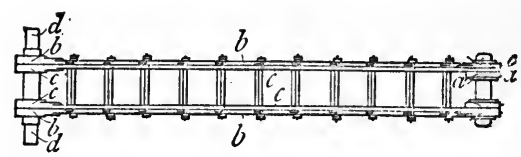
been sunk along the dip of the veins. In cases of this kind it is necessary to make. bends in the main rod corresponding to the crookedness of the shaft. Four methods of making an angle in the rod are: (I) the V-bob;* (2) the fendoff bob; (3) the runningloop; (4) hydraulic pistons.

The V-bob, as its name implies (Figs. 506 and 507 ), is a V -like frame, something like a bell-crank, interposed between the ends of the two rods. The two arms of the $\mathbf{V}$ are made of strong beams of timber strengthened by iron plates $b$ and $c$, and connected by two straps $a$, which prevent their being pulled apart. The arms are arranged so that each is at right angles to the

FIG. 508.

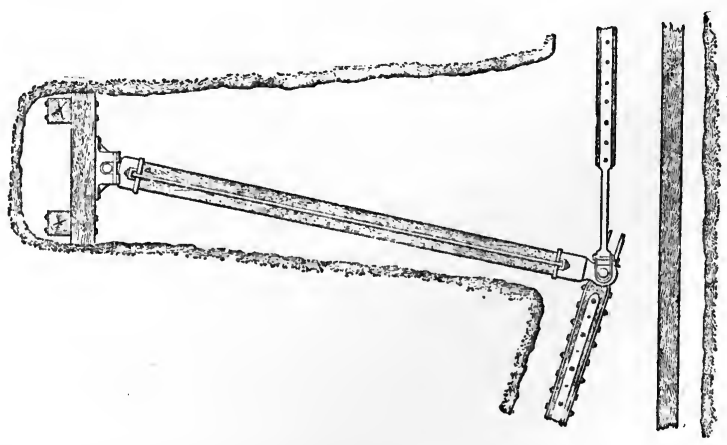

adjacent end of the rod at half stroke. At the point of the $\mathbf{V}$ there is a strong pin $d$ lying in brasses, about which the bob moves as a centre. It is usual to make the arms at least 20

* This figure and several of the others relating to pumps are copied, by permission, from a paper on "Cornish Mine Drainage," by Mitchell and Letcher. Forty.third Ann. Rep. R. Cornwall Pol. Soc., Falmouth, 1875. 
inches long for each foot of the stroke. Therefore for a stroke of 9 feet, the length of each arm would be $9 \times \mathrm{t} \frac{2}{3}$, or 15 feet.

A fend-off beam will be understood from Fig. 508, which is an example taken from Crenver and Abraham Mine in Cornwall. It is a long beam, strengthened by tie-rods, moving about a strong pin working in a block. The Cornish rule is to make the beam $2 \frac{1}{2}$ times as long as the stroke.

The running loop (Figs. 509 and 510 ) is sometimes used to save the expense of cutting out the large recess (plat) which is required in the case of a V-bob or a fend-off beam. The two parts of the main rod, $c$ and $d$, are connected by two loops of wrought

FIG. 509.

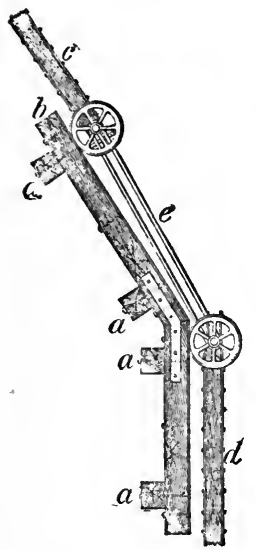

Side View.
FIG. 5 IO.

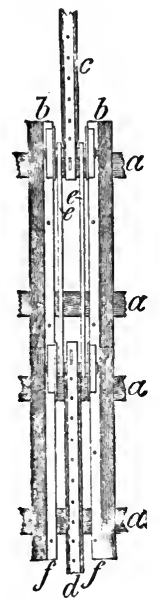

Front View.
FIG. 5 II.

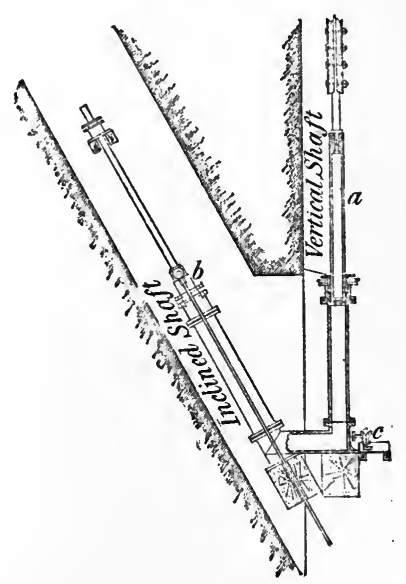

iron, $e$, of which one only can be shown in the side elevation. Each loop passes round the two pins, which are the axles of the two wheels. The wheels run upon flat bars of wrought-iron, $f$, laid upon the sleepers, $b$, which are supported by the strong cross-bearers, $a$ a.

West and Darlington effect the change of direction in the rods by two rams or plungers, working in cylinders connected at the bottom (Fig. 5II). The plunger $a$ in going down raises the plunger $b$, to which the main rod of the pumps is attached by a crosshead and two side straps. There is a valve at $c$, through which the plunger can draw in a little water to make up for any loss through the stuffing boxes.

(c) Pumps.-The main rod, which has just been described, is used for transmitting the motion of the engine to a pump or several pumps in the shaft. These pumps are of two descrip- 
tions: (I) lifting pumps; (2) force-pumps. The lifting pump, or drawing lift (Fig. 512), consists of the wind-bore or suction pipe, the clack-piece or valve-box, the clack-seat piece, the working barrel, the bucket with its rod and the column.

The wind-bore, or snore-piece, as it is sometimes called, is a cylinder of cast-iron, terminating in an egg-shaped or a flat bottom, with a number of holes through which the water is sucked up into the pump.

The clack-piece is a short cylinder of cast iron with a flat side door fastened on by bolts, the object of which is to enable the valve to be taken out and renewed. It receives the seat on which a clack or valve works.

The clack seat-piece is not always used; but it is often put in as a matter of precaution, in case the regular valve should accidentally fail while the pumps are under water. If a mishap of this kind occurs, a special clack can be lowered on to the clack seat-piece, and the pump can be worked with it temporarily.

The working barrel is a cast-iron cylinder, carefully bored so that the bucket may work in it smoothly and exactly; occasionally it is bushed with brass.

The bucket is merely a moving valve, consisting usually of a hollow cylinder of cast iron, surrounded by a band of leather or gutta-percha, and attached to a rod through which it receives its reciprocating motion. The seat, called the "form," may be made for a single valve or a double valve. The "form" shown in Figs. $5^{1} 3$ and $5^{1} 4$ is made for one valve, and it is held by a stout rod with two forks or "prongs." The mode of attachment of the prong $a$ to the form $b$, by the so-called half-moons $c$ and cotters, is evident from Figs. 5I4 and 5I5. When there are two valves the form is made as shown by Fig. $5^{1} 6$ or Fig. $5^{17}$, and the rod, now called a " sword," is attached by a central blade which passes through a corresponding slot in the middle rib.

The valve itself is made of a flat piece of leather riveted between two iron plates and fastened at one end (Fig. 5 I3) by spikes or bolts, or of two similar semi-circular pieces of leather attached at the circumference (Fig. 516) or in the middle of the form (Fig. 517). In either case there is a band of leather or gutta-percha round the form which makes the bucket fit exactly in the working barrel. This band is cut out in the shape of a segment, such as is shown in Fig. $5^{18}$, and is then bent round the form and kept in its place by an iron hoop or ring. Leather is usually employed, and is sometimes made from buffalo hide, in order to obtain great durability; with gutta percha there is the advantage of being able to utilise a worn-out band in making a new one. After it has been softened in hot water and well kneaded up with a little fresh gutta-percha, to supply the waste, it can be rolled out in a proper mould into a band of the desired shape. Richardson's composition consists largely of 
gutta-percha, and makes a durable and economical pump-bucket. The bucket is attached to the rod by a square sliding clasp and a cotter. The bucket-prong, or sword, has a little projecting ridge (Fig. 5 I4) which fits into a corresponding recess in the end of the rod; when the clasp has been drawn over and the key inserted, the joint is complete. The actual rod itself may be of wood or

FIG. 512.

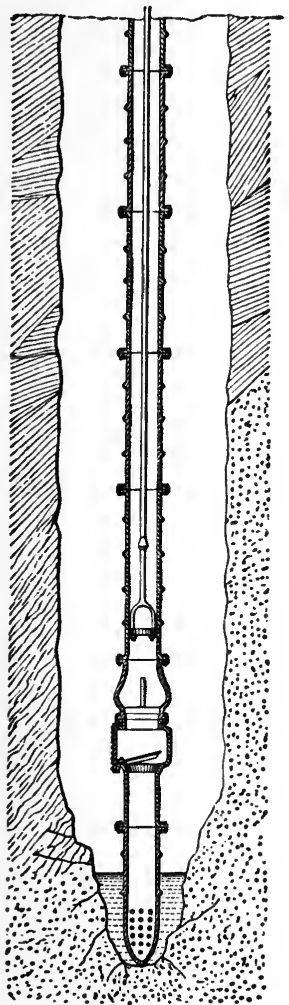

Fig. 5I3. Fig. 514.
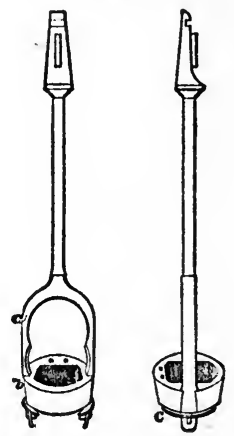

FIG. 515 .

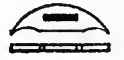

FIG. 516. FIG. 517 .
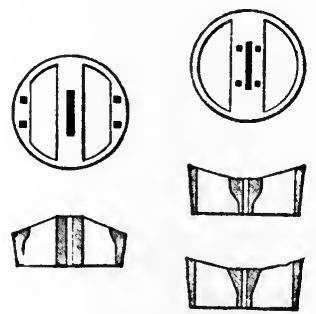

FIG. 518 .

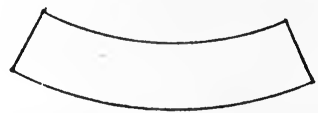

iron, and it may either work inside the column or outside. Fig. 5 I 2 shows the commoner method in this country, but both here and on the other side of the Atlantic the second plan is employed. Fig. 5 9 represents a lifting pump used in mines on the Comstock lode.* $\mathrm{S}$ is the windbore or suction pipe; $\mathrm{V}$ the fixed clack or valve; $\mathrm{P}$ the bucket, with its valve $v$, moving in the working barrel. The rod to which it is fixed passes through the

* Hague, "Mining Industry," United States Geohgical Exploration of the Fortieth Parallel, Washington, 1870, p. 124. 
stuffing box $g$, and is connected to the wooden rod $R$. The column of pipes, made of riveted sheet iron, through which the water is lifted, is shown by C. Three sheet-iron cylinders riveted together form one section. Each section is provided at both ends with a cast-iron flange, and two adjacent sections are fastened together by bolts. The cast-iron pieces $H$ carry the stuffing-box and join the column to the working barrel. Figs. 520 and 521 represent the mode of attachment of two sections, and also the manner in which the column is held in the shaft. Lap-welded sheet-iron pipes may take the place of the riveted pipes of the figure.

The columns of pumps in this country are generally made of cast-iron pipes with flanges; the standard length is 9 feet. The joint is made by inserting a ring of sheet iron, which has been wound round with coarse flannel soaked in tar, and tightening the bolts. A more perfect and durable connection is obtained if the flanges are properly faced and provided with a recess for an indiarubber or a gutta percha washer. Pipes of sheet iron and steel have the advantage of lightness, an important matter when transport is expensive, and it may be hoped that pipes of rolled steel made by the Mannesmann process will be available for the rising mains of mine-pumps ; fewer joints will be required, and the column will be lighter and less troublesome in every way.

Wooden pumps have not disappeared in countries where timber is abundant and metal expensive; the rising mains are formed of trees bored along the centre. Wood is also used in certain cases when the mine water is corrosive; thus at the Parys mine, Anglesey, where the water is highly cupriferous, pumps of this kind have to be employed. The wooden pipes made by Wyckoff \& Son, of Elmira, N.Y., are bored white pine logs turned outside, strengthened by a band of hoop-iron wound around spirally, and coated with asphalt. Pipes of this description are made with bores up to I 6 inches in diameter, and are capable of resisting a pressure of $160 \mathrm{lbs}$. per square iuch, or a head of water of 370 feet.

The disadvantage of the arrangement shown in Fig. 519 is that if a bucket fails, whilst the stuffing-box happens to be submerged, the "lift is lost," in other words the pump is utterly useless; whilst with the ordinary system (Fig. 5I2), the bucket can be drawn out and "geared" once more. To remedy this defect, a working barrel and a clack-piece may be inserted in the column; a new rod and bucket can then be lowered into it, and made to work until the water is sufficiently mastered for the old bucket to be changed.

On the other hand, the stuffing-box arrangement can claim the advantage of making the buckets last longer. No doubt the reason of this is that the stuffing-box acts as a guide to the rod; and prevents irregular friction of the bucket against the sides of the working barrel. 


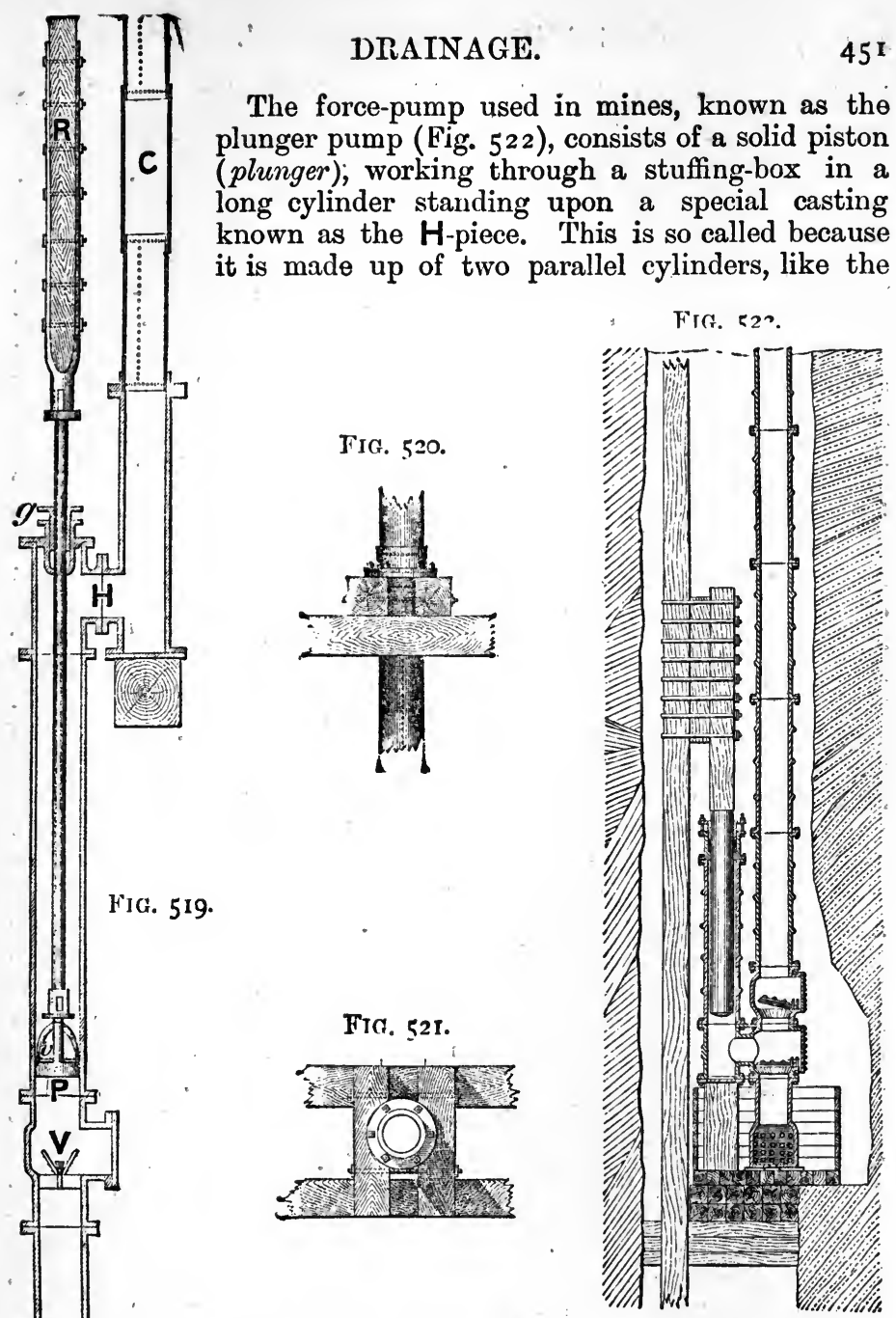

two upright limbs of the letter $H$, which are connected by a horizontal pipe, like the cross-bar. The $\mathrm{H}$-piece is often faulty from presenting a path with very sudden turns; all angles should be rounded off, so as to make the passage of the water as easy as possible. The $\mathrm{H}$-piece has a valve immediately above the wind-bore or suctionpipe. In the figure the wind-bore is flat-ender because it is resting in a cistern. Above the 
$H$-piece comes the door-piece with another valve, and then a series of pipes, the "column," generally of cast iron, but sometimes, as already stated, of wrought iron.

The action is easily understood. When the plunger is moved upwards, water is drawn in by the wind-bore, and when the plunger descends, the bottom clack closes, the top clack opens, and the water is forced up into the column. The plunger is a hollow cylinder of cast iron, accurately turned outside. Usually one end of a wooden rod is passed through it and wedged tightly at the bottom, and the other end is attached to the main rod by staples and glands, being kept at a proper distance from it by a piece of timber.

The plunger pump can claim superiority over the lifting pump for several reasons : it is less likely to get out of order, and, if it does begin to fail, its shortcomings are more quickly perceived and more easily remedied. The first advantage is almost self-evident; one need only picture the leathern rim of the bucket rubbing against the sides of the working barrel, and the solid plunger sliding up and down through the stuffing box, to feel convinced that it is more difficult to keep the former tight than the latter. Practical experience confirms this a priori reasoning. When the water contains sand in suspension, the bucket wears out rapidly and has to be changed at frequent intervals; consequently it must be performing much of its work in an inefficient manner. Incipient faults of the bucket causing but a slight diminution in the quantity of water raised are likely to pass unnoticed, whereas a leaky stuffing-box is at once detected. This latter defect can be speedily cured by the man in charge of the pumps (pitman), who has simply to take a spanner and tighten up a few nuts, whilst changing a bucket of an ordinary lifting pump involves the withdrawal of the whole length of rods to which it is attached, an operation causing some trouble and requiring time. Lastly, the efficient manner in which the plunger does its work renders it suitable for higher lifts than the bucket.

In the majority of cases a drawing lift is fixed at the bottom, because it can be lengthened as the shaft is deepened, a process going on continually in vein-mining, and further because it can be worked with less fear of a complete break-down than a plunger, if the water rises in the mine and submerges the working parts. This bottom pump lifts the water into a cistern in which stands the wind-bore of the plunger pump (Fig. 522), and the remainder of the pumping is done in stages. The first plunger forces the water up a column into another cistern, some 60 or more yards higher, where a second plunger continues the work and raises the water into a third cistern, and so on until it reaches the surface or the adit.

Pumping is usually done in stages because it is not always easy to keep the joints tight when the pressure of the water is 
very great. The difficulty is nowadays far less than it was formerly, and columns are made even as much as 600 metres (656 yards) in height vertically.

The subject of pumps would not be complete without a few words upon valves. The common leather clacks used in some buckets have already been briefly mentioned. The valves of pumps may be divided into two classes-viz., clacks and metal valves.

Figs. 523 and 524 represent a simple valve called the Hake's mouth valve. It consists of the seat, slightly conical below so as to fit into the proper recess in a casting, such as the $\mathrm{H}$-piece or clack-piece, and the moving flap made of a piece of strong leather between two plates of iron, held firmly together by copper rivets. The flap is attached to the "tail" of the seat by bolts, and the pliable leather not only makes the hinge, but ensures a water-tight contact.

\section{FIG. 523 .}
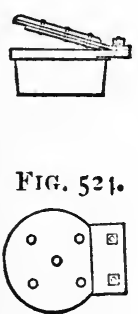

FiG. 525.

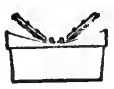

Fic. 526 .

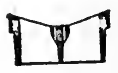

Fig. 527.

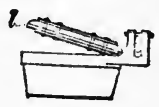

Fir. $5: 8$

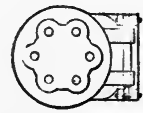

In the butterfly valve (Figs. $5^{25}$ and 526 ) there are two semicircular lids or flaps. In a clack known as "Jan Ham's clack," the two lids are hinged on the outside and look towards each other instead of from one another.

A valve which has given great satisfaction in Cornwall is known as Trelease's valve (Figs. 527 and 528). Its peculiarity is the great freedom of motion given to it by its hinge. The seat has two upright "risers" with slots in which the pin of the clack can move up and down. The valve is of metal with a sheet of leather $l$ riveted on for making it water-tight. It will be readily understood that, as the leather is not playing the part of a hinge, a valve of this description will last longer than those described previously; it can also be used with a bucket.

If the water is corrosive, as too frequently happens in mines, the seat and the valve are made of brass, gun-metal, or bronze, and a recess is made in the circumference of the seat for the insertion of wood, which will last longer for the "beat" than metal.

Teague's noiseless valve (Figs. 529 to $53 \mathrm{I}$ ) is made by inserting 
a small valve into the flap of a Hake's mouth valve. It is said to remove entirely the concussion met with in large pumps.

Among the metallic valves the most important is the doublebeat valve, the object of which is to afford as

FIG. 529. great a waterway as possible with a small rise

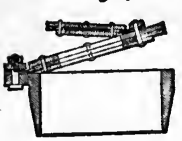

FIG. 530 .

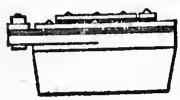
of the valve. A double-beat valve may be briefly described as a bell with a large hole at the top, and surfaces of contact at top and bottom; when the bell is raised by the pressure underneath, there are two passages by which the water can escape, one sideways, all round the bottom, and one upwards, through the top. It was invented originally for steam engines, and long afterwards was applied to pumps. The valve shown in Figs. $53^{2}$ to 534 consists of a shell $a$

FiG. 53 I.

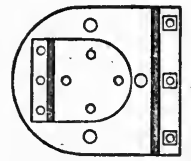
connected to a ring $i$ by radial arms $c$. The letters $b$ indicate strengthening ribs on the outside of the shell; they are inclined a little so that the stream of water passing through the valve may cause it to turn slightly each time it is opened, and beat in a different position., This ensures even wear and keeps the valve water-tight. The two " beats," that is to say the two surfaces of contact, marked $n$ and $m$, are rings of white metal, gutta-percha, or india-rubberfitted in grooves in the two seats $q$ and $l ; r$ is a guide for the central ring $i$ which is bushed with brass, indicated by the black line; $o$ and $p$ are radial arms on which slides the brass bushing of the lower ring of the shell, and they are stayed by the cylindrical piece

FIG. 532.

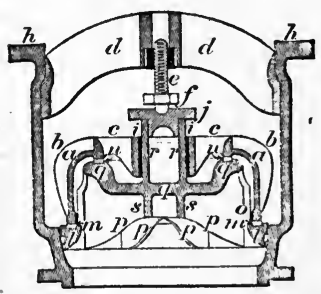

FIG. 533.

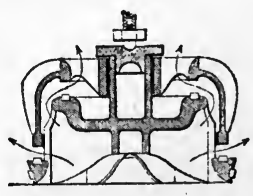

FIG. 5 ?4.

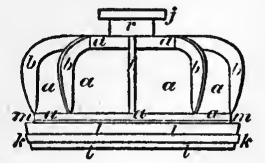

$s$ and the ring $l$. The rise of the valve is limited by $j$, which is kept in its place by the screw $e$, held by a nut in the cross-bar $d ; h h$ is the chamber in which the valve works. Fig. 533 shows the valve open, and Fig. 534 is an elevation of the valve and lower seat, which will greatly assist in making its mode of action plain.

The number of beats is sometimes increased to three or four.

Rittinger Pump.-The Rittinger pump is an important variety which has been introduced on the Continent, for remedying one of the defects of the ordinary pumping plant-viz., 
its intermittent action. The Cornish engine makes a sudden start, the "outdoor" end of the beam goes up, and with it the main 'rod and the plungers; then comes a pause, and all this time no useful work of raising water is being done. Lastly, the beam and the main rod slowly descend and the plungers force up water. The actual work of pumping proper is accomplished in a short part of the time occupied by a double stroke. It is evident that a smaller engine doing work continuously would be just as effective as the large one acting at intervals.

The Rittinger pump (Figs. 535 and 536) may be described briefly as a differential pump, with two hollow plungers, one fixed and the other moving. A B is the moving part of the pump, consisting of the air-chamber and plunger case $A$, the hollow plunger B, and the quadruple-beat valve C. It is drawn up and down by the side rods $\mathbf{D D}$. $\mathbf{E}$ is the top of a lower section of the rising main, and $F$ a large pipe constituting a cistern. $G$ is a valve at the bottom of the plunger case $H$. At the top there is the second hollow plunger $\mathrm{I}$, which is fixed, working through a stuffing-box in $A$, and $K$ is the rising main; $L$ is the space for air.

When the moving part A $\mathbf{B}$ ascends $\mathbf{C}$ closes, and water is drawn up into $\mathrm{I}$ and $\mathrm{K}$; at the same time $\mathrm{G}$ opens, and water makes its way through it into $H$. When $A B$ descends the space above $G$ is diminished, $\mathrm{C}$ rises, and water flows into $\mathrm{A}$. The descent of $\mathbf{A} \mathbf{B}$ increases the space above the valve $C$, but as the plunger $B$ is larger than the plunger I, more water flows into $\mathrm{A}$ than it can accommodate; consequently some of it must ascend through $\mathrm{K}$. The amount so passing will depend upon the relative diameters of the two plungers. In considering the quantity pumped during each stroke, it must be observed that the two hollow plungers displace just as much as if they were solid, because they are always filled with water; therefore the effective area of each is :

$$
\left(\frac{\text { outside diameter }}{2}\right)^{3} \times \pi \text {. }
$$

Let $\mathrm{P}$ and $p$ represent these areas of the large and the small plunger respectively and $L$ the length of the stroke. When A B makes its up-stroke, a quantity of water equal to $\mathrm{L} p$ is drawn up into $\mathrm{K}$; during the down-stroke the amount rising into $\mathrm{K}$ is equal to the difference of the volumes displaced by the two plungersviz., $\mathrm{L} \mathbf{P}-\mathrm{L} p$ or $\mathrm{L}(\mathrm{P}-p)$. If it is desired that the delivery shall be the same at each stroke, whether up or down, we must make

From this we get,

$$
\begin{gathered}
\mathrm{L} p=\mathrm{L}(\mathrm{P}-p) . \\
2 \mathrm{~L} p=\mathrm{I}, \mathrm{P} . \\
p=\frac{\mathrm{P}}{2} .
\end{gathered}
$$


In other words, the area of the section of the small plunger must bo FIG. 535 .

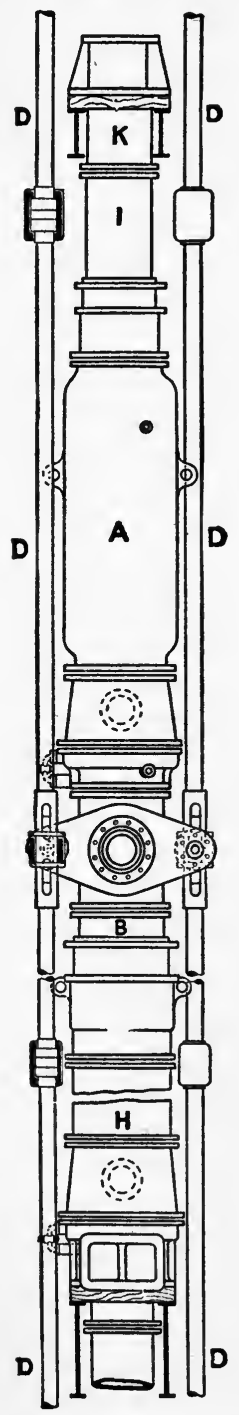

FIG. 536.

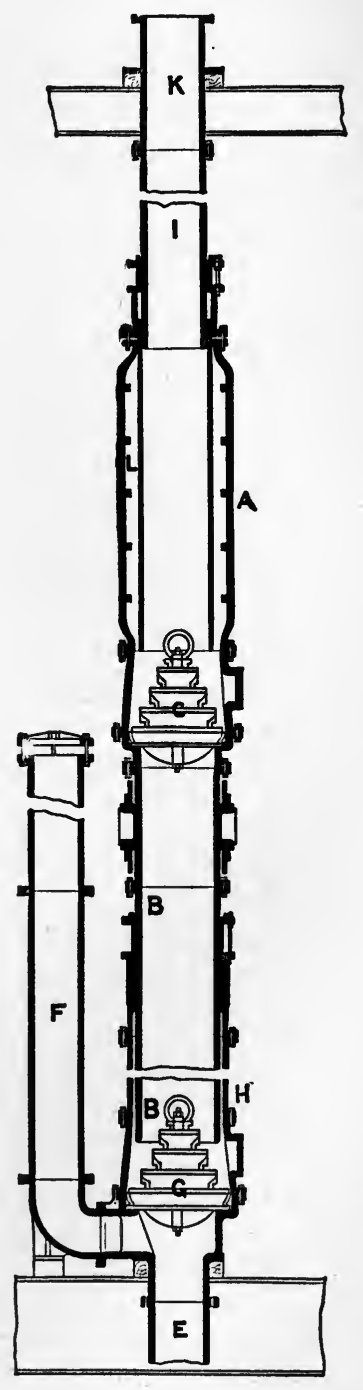

one-half that of the large one. This is carried out in practice; in one of the large pumps at Mansfeld the diameter of the large 
plunger is $0.90 \mathrm{~m}$. ( $2 \mathrm{ft}$. I I $\frac{1}{2} \mathrm{in}$.), and that of the small one $0.64 \mathrm{~m}$. (2ft. rin.). The areas are therefore $0.63 \mathrm{sq} . \mathrm{m}$. and 0.32 sq. m.

It is possible to dispense with the main rod altogether by interposing the rising main between the two plungers, one being placed at the bottom of the shaft and the other at the top; but this plan does not meet with general approval, because, although it saves the cost of a main rod, it subjects a long column of pipes alternately to tension and compression, with the result of trouble from leakages. \&c.

(d) Accessory Arrangements: Counterbalances, Catches,

Counterbalances.-The weight of the main rod, with its strapping plates or other connections, is generally greater than is required for the purpose of forcing up the column of water in the pumps, and overcoming the friction of the various parts of the

FIG. 537.

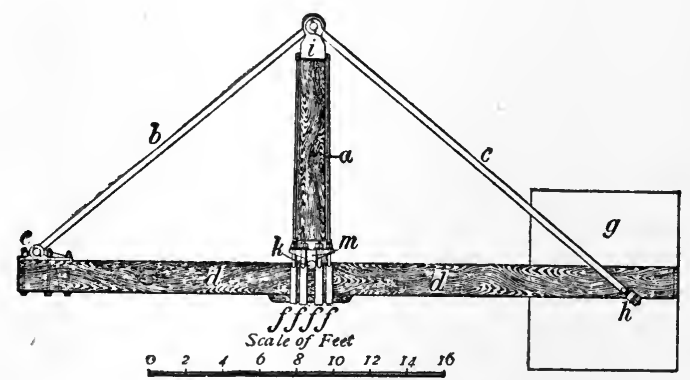

machinery. It becomes necessary, therefore, both in order to avoid useless waste of power in lifting the main rod, and to prevent its descending with too great a speed, to counterbalance so much of the weight as is not actually employed in doing useful work. The commonest form of counterbalance is a "bob" such as shown in Fig. 537. It is a beam $d d$ working upon pivots (gudgeons) $k$, which lie in brasses; the end $e$, called the nose of the bob, is attached to the main rod by a long connecting rod, whilst $g$ is a box which is filled, or partly filled, with old iron or stones. The beam is stiffened by the upright "king post" $a$, and the straps $b c ; f f f f$ are staples and glands fastening the casting $m$ to the beam, and $i$ is the " bishop's head " at the top of the "king post." Cast-iron beams, precisely like the beams of an engine, fulfil the same office at some mines, and the counterbalance is a huge piece of cast-iron (Fig. 544). There is usually a " balance bob" at the surface, and others are fixed at intervals in large recesses (bob-plats) cut out in the side of the shaft.

West and Darlington have.introduced the counterbalance shown 
in Fig. $538 ; a$ is a plunger attached to the main rod of the pump by a set-off, $b$ is a horizontal pipe connecting the two plunger-cases, $e$ is the second plunger carrying the box $f$, which is weighted as required; $g g$ are its guides. The slight losses of water are made up from the pipe $h$, which communicates with a cistern, or, when this method cannot be used, a little plunger $j$ will draw up and force in the necessary supply. Fig. 539 represents the same kind of counterpoise applied to an inclined shaft.

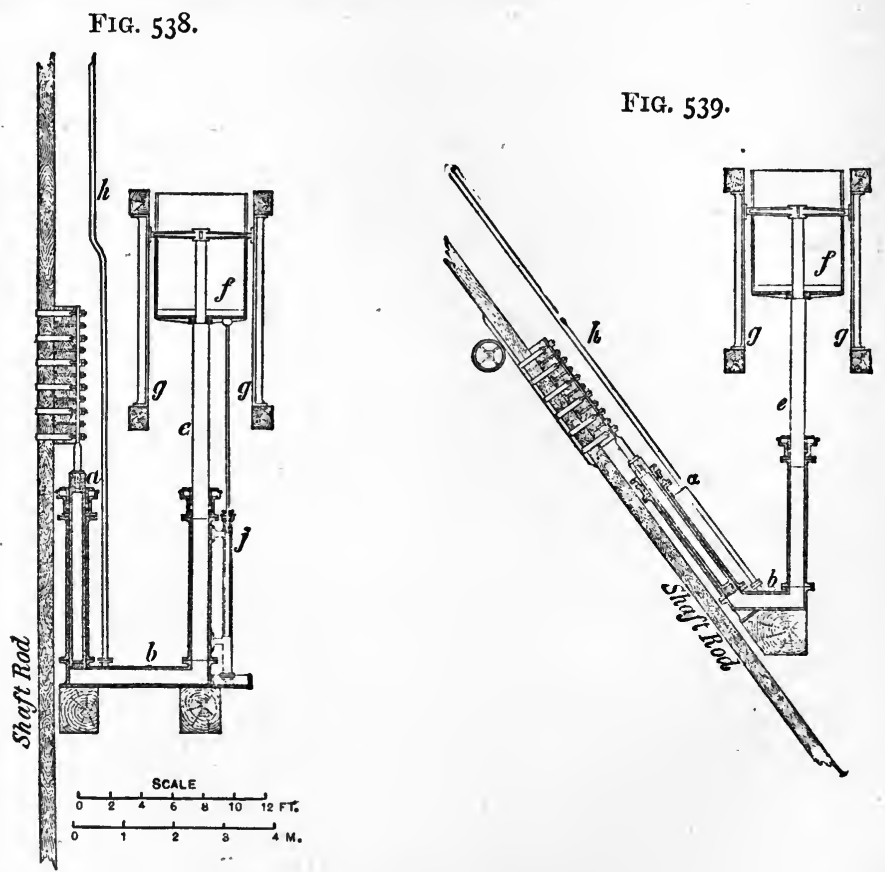

Hydraulic counterpoises have been found to be the most advantageous with the huge pumping engines of 1000 horse-power at Mansfeld. Probably at no mines in the world has the question of pumping on a large scale been more carefully studied than in that district, ${ }^{*}$ and the engineers have come to the conclusion that it is advisable to make their wrought-iron rods act invariably by tension and never by compression. They therefore have a weight at the end of the rod, and the rod + the weight must be so balanced that the machine has no work but that of raising the water and overcoming the friction.

* Hammer, "Die neueren Wasserhaltungen beim Mansfelder Kupferschieferbergbau," Der iv. allgemeine Deutsche Bergmannstag, in Halle, Saale, 18S9. Fesibericht und Verhandlungen, p. 39. 
The special counterpoise known as the Bochkoltz regenerator (Fig. 540*) is added to some pumps for the purpose of aiding the main rod on beginning its downward course, when it has not only to overcome the weight of the water in the column, but also to open the clacks. The regenerator has been applied on the assumption that at this moment there is an excess of work, because the pressure of the water on the under side of the valve is acting upon a smaller area than the water on the upper side, the difference being the area of the beat. Bochkoltz attaches a very heavy weight to the counterpoise at the surface, at right angles to the beam. If the balance beam in Fig. 537 is reversed, so that the king-post hangs downwards, and if a weight is fixed to the bishop's head, you have a Bochkoltz regenerator. In Fig. 540 $A$ is the cylinder of a Bull engine; $\mathbf{B}$, the piston-rod; $\mathbf{C}$, the main rod of the pumps; $\mathrm{D}$, the beam; E, a weighted box; F, a weighted box.

Suppose that the plunger has finished its up-stroke. The Bochkoltz weight now hangs like a pendulum about to begin an oscillation, and in descending under the action of gravity it assists the main rod in its work; as it approaches a vertical position its influence is lessened, and finally it creates a resistance when it has to be raised again. It does good at the beginning of the stroke by helping the weight of the rods, and it does good at the end of the stroke by diminishing the velocity gradually, and by FIG. 540.

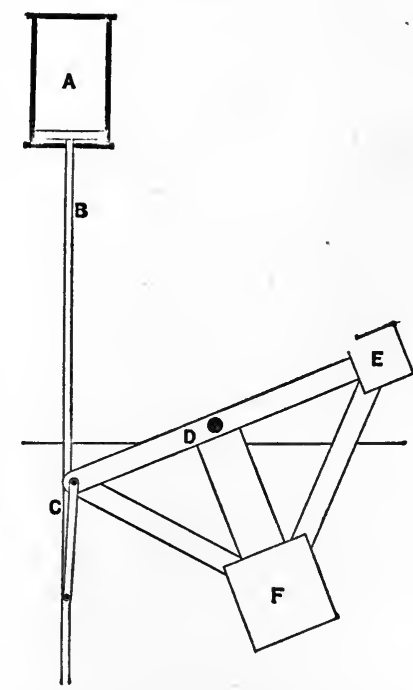
bringing the pumping machinery to a standstill without a shock. The idea that there is an excess of pressure upon the clacks at first is not borne out by experiments, but the regenerator has the advantage of enabling the engine to be started at a higher speed than would be safe without it; the mean speed is thus increased, and the engine is able to make a larger number of strokes safely per minute.

The same effect as that of the Bochkoltz regenerator is obtained in a very simple manner by $M$. Rossigneux, $\dagger$ who gives the beam a curved bearing surface which rolls upon a plane

* Callon, Lectures on Mining, Atlas, vol. ii., plate lxxxii.

† Exposition Universelle de 1889. Notice sur la Société Anonyme des IIouillères de Mlontrambert et de la Béraudière, Saint-Etienne, 1SS9, p. 52. 
(Figs. 541 and 542). By this device the ratio of the lengths of the two arms of the beams is always varying: at the commencement of the down-stroke, the weight of the main rod is acting with a long leverage compared with that of the counterpoise, at the end of the stroke the conditions are reversed. The excess of pressure due to the length of leverage accelerates the motion at first, and then, as this leverage diminishes, the weight of the counterpoise becomes more and more felt and the rod is stopped gradually. The same effects occur during the up-stroke of the main rod. The counterpoise begins by accelerating the motion, then its

Fig. 54 I.

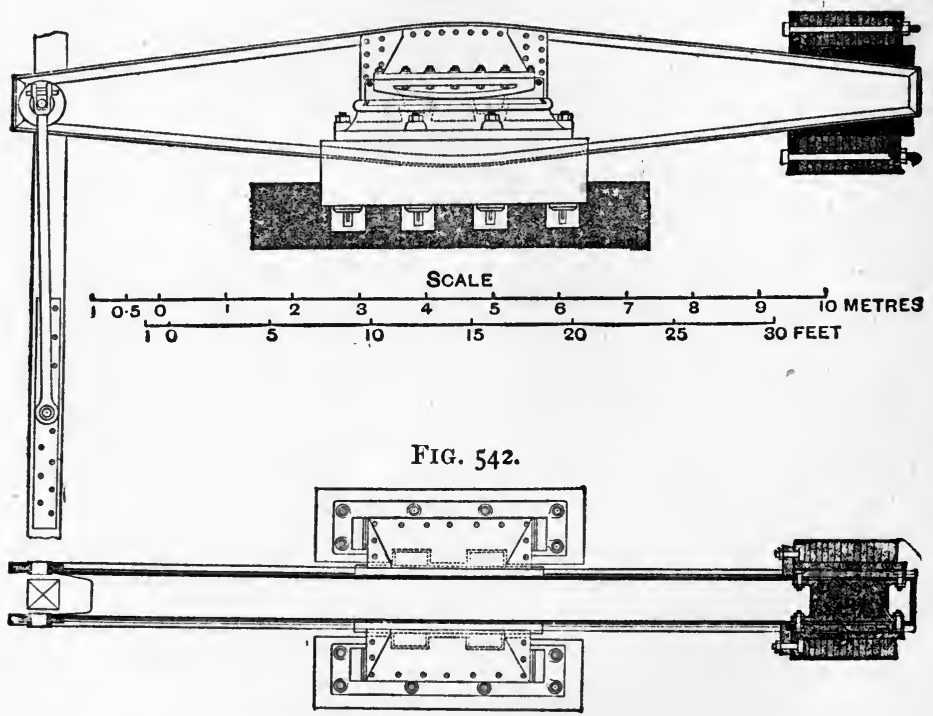

influence is less and less felt until the rod stops. Rossigneux's system can be applied to any existing beam with comparatively little expense; indeed it was first adopted in the case of a Cornish pumping engine, which was becoming incapable of coping with an additional influx of water, owing to the deepening of the shaft. The variable counterpoise rendered it possible to increase the number of strokes per minute with safety, and so enabled the engine to do more work.

Catches.-Provision must be made for a possible breakage of the main rod, which might have very disastrous results for the mine. If such an accident happened without any of the ordinary safeguards, the beam would come down with great force and play havoc in the engine-house, whilst the main rod dropping in the shaft would be sure to do damage to the pumps. 
The indoor end of the engine-beam is therefore fitted with two projecting arms of iron, which come down so as almost to touch two strong beams at every stroke; if a breakage happens, they arrest the motion of the engine-beam before it has had time to do any harm.

Catches are also fixed in the shaft; they are strong beams of timber $c$ c (Fig. 543, and S, Figs. 546 to 550), stretching across the shaft and resting in good "hitches," with the main rod $a$ working between them. The wings $b b$ are attached to the main rod by straps with bolts ("staples and glands"), and are so adjusted that the end of the wing almost touches the catch at the end of each down-stroke of the rod. A catch of this kind limits the possible fall of the main rod to the length of the stroke. Catches placed in the reverse direction are also useful in supplementing the action of those placed upon the beam in the engine-house.

Lastly, it must be recollected that large pumping machinery requires tackle capable of dealing with the heavy weights which have to be moved. High shears erected at the top of the pit enable pieces of main rod, often 60 feet in length, or heavy $\mathrm{H}$-pieces, to be raised and lowered by means of a strong hempen or steel rope worked by a capstan moved by men, or better by a drum driven by a FIG. 543 . special steam engine.

Hammer, of Mansfeld, strongly recommends that every large pumping engine should have its hydraulic press for lifting the beam, when changing the brasses or making repairs, the slight extra cost being amply repaid by the convenience of having such an appliance always ready at hand; a similar press for raising the heavy fly-wheel, if used, is likewise desirable.

Pumping Plant.-After these general considerations about pumps, it will be well to take an example and show how the various parts are combined in order to carry on the work of drainage. The seven Figures, 544 to $55^{\circ}$, illustrate the pumping plant at Shakemantle Mine in the Forest of Dean, erected by Mr. Thomas Smith, the manager, to whom I am indebted for drawings, and for verbal explanations on the spot.

The shaft is oval, 22 feet 6 inches by $x$ f feet 6 inches; it is "steened" or walled from top to bottom with sandstone, the stone being set in ordinary mortar where the ground is dry, and in hydraulic mortar where it is wet. The engine is a low-pressure condensing beam engine, with a 70 -inch $(\mathrm{r} \cdot 80 \mathrm{~m}$.) cylinder $\mathbf{A}$, working, with a I2-feet $\left(3^{\circ} \sigma_{5} \mathrm{~m}\right.$.) stroke, the heavy fly-wheel $B$, which can be driven at as slow a speed as three revolutions a minute. The main rod $\mathrm{C}$ is made of round wrought iron, 
FIG. 544 .
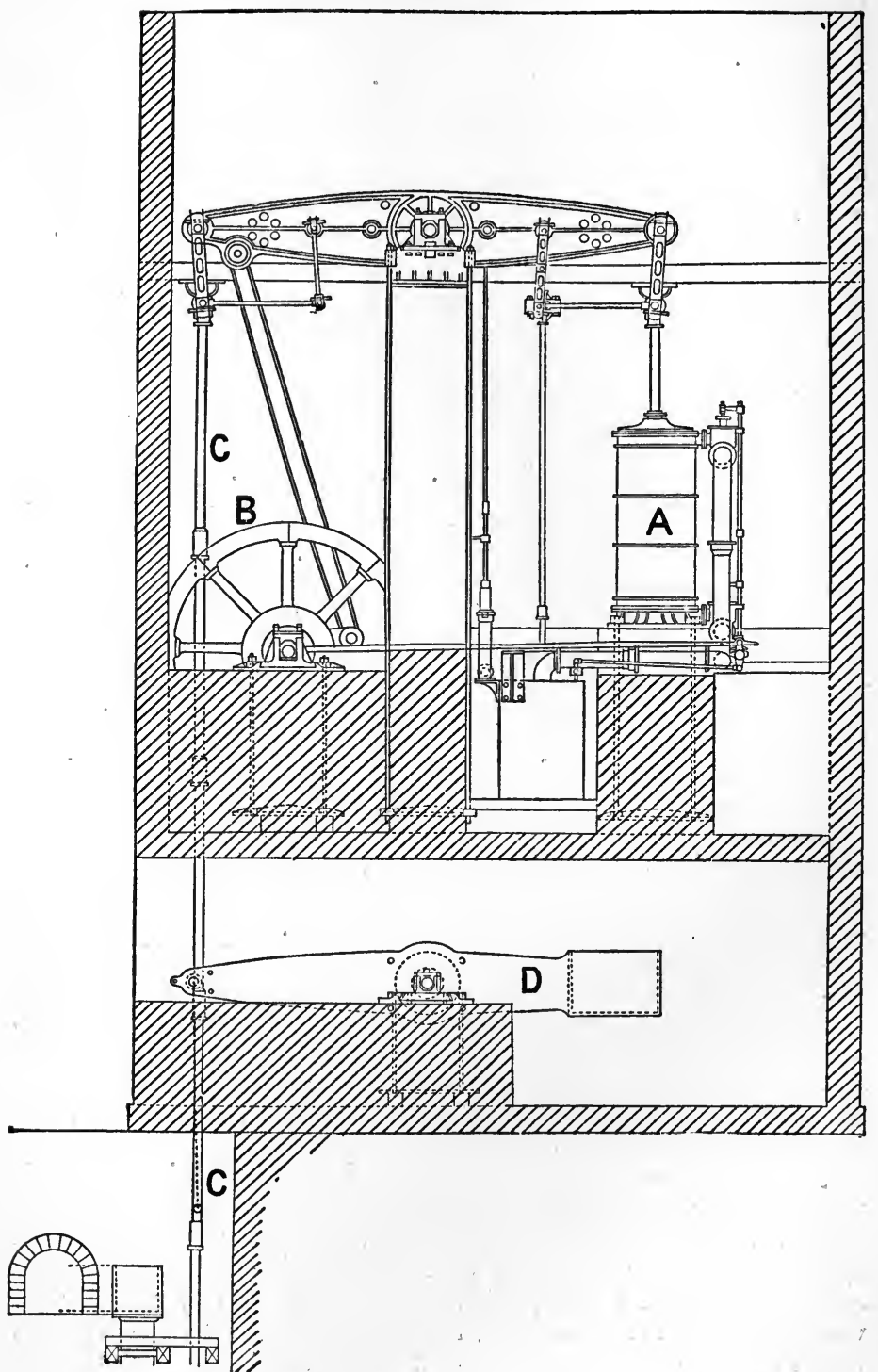
8 inches in diameter at the top, diminished gradually to 6 inches at the bottom. $\mathrm{D}$ is a beam or "bob" for counterbalancing so much of their weight as is not required for raising the water and overcoming friction. There are three plungers, each 27 inches (0.686 m.) in diameter, arranged in a straight line with the main rod; this is managed by attaching the rod to a cross-head E (Fig. 547) above each plunger, and bringing down two rods $\mathrm{F} F$, one on each side of the $\mathrm{H}$-piece $G$, to a lower crosshead $\mathbf{E}^{\prime}$ - from which the main rod is continued in the same line as before. The other parts are as follows: $\mathrm{H}$, plunger; I, cast-iron supporting girder, resting upon cast-iron shoes built into the sides of the shaft; J, cistern made of castiron plates bolted together, with the joints lined with cement, and screwed down to the top of the column K ; L (Fig. 546), spring to steady the cistern; $M$, hanging rods which have the same object ; $\mathrm{N}$, windbore in the cistern; $\mathrm{O}$, windbore at the bottom of the shaft; $P$, the door for changing the bottom valve; $Q$, door for changing the top valve; $R$, door to a butterfly valve, which keeps up the water in the column while the valve at $Q$ is being changed; $S$, beams across the shaft to catch the rod by the cross-plates $T$ in case of a breakage; U, air-chamber.

The general substitution of iron for timber effects a great economy of space in the shaft; the fly-wheel, which prevents any jerk at the beginning of a stroke, the air-chambers, and the arrangement of the plungers in the

FIG. 54j.

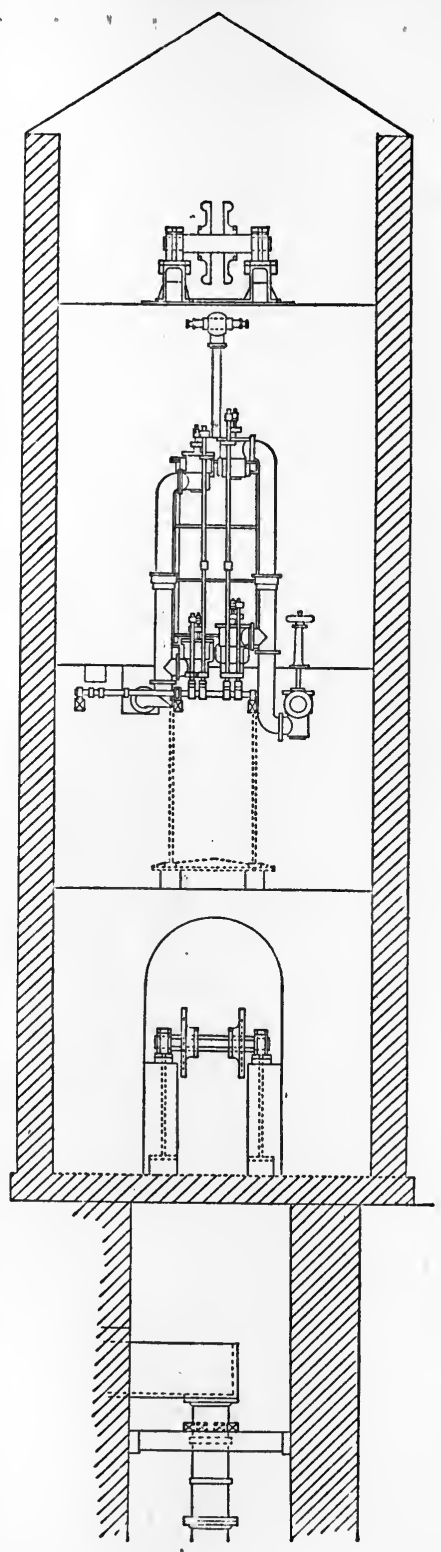


FIG. 546.
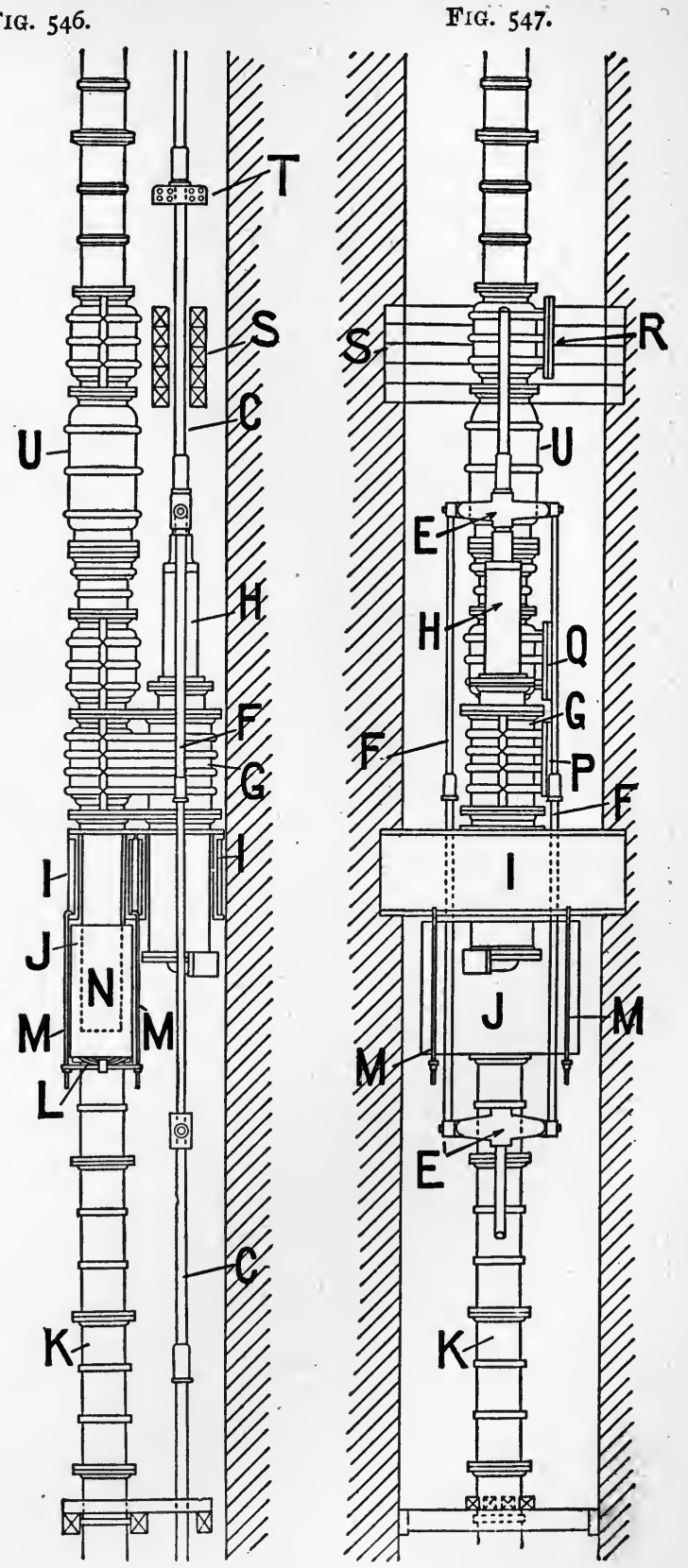


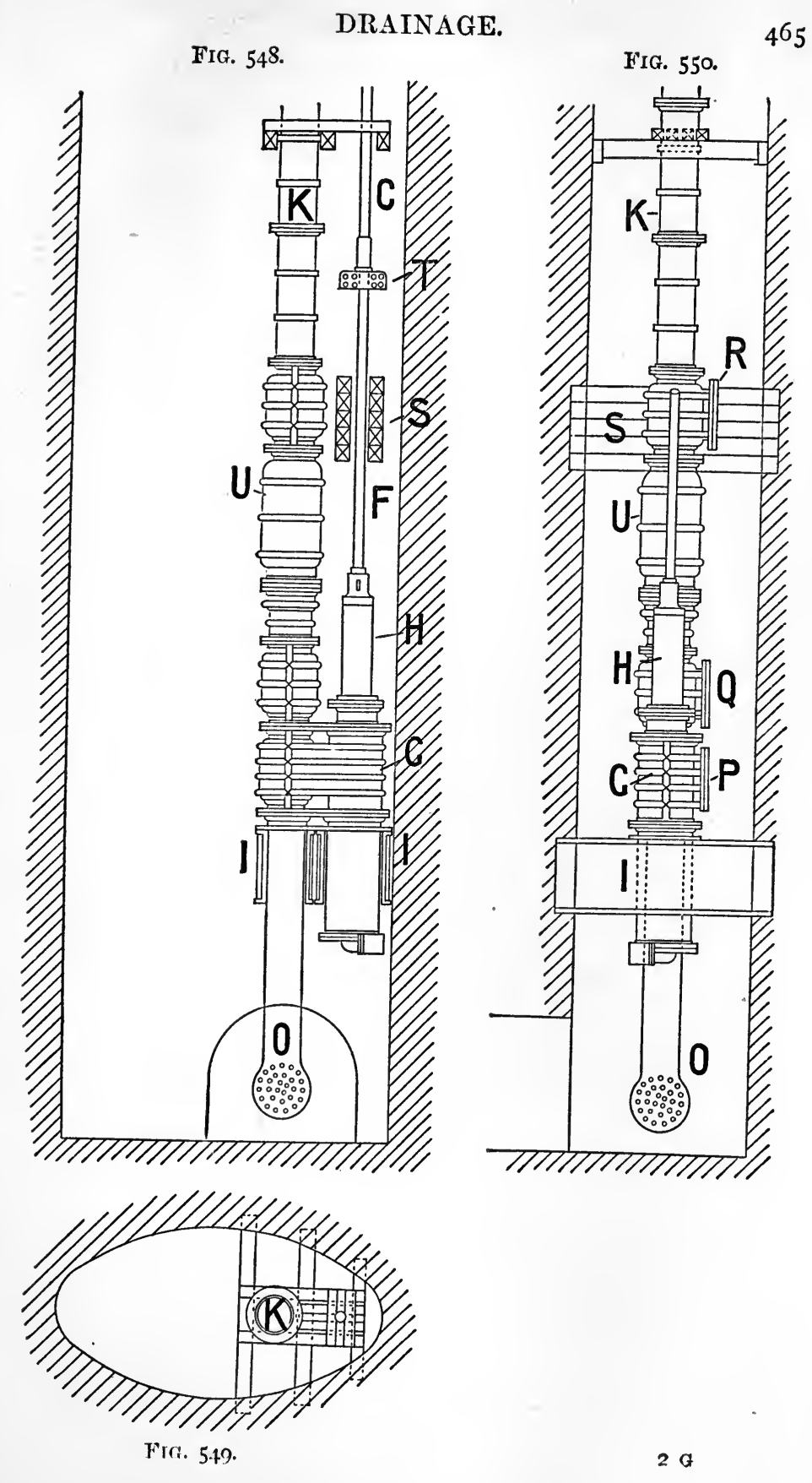


same straight line as the rods, all aid in securing a freedom from vibration and a smoothness of motion which are highly conducive to good working. The result is that the dryness of the shaft and the absence of noise are remarkable, considering the large quantity of water lifted-viz., nearly 1000 gallons ( $4 \frac{1}{2}$ cubic metres) of water per minute when the engine is going at the speed of only 4 strokes. Some idca will be gained of the massiveness of the pitwork by mentioning that the $\mathrm{H}$-piece alone weighs $16 \frac{1}{4}$ tons.

Class II.-Force Pumps worked by an Engine at or near the bottom of the Workings. - The advantage of being able to dispense with the ponderous main rod, its counterpoises, catches and succession of plungers, is only too obvious, to say nothing of economy in first cost and more speedy erection; and this second class of pumping machinery is being more and more largely used where circumstances admit of its adoption. The objection to the system is the danger of the machinery being "drowned," and so rendered useless, by any unusual influx of water, because a mishap of this kind would involve the erection of new pumping plant for draining the mine. Where the engine is at the surface, such a contingency as the drowning or partial drowning of the workings is not irremediable. It was this consideration which led the authorities at Mansfeld to have some of their engines above ground; for in that district huge cavities full of water (Schlotten) may be encountered unexpectedly at any moment and for a time overpower all the available pumping plant. On the other hand, at Mechernich, under different conditions, the Cornish engines at the surface have been given up and replaced with great advantage by underground machines.

Underground pumping engines are divided, according to the source of power, into those worked by steam, water, compressed air, electricity or by petroleum engines.

Steam.-At the present day we have to deal mainly with steam engines when speaking of pumping on a large scale. The steam may be generated above or below ground; if the boilers are placed above ground, great care has to be taken in jacketing the steam pipe which comes down the shaft, in order to prevent loss of heat by radiation and the consequent unprotitable expenditure of fuel.

It is necessary to mention two types of engines which are most commonly met with : (I) horizontal engines without fly-wheel ; (2) horizontal engines with fly-wheel. The engine may be simple or compound, but the latter class is naturally more in repute.

(I) In this first class comes the differential engine of Davey, which has been already described in speaking of engines used at the surface. Instead of working the pump by the intermediary of the bob and the main rod, the plunger is attached in a line with the piston-rod, and forces the water up the column. The height to which such a column can be taken is governed by the 
strength of the pipes, and the difficulties of making joints sufficiently tight to resist pressures measured by hundreds of pounds to the square inch. At La Louvière Mine in Belgium the column is 630 yards $(576 \mathrm{~m}$.) high, and probably there are few much higher than this at the present day; such a column means a pressure at the bottom of 556 atmospheres, or 8 I 7 pounds to the square inch.

Davey provides for the possible drowning of the lower part of a mine, through an inrush or unusual influx of water, by placing his main engine at a sufficient height above the bottom to render it practically safe from flooding; he lifts the water to it from the bottom by means of an auxiliary pumo. This latter pump is worked by hyciraulic power transmitted by pipes, and it will perform its work efficiently even if it is drowned.

There are many of these direct-acting pumps without fly-wheels in the market, such as those of Knowles, Tangye and Worthington, but want of space prevents my describing them.

(2) Fly-wheels are added in order to secure that smooth and regular action which is so conducive to the efficiency of machinery. Figs. 55 and $55^{2}$ give a general idea of one of the underground pumping engines at Mansfeld. It is a horizontal compound engine working four plungers or rams. A is the highpressure cylinder, 2 feet $\mathrm{I} I \frac{1}{2}$ inches $(900 \mathrm{~mm}$.) in diameter, $\mathrm{B}$ the low-pressure cylinder, 3 feet $9 \frac{1}{4}$ inches $(I \cdot 150 \mathrm{~m}$.) in diameter, $\mathrm{C}$ is the fly-wheel, $\mathrm{D}$ and $\mathrm{E}$ are crossheads connected by the rods $\mathrm{F}$ and G, and similarly $\mathrm{H}$ and $\mathrm{I}$ are crossheads connected by the rods $\mathrm{J}$ and $\mathrm{K}$; L M N O are the four rams, each $9 \frac{3}{4}$ inches $\left(0^{\circ} 25 \mathrm{~m}\right.$.) in diameter, having the same stroke as the pistons of the engine, 4 feet $\mathrm{x} \frac{1}{4}$ inches $\left(\mathrm{r} \cdot 250 \mathrm{~m}\right.$.). $\mathrm{P} \mathrm{P}^{\prime}$ and $\mathrm{Q} \mathrm{Q}^{\prime}$ are delivery pipes leading to a main delivery pipe $R$, which goes to the rising main in the shaft. When the engine is working at the rate of 30 revolutions per minute, it is calculated that it raises $\mathrm{I} 540$ gallons ( 7 cubic metres) of water per minute to a total height of $6 \mathrm{I} 2$ feet $\left(186 \cdot 5 \mathrm{~m}\right.$.). The specific gravity of the water is $I^{\prime} 2$.

This type of pumping engine is likewise found satisfactory on all points at Mechernich. When a Cornish engine was employed the consumption of coal was 4 kil. per effective horse-power, measured in water actually raised, now it is only $2 \cdot \mathrm{r}$ kil. A strong door is erected outside the pump-room, which can be closed so as to shut it off for some time even when the water rises considerably.

Riedler bases his system of constructing pumps upon some of the same considerations as those which guided Burckhardt and Weiss in improving air-compressors; he works his valves by gearing, and so secures the advantage of driving his pumps at very much higher speeds than are possible with valves which open and close of themselves. As in the case of the air-compressor, this rapidity of stroke enables a smaller machine to be employed for doing a given amount of work. 
Pulsometer.-The pulsometer (Fig. 553) is a form of pump used at mines for heights not exceeding 70 or 80 feet, and usually only for temporary purposes. The steam arriving by the pipe $e$ presses directly upon the surface of the water in a chamber $a$,

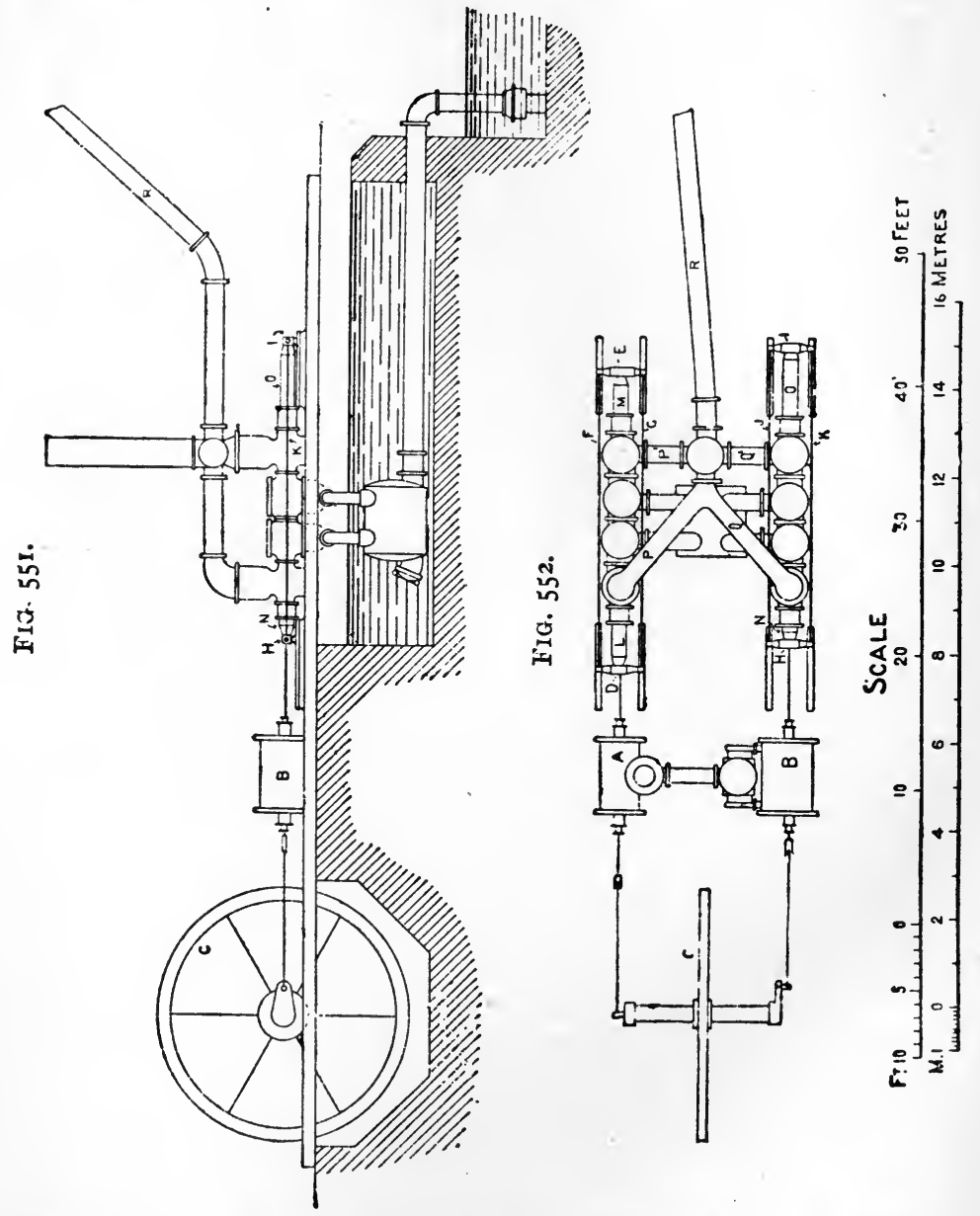

and drives it through an opening $d$ and a valve into the rising main. When the discharge is all but complete, the steam passing with the water through $d$ creates a disturbance and in consequence is condensed; this causes a ball-valve $f$ at the top of the adjoining chamber to pass over and shut off the entry of the steam. The steam now enters the adjoining 
chamber, and, acting as before, forces its contents up the rising main. In the meantime the steam in the first chamber is being condensed, and its place is taken by water drawn up the suction pipe $c ; b$ is an air-chamber, $g g$ are the suction-valves, and $h h$ stops which arrest them. The action is repeated first in one chamber and then in the other, so that a continuous stream of water is forced up.

The pulsometer will pump muddy or gritty water, it occupies little space, is very portable, and is easily fixed; in fact, it may be even hung in a shaft from a chain; it disposes of its own exhaust steam, it requires no special attendant, and so long as it is supplied with steam it will go on working. Under these circumstances it is evident that the pulsometer is capable of rendering very useful services to the miner.

Water.-Some successful applications of the

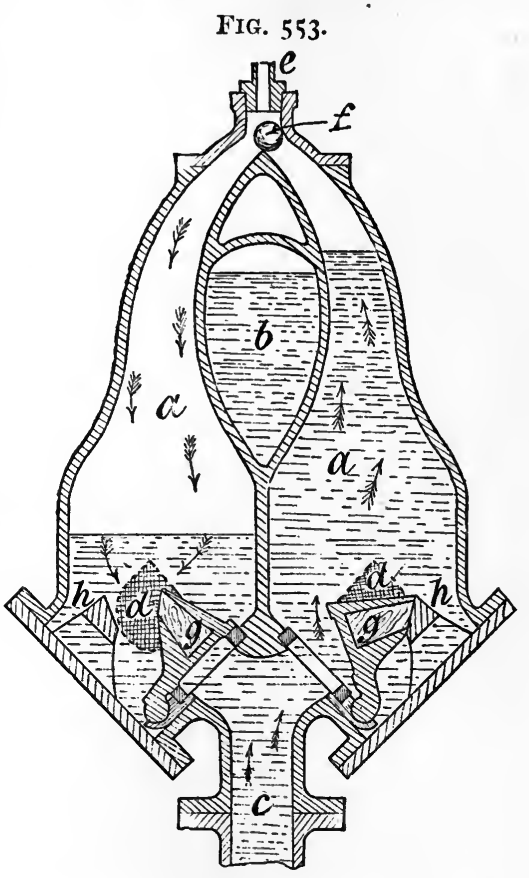
method of working pumps underground by hydranlic power transmitted from the surface have been carried out at mines in Scotland and on the Comstock lode in Nevada.* A horizontal engine erected at the surface (Fig. 554) works two rams $d . d^{\prime}$, and these force water down the two pipes $\mathrm{E} \mathrm{E}^{\prime}$ to the underground rams $\mathrm{D} \mathrm{D} \mathrm{D}^{\prime} \mathrm{D}^{\prime} ; g g$ are valves through which water is supplied to the pressure-pipes from cisterns. The plungers of D D and $D^{\prime} D^{\prime}$ are attached to a cross-head $C$ which carries the two pumping plungers $A$ and $B$. The ram $d$ forces water into the two power rams $\mathrm{D}$, and the ram $d^{\prime}$ into the two opposite rams $\mathrm{D}^{\prime}$. If water is being driven down by $d$, the cross-head $\mathrm{C}$ will be moved towards B; the mine-water will be forced up by its

* Joseph Moore, "On Hydraulic Machinery for Deep Mining," Trans. Inst. Eng. and Shipbuilders in Scotland, vol. xxv., 1882, p. 177. R. 'T. Moore, "On an Improved Arrangement for Working Underground Pumps by Means of Hydraulic Pressure," Trans. Min. Inst. Scotland, vol. v., 1884, p. 290. "Moore s Hydraulic Pump," Engineering, vol. xli., 1886, p. I26. 
plunger, and sucked up by A. At the same time the power water in $\mathrm{D}^{\prime} \mathrm{D}^{\prime}$ will be driven back a little way, ready to move in the opposite direction as soon as $d^{\prime}$ makes its stroke. The underground pump thus follows precisely the movement of the engine at the surface; the pressure in the transmitting pipes is not less than $1000 \mathrm{lbs}$. per square inch, and this enables small pipes to be employed. The pumps may be placed as desired, and the system has been used not only for permanent work, but also in the case of sinking a shaft.

Compressed Air and Electricity.-Pumps driven by compressed air or electricity are very convenient in situations where steam power is forbidden by the conditions of the workings, such as were set forth at length in a previous chapter. The

FiG. 554.

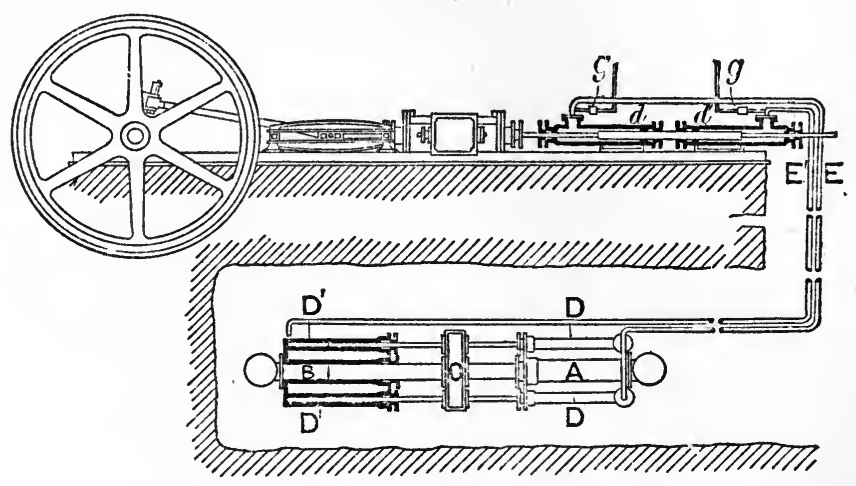

pumps worked by electricity mostly take the form of three rams, driven from a common crank shaft, fixed upon the same bed-plate as the motor. The high speed of the motor is reduced by gearing, so as to give the crank shaft a number of revolutions per minute suitable for pumping. The choice between compressed air or electricity will depend in many cases upon what plant is in use at the mine for other purposes. If compressed air is being generated for boring machines or haulage, it is only natural to make use of it instead of putting up a special engine to drive a dynamo.

Where compressed air is laid on in a mine, it is easy to employ it for working a Knowles, Cameron, Tangye, or other direct-acting pump; but water may be raised in a still simpler fashion by the Pohlé pump, which is giving satisfaction at mines in Colorado,* and in supplying factories near New York. It is merely a pipe

* E. Le Neve Foster, M.S. Notes, and Browne and Behr, "Dr. Polhlé's Air-lift Pump," Trans. Technical Soc. Pac. Coast, vol. vii., Feb. 1890. 
full of water with a jet of air at the bottom. A B (Fig. 555) is the so-called well, a piece of ordinary wrought-iron pipe 3 inches in diameter; it is connected by a bend to the $\mathrm{T}$-piece $\mathrm{C}$, through the bottom of which passes a piece of $\frac{1}{2}$-inch pipe, bringing in air at a pressure varying from 30 to $70 \mathrm{lbs}$. per square inch. The water-column proper is made of 2-inch pine, D E F. which turns over at the top and discharges into another well $\mathrm{G}$. The heiglit from the bottom of $\mathrm{C}$ to the top of the water in $G$ is $100 \mathrm{f}$ et, but as the level of the top of the water in the well A B is 50 feet above $\mathrm{C}$, the actual lift effected by the air is only 50 feet. By a succession of such lifts the water can be raised to any desired height. This pump commends itself by its simplicity, by the ease and cheapness with which it can be constructed, and by the absence of any expense for keeping it in order.

- For some time past Messrs. Evans and Veitch have been raising water at Cae Coch Mine, in Carnarvonshire, by the direct action of compressed air. Their latest pump (Figs. 556 and 557) consists of two forcing chambers $A$ and $A^{\prime}$ submerged in water, each provided with an inlet valve, $\mathbf{B}$ and $\mathrm{B}^{\prime}$, and a discharge valve, $\mathrm{C}$ and $\mathrm{C}^{\prime}$, which lead into a common rising main D. Compressed air, brought into the two chambers alternately by the pipes $\mathrm{E}$ and $\mathbf{E}^{\prime}$, presses upon the surface of the water and forces it up the pipe $F$ or $F^{\prime}$ into $D$. The

FIG. 555 .

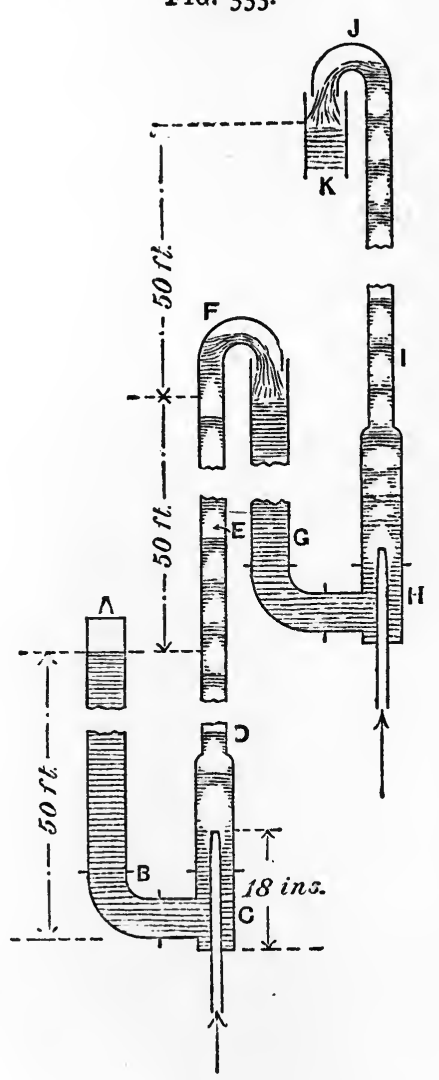
compressed air is turned alternately into $\mathbf{E}$ or $\mathbf{E}^{\prime}$ by the action of a valve worked by the independent cylinder $G$, placed in any convenient situation. $\mathrm{H}$ (Fig. 557) is a pipe bringing air from the compressor to the valve-chest $I$, with its piston valve $J$. In the position shown, $\mathbf{E}^{\prime}$ is receiving air by the port $e^{\prime}$, whilst $\mathbf{E}$ communicates with atmosphere through $e$. The valve $\mathbf{J}$ is moved by the tappets $\mathrm{K} \mathrm{K}^{3}$, which are struck by the crosshead $\mathrm{I}$, attached to the rod which is cummon to the two pistons $\mathrm{M}$ and $\mathrm{N}$. 
$O$ is the piston-valve admitting compressed air into the cylinder $\mathbf{G}$ from the pipe $\mathbf{P}$; it is worked by the tappets $K^{1} \mathbf{K}^{2}$. The cylinder $Q_{\text {is }}$ full of oil, which can be drawn from one side to the

FIG. 556.
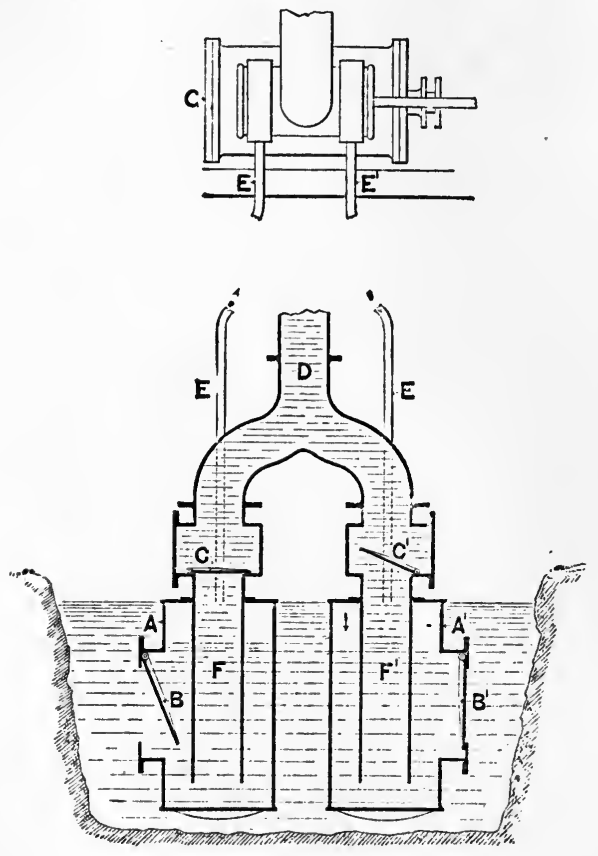

Fig. 5.57 .

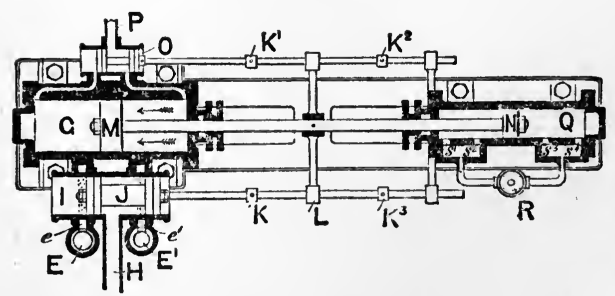

other by the piston $\mathrm{N}$ if the cock $\mathrm{R}$ is open. The travel of the piston in $\mathrm{N}$ can be regulated by the cock; the more nearly it is closed the slower will the piston move. In order to make sure that the valve $O$ shall not stick partly open, two sets of holes, $s^{1} \quad s^{2} s^{8} \quad s^{4}$, are provided, and when the piston passes, for instance, between $s^{1}$ and $s^{2}$, the oil can make its way round without going through the cock; the decrease in the resistance quickens the stroke and makes it sharp and decisive at the end.

With the object of economising the compressed air, the inventors propose in some cases to take the exhaust from the pipes $\mathbf{E}$ and $\mathbf{E}^{\prime}$ direct to the compressing cylinder, allow it to expand behind the piston and so return a little of the power expended in compressing it. The two chambers A $\mathbf{A}^{\prime}$ may very well be joined together in one casting, as they are in the pulsometer, and they may of course be far more deeply submerged than is shown in the figure.

Duty.-In accounts of pumping engines the student will often meet with the expression "duty." This term means the number 
of pounds of water raised I foot high by the consumption of I I 2 pounds of coal; as used by Watt the quantity of coal was I bushel, reckoned at 94 pounds. In the early part of this century much interest was evinced in Cornwall with reference to the work done by the various pumping engines of the county, and there was great rivalry among the engineers, who vied with each other in getting the highest duty from the engines and the machinery under their charge. The consequence of various improvements in engines and boilers resulted in reaching duties which approached and even for short periods exceeded roo millions.

The performance of each engine was ascertained by attaching a counter to the beam, which registered the number of its oscillations; the counter was kept under lock and key and examined monthly by an independent observer. The number of strokes made by the engine was thus known. The work done in pumping was calculated from the number and depth of the various lifts, the size of the plungers and the stroke of the engine, and a record was kept of the amount of coal consumed. With these data the duty could be determined, and the figures were published every month. Nowadays this spirit of emulation among Cornish agents seems to have disappeared, few engines are "reported," and the duties recorded do not as a rule exceed $5 \circ, 60$, or 70 millions.

Though the knowledge of the duty is valuable in indicating the general efficiency of the pumping plant, the mere determination of this figure does not give all the information that ought to be in the hands of the mining engineer, for it does not tell him where he can and should make improvements. When he finds a difference in the respective "duties" of two pumping engines at his mine, there is nothing to tell him whether the fault of the less effective plant lies in the coal, the engine, the boilers, the transmitting arrangements, or the pumps themselves. It is important, therefore, that the engines should be indicated, and that the indicated horse-power of the engine should he compared with the actual useful effect in water raised. Hammer * has found that the power consumed in some cases by the mere friction of the guides in the shaft is as much as 24 to 30 per cent. of the total power given out by the engine. Too much importance cannot, therefore, be paid to the accurate fixing of the main rod and its guides.

Slip.--In calculating the delivery of a plunger it is usual to make an allowance for the running back of some of the water through the valve, from its not closing completely when the down-stroke commences. This is what is known as "slip," and it is sometimes estimated at 20 per cent. of the actual delivery, though in reality scarcely appreciable in the best pumps. $\dagger$

Co-operative Pumping.-Owing to the subdivision of pro-

* Op. cit., p. 45.

† Rankine, A II anual of Civil Enginecring, London, 1883, p. 735. 
perty in this country and want of appreciation of the importance of the subject, too little attention has been paid to what may be called co-operative drainage. One successful application of the principle, the Halkyn Tunnel, has been mentioned, and another instance deserves to be noticed, though in this case the mineral is coal. The South Staffordshire Mines Drainage Commission is a corporate body constituted under several Acts of Parliament,* passed during the last twenty years, for the purpose of facilitating the drainage of mines in parts of South Staffordshire and East Worcestershire. The Commissioners have power under their Acts to levy a rate of $9 d$. for every ton of coal, slack and ironstone raised within a certain district, and $3 d$. for every ton of fireclay and limestone. In order to have some check upon the statements of output made by the mine-owners, the Commissioners have by their last Act obtained the right of placing inspectors to report upon the quantities of minerals raised.

It is not merely by erecting pumping engines of the most approved and economical types at suitable centres that the Commissioners have done good work; but the results of their labours in preventing surface water from finding its way down are well worth recording. To use their own words, "By carrying out surface drainage works, such as rendering water-tight the canals and streams throughout the district, draining large ponds of accumulated water on the surface, diverting or enlarging such watercourses as caused overflows in seasons of great rainfalls, and such other works as were necessary to reduce the volume of water flowing into the mines by percolation to a minimum amount," they reduced "the average quantity of water which has to be pumped in the Tipton district every 24 hours from $22,705,000$ gallons in 1875 to Ir, 643,000 in 1882 , a decrease of nearly 50 per cent." When considering this remarkable and very satisfactory result, the special circumstances of the district must not be left out of sight. In no mining district in this country are the effects of subsidence more apparent than they are in places where the thick coal of South Staffordshire has been worked underneath, and therefore the cracked and fissured overlying straia were ready to exaggerate the evils of percolation; but at the same time this very fact rendered the application of a remedy all the more difficult.

According to the Annual Report published in 1892, $\uparrow 27 \frac{1}{2}$ tons of water were raised for every ton of mineral extracted from the mines, and at a cost, so far as the Commissioners' engines were concerned, of 0.18 of a penny, or less than one farthing, per ton of water raised.

* 36 \& 37 Vict., c. $150 ; 41$ \& 42 Vict., c. 81 ; 45 \& 46 Vict., c. 131 ; 54 \& 55 Vict., c. 135 .

† Culliery Guardian, vol. lisiv., I892, p. 648 . 


\section{( 475$)$}

\section{CHAPTER X.}

VENTILATION.

Atmosphere of mines-Causes of pollution of the air in mines-Natural ventilation-Artificial ventilation by furnaces and by mackines-Fans -Testing for fire-damp-Determination of carbonic acid and oxjgen -Anemometers-Water-gauge-Efficiency of fans-Friction.

ATMOSPHERE OF MINES.-The composition of the air of the atmosphere is about one-fifth by volume of oxygen and four-fifths of nitrogen, with a little carbonic acid gas; more exactly, the standard amount of oxygen may be taken at 20.9 per cent., and that of the carbonic acid gas at 0.03 to 0.04 per cent.

The atmosphere of mines is subject to various influences which are constantly rendering it less fit for supporting life; not only do noxious gases escape from the rocks into the underground excavations, but the very agents themselves employed in the execution of the work pollute the air considerably.

Gases sometimes given off in mines are : carbonic acid, marsh gas, nitrogen, sulphuretted hydrogen, and the vapours of mercury and volatile hydro-carbons.

Carbonic Acid is known to exuile from coal, and is also met with in beds and veins of other minerals. It is common, for instance, in the Sicilian sulphur mines, ${ }^{*}$ where it is called by the miners rinchiusu.

At the lead mines of Pontgibaud, in Central France, it is so abundant that special fans have to be provided for getting rid of it; very distinct issues of this gas may be observed at the Foxdale lead mines in the Isle of Man. $\dagger$ Emanations of this gas from "lochs" or "vugs" have been reported to me as occurring at Great Laxey mine, in the Isle of Man, and at Pennerly and Roman Gravel mines in Shropshire; however, in none of these, as far as I am aware, has the issue been so strong or so lasting as at Foxdale. In the Alston Moor district, according to Mr. Wallace, the quantity of carbonic acid discharged both

* Baldacci, Descrizione geologica dell '1sola di Sicilia, Rome, 1886, p. 362 .

+ C. Le Neve Foster, "An Emanation of Carbonic Acid at Foxdale Mine, in the Isle of Man," Trans. R. Geol. Soc. Cornwall, vol. x., p. 175. 
by the veins and the enclosing rocks is occasionally very considerable.*

Carbonic acid is thought by Blount $\dagger$ to exist sometimes in the liquid state in minute pores or fissures of chalcopyrite, and he ascribes the decrepitation of certain kinds of pyrites, when heated, to its presence. No doubt such pyrites would be capable of giving off the gas slowly at the ordinary temperatures of mines.

The hot springs and their accompanying gases at Sulphur Bank mine $\downarrow$ in California are very remarkable. An analysis of the gas gave:

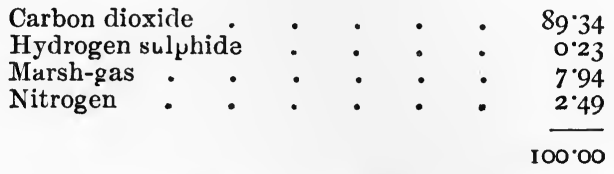

Some of the emanations contained ammonia, and the temperature of the water escaping from cracks in one of the levels was $176^{\circ} \mathrm{F}$. $\left(80^{\circ} \mathrm{C}\right.$.), or more than the highest temperature observed at mines on the Comstock lode.

Marsh-gas is the main constituent of fire-damp, which is by no means confined to coal mines, as some might suppose. In this country it is found in small quantities in the stratitied ironstone of the Cleveland district, and also in the Cheshire salt mines. As minute bubbles of the gas may be noticed in the brine which is pumped up from bore-holes near Middlesbrough, it is probable that it accompanies rock-salt in that region also. Mill Close lead mine, $\S$ in Derbyshire, was the scene of a disastrous explosion of fire-damp, some years ago, by which five men were killed, and in 1884 two men were burnt by the gas taking fire in a level at Holway Consols Mine,\|near Holywell in Flintshire, where a fatal accident had happened from an explosion fifteen years previously.

At the famous Van Mine $\mathbb{T}$ in Montgomeryshire, fire-damp was found at the adit, and at nearly every level below, while "tapping" the lode; in other words, while making the first drivages in it The miners regard it as a sure harbinger of lead ore.

Even the tin mines of Cornwall are not entirely free from firedamp. Inflammable gas was given off by the bed of stream-tin

* The Laws which Regulate the Deposition of Lead Ore in Veins, London, s86i, p. I30.

† "Decrepitations in Samples of so-called Explosive Prrites," Jour. Chem. Soc., vol. xlvii., 1885, p. 593 ; and Min. Jour. vol. lv., I885, p. 1297.

$\ddagger$ Becker, "Geology of the Quicksilver Deposits of the Pacific Slope," Mun. U. S. Geol. Survey, vol. xiii., Washington, I888, p. 258.

$\S$ Reports of H.M. Inspectors of Mines for the Year 1887, p. 316.

II Ibid., 1884, p. 204.

T C. Le Neve Foster, "Notes on the Van Mine," Trans. R. Geol. S"sc. Cornuall, vol. x., p. 36 . 
worked under the mud of Restronguet Creek,* near Falmouth, in r 873 , and three comparatively slight explosions took place at Ding Dong Mine, $\dagger$ near Penzance, about the year 1860 , on re-opening a level which had long been under water; but in this case, as in some others which will be mentioned, the gas seems to have been formed by the decomposition of the timber supports of the level.

Turning to the Continent, it is not surprising to meet with large quantities of inflanmable gas in oil-wells and in ozokerite mines. The work of sinking oil-wells in Roumania $\ddagger$ is much impeded by emanations of marsh-gas; artificial ventilation becomes necessary when a depth of 50 feet $(15 \mathrm{~m}$.) is reached, and the first thing the men have to do in the morning is to work the fan for three hours. Even then the sinker cannot stay down more than about two hours at a time, and when the bottom of the shaft is approaching the oil-bearing stratum, he cannot stay more than a quarter of an hour. $\mathrm{He}$ is always fastened to a rope, and two men at the surface are constantly on the alert to draw him up at . once, if he makes the least sign by pulling it. The sinker is sometimes quite giddy when he reaches the surface.

The conditions at the petroleum wells of Burma are still more unfavourable. There is so much gas that breathing is difficult, and the longest time a young and strong man can stay below without becoming unconscious is 290 seconds. Often a man can work only I or 2 minutes; he can be lowered to a depth of 200 feet in $\frac{3}{4}$ minute and raised in $I$ to $I \frac{1}{2}$ minutes; in the upper parts of a well, where there is no gas or only a little, he can remain below much longer.§

There are probably few, if any, mines more fiery than the ozokerite pits of Boryslaw. Explosions have often happened, and the mines have to be worked with safety lamps. However, it is likely that both here, and in the oil regions, the inflammability of the atmosphere is due not only to marsh-gas, but also to the vapour of volatile hydrocarbons given off by the crude petroleum, which may be seen on the floor of the workings. Mere marsh-gas alone would not account for the spirituous taste of the air and the slight smarting of the eyes which are noticed underground. The effect of the gases is to produce all sorts of hallucinations and make the men wander in their talk.

The sulphur rock of Sicily \| emits fire-damp very frequently,

* Taylor, "Description of the Tin Stream Works in Restronguet Creek, near Truro," Proc. Inst. Mech. Eng., 1873, p. 159.

+ Higgs, "Notice of an Accumulation of Carburetted Hydrogen, or 'Fire-damp,' in the Ding Dong Mine," Trans. R. Geol. Soc. Cornwall, vol. ix., p. 34 .

p. 34 Exposition Universelle de Paris en 1889 : Notice sur la Roumanie, Paris, I889, p. 60 .

$\S$ Noetling, "Oil-field of Twingoung and Beme, Burma," Rec. Geol. Survey India, vol. xxii., 1889, p. 98 .

\|l Baldacci, op. cit., p. 362 . 
and the official list of disastrous explosions shows that it is an enemy not to be despised by the miner. 'The gas fills cavities existing in the bed of mineral, and also comes out of the bituminous shale of the partings; it is called antimonio by the men.

Marsh-gas accompanies salt on the Continent, as it does in England; a jet of the gas, which has been piped off from a blower and now serves for illuminating purposes, may be seen constantly burning in the salt mine at Bex in Switzerland. Small explosions have taken place in the Stassfurt district.

Several men were killed by an explosion of fire-damp in a tunnel in the Oxford Clay, ${ }^{*}$ which was in course of being driven under the Col de Cabres, on the boundary of the Departments Drome and Isère in France, during the year 1887 , and the gas is given off in such quantities in the clay pits at Klingenberg on the Main $\dagger$ that safety lamps have to be used by the miners.

Inflammable gas is not noticed in working the copper shale itself at Mansfeld, though the large amount of bituminous matter which the seam contains might make one fear it would be troublesome; a little has been met with in driving levels in some of the surrounding rocks and especially in the gypsum.

Large quantities have been observed in Silver Islet mine, $\ddagger$ Lake Superior, where several explosions occurred ; and at Duncan mine, $\S$ Port Arthur, upon the same lake, vugs were noticed to contain hydrocarbon gas under great pressure.

Becker records emissions of inflammable gas at several of the quicksilver mines in California.\| Inflammable gas, probably marsh-gas, caused a disastrous explosion at the Bell tunnel of the New Idria Mine, and marsh-gas escapes at the Atna Mine. At the Phœnix Mine inflammable gas issues from cracks in the 150 and 3oo-foot levels, the chief component being marsh-gas, as shown by the following analysis :

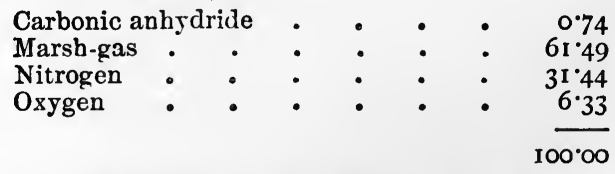

Treloar 9 gives an account of an issue of inflammable gas at the Morro Velho gold mine in Brazil; it took fire while the men were boring a hole.

* Comptes Rendus, Soc. Ind. Min., August 1887.

+ Colliery Guardian, vol. lvi., 1888, p. 192.

¥ Macfarlane, "Silver Islet," Trans. Amer. Inst. M1.E., vol. viii., rSSo, p. 24 I ; Eng. Min. Jour., vol. xxxiv., 1882, p. 322.

$\S$ Trans. Amer. Inst. M.E., vol. xv., 1887, p. 673 .

II "Geology of the Quicksilver Deposits of the Pacific Slope," Mon. U. S. Geol. Surve?, Washington, 1888, pp. 308 and 373.

I Trans. IR Geol. Soc. Cornwall, vol. vii. p. 345. 
Fire-damp is frequently encountered in the old workings of alluvial mines in the goldfields of Victoria ; * in some instances it is doubtless due to the decomposition of prop timber, as at Ding Dong, and in others to the gradual alteration of driftwood or organic matter in the alluvial beds themselves. A serious accident, caused by a fire-damp explosion, is recorded as having injured two men at the Try-again Company's mine, El Dorado, in the Beechworth Mining district. $\dagger$

Nitrogen, if given off in small quantities, is likely to pass unnoticed by the miner; but it makes its presence felt occasionally. Miners in Sirinesdale tunnel, near Stockport, have been troubled by the escape of nitrogen from fissures in the rock. It has been ascertained by analysis that the gas consists of 92 volumes of nitrogen, 8 volumes of oxygen, and a trace of carbonic acid. It came from openings in the roof, sides and floor, and was strong enough, in one case, to put out a candle 18 inches away from the fissure. The men became sick and dizzy, and their limbs were semi-paralysed. On some occasions the fissures drew the candleflame in, instead of blowing gas out, suggesting a communication with old workings in the neighbourhood.

The highly poisonous sulphuretted hydrogen is of frequent occurrence in the Sicilian sulphur mines, where the water is often saturated with it. At the 3000-foot level of the Comstock $\ddagger$ lode, the water is charged with carbonic acid and sulphuretted hydrogen, and has a temperature of $170^{\circ} \mathrm{F}$. $\left(76.7^{\circ}\right.$ C.). A blower of the gas, met with in a copper mine at Ducktown, $\S$ Tennessee, was strong enough to drive the men away from their work for a time. Two bad accidents took place in sinking a shaft at Stassfurt, through rock-salt, from sudden irruptions of the gas : on one occasion eight persons, and on the other seven persons, were stifled. Various fatalities are ascribed to sulphuretted hydrogen at the ozokerite mines of Boryslaw, but here it is thought that the gas was generated by some process of decomposition in old workings, which were "holed into' by the miners. Sulphuretted hydrogen produced in a somewhat similar way is supposed to have been the cause of a death at a mine on the Gympie goldfield, Queensland.\|

As a natural emanation in mines, sulphurous acid is very rare, but Becker has noticed a pungent gas near the 150 foot level at the Redington quicksilver mine in California, which he considers must contain both it and sulphuretted hydrogen. 1

* Report of the Chief Inspector of Mines, Victoria, for the Year 1874, Melbourne, 1875, p. 9 .

+ Reports of the Mining Registrars for the Quarter ended 30 th September, 1885 , Melbourne, p. 15 .

† Becker, op. cit., p. 3.39 .

$\S$ Phillips, Ore Deposits, I884, London, p. 574.

II Fryar, Grases in MFines, Brisbane, 1890, p. 8 .

I Op. cit., p. 287. 
Sulphurous acid is generated in the underground fires of sulphur mines in Sicily, and some will be formed in other cases of underground fires, if the rock contains iron pyrites.

Small quantities of mercurial vapour are stated to be found in quicksilver mines, and to be the reason of their unhealthiness; but one may also suggest that constant contact with cinnabar, inhaling the dust of the mineral, and allowing some to enter the stomach from eating with dirty hands, may possibly account for all the symptoms observed, without having recourse to the theory that the vapour is present in the atmosphere of the mine.

Artificial Pollution of the Air in Mines.-The pollution of the air is not due solely to gases introduced naturally from the surrounding rocks; various other causes combine to render the atmosphere of the mine unfit for life, and among them may be mentioned the following:

1. Respiration of the persons and animals in the pit ; exhalations from their skin, and emanations from excrement left underground.

2. Combustion of the lamps and candles used for lighting the working places.

3. Absorption of oxygen by pyrites and other minerals.

4. Putrefaction of timber.

5. Explosion of gunpowder, dynamite, \&c.

6. Stone dust from boring.

I, 2. Dr. Angus Smith* reckons that two men working eight hours, and using $\frac{1}{2} \mathrm{lb}$. of candles and $12 \mathrm{ozs}$. of gunpowder, produce $25.39^{2}$ cubic feet of carbonic acid at $70^{\circ} \mathrm{F}$.- viz., 10.32 by breathing, $12^{\cdot} 276$ by candles, and $2^{*} 796$ by gunpowder.

It is considered by some medical authorities that the injurious effects of breathing an atmosphere polluted by the products of respiration, are due more to organic matter than to the small proportion of carbonic acid it contains. The quantity of carbonic acid serves, however, as an index of the amount of organic pollution, and when the air of a room is found to contain 0.06 per cent. by volume of the gas, the atmosphere is said to be unhealthy. Care should be taken to prevent the men from habitually using the workings as latrines, and to apply suitable disinfectants if the rule has been disobeyed.

3. Where the ventilation is sluggish, the absorption of oxygen by pyrites, or by ferruginous minerals passing to a higher state of oxidation, is sometimes very marked.

4. More important is the foulness of the underground atmosphere produced by the decay of the timber supports. The rapidity with which timber rots underground in certain circumstances has already been mentioned; the practice of leaving the useless decaying timber to infect the new pieces that are put in, turns a

* Report of the Commissioners appointed to inquire into the Condition of all Mines in Great Britain to which the Provisions of the Act $23 \& 24$ Vict. c. 151 do not apply, Appendix B., London, I854, p. 224. 
level in some instances into a hotbed of putrescent matter, offensive to the smell, and injurious to the health of the men. Steel supports should be welcomed, if only for ridding mines of one source of pollution of the atmosphere. One of the recommendations of the Ventilation Board in Victoria is that all the bark should be removed from the timber before it is sent down underground.*

5. The nature of the gases and solid residues produced in blasting has been already explained in Chapter IV., and the statement made by some manufacturers that their explosives produce "no noxious fumes" is evidently misleading. In the case of gunpowder, we have the smoke made up of fine particles of carbonate and sulphide of potassium with some sulphur, whilst the explosive force has been due to the formation of a number of invisible gases, especially carbonic acid, carbonic oxide and nitrogen, with sulphuretted hydrogen, marsh-gas and hydrogen.

Nitro-cotton should produce nothing by its explosion but carbonic acid, carbonic oxide, hydrogen and nitrogen ; and nitroglycerine only carbonic acid, nitrogen, and oxygen. But when imperfectly detonated the resultant gases are more noxious ; both explosives generate a large proportion of nitric oxide, and carbonic oxide is liberated in considerable quantity. Dynamite produces the same gases as nitro-glycerine, but, in addition, it sends into the atmosphere, in a very finely divided state, the 25 per cent. of infusorial earth which it contains. Tonite, made from guncotton and nitrate of barium, produces solid carbonate of barium, and the quantity is estimated to be 55 per cent. of its weight. $\dagger$

More has been written of late years about the fumes of roburite than about those of any other explosive, and many useful observations have been made concerning it. After a close examination and an analysis of the fumes produced by tonite and roburite, Prof. Bedson and two medical men $\ddagger$ have come to the conclusion that these two explosives are no worse for the health of the miner than gunpowder. With all three explosives they found traces of carbonic oxide in the air, and they recommend in consequence that an interval of five minutes be allowed to elapse before the men return to their working places after firing. The ore-miner, in studying these conclusions, must not forget that the recommendation is made in the case of working-places which were being swept out by air-currents of I 100 to 5000 cubic feet per minutein other words, the moral is, that if no such currents exist, a longer interval should be given. No nitrobenzene was detected

* Report of the Ventilation of Mines Board, Melbourne, 1888, p. x.

+ "An Investigation as to whether the Fumes produced from the Use of Roburite and Tonite in Coal Mines are injurious to Health," Trans. Fed. Inst. Min. Eng., vol. ii., 1891, p. 380 .

$\ddagger$ lbidem, p. 388 . 
in analysing the air after firing roburite, though its odour was noticed on some occasions.

6. We now, lastly, come to stone du-t, which is certainly not the least noxious of the impurities of the atmosphere breathed by the miner. It is formed in the process of boring holes for blasting, by the shots themselves and by the attrition of pieces of ruck tumbling about during the ordinary processes of mining. However, it is probable that the first cause is the one from which the miner is most likely to suffer injury: when he is boring a hole downwards he puts in water, which serves the double purpuse of facilitating his work and of preventing any dust from being formed; but when he bores an "upper" by hand, water is not used, and even where machine drills are employed, it is not always that one sees a jet of water under pressure applied to the borehole. The result is that the atmosphere of an "end " or other working place may contain a quantity of fine particles of stone in suspension, which are inhaled into the lungs, and irritate the air-passages ; very probably they are the principal cause of the comp'aint known as "miner's asthma" or "miner's consumption."

Having pointed out the manner in which the atmosphere of mines is constantly being deteriorated, it is necessary to explain how it can be renewed, and so kept in a fit state for the workmen employed underground.

NATURAL VENTILATION.-Two systems of ventilation are employed in mines-natural and artificial, either separately or combined. Under the former, currents set up by natural differences of temperature change the air of the workings ; under the latter, artificial means are employed to bring about the same result.

'The I rinciple upon which natural ventilation depends is very easily ul de stood. The temperature of the earth increases at the rate of $I^{-F}$. for about every 60 feet of depth, and this natural heat is the mainspring in creating air-currents. Suppose a very simple case, two shafts AB, CD (Fig. 558), connected by a horizontal level B D. The air in the shafts and level, warmed by its contact with the sides of these underground passages, gradually assumes their temperature, which will be usually higher or lower than that of the external atmosphere; the problem is simply that of two communicating vases. At the point $\mathrm{D}$ we have the pressure due to the weight of the column of air CD + the weight of the atmosphere at $C$. At $B$ the pressure is due to the weight of the smaller column $\mathrm{AB}+$ the weight of the atmosphere at $\mathbf{A}$.

Draw the horizontal lines $\mathrm{CF}$ and $\mathrm{AE}$ and prolong the line of the shaft AB upwards by the dotted lines. The pressure of the atmosphere at $\mathrm{F}$ and $\mathrm{C}$ is the same, and therefore any difference of pressure at $\mathrm{B}$ and $\mathrm{D}$ depends upon the relative weights of the columns $\mathrm{FB}$ and $\mathrm{CD}$; but $\mathrm{AB}$ is equal to $\mathrm{ED}$, so 
that the real difference depends upon the weights of the two columns of air FA outside the mine and CE inside the mine. In this country the external atmosphere in summer is often hotter than that of the mine; therefore the column $\mathrm{CE}$ will be heavier than the column FA. The column CD will overcome the resistance presented to it by the column $\mathrm{AB}$, and create a natural current going in the direction CDBA. In winter the conditions are

FIG. $55^{8}$.

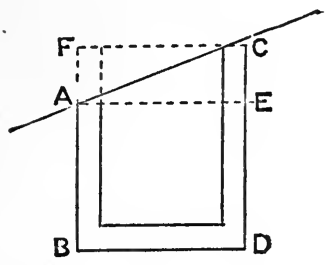

FIG. 559 .

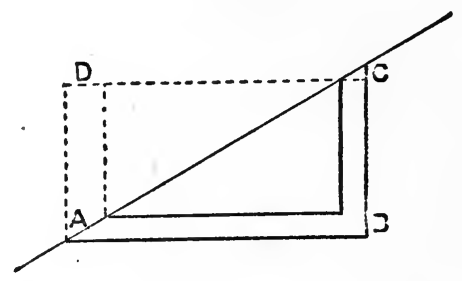

reversed. The cold external column FA is heavier than the comparatively warm internal column $\mathrm{CE}$, and the weight of the entire column FB will be greater than that of the column CD. The result is that the weight of the column FB will cause motion in the direction $\mathrm{ABDC}$.

A still simpler case is one of common occurrence in vein mining (Fig. 559). Let $\mathrm{AB}$ be an adit driven into a hill-side. Draw CD horizontal, and by the dotted lines AD indicate a column of air. The pressure of the atmosphere at $C$ and $D$ is the same; the pressure at $\mathrm{A}$ is that of the column of air $\mathrm{AD}+$ the weight of the atmosphere above the line CD, whereas at $\mathrm{B}$ one has the same constant weight above the line DC together with the column $\mathrm{CB}$. If $\mathrm{AD}$ is warmer than $\mathrm{BC}$, there will be a greater pressure at $B$ than at $A$, and the current will move in the direction $\mathrm{CBA}$; if $\mathrm{AD}$ is colder than BC, a condition of things happening in winter, the current moves in precisely the opposite way.

Another state of things is shown in Fig. 560 , in which there are two shafts of unequal depth connected by an inclined passage or drift. If $\mathrm{AE}$ is

Fig. 560 .

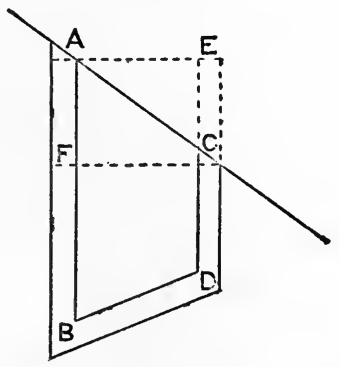
drawn horizontal, as before, at the level of the higher opening to the mine, and CF parallel to it at the level of the lower opening, the air in the bent tube, so to say, CDB, will exactly balance that contained in the vertical shaft $\mathrm{FB}$, and for motive power we have to depend upon the difference in weight of the two columns $\mathrm{AF}$ and $\mathrm{EC}$, a difference depending upon their relative tempera- 
tures. Therefore in summer we get a current travelling in the direction $\mathrm{ABDC}$, whilst in winter it is reversed.

In any one of these cases, the greater the difference in temperature, the greater will be the velocity of the ventilating current. In winter the ventilation will be more active than in summer, because there will be more difference between the outside and inside temperatures ; and, furthermore, though there are differences between the day temperature and the night temperature, still the tendency is always to produce a current in the same direction. In summer the nights may be cold though the days are hot, and therefore the difference in temperature between the air of the mine and that of the surface may be acting in two opposite ways according to the period of the day or night. A shaft which is drawing up, or is an "upcast," during the heat of the day may have a descending current, or be a "downcast," in the cool hours of the night, and practically have no current at all while the outside and inside temperatures are alike.

There is not only this objection to natural ventilation that it may vary in direction during the course of the twenty-four hours, but the still greater objection that at certain seasons of the year it may be nil, because there is no difference in temperature between the outside and inside air to make one column heavier than the other.

The creation of a natural air-current is not due solely to the difference of temperature caused by the natural warmth of the rocks. The heat engendered by the respiration of the men and animals, by the combustion of the candles or lamps, and, lastly, by the explosives is also a factor in making the air of the mine warmer than that of the surface and so setting up a current. The character of the sides of the shaft itself may also play its part. A shaft which has water dropping down it, either from natural springs that find their way in, or from slight leaks in the pumping plant, will naturally become the downcast, if the other orifice is dry.

The strength of the current may be improved, or a natural draught crented where none existed before, by building a chimney above one of the shafts, and so producing artificially a difference of level between the two outlets. The direction of the wind may also turn the scale, and it is often found that a mine is better ventilated with some prevailing winds than with others. As an illustration of an effect of this kind, I need only refer to smoky chimneys, commonly caused by the wind striking some natural or artificial obstruction, which directs it downwards and makes it overcome the upward draught of the fire. The result is sometimes so marked that the householder can tell the direction of the wind, before looking out of doors, by noticing which of his chimneys is giving trouble. With some mines in which the natural current has less force than that of a chimney, it is not to be wondered thit sinilar occurrences take place. 
When speaking of natural ventilation, the property of diffusion requires a word of comment. This property is one by which two bodies of gas placed in juxtaposition with one another gradually become mixed, even if the lighter occupies the higher position. The process is slow compared with the mixing that is brought about by convection, but still it has some effect in causing the dispersion of noxious fumes.

In the examples of natural ventilation just given, it has been assumed that the mine has two orifices; but many workings, at all events at the beginning, have only one. Let us take the three typical cases of a level, a shaft, and a "rise."

Let Fig. 56I represent a level driven a short way into the

FIG. 56r.

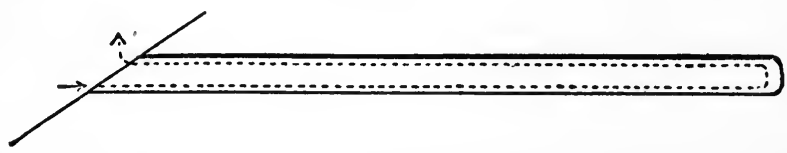

side of a hill. How is the atmosphere of the "end" renewed without artificial appliances? On entering such a level after blasting, the explanation becomes apparent: a current of powder smoke is seen hugging the roof, whilst the lower half of the level is clear. If a candle is set up on the floor, its flame is deflected inwards or towards the "end." The heated gases from the explosive, accompanied by air warmed by breathing and the combustion of the candles, rise as much as they can, and make their way out by the upper part of the level, while their place is taken by cold air from the outside. The course of the gentle current is shown by the dotted lines. The same phenomenon may be observed in

Fig. 562 .

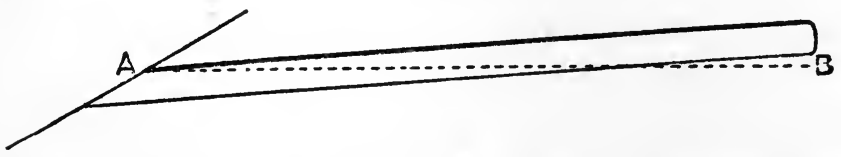

a cross cut driven out from a shaft. This explains the importance, or indeed the necessity, of keeping a level as horizontal as possible if it is being ventilated naturally. 'Take an exaggerated case, in which the men have allowed their " end" to rise considerably, as shown in Fig. 562, so that the floor of the working place is three feet above a horizontal line drawn through the top of the mouth of the tunnel. Smoke and warm gases produced in the "end" will rise, and, finding no means of exit, will remain in th" highest part until they cool down and diffusion has had time to play its part.

It might seem at first sight that a current could not be formed in a shaft which does not communicate with other workings; but 
even when no partition of any kind has been put in, the sides of the pit kept cool by trickling water may cause tie air to form descending currents, whilst in the centre there is an ascending current, as shown in the diagram (Fig. 563). In an incline (Fig. 564) the ascent of the warm smoke along the dry roof and the influx of cold air along the floor are sometimes very noticeable.

When the working place is a "rise," it is evident theoretically, and still plainer practically, that the warmth of the foul gases at the top tends to keep them in that position, and that the evil must increase as the place gets hotter (Fig. 565). The nature of the excavation prevents things from improving, and the necessity for artificial ventilation is nowhere more apparent than in a working place of this kind; especially if the space is confined. The common statement that carbonic acid collects in the lowest part of the workings is correct only in cases where the gas is

FiG. $5{ }^{63}$.

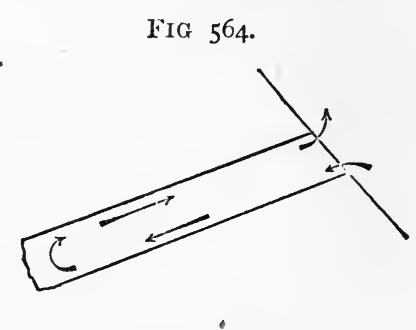

F1G. 565 .
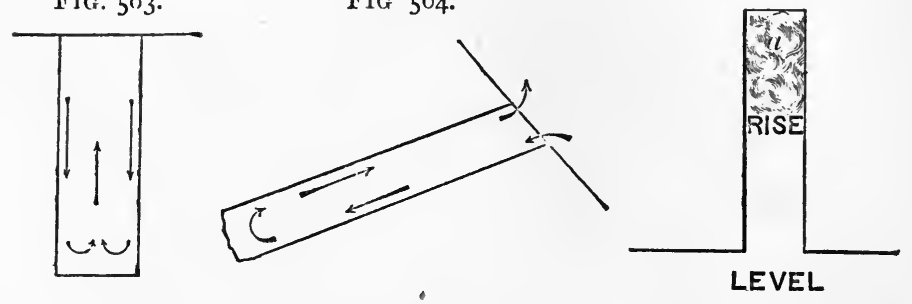

issuing forth from the rocks and sinks down like water. Where it is produced by respiration, candles, lamps, or explosives, it is diffused through a warmed atmosphere, ascends with it and does not separate from the other gases. The consequence is that a "rise" may be found badly ventilated although the air in the level below is fresh and pure.

We will suppose that by reason of the difference in level of the two main orifices of the mine, a trunk ventilating current has been established. The air will then take the easiest road from one shaft to the other, and will not penetrate into any other parts of the workings unless compelled to do so. The turning of the current into any required direction is effected by putting in partitions and doors. In a few cases, the partition serves to make a clean and sharp line of division between two currents which would to a certain extent exist naturally. Thus, we have seen that when the length of a level is not great, an outward current travels along its roof, and an inward current along its floor (Fig. 56I); between the two there is a dead space more or less interfering with both currents by making their boundaries ill-defined. If a horizontal partition of planks (air-sollur) is put in (Figs. 566 and 
567), the two currents are kept perfectly distinct, and the natural ventilation, aided in this way, proceeds in a much more effective manner; the level can therefore be driven further without having recourse to machinery for creating an artificial current.

A common problem is the ventilation of the far end of a drivage, $\mathrm{AB}$ (Fig. 568), provided with a little shaft, CD, which, in winter, naturally creates a current proceeding from A to D, and ascending at once to $\mathrm{C}$. The desired effect may be attained by putting in an air-sollar DE, which compels the air to travel to the far end before it can begin its ascent; another plan consists in covering the bottom of the shaft by a platform (sollar), and carrying a pipe from it all the way along the roof of the level to the "end." This has, of course, the same effect as the air-sollar, but, unless the pipe is large, it does not give

- FIG. 565. FIG. 5 C7.

FIG. 568 .

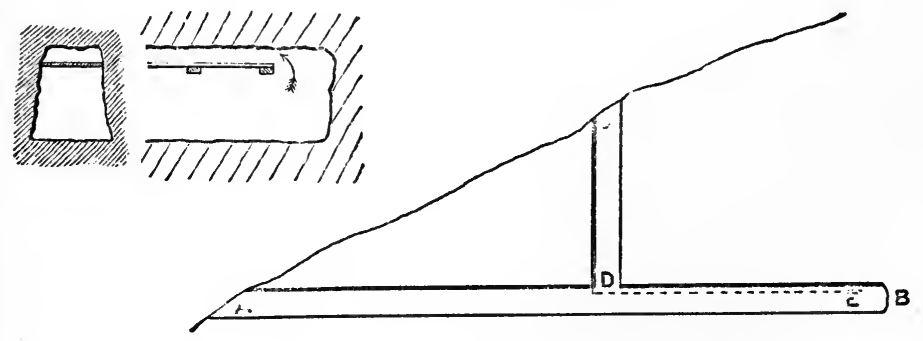

so much area for the current. Pipes have the advantage that they are very easily put in and that they can be used again and again. These methods of conducting an air current are so self-evident, that I should not have mentioned them, were it not for the fact that some mine agents appear to be ignorant of these simple expedients for improving the ventilation of their drivages.

Where the level is wide enough, the partition may be placed vertically; it is then called a brattice. If required for temporary purposes it may be made of canvas, tarred to prevent its rotting (brattice cloth). More lasting and effective partitions are constructed of plank or of brick.

Any close vertical partition in a shaft dividing it into two separate compartments invariably improves matters, when the ventilation of a sinking is becoming sluggish; some trifling difference in the condition of the two compartments decides which is to be the upcast and which the downcast. Where it is not convenient to put in a partition, a separate air compartment may be formed by fixing a large pipe against one side of the shaft and taking it up 30 or 40 feet above the level of the ground 
(Fig. 569); in this manner two columns of unequal height are produced with the desired effect.

If a rise is being put up, or if stoping is being carried on without any winze, there is no difficulty in diverting a natural current existing in the level below and making it serve the working place. All that is required is to block the passsage of the current along the level, and so force it to take the only road that lies open to it. In Fig. $570, \mathrm{AB}$ is a level, and $\mathrm{C}$ the top of a rise, which has an open compartment at each end; one is fitted with ladders, and the other serves as a shoot, down which ore or rubbish can be thrown into the level below. They are separated by the thick partition of rubbish piled up $n$ a platform in the roof of the level and confined by timber at both ends. By putting a

FIG. 569.

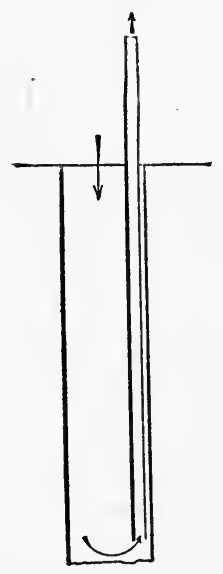

FiG. 570.

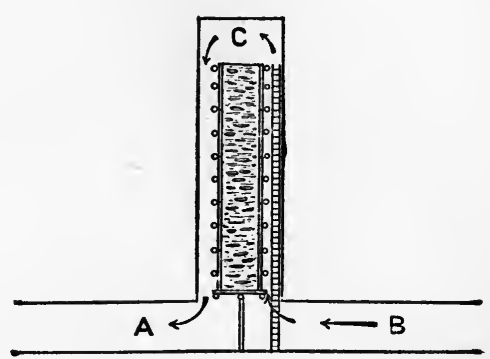

partition in the level, the air is made to pass up one end of the rise, sweep out the foul air produced by the men, candles and explosives at $\mathrm{C}$, and then descend into the level once more. The partition may be a wooden door closing tightly against its frame, or a piece of brattice cloth hung from the roof, which is readily lifted when a tram waggon has to pass underneath. In the case of stopes the mode of procedure is identical, but the air current has not to make such sharp turns.

The case represented in Fig. 568 is that of workings at one level. In vein mining the ore is generally being excavated, or at all events preliminary drivages are being made, at more than one horizon. In Fig. $57 \mathrm{I}$ two shafts have been sunk, and two drivages have been made, one below the other. It is easy to understanci that at an earlier stage of the working, before the shafts had been sunk to $\mathbf{E}$ and $F$, and the level $\mathbf{E F}$ driven, 
a current was set up from $\mathrm{A}$ to $\mathrm{O}$ vi $\hat{a} \mathrm{~B}$ and $\mathrm{D}$, or from $\mathrm{C}$ to $\mathrm{A}$, according to the season of the year; but when the level $\mathbf{E F}$ has been driven, what is to bring the current down to $\mathbf{E}$, for instance, when it has the shorter and easier road direct from $B$ to D? It often happens that special conditions in the shafts themselves, to which allusion has already been made, would in any case cause a movement in the air from $\mathrm{B}$ to $\mathrm{E}, \mathrm{F}$ and $D$, even if the two columns of different height did not exist above them, and in that case some air FIG. 57 I.

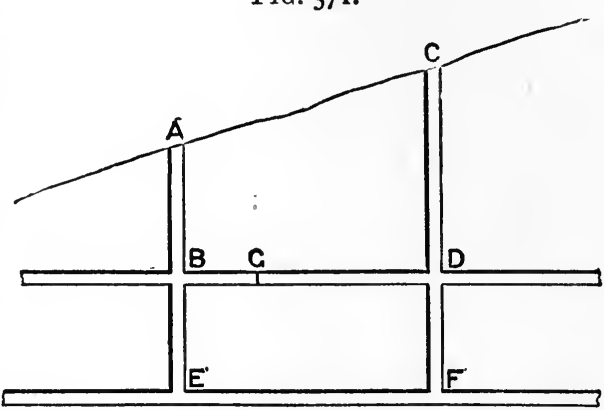
would find its way down to $\mathrm{E}$ and $\mathrm{F}$; but by putting a door at $\mathrm{G}$, somewhere between $\mathrm{B}$ and $\mathrm{D}$, the main current can be forced to proceed by the longer road and ventilate the lower workings. If air is required for men working in the level $\mathrm{BD}$, the partition, or door $\mathrm{G}$, is not made close; then part of the main current takes the shorter road from $B$ to $D$, and part the longer road from $\mathrm{B}$ to $\mathrm{E}, \mathrm{F}$ and $\mathrm{D}$.

Owing to the number of shafts which are usually sunk in working veins, and differences in the level of their mouths, natural currents are set up to a much greater extent than is the case in

FIG. 572.

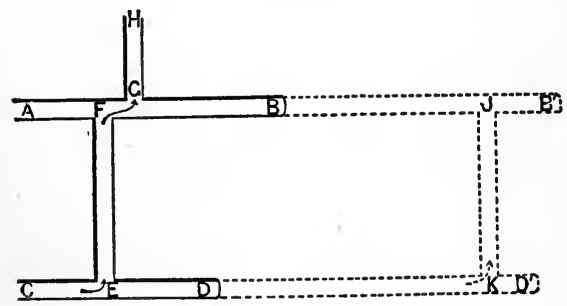
working beds, where a couple of pits situated close to one another and at the same level have to serve as the sole inlet and outlet orifices. Fur this reason natural ventilation is often found to provide a fairly sufficient supply of air along the main course of the current, and the miner has merely to provide for the ventilation of workings in the form of a cul-de-sac, such as ends, rises, and winzes, which are at a distance from this current.

A common method of procedure is to sink winzes at frequent intervals; if $\mathrm{AB}$ and $\mathrm{CD}$ (Fig. 572) represent two levels, 1o to 15 fothoms apart, which are being driven from $\mathbf{A}$ to $\mathbf{B}$ and $\mathbf{C}$ to $\mathbf{D}$ respectively, we will suppose that a ventilating current exists as 
shown by the arrows. B and D are blind alleys, so to say, but so long as their ends B and D are not far from the main draught, they may be sufficiently ventilated by convection currents, set up in the manner explained in Fig. 56r. Soon, however, this mode of supplying air becomes inadequate, and the miner establishes another communication between the two levels by a fresh winze or rise $\mathrm{JK}$; the current is made to take the road shown by the dotted arrow, if a stopping of some kind is put into the winze FE. The name "winze," sometimes written "winds," suggests that the original purpose of the intermediate shaft was to furnish air. In some mines winzes are sunk at fairly regular intervals of 30 fathoms; of course, in selecting a place for a winze, preference is given to ore-bearing parts of the vein, because the cost of sinking will then be partly or wholly repaid by the mineral excavated. Even when the indications at the top may not warrant the assumption that ore is present in paying quantities, the winze serves to prove the ground and sometimes to reveal unsuspected sources of profit. Winzes may be said, then, to have five useful purposes : ventilation, exploration, starting-points for stoping, shoots for ore or rubbish, ladder-roads for the miners.

I have thought it advisable to devote more space to natural ventilation than the coal-miner would think it deserves, because it is the method by which the trunk ventilation of most veinmines is carried on at the present day, and has been carried on for centuries. Nevertheless, I am fully alive to its two weak points-viz., want of constancy and want of strength. The miner is therefore often driven to seek artificial aid in order to make up for these defects.

ARTIFICIAL VENTILATION.-Artificial ventilation is produced either by (I.) furnaces, or (II.) machines.

I. FURNACE VENTILATION.-By employing a furnace, the miner can effect an artificial difference of temperature between two columns of air in the mine, and so produce a current similar to the natural draughts just described.

In small undertakings a fire lit at or near the bottom of the upcast shaft, or contained in an iron vessel suspended in the pit, suffices to create a current, when the natural ventilation is no longer adequate, owing to the state of the external atmosphere. From small beginnings of this kind has developed the large underground furnace, which is, however, in the vast majority of cares, corfined to the domain of the coal-miner, and even there is heing gradually replacerd by fans. My description may, therefore, be extremely brief. The ventilating furnace (Figs. 573, 574, $575)^{*}$ is a huge fireplace at or near the bottom of the upcast shaft, over which is led either all the air of the mine, or a part of it, The air heated in this way is rendered specifically lighter, and tho

$$
\text { * Callon, lectures on Mining, rol. ii., plate lxxxvi. }
$$


weight of the column of cold air in the downcast shaft orercomes that of the air in the urcast and causes it to ascend. It is precisely the same action as that which takes place with the usual domestic fireplace in this country, the chimney playing the same part as the upcast shaft. Cold air is drawn in from crevices around the doors and windows, is heated by the fire, and ascends the chimney.

If the air of the workings is charged with a dangerous proportion of inflammable gas, it is led into the upcast shaft by a special drift-the dumb drift-at a point where there is no danger of its

IIIG. 573 .

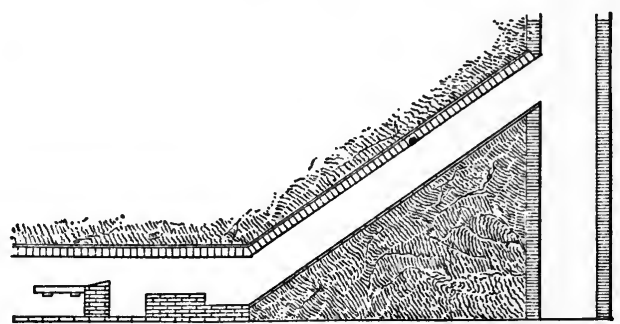

FIG. 574.

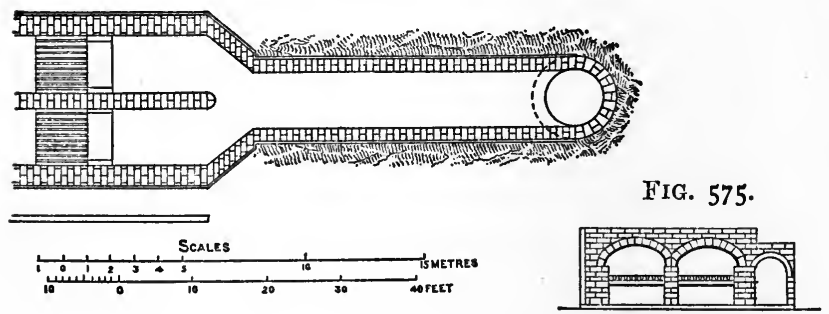

taking fire. In this case the air in the shaft becomes warmed in its upward passage, not only from mixing with the current coming from the furnace, but also by absorbing caloric from the heated sides of the pit.

II. MECHANICAL VENTILATION.-The methods of mechanical ventilation may be classified as follows :

(I) Water blast.

(2) Steam jet.

(3) Air pumps $\left\{\begin{array}{l}\text { (i) Reciprocating. } \\ \text { (ii) Rotary. }\left\{\begin{array}{l}a . \text { Acting by displacement. } \\ b . \quad, \quad, \text {, centrifugal force. }\end{array}\right.\end{array}\right.$

(I) The ordinary water blast is a very simple appliance: it is the well-known tromp, used in some countries for blowing smiths' 
forges. A stream of water falls down a pipe, entangling air drawn in by lateral holes, and drops into a box or barrel with two orifices; these are so arranged that the air shall escape by one, under a slight pressure, and the water from the other. The current of air is carried by square pipes made of boards, or, better, by cylindrical pipes made of sheet zinc, to the place where ventilation is required.

The fall of water is also applied by Williams's water-jet apparatus (Fig. 576). The water brought down in a pipe from a reservoir, or from the FIG. 576 .

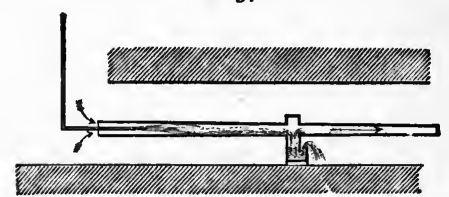
rising main of the column of pumps, issues in the form of a jet from a nozzle, and, driving out the air in front of it, draws in air behind. The water is let off by a box with a discharge designed, like that of the tromp, to give a little pressure, whilst the air-current proceeds through a series of pipes to the "end" or other working-place. The water-blast has the merit of supplying a stream of cool moist air which is very acceptable where the working-place is dry and dusty. By reversing the apparatus the current may be made to flow in the opposite direction, and the "end" is then ventilated by having its foul air drawn out and replaced by an inward draught along the level, instead of being supplied directly with fresh air from the outside or from the main ventilating current.

(2) A steam jet may be applied, like a jet of water, to create an exhaust and to draw out the foul air. For instance, we will suppose that during the sinking of a shaft the air-pipe in Fig. 569 fails to act in an adequate manner, owing to a change in the atmospheric conditions. The agent desires to remedy this state of affairs by some cheap and temporary expedient. If he brings a pipe from the boiler of the winding engine to the upright ventilating pipe, and provides it with a nozzle pointing upwards, he can speedily and at small expense produce an upward current by turning on steam. The steam jet drives air in front of it up the pipe, and at the same time warms it slightly. The exhausting effect produced in this way at the bottom of the pipe is sufficient, in small sinkings, to draw out all the foul air.

A draught may be produced in an upcast shaft by a ring at the bottom, from which issue a number of jets of steam. Such a mode of ventilation may be useful in cases of emergency.

(3) Air Pumps.-Mechanical ventilation on a large scale is always effected bv some kind of air pump, and generally by one which has a rotary action.

(i) Among the pumps which have a reciprocating action, the ordinary air compressor nust be named first, as its utility 
as a ventilating agent is great. The air escaping from boring or other machines renders good service in driving out foul gases generated in the workings, and there is the advantage that, after blasting, a powerful stream of air can be turned on for a short time so as to sweep out the noxious fumes completely. Even where the ground is soft and no machine drill required, it is easy to bring in air from the rain by a line of smaller pipes, and turn on a fresh current when needed. In one sense it is very uneconomical to bring air to a pressure of 60 or $70 \mathrm{lbs}$. to the square inch for ventilating purposes only; but where compressing machinery is always at hand for working underground engines, it is better to be a little wasteful of a cheap power at the surface than to go to the greater expense of having a boy or a man to work a fan.

In a long level driven by boring machinery, with its "end" far removed from the main ventilating current, the smoke produced by blasting, though driven away from the actual working face, still hangs about for a time, and pollutes the atmosphere which the miner has to breathe in going backwards and forwards. In such cases it is best to draw away the foul gases as soon as they have been produced, and prevent their mixing with the air of the level. With compressed air at his command, the miner can easily work an aspirator of some kind, such as Körting's, or the somewhat similar contrivance of Mr. Teague (Fig. 577). The ordinary air-main for bringing in the compressed air working the boring machinery is shown at the bottom

FIG. 577 .

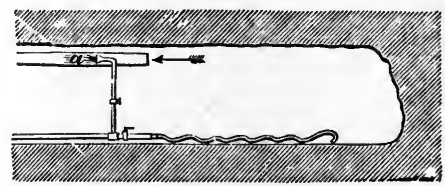
of the level, with the piece of flexible hose at the end. The boring machine has been removed and the air shut off from the hose; by turning another cock, it passes up the upright piece of pipe and rushes out of the nozzle in a direction opposed to that of the drivage. This has a powerful exhausting effect, and the "end" can be cleared of smoke in a few minutes.

The Hartz blower (duck machine, Cornwall) (Figs. 578 and 579) is an air pump of simple construction which can be made up by any mine carpenter. It consists of two round or rectangular boxes, one fitting inside the other, and moved up and down by being connected to the main rod of the pumps; the upper box has a valve at the top, and the lower box is provided with a pipe also having its valve. The lower box is partly filled with water so as to make an airtight connection. With the valves arranged as shown in Fig. 579, the machine will act as an exhausting pump and draw out the foul air; if the play of the valves is reversed it acts as a blower. 
Struve's ventilator is a gigantic double-acting machine of this class, so constructed that it draws air from the mine during the down stroke as well as during the up stroke.

(ii) $a$. A mong the rotary air pumps acting by displacement may be mentioned Roots's ventilator, of which various sizes are made, suitable to the requirements of the whole of a large mine or merely to those of a single "end."

This air machine (Fig. 580) consists essentially of two similar pistons upon parallel shafts, revolving in a casing, but without actually touching each other or the casing. The clearance in a large ventilator is under $\frac{1}{8}$ inch. The pistons are of such a shape

FIG. 578. FIG. 579 .

FIG. 580.
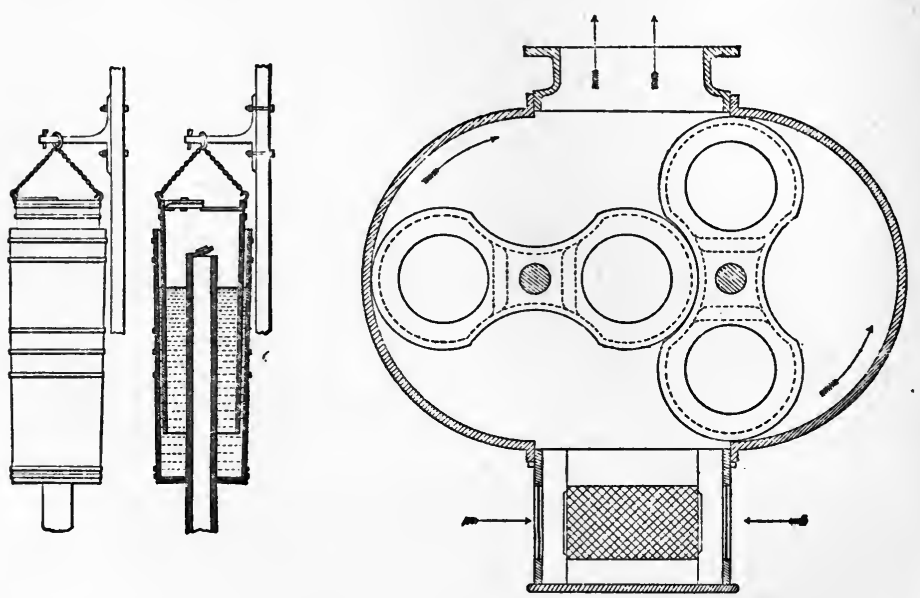

that a definite volume of air is drawn in or forced out by each half-revolution. As the pistons are always kept in pesition by gearing, there is no fear of one coming in contact with the other.

(ii) $b$. Centrifugal Ventilators or Fans.-This class includes all the most important ventilators in use at the present day. They are characterised by the fact that the current is produced by blades or vanes fixed to a shaft, revolving at a high speed. The air lying between them is whirled round and flies off tangentially at the tips, like a stone from a sling. The space occupied by this air is at once filled by supplies coming in at the centre, and the process goes on continuously. The centrifugal ventilators or fans are generally used as exhausters-that is to say, they are arranged so as to suck air out of the mine, instead of forcing it in. They can claim the merit of great simplicity, and of being capable of withdrawing very large volumes of air. 
Four types of fans very largely used in this country at the present day are the following: Capell, Guibal, Schiele and Waddle.

The Capell fan (Figs. 581 and 582) consists of two concentric cylindrical chambers, each provided with six curved vanes or blades, the convex sides of which are turned in the direction of the rotation. The cylindrical shell or drum, $b$, between the two sets of vanes contains openings, or portholes, $d d$, allowing the air to pass from the inner to the outer chambers. There is one such opening between every two vanes. The air contained between any two of the inner vanes, $c$, is thrown out by centrifugal force when the fan revolves, and passes at a high velocity into the corresponding outer chamber. Here it is supposed to strike against the concave vane, and give back to it the greater part of the impulse received from the inner chamber. The object of the inventor of this and of other fans is to discharge

FIG. 58I.

FIG. 582 .
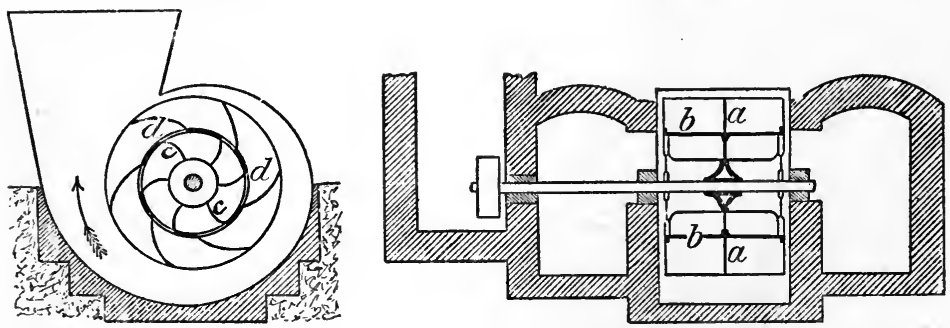

the air with the least possible velocity, for velocity imparted to the ontgoing air means work done to no purpose, or, in other words, a diminution of the useful effect of the power employed in driving. The advantage claimed for the fan is that it succeeds in effecting this object even when driven at a high speed, and that, therefore, it can do a large amount of work in spite of its comparatively small diameter. The smallness of the fan of course reduces its first cost. It is not only capable of withdrawing large quantities of air, but also of effecting a considerable diminution of pressure.

The fan may be made with an inlet on one side only or with an inlet on both sides. It runs in a spiral casing, not fitting closely, which gradually gives a larger and larger outlet for the air and then finally discharges it into an expanding chimney. Figs. $58 \mathrm{I}$ and 582 show a double inlet fan, $a$ being the close vertical diaphragm separating it into two parts. A spe ial passage (fan drift) brings the air from the upcast shaft to the ventilator, which is set in motion by a belt driven by the fly-wheel of a pair of horizontal engines.

These fans are made of diameters varying from 8 to ${ }_{5}$ feet; 
the width of the small ones is 7 feet, that of the largest $\mathrm{I} I \frac{1}{2}$ feet; they are driven at speeds varying from 180 revolutions per minute in the case of the largest fans, to 300 in the case of the smallest. Under these conditions the smallest fan is said to be capable of passing a volume of 100,000 cubic feet of air per minute, with a diminution of pressure (water-gauge) of $2 \frac{1}{2}$ inches, whilst the large fan moves the enormous quantity of 300,000 cubic feet per minute. The power required is estimated at 60 I.H.P. in one case and 180 in the other.

The Guibal fan, brought to us from Belgium (Fig. 583); has deservedly been a favourite for many years. It is a fan with eight

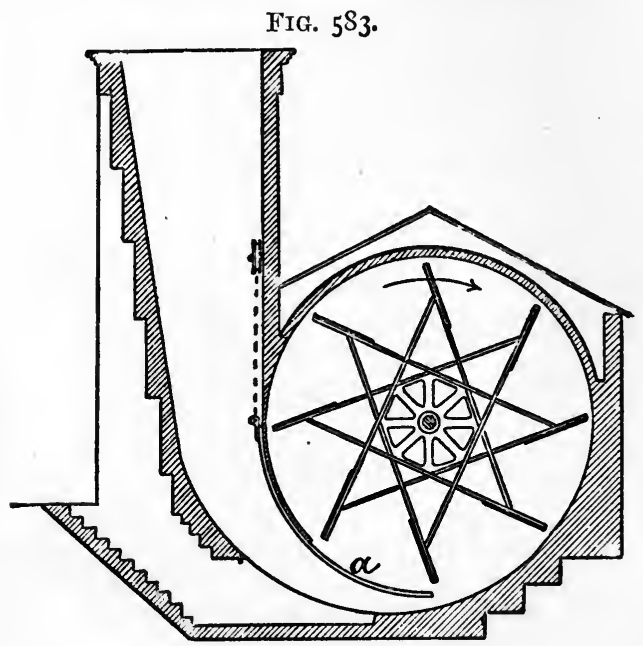

or ten straight blades, which are not set radially. An important peculiarity, introduced by Guibal and since copied by others, is the expanding stack or chimney, which gradually lessens the velocity of the air as it travels towards the point of discharge into the outer atmosphere, and the sliding shutter, $a$. The shutter enables the opening of the fancasing into the expanding chimney to

be regulated at pleasure: if this opening is too big, eddies are formed and air re-enters the fan; if, on the other hand, the opening is too restricted, an unnecessary amount of force is required to work the fan, and the air escapes with too great velocity. By careful regulation the best possible effect is attained.

The regulating shutter has been greatly improved by Messrs. Walker Brothers of Wigan, who make the opening in the form of an inverted V, with the object of producing a gradual instead of a sudden change as each blade passes into the enclosed part of the casing. The consequence is that the amount of vibration is greatly reduced and the fan rendered nearly noiseless. They build their fans entirely of iron or steel.

Guibal fans are made of diameters varying from 20 to 46 feet, and widths varying from 6 to 13 feet. Fans 30 feet in diameter are usually driven at a speed of about sixty revolutions per ninute, and the large fans of 40 to 46 feet at fifty revolutions. 
The Schiele fan is somewhat like the Guibal. It has the same expanding chimney, but the blades are curved and the casing is not close (Fig. 584); besides, the width of the blades is not the same throughout. The blade is widest in the middle, and then it decreases both towards the centre of the fan and towards the tips. It is a small fan compared with the Guibal, the diameter varying from 5 to 20 feet, width from $I$ to 3 feet. The speed of driving is 500 revolutions per minute for

FIG. 584 .

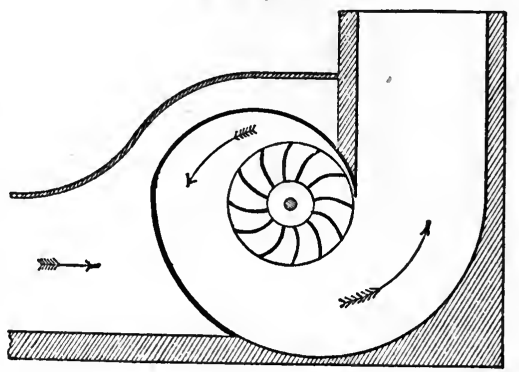
the smallest fans and rio per minute for the largest. The air is always taken in on both sides.

We come lastly to the Waddle fan, which differs from those just described by running open-that is to say, it is not enclosed in any external casing (Fig. 585). It is a very flat hollow truncated cone, with the base closed and a central opening on the other

FIG. 585 .

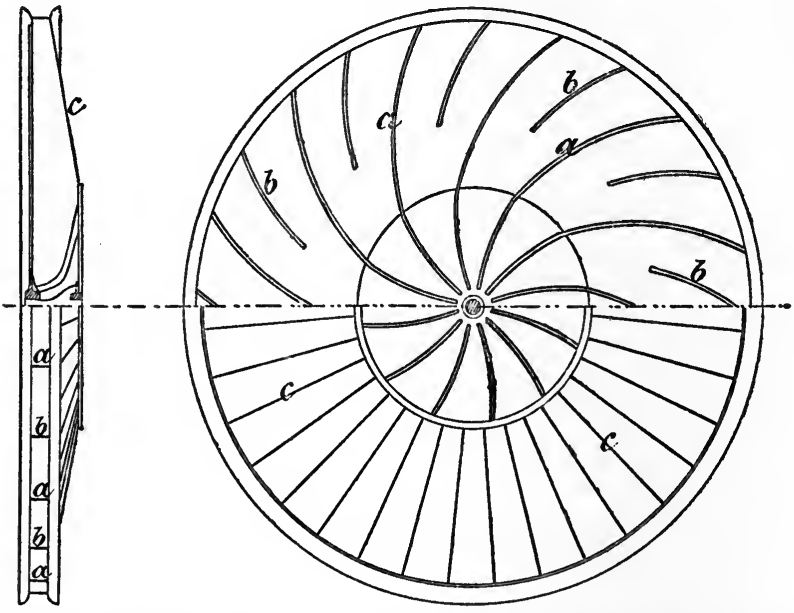

side. Originally the blades $a b$ were curved, as shown in the figure, but latterly they have been made radial; $c c$ are some of the outer plates. The air passes in at the centre and is discharged at the circumference. These fans are made with a diameter of 30 to 45 feet. A recent improvement is the addition of a 
divergent outlet-in other words, the two rims projecting beyond the blades are inclined outwards. The velocity of the air leaving the fan is thus lowered, and less power is required for driving. A Waddle fan, described by Mr. Walton Brown, ${ }^{*}$ had the following dimensions :

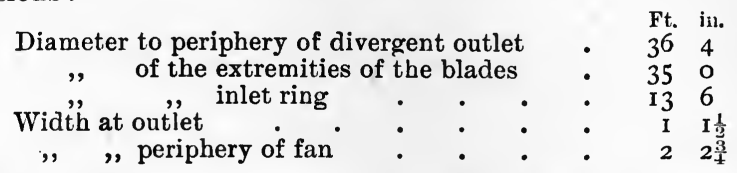

The Waddle, like the Guibal, is a slow-running fan, which can be driven directly from the engine without the aid of belts or gearing.

Professor Lupton $\uparrow$ has designed a fan, which he calls the Medium fan, in which he considers that he has brought together the good points both of the large fans, such as the Guibal and the Waddle, and of the small fans, such as the Schiele and the Capell. It is from 15 to 25 feet in diameter.

TESTING THE QUALITY OF THE AIR.-In a wellregulated mine the manager should be able to determine the quality and quantity of the air circulating in the workings, and the efficiency, from a mechanical point of view, of the machinery employed for ventilation.

A knowledge of the quality of the air is necessary for two reasons : it may contain gases capable of causing accidents by explosion or suffocation, or it may be polluted by gaseous and other impurities likely to injure the health of the men who have to breathe it.

Fire-damp.-Though ore and stone miners are rarely exposed to any danger from fire-damp, exceptional cases arise in which carburetted hydrogen is emitted naturally or formed artificially in mines, as mentioned in the beginning of this chapter. It is therefore essential that the miner should have some knowledge of the means employed in testing for fire-damp, even if he is not going to manage a colliery. However, the subject must be treated briefly, and the student desirous of further information may be referred to treatises on coal-mining.

Indications of fire-damp are afforded by the singing noise made by the gas if it is issuing forth in large quantities from moist coal, by its bubbling up in water, and by the cracking noise of bubbles as they burst ; but its presence is commonly detected by its effect upon the flame of a lamp burning oil, benzine, alcohol, or hydrogen. The additional brilliancy which it imparts to a platinum wire made incandescent by the passage of an electric current may also be employed as a test, or the diminution in the volume of a measured

* "Waddle Patent (I89o) Fan," Trans. Fed. Inst. M. E., vol. ii.. 18909I, p. 173 .

+ Notes on the Medium Fan, Proc. Fed. Inst. Mr. E., vol. i., I89o, p. 65. 
quantity of air, exposed to the action of a red-hot palladium or platinum wire, causing combustion.

The lamp employed should be a safety lamp, for fear that an accidental ignition of the gas should cause an explosion. A fewsafety lamps will be described in the next chapter. They are fed with vegetable or mineral oil, or with a mixture of them. In testing for "gas," the wick is drawn down until the yellow flame almost disappears, and the lamp is held in the place where the fire-damp is supposed to be present; on account of its specific lightness it lodges against the roof, and it is there, if anywhere, that it is most likely to be found. If fire-damp is present in suffcient quantity, its combustion produces a pale blue "cap" (halo, or aureola) around the little flame, and the greater the proportion of fire-damp, the higher the cap. According to Professor Galloway* 2 per cent. of fire-damp in the air will give an exceedingly faint cap $\frac{1}{8}$ inch high, whilst 4 per cent. gives a conical cap $\frac{1}{2}$ to $\frac{5}{8}$ inch high. If a lamp fed with benzine is used, the phenomena are plainer. The appearances of the flame burning in mixtures of air and marsh-gas of different proportions are well represented by coloured plates in a report made by Professors Kreischer and Winkler, $\dagger$ and in the Proceedings of the Austrian Fire-damp Commission. $\ddagger$ With I per cent. of fire-damp there is a faint aureola, and with 2 per cent. it is plain, conical at the top and $\frac{2}{5}$ inch (10 $\mathrm{mm}$.) high ; when the proportion is increased to 3 per cent., there is a well-defined cap $\frac{3}{4}$ inch $(20 \mathrm{~mm}$.) high. By using a dead-black background, it is claimed that Ashworth's modified benzoline safety-lamp $\S$ will give a distinct cap $\frac{1}{4}$ inch high with $\frac{1}{2}$ per cent. of fire-damp.

The blue non-luminous flame of alcohol enables still smaller quantities of fire-damp to be made known, and the Pieler lamp\|

* "On the Fire-damp Cap," Proc. South Wales Inst. Eng., vol. x., I876-7, p. 290.

† "Untersuchungen über Sicherheitslampen," Jahrb. f. d. Berg- und Hüttenwesen im K. Sachsen, I884, p. 54, and plates ii. to vi.

$\ddagger$ Verhandlungen der Centralcomités der österreichischen Commission zun Ermittlung der zweckmässigsten Sicherheitsmaassregeln gegen die Explosion, schlagender Wetter in Bergwerken. 3 Heft. Vienna, 1890, plates ii. and iii., p. 225 .

$\S$ Clowes, "On the Application of the Hydrogen Flame in an ordinary Safety-lamp to the Detection and Measurement of Fire-damp," Proc. Roy. Soc., vol. li. I892, p. 90.

|| Pieler, Ueler einfache Methoden zur Untersuchung der Grubenwetter, Aix-la-Chapelle, 1883. Kreischer and Winkler, op. cit., p. 77. C. Le Neve Foster. "On the Pieler Lamp for indicating small quantities of Firedamp," Trans. Geol. Soc. Manchester, vol. xvii., 1884, p. 252. Broockmann. "Untersuchung der durch Sumpfgas hervorgebrachten Erscheinungen der Pieler-Lampe," Anlagen zum Haupt-Berichte der Preussischen Schlaguetter Commission, vol.i., p. 129, vol. iii., p. 167, and plates. Walton Brown, "The Pieler Spirit-lamp as a Fire-damp Indicator," Trans. N. E. Inst. $M$. $E$., vol. xxxviii., I890, p. 177 and plates. Austrian Fire-damp Com mission, op. cit., plate ir. 
is based upon this fact. It begins to indicate with $\frac{1}{4}$ per cent. of fire-damp, and even with $\frac{1}{2}$ per cent. the cap or aureola is 2 to $2 \frac{1}{3}$ inches high, and clearly recognisable; with I per cent. it is nearly 4 inches high.

Chesneau * obtains a plainer and more brilliant cap by adding a little nitrate of copper and an organic chloride to the alcohol, and Stokes has introduced the improvement of combining a detachable alcohol-reservoir with an ordinary safety-lamp, and so enabling the official to test with the oil or the spirit flame at pleasure.

Mallard and Le Chatelier pointed out the value of the hydrogen flame as a fire-damp indicator in a report to the French Fire-damp Commission, and Pieler made use of it for testing samples of mine air which were brought to a laboratory at the surface. Quite recently Prof. Clowes $\nmid$ bas construsted a hydrogen lamp sufficiently portable for use underground in the working places themselves. The lamp is so constructed that it. will burn either an illuminating oil or hydrogen as required. A little tube is brought up through the oil reservoir, and, on turning a cock, a jet of hydrogen issues forth close to the ordinary oil flame. It ignites at once, and the wick of the oil flame is pulled down till it goes out; the non-luminous hydrogen flame:now serves as a delicate indicator. The oil flame is relighted from the hydrogen flame when the testing is concluded, and the gas is then turned off. The cap with $\frac{1}{4}$ per cent. of fire-damp is $\frac{2}{3}$ inch ( $17 \mathrm{~mm}$.) high, and with I per cent. it is $\frac{7}{8}$ inch $(22 \mathrm{~mm}$.) high. The hydrogen is contained in a small steel cylinder which can be attached to the lamp in the form of a handle.

The combination of a very delicate testing apparatus with the ordinary lamp has the advantage of enabling the official to do his work with one lamp instead of two.

Liveing's $\ddagger$ patent gas indicator depends upon the fact that fine platinum wire, made red-hot by the passage of an electric current, will glow with greater brilliancy when there is firedamp present in the atmosphere than when there is none. This phenomenon is due to the heat given off by the combustion of the fire-damp in immediate contact with the wire; and the greater the heat, the more the wire will glow. The increase in brilliancy corresponding to a given percentage of fire-

* “ Notes sur un nouvel indicateur de grisou ; " "Essais effectués dans les mines avec l'indicateur de grisou de G. Chesneau;" "Instruction pour l'emploi de l'indicateur de grisou de G. Chesneau," Ann. des Mines, Paris, I892 and 1893. Comptes-rendus Soc. Ind. Min., 1894, p. 25.

+ "On the Application of the Hydrogen Flame in an ordinary Safetylamp to the Detection and Measurement of Fire damp," Proc. Roy. Soc., vol. li., 1892, p. 90.

‡ Liveing, On an Instrument for the Detection and Measurement of Inflammable Gas in the Atmosphere of Mines. L. Clark, Muirhead and Co., Westminster, London, I\$8I. 
damp is measured by a small photometer, which cannot be understood without a tigure.

Shaw's apparatus is based upon the principle of determining the limits of inflammability of gaseous mixtures, or, in other words, of ascertaining the precise degree of dilation which renders the mixture just capable of being ignited. It consists of two main parts, an ingenious mixing apparatus and an exploding chamber. By the aid of the first, a mixture of pure air with inflammable gas, or with mine air, can be prepared in any desired proportions, and then driven into a cylinder, where it meets with a naked flame. If the mixture contains a sufficient proportion of inflammable gas to explode, a loose stopper is bluwn out and strikes a bell, giving an audible signal. By making a succession of experiments, the exact volume of mine air required to bring a known mixture of gas and air to the ignition point can be ascertained, and from this the percentage of fire-damp is determined. Samples of mine air can thus be tested at the surface with a considerable amount of accuracy by any intelligent foreman.

Carbonic Acid.-Two evils are feared from the presence of this gas in the atmosphere of mines-either suffocation when the proportion is large, or injury to health when the proportion is smaller. If the gas is issuing from the rocks, it settles down at the bottom of the excavation in virtue of its specific gravity, and men have been asphyxiated by descending into shafts or wells in which the gas had accumulated without their knowledge. Where danger of this kind may be apprehended-for instance, in mines known to be liable to emissions of carbonic acid, or in the case of old workings that have not been recently entered, the usual test is lowering a lighted candle. If the candle is found to burn brightly, it is concluded that there will be no danger in making the descent; if it goes out, it is evident that the air is untit to support combustion and human life; if it burns dimly, there is need for the greatest caution.

The ore and stone miner also relies upon the candle for testing the air of his working place, in cases where the proportion of carbonic acid falls very far short of thit required to produce suffocation. He is apt to consider that if the candle burns freely when held upright, and does not go out when moved quicklv from side to side, the ventilation must be good. Dr. Angus Smith states in his report to Lord Kinnaird's Commission * that this is a fallacy, and he considers that the candle test affords no distinct sign that the air is bad, until the impurities have reached an amount beyond the maximum which is consistent with good ventilation. Thus, the candle affords no indication of the presence of $\frac{1}{4}$ per cent. of carbonic acid; if the percentage is greater than this he says that men should not be allowed to work, and, to use his own words, "it follows therefore that the candle, as used, is only valuable

$$
\text { *Op. cit. Appendix B. p. } 254 \text {. }
$$


when the air is so bad that no one should be allowed to remain in it."

$\mathrm{He}$ is of opinion that the carbonic acid of dwelling rooms should not be allowed to exceed 0.06 or 0.07 per cent., and agrees with Pettenkofer,* who lays down $0^{\circ}$ I per cent. of the gas as the beginning of decidedly bad ventilation. The latter says : "A series of examinations have resulted in the conviction that one volume of carbonic acid in rooo volumes of room air indicates the limits which divide good from bad air. This is now generally adopted and practically proved, always provided that man is the only source of carbonic acid in the space in question." Other good authorities $\uparrow$ write to the same effect.

Such small percentages of carbonic acid, which are wholly unrecognisable by the candle test, can be readily detected and easily measured by methods which are quite within the powers of an ordinary mine agent.

Angus Simith's Process - The first process is one proposed by Dr. Angus Smith $¥$ in $186_{4}$-viz., shaking a known quantity of lime-water with a known volume of air, and observing whether there is sufficient carbonic acid in the air to neutralise the lime. The only alteration I propose is the use of phenolphthalein as an indicator, instead of turmeric paper or rosolic acid.

The necessary apparatus consists simply of :

I. One 8-oz. bottle and cork.

2. Une 5-oz. bottle and cork.

3. One bottle of lime-water with excess of lime.

4. One pipette or measure holding $\frac{1}{2} \mathrm{oz}$.

5. Four $\frac{1}{2}-\mathrm{oz}$. bottles corked.

6. One $\frac{1}{4}-\mathrm{oz}$. bottle containing an alcoholic solution of phenolphthalein.

7. One piece of india-rubber tube, about a foot long.

According to Dr. Angus Snith, lime-water is fairly constant in strength, and sufticiently so for his process of air-testing. After the battle (No. 3) has been well shaken up several times with the excess of lime, the solution is allowed to stand till it is quite clear. $\frac{1}{2}$ ounce of it is measured exactly, and poured into the 5 -ounce bottle, which is then filled up with distilled water or boiled rain water. This gives a solution of one-tenth the strength of the original lime-water. Add a drop or two of the solution of phenolphthalein, and the lime-water at once assumes

* The Relations of the Air to the Clothes we Wear, the House we Live in, and the Soil we Dwellon. Abridged and translated by Augustus Hess. London, 1873 .

$\dagger$ Parkes and de Chaumont, "A Manual of Practical Hygiene," 6th edition, London, 1883, p. 153. Meymott Tidy, "Handbook of Modern Chemistry,"' Iondon, 1878 , p. I02.

$¥$ Op. cit. Appendix B, p. 239. C. Le Neve Foster, "On One of Dr. Angus Smith's Methods of Testing Air," Truns. Ilin. Assoc. and Inst. Corn., vol. ii., part 2, p. 40. 
a beautiful pink colour, which remains so long as there is any lime un-neutralised. This dilute lime-water is now of a strength that $\frac{1}{2}$ ounce of it will neutralise the carbonic acid in an 8-ounce bottle,* if the air in it contains $\frac{1}{4}$ per cent. of this gas by volume. This percentage has been proposed as a standard which should not be exceeded.

In order to make a test, fill the 8-ounce bottle with the air of the place, by sucking out its contents with a piece of indiarubber tube, of course taking special care not to breathe into it afterwards ; then add $\frac{1}{2}$ ounce of dilute lime-water, cork the bottle and shake it. If the pink colour disappears, the air contains more than $\frac{1}{4}$ per cent. of carbonic acid; if the colour is not discharged, the air contains less than that amount. If the colour fades slowly, and does not finally vanish until after a great deal of shaking, it may be assumed that the percentage of carbonic acid does not greatly exceed $\frac{1}{4}$, whereas if the disappearance is rapid after a few shakes, the contrary of course is the case.

It need hardly be said that the accuracy of the process depends upon the precision with which the solution is measured, and for this purpose a pipette, or a burette, will do better than a graduated glass cup. I think it best to carry each separate $\frac{1}{2}$ ounce of lime-water in its own bottle, and it is well to see by actual measurements that $\frac{1}{2}$ ounce can be poured from the little bottle, for a few drops always remain behind.

However, even if all precautions are taken, the observations cannot pretend to vie with Dr. Hesse's method (p. 505) in accuracy, because changes of temperature and pressure alter the weight of the air contained in the 8-ounce bottle. Luckily in the case of mines, the two sources of error act in opposite directions, and sometimes may neutralise each other, the tendency to expand, owing to increased temperature, being counteracted by a greater barometric pressure due to the depth of the mine.

A leather case containing an 8-ounce bottle and four halfounces of lime-water, by means of which four tests can be made, measures only $7 \frac{1}{2}$ inches by $3 \frac{1}{4}$ inches by $2 \frac{3}{8}$ inches, and is sufficiently portable to be easily carried, even when climbing up "rises" or "stopes."

Lunge's Apparatus.-Instead of simply deciding whether or no the carbonic acid exceeds the proposed standard of 0.25 per cent. by volume, it may be sometimes desirable to ascertain the precise amount of the impurity. This can be done by Dr. Lunge's $\dagger$ little apparatus which I described some years ago. $\ddagger$ The method was

* The exact size should be $8 \frac{1}{50}$ oz., the volume of air being $7 \frac{26}{6} \mathrm{oz}$., because the lime-water occupies $\frac{1}{2}$ oz. ; but an ordinary 8-oz. bottle is near enongh for the purpose.

$+Z u r$ Frrege der Ventilation, Zurich, 1877.

$\mp$ C. Le Neve Foster, “On Dr. Angus Smith's Method of Testing the Air of Mines and Dwelling-houses," Ann. Rep. Min. Assoc. Corn. and Devon for 1882, p. 7 . 
originally suggested by Dr. Angus Smith, * and his process consisted in pumping the air of the working place through lime-water until a known standard of milkiness or opacity of the solution was attained. Bad air would cause the standard amount of opacity with very few strokes of the pump, whilst good air required many. I now find it convenient to use lime-water of known strength, and to go on with the pumpings until the pink colour given by phenolphthalein is discharged. This method is, I consider, more accurate than endeavouring to reach the proposed standard of milkiness.

Dr. Lunge's apparatus consists (Fig. 586) of a No. I, or $\mathrm{I}$-ounce, flexible ball-syringe A, connected by a piece of indiarubber tube $B$, with the bent glass tube $D$; at the point $C$ a slit about $\frac{3}{8}$ inch long is cut in the tube with a very sharp knife.

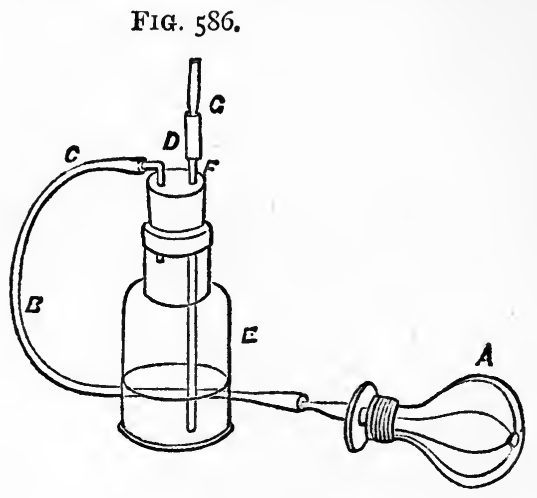

FIG. 587 .

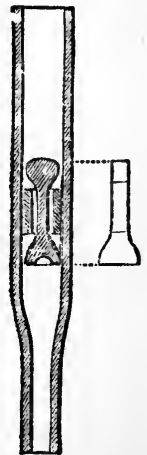

This acts as a valve. The tube $\mathrm{D}$ passes very little beyond. the cork of the bottle $\mathbf{E}$, which holds about two ounces. $\mathbf{F}$ is a tube extending nearly to the bottom, connected by a small piece of india-rubber pipe with the valve-tube $G$, shown on a larger scale in Fig. 587. It is simply a piece of glass tube, with a ring made of india-rubber tube, supporting a glass valve. The top part of the valve is flat, not spherical, and it allows free passage of the air when in the position shown in the figure.

If you squeeze the ball $A$, supposing the bottle partly full of water, the valve in $\mathrm{G}$ rises and prevents any escape of liquid, and the air rushes out at $\mathrm{C}$. On allowing the ball $\mathrm{A}$ to expand again, the slit $\mathbf{C}$ closes, air enters through G, and bubbles up from the bottom of $\mathrm{F}$ into the bottle.

In order to make the bottle as portable as possible, I prefer to use one piece of tube containing the valve instead of having a separate valve-tube as shown; however, this is a mere detail of minor importance.

$$
\text { Op. cit., p. } 238 .
$$


Half an ounce of lime-water or baryta-water of known strength, and coloured pink by phenolphthalein, is put into the bottle; the ball is squeezed and allowed to expand, and a definite volume of air is drawn into the apparatus. A good shaking is given, and continued long enough to cause the absorption of all the carbonic acid by the solution. This process of squeezing the ball and shaking the bottle is repeated until the pink colour is discharged, and knowing the strength of the solution and the volume of air passed through, it is easy to calculate the percentage of carbonic acid contained in the air.

Lunge reckons that each squeeze of a No. I ball causes the entry of 23 cubic centimetres of air. The "No. I" means a one-ounce size; it really contains about 28 cubic centimetres, but the whole of this cannot be expelled by squeezing. To save the trouble of making calculations each time, a table should be drawn out once for all with two columns, the first giving the number of squeezes, and the second the corresponding percentages of carbonic acid.

Further details are given by Winkler, * but the form of bottle shown by him, with a long projecting valve tube, is not so portable as the one which I use with the valve contained in the piece of tube inside the bottle. My case is not larger than a field-glass, and holds all that is necessary for making six determinations underground; it is most convenient to wear it upon the belt, in the same manner as the "Tscherpe-Tasche," or pouch of the Saxon miner.

Where greater accuracy is required, I recommend Hesse's apparatus, $\uparrow$ with which I have made a very large number of carbonic acid determinations in the working places of mines. The leather case, which contains the necessary bottles, burettes, barometer and thermoineter, measures 15 inches by $9 \frac{1}{8}$ by 5 .

Oxygen.-The unfitness of air for breathing is indicated not only by an excess of carbonic acid, but also by a deficiency of oxygen. When there is both a lack of oxygen and an undue proportion of carbonic acid, it is evident that some process of oxidation has been going on, such as the respiration of the miners, the burning of candles or lamps, the slow combustion of coal or pyrites, or, lastly, the putrefaction of timber or other organic matter in the mine. All four causes may combine to render the atmosphere unhealthy.

Dr. Angus Smith considers that when the proportion of oxygen

* Lehrbuch der technischen Gasanalyse, Freiberg, I88j.

† Hesse, "Anleitung zur Bestimmung der Kohlensäure in der Luft, nebst einer Beschreibung des hierzu nöthigen Apparates." Eulenberg's Vierteljahrsschrift für gerichtliche Medicin und öfjentliches Sanitätswesen, Neue Folge, vol. xxxi., Berlin, 1879, p. 357. Hesse, "Zur Bestimmung der Kohlensäure in der Luft," Ibid., vol. xxxiv., 188I, p. 36r. IVinkler, Anleitung zur chemischen Untersuchung der Industrie-G'ase, Freiberg, 1877, p. 375. Winkler, Lehrbuch der technischen Gasanalyse, Freiberg, 1885, p 67. 
by volume has been reduced below $20^{\circ} 9$ per cent., the atmosphere is impure, and when the percentage descends below $20^{\circ} 6$, he calls it exceedingly bad.

Lindemann's Apparatus.-For determining the percentage of oxygen in the air of mines, the simplest apparatus is that of Lindemann, which is figured and described by Winkler.* It is based upon the property possessed by moist phosphorus of combining with the oxygen of the air at ordinary temperatures; if a large surface of phosphorus is presented to the air, the absorption takes place comparatively rapidly at temperatures between $60^{\circ}$ and $70^{\circ} \mathrm{F}$. $\left(15^{\circ}\right.$ to $20^{\circ}$ C.). This apparatus, and instruments of a similar class in which an alkaline solution of pyrogallic acid is used as an absorbent of oxygen, are better suited for use in the laboratory than for making determinations in the mine itself, unless it is desired to confine the observations to one spot. The box containing Lindemann's apparatus is $\mathrm{I} 7 \frac{1}{2}$ inches high by r $\circ \frac{3}{4}$ inches wide, and $5 \frac{1}{2}$ inches deep, and the weight when ready for use is $8 \mathrm{lbs}$. The dimensions and weight are not prohibitive, but it would not be safe to carry such a box with its glass vessel of phosphorus when climbing up stopes by a chain; and there are two other important objections to its use underground: (I) it is difficult to manipulate such instruments with the dirty hands inevitable in mines; and (2) in each working place it would be necessary to wait until the whole of the apparatus had assumed the temperature of the surrounding atmosphere, because unless this were done the results would be erroneous from changes of volume. However, it is easy to bring up samples in suitable glass bottles, and then submit them to analysis in a laboratory above ground. The manipulations are not difficult, and any mine agent capable of doing the delicate work required for an accurate mine survey or the assay of an ore, would find no difficulty in making determinations, sufficiently exact for his purpose, of carbonic acid and oxygen in underground air.

When the task consists in determining the proportion of such gases as sulphuretted hydrogen or the quantity of organic matter, he must call in the services of the chemist.

MEASURING THE QUANTITY AND PRESSURE OF THE AIR.-More attention is paid by miners to measurements of quantity than to determinations of quality. The quantity of air passing through any given passage can be calculated by measuring its sectional area and ascertaining the speed of the current. In the old days there were two rough methods of estimating the velocity of an air-current: (r) by carrying a candle in the hand and regulating the pace so that the flame was not deflected either backwards or forwards, the rate of walking was therefore precisely that of the current; $(2)$ by

"Lehrbuch der lechnischen Casanalyse, Freibers, 1SS5, p. 58. 
exploding a little gunpowder and observing how long the smoke took to travel along a measured distance in a level. These methods have been abandoned in favour of speed-measuring instruments known as anemometers.

Anemometers. - Two kinds may be mentioned : fan-plate type and windmill type.

Dickinson's* is one of the former class; it consists of a plate of mica, hung from two fine bearings, and counterpoised so that a very light breeze will deflect it from its normal vertical position. The deflection is measured by a quadrant attached to the frame of the fan-plate, and, instead of marking the angles, it is usual to show by the graduations the velocity of the air in feet per minute. The instrument is graduated by actual experiments upon a testing machine.

In anemometers of the second type, the speed of the aircurrent is determined by the number of revolutions of an instrument provided with vanes like those of a windmill. Biram's anemometer, one very commonly used, has eight or ten vanes made of mica or vulcanite or aluminium, attached to arms radiating from a small central wheel. The instrument is held up at arm's length in the current, and by the aid of suitable gearing and dials and pointers, like those of a gas-meter, it registers either the number of its revolutions, or the rate in feet or metres at which the air is travelling, during a short period of time, measured by a watch.

As a slow current of air will not make the vanes move round, from its being unable to overcome the friction of the parts, the makers usually supply a certificate with each instrument showing what correction must he made on this account. The correction is determined by a testing machine, on which the anemometer can be whirled round at various rates of speed; it can then be seen how far the readings of the anemometer agree with the known velocity at which the whirling has been carried on.

Messrs. Davis and Son, of Derby, make a self-timing anemometer which dispenses with the use of a watch; it is held up in the current and when the vanes are considered to be revolving at a constant speed, a catch is pressed; this allows the vanes to act on a pointer which indicates on a, dial the velocity in feet or in metres per second.

In making observations with the anemometer, it is essential that an airway of uniform section be taken; levels which are lined with brick arching are well adapted for the purpose. If the airway is not regular, eddies will be set up interfering with the accuracy of the results. A further necessary precaution is taking observations in various parts of the area chosen for the experiment, because the velocity is not uniform through-

*Dickinson, "On Measuring Ai- in Mines," Trans. Manclester Geol. Suc., vol. xiv., 1878, p. 31 . 
out this area. The mean of the readings gives the mean velocity of the current. In the instructions laid down by a committee appointed by three of the British Mining Institutes, ${ }^{*}$ the area at which the observations are made has to be divided up by horizontal and vertical strings into sixteen equal parts, and a reading of the anemometer taken in each.

Water-Gauge.-For calculating the efficiency of the ventilating machinery, a mere knowledge of the volume of air passed through the workings does not suffice; in addition, its pressure has to be determined, or rather the difference between its pressure and that of the external atmosphere.

The instrument employed for this purpose is the manometer, or water-gauge. It is a glass tube bent in the form of a $U$, partly filled with water; one leg is in communication with the outer atmosphere and the other with that of the mine. Usually it is placed in the engine-house of the fan, and a pipe is carried from it into the fan drift. The suction of the fan causes the pressure of the air in the mine to be less than that of the external atmosphere, and the diminution of pressure is indicated by the difference in the heights of the two columns of water in the U-tube,

The manner in which a water-gauge acts can

FIG. 588.

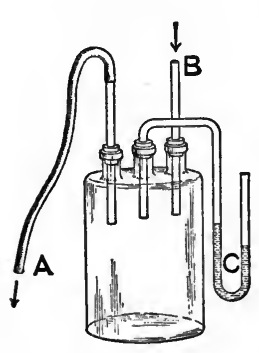
easily be explained to students by constructing a model from a Woulff"s bottle (Fig. 588), or any other bottle or jar which will take three pieces of glass tube. If the mouth is applied to the piece of india-rubber tube $\mathbf{A}$, air can be drawn through the bottle in the direction indicated by the arrows. With a certain degree of suction, the resistance caused by the passage through the tube $B$ becomes plain, and a strong air current is not produced until the external pressure is decidedly greater than that inside the bottle, which is indicated by the rise of the coloured water in the gauge $C$, as shown in the figure.

In the instruments employed in mines, the difference in pressure is measured by a scale which can be moved up and down by a screw, so as to make the zero correspond with the level of the water in the free limb. It usually varies from I to 4 inches. In order to prevent the water in the gauge from oscillating rapidly up and down, which would happen if the current were irregular, the tube connecting the two upright limbs is contracted, or, what comes to the same thing, the gauge is

* Joint Committee of the North of England Institute of Mining and Mechanical Engineers, Midland Institute of Mining, Civil, and Mechanical Engineers, and the South Wales Institute of Engineers, "On Mechanical Ventilators, 1888," "()b-ervations to be Made, and Instructions to the Engineers." Trans. N. E. Inst. MI. MI. Eng., vol. xx $\times$ vii, I887-8, p. I90. 
made in the form of two chambers with a glass front and a connecting aperture, the size of which can be regulated by a tap. This is Dickinson's water-gauge, * which is a brass box 6 inches high, 4 inches wide, and 3 inches deep, with a partition in the middle, making two chambers each 2 inches by 3 inches. A glass front shows the two columns of water, and a scale, graduated into inches and tenths, enables the difference in their heights to be measured.

Efficiency of Ventilating Appliances.-The efficiency of a fan or other ventilator is calculated by comparing the work which it does in drawing air through the mine, with the work done by the steam in moving the piston of the engine that drives it.

The work done in moving air is reckoned from the volume displaced and the pressure; the former is ascertained by the anemometer and the latter by the water-gauge. As a cubic foot of water weighs 62.425 pounds, each inch inclicated by the watergauge will represent pressure of one-twelfth of this amount, or $5^{\circ} \mathbf{2}$ pounds per square foot. A depression of the water-gauge of 2 inches will mean $2 \times 5^{\circ} 2$ or $10^{\circ} 4$ pounds pressure per square foot. In common parlance the word "depression" is understood, and the miner speaks of a "water-gauge" of 2 inches, for instance, meaning thereby a depression of the water-gauge.

The work done is looked upon as that of pushing a volume of air through a pipe under the pressure indicated by the watergauge. Let $\mathrm{A}$ represent the area of the airway in square feet, $\mathrm{V}$ the velocity of the air current in feet per minute, as measured by the anemometer, $\mathrm{W}$ the water-gauge in inches, $5^{\cdot} \cdot \mathbf{2}$ pounds being the weight of a column of water one inch high with an area of I square foot, $\mathbf{E}$ the useful effect of the ventilator.

Then

$$
\mathrm{E}=\left(\mathrm{A} \mathrm{V} \mathrm{W} \times 5^{\circ}\right) \text { foot-pounds per minute. }
$$

To ascertain the horse-power it is only necessary to divide by 33,000 , and we may state:

$$
\mathrm{E}=\frac{\mathrm{A} \mathrm{V} \mathrm{W} \times 5.2}{33,000} \text { II. P. }
$$

Thus to take an example :

If the quantity of air in circulation, $\mathrm{A} \mathrm{V}$, is 100,000 cubic feet per minute, the water-gauge $I^{\cdot} 5$ inches, the useful effect of the ventilation will be:

$$
\frac{1 \mathrm{co,000} \times 1.5 \times 5 \cdot 2}{33,000}=23.63 \text { H. P. }
$$

The efficiency of the ventilating plant is the ratio of the horsepower of the ventilation so calculated to the indicated horsepower of the driving engine.

* Dickinson, op. cit., p. 12. 
Supposing that the indicated horse-power was found to be 45 , we should have the ratio of 23.63 to 45 as denoting the efficiency. In other words :

$$
\text { Efficiency }=\frac{23 \cdot 63}{45}=\cdot 5251 \text { or } 52.51 \text { per cent. }
$$

Resistance caused by Friction.-The amount of power required to overcome the friction of the air current in passing through the passages of the mine must be studied, because it is an important factor in the problem of ventilation; and unless its effects are appreciated the best method of arranging the ventilation will not be understood.

The amount of friction depends upon five conditions :

I. The length of the airway, which we may call $\mathrm{L}$.

2. The perimeter of the airway, $P$.

3. The sectional area of the airway, $\mathbf{A}$.

4. The velocity of the current, $\mathrm{V}$.

5. The nature of the rubbing surface, the effect of which may be expressed by a co-efficient $\mathrm{C}$.

The friction is directly proportional to the length of the airway and its perimeter; in other words, if there is twice as much rubbing surface, there is twice as much friction. It is inversely proportional to the sectional area of the airway - that is to say, a level 7 feet high and ro feet wide will cause only one-half of the friction produced in a level of the same height, but 5 feet wide. Lastly, the friction increases as the square of the velocity.

These relations may be expressed by the general formula :

$$
\text { Resistance due to friction }=\mathrm{C} \frac{\mathrm{L} \mathrm{P} \mathrm{V^{2 }}}{\mathrm{A}}
$$

It is evident from this formula that it is desirable to shorten the path of the air as far as possible; much is done in this direction nowadays by "splitting" the air current-that is to say, dividing it into separate branches instead of causing the whole of the current of the downcast shaft to travel through the entire length of the workings.

With regard to the second factor, the perimeter, it may be well to notice that a circular section is the one with which a given length of perimoter affords the largest area. Take, for instance, the case just cited of a rectangular airway, 7 feet high by 5 feet wide, with a perimeter of 24 feet and an area of 35 square feet. A circle having a circumference of 24 feet would have an area of $45^{\circ} 8$ square feet, or 30 per cent. more than the rectangle.

Splitting has also the effect of reducing the velocity required for the passage of a given quantity of air through the mine. Suppose that 90,000 cubic feet are wanted per minute in order to ventilate the mine; if the mine is divided into three equal and similar districts and each is ventilated separately by one- 
third of the main current, the velocity of the minor currests need be only one-third of what would have been necessary if all the air had had to travel by one road. Reducing the velocity to one-third means, according to the formula, a diminution of the resistance caused by friction to one-ninth.

The co-efficient, $\mathrm{C}$, varies according to the nature of the rubbing surface; in smooth passages, such as those of levels lined by an arching of brick, it will naturally be less than in the irregular airways along the working face, or in an airway with frames of timber, forming a succession of projecting obstacles at short intervals.

FIG. 599 .

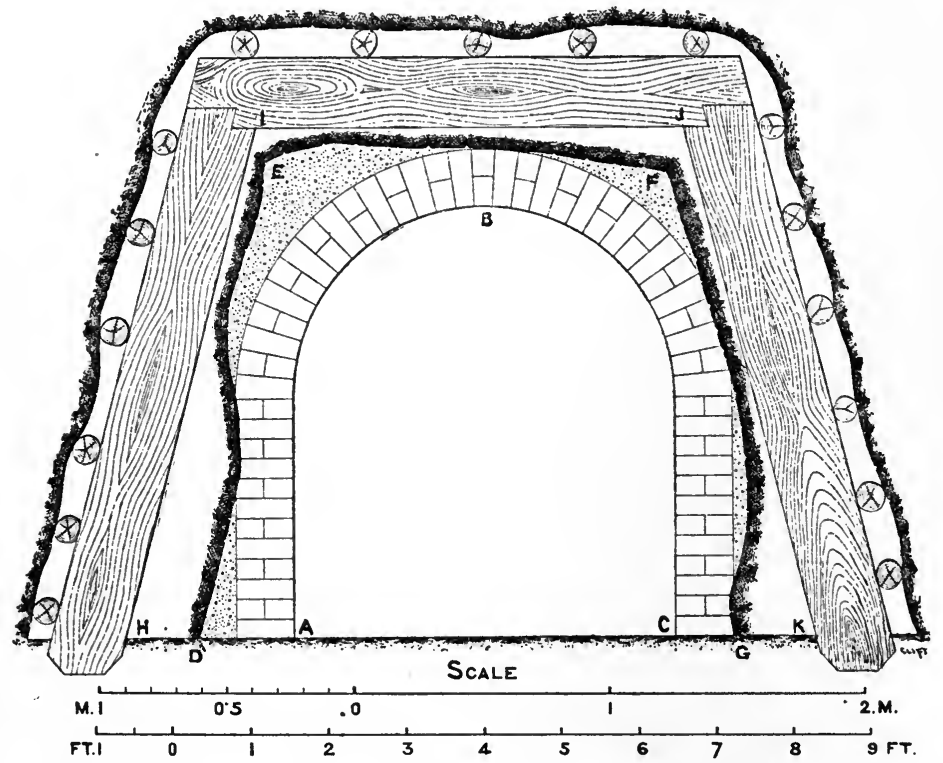

If the resistance due to friction, or, in other words, the pressure required to overcome it, is measured in pounds per square foot, then taking $\mathrm{L}$ and $\mathrm{P}$ in feet, $\mathrm{V}$ in thousands of feet per minute, and $\mathrm{A}$ in square feet, the co-efficient $\mathrm{C}$ varies from 0.002 to $0.014^{*}$ according to the nature of the airway.

Mining engineers owe a debt of gratitude to M. Murgue $†$ for his graphic representation (Fig. 589), which illustrates the influ-

* Elwen, "An Account of Experiments on the Resistance to Air Currents in Mines," and Walton Brown in the discussion. Trans. N. E. Inst. M. E., vol. xxxviii., 1888-9, p. 205-218.

$\dagger$ "Recherches Expérimentales sur la Perte de Charges dans les Parcours Soutersains," Bull. Soc. Ind. Min., vol. vii., 1893, p. 5 ; and translation in Trans. Amer. Inst. M. E., vol. xxii., 1893-1894. 
ence of the sides of an airway in a most striking fashion. $\mathrm{He}$ compares three kinds of airways : one arched, A B C; a second, D E F G, in bare rock; and a third, H I J K, lined with timber; and he shows that, with the dimensions given in the figure, all three airways produce the same amount of friction, or callse the same loss of "head." In other words, the arched passage A B C, in spite of its small dimensions, offers no greater resistance to the air current than the large timbered tunnel $\mathrm{H} \mathrm{I} \mathrm{J} \mathrm{K}$; whilst you may put the brick lining A B C inside a level D E F G without in any way requiring additional ventilating power. He concludes that it is more important to diminish the friction in the airpassages than to seek for better ventilators, and that the miner can lessen the resistance to air-currents not only by increasing the size of his levels, but also by lining them with brick or stone in place of timber, and by keeping them as straight as possible. 


\section{CIIAPTER XI.}

\section{LIGHTING.}

Reflected daylight-Candles, candle-holders-Lamps and lamp oil-Wells light-Magnesium wire-Safety lamps: Davy, Clanny, Mueseler, Marsaut, Hepplewhite-Gray-Locks: lead rivet, magnetic bolt, Cuvelier's lock-Coal gas-Electricity.

Mines are usually lighted by candles, torches, lamps, gas, or electricity.

In a few cases the miner does his work without artificial light. In sinking oil-wells in Burma,* the quantity of explosive gas is so great that no naked light can be used, and even if the workman had a safety lamp, he would be unable to stay below ground long without being affected by the noxious atmosphere. $\mathrm{He}$ therefore carries no light at all, and has his eyes bandaged up before he goes down, because otherwise it would take longer for his eyes to become accustomed to the semi-darkness of the bottom of the pit, than the whole time he can stay below ground.

Reflected Daylight.-For sinking oil-wells in Japan $\dagger$ reflected daylight is used. A piece of yellowish translucent oilpaper, about 5 feet by $3 \frac{1}{2}$ feet, is suspended over the well at an angle of $45^{\circ}$ and throws light down the pit. The wells are about $3 \frac{1}{2}$ feet square, and are dug to a depth of 600 to 900 feet.

In driving the Bell tunnel at the New Idria quicksilver mine, in California, there was a disastrous explosion from the ignition of some inflammable gas, and after this occurrence the tunnel was lighted by the reflection of the sun's rays. A mirror was kept at the mouth of the drift at the proper angle to effect this, and with a straight tunnel and in a sunny country like California the device answered perfectly.

Candles.-The candles used by miners are very frequently the so-called "dips" - that is to say, they are made by dipping a wick into molten tallow and allowing it to take up grease; the process is repeated several times, until the thickness of tallow is sufficient. The wick is made of cotton, or of cotton and linen.

* Noetling, Rec. Geol. Surrey India, vol. xxii., r889, p. 97.

$\dagger$ Redwood, "Petroleum and its Products," Jour. Soc. Arts, vol. zxxiv., 1886, p. 832.

† Becker, "Geology of the Quicksilver Deposits of the Pacific Slope," Mon. U.S. Geol. Survey, vol. xiii., I888, p. 308 . 
At Snailbeach Mine, in Shropshire, the manager stipulates that the wick shall be made of three threads of cotton and three of linen; this is folded, and the candle therefore has a wick of six threads of cotton and six of linen.

The size of the candles is reckoned by the number that go to a pound, which varies from 20 to 6 . Candles of sixteen to the pound are very commonly used by the miners, while the agents, who want an extra amount of light for their examinations, find it convenient to have "eights" and occasionally "sixes." These candles require snuffing from time to time, though I have seen snuffless dips employed in exceptional cases. In hot mines special dips are necessary, for those made of ordinary tallow become soft and bend down.

As a rule the British ore-miner holds his candle in a lump of clay, which forms a very convenient support. It has the advantage that the candle can be stuck up at any point where it is wanted, without a moment's delay in seeking for a place to fix it; it is also readily stuck upon the hat when the miner wants to climb a ladder or a chain. But the clay must be soft, well kneaded, and free from stones or lumps; from time to time it has to be moistened, and care and practice are required in order to work it down properly as the candle is consumed.

In the Forest of Dean many years ago, the candle was stuck into a c'eft stick, which was carried in the month. Nowadays metal candle-holders are used instead, with a point which can be stuck into the timber or a crevice in the rock.

The tallow candle has the disadvantage of guttering in a draught and of causing a good deal of smoke, which is bad if the working place is at all close. The Festiniog men guard their candles against draughts, when walking to and from their work, by shades made out of old meat-tins with a handle of wire. If there is much water dropping down a shaft the miner can protect his candle by a shield of tin-plate nailed to a piece of wood.

Grease is bad for amalgamation, and sperm candles are adopted in some gold mines, as they are less objectionable than those made

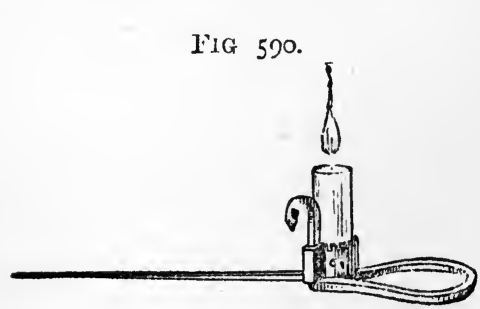
of tallow. Paraffin, stearine and "composite" candles may be and are used in place of the common dip; they do not stand a strong draught or drops of water so well as the latter, but they give less smoke and do not gutter so much.

Moulded candles are convenieutly carried by a holder, such as is seen in the United States, made of a small rod of iron with one end bent into a handle and the other pointed (Fig. 590). In the middle there is a cylinder of thin sheet iron which has 
spring enough to clip the candle firmly; a sharp hook, sticking up at right angles to the horizontal rod, enables the holder to be hung on to the slightest little projection, if there is no convenient crevice or piece of timber into which its point can be thrust. The Australian has a somewhat similar holder made of wire, known as the "spider." * The wire is about one-sixteenth of an inch thick, twisted as shown (Fig. 59I); the spiral portion holds the candle, and the little hook will hang on to the face of the rock.

A candle-holder of some kind is more convenient to an official who has to make notes underground, than the usual lump of clay; with the latter it is difficult to keep the notebook clean.

Torches.-Torches are employed in a few exceptional instances. The foremen at Falun, in Sweden, carry torches consisting of bundles of pine sticks held together

by an iron ring, and some gold mines in Japan $\dagger$ were lighted a few years ago by torches made of dried bamboo twigs; fires of pitch-wood have been used at night when washing down gravel by the hydraulic process. $\neq$ Large underground chambers may be lit up for a short time, in order to examine the roof, by burning a bundle of wood shavings soaked with naphtha and petroleum.

Lamps.-Lamps vary much in shape and size. The Sicilian miner has a lamp of the simplest construction imaginable; it is a mere open cup of unglazed pottery, about. 2 inches in diameter and $\mathrm{I}$ inch deep, with a little lip for holding a cotton wick, which lies loosely in the olive oil used as an illuminant. It is ruder than the old Roman lamps found at Pompeii, which somewhat resemble those still employed in the Hartz. The latter are provided with a hook, by which they can be held between the thumb and forefinger when climbing ladders; the hook. has a sharp point which the miner can stick into a timber prop or a crevice in the rock while at work. The body of the lamp is closed; it has a tube for the cotton wick and a hole with a screw-plug through which the supply of oil can be replenished.

* Annual Report of the Secretary for Mines, Victoria, for the ycar I\$88, Melbourne, I889, p. 36.

t Frecheville, "The Mining and Treatment of Gold Ores in the North of Japan," Min. Proc. Inst. C.E., vol. Ixxv., 1883-84, p. 169.

† Bowie, Hydraulic Mining in California, New York, 1985, p. 246. 
A pricker for trimming the wick is attached by a light chain. A smaller but similar lamp is met with in France, northern Italy, and parts of Spain; the body is lenticular, and is suspended by a long hook.

The foremen in the Hartz mines prefer a somewhat similar lamp in which they can burn tallow; it is an open tray with a rim around it and a lip for the cotton wick; a large lump of tallow lies in the lamp at the opposite side to the wick, and if the agent wishes to make a flare-up, to illuminate a working place more thoroughly, he need only push a good supply of tallow towards the wick holder, and soon obtains the desired effect.

In the Mansfeld copper district the miner has a small tin lamp which can be hung by a wire loop to a hook on the hat, if he is climbing, or be placed upon the ground in the working place. It has a double case, the outer one serving to catch any oil which may run over from the spout-like wick-tube.

'The Saxon miner still adheres to the "Blende," a wooden case lined with tin-plate or brass, in which he carries a small globular oil lamp. The case is useful in walking or climbing in very draughty parts of the mine, and can be hung from the neck by a leather strap.

In Scotland and in some parts of the United States, a small but serviceable tin lamp, of the shape shown in Fig. 592, is very common.

FiG. 552 . It can be hooked on to the hat when climbing

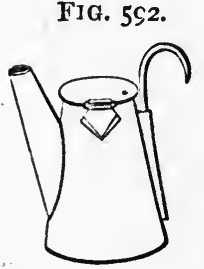
ladders, or on to the rock. Olive oil or rape oil is burnt in the lamps just described, and the miner carries with him a supply in a little flask.

Lamps have the advantage of being cheaper and cleaner than tallow candles, but the latter do not seem likely to be displaced in English and Welsh ore mines, though the Scotch lead miner prefers the former.

Mineral oils are occasionally used instead of vegetable oils for ordinary miners' lamps. At the underground stone quarries near Bath the men employ small lamps fed by benzoline, which is held by a sponge in the reservoir. Petroleum "Hurricane" lamps for lighting up pit-bottoms and landings (plats) are not uncommon, and even levels are lit up in this way by hanging a lamp at each bend in the road. This saves the miner the trouble of carrying a lamp, and the light is quite sufficient for the purpose of tramming, even if the stretches are somewhat long.

Flare lamps, similar to those used by "Cheap Jacks," which generate gas from naphtha, or a mixture of naphtha and petroleum, flowing into a hot burner, may occasionally be seen in parts of underground slate quarries, where a good deal of light is required for hooking-on and unhooking waggons.

Wells Light.-Among recent inventions for illuminating, I 
must specially mention the Wells light, which, after being largely used for surface works, is now finding applications underground. The Wells light is a contrivance for burning tar oils converted into gas, when forced through a heated burner by pressure produced by a hand air-pump.

Fig. 593 shows the principal parts of the lamp, A is a closed cylinder made of steel boiler plate, B is a pump worked by the handle $\mathrm{C}$, which can be used for pumping in either air or oil; whilst the light is running, the oil is drawn from a bucket by the piece of hose D. $\mathbf{E}$ is the oil which has been pumped in, thereby compressing the air above it to about $20 \mathrm{lbs}$. per square inch. On turning the tap $G$, the oil is forced up the pipe II to the generating tubes I 1, which have been pre. viously heated by lighting some cotton waste and oil in the tray $K$. The preliminary heating may also be effected by burning a spray of the oil, produced by a special starting appliance forming part of the lamp. The oil in its passage through the hot burner $I$ is converted into vapour, which issues forth from the nozzle $\mathrm{L}$ and produces a flame of 12 to 30 inches in ler sth, with a consumption of half a gallon to $1 \frac{1}{2}$ gallons of oil per hour, giving a light of 500 to 4000 candles. $\mathrm{O}$ is a plug connected to a rod which serves FIG. 523.

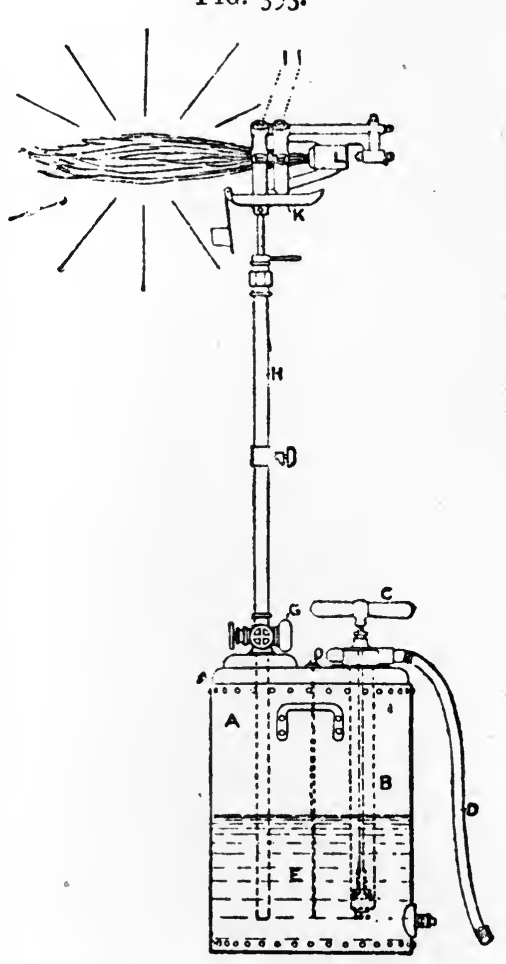
the double purpose of letting off the air quickly at any time, and also of gauging the depth of the oil in the cylinder.

The lamp is easily carried about from place to place. The smallest size and the larger one, No. 3, have both been employed of late in the large chambers of the Festiniog slate mines for examining the roof and sides, and also for plate-laying. The pressure of the air in the reservoir is kept up by a few strokes of the pump from time to time.

The brilliant light emitted by burning magnesium is utilised at 
Festiniog, in addition to the Wells light, for examining the, underground chambers. The agents of some of the mines carry a little stock of magnesium ribbon in their pocket-books, and set fire to a piece if they wish to throw a powerful light upon any particular spot which may require special attention. At two of the mines the metal is burnt in a special lamp. It consists of a coil of magnesium ribbon about $\frac{1}{8}$ inch wide wound upon a reel, which is fed by clock-work, so that it issues from a tube at the focus of a silvered mirror about 8 inches in diameter. The lamp is held by a convenient handle, and the light can be directed on to any given point without dazzling the eyes. The ribbon is consumed at the rate of about ro inches per minute; the lamp can be started and stopped by touching a catch which controls the clock-work, and there are means of altering the speed at which the ribbon is fed forwards.

Safety Lamps.-The subject of safety lamps-that is to say, lamps which can be used in an atmosphere containing a certain amount of inflammable gas without fear of causing an explosion - may seem out of place to some who suppose that their use is confined to coal pits: but when we recollect that firedamp has been met with in mines worked for diamonds, gold, iron, lead, quicksilver, salt, silver, sulphur, and tin, and further that a lead mine in this country is lighted entirely with such lamps, and that they are indispensable in the case of ozokerite, it is evident that miners generally should have some knowledge of the principles upon which they are constructed, and the manner in which they are used. However, in the mines with which we are dealing, safety lamps are the exception, and, therefore, the subject can be dealt with in a summary manner.

The construction of the safety lamp is based upon the fact that gauze of a certain mesh, made with wire of a certain gauge, is capable of cooling burning gases to a point below that at which combustion will take place-in other words, it will prevent the passage of flame. Therefore, when a lamp enclosed in a suitable cylinder of this gauze is placed in an atmosphere containing fire-damp, the inflammable gas inside the envelope will burn without igniting that which is outside.

I will now describe briefly the lamps most commonly in use in mines containing inflammable gas; they are named after their inventors, viz., the Davy, Clanny, Mueseler, Marsaut, and Hepplewhite-Gray lamips.

The ordinary Davy lamp (Fig. 594)* consists of a brass oil vessel $b$, on to which is screwed a cylinder of wire gauze $a$, about $1 \frac{1}{2}$ inches in dianeter and $4 \frac{1}{2}$ to $5 \frac{1}{2}$ inches high. The

* The materials used in constructirg the lamps are indicated thus: 
cylinder is further closed at the top by a cap of wire gauze $e$, which overlaps the main gauze for a distance of $I$ inch to $I \frac{1}{2}$ inches. In the centre of the oil-vessel is a round tube containing a cotton wick, which can be trimmed from the outside by a piece of wire $f$ passing up through the bottom. The gauze used has 28 holes or meshes per linear inch, or, in other words, 784 per square inch. The wire varies slightly in size; some which I very carefully measured was 016 inch in diameter, and was probably intended for No. 27 S.W.G. A maker of repute informs me that he usually einploys No. 30 of the olil B.W.G. Spenking roughly, the holes are $\frac{1}{30}$ inch $\left(\frac{1}{2} \mathrm{~mm}\right.$.) square. Three rods $c$, attached below to a ring screwed on to the oil-vessel and above to a plate, protect the gauze to a certain extent. The lamp is carried by a strong wire ring fastened to the top plate $d$. Rape, colza, or seal oil, alone or with the addition of petroleum, are used as illuminants.

The Davy lamp has several grave defects: in the tirst place it gives very little light; and secondly, as pointed out by the Royal Commission on Accidents in Mines,* it will fire an explosive mixture if

FiG. 595 .

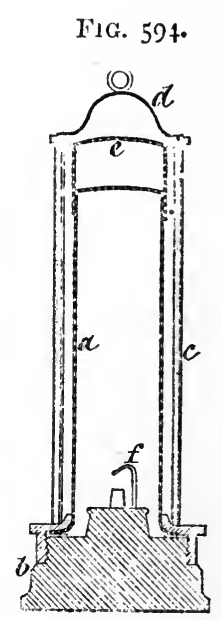

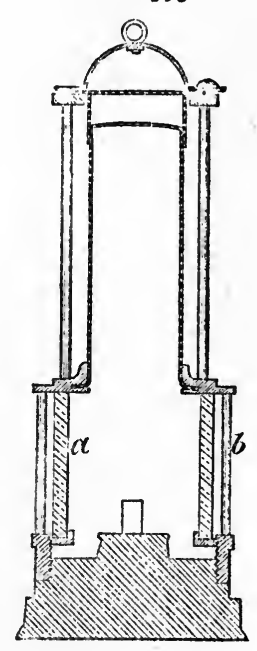

the velocity of the current exceeds 6 feet a second. According to the photometric tests made for the Royal Commission by Professor Clifton, $\rightarrow$ the light of the Davy lamp varied from 7 to 22 per cent. of that of a standard candle ; these were laboratory experiments, in which the light was not further diminished by the accumulation of dirt, grease, soot, and coal dust upon the gauze, as may often happen underground, and nothing is said about the absence of illumination immediately above the lamp.

With the powerful ventilating currents in use nowadays, the second defect is a very real one; it is sometimes overcome by placing the Davy lamp in a cylindrical tin case with a glass window.

It was very natural to attempt to remedy the first defect of the Davy lamp by using glass instead of gauze, for the lower part of the enclosing cylinder.

In the Clanny lamp (Eig. 595), constructed upon this principle

* Preliminary Report, I88I, p. xiii.

+ Final Report, isS6, Appondix xxiv., p. 87. 
the air which feeds the flame comes in through the gauze just above the glass $a$, descends along its inner face and goes to the wick; the products of combustion then pass up the centre. Nothing separates the descending current of air from the ascending current, and consequently the oil, from want of a direct supply of fresh air, does not always burn so brightly as it does in a lamp fed from under the gauze; but the light is far better than that of a Davy lamp. . The letter $b$ represents one of the metal rods for protecting the glass. Professor Clifton's experiments usually gave 26 to 50 per cent. of the light of a standard candle, or, on an average, more than twice as much light as the Davy. In a current having a velocity of more than 6 feet a second it behares like the Davy, and ignites an explosive mixture.

Mueseler's lamp (Fig. 596) may be conveniently described as a Clanny lamp, with a chimney $a$ fixed above the flame, and attached

FIG. 596.

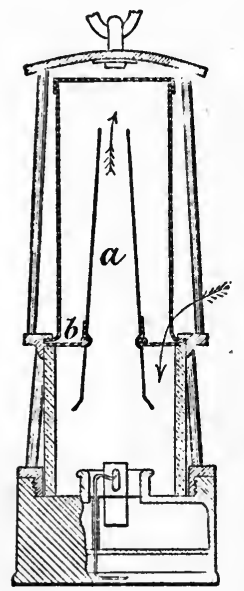
at the level of the top of the glass to a diaphragm or horizontal partition of wire gauze b. The path taken by the air is shown by the arrows. The fact of the inward current of fresh air being kept separate from the outward current of foul air assists the illuminating power of the lamp. The wick is sometimes flat.

The Mueseler lamp, which is the only one allowed in fiery pits in Belgium, is a favourite in many countries, and leaving aside its use in collieries, I may mention that it is the only lamp employed at the very dangerous ozokerite mines of Boryslaw and at the Mill Close lead mine in Derbyshire. It has the merit of going out in an explosive atmosphere, and of so removing a cause of danger. The lamp is extinguished because the chimney is unable to carry off the products of combustion quickly enough; they spread out under the bottom edge of the chimney, and pollute the fresh current to such an extent that it becomes incapable of supporting the combustion of the oil.

The lamp will not stand being jerked or inclined, for anything which will turn the currents out of their proper course causes the bottom part of the gauze to be filled with the products of combustion and puts the flame out. It is evident that when the lamp is held in an inclined position, all the foul gas will not go up the chimney, and that some will become mixed with the inward current; a jerk downwards checks the supply of air passing in through the gauze, and again the lamp is extinguished. On the other hand, it resists a horizontal current better than the two lamps mentioned previously. If the lamp is struck 
obliquely by the current an explosion may sometimes take place inside it.

Before concluding this very short account of the Mueseler lamp, it is important to point out that a mere diaphragm with a chimney does not necessarily constitute a lamp of the original Belgian pattern. The dimensions of the parts are carefully prescribed by law in Belgium, for it has been found that a slight departure from them may affect the properties of the lamp very materially.

A lamp which has come largely into use of late years, and especially in this country after the favourable report of our Royal Commission, is that of M. Marsaut, of Bessèges, to whom miners Fig. 597 .

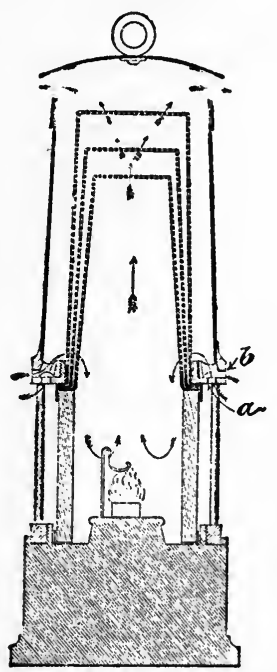

FIG. 598.

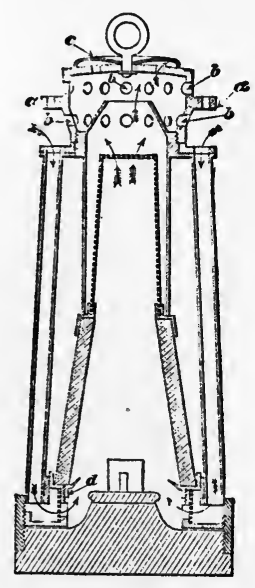

are indebted for many useful investigations (Fig. 597). It is of the Clanny type - that is to say, it has a glass cylinder with the air entering above it, and no chimney; but it has the extra safety afforded by a second or even a third gauze, and a bonnet or shield of sheet iron. These additions enable it to resist currents of 2000 feet per minute; other advantages are an illuminating power of about two-thirds of a standard candle, simplicity and strength, for the gauze is protected by the shield from accidental blows of the pick or other sources of injury. The outer shield adds somewhat to the weight of the lamp, but the slight diminution of portability is anply repaid by the increased security which it affords.

The Hepplewhite-Gray lamp, with some modifications introduced by Ashworth (Fig. 598), is of a totally different type; the wick is fed with air coming in below the glass, through a ring 
of wire gauze $d$, on the inside of an annular chamber. When testing for "gas," the openings at the bottom of three brass tubes, through which the air passes into the annular chamber, are closed, and the lamp draws its supply of air from the top of tubes. 'The path taken by the air is shown by the arrows; $b b$ are the holes by which the products of combustion escape. The glass is no longer cylindrical, but is made in the form of a truncated cone, with the object. of illuminating the roof ; the smallness of the top of the shield $a$ conduces to the same desirable object. If the inside of the glass is blackened at the back, the efficiency for testing is decidedly increased, as images of the flame, such as are reflected from both sides of the ordinary glass, no longer trouble the observer. This lamp has the further advantage for testing that it takes in its supply of air from the top, and will therefore test a layer of air close to the roof which could not be examined by an ordinary lamp, except by tilting it so much that there would be danger of its going out.

Locks.-In order to prevent careless and imprudent men from risking their lives and those of their comrades by opening their lamps, it is nece:sary to lock them securely before they are taken into the workings. Various devices have been proposed and adopted.

A little bolt screwed in by a key like a large watch-key, through the ring holding the glass or the gauze, was thought at first to off'r sutficient guarantee of security ; but it was soon found that ingenious miners could pick a lock of this kind without difficulty, and other plans had to be devised to baffle their skill. The must common systems employed are the lead rivet, the magnetic bult, and the Cuvelier fastening.

The lead rivet is placed through two holes, one in the brass ring holding the glass and the other in the oil-vessel; it is then firmly squeezed with a pair of nippers, and thus impressed with a mark, which can be changed from day to day if necessary. When this has been done, the lamp cannot be opened without cutting the rivet, which would at once be noticed when the miner handed it in at the end of the shift. The lamp-man easily cuts the rivet before proceeding to clean the lamp; the pieces of letd are collected, melted up again, and once more cast into rivets. 'The cost of this very effective method of locking is but slight.

Several inventors have resorted to magnetism in order to obtain an unpickable form of lock, and Wolf's fastening is one of this description. It consists of a bolt held in its place by a spring, which can only be drawn back when the lamp is placed against a very powerful magnet. This form of lock is largely used.

Cuvelier's ingenious fastening, which gives great satisfaction at some French collieries, may be described as a vertical bolt which keeps the lamp locked until it is set free by hydraulic pressure. 
The two cnds of a piece of metal tube, bent into the form of a circle, come close together under the bolt, whilst on the opposite side there is a projecting tube with a very small hole. If hydraulic pressure is exerted on the inside of the tube by means of an accumulator acting through the little hole, the two arms tend to straighten out, and the ends move a little away from one another; in so doing they allow the bolt to fall from its own weight and the pressure of a spiral spring. The operation of opening is very quickly performed, and the hole in the projecting tube is so smail -only $\frac{1}{5}$ to $\frac{1}{4}$ of a millimetre in diameter-that the quantity of water used is insignificant. The hole is on the under side of the tube and has not been found to become choked up by dirt, as might have been expected.

Gas.-Gas is employed for lighting pit-bottoms, hanging-on places, or sidings, where there is a large amount of traffic.

Electric Light.-Up to the present time, owing to its want of portability, the electric light has not displaced candles and ordinary lamps in the work of "getting" minerals, save in a few special cases. It is true that various small portable incandescent lamps have been invented and tried, but until lately they have failed to satisfy all the conditions which are necessary for commercial success.

More promising than its predecessors is the Sussmann lamp, which is now coming into the market. A (Fig. 599) is a steel case enclosing a dry storage battery; B is an outer protecting cylinder of glass, held between four upright rods, C ; $D$ is the vacuum bulb with the filament which becomes incandescent; $\mathbf{E}$ and $\mathrm{F}$ are conical whitened reflectors destined to make the best possible use of the light. The back half of the glass cylinder is whitened for a similar reason.

The lamp is $2 \frac{3}{4}$ inches square at the base and 8 inches high ; it weighs 3 lbs. Io oz. (r.64 kil.). One pattern is said to give a light of one canillepower for fourteen or fifteen hours, and another three candle-power for nine and a half hours. The advantage of this lamp over those previously brought forward is the absence of any liquid. The interior of the battery is solid, and consequently the lamp can be held or laid in any position. The company owning the patents is ready to make contracts with mine-owners to supply lamps, charge them daily, and keep them in repair for $4 d$. per lamp per week, or about what oil alone is costing at the present time.

As regards its safety, it is stated, as the result of numerous experiments, that the smallness of the filament prevents any chance of its igniting explosive mixtures, in the event of both the 
outer cylinder and the bulb being broken. Like all other electric lamps, it has the defect of affording no indication of fire-damp or carbonic acid.

Where a fixed light can be used-in other words, where the nature of the excavation to be lighted is not rapidly changingthe electric light is rendering incalculable services. Thus, in sinking shafts, a few incandescent lamps hung from an electric cable enable the miner to do his work under unaccustomed conditions of brilliancy. He not only gets better illlumination, but he is relieved from all trouble about candles or lamps, and can set about his work as a navvy would at the surface. This means a saving of time which is often well worth paying for. While blasting is going on, the lamps are drawn up out of the way of stones which might be hurled up and break the glasses.

Fixed glow lamps form a convenient and desirable means of lighting up pit-bottoms, on-setting places, levels and sidings where the traffic is large, and ladder-ways and man-engines which are much frequented.

When the area to be illuminated is large, an arc-lamp may be employed with advantage. Among the first successful applications of electric lighting to underground excavations may be mentioned that of M. Blavier at the Angers slate quarries.* In the year 1879 he fixed two Serrin lamps in one of the large underground chambers with an area of 2400 square yards, and he found that they gave light enough for all the men at work. The total cost, reckoning everything-viz., coal, carbons, repairs, labour, depreciation of plant, and interest on capital-was 50 francs a day; the gas formerly in use cost 54 franc's a day and gave much less light. 'The large chambers in the salt-mine of Maros-Ujvar in Hungary $t$ have been lighted up by electricity since 1880 . The cost is somewhat greater than that of the tallow, oil, or petroleum formerly in use ; but, per contra, the illumination is better, the men can do more work and are more easily supervised, whilst the air of the mine is not deteriorated by the products of combustion of the lamps. Slanic salt-mine in Roumania has been lit with the electric light in a similar manner since 1883 .

In a previous chapter I described the working of the thick bed of lead-bearing sandstone at Mechernich by large underground chambers, which eventually are allowed to collapse. Of late years arc lights have been largely used for illumination, although the number of men in one chamber is never more than six and often not more than two. The great advantage derived from the use of the powerful light has been the possibility of removing with safety thousands of tons of ore, which otherwise would have been left undergound for fear of accidents in taking it down.

* Blavier, "L'Eclairage électrique aux Ardoisières d'Angers," Annalcs des Mines, sér. 7 , vol. xvii., 1880 , p. 5 .

+ Oest. Zeitschr. B. u. II. IT., is82, p. 296. 
It is proposed to use are lights with reflectors, similar to the naval search lights, for examining the roofs and sides of the large underground chambers in the Welsh slate mines.

Arc lights stand in good stead when work has to be done at night above ground. Thus, at Rio Tinto, the great open-cast is lit up by two arc lights, one at each end of the major axis of the elliptical pit. In the same way two arc lights of 2000 candle power are used for night-work in washing down auriferous gravel at the works of the Osceola Company in Nevada.* As the use of electricity spreads for the purpose of transmitting power, we may naturally expect further development of the lighting of parts of mines from the same source.

* Eng. Min. Jour., vol. li., 1891, p. 630. 


\section{CHAPTER XII.}

\section{DESCENT AND ASCENT.}

\section{Steps and slides-Ladders-Bucket or cage-Man-engine, single and} double.

Ar first sight this subject might seem scarcely to deserve a separate chapter; but if one considers the time occupied by the miner in going to and from his work, and recollects that his hours are reckoned "from bank to bank"-i.e., from the moment he leaves the surface till he reaches it again-and if one further dwells upon the terrible waste of energy involved by climbing up and down deep shafts by ladders, it will be admitted that the question of descent and ascent requires to be discussed.

Where mines are worked by adit levels, the men naturally walk in along the ordinary roadways. Such mines, however, are exceptional, and the workmen generally have to climb down and up by ladders, or are lowered and raised by the winding machinery. The means of access to and from the workings may be classified as follows :

1. Steps and slides.

2. Ladders.

3 Bucket or cage.

4. Man-engine.

Steps and Slides.-If the dip of a seam or vein is small, an inclined pathway, leading down through the old workings, forms a safe and pleasant travelling road into the mine, and it has the further advantage that the ponies or horses can be brought out at the end of each shift.

When the inclination reaches $20^{\circ}$ it is well to have regular steps, instead of making the men scramble down an irregular path; it is true that the miner, accustomed to the road, does not lose so much time as a stranger in picking his way along a rough or slippery track, but still a bad path causes a little unnecessary delay which is best avoided. Steps are much less fatiguing than ladders placed so flat that part of the weight of the body has to rest upon the arms.

Steps may be cut in the rock itself, if it is hard enough, and if not, wooden or stone stairs can be put in, with a handrail. When the dip is too high for making the stairs straight, they may be 
arranged in a zigzag line, provided that the excavation affords sufficient space. The height of the steps should not exceed 8 inches, so as to avoid a fatiguing lift of the foot.

In parts of the Sicilian sulphur-mines,* where the dip does not exceed $30^{\circ}$ to $35^{\circ}$, the steps are from 8 to ro inches high and 12 to 14 inches broad, and occupy the whole width of the travelling road; if the dip is from $40^{\circ}$ to $50^{\circ}$, two sets of steps are made, so that the level of the tread on one side corresponds with the middle of the height on the other. This system is known as that of the scaloni rotti, and greatly facilitates the ascent up such steep roads.

In some of the Austrian salt-mines the men descend by wooden slides inclined at angles varying from $30^{\circ}$ to $50^{\circ}$, flattening at the bottom so as to reduce the velocity gradually; the miner can increase his speed by leaning forwards or lessen it by leaning back. The ascent is by steps.

Ladders. - Ladders are very largely used in ore-mines all over the world, but they vary a good deal in different countries. In Mexico and in Chili, the common ladder is merely a pole with notches at the sides for receiving the feet. These ladders, especially when worn, are better fitted for barefooted or sandaled miners than for those wearing a heavy and unyielding boot.

The so-called "centipede ladder," met with in out-of-the-way parts of Australia, and even sometimes seen in Europe, is very properly condemned by the inspectors of mines in Queensland. $\uparrow$ It is made of a single pole, often a sapling with the branches cut off, with auger holes through which wooden pegs are inserted at regular intervals. The projecting pegs form the rungs of the ladder. If such a ladder is new, with the pegs set, evenly and firmly, and placed at a proper angle, it will serve for shallow depths; but ladders of this description are usually put in by men who are not good at carpentry, they are hung vertically, the pegs are uneven originally or are allowed to get rotten, and the successive ladders are not securely joined; the task of climbing then becomes a dangerous one.

The ordinary ladder consists of two sides and a series of rungs (staves, Cornwall). The principal points that have to be considered are the material, the size, and the mode of fixing.

In this country the mine ladder is most commonly made with wooden sides and iron rungs. The sides are easily formed by putting a sawcut through a plank as supplied by the timbermerchant, 2 inches thick by 8 inches wide, giving two pieces 4 by 2 inches; pitch-pine is largely used on account of its durability. The two sides are fastened together temporarily, and auger holes bored through them both, so that they match exactly. The rungs

* Parodi, Sull' Estrazione dello Śolfo in Sicilia. Florence, 1873, p. 24.

+ Ann. Rep. Dep. Mines, Queensland, for the Tear 1889, p. I22; I89o, p. 130 . 
are made of pieces of round iron, $\frac{3}{4}$ to $\frac{7}{8}$ inches in diameter. It is true that one may see $\frac{5}{8}$ inch iron employed for the rungs; but, leaving aside the question of safety, this is false economy. The thin rung wears quickly, if there is much traffic, and soon has to be replaced, entailing an expense which would have repaid the extra cost of the thicker iron in the first instance.

On the Continent wooden rungs are common, and oak is preferred on account of its durability ; the wooden stave is often made flat, instead of round, so that it may last longer, and iron sides may be seen where dry rot is very bad. A ladder made entirely of wood is lighter than one with iron staves, and this is an advantage if it has to be moved about much. In places where an ordinary ladder would be knocked to pieces by blasting, such as the bottom of a shaft in course of sinking, a short length of chain ladder is put in; the sides are made of pieces of chain, and iron rungs are attached at suitable intervals. Wire rope is also used for the sides of ladders, and Rochebeau uses steel tube for the rungs. He supplies the ladders of this description, which can be rolled up into a coil and kept in readiness in case of an emergency.

A very important point is the distance between the rungs : it should be chosen so as not to cause too great a lift of the foot at each step, whilst at the same time the number of steps must not be increased out of reason. Experience shows that a distance of 10 inches from centre to centre is very suitable; ladders with a step of II inches or 12 inches are far more fatiguing to climb. The two end rungs of ten have collars, and, like them, the middle rung is screwed at the ends for nuts; these add to the general strength of the ladder; the sides are thus kept permanently about I I inches apart. If not secured in some fashion the ends may come together a little and the middle bulge out. It is advisable to have a uniform pattern for all the ladders in a mine, such as 14 feet, for instance, and when an old ladder has tobe replaced, a suitable new one is ready in stock, without any delay for taking measurements or making it. Two such ladders joined together form a very convenient length for a "footway" in a shaft; they make a ladder 28 feet long, and allowing 4 feet to project above the platform, for safety and comfort in getting on and off, there remains a length of 24 feet for actual climbing between the platforms or sollars. The two ladders can be fastened together by an iron strapping-plate on each side, held in position by the nuts of the two terminal rungs. Where the ladders have plain rungs at the ends a strong wooden cleat nailed on to both ladders makes the connection. In making the joint between two ladders, care should be taken to maintain the proper distance between the staves and the regular inclination; for when once a man has got into the rhythm, so to say, of climbing, he is liable to miss his step and fall if a rung fails to come just where he expects it. 
Fig. 600 represents a ladder* made entirely of iron, such as is largely used in mines in the north of France. The sides are of flat iron, $7 \times 70 \mathrm{~mm}$. (about $\frac{1}{4} \times 2 \frac{3}{4}$ ins.) and the rungs are of round iron, $22 \mathrm{~mm}$. $\left(\frac{7}{8}\right.$ inch) in diameter; they are $25^{2} \mathrm{~mm}$. ( $9^{\circ} 9$ inches) from centre to centre. Three of the rungs are bolts with nuts, and the others are riveted; the manner of joining two ladders

FiG. 600.

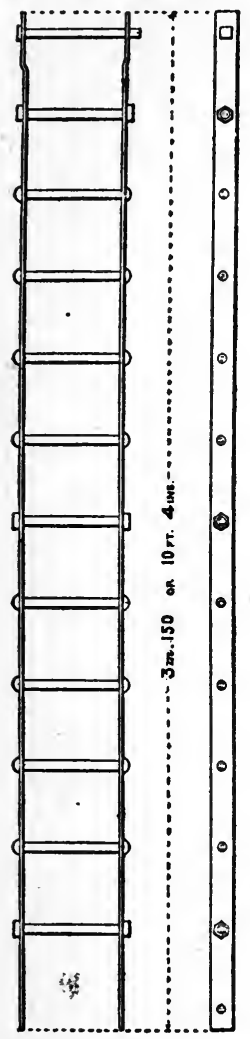
by a cotter bolt with a square end is evident from Fig. 601. The iron may be galvanised to prevent rusting. Ladders of this description weigh 10 kil. per metre (20 lbs.) per yard.

Platforms (sollars, Cornwall) should be fixed at short intervals; though our British law allows them to be placed 60 feet apart, the distance can be reduced with great advantage

Fig. 60I.

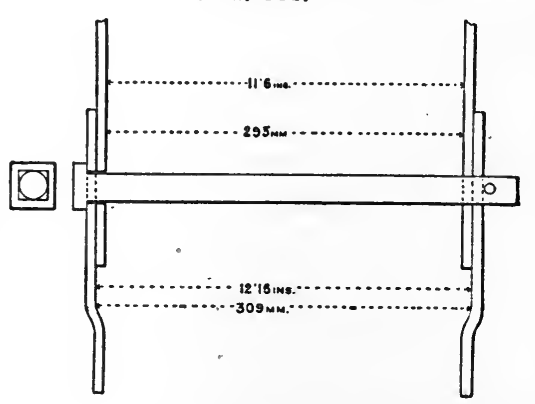

to 18,20 , or 24 feet in perpendicular or highly inclined shafts. A much shorter interval would mean too many changes, and a longer one would render falls more dangerous, besides curtailing the number of enforced short rests, which are a relief in climbing up from great depths. One side of the ladder may be fastened to timber in the shaft by strong staples; and if not, it should be kept rigid by stays, so as to prevent any swaying.

Lastly comes the question of the angle at which the ladder should be inclined. The mine-owner should spare no pains to render the "travelling" as safe and as easy as possible, and should recollect that the miner climbs with the least amount of fatigue, when the greater part of the work of raising the body is thrown upon the muscles of the legs and not upon those of the

* One of the patterns supplied by Romain Sartiaux, of Hénin-Liétard, Pas-de-Calais. 
arms; the part played by the arms should be keeping the body in a proper position and preventing falls. It may here be noted that the miner does not climb a ladder like a bricklayer or a house-painter. The latter place their hands upon the sides of the ladder; the miner grasps the rungs, and even if his foot slips, or if a faulty rung gives way under him, he has a chance of saving himself. In climbing down he frequently misses every alternate stave with his hands, or, in other words, he makes two steps with his feet for one grasp with the hand.

The most convenient angle for ladders is about $20^{\circ}$ from the vertical; if they are much flatter than this, the arms have to be used in order to prevent the body from falling forwards; if they are steeper, the arms have to lift part of the weight of the body. In either case there is fatigue for the arms, and in the latter the danger of falls is increased; these disadvantages become very marked when the ladders are placed in a vertical or overhanging position. Ladders so fixed are prohibited by law in this country, for it is not only the life of the man who falls which is endangered, but he may sweep off several men beneath him. Unfortunately, our present law does not go quite far enough ; it forbids a vertical ladder, but permits a ladder inclined at an angle of $I^{\circ}$ or $2^{\circ}$ from the vertical, provided the shaft is not large enough to admit of any better arrangement. In other words, it does not compel the mine-owner to sink FIG. 602. a shaft large enough for a proper ladder-

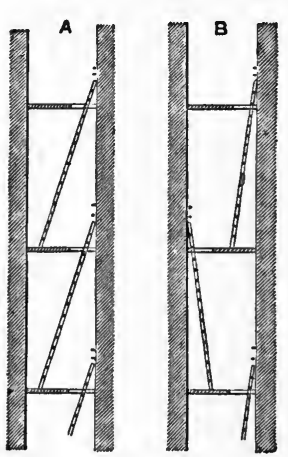
road. The Belgian law,* enacted twentyone years before ours, is more wisely worded; it decrees that no ladder shall be inclined at an angle of less than $10^{\circ}$ from the vertical.

Furthermore, of the two arrangements shown in Fig. 602, $\mathrm{A}$ is better than $\mathrm{B}$, because it not only affords a greater inclination for the ladders, but also renders it less likely that a man will drop through the opening (manhole) in the platform (sollar) if he loses his hold and falls. In planning the regular permanent ladder-road for the miners, it is well to avoid shafts in which other operations, such as winding or pumping, are going on. By law, in this country, the ladder compartment has to be partitioned off from the winding compartment ; a better plan, if possible, is to provide an entirely separate shaft for a footway. In vein mines, a number of the winzes can conveniently be set apart for " travelling" purposes. Occasionally the ladderway is made double in the upper part of the mine, so

- Arrêté rosal du Janvier 185 I, Article 2. 
as to prevent loss of time at the change of the shifts, when an ascending stream of men meets a similar descending stream.

Some of the matters just mentioned may seem trifling, but, leaving aside the question of safety, the economy derived from fixing the ladders at the best possible inclination is by no means small. To make this apparent, we must recollect the depths to and from which men have to climb-viz., 300, 400, and even 500 yards or more. It is, therefore, important to save every unnecessary expenditure of energy, which, though trifling for one ladder, becomes considerable if very frequently repeated. When a mine has reached a depth of roo yards, and a fortiori when it has exceeded it, mechanical appliances should certainly be introduced for raising and lowering the men, because time and strength are wasted by climbing; besides which, medical men are agreed that excessive ladder-climbing is injurious to the health of the miner. Therefore upon hygienic and upon financial grounds, one of the first thoughts in working a mine should be the conveyance of the men down and up the shaft with the least possible fatigue, by means of machinery.

Buckets and Cages. - This method of going down and coming up from mines recommends itself by its simplicity, and when carried out with modern appliances it is remarkably safe

If the machinery is being worked by hand, the miner usually stands with one foot in the kibble and uses the other to guide himself, while he holds the rope in his hands; this guiding is specially necessary when going down an inclined winze with rough and rugged sides. Some men prefer to have one foot in a loop at the end of the rope, whilst others like a specialstir rup.

At the ozokerite mines of. Boryslaw, and also in sinking oilwells in Burma, special precautions are taken in case the men should become unconscious from breathing an atmosphere highly charged with noxious gases. In every case the man is secured by a second rope, so that he can be drawn up even if he falls from the bucket. The Boryslaw safety-gear is a strong leathern waist-belt to which is attached a broad strap divided into two at each end. One thong passes over each shoulder and is buckled to the belt, and one under each leg is attached in a similar manner. An iron ring between the shoulders completes the gear. It serves for attaching the second rope, or life-line, coiled upon a separate windlass, and paid out as fast as the main rope with the bucket in which the man stands with one leg. Many of the shafts worked in this way are more than 150 yards deep, and one has attained a depth of 262 yards (240 metres).

Guides are compulsory in this country after a depth of 50 yards is exceeded, unless the owner of the mine has obtained an exemption from the inspector of the district. I explained in the chapter upon winding how they can be applied to the kibble or bucket even in a sinking shaft; but the usual method of ascent and 
descent is by the cage, or some form of guided box. Little need he said about the process of lowering and raising, for it is practically the same as winding mineral. Rules are made defining the number of men allowed to ride at one time, and generally there is a bar near the top of the cage which the men can hold, in case there should be a little jerk. In some countries it is necessary that the cage should be so enclosed that there is no possibility of a man falling out during his rapid ride. As sending the men down and up in this fashion interferes with the winding of minerals, access to the cage should be easy ; even stooping causes a little loss of time, and the despatch of the men into the mine will be expedited if the cage is high enough for them to walk in upright without any thought for their heads. If the space is too low for standing up conveniently, the men may be made to crouch down in mine-waggons, which are pushed on to the cage as if they contained mineral.

The extent of the interference with the regular winding operations will be best understood by examples. The Government regulations at Mansfeld* do not allow a greater speed than 328 yards per minute ( 5 metres per second) when men are being wound. At Ernst I. shaft, which is 4 I I yards ( 376 metres) deep, it was reckoned, a few years ago, that seven hours out of the twenty-four were occupied with the descent and ascent of 1069 persons, thus:

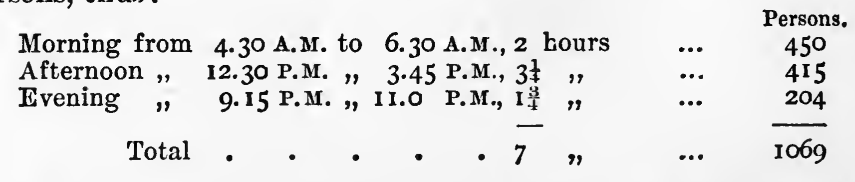

At Ernst III. shaft, which is 273 yards $(250 \mathrm{~m}$.) deep, the figures were as follows:

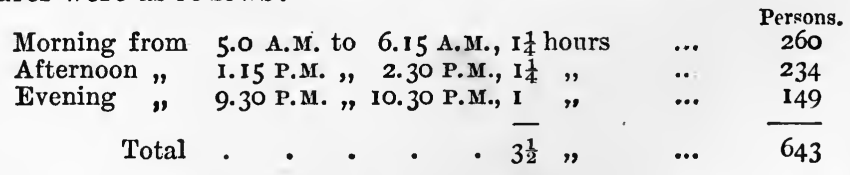

The cage at the former shaft took seven men at a time, and that of the latter, sixteen men, as it was double-decked.

With the object of relieving the ordinary winding-plant from this task in one part of the district, a new shaft was sunk solely for raising and lowering the men.

The British law demands that, in addition to the guides already mentioned, there should be a cover overhead, so as to protect the men from things accidentally falling down the shaft. The use of

* Der Rupferschieferbergbau und der Hüttenbetrieb zur Verarbeitung der gewonnenen Minern in den beiden Munsfelder Kreisen der Preuss. Provinz S'achsen. Halle an der Saale, I889, p. 72. 
a single-linked chain is forbidden, except for the short coupling piece connecting the cage to the rope. There must be flanges to prevent the rope from slipping off the drum; the winding machine has to be provided with an adequate brake and a proper indicator ; and, lastly, there must be means of signalling up and down from every landing-place in the shaft. In some countries safety catches are compulsory.

An ingenious and useful method of signalling is that of Mr. Armstrong, who inserts an electrically insulated wire into the centre of the winding rope for the purpose of communicating from the cage itself to the engineman, no matter whether the cage is in motion or not. The electric wire is brought into contact with an insulated metal ring placed upon the crank shaft of the engine, and a copper lever pressing upon this ring places the wire in communication with a small battery. The wire rope itself serves as a return. The circuit can be completed by pushing a button inside the cage, or another placed upon the roof, and the ringing of a bell at the surface gives the necessary signals to the engineman. This rope, which is made by Messrs. Haggie \& Co., of Sunderland, is being used with success at collieries in the north of England, and at one of them a separate shaft is set apart for the men, so as not to interfere at all with the winding of coal ; the cage carries twenty men at once, and is always in charge of a conductor, whose duties resemble those of the attendant at an hotel lift or elevator. By merely pressing a button he signals direct to the engineman to start or to stop as required.

At mines under the Coal Mines Act in this country, the rate of winding men must not exceed three miles an hour after the cage has reached a point in the shaft which is fixed by Special Rules. However, this regulation applies only in cases where the hoisting apparatus is not provided with some automatic contrivance to prevent overwinding. In Germany a speed indicator has to be applied when men are being raised or lowered; among instruments of this class may be mentioned the tachometer of Messrs. Schäffer and Budenberg, which indicates the rate of winding by a pointer on a dial in full view of the engineman.

Winding by the cage is not confined to perpendicular shafts. At Carn Brea Mine in Colnwall a two-decked cage, holding sixteen persons, runs in a shaft which is perpendicular for the first I 20 fathoms and then follows the changing dip of the lode for 170 fathoms more. The inclination varies from about $10^{\circ}$ to $30^{\circ}$ from the vertical. In a shaft of this kind it is impossible to wind with safety at speeds which are common at collieries; nevertheless the cage does very useful work, and as the rope is renewed every four months, there is little chance of a breakage. The cage at Junge hohe Birke* Mine, near Freiberg, consists of

* Freibergs Berg- und Hüttenwesen, 1893, p. 156. 
five small compartments one above the other, each forming, as it were, a separate link of a chain; the cage can thus accommodate itself to bends in the shaft. Each compartment takes two men.

Man-engine.-The first man-engine was put up in the Hartz in 1833 , and nine years later a similar machine was fixed in Tresavean Mine in Cornwall. Since that time this useful means of conveying men up and down shafts has been resorted to in other mining districts, such as Belgium, Westphalia, and Saxony.

Two kinds of man-engine are in use-the double-rod and the single-rod machines.

'The double-rod, or original man-engine, consists of two reciprocating rods, like the main rods of pumps, carrying small platforms upon which the men stand. The stroke Figs. 60:604. is from 4 to 16 feet, and the little platforms are arranged so that they are always opposite each
other at the beginning and end of each stroke. Figs. 603 and 604 represent the rods in the two final positions. A man who wishes to go down, steps upon platform $b$ (Fig. 6०3), the rod B goes down and A goes up, so that $b$ is brought opposite $c$ (Fig. 604). The man steps across from $b$ to $c$, the rod A makes a down stroke, and $\mathrm{B}$ an up-stroke. Platform $c$ is now opposite $d$ (Fig. 603), and the man again steps across; and thus, by constantly stepping from the rod as it completes its down-stroke, the man is gradually conveyed to the bottom of the shaft. By reversing the process, or, in other words, by stepping off on to the opposite platform as soon as the rod has completed its up-stroke, the man is raised to the surface without any fatigue beyond the very slight effort of stepping sideways. If each rod makes four up and down strokes of 10 feet each per minute, the rate of ascent or descent will be 80 feet per minute.

The single-rod man-engine has one rod carrying steps, while fixed platforms are arranged in the shaft so as to correspond exactly with them (Fig. 605). If a man wants to go down, he steps on to A when the up-stroke is comjleted; the rod goes down and the step A is brought opposite the fixed platform $b$, on to which he steps off. He then waits on $b$ until Fig. 605 .

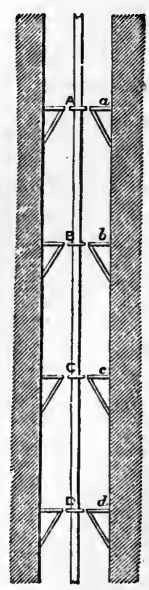
the rod has finished its up-stroke. B is brought opposite $b$, he steps on to $\mathbf{B}$, the rod goes down and he is brought opposite $c$, where he again steps off and waits. By reversing the operation he is gradually lifted up to the top of the shaft. The single-rod engine may be used by men going up while others are 
going down, provided that there is sufficient room upon the fixed platforms (sollars, Cornwall). It is best to have platforms right and left, as shown in the figure, and then the ascending men step off always to the left, for instance, while the descending men take the right hand sollars. The ascending man steps on to the manengine as soon as the descending man steps otf, and so the rod may be always carrying men up or down. The usual stroke in Cornwall is 12 feet, and there are from 3 to 6 double strokes per minute. With 5 strokes the men descend ro fathoms a minute, or, in other words, a descent or ascent of 300 fathoms occupies half-an-hour. However, after the tirst man has reached the bottom, the rest will be coming down at the rate of five a minute. The reciprocating motion is best obtained from a crank (Fig. 706), because in this case the speed is gradually diminished at the dead points, and the danger of an accident in stepping off wnd on is thereby lessened ; man-engines, however, are sometimes ciriven by direct-acting engines, and, at Laxey Mine, in the Isle of \Lan, a water-pressure engine furnishes the motive power for one of these machines.

Man-engine rods are constructed of wood or iron; and at St. Andreasberg, in the Hartz, each rod was replaced by two wire ropes. Like a pump rod the man-engine rod requires proper balance-bobs and catches, and for the safety of the men a handle is provided at a convenient height above each step. Sloping boards should be fixed under each platform, so as to make a funnel-shaped passage guiding the man's head into the proper channel, in case he is not standing upright when "riding" up. A useful addition is a small wire rope passing down from sollar to sollar, and placed within easy reach of a man when standing on a step; he grasps this with one hand as he steps off on going down, and steadies himself by it if necessary. When riding up, he passes through the sollar and sees where he is going to step before he gets off, so it is not required on both sides of the fixed platform. There should be a signal line, with means of working it, at every sollar, for enabling any miner to ring and stop the man-engine in case of an accident. It is well, too, to have a ladder-road at the side of the man-engine, in order to affurd a means of going up or down in the event of some unexpected breakdown of the machinery; but the plan of fixing this ladderway between the two rods of a double engine is not to be commended, for the wider the space between the rods the greater the chance of an accident.

The man-engine has the advantage that it can be safely applied in inclined and crooked shafts, and it is convenient in vein-mining where the men have to work at very many different levels.

The cost of raising and lowering men by the machine is not great. At Dolcoath, a tin mine in Cornwall, more than 400 fathoms deep, it was reckoned a few year's ago that $1 \frac{1}{2} d$. per man 
per day covered all expenses, including interest upon the capital expended and depreciation of plant.

Judging by what has taken place during the last ten years, it seems likely that the man-engine will eventually die a natural death. It has all but disappeared at Mansfeld, being replaced by the safer and more convenient cage, and there seems little probability of new machines being erected in Cornwall. 


\section{CHAPTER XIII.}

\section{DRESSING.}

I. Mechanical processes : (I) Washing in order to separate clay, mud and sand-(2) Hand-picking-(3) Breaking up, subdivision, or shaping(4) Agglomeration or consolidation-(5) Screening or sifting. II. Processes depending upon physical properties: (I) Motion in water-(2) Motion in air--(3) Desiccation-(4) Liquefaction and distillation-(5) Magnetic attraction-(6) Separation according to degree of friability. III. Processes depending upon chemical properties : (I) Solution, evaporation, and crystallisation-(2) Atmospheric weathering-(3) Calcination-(4) Cementation or precipitation by iron-(5) Amalgamation.

Examples-Loss in dressing-Sampling.

UNDER the convenient term of "dressing" are included the processes by which the miner prepares his mineral for sale, or by which he extracts a marketable product from it. These processes are very various, and cannot all be properly comprised under the French heading "Préparation mécanique," because, in addition to using mechanical means, the miner often invokes the aid of heat, magnetism, or chemical affinity, in order to separate the valuable material, from the worthless rock with which it is associated in the earth. It must also be recollected that there is a borderland between mining and metallurgy, on which both miner and smelter may fairly claim a footing, because the former does not always send away his ore in the same state of elaboration. Some may be inclined to cut the knot by saying that the business of the miner is at an end when the mineral is landed at the surface; but in actual practice this is the exception, and the person in charge of the mine has usually to superintend certain processes which are carried on in order to obtain a readily saleable article.

I propose in this chapter first to describe the various dressing processes, and then to explain how they are applied to the most important minerals with which the miner has to deal.

In order to have a clear idea of the principles which guide the miner, it is requisite that we should classify the processes which he employs; and we may at once make three main divisions, according as the process is effected solely by mechanical means, or is based upon the physical or chemical properties of the minerals treated. This classification is somewhat arbitrary: differences of opinion may exist, for instance, concerning solution, some persons considering it as a chemical process, others, as a mere 
change of state without any chemical action; again the process by which a physical property is brought into play is usually effected with the aid of mechanical appliances; and lastly, chemical and physical actions may both be involved in the method of treatment. It must, therefore, be understood that the classification is established rather for the convenience of the student, than with the idea that the subdivisions of the subject are strictly defined in reality. It will be seen also as we proceed, that many of the sub-classes refer to exceptional processes applicable only to special minerals.

The following table gives an outline of the operations employed in dressing:

\section{Mechanical Processes.}

1. Washing in order to separate clay, mud and sand.

2. Hand-picking.

3. Breaking up, subdivision, or shaping.

4. Agglomeration or consolidation.

5. Screening or sifting-i.e., classification according to size.

II. Processes depending Upon Physical Properties.

I. Motion in water.

2. Motion in air.

3. Desiccation.

4. Liquefaction and distillation.

5. Magnetic attraction.

6. Separation according to degree of friability.

III. Processes depending upon Chemical Properties.

I. Solution, evaporation and crystallisation.

2. Atmospheric weathering.

3. Calcination.

4. Cementation or precipitation by iron.

5. Amalgamation.

\section{MECHANICAL PROCESSES.}

(I) WASHING.-The object of washing is twofold : removal of earthy impurities, and preliminary cleansing previous to handpicking, for the valuable mineral, as it comes from the mine, is often completely masked by a coating of dirt.

The process is carried out by hand or by machinery. 'The simplest appliances are the pan and the batea, which are specialıy used in the case of gold and tin. The pan is a circular dish made of tin-plate or stamped iron or steel, about 15 or 16 inches in "diameter at the top and Io or I I at the bottom, with a depth of 3 or 4 inches. After having been partly filled with the mineral to be washed, it is held in a pool of water, or a vat, in which it can be moved so as to impart a circular motion to its contents. By suitably inclining the edge, the muddy stream is made to flow off, more clean water is taken on, and the process is repeated until there 
remains nothing but well-washed sand and gravel in the bottom. The big stones are taken out and examined; and thrown away if worthless; large nuggets, if present, are now visible and can be picked out, whilst the small stones and sand are again mixed with water and washed, so that the lighter particles flow over the edge and the heavy ones remain in the pan. By careful manipulation the water is made to run repeatedly over the residue, and separate the various ingredients according to their specitic gravities, as will be explained later. The pan, therefore, acts not only as a washer, but also as a concentrator.

Though the main use of the pan is for prospecting, it must be remembered that very large quantities of alluvial gold have been extracted by its aid.

The batea fulfils the same purpose as the pan. It is usually a shallow conical bowl made of wood, stamped sheet iron, hammered copper, or spun aluminium or copper. Convenient dimensions are: diameter 18 to 20 inches and depth $2 \frac{1}{2}$ to 3 inches. In some parts of India the wooden gold-washing dish is rectangular. The mineral is treated much in the same way as in the pan, but the batea has the great advantage of bringing all the heaviest particles to a point, instead of an edge. Much gold has been obtained with this primitive appliance, especially in South America and Central America, whilst in the Malay Peninsula it is used for extracting tin ore from gravel, and in Brazil for washing out diamonds. In prospecting the batea is invaluable.

If large quantities of mineral have to be handled, it is necessary to separate the adherent dirt in some cheaper fashion. Occupying an intermediate position between the hand-bowls and the rotary machines are simple washing pits of different descriptions.

Some of the lead ore of North Wales occurs in the form of solid lumps of galena enveloped in clay. The ore coming from the mine is thrown into a stone-lined pit about I8 inches deep, partly filled with water, in which it is pushed backwards and forwards until the galena is separated from its clayey matrix. This kind of washing pit is known as a "jobbing buddle."

Phosphatic nodules are cleansed from sand in a similar manner, by being raked or shovelled backwards and forwards in long wooden troughs full of water.

The Australian puddling machine is an example of an appliance for doing similar work by the aid of a horse or other available power. It is a circular pit in which gold-bearing gravel is stirred up with water by knives attached to radial arms, which are carried round by a vertical axis.

The rotary washing machine employed at the diamond mines (Fig. 606) is identical in principle. The object is to free the weathered "blue ground" from the finest sand and mud and leave a clean gravel in which the diamonds shall be distinctly visible. The 
rotary washer is an annular iron pan A (Fig. 606) 8 to 15 feet in diameter and 16 inches to 2 feet deep externally, whilst the inner rim, B, 4 feet in diameter, is only 6 inches deep. In the centre is a revolving vertical shaft, $C$, carrying 8 or ro radial arms, D, each provided with 6 or 7 vertical blades which dip into the mud and gravel, and stir it up as they revolve. At De Beers mine the washers are usually 14 feet in diameter. The stuff is fed in at the outer circumference by a shoot coming from a screen, and the muddy water escapes over the low inner rim of the pan. The teeth or stirring knives are arranged so as to bring

FIG. 606.
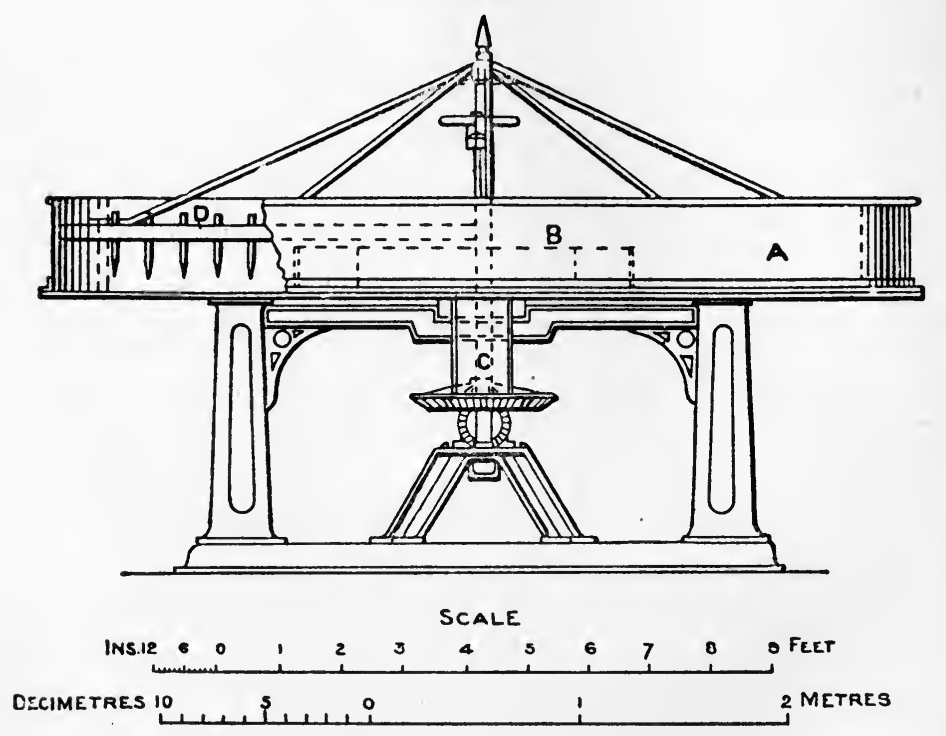

the heavy gravel towards the outer circumference. As a precaution, the muddy water flowing out of the washer is run into a similar machine, and is again stirred up so as to catch any diamonds which may by chance have escaped in the first operation. When the pan has been at work for twelve hours, a sliding door is pulled out at the bottom, through which the gravel falls into a truck underneath, as it is drawn round by scrapers attached to the arms.

Another form of mechanical washer* (Fig. 607) is a revolving sheet iron drum, made in the form of a truncated cone revolving upon a horizontal axis, and provided with internal stirring blades. The "stuff" to be washed is fed in at the centre of the small end

- Linkenbach, Die Auflereitung der Erze, Berlin, I887, plate II. 
with a stream of water. In Fig. $607, a$ is the drum, $b$ the conical mouth, $c c$ the arms which attach the drum to the central shaft $d$; $e e$ are teeth, $f$ the shoot from a hopper, $g$ a pipe bringing water, the amount of which can be regulated by a cock. The greater part of this particular drum is perforated, and it acts as a sizing machine after having done the washing; $m$ is the driving pulley, $h$ an iron trough catching the discharge of the sieve, and $i$ a small trough which takes the stones discarded by the sieve.

This machine is intended for washing small stuff ("smalls") previous to picking. The washing of the larger lumps is often effected by turning a stream of water upon them over a coarse iron grating.

FiG. 6ว7.

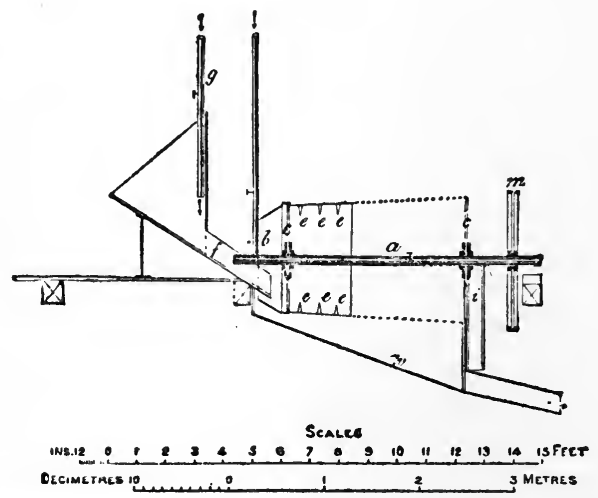

(2) HAND-PICKING.-No process is simpler in principle, it is merely the separation by hand into classes of varying quality and richness; the difficulty in practice is to know how far it should be carried, before the mineral is treated by machinery.

In many cases hand-picking may begin underground, and where worthless rock can be so separated without difficulty, it should be removed with care, so as to avoid useless expenditure for tramming, hoisting and dressing. If a mineral is specially valuable, it is often worth while picking it out and sending it up by itself, with a view to preventing loss or theft in transit, or loss in dressing due to the admixture of a large proportion of refuse. Picking of this kind is resorted to in working rich pockets of gold or silver ore under the superintendence of a foreman. Pieces of pure ozokerite are picked out by the Boryslaw miners and sent to the surface in sacks, and the men are stimulated to do the work as thoroughly as possible by a premium paid for the clean lumps.

By the dim light of a candle the picking process cannot, as a rule, be carried further than the separation of worthless rock, and, 
occasionally, the selection of some very rich pieces of mineral ; nor; if the light were better, would it be advisable to do more, for the underground traffic would be complicated if a number of classes of mineral were made, and the work of picking can be better performed by keen-eyed boys and girls at the surface than by the miners underground, especially after they have passed middle age.

Picking is generally carried on after the mineral has been subjected to a washing process of some kind. The washed mineral is spread out on a table, and boys and girls, standing by the side, separate the stones that lie before them according to their richness and the subsequent processes they will have to undergo. A scraper made of a piece of iron, bent as shown by Fig. 608. Fig. 608, assists them in drawing the lumps towards

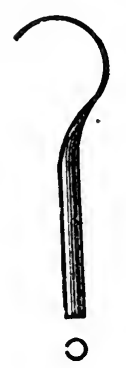
them or into a box, waggon, or barrow by the side of the table.

In a lead-mine we may have (a) clean galena; $(b)$ mixed ore, i.e., pieces consisting partly of galena and partly of barren veinstone; $(c)$ barren veinstone and pieces of the surrounding rocks (country). This is a most simple case; but very frequently one has to deal with a deposit producing the ores of two or three metals, especially in the case of lead and zinc, and then the classification into various qualities becomes more complicated.

Where the amount of mineral to be picked is considerable, labour may be economised by self-discharging tables, of which there are two kinds-revolving round tables and travelling-belts.

With the former the mineral is fed on at some point of the circumference and the picking is done by boys or girls standing around. They select pieces of certain qualities and richness as the table revolves in front of them, and finally, when a revolution is all but completed, nothing remains on the table but mineral of one quality, which is swept into a box or waggon by a fixed projecting scraper.

Endless belts are made of hemp, wire-gauze, or steel plates attached to endless chains, and they are sometimes as much as 4 feet wide. The refuse is picked off as the mineral travels by, and the clean product can at once be delivered into railway waggons, ready for despatch to smelting works or to some further process of dressing.

(3) BREAKING UP, SUBDIVISION, OR SHAPING. - Reduction in size is necessary for various reasons. Even when an ore is clean enough for the smelter, the large lumps are often crushed by the miner for the sake of obtaining a fair sample of the whole, or of supplying a product which is at once fit for the furnace. Fertilisers, cements and pigments have to be finely ground before they can be used, and the grinding may or may 
not take place at the mine. The chief object of breaking up, however, is to set free the particles of ore, which are generally found enclosed in or adhering to particles of barren veinstone.

Few processes in dressing are of more importance than the proper breaking up of the ore or other mineral. A very large number of machines are employed suitable for the different substances which have to be treated, and it will be impossible

FIG. 609.

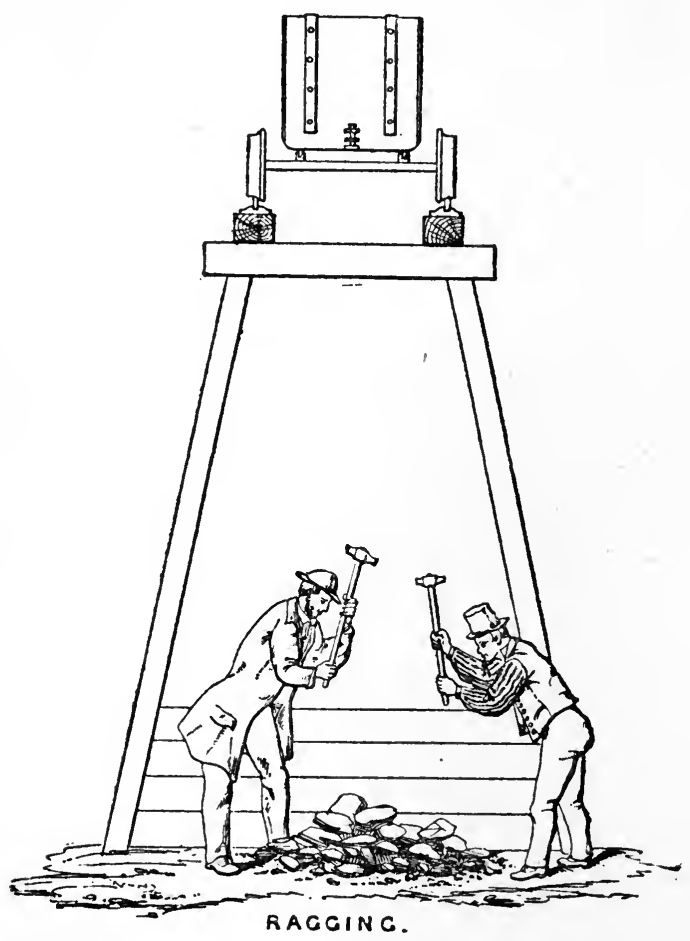

within the limits of this chapter to do more than pass the most important in review in a somewhat summary manner.

The breaking may be done by hand or by machinery.

The processes of breaking by hand may be divided, according to the precise object in view, into :

$a$. Breaking with the sledge hammer [ragging and spalling].

$b$. Cobbing.

c. Bucking.

d. Splitting.

c. Trimming into shape with the saw, axe, hammer, or knife. 
a. Breaking with the Sledge Hammor.-The term "ragging" is applied, in Cornwall (Fig. 609)*, to the process of breaking up the very big lumps (rocks) as they come from the mine by a large slelge hammer weighing about 10 or $12 \mathrm{lbs}$. The

Fig. 6io.

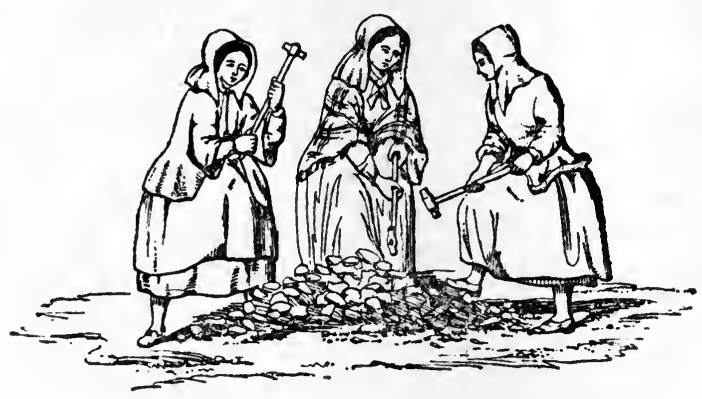

SPALLING.

work is done by men, who, in addition to breaking the lumps, may separate the broken pieces into various categories according to quality.

Spalling is work of a similar nature, but performed with a smaller sledge, weighing 4 or 5 lbs., which in Cornwall can be wielded by a woman (Fig. 6ro). Sometimes there is a little

Fig. 6II.

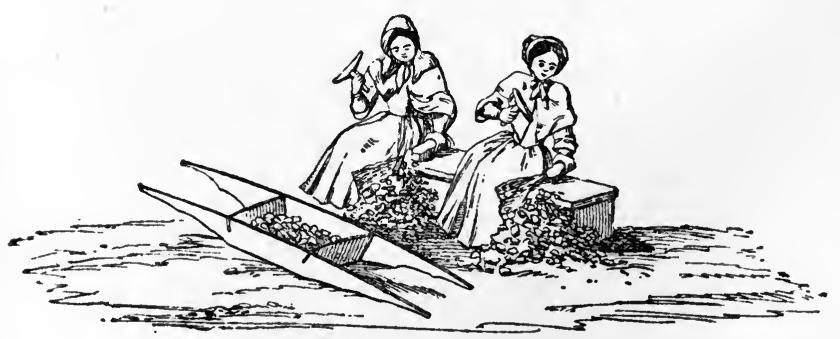

COBBING.

picking at the same time. The process of spalling is often a preliminary to crushing by stamps or rolls.

$b$. Cobbing.-Cobbing is a special kind of breaking with a small hammer, in which the blow is directed with the object of knocking off a piece of poor rock from a lump of mixed ore and refuse. The work is usually performed by women (Fig. 6II),

* Henderson, "On the Dressing of Tin and Copper Ores in Cornwall," Proc. Inst. C.E., vol. xvii., $3857-58$, plate 7 . 
girls, or boys, who commonly sit down and strike the lumps upon an anvil of some kind, often an old stamp-head. As the lumps are held in position by the left hand, a badly directed blow may

FIG. 612.

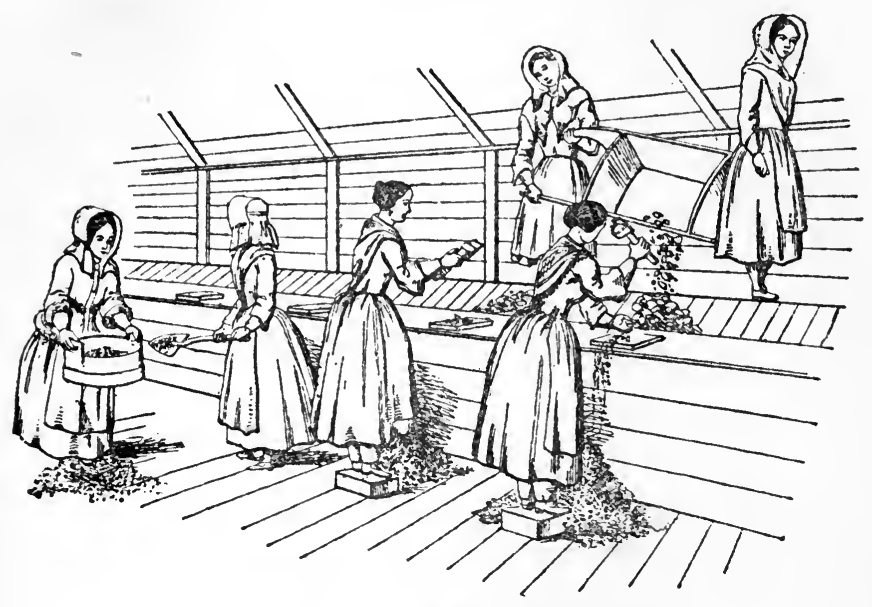

BUCKINC MILLS.

cause a nasty wound; to prevent injuries of this kind, the girls formerly employed in cobbing copper ore, at the Mona and Parys mines in Anglesey, wore pieces of iron around their fingers, and short pieces of india-rubber tube are used for the same purpose.

c. Bucking.-Bucking is breaking with a very broad flat hammer in order to reduce an ore to coarse powder. The hammer, called a "bucking-iron," is about 4 inches square with a steel face; the handle is from 18 inches to 2 feet long. The ore is struck upon a thick flat plate of iron (Fig. 612).

d. Splitting.-Splitting is required with slate, and also with stone which will rend along certain directions other than cleavage planes, such as planes of bedding. It is done with a wedge of some kind, increasing in sharpness with the thinness of the slice required. Blocks of slate are split by the Welsh quarrymen with a stout wedge into slabs about 3 inches thick, and the process is then repeated with a thin one (" cyn maen FIG. 613. hollti") (Fig. 613) until they obtain a roofing material often not more than $\frac{1}{7}$ or $\frac{1}{8}$ inch thick.

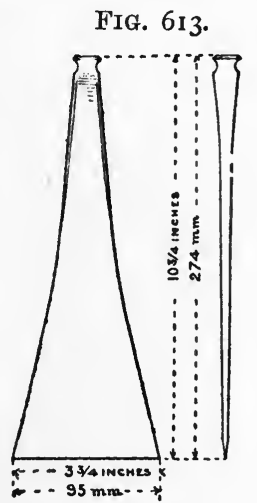


e. Trimming.-Trimming into shape is necessary with many kinds of stone. Thus the Bath freestone is resawn by hand at the surface (Fig. 156), if the blocks are not quite suitable for the market as they come from the mine. The hearthstone raised at, Godstone in Surrey is hewn into neat blocks by a peculiar doubleheaded axe, whilst paving-stones, chert, and gun-flints are fashioned with the hammer; rooting-slate is chnpped into rectangular pieces with a large knife.

Many of these hand-processes are gradually disappearing, owing to the introduction of machinery which will perform the work with a saving of time and labour.

Machines for breaking up, subdividing, or shaping ores and stone may be classed as follows:
a. Breakers with reciprocating jaws.
b. Stamps.
c. Rolls.
d. Mills.
e. Edge-runners.
$f$. Ball-grinders.
g. Disintegrators.
$h$. Conical grinders and breakers.
$i$. Centrifugal grinders.
$j$. Pneumatic pulverisers.
$k$. Miscellaneous pulverisers.
l. Sawing machines.
$m$. Planing machines.
$n$. Slatemaking machines.

a. Jaw-breakers.-These machines, often called rock-breakers and stone-breakers, crack stones by the near approach to one another of two powerful iron or steel jaws. The best known stone-breaker is the machine invented by Blake, which has rendered inestimable services to the miner for the last thirty years, and the introduction of which constituted a most important step in advance in the art of ore-dressing. Its mode of action is very simple. When the shaft A (Fig. 6r4) revolves, an eccentric raises the pitman $\mathrm{B}$, and by means of the toggle-plates $\mathrm{C} C$ causes the movable jaw $D$ to approach the fixed jaw $E$, and so crack any stones lying between them. During the descent of the pitman the jaw $D$ is drawn back by an india-rubber spring. The jaws are usually toothed, the ridges of one jaw being opposite the grooves of the other when the machine is employed for breaking stones at mines; if the object is to make road-metal, the two sets of ridges are brought opposite each other. The wearing parts of the two jaws E E and D D are replaceable, and if these castings cannot be immediately obtained in a distant country, it is possible to do good work with flat plates of steel.

The stone-breaker used at mines commonly has the renewable part of each jaw made of one casting instead of two as represented in the figure. The distance between the two jaws, and conse- 
quently the fineness of the product, ean be regulated by raising or lowering the wedge-piece on the right-hand side of the figure, or by inserting other toggle-plates.

The Blake rock-breaker, with the improvements introduced by Marsden, is made in various sizes, so as to take stones as large as 34 inches by 18 inches; the smallest machine is ro inches by 8 inches in the mouth.

Various similar machines are in the market. Baxter claims that he produces fewer small chips and less dust-matters of importance in making road-metal-by his so-called "knapping-motion." Marsden has a breaker with what he calls a "lever motion," in which the toggle-plate moving the jaw forwards is impelled by a

FIG. 6I4.

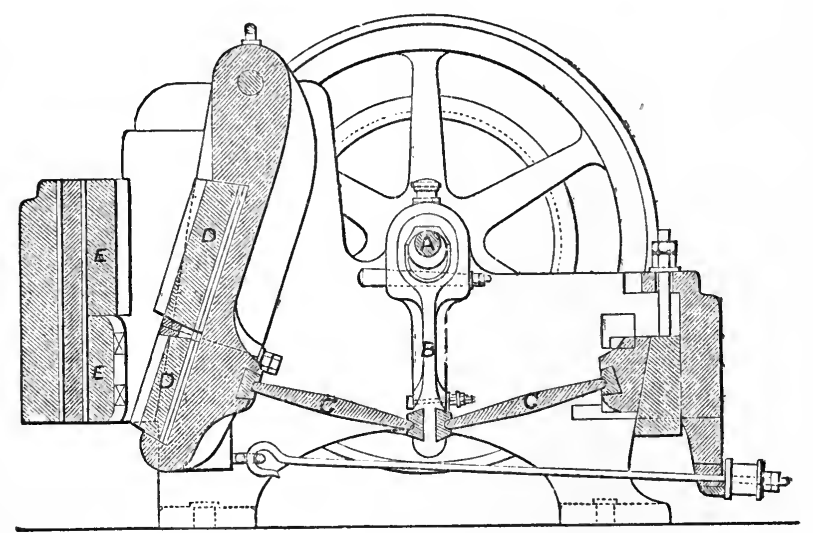

bent lever worked by crank. Hall has two movable jaws placed side by side which act alternately; as all the parts are balanced, less power is said to be required to drive it. Lester's machine is very simple, as the moving jaw is driven directly by the pitman without the intervention of any toggle-plates.

For crushing to finer sizes, Marsden has an ingenious pulveriser. It resembles his stone-breaker by having two jaws, one fixed and the other movable, but the moving jaw has a rubbing as well as a squeezing action. The machine is supplied with a sieve, so that any part of the product not fine enough for use is returned automatically so as to be recrushed.

The Dodge crusher (Fig. 6r $5^{*}$ ) differs from those just described

* Copied by permission from a paper by Mr. A. H. Curtis, which may be consulted with advantage by those who desire information on the subject of crushing: "Gold-quartz Reduction," Proc. Inst. C. E., vol. cviii., I891-9z, p. 108. Further details are given by Professor Egleston in his useful paper, "California Stamp Mills," Engineering, vol. xli., 1880, pp. 19r 85, 163,256 . 
in having the moving jaw pivoted below, instead of above. Consequently the effect of the stroke is felt most at the top. One object of this arrangement is to obtain a more uniform product than is possible with a constantly varying discharge orifice, like that of the Blake breaker.

FIG. 6I5.

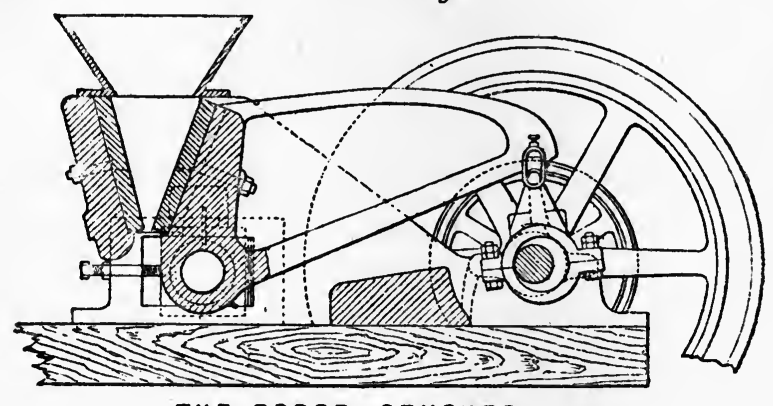

THE DODGE CRUSHER .

b. Stamps.-Though used at mines for several centuries, stamps still hold their own in spite of many competing forms of crushing machinery. The simplest mode of deșcribing stamps is to say that they are pestles worked by machinery in large mortars. In most instances the blow of the pestle is caused by its mere weight, sometimes a spring is added, and occasionally the action of gravity is aided by compressed air, or by steam pressure. We thus have four kinds of stamps:
a. Gravitation stamps.
$\beta$, Stamps with spring.
$\gamma$. Compressed air stamps.
$\delta$. Steam-hammer stamps.

A little study of the accompanying figures $(6,6-620 *)$ will explain the most important characteristics of a modern stampbattery.

a. A A (Fig 6r6) are blocks of timber forming the solid foundation, which is required on account of the heavy pounding action of the machinery; B B, the transverse sills, with the battery-posts $\mathbf{C ~ C}$, the braces $\mathbf{E}$ and the tie-timbers D D form the framework holding the mortar or battery-box (kofer, Cornwall) F, in which the mineral is pounded by any one of the five stamps moving up and down in it. $G$ is a perforated plate or screen which prevents the mineral from leaving the mortar until it has been brought down to the required degree of fineness. $H$ is the shaft carrying cams, which lift the stems by tappets; $\mathrm{K} \mathrm{K}$ are the ends of the stems or lifters of the stamps proper; $\mathrm{L}$ is the pulley through which motion is transmitted to the cam shaft by

* Curtis, Op. cit. 
the belt upon the driving pulley $\mathrm{M}$. $\mathrm{N}$ is the gear by means of which the driving belt can be tightened.

FIG. 6 I6.

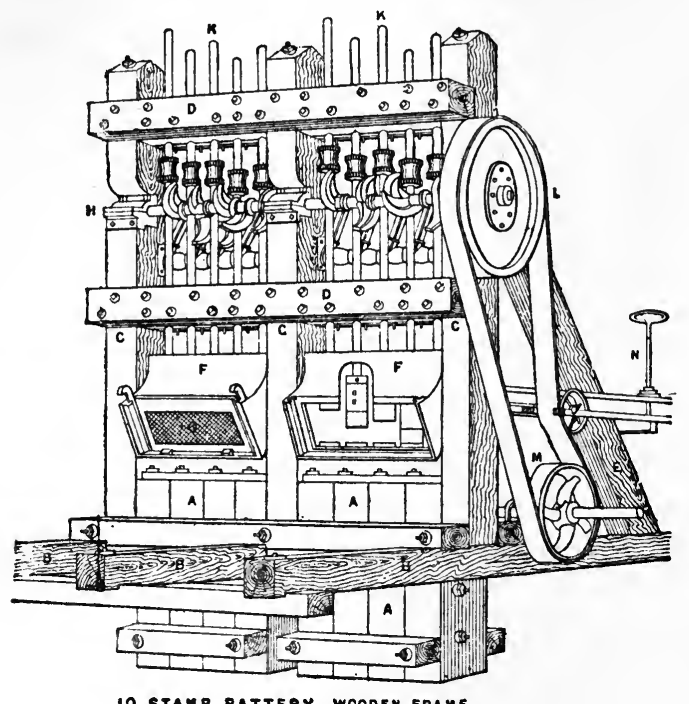

IO STAMP BATTERY, WOODEN FRAME.

Each stamp proper, K K, consist; of a turned rod of iron with tapering ends, either of which will fit into a corresponding hole in a cast-iron cylinder known as the "head" (Figs. 6I 7 and 620).
FIG. 617.
Fig. 6IS.
Fig. 6ig.
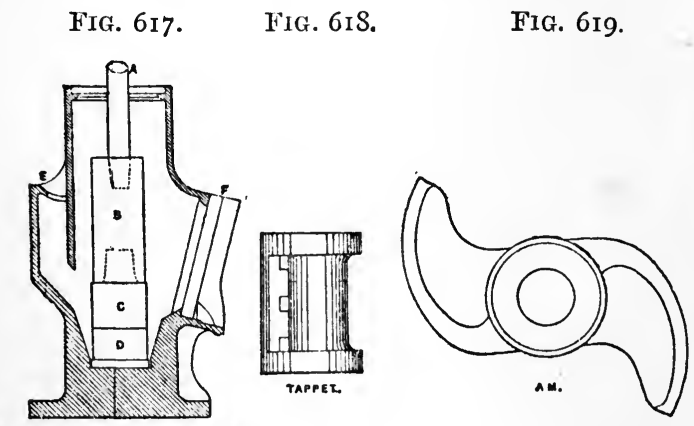

FIG. 620 .

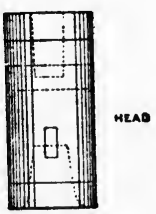

SINGLE DISCHARGE MORTAR.

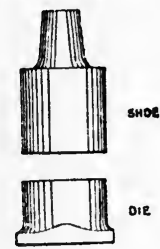

The conical hole or socket in the bottom of the head receives tho shank of the "shoe," which is made of cast-iron, cast-steel, or forged steel. When worn the shoe can be removed from the head 
by driving a steel key into a slot above it (Fig. 620), and the stem or lifter is extracted in a similar manner by means of a second slot at right angles to the first.

The mortar is shown on a larger scale in Fig. 6r. It is a cast-iron box with an opening $\mathbf{E}$ at the back for feeding, and one in front, into which is wedged the frame $\mathrm{F}$ of the screen. Sometimes there is a screen behind as well as one in front, or screens at both ends as well as at the two sides.

Fig. 618 represents the tappet, a hollow cylinder of cast-iron, which is fastened to the lifter by steel keys and a gib. The gib is

FIG. 62I.
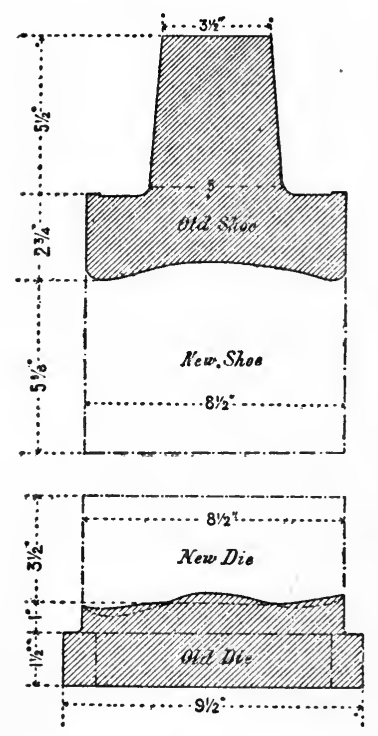
a piece of wrought-iron fitting the curved surface of the lifter and capable of being jammed against it tightly when steel keys are driven into three holes in the tappet. As the shaft $\mathrm{H}$ revolves, the cams (Fig. 6I9) lift the tappets, and at the same time cause a slight rotation of the stamp, which conduces to regular and even wear.

The head B, with its shoe C (Fig. 6I7), drops upon a cylinder of similar metal known as the die, and it is between $\mathrm{C}$ and $\mathrm{D}$ that the mineral is pulverised. Both shoe and die wear away and have to be changed from time to time. The worn shoe and die represented in Fig. $62 \mathrm{I}$ were reckoned to have stamped 150 tons of gold quartz at the Morgan mine, North Wales, before they were given up; they were made of Fraser and Chalmers' forged steel. The order in which the heads drop is not invariable; the object of any arrangement is to make each head do its fair share of work. Egleston mentions six different orders of dropping which are in use, and this shows how much opinions are divided on the subject. Among them may be mentioned 3, 4, 5, 2, I, and I, $5,2,4,3$.

The screens through which the pulverised mineral has to pass are made of punched iron, steel, or copper plates, and occasionally of wire gauze. The holes are round, or in the form of long narrow slots. The size of the holes is better expressed by their actual dimension than by their number per linear inch or centimetre.

The total weight of each stamp when new, that is to say stem, head and shoe, varies from 500 to $950 \mathrm{lbs}$; weights of 700 to $800 \mathrm{lbs}$. are common. The precise height and number of the drops are further points requiring consideration; the height varies 
generally from 8 to II inches, and there are 70 to roo drops per minute. Ore may be stamped dry or wet ; in the latter case, water constantly flowing into the mortar-box carries off the mineral through the screens in the form of a muddy stream known as "pulp." Egleston reckons that the quantity of water used in wet stamping is from $\frac{1}{4}$ to $\frac{1}{3}$ cubic foot per stamp per minute, or 200 to 300 cubic feet per ton of rock stamped.

The quantity stamped per head per day must necessarily vary within very wide limits, according to the weight of the stamps, the nature of the stone treated, and the degree of fineness desired. Speaking roughly, it may be said that each head will stamp 2 tons per 24 hours and require 2 h.-p.

Regular feeding is of much importance, and several automatic arrangements can be applied to the battery for securing the desired result. Most frequently a tappet upon one of the stems comes into play when the stamp has a longer drop than usual, owing to want of ore under it, and strikes a lever which brings the ore-feeding contrivance into action.

$\beta$. Spring stamps are but little used. Patterson's "Elephant" stamps belong to this class : the object of the inventor was to secure a stronger and quicker blow than would be given by a mere fall, and so enable a small machine to do more work than would be possible if gravitation were acting alone. The stamp is worked by a crank, and interposed between the striking head and the connecting rod there is a strong spring, which assists by its recoil and allows for the varying height of the ore in the battery-box.

$\gamma$ Husband's pneumatic stamps were designed with the same intention-viz., a quicker and a harder blow. The stem or lifter of the stamp is attached to a piston working in a cylinder which is lifted rapidly up and down by a crank. There are holes in the cylinder which allow the air to escape during the middle of the stroke, but after it has been raised beyond a certain point, the air below the piston becomes compressed and the stamp is lifted. The cylinder in its downward course travels quicker than the stamp would fall, and compressing the air above the piston helps to drive it down and with it the stamp; it thus increases the force of the blows, which can be given at the rate of 140 per minute. Though good results have been obtained in some cases, these stamps have not made their way into general use, for mining engineers seem to consider that the simplicity of the ordinary stamps, and the ease with which any slight defects can be repaired, make up for the disadvantages which Husband tried to remedy.

$\delta$. We now, lastly, come to the steam-hammer stamp, which has proved a most efficient machine at the Lake Superior mines for the treatment of rock containing native copper. The first stamps of this kind were constructed by Ball in 1856 ; since then great improvemerits have been made, and the present Leavitt stamp will crush $25^{\circ}$ tons of copper-bearing rock in 24 hours. 
The Ball * stamp (Fig. 622) consists of a vertical steam-cylinder, $\mathrm{C}$, with the stamping head attached to the piston-rol. The various parts are designated as follows:-D, cast-iron die; $\mathrm{E}$, cast-iron shoe; F, frame of mortar; G G, grates of punched sheet steel; $\mathrm{H} \mathrm{H}$, cast-iron head posts; L, cast-iron sills or girders; M, cast-iron mortar; $\mathrm{P}$, pulley by which the valve is

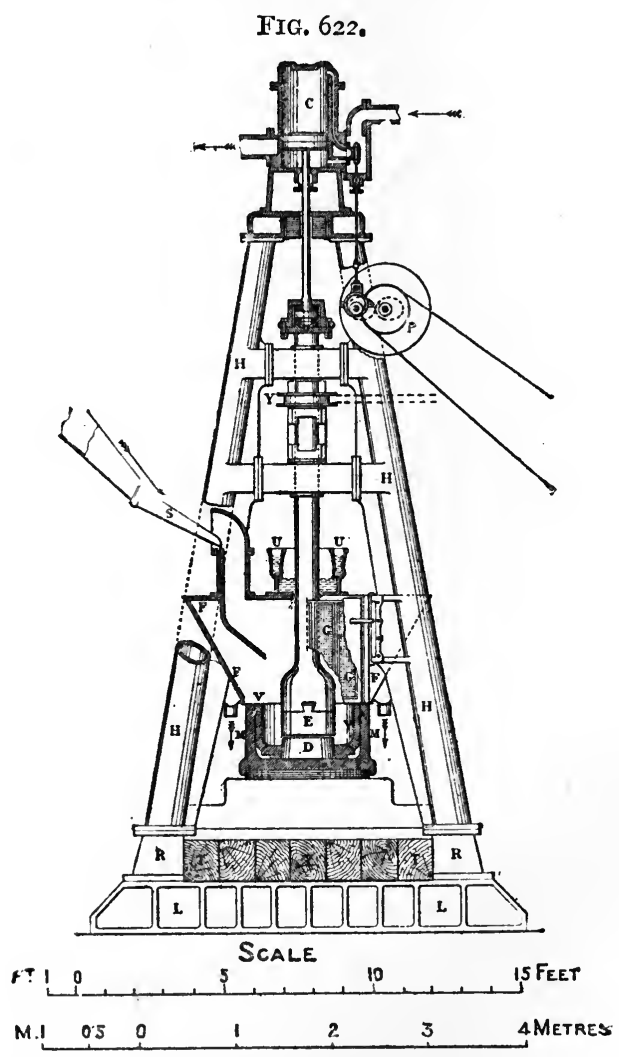

driven ; R R, cross sills ; S, shoot supplying the ore; T T, spring timbers; U, " urn" or cistern supplying water; V V, cast-iron lining plates, resting upon a cast-iron ring surrounding the die; $\mathrm{Y}$, pulley by which the stamp is rotated.

The slide-valve is worked from the pulley $\mathrm{P}$ by the elliptical spur-wheels indicated by the dotted lines; the valve is opened fully for making the down-stroke, and the pressure of the steam

* Rathbone, "On Copper Mining in the Lake Superior District," Proc. Inst. Mech. Eng., 1887, p. 96. 
greatly increases the blow due to gravity, but for making the up-stroke the steam is admitted sharply, and in just sufficient quantity to lift the head.

The peculiarity of the Leavitt* stamp lies in the differential steam-cylinder (Fig. 623). There are two cylinders, one above the other: a large one $\mathrm{A}$ with a piston $\mathrm{B}$, above a small one $\mathrm{C}$ with a piston D. Steam is admitted on to the top of piston $B$ through the valve at $\mathrm{E}$, and is exhausted through a valve at $\mathrm{F}$ into the condenser. The space under the piston $\mathrm{D}$ in the cylinder $\mathbf{C}$ as well as the annular space $G$ is filled with steam admitted through the opening $\mathrm{H}$, and kept by a regulator at a uniform pressure sufficient to raise the stamp. The stamp is thus lifted by the lower piston, and is forced down by the large upper one against the constant pressure exerted by the lower. The valves regulating the admission of the steam and the exhaust valves are worked by cams upon a shaft driven by a belt from some independent source of power. The cams which open the steam and close the exhaust valves are fixed, but the cams which close the admission of steam and open the exhaust can be adjusted at pleasure.

The moving parts of each Leavitt stamp at the Calumet and Hecla mine weigh about $5000 \mathrm{lbs}$., and the blow is struck with a velocity of 20 to 22 feet per second. The

FIG. 623 .

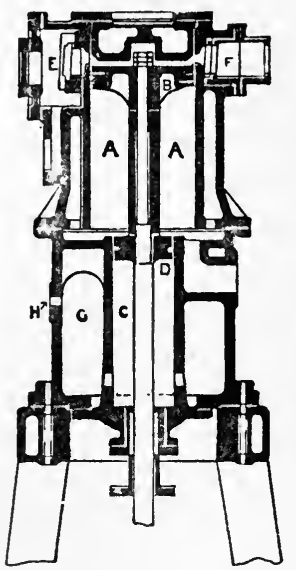
number of blows is 98 per minute; the screens are made of the best steel $\frac{1}{10}$ inch thick, punched with round holes $\frac{3}{16}$ inch in diameter, and speaking roughly about ro tons of rock an hour are stamped fine enough to pass through them, and are carried away by water to the concentrating machinery.

c. Rolls.-Rolls were introduced into the West of England in the early part of the present century to replace bucking by hand. They are a pair of smooth, fluted, or toothed cylinders, made of cast-iron or steel, which revolve in opposite directions, and crush any stone which is allowed to fall between them.

The cylinders or rolls are generally from $I$ foot to 3 feet in diameter, and I foot to 3 feet wide; they are kept pressed together by levers or springs. For crushing metallic ores, the diameter of the roll is generally from two to three times its width.

The original form of crushing rolls, and one still largely used

* F. G. Cogging. "Notes on the Steam Stamp," Engincering, vol. xli., I886, pp. I 19, I30, 200. 
in this country, is represented in Fig. 624, in which the letters have the following meanings: $G$, hopper, into which the ore is shovelled from the floor, $\mathrm{H} \mathrm{H} ; \mathrm{A} \mathrm{B}$, the two cylinders or rolls shown on a larger scale in Fig. 625. The roll $B$ has plummerblocks which can slide along a bed-plate, and so allow the opening between it and the roll $\mathrm{A}$ to be increased or diminished; $\mathrm{C}$ is a bent lever, to one end of which is attached a weighted box, whilst the other constantly presses a pin against the plummer-block of $\mathrm{B}$; the crushed rock after leaving the rolls falls into a revolving cylindrical sieve. All that fails to pass through the sieve drops into the "raff-wheel" $\mathrm{E}$, which has buckets on the

FIG. 624.

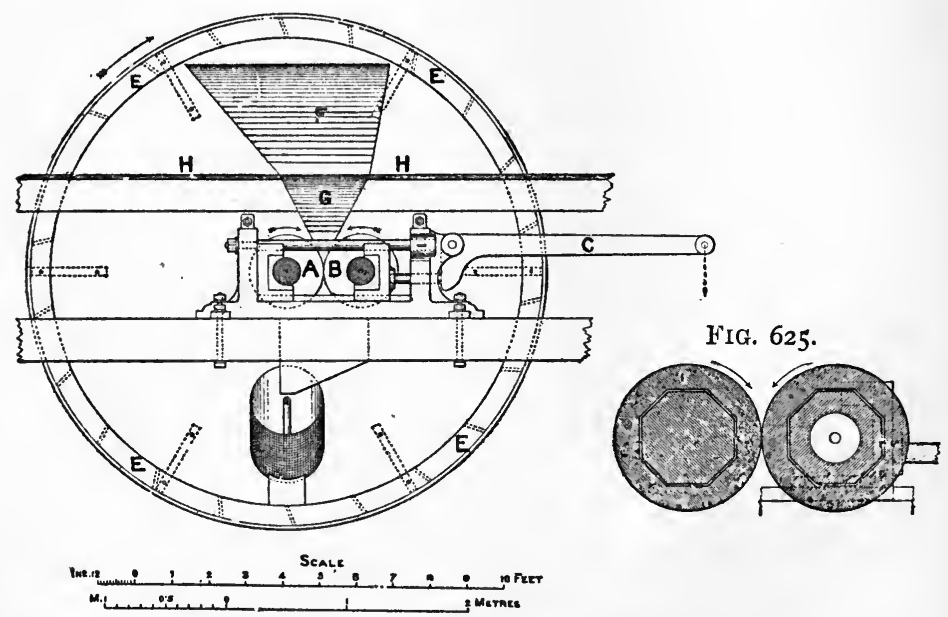

face turned towards the crusher; these carry up the coarse fragments as the wheel revolves and tip them on to a sloping apron $F$, whence they fall again into the hopper $G$ to undergo a further crushing.*

One end of the shaft of the roll $\mathrm{A}$ is coupled to the main driving shaft of the machine, which carries the raff-wheel; the other end has a cog-wheel which gears into a similar one on the shaft of B, and so drives it. The inclined sieve is driven from the shaft of $\mathrm{A}$ by means of bevel gearing.

An improved form of the Cornish rolls has been introduced by Krom, $\dagger$ and is meeting with approval. His improvements are:

* Fergnson, "On the Mechanical Appliances used for Dressing Tin and Copper Ores in Cornwall," Proc. Inst. Mech. Eng., I 873 , plate liv., and p. 133 .

+ Krom, "Improvements in Ore-crushing Machinery," Trans. Amer. Inst. MI. E., vol. xiv., IS85, p. 497. 
Steel tires, pulley gearing, housing to enclose the rollers, swinging pillow-blocks, tie-bolts to take the crushing strain, hopper for automatically ensuring a regular feed.

The tires (Fig. 626) are made of mild forged steel,* and are held by two cores in the form of truncated cones. One of the cores is shrunk firmly on to the main shaft, the other is split on one side, but when drawn in towards its fellow by bolts, it grips the shaft very tightly, and at the same time fastens the tire securely. The main shaft (Fig. 627 ) $\uparrow$ is driven by a pulley, indi-

Fig. 626.

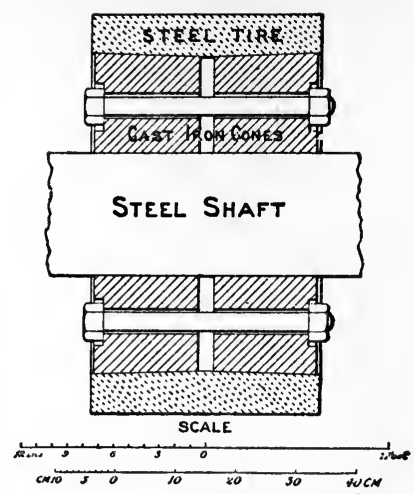
cated by the dotted line, revolving at the rate of 80 to roo times

Fia. 6ะ7.
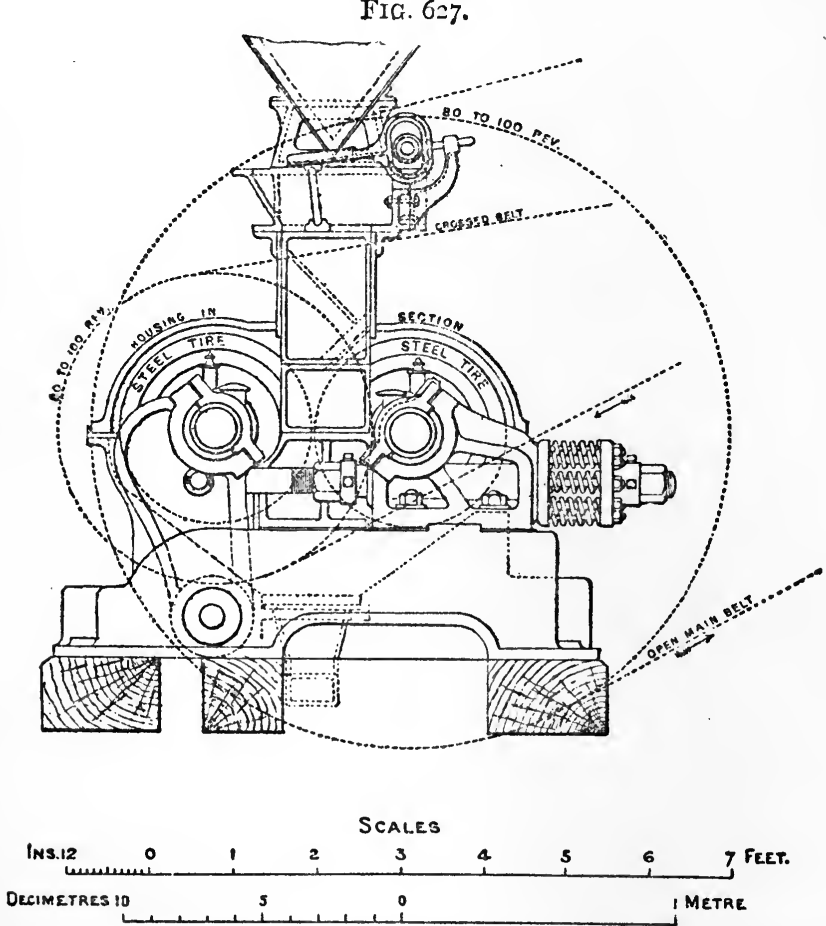

* Messrs Bowes Scott and Western use a special steel of their own which is said to be exceedingly durable. t Curtis, op. cit. 
a minute; the other shaft is driven at the same speed, but in the opposite direction, by crossing the driving belt of the smaller pulley. The bearing of the shaft of the movable roll is carried by a swinging pillow-block pivoted underneath, and constantly drawn towards the other roll by the strong spiral springs. The upper part of the figure represents the bottom of the hopper which supplies the rolls, and the oscillating feed-tray, set in motion by an excentric.

Actual experience extended over a considerable time has proved that a pair of Krom rolls at the Bertrand Mill, in Nevada, will crush 150 tons of quartzose silver ore in 24 hours, so as to pass through a screen with 16 holes to the linear inch. It is claimed that less fine dust is produced with these rolls than with stamps, a matter of importance, owing to the losses in dressing or lixiviation when there is a large proportion of slime.

Fluted rolls are used in crushing rock-salt, and toothed rolls are used for breaking comparatively soft minerals such as rocksalt or gypsum, and even hard stone for road-metal. Some of the rolls for rock-salt are made of toothed rings threaded upon a shaft, and the two rolls are arranged so that the teeth of one lie between those of the other.

d. Mills - The term "mill" has a very vague signification among miners; all sorts of machines employed in crushing and grinding are commonly known as mills. I propose to restrict the term to grinders, in which the working parts consist of flat or approximately flat surfaces, ove of which revolves. They are called into requisition for reducing a mineral to a fine state of division.

The typical mill of this class is the well-known flour mill, made of two horizontal cylindrical stones, one fixed, the other revolving; sometimes it is the lower stone that is fixed, sometimes the upper. Mills of this kind serve to grind barytes and fertilisers. The stones are generally the French burr, and have to be dressed from time to time as they wear. The mineral is fed in at the centre, and is discharged at the circumference. Instead of one top stone, there may be several separate pieces; this combination forms the "arrastra" employed for grinding and amalgamation.

When the mill is made of iron, with iron or steel replaceable wearing parts, it is generally called a "pan "; like the arrastra, it serves for fine grin ling and amalgamating.

Millstones need not necessarily be arranged horizontally; the first grinding of phosphate of lime is sometimes done by stones set vertically, the moving stone being fixed upon a horizontal axis.

e. Edge-runners. - The edge-runner is a cylinder turning upon a horizontal axis which is made to revolve around a vertical axis. In its simplest form, it is a large stone wheel, the horizontal axis 
of which is drawn round an upright post by a mule. The stone crushes by its weight, and as it has to slide a little in order to keep its circular path upon the bed, there is also a rubbing action. This primitive form of edge-runner, known as the Chilian mill, is employed in crushing and amalgamating gold and silver ores. It is better to have two of the upright wheels at opposite ends of the horizontal axis, as then the machine will work more smoothly (Fig. 628). Each wheel is made of a strong tire of chilled cast-iron wedged to a centre-piece of ordinary cast-iron, and the bed is composed of sectors of chilled cast-iron, which can

FIG. 628.

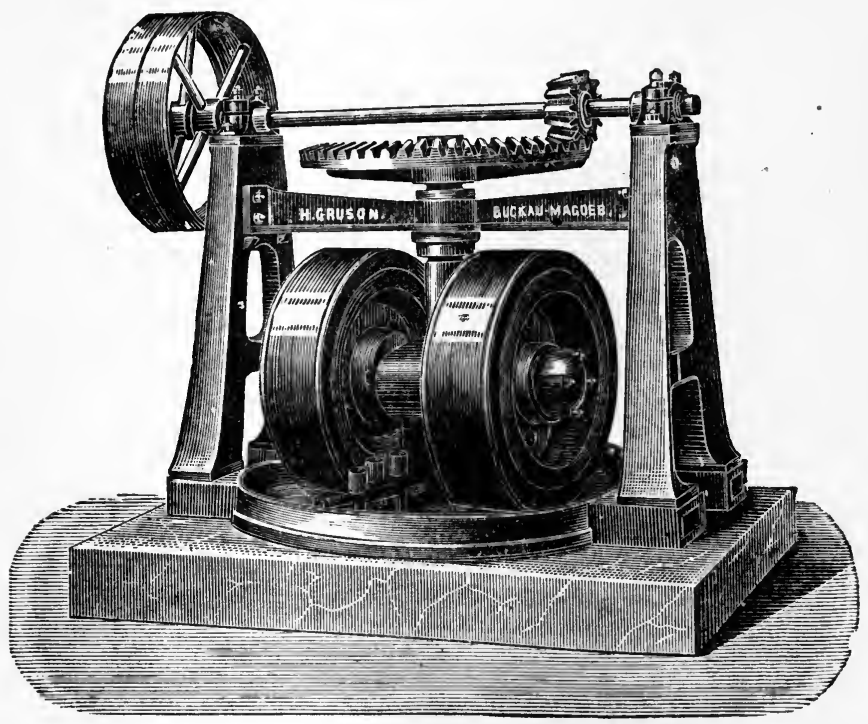

be changed when they are worn. The driving gear may be above or below.

$f$. Ball-grinders.-In machines of this class the mineral is pulverised by its contact with a number of cast-iron balls, which are constantly rolling against each other when the case containing them revolves.

Jordan's Centrifugal Grinder and Amalgamator is a circular pan set upon an inclined axis with a few large iron balls like cannon-balls which lie in the lowest part ; the machine is supplied with crushed ore, which is soon ground fine and escapes through a sieve placed around the outside of the pan.

The ingenious "Grusonwerk" ball-grinder (Figs. 629 and 630), now made by Krupp, has a continuous feed and discharge. It consists of a horizontal iron cylinder provided with several curved plates 
$a a$, which carry a number of steel balls. The stuff which is fed in by the hopper $h$ falls among the balls and is ground by their rubbing. During each revolution of the drum, they drop five times as they come to the edges of the plates. The ground mineral passes
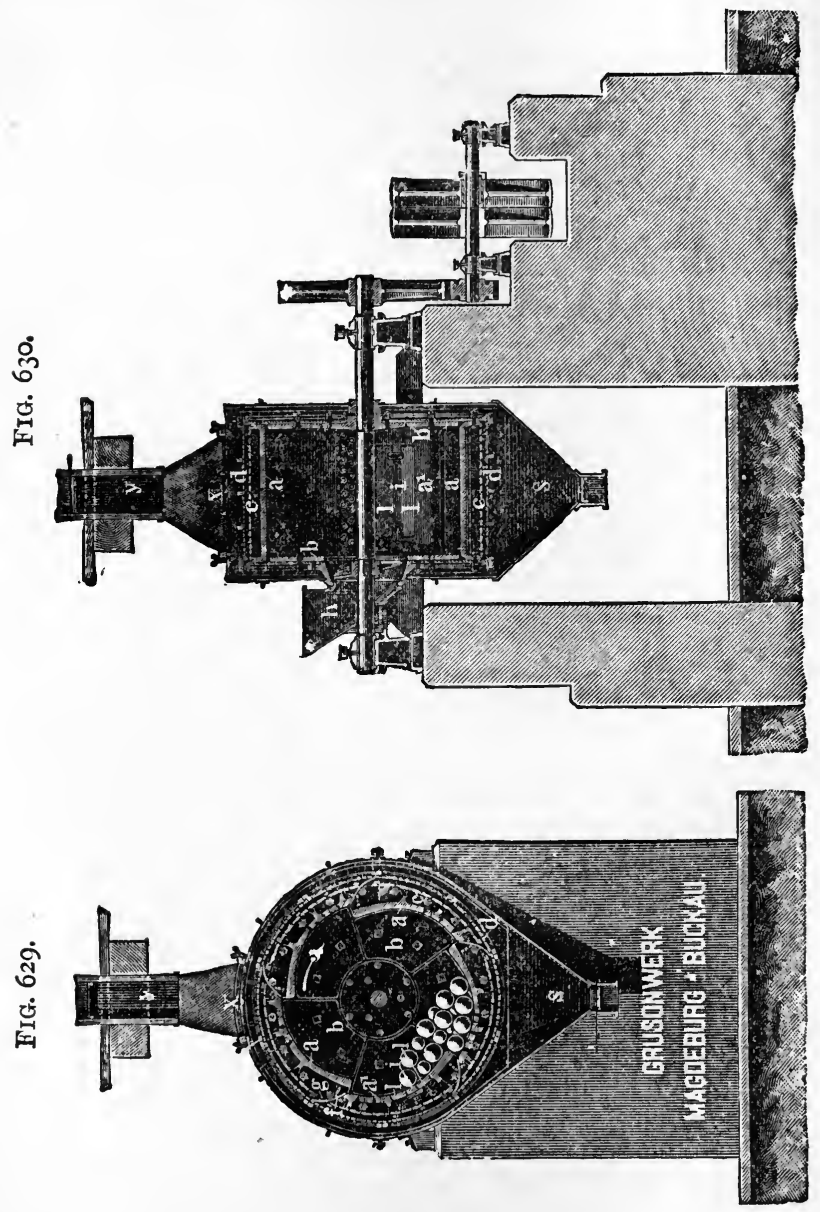

through holes in the curved plates $a a$, and in the cylindrical sieve $c$ made of punched steel plate; it now meets with the fine wire gauze sieve $d$, which lets through all that is sufficiently pulverised into the hopper $s$, whence it can be drawn off at pleasure. The object of the punched steel sieve $c$ is to prevent the unnecessary wear of the fine wire gauze, which would naturally suffer if it 
were exposed to the rubbing of coarse particles. The stuff which is too coarse to pass through the fine outer sieve $d$ is collected by plates $f$ and led back into the inside of the drum, where it is again exposed to the grinding action of the balls; $b b$ are lining plates to prevent the wear of the ends of the cylinder; $l l$ and $i$ denote bars closing a manhole which can be opened after tho removal of the sheet-iron casing surrounding the whole machine.

$g$. Disintegrators.-Though any reduction of a mineral ints fragments or powder may be spoken of as "disintegration," the word disintegrator has been appropriated by the grinders which do their work with revolving bars or beaters. The best-known machine of this class is Carr's disintegrator (Fig. 63r). It

Fig. 631.

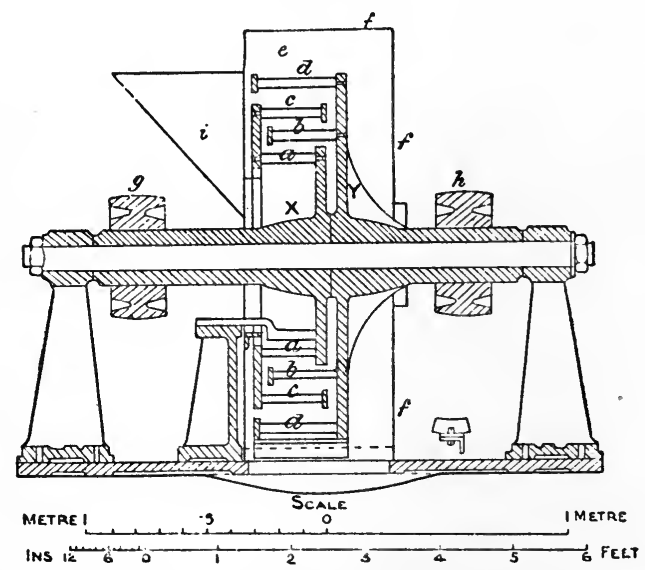

may be described as consisting of two cylindrical cages, revolving one inside the other in opposite directions. Each cage is made up of two concentric sets of bars, attached to a disc on one side and to a ring on the other. The stuff which is fed into the centre is thrown by the bars $a a$ of the cage $\mathrm{X}$, against the bars $b b$ of the cage $\mathrm{Y}$; thence it flies against the outer circle of bars $c$ c of $\mathrm{X}$, and finally against the outer circle of bars $d$ of the cage $\mathrm{Y}$. It then enters the circumferential space $e$, whence it can be allowed to escape by a suitable opening in the outer casing $f$.

It is claimed for this machine that some of the pulverising is done by the impact of the particles one against the other, and that consequently the wear of the steel bars is less than might be expected. However, the disintegrator is found most fitted for comparatively soft materials, such as coal, gypsum, phosphates, and rock-salt.

Instead of being arranged in the form of concentric circles in 
this cage-like manner, the beaters are sometimes radial, and, when revolving at a very high speed, quickly reduce soft minerals to powder.

$h$. Conical Grinders.-In these grinders the crushing action is usually produced by the revolution of a toothed cone, inside a toothed cup; they thus resemble in principle the oldfashioned coffee-mill. The Gates crusher (Fig. 632) acts differently. It consists of an outer conical shell Q (Fig. 632), lined with removable plates $\mathrm{E}$, around which travels the conical breaking

FIG. 632.

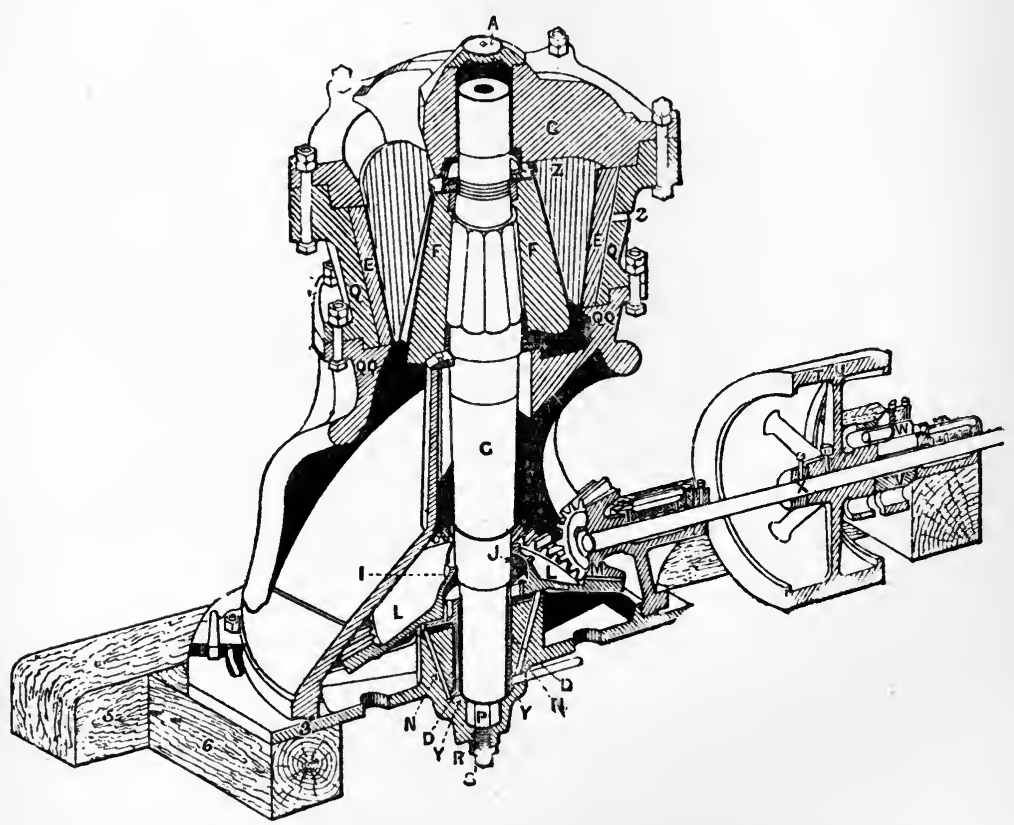

head $\mathrm{F}$ carried by the upright spindle $\mathrm{G}$; both $\mathrm{E}$ and $\mathrm{F}$ are made of chilled cast-iron. The lower end of the spindle $\mathrm{G}$ fits loosely in the excentric box $\mathrm{D}$, and is a little out of the centre; it is supported by the step P, which can be raised or lowered by the screw $\mathrm{S}$, in order to regulate the distance between the breaking head and the shell, and consequently the fineness of the crushed product. The upper end of the spindle $G$ lies loosely in a socket in the top framing $\mathrm{C}$. The belt-pulley $\mathrm{T} U$ is loose upon the shaft $\mathrm{X}$, and it drives it by means of the clutch $\mathrm{V}$, firmly keyed to $X$, and the pin W. In case of any undue strain, the pin $W$ breaks and prevents damage, for the machine at once stops until the obstruction is removed and a new pin has been inserted. 
The bevel pinion upon $\mathrm{X}$ drives the bevcl wheel $\mathrm{L}$ with its excentric box; when $L$ revolves, the lower end of $G$ is carried. round excentrically, whilst the top moves in its socket. The breaking head is thus made to approach and recede from each part of the shell in succession, producing practically the same effect as the reciprocating jaw of the Blake machine. The loose collar I serves to keep out dust, and it has a hole J, through which the machine is oiled; $\mathrm{N} \mathrm{N}$ are holes for conveying oil to the space Y. The material to be crushed is fed in through three large openings in the top frame; it falls between $\mathbf{E}$ and $\mathbf{F}$, is

FIG. 633 .

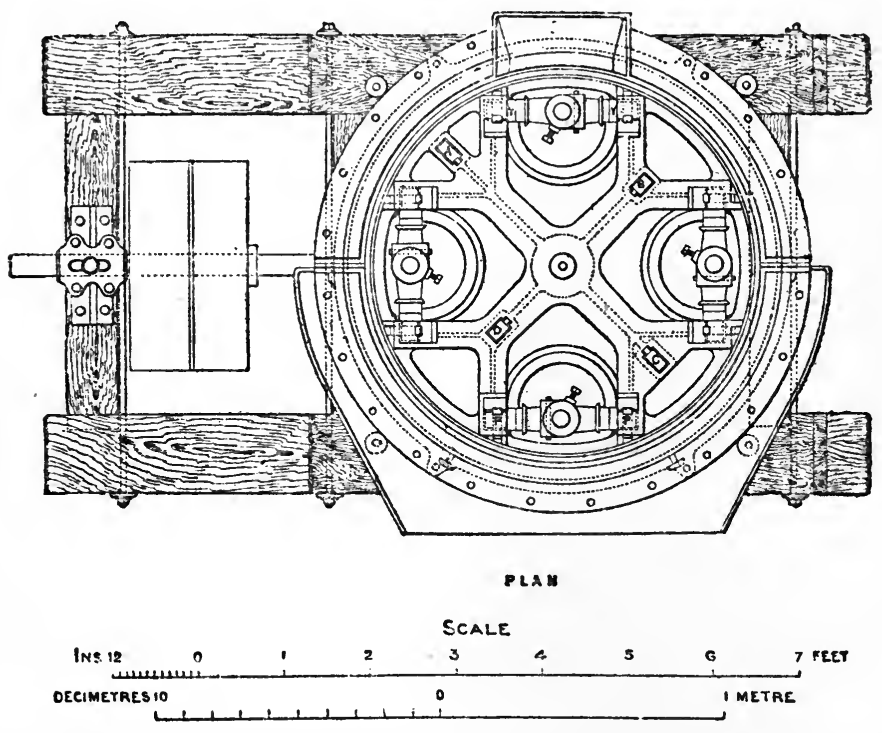

crushed by the movement of the breaking head and drops through at $\mathrm{Q} Q$ on to an inclined apron, whence it slides into any convenient bin or receptacle.

$i$. Centrifugal Grinders.-There are several grinding machines in which a roller is whirled round upon the inside of a cylinder against which it presses by centrifugal force. The machine of this class most largely employed is the Huntington mill (Figs. 633 and 634). A vertical shaft $G$, driven by bevel gearing from below, carries a horizontal frame, which supports four grinding rollers by the yokes $\mathrm{Y} Y$ lying in the pockets $\mathrm{P}$. The yoke allows a radial swing of the crushing roller against the steel ring (Fig. 634) lining the pan in which the grinding takes place. The construction of Paxman's improved roller is shown by 
Figures 635 to $637 . \quad R$ is a steel ring which does the actual grinding and is renewable when worn; it is fixed by wooden

FIG. 634.

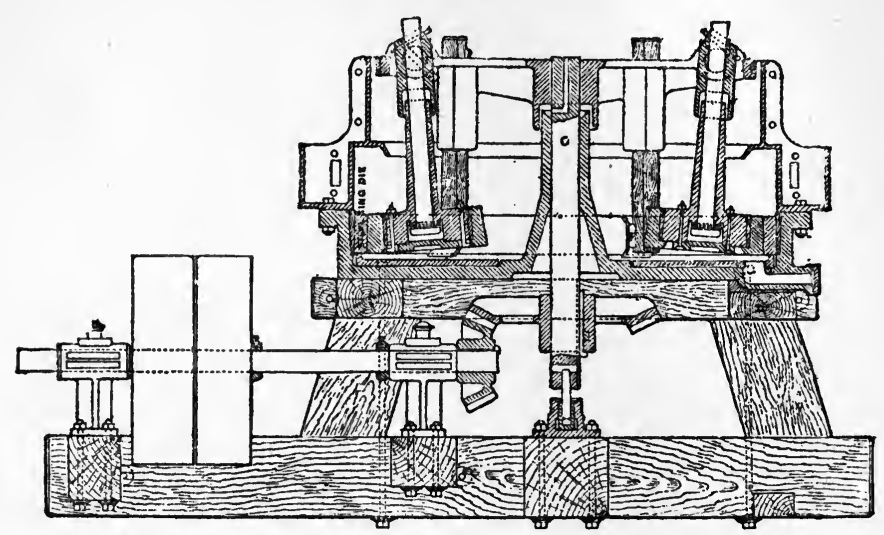

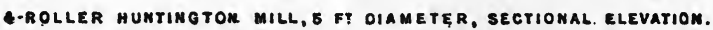

Vins.12

wedges $\mathrm{W}$ to the crre $\mathrm{G}$, and a sleeve bolted on to the core receives the spindle S. From this explanation it will be seen that

FIG. 635 .

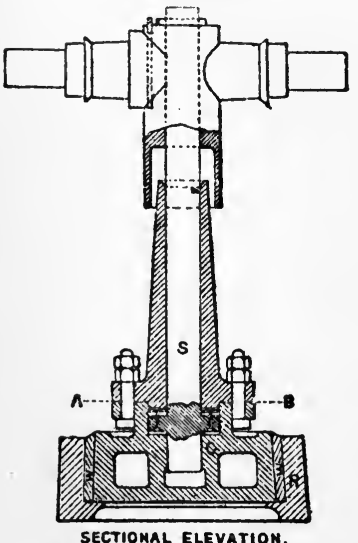

Fig. 636 .
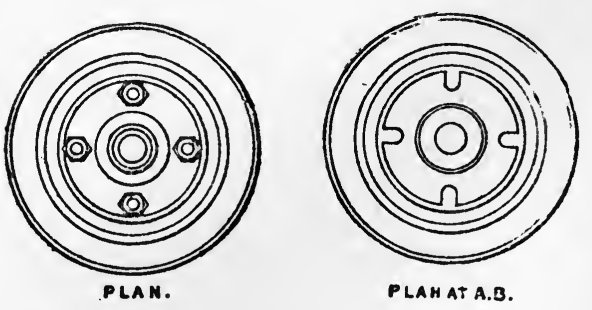

SCALE
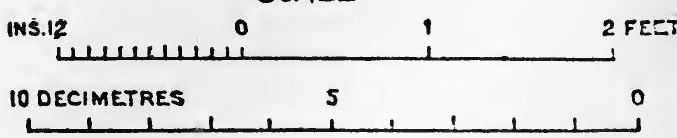

the roller can revolve round the spindle $\mathrm{S}$, but that the latter does not turn upon its own axis when it is carried round by the revolving frame supporting the yokes. A, B, C, D (Fig. 633) are 
wooden scrapers which force the ore from the centre to the circumference and so bring it under the action of the rollers. It is easy to understand, therefore, that when the shaft $G$ revolves the rollers are thrown out by centrifugal force against the annular lining, and crush and amalganate the ore. The stutf which is pulverised sufficiently fine escapes through a wire-gauze sieve placed on the side of the pan, just above the lining ring. As this sieve has not to resist the violent blows to which the screens of stamps are liable, it may be made of much finer material.

$j$. Pneumatic or Air-current Pulverisers. - In one of these pulverisers, it is proposed to crush the mineral by driving the particles violently against each other by means of two powerful opposite jets of air or superheated steam. To use a familiar illustration, it may be said that stone bullets are fired from air-guns against each other with such force that they break into powder upon meeting.*

The Cyclone Pulveriser, which excited a good deal of interest at the Paris Exhibition of $\mathrm{r} 889$, is based upon the same idca. It consists of two beaters, something like screw-propellers, driven at a speed of 1000 to 3000 revolutions per minute in opposite directions in a small cast-iron chamber or case, in the form of two truncated cones joined together at their larger bases. The material to be crushed is delivered regularly into this case by mechanical feeders, and the whirlwind created by the beaters hurls the particles against each other with such violence that they are almost instantly reduced to the state of impalpable powder. The fine dust produced in this way is constantly being sucked off by a fan, and allowed to settle in chambers whence it is conveyed mechanically into hoppers. It can then be drawn off into sacks as required. As the aspirating force of the fans can be regulated at pleasure, the mineral can be brought to any desired degree of fineness without any screening. Before treatment in this machine, the material must be crushed small enough to be set in motion by the hurricare-like blast of the beaters; in the case of a mineral like quartz the fragments must not be larger than walnuts.

$k$. Miscellaneous Pulverisers.-These are so numerous that it is out of the question even to think of giving their names. 'The Sturtevant mill bears some resemblance in its mode of action to the Cyclone pulverisers, inasmuch as the particles are flung against each other with great force and break up in mid-air, so to say. The stones are projected, however, by centrifugal force and not by air-currents. The Sturtevant mill is made of two horizontal hollow cups which revolve at great speed in

* Industrial Review, vol. i., 1886, p. 56. 
opposite directions. The mineral is fed into the interval between the two cups, and as fast as it makes its way into one of them, it is hurled out again by centrifugal force and strikes other fragments which are thrown across by the opposite cup. The powdered mineral is drawn off through a screen by a fan. Though the hurling cups are cylindrical, the crushed rock packs itself into the ends and forms a conical stone lining which prevents wear upon the iron surfaces. The Sturtevant mill is said to be largely used in the United States for grinding phosphate of lime.

The crushing machines in these descriptions have been arranged according to their modes of construction; it will be well to point out in conclusion the uses to which they are applied, viz.:

I. Preliminary breaking : jaw-breakers, and Gates rock breaker.

2. Coarse crushing : rolls.

3. Fine crushing : stamps, rolls, mills of various descriptions, and disintegrators.

l. Sawing Machines.-These are necessary in the case of stone and slate. The simplest machine is merely a plain blade held in a frame, moved backwards and forwards by a crank or excentric, whilst sand or chilled cast-iron shot and water are supplied to aid the saw in its cutting work. The wire saw, already described in a previous chapter, is employed for the same purpose.

Fig. 638.

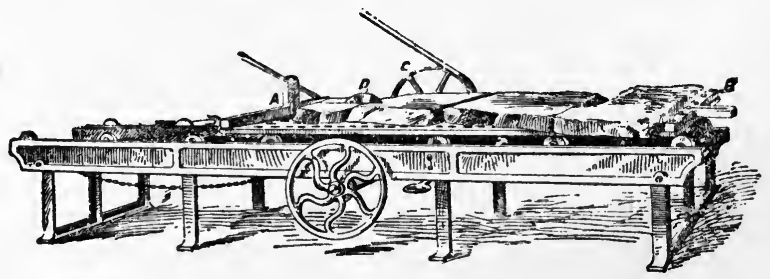

In the case of slate, the work is usually done with circular saws. The blocks, which have been split into slabs about 4 inches thick, are fastened by wedges upon a sarving table, such as is represented in Fig. 638. It is a cast-iron bed, A B, moving upon rollers, with holes into which wedges can be placed for fixing the slabs of slate. The pulluy $C$ drives the circular saw $D$, and at the same time gives motion to a chain which draws the table along from one end of its frame to the other. When the table has gone as far as possible, the workman turns a hand-wheel which reverses the motion, it is drawn back, and another set of slabs are arranged so that they may be cut when it again moves forward. The saw sometimes lies in a semicircular trough full of water, which serves to keep it cool.

$m$. Planing Machines.-Planing machines, somewhat similar 
to those used in engineering shops, are employed for making the smooth slate-slabs required for cisterns or billiard-tables. The tool is held in one direction only and is not reversed after each stroke.

n. Slate-making Machines.-Greaves' circular slate-dressing machine (Fig. 639) does precisely the same work as the quarryman's knife. It is a frame carrying two knives, $\mathrm{C}$, which are made to revolve by the pulley $A$ upon the same shaft as the little flywheel B. D is a fixed knife and $\mathbf{E}$ a cast-iron arm with a number of notches on the inside, which are gauges for enabling the quarryman to cut the slates to exact sizes. The belt pulley $\mathbf{A}$ is thrown in and out of gear by a clutch.

Another machine for doing the same kind of work acts like a

Fig. 639.

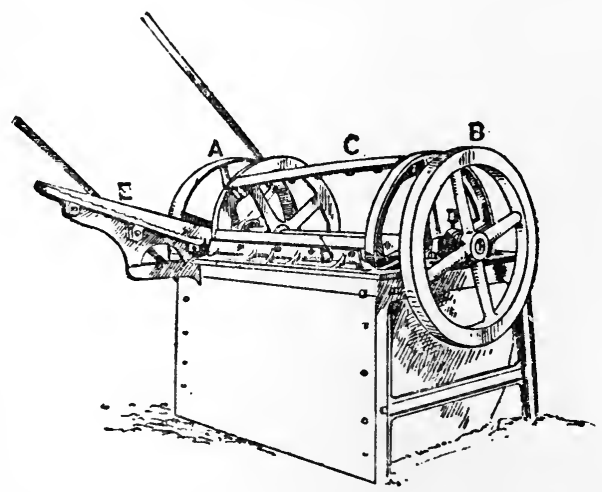

guillotine, and has a knife which slides up and down vertically between guides. In both machines the action of the hand-knife is imitated-that is to say, the cut is made gradually along the desired line.

(4) AGGLOMERATION OR CONSOLIDATION.-Processes of this kind are more particularly used in the case of coal or brown coal, small particles of which can be pressed, either with or without the addition of some cementing material, into blocks of fuel of convenient shapes and sizes. At the same time agglomeration is not confined to coal: some of the poor clayey phosphate of lime of the department of the Somme is made into bricks, so that it may be readily burnt in kilns and deprived of its moisture before being ground or sent away; the so-called "purple ore," the residue after the treatment of cupreous iron pyrites by the wet process, and other kinds of fine iron ore, are also sometimes made into bricks for the purpose of obtaining a product suitable for smelting in the blast-furnace. 
In order to get rid of water, washed graphite is pressed into cakes, which are then ready for the drying stove.

(5) SCREENING OR SIFTING.-This is an important branch of dressing. Sometimes it is a preliminary process which is necessary or advisable previous to concentration by specific gravity, or to picking by hand. Sometimes it is a final process previous to sale, and for several reasons : the purchaser usually requires cements, pigments, and fertilisers in a state of tine subdivision and free from any coarse particles, or, contrariwise, he may object to ores in the form of "smalls" or dust, which would choke his smelting furnaces. Lastly, in a case of coal, which is beyond the province of this treatise, the consumer prefers lumps, because they burn more readily than dust and afford a rough gnarantee of purity; whilst with anthracite the sifting process is carried out on a very elaborate scale, in order to obtain suitable kinds of fuel.

Minerals are classified according to size by means of sieves worked by hand or by machinery.

Hand-sieves are often employed underground for taking out "smalls" which are not acceptable to the purchaser. Thus at the Merionethshire manganese mines, the workmen shovel the fine stuff on to circular hand-sieves with holes $\frac{1}{2}$ inch square, and use all that goes through as material for filling up. In speaking of the iron ore worked opencast in Northamptonshire a similar separation of the fine was mentioned (Chap. VI., p. 288).

Sifting by hand is shown in Fig. $6 \mathrm{r}_{2}$ following bucking, so as to ensure a proper degree of hand-crushing. It is more economical to employ a rectangular sieve fixed in a steeply sloping position, and throw the mineral against it with the shovel. Inclined gratings (grizzlies, U.S.) formed of bars of flat iron or steel, on to which the waggons of mineral are tipped as they come from the mine, are another form of sifting apparatus.

Machine-sieves.-Most of the sizing at mines is performed by sieves set in motion by machinery; there are two principal kinds of machine-sieves: flat oscillating sieves and revolving cylindrical, conical, pyramidal, or spiral sieves.

The most common in ore mines are revolving sieves, either cylindrical or in the form of truncated cones. A sieve of this kind is often known as a "trommel." The word is expressive enough to the German; but it fails to tell the Englishman that the machine is drum-shaped, and it can be tolerated in our language simply on the score that it has so long been in use that it is practically naturalised.

The sifting is done by wire web or by perforated sheets of metal, either iron, steel, copper, brass, or bronze. Figs. 640, 64I and 642 represent sieves with round holes 1,2 , and 5 millimetres respectively. The holes are sometimes square or oblong.

The trommel consists of the perforated plate or the wire cloth bent into the required conical or cylindrical form, and supported by 
rings attached by arms to a central axis. The conical trommel has the advantage that its axle can be placed horizontal, for the slight inclination of the sieve causes the mineral to make its way from the feed or smaller end to the discharge or larger end, provided of course that the machine is in motion. If the trommel is cylindrical, its axis must be inclined in order to secure the same result.

FIG. 640.

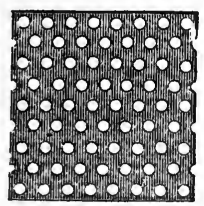

FIG. 64 I.

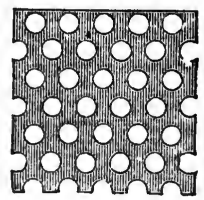

FIG. 642.

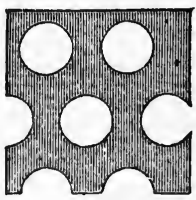

When it is necessary to separate a crushed mineral into a number of different sizes, the trommels are commonly arranged so as to discharge one into the other. This plan has the disadvantage of requiring much gearing or many belts, for the sieves have to be arranged step-fashion, each one a little below its predecessor. If, on the other hand, only one long trommel is used, with the holes increasing in size from the feed to the discharge end, there is the evil of letting the very coarse stuff

FIG. $642 a$.

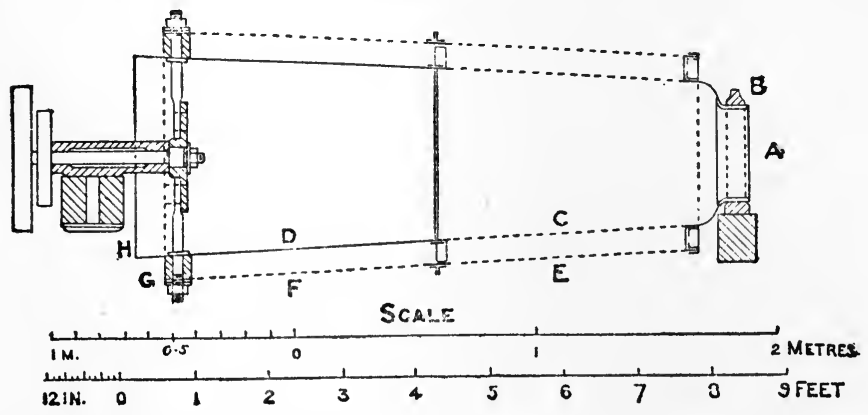

wear away the fine sieve, and cause more frequent repairs. A good form, made by Jacométy and Lenicque of Paris, is that shown in Fig. 642a. The feed-end A is free from cross-arms, having a large cast-iron ring $B$ as support, and there are in all three sieves C, E and F. Suppose, for instance, that the trommel is supplied with stuff which has left a crusher sieve with no particles bigger than 8 millimetres ( $\frac{1}{3}$ inch) across ; this passes on to the inner sieve $\mathrm{C}$ with holes of $6 \mathrm{~mm}$. ( $\frac{1}{4} \mathrm{inch}$ ). The next ring, $\mathrm{D}$, is of sheet iron. In this way the coarsest stuff never touches the fine sieve. 
The two sieves, $\mathbf{E}$ and $\mathbf{F}$, on the outside have holes of $2 \mathrm{~mm}$. and $4 \mathrm{~mm}$. Consequently this trommel makes four classes: smaller than $2 \mathrm{~mm}$., i.e., that which drops through the finest sieve, $\mathrm{E}$; size 2 to 4 $\mathrm{mm}$., dropping through sieve $\mathrm{F}$; size 4 to $6 \mathrm{~mm}$., discharged at $\mathrm{G}$; and, lastly, size 6 to $8 \mathrm{~mm}$., which passes out at H. An objection to trommels with concentric sieves is the difficulty of effecting repairs inside, if the plates become worn. This defect is remedied in the trommel figured by fixing on the perforated plates with screw bolts; they can then be taken off quickly and easily.

\section{PROCESSES DEPENDING UPON PHYSICAL PROPERTIES.}

(I) MOTION IN WATER.-Many of the more important dressing processes depend upon the rute at which particles of minerals fall in water. The velocity of fall depends upon the specific gravity and the volume. A piece of galena with a specific gravity of $7 \cdot 5$ sinks to the bottom more quickly than a piece of quartz of equal bulk, which has a specific gravity of only $2 \cdot 6$. Nevertheless, if the piece of quartz is large enough, it will fall to the bottom as fast as the smaller piece of galena Particles which have equal velocities of fall, though differing in size and specific gravity, are said to be like-falling or equivalent.

$P$. von Rittinger * gives the following table to show the rates of fall of spheres of three minerals differing considerably in specific gravity :

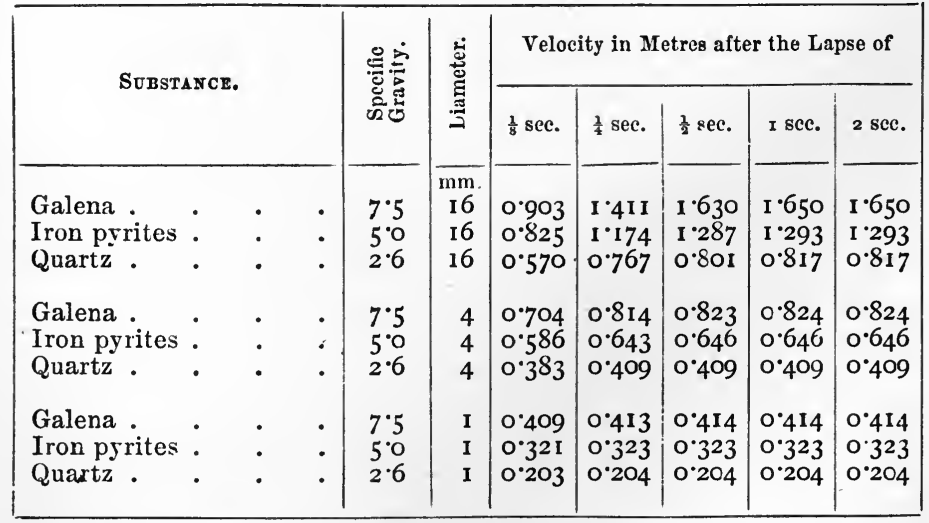

This table shows that the particles at the very outset have an accelerated velocity, and that the velocity speedily becomes uniform. It also shows that a small sphere of quartz 4

* Lehrbuch der Aufbereitungskunde, Berlin, 1867, p. 178. 
millimetres in diameter sinks down at almost precisely the same rate as a sphere of galena only I millimetre in diameter. These two particles are therefore like-falling or equivalent. It is evident that if the sphere of galena has a greater diameter than I millimetre it will fall faster than the grain of quartz which is 4 millimetres across. Consequently, if a mixture of minerals differing decidedly in density is separated by sifting into lots consisting of particles nearly alike in size, there is no difficulty in effecting a separation by their mere descent through still water.

This fact may be rendered very plain by a simple experiment. Prepare a mixture of likesized grains of coal, calc-spar, and galena by sifting the pounded minerals and retaining, for instance, the portion which has no particles more than $\frac{1}{8}$ inch in diameter or less than $\frac{1}{10}$. Put the mixture into a glass tube 4 or 5 feet long and $\frac{3}{4}$ inch or $I$ inch in diameter, corked at one end (Fig. 643). Fill completely with water and cork the other end ; reverse the tube briskly and hold it upright. The galena will fall to the bottom first, then the calc-spar, and lastly the coal, and the three minerals will form separate layers distinctly marked by their differences of colour. A shorter and narrower tube may be used, but the greater the depth of the water the more accurately can the descent of the particles be watched.

The experiment may be repeated by reversing the tube, for the galena will soon make up by its high specific gravity for the slightly longer path which it has to travel.

Though the final velocity attained by a particle of a mineral falling through water depends both upon its volume and its specific gravity, it is nevertheless true that in the early part of FIG. 643 .

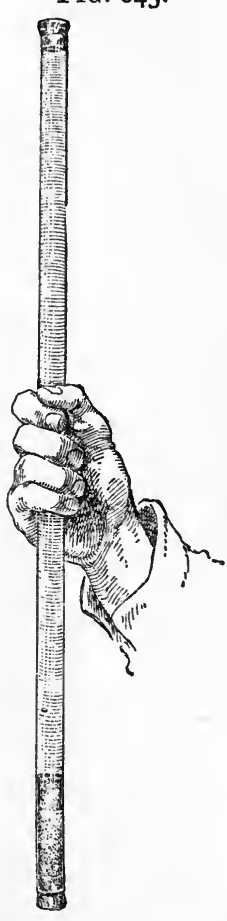
the fall the influence of the specific gravity preponderates, and the denser particles take the lead. This appears from the table. Take, for instance, a particle of quartz 16 millimetres in diameter and one of galena of 4 millimetres, which are practically likefalling after the lapse of a second; at the end of $\frac{1}{8}$ second, on the other hand, the galena is falling with a velocity 25 per cent. greater than that of the quartz. This fact is utilised in practice, for instead of simply letting the mixture of minerals fall through a certain depth of still water, it is made to undergo a rapid succession of very small falls. In this manner, particles varying in specific gravity can be separated into distinct layers, although they have not been so closely sized as would have 
been requisite if the separation had depended upon equivalence alone.

In a few exceptional cases the valuable mineral rises, as it is lighter than water; when a mixture of ozokerite and clay is thrown into water, the waste falls to the bottom whilst the useful substance floats and may be skimmed off at the top. Bitumen, too, comes to the surface when bituminous sandstone is thrown into boiling water and stirred.

Croll's process for extracting sulphur from rock containing the element in the native state, now abandoned on account of practical difficulties, is another instance of a separation by buoyancy. A solution of chloride of calcium was prepared strong enough to have a specific gravity decidedly above 2 ; when the rock was plunged into a hot solution of this kind, the sulphur gradually liquefied, oozed out and rose to the top, leaving the heavier matrix at the bottom.

A second method of utilising the fall in water consists in subjecting the particles to a current flowing upwards; by suitably regulating its force, light particles can be carried away and only the heavier allowed to sink.

Lastly, a third kind of motion is that of small particles carried down inclined planes by a thin sheet of water.

We have now to consider the various machines by which the full in water is made to effect a separation on a commercial scale.

\section{Simple Fall in Water.}

Keeve or Dolly-tub.-This appliance is merely a vat or tub in which the finely divided ore is stirred and then allowed to settle; it is specially used for the final treatment of tine lead ore and tin ore. The stirring may be done with a shovel whilst the ore is thrown into the water, but more commonly blades, attached to a vertical axle driven by gearing (Figures 644 and $645),{ }^{*}$ are made to keep the mixture of ore and water in a thorough state of agitation. When enough ore has been added, the stirring process (tossing) is stopped and the agitator removed; the contents of the vat are allowed to settle, while the water is kept in a state of vibration by taps upon the outside from the iron hammer $b$, lifted by the cams $c$, upon the driving shaft. This process of settling is locally called packing; as soon as it is complete, the water is baled out or drawn off by removing plugs in the side, and the deposit is scraped off layer after layer, increasing in richness as the bottom is approached.

Jigger or Jig.-The principal machine for concentrating particles varying in size from $I$ inch to $\frac{1}{50}$ inch is the jigger. 'The hand-jigger is merely a round sieve which is charged with the crushed ore and then moved up and down in a tub full of

" Teague, "On Dressing Tin Ore," Proc. Min. Inst. Cornzall, vol. i. 
water. Each time that the sieve is lowered sharply into the water, the particles are free to drop a short distance, and they gradually arrange themselves in layers, the heaviest at the bottom

FIG. 644.

FIG. 645 .

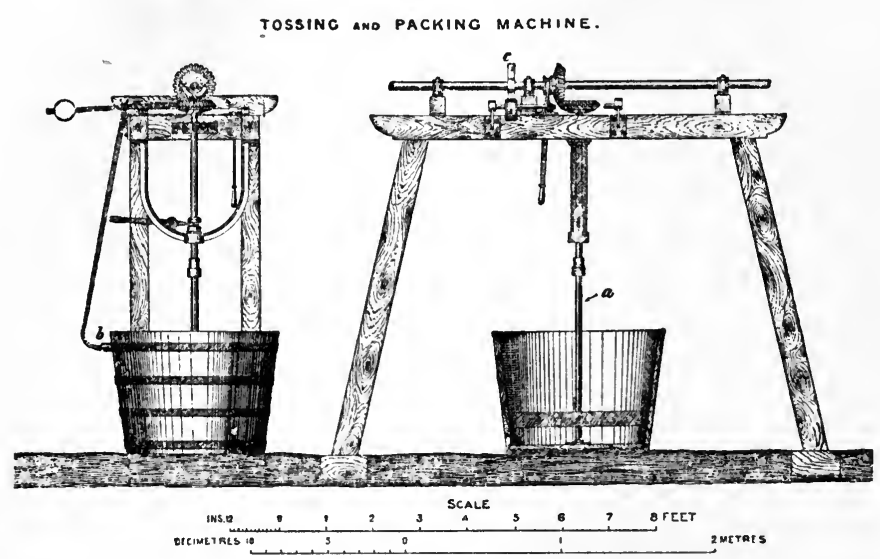

and the lightest at the ton. On lifting out the sieve the light waste can be skimmed off with a scraper, leaving a well-defined layer of the heavy rich mineral at the bottom, which is removed separately.

This process of separation can be watched by the aid of a very simple piece of apparatus which the student can construct for himself (Fig. 646). A model jigging-sieve can be made with a cylindrical lamp-glass by fixing on a piece of wire gauze by means of sealingwax, or by tying on a piece of any net-like fabric. A mixture of crushed coal, calcspar, and galena, prepared as in the previous case, is placed upon the sieve, and the glass cylinder is now moved down and up in a large tumbler partly filled with water. A distinct separation is soon effected.

Instead of moving the sieve in still water, it is more common nowadays to make the sieve stationary and to force Fig. 646.

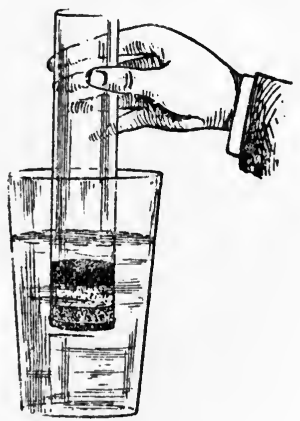
water up through it with a pulsating action. The particles are thus subjected to a series of repeated lifts and falls, and after the lapse of a little time the charge of crushed ore placed upon the sieve becomes separated into a layer of rich mineral at the bottom, and a layer of light waste at the top; in the middle there may be a 
layer consisting of rich particles with more or less waste material attached to them.

An illustrative model is again easily constructed (Fig. 647) by fixing a piece of wire gauze in a lamp-glass, between two rings cut from india-rubber hose of suitable diameter, whilst a flexible ball syringe supplies the means of pumping water up and down.

However, this is not the form in which the jigger FIG. 647. is made in actual practice. It usually consists of a

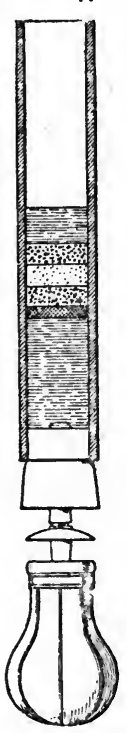
box (hutch) divided by a partial partition into two compartments ; in one is fixed a flat sieve $s$ (Figs. 648 and 649), which carries the ore, and in the other a piston, $p$, is made to work up and down by an excentric. The mode in which the separation is effected can be watched in a model made out of a $U$-tube, with a round stick or a test-tube as the piston (Fig. 650).

The great advantage of these jiggers is that they readily allow a continuous feed of the ore and discharge of the products without any stoppages. The ore is fed on by a hopper placed at one end of the machine, or is delivered already mixed with water. Several methods of discharge can be adopted: viz., $(a)$ at the end; $(b)$ in the centre; and $(c)$ through the meshes of the sieve.

(a) With the first kind of discharge, the enriched product lying on the sieve passes out through openings at the end of the jigger, and the amount escaping is regulated by an adjustable shutter which enables the size of the outlets to be increased or diminished at pleasure ; the middle product can be drawn off by openings placed at a slightly higher level, whilst the waste is washed over a sill at the end of the sieve at each pulsation. Very often a first sieve simply separates a concentrated product and discharges a poorer product on to a second sieve where a similar separation is effected.

(b) With the central discharge method, a pipe is brought up through the middle of the sieve, and the size of the opening for the escape of the concentrated ore is governed by a cylindrical cap, which can be raised or lowered by a screw.

(c) The discharge through the sieve is specially adapted for the finer products from the crusher, though it is also used for grains up to and even above $\frac{1}{4}$ in. in diameter. The mesh of the sieve is chosen so that the particles under treatment will just pass through, but above the sieve is a layer (bed) of clean ore, or of some substance of about the same density, in fragments too large to drop through. The pulsations of the water cause the usual separation into layers, and the heavy rich particles find their way down through the bed of mineral of like specific gravity and 
drop into the hutch, whence they can be drawn off through a hole as required. The poorer part passes over a sill at the end

FIG. 648.

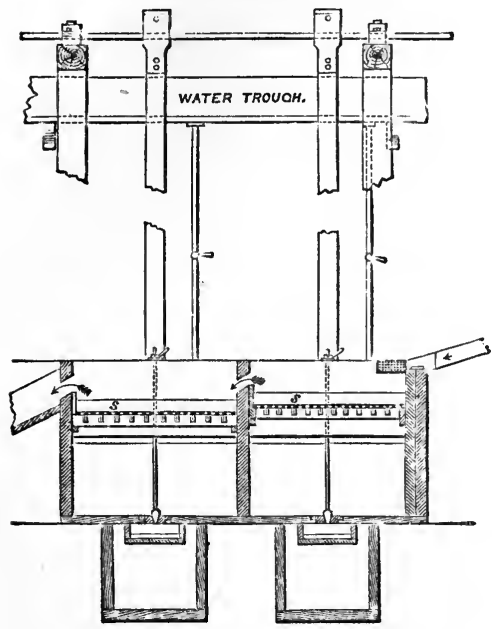

FIG. 649.

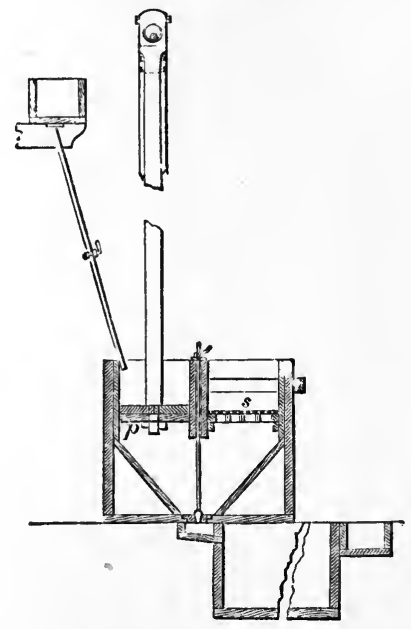

of the sieve, as a worthless product, or on to a second sieve, so that more valuable mineral may be taken out of it. Three or four sieves are often arranged in a row in one machine, and, by proper arrangement in dressing mixed lead and zinc ores, the first compartment may be made to yield clean galena, the second a mixture of galena and blende, tho third clean blende, the fourth inixed blende and rock, whilst the greater part of the waste material passes over the sill at the end. These jiggers, with the discharge through the sieve, are commonly known as Hartz jigs.

The number of strokes per minute, the length of stroke and the thickness of bed depend upon the fineness of the particles under treatment; the former gradually increases, while the two latter decrease as the particles diminish in size.

The piston of the jigger need not necessarily be horizontal. Messrs. Kitto and Paul place it vertically in the jiggers employed at Fig. 650.

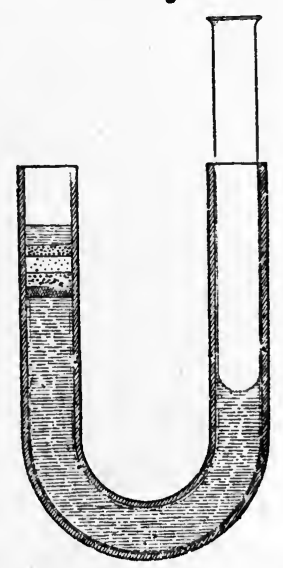
Frongoch mine, Cardiganshire, for treating blende and galena. $\mathrm{A}$ and $\mathrm{B}$ (Fig. 65I $^{\mathrm{I}}$ ) are the two hutches, and $\mathrm{C}$ is a partition in the middle. $\mathrm{D}$ is the piston working between two plates of 
iron $\mathrm{V} \mathrm{V}$. The piston occupies the whole length of the jig, shown by $\mathrm{T}$ (Fig. 652); it is worked by the rod E, guided at $F$, and passing through a stuffing-box, G. The reciprocating motion is given by a crank $M$ through the connecting-rod $L$ and

FIG. 65I.

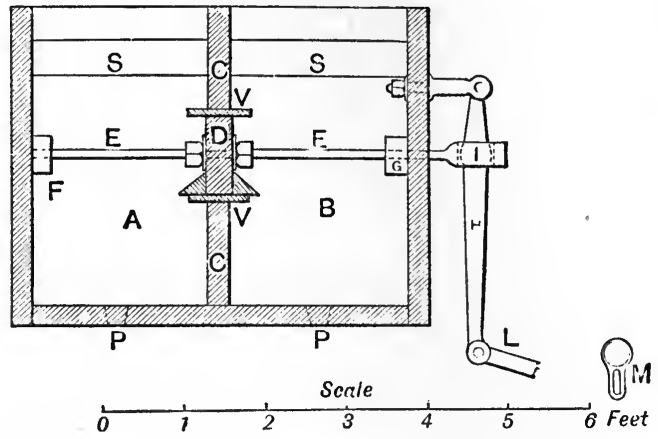

lever $\mathrm{H}$, which traverses the head of the piston-rod I. The crank has a long loop, which enables the stroke to be varied. The same end can be attained by an excentric with a slot, which allows the excentricity to be altered at pleasure. $\mathrm{N}$ shows where the ore is fed on, and $\mathrm{O}$ is the place of discharge of the waste or impoverished

FIG. 652.

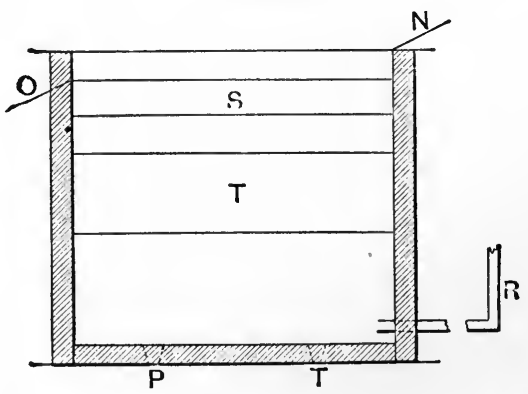

ore. $\mathrm{S}$ is the sieve, and $\mathrm{P} \mathrm{P}$ are holes with plugs manipulated by handles not shown in the figures, by which the concentrates which pass through the sieve are drawn off. $R$ is the pipe bringing in clean water.

\section{Upward-current Separators.}

We must now pass on to the second method of utilising the motion of minerals in water, viz., by subjecting them to an upward current; and here it may be remarked that the con- 
tinuous jig to a certain extent produces an action of this kind, for the light waste, brought to the top by the pulsating movement, is finally carried away by the outflow of the fresh water.

Upward-current separators are usually inverted pyramidal or conical boxes with water under pressure brought in near the bottom. A stream of ore and water is fed in at the top, some of the heavier particles sink and make their escape with a portion of the water, at or near the bottom, whilst the lighter grains are carried over the edge of the box. A separator of this

Figs. 653 and 654 .

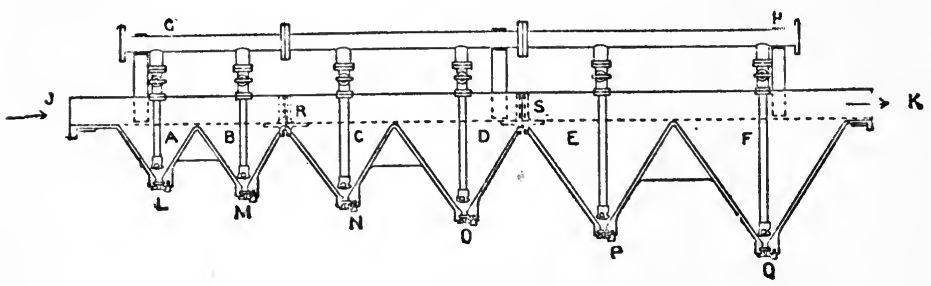

SCALE
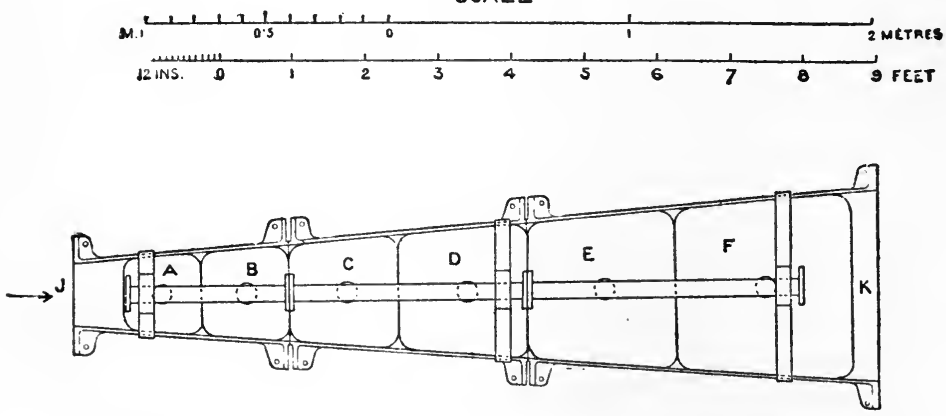

kind simply extracts a number of like-falling particles, and the product may require further treatment before a sufficient degree of concentration is obtained.

Jacométy and Lenicque's Separators.-Figures 653 and 654 represent Jacométy and Lenicque's pyramidal separator with six compartments, A, B, C, D, E, F, which make seven categories from pulp with all its particles under $1 \mathrm{~mm}$. in diameter. Each compartment is merely a box in the form of an inverted pyramid, and for convenience of transport, the machine is made in three separate castings, which can be easily bolted together, as shown at $R$ and $S$. Pipes bring down water from the main G H, and the amount supplied to each division can be regulated by a cock; the water strikes a little plate attached to the end of the pipe and rises up. 
The pulp is fed on at $\mathbf{J}$ and escapes at $K$. Particles which can overcome the upward current are discharged continuously through a nozzle at the apex of each pyramid. These nozzles are shown at $\mathrm{L}, \mathrm{M}, \mathrm{N}, \mathrm{O}, \mathrm{P}, \mathrm{Q}$; they are easily detachable, and can be takeu

FIG. 655 .

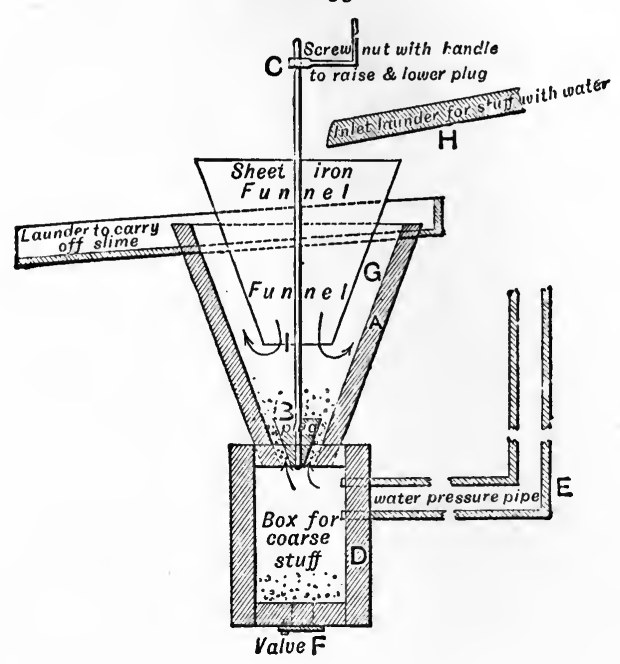

FiG. 656.

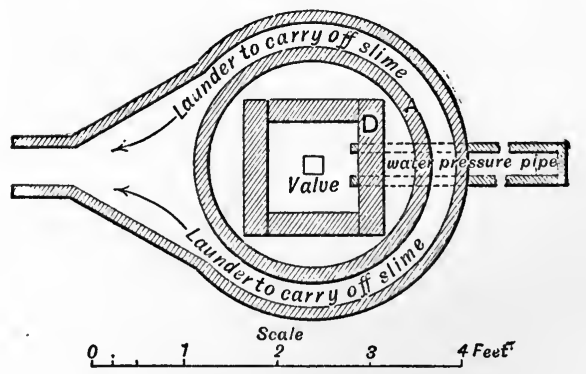

off during the progress of the work, if by any chance they become choked.

Though separators of this kind are usually employed for the treatment of fine sand and slime, they are occasionally applied to comparatively coarse stuff. The separator shown in Figures 655 and $65^{6}$ is used at Frongoch mine, Cardiganshire, for treating an ore consisting of blende and galena, mixed with slate, just as it leaves the rolls, after having been crushed fine enough to pass 
through a sieve with 12 holes per square inch ( 3 holes by 4 holes). The coarse goes to the jigs, the fine to the buddles. It is an inverted wooden cone A, which can be more or less completely closed at the bottom by a plug B, controlled by a handle C. The cone stands upon a wooden box $\mathrm{D}$, which receives water under pressure from a pipe $\mathbf{E}$, and is provided with a discharge valve $\mathrm{F}$, a mere flat plate of iron, working on a pin, which can be pushed sideways so as to close the orifice partially or entirely. Inside the wooden cone there is a sheetiron funnel $G$, which receives the stream of ore and water from a launder $\mathrm{H}$, and causes it to descend to the level I. There it meets with the upward current of clean water, and a separation is effected. The coarse and heavy particles which can overcome the stream pass into the box below, and flow out continuously at $\mathrm{F}$, while the fine and light particles are mastered by the current and carried over the top edge of the wooden cone, which is surrounded by a circular launder. By regulating the upward current of clean water and the size of the discharge orifice, the separator can be adjusted to the requirements of any particular case.

Lockhart's Automatic Gem Separator.-In this machine the particles of minerals fall into a current of water ascending in an annular space, purposely made narrow in order to prevent eddies, which would interfere with the desired results. The velocity of the current can be regulated by stop-cocks, and arranged so that only the denser of any like-sized particles shall be able to overcome it and sink. Its primary object is to treat clean-washed concentrates from gem-bearing gravel after a careful preliminary sizing by screens.

Siphon Separator.-A most successful application of an upward current of water is in the machine known as the siphon separator, though its action is not based upon the principle of the appliance from which it takes its name.

It consists of a rectangular box (Figs. 657, 658, and 659),* made of sheet iron or wood with a partition, dividing it into two chambers $B$ and $E$. The front one $B$ resembles a pyramidal separator, receiving an upward current of fresh water from the adjacent compartment $E$ and an orey stream from the launder $G$, the continuation of which carries away the light waste. The compartment $E$ has a partition $z$, dividing it into two parts: $A$, which receives a supply of fresh water by means of the pipe $a$, and $C$, which has the regulating float $s$. To prevent shocks and eddies, the water does not fall directly into $E$, but first passes through holes in the partition $u$. The precise position of the float $\boldsymbol{s}$ can be altered at pleasure by the rod $f$, which connects it to the lever $h$, movable about the fulcrum $i$ attached to the

* Heberwäsche des Mechernicher Bergwerks-Actien-Vereins, B. u.h. Z., I386, p. 476 . 
upright bar $t$. The travel of the lever is controlled by means of the rod $g$. A light rod $e$ carrying the outlet valve is attached to the lever at $d$; this valve is set in the middle of a pyramidal sieve bottom $b$, and governs the discharge into the pipe $q$, which
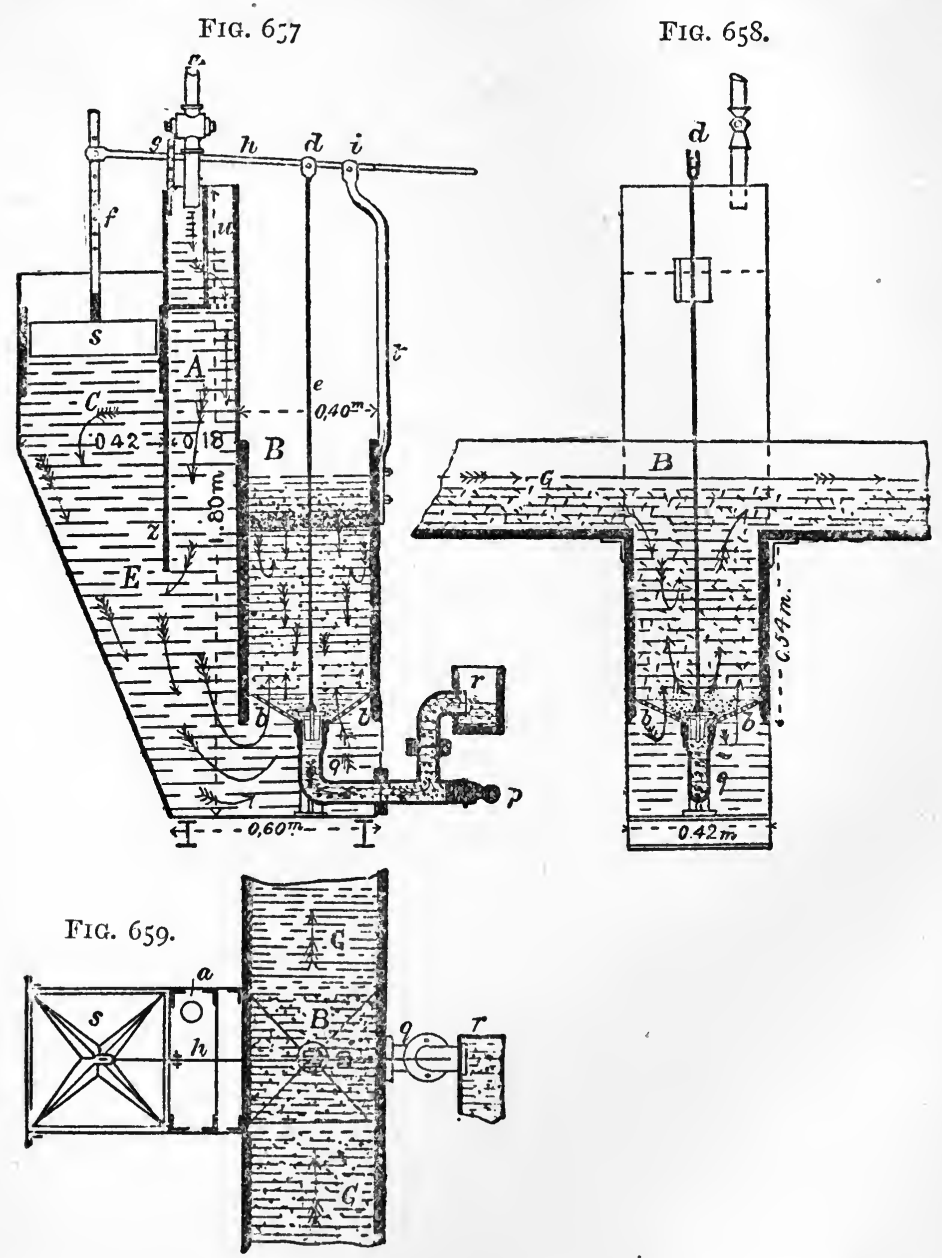

leads to the outlet orifice $r$. The object of these arrangements is to obtain a self-regulating discharge, the action of which is very simple. As the ore-bearing stream passes along over the box $B$, the heaviest particles overcome the upward pressure of the ascending current and drop; if the valve is shut, they. 
accumulate upon the sieve, and prevent the passage of some of the water through it. The obstruction causes the water in the chamber $C$ to rise, the float ascends at the same time, and in so doing lifts up the valve and allows the discharge of the grains of ore into the pipe $q$. The float then sinks, the valve goes down, another little deposit of ore causes an obstruction and the process is repeated.

These separators are some of the principal machines employed at Mechernich for the treatment of the friable lead-bearing sandstone ; in fact, there are no less than I24 of them in use. They are remarkable for their simplicity and for the large amount of stuff that they will treat. The quantity of broken sandstone which can be successfully passed through one machine per hour is from 270 to 300 cubic feet ( 8 to 9 cubic metres). Sometimes two or three of these machines are placed one after the other, the second receiving the overflow of the first, and the third the overflow of the second.

The quantity of water required is somewhat large-viz., 9900 gallons (45 cubic metres) per hour; but at Mechernich it is used over and over again, after the fine matter in suspension has been allowed to settle.

\section{Separation by Water flowing down Planes.}

We lastly have to deal with the third manner of utilising the motion of mineral particles in water, that is to say, allowing them to be carried down inclined surfaces by a stream of water.

Two classes of appliances are used: those in which the deposit is cleaned off as soon as a thin layer has settled down, and those in which the deposit is allowed to go on forming until it has attained a thickness of at least several inches or a foot.

(I) The first class includes various kinds of plane and conical tables, certain percussion tables, and the travelling belts.

Plane Tables.-Plane tables, of ten called "frames," and sometimes, but incorrectly, called "buddles," are slightly inclined rectangular surfaces of wood down which the pulp flows in a regular stream. An even flow over the whole width of the table is secured by first passing the stream over a head-board, which divides it into a number of little rills. The strength of the current depends upon the quantity of water, and upon the inclination given to the table. These are arranged so that some of the mineral under treatment will settle down and resist the action of the water, which is always tending to carry it on further. After a deposit of this kind is formed, clean water is often allowed to run down over the table to carry off any light particles intermixed with the heavy ore, and its action is aided by brushing lightly with a broom. The deposit is then washed off and collected in a tank for further treatment. 
Where the mineral to be treated is poor, the tables have to be worked with as small an expenditure of labour as possible; and

FIG. 660.

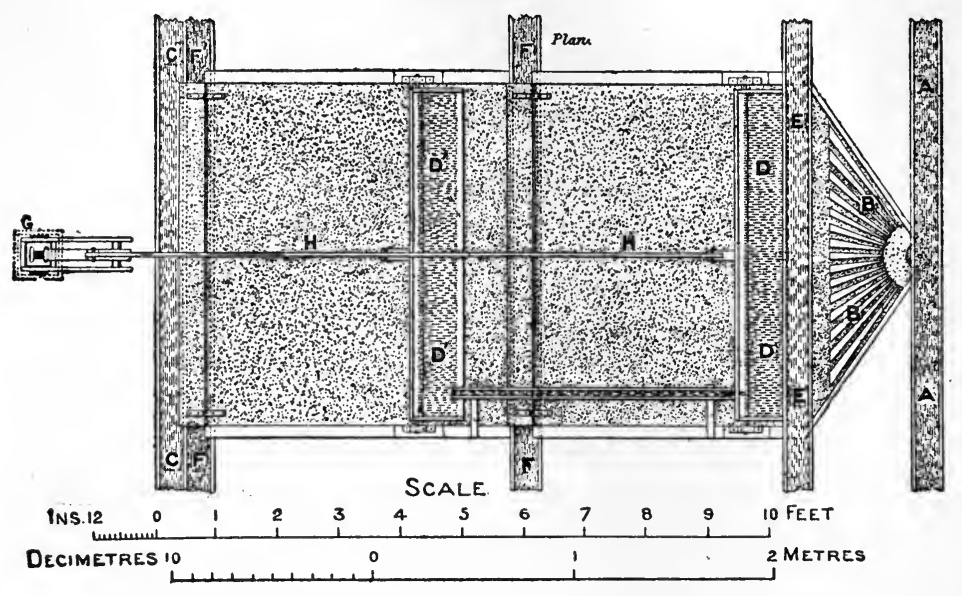

FIG. 66r.

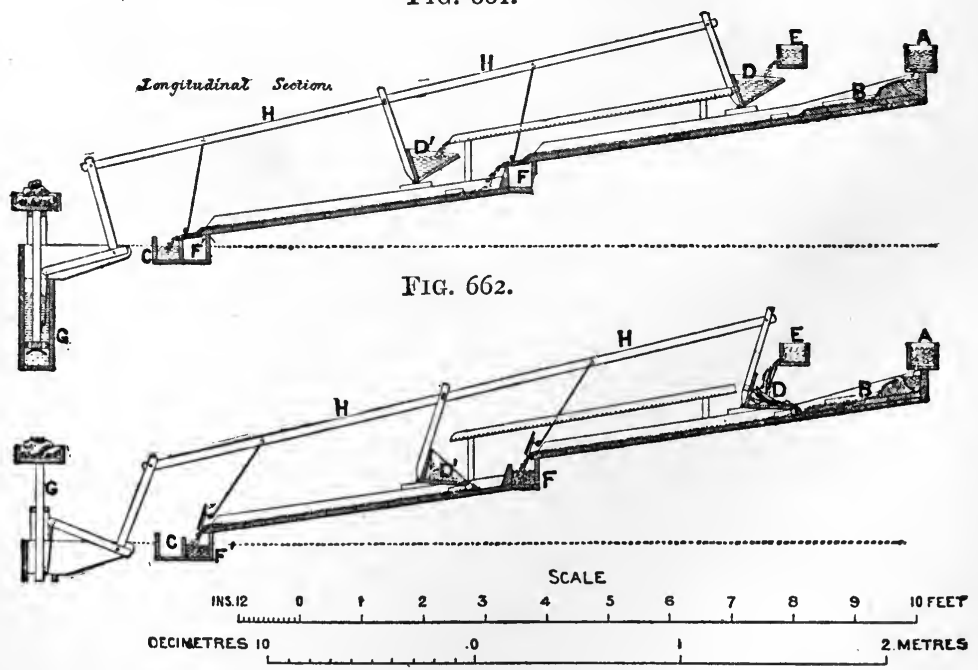

the device adopted in Cornwall is explained by Figs. 660 to 662. * A is a launder bringing the pulp, which flows down over the head-

Ferguson, "On the Mechanical Appliances uscd for Dressing Tin and Copper Ores in Cornwall," Proc. Inst. M. E., 1873, p. 130. 
board $\mathrm{B}$ on to the inclined surface of the table, leaving upon it, in virtue of their high specific gravity, some of the heavy particles of tin ore, and carrying the lighter refuse into the launder C. While this action is proceeding, the clean water launder $\mathbf{E}$ is filling the two $\mathbf{V}$-like troughs $\mathbf{D}$ and $\mathbf{D}^{\prime}$. When these are full, they tilt over (Fig. 662) and discharge their contents suddenly on to the table, washing off the deposit. The troughs $\mathrm{D}$ and $\mathrm{D}^{\prime}$, on turning over, carry the bar $\mathrm{H} \mathbf{H}$ forwards, and thus lift the flaps at $F$ and $F^{\prime}$, so that the upper and richer part of the deposit is washed into the launder $\mathbf{F}$, the lower and poorer part into $\mathrm{F}^{\prime}$. As soon as the troughs have discharged their water, they are brought back into their original position by the simple cataract $\mathrm{G}$, and the process is repeated.

Round tables are bluntly conical, convex or concave surfaces; with the former the pulp is fed on at the centre and runs down to the circumference; with the latter, the direction of flow is reversed. The tables are made of wood, planed cast-iron, or cement; the wooden tables may be plain or covered with india-rubber. They are stationary or revolving.

An excellent stationary table is that of Linkenbach* (Figs. $66_{3}$ and 664). The table itself, $a$, is made of masonry with a smooth surface of cement; $b$ is an upright shaft, which carries the pulp-distributor and the pipes supplying water for cleaning and for washing off the deposit; it is set in motion by the worm $d$ and wheel c. Two of eight radial arms, borne by a centre-piece, are indicated by $e e$; they carry the apron $g$, the clean water pipes, $h, h, h$, the position of which can be regulated at pleasure, and the washingoff pipe $i$. The clean water is brought in by the circular box $k$, rotating with the arms $e$, and supplied from the pipe $l$; the pulp is delivered through the pipe $m$, which passes along the conduit $n$ under the table into the inner ring $o^{\prime}$ of the adjustable distributor $o$. The distributor is constructed so as to deliver pulp at $o^{\prime \prime}$ and clean water at $o^{\prime \prime \prime} ; p p$ are pipes bringing down clean water from the rotating launder $k$, and $q^{\prime}, q^{\prime \prime}, q^{\prime \prime \prime}$ are three concentric gutters, by which the various products are led away. The innermost gutter takes the waste "tailings," the middle one the mixed product, and the outer gutter the clean concentrate. The two latter products are conducted each into its proper channel by the apron $g$, which is made of sheet zinc.

The mode of action of this table is easily understood. The distributor is constantly feeding on slime by the part of its circumference $r$ os (Fig. 664); a deposit forms on the table, whilst the lighter tailings run off into the gutter $q^{\prime}$, which is freely open to them in the absence of the apron. As soon as the feeding part of the distributor has passed, clean water begins to flow down over the deposit from the trough $o^{\prime \prime \prime}$, carrying off the middlings into the gutter

\footnotetext{
vi.

* Linkenbach, Die A uflereitung der Erze, Berlin, 1887, p. I0I, and plate
} 
FIG. 664 .

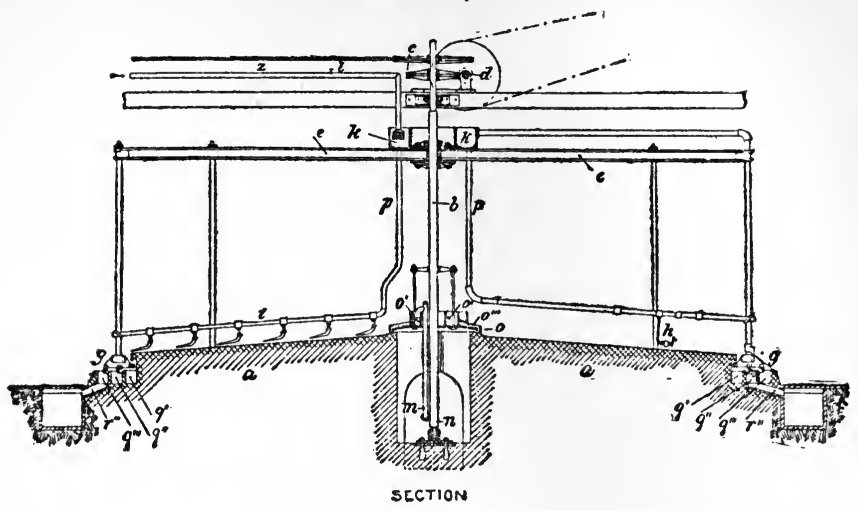

FIG,664.

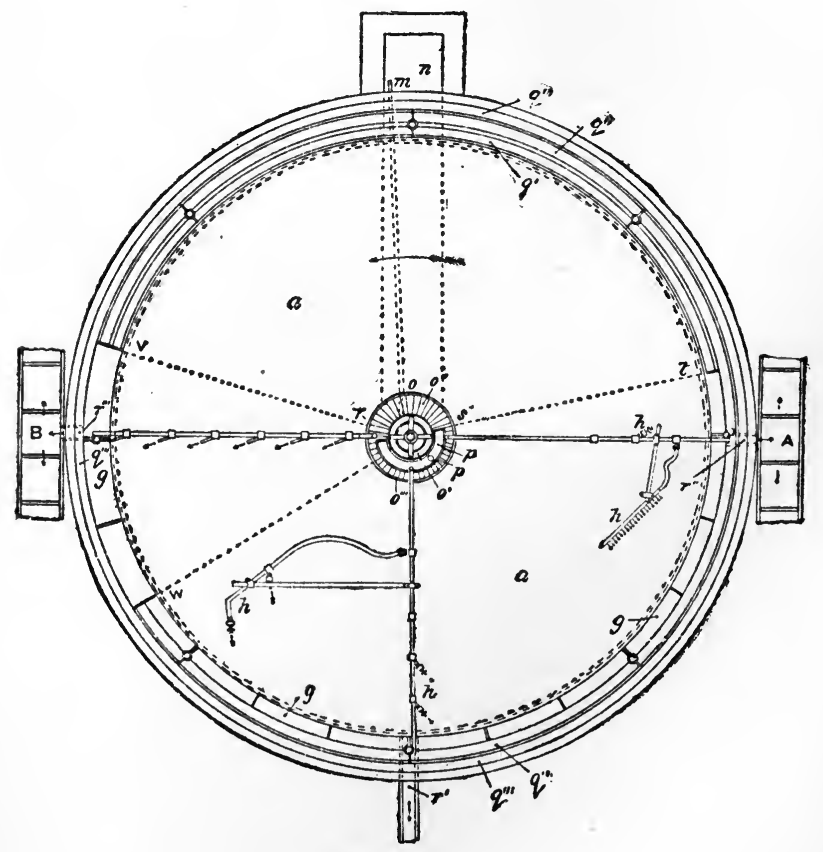

GROUNO PLAN

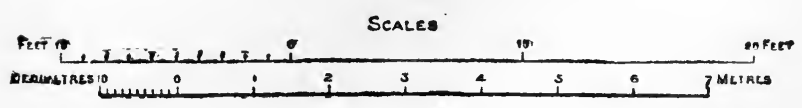


$q^{\prime \prime}$, and having its action aided by the washing-off jets $h$. There now remains on the table nothing but a clean concentrate, and this is washed off into the gutter $q^{\prime \prime \prime}$ by the jets $i ; r^{\prime}$ is a launder carrying away the waste; $r^{\prime \prime}$ conducts the middlings to a settling pit $A$, and the concentrate escapes by a similar launder $r^{\prime \prime \prime}$ into B; $z$ is a wire rope for driving a second table.

An easy way of realising the mode of action of this table is to divide it mentally into three portions-viz., the sector from $t$ to $v$, which is receiving the slime; the sector from $t$ to $w$, from which the middlings are being washed off; and lastly, the sector from $v$ to $w$ with the clean concentrate, which yields to the jets issuing from $i$, and passes over the apron into the outer gutter $q^{\prime \prime \prime}$.

Where the amount of space is limited, Linkenbach places three tables on the same central shaft; but the economy of space and of original first cost is accompanied by less easy supervision.

The mode of action of round tables is very often just the reverse of what has been described; that is to say, the table revolves and the distributor is stationary. Linkenbach points out that a revolving table is necessarily subject to vibrations, which must interfere with the evenness of the flow down the inclined surface, whilst the fixed table with a travelling distributor is free from influences of this kind and is likely to work more regularly.

Nevertheless, in spite of this objection, revolving round tables may be seen doing good work. The table represented in Figs. $66_{5}$ and 666 is one designed by MM. Jacométy and Lenicque. $A$ is the head-board or distributor which feeds the table $B$ with a stream of the fine slime; the table is made of arms of T-iron, radiating out from a cast-iron centre-piece $\mathrm{C}$, which support a light covering of planks. Over this is stretched sheet india-rubber, which forms a smooth surface, free from any liability to warp and get out of shape. The table is set in motion by the vertical shaft $D$, driven by the wheel $G$ and worm $H$. L L are various pipes bringing clean water, supported by rods $\mathrm{N} \mathrm{N}$, and capable of being placed in any suitable position. M MI are pipes which wash off the deposit from the table; they are held up by standards $\mathrm{N}^{\prime} \mathrm{N}^{\prime}$, which can be shifted about at pleasure. $K$ is a circular launder round the table, with discharge holes $t t$, and movable wooden partitions $s, s^{\prime}, s^{\prime \prime}, s^{\prime \prime \prime}, s^{\prime \prime \prime \prime}$; lastly, the pipe $O$ sends out jets of water which clean off everything remaining upon the table. If the table is supposed to be moving in the direction of the arrow, it is evident that products of different kinds will be washed off at different periods of the revolution, and that towards the end nothing will remain on the table but the heaviest particles. By suitably arranging the amount of feed and the position of the different washing-pipes, the table can be made to give clean ore, waste, and intermediate products; the latter are passed over the same or a similar machine once more. 
The tahle is 16 feet 5 inches $(5 \mathrm{~m}$.) in dismeter, with a useful working surface 4 feet II inches (I $50 \mathrm{~m}$.) hong; it makes one revolution in $3 \frac{1}{3}$ minutes, requiring less than $\frac{1}{10} h_{0}-p$ to work it. The quantity of water used is about 26 gallous ( 120 litres) per minute, sad the table will treat from 5 to $\$$ tons of slime in ten hours As it is made of eight seguents bolted together, it is easily transported and erected.
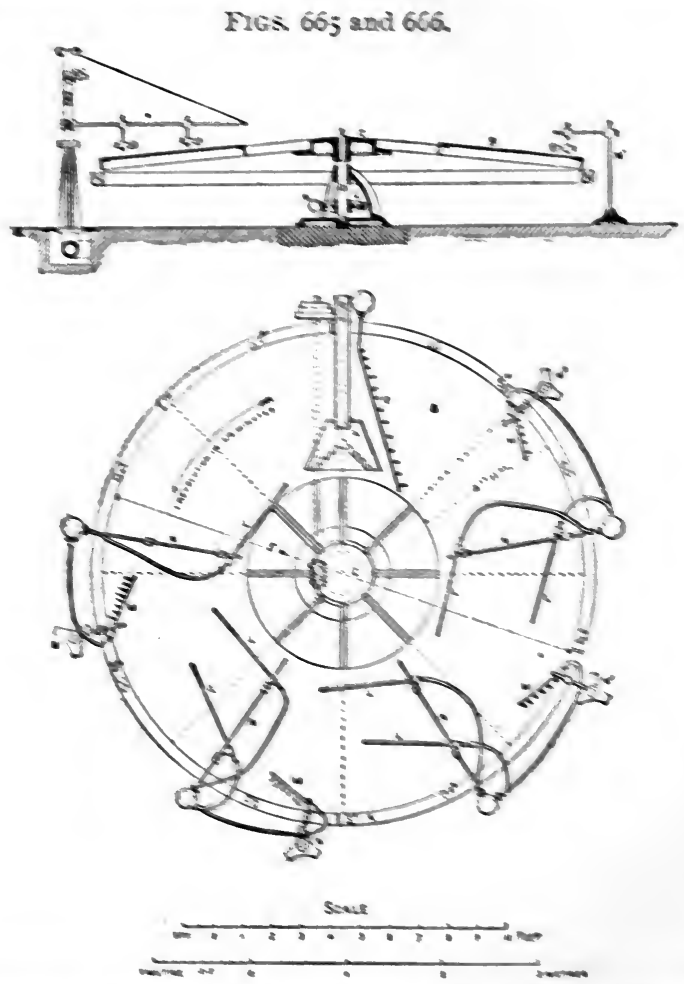

Iercussion Tables-Rittinger's sile-blow percusion table (Fig. 66j) is an inclined rectangular platform suspended by the four corners A B C D, receiving thows and bumps on the side. A stream of crey water $S$ is fed on to the corner $A$, snd clean water W runs down from other head-bcands H H H. Br means of cams upon a revolring shaft, the table is pushed out in the direction of the arrow, and it is then driven tack by a spring. so that the cros-piece E strikes against the bumping block $\mathrm{L}$. The light purticles travel down the table much faster than the beary ones, and taking a compantirely straight course, lesve the table st $\mathbf{K}$; wheress 
the heavy and richer particles remain on the table, subject to the influence of the side-blows, for a much longer time, and travelling along a curved path reach the bottom at F. An intermediate product is discharged at $G$. The exact degree of richness or poorness can be regulated by pointers, strips of wood which can be turned so as to divide the stream of ore and waste where thought most desirable. The great advantage of this machine over the old percussion frame is its continuous action.

Travelling Belts. - We now come to the travelling belts, of which there are many varieties. An early form was that of Brunton,* an endless belt of canvas acting in the same way as

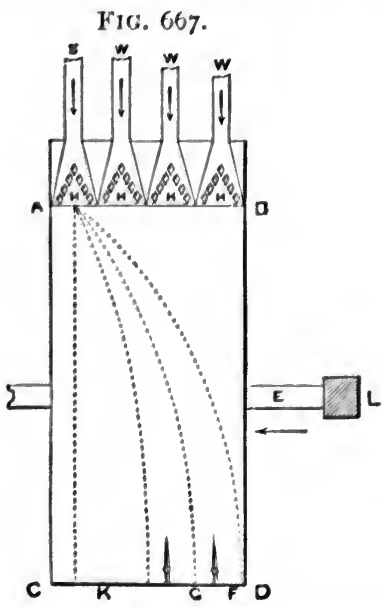

F19. 668 .

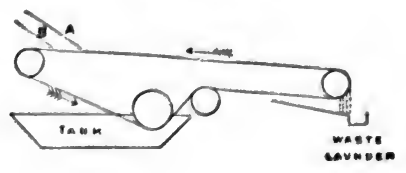

the now favourite Frue-vanner, save that there was no shake sideways. In fact, the latter machine is regarded by some as an improved form of the Brunton cloth.

The Frue-vanner (Fig. 668) is an endless band of india-rubber cloth, 4 feet wide and 27 feet long, with an upper working surface of about $\mathbf{2} 2$ feet in length. The belt is supported by a frame with a number of small rollers on which it travels easily, and it is driven slowly in the direction of the arrows by the upper end roller shown in the figure. The small roller by the side of the large one, which dips into the tank, serves for tightening up the belt when required. The whole frame carrying the belt receives a motion sideways from three little cranks upon a small shaft running parallel to its length. The pulp is fed on by the head-board $A$, and clean water by another B. The natural path of the particles is down the inclined belt, but those which can resist the action of the

"Sopwith, "The Dressing of Lead Ores," Proc. Inst. C. E., vol. xxx., 187a, p. 112. 
stream of clean water at B, go over the top end, and are washed off as the belt passes through the tank. The poor stuff is discharged into the waste launder at the other end. The degree of concentration can be regulated by the slope and speed of the belt and the strength of the streams of ore and water. The Frue-vanner has the disadvantage that it makes only two classes, rich and poor, without any intermediate product.

The success of the Frue-vanner has naturally brought a number of somewhat similar contrivances into the market. The Embrey concentrator may be likened to a Frue-vanner, with a longitudinal instead of a lateral shake.

The Woodbury ore concentrator is made up of several narrow belts each with its own flanges, instead of there being one broad. band. The object of this arrangement is to prevent unevenness of flow, for if strong, irregular currents are formed in the centre of the belt, they may carry away good ore into the waste launder.

Stein's endless belt, which has been improved by Bilharz, has a totally different mode of action. It resembles the Rittinger percussion table in its manner of effecting a separation, but the work is done on a travelling belt instead of an unchanging surface. Stein's machine* (Figs. 669, 670, and 67I) is a rectangular frame $a$, suspended between two posts $p$, by rods $i$, at the four corners, so that it can swing in the direction of its long side. The inclination of the frame can be altered at pleasure, by the handle attached to the cross-beam $l$, which works upon the screw $e$, but the long side always remains horizontal. The frame is drawn slightly out of position by cams $r$, acting upon the lever $m$, and as suon as it is released it is pulled back against a bumping-piece $t$, by a spring $n$. The frame has two large rollers $c c$, and three small ones underneath, which carry an endless belt of india-rubber $f$, the upper part of which is further supported by the flat bed of boards $b$. The belt slides over this bed, and is prevented from sticking to it by a constant flow of water, supplied by the pipe $g$, along narrow diagonal grooves. One of the end rollers is made to revolve and carries the belt with it. The pulp is fed on by a head-board $k$, and clean water is turned on through holes in the pipe $o$. The direction of travel of the belt is indicated by the arrow. The concentrating action is like that of a Rittinger table. The lightest particles run down at once, and leaving the belt at the right-hand end of the table, fall into the first compartment of the launder $q$, whilst the heaviest remain on the table much longer, and are finally discharged at the left-hand end. Intermediate products run off in the middle.

(2) The second set of appliances includes the buddles and ordinary percussion tables.

* Blömeke, "Ueber den Stein'schen Plannen-Stossherd,". . u. h. Z. IS9I, p. 69. 
Buddles. - The hand-buddle is a rectangular wooden box with a sloping bottom. A stream of pulp is fed in by a head-board at

Figs. 669 and 670.
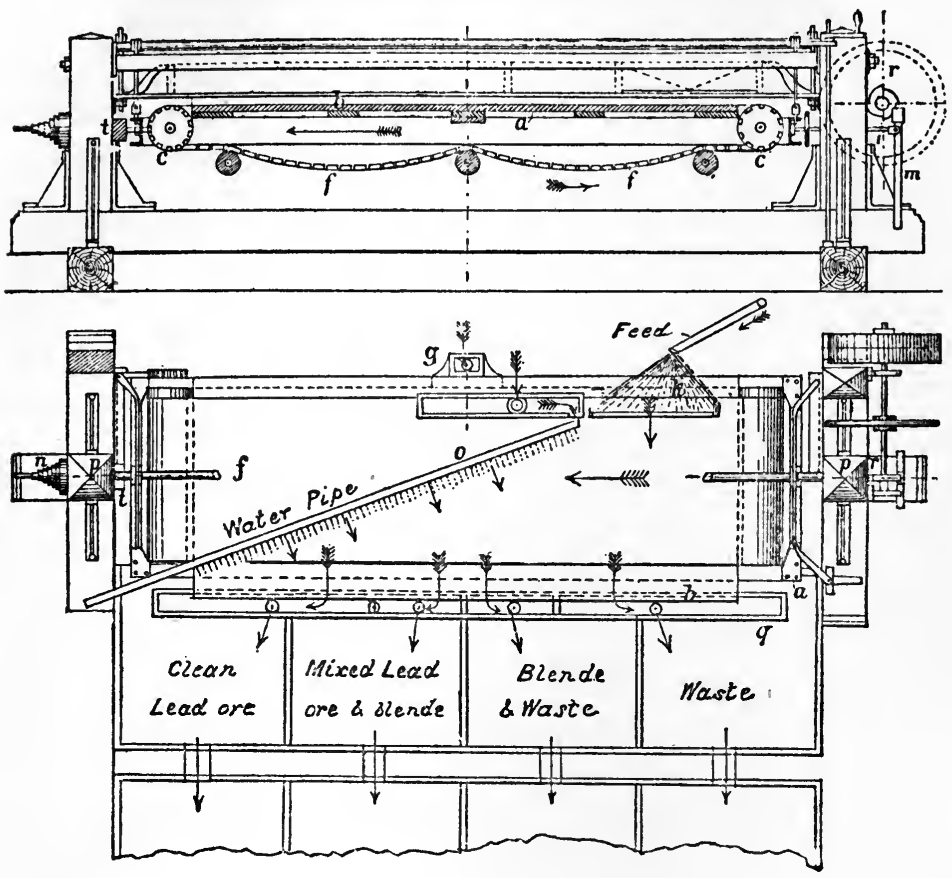

FIG. 671

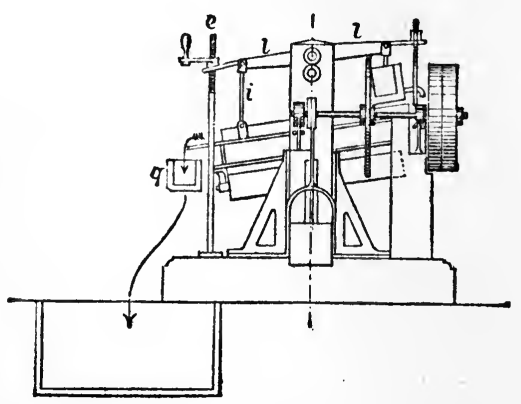

the upper end and gradually forms a deposit on the floor of the buddle. A boy with a broom keeps the surface of the sediment even, so as to ensure regularity of action. After a thick deposit 
has accumulated, it is dug out in sections, which decrease in richness from the upper end (head) to the lower end (tail).

Round buddles bear the same relation to hand buddles that round tables do to hand frames. They may be concave or convex, but the latter are the more common.

The convex round buddle (Figs. 672 and 673) is a circular pit* with a truncated cone, or head, of varying size in the centre, and a bottom sloping lowards the circumference. The orey stream, A,

FIG. 672 .

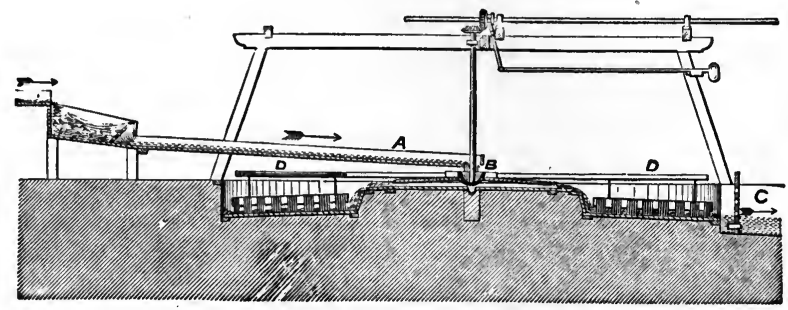

Fig. 673 .

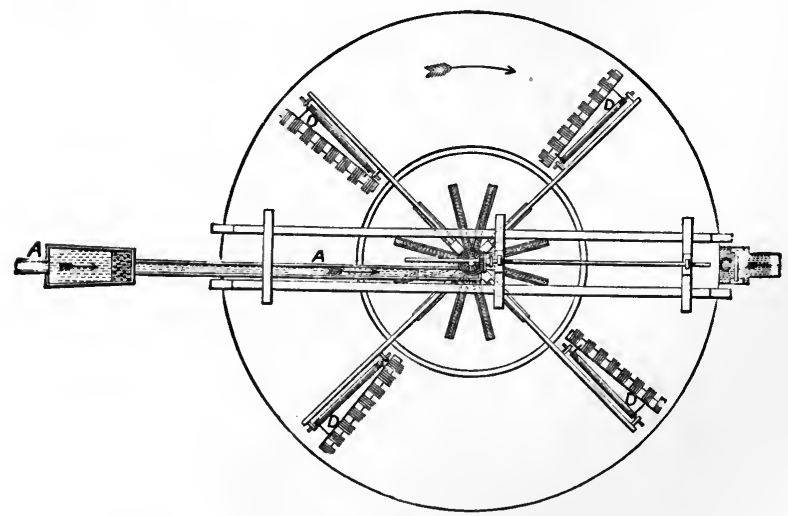

falling over this head runs down gently, depositing the heaviest particles near the top, the lighter ones further down, while the lightest of all flow away at C. The surface of the sediment is kept even by the revolving brushes $\mathrm{D}$. This machine may be compared to a number of hand-buddles arranged radially round a centre. The deposit which is formed is dug out in rings of varying richness.

The concave buddle is a circular pit with the bottom sloping

* Henry T. Ferguson, "On the Mechanical Appliances used for Dressing Tin and Copper Ores in Cornwall," Proc. Inst. Blech. Eng., I873, plate xli., and $\mu$. 124. 
towards the centre. The stream of ore is fed all round the circumference, and runs inwards towards the middle, where the lightest particles escape. The rich head is, of course, near the circumference.

Ordinary Percussion Table.-The ordinary percussion table, though rarely if ever seen in this country, is still employed in Germany and regarded with favour. Those familiar with the hand-buddle will understand what it is like, if it is described as a swinging hand-buddle which is continually being bumped at the upper end. It is a shallow rectangular sloping wooden or iron tray suspended from the four corners, so that it can move backwards and forwards in the direction of its length, and as soon as it has been pushed out of position by a cam, it is at once forced back by a spring against a fixed wooden bumping-block at the upper end. The pulp is fed on at the upper end by a head-board, and the lightest particles run off at the lower end, which has no rim, whilst the heavier and richer ones form a gradually thickening layer upon the bed. When sufficiently thick, the deposit is shovelled off in sections varying in richness as they do in a buddle. The bump assists in making the particles settle, just as it does in the "keeve," and at the same time, in virtue of the vis viva acquired during the backward stroke of the table, grains of ore are constantly being thrown up a little, as they are with the German hand-washing dish.

Machines of this class have two grave defects : careful watching is necessary, in order to keep the surface of the deposit perfectly even; otherwise gutters are formed, down which the water runs with tco great a velocity, carrying away rich ore or depositing it near the tail end when it ought to lave subsided at the head. Secondly, the deposit has to be shovelled off, and the parts requiring further treatment have again to be mixed with water and brought into a proper consistency, before they can flow on to other machines. In spite of these drawbacks, buddles and percussion tables are still largely employed.

(2) MOTION IN AIR.- In countries where water is scarce, or where the valuable mineral is specially liable to be affected or carried off by water, engineers have long desired to employ air as the medium in which the concentration should be effected.

Three kinds of machines are used : the pneumatic jig, the fan, and the centrifugal concentrator.

Pneumatic Jig.-The pneumatic jig resembles the hydraulic jig in principle; that is to say, particles of minerals varying in specific gravity can be separated if they are lifted and then allowed to fall again, provided that the sizes of the grains do not differ too widely, and that the specific gravities do not approach too closely. The principle will be most easily grasped if the student constructs a very simple model (Fig. 674). A piece of glass tube with the upper end covered by net or muslin is 
inserted into a slightly larger tube. The lower end is then connected to an india-rubber pump, such as is used with scent diffusers. Pour a mixture of like-sized grains of galena and sund on to the sieve, and give the pump a succession of gentle squeezes.

Puffs of air are sent up through the sieve, and the two FIG. 674. minerals arrange themselves as shown, the galena below,

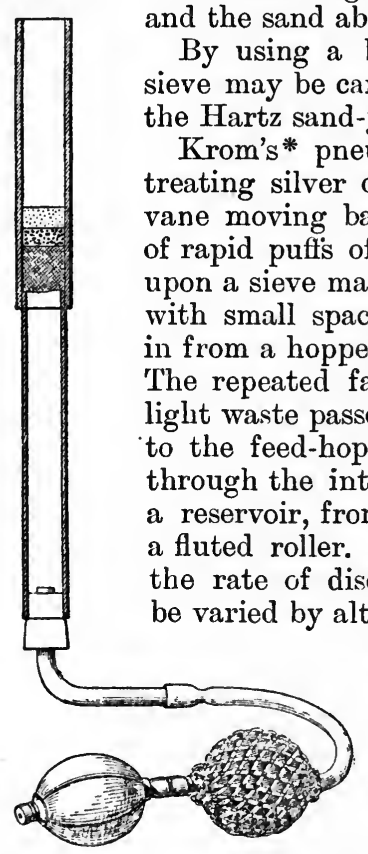

By using a bed of fine shot, jigging through the sieve may be carried out, the action resembling that of he Hartz sand-jigs.

Krom's* pneumatic jig, which is in actual use for treating silver ore, is a wooden chest in which a flat vane moving backwards and forwards sends a number of rapid puff's of air through a bed of fine ore, resting upon a sieve made of short upright tubes of wire cloth, with small spaces between them. The fine ore is fed in from a hopper on one side of the long narrow sieve. The repeated falls bring about a separation, and the light waste passes over the edge of the sieve opposite to the feed-hopper, whilst the concentrate sinks down through the interspaces between the sieve tubes into a reservoir, from which it is drawn off gradually by a fluted roller. As this reservoir is always kept full, the rate of discharge and degree of concentration can be varied by altering the speed of the roller.

Fans.-A fan is used in connection with some grinding machines in order to draw off the powdered mineral, and, in dealing with a homogeneous substance, the amount of suction can be regulated so as not to draw the mineral out of the machine until it has been sufficiently pulverised. If the dust-laden air is then discharged into a large chamber, the coarsest particles will settle down first, whilst the finest will be wafted to the far end.

As an instance of fan-action, the dressing of phosphate of lime may be mentioned. Some of the phosphate of lime which is ground between millstones in France is not passed through any sieve at all; a fan is adjusted so as to draw it away from the mill sufficiently fine to be put into sacks at once. Tests are made from time to time to see that the product is properly ground, for it is sold with the guarantee that not more than a certain percentage shall be too coarse to pass through a given sieve.

Another example may be taken from some of the fuller'searth dressing establishments. The earth is ground in an

* Callon, "Lectures on Mining," Paris and London, 1856, vol. iii., p. 104 and Atlas, plate civ. 
Askham mill and forced by a fan into a chamber some 50 feet long by ro feet wide, where it drops upon the ground; the deposit is shovelled away afterwards in sections, which are finer and finer as one goes away from the orifice through which the dust enters. The requirements of different customers can thus be satisfied.

When a fan is employed for drawing off the fine product from a mill or crusher, it likewise serves the useful purpose of preventing the atmosphere of the works from being polluted by noxious dust.

Centrifugal Concentrator.-These concentrators are based' upon the fact that when bodies of equal volume are whirled round, the centrifugal force developed is proportional to their densities. Therefore, if the like-sized particles are projected by centrifugal force from a machine, the denser ones, with their larger store of energy, will be better able to overcome the resistance of the air than those which are specifically lighter, and will consequently travel further. The truth of this can be made manifest with a child's top. Spin the top in a saucer or dish raised a little above the table, previously covered with a sheet of paper or cardboard, and feed on to its flat upper surface a thin stream of finely powdered galena and sand, which has passed through a sieve with I 00 holes to the linear inch and refused to pass the I 20 mesh. The particles will be whirled off, light sand will drop close to the saucer or even into it, whilst the heavy galena picks up a larger amount of energy from the spinning-top and flies further away before settling. By brushing up the dust concentrically, the effect will be apparent.

The Clarkson-Stanfield concentrator (Fig. 675) works precisely in this way. $B$ is a distributor, which is made to revolve rapidly by its spindle C. The hopper A supplies it with finely powdered and carefully sized

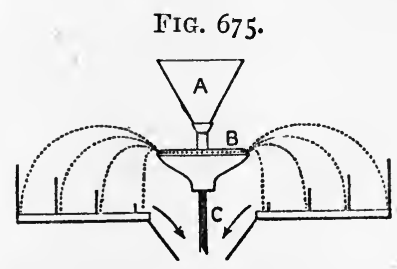
ore, which escapes by a number of radial holes. The dotted lines show the paths taken by the particles of mineral, which drop into a series of concentric troughs from which they can be swept by revolving brushes into discharge-spouts.

In order to work successfully, the ore must be very carefully separated by screening into particles of approximately the same volume. The machine is new, and has yet to bear the test of actual practice on a large scale at mines, but it is worth noting that a similar appliance is used at mills * for freeing semolina from bran and dust. The Pape-Henneberg $\dagger$ ore concertrator is identical in principle with that of Clarkson and Stanfield.

A disadvantage of all pneumatic dressing is that the ore has to

* Spon's Dictionary of Engineering, London, 1873, vol. vii., p. 2499.

+ B. u. h. Z., 1 893 , p. 191 . 
be very thoroughly dried, for otherwise the particles stick together slightly and counteract the action of the forces which should effect the desired separation.

(3) DESICCATION.-Various reasons call for the drying of minerals. Sometimes the mineral cannot be ground until it is freed from moisture; in other cases drying is advisable in order to save the payment of carriage upon a useless ingredient ; it is likewise necessary before a mineral is roasted in furnaces, or passed through certain magnetic separators, and, as has just been remarked, it is indispensable when the subsequent treatment is effected by a pneumatic process.

Drying may be carried on in one of the following ways :

a. By exposure to the air.

b. By open fires.

c. On open floors or pans.

d. In enclosed stoves or kilns.

e. By filter presses.

a. Air Drying.-Simple exposure to the action of the atmosphere, under a light roof as a protection from occasional showers, is quite sufficient for the purpose of drying many minerals, provided that the weather is fine. China clay and ochre are sometimes dried in this way. The roughly cubical clods are piled up one above the other, allowing free access of air, and, if the weather is favourable, a sufficient amount of moisture evaporates naturally to render the mineral fit for the market; but a wet season sadly interferes with the work, frost will cause the clods to crumble, and artificial drying often becomes necessary in order to satisfy the demands of customers.

In Chili the crystals of nitrate of soda are soon dried perfectly by exposure to the atmosphere.

b. Open - fire Drying. - The phosphate of lime dug or dredged in South Carolina is sometimes dried by heaping it upon piles of wood which are set alight.

c. Drying on Heated Open Floors.-Heated floors are employed in drying barytes, fuller's earth, and phosphates previous to grinding, other minerals previous to roasting, and china clay previous to sale.

Fig. 676 shows a Cornish "dry" for china clay.* The letters $l l$ represent the "settling tanks" or stone-lined pits into which the clay is run, in the form of a thin mud, after the coarsest particles of the decomposed granite have been separated. Here it forms a sediment of the consistency of thick cream, which is trammed to the "dry," after the water has been drawn off. The dryinghouse is composed of the dry proper $m m$, and the storing sheds or "linhays," $o o$. The floor of the dry is made of large fire-clay tiles, which cover a number of flues, each about 14 inches wide,

"Collins, "The Hensbarrow Granite District," Truro, I878, p. 20. 
leading away from the fireplaces, $s s$. The tiles are 5 or 6 inches thick over the fires, where the heat is greatest, and the thickness is reduced to $2 \frac{1}{2}$ or 2 inches at the other end of the building. The clay is trammed in along the road $t t$, and tipped on to the floor or "pan" $m m$, until it forms a layer 9 inches thick at the fire-end and 6 inches thick at the stack-end. The clay at the fire-end is dried in 24 hours; it is cleared off and stored in the linhay $o o$, and another charge of wet clay trammed in; the further the clay is from the fire, the longer it takes to dry, and at the stack-end, the "pan" can be cleared and re-loaded only twice or three times a week. It appears that much more of the

Fig. 676.

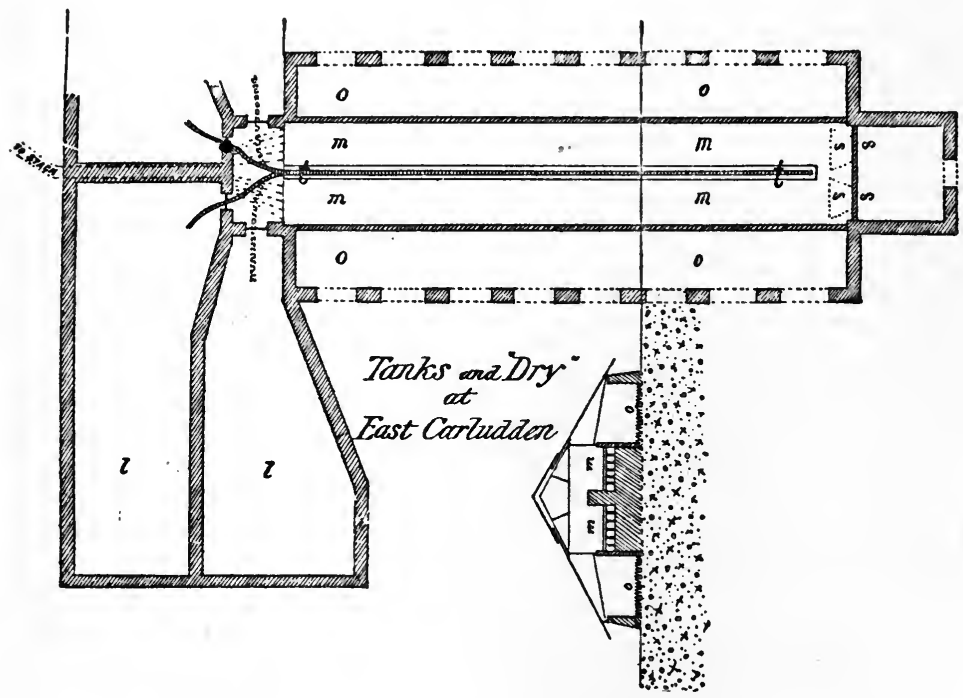

moisture soaks down through the tiles and is carried away as steam by the flues, than evaporates from the surface of the pan, and for this reason the tiles are made as porous as possible.

The open floors used for drying phosphate of lime in the North of France previous to grinding have the bed madc of sheets of iron. The plates are about one metre square and are laid upon a series of parallel flues formed of little walls one brick thick. The floors are often about 20 metres long and 4 metres wide. In order to accelerate the process of drying the sandy phosphate is shovelled over from time to time by men, but the cost of labour can be reduced by using Arnett's mechanical hoe which performs the same office. It is a frame stretching across the whole width of the floor, carrying a single row of broad blades or spades, which can be inclined at any 
desired angle to the bed; it is drawn backwards and forwards by machinery. The blades pass into the layer of phosphate on the floor, heap up the stuff in front of them, and cause the particles to mount up, and then fall over on to the bed again. Each time the hoe passes along, the stuff is shifted forwards a little, so that when the frame arrives at the end of its course, it pushes off a portion of the charge, which is now dry enough for milling, as it has travelled along the full length of the bed. As the inclination of the blades can be altered, the rate at which the stuff is carried forwards can be regulated so as to prolong or shorten the drying process, as required. The machine is made to reverse its direction of travel automatically, but it does no stirring on the return stroke.

Thelen's drier is an open semi-cylindrical iron pan heated by a fire below, in which the charge is stirred by knives moved mechanically.

$d$. Stoves and Kilns.-The number of kinds of enclosed stoves and kilns employed for drying minerals is very great; and it is especially in the case of brown coal* that the ingenuity of inventors has been exercised to devise means of getting rid of moisture. However, as the subject of brown coal does not belong to this work, the special stoves made use of cannot be dealt with at length; still it is right that they should be mentioned, as some of them could be used for other minerals.

With such a large number of drying stores, it is absolutely necessary that there should be a classification of some kind, for otherwise the student runs the risk of being confused.

It is perhaps most convenient to classify them first of all according to the mode of heating, and then make a further subdivision according as kiln or furnace is stationary or revolving.

\section{Enclosed Kilns and Stoves.}

Mode of Heatirg. $\quad$ Kind of Drying Surfuce. Name of Drying Stove.

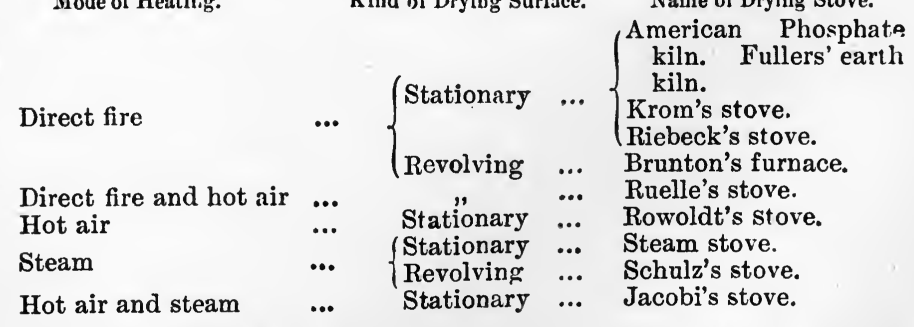

American Phosphate Kiln.-The kilns employed for drying phosphate of lime in South Carolinat after washing are simply

* Vollert, Der Braunkohlenbergbau im Oberbergamts-Bezirk Halle und in den angrenzeriden. Stacten, Halle a. d. S. 1889, p. 249.

+ Benedict, "Mining, Washing, and Calcining South Carolina Land Tho:phate, Eng. Min. Jour., voi. liii., 1892, p. 349, 
rectangular chambers, built of brick and roofed with wood. The whole of the bottom is covered with a pile of wood, on to which the wet phosphate is tipped from barrows. The wood is set alight and flues supply it with air for combustion. Each kiln holds from r 000 to 1200 tons of phosphate; the fire burns out in from two to five days, and the phosphate is then ready for export.

Fullers' Earth Kiln.- The fullers' earth kiln may be taken as another example of the first class. It is a brick or stone building about 36 feet long and 15 feet wide, with an arched roof of brick (Fig. 677) or a sloping roof of slate. About 9 feet above the bottom is a floor $a$, made of castiron plates full of holes about $\frac{1}{8}$ inch in diameter, underneath which are two sets of sloping shelves, made of sheets of iron, $b b$, $c c$, which can be taken out at pleasure; $d$ is a deep tlue bringing in air from the outside, and having two openings into the kiln, covered with fire-bars, upon each of which a coke fire, $e$, is maintained. A sheet of corrugated iron, $f$, is hung . up over each fire, in order to prevent the clay immediately above it from being too strongly heated. Both the upper and lower floors of the kiln can be entered by large doors. The charging is all done from the floor $a$; a few of the plates are taken up on each side, the sheets $b b$ removed, and clay
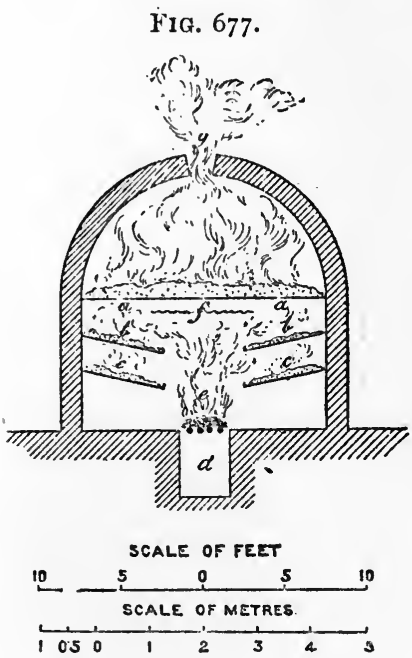
is wheeled in barrows along $a$ and tipped on to $c$. The plates $b$ are replaced and similarly covered with a charge of clay, and finally $a$ receives a layer of damp clay 6 or 8 inches thick. The doors are shut and the fires lighted; though the heat is considerable, it is not enough to prevent men going in from time to time to put on more fuel, if required. The moisture-laden air ascends and escapes through the roof at $g$.

Krom's Stove.-Krom's stove has a series of inclined shelves, something like those of the Hasenclever furnace, down which the mineral gradually makes its way under the action of gravity, while exposed to the direct action of the hot gases coming from a fire.*

Riebeck's Stove.-Riebeck's "Tellerofen" consists, as its German name denotes, of a number of superposed circular platelike shelves; a central revolving shaft carries arms with

* Sahlin, "Magnetic Separation of Iron Ore," Eng. Min. Jour., vol, liii. 1892, p. 638 . 


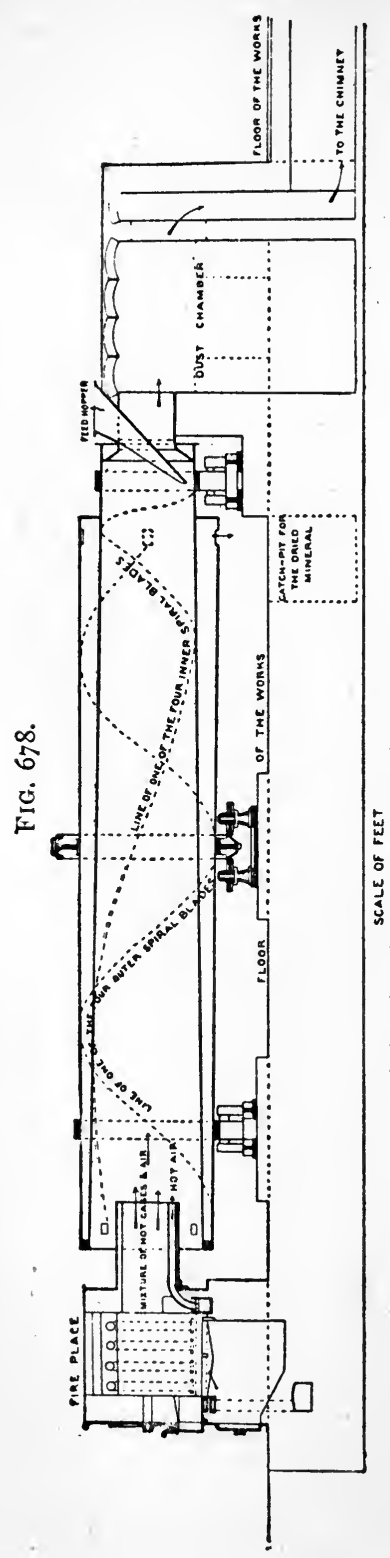

teeth or knives which alternately cause the mineral to travel outwards and inwards. Thus the mineral fed on to the top shelf, for instance, will be made to travel outwards to the circumference, where it drops through holes on to shelf No. 2 ; here the revolving teeth, arranged in the reverse fashion, draw it in gradually to the centre, where it falls upon shelf No. 3, and it goes on travelling backwards and forwards in this fashion until it reaches the bottom of the kiln. During all this time it is subjected to the action of the hot gases coming from a fire below.

Brunton's Furnace.-Though Brunton's calciner (Fig. 692) was invented for the purpose of roast- ing ores, driers have been constructed upon the same principle; the stove is a circular revolving horizontal bed, with teeth fixed above it which cause the mineral, fed in at the centre, to travel gradually to the circumference. A fireplace on one side sends the products of combustion directly upon the mineral. This stove is - used for phosphate of lime, be-

. sides being employed in the 1. manufacture of patent fuel.

Ruelle's Stove.-Ruelle's revolving drier (Fig. 678), on the other hand, recalls the Hockin and Oxland calciner. It is made of two long truncated cones of boiler-plate, one inside the other ; the inner one is destined for the drying proper, and the outer one allows the very hot mineral to cool down a little before it is discharged and sent to be ground.

The outer shell runs upon friction rollers, and both it and the 
inner case have internal projecting spiral blades, which lift the mineral a little and cause it to travel along. At one end there is a fireplace; at the other a charging hopper and a dust-chamber. The mineral fed by the hopper into the inner cone is gradually brought along by the spiral blades towards the fire-end, whilst it is being exposed to the hot gases of the fire, as well as to a current of hot air blown in by a fan, and heated by its passage through pipes at the side of the fireplace. On reaching the fire-end of the inner cone, the mineral falls through one of four holes into the outer shell, and is now conveyed back by spiral blades to the other end, where it drops into the pit of an elevator, which lifts it high enough for the hopper of the mills. Any dust carried off by the draught is deposited in a chamber built for that purpose. 'This drier does good work at phosphate mills.

Rowoldt's Stove.-This stove, which is specially designed for brown coal, is made up of a number of small lattice-like shelves down which the mineral gradually drops, while surrounded by air warmed to $75^{\circ} \mathrm{C}$. ( $167^{\circ} \mathrm{F}$.) by its passage through small pipes heated by steam.

Steam Stove.-The steam stove, also designed for brown coal, is somewhat like the ordinary "Tellerofen." A number of circular drying plates are superposed one above the other in a cylindrical casing, and are heated by steam passing under them.

Schulz's Stove.-Schulz's steam stove is a large revolving iron cylinder like a tubular boiler, 19 feet to 20 feet long, and 7 to 8 feet in diameter, traversed by 180 or 200 small pipes 4 inches in diametor and a large central one. The cylinder is inclined to the horizon at an angle of $5^{\circ}$ to $6^{\circ}$. The exhaust steam from an engine is passed into the large central tube and finds its way through holes into the space outside it, heating the small tubes and their contents. The mineral is carefully fed from a hopper into the small tubes at the upper end, so as to prevent any choking, for otherwise the free passage of the air would be impeded, and the drying would be very imperfect.

Jacobi's Stove.-In the Jacobi stove the mineral falls down over a series of pentagonal cast-iron pipes heated by the passage of steam, instead of the plain lattice-like shelves of the Rowoldt apparatus, in addition to being exposed to an atmosphere of hot air.

Many of the brown-coal driers are specially designed so that the products of combustion of the fire do not come into contact with the mineral, for fear the charge might be ignited accidentally. This difficulty does not crop up with many of the other minerals which have to be dried, though it is important with some that the degree of heat to which they are exposed should not be too great.

(4) LIQUEFACTION AND DISTILLATION. - The miner resorts to melting as a purifying or preparatoly process in 
treating amber, antimony ore, asphalt, ozokerite, and sulphur; and in the very exceptional case of carbonic acid, a gas is compressed to the liquid state.

Small lumps of amber, after having had the dark outer rind dissolved away, are melted together before being sold to the varnish merchants.*

The liquation of antimony ore is usually regarded as a metallurgical process ; but if a mere melting is carried on at the mine in order to rid an ore of earthy matters, there is no more reason for refusing this operation a place among "dressing" processes, than there would be for excluding the similar purification of asphalt, ozokerite, or sulphur. This is an instance of the difficulty of defining the boundaries between the province of the miner and that of the smelter. The domain of the former is already so large that it does not require to be extended unnecessarily, and as the liquation of antimony ore is fully described in many metallurgical text-books the process may be dismissed here in a very few words. It is based upon the easy fusibility of stibnite. The impure ore coming from the mine is subjected to the action of heat in pots or tubes; the stibnite melts, trickles away from the earthy matters with which it is mixed, runs into moulds and is allowed to cool gradually, furnishing the crude antimony of commerce.

Trinidad pitch is purified or refined in the island by being melted in iron pans; much of the intermingled earthy matter sinks, and the supernatant comparatively pure product is ladled out into moulds.

The asphalt rock of Seyssel $\uparrow$ is prepared for the market by melting it up with Trinidad pitch, or pitch obtained from bituminous sandstone, in the proportion of I of pitch to 14 of the finely crushed rock. When the mixture has become pasty, it is cast into blocks weighing about $\frac{1}{2} \mathrm{cwt}$. each. 'Tuese are now realy for sale for making pavements.

The sponge-like masses of gold obtained by the distillation of amalgam are melted in crucibles and cast into ingots for sale.

The comparatively clean pieces of ozokerite, which have been picked out, below and above ground, and scraped clean, are more fully purified by melting; the heavy refuse sinks to the bottom, whilst the pure wax is decanted off and poured into cylindrical moulds.

By far the greater portion of the native sulphur of Sicily is extracted from the limestone, or other rock by which it is accompanied, by a simple process of liquation in kilns; the necessary heat is produced by the combustion of part of the sulphur in the rock, it being cheaper in Sicily to do this than to import

\footnotetext{
* J. u. h. Z., 1887, p. 24.

+ Malo, L'Asphulte, Paris, 1888, p. 52.
} 
fuel. The "calcarone," * or large kiln (Figs. 679 and 680), as distinguished from the "calcarella" or small one, is a circular pit surrounded by a wall, having a sloping bed leading to a rectangular aperture in front. The bed is covered with a layer of burnt refuse (ginese) from a previous operation, which is stamped down hard. The charging proper then begins, the large lumps are placed on the bottom, and various small vertical chimneys are left as passages for the air; when the "calcarone" is full up to the level $b e$, the mineral is heaped up so as to form a conical pile $b c d e$, which is covered over with a

FiG. 679.

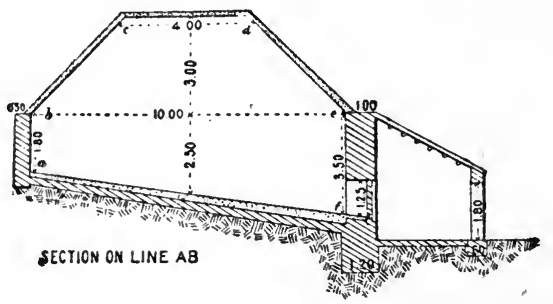

FIG. 680.

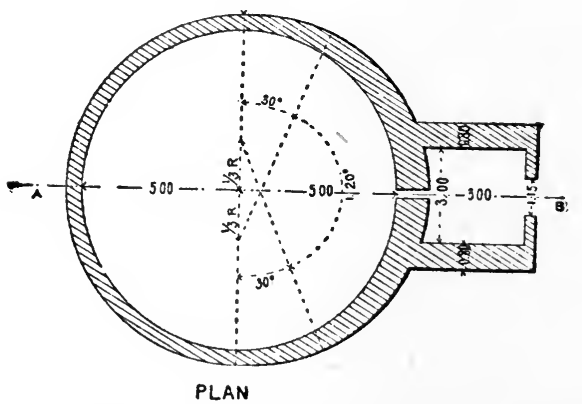

layer of fine "ginese." The thickness of the outer covering of refuse varies according to the season. The total charge of a large "calcarone" may be as much as 700 tons. The aperture $f$ in front is closed with a thin wall, built with plaster of Paris, and the charge is lit at the little chimneys. The heat produced by the combustion of part of the sulphur liquefies the remainder, which gradually runs down the bed to the front wall, and is either tapped from time to time or is allowed to escape continuously into moulds. Some of the large "calcaroni" take three months before they are burnt out completely.

It is reckoned that one-third or even two-fifths of the sulphur

* Parodi, Sull'estrazione dello solfo in Sicilia, Florence, 1873, p. 49. The word "calcherone" is also used. 
in the rock are consumed in liquefying the part that is obtained. This immense loss of such a valuable material has very naturally caused inventors to turn their attention to cheaper methods of extraction; but even as late as the year 1889, nearly seven-eighths of the total quantity of sulphur obtained in Sicily were extracted by the " calcarone" process. A little was got by a steam extractor and about ro per cent. of the total production by Gill's regenerative furnace; * the former is an iron vessel into which steam is conducted after it has been filled with mineral; the sulphur melts under the action of heat and runs out at the bottom.

Rich sulphur rock is sometimes subjected to distillation in iron retorts in order to extract the valuable element with less loss than that of the kilns, and the process is also employed in expelling mercury from amalgam.

In order to produce a commercial article suitable for despatch to a distance, the natural carbonic acid of Germany is compressed into the liquid state. The gas coming from the bore-hole is led to a double pump. . The first pump compresses the gas to a certain extent, and forces it through a worm in a cooling tank; a second pump then takes up the process, and compressing the gas still further sends it through a second cooling worm into strong bottles, made of wrought-iron or steel, in which the actual liquefaction takes place at a pressure of $3 \mathbf{I}$ atmospheres.

The bottles are of four sizes, for holding 4,8, , 1 , or 20 kilos. of liquid acid. An 8-kilo. bottle weighs 37 kilos. when empty, or 45 when full; the dead weight which has to be transported is therefore very great.

(5) MAGNETIC ATTRACTION.-Magnetism is applied in dre'ssing either for treating poor iron ores, in order to pruduce a concentrate richer in metal and freer from noxious elements than the crude material, or for extracting magnetic particles from ores of bismuth, copper, gold, lead, or zinc, in which iron minerals play the part of troublesome refuse.

The machines for treating ores magnetically may be classified as follows :-

\begin{tabular}{|c|c|c|c|}
\hline Kiud of Machine & Name of Inrentor or Machine. & & Mode of Working. \\
\hline & a. Chase & $\ldots$ & Wet or dry. \\
\hline & b. Conkling & & Wet. \\
\hline Endless belt & c. Edison & ... & Dry. \\
\hline & d. Hoffman & $\cdots$ & " \\
\hline & f. Lovett-Finney & $\ldots$ & wet. \\
\hline & g. Ball-Norton ("Monarch") & ... & Dry. \\
\hline Rolls & h. Buchanan & $\cdots$ & $"$ \\
\hline Lons & $j$. King & ... & $"$ \\
\hline & $k$. Wenström & $\ldots$ & " \\
\hline Deflection & l. Edison & $\ldots$ & ," \\
\hline
\end{tabular}

* Rivista del servizio minerario nel 1889, Florence, 1890, p. $\mathbf{3 3}$. 
Endless Belts.-(a) The Chase separator* (Fig. 681) has two endless belts with magnets underneath. A, B are two revolving iron rollers 4 inches in diameter and 3 feet long, converted into magnets by electric currents, and the space between them is occupied by a stationary electro-magnet; $\mathrm{C}$ is a driving pulley, and $\mathrm{D}$ a tightening pulley. A cotton belt is made to travel round these four pulleys in the direction shown by the arrow. $\mathrm{F}$ is another magnetic roller, and $\mathrm{G}$ a driving pulley for the second belt, travelling as shown.

'The ore is fed on to the belt at the point $\mathbf{E}$, and on arriving at A the non-magnetic waste is thrown off by centrifugal force, whilst the magnetic particles are attracted and held against the belt. All the time they are passing from A to B they are subject to the influence of the electro-magnet, and owing to its construction they come under the influence of a succession of poles alternating in polarity. This causes the particles to turn over constantly and so free themselves from the non-magnetic or slightly magnetic

Fig. 68 I.

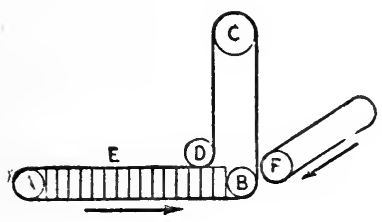

FIG. 682.

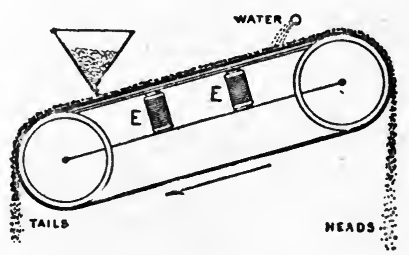

grains, which fall into the compartment immediately below the belt, destined for the middlings. The thoroughly magnetic particles travel with the belt to $B$, and as it moves up and the influence of $\mathrm{B}$ becomes less sensible, they are attracted by the third magnetic roller $\mathrm{F}$, and at last leaping across the small intervening space, they are carried up the belt to $G$, where they drop off into the box containing the "heads." In making the little jump from $B$ to $F$ they still further free themselves from incompletely magnetic middlings.

(b) The Conkling machine (Fig. 682) is an inclined endless belt travelling upon a roller at each end, with stationary electromagnets E E under the upper half. The ore is fed on from a hopper, and is subjected to the action of a stream of water; this washes down the non-magnetic particles, whilst the magnetite adhering to the belt is carried over the top end. The Conkling machine may therefore be looked upon as a Brunton separator

* Sahlin, "Magnetic Separation of Iron Ore," Eng. Min. Jour., vol. liii., 1892, p. 663. This article gives recent information on the subject of magnetic separation, and has furnished not only the account of the Chase machine, but also many of the details concerning some of the others. Sce also Trans. Amer. Inst. MI.E., vol. xvii., I 890, p. 728. 
in which the rich grains are held against the belt by magnetic attraction, and thus enabled to resist the force of the stream of water.

(c) Edison's second separator, which is used for the final treatment of re-crushed concentrates, furnished by the deflection machine (p. 606), is an endless belt placed vertically, with electromagnets behind one side; they at tract the fine particles of magnetite and cause them to adhere sufficiently to be carried upwards, whilst the non-magnetic grains drop. The electro-magnets are arranged so that the particles travel over magnets alternating in opposite polarity; this causes, as in the Chase machine, a succession of tumbles or somersaults, which set free the non-magnetic particles and allow them to fall. The magnetite is carried up over the top roller by buckets attached to one side of the belt.

(d) The Hoffman separator* (Fig. 683) is an endless belt arranged horizontally upon the two

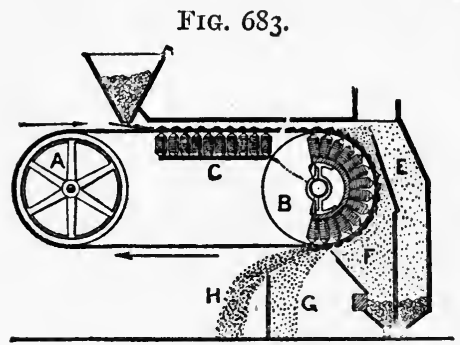
drums $\mathrm{A}$ and $\mathrm{B}$, provided with two sets of magnets. The magnets $\mathbf{C}$ and also those inside the drum $B$ have their poles arranged alternately. When the ore is fed on to the belt from the hopper, it travels along over the magnets $\mathrm{C}$, and is subject to magnetic attraction varying in amount, according to the distance from the pole, and also in polarity. This action tends to make the magnetic particles group themselves into a layer resting immediately upon the belt, whilst the non-magnetic particles lie upon the top. On arriving at B these latter are easily thrown off by centrifugal force, and fall into the compartment $\mathrm{E}$, whilst the magnetic grains still cling to the belt. Those which are incompletely magnetic drop at $\mathrm{F}$; a better product is collected at $G$, and a clean concentrate at $H$. The partitions, which separate the waste and divide the orey shower into classes of varying richness, can be set so as to obtain any kind of classification which is most suitable to the ore under treatment.

A blast of air is drawn along the face of the belt in the opposite direction to that of its travel, and helps to set free any nonmagnetic grains caught up between the others.

(e) Kessler, $\uparrow$ of Oberlahnstein, is the iliventor of a machine acting in a totally different manner (Fig. 684). It is a broad, endless belt or chain, armed with a number of iron points, travelling over the two rollers $A$ and B; the former is an electro-

* "The Hoffman Magnetic Separator," Eng. Min. Jour., vol, lii., I89r, p. 680 .

+ B. u. l. Z., 1891, p. 382 . 
magnet, the latter is made of wood. The stuff falls from the hopper $\mathrm{F}$ into the conveyor $\mathrm{C}$, which feeds it across the whole width of the cylinder $\mathrm{A}$, and then drops into the curved gutter $\mathrm{G}$, where the iron points are drawn through it as the belt revolves. The points, while under the influence of the electro-magnet $A$, pick up the magnetic particles, and let them drop into the compartment $\mathbf{E}$ on losing their power, while the non-magnetic particles fall at $D$. The partition between can be placed

FiG. 684 .

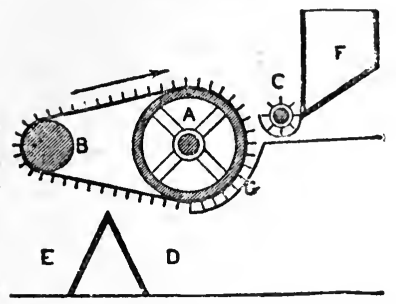

F1G. 685 .

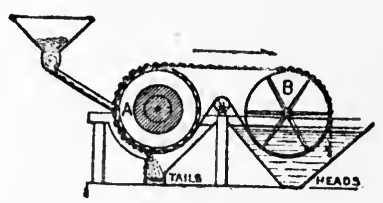

in any suitable position. This machine has been used in Spain for separating iron ore from calamine, after the former has been inade magnetic by a reducing calcination.

$(f)$ Lovett-Finney machine (Fig. 685) in some respects resembles the Conkling separator. It is a wet machine, consisting of an endless canvas belt travelling upon two drums, $A$ and $B$, one of which, A, has its outer surface made of bars of iron ; these become magnets of alternate polarity, as they are connected alternately with the iron di:cs forming the ends of the drum, which form the poles of an electro-magnet. The ore is fed against the belt about half-way up the magnetic drum $A$, and as the belt revolves with the drum, the magnetic particles are carried up, whilst the non-adherent waste is washed off by a stream of water. The concentrate is conveyed over the pulley B into a tank, and drops off, as it is no longer subject to the attractive force.

(g) Rolls.-In the Ball-Norton machine (Fig. 686) the magnetic particles are drawn against revolving drums made of paper pulp, FIG. 686.

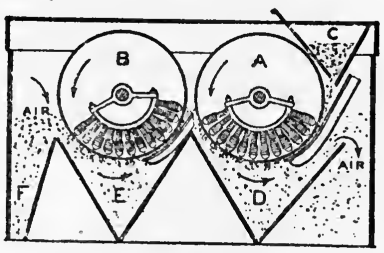
instead of being attracted to the surface of a canvas belt. There are two drums, $A$ and $B$, revolving in thesame direction, in each of which are arranged electro-magnets capable of holding magnetic particles against a certain portion of the under surface. As usual, the magnets are alternate in polarity. The ore is fed from a hopper $\mathrm{C}$ against the roll $A$, the tails drop at once into $D$, and the adherent magnetite travels along with the roll till it begins to leave the 
magnetic field; the centrifugal force now overpowers the magnetic attraction, throwing the grains against the roll $\mathrm{J}$. Those which are completely magnetic attach themselves to $\mathrm{B}$, while ore mixed with waste falls into the compartment $\mathbf{E}$; lastly, the clean magnetite, on escaping from the influence of the magnets, yields once more to the centrifugal force and is deposited at $\mathbf{F}$. A strong current of air is being constantly drawn through the machine in the opposite direction to the travel of the ore and assists in the cleaning.

(h) The Buchanan separator* (Fig. 687) is made of two castiron rolls, revolving in opposite directions, supported on the ends

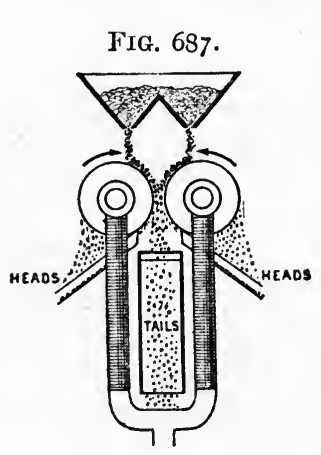
of an electro-magnet; the two rolls thus become the poles of a huge horse-shoe magnet, and the magnetism is most strongly developed where they most closely approach each other. As the ore drops down between the rolls, the magnetic particles fly to them, and are carried along until they fall off at the sides, when the centrifugal force overpowers the now diminishing magnetic attraction. The poor non-magnetic particles fall vertically.

(i) Zinc blende found mixed with chalybite at Friederichssegen is roasted, so as to convert the latter mineral into magnetite, and then treated in the machine shown in Figures 688 and 689. It is composed of a brass cylinder $\mathrm{A}$, with a number of little ridges $\mathrm{S}$, parallel to the axis, and four sets of stationary electro-magnets $\mathrm{B}$. $\mathrm{T}$ is the ore-hopper which supplies the feeder $\mathrm{D}$ : this is a sheet-iron tray, which is made to oscillate by cams upon a little shaft driven by the pulley $\mathbf{Q} . \quad \mathbf{P}$ is the main belt pulley upon $H$, the shaft of the brass drum, and $R$ is a pulley which drives $Q$ by a belt. $\dagger$

A regular stream of fine ore is fed against the brass cylinder by the feeder D, and the grains of blende at once fall into the compartment $Z$; the magnetic oxide of iron is held against the cylinder by the attraction of the electro-magnets, and is carried over by the little longitudinal ridges until it falls into the compartment $\mathrm{F}$.

( $j$ ) King's $\ddagger$ magnetic dressing machine works by the aid of permanent magnets fixed upon a revolving drum. Like other inventors he arranges his magnets so that their poles alternate,

* Eng. Min. Jour., vol. xxxv., 1833, p. 133 ; vol. xlvii., I899, p. 542.

+ Bellom, "Etat actuel de la préparation mécanique dans la Saxe, le Hartz et la Prusse Khénane," Annales des Mines, sér. 8, vol. xx., I89I, p. 5 ; li. u. h. Z., I892, p. 37.

† Fifty-third Ann. Rep. R. Corn. Pol. Soc. Falmouth, 1885, p. 44, 
and he thus makes the grains tumble over and shake off any loosely intermingled non-magnetic particles.

(k) The Wenström * is a Swedish machine, which has been in use at Dannemora and other mines for some years (Fig. 69c). It has a stationary electro-magnet $\mathrm{A}$, and a revolving armature barrel $\mathrm{B}$, consisting of a number of soft iron bars separated by strips of

FIG. 688.

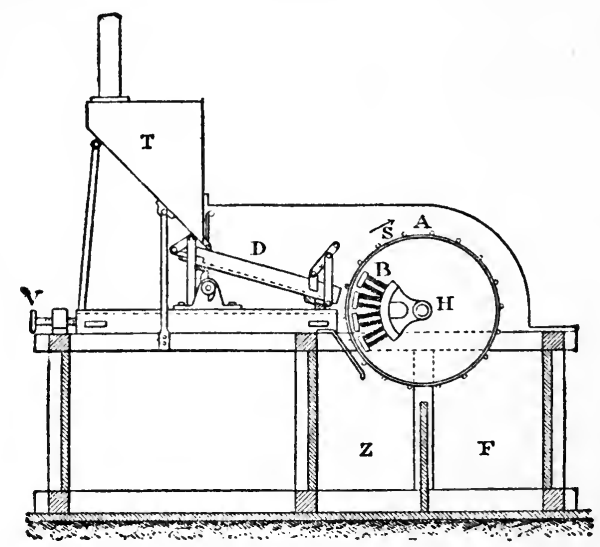

FIG. 6S9.

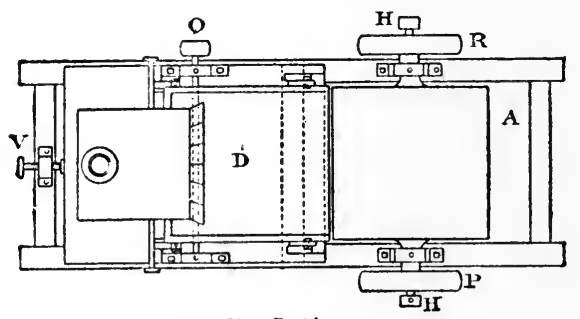

Scale ${ }^{1 / 36}$

wood. The electro-magnet lies on one side of the centre of the barrel, so that the iron bars of the armature become magnetised only during part of the revolution. $\mathrm{C}$ is a tray feeding the ore on to the top of the barrel, D a shoot for the non-magnetic particles, and $\mathbf{E}$ the shoot for the concentrate. The magnetic grains adhere to the soft iron bars when these are close to the electro-magnet, and are carried past $\mathrm{D}$ as the barrel revolves;

- E, M. J., vol. xlvi., I888, p. 437. B. u. h. Z., I891, p. 178. 
as the bars recede from the electro-magnet, they lose their power and let the iron ore drop into $\mathrm{E}$.

(l) Deflection.-The simplest of all magnetic separators is one devised by Ldison (Fig. 69r).* It is based upon the fact that if a thin sheet of finely crushed ore drops past a powerful electromagnet, the magnetic particles will be drawn towards it and deflected from their direct downward path, whereas the nonmagnetic particles will fall vertically. If a partition is fixed in a suitable manner, the concentrate falls on one side and the waste on the other. Diagrammatically the machine may be shown thus :-A A represent the electro-magnets, B a hopper delivering the fine ore through a long narrow slit; $\mathrm{C}$ is a thin partition. The waste falls vertically into the compartment $D$, and the iron ore into $\mathrm{E}$.

Magnetic separators are chiefly used for concentrating the FIG. 690. Fig. 69I.
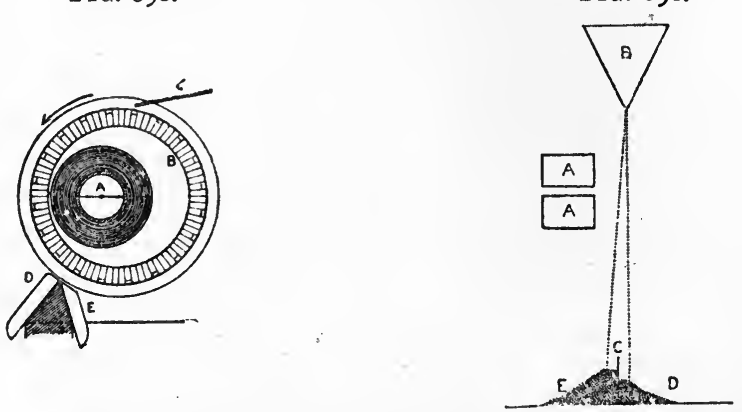

magnetite from ores that are too poor to go to the furnace in the crude state; and it has been proposed to make brown hæmatite magnetic by partial reduction at a low red-heat, but other uses have been mentioned in describing the various machines. For instance, by the ordinary washing processes it is impossible to separate chalybite with a density $3 \cdot 7$ to $3^{\circ} 9$ from blende with a density of 3.9 to 4.2 . The aid of magnetism is here invoked with success as already explained.

The Namaqua Copper Company use King's magnetic separator for extracting the magnetite which is mixed with bornite and chalcopyrite, in order to obtain a product richer in copper.

In a similar manner a magnetic concentrator of the Ball-Norton type has been employed in Queensland for treating a mixed concentrate of magnetite and bismuth ore, obtained by a wet-dressing process. The percentage of bismuth is raised in this way from ro or 12 to 20 per cent.

On a small scale, the magnet is of service for extracting magnetic

* E. M. J., vol. lix. 1889 , p. 479 , and vol. liii. 1892, p. 662. 
particles when washing samples of tin ore on the vanning shovel, or gold in the batea.

(6) FRIABILITY.-Some minerals are more easily crumbled and reduced to powder than others, and if the difference in friability is great, it is possible after crushing to effect a separation by a mere process of sifting. An instance of this rare method of concentration occurs at the graphite mines near Passau, in Bavaria.* The softer kinds of mineral obtained from the mine are ground in mills, when the thin greasy elastic plates of graphite arrange themselves parallelly to the surface of the stones, and preserve their flat shape, while pieces of more brittle minerals are reduced to the state of fine powder. The ground product is sifted upon fine silk cloth, the dust poor in graphite passes through the fine holes, but the scales of graphite are left behind. As might be supposed, the separation is not very thorough.

Büttgenbach $\uparrow$ has separated blende from iron pyrites in a somewhat similar way, the former mineral being much more easily pulverised than the latter. He used a Vapart disintegrator to treat a mixture of blende and pyrites, in grains $\frac{1}{4}$ inch to $\frac{2}{5}$ inch across, and by suitably regulating the speed, he was able to reduce the blende to the state of fine sand without affecting the pyrites to any appreciable extent. The blende extracted by sifting contained 50 to 55 per cent. of zinc, whilst the pyrites was almost free from this metal.

The dressing of the plumbiferous sandstone of Mechernich is probably the most important instance of a difference in friability affecting the method of treatment. The little concretions of galena and quartz are comparatively hard and the sandstone very friable. The greater part of the stuff coming from the mine has crumbled to the state of loose sand before it reaches the works, so that the first comminution, which sets free the rich knots, is sufficiently effected by the mere handling, without the powerful crushing machinery usually required for the preliminary treatment of a lead ore.

\section{PROCESSES DEPENDING UPON CHEMICAL PROPERTIES.}

(I) SOLUTION, EVAPORATION, AND CRYSTALLISATION.-Processes of this kind are employed by the miner in some of the few cases where the mineral is soluble in water; aid is derived from certain other solvents, such as benzine and hydrochloric acid.

The principal minerals soluble in water are borax, nitrate of soda, potassium salts, and common salt.

* Andrée, "Der österreichische und bayerische Graphitberghan," B. u. h. Z., 1890, p. 270 .

+ "Aufbereitung von Blende und Schwefelkies," B. u. h. Z., I881, p. 294 
The crude burax of California* is ground and thrown into a pan containing a boiling saline solution, frequently the motherliquor from the second crystallisation. The salts dissolve and the sand sinks to the bottom. The hot solution is allowed to stand so as to clarify, and is then run off into pans and left to cool for five to nine days, during which time the borax crystallises out. The crystals obtained in this way are somewhat impure. They are refined by being dissolved and allowed to crystallise a second time.

Nitrate of soda is treated on a larger scale. $\dagger$ The caliche, crushed into lumps about 2 inches across, is tipped into large tangular boiling tanks full of water, which are heated by a iral 3-inch steel pipe with steam at a pressure of $60 \mathrm{lbs}$. to e square inch. The boiling is carried on by Shanks' lixiviating stem, which causes a continual circulation of the lighter liquid the other boiling tanks by following the denser and heavier plution. As soon as the solution is concentrated to r ro by 'waddell's hydrometer, it is allowed to settle for a short time, nd is then drawn off to the crystallising tanks. The refuse in he boiling tanks is again treated with water in order to extract a ittle nitrate which it still contains.

The crystals are shovelled out on to drying floors and put up in sacks for export.

The mother-liquor, which contains a little sodium iodate, is added to the water used for dissolving a fresh stock of "caliche," and by repetitions of the process it becomes rich enough for the extraction of the iodine; this is precipitated by sodium bisulphite, washed and pressed into cakes. The crude iodine so obtained is purified by sublimation.

The principal potassium salt of Stassfurt is carnallite, a hydrated double chloride of potassium and magnesium. Some of it is treated on the spot in order to produce commercial chloride of potassium.

The crude mineral, after being coarsely ground, is treated with hot water, and the strength of the solution is so arranged that only the chlorides of potassium and magnesium are dissolved out. The residues are treated with cold water which dissolves out some sodium chloride and leaves behind kieserite (bydrated magnesium sulphate). This is passed through a fine sieve, moulded into blocks, and sold.

The solution of the chlorides of potassium and magnesium is allowed to settle and cool, and three products are obtained from it : $(a)$ crystals of potassium chloride; $(b)$ mother-liquor; $(c)$ slimes. The crystals $(a)$ still contain a little sodium chloride. They are lowered into water in iron vessels and much of the sodium chloride

* C. Napier Hake, "An Account of a Borax Lake in California," Jour. Soc. Chem. Ind., vol. viii., I889, p. 854 .

+ Harvey, "Machinery for the Manufacture of Nitrate of Soda at the Ramirez Factory, Northern Chili," Proc. Inst. C. E., vol. Ixxxii., 1884-85, p. 337 . 
is dissolved out; they now contain 80 per cent. of potassium chloride, and after being freed from moisture in Thelen's drier, they are packed in bags and sold.

The mother-liquor $(b)$ is heated and gives crystals of artificial carnallite, which are treated again in the same way as the native mineral. On evaporation the final mother-liquor yields hydrated magnesium chloride.

'The siimes $(c)$ are put into a filter press, and the solid cakes so obtained are calcined and sold as manure after being ground. They owe their fertilising value to some potassium chloride which they still contain.

The evaporation of brine may be carried out naturally or artificially. In Southern Europe, and in other countries where the sun has sufficient power, sea water led into shallow ponds gradually becomes concentrated enough to deposit salt. In Germany, weak brine is strengthened by allowing it to trickle down through brush-wood contained in huge frameworks of timber. A great surface is thus exposed to the atmosphere with much evaporative effect if the weather is dry.

In this country common salt is mostly obtained from brine pumped up out of bore-holes or out of inundated salt mines. After being allowed to settle, the brine is evaporated in large sheet-iron pans heated by the flame of a coal fire passing underneath along flues. Some of the pans in the Mildlesbrough district are 70 feet long and 24 feet wide, with a depth of 20 inches at the fire-end, and gradually lessening to 16 inches at the other. In Cheshire, even larger pans may be seen, some, in fact, as much as 100 feet long by 45 feet wide. The heat of the fire gradually drives off the water, and crusts of salt form on the surface; they fall to the bottom and are shovelled out; after being allowed to drain, the salt is ready for despatch to the alkali works.

At Bex, in Switzerland, where fuel is dear and water-power abundant, the brine is evaporated in a closed boiler, like a large egg-ended steam boiler, heated from below; the process of evaporation goes on continuously, brine being constantly pumped in and salt being drawn off as it is deposited.

Benzine is employed in the exceptional case of ozokerite for dissolving out remnants of the mineral left in some of the residues.

Heavy spar stained by oxide of iron is "bleached " by sulphuric acid; the mineral, after being crushed to the state of coarse powder, is put into lead-lined vats with dilute sulphuric acid, which is bruaght to the boiling-point by the injection of steam. The acid dissolves the oxide and leaves white barytes ready for grinding after it has been dried.

Tin ore contaminated with copper ore may be freed from the latter metal by hydrochloric acid ; the so-called "burnt leavings," that is to say the tailings produced in washing the roasted concentrates of tin ore, originally envelored or accompanied by 
sulphides, are treated with hydrochloric acid; the coppery solution is led into pits, where the metal is precipitated by iron.

(2) ATMOSPHERIC WEATHERING.-I must point out that though weathering of ten results from mere loss of water, it may in other cases be caused by the chemical decomposition of one of the minerals contained in the stuff under treatment. As already stated, the boundaries between the various dressing processes are not distinctly defined.

The crumbling-up of the diamond-bearing rock under atmospheric agencies plays an important part in the extraction of the gems, and with no other mineral is a weathering action of this kind carried out on so large a scale or in such a systematic manner. The floors devoted to this process at De Beers* mine occupy some thousands of acres. They are merely fairly level ground from which the bush and grass have been removed, and which has been rolled to make it hard. The ground is laid out in rectangular sections, 600 yards long and 200 wide, and is enclosed by high wire fences. Main lines of rails on each side of the floors and subsidiary portable lines serve to bring the trucks of "blue," which is tipped and spread out so that a load, i.e., I 6 cubic feet or $1600 \mathrm{lbs}$., will occupy an area of 21 square feet.

After being left for some time, the "blue" is broken up by means of picks into pieces not larger than 4 inches cube, and is again left to dry for a further period, until most of the natural water has evaporated. The artificial "diamond field" is then watered, to aid the disintegration, and lastly harrowed and rolled; in fact, the miner endeavours to bring about the pulverisation somewhat in the same way that the farmer prepares his land for tillage.

The stuff is known at first as "coarse blue ground," then as "broken blue ground," and finally, after the rolling, as " pulverised blue ground."

The length of time required for this disintegration depends not only upon the atmospheric conditions - that is to say, the season of the year and the amount of rain-but also upon the mine from which the blue is obtained. The blue from Kimberley mine becomes sufficiently disintegrated in three months in summer, whilst the De Beers blue requires double that time. It is evident, therefore, that a very large stock of blue has to be kept on the floors, if the washing machines are to be supplied regularly.

'The diamond is not the only gem which may be released from its matrix by disintegration under atmospheric agencies. The garnetiferous gravel of Bohemia $\dagger$ was at one time allowed

* De Beers Consolidaterl Mines, Limited, Second Annual Report for the Year ended 31 st March, 1890, p. 18.

$\dagger$ Raymond, Di-cussion upon Kunz's papes on "Bohemian Garnets," Irans. Amer. Inst. M. E., vol. xxi., I892, p. 249. 
to weather for three months on the surface, in order to fit it for the subsequent washing process.

Phosphate of lime occurring in the form of nodules in clay is treated in a like manner. The phosphate dug from open pits in the Lias in the department of the Haute-Saône ${ }^{*}$ is left exposed to the air often all the winter; a part of the earthy matter falls off, and the nodules have simply to be screened dry, in order to separate a large portion of the clay with which they were only originally mixed. Again, in the Vosges there is a phosphatic bed of the same geological age, consisting of soft nodules forming only $\frac{1}{10}$ or $\frac{1}{8}$ of the bed of brown clay by which they are enveloped. The stuff is spread out on the fields and raked over occasionally. The clay crumbles off, and at the same time the nodules harden from losing their moisture; they are then picked out by hand.

Nodules of clay ironstone are freed from shale in a similar way; and ores of iron more or less contaminated with iron or copper pyrites gradually have a portion of their sulphur washed out in the form of soluble sulphates, if exposed for a sufficient time to the action of air and rain.

Fire-clay is found to be better suited for making bricks after weathering for some months, than when first raised from underground.

(3) CALCINATION OR ROASTING.-The object of calcination or roasting may be :

a. To effect a change in the chemical composition of a valuable mineral, and so produce either an ordinary article of commerce or one that is more readily saleable than the raw material.

$b$. To effect a change in the chemical composition of some of the substances accompanying a valuable mineral, and so get rid of them partially or render them more easily separable by other processes.

The commonest example which can be cited is burning limestone; the action of heat is made use of to drive off the carbonic acid and leave quicklime. Another instance is furnished by clay ironstone, or any ore in which the iron occurs mainly in the form of carbonate. Simple exposure to heat converts ferrous carbonate into magnetic oxide; the former contains 48 per cent. of iron, the latter 72 per cent.; consequently, if the ore has to be sent to a distance there is a saving in freight, besides which the ore is more acceptable to the ironmaster for his furnaces.

Gypsum is calcined in order to expel the water chemically combined with it, and convert it into plaster of Paris.

With the ores of arsenic, it is the valuable ingredient which is driven off. Mispickel and other arsenical ores are roasted at

* Statistique de l'industrie minérale en France et en Algérie en 1886, Paris, I888, p. 268 and p. 282. 
mines in order to produce arsenious acid, which is collected in special flues.

Ores of copper are sometimes calcined at mines, with the object of extracting the arsenic before sale to the smelters, who would pay nothing for this latter metal and prefer its absence.

Calcination is resorted to in the case of some iron ores in order to get rid of the sulphur, due to intermixed iron pyrites or pyrrhotine, and so free the ore from an element which the smelter dislikes. Thus in Northamptonshire the undecomposed greenish lumps in the bed are picied out on account of the sulphur they contain, and put aside. When a sufficient quantity has accumulated, a heap is made with a little coal and fired; the ore loses nearly all its sulphur in the burning and is thus fitted for the blastfurnace.

Auriferous ores are roasted in some instances for the purpose of liberating the gold which is so enveloped in sulphides and sulpharsenides, such as iron pyrites and mispickel, as to be caught with difficulty by mercury.

Partially concentrated tin ore (whits) is roasted in order to convert iron pyrites and mispickel into pulverulent oxides which can easily be separated by washing. Again, tin ore is occasionally associated with a considerable amount of wolfram, which approaches it so closely in density that separation by washing is impossible. The mixed concentrate obtained by the ordinary dressing processes, consisting of cassiterite mixed with wolfram, is roasted with carbonate or sulphate of soda; soluble tungstate of soda is produced, which is dissolved out by water, leaving behind the insoluble cassiterite fit for the smelter.

Lastly, we may take the case of zinc ore. Blake* renders the separation of blende from marcasite commercially possible, by roasting the mixed minerals at a temperature sufficient to convert the latter into oxide, while the former remains unchanged. The difference in specific gravity is then sufficient to allow the ordinary washing processes to take effect. Smithsonite mixed with limonite $\dagger$ is roasted with coal in order to reduce the ferric oxide to the state of magnetic oxide, and thus render it separable by a magnetic process.

It now remains to be seen how calcination is carried out. Minerals may be burnt in heaps, in kilns and in furnaces.

Clay ironstone is usually burnt in heaps with the addition of a little coal; but one variety, black band ironstone, contains a sufficient amount of carbonaceous matter to burn of itself.

The spathose ore underlying the limonite ("rubio") at Bilbao is now being successfully calcined on a very large scale previous to shipment. According to Mr. Windsor Richards, the raw oro

* "The Separation of Zinc Blende from Iron Pyrites." Trans, Amer. Inst. M. E., vol. xxii., I893-4; and (†) Payne in the Discussion.

‡ "Pres. Address to I. and S. Inst," Cull. Guard., vol. lxv., I893, p. 955 
contains 43 per cent. of iron and 25 per cent. of carbonic acid, whilst the calcined ore gives $5^{8}$ per cent. of iron and only 2 per cent. of moisture. One of the large kilns gets through $r_{5}$ co tons of raw ore weekly.

The commonest example of calcination in kilns is making lime. At large works the time-honoured semi-spheroidal kiln with intermitten action is often supplanted by the Hofmann kiln, in which the processes of charging, burning, and discharging go on continuously.

Some of the baking ovens used for converting gypsum into plaster of Paris, by the simple expulsion of the water of combination, are cylindrical brick kilns so arranged that the flame nowhere comes in contact with the mineral. The fireplace is in the centre, and the hot gases are drawn down flues into an annular arched passage all round the bottom of the kiln, and then ascend through the charge by means of a number of cast-iron pipes. The kiln is covered by a brick dome over which comes a conical hood or chimney.

In making Parian cement from gypsum a different oven is employed, in which a central coke fire sends out its hot gases directly on to the charge itself.

The furnaces used by the miner are usually of the reverberatory type, in which the flame plays into the space containing the charge; the bed may be stationary or revolving. The two most frequently employed in Cornwall and Devon, for roasting the ores of arsenic, copper and tin, are Brunton's calciner and Hockin and Oxland's calciner. The former (Fig. 692) $*$ has a revolving circular bed about 10 feet in diameter, supported by a vertical shaft, which is made to revolve slowly by any convenient source of power, whilst the flames of two fireplaces at the sides play upon it and produce the requisite amount of heat. Depending from cast-iron frames fixed in the roof of the furnace, are three sets of knives or teeth, inclined in such a manner as to shift the ore gradually from the centre, where it is fed on, towards the circumference, where it is discharged. The action of heat in the presence of atmospheric oxygen converts the sulphur and arsenic into sulphurous and arsenious acids, which escape with the other hot gases, and are led into long condensing flues. These are brick or stone passages high enough for a man to stand upright, with partial partitions so arranged as to make the hot gases take a tortuous path. There are large openings on one side for drawing out the arsenical soot at intervals. During the actual calcination these doors or manholes are closed by sheets of iron carefully luted with clay.

The Hockin and Oxland calciner is not unlike the Brückner furnace used in the United States, as it is a revolving cylinder

* Henderson. Op. cit. 
lined with fire-brick. Figures 693 and $694^{*}$ show the construction of such a furnace. A is the cylinder lined with fire-brick, set at a slight inclination and supported on rollers. It is made to revolve at the rate of six to eight revolutions per hour; B is a screw which

FIG. 692.

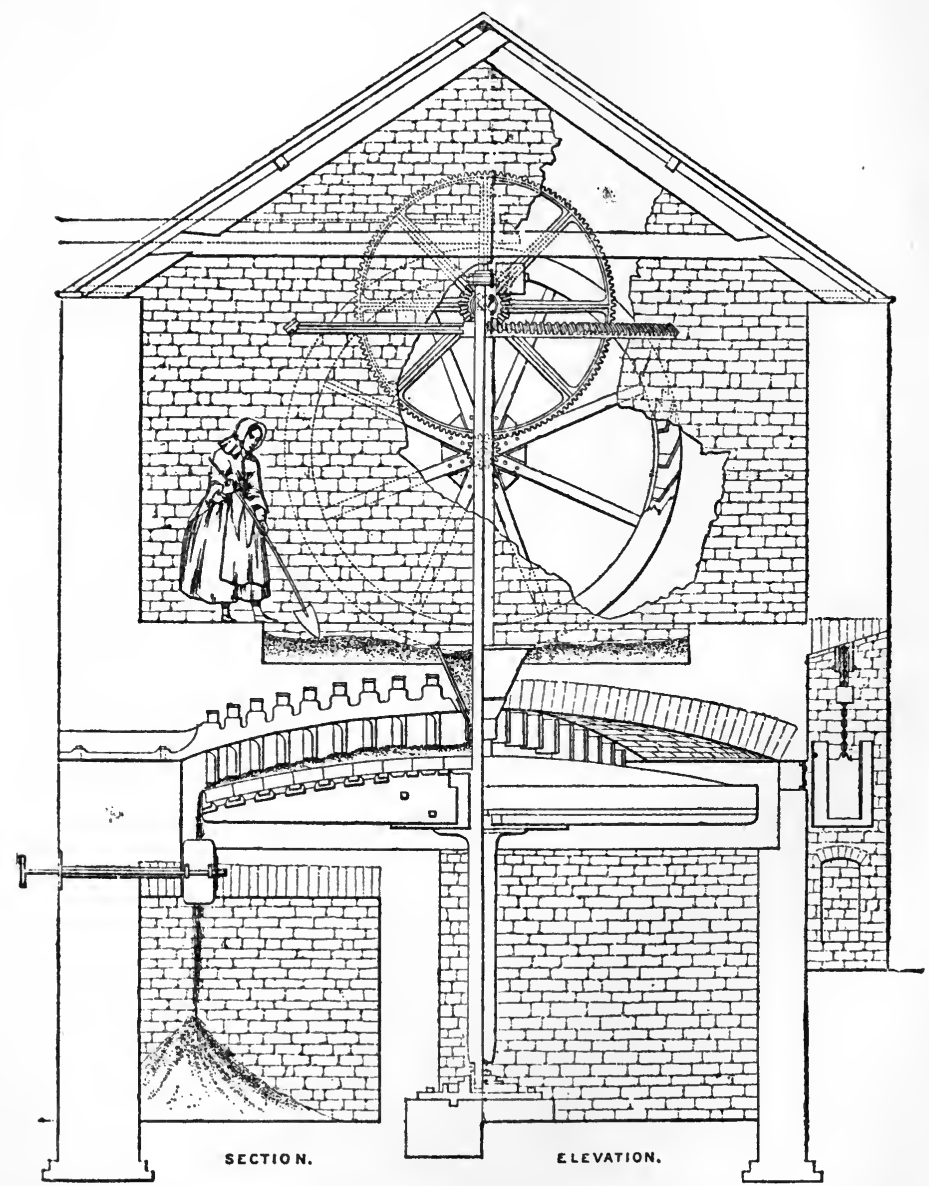

brings down a regular supply of ore from a hopper. The ore travels along very gradually in the direction of the arrow and finally drops into the chamber C. D is the fireplace opening into the lower end of the cylinder, and $\mathrm{E}$ is the beginning of the flues,

* Ferguson, "On the Appliances used for Dressing 'Tin and Copper Ores in Cornwall," Proc. Inst. Mlech. Eng., 1873, p. 128. 
in which the arsenious acid is condensed and through which the sulphurous acid passes on its way to the chimney. The longitudinal ribs of fire-brick, extending two-thirds of the length of the furnace from the lower end, serve to lift up the charge and let it fall, so as to expose new surfaces to the action of the air. One of these calciners used some years ago at Deron Great Consols mine was simply an old boiler tube, 3 o feet long by 3 feet 6 inches in diameter, lined with $4 \frac{1}{2}$-inch fire-brick, so that the clear diameter inside was 2 feet 9 inches. Another was made of an old boiler 5 feet in diameter. The inclination was $I$ in 24 .

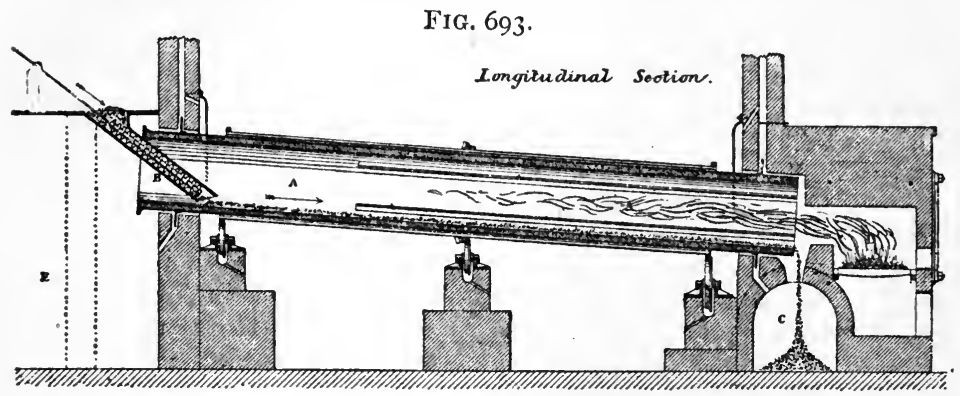

F1G. 694 .

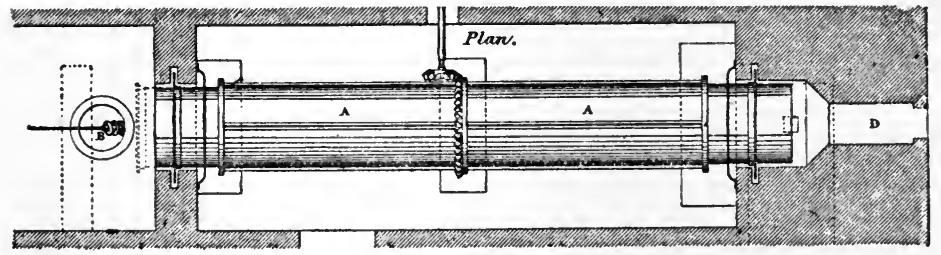

SCALE

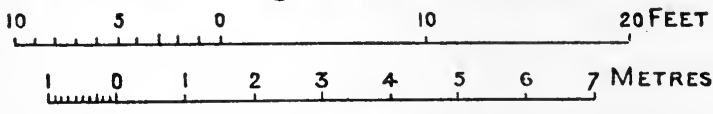

Some of the calamine at Monteponi, which has been concentrated by the ordinary wet methods tuntil it contains 20 per cent. of zinc, is still much mixed with oxide of iron and dolomite. Two per cent. of coal are added, and the ore is passed through the rotary furnace, 42 feet ( $\mathrm{r} 3 \mathrm{~m}$.) long, working continuously like the Hockin and Oxland calciner ; the iron is thus brought to the state of magnetic oxide. On leaving the furnace the ore is moistened with water, which causes the calcined dolomite to fall to powder. It is next treated on screens, and the various categories produced are sent separately to a magnetic concentrator.*

* Oest. Zeitschr.f. B. u. W. vol. xxxvii., 1889, p. 36 ; and Eng. Win. Jour., vol.liv., 1892, p. 77 . 
(4) CEMENTATION.-The precipitation of copper by iron may fairly be regarded as coming within the province of the miner, when the solution flows naturally out of an adit level or is pumped up from underground, or when it is obtained artificially as a by-product in tin-dressing. On the other hand, the metallurgist may fairly claim such operations as those conducted on a huge scale at Rio Tinto, where the cupreous solution is mainly produced by leaching the ore which has been burnt in heaps, or a mixture of burnt ore and raw ore. However, as in other cases, the line of demarcation between the two domains is an arbitrary one, and on this account it is alvisable that the mining student should be well grounded in metallurgy.

The famous old Parys mine in Anglevev, now shorn of its glory owing to the low price of copper, affords the most important example of cementation carried on at a mine in this country. Coppery water is pumped out of the mine, and is led into brick-lined pits containing scrap-iron. The iron is raked over from time to time, and eventually the old pots, kettles, shovels, meat-tins, \&c., pass into solution, while the copper is precipitated. As might be imagined, when one looks at the heterogeneous mixture of articles constituting the scrap-iron thrown into the pits, the precipitate is very impure and contains only some 20 to $3 \circ$ per cent. of metallic copper.

The iron used is not lost; the ferruginous solution running away from the precipitating pits is led into large pools, and there exposed to the action of air and rain. The dissolved iron gradually passes to a higher state of oxidation, producing insoluble ochre, and little by little a deposit of this substance forms upon the bottom of the big ponds. According to the strength of the irony solution supplied, the ponds are run dry and cleared out once in every two or three months. Wind and rain aid the process of oxidation.

(5) AMALGAMATION.-Two metals, gold and silver, are extracted from their ores by amalgamation, that is to say, by processes based upon their affinity for mercury; and here we are once more on the borderland between mining and metallurgical practice. In the case of silver ores, the processes are often complex and require the precious metal to be brought into the state of chloride before amalgamation is possible; besides which they are frequently carried on at works which do not belong to the mining company. I therefore consider that the miner would be encroaching upon the territory of his neighbour by interfering in this instance, whilst, on the other hand, with gold the process is generally simple, and the ore goes straight from the shaft or adit to crushing and amalgamating works owned by the same company as the mine.

The amalgamation of gold takes place by mere contact, either when the particles touch the mercury as they slide or roll along 
in a current of water, or when they are in some way mechanically rubbed against it.

An instance of the first kind of action has already been given in the description of hydraulic mining in Chapter VI., and another may be taken from the ordinary stamping mill of most gold mines in which auriferous quartz is being treated. The pulp discharged through the grates of the mortar-box is allowed to flow over an inclined table, covered with a sheet of copper which has boen simnlgamated. The surface of the copper plate is first very carefully zoured, then cleaned with a solution of cyanide of potassium, and finally rubbed with mercury and a little salammoniac. The bright silvery surface is then capable of picking up the little particles of gold in the pulp and retaining them in the form of a coating of amalgam, which is naturally thickest where the pulp first comes upon the table. When a sutficient thickness has accumulated, the amalgam is scraped off, washed, mixed with a little fresh quicksilver, washed with water, and finally squeezed through canvas or chamois leather. The hard amalgam so obtained is retorted.

Various devices are in use for making the little particles of gold turn over from time to time and so expose fresh surfaces to the quicksilver, in order to increase the chances of such intimate contact as will ensure amalgamation. Sometimes steps are made in the tables, giving the thin stream of pulp a little drop, sometimes the tables are shaken, whilst in the Hungarian mill the pulp flows orer the surface of a bath of mercury, the surface of which is lightly skimmed by revolving iron knives.

Amalgamation will not take place unless the two metals are bright and clean; any slight film upon the mercury, such as is produced by grease or tarnish, prevents contact, and the little particle of gold rolls or slides down over the plate, just as it would do on a plain sheet of copper, and is liable to escape. The greatest care has therefore to be taken to keep the amalgamated plates clean, and from time to time any tarnish may be removed by brushing them with a solution of cyanide of potassium. Other means of keeping quicksilver bright are the addition of a little sodium amalgam, or the production of nascent hydrogen upon the surface of a mercury bath by the passage of a current of electricity. This is the principle of Molloy's amalgamator, and that invented by Chaster and Beck. It is evident from experiments, when the mercury covered with water is connected to the negative pole of a dynamo, and lead plates forming the anode are connected to the positive pole, that the disengagement of hydrogen does keep the bath constantly bright and lively, and fully entitles the metal to its familiar name "quicksilver." Under these circumstances it takes hold of the gold more readily, but the process does not appear to have gone beyond the experimental stage at present. 
Considering the ease with which amalgamation is impeded or prevented by a flimsy coating upon the mercury or upon the gold, it is not surprising that rubbing of some kind should have been tried in order to brighten the surfaces of the two metals and so secure perfect contact. It seems probable that when gold was worked by the Romans in the Alps, the precious metal was extracted by rubbing the ore to powder with water and mercury upon slabs of gneiss by stone mullers. Subsequently, no doubt, the quern was pressed into the service of the gold-miner, and by adding a rude horizontal water-wheel to the quern, the hardy Pied montese miners developed their molinello, or small mill, by means of which large quantities of gold have been obtained. Proceeding one st. p further, we have the arrastra, the most perfect form of which can probably be seen in Italy, and substituting iron and steel for stone we have the various pans. All these mills perform a double service; they not only break up the ore and set free the minute particles of gold, but they at the same time scour the gold, make it bright and rub it against the quicksilver. Probably in many cases the gold makes a streak upon the bed, just as it would do if rubbed upon a jeweller's touchstone, and so gives a clean bright surface with which the mercury at once amalgamates. The mills may also be worked as concentrators, for if a stream of water is run through them while they are being driven slowly, the light particles are carried off, and the heavy metallic sulphides lie at the bottom in contact with the mercury, ready to give up the gold they contain as soon as they are crushed fine enough to liberate it. The heat developed by the friction of the muller is considerable and may assist the process of amalgamation, and indeed it may explain how it is possible to extract 80 per cent. of the gold from ores containing Io to 20 per cent. of iron pyrites by simple amalgamation in arrastras. The arrastra is a more suitable amalgamator for such ores than the copper plate, but it is a slow grinder and it causes a large loss in quicksilver when raw ore is treated by it. Various other mills are used for the same purpose.

APPLICATION OF PROCESSES.-Having now passed in review the various mechanical, physical, and chemical processes which are employed by the miner in preparing his minerals for sale, it remains to say a few words upon the manner in which they are applied in different cases. Space will not admit more than an outline, nor is it necessary in a general text-book to enter deeply into details.

For the sake of convenience the various minerals will be taken in alphabetical order.

Amber.-The lumps are separated by washing from the enclosing sand, and are sorted according to colour and size. The small pieces are treated in a steam bath at a temperature of $150^{\circ}$ with certain re-agents in order to remove the dark rind, and the clear 
kernels which remain are melted up together and sold to the varnish merchants.

Arsenic.-Arsenious acid is obtained by roasting and sublimation. The crude arsenic resulting from the treatment of tin "whits" is usually of a dirty grey colour owing to the admixture of solid carbonaceous particles deposited by the smoke; it is spoken of as "arsenical soot," and is sold by the miner to works where it can be purified by being re-sublimed.

At some mines, however, which yield large quantities of mispickel, the final purification is performed on the spot, and white sublimed arsenic and arsenical glass are prepared by re-sublimation, put into barrels and sent out into commerce.

Asbestos.-The dressing of the asbestos (chrysolite) of Canada is simply a process of cobbing-i.e., the separation of the valuable mineral from the enclosing serpentine by well-directed blows of the hammer.

Asphalt.-The crude Trinidad pitch is purified or refined on the island by melting it in iron pans and allowing the earthy matter to fall to the bottom. In France the process is somewhat different: the crude pitch is boiled with a heavy tar oil obtained from the distillation of shale, in the proportion of 9 of pitch to 4 of tar oil. The 30 per cent. of water in the pitch is driven off and a small amount of earthy matter is deposited, but the refined pitch, consisting of the two ingredients which were mixed, still contains a large percentage of clay.

Bituminous sandstone * is made to yield up its pitch by melting with water. The sandstone is broken up into lumps about 3 inches across, thrown into cauldrons of boiling water, and stirred for an hour. 'The bitumen melts and rises to the top, whilst the sand falls to the bottom. The bitumen is skimmed off; though it is by no means free from sand, if the original sandstone was finegrained. It is then re-melted and the sand allowed to sink; the liquid bitumen is drawn off and allowed to cool in moulds, but the sandy deposit at the bottom still contains a good deal of pitch which cannot profitably be separater.

The treatment of the bituminous limestone of Seyssel has already been described in the general part of this chapter.

Barytes.-The principal processes in preparing barytes for the market are drying and grinding.

The barytes coming from the mine is washed and picked, and pieces intermixed with rock are cleaned by cobbing. The lumps are dried upon a tiled floor heated by flues underneath, and are then crushed, either by rolls or an edge-runner, to a coarse powder, which is twice ground in mills like flour-mills. French burr stones are preferred. The second grinding vields a powder as fine as flour, which is put up into barrels ready for sale.

$$
\text { * Malo, L'Asphalte, Paris, 1888, p. } 68 .
$$


Iron-stained barytes is "bleached" by acid, as already ex: plained.

Borax.-The earth obtained at the borax lake, California, is ground, and then dissolved in water brought to the boiling point in large iron vats by injecting steam. The contents are allowed to settle, and the clear solution, containing the carbonate, sulphate, chloride, and borate of sodium, is drawn off into pans and allowed to cool. The borax is the first to crystallise out, and the crystals are collected and sold, or are re-dissolved; this second solution furnishes, on crystallising, the refined borax of com.merce.*

Boric Acid.-The solution of boric acid, obtained in Tuscany by passing natural steam-puffs (soffioni) through water, is evaporated either by the heat of some of these soffioni, or artiticially, until the gypsum and other impurities separate; the liquid is drawn off and the acid is allowed to crystallise out.

Carbonic Acid.-If not at once piped off to white lead or soda works, carbonic acid is compressed and sold in the liquid state.

Clay.-Common clays are used on the spot, and made into bricks, tiles, or drain-pipes. The potter's clay of Devonshire is sent away in cubical lumps just as they come from the pit, but the china clay is obtained by a true dressing process. The stream of water running down the side of the openwork, and carrying with it all the ingredients of the decomposed granite, is led into a pit where the coarse particles of quartz settle, $\uparrow$ whilst the clayey water is conducted into long channels in which fine sand and mica are deposited gradually. Lastly, the milky stream reaches circular pits, 20 to 40 feet in diameter, and 6 to 20 feet deep, drops its kaolin, and passes off as almost clean water. The creamy deposit is dried in the manner already described (Fig. 676), and the china clay of commerce is the result.

Fuller's earth is also a clay which has to be dressed before being sent into the market. The processes to which it is usually subjected are drying, sifting, and grinding.

The clay coming from the pits is dried in kilns (Fig. 677) and sifted by hand to take out the fine, if the customer insists upon having nothing but lumps. The dry lumps are put up into sacks, and the small is sifted again. The very fine, below $\frac{1}{8}$ inch, is thrown away, and the courser part is ground to fine flour in an Askham mill, and so sold.

In addition to this dry dressing, some of the clay is ground in an edge-runner, run into settling tanks, and dried much in the same way as china clay.

* Napier Hake, "An Account of a Borax Lake in California," Jour. Soc. Chem. Ind., vol. viii., 1889, p. 856; E. L. Fleming, "Borax," Chem. News, vol. lxiii., 1891, p. 74.

† Collins, The Hensbarrow Granite District, Truro, 1878, p. 18. 
Copper Ore.*-The ores of copper are so different that no general scheme of treatment suitable to all of them can be prescribed. Thus, for instance, the copper shale of Mansfeld is merely picked at the mine before going to the smelting works, which receive an ore containing only 2 to 3 per cent. of metal. At the Lake Superior mines concentration by water can be carried to such a pitch that the "barrel copper" leaving the dressing establishments often has more than 70 per cent. of metal.

Hand-picking is generally an important part of the dressing when the ore consists largely of a mineral like chalcopyrite, because it is easily crushed to powder liable to be carried away by water in washing. At the Rio Tinto mines $\uparrow$ the following are the principal varieties separated by picking:

$a$. Rich ore with $5 \mathrm{cr} 6$ per cent. of copper, which is smelted on the spot.

b. Lump ore with 2 to 3 per cent of copper, which is exported.

c. Lump ore with 2 per cent. of copper, which is burnt in heaps on the spot.

$d$. Fine ore, which is added to the burnt ore, so that its copper may be gradually rendered soluble.

e. Quartzose ore, which is retained for the furnaces.

When copper pyrites occurs coarsely intermixed with quartz and other earthy minerals, the dressing usually begins with hand-picking and crushing by rolls ; the coarser grains are jigged, and the finest particles are cleaned and rendered rich enough for sale, by buddles, frames, revolving tables, or endless belts. Intermediate products made up of ore and waste have to be re-crushed before a complete separation is possible.

At the Lake Superior mines, where the mineral is native copper, the treatment is different. The rock from the mine is stamped by huge Ball or Leavitt stamps until it will pass through holes of $\frac{3}{16}$ inch, and the copper-bearing stream is delivered into upward current separators, which make five classes; the four coarsest sizes are treated on Collom jigs, and the fifth upon revolving tables.

Diamonds.-The dressing of the diamond-bearing rock of South Africa $\ddagger$ may be divided into the following separate operations :

a. Natural disintegration, under atmospheric agencies, aided by watering, rolling and harrowing.

* Egleston, "Copper Dressing in Lake Superior," Metallurgical Review, New York, vol. ii., r 878.

Henderson, "On the Methods generally adopted in Cornwall in Dressing Tin and Copper Ores," Proc. Inst. C. E., vol. xvil., I857-58, p. Io6.

Rathbone, "On Copper Mining in the Lake Superior District," Troc. Inst. Mech. Eng., I887, p. 86.

+ Collins, "On the Geology of the Rio Tinto Mines," Q. J. Geol. Soc., vol. xli., I 883 , p. 256.

$\mp$ De Beers Consolidated Mines, Limited, Second Annual Report, for the Year ending 31 st March 1890, p. 19. 
b. Screening in a revolving screen, with holes $\mathrm{I}$ inch by $\mathrm{I}$ inch, or $\mathrm{I}$ inch by $\mathrm{I} \frac{1}{4}$, which take out coarse lumps ; these are returned to the depositing floors to undergo the weathering process a little longer.

c. Washing the fine in rotary pans, which separate clean gravel from the fine sand and mud; the latter flow into another similar washer, where the process is repeated in case any diamonds should have escaped in the overflow from the first.

$d$. Screening the clean gravel through a cylindrical sieve, with round holes varying from $\frac{1}{8}$ inch to $\frac{3}{8}$ inch in diameter, making in all five sizes. The largest grains discarded by the sieve are picked at once.

e. Treatment in a "pulsator," which is simply a jig with continuous feed and discharge like the Hartz jigs. The bed is formed of leaden bullets. A concentrate, containing the diamond-, passes through the bed, and refuse goes over the edge of the jig.

$f$. Picking out the diamonds by hand, first by white men when the gravel is wet, and then by native convicts when it is dry. The operation of picking is repeated as often as enough diamonds are found to repay the cost of the labour.

Flint and Chert.-Flints are trimmed into square-faced lumps for building purposes, or are split and trimmed into gun-flints. Chert is trimmed by hammering into blocks for use in the potteries.

Gold. -The precious metal may be extracted from simple sand and gravel by mere washing, or by washing combined with amalgamation. Hydraulic mining affords an example of the latter method. When the gold is enclosed in hard rock such as quartz, or occurs in a hard tightly cemented conglomerate, the aurifercus stone has to be crushed in order to set the metal free.

The crushing is most often effected by a stonebreaker, followed by stamps, and the pulp is run over amalgamated copper plates. Mercury is often added in the battery so as to catch the coarse gold at once. The amalgam scraped off the plates and taken out of the battery-box is cleaned and retorted, giving spongy gold, which is melted in crucibles and cast into bars. If the ore contains much pyrites or other heavy metallic sulphides, the stuff leaving the amalgamated plates is taken to a dressing machine of some kind, such as a Frue-vanner, which furnishes a concentrate consisting largely of metallic sulphides, more commonly known to miners by their older name of "sulphurets." These are sure to contain gold, and they are further treated in various ways : by direct amalgamation in pans, which means a still tiner grinding, to liberate more of the fine particles of gold, by smelting, by chlorination, or by the cyanide process.

Gold is also extracted by grinding up the ore in mills or arrastras with water and a little mercury. Excellent results have 
been obtained in Italy by this method, even with highly pyritic ores.

It is very necessary that the miner should recollect that gold does not always exist in the same state in the ore, and that the value of the ore depends not only upon the amount of metal in it, but also upon the ease with which it is extracted. A mere assay gives information upon the first point only. It tells how much gold there is per ton, but it does not say whether the metal is in the native state, or whether it is combined with some other element which may render extraction by amalgamation quite impossible. Even when the gold is all native, the size of the particles varies considerably, and they may or may not be wrapped up in iron pyrites or other metallic sulphides. Consequently it is futile to suppose that all gold ores can be treated by one and the same method.

Graphite.-The graphite of Ceylon is first picked at the mine, and then despatched to Colombo to undergo the processes of cobbing, picking, and screening. Men and women, using a tool like a little axe, chip off the waste material from the lumps, and sift the small fragments upon slightly inclined screens made of sheet-iron. They also clean the lumps with brushes made of cocoa-nut husks. In this manner four different kinds of graphite are produced-viz., "large lumps," pieces about as big as the fist or larger ; "ordinary lumps," about the size of walnuts ; " chips," about the size of grains of wheat; and "dust," which includes everything smaller. The graphite is now ready to be barrelled for export.

One mode of concentrating certain kinds of graphite has been mentioned as an instance of a method depending upon differences of friability; but in addition to these dry processes, graphite is also dressed by the aid of water. In Moravia and Bohemia graphite is found in gneiss, and may be intermixed with limestone, quartz, iron pyrites, garnets and hornblende. Rock of this kind is pulrerised by grinding in mills, or by stamping, and the pulp is made to flow into rectangular wooden boxes in which the coarser particles and part of the rock and pyrites are deposited. The graphite-bearing water passes on into a number of long rectangular wooden troughs (tyes, strips, or strakes, Cornwall), in which the graphite deposits itself gradually, whilst clean water flows out of the last trough. The first trough has the worst graphite, and the last the best quality of the mineral. The deposit is dug out, pressed in filter presses, and the resulting cakes are dried in stoves.*

Gypsum.-The preparation of gypsum for the market resolves

* Andrée, “Der österreichische und bayerische Graphitbergbau," $B . u$. h. Z., I890, p. 269.

Schauenstein, Denlibuch des österreichischen Berg- und Hüttenussens, Vienna, 1873 , p. 116. 
itself into picking, breaking, burning and grinding ; or where the gypsum is required for other purposes than cement making, the burning or baking is omitted.

In Sussex the waggons coming from the mine are tipped on to a floor, the large lumps are broken up with a sledge hammer, and any pieces much mixed with worthless rock are picked out as useless. The remainder is sent to a stonebreaker, and the broken lumps go either to a baking oven to be made into plaster, to a burning oven if Parian cement is required, or to a grinding apparatus if the gypsum is sold to manure merchants.

After burning or baking, the product is ground, first by toothed rolls and then under edge-runners. It is now taken up by an elevator, put through a tine revolving screen, and is drawn off into sacks.

Iron.-With a substance of small intrinsic value like iron ore, the methods of dressing must be inexpensive if they are to be commercially profitable; and at the present time it may be said that most of the iron of commerce is obtained from ores which go direct to the smelter without any preparation beyond picking out refuse underground. A few instances of calcination have already been noted, and also the separation of fine ore by a sieve. Iron ore is sometimes washed in order to get rid of adherent clay, and at the mines of North Lancashire some of the hæmatite, mixed with clay and siliceous matter, is made fit for the blast furnace by crushing and jigging.*

The same line of treatment is pursued in the dressing works of the Chateangay Ore and Iron Company, at Lyon Mountain, N.Y. The mine produces magnetic iron ore, the richer parts of which are picked out, whilst the leaner parts, consisting of grains of magnetite disseminated through gneiss, go to the mills for concentration. This mixed ore is crushed by Blake breakers, and after screening is treated in Conkling jigs. $\dagger$

Hæmatite for fettling puddling furnaces is ground under edgerunners, and that which is used for making castings malleable is carefully screened. Special qualities are picked out for these purposes.

In this country the supply of magnetic iron ore is insignificant, and consequently we cannot show examples of concentrating by the aid of magnetism, such as may be found in Sweden and the United States, where this method is occupying much attention, as may be inferred from the descriptions of magnetic separators just given.

Lead.+-A few mines produce lumps of galena so pure that

* J. G. Lawn.

+ Ruttmann, "Concentrating Magnetite with the Conkling Jig at Lyon Mountain, N.Y.," Trans. Amer. Inst. M.E., vol. xvi., 1888, p. 609 ; and E. M. J., vol xlvi., i 888, p. 870 .

$\ddagger$ For details consult Bellom, " Etat actuel de la préparation mécanique 
they merely require washing in order to be ready for sale to the smelter or the potter.

Much of the lead ore from veins is dressed by crushing, sazing and jigging; the particles under $\mathrm{I} \mathrm{mm}$., or at all events under $\frac{1}{2} \mathrm{~mm}$., are treated by revolving tables, percussion ables, endless belts, or buddles.

The crushing is done first by a stonebreaker and then by rolls. Blende is often associated with galena, but owing to the difference in their specific gravities, a separation can be made by the appliances just mentioned. Products obtained from the jigs consisting of mixed minerals have to be re-crushed, and then treated once more by machinery similar to that used for the original ore.*

The soft lead-bearing sandstone of Mechernich $\dagger$ crumbles to pieces so easily, that by the time it reaches the dressing establishment, after having fallen down in the underground chambers and dropped through shoots into the waggons, most of it is in a fit state for the concentrating machinery. The works are specially designed for treating very large quantities of poor ore consisting almost entirely of galena and quartz sand; their main feature is the use of the siphon separator (p. 578), by which a very large proportion of the stuff is at once concentrated into clean concretions (Knotten) containing about 22 per cent. of lead. This concentrate goes to another establishment, where it is stamped and passed through siphon separators, jigs, revolving tables and round buddles, in order to separate lead ore fit for the furnaces.

Manganese.-The only preparation of the Welsh manganese ore is separating the fine ore under $\frac{1}{2}$ inch, by sifting in the mine, and picking out of any pieces of waste or very poor rock.

The Devonshire ore, which consisted largely of psilomelane, was washed and picked, and the "smalls" were jigged. Some of the large ore was crushed; the coarse part was jigged, and the fine cleaned in buddles.

Mica. $\ddagger$ The rough blocks obtained from the mine are cleaved by means of steel wedges into sheets $\frac{1}{8}$ inch or less in thickness. and these are cut by the "scriber" into the shapes required for stove windows. There are a very large number of patterns, ranging in size from I $\times 1$ to $8 \times 10$ inches. The cutting is done

des minerais dans la Saxe, le Hartz et la Prusse Rhénane," Annales des Mines, sér. 8, vol. xx., I891, p. 5 .

Munroe, "The New Dressing Works of St. Joseph Lead Company, at Bonne Terre, Missouri," Trans. Amer. Inst. M.E., vol. xvii., I888, p. 659.

* Sopwith, "The Dressing of Lead Ores," Proc. Inst. C. E., vol. xxx., 1869-70, p. 106.

+ Der Bergbau und Hüttenbetrieb des Mechernicher Bergwerks-ActienVereins, Cologne, 1886, p. 10, and Tables II. and III. ; and $B . u$. h. Z̈., 1886, p. 476.

$¥$ Phillips, " Mica Mining in North Carolina," Eng. Min. Jour., rol. xlvi., I888, p. 418 . 
with a knife along the edges of a template made of iron or tinplate. The blocks of crude mica yield from $\frac{1}{10}$ to $\frac{1}{8}$ of cut mica fit for the market. The refuse scraps are now ground up into fine powder and used in the manufacture of wall-paper, tinsel, hair-powder, and lubricants.*

Nitrate of Soda.-The process of extracting the commercial nitrate from the crude caliche has already been sufficiently described, in speaking of the preparation of minerals by solution and crystallisation.

Ochre. - Native ochre is ground under an edge-runner with water, and the product is run into settling pits. Coarse sand settles first, and further away the sediment consists of tine ochre, which is dug out and dried. The ochre deposited by the water coming from cernentation pits has simply to be dug up and dried.

The native umber of Devonshire is stamped and ground under edge-runners; the umber suspended in water is pumped up and allowed to settle in tanks until it can be dug out. It is then dried in the same way as china clay. $\uparrow$

Ozokerite.- Some of the mineral is brought up in the form of fairly clean lumps which have been picked out underground and put into sacks. These, together with similar pieces picked out above ground and scraped free from dirt, are melted in large semi-spherical open cast-iron pans and boiled. When allowed to settle, the earthy matter falls to the bottom and clean ozokerite floats on the top. This is ladled out into cylindrical moulds, and on cooling furnishes the large loaves of commercial ozokerite. Water is added to the earthy residues at the bottom of the pans, and the whole brought to the boiling-point. Ozokerite rises to the top and is skimmed off, whilst the residues remaining at the bottom, which still contain some ro per cent. of wax, are sold to dealers who extract it by means of benzine.

The small stuff coming from the mine which will go through a grating with bars 2 inches apart is put into a tub of water; the wax rises, is skimmed off with a sieve and purified by melting, and the earthy residues are sold, or are stocked until the miner puts up plant for extraction by benzine.

Phosphate of Lime.- The varieties of this mineral are so numerous, from the hard compact apatite of Canada to the pulverulent mineral of the Somme district, that the modes of treatment must necessarily be extremely different; sometimes also the mineral is sold finely ground and put up in sacks ready for the farmer, in other cases the miner satisfies himself with removing all waste, and leaves to other persons such processes as milling or manufacture into superphosphate.

* Nitze, "Ground Mica Industry in North Carolina," Eng. Min. Jour., vol. liv., 1892, p. 292.

† Frecheville, "The Umber Deposits at Ashbuston," Trans. R. Gzol. Soc., Cor nucall," vol. ix. p. 219. 
As a rule, the treatment may be summed up as drying and grinding, of ten preceded by a preliminary washing. For instance, the phosphate of the Somme is dried first upon iron-plated floors, and then in a Ruelle stove or a revolving calciner. This prepares it for grinding. The first grinding is done between two vertical stones, and all that is fine enough is drawn out by an exhaust fan; the portion which is too coarse to be sucked up by the current of air passes into a mill with horizontal stones and is reground. After being put into sacks it is ready for the manure merchant, or for the farmer if he applies it to his land direct.

The nodules of the South Carolina phosphate are freed from the sand and clay by a mechanical washer, in the form of a helix revolving in a trough. The material is fed in at the lower end and is gradually screwed up to the other against a strong stream of water. The water carries away the waste, and clean lumps are delivered at the other end. The washed nodules are dried in kilns and are then ready for export.*

Potassium Salts.-The two principal potassium salts obtained by mining are carnallite and kainite. Simple grinding is often the only preparation before sale, but in some cases, as explained on page 608, the carnallite undergoes a complicated treatment by solution and crystallisation, for the purpose of extracting chloride of potassium and utilising the by-products obtained in these processes.

Quicksilver.-The great intrinsic value of quicksilver ore enables hand-picking to be carried further than would be compatible with a mineral of little worth. At Idriat the loss of mercury was so great under the old system of wet dressing, in spite of the high specific gravity of cinnabar, that this method was given up some fifty years ago. Nowadays, the preparation for the smelting is done solely by crushing, sizing, and hand-picking. The stuff broken in the mine is separated underground into waste, poor ore and rich ore. The first is left in the workings, and the two kinds of ore are tipped separately on to a grating with holes of 4 inches (100 mm.) across. The coarse lumps are crushed by Blake's stonebreakers, and the broken ore which is too big to pass through holes of $\frac{4}{5}$ inch $(20 \mathrm{~mm}$.) is hand-picked; the portions so separated are made ready for the smelting works by further crushing. When poor ore is being treated, waste can be picked out and thrown away at once. The stuff passing through the $20 \mathrm{~mm}$. mesh is crushed by rolls and sent to the smelting works.

The "smalls" which passed the $100 \mathrm{~mm}$. grating are screened on a 2-inch $(5 \circ \mathrm{mm}$.) sieve; the coarse goes to the stonebreaker and the fine to screens of different sizes. All that is over $\frac{4}{5}$ inch

* Benedict, "Mining, Washing, and Calcining South Carolina Phosphate," Eng. Min. Juur., vol. liii., I892, p. 349.

+ Das k. k. Quecksilberwerk zu Idria in Krain, Vienna, 188ı, p. 19. 
(20 $\mathrm{mm}$.) is picked, and some waste taken out; what is uniler this size is passed through the rolls and so made fit for the furnaces.

Salt.-The mode of making a saleable product from brine has already been described; but it must not be forgotten that brine itself is sold as such to works which make alkali by the Solvay process.

Some rock-salt is prepared for the market by crushing. At one of the Cheshire mines there are three pairs of crushing rolls one above the other, the first pair coarsely fluted, the second pair fluted, but less coarsely, and the third or lowest pair smooth. The rolls are from 18 inches to 2 feet in diameter and $2 \frac{1}{2}$ feet long. The rolls of another crusher are made up of toothed rings threaded upon shafts, and so arranged that the teeth of one roll fit between two of the rings of the opposite roll. Some of the salt is also ground by a disintegrator.

Silver.-The ores of silver may be divided into two classes: silver ores proper and argentiferous lead and copper ores.

Many of the silver minerals are very friable, and are liable to be carried off with the refuse, if subjected to the ordinary wet dressing processes; the preparation of such ores at the mine is generally limited to crushing, picking, and cobbing. The miner then relegates to others the task of extracting the precious metal by methods based upon its affinity for quicksilver or molten lead, or upon the leaching properties of hyposulphite of soda.

Argentiferous lead and copper ores are concentrated by the processes in vogue for the baser metals; but if the proportion of silver is large, a greater amount of labour may be expended upon hand-picking and cobbing than would be permissible with ores of lead and copper alone.

Slate.-Two articles of commerce are made at the quarries: roofing slates and thick slats used for cisterns, billiard-tables, and tombstones. The slate arrives at the surface in the form of large blocks, often weighing two tons or more. These are divided by splitting into slabs about 3 inches thick, which go to the sawing taioles. The circular saws cut up the slabs into pieces suitable for the operation of fine splitting; by the careful and dexterous use of his wedge and mallet, the quarryman is able to split the slab into thin sheets, which at Festiniog often do not exceed $\frac{1}{7}$ inch in thickness. These have to be trimmed, generally into a rectangular form. Though this operation can be and often is performed by hand, it is more common to use some kind of knife worked by machinery (Fig. 639). The slates are then sorted by hand according to their quality. The slabs are first split out of blocks, and are finished by being sawn into shape and planed smooth by machinery.

Stone.-It is impossible in a general treatise to enter into any details concerning the preparation of stone at mines and open- 
works. Some stone is shaped by hammering, into paving blocks or "setts"; much is crushed by stonebreakers and sold as roadmetal after removal of the fine by screening; freestone is sawn so as to suit the builder; flags are obtained by splitting micaceous sandstone along the planes of bedding and trimming the edges, and, lastly, gunflints are made from the well-known nodules by the dexterous chipping of the "knapper."

Sulphur.-This element is obtained from the rock, which contains it in the native state, by simple liquation in a kiln of some kind, intermittent (calcarone) (Fig. 677) or continuous (Gill's furnace), by liquation in steam-heated cylinders, or by distillation in iron retorts ; this last process, which was at one time practised with rich ore in the Romagna, is now almost entirely abandoned.

Tin.*-'The tin ore obtained from veins usually contains the cassiterite so finely disseminated through the stone, that a considerable amount of comminution is required before the valuable grains are thoroughly liberated, and so rendered capable of being separated by washing. In Cornwall the first process is a preliminary crushing by a Blake's stonebreaker, followed by stamping until the pulp will pass through a fine grate. The pulp is led into round buddles in order to produce a first concentrate, containing not only all the cassiterite, but also the iron pyrites, mispickel and other metallic sulphides with which it is so often associated. By repeating the operation of buddling, a concentrate is obtained, which is subjected to "tossing and packing " in order finally to prepare it for the furnace. This first concentrate, known in Cornwall by the name of whits, is dried upon the top of the calciner and then roasted in the manner already described. After roasting, the buddling is repeated, and, lastly, the tossing and packing, with the result that clean tin ore with 65 to 70 per cent. of metal can be put away in bins, ready to be done up in sacks and despatched to the smelting works. In some cases the ore is not contaminated with sulphides, and no roasting is required.

The tin-bearing sand and gravel, which have furnished and are still furnishing such a large proportion of the world's supply of the metal, can be treated in a speedier fashion. The wash-dirt is simply shovelled or hoed against a stream of water in a ditch or trough; the light waste is washed away, and the heavy pebbles and clean grains of cassiterite are left at the head. This is the method usually employed in the East.

'I'he tin-gravel worked at Restronguet Creek, + near Truro, was washed with water in order to separate adherent clay, and then

* Ferguson, "On the Mechanical Appliances used for dressing Tin and Copper Ores in Cornwall," Proc. Inst. Mlech. Eng., 1873, p. I19; Hencierson, "On the Methods generally adopted in Cornwall in dressing 'lin and Copper Ores," Prcc. Inst. C.E., vol. xvii., 1857-58, p. 106.

† Taylor, "Description of the Tin Stream Works in Restronguet Creek, near Truro," Proc. Inst. Mech. Eng., I 873, p. 161. 
passed to a revolving sieve. The fine stuff was jigged, and finally cleaned by a propeller-knife buddle; the large pebbles were picked over, and those containing tin were stamped and treated like vein rock.

At Mount Bischoff,* in Tasmania, the process of dressing may be briefly summed up as follows: Comminution by stamps, and extraction of the tin ore from the pulp by jigs and revolving tables.

Zinc.-Calamine has sometimes to be washed, in order to rid it of clay, before it is crushed and jigged like lead ore.

Blende is dressed in the same way as lead ore, and is often obtained from one compartment or portion of a dressing machine, whilst galena is being discharged from another.

\section{LOSS IN DRESSING.}

The loss in dressing is frequently very great, and proofs of this fact constantly come under one's notice. Old heaps of mining refuse left by former workers may be seen yielding an abundant harvest to a later generation, and even with the machinory of to-day the extraction is far from perfect. For instance, in the year I891 no

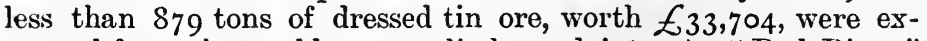
tracted from the muddy water discharged into the "Red River" and its tributaries by some of the large tin mines near Camborne and Redruth.

The loss is due to several causes. First comes imperfect severance of the valuable mineral from the worthless constituents of the ore during the crushing process ; this is unavoidable if the mineral occurs in the state of very minute particles. Secondly, the thickness of the dirty water escaping from the machines, which impedes the subsidence of the fine grains; thirdly, want of care on the part of the persons placed in charge of the machinery. In addition to these causes, which are general, special reasons accounting for loss will be found with certain minerals: the amalgarration of gold is prevented by grease, by any coating or film upon it which impedes close contact with the mercury, by the presence in the ore of substances which have an injurious effect upon the mercury, " sickening" it, or in other words depriving it of its natural activity. Again, if the mineral is flaky, it will not fall so easily in water as if the particles more nearly approached a spherical shape.

The actual loss has been very carefully ascertaired in some cases, though less attention is paid to exact determinations than the subject deserves. M. Bellom t cites three cases of loss at mines producing argentiferous galena and blende.

The ore delivered to the Himmelfahı't Works, near Freiberg,

* Kayser, "Advantages of Ore-dressing by Automatic Machinery," Trans. Jlin. Assoc. and Inst. Cornuall, vol. ii., i888, p. 51.

+ Op. cit., p. 624 . 
contains $2 \frac{3}{4}$ per cent. of lead, 0.275 per cent. of zinc, and $7 \cdot 3$ ozs. of silver per metric ton ( 23 grammes per roo kil.), besides a little copper, $\frac{1}{2}$ per cent. of arsenic, and 5 per cent. of sulphur. The galena is dressed to 85 per cent. of lead and 96 ozs. of silver ( 300 grammes per 100 kil.), the blende to 40 per cent. of zinc and $9^{\circ} 6$ ozs. of silver ( $3 \circ$ grammes per Ioo kil.), the pyritic minerals to 40 per cent. of sulphur and 16 ozs. of silver (50 grammes of silver per roo kil.). The losses are found to be $2 \mathrm{r}$ per cent. of the silver, $3^{8}$ per cent. of the lead, and 60 per cent. of the sulphur.

At the Churprinz Works, also near Freiberg, the raw ore contains 3 per cent. of lead, and 3 ozs. of silver per metric ton $\left(9 \frac{1}{2}\right.$ grammes per too kil.), and a dressed product is prepared with 70 per cent. of lead and 16 ozs. of silver per ton (50 grammes of silver per $100 \mathrm{kil}$.). The loss in dressing is 22.8 per cent. of the silver and 14.9 per cent. of the lead.

The ore treated at Ems contains 4 per cent. of lead, $2 \frac{1}{2}$ per cent. of zinc, and $I^{*} 7$ ozs. of silver per metric ton $\left(5^{*} 4\right.$ grammes per 100 kil.), but the enrichment by washing is not carried so far as at the other works. The galena is dressed to 36 per cent. of lead and 9.6 ozs. of silver per metric ton ( 30 grammes per roo kil.), and the blende, which is not argentiferous, to $44 \frac{1}{2}$ per cent. of zinc. Tho losses are 8 per cent. of the silver, 6 per cent. of the lead, and 34 per cent. of the zinc.

It is to be regretted that so many dressing establishments in this country are working entirely in the dark, and are, therefore, utterly ignorant of the losses that are going on.

At few places in the world is the loss more carefully studied than at the mines of the Pestarena Company in Northern Italy, for a sample is taken from every waggon of crushed ore before it goes to the mills. The quantity of gold in the ore treated can, therefore, be ascertained with great accuracy, and by comparing this amount with the quantity extracted, it is found that about one-fifth escapes amalgamation and is lost; the ores sometimes contain ro to 20 per cent. of pyrites.

Another kind of loss which requires to be ascertained is the purely mechanical waste in preparing stone for the market. In the case of slate it is very large, for the blocks brought from the workings into the mills frequently yield only 25 per cent. of roofing material. As the amount of rubbish produced in getting out the blocks is also considerable, the quantity of saleable slate is often only one-twelfth of the actual rock excavated.

Seeing that the proportion of waste material, whether in ore mines or stone mines, is usually large, it behoves the miner in laying out his dressing establishment, to make provision for the disposal of great quantities of refuse. 


\section{SAMPLING.}

The miner may have to sample the produce of his mine for a variety of reasons. Sometimes sampling is necessary in order to ascertain the amount of money due to the workmen; it is indispensable when the loss in dressing has to be ascertained, and, lastly, the miner, after preparing his various products for sale, requires samples for possible purchasers.

Sampling may be done by hand or by machinery. Four methods of hand-sampling may be mentioned:

HAND-SAMPLING.- $I$. Sampling by taking out small lots. - If the mineral is in coarse lumps and the valuable ingredient irregularly distributed, picking up a few stones here and there is not likely to yield a very correct sample; but, on the other hand, if the mineral is already crushed, and if the small lot is taken regularly, say for instance every tenth shovelful, it is possible to obtain great accuracy. Thus at the Pestarena mines the gold ore before being milled is crushed by rolls until it will pass a sieve with three holes to the inch; and from each waggon of crushed ore about 2 kilos. are taken by a tin measure. The load is spread out horizontally with the hand and a tin measure is filled from this flat surface and thrown into a tub. Each waggon is weighed, and the 2 kil. represent about $\frac{1}{2} \frac{1}{5}$ th of the load. At the end of the day the tubful is taken as the sample of the stuff sent to the mills. From this large sample a small one is prepared by the process of quartering, which will be described immediately.

This method of sampling will also suffice in the case of an ore of small intrinsic value, such as an iron ore, consisting in the main of one mineral.

2. Trenching.-In order that this method of sampling may be accurate, it is necessary that the mineral be well mixed, and where a valuable ore is concerned, great care is expended upon the operation. It may happen that there are a number of small henps of dressed ore, each produced by a different gang of men, which have to be mixed before being sold in one lot. The stuff from the first heap is spread out evenly on a smooth flat floor. Layer after layer is added from the other small heaps until a large square or rectangular pile is obtained made up of horizontal strata. The mixing is now carried out by taking off a slice from the side of the heap with a shovel, so as to cut through all the layers; the stuff is tossed on to the floor and spread over a large area, and the thorough intermingling is aided by a boy who stirs it as it falls. The original heap is cut away slice after slice, and gradually, at the side of it, another heap is formed with the particles thoroughly mixed, which is ready for the operation of trenching; it may be, for instance, io ft. wide by $15 \mathrm{ft}$. long, and 18 inches high. If the operation of turning 
over and mixing was carried on along the long side of the rectangle, a couple of trenches are dug across the heap at right angles to this direction, or in other words parallel to the short sides: The trenches are cut down to the bottom, and after they have been carefully swept out, the sampler slices off small portions of the sides with his shovel. All that he cuts down in this way is shovelled into hand-barrows, and constitutes the large sample, which has simply to be reduced in bulk by quartering.

With coarsely broken mineral the part shovelled out in making the trench is of ten taken as a first sample and not the thin slices from the sides, as is done with fine material.

The two trenches are sometimes cut at right angles to one another, forming an ordinary cross, or along the diagonals, forming a St. Andrew's cross, and the heaps are often round instead of being rectangular.

(3) Quartering.-Quartering is a process of dividing a given lot of mineral again and again until a sufficiently small sample remains. The mineral is made into a conical heap by letting each

FIG. 695 .

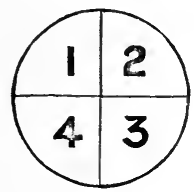

Fig. 696.

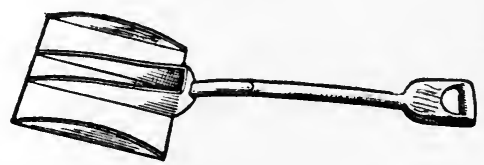

shovelful which is emptied fall down evenly over the apex of the cone. The apex is pressed down, and the heap is spread out till it forms a low truncated cone, a cross is marked upon it with the point of the shovel, and the two opposite quarters, say I and 3 (Fig. 695), are scraped aside and discarded, leaving 2 and 4, or one-half of the original sample. These two quarters, 2 and 4 , are mixed by hand, a new conical heap made and the quartering repeated. The next time the sampler will retain the quarters $\mathrm{r}$ and 3 , and put aside 2 and 4 . If the mineral is not fine, it should be crushed once or twice and put through a finer sieve during the process. In this manner a large sample is reduced sufficiently in bulk, to give the miner a small lot which is a fair average of the whole.

(4) Sampling Shovel.*-This implement is designed for the purpose of obtaining an average sample of a heap of mineral by merely shovelling it over. It consists of a flat rectangular plate with vertical sides (Fig. 696 ), and two vertical partitions which enclose a central compartment occupying one fourth of its area. This compartment is closed at the back or handle end, whilst the rest of the plate is open. After the

$$
\text { * Eng. Mlin. Jour., vol. li., 189r, p. } 718 .
$$


shovel has been filled by a thrust into the heap of finely crushed mineral, it is easy to discharge the outer three-fourths of its contents over the back end, and then, turning it over, to deposit the central quarter in a separate place as the sample.

MACHINE SAMPIING.-While we have generally been content on this side of the Atlantic to go on with the oldfashioned methods of hand-sampling, much ingenuity has been displayed in the United States with the object of producing machinery for doing the work, and thereby saving time and labour, to say nothing of furnishing more accurate results.

According to the principle upon which they work, sampling machines may at once be divided into two great classes : *

(I) Machines which take part of the stream of material for the whole of the time.

(2) Machines which take the whole of the stream of material for part of the time.

(I) In the former class a spout or opening of some kind is arranged so as to divert part of the stream of ore, coming from a crusher for instance, into a separate receptacle.

Two samplers used some years ago in Colorado belong to the first class. One of them is a hollow cone with four large holes ; the stream of crushed ore falls upon the apex, and the particles spreading themselves out slide down over the steep surface. The path of some of the particles leads them to the holes, where they drop through, forming a sample of the whole. The size of the holes can be arranged so as to extract a given percentage of the total quantity, and this first sample can be reduced in bulk by a second passage over the cone.

In the other the desired result is obtained by letting the ore fall on to three inclined shelves one above the other. $\dagger$ Each shelf has openings which allow a portion of the ore to drop through. The ore dropping through the first shelf falls upon the second, which in its turn eliminates part and lets the remainder drop on to the third shelf, where the process is repeated. The portion which has passed through the three shelves constitutes the sample.

Clarkson's Rapid Sampler, an English màchine (Fig. 697), consists of a revolving conical hopper, supplied with the mineral, which runs through a hole in the bottom, and drops on to the apex of a cone. In the path of the falling stream of mineral, now converted into a hollow rotating cylinder, there are two segmental spouts, which intercept any desired proportion of it, and so furnish two independent samples. The size of the spout determines the percentage which is diverted as a sample.

\footnotetext{
* Bridgman, "A new System of Ore-sampling," Trans. Amer. Inst. M.E., vol. xx., 1891, p. 416 .

+ Fgleston, "Sampling Ores in Colorado," Engincering, vol. xxii., 1876, p. 495 .
} 
(2) In the second class the whole stream is deflected at regular intervals, and this method has the advantage of ensuring the proper proportion between the fine and the coarse, which cannot always be attained by the fixed spout; where the constituent minerals vary in friability the accuracy of the result must depend upon this proportion being strictly maintained. In Brunton's* sampler the stream of ore falling down a vertical trough is diverted to one side or the other by a partition which is moved backwards and forwards by very simple machinery. There are means of regulating the proportion of the time during which the stream is being turned into the side for receiving the sample.

Bridgman's ore-sampler $\uparrow$ has the advantage of supplying two

FIG. 697.

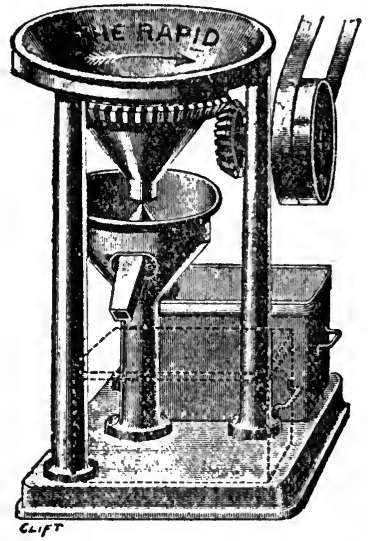

FiG: 698.

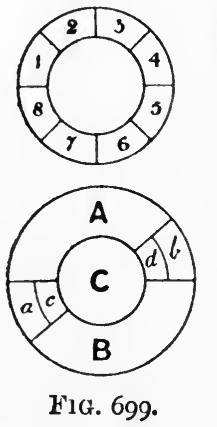

absolutely independent samples, and it divides them as often as desirable previous to a recrushing.

The work is begun by a horizontal revolving wheel formed of two concentric rings, with rertical partitions dividing it into eight segments (Fig. 698). Underneath this first "apportioner," as it is called by the inventor, comes a second one (Fig. 699); it is a funnel with openings, $a, b, c, d$, on the side, and is made to revolve in the opposite direction to the first. It is succeeded by a third of similar construction. The ore is fed from a pipe on to some point of the first apportioner, and each segment necessarily receives one-eighth of the stream; segment No. I has a spout which travels round the outer circumference of the apportioner below it, passing over the holes $a$ and $b$, whilst the spout of No.

* “A new System of Ore-sampling," Trans. Amer. Inst. M.E., vol. xiii., I $88_{5}$, p. 639 . + Op. cit. 
5 takes an inner path, including the holes $c$ and $d$; the spouts of $2,3,4,6,7$, and 8 , deliver their ore into the centre $\mathbf{C}$. Oneeighth of the stream from the spout of No. I drops through $a$ and another eighth through $b$; the rest falls on to the parts $A$ and $B$ of the funnel and is discharged into the centre. Likewise the original one-eighth from spout 5 drops in part through $c$ and $d$, and in part on to $A$ and $B$. The portion passing down through $a$ and $b$, or through $c$ and $d$, is therefore onequarter of one-eighth, or one-thirty-second, of the original bulk. The third apportioner again collects one-quarter and discards three-quarters of each of the two samples coming to it, so that the final samples furnished by the machine are both $\frac{1}{128}$ of the total. These first samples are then recrushed and passed through another machine of simi'ar construction but giving only one sample.

Mr. Bridgman has likewise devised a small sampler for use in the laboratory. 


\section{$(637)$}

\section{CHAPTER XIV.}

\section{PRINCIPLES OF EMPLOYMENT OF MINING LABOUR.}

\section{Modes of payment, according to time, measure or weight ; tribute systems.}

Persons employed at mines may have their wages reckoned in one of four different ways :

I. By time.

2. " measure or weirht.

3. " a combination of Nos. I and 2 systems.

4. " value of the mineral obtained.

(I) The first system is largely adopted for surface labour, such as is required on the dressing floors. Enginemen, stokers, millmen, smiths and carpenters are likewise paid so much a day of a stated number of hours. A time-book is kept, and the wages are reckoned up at the end of the week, fortnight, or month by a simple multiplication sum. For true mining or quarrying - that is to say, for excavating valuable mineral and removing worthless rock-this system is far less common than the other three. There are objections to it both on the part of mine-owners and on the part of many of the men. The owner has to employ more foremen to look after the work, and an amount of supervision which would be sufficient at the surface is utterly inadequate below ground, because the working places are not within sight from any one point, and can only be reached by traversing low and tortuous passages, or by climbing down and up ladders. The men, too, in many cases prefer to be paid on some system which gives the skilled and steady miner the advantage of deriving some profit from his exertions, over and above the average daily wage he would receive if time were the only standard for good and bad workers alike.

In rare cases persons are hired for the day only; this is done sometimes at the ozokerite mines at Boryslaw, where the agent picks out in the morning as many men as he wants from those assembled at the top of the pit.

In new countries or districts, payment of miners by the day may be necessary at first, because the work is so strange that the men are afraid to enter into contracts, which would appear perfectly reasonable and satisfactory to them if they had been 
used from boyhood to this system of arranging earnings. After the more enterprising men have learnt by actual practice what they are capable of doing, they drop into the contract system, and in due course of time the others follow them.

(2) Much of the work at mines is regulated by a system of piecework of some kind, calculated by measure or by weight. In Cornwall and some other districts, work done in this fashion is known as "tutwork." No doubt the original meaning of the word was "dead work," from the German word " todt," because preliminary and unremunerative work was paid for in this manner; nowadays the meaning of the term is extended, and it includes the excavation of ore. In driving a level, for instance, the manager specifies that the height shall be 7 feet and the width 5 feet, and agrees to pay so many pounds for every yard or fathom of advance. As a rule the mine-owner provides all the necessary materials, and deducts their value at the end of the contract. An example or two will make the system plain.

\section{THE ADVENTURE MINING COMPANY, LIMITED.}

Tutwork pay for the Month of May 1886.

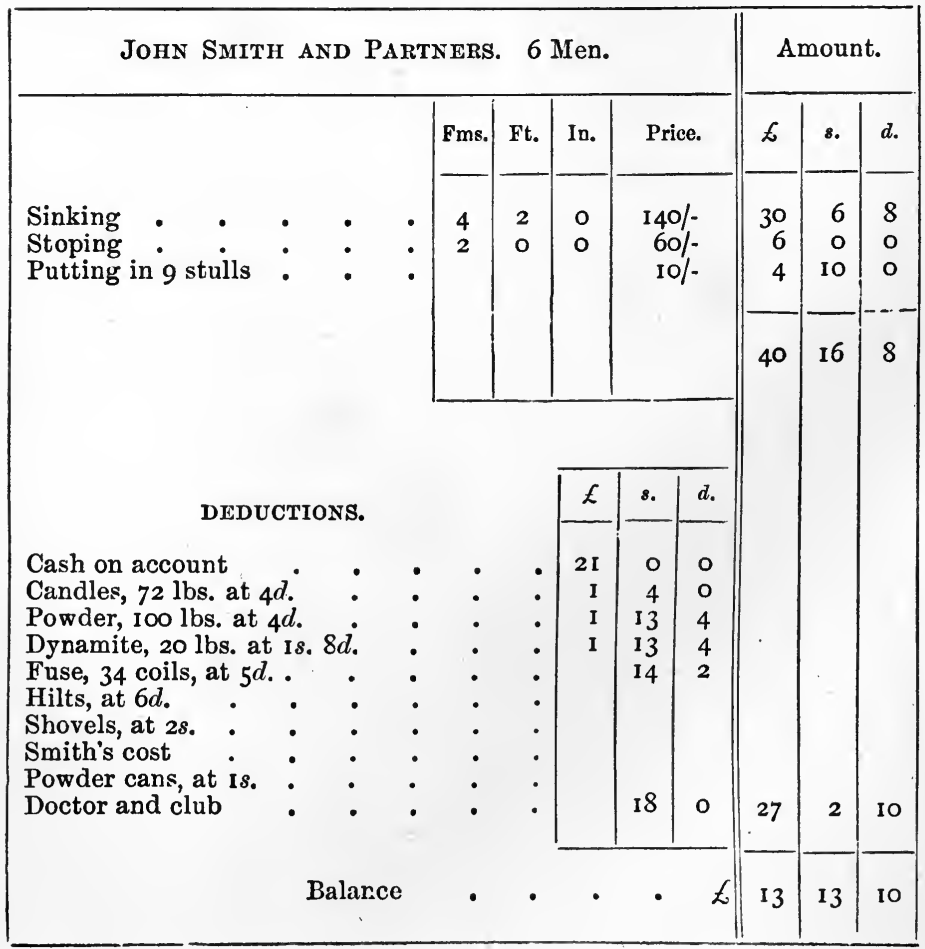


The meaning of this pay-bill is that John Smith and five other men took a contract to sink a certain shaft at $£ 7$ per fathom, and to stope part of the lode at $£ 3$ per fathom. They sank the shaft 4 fathoms 2 feet, and stoped away 2 fathoms; in addition to this they put in some timber, a matter not included in the original contract, and for which they are credited with $£_{4}$ ros. extra. The gross balance due to them is therefore $£ 40$ I $6 s .8 d$., against which they are debited with the cost of the candles and explosives supplied to them, and with their subscriptions for medical attendance and accident club. While the contract was running they received $f_{2}$ I on account, so that on the payday they took up a balance of $\mathrm{EI}_{3} \mathrm{I} 3 s$. rod. In a contract of this kind the leading man, John Smith, is known as the "taker."

In stoping a vein, the price is calculated per square fathom of advance for its whole width; thus if a lode is 4 feet wide, stoping I fathom of ground means the removal of a block $6 \mathrm{ft}$. high $6 \mathrm{ft}$. long and 4 feet wide ; in other words, 144 cubic feet. In wide lodes the men are sometimes paid per cubic fathom excavated. At one British lead mine, where the lode sometimes measures several fathoms from wall to wall, a standard price is arranged for a width of 6 feet, and where the stopes are wider than this the men are paid extra. In order to prevent loss of ore through carelessness, the men are paid a premium of $15 s$. a ton for all the lead ore they save.

Another example (p. 640) gives an instance of " tutwork" wages calculated by weight. It is copied from the figures on the back of the little envelope in which the money is handed to the "taker" on the pay-day. The account shows that Richard Williams and his six partners excavated 120 tons 9 cwt. of tin ore ("tinstuff") at 6s. per ton, and were credited with $£_{36}$ 2s. 8d. Against this they had to pay $£ 54$ s. $4 d$. for materials (candles, explosives, \&c.), 7s. for doctor, $5 s .3 d$. for club and $18.9 d$. for barber,* leaving a balance of $£_{3 \circ} 4 s .4 d$. to be divided among them, that is to say $\mathcal{E} \mathrm{I}$ Is. $7 d$. per man per week.

A third basis of payment is the number of inches bored in the shift. This plan was in vogue in stoping the wide lead-lodes in the Upper Hartz some years ago ; it necessitated careful supervision, for otherwise the men bored their holes in the softest places they could find, or in positions enabling them to wield their hammers with the greatest ease, without any thought for the work required from the shots. A foreman came round at the beginning of the shift, and pointed out how the holes were to be placed; in the middle of the shift he returned, measured the depths bored, and then charged and fired the holes while the men rested. The positions for fresh holes were then indicated, and at the end of

* The item "barber," a charge of $3 d$. per man per month, still remains in a few of the oldest mines in Cornwall. The barber attends at the mines on Saturdays. 
the shift the depths were measured and booked, previous to the charging and blasting. The price paid was I M. 38 Pf. per metre of hole bored upwards, and I M. I 3 Pf. per metre of hole bored downwards; in the latter case the men could put water in the holes, which keeps the finely powdered rock in suspension and allows the cutting edge of the tool to do better execution.

The men working away the great pyrites deposit at Rammelsberg in the Lower Hartz by means of boring machinery are paid

\section{WHEAL CHANCE.}

RICIIARD WILLIAMS AND PARTNEIS.

Pay for 4 weeks ending 27th May.

Paid roth June I893.

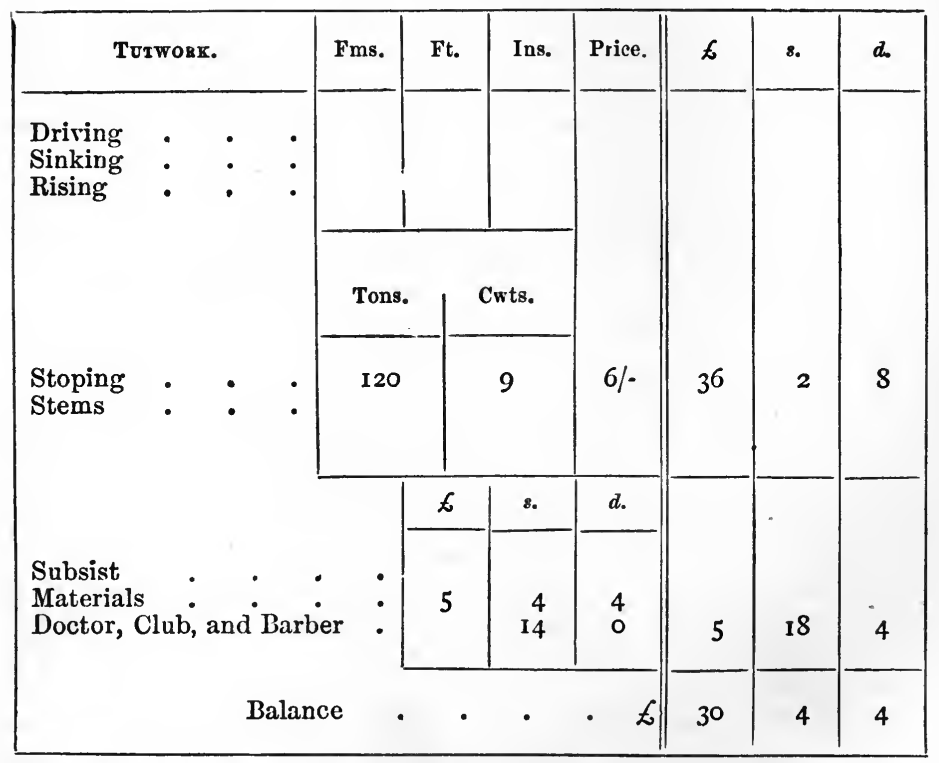

per metre of hole bored, as this method is more convenient than measuring up the amount of "ground" removed in wide workings and paying per cubic metre. The latter system, however, is adopted in driving levels and sinking shafts where the dimensions of the excavation are regular.

In removing overburden, where everything has to be sent away indiscriminately, payment per cubic yard excavated is common, just as it is in making railway cuttings; this system is adopted with the men who uncover the iron ore in Northamptonshire (Fig. 324), whilst those employed in getting the ore are paid so much per ton put into the waggons. 
(3) The combination of the two methods, paymant by time and payment by measure or weight of some kind, may be adopted when men are too inexperienced or too timid to take contracts depending solely upon results. This plan has been found to answer at a pyrites mine in North Wales, where the mineral is got by the aid of rock drills worked by compressed air. The miners receive a fixed wage of a pound per week and a premium of a penny per foot for every foot bored over 12 feet per day of eight hours. The company finds the machines and all tools. The mine is worked in three shifts of eight hours each; in two of them the men are merely boring, and in the third shift a set of blasters come round to charge and fire the holes. Of course, as in the Hartz, the position of the holes is planned by the foreman. By working in this way the men generally make from $3 s$. to 48 . a week extra pay, for they are able to bore 40 or 50 feet a week more than the standard task. The ore is fairly uniform in hardness, for otherwise it would be impossible to maintain a single tariff for the whole of the mine. This system has been advantageous both to the men and to the company. Previous to its introduction the men were all on one dead level, and had no interest in exerting themselves; they each got their $\mathcal{E I}_{\mathrm{I}}$ a week by doing the minimum amount which enabled them to escape a scolding from the foreman, whilst now the man who works hard feels that he will get some recompense for his extra exertions. The company benefits by having an increased output at a smaller cost per ton, without any extra plant.

(4) We now come to the fourth or last system-viz., payment by value of the product. This system has had its home in the south-west of England for many years, and has been transplanted by the ubiquitous Cornishman to many other ore-mining districts. In Cornwall it is known as working on "tribute."

Under the tribute system a gang of men agree to hand over to the mining company all the ore they raise, on condition that they receive a certain proportion of its value. Thus, supposing that the tribute is $\frac{1}{4}$, or $5^{s}$. in the $£ \mathrm{I}$, and that a couple of men produce marketable copper ore worth $£ 50$, their share will be $E_{50} \div \frac{1}{4}$ or $£ \mathrm{I} 2$ IOs., less the cost of the materials they have ween supplied with, and all the expenses for winding, dressing, sampling, \&c. In other words, the tributer may be said to take a sublease of part of the mine and pay a royalty, in this case of $\frac{3}{4}$ or 75 per cent. for the permission to work accorded to him. But it must be recollected that the mining company renders the place accessible to him, keeps it drained and ventilated, and supplies him with machinery for raising his ore to the surface and dressing it, which he could not provide. The tributer is therefore a person who can speculate upon the value of the ore in a certain small working area, without having any capital beyond his brain and his muscle. 
The precise nature of this mode of payment will be best understood by an actual example.

John Jones and Partners,

WHEAL CHANCE.

Pay for 4 weeks ending 27th May.

Paid roth June, I893.

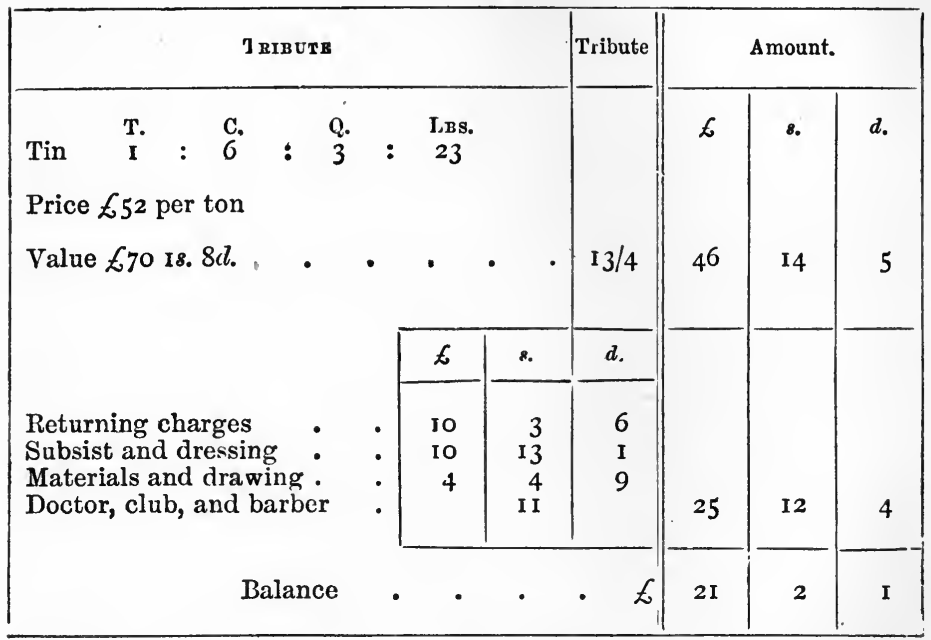

The pay-ticket shows that John Jones and his partners, a gang of three men, raised a certain quantity of crude tin ore (tinstuff) which, according to assays, contained $\mathrm{r}$ ton 6 cwt. 3. qrs. 23 lbs. of clean tin ore (black tin). The value of this quantity, at $£_{52}$ per ton, is $£_{70}$ rs. $8 d$. The pay-ticket also states that the tribute was $3^{s}$. $4 d$. in the pound, or, in other words, two-thirds of the value. The gross total credited to the gang was therefore $\mathcal{L}_{4} 6 \mathrm{I} 4 \mathrm{~s} .5 \mathrm{~d}$. Against this come the returning charges, subsist, dressing, drawing, and sampling, as follows :-

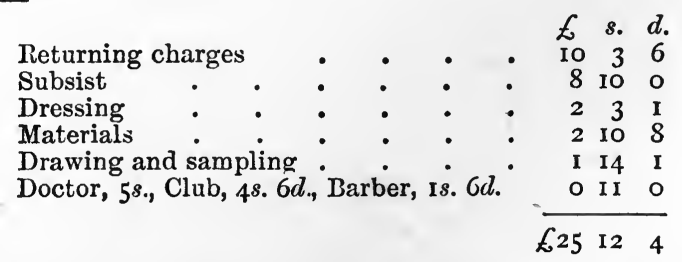

These deductions require a word of explanation. The returning charges represent the cost of treating the "stuff" from the time it goes to the stamps until the dressed tin ore (black tin) 
is fit for the smelter. The amount charged varies slightly in different mines.* "Subsist" is another name for an advance, or money paid on account, during the running of the contract, which in this case lasted eight weeks. The term "dressing" as used in these accounts is not very happily chosen, because the returning charges represent all the cost of stamping and washing. The "dressing" referred to in the pay-bill is the preparation of the "tinstuff" for the stamps by "ragging," "spalling," \&c. The charge varies from $4 d$. to $6 d$. per ton, according to the hardness of the veinstuff. In this case the books of the company showed that 96 tons $6 \mathrm{cwt}$. I $\mathrm{qr}$. of tinstuff had been dressed. The "materials" included candles, powder, fuse, dynamite, pick hilts, detonators, a shovel, clay for the candles, and the smith's cost for sharpening drills and picks.

"Drawing" is the Cornish term for winding, and is charged at the rate of $3 d$. per ton. The "sampling" refers to the assays of the tin ore made upon the vanning shovel by the mine agent; they are charged at the rate of $1 s$. each, and it is upon the results of these assays that the mine-owner ascertained that the 96 tons 6 cwt. I qr. of " tinstuff" contained I ton 6 cwt. 3 qr. 23 lb. of "black tin." One of the three men being a bachelor, paid only $6 d$. per month for the doctor, instead of the usual $\mathrm{r} s$. of the married man, whose wife and family are likewise entitled to receive medical attendance.

In former days the "tribute," or proportion of the value retained by the workmen, was publicly fixed by Dutch auction on the "setting" day. The miners assembled outside the mine office (counting-house), and the manager, after reading out the nature of the "pitch," or working place, asked for bids; the lowest bidder received the contract. If a certain place seemed likely to be profitable, there was frequently much competition among the men in order to get the "pitch." Nowadays the agreements are often made privately. It is evident that the richer the lode, the smaller will be the proportion of the value necessary for giving the men a fair return for their labour; in other words, the tribute will decrease as the lode improves.

This system of working has many advantages, which have rendered it popular with men and masters in Cornwall and elsewhere. The man's pay does not depend solely upon his muscular exertion, but also upon his judgment. He exercises his wits, he

* Common rates are :-

\begin{tabular}{|c|c|c|c|c|c|c|c|c|c|}
\hline \multicolumn{4}{|c|}{ On tinstuff producing $1 \frac{1}{2} \%$ (or less) } & \multicolumn{3}{|c|}{ of " black tin," } & \multicolumn{3}{|c|}{20 per ton. } \\
\hline " & " & $"$ & I $\frac{1}{2} \%$ to $2 \frac{1}{2} \%$ & $n$ & $"$ & $"$ & 3 & 0 & $n$ \\
\hline ," & $"$ & ", & $\frac{1}{2} \%, 3 \frac{3}{4} \%$ & $"$ & " & $"$ & 3 & 6 & $"$ \\
\hline ," & $"$ & " & $\% 5 \%$ & $"$ & $"$ & $"$ & 4 & o & $"$ \\
\hline ,", & " & $"$ & " $6 \frac{1}{4} \%$ & $"$ & $"$ & " & 5 & o & $"$ \\
\hline ," & $"$ & $"$ & & $"$ & " & ", & 7 & $\mathrm{o}$ & $"$ \\
\hline ," & $\eta$ & " & I0 $\%$ & ", & , & ," & 10 & 0 & $"$ \\
\hline
\end{tabular}


observes the nature of the ground, and notices what conditions are most favourable for ore-bearing, such as colour and texture of the surrounding rock; what signs are the forerunners of richness or poverty of the lode, such as intersections with "droppers" or "feeders," joints in certain directions the appearance of associated minerals. Guided by slight indications of this kind, which would pass unnoticed by the inexperienced, he is ready to back his favourable opinion of a certain working place (pitch) by agreeing to work it at a price (tribute), which would seem quite inadequate if one judged by the actual ore in sight at the time of making the agreement. If he is correct in his inference, he may make a large sum of money, and receive, for instance, one fourth of $£ 200$, instead of one-fourth of $£ 50$, which seemed probable from the original appearance of the ground.

This constant study of the geological features of the working places and the calculations concerning the probable expenditure for explosives and other materials, educate the miner, make him brighter, shrewder, and more self-reliant, and so raise him mentally.

The advantages of this training are also felt by the mining company; they have in the mine a body of expert detectives constantly on the watch for clues to lead them to hidden orebodies which might otherwise go undiscovered, and while the tributer is at work in any given "pitch," the mine-owner feels little fear of ore being thrown away in the rubbish, or of "waste" being unnecessarily sent to the surface. As the interests of the employer and the employed are in these respects identical, the former knows that little or no supervision is required on his part to prevent loss from either of the two causes just mentioned. The tributer is therefore left much more to himself than the man employed upon tutwork. Lastly, it may be pointed out that so long as the profit made out of each bargain is sufficient to pay its proportion of the general expenses of pumping, ventilating, and management, the mining company cannot lose by employing tributers. It is not to be wondered that with these advantages the tribute system should be vaunted to the skies by many mining engineers.

The other side of the picture must not be forgotten. In the first place, the system is apt to promote duplicity among the men. They are constantly endeavouring to outwit the agent by fair means or foul, and will candidly confess that "the whole art of mining is fooling the captain." The latter has often been a tributer himself, and is fully alive to all the tricks which the men are likely to practise upon him, such as conceal:ng any indication of an approaching improvement, in order to get better terms at the next "setting." This is not all ; it may happen that two "pitches" not very far from one another axe being worked at very different tributes, one bargain being rich and the other 
poor. One gang may be getting two-thirds of the value of the ore they raise, the others only one-tenth; the men with the low tribute, that is to say, the men in whose working place the ore is abundant, are often ready enough for a consideration to part with some of their stock to their neighbours, who transfer it secretly to the "pile" which they are sending up to the surface, carrying it perhaps from one working place to the other in an improvised sack made out of a pair of trousers. The result is that the squad with the high tribute are paid at a far better rate for some of their ore, than the trouble of getting it warranted. When the rates of tribute vary between narrow limits the case is different. For instance, the manager of a zinc mine was lately paying 40s. per ton for blende as the highest tribute and 308. as the lowest, which, with the ore selling at $£ 5$ per ton, corresponded to $8 s$. and $6 s$. in the pound respectively; there was therefore little or no temptation to transfer ore from one "pitch" to another, and so defraud the company.

The training in trickery which is inherent to this system may have its effect later on, when the tributer is promoted to a higher position; from having been taught to consider that cheating the captain is perfectly fair and legitimate, he may be ready to conclude that "the whole art of mining is fooling the public." And blunting of the moral sense of the men is an undoubted evil.

Payment by tribute involves the necessity of ascertaining the value of each gang's raisings separately. In the case of tin ore the percentage of cassiterite is learnt by washing a sample upon the vanning shovel, and from the result of this assay tho total amount is easily reckoned; but with lead and zinc each parcel is dressed by itself, and the final lots of clean galena or clean blende are weighed separately, before being mixed and made into heaps for sale to the smelter. This multiplication of small operations, cleanings-up, and weighings, naturally makes the cost of dressing higher than it would be if all the ore were treated alike, without regard to the persons who had raised it.

Another objection to the tribute system is that the lessened amount of supervision for commercial purposes may tend to a lessened amount of supervision for purposes of security; the working place is not visited so often by the agent, and he has fewer opportunities of pointing out to the men possible dangers from want of timbering or other sources. The men sometimes court this lack of supervision by making access to their "pitch" difficult, or, at all events, troublesome. Lastly, there is an element of gambling involved in the tribute system, which it is scarcely advisable to cultivate. The tributer is a speculator, who hopes by a lucky hit, as comrades have done before, to make a lot of money in a short time. Where one succeeds in so doing, how many fail? According to the report of Lord Kinnaird's Commission in 
1864 ,* the tutworker at that time was better housed than the tributer ; the moral of this is that, on the whole, it is better for the working miner to be in receipt of fairly constant regular wages than to trust to the chance of occasional runs of luck.

The advantages accruing to a mine from the tribute system are far less marked when there is a lode of pretty even character, than when the deposit is fitful and uncertain in its nature. This explains, to some extent, why the tribute system occupies a less important place in Cornwall now than it did in the first half of this century. Cornish mines at the present day are mainly dependent upon tin lodes, in which the cassiterite is finely disseminated through a hard close-grained rock. The consequence is that it is impossible to do much picking underground, or indeed at the surface; the whole of the stuff raised from the stopes has to be sent to the stamps. For deposits of this kind it is more advantageous to employ the tutworker, who excavates the ground at so much per fathom, than the tributer. Fifty years ago things were different; copper was then the mainstay of Cornwall, and the chief ore was chalcopyrite. While cassiterite is a mineral well adapted for dressing by water, chalcopyrite is not ; it crumbles to dust very easily, and the fine particles are liable to be washed away with the refuse. A large amount of hand-picking was required, in order to save as much of the ore as possible from treatment in water. The care of the tributer in the stopes of copper mines was a matter of vital importance in the old days, and his services were really valuable.

Where an old mine is re-worked after a period of abandonment, the tribute system of ten does good service, especially if the object is to recover some mineral considered worthless in former times, or when branches of ore exist in the sides, after the main part of the vein has been removed.

In a like manner it proved a valuable remedy $\dagger$ in the Eureka district for evils which had resulted from the plan of working the ore by day labourers. The ore occurs in bodies of irregular shape and size; men working by the day had not been careful to get out as much ore as they might have done, and others were induced by the tribute system to extract the portions remaining ' behind, which would otherwise have been lost altogether. Besides which it was known that small ore-bodies had been passed over as too poor or too insignificant to be worth removing in the ordinary way, but which were quite good enough to afford a scope for the talents of a man who had a direct interest in the ore he got out. In 188 I the men received $\$ 2.5^{\circ}$ for all ore assaying $\$ 30$

* Report of the Commissioners appointed to Inquire into the Condition of all Mines in Great Britain to which the Provisions of the Act $23 \& 24$ lict. c. I5I do not apply.

† Curtis, "I'be Silver-lead Deposits of Eureka, Nevada," Mon. U.S. Gicol. Survey, vol. vii., Washington, I\$84, p. I5 I. 
per ton, and 50 per cent. of all that it assayed above $\$ 30$. Thus an ore worth $\$ 65$ per ton brought to the tributer $\$ 2.50+$ $\$ 17.50$, or $\$ 20$. In cases of this kind the services of the tributer are often requisitioned with good results to the mine; that is to say, when the greater part of the ore has been extracted by some other method of payment, and when more judgment and care are required to ferret out and take away partly hidden treasures distributed here and there in the workings.

Under the old Cornish system of tribute, the partners are all working men, who are all employed in the particular "pitch" assigned to them; but in Colorado one meets with a modification of the method, in which the actual miner avails himself of outside aid, and may or may not employ labourers who have no interest in the adventure. A party of miners who have confidence in the future resources of some part of a mine, take it upon lease and obtain the assistance of shopkeepers or others in the neighbourhood, in order to buy tools, explosives, and materials, and to have means of living during the unproductive stage of the undertaking. If the hopes of the miners are realised, the sleeping partners receive a share of the profits; if the speculation turns out badly, the miners have had a bare subsistence, and the petty capitalists lose their money. This system has the advantage that it enables a certain amount of dead work to be combined with the extraction of ore. Under the Cornish system working men will not drive levels and sink shafts in unproductive ground; because, however high the tribute may be, they receive nothing so long as they raise no ore, and they cannot afford, on their own resources, to spend weeks and months in making the preliminary openings, which may be required before some given block of ground is made ready to yield up its supposed riches. A little outside capital tides the workers over their difficulty, and gives them a chance of making money by the exercise of their brains as well as by the expenditure of their muscular strength. The question will be asked: How does the small capitalist guard himself against the risk of having to provide for the living of some lazy miners, who, hidden below ground, are merely making a pretence of working? In the first place, he may take a precaution, of ten omitted by the large capitalist, of associating bimself only with men whom he knows and can trust, and secondly, as he is frequently a bit of a miner himself, he visits the mine from time to time, and watches the progress of the work.

The mine-owner favours this system, and even becomes a partner himself, because he gets some of his dead work done without any risk to his pocket. In the case of mines drained by adit-levels and swept through by natural draughts, as is commonly the case in Colorado, the mine-owner is put to no cost whatever for pumping or ventilation, and therefore he loses no money even if 
the "lease" turns out a failure, whereas he is bound to be a gainer if any ore is met with.

The following are two actual examples which explain the system very clearly :-

\section{Colorado Lease.}

Profitable Lease to both Company and Lessee. Company or Owner having $\frac{3}{4}$ interest, and Lessee $\frac{1}{4}$ interest.

\section{LEASE ACCOUNT.}

Nov. 30. To Lessee's wages

Dr.

$\$$ c.

72.00

407.00

I9. 25

30.20

99. 55

I 2.40

". Hauling ore to mill $\quad$ - $\quad$ • $\quad$ - 26.70

Blacksnithing

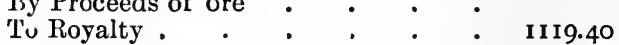

78.00

573. IO

27.05

20.00

131.45

17.25

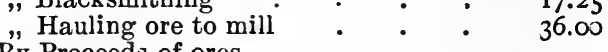

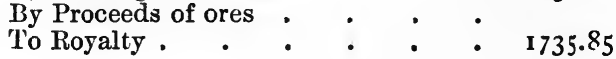

$\overline{4405.20}$

Net profit on lease . . . . 1305.50

$\$ 5710.70$

2238.95

3471.75

5710.70

$\$ 5710.70$

Lessee received :

Wages for his labour . . . . I 50.00

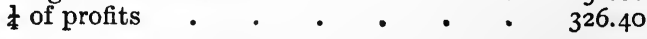

Company or owner received:

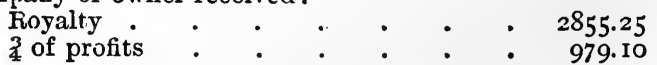

Cost of work exclusive of lessee's labour $\quad 3834.35$ 


\section{Colorado Lease.}

Unprofitable Lease to Lessee. Owner $\frac{1}{2}$ Interest, and Lessee $\frac{1}{2}$ Interest.

LEASE ACCOUNT.

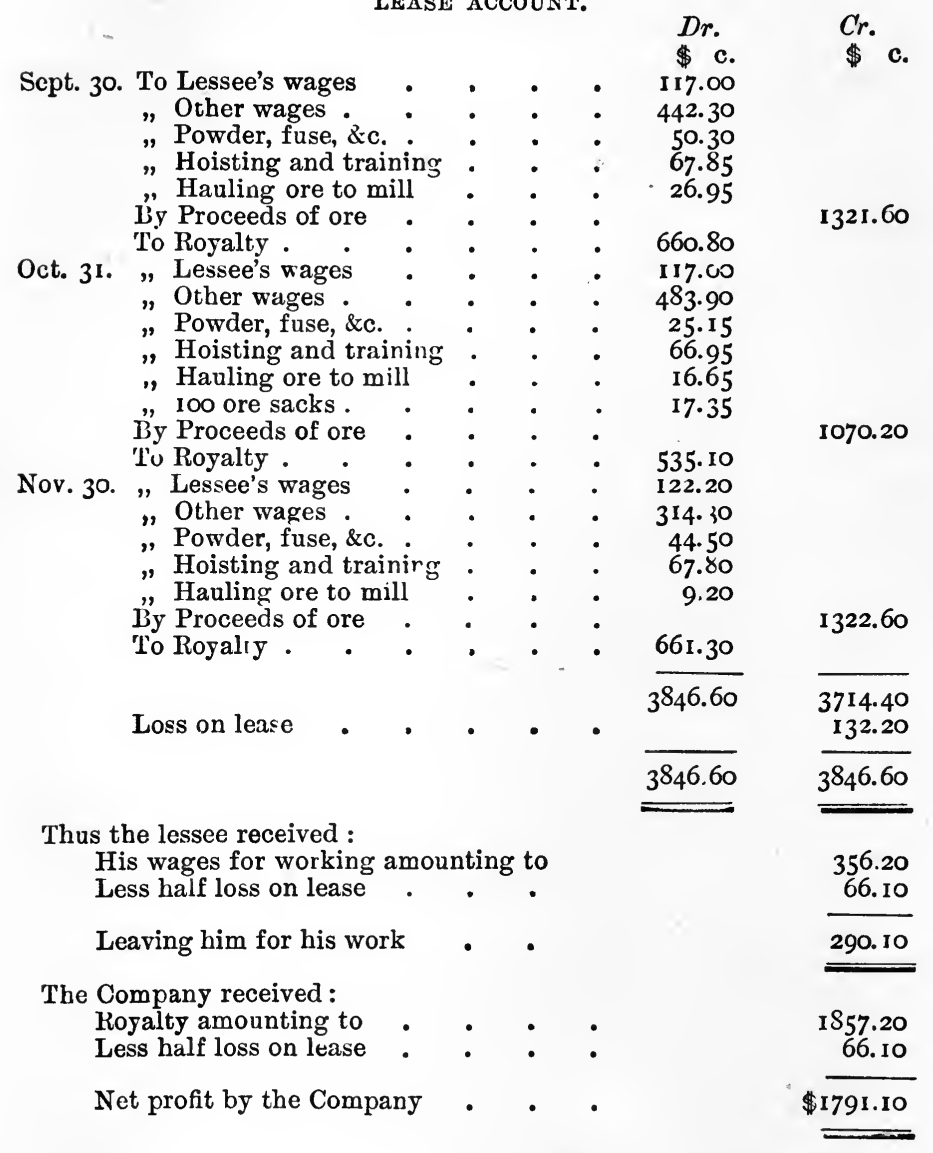

The men who are excavating slate rock (rock-men), and those who are subdividing it into merchantable slates (quarry$m e n)$, in the Festiniog district, are paid by a method which in principle resembles the tribute system. The earnings of the men depend upon the value of the stock of merchantable slate which they obtain from their working place or " bargain." At the end of the month the stock of each partnership is counted, 
and the men are credited with the value of their make according to a fixed tariff. Thus, for instance, we may suppose that the men had made fourteen hundred slates of the size $24^{\prime \prime} \times 14^{\prime \prime}$, at 27s. $6 d$. per thousand; for this their account would be credited with $f_{\mathrm{I}}$ I8s. 6d., and so on with each size. On looking down an account, it will often be found that the men have made "best" slates of twenty different merchantable sizes, to say nothing of several kinds of " seconds." The total of these various items is a first basis of the amount due to the partnership; but as the " rock" varies in quality in the different working places, owing to the presence or absence of joints, the interference of quartz veins, or alterations of texture, the result of a given amount of labour must necessarily vary also. In good rock the men will make a large quantity of "best" slates of large sizes; elsewhere, though working equally hard and excavating quite as many cubic feet, they will be able to make only slates of small sizes, or "seconds" in the place of "bests." Tle companies find the simplest method of adjusting these differences is to pay a premium or allowance, varying with the quality of the rock in each " bargain," and determined at the "letting," i.e., at the time of making the contract. A "bargain" may be let for a month or for several months. The premium is called "poundage."

Thus to take an actual case :

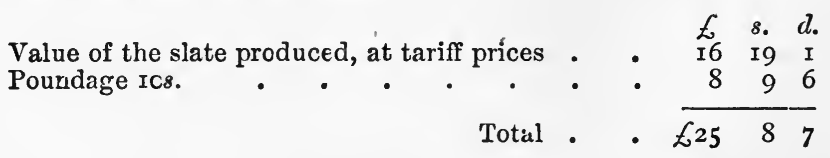

The "poundage" of Ios. means a premium of Ios. in the pound; for every pound's worth of slate at tariff prices, the workmen receive an additional half-sovereign; in other words, the value of the total make is reckoned at 50 per cent. more than the tariff prices. If the bargain is a good one, the poundage will be low; if the rock deteriorates in quality, the poundage will have to be raised at the next letting.

Another example will make this plainer:

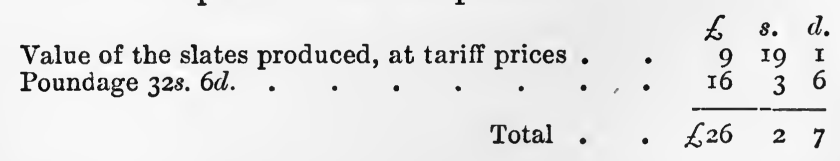

These two amounts, $£_{25} 8 s .7 d$. and $£_{26}$ 2s. $7 d$., are the gross earnings, in each case, of four men for a month, and are subject to deductions for materials supplied.

In the former case the deductions were: explosives, $6 s .6 d$, fuse, Is., candles, $4 s$. , smith, $5 s$. I I $d$., or I $7 s$. $5 d$. in all, leaving a balance of $£_{24}$ IIs. $2 d$. which was handed to the men. In this 
bargain there were three partners, who employed a labourer, and worked twenty-four days. The company leaves the division of the money to the men themselves, but keeps an account so as to know precisely what the earnings are. The recognised wages of a labourer at Festiniog were $4 s .2 d$. a day, so the labourer was paid $\mathcal{E}_{5}$, i.e., twenty-four times $4 s$. $2 d$. There remained, therefore, a llet balance of $\mathcal{L}_{\mathrm{I}} \mathrm{I}$ IIs. $2 d$. to be divided among three men. According to the time-book, these men worked $70 \frac{1}{2}$ days between them, and therefore their average wages were $5 s .6 d$. per man per day.

In the other case the account stood thus :

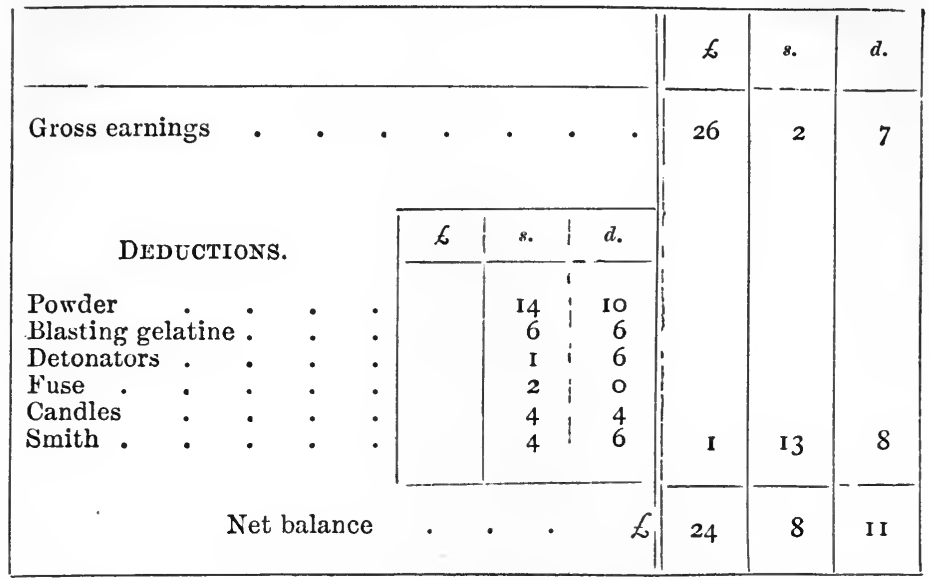

Here there were four partners and no labourer; they made 94 days between them, or at the rate of $5 s$. $2 d$. per man per day. In spite, therefore, of the very great difference in the rock, the poundage was so fixed beforehand as to enable each set of men to earn very nearly the same wage per day.

At Festiniog the partnership commonly consists of four persons: two working below ground, and engaged in getting the slaterock, and two working above ground in the mills, engaged in making the blocks into merchantable slates The reason for this arrangement is the fact that the yield of slate from any given block depends very largely on the skill of the dressers, and if the splitting and making of the slates were confided to men paid by the day, these would have no interest in doing their best with the material delivered to them. Now the men working below ground can rely upon their own partners to work up the blocks into slates with the least possible loss; the case is a totally different one from dressing a metallic ore. Owing to the nature of the substance which is being quarried, the payment by a varying "poundage" is free from some of the objections which 
are inseparable from the "tribute" system at ore mines. At the latter the change in the value of a lode may be so sudden, that a single blast will convert a " pitch" originally " set" at a tribute of two-thirds, into one which could be worked profitably by the men at one-twentieth. If such a change takes place some time before the end of the contract, the men raise far more ore than was thought possible when the bargain was arranged, and make what is known to Cornishmen as a "start" or "sturt," in other words "a big haul." Cases are known in which a party of tributers have earned as much as $f_{100}$ each in a month, instead of the expected $£ 4$ or $£ 5$. The possibility of such good fortune naturally encourages the miner to take the risks incident to working upon tribute, and at the same time prompts him to deceive his superiors if he can. With slate, the "rockman" may be favoured by unexpected joints, and he may be able to earn twice as much as was expected when he entered into his contract, but he does not get twenty times as much, nor is he liable to find his "bargain" so suddenly become poor or absolutely worthless as may happen with a copper lode in Cornwall. There are also fewer opportunities of hiding coming improvements from the eyes of the agents. The result is that there are fewer attempts at concealment, and consequently there is less chance of the moral feeling being blunted; sudden great variations in the earnings are rare, and the solution of the problem of payment by results seems very satisfactory.

As a final instance of the payment of wages, may be mentioned that of piecework combined with premiums for good conduct. This system was introduced at the large stone quarries of Quenast in Belgium* in order to make the men stick to their work during the regular hours, and not absent themselves on the pretext that, as they were paid by results, they could do as they pleased. The company instituted a higher rate of wages and prices applicable only to men who did not leave the quarry during working hours without permission. The men soon discovered that it was to their advantage to get the higher tariff, the public-houses were less frequented, the average earnings increased, and the company had more work done.

* “Continental Notes," reporting communication by Urban to Brussels Section of the Liège Engineers. Coll. Guard., vol. Ixiii. 1892, p. 844 . 


\section{CHAPTER XV.}

\section{LEGISLATION AFFECTING MINES AND QUARRIES.}

Ownership-Taxation-Working regulations ; Metalliferous Mines Regulations Acts, 1872, 1875, and I891 ; Coal Mines Regulation Act, I 887 ; Alkali Acts-Boiler Explosions Acts-Brine Pumping (Comrensation for Subsidence) Act-Elementary Education Acts-Employers' Liability Act-Explosives Act ; Factory and Workshop Acts-Quarry Fencing Act Rivers Pollution Prevention Act-Stannaries Act, 1887Truck Acts.

TnE object of this chapter is to call the student's attention to the principal laws aflecting the working of mines and quarries in the British Isles.

The subject may be taken under the following heads :

I. Ownership.

2. Taxation.

3. Working regu'ations.

4. Sundry special statutes.

I. Ownership.--In the United Kingdom the person owning the surface is prima facie entitled to all the minerals underneath, excepting in the case of mines of gold and silver, which belong to the Cruwn. The Crown, however, does not claim gold and silver extracted from the ores of the baser metals. Thus we find that the Crown receives a royalty for the gold extracted from auriferous quartz raised upon private property in Wales, but gets nothing whatever for the silver contained in argentiferous galena.

The ownership of the minerals can be, and often is, severed from that of the surface, the latter being sold whilst the mineral rights are reserved by the original owner. Minerals lying under the surface between high and low water mark are claimed by the lord of the manor, while everything under the sea and beyond low water mark is the property of the Crown.

In the majority of cases in the British Isles, * the proprietor of the minerals does not work them himself, but concedes the right

* Final Report of the Royal Commission appointed to Inquire into the subject of Mining Royalties. London, 1893. This Report contains much information also about the Mining systems of the Colonies and foreign countries. 
to another person in return for an annual rent and a royalty. Usually a cartain minimum rent is fixed, which has to be paid even if no mineral is being raised, but this rent merges in the royalties; that is to say, the amount paid as royalty is put to the credit of the rent, or, if sufficient, covers it entirely.

The royalty may be:

(a) A fixed sum per acre worked.

(b) A fixed snm per ton raised.

(c) A fixed proportion of the value of the mineral raised.

(d) A varying proportion of the value of the mineral sold, regulated by a sliding scale.

The first principle is more especially adopted in the case of coal; on the other hand, a fixed rate per ton is common in the case of stratified ironstone. In the Cleveland district, the royalty is $6 \mathrm{~d}$. per ton on an average, and the leases extend for 42 years.

Mineral veins are generally worked upon the third system; royalties vary from one-tenth downwards, though this amount is quite exceptional. It is not uncommon for the lessee to pay oneeighteenth or one-twenty-fourth as royalty, and if a mine is struggling against low prices of metal, the "lord" is often induced to abate his legal claims very considerably, or even to agree to forego all payments until trade revives. The royalty is calculated upon the ore made ready for the market. Thus, for instance, in one of the reports of Dolcoath mine in Cornwall we read :

By tin ore, 257 tons I 9 cwt. I qr. 7 lbs

Deduct G. L. Basset, Esq., dues I-20th. .

$$
\begin{array}{r}
£ 19,596 \text { 13 } 6 \\
979 \text { 16 } \\
\hline £ 18,616 \text { 16 10 }
\end{array}
$$

Leases in Cornwall are usually granted for $2 \mathrm{I}$ years. The lessor stipulates that a certain number of men shall be kept constantly at work. Ground for tipping rubbish has to be paid for, and sometimes at extravagant rates. When a lease is drawing to a close, a new one is usually granted upon terms at least as favourable as those of the old ones; but cases have arisen in which the "lord" has required a heavy premium before he would grant a new lease.

The hæmatite of the Carboniferous Limestone of Cumberland and North Lancashire is usually leased upon a sliding scale, which increases the proportion paid as royalty when the price of ore goes up. Thus if iron ore is selling under $9 \mathrm{~s}$. per ton the lessor receives rod. per ton as royalty, i.e., exactly one-tenth if the price is $8 \mathrm{~s} .4 \mathrm{~d}$. Supposing the value of the ore to rise to $\mathrm{I} 4 \mathrm{~s}$. per ton, the lessee would have to pay $2 \mathrm{~s}$. or one-seventh. With intermediate prices the fraction might be one-eighth or one-ninth. The leases are for 2 I years. 
Many centuries ago the Crown claimed the right to all minerals, and, in order to promote mining, privileges were granted to persons who would endeavour to discover and work mines; from these privileges and from old usages have resulted special mining rights peculiar to certain districts. Those pertaining to Derbyshire have now been definitely fixed by two special Acts of Parliament, the High Peak Mining Customs and Mineral Courts Act, 185 I (I4 \& I5 Vict. c. 94) and the Derbyshire Mining Customs and Mineral Courts Act, 1852 (1 5 \& I 6 Vict. c. 43). Again, there are two special statutes (I \& 2 Vict. c. 43 and $24 \& 25$ Vict. c. 40 ) which regulate the opening and working of mines and quarries in the Forest of Dean, where the "free miners" have certain peculiar rights.

These Acts are merely of local importance, but they are of interest as preserving old customs.

2. Taxation.-Mining companies have to bear their share of Imperial taxes and local rates.* By "The Rating Act, 1874" $(37 \& 38$ Vict. c. 54$)$ tin, lead, and copper mines are assessed on the amount of dues payable, and in some districts a large proportion of the rates may be paid by the mines, an arrangement which is not unfair, if they are the cause of heavy burdens being thrown upon the community.

3. Working Regulations.-We now come to the third division of this chapter, viz., the statutory regulations which are in force for the safe working of mines.

Special legislation for promoting the safety and well-being of the miner is a growth of the last half-century. I do not mean by this that there were absolutely no regulations in days gone by ; there were rules which had grown up in some places, from customs and privileges so carefully preserved that they had become laws, but these related mainly to the acquisition and preservation of mining property, and only incidentally to the prevention of accidents.

In order to make the state of our laws clear, and especially to those who may be accustomed to Continental regulations, it is necessary to point out once more that the sources from which we obtain minerals are of three kinds :

$a$. Open works, that is to say workings open to the sky.

$b$. Mines, that is to say workings carried on underground by artificial light.

c. Boreholes, or old flooded mines, from which brine is pumped.

As was said in Chapter I., it is the nature of the excavation and not the nature of the mineral, which settles, in this country, whether a given working is a mine or not. Consequently it must

* Coal, Ironstone, and other Mines (Rating). Parliamentary Paper No. 405, Session I8go. Price $2 \frac{1}{2} d$. 
be understood that the purely mining Acts in no way affect open workings, save such as may form part and parcel of a true mine.

The actual mining statutes now in force are as follows, in chronological order:

The Metalliferous Mines Regulation Act, 1872 ( 35 \& 36 Vict. c. 77$)$.

The Metalliferous Mines Regulation Act, I875 (38\& 39 Vict. c. 39$)$.

T'he Slate Mines (Gunpowder Act), 1882 (45 Vict. c. 3).

The Coal Mines Regulation Act, I 887 (50 \& 5 I Vict. c. 58 ).

The Metalliferous Mines (Isle of Man) Act, I891 (54\&55 Vict. c. 47).

The first of these Acts was passed after the report of the Royal Commission appointed in 1860 to inquire into the condition of mines which were then not under inspection, and it was made to embrace every mine to which the sister Act, the Coal Mines Act of 1872 , did not apply. Therefore every mine in the kingdom is under inspection : either it is subject to the provisions of the Coal Mines Act, 1887, which has taken the place of the 1872 statute, or it is under the Metalliferous Act of 1872 . The former Act applies to mines of coal, stratified ironstone, shale, and fire-clay, and therefore the latter takes cognizance of everything else. The titles of the two Acts are misleading. Three times as much iron ore is obtained from mines under the Coal Act as from mines under the Metalliferous Act, and the largest mine under the latter does not produce metallic ores. Soon after the passing of the Metalliferous Act, the owners of an underground slate quarry in North Wales refused to have their workings treated as mines. They asserted with some plausibility that the Statute was the "Metalliferous Mines Act," and that their workings had invariably been known as "quarries," and never as " mines." The matter had to be brought before the Court of Queen's Bench, and there it was speedily decided that, in spite of popular phraseology, the Festiniog underground quarries were legally "mines," and, as such, subject to inspection, quite as much as the Cornish tin mine, the Cumberland iron mine, or the Derbyshire lead mine.

I will now proceed very briefly to pass in review the most salient points of these two Acts of Parliament, beginning with the simpler, and incidentally point out the slight modifications introduced by the other three statutes mentioned in my list.

The Metalliferous Act is divided into three parts.

Part I. deals with employment of women, girls, and boys. No females can work below ground, nor can any boy under 12 years of age. Boys under 16 cannot be employed more than 54 hours in any one week, or more than ro hours in any one day.

The person in charge of machinery for raising and lowering men must be a male of at least i 8 years of age. 
Wages must not be paid in public-houses.

An Annual Return has to be sent every year to the Inspector of Mines of the district, specifying the number of persons employed, and the output of mineral. Under the 1872 Act, the mine-owner was not obliged to furnish this return for any given year until ist August following. This delay in the despatch of the return was manifestly absurd, for the statistics based upon them could not be published until they had lost much of their interest; the fault in the 1872 Act was corrected by the short amending Act of 1875 , which changed the date from the Ist August to the ist February every year.

The owner* or agent has to send to the Inspector of Mines of the district notice of every fatal accident, of every accident causing serious personal injury, and of every accident, no matterhow trifling, causing personal injury by reason of any explosion of gas, powder, or of any steam-boiler. 'The word "serious" gave a little trouble at first. Some agents were inclined to interpret it as meaning " likely to prove fatal," and did not; report broken arms and legs, because there was every reason to suppose that the man would recover. Nowadiys, when the period of disablement is likely to exceed a week or ten days, the accident is usually notified.

Notice of opening, discontinuance, recommencement or abandonment, has to be sent within two months.

The section which follows (sec. 13 ) is one which was very much wanted, and which is still often called into requisition. It is the portion of the Act which provides for the secure fencing of shafts and side entrances of mines which are no longer at work. In working mineral veins, the "old men" sank their shafts as close to one another as they still do in mining ozokerite at Boryslaw, and the surface of open and uninclosed land was often riddled with holes like a sieve. If the tops of these shafts were in hard rock or were lined with stone, they remained open, and were a source of danger by day and by night, for many were close to roads or foot-paths, and, when partly or entirely concealed by brambles or bushes, they formed veritable man-traps. In other cases the timber lining at the top had decayed and the ground had run in, leaving a huge yawning crater, Io or 20 yards across, leading to a pit hundreds of feet deep. It is true that a visible danger of this kind was known to the inhabitants of the district and could be avoided by daylight, but strangers were exposed to a considerable amount of peril. Five and twenty years ago the state of some of the open commons in Cornwall and Flintshire was simply scandalous; and even now there are often good grounds for complaint on the part of the public, as fences become defective from having been constructed originally in too flimsy a manner, or

* The word "owner" has a special interpretation under the statute and refers to the lessee or company working the mine, and not to the proprietor of the soil or mineral rights. 
from the mischievous pranks of passers-by. Occasionally, too, an unknown shaft comes to light from the decay of the platform of planks which had been put over it and covered with earth when the mine was abandoned. If treated in this way the top soon becomes grown over with grass, and recollection of the shaft gradually fades away. These timber " sollars," as they are called, should never be put in unless there is also a secure fence. Many narrow escapes have occurred in Cornwall from the giving way of such coverings, where the presence of a shaft was quite unsuspected.

Abandoned mines are not only a source of danger to the general public by creating pitfalls, but they may also threaten the workers in the vicinity by holding accumulations of water or gas, liable to be tapped unexpectedly if the boundaries of the old workings are not known. To guard against such possibilities, the owner, who is bound to keep an accurate plan and section of his mine during the progress of the workings, is further obliged to deliver up a copy when he abandons them; these plans are filed at the Home Office, and can be consulted if necessity arises. They serve also to show new-comers, who propose to reopen an old mine, what work has been done by their predecessors.

-The next section of the Act relates to the Inspectors of Mines, who are appointed by the Secretary of State for the Home Department. The Inspector may not practise as a mining engineer, manager, agent or valuer of mines. In addition to enforcing the provisions of the Act, the Inspector has the right to complain of any thing or practice in the mine which is dangerous, or defective, or, in his opinion, threatens or tends to the bodily injury of the persons employed. In order to prevent an unreasonable Inspector from pushing matters too far, the owner and agent are duly safeguarded. They can object to the Inspector's notice about these alleged defects and have the matter referred to arbitration.

Each Inspector has to make an Annual Report, which is laid before Parliament and afterwards published as a Blue-book.

This is a convenient place for explaining that the United Kingdom is divided, for the purposes of inspection, into thirteen districts, each under a Chief Inspector, who, as a rule, has from one to three assistants.

The following separate publications are issued annually by the Home Office:

Report by each Inspector for his district

Statistical Summaries showing the number of persons employed, the deaths from accidents, and the quantity of mineral raised, together with the corresponding figures for previous years.

List of all the Mines in the United Kingdom. 
List of Record Plans deposited at the Home Office.

Mineral Statistics of the United Kingdom.

The last section of Part I. of the Act refers to the duties of the coroner, who cannot conclude an inquest upon the body of a person killed by a mine accident, unless due notice has been given to the Inspector of the district. As a rule the Inspector attends the inquest, and can be of much assistance to the coroner in eliciting evidence, for he will have seen the place where the accident took place, and will know whether it is likely that it has been caused by pure ill-luck or through neglect of proper precautions.

Part II. of the Act contains the General Rules, and sets forth the mode of establishing Special Rules.

The General Rules are a series of nineteen regulations which have to be observed in every mine.

Ventilation.-Rule I relates to ventilation. It prescribes that an adequate amount of ventilation shall be constantly produced, so that the various parts of the mine shall be in a fit state for working and passing therein. No standard of ventilation is laid down, nothing is said about the number of cubic feet per minute that have to be supplied, nor as to any given percentage of noxious gas rendering the ventilation "inadequate."

Explosives and Blasting.-Rule 2 defines how explosives are to be taken into the mine, and lays down the precautions which have to be observed while they are being used. Storage underground is forbidden; the mine should have a proper magazine above ground, from which explosives should be dealt out daily to the miners in small lots as required. In order to save trouble in keeping the account of the small daily doles, a subsidiary magazine is sometimes kept up, in which each gang of men has a locker. A proper attendant then serves out explosives every day from the lockers, without weighing the quantities.

The explosives must be taken into the mine in a case or canister which must not contain more than four pounds.

Iron and steel needles or prickers are prohibited, but the Secretary of State has power to exempt mines from this restriction if he thinks fit. Exemptions of this kind have been granted in the case of the salt mines of Cheshire. Iron and steel tamping bars may not be used for ramming in the wadding or the first part of the tamping. It is lastly illegal to pick out or bore out the tamping of a charge of powder which has missed fire.

By the Slate Mines (Gunpowder) Act, 1882, the Secretary of State has power to relax the restrictions concerning explosives. This Act was passed for the convenience of workers in slate mines, who occasionally have to fire large blasts of 8,10 or 12 pounds of powder, in order to sever a large block of slate which has not been rompletely released by the original shot. The powder is 
sometimes required on the spur of the moment, as water might fill up the crack by the time the man had made the journey to and from the surface for a supply. Many agents of slate mines are of opinion that it is safer to carry powder into the mine in the 25-pound kegs coming direct from the manufacturer than in the ordinary 4-pound canisters. Where exemptions have been granted under this Act, the dangers incident to storing these kegs of powder and opening them by candle-light are reduced as far as possible by stringent special rules.

Inclined Planes and Horse Roads.-Rules 3, 4, and 5 relate to signals and refuge places on inclined planes or horse roads.

Shafts.-In Rules 6, 7, and 8 are very important regulations concerning shafts. The sides have to be made secure, and the top of the shaft and all entrances to it have to be fenced.

Descent and Ascent.-The next seven rules relate to the descent into mines and ascent therefrom, whether by ladders or machinery.

If ladders are used, the ladderway must be partitioned off from the winding compartment. The object of such a partition is not only to prevent men from falling into the winding compartment, but also to protect them from stones, which might drop from the bucket or skip during hoisting operations. Vertical and overhanging ladders are forbidden, and substantial platforms are required at intervals not exceeding 20 yards. The rule also says that "a ladder shall be inclined at the most convenient angle which the space in which the ladder is fixed admits." The wording is unfortunate, because it sometimes fails to secure a proper inclination for ladders; there is nothing to prevent a person from sinking too small a shaft, and then alleging want of space as an excuse, when a complaint is made to him about the great steepness of his ladders. The Belgian law is worded better, for it says that no ladder shall be inclined at an angle of less than $10^{\circ}$ from the vertical.

The only statutory enactment about man-engines is that they shall be partitioned off from the winding compartment of the shaft.

We now come to ascent and descent by winding machinery. Guides and signalling apparatus are required as soon as a shaft exceeds 50 yards in depth, and a cover overhead is obligatory unless an exemption has been granted by the inspector. A single linked chain is forbidden; the winding drum must be provided with flanges to prevent the rope from slipping off; there must be an adequate brake, and an indicator to show the position of the load in the shaft.

Dressing-room.--It was quite right on the part of the Legislature to make provision by Rule I 6 for a changing house, or "dry," enabling the men to change their clothes in comfort, and have easy means of drying their wet underground suits ready for the next day; but the wording might have been a little more elastic. 
As the law stands, a mine need not have a "dry" if fewer than thirteen persons are employed below ground; and yet one meets with wet sinking shafts employing only ten or a dozen men, where some accommodation is desirable, and with large mines which are so dry that a changing house, as generally understood, is superfluous.

Fencing Machinery.-Rule I 7 prescribes that all dangerous machinery must be fenced.

Steam Boilers. - The only statutory regulations concerning steam boilers are found in Rule 18, which says that every such boiler must be provided with three fittings, viz., a steam gauge, a water gauge, and a safety valve.

Wilful Damage.-The last Rule, No. I9, forbids the wilful damage of, or removal of fences or appliances provided for the safety of the men.

In order to make the owner and agent responsible for the proper carrying out of these essential regulations, this section of the Act concludes with a very strict clause. As a rule, in this country, a man is assumed to be innocent until he is proved guilty. In mining, it is different; if a contravention of the Act by any person whomsoever, for instance, a workman, is proved, the owner and the agent are each made guilty of an offence and are liable to punishment, unless they can prove that they had taken all reasonable means to prevent the contravention by publishing, and to the best of their power, enforcing the rules. The Legislature has therefore taken strong means in order to render the miner's calling safe. On the other hand, the owner and agent are thoroughly safeguarded by a clause, which governs the whole of the section, and says that the rules are to be observed "so far as may be reasonably practicable."

Special Rules may be regarded as by-laws framed to suit the conditions of any particular district or mineral deposit; when once established with the formalities prescribed by law, they have all the power of the statute itself. They are a very useful institution, and as there are simple means of modifying them, changes can be introduced from time to time, without having to set in motion the ponderous machinery required to alter an Act of Parliament. At mines under the Metalliferous Act, special rules are not compulsory as they are under the Coal Mines Act; but the Secretary of State can propose any rules he thinks fit to the owner of the mine, who may object and have the matter decided by arbitration.

An Abstract of the Act, and a copy of the Special Rules (if any) have to be posted up in a conspicuous place at the mine, where they can be conveniently read by the workpeople. The name and address of the Inspector of the district have to be appended, so that every one may know to whom to apply in case of need.

Part III. deals with penalties for offences and the technicalities. 
relating to lesal proceedings. The penalties to which a person is liable for a breach of the Act are a maximum of $f_{20}$ if he is an owner or agent, and a maximum of $£^{2}$ if he is any other person; the fine may be increased by $\mathcal{E}_{\mathrm{I}}$ a day so long as the offence continues, if the offender has received notice in writing from the Inspector. For wilful neglect, endangering life and limb, a person may be sentenced to imprisonment, with or without hard labour, for a period not exceeding three months.

The owner and agent eannot be prosecuted except by an Inspector, or with the consent in writing of the Secretary of State. The workman ean be prosecuted by his master; and proceedings against the men become necessary when the master finds that mere words fail to secure strict obedience to regulations, which is imperative in a dangerous occupation like mining.

Strange to say, the clause which prevents interested magistrates from sitting in cases under the Coal Mines Act, is omitted altogether in the Metalliferous Act.

Where a penalty amounts to or exceeds half the maximum, the person convicted may appeal to a higher court.

The last Mining Act, that of r89r, was passed in order to correct a curious omission in the old statute of 1872 , which failed to define the Court of Summary Jurisdiction in the Isle of Man before which proceedings could be taken.

Having thus briefly explained the statute by which the working of many ore and stone mines is regulated, we must now pass on to the Coal Mines Regulation Act, 1887, which governs mines of stratified ironstone, shale and fireclay, as well as collieries. Compared with coal, it is true that these minerals are of minor importance; but as their total output amounts to more than I $2,000,000$ tons annually, of which $7,000,000$ tons are ironstone, it is evident that even the ore miner should be acquainted with the requirements of this statute.

It presents many points of resemblance with the Metalliferous Mines Regulation Act, but it is far more elaborate in its details; to save repetition it will be best to dwell more especially upon the points in which it differs from the Act which we have just been discussing.

In Part $\mathrm{I}$. the principal now features are:

Hours of Labour.-Regulation of the hours of labour of boys and females employed above ground.

Check Weigher.-If the majority of the men wish it, they may appoint a check weigher to see that the weighing is done correctly, and that deductions are made fairly.

Prohibition of Single Shafts.-The object is to provide two means of egress in case of accident; certain mines may be exempted from this provision.

Division of Mine into Parts.-Under certain circumstances each part must be treated as a separate mine. 
Certificated Managers. - This is one striking difference between the Metalliferous Act and the Coal Act. Under the former a person without any pretensions to professional qualifications may be placed in charge of a mine; under the latter every mine employing more than thirty persons below ground must have a certificated manager. In order to obtain a certificate the candidate must have had practical experience in a mine for at least five years, and must then pass an examination. For the purpose of granting certificates, boards for examination have been appointed in each of the twelve districts into which the kingdom is divided for the purposes of the Coal Mines Act. Unfortunately the statute makes no provision for securing uniformity in the examinations. Even the limits of age are not the same; but, nevertheless, a certificatè when once obtained, is good for any part of the kingdom.

Returns.-The Annual Return which has to be furnished under the Coal Mines Act not only gives the output of the mine and the number of persons employed, but also supplies details concerning the mode of ventilation; the part relating to the quantity of mineral wrought cannot be published, save by consent of the person making it, or of the owner of the mine. This restriction prevents the publication of such details as appear in the "Mineral Statistics" in the case of mines under the Metalliferous Act.

Inquests. - At coroners' inquests, a relative of the person killed, the owner, agent, or manager of the mine in which the accident happened, and any person appointed by the order in writing of the majority of the workmen employed in the mine nidy attend and examine witnesses. No such power is conceded under the Metalliferous Act.

Part II., as in the other Act, contains the General Rules, and regulates the establishment of Special Rules, which are compulsory instead of being voluntary.

The General Rules are 38 in number, or twice as numerous as those in the sister Act. They may be passed in review very briefly as follows:

Ventilation $(1,2,3)$.--Amount of ventilation to be arlequate; quantity of air to be measured monthly; special airway to carry the return current clear of the ventilating furnace; ventilating machines to be placed where they will not be injured by explosions.

Inspections by Officials $(4,5)$.- -The working place has to be inspected before men begin their work, and during the progress of their work. Machinery must be inspected daily and shafts weekly.

Fencing (6).-Dangerous places must be fenced off.

Withdrawal of Men (7).-Men must be withdrawn from dangerous places.

Safety-Lamps (8, 9, Iо, I I).-Use, construction, and examination of safety-lamps. Situation of lamp stations. 
Explosives (I 2).--Prohibition of iron and steel tools for charging holes, and special precautious for blasting in mines where tiredamp has been noticed, or which are dry and dusty.

Advance Boreholes (13).-These are made compulsory when approaching water.

Signalling and Man-Holes for Travelling Roads (14, 15, 16).Very like the rules in the Metalliferous Act.

Dimensions of Travelling Roads ( $\mathrm{I}$ 7).--Here we find that the comfort of animals is not forgotten, for roads must be big enough to allow the horses or ponies to pass along without rubbing.

Fencing of Shafts (18, 19).- Very like the rules in the Metalliferous Act.

Securing of Shafts (20).-Identical with the rule in the Metalliferous Act.

Securiny of Travelling Roads (2 I).-This very useful rule, though contained in the Coal Mines Act of 1872 , was not incorporated with the Metalliferous Act.

Timber (22).- Props have to be provided at a convenient place in the mine.

Descent and Ascent (23 to 30 ).- - In addition to the regulations found in the Metalliferous Act, there is a rule preventing a speed of more than three miles an hour after the cage has reached a certain point in the shaft, when the winding apparatus is not provided with some automatic contrivance for preventing overwinding. Men may use the downcast shaft for descent and ascent if they wish to do so. No mention is made of ladders or manengines, which are not in use at mines under the Coal Mines Act.

Fencing Machinery (3I).- Identical with the Rule in the Metalliferous Act.

Fittings for Steam Boilers (32).-Very like the Rule in the Metalliferous Act.

Barometer and Thermometer (33).- -These have to be placed in a conspicuous position at the mine.

Ambulances (34).- - As suffering may be mitigated or life saved by having proper appliances at hand for relieving and moving injured men, the statute requires that stretchers, splints, and bandages shall be kept ready for immediate use.

Wilful Damage to Fences, or Appliances for Safety (35).- -Very like the rule in the Metalliferous Act.

Observance of Directions (36).- $M$ - are bound to obey directions with respect to working, given with a view to comply with the Act or Special Rules.

Books recording Results of Inspections (37).-These have to be kept at the office of the mine.

Periodical Inspection on Behalf of Workmen (38).-The men may appoint two practical working miners to inspect the mine, at their own cost, once a month. The result of the inspection has to be recorded in a book, and if the report states the existence or 
apprehended existence of any danger, the inspector has to be informed of it.

Experienced Workmen (39).-Men are not allowed to work alone in getting coal or ironstone at the face of the workings unless they have had two years' experience in or about the face of the workings of a mine.

Part III. relates mainly to legal proceedings, and the only special point to which attention need be called is the section which prohibits persons interested in mines, or their near relations, from sitting on the Bench and adjudicating upon breaches of the Act.

4. Sundry Special Statutes.-It might be thought that statutes framed for regulating mines would contain all that the law requires for their safe and proper working; but such is not the case in this country. Miners and workers of open pits are often affected by one or more of the following Acts of Parliament, which are arranged in alphabetical order :-

Alkali, \&c., Works Regulation Acts, I88I and I892 (44 \& 45 Vict. c. 37 , and 55 and 56 Vict. c. 30 ).

Boiler Explosions Acts, I 882 and I 890 (45 and 46 Vict. c. 22, and 53 and 54 Vict. c. 35$)$.

Brine Pumping (Compensation for Subsidence) Act, I891 (54 and 55 Vict. c. 40 ).

Elementary Education Acts, I870 to I89 I (33 and 34 Vict. c. $75 ; 38$ and 39 Vict. c. 79 , and 43 and 44 Vict. c. 23; 53 and 54 Vict. c. $22 ; 54$ and 55 Vict. c. 56).

Employers' Liability Act, I880 (43 and 44 Vict. c. 42).

Explosives Act, 1875 ( 38 Vict. c. 1 7 ).

Factory and Workshops Acts, I878 and I 89r (4I and 42 Vict. c. 16 , and 54 and 55 Vict. c. 75).

Quarry Fencing Act, I 887 (50 and 5 I Vict. c. 19).

Rivers Pollution Prevention Act, I 876 (39 and 40 Vict. c. 75). Stannaries Act, I 887 (50 and $5 \mathrm{r}$ Vict. c. 43).

Truck Acts, I 831 and 1887 ( 1 and 2 William IV. c. 37 , and 50 and 5 I Vict. c. 46$)$.

The Alkali Acts were passed with a view to prevent noxious and offensive gases produced in manufacturing processes from being discharged into the atmosphere, or at all events to reduce their escape to a minimum. These Acts apply to a few mineral workings-viz :

(I) Salt works in which brine is being evaporated for the manufaoture of salt.

(2) Cement works in which clays are made into cement.

(3) T:n and copper mines where ores containing arsenic are being roasted.

(4) Collieries where tar and ammoniacal liquor, obtained from the waste gases of coke ovens, are being treated ; the former is distilled for the production of paraffin and burning oils, the lattcr is made into sulphate of ammonia. 
The Acts are administered by Inspectors under the Local Government Board.

The Boiler Explosions Acts compel the owner of a mine to report to the Board of Trade any explosion of a steam boiler, which may happen at his works whether above or below ground. The Board of Trade officials can then make a preliminary investigation into the cause of the explosion, and afterwards hold a formal inquiry if they think fit. The Court holding this formal inquiry is usually composed of two Commissioners specially appointed by the Board of Trade, who are endowed by the Acts with ample power for punishing the owners and agents of mines, if an explosion has in any way been caused by their neglect. The Commissioners cannot inflict a "fine" in a criminal sense, such as is imposed by a Court of Summary Jurisdiction at proceedings taken under the Mines Regulation Acts; but, where neglect has been proved, the responsible persons have been ordered to pay as much as $\mathcal{E}_{\mathrm{f}} \mathrm{oo}$ or $\mathcal{E}_{20}$ to the solicitor of the Board of Trade "towards the costs and expenses of the investigation," which practically comes to the same thing. Under the Mines Regulation Acts the mineowner can appeal to a superior court and have the matter re-heard; but the decision of the Commissioners under the Boiler Explosions Act is tinal and not subject to review.

The Brine Pumping Act provides compensation for owners of property who suffer through the subsidence of the ground caused by the pumping of brine. The working of the Act is controlled by the Local Government Board.

The Elementary Education Acts make provision for the education of children: they prohibit absolutely the employment of children below the age of 10 , and do not permit the employment of children below the age of I 3 unless they have reached the standard of education fixed by the by-laws in force in the district. Children between I 3 and I 4 are allowed to work if they can produce a certificate of proficiency or of previous due attend. ance at school. After they have attained the age of 14 , they are no longer "children" within the meaning of the Education Acts.

The Employers' Liability Act extends and regulates the liability of employers to make compensation for personal injuries suffered by workmen in their service. Until this Act was passed a workman could not claim compensation for injuries due to the neglect of a fellow-servant. The statute of I880 has broken down this doctrine of "common employment" to a certain extent, and has made the master liable if the injury was caused by the negligence of a foreman or person entrusted with superintendence; but it does not make the master liable for the negligence of all tho fellow-servants.

The Explosives Act regulates the manner in which licences for storing explosives are obtained, the construction and maintenancu of the magazines at mines, the subdivision of the trade packages, 
and the delivery to the men. The Act is enforced by Inspectors under the Home Department, and also by the Police on behalf of the Local Authorities.

The two Factory and Workshop Acts, which are enforced by Inspectors serving under the Horne Department, apply to certain quarries, and to surface works at mines under the Metalliferous Act, such as the dressing sheds. They contain provisions for promoting the health and safety of the workpeople, and regulate the hours of employment of women, young persons, and children. It is probable that all quarries will eventually be placed under the supervision of the Inspectors of Mines.

The object of the Quarry Fencing Act is evident from its title, and it is the business of the Local Authorities to see it enforced.

By'section 5 of the Rivers Pollution Prevention Act, the mineowner is prohibited from discharging into streams any solid matter in such quantity as to prejudicially interfere with its flow, or any poisonous, noxious or polluting solid or liquid matter, unless he proves that he is using the best practicable and reasonably available means to render such matter harmless. The administration of this law rests with the Sanitary Authority of the district, and in this, as in other matters, the work of the Sanitary. Authorities is supervised by Inspectors acting under the Local Government Board.

The large amount of refuse which is produced in extracting some minerals from their ores, makes the task of getting rid of it, without polluting the rivers, far from easy; and the miner often incurs the wrath of the fisherman, who stirs up the Sanitary Authorities or Piver Conservancy Boards into action. Coarse waste, such as comes from jigging the larger sizes of the crushed rock, can always be made into heaps upon the land; but the fine slimes, whether coming from stamping or other dressing processes, are carried away in suspension, and turn a bright trout stream into a muddy drain, or are spread over the meadows in flood time, to the annoyance of the farmer. These evils may be greatly lessened by providing large pits into which the water from the mine is allowed to settle, and so deposit much of the solid matter which it contains in suspension. Effective filtering pools have been made in Germany from the coarse refuse (skimpings) from the jigs. It is tipped so as to form high banks enclosing a rectangular area, into which the muddy water from the "floors" is led, and allowed to form a large pool. Some of the solid matter settles down on the bed of the pool, as it would do in any ordinary pond, and the rest is depasited in the bank itself, as it permeates through the tortuous passages left between the little fragments of stone. In time, the inner sides of the banks become somewhat choked with slime and the percolation no longer proceeds so rapidly; this state of things is remedied by letting out the water during a holiday, and scraping 
down the sides, so as to expose a fresh unchoked surface to the slimy water. Old heaps of mine refuse can be utilised in a similar manner; the stream of dirty water led into the top will escape fairly clear at the bottom. As soon as one part of the heap becomes choked with slime, the out-fall of the "floors" must be shifted to another part of the bank.

The Stannaries Act, I887, was passed to remedy certain evils of which miners and shareholders complained at mines in Cornwall and Devon. The Act extends only to metalliferous mines and tin streaming works-i.e., works where tin ore is extracted from the dirty water flowing away from mines, within the Stannaries. The miner now has a first charge upon the property of a mining company, and is less likely to lose his earnings when a mine is stopped for want of funds, than he was some years ago. Surface hands have to be paid once a fortnight; miners employed by contract below ground are entitled to claim "subsist" once a fortnight-that is to say, a payment on account equal to the estimated amount of their earnings. Money deducted for sick and accident funds has to be accounted for, and a copy of the balancesheet must be posted up in the "dry" or changing house. The miners have the power to appoint a check-weigher. Meetings of the shareholders of every "cost book" mine must be held at least once in every sixteen weeks. Tools and materials supplied to the miners have to be charged as nearly as possible at the market prices. Other regulations relate to the settlement of disputes, mortgages, relinquishment of shares, and registration of companies. A copy of the Act has to be kept posted up in the smith's shop and in the changing house of every mine.

The object of the Truck Acts is to prevent the mine owner from making a profit out of the tools and materials which he supplies to his men; but he has a right to make deductions from the men's wages for medicine, medical attendance, materials and tools, provided that they agree in writing to this system. As a rule the men would sooner obtain the necessaries for their work in this way, than purchase them at the shops in the district. The Truck Acts have to be enforced at mines by the Inspectors under the Mining Acts.

From the foregoing pages it is very evident that the manager of a mine in this country may have to make himself well acquainted with a considerable number of legal enactments, mostly of recent date, if he desires, as he should do, to carry on his work in strict accordance with the law. 


\section{CHAPTER XVI.}

\section{CONDITION OF THE MINER.}

Clothing : hat, boots, jacket-Housing: barracks, cottages, changing houses-Education-Sicknes;-Thrif-_Recreation.

IT is perfectly impossible to do justice to the importance of this subject in the few pages that can be devoted to it in a general text-book; but the following remarks will serve to call the attention of the student to matters with which he may have to deal when he enters into the active duties of his profession, and becomes either an employer of labour himself, or the agent of a mining company.

I propose to treat the subject under the following heads:
I. Clothing.
2. Housing.
3. Education.
4. Sickness.
5. Thrift.
6. Recreation.

I. CLOTHING.-At the surface we clothe ourselves in order to keep our bodies warm, and to protect ourselves from the sun and rain; in the mine the conditions are totally different, and the clothing may be altered accordingly. On the whole the temperature is more uniform than it is above ground; the miner in most cases finds his working-place warmer in winter and cooler in summer than it would be if he were working in the fields in the neighbourhood. It is the exception to have the temperaturg below $32^{\circ} \mathrm{F}$. in mines even in winter. Oecasionally in this country a freezing wind rushing down the shaft will coat the ladders with ice and make climbing unpleasant and risky, and where the climate is cold and the openings to the surface large, the effects of frost are felt far deeper than they are here. The sinkings through alluvial deposits in Siberia are instances of great cold in mines; and even where the operations are more truly underground the temperature is sometimes below freezing point. This is the case at the Algachi silver mine.*

The other extreme was found in the workings on the Comstock

* Kennan, "In East-Siberian Silver Mines," The Century Magazine, vol. xxxviii., 1889, p. 803 . 
lode** In the year 1 868, when a depth of 1000 to 1200 feet had been reached, the heat in some drifts was becoming unbearable. In August I 868 at a depth of 1100 feet in the Chollar-Potosi Mine, the temperature was $100^{\circ} \mathrm{F} .\left(37^{\circ} 7 \mathrm{C}.\right)$, and in the lower level of the Hale and Norcross I I $0^{\circ}$ F. (43.3 C.) In June I 870 at the 900 -foot level of the Yellow Jacket Mine the temperature was $97^{\circ} \mathrm{F}$. (36. I C.) at a point only 300 feet from the shaft, although blowers were at work. The highest temperatures were observed when long levels were driven without any ventilating shafts or winzes. As soon as a proper air-current was established the temperature usually sank rapidly. Thus the thermometer stood at $130^{\circ}$ to $140^{\circ} \mathrm{F}$. (54 to $60^{\circ} \mathrm{C}$.) in a drift at the $185^{\circ}-$ foot level of the Bullion Mine, but when connection was made with another shaft the thermometer went down to $100^{\circ} \mathrm{F}$. $\left(377^{\circ} \mathrm{C}\right.$.) The miners working in the hot levels were supplied with ice, which was sent down by the ton. Their average daily consumption in the hottest parts of the California and Consolidated mines during the summer of 1878 was 95 pounds of ice per man, and they would commonly drink as much as three gallons of water in the shift of eight hours.

It was not only the air of the mine which was hot, the water was even hotter. The spring in the Savage mine had a temperature of no less than $157^{\circ} \mathrm{F}$. $\left(69^{\circ} 4^{\circ} \mathrm{C}\right.$.), and the incline was filled with scalding vapour. Up to the end of 1877 the highest recorded temperature of the water was $154^{\circ} \mathrm{F} .\left(67.7^{\circ} \mathrm{C}\right.$.) ; but since then an increase in the water temperature to $170^{\circ} \mathrm{F} .\left(76.6^{\circ} \mathrm{C}\right.$.) has been noted. The Comstock mines are the hottest in the world.

At Dolcoath, $\uparrow$ the largest and deepest tin mine in Cornwall, the temperature of the water issuing from the rock in the lowest workings is nearly $100^{\circ} \mathrm{F}$. $\left(37^{\circ} 7^{\circ} \mathrm{C}\right.$.) and that of the air $96^{\circ} \mathrm{F}$. $\left(35^{\circ} 5^{\circ}\right.$ C.) The bottom level is now 2424 feet vertically below the surface.

In the adjacent Cook's Kitchen mine, which approaches its neighbour in depth, the air in the end of the 394-fathom level, at no great distance from a winze, will raise the thermometer to $95^{\circ} \mathrm{F}$. $\left(35^{\circ} \mathrm{C}\right.$. $)$, whilst in the ends of the 420 -fathom level, driven out but a very short distance from the bottom of the shaft, the temperature of the air is $100^{\circ} \mathrm{F} .\left(37^{\circ} 7^{\circ} \mathrm{C}\right.$.) and that of the water slightly higher. Some workings for copper at St. Day, Cornwall, were even hotter, but the mine has long been abandoned. The submarine mines near the Land's End are also warm, and airtemperatures above $90^{\circ} \mathrm{F} .\left(2^{\circ} \mathrm{C}.\right)$ are often recorded. In Cornwall, as in Nevada, the hottest places are "ends" or "rises" before they are "holed" to other workings. When once a communication has been effected and a through draught established, the rock-faces cool down quickly.

* Lord, "Comstock Mining and Miners," Monographs U.S. Gcol. Survey, Washington, 1883 , p. 391 et seq.

t MS. information from Mr. W. Thomas, F.G.S., IS93. 
With the temperatures just mentioned, it is evident that the miner requires very little clothing, but even when the air is comfortably cool, he often strips himself to the waist, in order to secure that freedom of limb which so much conduces to the efficiency of muscular labour.

In some cases, such as in the salt mines of this country, the working-places are very comfortable; indeed the miner is better off than the labourer at the surface. He is not exposed to the burning sun, cutting winds or torrents of rain; but he works in a cool and pleasant atmosphere, varying little in temperature, and he has not to assume a cramped posture. On the other hand, the miner's working-place may be moist and steaming, or hot, dry and dusty, or cold, wet and draughty; and on reaching the surface in a cage, he may have to face an icy blast after leaving a tropical atmosphere only a minute or two before. Where circumstances are so unlike, the clothing worn in the mine must necessarily vary, to say nothing of differences in attire due to the habits of the people. The South African native, content with a waist-cloth above ground, requires nothing more when he descends into the diamond mines, whilst the white man, true to his bringing up, needs, or thinks he needs, more abundant vestments.

Hat.--Some of the clothing used below ground has to serve a different purpose to that required of it at the surface. One object of the miner's hat is to preserve his head from blows, as he walks along low and rugged tunnels, and from falls of stones while working in shafts. 'The Cornishman wears a hat made of felt and rosin, shaped like an ordinary "pot hat" of everyday life. It is cheap and durable, and affords admirable protection against hard raps; but it is not ventilated, and it is heavy, weighing about one pound, or four times as much as an ordinary felt hat. Under it the Cornishman wears a cap of calico or linen, which often constitutes the headgear in the working place itself, whilst the hard hat is donned in going to and from the surface. A few gimlet holes improve the Cornish hat, by affording a little vent for the perspiration given off so freely when climbing ladders in warm shafts.

The Cornish hat is servictable as the brim keeps the neck dry, and in sinking very wet shafts a waterproof flap can be added, so as to increase the amount of protection. Lastly, the lump of clay used as a candle-holder can be easily and safely stuck upon the hat, leaving the miner both hands free when he is climbing abcut the workings by rope, chain or ladder.

The British miner, working upon seams of stratified ironstone, affects a leathern cap, which he wears with the small peak turned towards the back. It is far lighter than the Cornish hat, but it is not capable of resisting so hard a blow.

In France a leathern hat, in shape like the Cornishman's, 
is common. It is made of thick solid leather, and is therefore very strong and durable, but it is heavy and expensive.

In some parts of Germany the miner wears a brimless hat, something like a busby, made of loose-textured felt, thick enongh to prevent a tolerably hard knock from doing any harm, and yet porous enough to admit the passage of perspiration. In sunless workings a brim is not required for guarding the eyes, and in dry mines the German hat with an undercap of linen forms a very suitable head covering. It is light, weighing only about half a pound, and it can be folded, which is an advantage if one is travelling. On the other hand, its porosity and its want of a brim render it unfitted for very wet places, and it cannot be used for carrying the candle in the same way as the Cornish hat.

The hat of the Mansfeld copper miner is made of thick black felt and weighs half a pound; it has a broad brim which is turned up in front and covered with leather. A piece of wire sewn on under the leather serves as a hook for carrying the lamp on the head, though, now that the shafts are mostly provided with cages, there is little ladder work to make this necessary. The felt is thick enough to save the head if struck, and the brim protects the neck from drops of water. It is a light, comfortable and cheap hat.

In sinking oil wells in Roumania, the miner adopts a conical hat, shaped like that of the Chinaman, but made of tinplate, which serves to keep off the drops of water and petroleum.

Looking at the number of accidents from falls of roof, to say nothing of accidents from things falling down shafts, the nature of the head-gear adopted by the miner is not without importance. It is especially necessary that shaft-sinkers should be careful to have suitable hats. An ideal hat would be light, but strong, wellventilated, and with brim enough to prevent water from running down the neck.

Boots.-Turning to the other extremity of the body, it is frequently noticed that the Cornishman, though careful about his liead, pays very little attention to his feet. He often has to walk throngh wet levels, and knowing that he cannot reach his working-place dry-shod, he is quite content with any dilapidated foot-gear. Unfortunately this carelessness is sometimes the cause of accidents, for men have been known to slip from ladders from wearing shoes which did not give them a proper foothold.

In some of the Welsh ore mines the clog is very commonly worn ; it is a boot with wooden soles and leather "uppers." The sole is protected from too rapid wear by irons at the bottom and sides. Many miners like clogs, as the wooden sole is warmer than leather, and consider that they are less likely to slip than ordinary boots or shoes in climbing up and down ladders or steep "stopes." I can well imagine that the stiff wooden sole gave a better foothold on the vertical ladders of the Flintshire mines years ago than yielding leather. The clog has the 
further merit of cheapness, but the unbending sole renders it therefore less comfortable than the ordinary foot-gear for much walking. Men who use clogs below ground often walk to and from the mines in leathern boots or shoes.

The Festiniog "rockman," whose working-place lies among smooth surfaces of slate, trusts to a strong laced boot well shod with nails to prevent his slipping, while be climbs about chain in hand. Another reason for the strong foot-covering is the fact that the fragments of rock are often sharp and cutting.

Many miners in France still wear the clumsy but cheap wooden shoe or "sabot," whilst in Spain they have sandals made of esparto grass. These cost only $3 d$. or $3 \frac{1}{2} d$. per pair, and last from three weeks to a month. Lastly, when we travel further afield, we find the hardy miner going barefoot, provided by nature alone with a tongh outer tegument, which gives him a better hold on rock or ladder than any which art can furnish.

Jacket.-Little need be said about the clothing of the worker at the surface, save that where he is engaged near machinery it is advisable that the jacket should fit closely. Accidents have happened from loose clothing being blown on to revolving gearing or shafting, which could not be stopped until the unfortunate workman had been drawn in and mangled.

As has been already explained, it is necessary from time to time to clean out the flues in which arsenic has collected from the calcination of ores containing mispickel. Under the Special Rules in force at some of the Cornish mines, the owner has to provide suitable clothing for this work; probably the best is a combination suit consisting of jacket and trousers in one garment, such as is used for going into boilers. The legs of the trousers should be tied round the ankles, and the sleeves round the wrists, in order to prevent any particles of arsenic from finding their way to the skin and so doing mischief.

2. HOUSING.- It may or may not fall to the lot of the mine-owner to provide dwellings for some or all of his workmen, but in any case it is his duty to interest himself in the question of the living accommodation for them and their families. Even if he is not moved by considerations of a humanitarian nature, as he certainly ought to be, the mine-owner must recognise the fact that it does not answer commercially to let his men fall sick, become prematurely unfit for work or die at an early age ; nor does it pay to have the working staff constantly changing. A valuable horse is put into a good stable, is well tended and not overworked, if the master wishes to derive as much profit as possible from it; and it cannot be expected that the best results will be got from the miner's labour, unless he is treated with at least as much consideration as the lower animal. Therefore on the score of profit as well as upon the score of humanity, the mine-owner should insist upon proper dwellings being available for his men. 
When mining is carried on in the midst of a fairly populnus district, private enterprise may often be relied on for providing suitable cottages, nevertheless even here the mine-owner may do good by calling the attention of the local authorities to insanitary dwellings or cases of overcrowding. It frequently happens; however, that mines are worked in out-of-the-way places, where, at all events in the early days of the enterprise, there is a total absence or utter inadequacy of accommodation for the workpeople. The mine-owner is then obliged to take upon his own shoulders the burden of providing dwellings. Two classes may be erected : (I) Barracks, which serve for unmarried men, or for married men whose homes are not within the reach of a daily walk; (2) Cottages for married couples and their children.

Barracks. - Excellent examples of barracks are found, for instance, at the Mechernich lead and the Mansfeld copper mines, owned by two enlightened and prosperous companies. The large workmen's hotel at Mechernich is capable of accommodating about $400 \mathrm{men}$. The workmen are perfectly free to do as they like, as regards living in the barracks or not; but if they do live there, they must conform to the regulations.

The cost of lodging is $9 d$. per week; for this a man gets a comfortable bed with a spring mattress, and clean sheets and blankets. The beds are such as I would sleep in without hesitation. The space allowed in the bedrooms is 400 cubic feet per man, and in winter the rooms are warmed by hot air. They are kept scrupulously clean, and the men are obliged to change their working clothes as soon as they come in, and put on other suits.

The men can be supplied with their meals at stated hours in the large dining hall at low prices, and boiling water is always ready for them gratis, so they can make coffee from their own store if they like. The dining hall has a tiled floor, and the tables are scrubbed until they are exquisitely clean.

The sanitary conveniences are ample and well kept, and the men can have warm shower-baths free of cost.

The mental comforts are not forgotten. There is a readingroom, with newspapers, which is open after working hours, and a library, from which the men can borrow books.

At the Mansfeld copper mines the company have provided no less than nine barracks, capable of accommodating 2268 men and 48 females. The barracks at Eisleben, which will house $35^{\circ}$ men, are represented in Figs. 700 and 701 , taken from the long and careful report of Oberbergrath Taeglichsbeck.* The house is a three-storey brick building, with bedrooms for nine, ten, or eleven men each. In accurdance with official regulations, there is an air

* "Die Wohnungsverhältnisse der Berg- und Salinenarbeiter im Oberb'rgamtsbezirke Halle, einschliesslich der Mansfelder Hiittenarbeiter," Zeitschr. f. B.- H. - u. S.- Wesen im Preuss. Staate, vol. xl. 1892, p. 44. 
FIG. 700 .

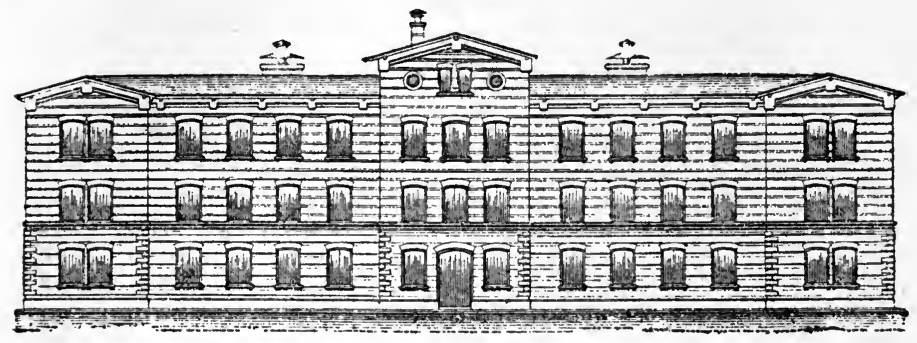

Front Elevation.

FIG. or.

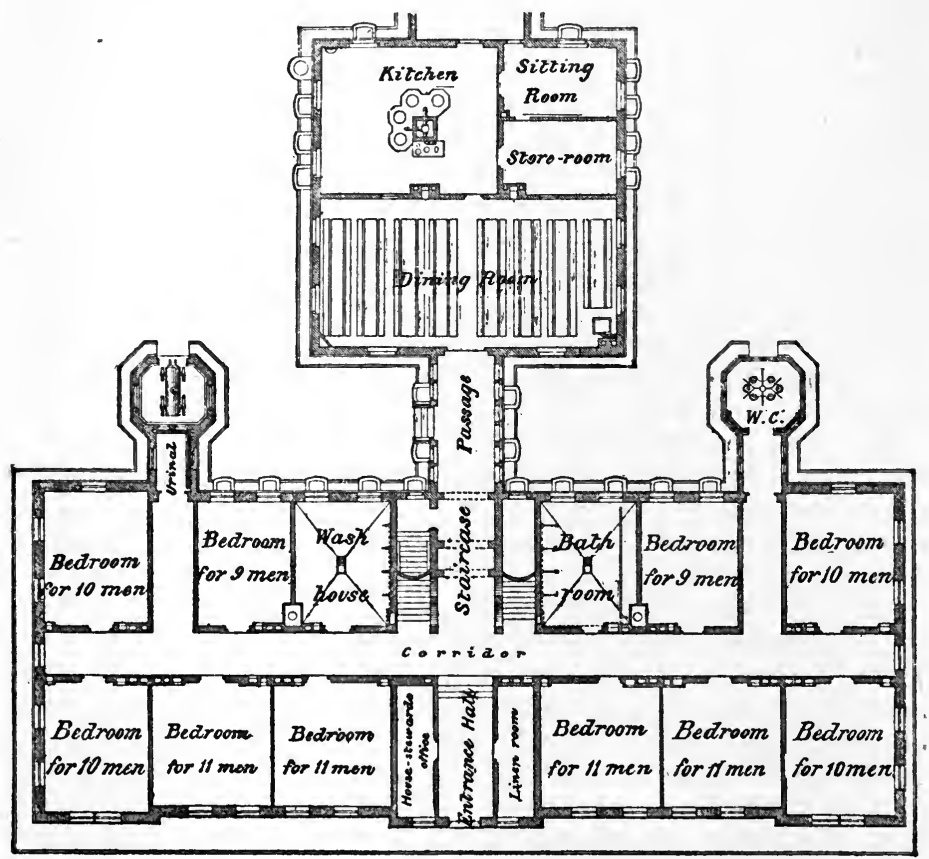

Ground Plan.

\begin{tabular}{|c|c|c|c|c|c|c|c|c|}
\hline \multicolumn{9}{|c|}{ SCALE } \\
\hline 5METRES & & 5 & & & 15 & & 20 & METRES 25 \\
\hline 10FEET 0 & 10 & $\frac{1}{20}$ & 30 & 40 & 50 & 60 & 7 & FEET $B O$ \\
\hline
\end{tabular}


spuace of 350 to 400 cubic feet ( 10 to I I cubic metres) per man. The roms are beated with hot air in winter, and there is a larse. dining-hall adjoining the kitchen, in a separate building, connected with the dormitories by a corered way. This building cont f9370, including house for the steward. who superintends everything, and laying on water. The barracks are built in airy situations, and are mostly surrounded by gardens. They are provided with all sorts of conreniences, baths, reading-rooms, libraries, skittle-alleys, tco.

The men ladging at the barracks pay the fixed tariff of $g d$. per day for their board; for breakfast each man gets $\frac{1}{2}$ litre of coffee and milk; for dinner I'I litre ( 2 pints) of thick soup or regetables, with $\frac{1}{8} \mathrm{kil}$. ( $4 \frac{3}{4}$ ars.) of beef or pork, weighed after oooking and without bone; and for supper I litres (3 pints) of thick soup, made with suet, or coffee and milk. In addition to this, he receires weekly two hoares of bread, each weighing 3 kil. ( 66 lbs), $\frac{1}{4} \mathrm{kil}$. ( $\frac{1}{2} \mathrm{lb}$ ) of butter, and the same amount of fat. Those who prefer it can take ham, sausage, or bacon instead of the butter and fat. For lodgings, lights, and firing, each boarder bas to par $0.6 d$. (57. $\left.f^{\circ}\right)$ per day in summer and o.gd. (S p.f.) per day in winter.

Order and cleanliness are enforced by a code of regulations, which hare to be strictly observed by all the boarders. The rules prescribed for the barracks at Mansfeld. Stassfurt, kc, are given at length by Treglichsbeck. *

The barrack system is also found in this country, especially in Forth Wales, but not on so large or so sumptuons s scale as in Germany. In Wales the men of ten sleep twro in a bed, upon straw mattresies; and, as a role, there is not a separate eating-room, nor are there any arrangements for supplying meals. One sees the men arrire on a Monday morning, carrying their provisions for the week on their backs; and they cook their food themselres by the common fire of the eating and sleeping apartment. Otten there is no person provided for keeping the rooms clean, and the disorder and discomfort are consequently great. Sheer igmorance is sometimes the cause of some of the erils. I hare seem bunks prepared for 2 I men in a room without a window or a chimmer, and containing only 2200 cubic feet of space-iben about one-third of the smallest amount which sanitarians mould oonsider requisite. If mining companies build barracks, they should emaploy sowe one acquainted with the radiments of sanitary science to design them; the eating-room shovild be separate from the dormitories, and the honse should be kept clean and tidy.

The most extensive derelopwent of the barrack system in any British possessions is at the Kimberley diamond mines, where the particular exigencies of the case bave-led to a modification which is not found elsewhere. One great difficulty of dismond 
mining in the early days was the prevention of thefts of valuable stones. Gems of great value can be so easily secreted about the person, or indeed swallowed, that the mine owner could be, and was, robbed with little fear of detection. It is true that since the passing of the Illicit Diamond Act, the disposal of stolen diamonds has become more difficult, but the protection afforded by this statute does not entirely suffice. The plan now adopted with the native miners is to confine them for the length of their contract, often three months, and not allow them on any pretext to leave the company's premises. They go straight from their barracks to the mine by a securely enclosed way, and return to them as soon as work is over. The barracks consist of one-storey buildings, made of corrugated iron, arranged so as to form the four sides of a large square, and divided into rooms holding about twenty natives each. The "compound," as it is called, of ten covers several acres; and it is surrounded by a high iron fence ro feet from the building. The natives can procure all the necessaries of life from a store within the compound, whilst food and water are supplied free. A large swimming bath enables them to enjoy a dip whenever they like. If perchance a man falls ill, he is taken to a hospital, also belonging to the company.

Of course, this system would not find favour with European miners, who would resent the enforced confinement and regard it as an irksome imprisonment; but the native, with fewer wants, is quite content to put up with the temporary loss of liberty for the sake of getting good wages.

Cottages.-Enough has been said about barraciss, and we may now pass on to cottages for families. At many of the collieries of this and other countries, great attention has been paid to the erection of workmen's villages, and a large amounc of capital has been sunk in providing comfortable and convenient dwellings. It is an advantage to the mine-owner to have his men on the spot, coming to their work without the fatigue of a long walk; and it is a benefit to the man to have his home within easy reach. When, therefore, the preliminary explorations and workings have revealed the existence of enough mineral to supply a mine for a number of years, a company is thoroughly justified in spending money upon houses.

Figures 702 to 705 represent the type of miner's cottage lately erected by Mr. Emerson Bainbridge for the Bolsover Collieries in Nottinghamshire. It will be seen that each cottage has a good living-room and scullery on the ground floor, two good bedrooms on the first floor, and an attic above.

Many a workman, however, would rather be his own landlord, and not feel the restraint of living in a cottage belonging to the company, because he may have to quit it if he goes to work at

* Second Annual Report of the De Beers Consolidated Mines, Limited, for the year ended March 1890, p. 23. 
another mine, or because he feels the natural ambition of wishing to own a house himself. In order to encourage this very laudable object, mining companies of ten make it easy for the workman to buy his cottage by small instalments, and they thus gather around their mines a number of small householders, who are less likely to encourage disturbances than men who have no sl ecial interest in the preservation of order. To the workman there are advantages

FIG. 702.

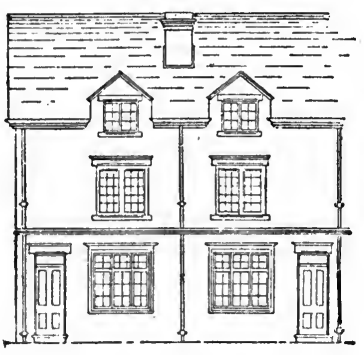

FRONT ELEVATION

Fig. 704.

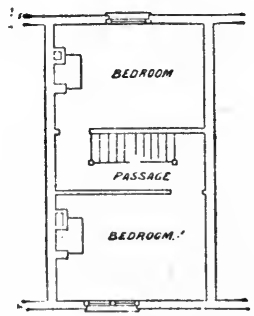

13 FLOOR PLAN
Fig. 703.

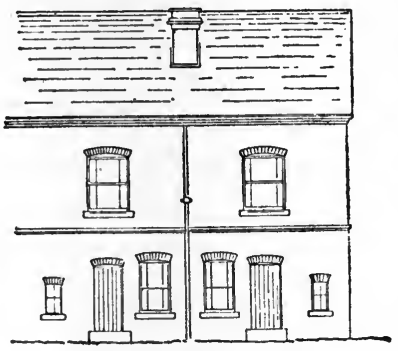

BACK ELEVATION

FIG. 705.

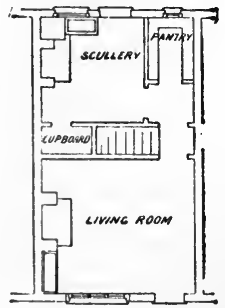

CROUND PLAN

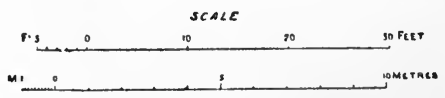

as well as disadvantages; if the cottage belongs to him, he has a feeling of independence, and he does not mind spending money to embellish or improve it, which he would not do if it were the property of somebody else. The purchase may be a wise and profitable one, if he feels pretty sure that he is going to spend all bis days in one place; but this fixedness to one district cannot always be assured or advised. Wages may be better in an adjoining county or in some foreign land, mining may decline at home or entirely cease, and a move may become a necessity, with no chance of selling the cottage property. Under such circumstances the earnings spent in buying a cottage will have been badly invested. 
It also happens that during a period of high wages, a man is tempted to arrange for the purchase of his house with one of the numerous building societies, and he agrees, for instance, to pay Er per month for ten years, at the end of that time becoming the owner of a house worth $E_{120}$. If his wages are $E_{7}$ a month he can manage the monthly instalments without difficulty; but let wages drop to $£ 5$, and he will find it far less easy to keep up his payments.

As an example of the manner in which workpeople are housed, I will again extract some figures from Taeglichsbeck's report.** For the Halle district he gives the following numbers and proportions :

\begin{tabular}{|c|c|c|c|c|}
\hline \multirow[t]{2}{*}{-} & \multicolumn{4}{|c|}{$\begin{array}{l}\text { Find of Dwelling-house and Percentage o } \\
\text { the Total Number of Persons. }\end{array}$} \\
\hline & $\begin{array}{l}\text { Rent free, } \\
\text { but Rent } \\
\text { reckoned } \\
\text { as part } \\
\text { of Wages. }\end{array}$ & $\begin{array}{l}\text { Living in } \\
\text { their own } \\
\text { Houses. }\end{array}$ & $\begin{array}{c}\text { Living in } \\
\text { hired } \\
\text { Houses. }\end{array}$ & $\begin{array}{l}\text { Living in } \\
\text { Barracks, } \\
\text { \&c. }\end{array}$ \\
\hline $\begin{array}{l}\text { Workmen. } \\
\text { Private works (40,372 persons) } \\
\text { Government works (3274 persons) } \\
\text { Officials. } \\
\text { Private works (I } 196 \text { persons) } \\
\text { Government works (I22 persons): }\end{array}$ & $\begin{array}{r}0.53 \% \\
0.36 \% \\
45.82 \% \\
73.77 \%\end{array}$ & $\begin{array}{r}21.85 \% \\
27.92 \% \\
17.23 \% \\
9.84 \%\end{array}$ & $\begin{array}{l}70.11 \% \\
71.14 \% \\
36.95 \% \\
16.39 \%\end{array}$ & $\begin{array}{c}7.51 \% \\
0.58 \% \\
= \\
-\end{array}$ \\
\hline
\end{tabular}

He further shows that 25 per cent. of the persons employed at, the Mansfeld copper mines are living in their own houses, of which nearly one quarter have been purchased with the assistance of the Company.

Before concluding this subject of housing, a word may be said about the "dries," or changing houses, which have to be provided at mines under the Metalliferous Act, when more than twelve persons are employed below ground. Such a house is very necessary when the men come up wet and dirty, and often soaked with perspiration from working in hot places or from climbing long runs of ladders. They then change all their clothes, and leave them to be dried ready for use on the following day. One of the best modes of heating a "dry" is by steam; the shell of an old boiler is placed along the centre of the house and is supplied with steam from any convenient source. Owing to the large surface of the shell the room is speedily heated, and the clothes hung about it are quickly dried. The water condensing from the steam may be drawn off by a cock and used for washing purposes. Figs. 706 and 707 represent the changing house erected at Levant Mine in Cornwall by Mr. Eustice, which has the advantage of being put into communication with the man-engine shaft by a passage and staircase, so that the men stand no risk of

* Op. cit. p. 7. 
630 ORE AND STONE-MINING.

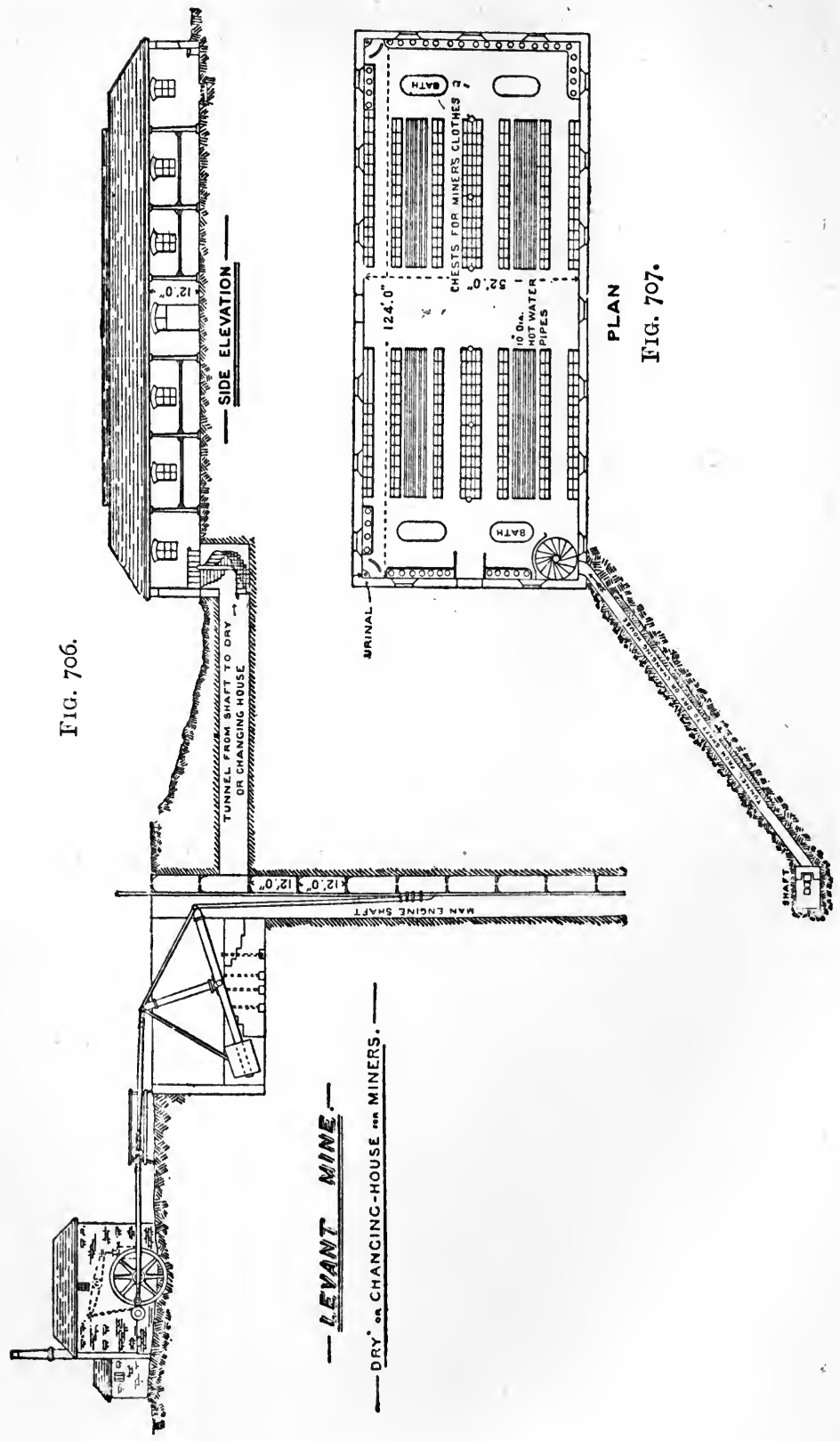


exposure to the fierce breezes coming straight off the Atlantic, which might sometimes be trying after the underground warmth. It is heated by rows of hot-water pipes.

The floor of the "dry" should be made of cement and not of boards, to permit the application of the hose for washing it. Benches and lockers should be removable in order to facilitate the cleaning, which is frequently necessary, considering the amount of dirt which cannot fail to accumulate in such a place. A wooden floor has the disadvantage that the boards are sure to shrink under the constant warmth, and when once full of

FIG. 708.

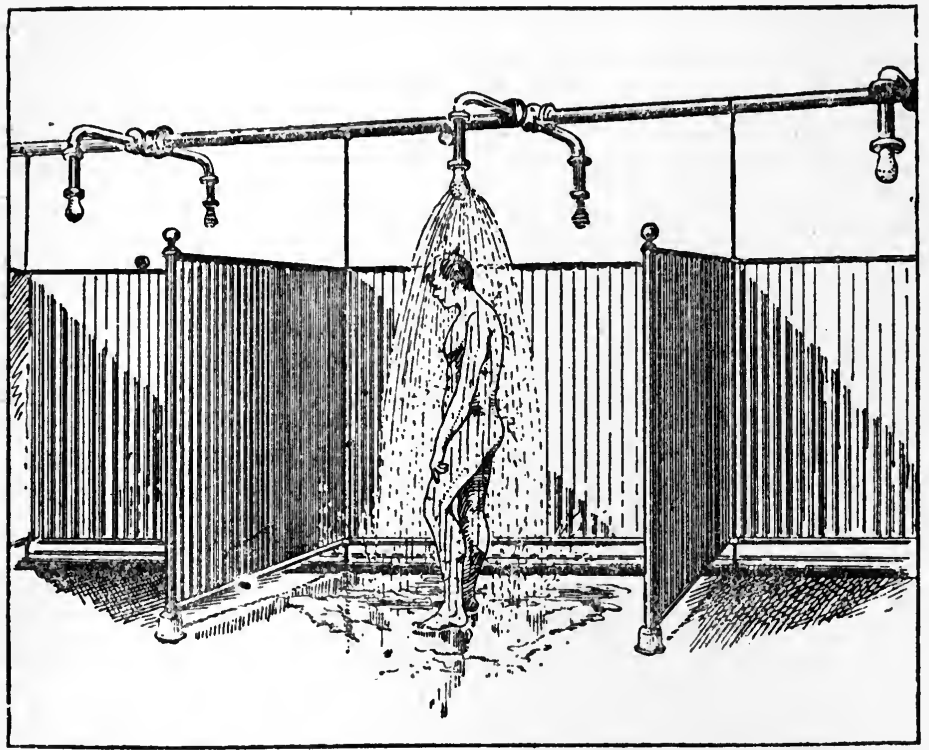

gaping chinks it can never be effectually cleaned; besides, there is the danger from fire, either from matches left carelessly about or from the men smoking in a place where the wood gets as dry as tinder. The walls should be whitewashed at regular and frequent intervals, in order to keep the place thoroughly sweet.

It is not difficult to give the miner the luxury of a showerbath at a small cost, and it seems to me far better that the miner should change and perform all necessary ablutions at the mine, than go home in his underground clothes, and depend upon the resources of his cottage for washing himself and drying his working apparel.

At the Anzin collieries, in the North of France, a large number of shower-baths (Fig. 708), are provided at the different shafts, so 
that the men have not to wait for their turn. The Anzin arrangements are excellent, and might be copied with advantage at some of our mines.

3. EDUCATION.-The school education may be of two kinds, general and technical. In this and other countries, where the primary education is free, the mine-owner need not concern himself with providing schools and teachers; but where the State does not take this paternal care of the rising generation, a certain responsibility for the young is of ten felt by the shareholders of the mining companies, and they endeavour to equip the children of their workmen, at all events, with the three R's.

For carrying on mining, it is not sufficient merely to provide strong bones and well-developed muscles; there must also be brains, or, in other words, no matter how good the miners are, their work must be directed by trained engineers and competent foremen. The latter may well be recruited from among the actual working men, who should have some general knowledge of science and some special training in the various branches of their profession.

This scientific and technical training is frequently provided by the large foreign mining companies at their own expense. The best of the young men attend classes out of working hours, and thus manage to cirry on their lecture-room teaching hand in hand with the practical instruction which they are acquiring in the mine itself.

In this country the education of the young miner is largely aided by classes held in the evenings, under the auspices of the Science and Art Department, the City and Guilds of London Institute, and some of the County Councils. The energetic and ambitious workman can nowadays obtain instruction in mathematics, mechanics, chemistry, physics, geology, the principles of mining, ore-dressing, assaying and mine-surveying in any large town and often in outlying villages. To those preparing to pass the examination for a certificate under the Coal Mines Act, these classes are very valuable.

The success of local schools and classes depends a good deal upon the attitude assumed by the managers of mines in the neighbourhood. If educational work is pooh-poohed by the masters, the men follow suit and the teaching languishes. On the other hand, if the head-piece of the school is one of the chief mining engineers of the district, pupils flock to the lecture-rooms and laboratories, and success is almost a certainty. By forming and encouraging these local schools or classes, owners and managers of mines are not only promoting the welfare of the rising generation around them, but they are at the same time doing good to mining generally, and are contributing to the introduction of the most improved methods of extracting minerals. Just as the success of an army depends largely upon its trained 
non-commissioned officers, so the prosperity of a mining enterprise is largely influenced by the competency of the foremen; many of them by virtue of their talent and industry rise from the ranks and become excellent managers of mines.

The training of foremen must not be carried on to the exclusion of all thought for their sisters, who will make better wives and mothers if they receive some instruction in the arts which belong more particularly to the domain of women, such as housekeeping, cookery and nursing. Teaching of this kind becomes more than ever necessary in localities where females are largely employed on the dressing floors, for then the girls fail to receive that practical training in household work, which would otherwise fall to their lot, if they entered domestic service, or assisted their mothers in their own homes.

4. SICKNESS. - At first sight it might be supposed that mining is necessarily an unhealthy occupation, that confined for hours in dark and gloomy passages a man cannot keep well and strong. Stubborn facts and figures show that a general assertion of this kind is not well-founded; but nevertheless the miner does suffer in some cases from diseases inherent to his calling, and these can be best combated if their causes are thoroughly understood by all who are connected with mining operations.

The diseases to which miners are most liable have been carefully studied by Dr. Ogle,* who with infinite pains has worked out the death-rates for mining, as well as for other occupations, from the figures contained in the national register of deaths. Of course it is very difficult, if not impossible, in comparing the death-rate of the miner with that of some other working man, to say precisely how much of the difference is due to the effect of the calling. The miner is to a certain extent a picked man; the weaklings of a family do not go to work underground, consequently in the race of life the miner has, so to say, a start, which ought ceteris paribus to make him a winner. The actual death. rates of some occupations are given in the table on p. 684, extracted from Dr. Ogle's much more complete list. The comparative mortality figure affords the easiest means of contrasting the differences between the various callings as regards healthiness. The figure 1000 represents the total number of deaths among a certain number of male persons between the ages of 25 and 65 for the whole of England; then taking the same number of 'persons in any particular calling at the same ages, Dr. Ogle has calculated the corresponding number of deaths. The lower the figure, the healthier the occupation. In very healthy districts the mortality figure is as low as 804 , that of the agricultural labourers is only 70I. If we take miners, we do not find a high mortality figure for the collier, nor for the ironstone

* Supplement to the Forty-fifth Annual Report of the Registrar of Births, Deaths and Marriages in England. London, 1885, pp. xxv., et seq. 
miner; but the figure for Cornwall is appalling. Mining coal and ironstone appears to be less fatal to life than baking bread or making boots and shoes.

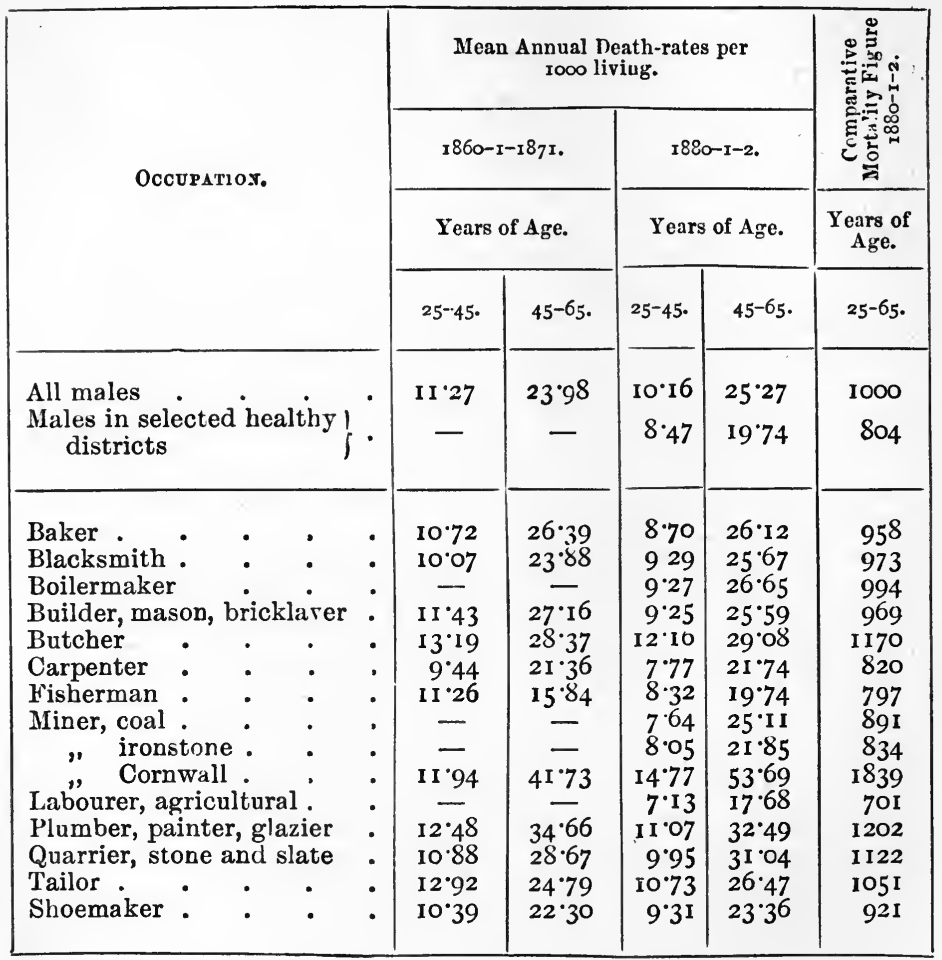

The diseases inherent to the miner's calling are due to the following causes :

\footnotetext{
Breathing a polluted atmosphere.

Excessive ladder climbing.

Working in constrained positions.

Exposure to heat and cold.

Wurking in compressed air.
}

Of these various causes the first is undoubtedly by far the worst : it brings on phthisis and other diseases of the respiratory organs. There is nearly six times as great a mortality from these diseases among Cornish miners as there is among fishermen. The manner in which the air of mines is polluted has been explained in the chapter upon Ventilation-viz., by the breathing of the men and animals in the pit, the combustion of lamps or candles, exhalations of decaying timber, smoke of explosives, natural emanations 
of gases, and dust. It is the opinion of the best qualified judges that dust is largely responsible for the respiratory ailments from which the miner so often suffers. The difference between tho atmosphere of a mine and that of the external atmosphere is often made very plain by the state of the nostrils after a few hours spent in underground workings; it is found that they have strained off a part of the solid particles floating about in the air of the mine, and the amount so arrested will serve as some gauge of the quantity inhaled. Besides, men commonly breathe a great deal through the mouth, and lose the benefit of their natural air-filter.

The dust acts mainly mechanically, but in a few exceptional cases its evil effects are due also to poisonous chemical properties. The mechanical action is at first an irritation of the delicate lining membrane, and then the particles make their way into the tissues, choke them and harden them, and so render them unfit for allowing the chemical action of the air upon the impure venous blood which is necessary to life. The diseases caused by the inhalation of dust in this way are bronchitis, shortness of breath, asthma and consumption.

A large proportion of the dust is produced in the process of boring holes for blasting in an upward direction. If the hole has a downward inclination the miner puts water in, which not only prevents any dust, but also renders his work easier by allowing the edge of the tool to act more fairly against the rock. When, on the other hand, the miner is boring upwards, the dust is scraped out or falls out, and though the coarsest particles may at once drop to the ground, the very fine and light ones float about, and produce a cloudy and noxious atmosphere. If machine drills are employed, the amount of dust produced in a given time is often considerable, as will be instantly recognised by any one dressed in a dark suit who stands by one of these machines while it is working in dry ground.

Prevention is better than cure, and the evil consequences can be averted by forcing a jet of water into the hole during the boring operations. The jet may be produced either by allowing the compressed air to act upon the surface of a tank containing water, or by bringing down a supply in a pipe from a tank situated at a higher level ; keeping the sides of the level moist is another precaution, the particles of dust wafted against the wet surface are caught, like flies upon sticky paper, and so rendered harmless.

Some of the dust arises from the rock being broken up in the process of blasting, and some comes from the explosive itself, if it consists, for instance, of infusorial earth mixed with nitroglycerine.

A fine spray is very effective in laying the dust and fumes produced by blating, and an easy method of producing it is to 
turn a jet of compressed air into a pipe supplied with water.* An appliance of this kind is specially desirable when the blasting in an "end" is done by volleys, when the miner has to walk into the smoke of one blast in order to charge another set of holes. Some men make use of a sponge as a respirator while exposed to the dust and fumes, and no doubt with good effects; but it is well to delay the return as long as possible, unless the "end" is provided with such an apparatus as 'Teague's ventilator, which speedily withdraws all noxious fumes from the working place. If it is necessary in some particular case to go into an "end" full of smoke, the harmful effects may be reduced by making use of Nature's respirator, namely, the nose, and not breathing at all through the mouth.

Dusts which have a poisonous effect are those of certain minerals containing arsenic, lead and mercury.

According to Dr. Härting and Dr. Hesse, $\uparrow$ cancer in the lungs is not uncommon among the men working in the cobalt mines of Schneeberg in Saxony, and they ascribe the disease to dust containing arsenic in combination with cobalt, which produces a permanent chemical irritation in the delicate air-passages. It seems to be mainly the mineral speiscobalt or smaltite $\left(\mathrm{CoAs}_{2}\right)$ which is the source of the disease, the cobalt minerals containing sulphur in addition to the arsenic are far less poisonous, as they are less readily decomposed. When one reflects how soon cobalt bloom, the hydrated arseniate of the metal, is formed upon the ores in a damp atmosphere, it is not surprising that a similar action should go on with minute particles of smaltite imbedded in the lung tissue, and eventually set up a considerable amount of irritation.

Far more dangerous than the dust of arsenical minerals underground, are the fumes produced in roasting ores containing mispickel, a process which goes on in many tin mines and some gold and copper mines. Particles of arsenious acid attach themselves to the skin, in places where it is moist from perspiration, and produce nasty sores, whilst those which enter the body give rise to various disturbances of the digestive organs. The best means of avoiding the ills due to arsenic have been pointed out by Hirt $\ddagger$ at some length. Only thoroughly healthy men should be allowed to work in places where there is danger from arsenic, and they should be relieved at regular intervals. Bottles of hydrated oxide of iron, in the form of an emulsion should be kept in readiness, both as a preventative and an antidote. The men must be compelled to exercise the greatest cleanliness, and when exposed to the dust and vapours should cover the mouth with a dry cloth. Arsenical sores

- Reports of H.M. Inspectors of Mines for the Year 1879, p. 527.

+ "Der Lungenkrebs, die Bergkrankheit in den Schneeberger Gruben." Eulenberg's Vierteljahrsschrift für gerichtliche Medicin. Neue Folge, xxx. Band, p. 296, Berlin, 1879.

¥Arbeiter-Schutz, Leipsic, 1879, p. I3I. 
should be plastered over with fuller's earth moistened with water and hydrated oxide of iron; strong drinks, especially brandy, must be avoided, but milk and greasy soups help to resist the poison.

In an ordinary lead mine, where the ore consists entirely or almost entirely of galena, plumbism is rarely heard of ; but when the ore is cerussite, a different state of things arises and the disease may be rife. It is well known that the artificial carbonate, the white lead of commerce, produces poisoning among painters, so much so indeed that one of the ailments due to lead is known as "painters' colic;" it cannot therefore surprise us, when mere handling is injurious, that breathing a lead-laden atmosphere should likewise be pernicious. Plumbism among miners has probably never been so prevalent as in the Broken Hill district in New South Wales, where some of the ore in the shallow levels is a pulverulent earthy carbonate of lead. According to published accounts, ${ }^{*}$ the state of things must have been very bad indeed comparatively lately. Miners suffered more than the smelters, but even the ore-pickers were not exempt from the malady. From this fact we may conclude that lead may have entered the system in some cases by eating food with dirty fingers, or, as suggested by the writer of the article alluded to, from smoking a pipe filled with tobacco rubbed in a leady hand. The baneful effects have been reduced by not allowing the men to work very long at one time in the parts of the mine where the soft carbonate occurs. The managers arrange, for instance, that a man shall take one fortnight at mining the earthy cerussite ; the next fortnight he is put to work at the surface and made to quarry the ironstone-i.e., the ferruginous outcrop of gossan, which is used as a flux at the smelting works; and then he takes a fortnight underground in mining the kaolin ore, which consists largely of kaolin and chloride of silver, and has no deleterious effect upon the men, or at all events does not cause lead-poisoning.

The precautions to be adopted against plumbism at mines of this description are: ample ventilation, laying the dust as far as possible by a spray of water, and the strictest cleanliness. The mine-owner should do his share by giving the men every possible convenience for washing themselves and changing their working clothes, but no amount of forethought on his part will suffice to prevent the evil entirely, if the men fail to avoid every chance of defiling their food or tobacco by lead ore.

Working in the quicksilver mines is found to be unhealthy, and the men suffer from mercurial poisoning unless special precautions are taken. Thus, at Almaden, even if the ventilation is good, the miner cannot work more than four to four and a half hours a day, nor can he work more than seven or eight days in a

* "Lead Poisoning," The Australian Mining Standard, vol. vi., IS9r, p. 13, and Report of Board of Inquiry at Brolien Ilill, Sydney, I893. 
month without injuring his health very rapidly.* . It is true that the miners suffer less than the smelters, which is the reverse of what happens at Broken Hill, and the explanation of this is that mercurial poisoning is mainly due to the vapour of the metal. At Almaden some of the mercury exists in the native state and is supposed to sublime slowly; $\dagger$ but even at Idria, where there is no native mercury, where the ore is less rich than at Almaden, and the ventilation excellent, the men work only four hours at a stretch-i.e., four hours in the morning and four in the afternoon, with an interval of rest of four hours.

The symptoms of mercurial poisoning noticed at Almaden are : inflammation of the mouth, salivation and loss of teeth, shiverings, gradual and general wasting away.

Excessive ladder-climbing has long been pointed out by medical men as a cause of disease. $\neq$ If the heart is over-stretched day after day and year after year, it becomes dilated, loses some of its contractile power, and is therefore less capable of performing its pumping action properly. The miner who for years has had 'to descend and ascend by ladders in deep mines, will generally be found to have a feeble heart and weak pulse on this account. Young miners should be careful to avoid the over-exertion caused by climbing with unnecessary haste. In these days of excellent steel wire ropes for winding men up in cages, it is perfectly absurd that a miner should be condemned to the treadmill toil of ladderclimbing, which has nothing to be urged in its favour. The shareholder has to pay for an unprofitable form of labour, his mine is conducted with less supervision than there would be if access to the workings were easier, whilst the unfortunate miner suffers in health and strength. When a mine reaches a depth of so० yards the owner should introduce means of raising and lowering the men mechanically without fatigue.

It is easy to conceive, when a man is working continuously for years in a constrained position, that certain muscles will be stunted in their growth from want of use, and that others will be abnormally enlarged from over-use, and so cause a distortion of the body. This happens to a slight extent with the men working on the thin bed of copper shale of Mansfeld.

The disease of the eye known as nystagmus has been noticed among colliers. A person suffering from nystagmus sees objects apparently moving in a circle; gas lights in a room, for instance, seem to dance; the man also suffers from headache and giddiness,

* Kuss, "Note sur l'état actnel de la mine et de l'usine d'Almaden," Annales des Mines, 8 me. série, tome xi., p. I38.

† Eng. Min. Jour., vol. xlvi., I888, p. 435 .

$\ddagger$ Dr Peacock, "Medical Report on the Condition of Miners"; Bankart, "Medical Report on the Condition of Miners in Cornwall and Devon"; Appendix B. to the Peport of the Commissioners appointed to Inquire into the Condition of all Mines in Great Britain to which the Provisions of the Act 23 \& 24 Vict. cap. I5I do not apply. P. 7 and p. 9j, London, I864. 
and the eyeballs are noticed to oscillate or rotate. According to Snell * the men most afflicted with nystagmus are those who have to work lying on their side; owing to this unnatural position the muscles of the eyes are unduly strained and suffer from overwork. Mere work upon the side is in some districts insufficient to set up the disease, for during a period of six years only two cases were noticed among the 14,000 Mansfeld copper miners. As these men use open lights, it is not unnatural that nystagmus should have been ascribed by some doctors to the insufficient illumination afforded by the safety lamp. .Snell combats this hypothesis, and cites cases of the disease in persons who have never used a safety lamp; therefore the want of a better light cannot be the only cause. To a layman it seems quite possible that both views may be correct; the two sets of doctors agree that the disease is produced by over-strain of the ocular muscles, and as either of the two causes appears capable of occasioning such a strain, why should there be a difficulty in admitting both explanations?

The great heat of the workings on the Comstock $\uparrow$ lode has been mentioned in the early part of this chapter, and many men are said to have lost their lives from it, being picked up dead in the mine. New-comers suffered more than the old hands. There was also the danger of falling into scalding water; men fell accidentally into pools of water at a temperature of $157^{\circ}$ or $158^{\circ}$ and perished in great suffering from their skin peeling off.

In some cases the effect of the hot air on the men is said to have been beneficial, acting like a succession of Turkish baths. When the heat on the Comstock lode first became intense, the miners suffered from pneumonia and rheumatism, because they went out at once into the cold and freezing atmosphere at the top of the shaft, although only a few minutes before they had been in the heated atmosphere of the lower levels. Such sudden changes of temperature were naturally injurious; and experience soon taught the men and the managers that risks of this kind could not be run with impunity. Good rooms were erected at the tops of the shafts, in which the men could change their clothes, and some were provided with baths. These precautions soon brought about an improvement in the general health of the men.

In ordinary mining operations, men are rarely subjected to a pressure considerably above that of the surrounding atmosphere; but as work in compressed air is occasionally necessary, it is well that the student should be reminded of its danger to health. Men who are employed in making foundations for bridges or in driving tunnels, where compressed air is used as a means of

* Miners' Nystagmus, Bristol, 1892.

† Lord, "Comstock Mining and Miners." Monographs U.S. Geol. Survey, vol. iv., Washington, I883, pp. 374 to 399. 
keeping out water, suffer at times from paralysis and intense pain in the back. These effects of the confinement seem to be mainly felt on coming out into a less dense atmosphere, and may be lessened by prolonging the stay in the air-lock, and so causing the diminution of pressure to be felt gradually.

5. THRIFT.-Remarks upon the condition of the miner would be incomplete withont some mention of the following subjects :-(I) Provision against loss of pay from sickness accidents, strikes, and old age; (2) Obtaining medical attendance at a small cost; (3) Procuring supplies of food and clothing upon the most reasonable terms.

Provident societies are no new thing for the miner; it has been pointed out by Dr. Wahle, the Director of the Mining Department at Freiberg, that they date back in Saxony to the fifteenth century, and are as old as mining itself. In this country at the present day three systems are in vogue: clubs for individual mines, general relief societies for large districts, and, lastly, the ordinary friendly societies, not confined to miners, which are resorted to by all classes of workmen.

In Cornwall and Devon, and in many parts of Wales, there is a club for each mine, and the men agree to a deduction being made from their wages every month for "doctor and club." At many mines the monthly deduction for the doctor is either sixpence, or one shilling, according as he attends the miner only, or his family also.* Under the provisions of the Stannaries Act, I 887, some of the old grievances of the Cornishmen have been made to disappear. Each man has a right to choose his own doctor, to whom the amount deducted from his wages is paid. If a surgeon renders himself unpopular by not attending to a case with sufficient care, the men do not select him another time, and his pay and reputation suffer. This check upon the doctors seems to be a sufficient guarantee of the system working smoothly, and to the satisfaction of those most interested in the matter-viz., the men themselves.

The usual deduction for "club" is $6 d$., and in a few cases $9 d$. per man per month; the usual "hurt pay" for disablement is 1s. per day. In the event of a fatal accident the funeral expenses are borne by the mine, and sometimes the sum of $\mathcal{E}_{\mathrm{r}} \mathrm{O}$ is given to the widow or dependent relatives, or a levy of $I s$. per man is made for their benefit.

The great faults of this system are: First, the want of some provision for widows, orphans, or dependent relatives of persons killed by accidents ; secondly, the fact that a man loses his " hurt pay" and is probably thrown on the parish if the mine in which he had been working is stopped; thirdly, the want of any

* Foster and Pike, "Suggestions for the Formation of a Miners' Permanent Club and Relief Society for Cornwall and Devon," Proc. Min. Inst. Cormuall, vol. i., p. I. 
provision for ordinary sickness. Of course the first and third objections might be removed by increasing the monthly subscriptions, but the second would still remain-viz., the uncertainty of the benefits being kept up permanently.

Far better than the clubs of individual mines are the permanent relief societies, of which British miners have reason to be proud. There are now nine of these societies in different parts of England and Wales, and there is also a central society for promoting and watching over their interests and extending their work to new districts.*

Though started for colliers, these societies include many ironstone miners and some lead miners and slate quarriers among their members. According to the annual report of the Association for I89I, there were 268,97 I persons members of these relief societies in the year 1890 , whilst the total number employed in and about the mines of the United Kingdom was 674,434 , inclusive of those employed on private branch railways and tramways, and in washing and coking coal on premises adja. cent to or belonging to the mine.

The exact nature of one of these societies will be best appreciated by examining the rules of the largest, which has done, and is still doing, much excellent work in the North of England. $†$ As it includes the Cleveland ironstone district, although this does not appear from the title, it is specially adapted for my purpose. Its objects are very clearly defined thus :

"The objects of this Society are the raising of funds by voluntary subscriptions amongst the members thereof, and by donations from others to make provision in case of fatal and non-fatal accidents as follows :

"(a) A sum at the death of a member.

"(b) A weekly allowance to the widow and children of married members.

“(c) A weekly allowance to members who suffer from non-fatal accidents.

“(d) An allowance to the parent, or sister, or brother of a deceased member during sickness or other infirmity.

“(e) Also to make a provision for miners over 60 years of age who are permanently unfit to work, the allowance to be paid to be in accordance with the contributions received."

The weekly contribution of each member is $4 d$., and of a halfmember-i.e., a boy under $18 \ddagger$ only $2 d$. Three-eighths of these sums are devoted to the superannuation fund.

* Central Association for Dealing with Distress caused by Mining Accidents, 3IA, King Street, Wigan ; George L. Campbell, Secretary.

+ Rules of the Northumberland and Durham Miners' Permanent Relief Fund Friendly Society. Established June 7, 1862. Chief Office5, Queen's Square, Newcastle-upon-Tyne. 1892.

5, Queen's Square, Newcastle-upon-Tyne. 16 may be a whole member if he likes; a boy under 16 can only be a half member. 
The benefits are in the case of

1. Non-fatal accidents.

2. Fatal accidents.

3. Old age.

If a member is disabled by an accident for more than a week, but not less, he receives the sum of $5^{s}$. a week or $10 d$. per working day, and a half-member $2 s$. $6 d$. per week or $5 d$. per day. The payments go on in this way for twenty-six weeks, when, if the person is still disabled, he becomes entitled to the higher relief of $8 s$. per week, or $4 s$. if he is a half-member, so long as he is unable to work from the effects of the accident.

In the case of a death by accident, the widow of a married member receives a legacy of $f_{.5}$, the relatives of an unmarried member receive $£^{23}$, and those of a half-member $\mathcal{E}_{12}$. The widow also draws 58 . a week from the funds for the rest of her life, so long as she remains unmarried, and 2s. a week for each child, until the boys are thirteen and the girls fourteen years of age.

Aged and infirm members over sixty years of age who are certified medically to be unfit to follow their employment receive 4s. per week; but the amount of the pension may be reduced if the funds at any time ure insufficient to keep up the present allowance.

During the year 1891 this Society had II 3,1 24 members; the contributions of the members amounted to $£ 90,169$, those of the owners of collieries to $£ 4860$, in addition to which there was an income of $£ 5208$ from invested funds. The following claims were made upon the Society:

Minor Accidents.-16,500 claims for relief were made; the average length of the period of disablement was about $3 \frac{1}{2}$ weeks each.

Permanent Disablement.-195 claims for accidents that have caused disablement lasting more than 26 weeks; the average duration of each is estimated to be $3 \frac{1}{2}$ years.

Fatal Accidents.-93 widows came on to the funds.

Children.- 185 children came on to the funds.

Old Age. -442 new claims for superannuation were made.

According to the report of the Central Association* the nine societies gave relief for 754 deaths by accidents, and for $39,4 \mathrm{II}$ cases of disablement during the year 1890 .

We learn from the Reports of Inspectors of Mines that there were 1206 deaths from accidents at all the mines of the United Kingdom in that year, consequently it is evident that a large proportion of the victims of these fatalities were insured, and that

* Central Association for Dealing with Distress Caused by Mining Accidents. Report of the Proreedings at the Tuelfth Annual Conference, London, I891, Tables VI. and V1I., pp. 36-7. 
their families or dependent relatives received some form of relief.

Altogether there were 2395 widows and 3496 children receiving benefits from the funds of the nine societies in the year 1890 .

The percentage proportion of the contributions of the colliery owners to those of the ordinary members is less in the Northumberland and Durham Society than in the others. In 1890 it repre. sented only 5.7 per cent., * whilst in the Lancashire and Cheshire Society it was $24^{\circ}$ I per cent., in the North Wales Society $25^{\circ} 2$ per cent., and in the Monmouthshire and South Wales Society 24 per cent. If we turn to Table IX. of the report, the reason of this difference becomes apparent; it will be seen that all, or a very large number, of the members of these three societies have entered into an agreement with the owners not to bring any claim against them under the Employers' Liability Act of I 880, or, to use the common expression, they have "contracted themselves out of the Act." They consider that the employer's contribution is worth more to them than the chance of occasionally obtaining compensation by proving negligence against him in a court of law.

Enough has been said to show the present state of the voluntary system of relief as it now exists in England and Wales; much of the distress caused by mining accidents is relieved by the nine principal societies, and, in addition, there are numerous smaller societies established for individual mines, having in the main the same objects as the larger ones.

Something more is needed-viz., relief in sickness, and old age pensions for all. Some of the existing clubs of individual mines give sick pay to their members, and there are the ordinary Friendly Societies established on a far firmer basis, which can be resorted to by the miner like any other workman. As far therefore as sicknıs; is concerned there is machinery available by which the miner in any part of the kingdom can make the necessary provision for himself and his family.

If he requires a pension, he can get one upon the very best security by going to the nearest Post Office. A young man of twenty can obtain a deferred annuity of $5 s$. a week, commencing at the age of sixty, by paying $£^{2} 3^{s}$. $4 d$. a year, or rod. a week. If the person wishes to discontinue his insurance, he can do so, and all the money he has paid will be returned to him, provided that an instalment of the annuity has not become due. However, as the facilities afforded by the Post Office have not been utilised to any great extent, compared with the numbers of the working classes, and as a large number of persons spend the last years of their lives and end their days as paupers in the workhouse, it is thought by most people that something more should be done. Great

* Op. cil. Tables IV. and V., pp. 34-5. 
difference of opinion exists upon the subject; much has been written, and still more said during the last few years, and the controversy has raged mainly upon the question of State aid. The proposals may be summed * up as involving one of the three following principles:

\section{State endowment. \\ 2. State assistance. \\ 3. State compulsion.}

I. The first, that of Mr. Charles Booth, means the free gift by the State of a pension of $5 s$. a week to every citizen on attaining the age of sixty-five years.

2. The best known scheme coming under the second head is that proposed by a Parliamentary Committee, $\uparrow$ presided over by Mr. Joseph Chamberlain, M.P. Its main features are as follows: If a young man pays $£ 5$ to the Post Office Savings Bank before the age of twenty-five, he is to be at once credited with II $_{5}$ more from a State pension fund; he will then have to pay $\mathscr{E}_{\mathrm{I}}$ a year to the Post Office for forty years, and at sixty-five he will become entitled to a pension of 5 s. a week. If he dies before the age of sixty-five, there are arrangements for granting a pension to his widow and children. It is also proposed that a male shall be able to purchase a pension of $5^{s}$. a week on payment of onehalf of the surns just mentioned; but in this case there is no provision for a family.

3. The last plan of providing old age pensions is that which has been advocated for so many years and with so much skill by the Rev. Canon Blackley. He would compel every one to deposit with the State, before the age of twenty-one, a sum of about

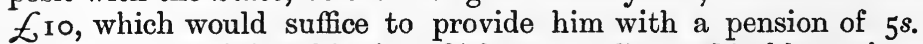
a week on attaining his sixty-fifth year. Canon Blackley points out that in his youth, before marriage, a man would be able to make the proposed saving, and that after this he would no longer be troubled by the thought of not being able to keep up his payments.

Many arguments may be adduced in favour of each of the three principles of old age pensions, but opinions concerning them must largely depend upon the "personal equation" of the individual-that is to say, upon his general views regarding the interference of the State in such matters.

The Gordian knot of this difficult question has been cut in Germany b" the Law of Insurance against Old Age and Infirmity $\ddagger$ passed in 1889. Under this law the means for providing the allowances to infirm and aged persons are made up of eontribu-

* Reports of the Chief Registrar of Friendly Societies for the Year 1891, London, 1892, p. 26.

$\dagger$ The Times, London, May 2I, 1892.

Translated in Parliamentary Paper (C. -5827 ), 1889, price $3 \frac{1}{d} d$. 
tions from the State, the employers and the persons insured, the two latter paying like amounts.

The method of insurance may be briefly described as that of State compulsion with State aid, together with obligatory contributions from the employer. This bold experiment will be watched with interest.

This subject of thrift must not be concluded without a few words about one requisite for the treatment of diseases-viz., hospitals. In this country the provision of such institutions is frequently left to private benevolence; in the great tin mining centre of Redruth, for instance, the burden of ensuring accommodation for the sick and injured has been taken by a charitable owner of mineral property. According to the balance sheets of the institution from 1885 to 1892 , he has paid on an average more than 40 per cent. of the total cost, which exceeds Er 300 yearly; the remainder is met by contributions from private persons, companies working nines in the neighbourhood and their workmen.

The Oakeley Hospital at Blaenau Festiniog, which ministers to the ills of some of the quarrymen, was built by the landowner, and is now supported by the largest slate mine.

Many of the large Continental mines keep up establishments of this kind, and throw them open gratis to their employés. The same plan is adopted by some of the large British cumpanies working mines abroad, and even at Boryslaw, where much of the mining is being carried on in the most primitive manner, a Galician company supports a small hospital, and admits not only its own servants, but also any urgent cases requiring surgical or medical attendance.

Fortunately, it often happens that a mine has not accidents enough to require the constant use of a hospital and the entire services of a surgeon. This is the case, for instance, at some large mines near Ems; the company has built a hospital and keeps it in readiness, in case of accidents or sickness, with a doctor on the premises; but, in consideration of his small stipend, he is allowed to have three rooms at his disposal in which he can treat private patients. In the United States sick and injured miners sometimes go to private hospitals, which are managed by medical men.

Before complete recovery from an illness or the effects of an accident, a man passes through a period of convalescence, luring which he requires little medical aid, but depends for his tinal restoration to health mainly upon good food, quiet and regular living, and plenty of fresh air. It is a question in some mining districts whether it is better to support a convalescent home in the locality itself, or to subscribe to one at a distance. The litter plan is in many cases cheaper, owing to the smaller cost for general expenses; and at the same time it is better for the patient, who profits by the change of air and scene, which in 
themselves are powerful remedial agents. In a small island like ours, it is not difficult as a rule for the patient to get to the sea coast without a ruinous expenditure of money in railway fares. At some of the sea-side convalescent homes a miner may be boarded and lodged for three weeks at a total cost of $£ \mathbf{r}$ r6s.; therefore if a mine is employing $500 \mathrm{men}$, and each man subscribes $\frac{1}{2} d$. per month of four weeks, more than $\mathcal{E}^{\mathrm{r}} 3$ can be raised annually, or sufticient to give seven invalids a stay of three weeks each at the sea.

In writing upon the question of thrift, mention must be made of co-operative societies, which give the workman the opportunity of buying his food and clothing at the most reasonable rates. They are so well known nowadays that no description of their advantages is required; but it is well to point out that their success does not necessarily depend upon their having a very large number of customers, such as could only be expected in a very populous district. Two instances of co-operative societies in the Isle of Man prove this fact, and show that such an institution may prosper commercially, and do good and useful work in a mere village depending upon a mine employing only 200 or 300 persons underground.

6. RECREATION.-I am well aware that many will say that in the matter of recreation the mine manager had better not interfere at all; I do not take this view. Men and boys require diversions of some kind in order to refresh their bodies after toil, and the manager of a large mine often has the opportunity of directing their amusements into the best channels. Tastes differ: some men will find relaxation in reading, and will be glad to be able to borrow books from a library; others are musical, and will prefer to join a band; boys, in spite of hard bodily work at the mine, will delight in active games as soon as they are free. As an example of what may be done I will cite the names of the clubs established at the collieries of the Douchy Company in the north of France as recreative institutions: Archers, crossbowmen, gymnasts, philharmonic, and pigeon fanciers. It will be seen from this list that a great many different tastes have been studied in order to encourage the men to employ their spare time in a wholesome manner instead of going to pot-houses, to the injury of their purses, if not to the detriment of their health.

An example on this side of the Channel may be taken from the extensive collieries in Derbyshire and Nottinghamshire, owned by Colonel Seely, M.P., who has established workmen's clubs, cricket club, football club, pig club, a band, and an annual flower show for the benefit of his men. The cricket ground is one of the best in Derbyshire, and the club-house is a large building containing three billiard-tables, reading and smoking rooms, and a lending library; the members can obtain any sort of 
refreshment they like at reasonable prices. The band plays three times a week in the club grounds. In addition, each separate colliery has its club with a billiard-table, and other appliances for recreation. All these institutions are under the control of committees of the workmen, presided over by the General Manager. 


\title{
CIIAPTER XVII.
}

\author{
ACCIDENTS.
}

Death-rate of miners from accidents-Relative accident mortality under yround and above ground-Fatalities: underground, from falls of roof, from accidents in shafts, from blasting accidents, from underground fires, from irruptions of water and sundry other causesAccidents above ground-Boiler explosions-Non-fatal accidentsAmbulance training.

Few persons will deny the dangers of the miner's calling; some, however, consider that the public form an exaggerated idea of these perils from dwelling too much upon occasional colliery explosions.

Death-rate of Miners from Accidents.-In the first place comes the question: What is a dangerous trade? If we look at the vital statistics quoted from Dr. Ogle in the last chapter, it appears that the majority of miners, thanks, partly, to their starting originally with a more than average good constitution, lead a longer life than many tradesmen in towns. In spite of the diseases and accidents to which he is liable, the average miner is better off than most people would have supposed, before they became acquainted with the figures. On the other hand, if we limit our attention to accidents, we find that the miner gets far more than his share.

It may be asserted without fear of contradiction that a calling with an annual mortality of I per I000 from accidents, is hazardous. The statistics concerning accidents in this country are given annually in the statistical summaries prepared by Her Majesty's Inspectors of Mines; and it will be seen from the published figures that, taking all the mines in the United Kingdom and including casualties above and below gruund, there was an average annual mortality from accidents of 2.18 per 1000 persons employed during the ten years 1873 to 1882 inclusive, and that in the next decade the mortality dropped to I 78 per 1000 .

In this country an accident is classed as fatal if it causes the death of the injured person within a year and a day of the date of the occurrence; it is therefore possible that in certain very rare cases, when more than a year elapses before a man succumbs to his hurts, an accident may be registered as nou-fatal, although it finally turns out to be fatal. Cases of 
this kind are so few that the correctness of the British statistics cannot be appreciably affected by them.

In an interesting report upon the Exhibition held in Berlin in I 889 of appliances for the prevention of accidents, M. Paul Habets gives a careful summary of the progress realised in Belgium, France, Great Britain, and Prussia.* He divides his results into periods of ten years:

\section{TABle I.}

Annual Death-rate from Accidents per 1000 Persons Employed.

\begin{tabular}{|c|c|c|c|c|c|}
\hline Period. & & Belgium. & France. & Great Britain. & Prussia. \\
\hline 1851 to 1860 & - & $2 \cdot 97$ & $3.40^{*}$ & 4.07 & $49 r+$ \\
\hline I86I to 1870 & . & $2 \cdot 60$ & $2 \cdot 96$ & $3 \cdot 32$ & $6 \cdot 33$ \\
\hline 1871 to 1880 & . & 245 & $2 \cdot 21$ & $2 \cdot 35$ & 4.90 \\
\hline I 880 to 1888 & . & $2 \cdot 13$ & I'57 & 1.94 & $2 \cdot 96$ \\
\hline
\end{tabular}

* I853 to I86o.

+1852 to 1860 .

These figures show a steady diminution in the number of accidents excepting in Germany, for in the decade 1861 to 1870 the mortality was terrible; but even the most favourable averages are far above the standard of I per I000, which has been assumed as the mortality ratio of a dangerous occupation.

Relative Accident Mortality amongst Underground and Above ground Workers.-Descending into details, let us examine how the two classes of mines-viz., those under the Coal and those under the Metalliferous Act-compare with one another. The figures will be made most plain by putting them in a tabular form.

Table II.

\begin{tabular}{|c|c|c|c|}
\hline $\begin{array}{l}\text { Decennial } \\
\text { Period. }\end{array}$ & $\begin{array}{l}\text { Average Number of } \\
\text { Persons t mployed } \\
\text { Underground } \\
\text { and Above-ground } \\
\text { Annually. }\end{array}$ & $\begin{array}{l}\text { Total Number of } \\
\text { Lives lost by } \\
\text { Acciuents in the } \\
\text { D'cennial } \\
\text { Period. }\end{array}$ & $\begin{array}{l}\text { Average Annual Death } \\
\text { rate from Acidents } \\
\text { per rooo Persons } \\
\text { Enployed. }\end{array}$ \\
\hline \multicolumn{4}{|c|}{ Mines classed under the Coal Mines Regulation Act. } \\
\hline $\begin{array}{l}1873 \text { to } 1882 \\
\mathrm{I} 883 \text { to } 1892\end{array}$ & $\begin{array}{l}503,428 \\
571,719\end{array}$ & $\begin{array}{l}11,294 \\
10,327\end{array}$ & $\begin{array}{l}2 \cdot 243 \\
1 \cdot 806\end{array}$ \\
\hline \multicolumn{4}{|c|}{ Mines classed under the Metalliferous Mines Regulation Act. } \\
\hline $\begin{array}{l}1873 \text { to } 1882 \\
1883 \text { to } 1892\end{array}$ & $\begin{array}{l}55,388 \\
42,481\end{array}$ & $\begin{array}{l}909 \\
612\end{array}$ & $\begin{array}{l}I \cdot 64 I \\
I \cdot 440\end{array}$ \\
\hline
\end{tabular}

According to these figures, work at mines under the Coal Mines

* “Les Accidents dans les Mines et l'Exposition Générale Allemande pour la Protection contre les Accidents (Berlin, 1889)." Revue Universelle des Mines, $3^{\circ}$ série; t. ix. et xi., $34^{\circ}$ année, 1890. 
Act presents decidedly more perils than work at mines under the Metalliferous Act. Speaking roughly, the relative degrees of danger were as I I to 8 in the first period and 9 to 7 in the second.

In order to make the comparison of any real value, it is necessary to go somewhat further. Owing to the amount of labour required for " dressing," the proportion of surface hands is much larger at a tin, copper, lead, or slate mine, than at a colliery. In round numbers about one-fifth of the persons employed at mines under the Coal Mines Regulation Act work above ground, and fourfifths underground; at mines under the Metalliferous Mines Act the proportions are two-fifths above ground, and three-fifths underground. Consequently, as the proportion of the surface hands with a small risk is twice as great in one case as in the other, it is impossible properly to compare the risks of the underground workers until this source of error has been eliminated. The death-rates calculated separately are as follows :

\section{TABLE III.}

Average Annial Death-rate from Accidents per 1000 Persons employed in and about the Mines of the United Kingdom of Great Britain and Ireland.

\begin{tabular}{|c|c|c|c|c|}
\hline \multirow{2}{*}{ Decennial Period. } & \multicolumn{2}{|c|}{ Below Ground } & \multicolumn{2}{|c|}{ Above Ground. } \\
\hline & $\begin{array}{l}\text { Coal Mines } \\
\text { Act. }\end{array}$ & $\begin{array}{l}\text { Metalliferous } \\
\text { Mines Act. }\end{array}$ & $\begin{array}{l}\text { Coal Mines } \\
\text { Act. }\end{array}$ & $\begin{array}{l}\text { Metalliferous } \\
\text { Mines Act. }\end{array}$ \\
\hline $\begin{array}{l}1873 \text { to } 1882 \\
1883 \text { to } 1892\end{array}$ & $\begin{array}{l}2 \cdot 572 \\
2.009\end{array}$ & $\begin{array}{l}2 \cdot 348 \\
2 \cdot 145\end{array}$ & $\begin{array}{l}0.919 \\
0.959\end{array}$ & $\begin{array}{l}0.578 \\
0.392\end{array}$ \\
\hline
\end{tabular}

In the first period the relative amounts of danger to underground workers were as $5 \mathrm{I}$ to 47 , a very different proportion from II to 8 as appeared from the other table; in the second period the mines under the Coal Mines Act have the advantage, whereas by the original table they seem to be more dangerous than those under the Metalliferous Act.

The necessity for considering the underground death-rate separately, when inquiring into the relative amounts of danger at different classes of mines is well illustrated in the case of the underground slate quarries of North Wales. These appear to be less dangerous than collieries, or more dangerous according as the surface hands are included or not in the calculations. Taking the ten years 1875 to 1884 , the annual death-rate from accidents at the underground slate quarries was 2.07 per 1000 among all the workers as a whole, and $3^{\cdot 2}$ per 1000 among the underground workers taken separately. The former rate is better than the corresponding 2.243 ('Table II.) of mines under the Coal Mines 
Act, and the latter is worse than 2.572 (Table III.). Consequently the average underground slate-quarrier has a more perilous calling than the average collier.

While correcting one misapprehension I must guard against another, and point out that the Coal Mines Regulation Act applies to mines of coal, stratified ironstone, shale, and fireclay. Therefore the figures given do not refer solely to coal-mines, and do not represent precisely the risks of the collier, and it becomes necessary to examine whether the introduction of certain disturbing elements affects the average risk to any great extent or not. Compared with coal, the amounts of fireclay, ircnstone, and shale are small, and the total quantity of these minerals raised in 1893 was less than 6 per cent. of the weight of the coal ; any error caused by the introduction of ironstone and other mines, is likely therefore to be inconsiderable. After coal, the most important mineral wrought under the Coal Mines Act is ironstone, and more than half the total quantity raised is obtained in the Cleveland district. From the figures given in the reports of the inspectors of mines, I find that from 1873 to 1882 there were 183 deaths from accidents underground in the Cleveland district, with an average annual underground staff of 6863 persons, consequently the average death-rate was 2.66 per 1000 ; in the following decennial period it was 2.21 per 1000.* Both these proportions are higher than the corresponding ratios calculated for the whole of the mines under the Coal Mines Act; therefore if all disturbing factors were eliminated, we may fairly assume that the average underground death-rate at the coal-mines proper did not exceed the figures given in Table III.

On the other hand, I must remark that the Metalliferous Mines Regulation Act applies to all mines not included under the Coal Mines Act, and the statistics under the former Act refer not only to mines worked for ores, but also to salt-mines and underground slate and stone quarries. The figures quoted cannot be taken as relating solely to true metalliferuus mines.

For the sake of comparison I have extracted from the annual reports of the inspectors of mines, the figures for the metalliferous mining district of Cornwall and Devon, including also a few mines in Somersetshire and Dorsetshire. During the ten years 1873 to 1882 there were 280 deaths from accidents underground, with an average underground staff of 10,629 persons. This means an average annual death-rate among the underground workers of 2.63 per 1000 . The corresponding figure for the ten years 1883 to 1892 was found to have been $2 \cdot 54$ per 1000 .

The conclusions arrived at from these statistics are, first, that

* From 1873 to 1883 the publisbed statistics refer to the whole of the North Riding of Yorkshire, where a little coal is worked, but not in sufticient quantity to affect the ratios perceptibly; since 1883 the Cleveland figures have been kept entirely separate. 
tho mines under the Coal Mines Regulation Act are not always more destructive of life than the mines under the Metalliferous Mines Regulation Act ; and secondly, that certain mines worked for metallic ores, such as the iron mines of Yorkshire, and the tin and copper mines of Cornwall and Devon, present more dangers to the underground worker than an average colliery, in spite of the almost complete absence of explosions of gas. In other words, as has been pointed out repeatedly, fire-damp is not the worst enemy the miner has to contend with. It is very evident also that if different classes of mines are to be compared as regards dangers, the figures must be restricted to those working below ground; and it is to be regretted that some of the official reports concerning mines in other countries afford no means of making the proper comparison. On the other hand, foreigners sometimes complain that our British statistics do not give them the true coal-mining accidents separately; but when the two minerals, coal and ironstone, are being worked in the same pit, and when the preliminary and exploratory work is common to both minerals, it is impossible to draw any strict line of division.

Classification of Accidents.-In order to obtain some general ideas concerning the kinds of accidents which occur at mines we must begin by classifying them. The basis of such a classification may be either the place where the accident happened, or the cause of the occurrence. Usually the classification is founded upon both.

Following the plan which was adopted in the early days of mine inspection in this country, the British classification begins by separating the accidents which happened underground from those which took place at the surface, and then the underground accidents are arranged under the four main heads :

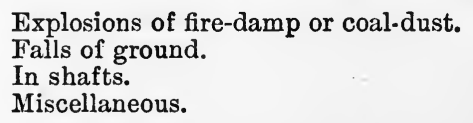

The classification is not strictly logical, because it to a certain extent mixes up cause and place ; there may be explosions of firedamp or falls of ground in shafts, but these would naturally be placed under the headings which most particularly describe them, so that the heading "in shafts" does not always include every accident which has happened there. However, the classification has been used so long, and is so well understood, that it would be absurd to make any great alteration now.

The relative importance of each of these classes is brought out by the following table, which has been calculated for the same periods as the preceding one: 
TABLE IV.

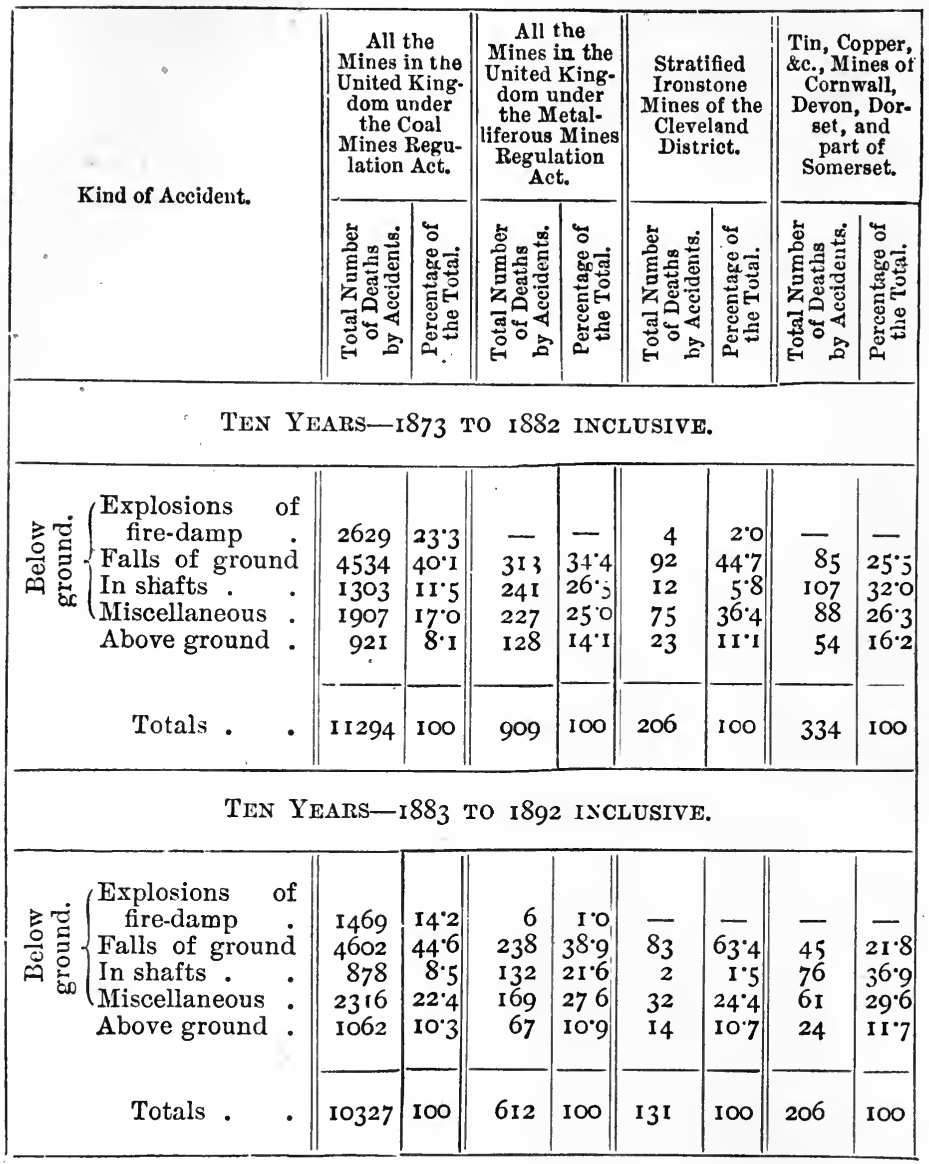

The further subdivision adopted in this country for classifying is given in the table below : 


\section{TABLE V. \\ Classification of Accidents.}

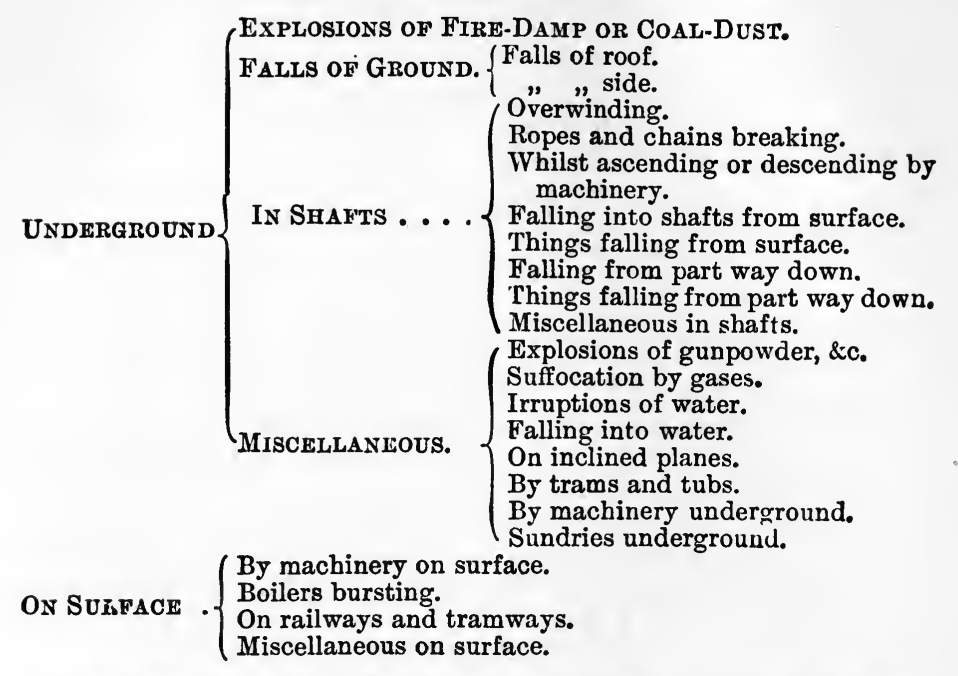

Explosions of Fire-Damp or Coal-Dust.-With few exceptions, fatalities from explosions of fire-damp in this country are confined to coal mines.

Falls of Ground.-Table IV. indicates plainly what point requires the special attention of the mine-owner, in his endeavours to ward off the dangers which threaten his workmen. By far the largest proportion of fatalities occur from falls of ground; and the same story is told by the statistics of other countries. Without attempting to refer to all the information which is published on the subject, it will suffice to say that 36 per cent. of the deaths at Prussian* coal mines in 1891 , and 47 per cent. of those at the ore mines, are ascribed to this cause. This cannot be a matter of surprise when we consider the conditions under which the miner carries on his labour: in the overhand stopes of an ore mine, he is constantly taking down the roof above his head; in working away a stratified deposit, he is continually pushing forward under a fresh part of the overlying stratum, which may have concealed and unsuspected joints ; at other times, he is engaged in removing from the parent bed liuge masses of rock weighing many tons each; no wonder, therefore, that he is occasionally caught by a fall.

These accidents are best guariled against by incessant watchfulness on the part of the men nd masters, by putting in supports, even when they do not appear implediately necessary, and by

$$
\text { * Zeitschr. f. B.-H.-u. S.-Wesen, rol. xl., 189a, p. } 32 .
$$


regulations defining how closely props shall be set. Testing the ground by "sounding"-i.e., by striking it with the hammer and noticing the sound emitted-often enables the workman to detect whether the rock is firm or not; but the indication is not always reliable. If the mass of rock is large, it may " sound " all right, and yet not be firmly attached as supposed. Besides, ground which is perfectly firm and safe when first laid bare by the miner, will often lose its stability with the lapse of time. Air and moisture penetrating into the minute concealed joints and acting for months or years have the effect of gradually loosening the adherence of the rock masses; the constant shaking produced by blasting, to say nothing of minute but oft-repeated earth tremors, are all acting in the same way, and therefore the miner has no right to conclude that places which were safe originally are going to continue so for ever.

Shaft Accidents.-The principal dangers that beset the miner in shafts are manifest from the different headings, and many of the means of guarding against them have already been explained in the chapters upon winding and descent and ascent. It must not be supposed that all the accidents classified under the third heading in the British statistics occurred during the ordinary times of going up and down; this division also includes fatalities which took place while men were occupied in making repairs, or were using machinery not intended for the purpose of raising men. The German official statistics contain a table in which these irregular ascents or descents are eliminated, and make it possible to institute a comparison between the relative degrees of safety of the different methods of obtaining access to the workings. Judging by the result of the ten years I88I to 1890 , the death-rate from accidents per 1000 persons was 0.060 with the cage, 0.066 with ladders, and 0.196 with the manengine; this last contrivance is therefore far more dangerous than the cage or ladders, although the list of man-engine fatalities was not swollen by any big catastrophe, such as happened in the previous decennial period. A distinction must be made between the single-rod and the double-rod machines, and the Prussian statistics include many of the latter. It will be readily understood that a fall in a naked shaft with few fixed platforms is far more likely to be fatal than a fall in the shaft of a single-rod machine, which is closed completely with the exception of the small manholes at intervals of 12 feet. As far as I am aware, no accident on a single-rod man-engine in Cornwall, even when a rod has broken with men on it, has ever caused more than one death; but there are two bad cases on record with double-rod engines in Germany.

In the year 1880 eleven men met with their death at Abraham mine near Freiberg by being precipitated down the shaft when one of the rods broke while they were "riding " upon it. It appeared from the official inquiry that the timber rod had become rotten, 
and that it ought to have been changed long before the accident. The other bad fatality was at Rosenhof shaft near Clausthal in the Hartz, where again eleven poor miners were suddenly killed from a similar breakage. These two accidents prove the incorrectness of the statement made by those who extol the man-engine at the expense of the cage, and say that no accident can happen with the former except through the miner's own carelessness ; but when making any such comparison it is essential to know precisely which kind of man-engine is meant. Thus if we take the case of Cornwall, where the double-rod machine no longer exists, we find just the reverse of what appears in Prussia. The death-rate from accidents on man-engines in Cornwall and Devon during the seven years 1873 to $1879^{*}$ was 0.14 per 1000 persons using them, whilst the annual death-rate per Iooo persons using ladders was higherviz., $0^{\circ} 2 \mathrm{r}$. If the actual distance travelled had been taken into account, the scale would turn more decidedly in favour of the man-engine.

In the Prussian figures just quoted, the ladder appears but little more dangerous than the cage; probably most of the mines provided with ladders are much shallower than those fitted with cages, so that if the men had been obliged to ascend from equal depths in both classes of mines, the list of ladder accidents would no doubt have been largely increased.

The Belgian machines, called warocquères after their constructor, are rendered safer than the Hartz or Saxon manengines by having a railing round the back of each platform on the rods. Some of the double-rod machines are made with large platforms, so that two persons can stand on them.

Miscellanoous Accidents Underground.-Explosions of Gunpowder, \&c.-Blasting accidents, which head this class, are possibly less numerous than many people would suppose, when reflecting upon the large quantities of gunpowder and other more powerful explosives which are annually consumed by the miner.

They occur in many ways :

a. Accidental ignition of powder, while carrying it or handling it, from a spark of the candle.

$b$. Getting in the way of blasts, either from not retiring to a safe place, or from a hang-fire of the fuse, or from erroneously supposing that a fuse had not been ignited by the "snuff."

c. Ignition of the charge during the operation of tamping. Sometimes, nu doubt, a spark is struck by an iron rammer and communicates fire to the charge by a train of powder lying either behind the fuse or in ragged portions of a hole bored in "vuggy" ground; in other casrs it is thought that just as German tinder can be ignited by the mere compression of air, so the

* Reports of HI.M. Inspect rrs of Mines for the Year I879, London, I880, p. 425 . 
charge itself may be fired by hard ramming at the commencement. The number of accidents of this class has been reduced by the introduction of the nitroglycerine explosives, which will exert their useful effect without hard tamping.

$d$. Illegally boring out or picking out the tamping of holes which have missed fire.

$e$. Exudation of nitroglycerine from dynamite left exposed to water in a hole which has missed fire. The sensitive oil may explode when the adjacent rock is struck by the pick or drill.

$f$. Unexploded remnants of dynamite or gun-cotton. It occasionally happens that the whole of a charge of one of the nitroglycerine or pyroxyline explosives does not go off completely: after firing a shot the miner may find that the blast has not rent the rock to the bottom of the hole, but has left a "socket"; to save himself a few inches of boring, he sometimes is tempted to use this in starting the next hole. Such proceedings have been proved to be most dangerous, for the blows of the steel tool may fire the unexploded remnants, and cause a serious disaster.

g. Miners, and indeed others, have been injured by the explosion of the fulminate of mercury in the detonators, or caps, when examining them incautiously, or while endeavouring to pick out sawdust with which they were choked.

The golden rule is to treat explosives as substances which will and do explode, but it is naturally difficult for the miner who is handling them day after day not to become somewhat callous to their dangers.

Suffocation by Gases.-Few fatalities in this country are put down to suffocation by gases given off naturally by the rocks.

Irruptions of Water.-Irruptions of water into mines happen in three ways:

Floods at the surface due to an unprecedented rainfall.

Extending the workings too close to the bottom of the sea or a river.

Breaking into old workings full of water.

All these causes have occasioned disasters in mines. The first danger may be avoided by keeping the top of every shaft of the mine well above the level of the lowest land of the district. If it happens that the only convenient site for a shaft is near the bottom of a valley, the top may be built up with masonry strong enough to resist a flood. Many lives were lost in Hungary in May $189^{2}$, from the bursting of a waterspout, which caused water to pour down some mine shafts.

Breaking into the flooded workings of old adjacent mines may happen through want of knowledge or want of care. Defective plans are one source of the irruptions, the miner being beguiled into a false security by inaccurate surveys of the adjacent property, or by ignorance that any workings had ever been made there before. 
The Coal Mines Act enjoins the precautions which are well known to every miner in approaching old workings-viz., boring holes in advance for the purpose of tapping the water, before there is any danger of the protecting partition giving way under the pressure behind it. The water can then be drained off slowly, and the partition need not be broken down until all chance of flooding is past.

On Inclined Planes.-Accidents may happen from men being caught and knocked over by waggons, while they are making use of inclines as travelling roads; the statutory manholes or refuge niches are designed to prevent dangers of this kind, but a better plan is to provide independent walking roads, or to partition off the walking road from the railroad. At some mines the men are prohibited from walking upon the inclines while trucks are being drawn up and down, and work is stopped at the changes of the shifts, in order to give them the means of descending and ascending in safety.

By Trams and Tubs. - It would be strange if men were not sometimes injured when moving tram waggons. Owing to an imperfection in the road, a waggon may turn over and catch a man in its fall, or in narrow levels a man may be nipped against the side.

By Machinery Underground.-Proper fences will prevent some of the fatalities from machinery underground, and such safeguards become all the more necessary in the dark or ill-lighted passages of a mine, where one may have to assume a cramped position in going past the moving mechanism.

Sundries Underground.-Under this heading will be found various accidents which cannot be placed in one of the other subdivisions. The most serious are underground fires; in fact, two of the worst catastrophes known in mining have happened from this cause; they are barely equalled by the worst explosions in collieries, and go to prove a fact already insisted on-viz., that coal mining is not the most perilous form of underground labour. I refer now to the underground fires at De Beers diamond mine and at P'ibram. In the year 1888 some of the timber in one of the shafts at De Beers accidentally took fire, the flames spread rapidly and soon filled the mine with smoke to such an extent that twenty-four white men and 200 natives were suffocated. The Pŕibram disaster of May 1892, was on an even larger scale. Again, some accident or carelessness caused the ignition of the timber in one of the shafts, and the burning wood produced such fumes that $318 *$ persons were asphyxiated in the mine, whilst one died a few days after his rescue.

These are not the only cases of great disasters arising from fires.

* "Der Grubenbrand in Pŕibram am 31 Mai 1892," L. u. h. Z., 1893, p. 2 I 2. 
At the Mauricewood Colliery, * in I889, sixty-three out of sixty. tive men who were in the mine lost their lives through an underground fire, the cause of which was never precisely ascertained; possibly a naked light carried on the head of one of the men came in contact with the very dry timbering on an incline or with some brattice cloth, and set it on fire. The accident was in no way due to the fact that the mineral worked was coal. Turning to ore mines, we find, for instance, that fires have happened on more than one occasion in the workings on the Comstock lode. Before the year I 869 they fortunately had no other evil effect than driving the men out of the workings; but in A pril of that year a fire broke out in the 80o-foot level of the Yellow Jack mine, possibly from a candle left near the timber, and it burnt along unnoticed until at last a "stull" gave way and drove a blast of foul air and smoke into the shafts. This happened at the change of shifts and thirty-four miners were suffocated. $\uparrow$ After unsuccessful attempts to rescue the men, and when all hope of their being alive had been abandoned, steam was forced into the mine two days after the accident for seventy-two hours. This proved insufficient, and steam was again forced in for two days. The fire was not completely subdued for several weeks, and even six months after the accident, smouldering timber was sometimes met with. According to the experience gained in this accident, steam is not effectual in extinguishing a mine fire, though it is useful as a temporary expedient for purifying the atmosphere of the mine and checking the flames, and so rendering it possible to put in dams and cut off the supply of oxygen to the conflagration.

In addition to the big catastrophe, there were several minor accidents of a like nature, and forty-nine persons in all lost their lives from underground fires at mines on the Comstock lode in seventeen years +

A fire at the Calumet and Hecla copper mines on Lake Superior in November 1888 claimed eight victims, and in addition to this loss of life caused a considerable loss of money. Judging by the accounts which are published from time to time in the mining newspapers, underground fires are not so uncommon in ore mines as one might suppose, and it may often depend upon a mere chance whether they become fatal to life or not. With a mineral so easily ignited as native sulphur, $\$$ the occurrence of fires in the Sicilian mines will not excite astonishment ; some of the accidents arise from carelessness with lamps and in blasting, but the most common cause is the heat generated by the friction of heavy

* Johnston and Bell, "Mauricewood Colliery, Report to the Secretary of State for the Home Department," Edinburgh, I89o.

+ Lord, "Comstock Mines and Miners," Monographs U.S. Geol. Survey vol. iv., Washington, 1883, p. 269.

$\ddagger$ Op. cit., p. 404 .

$\S$ Rivista del Servizio Jinerario nel 1888, Florence, 1890 p. 70. 
masses of the sulphur-bearing rock when there are falls, which, as has already been stated (Chapter VI.), are sometimes the result of the method of working adopted. Many of the fires last for a very long time, and in one instance sixty years elapsed before the burning rock was extinguished. The number of accidents from suffocation by sulphurous acid produced by underground fires at the Sicilian mines is by no means small; thirty-five persons perished in this way during the five years 1884 to 1888 , to say nothing of four deaths from inhaling carbonic acid gas, and thirteen deaths from sulphuretted hydrogen.*

The moral to be drawn from these unfortunate accidents is that at all events the main shafts, or other approaches to the underground workings, should be constructed in a manner calculated to prevent a repetition of such great disasters. Many of the shafts in mines, especially those devoted to pumping, are so wet that there is no fear of a fire even if they are lined with timber; in others the lining is of brickwork or masonry, and the guides are made of steel rails or wire ropes; the shaft is therefore uninflammable. In very dry mines, on the other hand, the danger does exist of the shaft being converted by some slight carelessness, or by an accident with a lamp, into a huge blazing furnace, which may send clouds of suffocating fumes into the workings and prevent the exit of the miners or the entry of rescuers. To guard against such a state of things, either timber linings may be e-chewed and replaced by incombustible linings, or the inflammability of the wood may be reduced by keeping it damp. As already pointed out, water is in some cases made to trickle over the shaft timber in order to prevent its being attacked by dry rot.

I have dwelt somewhat at length upon these fatalities from fires, because of the very serious consequences which have resulted from them in recent years.

Before passing on to the accidents which happen at the surface, it may be well to call attention to two recent rescues of entombed miners, as instances of the length of time men can exist without food, so that in case of the accidental imprisonment efforts to recover the sufferers may not be relaxed too soon. In July I 892 three miners were shut in by a fall at a brown-coal mine in Bohemia, and were rescued after the lapse of no less than seventeen days, during the whole of which time they were deprived of food, though sufficiently supplied with drinking water. A shade more wonderful is the escape of four men at Jeansville in Penusylvania, $\uparrow$ in February I89r. Seventeen persons were shut in by the irruption of water into the mine from adjoining workings, and they could not be reached until the level of the water had been lowered by pumping. When the rescuers were able to penetrate into the

* Op. cit., p. 54 .

† Eng. Min. Jour., vol. li. 1891, p. 447. 
workings, eighteen days after the disaster, four of the seventeen men were found alive, though of course extremely weak.

Accidents on the Surface.-By Machinery.-A very large proportion of the surface accidents are such as might happen at any factory. 'Though they cannot be prevented entirely, for men and boys will sometimes go into the most unexpected places, much good can be done by fencing; and it is always well to err upon the side of over-caution, and protect shafting or other moving parts which may at first sight seem quite innocent. If the lubricant cannot be supplied by one of the constant feeders, the attendant should do the oiling, as far as possible, when the machinery is stopped for meal-times or for some other purpose; the desirability of wearing tightly fitting clothes has already been mentioned, and it is always advisable to have the means of throwing machinery out of gear quickly, in case a person is caught by it.

For putting belts on to pulleys, a special "shipper" is safer than the hand.

Now that so many mines have cireular saws, it is well to recollect that the use of a guard, like the Lakeman guard for. instance, may occasionally save a man the loss of a finger or a hand.

Looking at the fact that millions of slates that are made annually by machines with revolving or guillotine-like knives, it is not strange that through momentary inadvertence men should now and then put the hand in a little too far and lose the end of a finger. It is impossible for any mortal to be continually on the watch against such occurrences as these, hour after hour and day after day, and the marvel really is that in spite of distractions the human machine works as correctly as it does.

Boiler Explosions.-The subject of boiler explosions concerns the general manufacturer quite as much as it does the miner, and it has been so thoroughly studied of late years that there is no longer any reason for ascribing such occurrences to mysterious and inexplicable causes. Boilers burst from weakness, which may be due to original malconstruction, to improper treatment, or to ordinary wear and tear. It is very desirable that every boiler should be cleaned out at least once in three months and then carefully examined internally, a record being kept at the office signed by the person making the inspection. In England, very many owners of boilers join such a society as the Manchester Steam Users Association and have their boilers periodically inspected by competent experts, who at the same time are able to give many valuable hints concerning safe and economical methods of working.

Miscellaneous on Surface.-Under this last heading are included a variety of accidents, which need no special mention.

It would be interesting to know the exact number of accidents 
which happen at open works, but unfortunately no official figures are published showing death-rates for the whole Kingdom, such as are calculated in the case of true underground mining. Judging by certain returns lately published,* it seems that some open quarries are decidedly more dangerous than the average mine.

Non-fatal Accidents.-Statistics concerning non-fatal accidents are of little use unless the extent of the injury is indicated in some manner. The Mining Acts prescribe that all serious nonfatal accidents, and all accidents causing personal injury arising from any explosion of gas, powder, or of any steam boiler shall be reported to the inspector. In France, on the other hand, the official statistics $\uparrow$ do not include non-fatal accidents which have disabled the person for less than three weeks.

Mining is sometimes a source of risk to the public as well as to the actual workers. The commonest danger arises from unfenced or insecurely fenced shafts, or, what are worse, shafts which

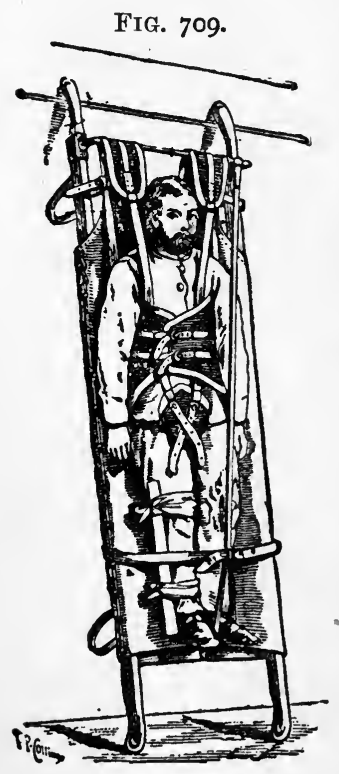
have been covered with timber and earth and become forgotten. Every now and then the local papers of mining districts record the sudden and unexpected giving way of a rotten "sollar," leaving a yawning crater in what was thought to be solid ground. Fatal accidents to men and beasts have taken place in this manner, to say nothing of many very narrow escapes.

Ambulance Training.-Though prevention is better than cure, and though the number of casualties may be reduced, it cannot be expected that mining will ever be quite exempt from them. Provision should therefore be made to render those that do occur as little harmful as possible. The Coal Mines Act of I 887 compels the owners of mines to keep a supply of splints and bandages ready, and many miners have learnt in the school of actual practice how best to assist their injured comrades before the arrival of a doctor. Nowadays the establishment of classes under the St.

John Ambulance Association $\ddagger$ has given the men the opportunity of acquiring systematic instruction in the best methods of ren-

* Report to Her Majesty's Principal Secretary of State for the Home Department by the Quarry Committee of Inquiry, London, 1894, Parliamentary Paper [C. -7237.]

+ Statistique de l'Industrie Minérale et des Appareils à vapeur en France ct en Algérie, pour l'Année I886, Paris, I888, p. 95.

₹ St. John's Gate, Clerkenwell, London, E.C. 
dering first aid to the injured, and of moving them without aggravating the mischief or causing needless pain. Miners all over the world have reason to be grateful to this excellent Society. Fig. 709 illustrates the "Furley" pattern stretcher, as

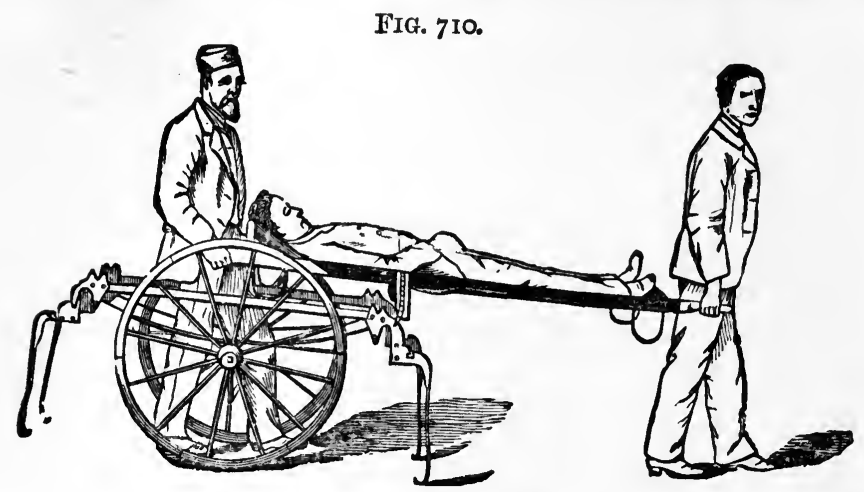

supplied by the St. John Ambulance Association, together with the "Lowmoor Jacket," by means of which an injured person can safely be placed at any angle. Figs. 7 ro and 7 I 1 represent the "Ashford Litter," a two-wheeled carriage for the conveyance of the injured person along roads. The former shows that the

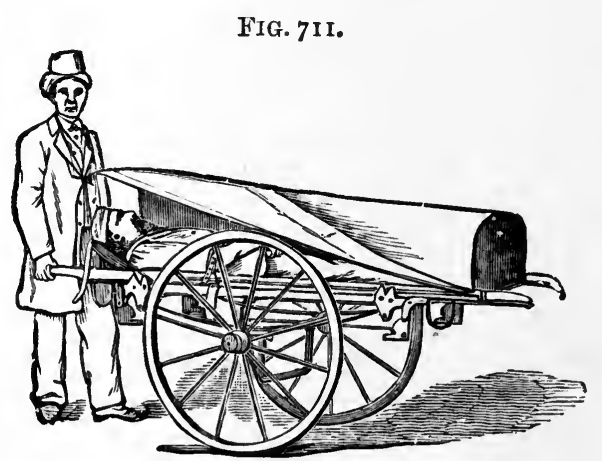

bearers of the stretcher can pass between the wheels, by stepping over a crank axle, and so avoid lifting the heavy weight over the wheels. At large mines there should be a horse ambulance carriage for the removal of sufferers.

Regular ambulance corps have been established at some mines ; probably the largest in the United Kingdom belongs to Colonel Seely's collieries, already notable for the aid given to sports and pastimes. The corps now musters some 400 men, or about one- 
tenth of the total number of employés; the members wear a neat uniform and are regularly drilled. Many others among the workmen, though not belonging to the corps, have received instruction in the ambulance classes. Incalculable good is done by trained men of this kind, who are ready on the spot to render first aid at any moment to an injured comrade and superintend his removal to a hospital; the excellent example thus set might well be followed in all mining districts. 


\section{N D E X.}

\section{$\Delta$}

ABEL and Noble, on fired gunpowder, 209

Aberllefenny, method of working slate at, 314

Abyssinian tube wells, 137

Acacia, 228

Accident club, deduction for, 639, 690

Accidents, carriage of injured persons, 713

classification of, 704

death-rate from, 698

first aid in case of, 712

from explosives, 706

from falls of ground, 704

from underground fires, 708, 709

in boring, 130

in coal mines and in metal mines, 700

in shafts, 705

miscellaneous, underground, 708

non-fatal, 712

on inclined planes, 708

on the surface, 7 II

societies for relief of distress caused by, 69I

statistics of, 698,703

Acme pick, 153

Acts, Alkali, 665

Boiler Explosion, 666

Brine, Pumping, 666

Coal Mines Regulation, 662

Elementary Education, 666

Employers' Liability, 666

Explosives, 666

Factory and Workshop, 667

Metalliferous Mines Regulation, 656

Quarry Fencing, 667

Rating, 655

relating to Derbyshire, 655
Acts-continued.

relating to Forest of Dean, 655

Rivers Pollution Prevention, 667

Slate Mines, 659

Stannaries, 668

Truck, 668

Adelaide drill, 195

Adit, Atlantic-Pacific, 437

Blackett level, Northumberland, 435

Cornwall County, 435

drainage by, 433

Ernst August Stolln, 434

Halkyn tunnel, 435

Kaiser Josef II., Ṕribram, 434

Kaiser Josef Erbstolln, 434

Mansfeld copper mines, 434

Monteponi, Sardinia, 435

Rothschon berger Stolln, 434

Sutro Tunnel, Nevada, 436

working deposit by, 308

Advantages of steel supports for levels, 257

Adventitious finds of valuable minerals, 95

Aërial ropeways, 380 incline, 406

Agglomeration, p*eparation for market by, 565

Air, causes of pollution of, 480

composition of, 475

evil effects of dust in, 685

friction of, 5 Io

measuring velocity of, 506, 507

testivg the quality of, 498

Air-brake for self-acting incline, Bilbao, 376

Air-compressors, 164

Ångström's, 165

Burckhardt and Weiss, 166

dry, I 66

Hanarte's, 165 
Air-cumpressors-continucd. Ingersoll-Sergeant, 167 injection, 166 water-column, 165

Air-current, resistance to, 510-51 2

Air-drying, 592

Air-hose, I7I

Air-lock, 278

Air-mains, 170

Air-pipe for ventilating shallow shafts, 488

Air-reservoir, 168 underground, advantages of, 169

Air-sollar, 486

Air-space required per man, 674,676 Alabaster, occurrence of, in Italy, $5 \mathrm{I}$

Algachi silver mines, cold at, 669

Algeria, discovery of phosphate of lime in, 96

Alkali Acts as affecting mines, 665

Alluvial beds, mode of working, 291 diamond deposits, 39 gold-mining, California, 318 tin ore deposits, 85

method of working, 316

Almaden, mercurial poisoning among miners, 687 mine, 72

Alta, definition of, I I in quicksilver mines, 73

Altenberg, calamine deposit, 19 Saxony, tin stockwork at, 84

Alum-stone, 20

Alunite, 20

Amalgam, retorting of, 598

Amalgamation, 616

Amber, dressing of, 618 liquefaction of, 598 mode of occurrence, 2 I working for, 304

Ambulance corps, 7 13 training, 712

American phosphate kiln, 594 pitch pine, 227 system of boring, I37

Ammonite, 215

Ammeberg, Sweden, beds of zinc blende at, 87

Amorpha canescens, IO4

Amygdaloid, copper-bearing, of Lake Superior, 35

Anaconda Mine, Montana, 37 gozzan, 102

Ardreasberg, St., man engine at, 535

$\Lambda$ nemometers, 507

Angers, arc-lamp at, 524
Argers-continued.

slate mining, 3 I4

Angle for ladders, 530

Àngström's air-compressor, 165

Animals as indicators, 105

Anomalies in mineral repositories, I7

Anticlinals, 47, 48

Antimony ore, liquation of, 598

mode of occurrence, 21

Antiseptics applied to timber, 230

Anzin collieries, France, shower. baths, $68 \mathrm{I}$ steel frames, 259

Arc-lamp at Angers, 524

Maros-Ujvar, 524

Mechernich, 524

Osceola Co.'s Mine, 525

Rio Tinto, 525

Ardennes; method of mining slate, 314

Arizona, copper in, 37

Armstrong's electric signalling, 533

Arrastra, 556, 618

Arrault, free-falling tools, 129

on boring rods, 125

Arsenic, preparation of, 619 flues, clothing worn when clearing out, 673

Arsenical minerals, effects of inhaling dust from, 686 ores, calcination of, 6I I, 6I3 mode of occurrence, 2 I sores, 686

Arsenious acid, preparation of, 619

Artificial ventilation, 490

Aruba Island, origin of phosphate of lime at, 69

Asbestos, dressing of, 619 mode of occurrence, 2 I

Ascensional theory of formation of mineral veins, I 5

Ascent, 526

Ashburner on the occurrence of natural gas in the United States, 59

Aspen case, 9

Asphaline, 2 I I

Asphalt, dressing of, 6I9

mode of occurrence, 22

rock, preparation for sale, 593

Association of minerals, 97

Atkinson, Messrs. L. \& U., on electric transmission of power, 172

Atlantic Copper Mine, Lake Superior, 37

Atlantic-Yacific Tunnel, 4.37

Atlas powder, 2 I 4

Atmospheric weathering, 6 ro 
Attaching hauling rope to hanger, Otto system, 382

Attachment of rope to bucket, cage, \&c., 402

of waggons to endless rope, 368,379

Anger, I 13

for boring holes for blasting, 154

stem, I39

Australia, candle-holder used in, 515

trees used for mining purposes, 228

Australian puddling machine, 539

Austria, graphite in, 50

slides for descent used in, 527

Automatic dumping cage, 419

skip, 4I 2

stopping gear to prevent overwinding, 424

water tank, Bowden's, 440

Galloway's, 438

Axles, attachment of, 357

lubrication of, $35^{8}$

\section{B}

BACK of lode, 106

Backstay, 366, 396

Bagnall's sleeper, 352

Bainbridge, Emerson, on mincrs' cottages, 677

on steel beams, 256

Baird's machine, 204

Baku, occurrence of petroleum at, 65

Ballarat " indicators," I3, I6

Ball-grinders, 557

Ball-Norton magnetic separator, 603,606

Ball stamp, 55I

Band-wheel, 138

Banket, or auriferous conglomerate, 4I

Barber, mine, 639

Barracks for workmen, Kimberley

Diamond Mines, 676

Mansfeld, 674

Mechernich, 674

North Wales, 676

Barrow drill, I 83

Barytes, 23

bleaching of, 609

dressing of, 619

vein in Shropshire, 13

Datea, 539

Bath, workings for freestonc, 3 ro
Bath-stone, 4 I

Bavaria, graphite in, 50

Baxter's stone breaker, 547

Bearer, 237

Beaumont's tunnelling machine, 206

Becker on inflammable gas in quicksilver mines, 478

on the Comstock lode, 76

on the interstitial space in sandstone, 18

on the quicksilver deposits of California, 71, 73

on the quicksilver deposits of the Pacific slope, 16

Bed of pyrites at Rammelsberg

Mine, Hartz, 32

Bed-planks, 405

Bed-rock, 318

Beds, 5

crumpling of, 88

faults and irregularities in, 88

occurrence of zinc-blende in, 87

recovery of faulted portion, 89

temporary pillars, 315

worked with permanent pillars, 309

Bedson on the fumes produced by roburite and tonite, $48 \mathrm{r}$

Bell.box, I3I

Bellite, 2 I 5

Bellom on loss in dressing, 630

Bell pits, Roumania, 3 I I

Belt, Brunton's endless, $5^{85}$

Stein's endless, 586

Belts, picking, 542

Benching, 3 I I

Bendigo gold-field, 47

Benzine, in preparation of ozokerite, 609

Bertrand Mill, work by rolls at, 556

Bex, Switzerland, blower of marsh gas, 478

use of bosseyeuse, 224

workings for salt, 307

Bilbao, iron ores of, 102

Biram's anemometer, 507

Bischoff, Mount, dressing tin ore at, 630

Bishop's head, 457

Bismuth ore, magnetic separator used in dressing of, 606

Bit for boring by hand, 157,158

Bits for machine drills, I8I

Bituminous limestone, preparation of, 598

Val de 'Travers, 22

iandstone in California, 22 treatment of, 619 
Biwabik iron mines, discovery of, 94

Blackett level, Northumberland, 435

Blackley, Rev. Canon, on old age pensions, 694

Blake's stone-breaker, 546

Blanchet, pneumatic hoisting apparatus, 427

Blanzy, boring ram at, 187

Blast, large, 290, 29I

Blasting, accidents from, 706 explosives used for, 209 gases produced by, $48 \mathrm{I}$ gelatine, 2 I4

Knox system, 162

laying dust produced by, 685

oil, 2 I2

safety fuse for, 217

tools for charging holes for, 160 under water, fuses for, 217

with gunpowder, 217

with nitro-compounds, 2I 8

Bleaching barytes, 609

Blende, dressing of, 625,630

occurrence of, 85

separation of, from iron pyrites, 607

Blondin for raising stone from quarries, 405

Blount on liquid carbonic acid in minerals, 476

Blue-ground, 38

method of working, De Beers mine, 34I

Bluestone of Anglesey, 33

Boats, conveyance by, 372

liochkoltz regenerator, 459

Bohemia, dressing of graphite in, 623

Boiler Explosion Acts, 666 explosions, 7 I I

Bolsover collieries, miner's cottage, 677

Bonanza, definition of, I I

Booming, 293

Boots, 672 worn by rockmen, Festiniog, 673

Borax, 23

lake, California, 23

preparation of, 608

treatment of, in California, 620

Bord, 3 I 5

Bore-holes, conveying water to bottom of, 187

deviation of, 148

extrastion of minerals by, 304

for extracting salt, Middlesbrough, 305
Bore-holes-continued.

lining for, $13 \mathrm{I}, 140$

remedying deviation of, 130

removal of debris from, 118,128 , 141

surveying, 147

triangular, 159

uses of, I 13

Borers, 157

Boric acid, mode of occurrence, 25 preparation of, 620

Boring, accidents to rods, \&c., I 30 ascertaining dip and strike of strata, 132

at Port Clarence, 137, 142

by American system, cost of 142

by percussion with rods, 124

with rope, 137

by rotation, 113

crown, Docwra's diamond setting for, 118

double-handed, 158

free-falling tools, Arrault, 129 Kind, 130

hand-power diamond drills for, 123

hand tools for, I 54

head, Mather's, I45

holes for blasting, prevention of dust, 685

holes of elongated section, 162

Mather and Platt's system, 142 method of sinking shafts, 27 I

Oeynhausen's sliding joint, 128

pits for wire saw, 205

portable set of tools for handpower, II 7

process of, 128

ram or bosseyeuse, I 86

rods, iron, 125

single-handed, $15^{8}$

tools, 127

with diamond drill, cost of, 122

with the diamond drill, I 18

with wooden rods, 134 cost of, 136 speed of, 136

Boryslaw, dressing of ozokerite at, 626

mode of occurrence of ozokerite at, 64

safety gear for hauling men, 531

sinking shafts with windlass, 388

steel rings for supporting shaft linings, 265

Eo :seyeuse, 186 
Bosseycuse-continued.

used for cutting groove, 224

Bower's coal.cutting machine, 206

Bowie, Hydraulic Mining, 293

Bowk, 408

Brain's high tension fuse, 220

Brandt's drill, 178

Brattice, 487

Breaker, Baxter's stone, 547

Blake's stone, 546

Gates' stone, 560

Hall's stone, 547

Lester's stone, 547

Marsden's stone, 547

Dreaking ground, $15 \mathrm{I}$

machines, uses of, 564

up minerals, 542

use of holes for, 207

Breast boards, 236

Brick linings for levels, $25 \mathrm{I}$ for shafts, 252, 267

Bridge-rails converted into sleepers, 353

Bridgman's ore-sampler, 635

Brine, eraporation of, 609 Pumping Act, 666 wells, 306

Briscale (Sicily), 102

Broach, 20I

Broken Hill mines, 78

cost of boring by the diamond drill at, 122

discovery of, 96

lead poisoning among miners, 687

outcrop of lode, 98

square set timbering, 249

Brough, on concrete livings for shafts, 254

on searching for iron ore with the magnetic needle, I 12

Brown coal bed at Brühl, 5

Bruccioni, Ioo

Brückner furnace, 6 I3

Brühl, bed of brown coal at, 5

Brunton's endless belt, 585

furnace, 596,613

sampling machine, 635

tunneller, 206

Buchanan, magnetic separator, 604

Bucket of lifting pump, 448

Buckets, for descent and ascent, 531

for hoisting, 404

Bucking, 545

Buddles, 587

Bulkhead (hydraulic mining) 295

Bull, i $5^{8}$
Bullahdelah Mountain, N.S.W., alunite at, 20

Bull engine, 443

Bullion mine, heat at, 670

Bullock Manufacturing Co., diamond drills, I I 9

Bull-wheel, I 39

Bunch of ore, definition of, I I

Bunning, 330

Buntons, 237

Burckhardt and Weiss air-compressor, I66

Burmah, oil-fields of, 65,66

working without light in, $5^{1} 3$

Butterfly valve, 453

\section{C}

C $\Delta \mathrm{E}$ Coch Mine, Carnarvonshire, 309 mode of working, 309

occurrence of pyrites, 83

pumping with compressed air, $47 \mathrm{I}$

Cage, advantages of winding men in, 688

Carn Brea mine, 533

Comstock lode, 4 I8

for descent and ascent, 532

Junge hohe Birke mine, 533

relf-dumping, 4I9

Calamine deposit, Altenberg, 19, 87 pansy, I04

roasting at Monteponi, 6I 5

Calcarone, for sulphur rock, 599

Calcination of arsenic ores, $61 \mathrm{I}, 6 \mathrm{I} 3$ clay ironstone, $6 \mathrm{I} \mathrm{I}, 6 \mathrm{I} 2$

copper ores, 612, 613

gypsum, 6I I, 6I3

limestone, 6I I, 6I3

ores, objects of, 6 I I

tin ores, 612,613

zinc ores, 612,615

Caliche, 62

mode of working, 296

preparation of, 608

California, bituminous sandstone of, 22

borax deposits of, 23

drift mining, 318

gold in, 45

hydraulic mining in, 302

quicksilver deposits of, 73

treatment of borax, 620

and Consolidated mines, heat at, 670

Callon on working salt marls of

the Salzkammergut, 307

Calumet and Hecla Mine, 36 
Calumet and Hecla mine-continued. fire at, 709 shaft timbering, 240 stamps at, 553

Canada, asbestos in, 2 r nickel ore in, $6 \mathrm{I}$

Canadian system of boring, 134

Cancer of lungs among miners, 685

Candle holders, 514, 515 used for testing quality of air, 501

Candles, sperm and composite, $5^{14}$ tallow, 513

Canton Mine, lode at, 8

Cap, in timbering, 232

on flame of alcohol lamp, 500

benzine lamp, 499

hydrogen lamp, 500 safety lamp, 499

Capell fan, 495

Capping ropes, 402

Capstan for hoisting, 388

for pumping machinery, $46 \mathrm{I}$

Caratal gold-field, 44

gold diggings, birds at, 105

Cart olineum, 23I

Carbonas, 84

Carbonic acid gas cunveyed by pipes, 374

mode of occurrence, 25

in air, an index of its impurity, 480

in the air of mines, 475,501

liquefaction of, 600 preparation of, 620 testing for, 501

Cariboo, timbering levels, 233

Carnallite, occurrence of, 70

Carn Brea Mine, winding men, 533

Carne, J., definition of a mineral vein, 6

Carrett and Marshall's machine, 199

Carriage of injured persons, 713 minerals by persons, 349,375

Carrière, definition of, I

Carr's disintegrators, 559

Cars, 355

Cartridges, hydraulic, 208 lime, 208

Cartridge-stick, I6 I

Casing boards, 238

Cassiterite, minerals associated with, 97

Jast-iron columns used at Halkyn tunnel, 255

lining for soft strata, 268

lining for tunnels, 263

props, 265

tubbing, 269
Catches, 460

Cementation, 6 I 6

Cement works affected by Alkali Acts, 665

Centrifugal concentrator, 591 grinders, $56 \mathrm{I}$

Ceylon, dressing of graphite in, 623 graphite in, 50

Chains, 401

Chamberlain, Mr. Joseph, on State pensions, 694

Chance discoveries of mineral deposits, 93

Changing house, 679

Channelling machines, 201

Chapeau en fer, or gozzan, Ioo

Chapin iron mine, Michigan, 54

Charging-spoon, I6I

Chase, magnetic separator, 601

Chateaugay Co., dressing magnetite, 624

Cheeks or walls of a lode, definition of, 10

Chert, dressing of, 622

Cheshire mines, preparation of salt, 628

jumper used at, 157

salt mines, 3 I I

salt wells, 306

Chesneau on testing for firedamp, 500

Chilian mill, 557

Chilled cast-iron shot, use of, for boring, 124

wheels, 357

Chimney built over shaft for ventilating, 484

China-clay, 27

discovery of, 99

dressing of, 620

drying of, 592

workings in Cornwall, 292

Chlorate mixtures, 211

Chocks or cribs, 245

Chollar-Potosi mine, heat at, 670

Chromic iron in New Caledonia, 28

Churns, Forest of Dean, 340

Churprinz mine, Freiberg, spherical dam at, 432

works, loss at, $63 \mathrm{I}$

Chute of ore, I I

Cinnabar, occurrence of, $7 \mathrm{I}$

Circular saw groove-cutters, 202 used for slate, 564

Clack, 448, 453 -piece, 448 seat piece, 448

Clanny lamp. 519

Clarkson's rapid sampler, 634 
Clarkson-Stanfield concentrator, 591

Classification of dressing processes, 538

mineral deposits, 5

rocks, 3,4

Clay, 26

Claỵing bar, I6I

Clay ironstone, calcination of, 6II, 612

weathering of, $61 \mathrm{I}$

Clays, dressing of, 620

Ciay-slant, 222

Cleaning-up. hydraulic mining, 299

Clearage of slate, 81

Cleveland, discovery of salt bed at, 96

district, royalties in, 654

iron-mines, jumper used at, 157

ironstone, method of working, 3 I 5

mode of occurrence of, 5 I53

Sorby on the origin of, I 8

Clevis, 402

Clifton, tests of light given by Clanny lamp, 520

Davy lamp, 519

Climax drill, I85

Clinograph, Macgeorge's, 147

Clinostat or dip-recorder, 147

Clogs, 672, 673

Clothing for men engaged near machinery, 673

of miner, 669

worn when cleaning arsenic flues, 673

Clowes hydrogen lamp, 500

Club, deductions for accident, 639

Coal, discovery of, in south-east of England, 97

Coal Mines Regulation Act, 662 accident statistics under, 700 tools for charging holes, I6I

Cobalt mines, Saxony, cancer of lungs among miners, 686

ore in Flintshire, discovery of, 93

New Caledonia, 28

Rhyl, Flintshire, 28

Skutterud, Norway, 27

Cobbing, 544

Coffering, 267

Cold at mines, 669

Colle Croce mines, Lercara, Sicily, thick sulphur seam, 32 I

Collieries affected by Alkali Acts, 665
Collins on the china clay of Cornwall, 27

on the Great Mother Lode of California, 46

on the ores of Rio Tinto, 33

on the pyrites deposits of Huelva, 32

Collom jigs, 621

Colorado, lead ores of, 57

lease system, 647

sampling machines used in, 634

tribute system in, 647

Colorados, I00

Colour as an aid to the prospector, 99

Comparative mortality figures, $68_{3}$, 684

Compound for native miners, Kim. berley, 677

engines for pumping, 443

Compressed air cartridge, 208

locomotives, 363

loss of power from ase of, 164

pipes, I70

fumping with, 470,471

reservoir 169

sinking by aid of, 277

stamps, 55I

use for ventilating workings, 493

Compressors, air, 164

Comstock lode, description of, 76

discovery of, 95

gases met with, 476

gozzan, Ioo

heat on the, 670

influence of heat on health, 689

lifting pump used on, 449

shaft timbering, 238

square-set system of timbering, 246

timbering for levels, 233

Concentrator, centrifugal, 59I

Clarkson and Stanfield, 59I

Embrey, 586

Woodbury, 586

Concrete blocks, 253

used for lining levels, 251 shafts, 253

Condition of miner, 669

Congenial beds, 13

Conglomerate, copper-bearing, 35

Conical grinders, 560

Conkling magnetic separator, 6or

Convolvulus althæoides, 104

Cook's Kitchen mine, heat at, 670

Co-operative pumping, 474

societies, 695 
Copper at Lake Superior, 34

extraction of, in solution, 307

precipitation of, 616

mines affected by Alkali Acts, 665

ore, discovery of on Yorke's peninsula; 93

calcination of, 612,613

dressing of, $62 \mathrm{r}$

in Germany, 29

in Spain and Portugal, 3r, 34

in the United States, 34, 37 occurrence of, 28

separation from tin ore, 609

Cores, ascertaining dip from, I32

cutting out, 133

extractor, II9

Arrault's, I 32

Bullock's improved, 121

modes of obtaining, 132

obtained by boring with flat rope, 147

produced in boring pits, 205

tube for diamond drill, 119

Corf, derivation of term, 405

Cornish "dry" for china cay, 592

miner's boot, 672

hat, $67 \mathrm{I}$

pumping engine, 443

rolls, 553

Cornwall, annual death-rate of miners, 684

county adit, 308

dressing of tin ore in, 629

gozzans, 102

mode of occurrence of tin in, $7,19,84$

royalties in, 654

tin lodes of, 7

Corrosive water, pumps for, 450 valves for, 453

Cost of aërial ropeway, 385

antiseptic treatment of timber, $23 \mathrm{I}$

barracks for workmen, 676

coffering shaft, 268

co-operative pumping, 474

cottages, 677

driving level at Bex, 224

electric haulage, 372

lodgings, \&c., for workmen, Eisleben, 676

sinking through watery strata, 271

steel supports for levels, 256, 257

transport by aërial ropeway, 386
Cost of-continued.

working Dolcoath man-engine, 535

working gold-bearing gravel, California, 320

Counterbalancing weight of pumprods, 457

rope in winding, 393

Counterpoise for rods, variable, 460

Country, definition of term, Io

influence of, on lode, I2

County adit, Cornwall, 435

Course of ore, definition of, I I

Cox, S. H., on an alunite deposit in N.S.W., 20

on the colour of vegetation, 104

Creep, 309

Crib, or curb, 252

Cross-course, or fault, 91

Crow's-foot, $\mathrm{s} 30$

Crump and Brereton's machine, 202

Crusher, 546

Cornish, 553

Dodge, 547

Gates, 560

Crushing in of workings, Sicilian sulphur mines, 321

Crystalline schists, 3

Crystallisation, borax, 608

nitrate of soda, 608

potassium salts, 608

magnesium chloride, 609

Cundill, on explosives, 209

Curb, cast-iron, 267, 270

Cuvelier's lock for safety lamps, 522

Cyclone pulveriser, 563

\section{D}

DAM, temporary, 433

Dams, masonry, 433

spherical wooden, $43 \mathrm{I}$

wooden, 430

Darkness, working in, $5 \mathrm{I} 3$

Darley, on boring by rotation, II 7

Darlington drill, 195

Daubrée on the artificial formation of minerals, 17

Dauntless diamond drill, I 19

Davey's differential pumping engine, 445,466

Davis' self-tining anemometer, 507

Davy lamp, 6r9

Day Dawn mine, pigsty timbering, 245 
Day Dawn mine-continued. shaft timbering, 239 timbering, 234

Day-level, 433

Daylight, working by reflected, in California and Japan, 513

Death-rate of miners from accidents, 698

Dcath-rates, annual, for various trades, 684

De Beers diamond mine, 38 endless rope haulage at surface, 376

head-gears, 397

method of working, 34r

self-discharging sikips, 412, 4 I 5

washing machine, 540

Deep leads of Australia, 85

Deflection magnetic separator, 606

Deposition from solution, formation of veins by, 14

Derbyshire, Mining Acts relating to, 655

Derrick for boring by percussion with rods, 125,136

by rotation, 117

with rope, 137

Descent and ascent of miners, 526

Desiccation in dressing, 592

Detaching hooks, 422

Detonators, 2 I 6 strength of, 2 r 9

Devonshire, dressing of clay, 620 manganese ore, 625 umber, 626

Diamond, substitutes for, for drilling, 124

Diamond-bearing rock, De Beers, dressing of, 621

method of working, 34 I

weathering of, 610

Diamond, discovery of, in South Africa, 93

occurrence of, 37

washing machine for, 539

Diamond drill, American Diamond Rock Boring Company's, I 2 I boring at Johannesburg, I 19 Northampton, 118

boring with the, II 8

Bullock Manufacturing Company's, II9, I 23

core extractor, II9

Bullock's improved, I 2 I

cost of boring by, 122

crown, 118

“Dauntless," I 99

differential feed gear, I 19
Diamond drill-continued.

for boring holes for blasting, 179, 180

Georgi's electric, 124

Little Champion, 123

prospecting, 123

sediment tube for, 119

Sullivan's prospecting, 124

Swedish for hand-power, 123

thrust register, I 21

Victorian "Giant Drill," 12 I

Dickinson's anemometer, 507

water-gauge, 509

Diepenlinchen, pumping engine at, 445

working zinc ore at, 345

zinc ore stockwork, 87

Diffusion of gases, 485

Dig, definition of, I I

Ding Dong mine, fire-damp in level at, 477

Dip, definition, 5

influence of change of on veins, 13

Dipping needle, II I

Discovery of minerals, 93

Diseases caused by arsenical minerals, 687

inhalation of dust, 685

ladder climbing, 688

lead ores, 687

quicksilver ores, 687

Disintegrators, 559

Distillation, of rich sulphur rock, 600 use in dressing, 600 .

Dividings, 237

Divining rod, II I

Doctor, deduction for, 639

Docwra, diamond setting for boring crown, ir 8

Dodge Crusher, 547

Dolcoath Mine, Cornwall, 328, 329.

man-engine, cost of working, 535

heat at, 670

Dolly, or swage, I8r

Dolly tub, or keeve, 570

Dorothea mine, Clausthal, underground traffic by boats, 373

Double-beat valve, 454

Douglas spruce, 228

Downcast shaft, $4 \mathrm{~S}_{4}$

Downthrow, 9I

Dowsing rod, I I I

Drainage, 429

by adit, 433

by pumps, $44 \mathrm{I}$

by siphon, 437

by winding machinery: 437 
Drawing lift, 449

Dredges, 175

grab, 176

Kincaid \& McQueen's, 175

Priestman's grab, 176

suction, 177

Dressing, definition of, 537

amver, 6I 8

arsenic ore, 619

asbestos, 619

asphalt, 619

barytes, 619

bituminous rock, 598, 619

blende, 625,630

borax, 620

boric acid, 620

carbonic acid, 620

chert, 622

china clay, 620

clays, 620

copper ore, 621

diamond-bearing rock, $62 \mathrm{I}$

flint, 622, 629

fuller's earth, 620

galena, 624,625

gold ore, 622

graphite, 623

gypsum, 624

hæmatite, 624

iron ore, 624

lead ore, 624

loss in, 630

magnetite (see magnetic separators), 624

manganese ore, 625

mica, 625

mispickel, 6I I, 6I 2, 613, 619

ochre, 626

ozokerite, 626

phosphate of lime, 626,627

potassium salts, 627

quicksilver ore, 627

salt, 628

silver ore, 628

slate, 628

stone, 628

sulphur rock, 629

Trinidad pitch, 619

tin ore, 629

umber, 626

zinc ore, 625,630

Drill, ratchet, 155

Drilling rig, 138 tools, 139

Drills, Adelaide, 195 automatic rotation of, 194

Barrow, 183

Brandt's, 178

classification of, 183
Drills-continued.

Climax, 185

Darlington, 195

diamond, 179

Eclipse, 187, I88

electric percussion, 198

Elliott. 154, 155

for boring by hand, 157

Franke, 189

Hirnant, 192

Ingersoll-Sergeant, 193

Jarolimek, 179

Marvin, 198

Optimus, I 89

percussive, I8 $\mathrm{r}$

rotary, 177

Sergeant, 193

sharpening, 158, 182

Steavenson, 180

steel for, 182

Drive-pipe, I40

Driving levels, 221

tunnels in soft ground, 263

Drums for winding, 39I

wil h reserve of rope, 392

Dry compressors, 166

for China clay, 592

or changing house, 679

rot, prevention of, 230

Drying of minerals, 592

Dubois and François air-compressor, 166

boring-ram, 186

Duck machine, 493

Ducktown mine, Tennessee, 108

blower of sulphuretted hydrogen, 479

Dudley, workings for limestone, 3 I I

Dumb fault, 87

Dunbar and Puston's steam navvy, 173

Dust in mines, evil effects on health, 685

in air of mines, 482

Duty of the miner's inch, 301

of pumping-engines, 472

Dykes, definition of, 14

Dynamite, 213

danger from exudation, 213

pan for thawing when frozen, 2 I3

$\mathbf{E}$

EAdie \& Sons', joint for lap-welded

pipes, $17 \mathrm{I}$

Eclipse drill, IsS 


\section{INDEX.}

Edge-runners, 556

Edison's deflection magnetic separator, 606

second magnetic separator, 602

Education Acts, Elementary, 666 general and technical, 682

Efficiency of ventilating appliances, 509

Eikleben, barracks for workmen, 674

Electric drill, Marvin, 198

Steavenson, I80

lamp, Sussmann, 523

light, 524

percussion drill, 198

railways, $37 \mathrm{I}$

Llectricity, firing by, 220

pumps worked by, 470

transmission of power by, 172

Elementary Education Acts, 666

Elephant stamps, 55I

Elliot's locked coil wire rope, 400

Elliott drill, I 55

multiple wedge, 208

Elwen on the resistance to aircurrents, 5 II

Embrey concentrator, 586

Emmons, S. T., on the geology of the Leadville district, 57

on the veins in the Rocky Mountain region, 7

Employers' Liability Act, 666

Eins, loss in dressing at, 631

End, ventilation of an, $485,487,492$, 493

going into, after blasting, 686

Endless chain system of haulage, 371

rope system of haulage, 367

advantages of, 369

attachment of waggons to 368,379

De Beers mine, 378

End-piece, 237

Equilibrium pipe, 274

Erigonum ovalifolium, 104

Ernst August Stolln, 434

Eucalyptus, species used for mining purposes, 229

Eureka, Nevada, silver-lead deposits of, 77

square-set timbering, 247

Europe, trees used for mining purposes, 227

Eustice, changing house at Levant Mine, Cornwall, 679

Evans and Veitch, pump for raising water by compressed air, 471

Evaporation of brine, 609
Excavating by water, 226 machinery, 173

Excavation of minerals underground, 308

under water, 302

Excavations, supporting, 227

Exploitation, 285

Explosions of fire-damp, 476,477

Explosives, accidents from, 707 strength of, 216

used in mining, 209

Explosives Act, 666

Extraction of minerals by wells and boreholes, 304

\section{$\mathbf{F}$}

FACTORY and Workshop Acts, 667

Fahlbands at Kongsberg, Norway, 12

Falls of ground, accidents from, 7C4

Falun, torches used at, 515

Fans, Capell, 495

efficiency of, 509

Guibal, 496

Schiele, 497

use of, in dressing, 590

Waddle, 497

Faults, 87

length of, 90

measurement of throw of, 89

recovery of lost part of bed, 89

recovery of lost part of lode or vein, 9 r

reversed, 90

variations of throw along the strike, 90

Feeders or droppers, definition of, 12

Fencing Act, Quarry, 667

Fend-oft bob, 446

Fernow on the trees available for mining purposes in the United States, 228

Festiniog, boot worn by rockman, 673

method of working slate at, $3 \mathbf{1 2}$ preparation of slate at, 628

slate mines, charging spoon used at, I6I

drivages at, 222

jumper used at, 157

tribute system at, 649, $65 \mathrm{I}$

Field, Mr. Justice, on the Richmond

$v$. Eureka case, 8

Filling up, working with complete, $322,331,335,34$ I 343,346

Fir, Scotch, 228 
Fire-clay, 26 weathering of, 6 I I

Fire-damp found in ore mines, 476 testing for, 498-501

Fireless locomotives, 363

Fires, accidents from underground, 708, 709

in sulphur mines, Sicily, 321

Fire-setting, 225

Firing by electricity, 220 explosives, 218

Firth's pick machine, 199

Flare lainp, 516

Flat-rope, winding with the, 393

Flattened strand wire rope, 400

Flint, dressing of, 622 mining at Brandon, Suffolk, 4I

Flints, shaping of, 629

Floating reef in Kimberley diamond mines, $3^{8}$

Flooded workings, breaking into, 707

Flookan, explanation of term, I4

Floor of a bed, definition of, 5 of changing house, 68I

Florida, phosphates of, 69

Flume, 294

Fluted rolls, 556

Foot-wall, definition of, Io

Forest of Dean, method of working hæmatite masses, 340

Mining Acts relating to, 655

Form for pump bucket, 448

Form of the ground indicating deposits, 98

Formation of mineral veins, I4

Formations or classes of lodes, 17

Foxdale lead mine, carbonic acid at, 475

mode of working lode, 335

strike of lode, 14

Frames, 579

for levels, steel, 260

wood, 233

for shafts, 236

France, underground workings for slate, 314

Franke drill, I 89

Franke's mechanical chisel, I99

Free-falling tools, Arrault, I29

Kind, 130

Free-milling ores, Ior

Freestone, $4 \mathrm{I}$

mode of working, 310

Freezing method of sinking shafts, 278

Freiberg, formations of lodes at, I7

French miner's hat, 67 I

Friability, use of in dressing, 607

Friction due to sides of airway, 510
Frongoch jigger, 573 self-discharging skip, $4^{1} 6$ separator, 576

Frozen dynamite, 213

Frue vanner, 585 for gold ores, 622

Fuller's earth, 27 dressing of, 620 kiln, 595

Furnace, Brunton's, 596, 613 roasting, $6 \mathrm{I} \mathrm{I}$ ventilation, 490

Furness district, temporary dam used in, 433

Fuse, electric, 220

for blasting purposes, 217

for simultaneous blasting, 220

\section{G}

GAD, 154

Galena, dressing of, 624,625

Galicia, Canadian system of boring in, 134

ozokerite mines of, 63

Galloway on the fire-damp cap, 499

Galloway's automatic water tank, $43^{8}$

double walling stage, 409

method of guiding kibble, 408

pneumatic water-barrel, 438

steel tram, 359

winding drum, 392

Garfield Mine, California, 79

Garland, 267

Garnier, discovery of nickel ore in New Caledonia, 99

Gas for underground lighting, 522

Gases produced by decomposition of gun-cotton, 215

of nitro-compounds, 212

explosion of gunpowder, 210 blasting, $48 \mathrm{I}$

Gates crusher, 560

Gätzschmann, on animals as indicators, 105

Gearing pump-buckets, 448

Geikie, Sir A., definition of a mineral vein, 6

Gelatine dynamite, 214

Gelignite, 2 I 4

Geology as a guide to minerals, 97

German miner's hat, 672

Germany, amber dredging, 304

carbonic acid gas in, 25

copper deposits of, 29

death-rate from accidents, 699

Law of Insurance, 694

occurrence of zinc ore in, $S 7$ 
Gerolstein, borings for carbonic acid gas at, 25

Giant granite, $5^{8}$ mines, 290 powder, 214

Gillott and Copley's machine, 203

Gill's furnace for sulphur extraction, 600

Githens system of boring, 162

Gobert's modification of Poetsch's freezing process, 283

Gold, amalgamation of, 616 associated minerals, 97

in gozzan, 100

modes of occurrence, $4 \mathrm{I}$

ores, treatment of, 622

Run Ditch and Mining Co., 302 worked in Alps by Romans, b18

Gold-bearing gravel, method of mining in California, 318

prospecting for in Siberıa, 278

working, 293

yield of, 302

Good conduct, premiums for, 652

Gooseneck, 402

Gouge, definition of, I I

Gozzan, 99

at the Anaconda mine, 37 at Rio Tinto, 33

influence of, on value of ore, IOI

Graphite, 50

dressing of, 623 in Bavaria, 607

Gravitation stamps, $54^{8}$

Great Basin, borax deposits of the, 23

Greathead shield, 263

Great Laxey Mine, locomotive, 363 overshot wheel, 442

Great Quartz Vein of California, length of, I I outcrop of, 99

Great Western quicksilver mine, California, 74

outcrop of lode, 98

Greaves' circular slate-dressing machine, 565

Grey box, 229

Griffith, on coffering, 268

Grime's graves or ancient workings for flint, 4I

Grimm, definition of a mineral vein, 6

Grinders, Grusonwerk ball, 557

ball, 557

centrifugal, $56 \mathrm{I}$

ennical, 560

Jordan's, 557

See also under Cnusinens
Grizzly, 299

Groove-cutters, 20I

Groove-cutting machines, 199

Grooves cut by circular saw, 202

travelling rock drill or jumper, 201

made by endless chain with cutters, 204

revolving bar with cutters, 206

wire saw, 204

Grusonwerk ball grinder, 557

Gudgeon, 457

Guibal fan, 496

Gruides for shafts, 408

Guillotine slate-dressing machine, 565

Guinotte, pumping-engines with flywheel, 444

Gun for clearing bore-holes, 160

Gun-cotton, 215

products of decomposition, 212, 215

Gunpowder, 209

charging holes with, 2 I 7

products of explosion of, 210

Gunpowder Act, Slate Mines, 659

Gutta-percha packing for pump, 448

Gympie gold-field, lodes of, 13

Gypsum, 50

calcination of, $6 \mathrm{II}, 6 \mathrm{I} 3$

discovery of, by sub-wealden boring, near Battle, 96

dressing of, 624

occurrence of, 50

quarries, Paris, 309

\section{$\mathbf{H}$}

HAASE process of sinking shafts, $28_{3}$ Habets on annual death-rate from accidents, 699

Hade, definition of, 9

Hæmatite at Iron Mountain, Michigan, 54

deposits of the Ulverston district, 19

dressing of, 624

method of working, 340, 343

searching for by piercing, 106

velns of the Lake District, Kendall on, 7

Haeuser process for sinking in quicksand, 284

Haggie's patent Protector rope, 400

Hake's mouth valve, 453

Hale and Norcross wine, heat at, 670 
Half-monns, $44^{8}$

Halkyn Drainage Tunnel, 223, 435 iron supports, 255

Halkyn Mine, Flintshire, slickenside at, 10

wooden pulley-frame, 395

Hallett, Judge, on the Aspen Case, 9

Hall's stone-breaker, 547

Hammer, of Mansfeld, on lifting beam of pumping et giue, $46 \mathrm{r}$

on the friction of guid-s for pump rods in shaft, 473

Hammers for boring by hand, 159

Hanarte's air-compressor, 165

Hand-barrows, 375

Hand-drilling, I 57, I6o

Hand-picking, $54 \mathrm{I}$

Hand-power diamond drill, 123 rotary drills, 155

Hand-sampling, 632

Hand-sieves, 566

Hand-tools, I 5 I

Hang-fire, 217

Haneing wall, definition of, Io

Haniel and Lueg's keps, 419

Häıting and Hesse, on cancer of lungs caused by dust, 686

Hartz blower, 493

Ernest Augustus adit, 434

foreman's lamp, 516

iron rails uscd as supports, 258

jig, 570

miner's lamp, 515

timbering chamber for waterwheel, 24 I

timbering for shaft, 240

use of water power, 442

Harvey on the occurrence of nitrate of soda in Chili, 62

Hat, Cornish miner's, 671

French miner's, 671

German miner's, 672

jdeal miner's, 672

iı onstone miner's, $67 \mathrm{I}$

Mansfeld miner's, 672

Roumanian miner's, 672

Hatches, 389

IIaulage, 348

electric railways, 37 I

endless chain, $37 \mathrm{I}, 379$

endless rope, 367

horses, 362

locomotive, 363

main and tail rope, 366

single-rope system, 365

IIead-gear, 394
Heat at mines, 670

of mines on Comstock Lode, 76

of workings, influence on bealth, 689

Heated floors, drying on, 592

Heave, 88

of vein sideways caused by slip along line of dip, 9 I

Heavy spar, bleaching of, 609 occurrence, 23

Heights (N. Lanca-hire), 344

Hepplewhite-Gray lamp, 521

Hercules powder, 2I 4

Hesse's method of testing the air, 503,505

Himmelfahrt works, loss at, 630

Hirnant drill, 192

Hirt, on prevention of illness from arsenic, 686

Hitches, I 54, 231

Hockin and Oxland calciner, 613 , 615

Hoffman magnetic separator, 602

Hofmann kiln, 6r 3

Hoisting, 387

Holes, arrangement of, for driving and sinking, 222, 225

Holway Consols mine, explosion of fire-damp, 476

Honigmann, soda locomotive, 364

Hönningen, carbonic acid gas at, 25

Hopper of hydraulic elevator, 300

Hoppet, 408

Horned sets, 233

Horse in lode, definition of, I 1 -whim, 389

Horses, underground haulage by, 362

Hospitals, 695

Hot springs, 476

Hottinguer shaft, Blanchet s pneumatic hoist at, 428

House, changing, 679

Housing of workmen, 673

Howard's steel sleeper, 352

Howell's steel tube prop, 266

H-piece, 45 I

Huanchaca silver mines, 78

Huelva, port of, $3^{80}$

Hund, 351

Hunting ton mill, 56r

Hurricane lamp, 516

Hurry, 344

Husband's stamps, 55 I

Hushing, 106

Hydranlic cartridge, $2 \circ 8$

drill, 180

elevator, 300

lock for safety lamps, 522 
Hydraulic-continued.

mining, 226, 292

power, I 71

for breaking ground, 163

transmission of power, 469

Hydrogen flame used in testing for fire-damp, 500

\section{I}

ICE, 5 I

Iceland, mode of occurrence of sulphur in, 82

Idria, occurrence of quicksilver ore at, 72

treatment of quicksilver ores, 627

Illicit Diamond Act, 677

Incandescent lamps in shaft sinking, 524 portable, 523

Inclination of a level, effect of, on ventilation, 485

of underground road, 355

Incline, natural ventilation of, 486

Inclined planes, accidents on, 708 underground, 362

shafts sunk on lode, 225

Inclines, 308 self-acting, 376

Indications of fire-damp, 498

Indicative plants, 103

Indicator for winding engines, $42 \mathrm{I}$

Indicators at Ballarat, 13,16

Inflammable gas, 59,476

Ingersoll bar-channeller, 201 -Sergeant air-compressor, 167

Injection compressors, 166 of veins, 14

Intersection of veins, II

Inversion of strata, 88

Inverted saddle-reefs of Victoria, 47

Iron and steel supports for levels, 255

shafts, 263

working places, 265

Iron-bark, 229

Iron hat, or gozzan, 100

Iron ladders, 529

Iron mines, Forest of Dean, method of working, 340

N. Lancashire, method of working, 343

Iron ores, dressing of, 624

occurrence of, $5 \mathrm{I}$

Northamptonshire open workings, 286
Iron pump-rods, Shakemantle mine, $46 \mathrm{r}$

Iron pyrites, Carnarvonshire, 83

Iron rails used for supporting roof of level, 256259

Iron rings for supporting shaft linings, 263

Iron rods for boring, 124

Ironstone blows (Australia), 100

Ironstone, methud of working in Cleveland district, 315

miner's cap, 671

Irruptions of water into mines, 707

Irving on the copper veins of Lake Superior, 36

Itabirite, 40

Italy, alabaster in, $5 \mathrm{I}$

asbestos mines of, 21

boric acid in, 25

carbonic acid gas in, 26

marble in, 58

mining law in, 1,2

mode of occurrence of sulphur in, 82,83

\section{$\mathbf{J}$}

JACK, on the Mount Morgan gold deposits, 48

on the outcrop of gold veins in Queensland, 98

Jacobi's stove, 597

Jacométy and Lenicque's separators, 575

table, 583

trommel, 567

Jacotinga, 44

Jad, 3 Io

Jagersfontein diamond mines, 39

Jan Ham's clack, 453

Japan, torches used in, 515

working by reflected daylight in, 5 i 3

Jarolimek's drill, I79

Jarrah, 228

Jars, 140

Jaw-breakers, 546

Jigger, 570

pneumatic, 589

Jiggers, discharge of, 572

Jog, 237

Johannesburg, deep boring at, I 19

gold-bearing rocks of, 42

thickness of beds of auriferous conglomerate 5

Joint for wooden rods. 445

Jordan's grinder, 557 
Jumper, 157

Junge hohe Birke mine, cage at, 533

\section{$\mathbf{K}$}

KAINITE, occurrence of, 70

Kaiser Josef Erbstolln, Hungary, 434

Kaiser Josef II. adit, Príibram, 434

Kauri gum, searching for by piercing, 106 pine, 229

Keeve, or dolly-tub, 570

Kendall on the geology of the Cleveland district, $4 \mathbf{I}$

on the hæmatite veins of the Lake District, 7

Kennedy on the efficiency of compressed air, 164

Keps, 419

Kessler, magnetic separator, 602

Kibble, 404

Kieselguhr, 2I 3

Kiln, American phosphate, 594

fuller's earth, 595

Hofmann, 6i 3

Kilns for drying, 594

Kimberley diamond district, 37 mines, compound for native workmen, 677

method of working at De Beers, $34 \mathrm{I}$

Kincaid and McQueen's bucket dredger, 175

Kind, free-falling tool for boring, 130

-Chaudron process of sinking shafts, 27 I

recent modifications, 276

King and Humble's detaching hook, 422

King,on the "indicators" at Ballarat, 13

on the Comstock Lode, 76

King-post, 457

King's magnetic separator, 604, 606

Kitto, Paul and Nancarrow, selfdischarging skip, 4 I6

Knots in the lead-bearing sandstone at Mechernich, 55

Knox system of boring holes for rending stone, 162

of charging holes, 220

Kongsberg silver mine, fire-setting, 225

silver veins of, $\mathrm{I} 2$

Korca, fire-setting in, 225
Kreischer and Winkler on the appearance of the fire-damp cap, 499

Krom rolls, 554

Krom's stove, 595

I

LABOUR, principles of employment of mining, 637

Ladder-climbing, diseases caused by excessive, 688

Ladders, 527 iron, 529

Lagging, 233

Laidler's sector wire rope, $40 \mathrm{I}$

Lake Superior, copper-bearing district of, 34

iron ores of, 54

mines, stamps used at, 55 I, 553

treatment of copper ore at, 621

La Louvière mine, Belgium, 467

Lamm and Franck's fireless locomotive, 363

Lamp, electric, 523

flare, 516

Hartz foreman's, 516

Hartz miner's, 5 I 5

Hurricane, 516

magnesium ribbon, 517

Mansfeld, 516

safety, 518

Saxon miner's, 516

Scotch, 516

Sicilian, 515

United States, 516

Lander, 4 ro

Lang's wire rope, 400

Larch for timbering excavations, 227

Lashings, 237

Latch and Batchelor's flattened strand wire rope, 400

Lateral secretion theory of formation of mineral veins, I5

Laths, 243

Lawn, on searching for hæmatite in the Furness district, 106 on working hæmatite in North Lancashire, 343

Laxey mine, locomotive at, 363 man-engine at, 535

strike of lode at, I4

Lead lode at Wheal Mary Ann, 6

ores, dressing of, 624

modes of occurrence, 55

state of in gozzan, IOI

plant, 104

poisoning, 687 prevention of, 687

rivet for safety lamps, 522 
Lead-bearing sandstone, Mechernich, 18

Lead, mode of working, 320

Leadville, Colorado, mode of occurrence of lead ores at, 55,57

Lease system in Colorado, 647

Leather packing for pumps, 448

Leats, 293

Leavitt stamp, 553

Legal definition of the term lode, 8

Legislation affecting mines and quarries, 653

Leg, or side-prop, 232

Legrand's steel sleeper, 352

Lenneschiefer, Lüderich mine, 85

Lesley on the composition of natural gas, 59

Lester's stone-breaker, 547

Levant Mine, changing house at, 679

Level, natural ventilation of end of, 485

use of air-sollar in ventilating end, 487

Levels, driving, 222

iron and steel supports for, 255263

lined with masonry, 250

methods of timbering, 232

ventilating lower, 489

Iiability Act, Employers', 666

Lid, 244

Liévin Company, shaft sunk by, 277

Lifts (Cleveland), 316

Lighting workings, 513

Lime cartridge, 208

Limestone, bituminous, Val de Travers, 22

burning of, 6 I 1,613

Lime-water test for the air of mines, 502,503

Lindemann's apparatus, 506

Lining boards, 445

bore-holes, I3I

tube, boring by revolving the, I 17

tube for brine well, 305

Linkenbach, stationary table of, 58I

Liquefaction of carbonic acid, 600 use of, in dressing, 597

Listings, 237

Lithofracteur, 214

Liveing's indicator for fire-damp, 500

Llanbradach Colliery, automatic water-tank at, 437 sinking arrangements at, 408 steel trams at, 359

Loading kibble, 405 skip in shaft, $410,4^{12}$
Loaming (Australia), 106

Lochs, definition of, 6

Locked coil wire rope, 382,400 socket for, 403

Lockhart's gem separator, 577

Locks for safety lamps, 522

Locomotives for underground use, 363

for use at the surface, 378

Lode at Wheal Mary Ann, 6

definitions of, 5,6

legal definition of, 9

modes of working, 325,340

narrow, mode of workivg, 330

wide, with weak sides, mode of working, '33I

worked away in slices parallul to dip, 335

Lode-lights, 107

Lodes, conditions affecting productiveness of, I I

length of, along strike, II

formed by alteration of the enclosing rock, 7

wide, worked with pillars and chambers, 338

Lofting, 256

Longwall workings for copper-shale at Mansfeld, 322

Loose ground, supporting excavations in, 242

timbering levels in, 236

Lorraine, iron ores of, 53

Loss in dressing at Churprinz works, 631

at $\mathrm{Kms}, 63 \mathrm{I}$

at Himmelfa hrt works, 630

at Pestarena, 631

cause of, 630

slate, $63 \mathrm{I}$

Lovett-Finney magnetic separator, 603

Lowmoor jacket, 713

Lubrication of mine waggons, 358

Lüderich zinc mine, 85

Lunge's apparatus for testing the air of mines, 503, 505

MACGEORGE on deviation of boreholes, 148

Machine drills, $18 \mathrm{r}$ sieves, 566

Machinery, accidents from, 7 II clothing for men engaged near, 673

Magnesium riblon lamp, 517 
M ıgnetic lock for safety lamps, 522 separation, 600

bismuth ore with magnetite, 606

Namaqua Copper Co., 606

objects of, 600

Queensland, 606

serarators, 600

Ball-Norton, 603,606

Buchanan, 604

Chase, 601

Conkling, 6or

Edison, deflection, 606 second, 602

Hoffman, 602

Kessler, 602

King, 604, 606

Lovett-Finney, 603

Wenström, 605

Magnetite, dressing of, 600 jigging, 624

Main and tail rope system of haul. age, 366

Majoluue, Colonel, on the effect of oil on safety fuse, 217

Malay Peninsula, tin-bearing alluvia of, 85

Mallard and Le Chatelier on testing for fire-damp, 500

Mallet, or sledge, I 54, I 59

Man-engine, 534 accidents on, 705

Manganese ore, dressing of, 625 occurrence of, 57

Man-feld copper-mines, 29 adit at, 434

barracks for workmen, 674

compound pumping engine,

Ernst IV. shaft, 443

compound pumping engine, Otto IV. shaft, 444

cross-cut lined with concrete, $25 \mathrm{I}$

descent and ascent of men, 532 employés living in own houses, 679

hydraulic counterpoise to pump rods, 458

lamp used at, 516

man-engine at, 536

method of working coppershale, 322, 325

miner's hat, 672

pick used at, 153

Rittinger pump at, 456

thickness of bed of coppershale, 5

treatment of copper ore at, $62 \mathrm{I}$
Mansfeld copper-mines-continuerl. underground air reservoirs at, 169

underground pumping engines at, 467

Marble, 58

Maros-Ujvar, arc-lamp at, 524

Marsant lamp, 52I

Marsden's pulveriser, 547 stone-breaker. 547

Marshall, discovery of gold in

California by, 94

Marsh gas, found in mines, 476

Marston Hall mine, 3 I I

Marvin drill, 198

Masonry, for lining levels, 249 shafts, 252

dam in shafts, 433

Masses, or non-tabular deposits of minerals, 18

methods of working, 340

Matai wood, 229

Mather and Platt's system of boring, 142

Mathet, joint for air-mains, 170

Matrix, definition of, II

Maul, I4I

Measure, pasment by, $638,639,640$ and time, payment by, 64I

Measuring the quantity and pressure of air in mines, 506, 512 staff, 231

Meat earth, 286

Mechanical picks, 199 processes of dressing, 538 ventilation, 49I

Mechernich, arc-lamp at, 524 barracks for miners, 674 dressing lead ore at, 625 friability of ore, 607 jumper used at, 157 lead-bearing sandstone of, 5, 55

method of working lead-bearir $g$ sandstone, 320

opencast, 289

pumping engines at, 467

siphon separator used at, 579

Medical attendance, deduction fur, 639

Medium fan, 498

Mercurial polsoning, symptoms of, 688

vapour in quicksilver mines, 480

Métales frios, or unchanged sulphides, Ior

Metallic supports for excavations, 255 
Metalliferous Mines Regulation Acts, 656 accident statistics, 700, 701

Mica, dressing of, 625 mode of occurrence of, 58

Middlesbrough, extraction of salt by bore-holes, 305 marsh-gas with brine, 476

Mill, Chilian, 557

Huntington, $56 \mathrm{I}$

Sturtevant, 563

Close lead mine, Derbyshire, explosion of fire-damp, 476

Mills for grinding, 556

or passes, 330

Mine, atmosphere of, 475 definition of, I derivation of word, $\mathbf{I}$

Miner, clothing of, 669 condition of, 669 regulations for benefit of, 655

Minera zinc mine, Wrexham, 86

Mineral deposits, classification of, 3 repositories, anomalies in, I7 veins, connection of, with faults, 89

formation of, 14

Minerals, ownership of, 653

Minero bird at Caratal, I05

Miners' cottages, 677

housing, 673

inch, definition of, $30 \mathrm{r}$

Minette, 53

Minières, definition of, $\mathbf{I}$

Mining, comparative healthiness of, 683

definition of, I

labour, principles of employment of, 637

law, in France, $I$

in Italy, 1,2

in the United Kingdom, I in the United States, 8, 9

statutes, 656

relating to Derbyshire, 655

to Forest of Dean, 655

subdivision of the subject, 2

Miscellaneous pulverisers, 563

Mispickel, treatment of, 6I I, 612, 6I3, 6I9

Miss-fire, 217

danger from, 213

Moil, 23I

Molinello, 618

Mona and Parys mines, cobbing at, 545

Monier system of using concrete, 254

Monitor, 296
Montana, copper deposits of, 37

Monte Catini, flora of, 104

Monteponi, Sardinia, adit at, 435 roasting calamine at, 6 I 5

Moore, pumps worked underground by hydraulic power, 469

Moravia, dressing of graphite in, 623

Mortality, comparative figures, 683 , 684

Moss-box, 273

Mother Lode or "Great Quartz Vein," California, 45

Motion of particles in water, 568

Mount Bischoff, dressing tin ore at, 630

Morgan gold mine, 48, 97

Mountfield gypsum mine, Sussex, 437

Mueseler's lamp, 520

Mulberry mine, near Bodmin, 19

mode of working, 290

Murgue, on the resistance to aircurrent due to sides of airway, 5I I

\section{$\mathrm{N}$}

NAMAQUA COPPER Co., magnetic separator used by, 606

Names of places, information afforded by, i 10

Natural gas, conveyance by pipes, 373

occurrence of, 59

Natural ventilation, 482

Needle, I6 I

Neu-Stassfurt mine, electric railway, $37 \mathrm{I}$

Nevada, Comstock lode, 76

mineral deposits at Steamboat Springs, 75

New Almaden, California, 73

Brunswick, antimony ore in, 21

Caledonia, cobalt ore in, 23 nickel ore in, 60

Idria. working by reflected daylight at, 5 I 3

Souch Wales, alunite in, 20 tin-bearing alluvia of, 85

Zealand, trees used for muing purposes, 229

Nickel ore, discovery of, in New Caledonia, 99

ores, mode of occurrence of, 60

Nitrate of soda, mode of occurruce of, 62

mode of working, 286

preparation of, 608 
Nitrate mixtures (explosives), 2 Io

Nitro-cellulose, 2 55

Nitrogen in mines, 479

Nitro-glycerine, 2 I I products of explosion of, 212

Noble and Abel, on fired gunpowder, 209

Noetling, on the oil-fields of Burmah, 66

Nog, 232

Nolten, on finding deviation of boreholes, 148

Northampton, deep boring at, I 18

Northamptonshire, mode of working iron ore, 286

North Lancashire, dressing hæmatite in, 624

working hæmatite deposits, 343 royalties in, 654

North Wales, iron pyrites, 83 slate mines, 312

washing pit used in, 539

Northwich, salt beds of, 75

Nunnery Colliery, steel beams, 256

Nystagmus, 688, 689

\section{O}

OAK for timbering excavations, 227

Ochre at Parys mine, 616 dressing of, 626

Ochsenius, on the origin of the nitrate deposits of South America, 63

Oeynhausen's sliding joint, I 28

Ogle, Dr., on annual death-rates in various trades, 683,684

Ohio, mode of occurrence of natural gas in, 59

Oil, effect of on safety fuse, 217

fields of Baku, 65

of Burmah, 65

of the United States, 67

Oil-wells, gases met with in sinking, 477

Oils used in lamps, 515, 516, 5 19

Olaf Terp, use of emery for boring, 124

Open-fire drying, 592

Open works, 285

Optimus drill, 189

Ormerod's detaching link, 416

Osceola Co.'s mine, arc-lamp at, 525

Otago, New Zealand, lodes of, 8

Otto's system of aërial ropeway, 382

Outcrop of lodes, 98

Overburden, 286
Overhand stoping, 329

advantages of, $33 \mathrm{I}$

Overlap fault, 90

Overwinding, 422

Ovuli, 5I

Ownership of minerals, 653

Oxygen, absorption of, 400

determination of, in the air, 506

necessity for a large proportion of, 505

Ozokerite, dressing of, 626

extraction of, by benzine, 609

mines, Boryslaw, inflammable gases at, 477

mode of occurrence of, 63

purification of, 598

\section{$\mathbf{P}$}

Packing plunger pump, 452

pump bucket, 448

Pacos (S. America), 100

Pan, for amalgamating gold ores, 622

for grinding and amalgamating, 556

for prospecting, 538

Paragenesis of minerals, 97

Parian cement, 613

preparation of, 624

Parodi on the Sicilian sulphur beds, 83

Parys mine, extraction of copper by solution, 307

precipitation at, 616

Pass, 332

best form of, 348,349

Patterson's stamps, $55 \mathrm{I}$

Paxman's roller for Huntington mill, 561

Pay-bill for payment by measure, 638

value of product, 642

weight, 640

Pay-lead, 318

Payment by measure, 638, 639, 640

time, 637

time and measure, 64I

value of product, $64 \mathrm{I}$

weight, 639

Pearce, on the tin-lodes of Cornwall, 7

Peeker, 222

Penhall's mine, Cornwall, succession of faults at, 92

Penrhyn slate quarry, 288

Pensions, 693 
Purcolation of surface water into workings, 429

Percussion tables, 584, 589

Perpendicular shafts, advantages of, 325

Pestarena, loss of gold at, 631

Petroleum, 65, 66 conveyance by pipes, 374 extraction by wells, 304

Petroleum engine, 163 for pumping, 445 for working drill, I8o

Pettenkofer, on the limit of carbonic acid in air, 502

Phenolphthalein, use of, in limewater test, 502

Phillips, on the mica of North Carolina, 58

Phosphate kiln, American, 594

Phosphate of lime, 67, 69 discovery of, at Beauval, France, 94 in South Carolina and Florida, 68, 69

search for, by piercing, 107

treatment of, 626

weathering of, 6 I I

Photometric tests of light given by safety lamps, 519, 520

Physical properties, dressing pro. cesses depending on, 568

Pick and gad work, 154 handles, 153

Picking by hand, 54I

Picks, 152 mechanical, 199 sharpening, 153 with separate blades, 153

Picric acid, explosives containing, 215

Pieler lamp, 499

testing for fire-damp with hydrogen flame, 500

Piercing, 106

Pigsty timbering, 245

for levels, 234

for shafts, 239

Pilař, on Franke's mechanical chisel, 199.

Pillaring of slate, $8 \mathrm{I}$ plane, 314

Pillars and chambers, working wide lodes with, $33^{8}$

left as permanent supports, 309 worked away, 315

Pine, varieties used for mining purposes, 227, 228

Pipe-lines, 374

Pipes, conveyance of minerals by, 349
Pipes-continued.

for compressed air, 170

for conveying water, 295

for pump column, $45^{\circ}$

wooden, 450

Pitch lake of Trinidad, 22

of a shoot of ore, definition of, I I

purification of, 598

pine, 227

Pit-head frame, 394

Plane tables, 579

Planing machines, 565

Plank tubbing for shafts, 266

Plants, indications of minerals afforded by, 103

Plaster of Paris, 613

Plat, 405

preparation of, 624

Plug and feathers, 203

Plumbism, 687

Plunger pump, 45I

Plutonic rocks, 3

Pneumatic hoisting, 427

jig, 589

Poetsch's freezing process, 23I

Pohlé pump, 470

Points and crossings, underground, 354

Poling, 236

Pollution Prevention Act, Rivers, 667

Pontgibaud lead mines, carbonic acid at, 475

Poppet heads, 394

Post, 237

Potassium salts, deposits at Stassfurt, 7o

discovery of, at Stassfurt, 96

method of mining, 315

treatment of, 627

Potosi, 78

Precipitation, 616

Premiums for good conduct, 652

Preparation of ores.-See DREssing, 537

Preservation of timber, 229

Pressure of air, influence on health, 689

box, 295

Pricker, 161

P.ibram, deep shafts at, 404 underground fire at, 708

Priestman's grab dredger, 176

Principles of employment of mining labour, 637

Prop, 244

Props, iron and steel, 265 
Prospecting, or search for minerals, 93

by the diamond drill, I I9, I 23

by the diamond drill, cost of, 122

Prospector, qualifications of, II 2

Provident societies, 690

Prussia, accidents from man-engines, 705

Puddling machine, Australia, 539

Pulley-frame, 394

Pulleys, 397

Pulsator, 622

Pulsometer, 468

Pulveriser, Cyclone, 563

Marsden's, 547

Pulverisers, miscellaneous, 563 pneumatic, 563

Pump column, 450 for extracting brine from borehole, 306

lifting, 448

plunger, 451

plunger, advantages of, 452

Pohlé, 470

pulsometer, 468

Riedler, 467

Rittinger, 454

rods, 445 counterbalancing, 457 iron, $46 \mathrm{I}$

valves, 453

Pumping engines, compound, 443445

duty of, 472

placed underground, 466

single acting, 443

machinery, moving heavy parts of, $46 \mathrm{I}$ plant, Shakemantle mine, $46 \mathrm{I}$

Pumps, drainage by, 44I

driven compressed air or electricity, 470

drowning of, $450,446,467$

wooden, 450

worked by hydraulic power, 469

Purifying water from dressing works, 667

Pyrites, Carnarvonshire, 83 mode of working in North Wales, 309

worked opencast, Rio Tinto, 289

Q

QUARRIES, definition of, r raising stone from open, 406
Quarries-continued.

slate, North Wales, 312

underground sıate, Ardennes, 314

stone, Bath, 3 Io

Quarry Funcing Act, 667

Quartering, sampling by, 633

Quenast quarries, premiums for good conduct, 652

Quicksand, Haase process of sinking in, 283

Poetsch process of sinking in, 283

Triger's process of sinking in, 277

Quicksilver, chance discovery of, in California, 94

mines of California and Nevada, Becker on, 16

mines, unhealthiness of, 687

ore, occurrence of, $7 \mathrm{I}$

ore, treatment of, 627

rock, 74,103

\section{$\mathbf{R}$}

RACK-A-ROCK, 2 I I

Ragging, 544

Rails, 35 I

Railways, electric, $37 \mathrm{I}$ surface, 376 underground, $35 \mathrm{I}$

Rammelsberg Mine, Hartz, pyrites deposit, 32

Rand, gold output, 43

Ratchet drill, 155

Rating Act, 655

Raymond, on indicative plants, 104 Recreation, 696

Red clay of New Caledonia, 28,60

Red bar (Johannesburg), 103

Redonda, phosphate of alumina at, 69

Red River, tin ore got from, 630

Reflected daylight, working by, $5^{1} 3$

Regulations for mines, working, 655

Regulations.-See AC'Ts, 656

Reservoirs for compressed air, 168

for hydraulic mining purposes, 293

Resistance to air-current, 510-512

Restronguet creek, dressing of tin ore at, 629

method of working tin-bearing gravel, 316

occurrence of tin-ore in alluvium of, 85

shaft sinking at, 268 
Reticulated masses, 19

Retorting amalgam, 600 sulphur ores, 600

Returning charges, 642

Reumaux's automatic speed checker, 425

Revolving round table, 583

Reversed fault, 90

Rewarewa. 229

Rhosesmor mine, Flintshire, 435

Rice's clutch, 369

Richness of lodes, conditions affecting, II

Richmond $v$. Eureka case, 8

Rickard, on Mount Morgan mine, Queensland, 49

on the saddle-reefs of the Dendigo gold-field, 47

Riebeck's stove, 595

Riedler pumps, 467

Riffles, 299

Rigg and Meiklejohn's machine, 203

Rinchiusu, 475

Rio Tinto, arc-lamp at, 525

character of ore at, 33

geology of the district, 3 I

gozzan, 33

lodes at, 32

mines, shipping arrangements at Huelva, 380

opencast, 289

pillar and chamber workings, 338

precipitation at, $6 \mathrm{r} 6$

timbering for levels, 233

treatment of copper ore at, $62 \mathrm{I}$

Rise, difficulty of ventilating, 486

mode of ventilating, 488

Rises, method of timbering, 344

Rittinger, fall of spheres in water, 568

Rittinger pump, 445, 454

Rittinger's percussion table, 584

Rivers Pollution Prevention Act, 667

Rivers, sinking shafts in, by freezing, 280

Roasting, 6I I, 6I 3

Roberts, C. Warren, sleeper, 353

Roburite, 215

fumes from explosion of, $48 \mathrm{I}$

Rock-boring competition, I 59

Rock-drills, 177

Rock-salt at Stassfurt, 70

Rods for man-engines, 535

for pumps, 445

Rolland's fireless locomotive, 363
Rolls, Cornish, 553, 554

Krom, 554

Roof of a bed, definition of, 5 slate mining, 312, 313

Root's blower, 494

Rope haulage, 365

preventing shock to, in winding, 427

sccket, 139, I40

Ropes for winding, steel, 399

modes of capping, 402

testing, 427

Rossigneux system of counterbalancing, 459

Rotary machine drills, 178

washing machine for diamonds, 540

Rothliegendes in Mansfeld district, 29

Rothschonberger Stalln, 434

Roumania, salt mines, 312

Roumanian miner's hat, 672

Round tables for picking, 542

for sluices, $5^{\text {? }}$ !

Rowoldt's stove, 597

Royalties, 654

sliding scale for, 654

Ruelle's stove, 596

Ruins, indications afforded by, 109

Running loop, 447,

Russia, manganese ores of, 57

occurrence of quicksilver in, 73

Ryland's glass-lined pipe, I 7 I

\section{$\mathbf{S}$}

SАвот, 673

Saddle reefs, Victoria, 47

Safety catches, 426

fuse, 2 I 7

on cage, 418

gear for hauling men at Boryslaw, 53 I

lamp, used for testing for firedamp, 499

lamps, 5 18

St. Agnes, Cornwall, tin lodes of, 84

St. Day mines, heat at, 670

Saint-Etienne, mine-waggon used at, $35^{8}$

St. Just, strike of lodes at, I4

Salisbury Mine, Johannesburg, 42

Salt, discovery of in Cleveland district, 96

excavating by water, 226

extraction by wells and boreholes, 304

$3 \mathbf{A}$ 
Salt-continued.

minerals associated with, 97

mines, Cheshire, 3I I

Roumania, 312

occurrence of, 75

preparation of, 628

workings for at $\mathrm{Bex}, 307$

works affected by Alkali Acts, 665

Salzkammergut, mode of working salt-marl, 307

Sampling by hand, 632

quartering, 633

taking out small lots, 632

trenching, 632

object of, 632

machine, Bridgman's, 635

Brunton's, 635

Clarkson's, 634

Colorado, used in 634

shovel, 633

Sandals, 673

San Domingos, 34

Sand-pump, 140

Sand-reel, 139

Sandstone, bituminous, California, 22

interstitial space in, I8

lead-bearing, Mechernich, 5, I 8 silver-bearing of Utah, 18

Sarrau and Vieille, on the decompo. sition of certain explosives, 212

Savage mine, beat at, 670

Sawing machines for stone, 564

Saws, circular, use for undercutting, 202

for cutting stone, 154

timbermen's, 23I

used in getting freestone, 3 ro

wire, 204

Sawyer on underset of props in in. clined beds, 244

Saxon gad, I 54

miner's lamp, 5 I6

Schäffer and Budenberg's speed indicator, 533

Schiele fan, 497

Schools, 682

Schrader on Franke's mechanical chisel, 199

Schulz's stove, 597

Scotch fir, 228 lamp, 5 I 6

Scotchman's United mine, Dorehole at, 148

Scraper, 160

Screening, 566

Screw-conveyors, 375

Seams, 18

Seasoning of timber, 230
Sector wire rope, 40 I

Securite, 2 I 5

Sediment-tube for diamond drill, I 9

Self-discharging skips, 412 advantages of, 417

Self-oiling pedestals, $36 \mathrm{I}$

Selvage, definition of, I I

Separator, Frongoch, 576

Jacométy and Lenicque's, 575

Lockhart's gem, 577

siphon, 577,579

Separators, upward current, 574

Sergeant drill, I93

groove-cutter, I99

Serpentine, occurrence of asbestos in, 2 I

occurrence of nickel in, $6 \mathrm{r}$

Sets or frames, 234, 236

Seyssel, France, bituminous limestone of, 22

treatment of asphalt rock of, 598

Shaft accidents, 705

arrangement of pumps in, $45 \mathrm{I}$, $46 \mathrm{I}, 464,465$

linings of iron, 263

natural ventilation of, 486

rolls, 446

use of air-pipe for ventilating, 488

Shafts, cost of sinking in watery strata, 27 I

crooked, arrangement of pump rods in, 446

deep, at Pribram, 404

freezing process of sinking, 278

for working mineral deposits, 308

for working veins, 325

Kind-Chaudron process of sinking, 27 I

lined with concrete, 253

lined with masonry, 252

natural ventilation by two, 483

Poetsch's freezing process for sinking, 28I

sunk by boring procsss, time

* required, 277

timbering of, 236

Shaft-sinking, 225

by incandescent lamps, 524

through bed of river, 268

Shakemantle Mine, pumping plant at, 46I

Sbanks' system of treating caliche, 608

Shaw's apparatus for testing for fire-damp, 5OI 
Shcba Mine, Barberton, 44

Gold Mine, 'aërial ropeway at, 384

Shell pump, I28

Shipping ores, arrangements for, 380

Stioading, I05

Shoad-stones, 106

Shoe of stamps, 549

wooden, 673

Shoot of ore, definition of, I I

shoots, 348, 373

mouth for regulating discharge of, 413

Shovel, I 5 I

Shower-bath for miners, Anzin, 68r

Siberia, freezing method of sinking pits, 278

Sicilian miner's lamp, 5 I 5

Sicilian mines, steps for descent or ascent, 527

Sicily, modes of working sulphurbearing limestone, 321 occurrence of sulphur in, 82

Sickness, 683

Side holes, 3 ro

Sidings, endless rope system, 370

Sieves, 566

Signalling, 420

from caye, 533

Sill, 233

Silver, chance discoveries of, 95

Silver ores, occurrence of, 76

Broken Hill, N.S.W., 78

Calico, California, 79

Comstock Lode, Nevada, 76

Eureka Richmond, Nevada, 76

Huanchaca, Bolivia, 78

Kongsberg, Norway, 12

Stormont, Utah, 79

treatment of, 628

Silver-bearing sandstone, Utah, 18

Simultaneous fuse, 220

Single-rope haulage, 365

Sink, 222

Sinker-bar, I 39

Sinking by compressed air method, influence on health, 689

Kind-Chaudron method, 27 I

Poetsch, or freezing method, $28 \mathrm{r}$

shafts, 225

through watery strata, cost of, 271

Triger's method, 277

Siphon, draining mines by, 437

Siphon separator, 577

Skertchly on the wining and knapping of flint, $4 \mathrm{I}$
Skip, 404, 4ro

loading in shaft, $4 \mathrm{IO}, 4 \mathrm{I} 2$

self-discharging, De Beers inclined shaft, 4 I2

for perpendicular shaft, 415

Skntterud, cobalt ore, 27

Slag-heaps, indications afforded by, I08

Slate, charging holes for rending, 219

circular saws used for, 564

dressing machines, 565

loss in dressing, $63 \mathrm{I}$

loss in mining, 314

methods of working, 312-3I 5

Mines (Gunpowder) Act, 659

occurrence of, 79

planing machines for, 565

preparation of, 628

splitting of, 545

Sledges, $3 ; 0,375$

Sleepers, steel, 352

Slickensides, 10, 89

Slide, 88

Slides for descent, 527

Sliding joint, Oeynhausen's, 128

Sliding scale for royalcies, 654

Slip, 473

Slopes, 308

Sludger, 128

S uices, 297

Smith, Dr. Augus, on the candletest, 501

on the pollution of the air in mines, 480

on the proportion of oxygen in respirable air, 506

process of testing air, 502

Tichard, on the gold-bearing conglomerate of the Transvaa 1,42

Snell, on miners' nystagmus, 689

Snore-piece. $44^{8}$

snow, disappearance of, from cutcrop of lode, 108

Societies, provident, 690

Sockets, joining two ropes by, 494

Solepiece, 233

Solfatara of Pozzuoli, sulphur from, 82

Solution, extraction of minerals by, 305

preparation of borax by, 608 nitrate of soda by, 608 potassium chloride by, 608

Somme department, occurrence of phosphate of lime in, 68 treatment in, 627

Somorrostro, endless chain haulage, 379

sulf-acting incline, 376 
Sorby, on the origin of the Cleveland ironstone, 18, 53

Sores produced by arsenious acid, 686

Sough, 433

Sounding, testing gromnd by, 705

Sources of mineral supply in Britısh Isles, 655

South Africa, discovery of diamonds in, 93

dressing of diamonds, $62 \mathrm{I}$

gold ore deposits, $4 \mathrm{I}$

South Carolina, phosphate beds, 68 treatment of phosphate of lime in, 627

Sonth Staffordshire Mines Drainage Commission, 474

Space required per head, in rooms, 676

Spain, cupreous pyrites deposits of, 3I-34 occurrence of quicksilver in, 72

Spalling, 544

Spathose ore, calcination of, $6 \mathrm{I}_{2}$

spear-rod, 445

Speed indicator for winding engine, 533

Spiuer (candle-holder), 5 I 5

Spiles, 345

Spilling, or spiling, 236, 242

Spiral drum, 393

splitting air-current, 5 10 slate, 545

Sprague electric diamond drill, I8o

Sprengel type of explosives, 215

Spring stamps, 55I

Spruce fir, 228

Square-set system of timbering, 246

Squib, 218

Stalls, 309

Stamps, gravitation, 548 pneumatic, 55I

spring, $55 \mathrm{I}$

steam-hammer, $55^{\mathrm{I}}$

Standards for wire ropeways, $3 S_{2}$

Stanley's tunneller, 207

Stannaries Act, 668

Stapff, on prospecting for phosphorite, IO4

Stassfurt, discovery of potassium salts at, 96

occurrence of potassium salts at, 70

preparation of salts at, 608

salt mines, sulphuretted hydrogen at, 479

treatment of potassium ealts, 627 workings for carnallite, 315

Stationary engines for haulage, 364 table of Linkenbach, $58 \mathrm{I}$
Statutes affecting mines or quarries, $656,659,662,665$

Mining, 656

See ACtrs of Parliament, 655

Steamboat springs, Nevada, 75

steam digger, 173

engines for winding, 390

hammer stamps, $55 \mathrm{I}$

jet for ventilating, 492

process for sulphur, 600

shovel, I73

stove, 597

Steavenson twist drill driven by power, I80

Steel beams used for supporting levels, 256, 258

car wheels, 357

frames for levels, 259 shafts, 263

mine-waggons, 356,360

props for working places, 266

pump rods, 445

sleepers, $35^{2}$

wire-ropes, 399

Stein's endless belt, 586

Stelzner, on the lateral sesretion theory, 15

Stempels, 240, 329

Step-fault, 88

Steps for descent and ascent, 526

or stopes in open works, width of, $286,288,289$

Stockworks, 19

quicksilver ore, 73

silver ore, 79

tin ore, 19,84

zinc ore, 87

Stokes' alcohol-reservoir for safety

lamp, 500

Stone, preparation of, 628 breakers, 546

Stoping, overhaud, 329

underhand, 327

Stoves, for drying, 594

Jacobi's, 597

Krom's, 595

Riebeck's, 595

Rowoldt's, 597

Ruelle's, 596

Schulz's, 597

steam, 597

Strapping plates, 445

Stratified deposits, 4

Straw for firing shots, 2 I 3

Stream works, tin ore, 85

Strength of explosives, 216

Stretcher-bar, 197

Stretchers, 7I 3

Strike, definition of, 5

iniluence of change of, on veins, 13 
Stringy bark, 229

Struvé's ventilator, 494

Studdles, 237, 243

Stull, 327

Sturgeon on the efficiency of compressed air, I64

Sturtevant Mill, 563

Styria, graphite in, 50

Sublimation, formation of veins by, I7

Sub-Wealden boring near Battle, 96

Suction dredge, 177

pipe for brine well, 306 pumps, 448

Sudbury, discovery of nickel ore at, 94

nickel ores of, $6 \mathrm{I}$

Suffocation by gases, 707, 710

Sulphate of iron used for preserving timber, 23I

Sulphur, distillation of, 600 liquation of, 598

mode of occurrence of, $8 \mathrm{I}$

preparation of, 629

rock, Sicily, fire-damp emitted by, 478

Bank Mine, California, 74

discovery of quicksilver at, 96

gas from hot springs, 476

bearing limestone in Sicily, 82

mode of working, 321

seams, outcrop of, 102

Sulphuretted hydrogen in mines, 479

Sulphurous acid in mines, 479

Sump, 326

Supporting excavations, 227

Surface accidents, 7 I I

drainage, 429

indications guiding the prospector, 97

Surveying bore-holes, 147

Surveys, danger from inaccurate, 707

Sussex, preparation of gypsum, 624

Sussmann electric lamp, 523

Sutro Tunnel, Nevada, 436

Swab-stick, I60

Swage, I8I

Sweden, iron ores of, 54

occurrence of zinc ore in, 87

searching for iron ore with the magnetic needle, I 12

Switzerland, workings for salt, 307

Sword, 449

Synclinals, 47,87
$\mathrm{T}$

TABLES, Jacométy and Lenicque's, 583

Linkenbach's, $58 \mathrm{I}$

percussion, $584,5^{S 9}$

picking, 542

plane, 579

revolving round, 583

Rittinger's percussıon, 584

round, $58 \mathrm{r}$

Tabular deposits, 5

'Tachometer, 533

Taeglichsbeck's report on housing of miners, 674,679

Tagieff's spoutiug oil-well, Baku, 65

Tailings, 243, 588

Tamarack copper mine, Lake Superior, 36,37

Tamping bar, 160 charge, 217

Tapering ropes, 404

Taxation of mines, 625

Tasmania, dressing tin ore in, 630

Teague's aspirator, 493 noiseless valve, 453

Teel's Marsh, borax deposit, 23

Telephones used for signalling in mines, 421

Ternper screw, I40

Temporary dam, 433

Testing air of mines, 498-510 ropes, 427

Thames gold-field, New Zealand, 13

Tharsis, pyrites mines, 34

Thawing dynamite, 213

Thickness of bed, measurement of, 5

Thrift, 690

Throw, or heave, 88

Throw of a fault, definition of, 89 mode of determining amount of, 89

Timber, decaying, affects air of mine, 480

kinds used underground, 227

preservation of, 229

seasoning, 230

supports compared with stecl, 257.

usea in Australia, 228

in England, 227

in United States, 228

withdrawing, from rubbish, Foxdale, 338

Timbering in loose ground, 242

levels, 232

pigsty system, 234, 239, 245

shafts, 236

special excavations, Hartz, 24 I

square-set, 246

working places, 244 
Time occupied in descent and ascent at Mansfeld, 532 payment by, 637 and measure, payment by, $64 \mathrm{I}$

Tin ore, alluvial deposit at Restronguet Creek, 316

calcination of, 612,613

dressing of, 629

lodes in granite, 7

mines affected by Alkali Acts, 665

mode of occurrence of, 83

separation from copper ore, 609

stockwork, Mulberry mine, near

Bodmin, 19

Toadstone, influence on lead veins

Tonite, 215 in Derbyshire, 13

fumes from explosion of, $4^{8} \mathrm{I}$

Tools used for working timber, $23 \mathrm{I}$

Toothed rolls, 556

Torches, 515

Torpedo, 304

Transmission of power, 163

Tran:port above ground, 373 underground, 348

Trays, 349

Treadwell Mine, Alaska, 47

Treatment of ores. - See Dressina, 537

Trelease's valve, 453

Trenching, sampling by, 632

Tribute, 64I

advantages of working on, 643 , 646

disadvantages of working on, 644,645

system in Colurado, 647

at Festiniog, 649, 651

Triger's method of sinking, 277

Trimming stone by hand, 546

Trinidad, Pitch Lake of, 22 dressing of, 619 purification of, 598

Tripoli, occurrence of beds of, in Sicily, 82

Trommels, 566, 567

Trouvé, apparatus for examining bore-holes, 150

Trubi, $\mathbf{8 2}$

Truck Acts, 668

Tubbing for shafts, cast-iron, 268 wood, 266

Tunnelling machines, 206

Turbine, used for hoisting, 389

Turgu-Ocna mine, $3^{12}$

Turn plates, 354

Tuscany, occurrence of boric acid, 25 preparation of boric acid, 620

Tutwork, 638, 639
U

ULVERstoN, hæmatite deposits of, 19

Umber, dressing of, 626 searching for by piercing, 106

Undercurrents, 299

Undercutting machines, 199, 202

Underground pumping engines, 466 workings, 308

Underhand stoping, 327

Underlie or underlay, definition of, 9

United Kingdom, death-rate from accidents, 700

United States, candle-holder used in, 514

gathering of natural ice, $5^{I}$

lamp used in, $5 \mathrm{I} 6$

legal definition of lode in, 9

occurrence of copper in, 34

gold ore, 45

iron ore, 54

lead ore, 55

natural gas, 59

petroleum, 67

phosphate of lime, 68

quicksilver ore, 71

silver ore, 76

trees used for mining purposes, 228

Universal pick, 153

Unstratified deposits, 4

Upcast shaft, 484

Uppers, dust from boring, 685

Upthrow, 9I

Upward-current separators, 574

Utah, silver-bearing sandstoue, 79

\section{V}

VAL-DE-Travers, Switzerland, bituminous limestone of, 22

Value of product, payment by, 64I

Valve, butterfly, 453

double-beat, 454

Jan Ham's, 453

Hake's mouth, 453

ordinary leather, 448

Teague's noiseless, 454

Trelease's, 453

Van den Broeck and Rutot, portable boring outfit, I 17

Van lode, length of, I I

Van mine, fire-damp at, 476

method of working the wide lode, 331

Vanner, Frue, 585

V-bob, 446

Vegetation on outcrop of lodes, 107 
Vcins, definition of term, 5

heave sideways caused by slip along line of dip, 9I

influence of change of strike on, 13

of enclosing rock on, I2, I3

intersections of, 12

mechanical filling of, 14

modes of working, 325-340

name applied to slate beds in

North Wales, 8I

origin of, 14

varying width of, 16

Zimmermann's rule for finding

faulted portion of, $9 \mathrm{I}$

Veinstone, definition of, I I

Velocity of air-current, measurement of, 506, 507

Venezuela, discovery of gold in by

Plassard, 94

occurrence of gold in, 44

Ventilating appliances, efliciency of, 509

Ventilation, 475

compressed air, 492

fans, 494

furnace, 490

steam jet, 492

water blast, 492

falling down shaft, 486

effect of, on timber, 230

measurement of amount of air passing, 506

natural, 482

Victoria, gold-fields of, 46

Villiers' stopping gear, 425

Viola calaminaria, I04

Volcanic emanations,sulphurfrom,8 I rocks, 3

Vom Rath on the outcrop of the silver veins of Butte, Montana, 98

Von Cotta, definition of a mineral vein, 6

on the Zwitter of Altenberg, 84

Von Groddeck, definition of a mineral vein, 6

Von Sandberger, definition of a mineral vein, 6

on the lateral secretion theory, I 5

Vugs, definition of, 6

Vulcano, sulphur from, 82

\section{W}

WADDLE fan, 497

Waggons for underground use, 350, $355-360$

points to be considered in designing, 36I
Wales, barracks for workmen, 676 manganese ore in, 58

lead ore in, 33I

slate in, 79

underground workings for slate, 312

Walker's circular saw, 203, 204

detaching hook, 423

shutter for Guibal fan, 496

Wallace on emanations of carbonic acid at Alston Moor, 475

Wallaroo lode, discovery of, 93

Walling, 249

Walling stage, Galloway's, 409

Wall-plate, 236

Wall-posts, 240

Walls, Cleveland, 315

Festiniog, 31 2

of a lode, definition of, Io

Walton Brown on the resistance to air-currents, 5 I I

Wardwell stone-channelling machine, 202

Warming pan for dynamite, 2 I 3

Warocquère, 706

Washer, Australian, 539

De Beers, 540

revolving drum, 54I

Washing ores, \&c., 538

Wash-out fault, 87

Washing-pit used in North Wales, 539

Water, amount used by siphon separator, 579

amount used in stamping, $55 \mathrm{I}$

barrel for winding, 437

column compressors, 165

excavating by, 226, 292

from dressing works, purification of, 667

gauge, 508

irruptions of, into mines, 707

jet ventilating apparatus, 492

motion of particles in, 568

power used for working pumps, 442

spray for laying dust, 685

tanks, automatic, 438

used for rending rocks, 208

wheel used for hoisting, 389

Watertight linings for shafts, 266

Weathering of diamond-bearing rock, 6 Io

fire-clay, 6I I

ironstone, $6 \mathrm{I} I$ phosphate of lime, 6ir

Wedge, I 54, 208

Elliott multiple, 208

Wedging-crib, 267, 270

Weight, payment by, 639 
Wells, 304 boring by rotation, 117 driven, 137

Wells light, 516

Welsh barracks, 676 manganese ore, occurrence of, 58

dressing of, 625

lead ore, $33 \mathrm{I}$

miner's clogs, 672

slate mines, 79, 312

Wenström magnetic separator, 605

Werner, definition of a mineral vein, 6

Wéry's stopping gear, 425

West and Darlington, hydraulic counterpoise, 458

hydraulic plungers for working inclined rods, 447

Wheal Mary Ann, section of lode at, 6

Wheelbarrow, 350

Wheels for mire-waggons, 357

Whipsiderry, 388

White's sleeper, 353

Whitney, on the "Great Quartz Vein" of California, 45

Wicks, candle, 513

Wide veins, method of working, 331

Wieliczka salt mines, 315 timber chocks, 245

Wind-bore, 448

Winding, 387 drum, 391 engines, 390

men at Carn Brea mine, 533 pulleys, 397 removing water by, 437

Windlass, 388

Windmills used for working pumps, 442

Winstanley's machine, 204

Winze, 326

Winzes, use of for ventilating, 489 , 490

Wire saw, 204
Witwatersrand, 4I

Wolf's magnetic lock for safety lamps, 522

Woodbury ore concentrator, 586

Wooden pipes, $45^{\circ}$

plugs used for rending rocks, 208

pulley frame, 395

Working barrel of pump, 448

in constrained position, effect on men, 688

masses by horizontal slices, ascending, 345 descending, 34I

mineral deposits, methods of, 285

places, iron and steel supports, 265

supported by masonry, 254

timbering, 244

regulations for mines, 655

Workings, carbonic acid in old, $50 \mathrm{r}$ laying out open, 288

Workmen, housing, 673

Wotherton mine, Shropshire, 13

Wrist, 3 Io

Wrysgan mine, 314

\section{$\mathbf{Y}$}

YELLOW Jacket mine, heat at, 670

\section{Z}

Zimmerman's rule for finding lost part of a vein, 91

Zinc blende, minerals associated with, 97

Diepenlinchen, method of working, 346

ores, calcination of, 612, 615

dressing of, 625,630

occurrence of, 85,86

Zwitter, or tin-bearing rock at Altenberg, 84 


\section{A CATALOGUE}

OF

\section{SCIENTIFIC AND TECHNICAL WORKS}

PUBLISHED BY

\section{CHARLES GRIFFIN \& COMPANY,}

\section{IMITED.}

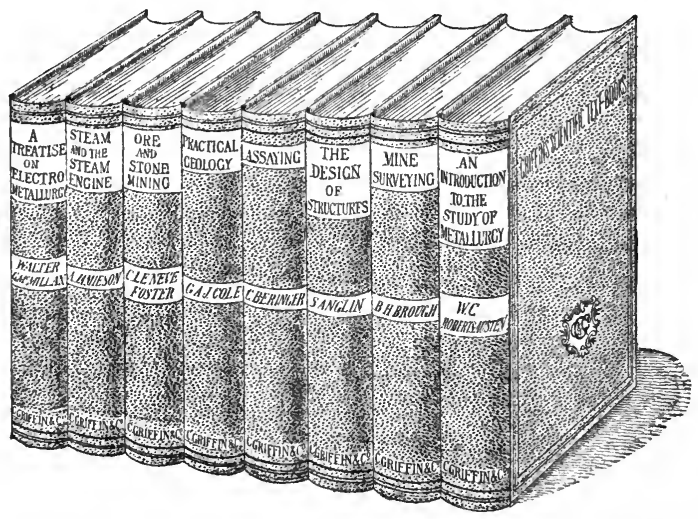

MESSRS. CHARLES GRIFFIN \& COMPANY'S PUBLICATIONS may be obtained through any Bookseller in the United Kingdom, or will be sent post free on receipt of remittance to cover published price. To prevent delay, Orders should be accompanied by a Remittance. Oheques and Postal Orders to be crossed "SMith, Payne \& SMiths."

GENERAL and MEDICAL CATALOGUES forwarded Post-free on Application.

\section{LONDON :}




\section{INDEX TO AUTHORS.}

ALLINGHAM (W.), Navigation, PAGE

$.5,21$

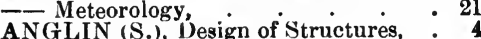

BARKER (D. WILSON-), Navigation and Seamanship, . $\quad . \quad 5,21$

BERINGER ( J. J \& C.), Assaying, 8

BLACKMORE (E.), British Mercantile Marine 6, 2

BLOUN'T (B.) and BLOXAM (A. (*.), Chemistry for Engineers and Manufacturers,

BLYTH (A Wynter) Foods and Poisong, BORCHERS (Dr.), Electric Smelting, 29 BROTHERS (A.), Photography, . • 8

BROUGH (B. H.), Mine-Surveying, . 10

BROWNE (W. R.), Fuel and Water, 44

- Vechanics, R. Fuel and

BUCK (R. C.), Algebra and Trigonometry,

BU'TTERFIELD (W, J. A.), Gas Manufacture,

COLE (Prof,), Practical Geology,

Open Air'Studies in Geology,. . 12

CRIMP (W.S.), Sewage Disposal Works, 13

DA V I ES (Surgeon-Major), Hygiene, . 14

DAVIS (Prof.), Biology,. • • . 15

- The Flowering Plant, . . . 15

- Zoological Pocket-Book, . 15

DONKIN (Bryan), (Kas and Oil Engines, 16

- Efficiency of $\mathbf{S}$ team Hoilers, 16

DUERR (Geo.), Bleaching and CalicoPrinting,

DUPRE \& HA K E ( Manual of Chemistry), 16

ETHERID(XE (R.), stratigraphical Geology,

EWART'(Prof), Preservation of Fish,

FIDLER (Prof.), Bridge-Construction, 17

FOSTER (Prof. C. le Neve), Ore and Stone Mining,

GRIFEIN (J'J,) Chemical Recreations, 18

GRIF WIN'S Electrical Price-Book, 19

GRIFFIN'S ENGINEERING PUB: LICATIONS,

GRIFFIN'S GEOLLOGICAL " and METALLURGICAL SERIES,

GRIFFIN'S NAUTICAL SERIES, 21

GRIFFIN'S SANITARY PUBLICA: T10NS

GRIFFIN'S TECHNOLOGICAL PUBLICATIONS,

GURDEN (R.), Traverse Tables, -

GUTTMA NN (O.), Blasting, : : 19

HARBORD (F. W.), Steel, : i1, 50

HUGHES-GIBB (E.), How Plants Live, 17

HUGHES (H. W.), Coal Mining,. . 24

HURS'T (Chas,), Valves,

HURST (G. H.), Painters' Colours, - 25

Garment Dyeing and Cleaning, : 25

- Colour Theory (Practical Applica. tions of),

JAMIESON' (Prof.), MANüas, Advalsced and Elementary,

- steam Engine,

Marnetism and Electricity

JENKINS (H. C.), Metallurgical Machinery,

JOHNSON' (J. C. F.), Getting Gold, : KN ECHT \& RA WSÓN, Dyeing, .

LAFAR (Dr. F.), Micro-Organisms (Utilization of),
LA WN (J, G.) Mine Accounts MACK ENZIE(T.), Applied Mechanics, 21,30 M'MILLAN (W. G.), Electro-Metallurgy, • • • 29 \& BORCHERS, Electric Smelting, 29 MILLAR (W. J.), Latitude and Longitude, . . 21, 30 MUNRO \& JAMIESON'S Electrical Pocket-Book,

MUNRO (Dr.), Agricultural Chemistry, 31 MUNRO (R. D.), Steam-Boilers, . 30 KY Kitchen Boiler Explosions, . - 30

N YSTROM'S Pocket-Book for Engineers, 31 PEARCE (W. J.), Painting and Decorating, . . 33 PHILLIPS \& BA UERMAN, Metallurgy, 34 POYNTING (Prof.'), Mean Density of the Earth,

PRAFGER (R. L ) Open Air Botany, 34

RANKINE'S Applied Mechanies, - 35

— Civil Engineering, . • . : 35

- Machinery and Millwork, . 35

Steam Engine \& other Prime Movers, 35 Useful Rules and Tables. A Mechanical Text-Book, . $\quad 35$

Miscellaneous Scientific Papers, 36

REDGRA VE (G. R.), Cements, : : 36

REDWOOD (Boverton), Petroleum,. . 37

REED (Sir E. J.), Stability of Ships, - 38

REID (Geo., M.D.), Practical Sanitation, 39

RICHMOND (H. D. ), Dairy Chemistry, 38

RIDDELL (Dr. Scott), Ambulance, : 40

RIDEAL (S., D.Sc.), Disinfection, . 39

ROBERTS - A USTEN (Prof.), Metallurgy and Alloys,

ROBINSON (Prof.), Hydraulics, : : 42

ROSE (T. K.), Gold, Metallurgy of, 43

ROTHWELL, (C. F. Seymour), Textile Printing,

SAL'TER (Chas.), Micro-Organisms, : $\mathbf{4 7}$

SEATON (A. E.), Marine Engineering, 45

SEATUN \& ROUNTHW AITE, Marine Engineers' Pocket-Book,

SEELEY (Prof.), Physical Geology, : 32

SEXTON (Prof.), Ellementary Metallurgy,

-Quantitative \& Qualitative Analysis,

SHELTON (W. V.) Mechanic's Guide

SM ITH, (Johnson), Shipmaster's Medical Help, 21, 40

SMITH (Prof. R. H.), Measurement Conversions,

Calculus for Engineers, $\bullet \cdot{ }^{\circ} \quad 48$

SYKES (Dr. W. J.) Brewing, 47

THOMSON \& POYNTING' (Profs.)

Text-Book of Physics, . . .

TRAILL (T. W.), Boilers, Land and Marine, . . . . TURNER (Thos.), Iron, Metallurgy of, 50 WALTON (T.), Know Your Own Ship,

WATKINSON (Prof. W. H.), Gas and Oil Engines,

WELLS (S. H.), Engineering Drawing, 5 s $^{\circ}$ WIGLEY (T. B.), Goldsmith and Jeweller's Art,

WRIGHT (Dr. Alder), The Threshold

of Science, ${ }^{\circ}$.

YEAMAN (C. H.), Elec. Measurements, 53

YEAR-BOOK of Scientific Societies, 


\section{INDEX TO SUBJECT.}

AGRICULTURAL CHER

HEMISTRY, . 31

AIR ENGINES, .

ALGEBRA,

ALLOYS,

AMBULÁNCE,

ASSAYING,
BACTERIOLOGY (Practical),

BIOLOGY,

BLASTING,

BO'TANY, $:-15,17,33,47$

BRIDGE-CONSTRUCTION, . . 17

BOILERS, Construction, . • . 49

— Efficiency of, . . . . 16

Kitchen, Explosions of, - . 30

- Management, . . . . 30

BREWING, . . . . . 47

CALCULUS FOR ENGINEERS, : 48

CALICO-PRINTING, . • • 14, 44

CEMENTS,

CHEMICAL ANALYSIS, Qualitative

and Quantitative,

CHEMICAL RECREATIONS, : 19,52

CHEMISTRY FUR ENGINEERS, • 7

- for Manufacturers, . . . 7

- Inorganic, . • • . . 16

COAL-MINING, . $\quad$. $\quad . \quad$. 24

COLOURS, . $\quad . \quad \cdot \quad \cdot 25$

COPPFR, lietallurgy of, : $\quad \cdot \quad 41$

DAIRY CHEMISTRY, - • • 38

DENSITY OF THE EARTH, - : 34

DESIGN (Engineering), . • . 53

DISINFECTION and DISINFECTANTS, 39

DRAWING (Engineering), • • . 53

DYEING, - : 25,27

ELECTRIC SMELTING, : : • 29

ELECTRICAL MEASUREMENTS, - 53

- Pocket-Book, . . . . 31

- Price-Book, . . 19

ELECTRICITY and MAGNETISY, : 26

ELECTRO-METALLURGY, • . 29

ENGINEERS, Pocket-books for, - 31,45 Useful Rules for, . . . $\quad 20,35$

ENGINEERING, Civil, : . • 35

Marine,

— Drawing and Design, : • • 53

FERMENTATION, • • • $\quad 47$

FISH, Preservation of, . $\quad$ • $\quad$ • 16

FOODS, Analysis of, . $\quad$ • $\quad .99$

FUEL and WATER, . $\quad$ • . $\quad .44$

GAS ENGINES,

GAS MANUFACTURE,

GEOLOGY, Introduction to,

Physical,

Practical,

Stratigraphical,

GOLD, Getting, Metallurgy of

GOLDSMITH'S ART,

HYDRAULICS, .

HYGIENE,
IRON, Metallurgy of,

PAOE

JEWELLER'S ART, • • • • $\quad 50$

KITCHEN BOILER EXPLOSIONS, . 30

LATITUDE and LONGITUDE,

To Find,

MACHINE DESIGN,

21,30

ACHINE DESIGN,

MACHINERY and MILLWORK, 33, 41

MAGNETISM, 26

MARINE BOILERS, : • • • • 49

Engineering, . • . . 45

MECHANICS, Applied-

— Elementary,. - . $\quad 21,26,30$

- Student's, : $\quad \cdot \quad \cdot \quad$. $\quad .10$

Advanced, : $\quad \cdot \quad \cdot \quad \cdot \quad 26,35$

MEASUREMENTS, Conversion of, . 48

- Electrical, . • . . . 53

MEDICINE and SंURGंERY, Domestic, 55

for Shipmasters, . . • 40

MERCANTILE MARINE, British, - 6

METALLURGY, Elementary, . . 46

Introduction to, . . . . 41

— General, . . . . . 34

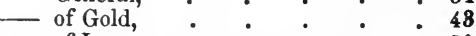

- of Iron,

MICRO-ORGANISMS, Utilization of, in the Arts and Manufactures, . 47 MINING -

- Accounts and Book-keeping, . 28

— Blasting, . . . . . 18

- Coal, : $\quad \cdot \quad \cdot \quad \cdot \quad \cdot \quad 24$

- Ore and Stone, . $\quad . \quad$ • 18

Surveying, : • . 10

NAUTICAL S̈UBंJECTS, : • : 21

NAVIGATION, • • • • • 5

OILS and FATS, . $\quad \cdot \quad \cdot \quad \cdot \quad \cdot 52$

OIL ENGINES, • • • • 16

ORE MINING, : $\quad \cdot \quad \cdot \quad 18$

PAINTING and DECORATING, - 33

PETROLEUM, • • • • . 37

PHOTOGRAPHY, - • $\quad$ - 8

PHYSICS, . $\quad \cdot \quad 26,49,52$

POISONS, Detection of, - $\quad$ is

SANITATION, . $\quad \cdot \quad 13,14,39$

SCIENCE, Popular Introduction to, . 52

SEAMANSHIP, . • • . . 5

SEWAGE, Disposal of, : $\quad$ - 18

SHIPMASTER'S MEDICAL GUIDE, 40

SHIPS, Loading, \&c., of, . . . 51

- Stability of, . $\quad . \quad$. 38,51

SOAPS, Manufacture of, $: 52$

SOCIETIES, Year-book of, . $\quad$ • $\quad$ - 54

STEAM ENGINE, Elementary, . $\quad 26$ Advanced. $\quad 26,45$

STEEL, Metallurgy of, $\quad \cdot \quad \cdot \quad 41,50$

STRUCTURES, Design of, : . $\quad$ - 4

SURVEYING, Mine, • • . 10

TEXTILE PRINTING, $\quad \cdot \quad \cdot \quad$ 14, 14

TRAVERSE TABLES, • • . 10

TRIGONOMETRY, • • 6

VALVES and VALVE-GEARING, : $\quad 23$

VARNISHES, Manufacture of, . . 25

ZOOLOGY, 


\title{
THE DESIGN OF STRUCTURES:
}

\section{Practical Treatise on the Bullding of Bridges, Roors, de.}

\author{
B y S. A N GL I N, C. E.,
}

Master of Engineering, Royal University of Ireland, late Whitworth Scholar \&c.

With very numerous Diagrams, Examples, and Tables.

Large Crown 8vo. Cloth.

SECOND EDITION, Revised. 16s.

The leading features in Mr. Anglin's carefully-planned "Design of Structures" may be briefly summarised as follows :-

r. It supplies the want, long felt among Students of Engineering and Architecture, of a concise Text-book on Structures, requiring on the part of the reader a knowledge of Elementary Mathematics only.

2. The subject of GRAPHIC STATICs has only of recent years been generally applied in this country to determine the Stresses on Framed Structures; and in too many cases this is done without a knowledge of the principles upon which the science is founded. In Mr. Anglin's work the system is explained from FIRST PRINCIPLES, and the Student will find in it a valuable aid in determining the stresses on all irregularly-framed structures.

3. A large number of Practical Examples, such as occur in the every-day experience of the Engineer, are given and carefully worked out, some being solved both analytically and graphically, as a guide to the Student.

4. The chapters devoted to the practical side of the subject, the Strength of Joints, Punching, Drilling, Rivetting, and other processes connected with the manufacture of Bridges, Roofs, and Structural work generally, are the result of MANY YEARS' EXPERIENCE in the bridge-yard; and the information given on this branch of the subject will be found of great value to the practical bridge-builder.

"Students of Engineering will find this Text-Book Invaluable."-Arckitect.

"The author has certainly succeeded in producing a THOROUGHLY PRACTICAL TextBook."-Bwilder.

"We can unhesitatingly recommend this work not only to the Student, as the BrsT TEXT-Book on the subject, but also to the professional engineer as an EXCERDINGLY vaLUABLE book of reference."-Mechanical World.

"This work can be confIDENTLY recommended to engineers. The author has wisely chosen to use as little of the higher mathematics as possible, and has thus made his book of REAL USE TO THE PRACTICAL ENGINERR. . . . After careful perusal, we have nothing but praise for the work."-Natwre.

LONDON : EXETER STREET, STRAND. 


\section{GRIFFIN'S NAUTICAL SERIES.}

\section{Price 5s. Post-free. \\ A MANUAL OE ELEMENTARY SEAMANSHIP.}

BY

D. WILSON-BARKER, MASTer MARINER; F.R.S.E., F.R.G.S., \&.., \&c.; YOUNGER BROTHER OF THE TRINITY HOUSE.

With Frontispiece, Twelve Plates (Two in Colours), and Illustrations in the Text.

General Contents. - The Building of a Ship; Parts of Hull, Masts, \&c.-Ropes, Knots, Splicing, \&c. - Gear, Lead and Log, \&c. - Rigging, Anchors - Sailmaking - The Sails, \&c. - Handling of Boats under Sail Signals and Signalling-Rule of the Road-Keeping and Relieving WatchPoints of Etiquette-Glossary of Sea Terms and Phrases-Index.

\footnotetext{
*** The volume contains the NEW RULEB OF THE ROAD.
}

"This admirable maNual, by Capt. Wilson-BakKer of the "Worcester," seems to us PERFECTLY DEsIGNED, and holds its place excellently in 'Grifriv's NadTiCal Series.' . Although intended for those who are to become Officers of the Merchant Navy, it will be found useful by ALL YACHTSMEN."-Athenæum.

"Five shillings will be WELL sPENT on this little book. CAPT. WILson-Barker knows from experience what a young man wants at the outset of his career."-The Engineer.

Price 3s. 6d. Post-free.

\section{NA VIGATION :}

\section{PRACTICAL AND THEORETICAL.}

By DAVID WILSON-BARKER, R.N.R., F.R.S.E., \&c., \&c., AND

\section{WILLIAM ALLINGHAM,}

FIRST-CLASS HONOURS, NAVIGATION, SCIENCE AND ART DEPARTMENT.

\section{Vuitb 任umerous Fllustrations and Examination Questions.}

General Contents.-Definitions-Latitude and Longitude-Instruments of Navigation-Correction of Courses-Plane Sailing-Traverse Sailing-Day's Work - Parallel Sailing - Middle Latitude Sailing - Mercator's ChartMercator Sailing-Current Sailing-Position by Bearings-Great Circle Sailing -The Tides-Questions-Appendix : Compass Error-Numerous Useful Hints, \&c.-Index.

"Precisely the kind of work required for the New Certificates of competency in gracles from Second Mate to extra Master. . . . Candidates will flnd it InvaLuable."-Dundee Advertiser.

"A CAPITAL LITTLE воок. . . specially adapted to the New Examinations. The Authors are CAPT. WILSON-BARKER (Captain-Superintendent of the Nautical College, H.M.S. "Worcester," who has had great experience on the highest problems of Navigation), and MR. AllingBaM, a well-known writer on the Science of Navigation and Nautical Astronomy." - Shipping World.

**For complete list of Griffin's Nautical Series see p. 21. 


\title{
GRIFFIN'S NAUTICAL SERIES.
}

\section{Price 3s. 6d. Post-free. \\ British Mercantile Marine.}

\author{
BY EDWARD BLACKMORE, \\ MASTER MARINER; ASSOCIATE OF THE INSTITUTION OF NAVAL ARCHITECTS; \\ FORMERLY A RESIDENT JUSTICE OF THE PEACE FOR THE COUNTY \\ OF RENFREW, N.B.; AND A MEMBER OF THE INSTITUTION \\ OF ENGINEERS AND SHIPBUILDERS IN SCOTLAND;
}

General Contents.-Hrstorical : From Early Times to 1486-Progress under Henry VIII. - To Death of Mary-During Elizabeth's Reign-Up to the Reign of William III.-The 18th and 19th Centuries-Institution of Examinations - Rise and Progress of Steam Propulsion - Development of Free Trade-Shipping Legislation, 1862 to 1875 - "Locksley Hall" CaseShipmasters' Societies-Loading of Ships-Shipping Legislation, 1884 to 1894 Statistics of Shipping. The Personnel: Shipowners-Officers-MarinersDuties and Present Position. Education : A Seaman's Education: what it should be-Present Means of Education-Hints. Discipline AnD DutyPostscript-The Serious Decrease in the Number of British Seamen, a Matter demanding the Attention of the Nation.

"Interestivg and Instructive . . . may be read with Profit and enjoyment."Glasgow Her'ald.

"Every BRANCH of the subject is dealt with in a way which shows that the writer 'knows the ropes' familiarly."-Scotsman.

"This ADMraBLE book. . . TEEMs with useful information-Should be in the hands of every Sailor."-Western Morning News.

\section{WORKS BY RICHARD C. BUCK,} of the Thames Nautical Training College, H.M.S. 'Worcester.'

\section{A Manual of Trigonometry:} With Diagrams, Examples, and Exercises. Price 3s. 6d.

*** Mr. Buck's Text-Book has been specrally PREPAREd with a view to the New Examinations of the Board of Trade, in which Trigonometry is an obligatory subject.

\section{A Manual of Algebra.}

[In Preparation.

** These elementary works on ALGEBRA and TRIGONoMETRY are written specially for those who will have little opportunity of consulting a Teacher. They are books for "sELFHELP." All but the simplest explanations have, therefore, been avoided, and ANsWERS to the Exercises are given. Any person may readily, by careful study, become master of their contents, and thus lay the foundation for a further mathematical course, if desired. It is hoped that to the younger Officers of our Mercantile Marine they will be found decidedly serviceable. The Examples and Exercises are taken from the Examination Papers set for the Cadets of the "Worcester."

** For complete list of Griffin's nautical series see p. 21.

LONDON : EXETER STREET, STRAND. 


\section{CHEMISTRY FOR ENGINEERS AND MANUFACTURERS.}

\section{A PRACTICAL TEXT-BOOK.}

BY

BERTRAM BLOUNT, AND F.I.C., F.C.S.,

Consulting Chemist to the Crown Agents for the Colonies.
A. G. BLOXAM, F.I.C., F.C.S.,

Consulting Chemist, Head of the Chemistry Department, Goldsmiths' Inst., New Cross.

With Illustrations. In Two Vols., Large 8vo. Sold Separately.

"The authors have sUCCELDED beyond all expectation, and have produced a work which should give FRESH l'OWER to the Engineer and Manufacturer."-The Times.

YOLUME I. Price 10s. 6a.

CHEMISTRY OF ENGINEERING, BUILDING, AND METALLURGY.

General Contents.-INTRODUCTION-Chemistry of the Chief Materials of Construction-Sources of Energy-Chemistry of Steam-raising-Chemistry of Lubrication and Lubricants-Metallurgical Processes used in the Winning and Manufacture of Metals.

"Practical throtghodT . . an admirable text-Book, useful not only to Students,

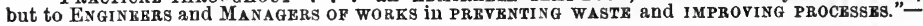
Scotsman.

"Eminentut PRactical."-Glasgow Herald.

"A book worthy of HIGH RANK. . . its merit is great. . treatment of the sulject of GASEOUS FUEL particularly good. : WATBR GAS and its production clearly worked out. of GASEO Altogether a most creditable production. We WARMLY RECOMMEND IT, and look forward with keen interest to the appearance of Vol. II."-Journal of Gas Lighting.

YOLUMEE II. Price 165.

THE CHEMISTRY OF MANUFACTURING PROCESSES.

General Contents. - Sulphuric Acid Manufacture-Manufacture of Alkali, \&c. -Destructive Distillation-Artificial Manure Manufacture-Petroleum - Lime and Cement-Clay Industries and Glass-Sugar and Starch-Brewing and Distilling-Oils, Resins, and Varnishes-Soap and Candles-Textiles and Bleaching - Colouring Matters, Dyeing, and Printing - Paper and Pasteboard-Pigments and Paints-Leather, Glue, and Size-Explosives and Matches-Minor Chemical Manufactures.

"Certainly a GOOD and USEFUL BOOK, constituting a PRACTICAL GUIDE for students by affording a clear conception of the numerous processes as a whole."-Chemical Trade Journal.

"We Confidentiy RECOMMend this volume as a Practical, and not overloaded TEXT-BOOK, of GREAT VALUE to students."-The Builder.

LONDON : EXETER STREET, STRAND. 


\section{ASSA YING (A Text-Book of):}

For the use of Students, Mine Managers, Assayers, \&c.

By J. J. BERINGER, F.I.C., F.C.S.,

Public Analyst for, and Lecturer to the Mining Association of, Cornwall.

AND C. BERINGER, F.C.S.,

Late Chief Assayer to the Rio Tinto Copper Company, London,

With numerous Tables and Illustrations. Crown 8vo. Cloth, 10/6. Fourth EDItION; Revised.

General Contents. - Part I. - Imtroductory; Manirulation: Sampling; Drying ; Calculation of Results-Laboratory-books and Reports. MerHoDs: Dry Gravimetric; Wet Gravimetric-Volumetric Assays: Titrometric, Colorimetric, GasometricWeighing and Measuring-Reagents-Formula, Equations, \&c.-Specific Gravity.

Part II.-Metals: Detection and Assay of Silver, Gold, Platinum, Mercury, Copper, Lead, Thallium, Bismuth, Antimony, Iron, Nickel, Cobalt, Zinc, Cadmium, Tin, Tungsten, Titanium, Manganese, Chromium, \&c. - Earths, Alkalies.

PART III.-Non-Metals: Oxygen and Oxides; The Halogens-Sulphur and Sut phates-Arsenic, Phosphorus, Nitrogen-Silicon, Carbon, Boron-Useful Tables.

"A REALLY MERITOzious wORK, that may be safely depended upon either for systomatic instructicen or for reference."-Nature.

"This work is one of the BEST of its kind. . . . Essentially of a practical character. Contains all the information that the Assayer will find necessary in the examination of minerals."-Engimeer.

New Edition in Preparation.

\section{P H O T O G R A P H Y :}

ITS HISTORY, PROCESSES, APPARATUS, AND MATERIALS.

Comprising Working Details of all the More Important Methods.

BY A. BROTHERS, F.R.A.S.

WITH TWENTY-FOUR FULL PAGE PLATES BY MANY OF THE PROCESSES DESCRIBED, AND ILLUSTRATIONS IN THE TEXT.

In 8vo, Handsome Cloth.

General Contents. - Part. I. Introductory - Historical Sketch; Chemistry and Optics of Photography; Artificial Light.PART II. Photographic Processes.-PART III. Apparatus.-PART IV. Materials.-PART V.-Applications of Photography ; Practical Hints.

“Mr. Brothers has had an experience in Photography so large and varied that any work by him cannot fail to be interesting and valuable. - . . A MOST COMPREHENSIVR volume, entering with full details into the various processes, and VERY PULLY illustrated. The PRACTICAL HINTS are of GREAT VALUE. . . Admirably got up."-Brit. Jour. of Photography.

"For the Illustrations alone, the book is most interesting; but, apart from these, the volume is valuable, brightly and pleasantly written, and MOST ADMIRABLY ARRANGRD." Photographic News.

"Certainly the Finest Illustrated handoook to Photography which has ever been published. Should be on the reference shelves of every Photographic Society."-Amateur Photographer.

"A handbook so far in advance of most others, that the Photographer must not fail to obtain a copy as a reference work."-Photographic Work.

"The COMPLETEST HANDBOOK of the art which has yet been published."-Scotsman.

LONDON: EXETER STREET, STRAND. 
WORKS BY A. WYNTER BLYTH, M.R.C.S., F.C.S., Barrister-at-Law, Public Analyst for the County of Devon, and Medical Officer of Health for St. Marylebone.

\section{FOODS: \\ THEIR COMPOSITION AND ANALYSIS.}

In Demy 8vo, with Elaborate Tables, Diagrams, and Plates. Handsome Cloth. Fourth Edition. Price 2ls.

GENERAL CONTENTS.

History of Adulteration-Legislation, Past and Present-Apparatus useful to the Food-Analyst-"Ash"-Sugar-Confectionery-HoneyTreacle-Jams and Preserved Fruits-Starches-Wheaten-Flour-Bread -Oats-Barley - Rye-Rice - Maize - Millet - Potato-Peas-Chinese Peas - Lentils - Beans - MrLK - Cream - Butter - Oleo-Margarine Butterine-Cheese-Lard-Tea-Coffee-Cocoa and Chocolate-AlcoholBrandy-Rum-Whisky-Gin-Arrack-Liqueurs-Absinthe-Principles of Fermentation - Yeast - Beer - Wine - Vinegar - Lemon and Lime Juice-Mustard-Pepper-Sweet and Bitter Almond-Annatto-Olive Oil - Water - Standard Solutions and Reagents. Appendix: Text of English and American Adulteration Acts.

\section{PRESS NOTICES OF THE FOURTH EDITION.}

"Simply IndispensabLe in the Analyst's laboratory." - The Lancet.

"ThE Standard WORK on the subject. - Every chapter and every page gives abundant roof of the strict revision to which the work has been subjected. . . The section on MILK is, we believe, the most exhaustive study of the subject extant. . . . An INDIsPensa BLe MaNUal for Analysts and Medical Officers of Health."-Public Health.

"A new edition of Mr. Wynter Blyth's Standard work, ENRICHed WITH ALL THE RECENT DISCOYERIES AND IMPROVEMENTS, will be accepted as a boon."-Chemical News.

\section{P O I S O N S: \\ THEIR EFFECTS AND DETECTION.}

Third Edition. In Large 8vo, Cloth, with Tables and Illustrations.

Price 2ls.

\section{GENERAI CONTENTS.}

I.-Historical Introduction. II.-Classification-Statistics-Connection between Toxic Action and Chemical Composition-Life Tests-General Method of Procedure-The Spectroscope-Examination of Blood and Blood Stains. III.-Poisonous Gases. IV.-Acids and Alkalies. V.-More or less Volatile Poisonous Substances. VI.-Alkaloids and Poisonous Vegetable Principles. VII.-Poisons derived from Living or Dead Animal Substances. VIII.-The Oxalic Acid Group. IX.-Inorganic Poisons. Appendix : Treatment, by Antidotes or otherwise, of Cases of Poisoning.

"Undoubtedly тнв Most complets wORK on Toxicology in our language."-The Analyst fon the Third Edition).

"As a PRACTICAL GUIDB, we know nO BETTRR work."-The Lancet (on the Third Edition).

* In the-Thibd Edition, Enlarged and partly Re-written, Now Axalytical MrThods have been introduced, and the CADAvEBIC ALKALOIDS, or PTOMAIN Bs, bodies playlng so great a part in Food-poisoning and in the Manifestations of Disease, have received special attention. 


\section{MINE-SURVEYING (A Text-Book of):}

\section{For the use of Managers of Mines and Collieries, Students} at the Royal School of Mines, de.

By BEN NET T H. B ROUGH, F.G.S., Late Instructor of Mine-Surveying, Royal School of Mines.

With Diagrams. Sixth Edition, Enlarged and Revised. Cloth, 7s. 6d.

\section{General Contents.}

General Explanations-Measurement of Distances-Miner's Dial-Variation of the Magnetic-Needle-Surveying with the Magnetic-Needle in presence of IronSurveying with the Fixed Needle-German Dial-Theodolite-Traversing Underground-Surface-Surveys with Theodolite-Plotting the Survey-Calculation of Areas-Levelling-Connection of Underground-and Surface-Surveys-Measuring Distances by Telescope-Setting-out-Mine-Surveying Problems-Mine PlansApplications of Magnefic-Needle in Mining-Appendices.

"Has PRoved itself a valuable Text-book; the BBST, if not the only one, in the English language on the subject."-Mining Fournal.

"No English-speaking Mine Agent * Mining Student will consider his technical library complete without it."-Natwre.

"A valuable accessory to Surveyors in every department of commercial enterprise. Fnlly deserves to hold its position as a STANDARD." - Caltiony Guardian.

\section{W O R K S}

BY WALTER R. BROWNE, M.A., M. INST. C.E., Late Fellow of Trinity College, Cambridge.

\section{THE STUDENT'S MECHANICS:} An Introduction to the Study of Foree and Motion.

With Diagrams. Crown 8vo. Cloth, 4s. 6d.

"Clear in style and practical in method, 'The STUdent's Mrchanics' is condially to be commended from all points of view."-A thenaum.

\section{FOUNDATIONS OF MECHANICS.} Papers reprinted from the Engineer. In Crown 8vo, Is.

\section{FUEL AND WATER:}

A Manual for Users of Steam and Water. By Prot. SCHWACKHÖFER AND W. R. BROWNE, M.A. (See p. 44.)

LONDON : EXETER STREET, STRAND. 


\title{
GAS MANUFACTURE (THE CHEMISTRY OF).
}

\section{A Hand-Book on the Production, Purification, and Testing}

of Illuminating Gas, and the Assay of the Bye-

Products of Gas Manufacture. For the

Use of Students.

BY

W. J. ATKINSON BUTTERFIELD, M.A., F.C.S., Head Chemist, Gas Works, Beckton, London, E.

With Numerous Illustrations. Handsome Cloth. Price 9s.

"The BEST wORK of its kind which we have ever had the pleasure of reviewing."-Journal of Gas Lighting.

\section{GENERAL CONTENTS.}

I. Raw Materials for Gas Manufacture.

II. Coal Gas.

III. Carburetted Water Gas.

IV. Oil Gas.

V. Enriching by Light 0ils.
VI. Final Details of Manufacture.

VII. Gas Analysis.

VIII. Photometry.

IX. Applications of Gas.

X. Bye-Products.

\begin{abstract}
* * This work deals primarily with the ordinary processes of Gas Manufacture employed in this country, and aims especially at indicating the principles on which they are based. The more modern, but as yet subsidiary, processes are fully treated also. The Chapters on Gas Analysis and Photometry will enable the consumer to grasp the methods by which the quality of the gas he uses is ascertained, and in the Chapter on The Applications of Gas, not only is it discussed as an illuminant, but also as a ready source of heat and power. In the final Chapter, an attempt has been made to trace in a readily-intelligible manner the extraction of the principal derivatives from the crude BYE-PRoDucts. The work deals incidentally with the most modern developments of the industry, including inter alia the commercial production and uses of acetylene and the application of compressed gas for Street Traction. The needs of the Students in Technical Colleges and Classes have throughont been kept in view.
\end{abstract}




\section{Works by GRENVILLE A. J. COLE, M.R.I.A., F.G.S.,}

Professor of Geology in the Royal College of Science for Ireland.

\section{PRACTICAL GEOLOGY ( A IDS I N): \\ WITH A SECTION ON PALAEONTOLOGY.}

Second Edition, Revised. With Illustrations. Cloth, ros. 6d.

GENERAL CONTENTS. - PART I.-SAMPLING OF THE EARTH'S CRUST. PART II.-EXAMINATION OF MINERAIS. PART III.-EXaminaTION OF ROCKS. PART IV.-EXAMINATION OF FOSSILS.

"Prof. Cole treats of the examination of minerals and rocks in a way that has never been attempted before.. DESERVING OF THB HIGHEST PRAISE. Here indeed are 'Aids' inNumerable and invaluable. All the directions are given with the utmost clearness and precision."-Athenaum.

"To the younger workers in Geology, Prof. Cole's book will be as INDISPRNSAELx as a dictionary to the learners of a language." -Saturday Review.

"That the work deserves its title, that it is full of 'AIDs,' and in the highest degree 'PRACTICAL,' will be the verdict of all who use it."-Nature.

"This EXCkLLENT MANUAL . . . will be A verY Great help. . . The section on the Examination of Fossils is probably the BEST of its kind yet published. . . FULL of well-digested information from the newest sources and from personal research." - Annals of Nat. History.

\section{O P E N - A I R S T U DIE S:}

\section{An Introduction to Geology Out-of-doors.}

With 12 Full-Page Illustrations from Photographs. Cloth. 8s. 6d.

General Contents. - The Materials of the Earth-A Mountain Hollow -Down the Valley-Along the Shore-Across the Plains-Dead Volcanoes -A Granite Highland-The Annals of the Earth-The Surrey Hills-The Folds of the Mountains.

"The fascinating 'Open-Air Strdies' of Prof. Cole give the subject a glow of ANIMATION . . . cannot fail to arouse keen interest in geology."-Geological Magazine.

"EMinentuy readable ... every small aetail in a scene touched with a sympathetic kindly pen that reminds one of the lingering brush of a Constable."-Nature.

"The work of Prof. Cole combines ELEgaNCE of STYLE with sCIENTIFIC THOROUGHNEss."Petermann's Mittheilungen.

"The book is worthy of its title; from cover to cover it is sTRONG with bracing freshness of the mountain and the field, while its ACCURACY and THOROUGHNESs show that it is the work of an earnest and conscientious student. . . . Full of picturesque touches which are most welcome"-Natural Science.

"A CHARMING BOoK, beautifully illustrated."-Athenæum.

** For the Companion-Volume on "Open Air Botany" see p. 33.

LONDON : EXETER STREET, STRAND. 


\title{
SEWAGE DISPOSAL WORKS:
}

\section{$\Delta$ Guide to the Construction of Works for the Prevention of the Pollution by Sewage of Rivers and Estuaries.}

BY

\author{
W. SA N T O C R I M P, M.Inst. C.E., F.G.S., \\ Late Assistant-Engineer, London County Council.
}

With Tables, Illustrations in the Text, and 37 Lithographic Plates. Medium 8 vo. Handsome Cloth.

Second Edition, Revised and Enlarged. 30 s.

\section{PART I.-INTRODUCTORY.}

Introduction.

Details of River Pollutions and Recommenda-

Settling Tanks.

tions of Various Commissions.

Hourly and Daily Flow of Sewage.

The Pail System as Affecting Sewage.

The Separation of Rain-water from the Sewage Proper.

Chemical Processes.

The Disposal of Sewage-sludge.

The Preparation of Land for Sewage Dis. posal.

Table of Sewage Farm Management.

\section{PART II.-Sewage Disposal Works in Operation-Their Construction, Maintenance, and Cost.}

Illustrated by Plates showing the General Plan and Arrangement adopted in each District.

Map of the LONDON Sewage System.

Crossness Outfall.

Barking Outfall.

Doncaster Irrigation Farm.

Beddington Irrigation Farm, Borough of Croydon.

Bedford Sewage Farm Irrigation.

Dewsbury and Hitchin Intermittent Filtration.

Merton, Croydon Rural Sanitary Authority.

Swanwick, Derbyshire.

The Ealing Sewage Works.

Chiswick.

Kingston-on-Thames, A. B. C. Process.

Salford Sewage Works.

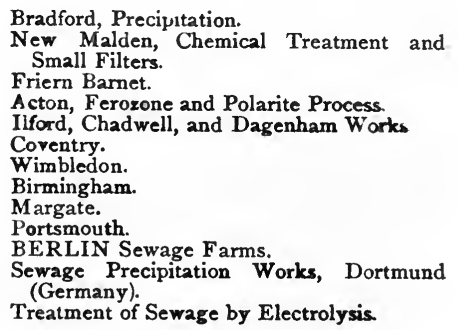

Acton, Ferozone and Polarite Process.

Ilford, Chadwell, and Dagenham Works

Coventry.

Wimbledon.

Birmingham.

Margate.

Portsmouth.

BERLIN Sewage Farms.

Sewage Precipitation Works, Dortmund (Germany).

Treatment of Sewage by Electrolysis.

** From the fact of the Author's having, for some years, had charge of the Main Drainage Works of the Northern Section of the Metropolis, the chapter on LoNDon will be found to contain many important details which would not otherwise have been available.

"All persons interested in Sanitary Science owe a debt of gratitude to Mr. Crimp. . . . His work will be especially useful to Savita RY AUTHORITIES and their advisers . : . EMENENTLY PRACTICAL AND USEFUL MOST IMPORTANT SEWAGE WORKS of England . . . with very valuable information as to. the cosT of construction and working of each. . . . The carefully-prepared drawings permit of an easy comparison between the different systems."-Lancet.

"Probably the MOST COMPLetr AND BEST TREATISE on the subject which has appeared in our language. Will prove of the greatest use to all who have the problem of Sewrage Disposal to face."-Edinburgh Madical Jowrnal. 


\section{Griffin's “Pocket-Book” Sepies.}

Pocket Size. Leather. With Illustrations. 12s. 6d.

\section{HYGIENE (A Hand-Book of),}

BY

SURGEON-MAJOR A. M. DAVIES, D.P.H.Oamb., Late Assistant-Professor of Hygiene, Army Medical School.

\section{General Contents.}

Air and Ventilation-Water and Water Supply-Food and DietingRemoval and Disposal of Sewage-Habitations-Personal Hygiene-Soils and Sites-Climate and Meteorology-Causation and Prevention of Disease -Disinfection.

"This ADMIRABLE HANDBOOK . . gives FULI infolmation compressed into the smallest possible bulk." - Edin. Med. Journai.

"The elegant dress of the little volume before $\mathrm{ns}$ is but the outer covering of $\triangle$ TRULY RICH KERNEL, and justly merits the praise it spontaneously calls forth. Attractive to the eye, SurgeonMajor DAvIEs' volume is equally attractive to the mind. Students will find that its 590 pages comprise ALL information necessary. COMPACT, HANDY, COMPREHENSIVE, it certainly merits a high place among the text-books of the day."-sanitary Record.

"We are glad to welcome Surgeon-NIajor Davies' book . . he has had ample opportunity to make himself A MASTER OF THE SCIBNCE, and he has a right to speak. ". . WONDERPULLY WELI UP TO DATE, well and clearly written, pleasant to read." - The Lancet.

"Really an ADMIRABLE BOOK. ... A MOST HANDY WORK OP REFERENCE full of information." -The Hospital.

"A singularly compact and elegant volume . . . contains an admirable précis of everything relating to Hygiene CLEARLY and LOGICAILT ARRANGRD and easy of reference. Likely, we think, to be the favourite text-book."-Public Health.

Large 8vo. Handsome Cloth. 12s. 6d.

\section{BLEACHING \& CALICO-PRINTING.}

\section{A Short Manual for Students and}

\section{Practical Men.}

\section{BY GEORGE D UERR,}

Director of the Bleaching, Dyeing, and Printing Department at the Accrington and Bacup Technical Schools; Chemist and Colourist at the Irwell Print Works.

\section{Assisted By WILLIAM TURNBULL} (of Turnbull \& Stockdale, Limited).

With Illustrations and upwards of One Hundred Dyed and Printed Patterns designed specially to show various Stages of the Processes described.

"When a READY WAY out of a difficulty is wanted, it is IN BOOKS LIKE THIS that it is found."Textile Recorder.

"Mr. DURRR's wORk will be found MOST USEFUL. . . The information given of GRBAT vaLUB. - . The Recipes thorodghly PRACTICAL," - Textile Manufacturer.

LONDON : EXETER STREET, STRAND. 


\title{
W O R K S
}

\section{BY J. R. A IN S WOR T H D A VIS, B.A., \\ PROTESSOR OF BIOLOGY, UNIVERSITY COLLRGE, ABERYSTWYTH; EXAMINER IN ZOOLOGY, UNIVERSITY OF ABERDEEN.}

\section{DAVIS (Prof. Ainsworth): BIOLOGY (An Ele-} mentary Text-Book of). In large Crown 8vo, Cloth. Second Edition.

Part I. Vegetable Morphology and Physrology. With Complete IndexGlossary and 128 Illustrations. Price 8s. 6d.

Part II. Animal Morphology and Physiology. With Complete IndexGlossary and ro8 Illustrations. Price ros. $6 \mathrm{~d}$.

\section{EACH PART SOLD SEPARATELY.}

\begin{abstract}
* Note-The SEcond Edition has been thoroughly Revised and Enlarged, and includes all the leading selected TYPES in the various Organic Groups.

"Certainly THE BEST 'BIOLOGY' with which we are acquainted. It owes its preeminence to the fact that it is an EXCELLENT attempt to present Biology to the Student as a CORRELATED AND COMPLETE SCIENCE. The glossarial Index is a MOST USEFUL addition."British Medical Journal.

"Furnishes a CLEAR and COMPREHENSIVE exposition of the subject in a sYSTEMATIC form." - Saturday Review.

"Literally PACKED with information."-Glasgow Medical Journal.
\end{abstract}

\section{DAVIS (Prof. Ainsworth): THE FLOWERING} PLANT, as Illustrating the First Principles of Botany. Large Crown 8 vo, with numerous Illustrations. 3s. 6d. SECOND EDITION.

"It would be hard to find a Text-book which would better guide the student to an accurate knowledge of modern discoveries in Botany. . . The SCIENTIFIC ACCURACY of statement, and the concise exposition of FIRST PRINCIPLes make it valuable for educational purposes. In the chapter on the Physiology of Flowers, an admirable reswme is given, drawn from Darwin, Hermann Müller, Kerner, and Lubbock, of what is known of the Fertilization of Flowers."

\section{DAVIS and SELENKA: A ZOOLOGICAL} POCKET-BOOK; Or, Synopsis of Animal Classification. Comprising Definitions of the Phyla, Classes, and Orders, with Explanatory Remarks and Tables. By Dr. Emil Selenka, Professor in the University of Erlangen. Authorised English translation from the Third German Edition. In Small Post 8vo, Interleaved for the use of Students. Limp Covers, 45 .

"Dr. Selenka's Manual will be found useful by all Students of Zoology. It is a compraHENarve and sUCCESSFUL attempt to present us with a scheme of the natural arrangement of the animal world." $-E$ dir. Med. Jowrmal.

"Will prove very serviceable to those who are attending Biology Lectures. . . . The tramalation is accurate and clear."-Larcet.

LONDON : EXETER STREET, STRAND. 


\section{GAS, OIL, AND AIR ENGINES:}

\section{A Practical Text-Book on Internal Combustion Motors without Boiler.}

\section{By BRYAN DONKIN, M. Inst.C.E.}

SECond Edition, Revised throughout and Enlarged. With numerous additional Illustrations. Large 8vo. 25s.

Grimral Contrnts.-Gás Engines:-General Description-History and Development-British, French, and German Gas Engines-Gas Production for Motive PowerTheory of the Gas Engine-Chemical Composition of Gas in Gas Engines-Utilisation of Heat-Explosion and Combustion. Oil Motors :-History and Development-Various Types-Priestman's and other Oil Engines. Hot-Air Engines :-History and Development-Various Types: Stirling s, Ericsson's, \&c., \&c.

"The вEST воOK NOW PUBLISHED on Gas, Oil, and Air Engines. ... Will be of VERY GREAT INTEREST to the numerous practical engineers who have to make themselves familiar with the motor of the day. . . Mr Donkin has the advantage of LONG PRACTICAL EXPERIENCR, combined with HIGH SCIENTIFIC AND EXPERIMENTAL KNOWLEDGE, and an accurate perception of the requirements of Engineers."-The Engineer.

"We HEARTILY KECOMMEND Mr. Donkin's work. . A monument of careful labour. . . . Luminous and comprehensive."-Journal of Gas Lighting.

\section{THE HEAT EFFICIENCY OF STEAM BOILERS (LAND AND MARINE).}

Many Experiments on Many Types, showing Results as to Evaporation, Heating Value of Fuel, Analysis of Gases, \&c., \&c. By Bryan Donkin, M. Inst. C.E. With Illustrations and Tables. In 4 to.

\section{INORGANIC CHEMISTRY (A Short Manual of).}

BY A. D U PRÉ, Ph. D., F.R.S., AN D WILSON HAKE, Ph.D., F.I.C., F.C.S., of the Westminster Hospital Medical School.

Second Edition, Revised. Crown 8vo. Cloth, 7s. 6d.

"A well-written, clear and accurate Elementary Manual of Inorganic Chemistry. . . . . We agree heartily in the system adopted by Drs. Dupré and Hake. WILL MAKr ExpreiMENTAL WORK TREBLY INTERESTING BECAUSE INTELLIGIBLE." - Saturday Reviez.

"There is no question that, given the PRRFECT GROUNDING of the Student in his Science, the remainder comes afterwards to him in a manner much more simple and easily acquired. The work is AN EXAMPLe OF THE ADVANTAges OF THE SYSTEMATIC TREATMENT of 2 Science over the fragmentary style so generally followed. BY A LONG WAY THE BHST of the small Manuals for Students."-Analyst.

EWART (J. Cossar, M.D., F.R.S.E., Regius Professor of Natural History, University of Edinburgh).

HINTS ON THE PRESERVATION OF FISH, in Reference to Food Supply. In Crown 8vo. Wrapper, 6d.

LONDON : EXETER STREET, STRAND. 
Srcond EdITION, Revised. Royal 8vo. With numerous Illustrations and 13 Lithographic Plates. Handsome Cloth. Price 30 .

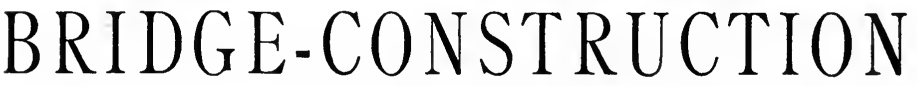

(A PRACTICAL TREATISE ON):

Being a Text-Book on the Construction of Bridges in Iron and Steel.

FOR THE USE OF STUDENTS, DRAUGHTSMEN, AND ENGINEERS.

B y T. C L A X T O F I L E R, M. I n T. C. E., Prof. of Engineering, University College, Dundee.

"Mr. Fidler's success arises from the combination of eXPERIENCE and sIMPLICITY OF TREATMENT displayed on every page. . . . Theory is kept in subordination to practice, and his book is, therefore, as useful to girder-makers as to students of Bridge Construction."-("The Architect" on the second Edition.)

"Of late years the American treatises on Practical and Applied Mechanics have taken the lead .. . since the opening up of a vast continent has given the American engineer a number of new bridge-problems to solve . but we look to the PRRsBNT TrRatise oN BRIDGr-Construction, and the Forth Bridge, to bring us to the front again."-Engineer.

"One of the VRRY BRST RBCENT WORKS on the Strength of Materials and its application to Bridge-Construction. . . Well repays a careful Study." Enginoering.

"An INDISPENSABLE HANDBOOK for the practical Engineer."-Nature.

\section{HOW PLANTS LIVE AND WORK:}

A Simple Introduction to Real Life in the Plant-world, Based on Lessons originally given to Country Children.

By ELEANOR HUGHES-GIBB.

With Illustrations. Crown 8vo. Cloth. 2s. 6d.

${ }_{*}^{*}$ The attention of all interested in the Scientific Training of the Young is requested to this DELIGHTFULLY FRFSH and CHARMING LITTLE BOOK. It ought to be in the hands of every Mother and Teacher throughout the land.

"The child's attention is first secured, and then, in language SIMPLE, YET SCIENTIFICALLY ACCURATE, the first lessons in plant-life are set before it."Natural Science.

"In every way well calculated to make the study of Botany atTractive to the young."-Scotsman.

LONDON : EXETER STREET, STRAND. 


\section{ORE \& STONE IMINING.}

BY

C. LE NEVE FOSTER, D.Sc., F.R.S.,

PROFESSOR OF MINING, ROYAL COLLEGE OF SCIENCE H.M. INSPECTOR OF MINES

Second Edition. With Frontispiece and 7 I6 Illustrations. 34s.

“Dr. Foster's book was expected to be ЕРОСн-мАKING, and it fully justifies such expectation. . . A MOST ADMIRABLE account of the mode of occurrence of practically ALL known minerals. Probably stands unRIValled for completeness."-The Mining Fournal.

\section{GENERAL CONTENTS.}

INTRODUCTION. Mode of Occurrence of Minerals : Classification: Tabular Deposits, Masses-Examples: Alum, Amber, Antimony, Arsenic, Asbestos, Asphalt, Barytes, Borax, Boric Acid, Carbonic Acid, Clay, Cobalt Ore, Copper Ore, Diamonds, Flint, Freestone, (rold Ore, Graphite, Gypsum, Ice, Iron Ore, Lead Ore, Manganese Ore, Mica, Natural Gas. Nitrate of Soda, Ozokerite, Petroleum, Phosphate of Lime, Potassium Salts, Quicksilver Ore, Salt, Silver Ore, Slate, Sulphur, Tin Ore, Zınc Ore. Faults. Prospecting: Chance Discoveries - Adventitious Finds - Geology as a Guide to Minerals-Associated Minerals-Surface Indications. Boring: Uses of Bore-holes-Methods of Boring Holes: i. By Rotation, ii. By Percussion with Rods, iii. By Percussion with Rope. Breaking Ground: Hand Tools-MachineryTransmission of Power-Excavating Machinery: i. Steam Diggers, ii. Dredges, iii. Rock Drills, iv. Machines for Cutting Grooves, v. Machines for TunnellingModes of using Holes-Driving and Sinking-Fire-setting-Excavating by Water. Supporting Excavations: Timbering-Masonry-Metallic Supports-Watertight Linings-Special Processes. Exploitation: Open Works :-Hydraulic MiningExcavation of Minerals under W ater-Extraction of Minerals by Wells and Boreholes-Underground Workings-Beds-Veins-Masses. Haulage or Transport: Underground: by Shoots, Pipes, Persons, Sledges, Vehicles, Railways, Machinery, Boats-Conveyance above Ground. Hoisting or Winding: Motors, Drums, and Pulley Frames-Ropes, Chains, and Attachments-Receptacles-Other AppliancesSafety Appliances-Testing Ropes-Pneumatic Hoisting. Drainage: Surface Water -Dams-Drainage Tunnels-Siphons - Winding Machinery - Pumping Engines above ground-Pumping Engines below ground-Co-operative Pumping. Ventilation: Atmosphere of Mines-Causes of Pollution of Air-Natural VentilationArtificial Ventilation: i. Furnace Ventilation, ii. Mechanical Ventilation-Testing the Quality of Air-Measuring the Quantity and Pressure of the Air-Efficiency of Ventilating Appliances - Resistance caused by Friction. Lighting : Reflected Daylight-Caridles-Torches-Lamps-Wells Light-Safety Lamps-Gas-Electric Light. Descent and Ascent: Steps and Slides-Ladders-Buckets and Cages-Man Engine. Dressing: i. Mechanical Processes: Washing, Hand Picking, Breaking Up, Consolidation, Screening - ii. Processes depending on Physical Properties : Motion in Water, Motion in Air-Desiccation-Liquefaction and DistillationMagnetic Attraction-iii. Chemical Processes: Solution, Evaporation and Crystallisation, Atmospheric Weathering, Calcination, Cementation, Amalgamation-A p. plication of Processes-Loss in Dressing-Sampling. Princlples of Employment of Mining Labour: Payment by Time, Measure, or Weight-By Combination of these-By Value of Product. Legislation affeeting Mines and Quarries: Ownership-Taxation-Working Regulations-Metalliferous Mines Regulation Acts -Coal Mines Regulation Act-Other Statutes. Condition of the Miner: Clothing -Housing-Education-Sickness-Thrift-Recreation. Accidents : Death Rate of Miners from Accidents-Relative Accident Mortality Underground and Aboveground-Classification of Accidents-Ambulance Training.

"This EPOCH-MAKING work... appeals to MEN OF EXPERIENCE no less than to students . gives numercus examples from the MINING PRACTICE of EVERY COUNTRY. Many of its chapters are upon subjects not usually dealt with in text books. . . Of great interest. . . . Admirably illustrated."-Berg-und Hüttenmännische Zeitung.

"This SPLANDID work."-Oesterr. Ztschrft. fuir Berg-und Hüttenwesen. 
Second Edition, 8s. 6d. Leather, for the Pocket, 8s. 6d.

\section{GRIFFIN'S ELECTRICAL PRICE-BOOK.}

For Electrical, Civil, Marine, and Borough Engineers, Local Authorities, Architects, Railway Contractors, \&c., \&c.

\section{EDITED BY H. J. DOWSING,}

Member of the Institution of Electrical Engineers; of the Society of Arts; of the London Chamber of Commerce, \&c.

"The Electrical Price-Book Removes all MYSTERy about the cost of Electrical Power. By its aid the EXPENSE that will be entailed by utilising electricity on 2 large or small sale can be discovered."-Anchitect.

"The value of this Electrical Price-Book CANNot Be orer-estimated. . . . Will save time and trouble both to the engineer and the business man."-Machinery.

GRIFFIN (John Joseph, F.C.S.) :

CHEMICAL RECKEATIONS: A Popular Manual of Experinental Chemistry. With 540 Engravings of Apparatus. Tenth Edition. Crown 8vo. Cloth. Complete in one volume, Parts I. and II. Cloth, gilt top, $12 / 6$.

Part II.-The Chemistry of the Non-Metallic Elements, Io/6.

\section{GURDEN (Richard Lloyd, Authorised Surveyor} for the Governments of New South Wales and Victoria) :

TRAVERSE TABLES: computed to Four Places Decimals for every Minute of Angle up to 100 of Distance. For the use of Surveyors and Engineers. Fol-RTH EDITION. Folio, strongly half-bound, 21/.

* Published with Concurrence of the Surveyors-General for New South Wales and Victoria.

"Those who have experience in exact SURVEY-wORK will best know how to appreciate the enormous amount of labour represented by this valuable book. The computations enable the user to ascertain the sines and cosines for a distance of twelve miles to within half an inch, and this BY REFERENCE TO BUT ONE TABLE, in place of the usual Fifteen minute computations required. This alone is evidence of the assistance which the Tables ensure to every user, and as every Surveyor in active practice has felt the want of sucb assustance, few knowing of their publication will remain without them."-Engineer.

In Large 8vo, with Illustrations and Folding-Plates. ros. $6 d$ B I A $S$ I I I G :

A Handbook for the Use of Engineers and others Engaged in Mining, Tunnelling, Quarrying, \&c.

By OSCAR GUTTMANN, Assoc. M. Inst. C.E.

Member of the Societies of Civil Engineers and Architects of Vienna and Budapest, Corresponding Member of the Imp. Roy. Geological Institution of Austria, \&ic.

General Contents.-Historical Sketch-Blasting Materials-Blasting Powder-Various Powder-mixtures-Gun-cotton-Nitro-glycerine and DynamiteOther Nitro-compounds-Sprengel's Liquid (acid) Explosives -Other Means of Blasting-Qualities, Dangers, and Handling of Explosives-Choice of Blasting Materials-Apparatus for Measuring Force-Blasting in Fiery Mines-Means cf Igniting Charges-Preparation of Blasts-Bore-holes-Machine-drilling-Chamber Mines-Charging of Bore-holes-Determination of the Charge-Blasting in Boreholes-Firing-Straw and Fuze Firing-Electrical Firing-Substitutes for Electrical Firing-Results of Working-Various Blasting Cperations-Quarrying-Blasting Masonry, Iron and Wooden Structures-Blasting in earth, under water, of ice, \&c.

"This ADMIRABLE work."-Colliery Guardian.

"Should prove a vade-mecum to Mining Engineers and all engaged in practical work. -Iron and Coal Trades Reviez.

LONDON : EXETER STREET, STRAND. 


\section{Griffin's Standard Publications}

FOR

ENGINEERS, ELECTRICIANS, ARCHITECTS, BUILDERS, NAVAL CONSTRUCTORS, AND SURVEYORS.

Applied Mechanies, . Rankine, Browne, Jamieson, 35, 10, 26

Civil Engineering, - . Prof. Rankine, - 35

Bridge-Construction, . Prof. Fidler, . - 17

Design of Structures, . S. Anglin, . . . 4

Sewage Disposal Works, Santo Crimp, . . 13

Traverse Tables, . . $\quad$ R. L. Gurden, . . 19

Marine Engineering, . A. E. Seaton, . - 45

Stability of Ships, - Sir E. J. REeD, - 38

The Steam-Engine, . . Rankine, Jamieson, . 35, 26

Valves and Valve-Gearing, Chas. Hurst, . . 23

Gas, Oil, and Air-Engines, Bryan Donkin, . 16

Boiler Construction, - T. W. Traill, . . 49

, Management, . R. D. Munro, . . 30

Chemistry for Engineers, Blount \& Bloxam, . 7

$\begin{gathered}\text { Fuel and Water (for } \\ \text { Steam Users), }\end{gathered} .\left\{\begin{array}{c}\text { SchWACKhöFER AND } \\ \text { BRowne, }\end{array}\right\} 44$

Machinery and Millwork, Prof. Rankine, . 35

Hydraulic Machinery, . Prof. Robinson, • 42

Metallurgical Machinery, H. C. Jenkins, • 41

Nautical Text-Books, - Captain Blackmore (Ed.), 21

Useful Rules and Tables $\quad\left\{\begin{array}{c}\text { Profs. Rankint and } \\ \text { Jamieson, }\end{array}\right\} 35$

for Engineers, \&c., $\left.\cdot \begin{array}{r}\text { Jamieson, } \\ \text { MUNRo and JAMinson, }\end{array}\right\}$

$\begin{array}{lll}\text { Electrical Pocket-Book, } & \text { Munro And Jaminson, } & 31 \\ \text { Electrical Price-Book, . } & \text { H. J. Dowsing, . } & 19\end{array}$

The Calculus for Engineers, Prof. Roвт. H. Sмiтн, 48

Graphic Tables for Con-

version of Measurements, Prof. Roвт. H. Sмітн, 48

Marine Engineers' Pocket-

Book, . . . . Seaton and Rounthwaite, 45

Nystrom's Pocket-Book, Dennis Marks, . . 31

LONDON : EXETER STREET, STRAND. 


\section{GRIFFIN'S NAUTICAL SERIES.}

\section{EDITED BY EDW. BLACKMORE,}

Master Mariner, First Class Trinity House Certificate, Assoc. Inst. N.A. ; AND WRITTEN, MAINLI, by SAILoRS for SAILORS.

In Crown 8vo. With Illustrations and Plates.

"A VERY USEFul SERIES."-Nature. "This ADMIRABLE SERIES."-Fairplay.

"The volumes of MESSRS. GRIFFIN'S NAUTICAL SERIES may well and profitably be read by ALL interested in our NATIONAL MARITIME PROGRESS."-Marine Engineer.

"EVERY SHIP should have the WHOLE SERIES as a REFERENCE LIBRARY. HAND. SOMELT BOUND, CLEARLY PRINTED and ILLUSTRATED."-Liverpool Journ. of Commerce.

The British Mercantile Marine: An Historical Sketch of its Rise and Development. By the EDITOR, CAPT. BLACKMORE. 3s. 6d.

"This ADMIRABLE book . . TEEMS with useful information. Should be in the hands of every Sailor."-Western Morning News.

Elementary Seamanship. By D. WILson-BARKer, Master Mariner, F.R.S.E., F.R.G.S. With numerous Plates, two in Colours, and Frontispiece. 5s.

"'This ADMIRABLE MANUAL, by CAPT. WILSON BARKER, of the 'Worcester,' seems to us PERFECTLY DESIGNED." - Athenceum.

Know Your Own Ship: A Simple Explanation of the Stability, Construction, Tonnage, and Freeboard of Ships. By THOS. WALTON, Naval Architect, Late Lecturer to Ships' Officers, Government Navigation School, Leith. With numerous Illustrations. THIRD EDITION. 5s.

"MR. WALTON'S book will be found VERY USEFUL."-The Engineer.

Navigation: Theoretical and Practical. By D. Wilson-Barker, Master Mariner, \&c., and WilliaM AliinghaM. 3s. 6d.

"PRECISELY the kind of work required for the New Certificates of competency in grades from Second Mate to extra Master. . . . Candidates will find it INVALUABLE."-Dundee Advertiser.

Latitude and Longitude: How to find them. By W. J. Millar, C.E., late Sec. to the Inst. of Engineers and Shipbuilders in Scotland. 2s.

"Cannot but prove an acquisition to those studying Navigation."-Marine Engineer.

Practical Mechanies: Applied to the requirements of the Sailor. By Thos. Mackenzie, Master Mariner, F.R.A.S. 3s. 6d.

"WELL WORTH the money. . . EXCEEDINGLY HELPFU

Ocean Meteorology: For Officers of the Merchant Navy.

WILLIAM ALLINGHAM, First Class Honours, Navigation, Science and Art Dep.

Trigonometry : For the Young Sailor, \&c. By Rich. C. Buck, of the Thames Nautical Training College, H.M.S. "Worcester." Price 3s. 6d.

Practical Algebra. By Rich. C. Buck.

[Shortly.

A Medical and Surgical Help for Shipmasters and Officers IN THE MERCHANT NAVY. Including First Aid at Sea. By WM. JoHnson SMITH, F.R.C.S., Principal Medical Officer, Seaman's Hospital, Greenwich. With Illustrations and Coloured Plates. Handsome Cloth, $6 \mathrm{~s}$.

"SOUND, JUDICIOUS,' REALLY HELPFUL."-The Lancet.

The Legal Duties of Shipmasters and Offleers. By Benedict Wm. GINSBURG, M.A., LL.D., Barrister-at-Law. 


\section{Griffin's Geological, Mining, and Metallurgical Publications.}

Geology (Stratigraphical) (Physical), .

R. Etheridge, .

,

(Practical), .

Mine Accounts, Prof. Seeley,

Prof. Cole,

" (Introduction to), Mine-Surveying, Mining, Coal, Ore and Stone, Blasting and Explosives, Assaying, . Prof."Lawn, $\quad \cdot \quad \cdot \quad 28$

B. H. Brough, . 10 H. W. Hughes, . . 24

Prof. Le Neve Foster, 18

O. Gutrmann, - . 19

J. J. \& C. Beringer, 8 Metallurgy, . . . Phillips and Bauerman, 34

,, (Introduction to), Prof. Roberts-Austen, 41

, (Elementary), . Prof. Sexton, . . 46 Gold, Metallurgy of, - T. K. Rose, . . 43 Getting Gold, . . . J. C. F. Johnson, . 28 Iron, Metallurgy of, . Thos. Turner, . . 50 Electro-Metallurgy, . - W. G. M'Millan, . 29 Electric Smelting, . . Borchers and M'Millan, 29

\section{Griffin's "Health" Publications.}

Ambulance, Dr. RidDell, .

Disinfection and Disinfectants, Dr. Rideal, • . 39 First Aid at Sea, . . Wm. Johnson Smith, . 40 Foods and Poisons,. . A. Wynter Blyth, . 9 Hygiene, . . . . Surgeon-Major Davies, 14 Practical Sanitation, . Dr. Geo. Reid, . . 39 Sewage Disposal Works,. Santo Crimp, . . 13 Hygienic Prevention of $\{$ Dr. SQuire. [See Medical Consumption, . . $\{$ Catalogue.] 


\section{Griffn's Chemical and Technological Publications.}

Chemistry for Engineers and Manufacturers, . Bleaching and CalicoPrinting, . .

Brewing,

Cements, Disinfectants, . Dyeing,

, and Cleaning,

Fermentation,

Foods, Analysis of, .

Gas Manufacture,

Oils, Soaps, Candles,

MM. Blount and Bloxam, 7

Geo. Duerr, . $\quad$. 14

Dr. SyKes, . . 47

G. R. ReDGrave, - 36

Dr. Rideal, • • 39

MM. KNECHT AND Rawson, 27

G. H. HuRst, - . 25

Lafar aNd SALter, . 47

Wynter Blyth, . 9

W. Atkinson Butter field, 11

Dr. Alder Wright, . 52

Painters' Colours, Varnishes, G. H. Hurst, . . 25

Petroleum, . . MM. REDWOOd aNd Holloway, 37

Photography, . . . A. Brothers, . . 8

Poisons, Detection of, - Wynter Blyth, - 9

Textile Printing, . . Seymour Rothwell, . 44

In Large 8vo. With Numerous Illustrations. Price 7s. 6d.

\section{VALVES AND VALVE-GEARING:}

A PRACTICAL TEXT-BOOK FOR THE USE

OF ENGINEERS, DRAUGHTSMEN, AND STUDENTS.

BY

CHARLES HURST, Practical Draughtsman.

" Useful and thorodghly PRActical. Will undoubtedly be found of GReat value to all concerned with the design of Valve-gearing."-Mechanical Wovld.

"Dealt with in a sIMPLE and INTERESTING manner. . . Almost EVERY TYPE of vALVE and its gearing is clearl set forth, und illustrated in such a wav as to be READILY UNDERSTOOD and PRACTICALLY APPLIED by either the Engineer, Draughtsman. or Student. -. Should prove both USEFUL and VAl.JABLE to all Engineers $\$$ eking for RELIABLE and CLEAR information on the subject. Its moderate price brings it within the reach of all."Industries an' Iron

"Mr. HURST's work is ADMIRABLY suited to the needs of the practical mechanic. It is free from any elaborate theoretical discussions, and the explanations of the various types of valve-gear are accompanied by diagrams which render them EAsILY UNDERSTOOD." -The Scientific American.

LONDON: EXETER STREET, STRAND. 


\title{
COAL MINING (A Text-Book of): FOR THE USE OF COLLIERY MANAGERS AND OTHERS ENGAGED IN COAL-MINING.
}

\author{
BY
}

H E R B ERT W I L L I M H U G H ES, F.G.S., Assoc. Royal School of Mines, Certificated Colliery Manager.

Third Edition. In Demy 8vo, Handsome Cloth. With very Numerous Illustrations, mostly reduced from Working Drawings. $18 s$.

"The details of colliery work have been fully described, on the ground that collieries are more often made REMUNERATIVE by PERFECTION IN SMALL MATTERS than by bold strokes of engineering. . . . It frequently happens, in particular localities, that the adoption of a combination of small improvements, any of which viewed separately may be of apparently little value, turns an unprofitable concern into a paying one."-Extract from Author's Preface.

\section{GENERAL CONTENTS.}

Geology: Rocks-Faults-Order of Succession-Carboniferous System in Britain. Ooal: Definition and Formation of Coal-Classification and Commercial Value of Coals. Bearch for Coal: Boring-various appliances used-Devices employed to meet Difficulties of deep Boring-Special methods of Boring-Mather \& Platt's, American, and Diamond systems-Accidents in Boring-Cost of Boring-Use of Boreholes. Broaking Ground: Tools-Transmission of Power: Compressed Air, Electricity-Power Machine Drills-Coal Cutting by Machinery-Cost of Coal Cutting-Explosives-Blasting in Dry and Dusty Mines-Blasting by Electricity-Various methods to supersede Blasting. Sinking: Position, Form, and Size of shaft-Operation of getting down to "Stonr-head"-Method of proceeding afterwards-Lining shafts-Keeping out Water by Tubbing-Cost of TubtingSinking by Boring-Kind - Chaudron, and Lipmann methods-Sinking through Quicksands -Cost of Sinking. Preliminary Operations: Driving underground Roads-Supporting Roof: Timbering, Chocks or Cogs, Iron and Steel Supports and Masonry-Arrangement of Inset. Methods of Working: Shaft, Pillar, and Subsidence-Bord and Pillar SystemLancashire Method-Longwall Method-Double Stall Method-Working Steep SeamsWorking Thick Seams-Working Seams lying near together-Spontaneous Combustion. Haulage: Rails-Tubs-Haulage by Horses-Self-acting Inclines-Direct-acting Haulage -Main and Tail Rope-Endless Chain-Endless Rope-Comparison. Winding: Pit Frames - Pulleys-Cages-Ropes-Guides-Engines-Drums-Brakes-CounterbalancingExpansion-Condensation-Compound Engines-Prevention of Overwinding-Catches at pit top-Changing Tubs-Tub Controllers-Signalling. Pumping: Bucket and Plungex Pumps - Supporting Pipes' in Shaft - Valves - Suspended lifts for Sinking - Cornish and Bull Engines-Davey Differential Engine-Worthington Pump-Calculations as to size of Pumps-Draining Deef Workings-Dams. Ventilation: Quantity of air requiredGases met with in Mines-Coal-dust-Laws of Friction-Production of Air-currentsNatural Ventilation-Furnace Ventilation-Mechanical Ventilators-Efficiency of FansComparison of Furnaces and Fans-Distribution of the Air-current-Measurement of Aircurrents. Lighting: Naked Lights - Safety Lamps - Modern Lamps - ConclusionsLocking and Cleaning Lamps-Electric Light Underground-Delicate Indicators. Works at Surface; Boilers-Mechanical Stoking-Coal Conveyors-Workshops. Preparation of Coal for Market: General Considerations-Tipplers-Screens-Varying the Sizes made by Screens-Belts-Revolving Tables-Loading Shoots-Typical Illustrations of the arrangement of Various Screening Establishments-Coal Washing-Dry Coal Cleaning -Briquettes.

"Quite THE BEST BOOK of its kind .. as PRACTICAL in aim as a book can be .... touches upon every point connected with the actual working of collieries. The illustrations are nXCRLLINT."-A thenaum.

"A Text-book on Coal-Mining is a great desideratum, and Mr. Hughrs possesses ADMIRABLE QUALIFICATIONS for supplying it. . . . We cordially recommend the work." - Colliery Guardian.

"Mr. Hughes bas had opportunities for study and research which fall to the lot of but few men. If we mistake not, his text-book will soon come to be regarded as the STA NDARD WORK of its kind."-Birmingham Daily Gazette.

** Note. -The first large edition of this work was exhausted within a few months of publication.

LONDON : EXETER STEERT, STRAND. 


\section{WORKS BY GEORGE H. HURST, F.C.S.,}

Member of the Society of Chemical Industry; Lecturer on the Technology of Painters' Colours, Oils, and Varnishes, the Municipal Technical School, Manchester.

NEW WORK BY Mr. IHURST.

\section{COLOUR-THEORY AND ITS PRACTICAL APPLICATION TO PAINTING, DYEING, and THE TEXTILE INDUSTRIES.}

In Large Crown 8vo. With Illustrations and Plates (some in Colours).

\section{HURST'S PAINTERS' COLOURS, OILS, AND}

VARNISHES (A Practical Manual). SEcond EDITION, Revised and Enlarged. With Illustrations. I2s. 6d.

General Contents. - Introductory-The Composition, Manufacture, AsSAY, and ANALYSIS of PIgMENTS, White, Red, Yellow and Orange, Green, Blue, Brown, and Black-LAKES-Colour and Paint Machinery-Paint Vehicles (Oils, Turpentine, \&c., \&c.)-Driers-VARnishes.

"This useful book will prove MOST valuable."-Chemucal News.

"A practical manual in every respect . . . EXCEEDINGLY INSTRUCTIVE. The section on Varnishes the most reasonable we have met with."-Chemist and Druggist.

"VERY valuable information is given."-Plumber and Decorator.

"A THOROUGHLY PRACTICAL book, . . the ONLY English work that satisfactorily treats of the manufacture of oils, colours, and pigments."-Chemical Trades' Fournal.

"Throughout the work are scattered hints which are INVALUABLE."-Invention.

\section{HURST'S GARMENT DYEING and CLEANING}

(A Practical Book for Practical Men). With Numerous Illustrations.

4s. 6d.

General Contents. - Technology of the Textile Fibres-Garment Cleaning -Dyeing of Textile Fabrics-Bleaching-Finishing of Dyed and Cleaned FabricsScouring and Dyeing of Skin Rugs and Mats-Cleaning and Dyeing of FeathersGlove Cleaning and Dyeing-Straw Bleaching and Dyeing-Glossary of Drugs and Chemicals-Useful Tables.

"An UP-TO-DATE hand book has long been wanted, and $\mathrm{Mr}$. Hurst has done nothing more complete than this. An imnortant work, the more so that several of the branches of the craft here treated upon are almost entirely without English Manuals for the guidance of workers. The price brings it within the reach of all."-Dyer and Calico-Printer.

"Mr. Hurst's work DECIDEDLY FILLS A WANT. . ought to be in the hands of EVERY GARMENT DYER and cleaner in the Kingdom"-Textile Mercury.

LONDON : EXETER STREET, STRAND. 
WORKS BY

ANDREW JAMIESON, M.INST.C.E., M.I.E.E., F.R.S.E, Professor of Electrical Engineering, The Glasgow and West of Scotland Techrical College.

\section{PROFESSOR JAMIESON'S ADVANCED MANUALS.} In Large Crown 8vo. Fully Illustrated.

1. STEAM AND STEAM-ENGINES (A Text-Book on). For the Use of Students preparing for Competitive Examinations. With over 200 Illustrations, Folding Plates, and Examination Papers. Twelfth Edition. Revised and Enlarged, 8/6.

"Professor Jamieson fascinates the reader by his CLEARNESS of CONCEPTION AND. sIMPLICITY OF EXPRESSION. His treatment recalls the lecturing of Faraday." $-A$ thenewm.

"The BEST BOoK yet published for the use of Students."-Engineer.

"Undoubtedly the MOST VALUABLE AND MOST COMPLETE Hand-book on the subject. that now exists."-Marine Engineer.

2. MAGNETISM AND ELECTRICITY (An Advanced TextBook on). Specially arranged for Advanced and "Honours" Students.

3. APPLIED MECHANICS (An Advanced Text-Book on).

Vol. I.-Comprising Part I.: The Principle of Work and its applica.tions; Part II.: Gearing. Price 7s. 6d. SECOND Edition.

"Fully Maintains the reputation of the Author-more we cannot say."-Pract. Engineer.

Vol. II.-Comprising Parts III. to VI. : Motion and Energy; Graphic Statics; Strength of Materials; Hydraulics and Hydraulic Machinery. Price 7s. 6d.

[Now ready.

\section{PROFESSOR JAMIESON'S INTRODUCTORY MANUALS. With numerous Illlustrations and Examination Papers.}

1. STEAM AND THE STEAM-ENGINE (Elementary TextBook on). For First-Year Students. FifTH Edition. 3/6.

"Quite the RIGHT SORT OF BOOK."-Eneineer.

"Should be in the hands of EVERY engineering apprentice."-Practical Enginerr.

2. MAGNETISM AND ELECTRICITY (Elementary Text-

Book on). For First-Year Students. FourTH Edition. 3/6.

"A capital text-BOOK . . . The diagrams are an important feature."-Schoolmaster.

"A THOROUGHLY TRUSTworthy Text-book. . . Arrangement as good as well can be. . . . Diagrams are also excellent. . . . The subject throughout treated as an essentially PRACTICAL one, and very clear instructions given."-Nature.

3. APPLIED MECHANICS (Elementary Text-Book on). Specially arranged for First-Year Students. SECond Edition. 3/6.

"Nothing is taken for granted. . . The work has VERY HIGH QUALITIES, which may be condensed into the one word "CLEAR." - Science and Art.

A POCKET-BOOK of ELECTRICAL RULES and TABLES. FOR THE USE OF ELECTRICIANS AND ENGINEERS.

Pocket Size. Leather, 8s. 6d. Twelfth Edition, revised and enlargod.

LONDON : EXETER STREET. STRAND. 
"The MOst valdable and USEFul wORK on Dyeing that has yet appeared in the English. language.. . likely to be THE STANDARD WORK OF REFERENCE for years to come."Textile Mercury.

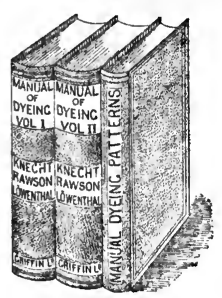

In Two Large 8vo Volumes, 920 pp., with a SUPPLEMENTARY Volume, containing Specimens of Dyed Fabrics. Handsome Cloth, 45s.

\section{A \\ IIANUAL OF DYEING :}

FOR THE USE OF PRACTICAL DYERS, MANUFACTURERS, STUDENTS, AND ALL INTERESTED IN THE ART OF DYEING.

BY

E. KNECHT, Ph.D., F.I.C.,

Head of the Chemistry and Dyeing Department of the Technical School, Manchester; Editor of "The Journal of the Society of Dyers and Colourists ;"
CHR. RAWSON, F.I.C., F.C.S., Late Head of the Chemistry and Dyeing Department of the Technical College, Bradford; Member of Council of the Society of Dyers and Colourists;

\section{And RICHARD LOEWENTHAL, Ph.D.}

General Contents. - Chemical Technology of the Textile FabricsWater-Washing and Bleaching-Acids, Alkalies, Mordants - Natural Colouring Matters-Artificial Organic Colouring Matters-Mineral Colours - Machinery used in Dyeing-Tinctorial Properties of Colouring MattersAnalysis and Valuation of Materials used in Dyeing, \&c., \&c.

"This most VAldable work . . . will be widely appreciated."-Chemical Neros.

"This authoritative and exhaustive work . . . the MOsT COMPLETE we have yet seen on the subject."-Textile Manufacturer.

"The MOst exhaUstive and COMPLETE wORK on the subject extant."-Textile Recorder.

"The distinguished authors have placed in the hands of those daily engaged in the dyehonse or laboratory a work of EXTREME VALUk॰and UNDOUBTED UTILITY . a appeals quickly to the technologist, colour chemist, dyer, and more particularly to the rising dyer of the present generation. A book which it is refreshing to meet with."-American Textile Record.

LONDON : EXETER STREET, STRAND. 


\title{
GETTING GOLD:
}

\section{A GOLD-MINING HANDBOOK FOR PRACTICAL MEN.}

BY

\author{
J. C. F. JOH N SO N, F.G.S., A.I.M.E.,
} Life Member Australasian Mine-Managers' Association.

Second Editiov. Crown 8vo, Extra. With Illustrations. Cloth, 3s. 6d.

\footnotetext{
"Should prove of the GREATEST VALUE. Almost every page bristles with suggestions."-Financial News.

"PRACTICAL from beginning to end . . deals thoroughly with the Prospecting, Sinking, Crushing, and Extraction of gold."-Brit. Australasian.

"Directors and those interested in the formation of companies would do well to purchase Mr. Johnson's book."-Mining Journal.

"The reader, be he miner or novice, will gain from Mr. Johnson's book a GRIP of the gold industry."-African Critic.

"Should be specially commended to all who have any idea of proceeding to the gold fields."-Financial Truth.

"The most striking elements are the numerous 'TIPS' and USEFUL WRINKLES given." -Standard.

"One is lost in admiration at the wealth of knowledge displayed."-Nature.

"Evidently the well-matured product of a scientist of well-trained and tried experience."South Africa.
}

\section{NEW VOLUME OF GRIFFIN'S MINING SERIES.}

Edited by C. LE NEVE FOSTER, D.Sc., F.R.S., H.M. Inspector of Mines, Professor of Mining, Royal School of Mines.

\section{Mine Accounts and Mining Book-keeping,}

A Manual for the Use of Students, Managers of Metalliferous Mines and Collieries, and others interested in Mining.

With very Numerous Examples taken from the Actual Practice of leading Mining Companies throughout the world.

BY

JAMES G. LAWN, Assoc.R.S.M.,

Professor of Mining at the South African School of Mines, Capetown, Kimberley, and Johannesburg.

In Large 8vo. Price 10s. $6 d$. 


\section{WORKS.BY}

WALTER G. M'MILLAN, F.I.C., F.C.S., Secretary to the Institution of Electrical Engineers; late Lecturer in Metallurgy at Mason College, Birmingham.

\section{ELECTRIC SMELTING AND REFINING :}

A PRACTICAL MANUAL OF

The Extraction and Treatment of Metals by Electrical Methods. Being the "Elektro-Metallurgie" of Dr. W. Borchers.

Translated from the Second German Edition

By WALTER G. M'MILLAN, F.I.C., F.C.S.

In large 8vo. With Numerous Illustrations and Three Folding-Plates. Price $21 \mathrm{~s}$.

* * The Publishers beg to call attention to this valuable work. Dr. Borchers' treatise is PRACTICAL throughout. It confines itself to ONE branch of Electro-Chemistry, viz. :-ELECTROLYSIS, a subject which is daily becoming of more and more importance to the Practical Metallurgist and Manufacturer. Already in the extraction of Aluminium, the refining of Copper, the treatment of Gold and other metals, electrical processes are fast taking the place of the older methods. Dr. BoRcHens' work is acknowledged as the standard authority on the subject in Germany.

\section{CONTENTS.}

Part I.-Alkalies and Alkaline Earth Metals: Magnesium, Lithium, Beryllium, Sodium, Potassium, Calcium, Strontium, Barium, the Carbides of the Alkaline Earth Metals. Part II. - The Earth Metals : Aluminium, Cerium, Lanthanum, Didymium. PART III.-The Heavy Metals: Copper, Silver, Gold, Zinc and Cadmium, Mercury, Tin, Lead, Bismuth, Antimony, Chromium, Molybdenum, Tungsten, Uranium, Manganese, Iron, Nickel, and Cobalt, the Platinum Group.

" COMPREHENSIVE and AUTHORITATIVE . . . not only FULL of VALUABLE INFORMATION, but gives evidence of a THOROUGH INSIGHT into the technical VALUE and POSSIBILITIES of all the methods discussed."-The Electrician.

\section{ELECTRO-METALLURGY (A Treatise on):}

Embracing the Application of Electrolysis to the Plating, Depositing, Smelting, and Refining of various Metals, and to the Reproduction of Printing Surfaces and Art-Work, \&c.

By WALTER G. M'MILLAN, F.I.C., F.C.S. With numerous Illustrations. Large Crown 8vo. Cloth 10s. 6d.

"This excellent treatise, . . . one of the BEST and MOST CompLETE manuals hitherto published on Electro-Metallurgy."-Electrical Revievo.

"This work will be a sTandaRd."-Jeweller.

"Any metallurgical process which REDUCEs the COST of production must of necossity prove of great commercial importance. . . . We recommend this manual to ALL who are interested in the PRACTICAL APPLICATION of electrolytic processes."-Nature. 


\section{MACKENZIE (Thos., Master Mariner, F.R.A.S.):}

PRACTICAL MECHANICS: APPLIED to the REQUIREMENTS of the SAILOR. Crown 8vo, with numerous Illustrations. Handsome Cloth. 3s. 6d.

[Griffin's Nautical Series.

General Contents. - Resolution and Composition of Forces-Work done by Machines and Living Agents-The Mechanical Powers: The Lever; Derricks as Bent Levers-The Wheel and Axle: Windlass; Ship's Capstan; Crab Winch-Tackles: the "Old Man"-The Inclined Plane; the ScrewThe Centre of Gravity of a Ship and Cargo - Relative Strength of Rope : Steel Wire, Manilla, Hemp, Coir-Derricks and Shears-Calculation of the Cross-breaking Strain of Fir Spar-Centre of Effort of Sails-Hydrostatics : the Diving-bell ; Stability of Floating Bodies ; the Ship's Pump, \&c.

“THIS EXCELLENT BOOK . . . contains a LARGE AMOUNT of information." - Nature.

"WELl worth the money . . . will be found EXCEedingLY HELPFul."Shipping World.

'No SHIPS' OFFICERS' BOOKCASE will henceforth be complete without Captain Mackenzie's 'Practical Mechanics.' Notwithstanding my many years' experience at sea, it has told me how much more there is to acquire."(Letter to the Publishers from a Master Mariner).

\section{MILLAR (W. J., C.E., late Secretary to the Inst.} of Engineers and Shipbuilders in Scotland) :

LATITUDE AND LONGITUDE: How to Find Them. Crown 8vo, with Diagrams. 2s. [Griffin's Nautical Series.

"CONCISELY and CleARLY wrITTEN . . . cannot but prove an acquisition to those studying Navigation."-Marine Engineer.

"Young Seamen will find it HANDY and USEFUL, SIMPLE and CLEAR."-The Engineer.

Sroond Edirion. Enlarged, and very fully Illustrated. Cloth, 4s. 6 d.

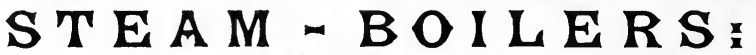

THWIR DEFECTS, MANAGEMENT, AND CONSTRUCTION.

\section{Bx R. D. M U N R O,}

Chief Engineer of the Scottish Boiler Insurance and Engine Inspection Company.

This work contains information of the first importance to every user of Steam-power. It is a PRACTICAL work written for PRACTICAL men, the language and rules being throughout of the simplest nature.

"A valuable companion for workmen and engineers engaged about Steam Boilers, ought to be carefully studied, and ALWAYS AT HAND."-Coll. Guardian.

"The book is VERY USEFUL, especially to steam users, artisans, and young engineers."-Engineer.

BY THE SAME AUTHOR.

KITCHEN BOILER EXPLOSIONS: Why they Occur, and How to Prevent their Occurrence? A Practical Handbook based on Actual Experiment. With Diagrams and Coloured Plate, Price 3 s.

LONDON : EXETER STREET, STRAND. 


\section{MUNRO \& JAMIESON'S ELECTRICAL POCKET-BOOK.}

TWELFTh Edition, Revised and Enlarged.

\section{A POCKET-BOOK}

OF

\section{ELECTRICAL RULES \& TABLES}

FOR THE USE OF ELECTRICIANS AND ENGINEERS.

BY

JOHN MUNRO, C.E., \& Prof. JAMIESON, M.Inst.C.E., F.R.S.E.

With Numerous Diagrams. Pocket Size. Leather, 8s. 6d.

GENERAL CONTENTS.

UNITS OF MEASUREMENT.

MEASURES.

TESTING.

CONDUCTORS.

DIELECTRICS.

Submarine Cables.

TELEGRAPHY.

Electro-Chemistr.

"Wonderfully Perfect. - . Worthy of the highest commendation we can give it."-E lectriczan.

"The Sterling Value of Messrs. Munro and Jamirson's Pockrt-Book."Electrical Revien.
Electro-Metallurgy.

BATTERIES.

DYNAMOS AND MOTORS.

TRANSFORMERS.

Electric Lighting.

Miscellaneous.

LOGARITHMS.

APPENDICES. 


\title{
Demy 8vo, Handsome cloth, $18 s$. Physical Geology and Palpontologgy, ON THE BASIS OF PHILLIPS.
}

BY

\author{
H A R R Y G O V I E R S E E L E Y, F. R. S., \\ PROFESSOR OF GEOGRAPKY IN KING'S COLLEGE, LONDON.
}

wattb frontispiece in Cbromo=Litbograpby, and Fllustrations.

"It is impossible to praise too highly the research which Professor SrmLeY's - Physical Geology evidences. IT IS FAR MORE THAN A TEXT-BOOK-it is a UIRECTORY to the Student in prosecuting his researches." - Presidential Address to the Geological Society, 1885, by Rev. Prof. Bonnoy; D.Sc., LL.D., F.R.S.

"Profrssor Seeley maintains in his 'Physical Geology' the high reputation he already deservedly bears as a Teacher." - Dr. Henry Woodward, F.R.S., in the "Geological Magazine."

"Professor Seeley's work includes one of the most satisfactory Treatises on Lithology in the English language. . . . So much that is not accessible in other works is presented in this volume, that no Student of Geology can aftord to be without it."-American Journal of Engineering.

\section{Demy 8vo, Handsome cloth, 34 s. \\ Stratigrnaphical Geologog \& Palæontoloǵg,

$$
\text { ON THE BASIS OF PHILLIPS. }
$$

BY

\author{
ROBERT ETHERIDGE, F.R.S.,
}

OF TRE NATURAL HIST. DEPARTMENT, BRITISH MUSEUM, LATE PAL FONTOLOGIST TO TKE GEOLOGICAL SURVEY OF GREAT BRITAIN, PAST PRESIDENT OF THE GROLOGICAL SOCIRTY, RTC.

waitb Map, Humerous $\widetilde{T a b l e s,}$ and $\widetilde{T b i r t y}=$ six Dlates.

* Prospectus of the above important work-perhaps the MOST ELABORATE of its kind ever written, and one calculated to give a new strength to the study of Geology in Britain-may be had on application to the Publishers.

\footnotetext{
"No such compendium of geological knowledge has ever been brought together before "Wastminster Review.

"If PROF. SRELEY'S volume was remarkable for its originality and the breadth of its newa, Mr. ETHERIDGe fully justifies the assertion made in his preface that his book differs in construction and detail from any known manual. . . . Must take HIGH RANK AMONG worke OF nurerence."-A theneum.
}

LONDON : EXETER STREET, STRAND. 


\section{Painting and Decorating:}

A Complete Practical Manual for House Painters and Decorators.

Embracing the Use of Materials, Tools, and Appliances; the Practical Processes involved; and the General Principles of Decoration, Colour, and Ornament.

$\mathrm{BY}$

WALTER JOHN PEARCE, LECTURER AT THE MAXCHESTER TECHXICAL SCBOOL FOR HOUBS-PAITTING AND DECORATIISG.

In Crown 8vo. extra. With Numerous Illustrations and Plates (some in Colours), including Original Designs. 12s. 6d.

* * Mr. Pearce's work is the outcome of many years' practical experience, and will be found invaluable by all interested in the subjects. of which it treats. It forms the Companion-Volume to Mr. Geo. HURST's well-known work on "Painters' Colodrs" (see p. 25).

\section{Open-Air Studies in Botany:}

SKETCHES OF BRITISH WILD FLOWERS IN THEIR HOMES.

BY

R. LLOYD PRAEGER, B.A., M.R.I.A.

Illustrated by Drawings from Nature by S. Rosamond Praeger, and Photographs by R. Weleh.

In Crown 8vo. extra. Handsome Cloth, 7s. 6d.

Gilt, for Presentation, 8s. 6d.

General Contents. - A Daisy-Starred Pasture-Under the Hawthorns -By the Kiver-Along the Shingle-A Fragrant Hedgerow - A Connemara Bog-Where the Samphire grows-A Flowery Meadow-Among the Corn (a Study in Weeds)-In the Home of the Alpines-A City Rubbish-HeapGlossary.

"A FRESH AND STIMULATING book . . should take a high place . . The Illustrations are drawn with much skill."-The Times.

"BEAUTIFULLY ILLUSTRATED. . . . One of the MOST ACCURATE as well as INTERESTING books of the kind we have seen."-Athenoum.

"Redolent with the scent of woodland and meadow."-The Standard.

"A Series of STIMULATING and DELIGHTFUL Chapters on Field-Botany."-The Scotsman.

** Companion-Volume to Prof. Grenville Cole's fascinating "Open-Air Studies in Geology" (see p. 12). 
Third Edition. With Folding Plates and Many Illustrations. Large 8vo. Handsome Cloth. 36s.

\section{ELEMENTS OF METALLURGY: A PRACTICAL TREATISE ON THE ART OF EXTRACTING METALS FROM THEIR ORES.}

By J. ARTHUR PHILLIPS, M.Inst.C.E., F.C.S., F.G.S., \&c. AND H. BAUERMAN, V.P.G.S.

GENERAL CONTENTS.

\begin{tabular}{l|l|l} 
Refractory Materials. & Antimony. & Iron. \\
Fire-Clays. & Arsenic. & Cobalt. \\
Fuels, \&c. & Zinc. & Nickel. \\
Aluminium. & Mercury. & Silver. \\
Copper. & Bismuth. & Gold. \\
Tin. & Lead. & Platinum.
\end{tabular}

* Many notable additions, dealing with new Processes and Developments, will be found in the Third Edition.

"Of the Third EDition, we are still able to say that, as a Text-book of Metallurgy, it is THE BEST with which we are acquainted."-Engineer.

"The value of this work is almost inestimable. There can be no question that the amount of time and labour bestowed on it is enormous. . . . There is certainly no Metallurgical Treatise in the language calculated to prove of such general utility."-Mining Journal.

"In this most useful and handsome volume is condensed a large amount of valuable practical knowledge. A careful study of the first division of the book, on Fuels, will be found to be of great value to every one in training for the practical applications of our scientific knowledge to any of our metallurgical operations."-Athenceum.

"A work which is equally valuable to the Student as a Text-book, and to the practical Smelter as a Standard Work of Reference. . . . The Illustration are admirable examples of Wood Engraving."-Chemical News.

POYNTING (J. H., Sc.D., F.R.S., late Fellow of Trinity College, Cambridge; Professor of Physics, Mason College, Birmingham) :

THE MEAN DENSITY OF THE EARTH: An Essay to which the Adams Prize was adjudged in 1893 in the University of Cambridge. In large 8vo, with Bibliography, Illustrations in the Text, and seven Lithographed Plates. I2s. 6d.

"An account of this subject cannot fail to be of GREAT and GENBRAL IXTERBST to the scientifie mind. Especially is this the case when the account is given by one who has contributed so considerably as has Prof. Poynting to our present state of knowledge with respect to a very difficult subject. . . . Remarkably has Newton's estimate been verified by Prof. Poynting."Athenoum.

POYNTING and THOMSON: TEXT-BOOK OF PHYSICS. (See under Thomson). 


\section{W O R K S B Y W. J. MACQUORN RANKINE, LL.D., F.R.S.,} Late Regius Professor of Civil Engineering in the University of Glasgow.

THOROUGHLY REVISED BY

W. J. MIL工A R, C. F., Late Secretary to the Institute of Engineers and Shipbuilders in Scotland.

\section{A MANUAL OF APPLIED MECHANICS :}

Comprising the Principles of Statics and Cinematics, and Theory of Structures, Mechanism, and Machines. With Numerous Diagrams. Crown 8vo, cloth, 12s. 6d. Fodrteenth Edition.

\section{A MANUAL OF CIVIL ENGINEERING :}

Comprising Engineering Surveys, Earthwork, Foundations, Masonry, Carpentry, Metal Work, Roads, Railways, Canals, Rivers, Waterworks, Harbours, \&c. With Numerous Tables and Illustrations. Crown 8vo, cloth, 16s. Twentieth Edition.

\section{A MANUAL OF MACHINERY AND MILLWORK :}

Comprising the Geometry, Motions, Work, Strength, Construction, and Objects of Machines, \&c. Illustrated with nearly 300 Woodcuts. Crown 8vo, cloth, 12s. 6d. Seventh Edition.

\section{A MANUAL OF THE STEAM-ENGINE AND OTHER PRIME MOVERS :}

With a Section on Gas, Orl, and Air Engines. By Bryan Donkin, M.Inst.C.E. Crown 8vo, cloth, 12s. 6d. Foorteenth Edition.

\section{USEFUL RULES AND TABLES :}

For Architects, Builders, Engineers, Founders, Mechanics, Shipbuilders, Surveyors, \&c. With APPENDIX for the use of EleCtrical EnginenRs. By Professor Jamieson, F.R.S.E. Seventh Edition. 10s. 6d.

\section{A MECHANICAL TEXT-B0OK :}

A Practical and Simple Introduction to the Study of Mechanics. By Professor Rankine and E. F. BAMber, C.E. With Numerous Illustrations. Crown 8vo, cloth, 9s. Foorth Edition.

**"The "Mechanical Text-Book" was designed by Profensor Rankinx as an ImmoDuction to the above Series of Manuals. 
Prot. Rankine's Works-(Continued).

\title{
VII. MISCELLANEOUS SCIENTIFIC PAPERS.
}

\author{
Royal 8vo. Cloth, 31s. 6d.
}

Part I. Papers relating to Temperature, Elasticity, and Expansion of Vapours, Liquids, and Solids. Part II. Papers on Energy and its Transformations. Part III. Papers on Wave-Forms, Propulsion of Vessels, \&c.

With Memoir by Professor Tait, M.A. Edited by W. J. Millar, C.E. With fine Portrait on Steel, Plates, and Diagrams.

“ No more enduring Memorial of Professor Rankine could be devised than the publication of these papers in an accessible form. . . The Collection is most valuable on account of the nature of his discoveries, and the beauty and completeness of his analysis. : . The Volume exceeds in importance any work in the same department published in our time "-Architect.

\section{ALCAREO US CEMENTS :}

\section{THEIR NATURE, PREPARATION, AND USES.}

With some Remaxks upon Cement Testing.

By GILBERT R. REDGRAVE, Assoc. Inst. C.E.

With Illustrations. 8s. 6d.

General Contents.-Introduction-Historical Review of the Cement Industry-The Early Days of Portland Cement-Composition of Portland Cement-Processes of MANufacture-The Washmill and the BacksFlue and Chamber Drying Processes-Calcination of the Cement MixtureGrinding of the Cement-Composition of Mortar and Concrete-Cemenr Testing - Chemical Analysis of Portland Cement, Lime, and Raw Materials - Employment of Slags for Cement Making - Scott's Cement, Selenitic Cement, and Cements produced from Sewage Sludge and the Refuse from Alkali Works - Plaster Cements - Specifications for Portland Cement-Appendices (Gases Evolved from Cement Works, Effects of Seawater on Cement, Cost of Cement Manufacture, \&c., \&c.)

"A work calculated to be of GReat and Extended utility."-Chemical News.

"Invaldable to the Student, Architect, and Engineer."-Building News.

"A work of the GREATEST INTEREST and USEFULNESs, which appears at a very critical period of the Cement Trade."-Brit. Trade Journal.

"Will be useful to all interested in the mandfacturs, ose, and Testing of Cements."Engineer. 


\section{P E T R O LEU IM AND ITS PRODUCTS:}

A PRACTICAL TREATISE.

BY

\section{B O VERTON RED WOO D, \\ F.R.S.E., F.I.C., Assoc. Inst. C.E.,}

Hon. Corr. Mem. of the Imperial Russian Technical Society; Mem. of the American Chemical Society; Consulting Adviser to the Corporation of London under the

Petroleum Acts, \&c., \&c.

Assisted by GEO. T. HOLLOWAY, F.I.C., Assoc. R.C.S.,

And Numerous Contributors.

In Two Volumes, Large 8vo. Price 45s.

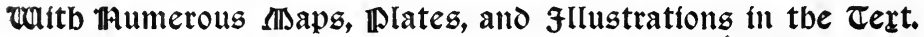

GENERAL CONTENTS.

I. General Historical Account of VIII. Transport, Storage, and Disthe Petroleum Industry.

II. Geological and Geographical Distribution of Petroleum and Natural Gas.

III. Chemical and Physical Properties of Petroleum.

IV. Origin of Petroleum and Natural Gas.

V. Production of Petroleum, Natural Gas, and Ozokerite.

vI. The Refining of Petroleum.

vII. The shale oil and Allied Industries. tribution of Petroleum.

IX. Testing of Petroleum.

X. Application and Uses of Petroleum.

XI. Legislation on Petroleum at Home and Abroad.

XII. Statistics of the Petroleum Production and the Petroleum Trade, obtained from the most trustworthy and official sources.

"The MOST COMPREHENSIVE AND CONVENIENT ACCOUNT that has yet appeared of a gigantic industry which has made incalculable additions to the comfort of civilised man. . . . The chapter dealing with the arrangement for STORAGE and TRANSPORT of GREAT PRACTICAL INTEREST. . . . The DIGEST of LEGISLATION on the subject cannot but prove of the GREATEST UTILITY."-The Times.

"A SPLENDID CONTRIBUTION to our technical literature."-Chemical News.

"This THOROUGHLY STANDARD WORK . . . in every way EXCELLENT most fully and ably handled : $:$ could only have been produced by a man in the very exceptional position of the Author. . . . INDISPENSABLE to all who have to do with Petroleum, its APPlications, manufacture, STORAGE, or TRANSPORT."-Mining Journal.

"We must concede to Mr. Redwood the distinction of having produced a treatise which must be admitted to the rank of THE INDISPENSABLES. It contains THE LAST WORD that can be said about Petroleum in any of its scienTIFIC, TECHNICAL, and LEGAL aspects. It would be difficult to conceive of a more comprehensive and explicit account of the geological conditions associated with the sUPPLY of Petroleum and the very practical question of its AMOUNT and DURATION."-Journ. of Gas Lighting.

LONDON : EXETER STREET, STRAND. 
Royal 8vo, Handsome Cloth, 258.

\section{THE STABILITY OF SHIPS.}

BY

SIR EDWARD J. REED, K.C.B., F.R.S., M.P.,

KNIGHT OF THE IMPERIAL ORDERS OF ST. STANILAUS OF RUSSIA; FRANCIS JOSEPH OF AUSTRIA; MEDJIDIE OF TURKEY; AND RISING SUN OF JAPAN; VICEPRESIDENT OF THE INSTITUTION OF NAVAL ARCHITECTS.

\section{With numerous Rlustrations ana Tiables.}

THis work has been written for the purpose of placing in the hands of Naval Constructors, Shipbuilders, Officers of the Royal and Mercantile Marines, and all Students of Naval Science, a complete Treatise upon the Stability of Ships, and is the only work in the English Language dealing exhaustively with the subject.

In order to render the work complete for the purposes of the Shipbuilder, whether at home or abroad, the Methods of Calculation introduced by Mr. F. K. BARNES, Mr. GRAy, M. RERCH, M. DAYMARD, and Mr. BrNJAMIN, are all given separately, illustrated by Tables and worked-out examples. The book contains more than 200 Diagrams, and is illustrated by a large number of actual cases, derived from ships of all descriptions, but especially from ships of the Mercantile Marine.

The work will thus be found to constitute the most comprehensive and exhaustive Treatise hitherto presented to the Profession on the Science of the STABILITY of SHIPS.

“ Sir Edward Reed's 'Stability of Ships' is inval.uable. In it the Student, new to the subject, will find the path prepared for him, and all difficulties explained with the utmost care and accuracy; the SHIP-DRAUGHTSMAN will find all the methods of calculation at present in use fully explained and illustrated, and accompanied by the Tables and Forms employed; the SHIPOWNER will find the variations in the Stability of Ships due to differences in forms and dimensions fully discussed, and the devices by which the state of his ships under all conditions may be graphically represented and easily understood; the Naval ARCHITECT will find brought together and ready to his hand, a mass of information which he would otherwise have to seek in an almost endless variety of publications, and some of which he would possibly not be able to obtain at all elsewhere."-Steamship.

"This IMPORTANT AND VALUABLE wORK . . . cannot be too highly recommended to all connected with shipping interests."-Iron.

"This VERY IMPORTANT TRRATISE, . . . the MOST INTELLIGIBLE, INSTRUCTIVE, an COMPLETE that has ever appeared."-Nature. Revieze.

"The volume is an ESSENTIAL ONR for the shipbuilding profession."-Westminster

\section{RICHMOND (H. Droop, F.C.S., Chemist to the} Aylesbury Dairy Company) :

DAIRY CHEMISTRY FOR DAIRY MANAGERS : A Practical Handbook. (Griffin's Technological Manuals.)

LCNDON : EXETER STREET, STRAND. 
Fourth Edition, Revised. With Additional Illustrations. Price 6s.

\section{PRACTICAL SANITATION:}

\section{A HAND-BOOK FOR SANITARY INSPECTORS AND OTHERS INTERESTED IN SANITATION.}

By GEORGE REID, M.D., D.P.H., Fellow of the Sanitary Institute of Great Britain, and Medical Officer, Staffordshire County Council.

\section{wattb an $\mathfrak{A p p e n d i x}$ on Santtary $\mathfrak{L}$ aw.}

By HERBER T MAN LEY, M.A., M.B., D.P.H., Medical Officer of Health for the County Borough of West Bromwich.

General Contents.-Introduction-Water Supply: Drinking Water, Pollution of Water-Ventilation and Warming - Principles of Sewage Removal - Details of Drainage ; Refuse Removal and Disposal-Sanitary and Insanitary Work and Appliances-Details of Plumbers' Work-House Construction - Infection and Disinfection - Food, Inspection of ; Characteristics of Good Meat ; Meat, Milk, Fish, \&c., unfit for Human FoodAppendix : Sanitary Law; Model Bye-Laws, \&c.

"A VERY USEFUL HANDBOOK, with a very useful Appendix. We recommend it not only to SANITARY INSPECTORS, but to HOUSEHOLDERS and ALL interested in Sanitary matters."-Sanitary Record.

In Large 8vo, Handsome Cloth. I2s. 6 d.

\section{DISINFECTION \& DISINFECTANTS}

\section{(AN INTRODUCTION TO THE STUDY OF).}

Together with an Account of the Chemieal Substances used as Antisepties and Preservatives.

By SAMUEL RIDEAL, D.Sc.Lond., F.I.C., F.C.S.,

Examiner in Chemistry to the Royal College of Physicians: formerly Lecturer on Chemistry, St. George's Hospital Medical School, \&c., \&c.

With Folding-Plate and Illustrations of the most Approved Modern Appliances.

** "Notwithstanding the rapid development of Sanitary Science in this country, there does not exist at the present time in the English language any book which deals exclusively with the composition of DisINPBCTANTS. The present volume will, therefore, supply a want which has been felt not only by the chemist and bacteriologist, but also by those who are concerned with the practical work of disinfection. . . "-EXTRACT FROM AUTHOR's PREFACB.

"DR. RIDRAL's volume is bound to prove of GBRAT vaLOE, both as a PRACTICAL GUIDE and as a WORK OF REFERENCR."-Pharmaceutical Journal.

“AN RXHADSTIVE TrEATISE, dealing with the WHOLR RANGR of the subject:-Disinfection by Heat, Chemical Disinfectants, Practical Methods, Personal Disinfection, Legal Regulations, and Methods of Analysis . . so very well done and so USEPUL that it will be valued by $A L$ connected with Sanitation and Public Health."-Chemist and Druggist.

"A book that has long been wanted . . . will prove of VBRY GRBAT VALUB."-Local Government Journal.

LONDON : EXETER STREET, STRAND. 
GRIFFIN'S "FIRST AID" PUBLICATIONS.

Qn $\mathfrak{L} \mathfrak{a} \mathbf{0}$.

Third Edition, Revised. Large Crown 8vo. Handsome Cloth. 4 s.

\section{A MANUAL OF AMBULANCE.}

By J. SCOTT RIDDELL, C.M., M.B., M.A.,

Assistant-Surgeon, Aberdeen Royal Infirmary ; Lecturer and Examiner to the Aberdeen Ambulance Association; Examiner to the St. Andrew's Ambulance Association. Glasgow, and the St. John Ambulance Association, London.

With Numerous IIlustrations and Full Page Plates.

General Contents. - Outlines of Human Anatomy and PhysiologyThe Triangular Bandage and its Uses-The Roller Bandage and its Uses -Fractures-Dislocations and Sprains-Hæmorrhage-Wounds-Insensibility and Fits-Asphyxia and Drowning - Suffocation-Poisoning-Burns, Frost-bite, and Sunstroke-Removal of Foreign Bodies from $(a)$ The Eye; (b) The Ear; (c) The Nose; (d) The Throat; $(e)$ The Tissues-Ambulance Transport and Stretcher Drill-The After-treatment of Ambulance Patients -Organisation and Management of Ambulance Classes-Appendix : Examination Papers on First Aid.

"A capital воoK. . . . The directions are short and clrar, and testify to the hand of an able surgeon."-Edin. Med. Journal.

"This little volume seems to us about as good as it could possibly be. . . Contains practically every piece of information necessary to render First aid. . . . Should find its place in EVERY HOUSEHOLD LIBRARY."-Daily Chronicle.

"So ADMIRABLE is this work, that it is diffleult to imagine how it could be better."Colliery Guardian.

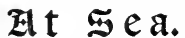

Crown 8vo, Extra. Handsome Cloth. $6 s$.

\section{A MEDICAL AND SURGICAL HELP}

\section{FOR SHIPMASTERS AND OFFICERS}

\section{IN THE MERCHANT NAVY.} INCLUDING

\section{FIRST AID TO THE INJURED.}

\section{By WM. JOHNSON SMITH, F.R.C.S.,}

Principal Medical Officer, Seamen's Hospital, Greenwich.

With Coloured Plates and Numerous Illustrations.

** The attention of all interested in our Merchant Navy is requested to this exceedingly useful and valuable work. It is needless to say that it is the outcome of many years PRACTICAL EXPERIENCE amongst Seamen.

"SOUND, JUDICIOUS, REALLY HELPTOL."-The Lancet.

"It would be difflcult to flnd a Medical and Surgical Guide more clear and comprehensive than Mr. JoHnson SMITH, whose experience at the GrekNWICH Hospital eminently qualifies him for the task. . . A MOBT ATTRACTIVR wORK. . . We have read it from cover to cover. . . . It gives clearly written advice to Masters and Offleers in all medical and surgical matters likely to come before them when remote from the land and without a doctor. . We RRCommend the work to EvkirY Shipmaster and Offlcer."-Liverpool Journal of commerce. 


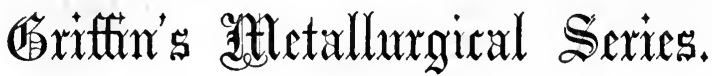

\section{STANDARD WORKS OF REFERENCE \\ FOR}

Metallurgists, Mine-0wners, Assayers, Manufacturers, and all interested in the development of the Metallurgical Industries.

EDITED BY

W. C. ROBERTS-AUSTEN, C.B., F.R.S.,

CHEMIST AND ASSAYER TO THE ROYAL MINT; PROFESSOR OF METALLURGY IN THE ROYAL COLLEGE OF SCIENCE.

In Large 8vo, Handsome Cloth. With Illustrations.

1. INTRODUCTION to the STUDY of METALLURGY.

By the EDITor. Fourth Edition. Revised and Enlarged, with

New Illustrations, Nicro-Photographic Plates of Different Varieties of

Steel, and Folding Plate. I5s.

"No English text-book at all approaches this in the COMPLETENESS with which the most modern views on the subject are dealt with. Professor Austen's volume will be INVALUABLE, not only to the student, but also to those whose knowledge of the art is far advanced."-Chemical News.

"INVALUABLE to the student. . . . Rich in matter not to be readily found elsewhere."-Athen oum.

"This volume amply realises the expectations formed as to the result of the labours of so eminent an authority. It is remarkable for its ORIGINALITY of conception and for the large amount of information which it contains. . . . We recommend every one who desires information not only to consult, but to STUDY this work."-Engineering.

"Will at once take FRONT RANK as a text-book."-Science and Art.

" Prof. ROBERTS-AUSTEN's book marks an epoch in the history of the teaching of metallurgy in this country."-Industries.

2. GOLD (The Metallurgy of). By Thos. Kirke Rose, D.Sc., Assoc. R.S.M., F.I.C., of the Royal Mint. Second Editron, 2Is. (See p. 43).

3. IRON (The Metallurgy of). By Thos. Turner, Assoc. R.S.M., F.I.C., F.C.S. I6s. (See p. 50).

\section{Will be Published at Short Intervals.}

4. STEEL (The Metallurgy of). By F. W. HARBord, Assoc. R.S. M., F.I.C.

5. COPPER (The Metallurgy of). By Thos. Gibb, Assoc. Royal School of Mines.

6. METALLURGICAL MACHINERY : the Application of Engineering to Metallurgical Problems. By Henry Charles Jenkins, Wh.Sc., Assoc. R.S.M., Assoc.M.Inst.C.E., of the Royal Mint.

7. ALLOYS. By the EDITOR.

** Other Volumes in Preparation.

LONDON : EXETER STREET, STRAND. 


\title{
SECOND EDITION, Revised and Enlarged. In Large 8vo, Handsome cloth, 348. HYDRAULIC POWER \\ AND HYDRAULIC MACHINERY.
}

BY

\author{
HENRY ROBINSON, M. INST. C.E., F.G.S., \\ FELLOW OF KING'S COLLEGK, LONDON ; PROF. OF CIVIL BNGINERRING, \\ KING'S COLLEGE, ETC., RTC.
}

Waitb numerous Woodcuts, and \$ixty=nine Dlates.

\section{General Contents.}

Discharge through Orifices-Gauging Water by Weirs-Flow of Water through Pipes-The Accumulator-The Flow of Solids-Hydraulic Presses and Lifts-Cyclone Hydraulic Baling Press-Anderton Hydraulic LiftHydraulic Hoists (Lifts)-The Otis Elevator-Mersey Railway Litts-City and South London Railway Lifts-North Hudson County Railway ElevatorLifts for Subways-Hydraulic Ram-Pearsall's Hydraulic Engine-PumpingEngines-Three-Cylinder Engines-Brotherhood Engine-Rigg's Hydraulic Engine-Hydraulic Capstans-Hydraulic Traversers-Movable Jigger HoistHydraulic Waggon Drop-Hydraulic Jack-Duckham's Weighing MachineShop Tools-Tweddell's Hydraulic Rivetter-Hydraulic Joggling PressTweddell's Punching and Shearing Machine-Flanging Machine-Hydraulic Centre Crane-Wrightson's Balance Crane-Hydraulic Power at the Forth Bridge-Cranes-Hydraulic Coal-Discharging Machines-Hydraulic DrillHydraulic Manhole Cutter-Hydraulic Drill at St. Gothard Tunnel-Motors with Variable Power-Hydraulic Machinery on Board Ship-Hydraulic Points and Crossings-Hydraulic Pile Driver-Hydraulic Pile Screwing ApparatusHydraulic Excavator-Ball's Pump Dredger-Hydraulic Power applied to Bridges-Dock-gate Machinery-Hydraulic Brake-Hydraulic Power applied to Gunnery-Centrifugal Pumps-- Water Wheels-Turbines-Jet PropulsionThe Gerard-Barré Hydraulic Railway-Greathead's Injector Hydrant-Snell's Hydraulic Transport System-Greathead's Shield-Grain Elevator at Frankfort-Packing-Power Co-operation-Hull Hydraulic Power CompanyLondon Hydraulic Power Company-Birmingham Hydraulic Power System -Niagara Falls-Cost of Hydraulic Power-Meters-Schönheyder's Pressure Regulator-Deacon's Waste-Water Meter.

"A Book of great Professional Usefulness."-Iron.

*** The SEcond Edition of the above important work has been thoroughly revised and brought up to date. Many new full-page Plates have been added-the number being increased from 43 in the First Edition to 69 in the present. Full Prospectus, giving a deacription of the Plates, may be had on application to the Publishers.

LONDON : EXETER STREET, STRAND. 


\section{GRIFFIN'S METALLURGICAL SERIES.}

Second Edition. Large 8vo. Handsome Cloth. 21s.

\section{THE METALLURGY OF GOLD.}

BY

T. KIRKE ROSE, D.Sc., Assoc.R.S.M., F.I.C., Assistant Assayer of the Royal Mint.

Revised and partly Re-written. Including the most recent Improvements in the Cyanide Process, and a new Chapter on Economic

Considerations (Management, Cost, Output, \&c.). With Frontispiece and additional Illustrations.

\section{LEADING FEATURES.}

1. Adapted for all who are interested in the Gold Mining Industry, being free from technicalities as far as possible; of special value to those engaged in the industry-viz., mill-managers, reduction-officers, \&c.

2. The whole ground implied by the term "Metallurgy of Gold" has been covered with equal care; the space is carefully apportioned to the various branches of the subject, according to their relative importance.

3. The MacArthur-Forrest Cyanide Process is fully described for the first time. By this process over $£ 2,000,000$ of gold per annum (at the rate of) is now being extracted, or nearly one-tenth of the total world's production. The process, introduced in 1887, has only had short newspaper accounts given of it previously. The chapters have been submitted to, and revised by, Mr. MacArthur, and so freed from all possible inaccuracies.

4. Among other new processes not previously described in a text-book are(1) The modern barrel chlorination process, practised with great success in Dakota, where the Black Hills district is undergoing rapid development owing to its introduction. (2) New processes for separating gold from silver-viz., the new Gutzkow process, and the Electrolytic process; the cost of separation is reduced by them by one-half.

5. A new feature is the description of EXACT METHODS employed in particular extraction works-Stamp-batteries of South Africa, Australia, New Zealand, California, Colorado, and Dakota; Chlorination works also, in many parts of the world; Cyanide works of S. Africa and New Zealand. These accounts are of special value to practical men.

6. The broliography is the first made since 1882 .

"Dr. Rose gained his experience in the Western States of America, but he has secured details of gold-working from ALL PARTs of the world, and these should be of GRFAT SERVICE to practical men. . . The four chapters on Chlorination, written from the point of view alike of the practical man and the chemist, TERM WITH CONBIDERATIONS HITHERTO UNRECOGNIB F, and constitute an addition to the literature of Metallurgy, which will prove to be of classical value."-Nature.

"The most complete description of the chlorination process which has yet been pnbliahed. - Mining Journal.

LONDON: EXETER STREET, STRAND. 


\section{Companion-Volume to MM. Knecht and Rawson's "Dyeing."}

\section{TEXTILE PRINTING:}

\section{A PRACTICAL MANUAL.}

Including the Processes Used in the Printing of COTTON, WOOLLEN, SILK, and HALF-SILK FABRICS.

By C. F. SEYMOUR ROTHWELL, F.C.S., Mem. Soc. of Chomical Industries; late Lecturer at the Municip l Technical School, Manchester.

In Large 8vo, with Illustrations and Printed Patterns. Price 2 Is.

General Contents.-Introduction-The Machinery Used in Textile Printing - Thickeners and Mordants-The Printing of Cotton Goods-The Steam Style - Colours Produced Directly on the Fibre-Dyed Styles-Padding StyleResist and Discharge Styles-The Printing of Compound Colcurings, \&c.The Printing of Woollen Goods-The Printing of silk Goods-Practical Recipes for Printing-Appendix-Useful Tables-Patterns.

"BY FAR THE BEST and MOST PRACTICAL BOoK on TEXTILE PRINTING which has yet been brought out, and will long remain the standard work on the subject. It is essentially practical in character."-Te.xtile Mercury.

"The MOST PRACTICal MaNUal of TeXtile PRinting which has yet appeared. We have no hesitation in recommending it."-The Textile "Hunfacturer.

"UNDOUBTEDLY the book is THE BEST which has appeared on TEXTILE PRINTING, and worthily torms a Companion-Volume to 'A Manual on Dyeing.' "-The Dyer and Calico Printer.

\section{SCHWACKHÖFER and BROWNE:}

FUEL AND WATER: A Manual for Users of Steam and Water. By Prof. FRANZ SCHWACKHOFER of Vienna, and WALTER R. BROWNE, M.A., C.E., late Fellow of Trinity College, Cambridge. Demy 8vo, with Numerous Illustrations, 9\%

Grneral Contents.-Heat and Combustion-Fuel, Varieties of-Firing Arrangements : Furnace, Flues, Chimney - The Boiler, Choice of -- Varieties - Feed-water Heaters-Steam Pipes-Water : Composition, Purification-Prevention of Scale, \&c., \&c.

"The Section on Heat is one of the best and most lucid ever written."-Engzneer.

"Cannot fail to be valuable to thousands using steam power."-Railway Engineer.

SHELTON-BEY (W. Vincent, Foreman to the Imperial Ottoman Gun Factories, Constantinople) :

THE MECHANIC'S GUIDE: A Hand-Book for Engineers and Artizans. With Copious Tables and Valuable Recipes for Practical Use. Illustrated. Second Edition. Crown 8vo. Cloth, 7/6.

LONDON : EXETER STREET, STRAND. 
Thipteenth Edition. Price 2is.

Demy 8vo, Cloth. With Numerous Illustrations, reduced from Working Drawings.

A M A N U L O F

MARINE ENGINEERING:

COMPRISING THE DESIGNING, CONSTRUCTION, AND WORKING OF MARINE MACHINERY.

By A. E. S E A T O N, M. Inst. C. E., M. Inst. Mech. E., M.Inst.N.A.

GENERAL C O N T E N T.

Part I.-Principles of Marine Propulsion.

Part II.-Principles of Steam Engineering.

Part III.-Details of Marine Engines: Design and CalPistons, Valves, Expansion Valves, \&c.

Part IV.-Propellers.

Part V.-Boilers.

Part VI.-Miseellaneous.

** The Thirteenth Edition includes a Chapter on Water-Tube Boilers, with Illustrations of the leading Types.

"In the three-fold capacity of enabling a Student to learn how to design, construct, and work a Marine Steam-Engine. Mr. Seaton's Manual has No RIVAL."-Times.

"The important subject of Marine Engineering is here treated with the THOROUGHNESS that it reaures. No department has escaped attention. . . Gives the results of much close study and practical work."-Engineering.

"By far the BEST MANUAL in existence. - . . Gives a complete account of the methods of solving, with the utmost possible economy, the problems before the Marine Engineer."-Athenoum.

"The Student, Draughtsman, and Engineer will find this work the most valUablz HАNDBOOK of Reference on the Marine Engine now in existence."-Marine Engineer.

Fourth Edition. With Diagrams. Pocket-Size, Leather. 8s. 6d.

A POCKET-BOOK OF

\section{MARINE ENGINEERING RULES AND TABLES,}

FOR THE USE OF

Marine Engineers, Naval Architects, Designers, Draughtsmen, Superintendents and Others.

BY

A. E. SEATON, M.I. O.E., M.I.Mech.E., M.I. N.A., AND

H. M. ROUNTHWAITE, M.I.Mech.E., M.I.N.A.

"Admirably fulfils its purpose."-Marine Engineer.

LONDON : EXETER STREET, STRAND. 


\section{WORKS BY A. HUMBOLDT SEXTON, F.I.C., F.C.S.,}

Professor of Metallurgy in the Glasgow and West of Scotland Technical College.

In Large Crown 8vo, Handsome Cloth, 6 s.

\section{ELEMENTARY METALLURGY}

(A TEXT-BOOK OF).

Including the Author's Practical Laboratory Codrse.

With Numerous Illustrations.

GENERAL CONTENTS.-Introduction-Properties of the Metals-Combustion -Fuels-Refractory Materials-Furnaces-Occurrence of the Metals in Nature-Preparation of the Ore for the Smelter-Metallurgical Processes-Iron: Preparation of Pig Iron-Malleable Iron-Steel-Mild Steel-Copper-Lead-Zinc and Tin-Silver -Gold-Mercury-Alloys-Applications of Electricity to Metallurgy-LABoratory Course with Nemerous Practical Exercises.

" The volume before us fully Enhances and confirms Prof. Sexton's reputation. . . Just the kind of work for Students COMmencis the study of Metallurgy, or for ENGINEERING Students requiring a GENERAL KNOWLEDGe of it, or for ENGINEERS in practice who like a HANDY WORK of REFERENCE. To all three classes we HEA RTILY commend the work."-Practical Engineer.

" Excellently got-up and well-ARranged. . . . Iron and copper well explained by EXCELLEN' diagrams showing the stages of the process from start to finish. . . The most Novel chapter is that on the many changes wrought in Metallorgical Methods by Electricity."-Chemical Trade Journal.

"Possesses the great advantagk of giving a Course of Practical Work." -Mining Journal.

\section{Sexton's (Prof.) Outlines of Quantitative Analysis.}

FOR THE USE OF STUDENTS.

With Illustrations. Fodrth Edition. Crown 8vo, Cloth, 3s.

"A CoMpact LABokatory GUIDE for beginners was wanted, and the want has been weLl SUPPLIED. . . . A good and nseful book."-Lancet.

\section{Sexton's (Prof.) Outlines of Qualitative Analysis.}

FOR THE USE OF STUDENTS.

With Illustrations. ThIRd Edrrion. Crown 8vo, Cloth, 3s. 6 d.

"The work of a thoronghly practical chemist."-British Medical Journal.

" Compiled with great care, and will supply a want."-Journal of Education. 
In Large 8vo. Handsome Cloth. Price 21s.

\section{B R E W I N G:}

\section{(THE PRINCIPLES AND PRACTICE OF).}

FOR THE USE OF STUDENTS AND PRACTICAL MEN.

BY

WALTER J. SYKES, M.D., D.P.H., F.I.C., EDITOR OF "THE ANALYST."

With Illustrations and Plates.

*** This work is intended to present a description of the FUNDAMENTAL PRINCIPLES on which the Art of Brewing is based, and also a bird's eye view of that Art as carried on in accordance with THE BEST AND MOST SCIENTIFIC MODERN METHODS.

In Large 8vo. Handsome Cloth. With numerous Illustrations.

TECHNICAL MYCOLOGY: THE UTILIZATION OF MICRO-ORGANISMS IN THE ARTS AND MANUFACTURES.

A Practical Handbook on Fermentation and Fermentative Processes for the Use of Brewers and Distillers, Analysts,

Technical and Agricultural Chemists, and all interested in the Industries dependent on Fermentation.

Br Dr. FRA N Z LA FA R,

Of the Royal Experimental Station for Industries dependent on Fermentation, Hohenheim, near Stuttgart.

With an Introduction by Dr. EMIL CHR. HANSEN, Principal of the Carlsberg Laboratory, Copenhagen.

Translated BY CHARLES T. C. SALTER.

In Two Volumes, sold ieparately.

* * It is hoped that the English version of the First Volume of this novel and important work will be issued in the autumn of 1897 ; that of the Second, during 1898. The extraordinary rôles played by Micro-organisms in Brewing and Distilling-in the manufacture of Sugar, of Vinegar, and Acetic Acid-in Tanning and Tobacco Manufacture-in Acricultural Industries and the Processes conuected with the Dairy : Souring of Cream, Cheese-Ripening, \&c., \&c.-combine to make Dr. Lafar's Text-Book one of great value and interest to a very wide circle of readers.

LONDON : EXETER STREET, STRAND. 


\section{WORKS BY PROF. ROBERT H. SMITH, AsSOc.M.I.C.E.,} M.I.M.E., M.I.El.E., M.Fed.I.Mi.E., Whit. Sch., M.Ord.Meiji.

\section{MEASUREMENT CONVERSIONS}

\section{(English and French):}

\section{GRAPHIC TABLES OR DIAGRAMS.}

Showing at a glance the Mutual Conversion of Measurements in Different Units

Of Lengths, Areas, Volumes, Weights, Stresses, Densities, Quantities of Work, Horse Powers, Temperatures, \&cc.

For the use of Engineers, Surveyors, Architects, and Contractors.

$$
\text { In 4to, Boards. 7s. 6d. }
$$

* * Prof. Smith's Conversion-Tables form the most unique and comprehensive collection ever placed before the profession. By their use much time and labour will be saved, and the chances of error in calculation diminished. It is believed that henceforth no Engineer's Office will be considered complete without them.

"The work is INVALUABLE."-Colliery Guardian.

"Ought to be in EVERY office where even occasional conversions are required. . . . Prof. SMITH'S TABLES form very EXCELLENT CHBCKS on results. . . A VERY USEF⿱宀 and good set of diagrams."-Electrical Review.

"Prof. Smith deserves the hearty thanks, not only of the ErginerR, but of the Commrarias. WorLD, for having smoothed the way for the ADOPTION of the MBTRIC STSTEM of MrASURKMRNT, 2 subject which is now assuming great importance as a factor in maintaining our HowD upon FOREIGN TRADE. There can be no doubt that the antiquated system of Weights and Measures used in this country is doomed to be superseded by the much simpler method of DBCIMAL. MBASUREMENT. The sooner this is recognised, the better."-The Machinery Market.

\section{THE CALCULUS FOR ENGINEERS AND PHYSICISTS,}

Applied to Technical Problems.

WITH EXTENSIVE

\section{CLASSIFIED REFERENCE LIST OF INTEGRALS.}

By PROF. ROBERT H. SMITH.

ASSISTED BY

ROBERT FRANKLIN MUIRHEAD,

M.A., B.Sc. (Glasgow), B.A. (Cambridge),

Formerly Clark Fellow of Glasgow University, and Lecturer on Mathematics at Mason College.

In Crown 8vo, extra, with Diagrams and Folding-Plate. 8s. 6d. 


\section{By PROFESSORS J. J. THOMSON \& POYNTING.}

In Large 8vo. Fully Illustrated.

\section{A TEXT-BOOK OF PHYSICS:}

COMPRISING

PROPERTIES OF MATTER; HEAT; SOUND AND LIGHT; MAGNETISM AND ELECTRICITY.

BY

J. H. POYNTING, sc.D., F.R.S., Late Fellow of Trinity College, Cambridge; Professor of Physics, Mason College, Birmingham.
J. J. THOMSON,

AND

\author{
I.A., P.R.s.,
}

Fellow of Trinity College, Cambridge; Prot. of Experimental Physics in the University of Cambridge.

Third Edition, Revised and Enlarged. Pocket-Size, Leather, also for Office Use, Cloth, 12s. 6 d.

\section{BOILERS, MARINE AND LAND: THEIR CONSTRUCTION AND STRENGTH.}

a Handbook of Roles, Formule, Tables, \&c., relative to Material, Scantuings, and Pressures, Safety Valves, Springs, Fittings and Mountings, \&d.

\section{For the Use of all $\mathfrak{\text { Iteam }}=$ Users.}

By T. W. TRAILL, M. Inst. O. E., F.E. R. N., Late Engineer Surveyor-in-Chief to the Board of Trade.

** To the Third Edition many New Tables have been added.

"Very unlike any of the numerous treatises on Boilers which have preceded it. . . . Really useful. - Contains an ENORMOUS QUANTITY OP INFORMATION arranged in a very convenient form. $\therefore$ Those who have to design boilers will find that they can settle the dimensions for any given pressure with aimost no calculation with its aid... A MOST USBPUL voLUMB supplying information to be had nowhere else."-The Engineer.

"As a handbook of rules, formulæ, tables, \&c., relating to materials, scantlings, and pressures, this work will prove aIOST USEFUx. The name of the Author is a sufficient guarantee for its accuracy. It will save engineers, inspectors, and draughtsmen a vast amount of calculation."-Nature.

"By such an authority cannot but prove a welcome addition to the literature of the subject.

We can strongly recommend it as being the MOST COMPLPTB, eminently practical work on the subjoct.; -Marine Engineer.

To the engineer and practical boiler-maker it will prove INVALUABIs. The tables in all probability are the most exhaustive yet published. Certainly deserres a place on the thalf in the drawing office of every boiler shop."-Prcctical Eingineer.

LONDON : EXETER STREET, STRAND. 


\section{GRIFFIN'S METALLURGICAL SERIES.}

\section{THE METALLURGY OF IRON.}

B Y

THOMAS TURNER, Assoc.R.S.M., F.I.C., Director of Technical Instruction to the Staffordshire County Council.

In Large 8vo, Handsome Cloth, With Numeroos Illustrations (MANY From Photographs). Price 16s.

\section{GENERAL CONTENTS.}

Early History of Iron.

Modern History of Iron.

The Age of Steel.

Chief Iron Ores.

Preparation of Iron Ores.

The Blast Furnace.

The Air used in the Blast Furnace.

Reactions of the Blast Furnace.

The Fuel used in the Blast Furnace.
Slags and Fluxes of Iron Smelting.

Properties of Cast Iron.

Foundry Practice.

Wrought Iron.

Indirect Production of Wrought Iron.

The Puddling Process.

Further Treatment of Wrought Iron.

Corrosion of Iron and steel.

"A MOst VALUABLe sUmmary of useful knowledge relating to every method and stage in the manufacture of cast and wrought iron down to the present moment . . . particularly rich in chemical details. . . An EXHA USTIVE and REALLY NERDED compilation by a MOST CAPABLE and THOROUGHLY UP-TO-DATE metallurgical authority."-Bulletin of the American Iron and Steel Association.

" This is A DrLIGHTFUL BOoK, giving, as it does, reliable information on a subject becoming every day more elaborate. . . . The account of the chief iron ores is, like the rest of this work, RICH in detail. . . Foundry Practice has been made the subject of considerable investigation by the author, and forms an interesting and able chapter."-Colliery Guardian.

"Mr. Turner's work comes at an opportune moment and in answer to a REAI DEMAND. . . A THOROUGHLY USEFUL BOOK, which brings the subject UP TO DATE. The anthor has produced an EMINENTLY READABLE BOOK. ... Whatever he describes, he describes well. . . . There is much in the work that will be of GREAT vaLUE to those engaged in the iron industry."-Mining Journal.

\section{IN PREPARATION.}

Companion-Volume on

\section{THE METALLURGY OF STEEL.}

By F. W. HARBORD, Assoc.R.S.M., F.I.C.

LONDON : EXETER STREET, STRAND. 
Third Edition. With Numerous Illustrations. Handsome Cloth. 5 s.

\section{KNOW YOUR OWN SHIP.}

By THOMAS WALTON, Naval ARchitect.

SPECIALLY ARRANGED TO SUIT THE REQUIREMENTS OF

Ships' Officers, Shipowners, Superintendents, Draughtsmen, Engineers, and others. This work explains, in a simple manner, such important subjects as :-

Displacement, Deadweight, Tonnage, Freeboard, Moments, Buoyancy, Strain, Structure, Stability, Rolling, Ballasting,

Loading, Shifting Cargoes, Admission of Water, Sail Area, \&c., \&c.

[Griffin's Nautical Series.

"The little book will be found EXCEEDINGLY HANDY by most officers and officials connected with shipping. . . . Mr. Walton's work will obtain LASTING SUCCESS, because of its unique fitness for those for whom it has been written."-Shipping World.

"An EXCELLENT WORK, full of solid instruction and INVALUABLE to every officer of the Mercantile Marine who has his profession at heart."-Shipping.

"Not one of the 242 pages could well be spared. It will admirably fulfil its purpose . . useful to ship owners, ship superintendents, ship draughtsmen, and all interested in shipping."-Liverpool Journal of Commerce.

"A maSS Of VERY USEFUL INFORMATION, accompanied by diagrams and illustrations, is given in a compact form."-Fairplay.

"A large amount of MOST USEFUL INFORMATION is given in the volume. The book is certain to be of great service to those who desire to be thoroughly grounded in the subject of which it treats."-Steamship.

"We have found no one statement that we could have wished differently expressed. The matter has, so far as clearness allows, been admirably condensed, and is simple enough to be understood by every seaman."-Marine Engineer.

\section{GAS AND OIL ENGINES:}

An Introductory Text-book on the Theory, Design, Construction, and Testing of Internal Combustion Engines without Boiler.

FOR THE USE OF STUDENTS.

BY

Prof. W. H. WATKINSON, Whit. Sch., M.Inst.Mech.E., Glasgow and West of Scotland Technical College.

In Crown 8vo, extra, with Numerous Illustrations. [Shortly.

LONDON : EXETER STREET, STRAND. 


\section{WORKS BY DR. ALDER WRIGHT, F.R.S.}

\section{FIXED OILS, FATS, BUTTERS, AND WAXES:}

THEIR PREPARATION AND PROPERTIES,

And the Manufacture therefrom of Candles, Soaps, and

Other Products.

BY

C. R. ALDER WRIGH'T, D.Sc., F.R.S.,

Late Lecturer on Chemistry, St. Mary's Hospital School; Examiner in "Soap" to the City and Guilds of London Institute.

In Large 8vo. Handsome Cloth. With 144 Illustrations. 28s.

" Dr. Wright's work will be found ABSolutely indispensable by every Chemist. Terms with information valuable alike to the Analyst and the Technical Chemist." The Analyst.

"Will rank as the Standard English Authority on Oils and Fats for many years to come."-Industries and Iron.

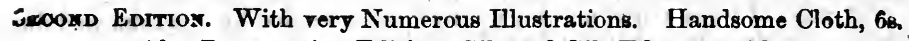
Also Presentation Edition, Gilt and Gilt Edges, 7s. 6d.

\section{THE THRESHOLD OF SCIENCE:}

\section{Simple and Amusing Experiments (over 400) in} Chemistry and Physies.

* * To the NEW EDIrion has been added an excellent chapter on the Systematic Order in which Class Experiments should be carried out for Educational purposes.

"Any one who may still have doubts regarding the value of Elementary Science as an organ of education will speedily have his doubts dispelled, if he takes the trouble to understand the methods recommended by Dr. Alder Wright. The Additions to the New Edition will be of great service to all who wish to use the volume, not merely as a "play-book,' but as an instrument for the TRAINING of the MENTAL FACULTIES."-Nature.

"Step by step the learner is here gently guided through the paths of science, made easy by the perfect knowledge of the teacher, and made flowery by the most striking and curious experiments. Well adapted to become the TREAsORED FaInND of many a bright and promising lad."-Manchester Bsaciminer. 


\section{Engineering}

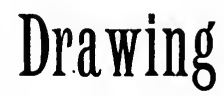

and Design

(A TEXT-BOOK OF).

Second Edition. In Two Parts, Published Separately.

Vol. I.-Practical Geometry, Plane, and Solid. 3s.

Vor. II.-Machine and Engine Drawing and Design. 4s. 6 d.

BY

SIDNEY H. WELLS, WH.Sc.,

A.M.INST.C.B., A.M.INST.MECH.R.,

Principal of, and Head of the Engineering Department in, the Battersea Polytechnic Institute ; formerly of the Engineering Departments of the Yorkshire College, Leeds; and Dulwich College, London.

With many Illustrations, specially prepared for the Work, and numerous

Examples, for the Use of Students in Technical Schools and Colleges.

"A Thorodghiy Jgervi work, exceedingly well written. For the many Examples and Questions we have nothing but praise." - Nature.

"A CAPITAL TEXT-BOOK, arranged on an EXCELIENT SYSTEM, calculated to give an intelligent grasp of the subject, and not the mere faculty of mechanical copying. Wr. Wells shows how to make COMPLETE WORKING-DRAWINGs, discussing fully each step in the design." -Electrical Review.

"The first book leads FASILY and NATURALLY towards the second, where the technical pupil is brought into contact with large and more complex designs."-The Schoolmaster.

\section{The Art of the Goldsmith and Jeweller}

(A Manual for Students and Practical Men).

B y THOS. B. W I G L E ,

Head of the Jewellers and Silversmiths' Association Technical School, Birmingham.

ASSISTED BY

J. H. STANSBIE, B.Sc. (Lond.), F.I.O., Lecturer at the Birmingham Municipal Technical School.

In Large Crown 8vo. With Numerous Illustrations.

\section{Electrical Measurements \& Instruments.}

A Practical Hand-book of Testing for the Electrical Engineer.

By CHARLES H. YEAMAN,

Assoc. Inst. E.E., formeriy Electrical Engineer to the Corporation of Liverpool.

LONDON : EXETER STREET, STRAND. 
Fourteenth Annual Issue. Handsome cloth. 7s. 6d.

\title{
THE OFFICIAL YEAR-BOOK
}

\author{
OF THE
}

\section{SCIENTIFIC AND LEARNED SOCIETIES OF GREAT BRITAIN AND IRELAND.}

\author{
COMPILFD FROM OFTICIAL SOURCES.
}

Comprising (together with other Official Information) LISTS of the PAPERS read during 1896 before all the LEADING SOCIETIES throughout the Kingdom engaged in the following Departments of Research:-

f x. Science Generally : i.e., Societies occupying themselves with several Branches of Science, or with Science and Literature jointly.

6. Mathematics and Physics.

3. Chemistry and Photography.

6. Geology, Geography, and Mineralogy.

5. Biology, including Microscopy and Anthropology.

6. Economic Science and Statistics.

7. Mechanical Science and Architecture.

8. Naval and Military Science.

9. Agriculture and Horticulture.

10. Law.

\$11. Literature.

12. Psychology.

13. Archrology.

14: MEDICINE.

"INDISPENSABLE to any one who may wish to keep himself abreast of the scientific work of the day."-Edinburgh Medical Journal.

"The YEAR-BOok of Socretrizs is a Record which ought to be of the greatest use for the progress of Science."-Lord Playfair, F.R.S., K.C.B., M.P., Past-President of the British Association.

"It goos almost without saying that a Handbook of this subject will be in time one of the most generally useful works for the library or the desk."-The Times.

"British Societies are now well represented in the "Year-Book of the Scientific and Learned Societies of Great Britain and Ireland." -(Art. "Societies" in New Edition of "Encyclopædia Britannica," vol. xxii.)

Copies of the FIRST ISSUE, giving an Account of the History, Organization, and Conditions of Membership of the various Societies, and forming the groundwork of the Series, may still be had, price 7/6. Also Copies of the following Issues.

The YEAR-BOOK OF SOCIETIES forms a complete INDEX TO THE SCIENTIFIC wORK of the year in the various Departments. It is used as a ready HANDBOoK in all our great Scientific Centres, Museums, and Libraries throughout the Kingdom, and has become an INDISPENSABLE BOOK OF REFERENCE to every one engaged in Scientific Work.

LONDON : EXETER STREET, STRAND. 


\section{A BOOK NO FAMILY SHOULD BE WITHOUT.}

Thirty-Second Edrtion. Royal 8vo, Handsome Cloth, 10s. 6d.

\section{A D I C TIONAR Y OF \\ Domestic Medicine and Household Surgery,}

BY

SPENCER THOMSON, M.D., EDIN., L.R.C.S., REVISED, AND IN PART RE-WRITTEN, BY THE AUTHOR,

BY

JOHN CHARLES STEELE, M.D.,

LATE of GUY'S Hospital,

AND BY

GE O. REID, M.D., D.P.H.,

Med. OfFiokr, Staffs. County Councir.

With Appendix on the Management of the Sick-room, and many Fints for the Diet and Comfort of Invalids.

In its New Form, Dr. Spencer Thomson's "Dictionary of Domestic Mediuine" fully sustains its reputation as the "Representative Book of the Medical Knowledge and Practice of the Day" applied to Domestic Requirements.

The most recent Improvements in the Treatment of the Sick-in Appliances for the Relief of Paix - and in all matters connected with Sanitation, Hygiene, and the Maintenance of the General Health - will be found in the New Issue in clear and full detail; the experience of the Editors in the Spheres of Private Practice, of Hospital Treatment, and of Sanitary Supervision respectively, combining to render the Dictionary perhaps the most thoroughly practical work of the kind in the English Language. Many new Engravings have been introduced-improved Diagrams of different parts of the Human Body, and Illustrations of the newest Medical, Surgical, and Sanitary Apparatus.

* * All Directions given in such a form as to be readily and safely followei.

\section{FROM THE AUTHOR'S PREFATORY ADDRESS.}

- Without entering upon that difficult ground which correct professional knowledge and educated judgment can alone permit to be safely trodden, there is a wide and extensive field for exertion, and for usefulness, open to the unprofessional, in the kindly offices of a true DOMESTIC MEDICINE, the timely help and solace of a simple HOUSEHOLD SURGERY, or, better still, in the watchful care more generally known as 'SANITARY PRECAUTION,' which tends rather to preserve health than to cure disease. 'The touch of a gentle hand' will not be less gentle because guided by knowledge, nor will the safe domestic remedies be less anxiously or carefully administered. Life may be saved, suffering may always be alleviated. Even to the resident in the midst of civilisation, the 'KNOWLEDGE IS POWER,' to do good; to the settler and emigrant it is INVALUABLE."

"Dr. Thomson has fully succeeded in conveying to the public a vast amount of useful professional knowledge."-Dublin Journal of Medical Science.

"The amount of useful knowledge conveyed in this Work is surprising."-Medical Times and Gazette.

" WORTH ITS WEIGHT IN GOLD TO FAMILIES AND THE cLERGY."-Oxford Herald. 
FIRST SERIES-THIRTY.SIXTH EDITION. SECOND SERIES-TENTH EDITION.

\section{MANY THOUGHTS OF MANY MINDS:}

\section{A Treasury of Reference, consisting of Selections from the Writings of the most Celebrated Authors. FIRST AND SECOND SERIES.}

OOMPILED AND ANALYTICALLY ARRANGRD

\section{By HENRY SOUTHGATE.}

Bach Series is complete in itself, and sold separately.

Presentation Edition, Cloth and Gold, . . . 12s. 6d. each volume
Library Edition, Half Bound, Roxburghe, .
Do., $14 \mathrm{~s}$.

In Square 8vo, elegantly printed on toned paper.

" 'MAкт Tнобантв,' \&c. are evidently the produce of years of research."-Examiner.

"Many beautiful examples of thought and style are to be found among the selections."-Leader.

"There can be little doubt that it is destined to take a bigh place among books of this class."Notes and Queries.

"A treasure to overy reader who may be fortilnate enough to possess it. Its perusal is like Inhaling essences; we have the cream only of the great authors quoted. Here all are seeds or genis." - English Journal of Education.

.Mr. Southgate's reading will be found to extend over nearly the whole known field of literature, ancient and modern."-Gentleman's Magasine.

"We have no hesitation in pronouncing it one of the most important books of the geason. Credit is due to the publishers for the elegance with which the work is got up, and for the extreme beauty and correctness of the typography." - Morning and correct

"Of the numerons volumes of the kind, we do not remember having met with one in which the selection was more judicious, or the sccumulation of treasures so truly wonderful."-Morning Herald.

"The selection of the extracts has been made with taste, judgment, and critical nicety."-Morning

Fosth

"This is a wondrous book, and contains a great many gems of thought."-Daily News.

"As a work of reference, it will be an acquisition to any man's library."-Publishers' Circular.

"This volume contaius more gems of thought, refined sentiments, noble axioms, and extractable sentences, than have ever before been brought together in our language." -The Field.

"All that the poet has described of the beautlful in nature and art, all the axioms of experience, the collected wisdom of philosopher and sage, are garnered into one heap of useful and well-arranged instruction and amusement."-The kra.

"The collection will prove mine rich and inexhaustible, to those in search of a quotstion." Art Journal.
"Will be found to be worth its weight in gold by literary nien."-T'he Builder.

" Every page is laden with the wealth of profoundest thought, and all aglow with the loftiest inspirations of genius." - Star.

The work of Mr. Southgate far outstrips all others of its kind. To the clergymen, the suthor, the artist, and the essayist, "Many Thoughts of Many Minds cannot fail to render almost incalculable service."-Edinburgh Mercury.

"We have no hesitation whatever in describing Mr. Sonthgate's as the very best book of the class. There is positively nothing of the kind in the language that will bear a moment's comparison with it." - Manchester Weekly Advertiser.

"There is no mood in which we can take it up without deriving from it instruction, consolation. and amusement. We heartily thank Mr. Southgate for a book which we shall regard as one of our best friends and companions."-Cambridge Chronicle.

"This work possesses the merit of being a MAGNIPICBNT GIYT-BOOK, appropriate to all times and seasons; a book calculated to be of use to the gcholar, the divine, and the public man." Freemason's Magazine.

"It is not so much a book as a library of quotations." - Patriot.

"The quotations abound in that thought which is the mainspring of mental exercise."-Liverpool Courier.

"For purposes of apposite quotation, it cannot be surpassed."-Bristol Times.

"It is impossible to pick out a single passage in the work which does not, upon the tace of it, justify its selection by its intringic merit." - Dorset Chronicle.

"We are not surprised that a SBCon D SBRIBs of this work should have been called for. Mr. South gate has the catholic tastes desirable in a good Editor. Preachers and public speakers will find that it has special uses for them."-kidinburgh Daily Review.

Review. The SBCond SBRIss fully sustains the deserved reputation of the FInst." John Bull. 



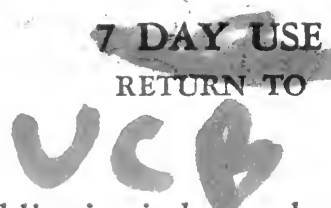

This publication is due on the LAST DATE and HOUR stamped below.

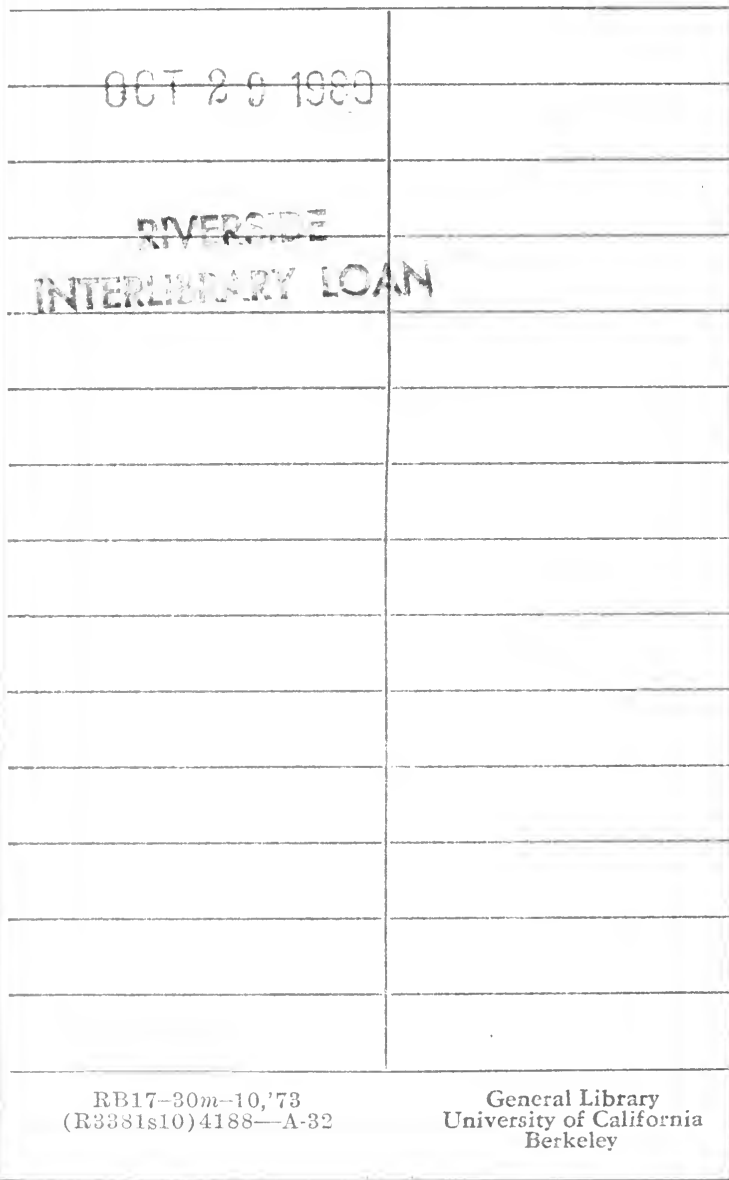




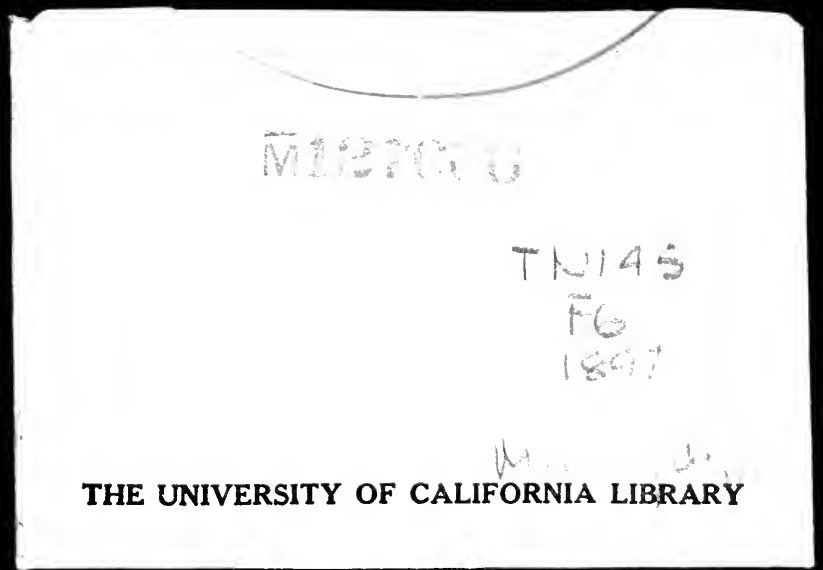


